Guido Rossi

\title{
Representation and Ostensible Authority in Medieval Learned Law
}




\section{Guido Rossi}

Representation and Ostensible Authority in Medieval Learned Law 
Studien zur

europäischen Rechtsgeschichte

Veröffentlichungen des

Max-Planck-Instituts

für europäische Rechtsgeschichte

Frankfurt am Main

Band 319

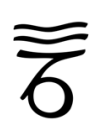

Vittorio Klostermann

Frankfurt am Main 2019 
Guido Rossi

\section{Representation and Ostensible Authority in Medieval Learned Law}

\section{$\overline{\bar{\sigma}}$}

Vittorio Klostermann

Frankfurt am Main 2019 
Bibliographische Information der Deutschen Nationalbibliothek Die Deutsche Nationalbibliothek verzeichnet diese Publikation in der Deutschen Nationalbibliographie; detaillierte bibliographische Daten sind im Internet über http://dnb.dnb.de abrufbar.

(C) Vittorio Klostermann $\mathrm{GmbH}$

Frankfurt am Main 2019

Alle Rechte vorbehalten, insbesondere die des Nachdrucks und der Übersetzung. Ohne Genehmigung des Verlages ist es nicht gestattet, dieses Werk oder Teile in einem photomechanischen oder sonstigen Reproduktionsverfahren oder unter Verwendung elektronischer Systeme zu verarbeiten, zu vervielfältigen und zu verbreiten.

Druck und Bindung: docupoint GmbH, Barleben Typographie: Elmar Lixenfeld, Frankfurt am Main

Gedruckt auf Eos Werkdruck.

Alterungsbeständig @ 1s09706 und PEFC-zertifiziert

Printed in Germany

ISSN 1610-6040

ISBN 978-3-465-04390-4 
to Peter Oestmann 


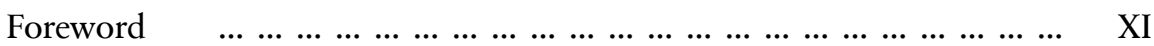

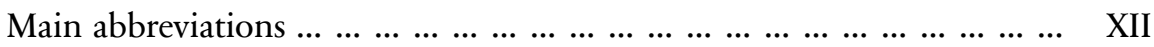

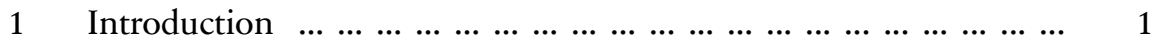

$\begin{array}{llllllllll}1.1 & \text { On the non-linearity of (legal) thought } & \ldots & \ldots & \ldots & \ldots & \ldots & \ldots & \ldots & \ldots\end{array}$

1.2 Invalid appointments, fugitive slaves and heretical prelates

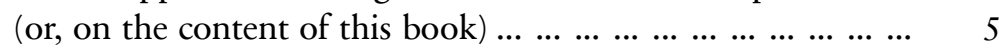

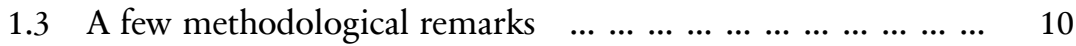

\section{Part I: From Accursius to Bartolus (via France)}

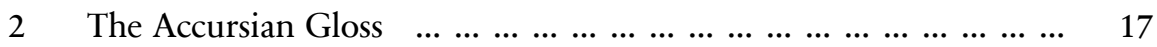

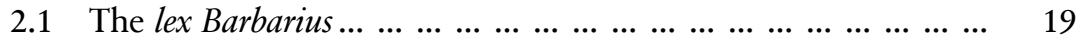

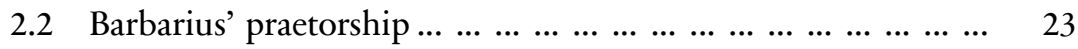

$\begin{array}{llllllll}2.3 & \text { Putative freedom and the validity of the acts } & \ldots & \ldots & \ldots & \ldots & \ldots & \ldots\end{array}$

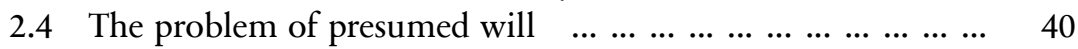

$\begin{array}{llllllllllllll}2.5 & \text { Applications of Barbarius' case } & \ldots & \ldots & \ldots & \ldots & \ldots & \ldots & \ldots & \ldots & \ldots & \ldots & \ldots & \end{array}$

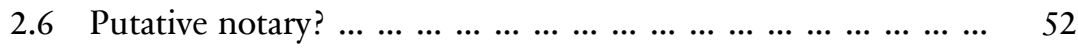

3 Postglossators and Common Mistake: a tale of Odofredus, $\begin{array}{llllllllllll}\text { Jacobus de Arena and Butrigarius } & \ldots & \ldots & \ldots & \ldots & \ldots & \ldots & \ldots & \ldots & \ldots & \ldots & \ldots\end{array}$

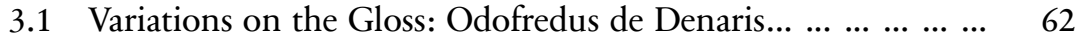

$\begin{array}{lllllllllll}3.2 & \text { The dissent of Jacobus de Arena } & \ldots & \ldots & \ldots & \ldots & \ldots & \ldots & \ldots & \ldots & \ldots\end{array}$

$\begin{array}{lllllllll}3.3 & \text { Butrigarius and the Accursian Orthodoxy } & \ldots & \ldots & \ldots & \ldots & \ldots & \ldots & \ldots\end{array}$

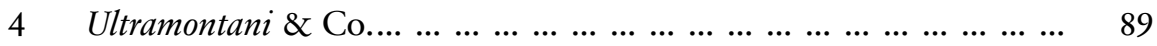

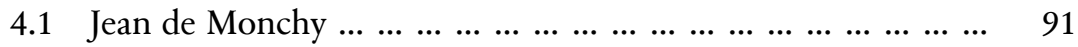

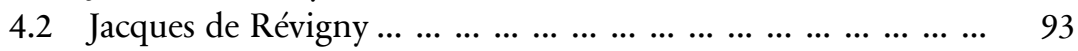

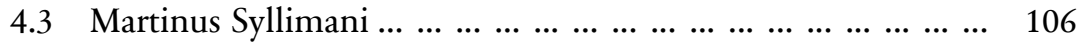

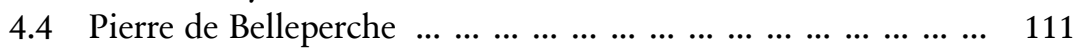

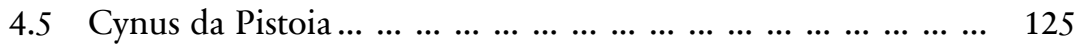

$\begin{array}{lllllllllllllllll}4.6 & \text { Guido da Suzzara } & \ldots & \ldots & \ldots & \ldots & \ldots & \ldots & \ldots & \ldots & \ldots & \ldots & \ldots & \ldots & \ldots & \ldots & \ldots\end{array}$

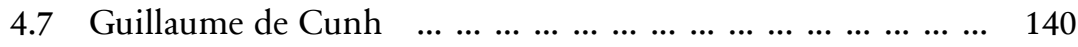

$\begin{array}{llllllllll}4.8 & \text { On the risk of being quoted by Cynus } \ldots & \ldots & \ldots & \ldots & \ldots & \ldots & \ldots & \ldots & \ldots\end{array}$

$\begin{array}{lllllllllll}5 & \text { A fragile synthesis: Bartolus de Saxoferrato } & \ldots & \ldots & \ldots & \ldots & \ldots & \ldots & \ldots & \ldots & \ldots\end{array}$

$\begin{array}{llllllllllllll}5.1 & \text { A strategic defence of the Gloss } & \ldots & \ldots & \ldots & \ldots & \ldots & \ldots & \ldots & \ldots & \ldots & \ldots & \ldots & \ldots\end{array}$

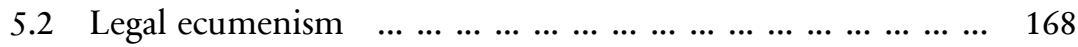


$\begin{array}{lllllllllllllllll}5.3 & \text { Ambiguous notaries } & \ldots & \ldots & \ldots & \ldots & \ldots & \ldots & \ldots & \ldots & \ldots & \ldots & \ldots & \ldots & \ldots & \ldots & \ldots\end{array}$

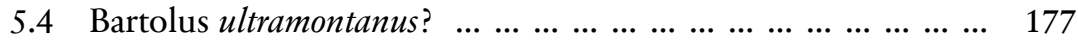

Part II: Canon law and the development of the concept of toleration

$\begin{array}{llllllllllll}6 & \text { From Gratian's Decretum to its Gloss } & \ldots & \ldots & \ldots & \ldots & \ldots & \ldots & \ldots & \ldots & \ldots & \ldots\end{array}$

$\begin{array}{llllllllll}6.1 & \text { Sacramental and jurisdictional powers } \ldots & \ldots & \ldots & \ldots & \ldots & \ldots & \ldots & \ldots & \ldots\end{array}$

$\begin{array}{llllllllllllll}6.2 & \text { Toleration in the Decretum } & \ldots & \ldots & \ldots & \ldots & \ldots & \ldots & \ldots & \ldots & \ldots & \ldots & \ldots & \ldots\end{array}$

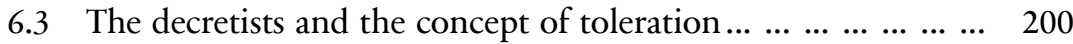

$\begin{array}{llllllllll}6.3 .1 & \text { From Rolandus to Huguccio } & \ldots & \ldots & \ldots & \ldots & \ldots & \ldots & \ldots & \ldots\end{array}$

6.3.2 The excommunication by the secret excommunicate... 211

6.4 Johannes Teutonicus and the Ordinary Gloss on the Decretum 228

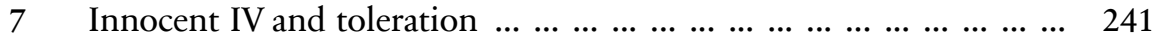

$\begin{array}{llllllllllll}7.1 & \text { Confirmation and toleration } & \ldots & \ldots & \ldots & \ldots & \ldots & \ldots & \ldots & \ldots & \ldots & \ldots\end{array}$

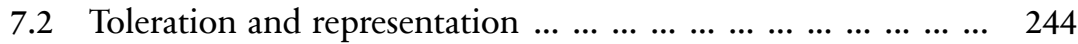

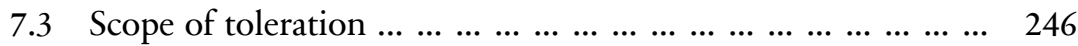

$\begin{array}{lllllllllllllll}7.4 & \text { Some specific applications } & \ldots & \ldots & \ldots & \ldots & \ldots & \ldots & \ldots & \ldots & \ldots & \ldots & \ldots & \ldots & \ldots\end{array}$

$\begin{array}{lllllll}7.5 & \text { Toleration, common mistake and public utility } & \ldots & \ldots & \ldots & \ldots & \ldots\end{array}$

$\begin{array}{lllllllllll}7.6 & \text { Innocent IV and the lex Barbarius } & \ldots & \ldots & \ldots & \ldots & \ldots & \ldots & \ldots & \ldots & \ldots\end{array}$

$\begin{array}{llllllllll}8 & \text { Toleration in the aftermath of Innocent IV } & \ldots & \ldots & \ldots & \ldots & \ldots & \ldots & \ldots & \ldots\end{array}$

$\begin{array}{lllllllll}8.1 & \text { Parmensis and the Gloss on the Liber Extra } & \ldots & \ldots & \ldots & \ldots & \ldots & \ldots & \ldots\end{array}$

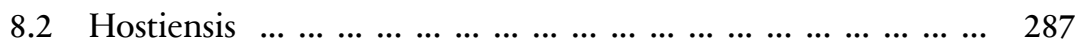

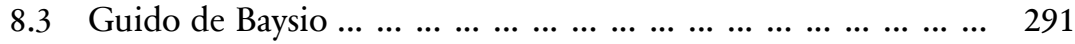

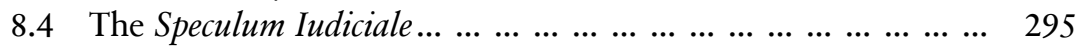

$\begin{array}{lllllllllllllllll}8.5 & \text { Johannes Andreae } & \ldots & \ldots & \ldots & \ldots & \ldots & \ldots & \ldots & \ldots & \ldots & \ldots & \ldots & \ldots & \ldots & \ldots & \ldots\end{array}$

Part III: Baldus de Ubaldis and the limits of representation

$\begin{array}{llllll}9 & \text { Toleration without representation: Albericus de Rosate } & \ldots & \ldots & \ldots & \ldots\end{array}$

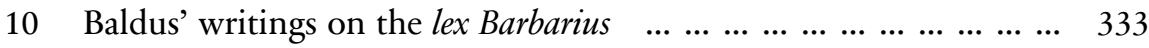

$\begin{array}{llllllllllllll}10.1 & \text { Two authors for one repetitio } & \ldots & \ldots & \ldots & \ldots & \ldots & \ldots & \ldots & \ldots & \ldots & \ldots & \ldots & \ldots\end{array}$

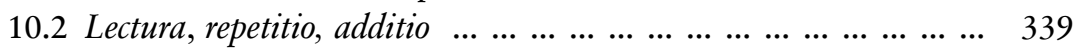

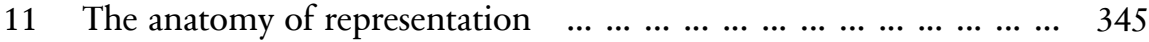

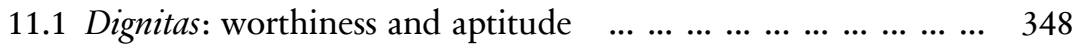

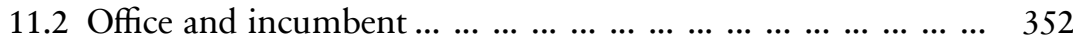

$\begin{array}{llllllllll}11.3 & \text { Collegiate bodies and possessory issues } & \ldots & \ldots & \ldots & \ldots & \ldots & \ldots & \ldots & \ldots\end{array}$

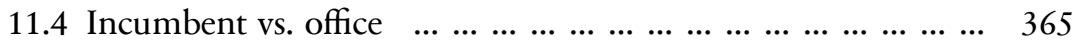




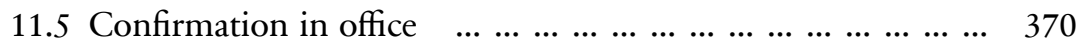

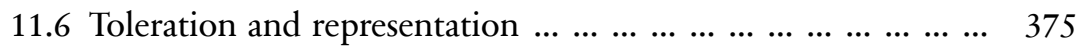

$\begin{array}{llllllllllll}11.7 & \text { Toleration and sacramental issues } & \ldots & \ldots & \ldots & \ldots & \ldots & \ldots & \ldots & \ldots & \ldots & \ldots\end{array}$

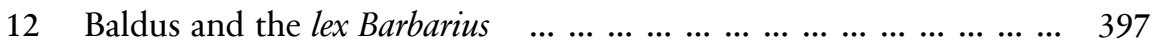

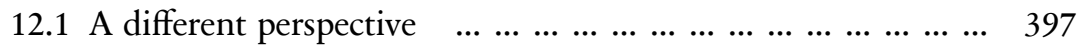

$\begin{array}{lllllllll}12.2 & \text { Barbarius and the problem of toleration } & \ldots & \ldots & \ldots & \ldots & \ldots & \ldots & \ldots\end{array}$

$\begin{array}{lllllllllll}12.3 & \text { Common mistake and public utility } & \ldots & \ldots & \ldots & \ldots & \ldots & \ldots & \ldots & \ldots & \ldots\end{array}$

12.4 From Innocent to Barbarius: Baldus' three-step approach ... ... 424

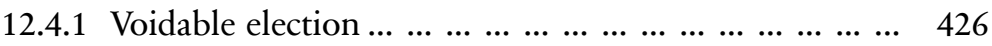

$\begin{array}{lllllllll}12.4 .2 & \text { Possession of ordinary jurisdiction } & \ldots & \ldots & \ldots & \ldots & \ldots & \ldots & \ldots\end{array}$

12.4.3 Public utility and representation:

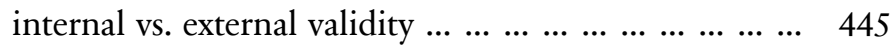

13 Extensions of the lex Barbarius to other cases (or vice versa) ... ... ... 463

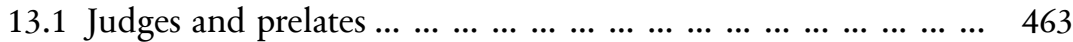

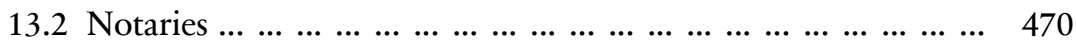

\section{Part IV: Barbarius post Baldum}

14 From the lex Barbarius to the brocard error communis ius facit $\ldots \ldots \quad 489$

14.1 Late commentators and early simplifications $\quad \ldots \ldots \ldots$......... 489

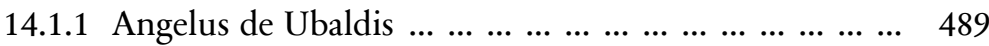

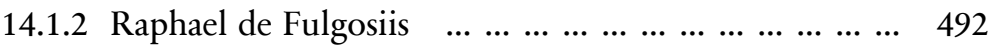

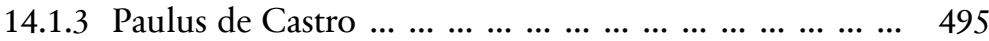

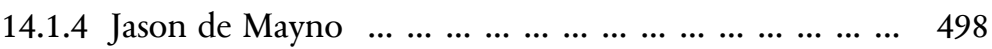

14.1.5 Felinus Sandeus, delegate judges and public utility $\ldots \quad 501$

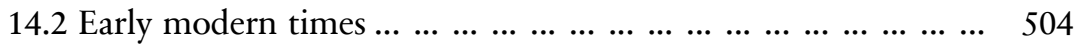

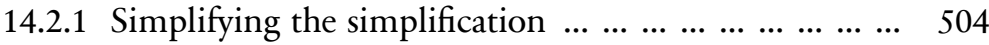

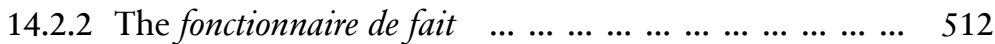

14.3 Toleration in late medieval and early modern canon law $\ldots \ldots \quad 514$

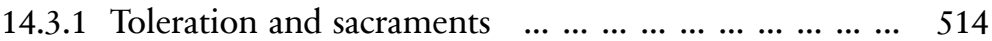

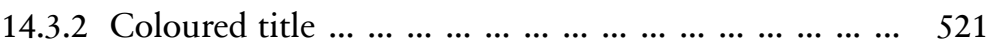

14.4 Bellapertica the American (or, a hint at the common

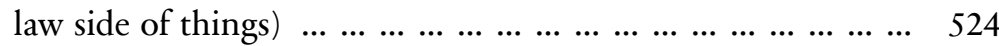

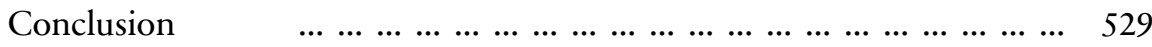

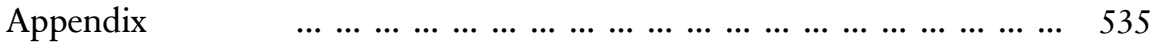

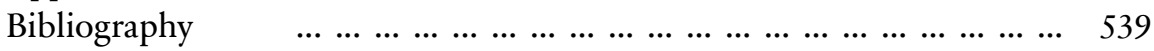

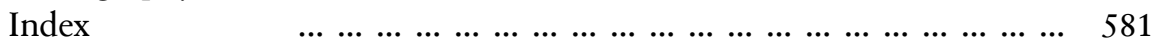




\section{Foreword}

The work for this book began in the spring of 2014 in the magnificent Robbins Collection in Berkeley, as a short article on the problem of the jurisdiction of the occult heretic in thirteenth-century canon law. Now it is a study on the problem of ostensible authority in medieval learned law, focusing mainly on the validity of the acts made by the illegitimate representative of a public office. The idea has not changed. Rather, I have found some more connections to the original topic.

None of the main divisions of the legal system that we use (the various 'branches' of the law) would have made sense to a medieval jurist, not even that between private and public law. Even the distinction between law and some other social sciences (especially economics, administration and political science) would have seemed curious. We are so accustomed to think in terms of discrete disciplines that doing without requires a conscious and prolonged effort.

In some paragraphs of chapters 11 and 12 I have re-elaborated and expanded some concepts that appeared previously in 'Baldus and the Limits of Representation', 86 (2018) Tijdschrift voor Rechtsgeschiedenis.

I am very grateful to all the friends and colleagues who helped me, whether debating legal issues or solving palaeographic riddles. This book was written at the University of Münster, thanks to a Fellowship of the Alexander von Humboldt Foundation. During my stay there, Peter Oestmann was the kindest and most generous host. It is my pleasure to dedicate this book to him.

Guido Rossi 


\section{Main abbreviations}

$\mathrm{X}$

VI.

Clem.

Inst.

Nov.

D.

Dig.

Cod.

C.

De cons.

De pen.
Liber Extra seu Decretalium Gregorii IX compilatio

Liber sextus decretalium D. Bonifacii Papae VIII

Clementis Papae V. Constitutiones

Institutiones Iustiniani

Novellae Iustiniani

distinctio (Decretum Gratiani, pars I)

Digestum Iustiniani

Codex Iustiniani

causa (Decretum Gratiani, pars II)

De consecratione, Decretum Gratiani (pars III)

Tractatus de penitentia, Decretum Gratiani (C.33, q.3) 


\section{Chapter 1}

\section{Introduction}

\subsection{On the non-linearity of (legal) thought}

Legend has it that the emperor of China wanted an accurate map of his empire. No scale would do, even the largest map could not report the tiniest details. The only map that he found satisfactory was as large as China itself - and thus useless.

Some simplification, in other words, is always needed. The problem is to what extent we should indulge in it. Many studies on European legal history especially those focusing on the history of legal ideas (which constitute the vast majority) - provide beautiful, majestic frescoes depicting a smooth, clear evolution of the subject across time and space and greatly helping the reader to make sense of changes and developments with admirable clarity. This linearity, however, comes at a high price: grand narratives are falsifications. The main problem lies in their teleological approach: the way one event is described as leading to the next. And when the events consist mainly in what somebody thought and wrote, putting them in their 'right' order becomes all too easy. Jurist A influences jurist B, who returns the favour to jurist C, and so on. In so doing, tracing the origin of an idea becomes simple enough. Better still: it becomes always possible. This way, incidentally, a few characters would do for the whole plot, since each jurist is chosen to represent a specific moment in time implicitly becoming the embodiment of his Zeitgeist.

A limited number of characters, clear connections and linear development make things convincing. Yet the moment the history of thought (legal or otherwise) starts to make clear sense is often the moment we start getting things wrong. If one were to keep to what one could find in the sources, finding a red thread to bestow continuity through centuries of intellectual history would be a very difficult, and at times a simply impossible operation. Jumping from one point to another in time, and building an ex post explanation for this series of jumps, is much easier - but just wrong. The challenge of the scholar is explaining (first to themselves and then to others) the history of a concept without artificially straightening a devious path.

The present work is just an example of what lies behind the façade of grand narratives. It is messy and convoluted - just as history tends to be. It comprises a 
study of the medieval interpretations of a short passage of the Digest, dealing with the apparent authority of an invalidly appointed magistrate. It is divided into three main parts: the approach of Accursius and the early civil lawyers to the false praetor; the way canon lawyers (especially Innocent IV) dealt with the similar problem of the false prelate; Baldus de Ubaldis and the application of canon law ideas back to civil law. In effect, the whole thing boils down to just three authors: Accursius, Innocent IV and Baldus. So the book could be much shorter. But that would be misleading, for at least three reasons. ${ }^{1}$

First, because the story could be shortened only with hindsight: at any given time it was far from clear what would have happened next. Accursius had no idea that, more than a century later, someone would solve the same legal problem using a wholly different approach. And those who opposed Accursius did so for their own reasons, which had precious little to do with that later solution.

Second, because very often characters whom we are tempted to neglect as 'minor' (just because what they said has no immediate relevance in our modern system) had a significant influence on the approach of the 'major' characters. All too often the specific way in which a 'major' character understood something and sought to apply (or not to apply) an idea was determined largely by the influence of those 'minor' characters. As this division between 'major' and 'minor' is one made with the benefit of hindsight, it has little to do with what (and who) those authors perceived as relevant or marginal. To understand the three 'major' characters in our story, in other words, it is necessary to look at many others whom we might consider as secondary.

Besides, even if we were to accept this division between primary and secondary characters, despite of its total arbitrariness, we would still need those secondary characters. Jurists did not write for posterity, nor were they engaged in an imaginary dialogue with authors of the past. Of course medieval jurists were expected to look at works written in the past and build on them. But they did so while engaged in discussion with their own contemporaries, because it was for them that they were writing. So if we ignore those contemporaries - 'minor' characters as they may have been - we run the risk of misunderstanding what our 'major' characters were trying to say.

Third, because taking things for granted is a dangerous business. Baldus worked out his 'modern' solution to the old problem of Accursius, but the way it has reached us is hardly what one would expect: a centuries-long process of simplification due to a growing series of misunderstandings. Crucially, this

1 I do not even mention the different but complementary question of the transmission of manuscripts and access to the sources, which would greatly complicate things. 
process was largely the product of chance: it was not aimed at clarifying a complex discourse, but at simplifying what was no longer clearly understood. Later authors had increasingly confused ideas as to the reasons behind the complex position of Innocent IV, and they struggled even more to understand why Baldus wanted to complicate the matter any further. To them, both Innocent and Baldus mystified something quite simple, which could well be restored to its pristine simplicity. Such simplification was thus in fact largely a misunderstanding. And yet it is precisely this misunderstanding that led to the modern theory of the de facto officer.

If we were to cut things short and ignore many of the authors mentioned in this book, it would be easy to show a linear development of the subject from the late Middle Ages to modernity. That, however, would not prove such a development. It would simply be a series of ideas duly purified from the context in which they were elaborated. This process of 'purification' would mean ignoring both the reason why something was written and how it was interpreted by later generations. Purified of their history, parallels are easy to make: old ideas and legal principles appear much closer to modern ones. In showing their similarity, we often feel exonerated from proving it.

Since we look backwards, we measure with hindsight. Whether purportedly, implicitly or even just unconsciously, we always approach the historical development of any given legal institution from our modern point of view. In so doing, we run the risk of making this point of view also our point of arrival. We typically study the development of a subject because we want to know how it arrived in its present state. Weighting the importance of any past event with criteria that do not belong to its historical context, however, means ascribing a value to the event that it did not necessarily possess. ${ }^{2}$ What leads to our modern approach is more relevant to us, hence the temptation also to consider it more important in absolute terms. Our goal-oriented approach, in other words, rewrites history. Detaching law from history leads to another and perhaps more deleterious consequence: cryptopandectism. The need to abstract legal principles from their historical context almost necessarily causes them to be considered as abstract rules. Geometry does not need the concept of time: thinking of the law as a geometrical system allows us to apply the same rule to any given historical period with the same result. Thus, the utility-based paradigm feeds on the geometrisation of the law: only a linear account can lead straight to us, and only abstractions can be linear.

The subject of this book puts that utility-driven paradigm (and thus the more geometrico approach to the law) to a harsh test, for neither of the main two 
medieval players won the day. Both apologists for the Gloss of Accursius and its detractors gave in to something entirely different - Baldus and the influence of canon law. This U-turn creates a serious problem: everything that happened before suddenly becomes almost irrelevant. All later developments of the subject - from the late Middle Ages to the entire early modern period and beyond - are effectively based on what Innocent IV said, and on his adaptation on civil law by Baldus. We could safely ignore most of what happened before Baldus and still be able to make sense of the development of the lex Barbarius from the late Middle Ages to modern times. But in so doing we would remove the issue from its historical context and reduce it to an abstract idea. And the moment we applied this abstraction back to history, we would effectively create a new history of our own.

In briefly recalling the early modern and modern developments of the subject, this final part of the book seeks to explain why - and especially, how - some medieval ideas evolved into modernity while others were forgotten. Looking at the evolution of legal ideas, one might be tempted to give in to relativism. In their historical development, those ideas that prevailed over others underwent a profound transformation. Often this transformation was involuntary: even if a rule did not undergo any change, the context in which it applied did change, and that change necessarily affected the application of the rule itself. In the long run, advocates of legal conservatism are often unwitting accomplices of change.

Just as 'winning' ideas are seldom able to withstand the test of time, forgotten ideas have a certain tendency to resurface at some point. History is always written by the winning side. The same applies to the history of any discipline, law included. A jurist would feel the need to mention a theory he did not agree with when he feared that this theory might prevail. When the opposing theory was already in decline, it was typically still mentioned so as to dismiss it for good. But when the adverse theory was already thoroughly dismissed, there was no longer any point in bringing it up. Initially, this might be due to chivalry - giving the coup de grâce to a moribund opponent is acceptable, exhuming the corpse of a foe to mutilate his dead body is somewhat unprofessional. One remembers Achilles for other virtues. As time goes by, however, the reason for not mentioning the old adverse theory becomes more banal: one simply forgets. Centuries after a theory is definitively discarded, it may well happen that someone comes up with exactly the same idea - thinking of it as a brand new and wonderfully modern one. When canon lawyers thought they had a new idea in the early seventeenth century, they were simply saying the same thing as some civil lawyers living in thirteenth-century France. During the nineteenth century, American courts came up with the same idea, happily ignoring both canonists and French jurists. Writing for posterity is an act of optimism. 
1.2 Invalid appointments, fugitive slaves and heretical prelates (or, the content of this book)

In the first book of the Digest, a text of Ulpian (Dig.1.14.3) speaks of a runaway slave who comes to Rome, portrays himself as a Roman citizen and is elected praetor. Are his deeds valid? Ultimately, this is the problem of the de facto officer (also known as fonctionnaire du fait or Scheinbeamter). This book deals with the medieval interpretations of that Roman law text, and so with the medieval approach to the de facto officer doctrine. It is divided into three main parts. The first part focuses on the Accursian Gloss, its supporters and its increasingly numerous detractors. The last part studies the wholly different interpretation provided by Baldus de Ubaldis a century and a half after the Gloss, and it seeks to understand how that interpretation would provide the basis for later developments in the subject. Between them, the central part of the book explores the approach of canon lawyers to a different yet contiguous concept - the jurisdiction of the secret heretic. The jurisdiction of the heretical prelate (especially the heretical bishop) is ultimately the canon law equivalent of the jurisdiction of the slave-praetor: from a legal perspective, the problem is identical. In both cases the person is legally unable to exercise the office, despite being widely believed to be entitled to it. The similarity with the concept of de facto officer is evident. And this similarity becomes identity if we describe the exercise of an office in terms of representation: the de facto officer is someone widely but mistakenly believed to be the legal representative of an office.

Modern legal representation, it is widely known, originates in medieval canon law. It should come as little surprise, therefore, that canon lawyers applied it to 'their' side of the problem - the heretical prelate - much earlier than civil lawyers. Civil lawyers came to apply the same concept to the slave-praetor (and, with it, to other similar cases) only later, mainly through the work of Baldus. This accounts for the tripartition of the book. The first part is in effect a study of the pre-representation approach of the civil lawyers to the problem; the second looks at the application of legal representation to the subject by canon lawyers, and the third to its extension to secular law by Baldus. A final chapter, pompously described as Part IV of the book because it would have ill-fitted the third part, simply hints at early modern developments of the subject.

\subsubsection{The Gloss and beyond}

The first part of this book looks at the greatest achievement of the early glossators, the Accursian Gloss, and its position on the problem of the slavepraetor. The Great Gloss bears the name of the Bolognese jurist Accursius (hence, Accursian Gloss) who wrote it, yet its content is largely pre-Accursian. In 
selecting and merging together the glosses of some of the most important jurists of the previous few generations (on our subject, chiefly Azo), Accursius provided a comprehensive commentary on the whole corpus of Roman law known at the time. While Accursius' commentary was doubtlessly comprehensive, the corpus of the texts glossed upon was hardly consistent. Had Accursius lived in the nineteenth century (or even in the early twentieth), he would probably have solved the problem by considering most of the oddities in the text as interpolations that needed to be fixed. Instead, he had to resort to formal logic, and so to the dialectic approach still very much in vogue during his time - the scholastic method. Hence the reason for the long series of distinctions and sub-distinctions, in which all contradictions would be solved, or at least generously watered down. It has been observed that early glossators did not really have a hierarchy in the sources of law. ${ }^{3}$ No part of the text could be considered ancillary and of lesser relevance (let alone dispensed with), for each part of the text had the same importance - it all lay on the same level. The forest of sub-distinctions was necessary precisely because it was impossible to fell any of the trees. The case of the slave-praetor provides a good example of this. The Accursian Gloss could not solve its ambiguities, because they were enshrined in the letter of the Ulpianean text. Accursius sought to strengthen the (both logically and legally, slightly wanting) conclusion of Ulpian, but he did not replace it with a better and more coherent one. He could not have done so: it would have meant going beyond the limits imposed by a literal exegesis of the text. This, in retrospect, is why Accursius' interpretation came to be increasingly criticised, and progressively overcome.

Ironically, Accursius wrote his Gloss at the same time as a different and considerably more flexible approach to the Roman texts was beginning to spread. This new approach is often credited to Accursius' contemporary and colleague, Jacobus Balduini, and especially to his pupils - from Odofredus onwards. Whether or not through the influence of the school of Balduini, during the same period the same approach starts to spread also elsewhere, both within Italy and beyond - initially in Orléans. If the positions of earlier glossators greatly differed from each other despite their literal exegesis of the text, it is easy to imagine how variegated such positions now became. ${ }^{4}$ This is perhaps one of the reasons why is it so difficult to classify all those jurists under a single definition. Indeed the main name in use, that of 'late glossators', makes sense precisely because it says nothing about what they wrote, but only about when they did. With a few exceptions, the late glossators have attracted little attention law as a higher source of law than civil law, as Schrage notes, did not imply a sense of hierarchy within either kind of law. 
among modern scholars. Yet the wealth of different approaches - and so, normative solutions - found in their writings can be genuinely surprising. This wealth of different solutions is clearly visible in the subject of the slave-praetor, not least as the Accursian Gloss kept rather vague on a crucial issue: the role of the 'common mistake'. Progressively, the issue of the common mistake acquired such importance among late glossators that Barbarius' case was often considered only as an example of a much broader issue - the exact relationship between volition and mistake, especially in the emerging sphere of public law.

\subsubsection{Roman law and Canon law}

The second part of the book looks at the development of canon law on the jurisdiction of the secret heretic. This part could in turn be divided into three sections: the approach of the decretists and earliest decretalists, Pope Innocent IV, and those coming after him. Just as the book is divided between pre- and a post-canon law, so its canon law part is also divided between pre- and postInnocent IV. Innocent IV, therefore, plays a pre-eminent role in our story. This pope-scholar left an indelible mark on the development of both laws - canon law first of all, but also civil law, especially (to use an anachronism) its public law sphere.

It is often said that canon law underwent a thorough 'romanisation'. After all, as the brocard has it, 'the church lives according to Roman law' (ecclesia vivit iure romano). This brocard however does not necessarily mean that canon law was free to develop as far as its Roman leash would allow. In particular, it does not distinguish between form and substance. As to the form, the brocard is undeniably true: what changed the ecclesiological rules governing the Roman church into canon law as we know it was surely the increasing borrowing of Roman law ideas, principles, and 'mechanisms'. As to the substance, however, in many cases the opposite is true: often it was Roman law that was influenced, and even transformed, by canon law principles. The case discussed in this work is obviously hardly proof of that (the subject would need a large number of thick volumes to be properly studied), ${ }^{5}$ and yet it provides a small but telling example in this direction.

In approaching the problem of the heretical bishop's deeds, one of the main texts used by canon lawyers was a short comment from Gratian (C.3, q.7, p.c.1), which in effect merged two excerpts taken from Roman law sources. At first sight, therefore, it would seem that the main influence was from Roman to canon law - not the other way round. The point is that, in the hands of canon

5 See for all Landau (1996), pp. 32-47. Cf. recently O. Condorelli, Roumy and Schmoeckel (2009-2016). 
lawyers, the Roman law excerpts were transformed so much that no Roman lawyer would have recognised them. And it was this new elaboration of the old rules that was finally 'reimported' into civil law. The Latin maxim cited above is sometimes found in a slightly different - but very telling - variant: 'Roman law lives in the church' (ius romanum vivit in ecclesia). The main difference is the subject: in one case it is the church, in the other Roman law. The concept apparently remains the same. The point is that the verb 'to live' (vivere) can be referred both to the church and to Roman law: ecclesia and the ius are both alive - both vivunt. If the church made ample use of Roman law, that same Roman law developed within the church. No comparative lawyer would ever say that, centuries after a 'legal transplant' occurred, the institution, concept or idea 'transplanted' would remain the same. Medieval canon law is in effect the first and foremost case of 'legal transplant' - with the rare peculiarity of being a transplant into a system that was developing much faster, and in a more sophisticated way, than the 'donor' system.

\subsubsection{Innocent IV, Baldus de Ubaldis and Ernst Kantorowicz}

As mentioned above, the third part of the book deals with the 'reception' of canon law ideas into civil law. More precisely, it focuses on the adaptation of Innocent IV's approach to the jurisdiction of the secret heretic to the problem of the slave-praetor by Baldus de Ubaldis. To show that Baldus was not really the first civil lawyer who noticed the argument, this part will start with a very short introduction to a previous jurist, Albericus de Rosate. Albericus perceived the importance of Innocent IV (and later canon lawyers inspired by him) on the subject, but did not fully understand it. The point is hardly meant to discredit Albericus as a jurist: to fully understand Innocent IV's position, an in-depth knowledge of canon law was needed. Innocent's stance on the secret heretic was itself an application of something much broader: legal representation. Ultimately, for Innocent the deeds are not performed by the heretic as an individual, but as a representative of the office. This is why the deeds can be valid despite the condition of the person who issues them. Thus, studying Baldus' adaptation of Innocent's ideas requires first of all looking at Baldus' concept of legal representation in (what we would call) public law.

Looking at Baldus' approach to representation (especially in public law), the present study cannot ignore one of the greatest works on medieval political thought of the twentieth century, Ernst Kantorowicz's The King's Two Bodies. Kantorowicz's genius for synthesis allowed him to accomplish one of the rare works of true interdisciplinarity at a time when that word was not yet used to justify mediocrity. Any scholar remembers Kantorowicz's book at the very least for the explanation of the difference between person and office, especially with regard 
to the highest office - that of the king. It has been noted that the medieval jurist by far most quoted in Kantorowicz is Baldus de Ubaldis. ${ }^{6}$ This is not for want of competition: medieval jurists abound in that book. Yet Baldus is the second most quoted author in the whole of Kantorowicz's book, closely following Dante. ${ }^{7}$ Kantorowicz's interest in Baldus is hardly fortuitous: no other medieval civil lawyer dealt with the concept of representation so extensively and in such depth.

Part of the charm of Kantorowicz's book lies in that it is never boring. In that respect, the fact that the author was not a lawyer by training surely helped: the best way to tedium is tormenting the reader with technicalities. This however left some gaps in Kantorowicz's approach. The relationship between office and office holder is described in its main features and contextualised with many examples, but its (legal) mechanism is not fully studied. That was the task of other authors, by and large medieval canon law scholars. Their work never reached the same universal success as Kantorowicz's, although the quality was just as excellent. Those studies typically described how the relationship between office and incumbent worked. In so doing, they focused on the physiology of representation, not its pathology. One of the most interesting things about the medieval approach to the slave-praetor's case is that, much to the contrary, it allows a focus precisely on the pathology of legal representation.

A legal analysis (or perhaps the déformation professionnelle of the lawyer) tends to focus more on the problems in any given solution. Historians, and especially Kantorowicz, highlighted the relationship between person and office. In so doing, however, they left aside the cases where the person cannot act for the office. Those cases are of particular interest, because it is only there that legal problems emerge clearly. To make full sense of those problems, in turn, it is necessary to look in more depth at the legal position of the office, not just as different from that of the incumbent, but as opposed to it. The case of the slavepraetor is precisely one of them - or rather, the case where Baldus dealt in more depth with the opposition between person and office. Just as the proverbial dwarf on the giants' shoulders, this book thus seeks to explore the boundaries of concepts described so magisterially by scholars of far greater calibre.

Studying Baldus' approach to the case of the slave-praetor also means juxtaposing it with the concept of representation in Innocent IV, to see the subtle but profound difference between the two jurists. It is a crucial step in the development of representation: the separation between the internal and the external validity of vitiated legal representation. Innocent IV's genius for legal principles left little room for the problems of human life. Innocent was no friend of legal ambiguities: any 'grey area' in the law ought to be clarified, no matter 
the cost. Applied to legal representation, this firm attitude led him to consider utterly void any relationship between office and third parties where the office was not validly represented by the incumbent. The external validity of representation, in other words, is for Innocent but a consequence of its internal validity. Unlike the pope, Baldus was more interested in 'grey areas' and ambiguous legal issues. Baldus' greater interest in problematic situations (or rather, his greater openness towards their equitable solution) led him to accept and, crucially, justify - the possibility that the office might act validly towards third parties (external validity) despite the fact that it was not validly represented. Baldus' explanation for the (external) validity of the office's deeds despite the invalidity of the appointment of its representative is ultimately what led to the modern concept of de facto officer. If Baldus went beyond Innocent, however, he did so only because he could build on the pope's revolutionary ideas.

\subsection{A few methodological remarks}

\section{Manuscripts and printed editions}

A reader looking occasionally at the footnotes would notice fairly soon the contrast between the author's compulsive research into manuscript sources in the first chapter (on the Accursian Gloss) and his reliance on printed editions in other (though not all) parts of the book. This is not due to the author's increasing laziness (or at least this is what he tells himself), but to the need to understand clearly Accursius' own position on the slave-praetor's case. The attack on Accursius began only a very few years after he wrote his Gloss. Some of his earliest detractors, such as Guido de Cumis, were actually examined by the same Accursius when they received their doctorate. ${ }^{\mathbf{8}}$ The Gloss was then enriched by later authors, but on our subject the critique against it was surely addressed at of Accursius himself! Meijers (1959a), p. 33, text and note 109 (where he transcribed the additio on Dig.5.3.31 pr, Leiden BPL 6C, fol. 66v). Meijers also transcribed a similar passage where Cumis told his students how someone else (quite significantly, just like Cumis himself, a student of Jacobus Balduini) did the same. This time however Accursius' wrath was such that the student not only failed the exam, but also abandoned his studies and even hastened to take the vows as a Franciscan monk, ibid., note 108 (transcription of the additio ad Dig.4.8.23.1 in Leiden, BPL 6C, fol. 54r). Cf. also Sarti (1990), pp. 62-63. Although Meijers did not say that also Cumis failed his examination, he was sometimes credited with that conclusion: see e. g. Gualandi (1968), pp. 463-64. It is true that the text of the additio might be easily interpreted in that sense, but it would be difficult to reconcile Cumis' bright and swift career with the consequences of such a disastrous failure. Cf. Cortese (2009), pp. 55-56. 
what Accursius himself had written. By contrast, when studying the approach of authors such as Baldus de Ubaldis, writing more than a century thereafter, it is no longer vitally important to know for sure whether a certain line is the work of Accursius or, say, of his son Franciscus.

\section{References in medieval legal sources}

A constant problem when dealing with ius commune sources is what to do with the overabundant and ever-present references in the texts. A healthy solution the one usually adopted - is to ignore them. In effect, doubt often emerges: do these references really add something to the underlying argument of the jurist? As a rule of thumb, the importance of citations decreases with time. It would take great courage to look for each and every specific quotation found in, say, a seventeenth-century legal text. And the few scholars who display such courage normally do so in order to have an idea as to the sources available to a specific author, only seldom to better understand the substance of his reasoning. This of course is a sensible approach, because the forest of citations feeds itself. An author could not be taken seriously if he did not show a good mastery of what previous and authoritative jurists had already said on the matter. A long list of citations was prima facie evidence of continuity. Thus, stating something and then adding a huge list of authors agreeing with the point meant invoking the strength of all those previous authorities in support of the statement - whether or not the support was in effect genuine. A second problem is deciding whether an author did cite something, or the citation was added later. This is another effect of manuscript circulation, which often resulted the text having a second (and much more complex) life. The constant reproduction of manuscripts poses yet another challenge, for often the original citation was changed into another. Further, if manuscript circulation gave a second life to the text, printed editions often resulted in a third one. Here as well citations were often used with flexibility, sometimes even fantasy.

So why bother at all? Admittedly, it is often just not worthwhile. Much, however, depends on the historical period, the specific subject and the particular author. Roughly speaking, up to the fourteenth century (especially in civil law) the references tend to be more on sources than on other jurists. Of course other jurists are often cited, but not as frequently as other normative sources (mostly, other Roman law texts). As long as the attention of the references was focused mainly on the law (and not - yet - on its interpreters), paying careful attention to those references might be of great importance. This is especially the case for those jurists who had a profound knowledge of the whole legal system. Certain authors made ample show of such knowledge, but sometimes it remained just a show. Other authors possessed a knowledge of the legal sources that today, much to our 
shame, would be unthinkable. Broadly speaking, looking at the citations furthers our understanding of the underlying legal reasoning. But sometimes the 'added value' is minimal, and does not justify the effort. At other times, however, it does.

As a rule of thumb, this added value tends to be greater for highly disputed points in the law, or during periods of transition in legal thought. The case of the slave-praetor combines these things: a very controversial subject discussed at a time of extremely important changes. In a society where elected officers were multiplying, the case of the slave-praetor was of great importance: its interpretation might allow the enduring validity of the deeds of city magistrates and other public officers even after their appointment was found out to be void. At the same time, however, the main normative source dealing with the slavepraetor presents undeniable textual ambiguities. An ambiguous passage whose interpretation would greatly affect the community was almost destined to be controversial. This is all the more the case since those controversies took place at a time of profound changes: first the progressive change in the approach of civil lawyers to the Roman law texts, and then the increasing influence of canon law on civil lawyers themselves.

Clearly, various jurists frequently repeated the same thing one after another, often reiterating the same concept, and even borrowing the same words (sometimes whole periods) from previous authors. So this is hardly an unconditional apology for the role of legal citations. Even so, a careful examination of references may prove more fruitful than sometimes assumed. At times, focusing on those references allows us to better understand the legal argument made in the text, and so the reasoning of a jurist, and to notice some subtle differences in the legal arguments of lawyers who apparently seem to say almost the same thing. This is true even for some differences that would appear minimal. Law is not mathematics: the commutative property does not apply to legal citations. Moving the order of the citations found in a previous author's work sometimes resulted in reaching the opposite conclusion: each of those texts cited underpinned a specific argument, and any lawyer knows well that the order of arguments does influence the overall conclusion - both in its logic and, consequently, in its strength.

Looking carefully at these citations may clarify some of the most obscure points in the discussion of the jurists. We will see, for instance, how much can be inferred from those references with regard to problems of mistaken will. Taken at their face value, many statements on the subject would appear cryptic, if not plainly rudimentary. Hence the impression that glossators and commentators alike paid little attention to the problem of the mistake as a pathology of the volition, and the resulting problems on the formation of consent. ${ }^{9}$ While it is 
true that medieval civil lawyers did not venture into profound, lengthy and elaborate discussions on the matter, looking at the precise way in which they referred to other leges reveals a considerably greater sensibility and attention to the subject that one might not otherwise fully realise.

\section{Scholarly literature}

Scholarly literature is cited on the basis of its instrumentality to the argument, not its subject. The construction of medieval public law was a monumental task, where civil lawyers borrowed from Roman (mostly private) law as much as they did from canon law. More correctly, in building public law concepts they started to lay the grounds for a division between private and public law. Canon law provided a large share of the principles, Roman law provided most of the materials. Thus the relationship between Roman law and canon law might at times resemble that between bricks and mortar. As the focus of this study is on neither those bricks nor that mortar, but on their combination in a very specific case, references will be rather selective. This accounts for the brevity of quotations on some vastly studied subjects. As this study touches upon many subjects, the alternative would be to provide a small legal encyclopedia of secondary literature, which would be of doubtful utility.

\section{Medieval reference system: the lex}

This work will often study the arguments of medieval jurists focusing on their specific use of normative references. Any reference to Roman sources will be called lex. That is obvious to the student of medieval law, but it might not be so immediate to other readers. Any paragraph in the medieval and early modern editions of the Corpus Iuris Civilis (whether or not it corresponds to a paragraph in modern editions) was considered a self-containing normative text, hence the term 'lex', identified by its opening word or (to avoid confusion) words. According to its length, the passage was often divided into different parts (which were sometimes sub-divided in their turn). But the unit was always the lex, which had its own internal logic - and thus also its legal coherence. For instance, the fragment of Ulpian in Dig.2.1.3 was always referred to as the lex Imperium. The passage was short but of crucial importance, as it contained several important definitions. The brevity of the passage, however, did not allow further segmentation. So each of those definitions, crucial as they were, constituted a separate section of the lex - but not a different lex.

This system might be considered the equivalent of the common law technique of citing the names of the parties of a specific case to identify the core of its decision, or the number of the article in a civil law code to refer to a 
specific provision (provided that this difference makes still sense today). The ius commune did not develop on the basis of procedure, as the common law did, nor of course was it codified. It developed on the basis of the combination of different passages of Justinian's compilation and of canon law sources (and, to a lesser extent, feudal law ones). Each system develops its own idiosyncrasies. Compared with either of the modern solutions above, the medieval reference system just looks more elegant.

\section{Medieval Latin}

Compared with the beauty of classical Latin, medieval Latin is simply bad. Poor as it was, however, it was a language in contemporary use among learned people. As such, the text was not amended unless doing so was strictly necessary. If few medieval jurists believed strongly in grammar, the percentage among scribes must have been even lower. Some emendations were therefore necessary, mainly where the spelling of a word would not otherwise allow to make sense of the precise case of the noun, or the tense or person of the verb. 


\section{Part I}

From Accursius to Bartolus (via France) 


\section{Chapter 2}

\section{The Accursian Gloss}

The case of the slave-praetor has fascinated jurists from the dawn of Bologna University to our days. If our interest is mainly scholarly, that of medieval jurists went deeper: a slave acting as praetor questioned the fundamental principles underpinning the whole judicial system. It was difficult to think of two figures less compatible with each other than praetor and slave. In medieval legal thought, the slave is the prototype of the inhabilis and the infamis: he embodies all legal incapacities and lacks any dignitas. In general, the infamis could not exercise any public office. ${ }^{1}$ Even more so, a slave could not be judge. This was both a consequence of general principles and a specific provision contained in a well known passage of Paul (Dig.5.1.12.2). ${ }^{2}$ We will see its importance in the course of this study.

Paradoxically, had the lex Barbarius spoken of a slave becoming emperor, the consequences would have been milder. The jurists would have likely taken it as an argumentum ad absurdum, pointing to the fact that the prince is above the law (legibus solutus). But a slave discharging the duties of praetor was a more serious business, because of the position of the praetor as the prototype of the high-

See esp. Gloss ad Dig.3.2.2.3, $\$$ Sacramento (Parisiis 1566, vol. 1, col. 341): 'iurat enim miles, secundum Vegetium, quod mortem non euitabit causa reipublicae, a quo sacramento soluitur propter infamiam qua afficitur. Si ergo soluitur a sacramento militiae secularis: multo magis ab ecclesiastico. Et idem forte in omni publico officio, et omni publico crimine ex quo quis est damnatus. Nam et qui infamis est, non fert testimonium ... eadem ergo ratione aliqua publica officia non exercebit: a dignitatibus autem constat eum esse remotum.' In this study, the Ordinary Gloss follows the above-mentioned 1566 Parisian edition of Merlin, Desboys and Nivelle (Pandectarvm Ivris Civilis, tomus primvs-quintvs ..., Apud Gulielmum Merlin ... et Gulielmum Desboys ..., ac Sebastianum Niuellium ..., Parisiis, 1566). While this edition is among the most accurate ones, comparisons have been made with others, from the Venetian ones (especially of 1484, 1491, 1494, 1499-1500) and the Lyon editions of 1539 and 1569 , the Perugia edition of 1476, the Milanese one of 1482-1483, the Roman one of 1476 and the Mainz edition of 1476-1477.

2 Dig.5.1.12.2 (Paul 17 ed.): 'Non autem omnes iudices dari possunt ab his qui iudicis dandi ius habent: quidam enim lege impediuntur ne iudices sint, quidam natura, quidam moribus. Natura, ut surdus mutus: et perpetuo furiosus et impubes, quia iudicio carent. Lege impeditur, qui senatu motus est. Moribus feminae et servi, non quia non habent iudicium, sed quia receptum est, ut civilibus officiis non fungantur.' 
ranking judge: neither the highest, nor the lowest. In other words, the judge par excellence. For medieval jurists, the higest judge was of course the prince. Those immediately below him (first of all the praetorian prefect, the urban prefect, consuls and quaestores) were illustres. The praetor was a step below: not illustris but spectabilis. ${ }^{3}$ Medieval jurists found these terms in the Authenticae (imperial edicts, mostly taken from Justinian's Novels), especially in Justinian's provisions on appeals in the eastern provinces (Coll.4.2.3=Nov.23.3). The Novel of Justinian spoke of maiores, medii and minores magistrates, and stated that appeals against the decisions of minores could be brought not just before the maiores (chiefly the praefectus augustalis) but also - so long as the value of the cause did not exceed a certain sum (ten auri) - before the spectabiles, such as praetors and proconsuls. It was easy for the civil lawyers to identify such spectabiles with medii magistratus, and so to conclude that the praetor was not the highest judge but still a highranking one. ${ }^{4}$ On this basis, at the beginning of the Digest's title on the office of the praetors, the Ordinary Gloss of Accursius (c.1182-1263), completed around 1230, drew a line: so far the Digest had dealt with illustres (i. e. in the titles on consuls, prefects and quaestores), now it moved to the spectabiles. ${ }^{5}$ That was not only the position of other eminent glossators such as Azo (d. ante 1233). ${ }^{6}$ Many

3 Or, more properly, two steps below - if one were to count also the title superillustris, a title chiefly attributed to the prince (e.g. Gloss ad Dig.1.9.4, $\$$ Qui indignus [Parisiis 1566, vol. 1, col. 120]), but sometimes also used for the consul. Cf. Lepsius (2008), p. 234. In terms of ranking, secular offices were equiparated to ecclesiastical ones. So, for instance, bishops and cardinals were of the same rank as the praetorian prefect: cf. Gloss ad Dig.1.11.1, $\$$ Iudicaturus (Parisiis 1566, vol. 1, col. 125). On the transposition of Roman law magistracies in the medieval world see e.g. Costa (1969), pp. 206-219 and again Lepsius (2008), pp. 233-237, text and and notes 27-31.

$4 \quad$ Gloss ad Coll.4.2.3 (=Nov.23.3), \$Illo videlicet (Parisiis 1566, vol. 5, col. 205). This interpretation found a confirmation in Coll.3.7pr (=Nov.20pr). There, Justinian merged together (among several other things) the administration of the provinces of Paphlagonia and Honorias (in northwestern Anatolia) under a single magistrate who took the name of praetor ('et interim, quoniam Paphlagonia et Honoria diuisae prius in iudices duos, in vnum eundemque reductae sunt praetoris nomen suscipientem', ibid., col. 154). See esp. Durantis' Speculum, lib. 1, partic.1, De Iurisdictione omnium iudicium, 1. \$Expedito (Gvl. Dvrandi Episcopi Mimatensis I.V.D. Specvlum Ivris ..., Basileae, apvd Ambrosivm et Avrelium Frobenios Fratres, 1574; anastatic reprint, Aalen: Scientia Verlag, 1975, p. 134, n. 5).

$5 \quad$ Gloss ad Dig.1.14: 'Hucusque de illustribus, nunc de spectabilibus. Nam praetor est spectabilis: vt in authen. de ap(pellationibus) coll. $4 \$$ simili quoque modo (Coll.4.2.3[=Nov.23.3]). Accursius.' Cf. BNF, Lat. 4462, fol. 15va; Douai 575, fol. 11rb; Firenze, BML, Plut. 6, sin. 3, fol. 10vb.

6 Ad Dig.1.14, BSB, Clm 3887, fol. 10ra; BSB, Clm 14028, fol. 9 ra; BNF Lat. 4463, fol. 12vb; Vat. lat. 2512, fol. 12rb; København, KB 394.1, fol. 13ra; Firenze, BML, AeD 417, fol. $11 r b$. 
Ordines iudiciarii portrayed the illustris as a high-ranking judge, just one degree below the very top. ${ }^{7}$

\subsection{The lex Barbarius}

More than half of the titles of the first book of the Digest are devoted to the office of various Roman magistrates. Their text is largely taken from Ulpian. There is a title on the consul, one on the praetorian prefect, one on the prefect of Rome, and so on. Of these, title 14 is devoted to praetors. It is a small title containing only four passages, and its internal logic is not immediately apparent. The reader would find little information on either the actual powers of the praetor or his legal position. Justinian's compilers seem to have followed an alternative rationale: looking for problematic issues where the jurisdiction of the praetor could be allowed or curtailed. The first two texts, both very short, look at some issues on personal status involving a praetor who is not sui iuris. The first text states that a paterfamilias can manumit before the praetor who is his son-inpower (Dig.1.14.1). ${ }^{8}$ The second text allows the emancipation or adoption of the same praetor to occur before himself and not before another praetor. In other words, the same praetor can be both the subject being emancipated or adopted and the magistrate before whom the proceedings take place (Dig.1.14.2). ${ }^{9}$ The fourth and last text (Dig.1.14.4) prohibits a praetor from appointing himself as warden or iudex specialis (a likely replacement in case of recusation of the 'standard' judge). ${ }^{\mathbf{1 0}}$ Especially with regard to wardship, the connection with the previous two texts seems clear: the issue is still about family law, but this time the praetorial office is treated as incompatible with a specific position (that of

7 E.g. Litewski (1999), p. 95.

8 Dig.1.14.1 (Ulp. 26 ad Sab.): 'Apud filium familias praetorem potest pater eius manumittere.'

9 Dig.1.14.2 (Paul 4 ad Sab.): 'Sed etiam ipsum apud se emancipari vel in adoptionem dari placet.'

10 Dig.1.14.4 (Ulp. 1 de omn. trib.): 'Praetor neque tutorem neque specialem iudicem ipse se dare potest.' The iudex specialis appears only three times in the whole Corpus Iuris - twice in the first book of the Digest (Dig.1.14.4 and 1.18.5, both Ulp. 1 de omn. trib.) and once in the Code (Cod.3.1.18, Iust. A. Iohanni PP.). Dig.1.18.5 is nearly identical to Dig.1.14.4 - this time it is the praeses provinciae who is forbidden from appointing himself as warden or iudex specialis. Cod.3.1.18 is a longer text issued by Justinian to the praetorian prefect on the recusation of the iudex specialis. The text does not clarify the nature of this judge, but it does explain that he was appointed by the emperor himself or by the highest magistrate of a province ('sive ab augusta fortuna sive ab iudiciali culmine in aliqua provincia') in place of a standard judge who had been recused. Cf. A. Berger (1991), s.v. 'Iudex specialis', p. 519, and, more recently, Goria (2000), p. 198, note 102 . 
warden). Being emancipated does not entail any conflict of interest with serving as praetor, but clearly appointing oneself as warden does. By the same token, the magistrate who assigns an ad hoc judge ought not to pick himself for the task.

Between the second and the fourth texts lies an altogether different and lengthier passage, the so-called lex Barbarius (Dig.1.14.3). While still dealing with incompatibilities (thus vaguely related to the fourth text), it has very little to do with any of the previous ones. It reads as follows: ${ }^{11}$

\begin{abstract}
Barbarius Philippus, while he was a runaway slave, stood as a candidate for the praetorship at Rome, and was designated praetor. Pomponius says that his condition as a slave was no obstacle to him: as a matter of fact, he did exercise the praetorship. But let us consider: if a slave, so long as he hid his condition, discharged the office of praetor, what are we to say? That the edicts and decrees he issued will be null and void? Would that go to the benefit of those who sued in his court on statutory grounds or on some other legal grounds? I think that none of these deeds should be set aside. This indeed is the more humane view to take, since the Roman people had the power of conferring this authority to a slave. And if they had known that he was a slave, they would have set him free. And the same power must all the more apply in [the case of] the emperor.
\end{abstract}

The autenticity of the passage has been discussed for centuries, together with a variety of possible emendations. ${ }^{12}$ While not everybody today would necessarily agree with Lenel that the text is a triumph of interpolations, ${ }^{13}$ some features would suggest a post-classical re-elaboration of a sort. Equally problematic is establishing the truth of Barbarius Philippus' praetorship. ${ }^{14}$ If one looks hard enough, it is possible to find some parallels in the sources. Whether such parallels have any merit (and to what extent the sources themselves are reliable),

Dig.1.14.3 (Ulp. 38 ad Sab.): 'Barbarius Philippus cum servus fugitivus esset, Romae praeturam petiit et praetor designatus est. Sed nihil ei servitutem obstetisse ait Pomponius, quasi praetor non fuerit: atquin verum est praetura eum functum. Et tamen videamus: si servus quamdiu latuit, dignitate praetoria functus sit, quid dicemus? Quae edixit, quae decrevit, nullius fore momenti? An fore propter utilitatem eorum, qui apud eum egerunt vel lege vel quo alio iure? Et verum puto nihil eorum reprobari: hoc enim humanius est: cum etiam potuit populus Romanus servo decernere hanc potestatem, sed et si scisset servum esse, liberum effecisset. Quod ius multo magis in imperatore observandum est.' The translation is based, with some amendments, on that of Watson (1985), vol. 1, p. 30 .

12 An excellent summary of the most relevant literature in Rampazzo (2008), pp. 360, 366-369, 411-414 (esp. p. 411, note 207, on the ambiguous 'quasi praetor' of Pomponius), and pp. 474-485. Cf. Knütel (1989), pp. 345-353. For further literature see also Herrmann (1968), pp. 66-73, Cascione (2003), p. 148, note 323, and esp. Lucifredi Peterlongo (1965), pp. 49-84.

13 Lenel (1918), p. 122. Cf. e. g. Hohenlohe (1937), pp. 130-131.

14 For a careful review of most sources on the subject see see Rampazzo (2008), pp. 370-379. Cf. Lucifredi Peterlongo (1965), pp. 40-49. 
is of course another matter. So, one Barbatius seems to have been quaestor (pro praetore) in $41 \mathrm{BCE}$. In his History of Rome, Cassius Dio writes of a large number of people (67 persons) who all became praetors just three years later (in 38 BCE) ${ }^{15}$ It cannot be ruled out that Barbatius was one of them, as in the usual cursus honorum the office of quaestor was followed by that of aedilis and finally of praetor. The same Dio reports another case of a slave serving as praetor in the same years - though in Dio's example the slave was found out and killed. ${ }^{16}$ The Suda Lexicon (a tenth-century Byzantine historical encyclopedia) refers to a

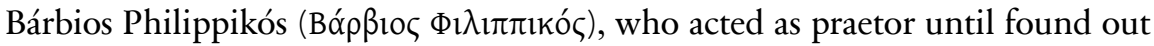
by his master. ${ }^{17}$

We are not interested in studying the text in its own terms - that is, according to Roman law itself. Classical (or even Justinian) Roman law and medieval law had little in common: their juxtaposition was seldom of help in the study of medieval legal problems. Medieval lawyers took the Ulpianean text at face value ${ }^{18}$ when studying the thinking of those medieval jurists, we should do likewise.

The only point in the text of the lex Barbarius that is relevant for its medieval interpretation is a rather self-evident one: the text consists of two parts. The first is Pomponius' statement that the office of praetor is valid despite the servile condition of its holder; the second is Ulpian's elaboration on it. Obvious as it may be, we must keep in mind this partition of the text, as it is crucial to appreciating the medieval jurists' comments on it. The more critical their reading of the text became, the more weight this bipartition would acquire.

For a long time, Accursius' Ordinary Gloss provided the standard interpretation of the lex Barbarius. To what extent this interpretation was the product of Accursius himself we do not know for sure. While it is very probable that it was entirely written by Accursius, ${ }^{19}$ it also seems likely that he built on what earlier

6 Ibid., 48.34.5. Even the punishment however is perplexing: the slave was flung from the Tarpeian Rock (as a Roman) instead of being crucified (as a slave). Cf. Rampazzo (2008), p. 374, text and note 64, where further literature is listed. Adler (1928), p. 454. See further Rampazzo (2008), pp. 376-379, text and notes, esp. note 70, and Lucifredi Peterlongo (1965), p. 41, note 137.

18 This way, incidentally, the status of Barbarius as praetor-elected (praetor designatus) was completely lost among medieval jurists. The result is somewhat ironic, because (as we shall see) of the great importance that the same jurists attributed to the modalities of Barbarius' entry in possession of the office. By definition, the praetor-elected became effectively praetor when he took possession of his office. The problem was only noticed in the early modern period, from Salmasius onwards. See again Rampazzo (2008), pp. 394-396.

19 References will be provided when examining each of the most important glosses on the lex Barbarius. The only exception is the initial gloss in printed sources that 
jurists had already said. The influence of Azo is particularly strong. It is also possible to envisage, although to a smaller extent, some influence of Ugolino de Presbyteris (d. post 1233), ${ }^{20}$ and of the teacher of both Ugolino and Azo, Johannes Bassianus. ${ }^{21}$ We also know that other pre-eminent jurists such as Placentinus (d.1192) also dealt with our subject, at least indirectly. We will seek to identify these different contributions in our analysis of the Gloss, but only insofar as instrumental to a deeper understanding of the Gloss itself.

Following Azo, ${ }^{22}$ the Gloss divides the lex Barbarius in three parts: the validity of Barbarius' praetorship, that of his deeds, and whether he received his freedom. This lex was hardly a masterpiece of clarity. Of the three issues, notes the Gloss, the lex gave a clear answer only to the second one (the validity of Barbarius' deeds). While it also argued in favour of his liberty, though in a rather unclear manner (confuse), it kept silent as to the validity of the praetorship. ${ }^{23}$ It is important to look at each of the three issues in turn, for they would be amply debated by generations of jurists. Before doing so, we may recall the position of

explains the casus, which was added later on, and it was taken from Vivianus Tuscus (fl.1256-1270), Casus longi super Digesto vetere (Lyon, 1490), ad Dig.1.14.3, $\$$ Barbarius, fol. $4 r$.

20 On the life and works of Ugolino see recently Chiodi (2013), pp. 1994-1997.

21 On Bassianus as the teacher of both Azo and Ugolino see already H. Kantorowicz and Buckland (1969), pp. 44 and 168. More recently see also Conte and Loschiavo (2013), p. 137.

22 Very likely, Accursius followed the same tripartition of the lex Barbarius as found in Azo's gloss: ad Dig.1.14.3: 'primum queritur an fuit pretor. Secundo an quae gessit seruentur. Tertio an libertatem consecutus sit. Prime non respondet. Aliis respondet. Az(o).' Vat. lat. 1408, fol. 12va; Vat. lat. 2512, fol. 12rb; Gent, Hs. 23, fol. $17 r a$; Bamberg, Msc. Jur. 11, fol. 13vb; BNF, Lat. 4463, fol. 12vb; BNF, Lat. 4459 , fol. $9 v a$ (the last one with a few small changes). It is very possible, however, that the tripartition predates Azo himself: see e. g. Troyes 174, ad Dig.1.14.3, $\$$ barbarius, fol. 19va. The gloss is anonymous, but it is part of a pre-Azonian apparatus (the latest glosses in the manuscript are those of Bassianus), and it comes immediately after another gloss of Irnerius, seemingly written by the same hand.

23 Gloss ad Dig.1.14.3, $\$$ Barbarius (Parisiis, 1566, vol. 1, col. 130): 'Tria quaeruntur in hac lege: primo, an Barbarius qui praeturam petiit, fuerit praetor; secundo, an ea quae gessit seruentur; tertio, an libertatem fuerit consecutus. Primae non respondet, secundum quosdam secundae sic; item tertiae, sed confuse: vt dices exponendo literam.' The gloss is not signed by Accursius, and several manuscripts leave it anonymous. Nonetheless, it should probably be ascribed to him, at least in its substance. Many manuscripts (whose text is on the point almost identical to that in the Parisian edition) report it with the name of Accursius: see e. g. Pal. lat. 733, fols. 23vb-24ra, and Pal. lat. 738, fol. 13va; Cologny, Bodmer 100, fol. 11ra; Firenze, BML, Edili 65, fol. 10vb; Bern, Cod. 6, fol. 15rb; BAV, SMM 124, fol. 13rb; ÖNB 2265, fol. 13ra; Firenze, BML, AeD, 417, fol. 11ra; BL, Harley 3700, fol. 9vb; Balliol 297, fol. 9ra; BL, Add. 14858, fol. $15 \mathrm{ra}$. 
the praetor as a spectabilis magistrate. Medieval jurists saw his iurisdictio as a senior judge stretching to both judicial and (to a limited extent) legislative competences. Accordingly, Ulpian's rethorical question ('what are we to say? That the edicts and decrees he issued [quae edixit, quae decreuit] will be null and void?') was interpreted as listing his main competences: edicere and decernere. In Accursius' Gloss edicere meant rendering a judgment between the parties, and decernere was interpreted as putting forward a new statute. ${ }^{24}$ The interpretation of decernere was consistent with the high but not supreme rank of the praetor, resulting in rather narrow legislative prerogatives. The praetor's imperium was not merum (absolute), so he could not change the law. ${ }^{25}$ It is however important to remark that the praetor was also - and especially for medieval jurists - an ordinary judge. ${ }^{26}$ His iurisdictio derived directly from his office, it was not delegated to him by someone else. The direct link between person and office highlighted the underlying problem with Barbarius: a slave is infamis, and the infames, as we have seen, are forbidden from public office.

\subsection{Barbarius' praetorship}

The first question in the Gloss is whether Barbarius became praetor de iure. The reason the Gloss deals with it first is not just that it is the first to appear in the text of the lex ('praetor designatus est'). It is also a question of logic: the issue of the validity of his deeds as praetor should depend on that of the validity of his appointment to the praetorship. The point could seem a truism, but its importance must be highlighted: from the Middle Ages to early modern times, the whole debate on the lex Barbarius focused on it. in many printed editions of the Digest (such as the Parisian one used here) the second gloss ( $\$$ Decreuit) was not signed by Accursius, there is little doubt as to its authorship: see e. g. Pal. lat. 732, fol. 4ra; Pal. lat. 735, fol. 15ra; Bologna, CS 285, fol. 15va; BSB, Clm 14022, fol. 15vb; Cologny, Bodmer 100, fol. 11rb. As to the first gloss ( $\$$ Quae edixit) see e. g. Pal. lat. 731, fol. 17ra; Pal. lat. 735, fol. 15ra; Pal. lat. 740, fol. 14ra; Bologna, CS 285, fol. 15va; BSB, Clm 14022, fol. 15vb; Cologny, Bodmer 100, fol. 11rb; Bern, Cod. 6, fol. 15va; Firenze, BML, AeD 417, fol. 11ra; BL, Harley 3700, fol. $9 v b$; Balliol 297, fol. $9 \mathrm{ra}$; BL, Add. 14858, fol. 15ra. pp. 178-185, and Maiolo (2007), pp. 143-145 and 153-155.

26 Gloss ad Dig.1.14.3, $\mathbb{V}$ Vel lege (Parisiis 1566, vol. 1, col. 130): 'id est iudicio ordinario peracto.' The gloss is not signed by Accursius but see e. g. Pal. lat. 738, fol. 13va; Bologna, CS 285, fol. 15va; BL, Harley 3700, fol. 9vb; Balliol 297, fol. $9 \mathrm{ra}$. Azo was more explicit: his comment on the same words reads ' $\mathrm{i}(\mathrm{d}$ est) iudice ordinario. Az(o)', Vat. lat. 1408, fol. 12va; Gent, Hs. 23, fol. $17 \mathrm{ra}$. 
The only clear element to be found in the text of the lex is that Barbarius' deeds are valid. The Gloss presupposes that the validity of the deeds depends on the validity of their source. The lex Barbarius stated that Barbarius' deeds were valid, though with rather confused arguments. The whole discussion in the Gloss sought therefore to reach a predetermined end: strengthening the ambiguous arguments of the lex to support the validity of Barbarius' deeds. The best way to prove as much was of course to argue in favour of the legal validity of Barbarius' position. Proving the validity of his appointment would automatically strengthen the validity of what he did in the exercise of his office. Although the Gloss discussed more the issue of Barbarius' praetorship and liberty, therefore, the ultimate purpose remained that of providing a clear basis for the validity of his deeds. The main obstacles as to the validity of Barbarius' praetorship were thus identified in two passages of the text. The first is the fact that Barbarius sought the praetorship (praeturam petiit). The second is that Pomponius described his exercise of praetorship in rather ambiguous terms (praetura eum functum).

Soliciting an office was a plain violation of the lex Iulia de ambitu (Dig.48.14), which prohibited such a practice. The prohibition in the lex Iulia de ambitu applied to secular and religious offices alike. ${ }^{27}$ This made perfect sense in Rome, given the increasingly political meaning of many religious offices - one needs only to think of how much Caesar spent on securing his election as pontifex maximus to appreciate why the prohibition referred to sacerdotium as well as magistratum. But when medieval jurists looked at this text, they clearly thought of sacerdotium in Christian terms and associated the lex Iulia de ambitu with the prohibition of simoniacal ordinations. The association was strengthened by a post-classical source, a decree of the emperors Leo I and Anthemius, which found its way in the Code (Cod.1.3.30, the lex Quemquem). ${ }^{28}$ This was the clearest reference against simony to be found in the whole Corpus Iuris Civilis. And it was one of the main problems that the Gloss identified in Barbarius' conduct. $^{29}$ magistratum aut sacerdotium quis petierit, per senatus consultum centum aureis cum infamia punitur.'

28 Cod.1.3.30pr-1 (Leo et Anthem. AA. Armasio PP): 'Si quemquem vel in hac urbe regia vel in ceteris provinciis, quae toto orbe diffusae sunt, ad episcopatus gradum provehi deo auctore contigerit, puris hominum mentibus nuda electionis conscientia sincero omnium iudicio proferatur. Nemo gradum sacerdotii pretii venalitate mercetur: qualiter quisque mereatur, non quantum dare sufficiat aestimetur.'

29 Gloss ad Dig.1.14.3, \Designatus (Parisiis 1566, vol. 1, col. 130): 'et quomodo hoc fuit, cum in legem Iul(iam) ambitus commisit: vt C. de episco(pis) et cler(icis) si quemquam (Cod.1.3.30)?' The gloss is reported as written by Accursius both in the printed edition and in most manuscripts. See e.g. Pal. lat. 731, fols. 16 
In the Gloss, Accursius reported three different solutions, all already present in Azo. ${ }^{30}$ The first was that, although Barbarius should not have sought the office, his election would nonetheless hold ('fieri non debuit: factum tamen tenuit'). ${ }^{31}$ The argument might beg the question, but in fact it was somewhat more complicated. It was based on the interpretation of a text within the title of the Digest devoted to specific cases (mainly appointments or condemnations) in which it was possible to appeal (Dig.49.4). The text was the lex Biduum (Dig.49.4.1.5), which looked at the case of a conditional decision. Decisions ought not be rendered under condition. But if they were, should the period to appeal start accruing from the moment the sentence was rendered or from the moment the condition was fulfilled? The lex Biduum opted for the first possibility: the period would start accruing immediately (statim). The Gloss notes the paradox: what is the meaning of a period to appeal against a decision that is void since it is made under condition? The condition may be set aside or considered as valid - the Gloss offers both possibilities. ${ }^{32}$ But either way the

vb-17ra; Pal. lat. 733, fol. 24ra; Pal. lat. 735, fols. 14vb-15ra, Pal. lat. 738, fol. 13va; Pal. lat. 739, fol. 13va; Pal. lat. 740, fol. 14ra; BSB, Clm 14022, fol. 15va; Cologny, Bodmer 100, fol. 11ra; Firenze, BML, Edili 65, fol. 10vb; Basel, UB, C.I.4, fol. 14rb; Bern, Cod. 6, fol. 15rb; Firenze, BML, Plut. 6 sin. 3, fol. 10vb; Girona 46, fol. 17rb; Douai 575, fol. 11rb; Assisi, BSC 216, fol. 13ra; BAV, SMM 124, fol. 13rb; Firenze, BML, AeD 417, fol. 11rb ( $\$$ quomodo).

30 Vat. lat. 1408, fol. 12va, ad Dig.1.14.3, \$petiit: 'cum preturam petierit et in legem commisit vt i(nfra) ad l. iul(iam) am(bitus) l. i. (Dig.48.14.1) et C. de episcopis et $<$ clericis>, 1. si quemquam (Cod.1.3.30) quomodo pretor fuit. Respondo fieri non debuit, factum tamen tenuit: idem et in eo qui symoniace ordinatur nam ipse ordinem et dignitatem habet vel dic publice petiit quod licuit vt i(nfra) de pollicitationibus 1. i. $\mathbb{S}$ i (Dig.50.12.1.1) et amministrat(ione) (sic) tu(torum) 1 . non existimo (Dig.26.7.54) vel melius hac lex iul(ia) non habet locum rom $<$ a $>$ e, ut in predicta l. i ad l. iul(iam) ambitus (Dig.48.14.1). Az(o).' Cf. BNF, Lat. 4459, fol. $9 v a$ (changing 'licuit' into 'placuit'); BSB, Clm 3887, fol. 10ra; Stockholm, KB, B.680, fol. 11va; Gent, Hs. 23, fol. 17ra; Bamberg, Msc. Jur. 11, fol. 13vb; BNF, Lat. 4463, fol. $12 v b$ (\$ preturam). In the printed edition of Azo's Summa see also ad Cod.9.26, $\mathbb{S} V t$ superiori (Azonis svmma avrea ... Lvgdvni, 1557; anastatic reprint, Frankfurt am Main: Minerva, 1968, fol. 232ra, n. 1): '... Et certe locum habet quando quis pecunia facit se elligi ( $s i c$ ad aliquam administrationem, non in ciuitate Romana. In ea enim elligit princeps magistratum: sed in municipio, vel in ciuitate alia, in qua non princeps, sed populus habet ellectionem (sic).' While it may not be excluded that Azo built on previous authors, perhaps Bassianus himself, at least part of his gloss might have been original. The gloss of Ugolino (infra, this paragraph, note 37 ) lists only the first two solutions, not also the third one (which was eventually adopted by Accursius).

31 Gloss ad Dig.1.14.3, $\$$ Designatus (Parisiis 1566, vol. 1, col. 130).

32 Gloss ad Dig.49.4.1.5, \$Statim (ibid., vol. 3, cols. 1607-1638): 'sed certe videtur quod non statim. Nam quod nondum tenet, quomodo rescindi potest?' The Gloss allowed two solutions: either the condition is to be considered as void and 
sentence holds. Therefore, concludes the Gloss, the prohibition does not entail the invalidity of what is done in its violation: 'nota hic quod fieri non debet, tamen factum tenet'. ${ }^{33}$ The same maxim, remarks the Gloss on the lex Barbarius, was even invoked for simoniac elections by those arguing that the ordination of the simoniacal prelate would confer both the sacrament and the office (ordo and dignitas). ${ }^{34}$ This is not the only time the Gloss refers to simoniac elections in connection with the lex Barbarius. ${ }^{35}$ We might want to remember the reference

the decision regarded as pronounced unconditionally, or the conditional decision may not be enforced until the condition is fulfilled - but the reckoning of the period to appeal starts accruing from the pronouncement of the decision and not from the fulfillment of the condition attached to it. Ibid., col. 1608: '... sed forte dices eam tenere vt puram: et tantum conditio vitietur ... vel dic quod tenet conditio vt ante non possit agi iudicati: potest tamen et debet ante appellari, et sic vnum pro condemnato, et aliud contra eum.'

33 Gloss ad Dig.49.4.1.5, \$Statim (ibid., col. 1608).

34 Gloss ad Dig.1.14.3, \$Designatus (ibid., vol. 1, col.130): 'Idem et in eo qui simoniace ordinatur. Nam et ipse ordinem et dignitatem habet: ar(gumentum) infra quando ap(pellandum) sit 1 . i $\$$ biduum (Dig.49.4.1.5) secundum quosdam.' The reference is vague, and it is difficult to ascertain with precision to whom it refers. The difficulty is magnified by the imprecision of the language of those who defended the validity of the simoniacal consecration. So, for instance, in his Dissensiones Ugolino touched on the subject to argue for the validity of the sacrament of ordination conferred simoniacally (in so doing, interestingly, he also referred to the lex Barbarius). But it is not clear whether his reference was only to ordo or also to executio ordinis(the power to exercise it validly). Hugolini dissensiones dominorum (G. Haenel (ed., 1964), p. 317), ad Cod.2.59.2, \$I Iusiurandum calumniae an remittatur parentibus uel patronis?, in fin.: 'Sed sacramentum, quod fit in principio caussae (sic), non remittitur, ut hic dicitur, quia comprehendit generaliter omnes personas, et sic est generaliter accipienda, ut D. de officio praet(orum) 1. 1 et 3 (Dig.1.14.1 and 3).' On the distinction between ordo and executio see infra, pt. II, \$6.1.The same lex Biduum found its way also into Gratian's Decretum (C.2, q.6, c.29), prohibiting the imposition of conditions on a decision. But the Ordinary Gloss to the Decretum watered down the prohibition, and stated that the fulfillment of the condition would retroact to the time of the pronouncement of the decision itself. Until that moment, the Gloss continued, the execution of the decision is suspended - unless it is a sentence of excommunication. Ad C.2, q.6, c.29, \$Statim (Basileae [Johann Petri \& Johann Froben], 1512, fol. 140va): '. .. licet modo nulla sit: speratur tamen et timetur quod sit valitura. Nam in conditionalibus obligationibus spes est in debitum iri ... vnde 1(icet) appellatio non inueniat quod extinguat: tamen conditione existente retro fingitur extitisse.' Ibid., $\$$ sub conditione, fol. 140va: 'de futuro: tunc suspendit sententia ... tamen sententia excommunicationis lata sub conditione tenet lxiii. di. <c.> salonitane (D.63, c.24).'

35 A significant case is discussed in the Gloss on Dig.50.12.11, $\mathbb{\$}$ sacerdotium (Parisiis 1566, vol. 3, col. 1784). In the text (Ulp. de off. curatoris rei pub.) someone promised money to be appointed to a secular or ecclesiastical office, but died before he could obtain it. The Gloss observed that this was in contrast with 
to ordo and dignitas, for we shall see later that it was on that basis (or rather, on the progressive distinction between the two concepts) that the canonists built their theory of toleration of jurisdictional acts.

The second solution was likely proposed by Johannes Bassianus and then reported by his students Azo and Ugolino: the prohibition in the lex Iulia de ambitu applies only when seeking an office secretly, not when seeking it publicly. The Accursian Gloss cites only Bassianus, ${ }^{36}$ so it is not clear whether Accursius

Cod.1.3.30.1 (the lex Quemquem). So it offered two different solutions. The first was that the promissor did not actually violate the prohibition to buy an ecclesiastical office since he died before he could receive it ('sol(utio) hic non suscepit honorem: ibi [scil., in Cod.1.3.30.1] sic.'). This was hardly satisfactory, so the Gloss suggested another solution - that in lex Barbarius ('vel dic vt not(atur) $s$ (upra) l. Barbarius, de offic(io) praeto(rum).'). Clearly the reference was to the gloss Designatus (see next note), the only one in the Accursian comment on the lex Barbarius that both dealt with simony and referred to Cod.1.3.30.1.

Gloss ad Dig.1.14.3, \Designatus (Parisiis 1566, vol. 1, col. 130): 'sed Io(hannes Bassianus) dixit quod publice petiit, quod licuit: vt infra de pol(licitationibus) l. i. $\$ \mathrm{i}$ [Dig.50.12.1.1: a promise made in consideration of an office is binding, see last note] et infra de admi(nistratione) tu(torum) 1. non existimo [Dig.26.7.54-a guardian should pay the usual interest rate to his ward, and not a higher one, if he promised publicly].' Cf. both Pal. lat. 733, fol. 24ra, and Cologny, Bodmer 100, fol. 11 ra: 'sed Jo(hannes Bassianus) dix(it) quod publice petiit quod licuit ut i(nfra) de pollicit(ationibus) 1. i $\$$ i (Dig.50.12.1.1) et i(nfra) de amm(inistratione) (sic) tu(torum) 1. non existi(mo) (Dig.26.7.54) ... ac(cursius).'

Instead of Bassianus, some manuscripts referred generically to 'someone' ('quosdam'). It is however possible that in some cases the hand skipped part of the argument on the simoniac election, thereby merging together the reference to the ordination of the simoniacal prelate with Bassianus' argument on the lex Iulia de ambitu. Compare e. g. Pal. lat. 734, fol. $16 v a$ with Pal. lat. 733, fol. 24ra, in the table below (emphasis added):

Pal. lat. 734, fol. 16 va

Item in eo qui simoniace ordinatur: nam et ipse ordinem et dignitatem habet ar(gumentum) i(nfra) qu(ando) ap(pellandum) sit 1. i $\$$ biduum (Dig.49.4.1.5) sed quosdam dixit quod publice petiit quod licuit ut $\mathrm{i}$ (nfra) in de polli(citationibus)

1. i. (Dig.50.12.1.1) et i(nfra) de ad(ministratione) tu(torum) 1 . non extimo

(Dig.26.7.54).
Pal. lat. 733, fol. 24 ra

Idem in eo qui symoniace ordinatur: nam et ipse ordinem et dignitatem habet ar(gumentum) i(nfra) qu(ando) ap(pellandum) sit 1 . i $₫$ i. biduum (Dig.49.4.1.5) secundum quosdam. sed Jo. dix(it) quod publice petiit quod licuit ut i(nfra) de pollicit(ationibus) 1. i $\$$ i (Dig.50.12.1.1) et $\mathrm{i}$ (nfra) de amm(inistratione) tu(torum) 1 . non existi(mo) (Dig.26.7.54).

Accursius used Azo's gloss but restricted Bassianus' argument only to secular offices: ad Dig.1.14.3, $\mathbb{}$ Designatus (Parisiis 1566, vol. 1, col. 130): 'Sacerdotium tamen, id est episcopatus datur inuito tantum: vt d. l. de episco(pis) et cle(ricis) 1. si quenquam (Cod.1.3.30).' Whether Bassianus actually meant what Accursius ascribed to him is less clear. Justinian's Novel 123 dealt, among other things, also with the ordination of the bishops. It stated that if a bishop, either before or after 
took it directly from him or from the writing of his students. ${ }^{37}$ It is interesting to note that both Azo and Ugolino explained this solution with reference to the same passage of Augustine found in the Decretum, stating that one should seek to become bishop to help others, not to help oneself. The reason for seeking office publicly, therefore, was ultimately to further the common good. Nonetheless somewhat surprisingly - neither Azo nor Ugolino stated as much expressly. The argument might have come from Bassianus himself: while Ugolino reported it in his comment on the lex Barbarius, Azo mentioned it only in his Summa on the Code. ${ }^{38}$ Also, when Odofredus reported the same argument, probably a few years after the Accursian Gloss, he also ascribed it to Bassianus. ${ }^{39}$

his consacration, wanted to give his goods to the Church, that should not be considered a sale but rather an offering ('non est emptio sed oblatio', Nov.123.3). Glossing on the word 'oblatio', Accursius noted that Bassianus held as lawful a donation made publicly with the intent of securing a bishopric. Ad Coll.9.15.3(= Nov.123.3), \oblatio (Parisiis 1566, vol. 5, col.511): 'quod si ita dixit palam, offero vt eligar in episcopum: licitum est ei, secundum Io(hannem Bassianum) vt ff. de polli(citationibus) 1. i. $\$$ non semper (Dig.50.12.1.1), et ff. de offic(io) praeto(rum) 1. Barbarius (Dig.1.14.3). Accursius.' Although not particularly elaborate, these references would seem to echo the in-depth discussions among coeval decretists on the validity of gifts made on the occasion of entry into religious life. See e. g. the classic study of Lynch (1976), pp. 112-122.

37 On Azo see supra, this paragraph, note 30. On Ugolino see BL, Royal 11.C.III, fol. $9 v b$, \$ petiit: 'ergo puniendus est leg. i. ambitus vt i(nfra) ad l. I. ambitus l. i. (Dig.48.14.1) dico licet male fecit quod petiit et male pretura habet pretor nichil omninus est et quod facit ratum habendum est. Uel dic petiit non priuatim sed publice uidens publice expedire vtilitatem ar(gumentum) $\mathrm{i}(\mathrm{nfra})$ de pollicitationibus 1. i. $\mathbb{~ i . ~ ( D i g . 5 0 . 1 2 . 1 . 1 ) ~ e t ~ f f . ~ d e ~ m i n o r i b u s ~ ( D i g . 4 . 4 ) ~ . . . ~ h ( u g o l i n u s ) . ' ~ T h e ~}$ rest of his gloss is reported in the next note.

38 Ugolino, BL, Royal 11.C.III, fol. $9 v b$, $\$$ petiit: '... et habetur ex sententia $\$$ qui pro bono ad episcopatum appetere bonum est non vt possit (sic) sed vt prosit vt augustinus (cf. C.8, q.1, c.11) h(ugolinus).' On Azo see his Summa ad Cod.9.26, Vt superiori (Azonis svmma avrea, cit., fol. 232ra, n. 1-2): 'Hoc tamen intelligo, si clanculo pecuniam alicui priuato det, vnde videtur ideo aspirare, vt pecuniam communem surripiat. Secus in publico concilio, vel concione, offerat vel promittat ciuitati uel municipio, quod velit prodesse ciuitati, non praeesse

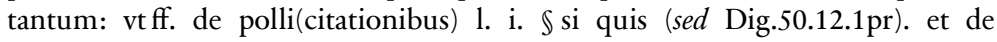
admi(nistratione) tu(torum) <l.> non existimo (Dig.26.7.54). Sic et Barbarius Philipus petijt praeturam et pretor designatus est: vt ff. de offic(io) pre(torum) 1 . barbarius (Dig.1.14.3). Sed Apostolus Paulus i. ad Timoth(eum) iii (1 Timothy 3:5) et transumptive v. Augusti(num) viii. q. 1. c. qui episcopatum (C.8, c.1, c.11) desiderat bonum opus desiderat.' Whether the mention of St Paul's letter is genuine is not clear. It is present in the Venetian edition of 1581 (Summa Azonis ... Venetiis, Sub Signo Angeli Raphaelis, 1581; anastatic reprint, Frankfurt am Main: Vico Verlag, 2008, col.906, n. 2), but other editions omit it. So for instance the 1489 Venetian edition reads: 'Sed et beatus Augustinus dicit qui episcopatum desiderat bonum opus desiderat' (Summa Codicis per Dominum Azonem [Venetiis, 1489]). Elsewhere, however, Azo seems to have some doubts as 
The third solution was the simplest one, and the one chosen by Accursius (and, before him, by Azo and others, such as Lanfrancus of Cremona, d.1229): ${ }^{40}$ it was the same lex Iulia de ambitu that carved out an exception for Roman magistrates, since they were no longer elected by the people but appointed by the emperor. ${ }^{41}$ Although the lex Barbarius seemed to imply that it was for the people to elect Barbarius, it also mentioned the prince - so the exception could safely be invoked. ${ }^{42}$

The second obstacle to Barbarius' praetorship was the remark of Pomponius, 'praetura eum functum'. Taken literally and isolated from its context, Pomponius' statement declared simply that Barbarius exercised the office of praetor, not that he was praetor - a point that later jurists would not miss. Accursius realised how this solution, which would deny the validity of Barbarius' praetorship, could receive support from the text of Dig.50.2.10, the so-called lex Herennius. That was a well known lex, and Accursius had to discuss it so as to provide an interpretation that would serve his purpose.

For the medieval jurists, the lex Herennius was the legal equivalent of the saying 'the cowl does not make the monk'. It stated that the simple enlistment as decurion did not make one such. ${ }^{43}$ The association between falsus decurio and

to the scope of this rule in ecclesiastical appointments. Azo, Summa ad Cod.9.26, Vt superiori (Azonis svmma avrea, cit., fol. 232ra, n. 2): 'Si autem clanculo porigat preces et exaudiatur, incidet in hanc legem. Aliud si forte alius supplicauerit pro eo inscio: licet secus dicatur in simonia.'

39 Infra, next chapter, note 24.

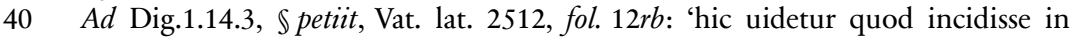
penam leg(is) iulie de ambitu vt i(nfra) ad l. iuliam de ambitu l. i (Dig.48.14.1), sed non incidit quia hic palam petiit, uel quia bene meruerit populus concessit sibi ... sed iste petiit in urbe et ideo non tenetur secundum $\mathrm{La}$ (nfrancum).' On Azo see supra, this chapter, note 30.

41 Dig.48.14.1 (Mod. 2 de poen.): 'Haec lex in urbe hodie cessat: quia ad curam principis magistratuum creatio pertinet, non ad populi favorem.'

42 Gloss ad Dig.1.14.3, $\$$ Designatus (Parisiis 1566, vol. 1, col. 130): 'Tu dic melius, quod hoc [scil., Barbarius' praetorship] fuit Romae, vbi non habet locum lex Iulia de ambitu: vt infra ad legem Iuliam de ambitu 1. i (Dig.48.14.1). Accursius.' On the sedes materiae itself, the Gloss further stated that the prohibition of the lex Iulia de ambitu would probably not apply when it was a third person to pay for the election, so long as the elected was unaware of that. Gloss ad Dig.48.14.1, $\$$ contra hanc legem (Parisiis 1566, vol. 3, col. 1518): 'scilicet per pecuniam: vt C. eo(dem) 1. fi. (Cod.9.26.1) et si hoc sit clam: secus si palam: vt ... de offi(cio) praeto(rum) 1. Barbarius (Dig.1.14.3) ... Sed quid si preces tantum? Videtur item, si clam ... Item quid si alius eo ignorante pecuniam dedit? forte non incidit iste in legem: licet decretistae dicant secus.' Cf. Azo's gloss, supra, this chapter, note 30 .

43 Dig.50.2.10 (Mod. 1 resp.): 'Herennius Modestinus respondit sola albi proscriptione minime decurionem factum, qui secundum legem decurio creatus non sit.' 
falsus praetor was rather obvious. But the Gloss brought the two cases even closer together. When commenting on the lex Herennius, the Gloss suggested that the person enlisted as a decurion might have perhaps been a minor or someone legally unfit (inhabilis) to serve in that capacity. ${ }^{44}$ This way the reason why the decurio was falsus became the same as that of the falsus praetor Barbarius: underlying legal incapacity. It was thus even easier to apply the rationale of the lex Herennius to the lex Barbarius: the simple discharge of the duties of an official (whether military or civil) does not make one such de iure. Given the remarkable similarity between the two cases, the Gloss had to find a plausible reason to tell them apart. This is probably why it is with regard to the lex Herennius that the all-important subject of the common mistake is mentioned for the first time in the Gloss on the lex Barbarius.

The difference with the falsus decurio, says the Gloss, is that the falsus praetor is widely believed to be truly praetor. And this common mistake makes law. ${ }^{45} \mathrm{It}$ is important to observe that Accursius invokes (without explaining) the maxim communis error ius facit, not with regard to the validity of Barbarius' deeds, but of his praetorship: the deeds become valid because (and inasmuch as) the authority of Barbarius acquires legitimacy. In stating as much, the Gloss might have sought to prevent the analogical application of the lex Herennius, even though this lex denied the validity of the appointment, not of the deeds. Whatever the reason, the clear position of the Gloss made the validity of the deeds even more dependent on the validity of the appointment. We will come back to this point.

The Gloss added also the case where one received the decurion's pay: ad Dig.50.2.10, $\$$ Albi (Parisiis 1566, vol. 3, col. 1734).

44 Gloss ad Dig.50.2.10, $\$$ Non sit (Parisiis 1566, vol. 3, col. 1734).

45 Gloss ad Dig.1.14.3, \$ functus sit (Parisiis 1566, vol. 1, col. 130): 'huic quaestioni primae secundum quosdam non respondet: sed dicunt quod non fuit praetor, et pro eis est i (nfra) de decur(ionibus) 1. Herennius (Dig.50.2.10). Tu dicas huic quaestioni responderi ibi supra, sed nihil ei etc. et sic fuit praetor ... Nec obst(at) $\mathrm{d}$ (icta) $\mathrm{l}(\mathrm{ex}) \mathrm{Here}<\mathrm{n}>$ nius, quia ibi solum salarium non facit. Hic autem est plus, scilicet communis error, qui facit ius.' In the printed editions this gloss is often anonymous, but most manuscript sources ascribe it to Accursius, e. g. Pal. lat. 731, fol. 17ra; Pal. lat. 732, fol. 4ra; Pal. lat. 735, fol. 15ra; Pal. lat. 738, fol. 13va; Pal. lat. 740, fol. 14ra; Cologny, Bodmer 100, fol. 11rb; BSB, Clm 14022, fol. 15va; Bologna, CS 285, fol. 15va; Firenze, BML, Edili 65, fols. 10vb-11ra; Firenze, BML, AeD 158.1, fol. 14rb; Basel, UB, C.I.4, fol. 14rb; Douai 575, fol. 11va; BAV, SMM 124, fol. 13rb; BL, Harley 3700, fol. 9vb; Balliol 297, fol. 9ra; BL, Add. 14858, fol. $15 \mathrm{ra}$. It is possible that the reference to the lex Herennius came from Azo: see

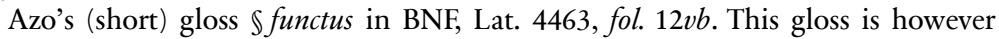
scarcely attested in other manuscripts reporting Azo's thought. 


\subsection{Putative freedom and the validity of the acts}

Another lex invoked against Barbarius' praetorship was Cod.4.55.4, the lex Moveor. ${ }^{\mathbf{4 6}}$ This was a rescript of Alexander Severus. A Roman citizen was sold by his own slaves with the provison that he ought not to reside in his country, and was then manumitted by his purchaser. In his rescript the emperor said that, if the allegation were true, the slaves would be put to death. But until the case was decided, the petitioner would keep his current status - that of a freedman. ${ }^{\mathbf{4 7}}$ The last statement was of particular importance for medieval jurists, for it established the principle that, until proven otherwise, one's current personal status was also one's legal one. ${ }^{\mathbf{4 8}}$ In its comment on the lex Moveor, however, the Accursian Gloss carved out an important exception to this principle: if a slave poses as a freeman, until his servile status is legally ascertained he will be considered as free. The reason for that exception was quite straightforward: a slave cannot litigate in court. In order to have locus standi, therefore, he needs to be considered free. ${ }^{49}$

Ad Dig.1.14.3, $\$$ functus sit (Parisiis 1566, vol. 1, col. 130): ' ... item quia debet dici quod talis fuerit medio tempore, qualis postea deprehenditur: et sic seruus: vt $\mathrm{C}$. si ser(vus) export(andus) 1. moueor in fi(ne) (Cod.4.55.4). Tu dicas huis quaestioni responderi ibi supra, sed nihil ei etc. et sic fuit praetor. Nam cum incertum est aliquid, perinde est ac si nec illud fit: vt C. de testa(mentis) 1. i. (C.6.23.1) et institu. de testa(mentis) $\$ sed cum aliquis (Inst.2.10.7) ... Item non ob(stante) lex illa, moueor (Cod.4.55.4), quia hic medio tempore fuit liber, vt in fine huius legis dicam.' This gloss likely built on Azo's gloss $\$$ quamdiu: 'cum incertum est an qui sit, perinde est ac si nec illud vt C. de testa(mentis) l. i. (C.6.23.1) argum(entum) contrarium C. si seruus expor(tandus) ven(eat) 1. moueor (Cod.4.55.4). Az(o)', Stockholm, KB, B.680, fol. 11va; Vat. lat. 1408, fol. 12va; BNF, Lat. 4463, fol. 12vb; Avranches 156, fol. 229rb; BNF, Lat. 4459, fol. 9va; Bamberg, Msc. Jur. 11, fol. 13vb. Vat. lat. 2512, fol. 12rb, reports the same gloss twice: once in full, the other in abbreviated form, both signed 'az'.

47 Cod.4.55.4pr-2 (Alex. A. Aureliopapiae): 'Moveor, quod te a servis tuis dominum eorum venisse adfirmas sub ea lege, ne in patria moreris, et ab eo, cui te prior emptor vendiderat, manumissum esse dicis. Quare competens iudex adversus eum, quem praesentem esse dicis, cognitionem suam praebebit et, si veritas accusationi aderit, exsecrabile delictum in exemplum capitali poena vindicabit. Sed quoad usque probaveris quae intendis, status tuus esse videtur, qui in te post manumissionem deprehenditur.'

48 Gloss ad Cod.4.55.4, \$Deprehenditur (Parisiis 1566, vol. 4, col. 872): 'scilicet libertinitatis. Et sic not(andum) quod statu te inuenero, eo te tenebo, donec contrarium videbo: vt hic, et $\mathrm{i}$ (nfra) de inge(nuis) ma(numissis) 1 . penul(tima) (Cod.7.14.13) et ff. de offic(io) praetor(um) 1. Barbarius (Dig.1.14.3).' Cf. also ibid., $\mathbb{\$}$ Moueor.

49 Gloss ad Cod.4.55.4, $\$$ Deprehenditur (Parisiis 1566, vol. 4, col. 872): 'Sed in causa libertatis et seruitutis, et etiam dum agitur vtrum seruus sit in possessione seruitutis, necne: habetur pro libero interim, et sic alio statu quam prius erat: 
This exception to the lex Moveor was strengthened by the curious reading of another text, Dig.40.9.19. This was a short text stating the obvious: the manumission effected by someone who is later legally pronounced to be a slave is void. ${ }^{50}$ The verb 'to pronounce' (pronuntiare), however, was ambiguous: it could refer to either a constitutive or a declarative pronouncement. In the first case, the manumissor would become slave only after having set someone else free; in the other he was already a slave, but his servitude would be ascertained only after the manumission. The Gloss reports both interpretations. Johannes Bassianus, says the Gloss, was for the constitutive nature of the pronouncement: for him the lex was a rather obvious application of general principles. Others, continues the Gloss, would on the contrary opt for the declarative nature of the sentence: for them, much on the contrary, the manumissor was already a slave when he freed another slave. ${ }^{51}$ Who are such 'others'? The Gloss does not say. It

vt ff. de libe(rali) ca(usa) 1. ordinata (Cod.7.16.14), et est ratio: quia ibi alias non posset esse in iudicio: hic vero potest, quia liber.' Cf. Gloss ad Cod.5.34.1. The text (a rescript of Alexander Severus) discussed the possibility of appointing a guardian to stand in court on behalf of a minor whose freedom was challenged. The Gloss justified the positive solution on the basis of the same rationale as the exception to the lex moveor: in disputes on one's personal status, the defendant is to be considered free until proven otherwise. Gloss ad Cod.5.34.1 $\ C v m$ tibi and \Quia interim (Parisiis 1566, vol. 4, cols. 1081 and 1082 respectively). The Accursian Gloss was probably building on Azo, although on that lex Azo highlighted the combined strength of possessio libertatis and common mistake, whereas Accursius expunged any reference to the common mistake and focused exclusively on putative freedom. Cf. Azo, ad Cod.5.34.1, Quo magis (Azonis, Ad singulas leges XII librorum codicis iustinianei, commentarius ... Parisiis, Apud Sebastianum Nivellium, 1577; anastatic reprint, Augustae Taurinorum: ex officina Erasmiana, 1966, p. 418, n. 1): '... erat enim in possessione libertatis, quare valet datus curator interim cum credebetur liber, sic et in Barbariu Philippo: vt ff. de offic(io) praesid(is) (sic) $<$ l. $>$ Barbarius, et in testibus adhibitis, vt in tit(ulo) i de testamen(tis) <l. $>$ testes (Cod.6.23.1).' Mention should also be made of the Gloss ad Dig.40.12.7.5. The Roman text (Ulp. 54 ed.) stated that if, at the time of the legal proceedings, the person whose liberty was disputed was 'in libertate sine dolo malo', then the burden to prove that he was indeed a slave would fall on the party asserting ownership on him; otherwise it would be up to the alleged slave to prove his free status. The problem of the Gloss was that, if that person was a slave at the time of the proceedings, he could not possibly fill the role of the plaintiff. So the Gloss interpreted the text as describing a case of putative freedom: the slave 'in libertate' was in fact just 'in possessione libertatis'

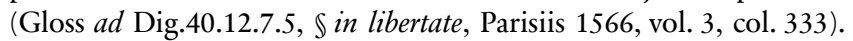

50 Dig.40.9.19 (Mod. 1 reg.): 'Nulla competit libertas data ab eo, qui postea servus ipse pronuntiatus est.'

51 Gloss ad Dig.40.9.19, \$postea seruus (Parisiis 1566, vol. 3, col. 323): 'factus ex aliqua noua causa: non aliter, secundum Ioan(nem Bassianum) ... quidam in seruo manumittente hanc intelligunt: vt licet ipse seruus pronuntietur, non 
is however possible that, among them, Accursius might have enlisted even Azo. While Azo's interpretation of this lex might have well been the same as that of his old teacher Bassianus, Azo did not say so openly. Taken at its face value, the way Azo referred to the lex Moveor in his comment on the lex Barbarius would rather point to the opposite conclusion: while discharging the duties of the praetor, Barbarius was in the same situation as the manumissor in Dig.40.9.19. ${ }^{52}$

Strengthened by this second reading of Dig.40.9.19 (declarative pronouncement, and so manumission effected by a slave), the Gloss used the exception to the lex Moveor (when the slave poses as a freeman) to invert the application of the same lex Moveor to Barbarius' case. As long as the servile status of Barbarius was not judicially ascertained, he ought to be considered as a freeman. ${ }^{53}$ In stating as much, however, the Gloss did not seek to fully equate putative and actual freedom. The accent was not on the legal status of the slave believed to be free, but on the validity of the acts carried out while in putative freedom. The purpose was to show how putative freedom might produce legally valid effects, especially when it was the result of a common (almost universal) mistake.

To that end, an excellent case was found in a rescript of Hadrian, reported both in the Institutes (Inst.2.10.7) and in the Code (Cod.6.23.1), on a slave who witnessed a will while believed to be free. Since the opinion as to his free status was widely shared, the emperor granted validity to the testament. Of the two sources, the Institutes were more detailed: the emperor declared the will to be valid 'out of his generosity' (ex sua liberalitate), whereas the Code shortened the

noceat manumissio, nisi et ipsi fiat quaestio.' In the same sense as Bassianus, Franciscus Accursius gave a practical example that would be incorporated in the Gloss: if I manumit my slave but then I become myself a slave (for instance, because I sell myself), this does not prejudice the manumission I already made. Ad Dig.40.9.19, $\$$ Nvlla (Parisiis 1566, vol. 3, col. 323): 'Manumisi seruum meum: postea ego efficior seruus alicuius, vt quia passus sum me vendi: non impeditur per hoc libertas a me data. Fran(ciscus Accursius).' Interestingly, however, the editors of the 1566 Parisian edition noted how this example was in contradition with the lex (or rather, the other interpretation of it): 'hic casus nunc non congruit huic legi modo correctae' (ibid.).

52 Azo, ad Dig.1.14.3, \$ heorum: 'nam et libertas ab eo data qui postea seruus pronuntiatus est competit vt $\mathrm{i}$ (nfra) qui et a quibus ma(numissi) $<\mathrm{l}$. $>$ competit. (dig.40.9.19). Simile est quod legitur i(nfra) de testi(bus) l. ad testimonium $\$$ i. (Dig.22.5.20). Az(o).' BNF, Lat. 4459, fol. 9va; Stockholm, KB, B.680, fol. 11va; Vat. lat. 1408, fol. 12va; Vat. lat. 2512, fol. 12rb; Gent, Hs. 23, fol. 17ra; Avranches 156, fol. $229 \mathrm{rb}$ (the text in all these manuscripts is perfectly identical). Azo's words (apart from the reference to Dig.22.5.20) were then incorporated in Accursius' Gloss on the lex Barbarius, $\mathbb{S}$ Reprobari (infra, this chapter, note 68).

53 Gloss ad Dig.1.14.3, \$functus sit (Parisiis 1566, vol. 1, col. 130): 'Item non ob(stante) lex illa, moueor (Cod.4.55.4), quia hic medio tempore fuit liber.' 
passage and relied exclusively on the common mistake. ${ }^{54}$ It is important to highlight this difference: while in both sources the rationale for the validity of the will lies in the common mistake, only in the Institutes does its legal basis remain the command of the emperor.

The validity of the will seems to have posed some problems to earlier glossators, especially those less prone to carving out exceptions to the law in the name of fairness. If we are to believe Azo, the text left Bulgarus particularly perplexed. Clearly a slave cannot witness a document. Surely, Bulgarus seems to have said, if he who was a slave also appeared as such, the will ought to be void even if he was subsequently manumitted. In all probability, he seemingly concluded, the Institutes opted for the opposite solution because witnesses are required for testaments but not for the validity of contracts at large. ${ }^{55}$ Some years after Bulgarus, Placentinus was less reluctant to accept the validity of the will, since it depended on the will of the prince to maintain the validity of testaments. ${ }^{56}$ Azo followed suit, but explained the version of the testament's case found in the Code on common mistake alone, without reference to the

54 Inst.2.10.7: 'Sed cum aliquis ex testibus testamenti quidem faciendi tempore liber existimabatur, postea vero servus apparuit, tam divus Hadrianus Catonio Vero quam postea divi Severus et Antoninus rescripserunt, subvenire se ex sua liberalitate testamento, ut sic habeatur atque si ut oportet factum esset, cum eo tempore quo testamentum signaretur omnium consensu hic testis liberorum loco fuerit, nec quisquam esset qui ei status quaestionem moveat.' $\mathrm{Cp}$. Cod.6.23.1: (Hadr. A. Catonio Vero) 'Testes servi an liberi fuerunt, non oportet in hac causa tractari, cum eo tempore, quo testamentum signabatur, omnium consensu liberorum loco habiti sunt nec quisquam eis usque adhuc status controversiam moverit.'

55 Azo, ad Inst.2.10.7 (Caprioli et al. eds. [2004], p. 210, n. 579): 'Quid si tempore testamenti faciendi seruus erat, uel pupillus et pro seruo habitus; et postea is liber est: an tenet testamentum? Bulgarus dicit: non. In testamento enim sunt necessarii testes ut ualeat; set quia ualeret contractus et sine testibus, in eis admittit eos, ut $\mathrm{D}$. de uerborum significatione, $<1 .>$ notione $<\mathrm{m}>\mathbb{S}$ instrumentorum (Dig.50.16.99.2-3). Az(o).' The reference to this last text was due to the fact that it mentioned the possibility of asking for an adjournment (dilatio) to let the person who carried out something appear in court, even if that person was a slave ('puta qui actum gessit, licet in servitute').

56 Placentinus, Summa Institutionum, ad Inst.2.10.7 (Placentini Ivrisconsulti vetvstissimi, in svmmam institutionvm ... libri IIII, Moguntiae [15]35; anastatic reprint, Augustae Taurinorum: ex officina Erasmiana, 1973, p. 79): 'Item notandum est quod conditionem testium inspiciemus, non eo tempore, quo testator moritur, sed quo testamentum signatur ... conditionem quoque, id est seruitutem uel libertatem siue ueram, siue putatiuam. Nam et uere seruus communi opinione liber creditus testamenti testis erit, ex principium liberalitate et testamentorum fauore.' 
emperor's liberality (as in the Institutes). ${ }^{57}$ Accursius' Gloss did the same. Accursius however omitted the reference to the liberality not only in the Code ${ }^{58}$ but also, moreover, in the Institutes. This way, the common mistake became the sole basis for the validity of the will. And the object of the common mistake was the putative freedom of the slave-witness: underpinned by the common opinion, putative freedom counted more than true status. ${ }^{59}$ This, concluded the Gloss, proved that the common mistake makes law - just as in the lex Barbarius. ${ }^{60}$

When the putative freedom is the product of a common mistake, its effects might reach well beyond simply witnessing a testament. They might even

Azo, lectura ad C.6.23.1, Testes Servi an Liberi (Azonis, Ad singulas leges XII librorum codicis iustinianei, commentarius, cit., p. 480): 'Licet inhibeatur testamentum servis et mulieribus, et hoc circa confectionem testamenti, vt inst(itutiones) $\$$ testes (Inst.2.10.6). Hic tamen non propter hoc quod adhibitus fuit servus, vitiatur testamentum, si tamen credebatur liber, ut hic dicit: multum enim facit communis opinio, ut hic: et ita facit ad illud generale, opinionem spectandam, et alias ff. ad Macedon(ianum) 1. 3 in princ(ipio) (Dig.14.6.3pr) et ff. de offic(io) praet(orum) <l.> Barbarius (Dig.1.14.3).' Without the element of common opinion, the solution would be the opposite: 'Sed tamen non credo quod testificari possit pro testamento, quia liberi tantum testantur, ut sub de testib(us) $<$ l. $>$ quoniam liberi (Cod.4.20.11)', ibid.

58 Gloss ad Cod.6.23.1, $\$$ Omnium (Parisiis 1566, vol. 4, col. 1263): 'error ergo communis aliquid facit: vt. ff. de officio praesi(dis) (sic) l. Barbarius (Dig.1.14.3) et infra de Lati(na) lib(ertate) tol(lenda) l. i $₫$ sed et qui domini (Cod.7.6.1.5) et ff. ad Macedon(ianum) 1. iii (Dig.14.6.3) et infra de senten(tiis) et interlocutio(nibus) om(nium) iudi(cium) 1. si arbiter (Cod.7.45.2).'

59 Gloss ad Inst.2.10.7 \$liber (Parisiis 1566, vol. 5, col. 186): 'libertate scilicet putatiua. Et sic plus valet quod est in opinione, quam quod est in veritate, sic ff. de su(pellectile) leg(ata) 1. iii in fi(ne).' Cf. Gloss ad Cod.6.23.1, $\mathbb{\$}$ Signabatur (Parisiis 1566, vol. 4, col. 1263): 'quo tempore consideratur conditio vera vel putatiua vt valeat testamentum: vt hic, et ff. eo [titulo] 1 . ad testium $\$$ conditio (Dig.28.1.22.1).' An indirect confirmation of the relevance of the testament case to the lex Barbarius may be found in the Gloss on Dig.28.1.22.1. According to this text, the status of the testament's witnesses must be assessed at the time as the will, not on the testator's death. The Gloss recalled the lex Barbarius to affirm the validity of a testament witnessed by a freeman who would become a slave before the opening of the testament. Gloss ad Dig.28.1.22.1, $\mathbb{S}$ contingerit (Parisiis 1566, vol. 2, col. 376): 'Item liber testificans, et ante aperturam tab(ularum) factus seruus, valet: vt ... de offi(cio) praet(orum) 1. Barbarius' (Dig.1.14.3).

60 Gloss ad Inst.2.10.7 \$omnium consensum (Parisiis 1566, vol. 5, col. 187): 'nota errorem prodesse: vt ff. de supel(lectili) leg(ata) l. iii in fi(ne) (Dig.33.10.3.5) et C. de La(tina) li(bertate) tol(lenda) $\$$ sed et si quis (Cod.7.6.1.5), et ff. de offi(cio) praet(orum) 1. Barbarius (Dig.1.14.3). Et error communis facit ius, vt patet in his versibus: Error communis ius efficit, vt manifestat testificans seruus, qui liber creditur esse.' Cf. ibid, col. 186, $\mathbb{S}$ Sed cum aliquis (ascribed to Franciscus Accursius). Cf. supra, this chapter, note 49. 
support the validity of a decision rendered by a slave. Such is the case with Cod.7.45.2 (the lex Si arbiter). The text (a rescript of Antoninus) spoke of an arbiter who fell into servitude after having rendered his verdict, and argued for the verdict's validity. Medieval jurists spared no effort to find contemporary equivalents to each part of the Roman formulary procedure. So the arbiter became a delegate judge. ${ }^{61}$ This made the case of Cod.7.45.2 even more problematic: the slave was not acting merely as arbiter, but as judge (even though only a delegate one). The wording of the text of the lex Si arbiter was somewhat ambiguous: the arbiter gave his verdict while dwelling in freedom (in libertate morabatur), and was subsequently brought to servitude (in servitutem depulsus). ${ }^{62}$ The problem of 'depulsus' was similar to that of 'pronuntiare' in Dig.40.9.19: it could refer either to the change of legal status or to the ascertaining of the true one. Also this time the Gloss offered both interpretations, ${ }^{63}$ but it clearly sided with the second one. The decision of the slave-arbiter (that is, of the slave-judge), rendered while he was in putative freedom, would remain valid even after his true status is ascertained. ${ }^{64}$ This way, the meaning of Cod.7.45.2 becomes remarkably stronger than that of the testament's case: the words 'in libertate morabatur' would allow moving from the mistaken common opinion about the freedom to the actual possession of such freedom. Clearly, the slave did not enjoy his freedom de iure, only de facto. But the common belief in his freedom allowed it to be qualified as a good faith possession, and so made it legally relevant. While this conclusion was not present in the text itself, it was underpinned by what earlier eminent jurists had already said. In his comment on Cod.7.45.2, Placentinus observed that the sentence pronounced while the

Gloss ad Cod.7.45.2 (Parisiis 1566, vol. 4, col. 1654), $\mathbb{\$}$ Si arbiter: 'id est iudex delegatus.'

62 Cod.7.45.2 (Ant. A. Sextilio): 'Si arbiter datus a magistratibus, cum sententiam dixit, in libertate morabatur, quamvis postea in servitutem depulsus sit, sententia ab eo dicta habet rei iudicatae auctoritatem.'

63 Gloss ad Cod.7.45.2 (Parisiis 1566, vol. 4, col. 1654), $\$$ Depulsus: 'id est inuentus seruus, et a domino vindicatus: vt ff. de officio praeto(rum) 1. Barbarius (Dig.1.14.3) et supra de testa(mentis) 1. i (C.6.23.1). Vel dic, de nouo factus est seruus ex ingratitudine, vel venditus ad precium participandum: vt ff. qui et a quibus l. competit (Dig.40.9.19). Accursius.' This time the Gloss shows a clear preference for the opposite solution with regard to Dig.40.9.19 (the example in the Gloss strongly resonates of that of Franciscus Accursius: supra, this chapter, note 51). But this interpretation did not have repercussions on the lex Barbarius (more specifically, on the reading of the lex Moveor as applied to the lex Barbarius).

64 Gloss ad Cod.7.45.2 (Parisiis 1566, vol. 4, col. 1654), Casus ad \$ Si arbiter: 'Iudex delegatus, qui liber credebatur de causa quadam cognouit, et pronunciauit: postea apparuit quod erat seruus: an retractanda sit sententia, quaeritur? Dicitur quod non.' 
slave was in possession of his freedom, a possession not vitiated by dolus, would stand even after his true status was ascertained. ${ }^{65}$ Azo used the same passage of the Code to state the matter in more general terms. Slaves are forbidden from serving as judges, just like women and infames. ${ }^{6 \mathbf{6}}$ So any sentence they pronounce is void. But when a slave is commonly believed to be free, so that he is in possession of freedom, then his decision would stand all the same. ${ }^{67}$

It is in the light of both cases above (the slave-witness and the slave-arbiter) that we should read an important gloss of Accursius on the lex Barbarius, the gloss reprobari. Commenting on Ulpian's words 'none of these deeds should be

Placentinus, Summa ad Cod.7.45 (Placentini Summa Codicis ..., Moguntiae, 1536, anastatic reprint, Torino, Bottega d'Erasmo, 1962, p. 347): 'Sententia quoque serui nulla est: nisi cum sententiam daret in libertatis possessione sine dolo maneret: tunc enim etiam sententia ab eo data, et libertas ab eodem praestita perseuerabit, ff. de offic(io) praeto(rum) 1. Barbarius (Dig.1.14.3). C. eod(em titulo) 1. ii. (Cod.7.45.2).' A similar observation may also be found in Placentinus' contemporary Pillius de Medicina (c.1167-c.1213), but the differences in the text are revealing. On the subject Pillus was both more prudent and more precise. More prudent, for he did not speak of a slave with possessio libertatis but only of a slave who behaved as a freeman, and especially because he was more hesitant in proclaiming the validity of his decision ('forte'). More precise, for he stated that the decision could be valid if the putative freedom of this slave was not based on dolus malus - not generically on dolus. The point is relevant, for this is not a case where the personal status was really uncertain. The slave was perfectly aware that he was not free. Speaking generically of the absence of dolus, therefore, was not sufficient. Pillius, Libri de Ordine Iudiciorum, lib. 3, ch. 15 (De allegationibus) (Bergmann ed [1965], p. 78, 11.24-26): 'Item [sententia] nec a servo ferenda est, ut Dig. de [receptis, qui] $\operatorname{arbitr(ium)~4,~8.~l.~Pedius~7;~nisi~forte,~}$ cum sententiam dicit, gerat se pro libero sine dolo malo. ut Dig. de off. praetor. 1, 14. 1 Barbarius. 3 et Cod. de sent. et interl. 7, 45. 1. 2.'

66 On the prohibition of infames from taking part in legal proceedings (especially as lawyers and judges) see esp. Migliorino (1985), pp. 154-157.

67 The position of Azo may be understood by reading together both his Summa and his Lectura on Cod.7.45. In the Summa, the slave would sit in judgment propter ignorantiam; in the Lectura, the same slave was in possessione libertatis. It would therefore seem that Azo qualified the slave's possession of his freedom in the same terms as Placentinus. Azo, ad Cod.7.45, $\$$ Qualiter (Azonis svmma avrea, cit., fol. 195va, n. 1): 'Sciendum est igitur sententiam esse nullam ... ratione iudicis: puta si is, qui sententiam tulit, iudex esse non poterat: vt quia seruus erat, vel mulier, vel infamis: vt ff. de iudic(is) cum praetor $\$$ non autem (Dig.5.1.12) ... Seruus tamen quandoque iudicat propter ignorantiam: vt infra eodem (titulo), 1. si arbiter (Cod.7.45.2), et ff. de offic(io) praeto(rum) <l.> Barbarius (Dig.1.14.3).' Cf. also Azo, ad Cod.7.45.2, $\mathbb{S} S$ i arbiter (Azonis, ad singulas leges XII librorum codicis iustinianei, commentarius, cit., p. 586): 'Quia sit seruus: vel quia prius moratus est in possessione libertatis: ut ff. de off(icio) praetor(um) $<\mathrm{l}$. $>$ Barbarius Philippus (Dig.1.14.3) et sub de testa(mentis) l. i (Cod.6.23.1).' Cf. also Azo's comment on Cod.6.23.1, supra, this chapter, note 57. 
set aside [reprobari]', Accursius wrote: 'note that what has been carried out well should not be reconsidered in the light of another event' ${ }^{68}$ Accursius' words gave a very different twist to Ulpian's statement, for they presupposed the original validity of Barbarius' deeds. The question was no longer to pronounce on their initial status (void or valid), but to decide whether to change their status from valid to void. When Ulpian spoke against 'setting aside' Barbarius' deeds, of course he did not mean to imply their initial validity. Accursius, however, did. Assuming the initial validity of the deeds lent considerable strength to their position, as it dispensed with Ulpian's effort to qualify as valid something that should be void. Accursius' reasoning introduced a second temporal layer in Barbarius' case, and he could do this on the basis of Barbarius' putative freedom. So long as he was in possession of his freedom (we might say, at time zero), there is no issue as to the validity of the deeds. The problem arises only at time one, when Barbarius lost possession of his freedom. Looking at the issue from this perspective, the problem becomes similar to that of the slave-witness (Inst.2.10.7 and Cod.6.23.1), the slave-arbiter (Cod.7.45.2), and possibly also the slavemanumissor (Dig.40.9.19).

Assuming the initial validity of the deeds, it was easy to find some footholds in the sources to argue against their subsequent invalidation. Accursius listed down some cases from both Code and Digest pointing in this direction. ${ }^{69}$ They all came from Azo's gloss on the lex Barbarius, ${ }^{70}$ with a single exception - the only reference to a case that called for the acts to be declared invalid.

This case (Dig.3.5.30.6) was on the validity of the transactions carried out by a widow on behalf of her son (a minor) according to the will of his deceased father. Although she does so out of pietas, says the text, her deeds are not valid. ${ }^{71}$ Unlike

Gloss ad Dig.1.14.3, $\$ Reprobari (Parisiis, 1566, vol. 1, col. 131): 'Item nota quod bene gestum est, non debet ex alio euentu resuscitari.' Both in the Parisian edition of 1566 and in most others, the gloss Reprobari is typically anonymous. Manuscript sources would however attest to Accursius' authorship: e. g. Pal. lat. 735, fol. 15ra; Pal. lat. 738, fol. 13va; Pal. lat. 739, fol. 13va; Pal. lat. 740, fol. 14ra; Firenze, BML, Edili 65, fol. 11ra; Kórnik, BK 824, fol.12va; Bern, Cod. 6, fol. 15va; Firenze, BML, Plut. 6 sin. 3, fol. 10vb; BAV, SMM 124, fol. 13rb; BL, Harley 3700, fol. 10ra; BL, Add. 14858, fol. 15ra; Balliol 297, fol. $9 \mathrm{ra}$.

69 Accursius' gloss Reprobari referred to the following texts: Cod.5.37.28pr; Dig.3.5.30.6; Dig.27.9.14; Dig.42.5.6.1; Dig.43.19.1.12; Dig.43.19.2. All references seem to be of Accursius and not later additions, as they are constantly present in the manuscripts listed supra, last note.

70 E.g. BNF, Lat. 4459, fol. $9 v a, \mathbb{\$}$ reprobari. Azo seems to have simply mentioned the texts without commenting on them.

71 Dig.3.5.30.6 (Papin. 2 resp.): 'Quamquam mater filii negotia secundum patris voluntatem pietatis fiducia gerat, tamen ius actoris periculo suo litium causa constituendi non habebit, quia nec ipsa filii nomine recte agit aut res bonorum eius alienat vel debitorem impuberis accipiendo pecuniam liberat.' 
the case of Barbarius and of those listed in its support, where the transactions were carried out 'bene', says Accursius, 'in this case it was not carried out lawfully [legitime]'. ${ }^{72}$ Why did Accursius choose this text to strengthen the validity of Barbarius' deeds carried out while in putative freedom? His acts were not lawful either. But the only argument in favour of the mother was her pietas towards the deceased husband. Commendable as they may be, feelings are not sufficient to produce effects on third parties. The text in Dig.3.5.30.6, therefore, declares void all her acts (both the alienation of property and the discharge of a debtor). By contrast, Barbarius' putative freedom was supported by the common belief as to its truth. This means that - much unlike the case of the widow - any third party would have relied on Barbarius' full capacity to sit on the bench. At the time they were carried out, in other words, Barbarius' deeds were held as lawful. It was only a subsequent event - the discovery of his true status - that put them into question. This way, the case added by Accursius at the end of his gloss reprobari strengthened his interpretation of Ulpian's remark. The problem is not whether the deeds are truly valid ab initio, but whether their apparent validity should be reconsidered when the putative freedom of the person who made them is later disproved. The communis opinio element, in other words, is not invoked to change the status of the deeds (from void to fully valid), but to retain their initial apparent validity (based on putative freedom). Given the rationale of common opinion - the need to protect innocent third parties - this logical twist acquires particular strength. In turn, and finally, Ulpian's rethorical questions in the text of the lex Barbarius ${ }^{73}$ are used to reinforce this interpretation. As the people who came before Barbarius in good faith could not be reproached, says Ulpian, it is 'humanius' to conclude in their favour. Ulpian's humanitas became fairness in the Gloss, thereby allowing for the standard opposition aequitas/ strictum ius. While the solution should be different in terms of strict law, observes the Gloss, 'benevolence [benignitas] is to be preferred to rigour. ${ }^{74}$

72 Gloss ad Dig.1.14.3, \Reprobari (Parisiis 1566, vol. 1, col. 131): 'ibi non fuerat legitime factum'.

73 Supra, this chapter, note 11.

74 Gloss ad Dig.1.14.3, $\mathbb{\$}$ Humanius est (Parisiis 1566, vol. 1, col. 131): 'de iure stricto alius esset. Et sic not(andum) quod benignitas praefertur rigori: vt infra de pact(is) 1. maiorem (Dig.2.14.8) et C. de iudi(ciis) 1. placuit (Cod.3.1.8). Accur(sius).' Accursius' authorship of this gloss seems rather clear, as a large number of manuscript sources report his name (even manuscripts that leave many other glosses anonymous, such as Firenze, BML, Plut. 6 sin. 3, fol. 10vb, and Leipzig, UB, 877, fol. 12ra). The first sentence may also be found in Azo's gloss on the lex Barbarius, $\mathbb{S}$ functus (BNF, Lat. 4459, fol. 9va): 'q(uod) d(icit) de iure stricto non esset. az(o).' Cf. also Stockholm, KB, B.680, fol. 11va, \$populus. Accursius' reference to the two leges Dig.2.14.8 and Cod.3.1.8 helps interpreting 
After all, the putative freedom of the slave-praetor inspired a similarly equitable solution in both the case of the slave-witness (where reference to the emperor's generosity was duly forgotten) and that of the slave-arbiter.

Accursius' emphasis on the possession of freedom was not just meant to introduce a second temporal layer, which allowed him to argue against 'reconsidering' the initial validity of Barbarius' deeds 'in the light of another event'. Stressing the importance of the possession of freedom was also a way of placing a different legal element between election to praetorship and its exercise. As a consequence, the validity of Barbarius' deeds no longer depended exclusively on the validity of the election, but on the legal consequences of the possession of freedom (quasi possessio libertatis), ${ }^{75}$ as supported by the common mistake.

\subsection{The problem of presumed will}

The text of the lex Barbarius does not close with Ulpian's reference to humanitas. The Roman people who relied on Barbarius' apparent status, continues Ulpian, should not also be penalised, because they could have set him free had they known of his servile condition. Of course the same, he concludes, applies even to the emperor. ${ }^{76}$

the Gloss' understanding of benignitas in the lex Barbarius. Both referred to the position of the debtor. The first (Dig.2.14.8, Pap. 10 resp.), on a question of concursus creditorum, stated that, in case of disagreement among the creditors, when neither part of them is stronger than the other, the praetor should opt for the most benevolent solution ('humanior sententia a praetore eligenda est'). The Gloss clarified that such a benevolence had to be interpreted with regards to the debtor: 'scilicet quae melior sit debitori' (Gloss ad Dig.2.14.8, \$Humanior, 1566 Parisiis, vol. 1, col. 271). The second reference (Cod.3.1.8, a constitution of Constantius and Licinius) was more general: justice and fairness ('iustitiae aequitatisque') should always prevail on strict law ('stricti iuris rationem'). The statement (obviously extrapolated from its original context) was too broad. So the Gloss read it as applying in case of contradiction between strict law and fairness: 'vbi aequitas ex vna parte, ius strictum ex alia est, et contradicunt: aequitas praeferenda est' (Gloss ad Cod.3.1.8 \$ Placuit, 1566 Parisiis, vol. 4, col. 434).

75 We will find this possession often described as quasi possessio. The reason for the 'quasi' has typically little to do with the underlying different truth. Rather, it depends on the incorporeal status of freedom, which therefore could not be possessed. It is however true that sometimes the term quasi possessio has a negative undertone, alluding to the difference between state of fact and true legal status. The resulting ambiguity can be intentional. See esp. infra, $\$ 5.4$, note 42.

76 Supra, this chapter, note 11. 
So far, the Gloss was carefully building on Barbarius' putative freedom to argue for the validity of his deeds. The argument had coherence, found support in a sufficient number of texts (whether directly or by loose analogy) and aimed to protect innocent third parties who relied on the common opinion as to Barbarius' apparent status. The putative freedom argument, interpreted on the basis of the common mistake, was in other words self-consistent. Ulpian's final statements, however, forced the Gloss to add a different argument in support of Barbarius' freedom: the presumed will to set him free. The Gloss could hardly avoid dealing with that. On the one hand, this last part of the text seems to have been one of the earliest parts of the lex Barbarius to attract the attention of glossators. ${ }^{77}$ On the other, and moreover, its ambiguity could not be ignored lest it might be used against the overall position of the Gloss on the subject. Even so, the new argument did more harm than good to Accursius' reasoning, for it considerably weakened his position, and left his overall conclusion exposed to the harsh critique of later jurists.

The main case in the Gloss where the sovereign intervened to make up for the invalid jurisdiction of the judge featured a judge of minor age. The same lex prohibiting slaves from judging (Dig.5.1.12.2) ${ }^{78}$ applied the prohibition also to impubes. The Gloss extended it also to those below 18 years of age - unless appointed by the prince or accepted by the parties. ${ }^{79}$ In so doing, the Gloss relied

Torino F.II.14, ad Dig.1.14.3, sobseruandum est: ' $\mathrm{y}$ (rnerius) si ab imperatore pretor qui seruus sit constituatur', transcription in Besta (1896), p. 16. Irnerius' initial is however absent from the other main manuscript on which Besta based his edition (Padova 941), ibid., note 26. Whether the will of the prince played such a central role already in Irnerius or only later, therefore, is hard to say. The position of the important Summa Vindobonensis on the slave-witness would match well with the gloss of Irnerius (Wernerii Summa Institutionum, Palmieri ed. [1914], ad Inst.2.10.7, p. 49), but for the fact that the Summa is very probably not of Irnerius himself (see for all Lange [1997], pp. 434-35, with ample literature on the point). In either case, the early composition of this Summa (which might therefore betray some influence of Irnerius) would strongly suggest that the central role of the will of the emperor predates the Accursian re-elaboration. It seems therefore likely that Accursius had to combine two elements - putative freedom and presumed will - that earlier glossators had already discussed but failed to relate to each other. Another possibility, but a rather speculative one, is that the putative freedom argument is slightly posterior to the presumed will one. This might explain Bulgarus' perplexities on the slave-witness and the different approach of Azo from that of Placentinus (which we have seen in the last paragraph).

78 Supra, this chapter, note 2.

79 Gloss ad Dig.5.1.12.2, Et impubes (Parisiis 1566, vol. 1, cols. 679-680): 'dic quod quatuor sunt aetates attendendae hic. Impubes ergo non, vt hic. Item adultus vsque ad decem et octo annos, non potest, nisi in duobus casibus, 
on another text (Dig.42.1.57, the lex Quidem consulebat). This stated as much with regard to the minor of 25 years, and extended the same argument also in favour of the appointment of a minor to the praetorship. If the appointment of the minor as iudex is strengthened by the consent of the parties, says the lex Quidem consulebat, the appointment of the minor as praetor must be all the more valid when the prince is aware of the minor age. ${ }^{\mathbf{8 0}}$ The Gloss sought to apply the same rationale to the lex Barbarius: in both the case of the minor and that of the slave, the consent of the prince cures the underlying incapacity. ${ }^{81}$ The parallel between minor and slave, however, highlights the difference between the two instances. The praetor of minor age was appointed by the prince with full knowledge of his incapacity - and with full intention to ratify the appointment. ${ }^{\mathbf{8 2}}$ Accursius'

quando princeps facit eum ordinarium vel delegatum. Item quando partes scientes eum minorem, in eum consentiunt: vt $\mathrm{i}(\mathrm{nfra})$ de re iudi(cata), l. quidam consulebat (Dig.42.1.57). Maior xviij annis vsque ad xx potest, sed non cogitur pronuntiare: vt $s$ (upra) ti. ii cum lege (sed Dig.4.8.41). Maior vero xx cogitur, nisi petat restitui: vt d(icta) l. cum lege. Ac(cursius).'

80 Dig.42.1.57 (Ulp. 2 disp.): 'Quidam consulebat, an valeret sententia a minore viginti quinque annis iudice data. Et aequissimum est tueri sententiam ab eo dictam, nisi minor decem et octo annis sit. Certe si magistratum minor gerit, dicendum est iurisdictionem eius non improbari. Et si forte ex consensu iudex minor datus sit scientibus his, qui in eum consentiebant, rectissime dicitur valere sententiam. Proinde si minor praetor, si consul ius dixerit sententiamve protulerit, valebit: princeps enim, qui ei magistratum dedit, omnia gerere decrevit.'

81 Gloss ad Dig.42.1.57, $\$$ Decreuit (Parisiis, 1566, vol. 3, col. 550): 'potuit etiam Barbario dare libertatem: vt s(upra) de offic(io) praesi(dis) (sic) l. Barbarius (Dig.1.14.3), et not(andum) quod princeps dat siue eligit huiusmodi magistratus in ciuitate Romana: vt $\mathrm{i}(\mathrm{nfra})$ ad leg(em) Iuliam ambi(tus) l. i (Dig.48.14.1).' The point was then further strengthened by Franciscus Accursius, who linked this text with that in Dig.5.1.12.2, and interpreted the lex Quidem consulebat (which speaks only of the minor of 25 years) as allowing also the appointment of the minor of 18 years both as judge and as praetor. Gloss ad Dig.42.1.57, Casus ad $\$$ Qvidam consulebat (Parisiis 1566, vol. 3, col. 549): 'Sententia lata a iudice minore xxv an(nis) maiore tamen xviij tenet: cum et si magistratus sit, tenebit quod faciet. Et hoc facit per me Francisco, cum adhuc sim intra aetatem xxv an(nis). Secundo dicit: etiam minor xviij an(nis) poterit de causa cognoscere: vt si ex consensu partium datus sit. Et sic de facto euenit in me Francisco. Nam cum esse intra aetatem xviij an(nis) datus fui iudex in quadam causa, et de ea cognoui. Hoc etiam si princeps fecit minorem xviij an(nis) praetorem vel consulem, nam sententiae quas dabit, tenebunt. Franc(iscus).'

82 The point is particularly clear in Gloss ad Cod.12.59(60).2, $\$$ Nvllus Affatibus (Parisiis, 1566, vol. 4, col.316): 'sic supra de cohor(talibus) 1. si quis ex [Cod.12.57.11 - in order to be reinstated in his rank, a soldier dishonourably dismissed must receive an imperial pardon first]. Sed contra s(upra) ad le(gem) Iul(iam) am(bitus) 1. i (Cod.9.26.1). Sol(utio) hic ex certa scientia: ibi non argu(mentum) supra C. de susce(ptoribus) $<$ l. $>$ si aliquid [Cod.10.72(70).12 - if a collector or receiver is condemned for fraud and fraudulently obtains an imperial 
problem with the lex Barbarius was how to speak of the prince's intention when the text clearly excluded any knowledge on his part.

There is little doubt that the Romans could have set Barbarius free. In principle, says Accursius, they could have even changed the law so as to allow slaves to hold public offices. ${ }^{83}$ That, however, was hardly necessary, he continues: if Barbarius acquired his freedom, no obstacle would stand against the validity $d e$ iure of his praetorship. ${ }^{84}$ To argue as much, Accursius looks at the opposite solution: if Barbarius remained a slave, then his praetorship would be void, and that in turn would invalidate all the business transacted before him. Therefore, he argues, it is clearly better to imagine that the people did set him free. ${ }^{85}$

The statement is clearly wanting, for it ascribes to the people an intention they did not necessarily have, all the more since they were not even aware of Barbarius' servile condition. Doubtlessly Accursius realised this, for he made an effort to apply the same rationale used for Barbarius' putative freedom: the protection of third parties. To highlight it, Accursius relied on the text that stated

rescript to hold the same office again, the rescript is void]. Ad idem facit quod in 1. contraria (Cod.9.26.1) no(tatur); item facit sub de re mili(tari) 1. semel [Cod.12.35(36).6 - the soldier who is discharged on account of illness may be reinstated only if it appears from a medical report and examination by the magistrate that he did contract a disease].'

83 Gloss ad Dig.1.14.3, $\mathbb{S}$ Seruo (Parisiis, 1566, vol. 1, col. 131). The gloss does not report Accursius' name, but see e. g. Pal. lat. 732, fol. 4ra; Pal. lat. 735, fol. 15ra; Pal. lat. 738, fol. 13va; Pal. lat. 740, fol. 14ra (\$seruo); Cologny, Bodmer 100, fol. 11rb; BSB, Clm 14022, fol. 15vb; Bern, Cod. 6, fol. 15va. The point was already made by Azo: 'si uellet legem predictam tollere quia constituit seruos non posse frui dignitate. Az(o)', Vat. lat. 1408, fol. 12va, Bamberg, Msc. Jur. 11, fol. 14ra; Avranches 156, fol. $229 \mathrm{rb}$ ( $($ potuit); BSB, Clm 14028, fol. 9ra; BNF, Lat. 4459, fol. $9 v a$ ( $($ Si uellet); Stockholm, KB, B.680, fol. 11va; BL, Harley 3700, fol. 10ra; BL, Add. 14858, fol. 15rb; Balliol 297, fol. $9 \mathrm{ra}$.

84 Gloss ad Dig.1.14.3, $\$$ Multo magis (Parisiis 1566, vol. 1, col. 131): 'Et secundum hoc dices, quod ius, scilicet in conferendo libertatem, non dico in faciendo seruum praetorem: imo et idem de praetore.' The gloss is anonymous, but see e. g. Pal. lat. 731, fol. 17rb; Pal. lat. 732, fol. 4rb; Pal. lat. 734, fol. 16va; Pal. lat. 738, fol. 13va; Cologny, Bodmer 100, fol. 11rb; BSB, Clm 14022, fol. 15vb; BSB, Clm 20, fol. 9ra; Bern, Cod. 6, fol. 15va; Douai 575, fol. 11va; BAV, SMM 124, fol. 13rb; Firenze, BML, AeD 417, fol. 11ra; BL, Harley 3700, fol. 10ra; BL, Add. 14858, fol. 15rb; Balliol 297, fol. 9ra-b.

85 Gloss ad Dig.1.14.3, $\mathbb{}$ Effecisset (Parisiis, 1566, vol. 1, col. 131): 'id est efficere potuisset. Vel credimus quod fecisset potius quam dignitatem eriperet ... Accursius.' Cf. Id., ad Cod.7.9.1 (Parisiis 1566, vol. 4, col. 1537), $\$$ manumissus est: 'sic ergo potest dari libertas: vt et ff. de offi(cio) praeto(rum) 1. Barbarius (Dig.1.14.3).' Also for the gloss effecisset there is little doubt as to Accursius' authorship: see e. g. Pal. lat. 731, fol. 17ra-b; Pal. lat. 738, fol. $13 v a$ ( $\$$ Et si fecisset); Pal. lat. 740, fol. 14ra; Cologny, Bodmer 100, fol. 11rb; BSB, Clm 14022, fol. 15vb; Bern, Cod. 6, fol. 15va; Firenze, BML, Plut. 6 sin. 3, fol. 10vb. Here as well, 
this most clearly: Cod.7.6.1.5. This was a rescript of Justinian to the praetorian prefect, dealing with the case of a funeral procession attended by many slaves of the deceased. To flaunt the liberality of the old master, the heir bestowed the felt cap (the pileus, representing the concession of freedom) on a large number of slaves: they would take part in the funeral wearing it, without being actually emancipated. The problem in the text was whether the slaves should become free even if their master had only intended to ostentate false generosity and had no intention of actually setting them free. In the text Justinian stated that the slaves would become free whatever the true intention of their master, so that the people may not be deceived ${ }^{\mathbf{8 6}}$ And the Gloss on this text duly remarked the need to protect the people: as they relied on what they could see, they would be deceived if the master had his way. ${ }^{87}$ Admittedly, the link with the lex Barbarius was tenuous at best: the circumstances of the two cases were not just different, but opposed to each other. In Barbarius' case it was not Barbarius' master who sought to deceive the people with his generosity towards the slave - the deceiver was Barbarius himself, a runaway slave posing as a Roman citizen. The Gloss on Barbarius, however, abstracted the rationale of that text from its context. What was left was only the idea that freedom may be granted to a slave so as to avoid deceiving the people unaware of his true status. ${ }^{88}$

The last statement of Ulpian - that the emperor could set Barbarius free even more easily than the people could - was not read in connection with the lex

Accursius probably looked at Azo: 'efficere potuisset. Uel credimus quod fecisset. $\mathrm{Az}(\mathrm{o})$ ', Vat. lat. 1408, fol. 12va; Vat. lat. 2512, fol. 12rb; Bamberg, Msc. Jur. 11, fol. 14ra; Douai 575, fol. 11va; Bamberg, Msc. Jur. 11, fol. 14ra; BL, Harley 3700, fol. 10ra; BL, Add. 14858, fol. 15rb; Balliol 297, fol. 9 ra.

86 Cod.7.6.1.5 (Iust. A. Iohanni PP.): 'Sed et qui domini funus pileati antecedunt vel in ipso lectulo stantes cadaver ventilare videntur, si hoc ex voluntate fiat vel testatoris vel heredis, fiant ilico cives Romani. Et ne quis vana liberalitate iactare se concedatur, ut populus quidem eum quasi humanum respiciat multos pileatos in funus procedentes adspiciens, omnibus autem deceptis maneant illi in pristina servitute publico testimonio defraudati: fiant itaque et hi cives Romani, iure tamen patronatus patronis integro servando.'

87 Gloss ad Cod.7.6.1.5, $\$$ Sed et qui (Parisiis 1566, vol. 4, col. 1528): 'Si serui alicuius voluntate ipsius vel heredis eius pileati antecesserint domini defuncti cadauer, statim fiant ciues Romani: ne populus credens eos liberos esse, deciperetur si secus fieret, patronatus iure patronis seruato.'

88 Gloss ad Dig.1.14.3, $\mathbb{E}$ Effecisset (supra, this paragraph, note 85): '... sed an hoc casu quando ignorauit fuerit liber? Dic quod sic: ne homines decipiantur: vt C. de Lati(na) li(bertate) tol(lenda) $\mathbb{S}$ sed quid si domini (sic) (Cod.7.6.1.5) ... Accursius.' Here as well, Accursius relied on Azo's gloss on the same $\$$ effecisset: 'immo efficit ut C. de latina li(bertate) tol(lenda) l. i $\$$ Sed et qui dom(ini) (Cod.7.6.1.5). Az(o)', Vat. lat. 1408, fol. 12va; Bamberg, Msc. Jur. 11, fol. 14ra; BNF, Lat. 4459, fol. 9va; Avranches 156, fol. 229rb (with small variations). 
Regia (transferring the sovereignty of the people to the emperor) and so had to be interpreted restrictively. Clearly, argued the Gloss, both emperor and the people had the same sovereignty. What Ulpian meant, therefore, is that it is much easier for a single person to decide something than it is for a whole people to agree on it. ${ }^{89}$

The Gloss sought to interpret Ulpian's final remarks (as far as possible) in the same way as it did with the rest of the lex Barbarius: the people relied on the validity of Barbarius' deeds, and the only way to uphold the deeds - and so to protect the people - was to maintain the validity of Barbarius' position. It was one thing, however, to ascribe some effects to Barbarius' putative freedom, but quite another to presume consent in the people and the emperor that was clearly absent from the text. The reference to Cod.7.6.1.5 was hardly conclusive, for that text spoke clearly in favour of the slaves' freedom against the wishes of their master. Indeed Accursius' solution was not unanimous. Ugolino for instance invoked the same text to reach the opposite conclusion. In that text the master let the slaves wear the pileus: that sufficed for their emancipation. In the same way, maintained Ugolino, if the people allowed a slave to be praetor, that was

89 Gloss ad Dig.1.14.3, $\mathbb{S}$ Multo magis (supra, this paragraph, note 84): 'immo perinde debuit dicere: vt C. de adop(tionibus) 1. ii in fi(ne) (Cod.8.47(48).2.1). Sed ideo dixit, quia facilius consentit solus princeps in manumittendo, vel aliud faciendo, quam populus: vt infra de liber(tis) vni(versitatum) l. i (Dig.38.3.1) et $\mathrm{i}$ (nfra) de (receptis qui) arbi(trium) l. item si vnus $\mathbb{S}$ principaliter (Dig.4.8.17.6). Vnde Persius: Mille hominum species, et rerum discolor vsus. Velle suum cuique est: nec voto viuitur vno.' Cf. Aulus Persius Flaccus, Satire 5, 11.52-53. The reference to Flaccus seems to be from Accursius, as the quotation is found in all the manuscripts reporting Accursius' name cited supra, this paragraph, note 84 . If Accursius quoted Flaccus; however, the explanation was probably not his own. The first part of this gloss likely came from Azo, who also mentioned the

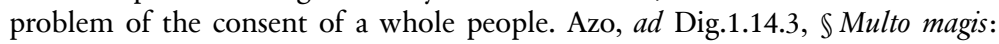
'immo perinde dicere debuit vt C. de adopt(ionibus) 1. ii in fi(ne) (Cod.8.47(48).2.1). Sed hoc quia difficile est populum consentire vt i(nfra) de libertis uniuersita(tum) 1. i (Dig.38.3.1). Az(o)', Vat. lat. 1408, fol. 12va; Vat. lat. 2512, fol. 12rb; Bamberg, Msc. Jur. 11, fol. 14ra; Avranches 156, fol. 229rb; BNF, Lat. 4463 , fol. $12 v b$. The same explanation may be found in Ugolino's gloss on the lex Barbarius, ad Dig.1.14.3, $\mathbb{\$}$ Multo magis: 'quod uidetur falsum cum dicimus populus et imperator parem habere potestatem vt C. de adopt(ionibus) 1. ii. in fi(ne) (Cod.8.47(48).2.1), ergo multo etc. $i(d$ est) facilius imperatore permittendo eum fungi pretura uel eligendo in eam, cum sciret eius condictionem daret ei libertatem quam populus, quia facilius consentire potest; uniuersitas enim difficilius in unum consentit vt s(upra) de orig(ine) iur(is) 1 . ii $\$$ Deinde quia difficile (Dig.1.2.2.9). H(ugolino).' BL, Royal 11.C.III, fol. 9vb; BNF, Lat. 4461, fol. $11 v b$ (the first manuscript reads 'difficile' instead of 'difficilius', but the second one has more errors). The same gloss may be found, but more fragmented, in BNF, Lat. 4463, fol. $12 v b$ ( $\$$ multo). 
sufficient to argue that they did set him free. However, he continued, this would only apply if the people were aware of Barbarius' servile condition, just as the master in the pileus case. ${ }^{90}$ A gloss attributed to Azo was even more explicit: in principle the Roman people or the prince could well have set Barbarius free; but since they were not aware that he was a slave, then clearly they did not consent to his manumission. It follows, continued this gloss, that Barbarius remained a slave, and so was neither free nor praetor. ${ }^{91}$

90 Ugolino, ad Dig.1.14.3, \liberum: 'hoc ipse enim quod permitteret eum preturam uti in liberum uideretur ei concedere libertatem si sciret eum seruum, et sic C. de lat(ina) lib(ertate) tol(lenda) 1 . i $\$$ sed et qui domini, $\$$ sed et si quis (Cod.7.6.1.5 and.9). H(ugolinus)', BL, Royal 11.C.III, fol. 9vb; BNF, Lat. 4461, fol. 11vb. Cf. Id., ad Dig.1.14.3, \$verum: 'non tamen potest dici quod fuit pretor vt C. de decurionibus <l. Herennius $>$ (Dig.50.2.10). H(ugolino)', BL Royal 11.C.III, fol. $9 v a$.

91 BNF, Lat. 4463, ad Dig.1.14.3, \$ Potestatem, fol. 12vb: 'hoc verum si scisset quod manumittere posset vt C. ex q(uibus) $\mathrm{c}$ (ausis) serui propter $\mathrm{p}$ (remium) li(bertatem) ac(cipiunt) 1. ii et iii (Cod.7.13.1-2). Imo etiam ipso solo quod eum imperatorem eligit cum finis sit $\operatorname{ar}($ umentum) vt $\mathrm{i}(\mathrm{nfra})$ nequid in $\mathrm{lo}(\mathrm{co})$ $\mathrm{pu}$ (blico) fiat $<$ l. $>$ litora (Dig.43.8.3pr) et C. de quadri(ennii) praes(criptione) $<$ l. $>$ bene (Cod.7.37.3) et Instit. qui ma(numittere) $<$ non $>$ possunt $\$ \mathrm{i}$ (Inst.1.6.1). Sed cum hic ignorauit non eum manumisit, quia consensisse non uidetur vnde dico eum pretorem non fuisse: vt $\mathrm{i}(\mathrm{nfra})$ de iudic(is) $<\mathrm{l}$.> cum pretor $\mathbb{\$}$ non autem (Dig.5.1.12.2). Tamen confirmauit eius sententias: immo factum confirmatiue uidetur ualuisse, ar(gumentum) C. de testa(mentis) l. i (Cod.6.23.1). Dic ergo eum non fuisse pretorem uel liber vt $\mathrm{i}(\mathrm{nfra})$ de fideico(mmissaribus) lib(ertatibus) $<1 .>$ generaliter $\$ si quis tutorem (Dig.40.5.24.9). Az(o).' Whether the gloss is really of Azo is not entirely clear. I could find it in only a single manuscript, whereas most manuscript sources reporting Azo's gloss skip it. At the same time, however, it would perfectly match another gloss clearly written by Azo. This other gloss states that, if the Romans wanted to appoint Barbarius as praetor, they should have first changed the law ('si uellet legem predictam tollere quia constituit seruos non posse frui dignitate'), supra, this paragraph, note 83 . The reference to Dig.43.8.3pr is particularly interesting as very representative of the jurists' approach. The text (Celsus 39 dig.) simply stated that the sea shores under Roman control belonged to the Romans ('Litora, in quae populus Romanus imperium habet, populi Romani esse arbitror'). Meaning 'control', however, the text said 'imperium'. As a result, if one ignored the subject matter, the text proclaimed the sovereignty of the Roman people over what pertained to them. Hence it could well be invoked to argue in favour of the power of the Roman people to set Barbarius free. The last text invoked by the gloss attributed to Azo (Dig.40.5.24.9, Ulp. 5 fid.) was particularly clear: the appointment as guardian of a slave mistakenly believed to be free is of no effect, and it does not entitle the slave to claim his freedom either ('certissimum est neque libertatem peti posse neque tutelam libertatis praestationi patrocinari'). It seems telling that, when commenting on it, the Accursian Gloss skipped entirely the issue of freedom, to focus only on that of the guardianship: Gloss ad Dig.40.5.24.9, 
What is of particular interest in this gloss ascribed to Azo is not just that it reached the opposite conclusion from that of Accursius, but the underlying logic it used. Azo (if he really wrote it) sought to keep the question of the validity of Barbarius' deeds as praetor distinct from that about the validity of his praetorship. This way he argued against Barbarius' freedom (and so, by implication, also against his praetorship), but in favour of the validity of his deeds as praetor. ${ }^{\mathbf{9 2}}$ In so doing, he relied on the same argument to reach two opposite results. The people's consent cannot be presumed, he argued, hence Barbarius is not manumitted. But his deeds remain valid, continued Azo's gloss, because those same people 'ratified his decisions' (confirmavit eius sententias). ${ }^{\mathbf{9 3}}$

Ugolino's similar position might strengthen the authenticity of the gloss attributed to Azo (and in turn might suggest some influence of their teacher Bassianus). Even so, however, it is telling that most other manuscripts do not report it. Within a short time Accursius' position became predominant: the validity of Barbarius' deeds depended on the validity of his appointment. The acts, in other words, would stand only if their source was lawful. The Gloss therefore insists on the validity of Barbarius' praetorship to preserve the validity of his deeds as judge. Although Accursius' defence of the personal position of Barbarius is a means to a different end, it links the validity of the deeds with the validity of the appointment. The point is important: although the ultimate end is to preserve the validity of the deeds, for the Gloss that outcome depends on the validity of the source of those deeds. This is why the Gloss invokes public utility to argue for Barbarius' freedom, and not - directly - to hold the deeds valid. Their validity has necessarily to follow on from the freedom of Barbarius. The validity of the deeds is the final purpose, not the means. Even if the people were unaware of Barbarius' servile condition, the Gloss maintains, it is necessary to argue for their presumed will to set him free. Doing otherwise would prejudice those who relied on his putative freedom. ${ }^{\mathbf{9 4}}$ Arguing for a direct link between the validity of the source and the validity of the deeds required the connection between the deeds and public utility to be indirect - for it had to depend on the person of Barbarius. This might explain why Accursius usually refers to public utility not in positive terms, but in negative ones ('ne homines decipiantur'): ${ }^{95}$ Barbarius must be praetor de iure so as to avoid the people suffering prejudice. Speaking of

$\$$ Patrocinari (Parisiis 1566, vol. 3, col. 251). Cf. also the Gloss on the closely related text of Dig.26.2.22 ( $\$$ Putabat liberum esse, Parisiis 1566, vol. 2, col. 129).

94 Gloss ad Dig.1.14.3, $\mathbb{E}$ Effecisset (Parisiis, 1566, vol. 1, col. 131). Cf. supra, this paragraph, note 88 .

Supra, last note.

Ibid.

Ibid. 
public utility in positive terms would have been more difficult: the people had no interest in setting Barbarius free, even less in making him praetor de iure.

The publica utilitas argument is invoked openly (and in positive terms) only towards the end of the Accursian comment on the lex Barbarius, when the Gloss deals with the issue of Barbarius' price. If the people (or the prince) were to set Barbarius free, reasons the Gloss, they would effectively expropriate private property. Would this mean that they should compensate Barbarius' master? Very interestingly, and unlike other jurists, Accursius answered in the negative. Since the expropriation took place on public utility grounds, no compensation is due. ${ }^{96}$

96 Gloss ad Dig.1.14.3, $\mathbb{\$}$ Multo magis (supra, this paragraph, note 84 ): ‘... Sed an vel imperator vel populus teneatur ad precium serui? Respon(deo) non, maxime si propter publicam vtilitatem faciat: vt C. pro quibus cau(sis) ser(vi) li(bertatem) accipi(unt) 1 . antepen(ultima) (Cod.7.13.2) et sic no(tandum) quod ex causa iusta princeps alienum seruum manumittit, non alias, vt puto quia licet omnia principis intelligantur, verum est quo ad protectionem, vt C. de quadri(ennii) praescrip(tione) 1. fina. in princ(ipio) (Cod.7.37.3pr).' Accursius' position is interesting, as it would seem to suggest that the presence of public utility allowed the prince both to proceed with the expropriation and to refuse compensation for it. Accursius did not elaborate a systematic doctrine of expropriation for public utility, yet on the point he seems rather clear: no payment is needed. This position clashed with the jurists on whom Accursius built most of his comment (also) on the lex Barbarius: Ugolino and Azo. Both of them (although perhaps just in theory: cf. supra, this paragraph, notes 90 and 91 respectively) required compensation for the expropriation of Barbarius. Public utility was necessary to dispense with private property, but not with the payment for its expropriation. On Azo see his gloss \$observandum: 'sed an tenetur imperator ad precium serui? $\mathrm{R}$ (espondeo) tenetur et maxime si propter publicam utilitatem faciat vt $\mathrm{C}$. ex quibus $\mathrm{c}$ (ausis) serui premio ac(cipiunt) li(bertatem) 1 . antepenult(ima) (Cod.7.13.2). Az(o)', Vat. lat. 1408, fol. 12va; Bamberg, Msc. Jur. 11, fol. 14ra; Avranches 156, fol. 229rb; Stockholm, KB, B.680, fol. 11vb. The same may be found in the final part of Ugolino's gloss $\$$ liberum: 'Sed numquid dominus posset precium a fisco petere? $\mathrm{R}$ (espondeo) sic, $\operatorname{ar}$ (gumentum) C. in quibus causis serui pro premio lib(ertatem) 1. ii (Cod.7.13.2). H(ugolino)', BL, Royal 11.C.III, fol. $9 v b$; BNF Lat. 4461, fol. 11vb. Sometimes the position of Azo and of Ugolino are found combined together. See e.g. BNF, Lat. 4463, ad Dig.1.14.3, fol. 12vb, $\$$ multo: '... tenetur imperator ad precium serui? Respondeo tenetur si propter pu(blicam) utilitatem faciat vt C. pro quibus serui pro $\mathrm{p}$ (remio) ac(cipiunt) li(bertatem) l. penult(ima) (Cod.7.13.3) Az(o). Et hoc dicit quod aliter non potest manumittere seruum meum. H(ugolinus).'

Medieval lawyers debated the issue animatedly for centuries, yet their discussions have not been studied by modern scholars working on expropriation in medieval law. I am purportedly avoiding to provide general references to the subject of public utility, as few subjects are as multifaceted and complex as this. Suffice to remember two classical works, that of Gaudemet (1951), pp. 465-499, and that of Nicolini (1940), pp. 189-289, esp. 205-211 and 243-254. The same work of 


\subsection{Applications of Barbarius' case}

The common mistake informing the lex Barbarius may be found in many other parts of the Gloss, up to the very last text of the last title of the last book of the Digest. ${ }^{97}$ The abundance of references to the lex Barbarius means that the Gloss invokes it not only in the most obvious cases, such as the exception to the Macedonian senatus consultum, ${ }^{\mathbf{9 8}}$ but in many other situations where its relevance was not so obvious. Let us take for instance Dig.29.2.30.3. The text (of Ulpian) dealt with the prohibition of the heir apparent entering upon the estate if the deceased's wife is pregnant. What happens, asks Ulpian, if the heir apparent thinks that the widow is not pregnant? If his belief is widely shared, he answers, then he may enter upon the estate. ${ }^{99}$ In commenting on this last statement, the Gloss refers both to the case of the slave-witness and to the lex Barbarius. ${ }^{100}$ Again, in Dig.1.18.17 Celsus argued that, when the praeses provinciae manumitted a slave or appointed a warden after his mandate had expired but before he knew of the arrival of his successor, the deed was valid. ${ }^{\mathbf{1 0 1}}$ In citing the

Nicolini is particularly useful to examine pre-Accursian jurists, and especially Azo, and their influence on the Accursian Gloss as to the limits of expropriation of private property (pp. 205-211). Nicolini mentions Accursius' gloss multo magis in passing (p. 246, note 2), but he does not look at other glosses on the lex Barbarius (apart from a short mention to Mayno's comment on it, p. 215, note 1).

97 Dig.50.17.211 (Paul 69 ed.) prohibited slaves from absenting themselves on State business. But the Gloss carved out an exception for the case the slave was commonly believed free: ad Dig.50.17.211, $\$ Seruus (Parisiis 1566, vol. 3, col. 1926): '... Ab hac 1 . excipe si communis error interueniat: vt supra de offi(cio) praeto(rum) 1. Barbarius (Dig.1.14.3). Ac(cursius).'

98 Gloss ad Dig.14.6.3 pr, $\mathbb{\$}$ Publice (Parisiis 1566, vol. 1, col. 1495): 'Not(atur) quod communis error excusat: vt supra de off(icio) praeto(rum) <l.> Barbarius (Dig.1.14.3), et infra de acquir(enda) haere(ditate) l. cum quidam $\$$ quod si ipse (Dig.29.2.3.3), et infra de aedil(icio) edict(o) quis sit, $\mathbb{S}$ apud Caecilium (sic) [Dig.21.1.17.15: cf. its gloss $₫$ Et in ea cella, Parisiis 1566, vol. 1, col. 1967] et infra de supelle(ctili) leg(ata) 1. iii in fine (Dig.33.10.3.5), et infra de eo qui pro tutore (Dig.27.5) per totum.'

99 Dig.29.2.30.3 (Ulp. 8 ad Sab.): 'Quod dicitur "si putetur esse praegnas", sic accipiendum est, si dicat se praegnatem. Quid ergo, si ipsa non dicat, sed neget, alii dicant praegnatem esse? Adhuc adiri hereditas non potest: finge obstetrices dicere. Quid si ipse putat solus? Si iusta ratione ductus, non potest adire: si secundum multorum opinionem potest.'

100 Gloss ad Dig.29.2.30.3, \$ Potest (1566 Parisiis, vol. 2, col. 645): 'scilicet adire. Et ad hoc ... supra de offi(cio) praeto(rum) 1. Barbarius Philippus (Dig.1.14.3) et C. de testa(mentis) 1. i (C.6.23.1) et insti. de testa(mentis) $\$$ sed cum aliquis (Inst.2.10.7).'

101 Dig.1.18.17 (Cel. 3 dig.): 'Si forte praeses provinciae manumiserit vel tutorem dederit, priusquam cognoverit successorem advenisse, erunt haec rata.' 
lex Barbarius the Gloss remarks how 'someone who is unaware can do what someone who is aware could not do'. ${ }^{102}$ While the first text (Dig.29.2.30.3) referred to a common (if possibly mistaken) belief, the second (Dig.1.18.17) pointed to the mistake of a single person, albeit committed while discharging a public office. Perhaps because of the combination of a single mistake and the public office of whoever committed it, the Gloss avoids particularly significant statements (whereas later jurists would be more thorough when examining the issue). By contrast, commenting on texts about the mistake of single, private individuals, the Gloss is clear in stating that the mistake of a single person cannot be invoked in support of the validity of a deed. A particularly clear case is Dig.2.1.15: pleading before one praetor thinking he is another one voids the proceedings. ${ }^{103}$ The Gloss clarifies that it was a case where someone pleaded before the urban praetor in the mistaken belief that he was the peregrine one. ${ }^{\mathbf{1 0 4}}$ In this case, comments the Gloss, the mistake was insufficient to argue for the validity of the deeds, for it was the mistake of a single person. It would be different, concludes the Gloss, if the mistake was a common one. ${ }^{105}$ The same reasoning may be found in a very well known text of Paul that distinguishes between ignorance of fact (ignorantia facti) and ignorance of the law (ignorantia iuris) (Dig.22.6.9). Normally, says Paul, ignorance as to a fact does not cause harm. But there are limits. So for instance it is not possible to invoke it on something that everybody else knows. ${ }^{\mathbf{1 0 6}}$ The argument a contrario is easy to make: if the ignorance of a single person is condemned as summa negligentia in the text, argues the Gloss, then the ignorance of most or even all people (as in Barbarius' case) should be condoned. ${ }^{107}$

102 Gloss ad Dig.1.18.17, \cognouerit aduenisse (Parisiis 1566, vol. 1, col. 149): ‘... et sic no(tandum) quod potest ignorans quod non posset sciens. Sic s(upra) de offi(cio) praefect(i) vr(bis) (sic) 1. Barbarius (Dig.1.14.3) et institu. de testa(mentis) $\mathbb{S}$ testes (Inst.2.10.6).'

103 Dig.2.1.15 (Ulp. 2 omn. trib.): 'Si per errorem alius pro alio praetor fuerit aditus, nihil valebit quod actum est. Nec enim ferendus est qui dicat consensisse eos in praesidem, cum, ut Iulianus scribit, non consentiant qui errent: quid enim tam contrarium consensui est quam error, qui imperitiam detegit?'

104 Gloss ad Dig.2.1.15 \$S Si per errorem (Parisiis 1566, vol. 1, col. 172).

105 Gloss ad Dig.2.1.15 \$Nihil (Parisiis 1566, vol. 1, col. 172): 'quandoque tamen error facit ius, si est communis: vt infra de supel(lectili) leg(ata) 1. iii in fi(ne) (Dig.33.10.3.5) et supra de offi(cio) praeto(rum) 1. Barbarius (Dig.1.14.3).'

106 Dig.22.6.9.2 (Paul iur. et fact. ignor. 1. sing.): 'Sed facti ignorantia ita demum cuique non nocet, si non ei summa neglegentia obiciatur: quid enim si omnes in civitate sciant, quod ille solus ignorat? ...'

107 Gloss ad Dig.22.6.9.2, \solus ignorat (Parisiis 1566, vol. 1, cols. 2101-2102): '... econtra parcitur alicui si ignorat quod maior pars vel omnes ignorant: vt supra de offic(io) praeto(rum) 1. Barbarius (Dig.1.14.3).' 
We have seen that the most important glosses on the lex Barbarius (on Barbarius' praetorship, on the effects of his putative freedom and on the presumed will of the people to set him free) all invoke the principle that the common mistake makes law. Apart from referring to the need to protect innocent third parties, however, none explains its meaning.

Whenever the Gloss invokes the maxim communis error facit ius in its comment on the lex Barbarius, it always refers to a text of little prima facie relevance to our case: Dig.33.10.3.5. The text asks whether a bequest of household furniture should include silver candlesticks. In principle, says Paul, the material of which the furniture is made is irrelevant, and so silver candlesticks should be part of the bequest. But if a silver candlestick is put with the silverware, then it is considered as part of the silver and not of the household furniture. The reason, according to Paul, is to be found in the practice of inexperienced people ('propter usum imperitorum'), who misinterpreted the rule. Such a practice led to an exception to the rules on household bequest. This way, the mistake of the imperiti ended up creating a specific legal rule - and so 'error ius facit'. ${ }^{108}$

Paul's text clearly pointed to a custom based on a banal misconception that was strong enough to form an (illogical) exception to the general rule. The text could have become extremely important for civil lawyers, perhaps even more so than the lex Barbarius itself, had not been for a single vowel. In the littera bononiensis (the version of the Digest in circulation) ${ }^{\mathbf{1 0 9}}$ 'imperitorum' reads 'imperatorum'. As such, the change in the rule was no longer the result of ignorance ('propter usus imperitorum'), but depended on the will of the emperors ('propter usus imperatorum'). Thus Paul's conclusion ('et error ius facit') had to be reassessed. The prince introduced an exception to the rules governing bequests. It was somewhat easier to accuse some ignorant people of a mistake than to accuse the emperor. So the Gloss duly explained that what ius facit is not a common mistake but rather the will of the prince, whom everybody else has to follow. ${ }^{110}$ This way, the strength of the maxim error ius facit was

108 Dig.33.10.3.5 (Paul 4 ad Sab.): 'Nec interest, cuius materiae sunt res, quae sunt in suppellectili. Sed craterem argenteum non esse in supellectili nec ullum vas argenteum secundum saeculi severitatem nondum admittentis supellectilem argenteam hodie, propter usum imperitorum si in argento relatum sit candelabrum argenteum, argenti esse videtur, et error ius facit.'

109 For a short explanation on the difference between the litera bononiensis (or vulgata) and the litera florentina see Dondorp and Schrage (2010), pp. 13-14.

110 Gloss ad Dig.33.10.3.5, \Usum imperatorum (1566 Parisiis, vol. 2, cols. 1221-1222): 'vtebantur imperatores: vt si vas argenteum relatum, id est annumeratum sit argento, tunc numero argenti non suppellectilis continetur: vt supra eo (titulo) 1. i (Dig.33.10.1) et hic ergo si numero non est argenti, continetur appellatione suppellectilis: et sic error principis facit ius, vt supellectilis appella- 
considerably reduced. As a consequence, the relationship between common opinion and mistake remained somewhat unclear - or rather, lacking precise normative ground. The problem of vitiated collective will, in other words, remained substantially unanswered. ${ }^{111}$

\subsection{Putative notary?}

Before concluding the analysis of the Gloss on lex Barbarius it is important to mention a particularly significant application of Barbarius' case, that would be amply discussed by civil lawyers and canon lawyers alike for centuries to come, well into the modern times. It is the case of the false notary.

The increasing reliance on notarial deeds in the twelfth century was accompanied by a similar growth in forgeries. The false notary was therefore a particularly relevant subject. ${ }^{112}$ One of the earliest normative sources on the point is to be found in a letter from Pope Innocent III to the archbishop of Milan (Philip of Lampugnano) in 1199, eventually incorporated in the Liber Extra (X.2.22.6), discussing the main kinds of forgery. One of the cases listed by the pope was the fact that the document was not drafted by a notary ('quia nec erat publica manu confectum, nec sigillum habebat authenticum'). A few years later other sources, such as the earliest notarial registers, also attested to an increasing awareness of false notaries, and to the need to control their authenticity. ${ }^{113}$

The same awareness can be also seen in contemporary litigation. A good example comes from the diocese of Koper in Slovenia. This diocese was

tione contineatur argentum ... Sed quomodo solius principis error facit ius? Resp(ondeo) quia et alij debent sequi quod ipse facit, argu(mentum) C. de episc(opali) au(dientia) 1. iii [Cod.1.4.3 - an imperial rescript excluding some crimes from a general amnesty] et sic communis error hic facit ius: sic et supra de offic(io) praeto(rum) 1. Barbarius (Dig.1.14.3).' Cf. Cortese (1964), vol. 2, pp. 105-106, note 14 .

111 On the maxim error facit ius, the Gloss often cited Paul's text on silver household furniture together with the lex Barbarius. See e. g. ad Dig.2.1.15, $\mathbb{\$}$ Nibil (Parisiis 1566, vol. 1, col. 172): 'quandoque tamen error facit ius, si est communis: vt infra de supel(lectili) leg(ata) 1. iii in fi(ne) (Dig.33.10.3.5) et supra de offic(io) praeto(rum) 1. Barbarius (Dig.1.14.3).'

112 The increasing importance of notarial deeds may be also appreciated in legal proceedings. The Fourth Lateran Council required ecclesiastical judges to avail themselves of a notary to record each phase of the proceedings (4 Lat. c.38). Cf. Brundage (2008), p. 147, text and note 75, where further literature is mentioned. In the Italian communes from the begining of the thirteenth century each phase of the proceedings - from beginning to end - was drafted as a public act. See e. g. Behrmann (1995), pp. 1-18.

113 So for instance the earliest entries in the register of the notaries of Bologna date to 1219: Ferrara and Valentini (1980), pp. 1-17. 
administered by the bishop of Trieste until 1184, when it finally became administratively independent with its own diocesan bishop. From that moment the local bishop, Aldericus, sought to recover his bishopric rights to a series of tithes that the diocese of Trieste had alienated or lost in the course of the previous decades. One of the first cases was the tithes of the island of Istria, which had been alienated in favour of the convent of St Mary of Aquileia. In 1189 the Patriarch of Aquileia sought to mediate between the two parties, but indirectly acknowledged the rights of the bishop. ${ }^{\mathbf{1 1 4}}$ The dispute dragged on, and in 1201 the bishop produced a notarial copy of the Patriarch's ruling as evidence of his rights. ${ }^{115}$ By then, however, the notary who drafted the original decision was dead, and the counsel for the nuns argued that he had not been a true notary and therefore that the original document was void. The bishop had to resort to witness depositions to prove the authenticity of the notary, ${ }^{\mathbf{1 1 6}}$ yet it seems he lost the case all the same. ${ }^{117}$ But the bishop was not a man to be easily discouraged.

114 The bishop of Trieste granted the tithes of the island of Istria to the convent of St Mary in 1166, although he had previously sworn not to alienate any income of the diocese of Koper. In principle, therefore, the alienation of the tithes was void, but the nuns had the good sense to obtain a series of papal confirmations of their privileges - tithes included. The bishop of Koper started suing the convent in $1188 / 9$, but with little success. His perseverance on the matter is attested by appeals to a series of popes (Clement III, Celestine III and Innocent III), who appointed a number of successive judges to hear the case. One of the first decisions, of 1189, found for the bishop. But soon thereafter the Patriarch of Aquileia modified the decision of his delegate so as to achieve an equitable - but fragile - compromise. The Patriarch left the tithes with the nuns, but required them to pay a pound of incense each year to the bishop. See Härtel (2011), pp. 55-57. The relevant documentation may be read in Härtel et al. (2005), doc. 32, p. 122 (decision in favour of the bishop), doc. 36, pp. 126-128 (ruling of the Patriarch of Aquileia, 20.12.1189), doc. 23, 28-29, 36, 38, 40, 45, pp. 111-142 (series of papal confirmations of the convent's privileges, ranging from 1174 to 1199$)$.

115 Zabbia (2013), pp. 203-204; Härtel (2011), p. 57. Cf. Härtel et al. (2005), doc. 49, p. 146 (1201).

116 Härtel et al. (2005), doc. 47 (12.4.1201), pp. 143-154, at 145: 'Giliolus de Sentella iuratus [scil., one of the witnesses] dicit se bene scire Martinum qui morabatur iuxta capella $(\mathrm{m})$ domini Gerardi Paduani episcopi fuisse notarium et habitum esse pro notario. Interrogatus quomodo scit dicit se scire quia instrumenta sua habebantur publica in tota terra Padue, et ipsemet testis habet de instrumentis factis per manum dicti Martini notarii, per publicam famam quia publica fama est per totam terram Padue quod erat notarius ... Albertus notarius iuratus dicit idem per omnia que Giliotus de Sentella ...' Cf. Zabbia (2013), pp. 203-204.

117 Härtel et al. (2005), doc. 48, pp. 145-146 (12.4.1201). Cf. Zabbia (2013), pp. 205-206. 
On the contrary, he put the episode to good use. Just a few months later he was busy suing the citizens of a town close to the island of Istria, Pirano, again on tithe issues. As it was up to the bishop to prove his right to the tithes, he could not use the same strategy as the nuns. But he could adapt it to a different situation. So the bishop claimed that the notary who drafted the counsel's mandate (the procuratio ad litem) was not a true notary, and that the mandate was therefore void. ${ }^{118}$ We do not know whether that was the first citation or a subsequent one, but perhaps the intention was to have the defendant declared contumacious, claiming that the town did not lawfully appear in court. The idea might have come from the poor technical preparation of the notary who drafted the town's mandate to the counsel - in all probability, it was a young notary still learning the ropes. The document he drafted had some imperfections, perhaps not serious enough to have it annulled but sufficient to cast some doubts as to the appointment of its author. ${ }^{119}$ The counsel for the town, interestingly, stressed both the validity of the notary's appointment and the fact that he was widely reputed a true notary. ${ }^{\mathbf{1 2 0}}$ This last statement might be related to the fact that the witnesses gave different versions of the notary's appointment, although it had taken place just a few months beforehand. ${ }^{\mathbf{1 2 1}}$ The court, however, did not much appreciate the bishop's cavil and found against him. But the bishop did not give up so easily and appealed against the decision. The second court appointed to hear the case would have probably come to the same conclusion

118 'Ac vero dictus episcopus econtra excepit dicens predictum instrumentum non esse publicum, nec esse confectum per tabellionem creatum ab eo qui habere auctoritatem eius creandi tabellionem.' De Franceschi (1924), doc. 20, pp. 17-21, at p. 18 (12.11.1201). Cf. Zabbia (2013), p. 193.

119 Zabbia (2013), pp. 196-198, looked at extant documents drafted by the same notary. The first dates to the middle of July 1201. From beginning to end, the document seems somewhat poorly drafted: the invocation is not the standard one in use at that time, and the document even lacks the notary's signum. Looking at a couple of documents drafted by the same hand between this first one and the one we are concerned with (two documents written in July 1202 and January 1203), it would seem that the new notary was (slowly) learning his job.

120 The notary, claimed the counsel for the defendant, 'econtra proposuit quod dictus tabellio in Pirano habetur pro tabellione, et contractus illius loci ipse scribit sicut tabellio, et instrumenta sua habent publicam auctoritatem, et ille tabellio $\mathrm{ab}$ eo est factus tabellio qui habet jus faciendi tabellionem.' De Franceschi (1924), doc. 20, pp. 17-21, at 18 (the same defendant insisted on the point also - and particularly - at the subsequent hearing, ibid., p. 19, 10.12.1201). Cf. Zabbia (2013), p. 193.

121 For a detailed discussion of these testimonial depositions see Zabbia (2013), pp. 198-206. 
as the first, for at some point the bishop recused it. ${ }^{\mathbf{1 2 2}}$ But he had more luck with the third attempt. The bishop of Trieste, appointed by Pope Innocent III to hear the case again, proved more sympathetic to his colleague than the previous judges had been, and found against the citizens of Pirano. ${ }^{123}$ It was now their turn to appeal. Pleading before the new judge (the bishop of Padua) the counsel for Pirano went back to the issue of the legitimate position of the notary who drafted the documents for the city. Surely the notary was a true one, said the counsel. But even if he was not, he was widely believed to be such and that would suffice - according, inter alia, to the lex Barbarius. ${ }^{\mathbf{1 2 4}}$ The new judge quashed both previous decisions, ${ }^{\mathbf{1 2 5}}$ and the dispute continued before yet another court. ${ }^{\mathbf{1 2 6}}$ To the disappointment of the legal historian, however, the issue of the validity of the notary's appointment no longer appears in the documents. ${ }^{127}$ The disappointment grows more profound when we consider that one of the two new judges was probably the great canonist Huguccio. ${ }^{128}$

122 A first appeal was heard in July 1202 in Rialto by the Abbot of St Felice, but it would seem that at some point the appellant (the Bishop) recused the court. De Franceschi (1924), doc. 32, pp. 39-40 (9.3.1202).

123 Ibid., doc. 42, pp. 50-51 (1203).

124 'Quod autem opponitur de tabellione quod non sit tabellio, Piranensibus non preiudicat, quia testibus Piranensium probatum est Dominicum tabellionem esse, et sicut tabellio instrumenta pubblica conficit, et in Pirano pro tabellione habetur ... Nam tabellio est et pro tabellione habetur sufficetur enim si tamen crederetur esse tabellio, ut in Extravagantibus, De iure patronatus, Consulta(tionibus) [Comp.1, 3.33.23(=X.3.38.19)], et in Decretis III, q. VII, $\mathbb{S}$ Tria (C.3, q.7, p.c.1), et in ff. De officio pretoris, lex Barbarius (Dig.1.14.3).' Ibid., doc. 44, p. 56 (1203). De Franceschi's transcription is slightly improved in Zabbia (2013), p. 208.

125 De Franceschi (1924), doc. 45, pp. 61-63 (18.10.1203).

126 Ibid., doc. 46-50, pp. 63-67 (October 1203 to January 1204).

127 Ibid., doc. 51-65, pp. 67-89 (January 1204 to October 1205). The nature of the documents (and their length) would seem to exclude possible gaps. The issue of the notary was therefore intentionally dropped. This seems to be confirmed by the fact that the new - and, it would seem, final - decision was rendered on the basis of an agreement between the parties (decison of 3.10.1205, ibid., doc. 65, pp. 87-89, 3.10.1205).

128 The new court appointed by Innocent III consisted of the bishop of Chioggia (Dominicus II) and that of Ferrara, Huguccio. The thorough study of Müller seems to strengthen the possibility that this bishop was indeed the author of the Summa: Müller (1994), pp.21-34. It would be interesting to know what Huguccio would have made of the argument of the notary's public fame in relationship with the lex Barbarius and its closest equivalent in the Decretum, Gratians' dictum Tria (on which infra, pt. II, $\$ 6.2$, text and note 26). The two judges had more important things to do than indulging in complex legal thinking, for the indefatigable bishop had in the meanwhile first excommunicated the inhabitants of Pirano and then, just in case, also put the city under interdict. 
While perhaps not everybody was as obstinate as the tithe-collecting bishop Aldericus, his case shows the increasing importance of the application of the lex Barbarius to the validity of notarial instruments. So far, the standard accusation was that the seal of the notary was forged - not that the seal was authentic but the notary himself was an impostor. ${ }^{\mathbf{1 2 9}}$ It is within this context that we should look at the approach of the Gloss to the subject. ${ }^{130}$

Justinian's Novel 44 prohibited notaries from letting their clerks make public instruments using their seal, but it did not sanction the infraction by declaring such instruments invalid. Because of the utility of the contracting parties, stated the Novel, the document would remain valid. ${ }^{131}$ The Gloss observed that such practice, perhaps, might still apply in Constantinople, but surely no longer in Italy: a document drafted by someone other than the notary is surely void. However, continued the Gloss, the same public utility argument might well be invoked in favour of the instrument's validity despite the dismissal from office of the notary who drafted it, just as in the lex Barbarius. ${ }^{132}$

129 It is considerably more difficult to find such accusations before the late twelfth century. A couple of cases of the early twelfth century may however be found in Padua. They are two contracts that were both subsequently declared void. But in both cases the reason was that they had been written by a local priest (who declared himself such), not by a self-proclaimed notary. The first case (of 1100) is only briefly mentioned in the records ('cartulam inanem nullo jure munitam nulloque tabellione conscriptam ibi ostendit quam Draco presbiter jam dudum fecerat'). The second one (of 1115) is slightly more elaborate. The defendant insisted that 'prenominata capella cum omnibus predictis rebus pertineret ad ecclesiam sancte Justine de civitate Padua per cartulam unam quam dicebant Draconem presbiterum fecisse quondam.' Upon close examination, the judges pronounced the documents false: 'Tunc iudices qui ibi aderant, perceperunt eas adduci. His ductis atque relectis, retulimus eciam plures cartas incisas ad predicto Dracone conscriptas, et quam noticiam falsam appellabant.' The documents are transcribed in Gloria (1877), doc. 334, p. 356, and Gloria (1879), doc. 70, p. 57 respectively. Cf. also Zabbia (2013), pp. 194-195.

130 The following notes concern only the problem of the false notary, not also that of the (true) notary declaring something false. On the increasing awarness as to this problem among civil lawyers (especially when notarial document and witness deposition diverged) see e. g. Bambi (2006), pp. 34-35.

131 Coll.4.7.1 (=Nov.44.1\$4): 'Si vero praeter hoc fiat, et alter delegetur: tunc subiaceat poenae tabellio, qui auctoritatem habet a nobis dudum definitam: ipsis tamen documentis propter vtilitatem contrahentium non infirmandis.' Cf. Ankum (1989), pp. 37-39.

132 Gloss ad Coll.4.7.1(=Nov.44.1ฐ4), $\$$ documentis (Parisiis 1566, vol. 5, col. 225): 'hic est argumentum, imo lex expressa quod tabellio non potest delegare discipulum suum ad componenda instrumenta. Sed si fecerit instrumentum, non vitiatur, sed tabellio poenam patitur. Sed certe hoc est in Constantinopolitana ciuitate tantum. Quid autem de aliis? ... Item not(andum) hic aliud optimum ar(gumentum) quod vbicunque tabellio perdit officium suum ... quod 
The statement is remarkably ambiguous, as it is not clear whether it refers to the validity of the instruments drafted before the dismissal of the notary or to those composed thereafter. At first, one would assume that it referred to those drafted after the dismissal. The alternative solution might appear rather plenoastic - the notary was dismissed precisely to avoid the production of further (valid) instruments. There is little need to invoke the lex Barbarius for what was done during time the appointment was perfectly valid. By contrast, referring to the lex Barbarius would make more sense if the purpose was arguing for the validity of the deeds of someone who could not lawfully make them - and so, for the instruments drafted after the notary was dismissed. Nonetheless, it is more likely that the Gloss referred to the documents already drafted before the notary's dismissal from office. The last part of the Gloss insisted on the validity of its conclusion ('hoc est verum') despite the contrary argument found in Cod.9.51.13. ${ }^{133}$ This was a rather complex text dealing with the will made by a son-in-power when his father suffered deportation. As deportation entailed capitis deminutio, the son would become sui iuris and so could make a valid will. But if the father was subsequently pardoned and restored to his former position, then the son would return under his father's potestas and the will would therefore become void. ${ }^{\mathbf{1 3 4}}$ It is now perhaps clearer why the Gloss might have singled out this lex as the main argument against its conclusion on the validity of the instruments made by the deposed notary. The reasoning of the Gloss seems to be as follows. At the time when they were made, both deeds (the notarial instrument and the testament of the son sui iuris) were valid. But the supervening loss of legal capacity of the testator led to the invalidity of his deed. Should the same happen to the instruments of the notary when he lost his capacity to draft them? ${ }^{\mathbf{1 3 5}}$ The Gloss of course answered in the negative. What is noteworthy is that it did so not by remarking the substantial difference between acts mortis causa and inter vivos, but rather by insisting on the common mistake and the public utility considerations of the lex Barbarius. Whether because of its

non ideo debent vitiari sua instrumenta. Et facitff. de offic(io) praet(orum) 1. Barbarius (Dig.1.14.3). Et hoc est verum: $\arg ($ umentum) contra(rium) tamen est C. de sen(tentia) pas(sis) 1. fina. (Cod.9.51.13).'

133 Ibid.

134 Or, at least, this was the interpretation of the Gloss, which noted that the text did not explain the problem of the validity of the will: Gloss ad Cod.9.51.13, $\mathbb{I n}$ quaestione (Parisiis 1566, vol. 4, cols. 2133-2134).

135 This seems to be also the interpretation of later jurists. Baldus, for instance, first looked at the validity of the notarial instruments already drafted by the notary who then became monk, and immediately thereafter discussed the case of Cod.9.51.13. Baldus, ad Cod.7.45.2, $\$ S i$ arbiter (Baldi de Pervsio Ivrisconsvlti clarissimi, svper VII, VIII et Nono Codicis ... Lvgdvni, typis Gaspar \& Melchior Trechsel, 1539, fol. 52va, n. 15 and 16 respectively). 
ambiguity or because of its somewhat doubtful importance (or possibly both), however, later jurists did not rely much on the Gloss' approach to the subject. When they wanted to argue that the instruments drafted after the deposition of the notary were void, they referred more often to Jacobus de Belviso (1270-1335), who repeated what Accursius had said, only more clearly. ${ }^{136}$

Rather than the Accursian Gloss, the starting point of later civil lawyers on the subject was typically the gloss of Azo. Azo invoked the lex Barbarius, with regard not to Novel 44, but to Novel 73 . This other Novel was mainly devoted to proving the authenticity of a transaction. In its third chapter, the Novel dealt with the problem of difformity between written evidence and witness report as to the content of a contract. The Gloss lingered on the probatory strength of the witnesses against that of a written instrument. ${ }^{137}$ Azo did the same. But he also noted that the Novel's chapter referred to a judgment (on the authenticity of the signature of the witness) that occurred in a far-off place - Armenia. ${ }^{138}$ So he also posed the question of the validity of a notarial instrument drafted in a remote land. The deed looks authentic, says Azo, but no one has ever heard of the notary who signed it. Is the form sufficient as to its validity? The question was extremely important at a time where forged instruments were the order of the day. Azo pronounced for the validity of such an instrument: if it was forged, he said, there would be many ways to prove its falsity. After all, he concluded, 'Barbarius Philippus was praetor almost in the form of a freeman, and the deeds he made were valid'. ${ }^{139}$ Taken alone, this quotation might point to Azo's approval of a

136 Jacobus de Belviso, ad Coll.4.7(=Nov.44) (Commentarii in Avthenticum et Consvetvdines Fevdorvm, Aureliae, 1511; anastatic reprint, Bologna: Forni, 1971): 'Item est hic argumentum quod vbicumque tabellio perdit officium suum quod est propter multas causas ... quod non ideo viciari debeant sua instrumenta vt ff. de offi(cio) praeto(rum) 1. barbarius (Dig.1.14.3), et hoc est verum dicit glo(sa). Sed tu dic quod instrumenta postea facta viciantur vt C. de suscep(toribus) et archa(riis) l. fi. aliquid lib. x (sic!) (Cod.10.72(70).15), vbi de hoc et notatur ff. de ede(ndo) 1. si quis ex ar(gentariis) $\$$ i (Dig.2.13.6.1).' Belviso was only repeating what Accursius had already said, just more clearly. Perhaps because of the ambiguity of Accursius' Gloss on the point, later jurists who recalled the same issue mentioned Belviso and not the Gloss: see e.g. Albericus de Rosate, ad Dig.1.14.3 (Alberici de Rosate Bergomensis iurisconsulti clarissimi ... In primamff. Veter. part. commentarij, Venetiis, 1585; anastatic reprint, Bologna: Forni, 1974, fol. 70vb, n. 32): ' $\ldots$ ibi loquitur in instrumentis confectis ante officium amissum, secus si postea, ut ibi per Iacob(um) de Belu(iso) uide vers(iculum) "sed quid si producitur", et uer(siculum) "et scias", et uer(siculum) "illud autem".'

137 Gloss ad Coll.6.3.3(=Nov.73.3), esp. $\$$ Cum iureiurando (Parisiis 1566, vol. 5, col. 304).

138 Coll.6.3.3(=Nov.73.3). Cf. Amelotti (1985), pp. 135-136; Ankum (1989), p. 34.

139 Azo, Summa ad Coll.6.3(=Nov.73) (Azonis svmma avrea, cit., fol. 323ra, n. 2): '... Sed quid si [tabellio] proferatur carta publica et in forma publica, et de alia terra, 
document drafted by a false notary who was widely believed to be a true one. However, read within its context, its meaning would rather seem the opposite. The simple fact that the name of the notary who drafted the instrument is not familiar should not prejudice the validity of the document. After all, if even the deeds of a slave who could not have become praetor de iure are to be kept, then a simple doubt as to the person of the notary should not suffice to void an instrument that looks perfectly regular.

This interpretation of Azo's position finds confirmation in the Margarita Legum of Albertus Galeottus Parmensis (d. post 1272), which was normally used to interpret Azo's remarks on the notary. Although not specifically concerned with the lex Barbarius, we might want to look at it briefly. Generally speaking, Galeottus' stance on the validity of notarial instruments was rather strict: even when an omission was dictated by necessity, he maintained, it would still invalidate the instrument. ${ }^{140} \mathrm{It}$ is important to keep this in mind when looking at his application of the lex Barbarius to the case of the notary. Galeottus did not invoke Barbarius' case to argue for the validity of the instruments of a false notary. Building on Azo, he only wondered whether common opinion could make up for the lack of evidence as to the notary's appointment. The problem was the same as in Azo. And the conclusion was not dissimilar either: in the absence of evidence as to the lawful appointment of the notary who drafted a document, the fact that he exercised his office publicly is evidence enough. ${ }^{\mathbf{1 4 1}}$ Thus the common opinion as to the notary's status suffices to argue for the validity of his deeds - but not of course to create him notary. As with Azo, Galeottus relied on the lex Barbarius only to make up for the lack of evidence as

vnde non cognoscitur qui scripserit? Respondeo ei esse standum, si appareat in publica forma esse facta, non vitiata in aliqua parte sui: vt C. de edi(cto) diui hadr(iani) tol(lendo) 1. fin. $\mathbb{~}$ i (Cod.6.33.3.4) ibi, qui ad hoc obijcit, probet contra: vt C. de probatio(nibus) l. sciant (Cod.4.19.25). Item videtur hec questio expediri, C. quemadmo(dum) test(amenta) aperian(tur) 1. ii (Cod.6.32.2). Nec obstat quasi quilibet possit hec conficere, quia multis modis falsitas sua reconuincetur vt $\mathrm{i}(\mathrm{nfra})$ eo (titulo) $\mathbb{\$}$ si tamen quisquam in $\mathrm{fi}(\mathrm{ne})$ (Coll.6.4). Item barbarius philippus quasi in forma liberi hominis fuit pretor, et valuerunt gesta per eum: vt ff. de offi(cio) pretoris 1. barbarius (Dig.1.14.3).'

140 'Sed quid si aliquid ex necessitate omittat nunquid uiciatur instrumentum? Dic quod sic. Et ad hoc ff. de int(egrum) rest(itutione) 1. diuus (Dig.4.1.7) et ff. de transact(ionibus) 1. cum hii (sic) $\$$ si pretor (Dig.2.15.8.17)', Madrid, BN 824, fol. $38 v a$; BNF Lat. 4489, fol. $112 v b$.

141 'Sed quid si non constet eum esse tabellionem qui dicitur confecisse instrumentum? Dic quod si publice exercebat officium illius erit ei habenda fides, ut ff. de off(icio) p(raetorum) 1. barbarius (Dig.1.14.3) et dic ut ibi no(tat) az(o) in summa C(odicis) $\$$ in aut(hentica) (Coll.6.3[=Nov.73.3]).' Madrid, BN 824, fol. 38va; Paris, BNF Lat. 4489, fol. 112vb (the latter manuscript mistakenly refers to Accursius instead of Azo). 
to the valid appointment of the notary, not to argue for the validity of his deeds in the absence of a valid appointment. While Galeottus approved of Azo's reasoning, he was less persuaded as to its scope. Notoriety may well make up for lack of evidence as to the valid appointment, so long as the problem arises where the notary is well known. But it remains only a probatory element. Invoking that notoriety elsewhere, in a place where the notary is quite unknown, would make considerably less sense. The notary might well be known in a region, and that is sufficient evidence of his appointment. If however the notarial deed is produced in a different region, pace Azo, it is far less clear whether the common opinion could support its validity. Because the lex Barbarius was invoked not to replace the requirement of a valid appointment but only to prove it, reasons Galeottus, the strength of common opinion as to the notary's appointment becomes considerably reduced when invoked elsewhere. ${ }^{\mathbf{1 4 2}}$ This opinion might have been quite widespread, as it is attested also in Belviso. ${ }^{143}$

142 'Sed pone questionem de facto. Quidam producebat instrumentum in alia prouincia factum nunquid erit ei fides adhibenda? $\mathrm{No}(\mathrm{tat})$ az(o) in summa $\mathrm{C}$ (odicis) aut(entica) de fide instrumentorum (Coll.6.3[=Nov.73]) quod sic et ad hoc C. quemadmod(um) te(stamenta) aperi(antur) l. ii (Cod.6.32.2). Alii contrarium in fi(ne) [scil., of the same Cod.6.32.2] constet illum in sua prouincia exercere officium ut in predicta 1. barbarius', Madrid, BN 824, fol. 38va; Paris, BNF Lat. 4489, fol. 112vb. The reference to Azo is not in the Parisian manuscript (as it was not a few lines above: supra, last note). The Madrid manuscript however omits the reference to the Authentica De fide instrumentorum.

143 Belviso, ad Coll.6.5(=Nov.73.5) (Belviso, Commentarii in Avthenticum, cit., fol. $45 \mathrm{rb}$ ): 'Queritur quarto quid si prefertur charta publica et in forma publica et de alia terra in loco vbi non cognoscitur qui scripsit an presumendum sit pro carta. Respondeo vt in summa huius ti(tuli) vbi hec questio formatur. Ei standum esse si appareat in publica forma esse factum non viciatum in aliqua parte sui, vt C. de edic(to) diui adria(ni) 1. fi. $\$$ i (Cod.6.33.3.1) ... Item barbarius quasi in forma liberi fuit pretor et valuit vt ff. de offi(cio) preto(rum) l. barbarius (Dig.1.14.3) ... Contra hoc videtur aperte vt s(upra) e(odem titulo) \$si vero moriantur (Coll.6.5.7[=Nov.73.7]), vbi dicitur simpliciter quod si tabellio non superest ... Item non obstat $\mathrm{l}$. barbarius quia ibi fuit communis opinio, que facit ius. Sed in casu nostro nulla erat opinio per instrumento in loco producti instrumenti apud homines nisi quatenus ex ipsa scriptura demonstrabatur.' 


\section{Chapter 3}

\section{Postglossators and Common Mistake: \\ a tale of Odofredus, Jacobus de Arena and Butrigarius}

We have seen how Accursius' comment on the lex Barbarius was likely to have been made of two different parts. The first dealt with putative freedom and its effects on the validity of the deeds, the second sought to provide a legal basis for Ulpian's speculative conclusion about the will of the people. As to the first part, Accursius added little to what other jurists, Azo especially, had already said. The overall argument was coherent enough, and Accursius just bound together its different components. The second part, however, was far more problematic. Taking literally what Ulpian had said, Accursius sought to rescue the text of the lex with a rather creative - but legally weak - interpretation, which might have gone against the opinion of other jurists.

In his effort to provide as coherent as possible a reading of the different parts of the lex Barbarius, Accursius made the validity of the deeds strictly dependent on the personal status of Barbarius. This left little choice to later jurists: either accepting his position in full, or dismissing it in toto. A first consequence was that the complex discussion about Barbarius' putative freedom was soon overshadowed by the issue of the de iure validity of his praetorship. And Barbarius could become fully praetor only if duly emancipated. To rescue Barbarius' deeds, in other words, it became necessary to accept the presumed will of the people to set him free, so that he could validly be praetor. The validity of the deeds thus required the validity of his praetorship, which in turn depended on his freedom.

What Accursius did left later jurists in a rather difficult position. Full acceptance of his Gloss required a leap of faith - or rather deliberately ignoring the weakness of some of its conclusions. On the other hand, a wholesale rejection of Accursius was no easy task, not least because of the weight that his Gloss had rapidly acquired. As a result, for more than a century most jurists adhered to its overall position - most jurists, but not all of them. Some showed signs of increasing dissatisfaction; others launched a full-scale attack against the Gloss. The earliest open attacks on the Gloss, however, did not come from the Bolognese (or anyway Italian) environment, but from the School of Orléans. That is hardly surprising - it is perhaps easier to list the occasions where the jurists 'beyond the mountains' (the ultra-montani) agreed with Accursius than to count all those where they did not. Drawing a clear-cut distinction between 'Italian' and 'French' environments is however misleading. Some among the 
most important early 'French' law professors had in fact studied in Bologna. They did not change their mind after they crossed the Alps. The seeds of doubt as to Accursius' reading of the lex Barbarius were already clearly visible in the teaching of some Bolognese jurists writing shortly after the Gloss. Indeed, if the French were the first to openly criticise Accursius' reading of the lex Barbarius, some of their Italian colleagues did not lose much time before joining them.

The academic rivalry between Accursius and some other colleagues, chiefly another eminent student of Azo, Jacobus Balduini (d.1235), is well known. ${ }^{1}$ At least in part, this rivalry was because their approach to the text was different and more sophisticated than that of Accursius, which was still mainly based on the distinctio. ${ }^{2}$ The triumph of the Accursian Gloss in effect coincided with the beginning of a different approach to the text, based on dialectics and syllogism. ${ }^{3}$ This is particularly visible in the lex Barbarius, especially comparing one generation of jurists with the next. Even in Bologna, as we shall see, the predominance of the Gloss hardly meant unanimity of opinion.

We will first focus on the Italians, then (in the next chapter) move to the French and to their influence among the Citramontani (i.e. those 'within the mountains' - the Italians), and (in Chapter 5) conclude with the last great Italian jurist to side with the Gloss - Bartolus. Admittedly, our journey will be somewhat less linear: the division will be based on the personal stance of each jurist, not on his geographical location. Therefore, some Italian jurists - even Bolognese ones - will be placed among the French.

\subsection{Variations on the Gloss: Odofredus de Denaris}

Our starting point is the position of those Bolognese jurists writing a few decades after the Gloss. Already by then the limitations of Accursius' reading of the lex Barbarius were becoming manifest. Even those who sought to defend his

1 E. g. Meijers (1959a), p. 33; Tuck (1998), p. 16, and esp. Sarti (1990), pp. 63-65. On the life and works of Balduini, as well as his position in the Bolognese university, see the same Sarti (1990), pp. 1-68, with ample literature (updated in Sarti [2013], pp. 1095-1096). On this 'other' school and its difference with Accursius' approach, mention shoud be made of the work of Bellomo, esp. Bellomo (1992), pp. 177-179; Bellomo (1995), pp. 174-175; Bellomo (1997b), vol. 1, pp. 131-135. Bellomo has often pointed out the continuity between Ugolino, Balduini and Odofredus. On the point see also Bellomo (1982), pp. 199-203, and Bellomo (1992), pp. 176-180 and 189. On the fortune of Accursius' Gloss (and so, of his approach) over the 'rival' school see again Bellomo (1992), pp. 182-194.

2 Errera (2006), esp. pp. 5-66, where ample literature is quoted. See also Errera (2007), pp. 79-97.

3 Errera (2007), pp. 101-119. 
conclusions had to adopt a different approach. To accept the outcome of the Gloss, in other words, it was necessary to go beyond it.

As often happens with mid-thirteenth-century authors, the commentary of Odofredus de Denaris (d.1265) is in effect a combination of his glosses, probably coming from some students' notes. In the case of his writings on the lex Barbarius, however, such notes appear particularly wanting in coherence sometimes they look more like a patchwork of his utterances rather than a consistent report of his ideas. Occasionally, an excerpt is even taken from other lectures. ${ }^{4}$ The result is neither systematic nor logically coherent, ${ }^{5}$ and it requires some flexibility in its interpretation. ${ }^{6}$ The disappointing quality of Odofredus' commentary on our text is not the only reason a modern reader may regret he was born too late to attend the actual lectures of its author. There are at least two other reasons. The main one lies in Odofredus' importance in applying a dialectical approach to the law, and so in his role in the transition from postglossators to proper commentators. ${ }^{7}$ The other one is that Odofredus was genuinely amusing, and knew well how to capture the attention of his audience.

4 In the comment on the lex Barbarius, for instance, when discussing the problem of the lex Iulia de ambitu the text refers to two leges: Dig.50.12.1 and the lex Barbarius itself. The text even invites the reader to look at Odofredus' commentary on the lex Barbarius, where Odofredus dealt in more depth with the subject: 'et sic intelligit, quod dicit aug(ustinus) qui episcopatum desiderat, bonum opus desiderat, vt ff. de polli(citationibus) 1. i $\$$ i et $<\$>$ si quis (Dig.50.12.1.1 and 6), et 1. barbarius (Dig.1.14.3) et ibi plenius dixi.' Odofredus, ad Dig.1.14.3 (In undecim primos pandectarum libros ... Lectura, Lvgdvni, P. Compater \& B. Guido, 1550; anastatic reprint, Bologna: Forni, 1967, fol. 28vb, n. 1).

5 Suffice it to report the main arguments in Odofredus' commentary on the lex Barbarius in the order in which they appear: (1) the lex Iulia de ambitu is no obstacle to Barbarius' praetorship; (2) common mistake makes law, and so Barbarius' election is valid; (3) Barbarius' deeds have the force of res judicata and should not be revoked, but that is only out of fairness (de equitate), not according to strict law (de rigore iuris); (4) the Roman people and the prince may set Barbarius free out of public utility but they have to compensate his master.

6 On Odofredus' commentary on the lex Barbarius, manuscript sources are not particularly useful. See e. g. Pal. lat. 732, fol. $4 \mathrm{ra}$.

7 The role of Odofredus has been long underestimated. Only recently has his dialectical approach been studied with more interest (cf. Padovani [2011], pp. 365-369), and put in relationship with the later and crucial developments in the period between the end of the thirteenth century and the beginning of the fourteenth: see esp. Padovani (2017), pp. 11-12 and 139-153. Cp. however Errera (2006), pp. 107-108. While the terms 'postglossator' and 'commentator' are often used coterminously, in this work the second will not include those jurists living in the mid and late thirteenth century. Among the manifold differences between late thirteenth-century jurists and fourteenth-century ones perhaps the main one is the distinction between text and rationale of the lex. Cf. Errera (2006), pp. 94-114. See further Errera (2007), pp. 97-149. 
These two points may be seen together: looking at the captivating Odofredian style, we can also appreciate its distance from the exegesis of Accursius.

In his typical style, Odofredus opens his lecture on the lex Barbarius with a very colourful and imaginative picture of the situation: ${ }^{\mathbf{8}}$

Gentlemen, this is a good law and you may see many good things about it ... There was one called Barbarius Philippus, he came from the province, or from France, and he was a slave. Either because he was exceedingly frightened of his master, or because the master often punished him, he escaped from him and went to Rome. But in Rome he did not portray himself as a slave. Rather, he dressed up in sumptuous and ornate robes and spoke much and in a pompous style. With his look and his bombastic speeches he threw dust in the eyes of the Romans, so that the day they had to elect the new praetor they chose him. Once elected he did not stay in his praetorship as a runaway slave, but like an emperor! And he did much in his office: he decided many things, issued decrees and pronounced many decisions. And so the Romans were very happy with him. His master came to hear about all that, and so he thought to go to Rome and see him. So he went to Rome and found him sitting in court. When Barbarius Philippus saw his master, he turned his head elsewhere and pretended not to know him. But one day the master secretly went to him and said: 'you know me'. Barbarius said: 'I do not'. The master said: 'you should know me well from the time I grabbed you by the hair. For I am your master, and you my slave, who run away from me.' But he replied, 'I have no idea what you are talking about'. The master said: 'since you claim that you do not know me, I will let the Romans know about this.' And so he went through the city and told the Romans: 'this is my slave, and I shall prove it to you!'

Odofredus, ad Dig.1.14.3 (In undecim primos pandectarum libros ... Lectura, cit., fol. $28 v a$, n. 1): 'Signori ista $1(\mathrm{ex})$ bona $1(\mathrm{ex})$ est et plura bona notabuntur vobis circa eam ... Quidam barbarius philippus nomine vocabatur, et erat de prouincia, vel de francia et erat seruus. Quia ibi erat dominus suus nimis preternus (sic), vel quia sepe corrigebat eum fugit a domino suo, et venit romam. Dum esset rome incedebat in magno habitu et pomposo non autem gerebat se tanquam seruus, et valde pompose loquebatur. Iste ex ornatu suo et ex boatu suo periecit puluerem in oculos romanorum, ita quod vna die dum tractaretur de pretore eligendo, romani creauerunt eum in pretore. Cum iste esset creatus pretor, non stabat tanquam seruus fugitiuus in sua pretura, sed tanquam imperator. Iste in officio suo multa fecit, et statuit, et decreuit, multas tulit sententias, ita quod factum suum multum placuit ciuibus romanis. Deuenit istud in noticiam domini sui: vnde cogitauit ire et videre eum: vnde venit in vrbem, et inuenit istum sedente pro tribunali. Barbarius philippus dum vidit ipsum, auertit caput in aliam partem, et dissimulauit cognoscere ipsum. Tamen dominus vna die in secreto intrauit ad eum, et dixit ei "cognoscis tu me". Dixit ipse, "non"; dixit dominus "bene deberes me cognoscere, vnde traxi iam te per capillos: quia sum dominus tuus, et tu es seruus meus qui fugisti a me". Dixit iste "nescio quod dicas". Dixit dominus "ex quo tu dicis, quod non cognoscis me, deducam hoc in noticiam romanorum". Vnde ibat per ciuitatem et dicebat romanis, "iste est seruus meus, et de hoc faciam vobis fidem". 
After such an opening, Odofredus knew he commanded the full attention of his students. ${ }^{9}$ And he used it to insist on the validity of Barbarius' election as praetor, focusing especially on the importance of the common mistake.

Already by his time (he might have delivered his lecture around the middle of the thirteenth century), this solution was no longer unanimous: 'As to the first question, we say that he was praetor, although some say he was not. ${ }^{, 10}$ The remark is interesting, though it is difficult to identify those early dissenting voices with precision. While Odofredus himself was not one of them, he was aware of the main weakness of the Accursian approach. This probably led him to stress the relevance of the common mistake more than the Gloss itself did.

Odofredus allows that the text of the lex Barbarius did not state unequivocally that Barbarius was praetor. 'Some argue - he says - that the text [likely, the part referring to Pomponius] is to be read not as stating a fact (assertive) but rather as raising a question (interrogative). ${ }^{\mathbf{1 1}}$ In effect, he continues, in the text the possible confirmation of the people or the prince seems to occur only when the true status of Barbarius is discovered, and so sometime after Barbarius' appointment as praetor. So, he says, even accepting that Barbarius did eventually become free and a true praetor, one might conclude that he remained a slave until that moment. ${ }^{12}$ The point was serious, for it would entail the invalidity of the deeds made between election and manumission. Odofredus' initial answer appears remarkably weak: he does not address the issue, but simply invokes the literal tenor of the lex Barbarius (as well as the authority of Bassianus and Azo) to dismiss the objection. ${ }^{13}$ In fact, he was only following the order of the Gloss. Shortly thereafter Odofredus comes back to the point. As already noted by Accursius, one of the main texts pointing against the validity of Barbarius' appointment was the lex Herennius (Dig.50.2.10): the mere discharge of the

9 Odofredus' peculiar style is often noted but seldom studied, and even more rarely appreciated as a teaching tool. An interesting exception can be found in the work of Tamassia (1981), pp. 48-87.

10 Odofredus, ad Dig.1.14.3 (In undecim primos pandectarum libros ... Lectura, cit., fol. 28va, n. 1): 'Ad primam questionem dicimus, quod fuit pretor; licet quidam dicant, quod non.'

11 Ibid., $\mathbb{\$}$ designatus est (fol. 28vb, n. 1): 'Or signori, hic consueuit queri, an in litera determinetur prima questio que est, an barbarius philippus fuerit pretor, et dicunt quidam quod non, quia litera ista non assertiue legenda est, sed interrogatiue.'

12 Ibid., 'Item si seruus erat, magistratum habere non poterat, vt infra de iudicijs 1. cum pretor (Dig.5.1.12.2), ita talis debet dici quod fuerit medio tempore qualis inuenitur, vt C. si seruus export(andus) vt 1. moueor (Cod.4.55.4) et sic seruus.'

13 Ibid., 'Sed certe nos dicimus secundum Joannem [Bassianus] et Azo(nem), quod ista questio determinatur in litera: quia in litera aperte dicitur, quod fuit pretor. Et ideo legimus eam plane sine aliqua subauditione, et verum est.' 
duties of an official does not make one such de iure. To avoid the application of this text, and again following the Gloss, Odofredus introduces the issue of the common mistake: much unlike Herennius, Barbarius was commonly believed to be free. Several leges, continues Odofredus, show that it is well possible to treat something as valid because it is widely believed so. It follows that Barbarius should be treated as free, and so also as praetor. A common mistake makes law, he says, in the sense that it bestows validity on something that would otherwise remain void. ${ }^{\mathbf{1 4}}$

Odofredus introduces the common mistake in the same way as the Gloss did, but the similarities between Accursius and Odofredus stop there. While Accursius interpreted the common mistake as presumed consent, for Odofredus it remains a mistake. Subordinating the effects of the common mistake to the presumed will of the people, as Accursius did, would pose an obvious problem:

Now gentlemen, here you have that if the Roman people had known that Barbarius Philippus was a slave, they would have set him free and then they would have elected him praetor. But he will never have become free, for they did not know that he was a slave. ${ }^{15}$

To avoid Accursius' impasse, Odofredus opts for a different approach: setting aside the presumptive will of the people ${ }^{\mathbf{1 6}}$ and focusing on the common

14 Ibid., $\mathbb{S}$ designatus est and $\$$ praetura functum (fol. $28 v b$, n. 1 and 2 respectively): 'dicunt ipsi [those who deny the validity of Barbarius' appointment] quod non fuerit pretor, quia sola salarii prestatio non facit eum decurionem qui non est, vt infra de decur(ionibus) 1. herennius (Dig.50.2.10). Ita iste petijt preturam non potuit eum facere pretorem cum esset seruus ... Et eum pretorem fuisse, quia communi opinione putabatur liber, et tanquam liber creatus est pretor igitur communis opinio facit ius, vt infra de supplemento legato $(s i c)$ l. iii in fin(e) (Dig.33.10.3.5) sic et alibi valet ratione communis erroris, quod alias non valeret. Institu. de testamentis $\$ sed cum (Inst.2.10.7) et C. de testamen(tis) et quemadmodum te(stamenta) or(dinantur) 1. prima (Cod.6.32.1) et C. de sent(entiis) 1. secunda (Cod.7.45.2) et infra ad mace(donianum) 1. iii (Dig.14.6.3). Non $\mathrm{ob}$ (stante) sola salarij prestatio non facit decurionem si decurio electus fuit, quia iste fuit electus pretor, et communi opinione putabatur liber, vnde erit pretor. Item non ob(stat) quod ipse erat seruus, igitur pro mortuo reputatur, quia quantum ad ius ciuile attinet etc., et quia seruus igitur abesse causa reipub(lica) non potest. Item si seruus erat, igitur habere magistratum non potest, quia illud verum est si sciretur seruus. Sed vbi creditur liber, et communis opinio est quod sit liber, facit eum pretorem vt hic dicitur.'

15 Ibid., $\$$ Observandum est (fol. 29ra, n. 3): 'Or signori habetis hic si populus romanus scisset barbarium philippum servuum, fecisset eum liberum, et postea creasset pretorem: sed nunquid erit liber effectus cum ignoravit eum servuum.'

16 Odofredus however agreed with the Gloss, if only in abstract terms, as to the interpretation of Ulpian's statement on the prince: he had the same right as the people to set Barbarius free. Ulpian's 'multo magis' had nothing to do with a higher level of sovereignty, but with the simple fact that the prince is one and the 
mistake. The advantage is clear: the common mistake cures the invalidity of the election, for it dispenses with the cause of Barbarius' ineligibility - his servile condition. ${ }^{17}$ Odofredus' reliance on the common mistake left little room not only for the presumed will, but also for the putative freedom, which was another important point in the Accursian Gloss. The common mistake leads to the validity of the election because it neutralises (so to speak) the legal incapacity of the slave. But Barbarius could not be at the same time both free and slave. A careful discussion of the effects of Barbarius' possession of his freedom was best avoided, for it would have highlighted the underlying invalidity of his election.

Odofredus relies on the common mistake, but he does not clarify its precise effects. Does the common mistake set Barbarius truly free or does it simply bar the exception as to his underlying legal incapacity? Although the point is not entirely clear, from Odofredus' description of the effects of the common mistake ('factus est pretor et liber et valent statuta ... quia communis error facit ius'), it would seem that the common mistake operates at a substantive level and not just at a procedural one, so that Barbarius becomes free de iure. A second element Odofredus' insistence on the duty of the Roman people to compensate Barbarius' master for the emancipation of his slave ${ }^{\mathbf{1 8}}$ - is not resolutive. Other

people many. Cf. supra, last chapter, note 89. It is worth reporting Odofredus' comment on the point, if only for his imaginative style: 'hic est ratio, quia populus est vniuersitas: vnde facile dissentirent, vt ar(gumentum) i(nfra) de (receptis qui) ar(bitrium) 1. si vnus $\$$ principaliter (Dig.4.8.17.6), et ideo vniuersitates consentiunt cum difficultate, vt i(nfra) de liber(tis) vniuersi(tatum) l. vnica (Dig.38.3.1), et ait Satirus, mille hominum species est rerum discolor vnus velle suum cui datur, nec voto viuunt vno. Nam homines non concordant in specie et ideo dicit mille homines species similiter res non concordant adiuicem imo infiniti sunt colores rerum sed vnum est in quo satis concordant, scilicet quod homines leuiter discordant imo quod plus est si sunt plures homines in aliquo loco et proponitur aliquid coram eis vt consulant quid sibi placet si vnus surgit, quod cuilibet datur votum suum' (ibid., $\mathbb{\$}$ Observandum est, fol. 29ra, n. 2).

Ibid., n. 3: 'dicimus quod sic, quia communis error totius populi romani facit ius, vt $s$ (upra) dixi. Vnde si credebatur eum liberum ipsa electione factus est pretor et liber et valent statuta ab eo quod totum procedit, quia communis error facit ius, et propter autoritatem rerum iudicatarum et quia legitime factum est non debet superuenienti casu retractari vt $\mathrm{C}$. de admi(nistratione) tut(orum) 1 . $s<$ an $>$ cimus (Cod.5.37.25) et $\mathrm{i}(\mathrm{nfra})$ de itinere actuque pri(vatu) 1. i. in fi(ne) et 1 . seq. (Dig.43.19.1-2).'

18 Ibid.: 'Item not(andum) quod populus romanus servuum tui privati (sic) ob publicam vtilitatem potest ad libertatem producere dato precio, similiter et imperator, vt C. per quibus causis serui acci(piunt) liber(tatem) 1. vlt(ima) (Cod.7.13.4) ... Similiter et populus romanus et imperator potest rem alicuius priuati confiscare ob publicam vtilitatem dato precio ut $\mathrm{i}(\mathrm{nfra})$ de rei ven(dicatione) 1. item si verbe $\mathbb{S}$ i (Dig.6.1.15.1) et $\mathrm{i}$ (nfra) loca(ti) et con(ducti) 1. si 
jurists who denied Barbarius' freedom discussed the issue of expropriation just in abstract terms, and simply because it was mentioned in the Gloss. ${ }^{19}$

Given the central position that the common mistake occupies in Odofredus' reasoning, one would expect to find it coupled with public utility - common mistake makes law because (and, perhaps, to the extent to which) it furthers public utility. But that is not the case. This seems hardly imputable to an omission in the notes of his students. ${ }^{20}$ Just like the Gloss, Odofredus insisted on the importance of public utility both before and after speaking of common mistake: afterwards, when talking about Barbarius' (hypothetical) manumission by the people; ${ }^{21}$ and beforehand, when rejecting the classical objection that Barbarius' election contravened the lex Iulia de ambitu. What is surprising is that he did not mention public utility during his discussion of common mistake.

Odofredus' use of public utility when discussing the lex Iulia is particularly relevant. We have seen how Accursius, following Azo, provided three different solutions as to its application to Barbarius' case (what is done should not be reconsidered; the lex Iulia does not apply to public requests; the lex Iulia no longer applies in Rome). Both Azo and Accursius opted for the third one. ${ }^{22}$ Odofredus also speaks of three alternatives, but he lists only the first two. Between them, he clearly shows his preference for the second one, arguing for the validity of the public request on the basis of the petitioner's intent to further public good. In so doing Odofredus builds on Azo and especially Bassianus, ${ }^{23}$ explicitly linking public request with public utility. If one publicly seeks an office not for personal gain but to accomplish much-needed reforms, says Odofredus, he can be hardly accused of contravening the lex Iulia, let alone of simony. ${ }^{24}$

fundum (Dig.19.2.33) et i(nfra) de euict(ionibus) 1. lucius (Dig.21.2.11 pr), sed alias nisi propter publicam vtilitatem non potest manumittere vel confiscare nec $\mathrm{ob}$ (stat) quod omnia sunt principis: vt C. de quadri(ennii) pres(criptione) 1 . bene a zenone (Cod.7.37.3) quod illud est verum quo ad protectionem.'

Further, as Odofredus discarded the presumed will of the people to set Barbarius free, it would be difficult to explain why the same people should pay for an expropriation that occurred without their knowledge.

20 Cf. also ÖNB, 2265, fol. 13ra, where a second and later (likely, fifteenth-century) layer of glosses (at the bottom) provides a summary of both Odofredus and of Bartolus on the point. For Odofredus, the hand only notes: 'Communis error facit ius. S(ingularis) error facit non ius. Odof(redus).'

21 Supra, this chapter, note 18.

22 Supra, $\$ 2.2$.

23 Supra, last chapter, note 38.

24 Odofredus, ad Dig.1.14.3, \$Designatus est (In undecim primos pandectarum libros ... Lectura, cit., fol. 28va-b, n. 1): 'Or signori secundum Jo(hannem Bassianum) et Azo(nem) hic op(inio) ita si barbarius philippus petijt preturam rome. Ergo iure nostro commisit in l. iu(liam) ambitus et iure can(onico) simoniam vt C. ad 1. iu(liam) ambitus l. vnica (Dig.48.14.1) et C. de epi(scopis) et cle(ricis) <l. $>$ si 
The all-important role of public utility in Odofredus' discussion of the lex Iulia becomes remarkably marginal in his explanation of the common mistake. Odofredus hints at their relationship only once, and very briefly. When the mistake as to Barbarius' status is found out, says Odofredus, his previous deeds would stand because they have the strength of res judicata. Although this alone might not be sufficient ground, he adds, out of fairness (de aequitate) the deeds should not be revoked. ${ }^{25}$ Odofredus does not elaborate further on the point. This

quemquem (Cod.1.3.30). Si commisit in 1. iu(liam) ambitus, factum est lege prohibente. Vnde quicquid ab eo vel ob id sequitur, cassum et inutile est, vt C. de leg(ibus) et co(nstitutionibus) 1. non dubium (Cod.1.14.5). Vnde non sit pretor, quod hic statim dicitur. Ad istud vos dicetis tribus modis. Et vno modo sic: hic barbarius philippus petijt preturam rebus et factis et bonis operibus mediantibus, vnde sibi licuit hoc facere, nec committit hoc casu in lege iu(lia) ambitus, iuxta dictum agustini qui episcopatu desiderat bonum moribus, videlicet desiderat non vt presit, sed ut prosit. Si autem barbarius philippus petijsset preturam precio vel precibus, quia commisisset in legem iu(liam) ambitus non fuisset pretor, vt in 1. contraria (i. e. Dig.48.14.1). Vel potest dici secundo modo secundum Jo(hannem Bassianum): aut petitur dignitas secularis vel ecclesiastica precibus vel data pecunia sub capa vel mantello et tunc committitur ambitus iure nostro, vel simonia iure cano(nico) et iste non adipiscitur honorem lege refragante. Et ita loquuntur l(eges) ille que signantur pro contrariis. Sed si aliquis petijt honores secularem vel eccesiasticum non clam sed palam, quia dicit vos estis in discordia de isto officio, vnde si vos eligitis me, bene facitis et mihi placet: quia nolo ideo habere vt non faciam mihi vtilitatem, sed vt reformem vos. Et tunc non committitur ambitus, vt i(nfra) de pollicit(ationibus) l. i $\$$ i et l. si quis (Dig.50.12.1.1 and 50.12.2pr). Nam qui petit clam videtur delinquere, qui petit palam non videtur delinquere, sed potius errare. Similiter si tutor convertit in usus suos pecuniam pupilli clam, tenetur ad centesimas usuras si palas ad legitimas vt i(nfra) de admi(stratione) tuto(rum) 1. non existimo (Dig.26.7.54) ... Et sic exponimus vno modo barbarius philippus petijt preturam moribus bonis et operibus mediantibus, quod sibi licuit facere.' The same rationale, continues Odofredus to better explain it, also applies in canon law: 'Si autem petit quis honorem palam, nam veniet bonus homo coram principe et dicet, domine talis episcopatus est inter tartaros: nullus vult eum habere eo volo eum habere, non vt $\mathrm{pr}<\mathrm{a}>\mathrm{esim}$, sed vt prosim, vt edificem, et volo ibi expendere pecuniam meam. Iste non est simoniacus de iure cano(nico) vel de iure ciuili non committit in 1 . iu(liam) ambitus. Et sic intelligit, quod dicit aug(ustinus) qui episcopatum desiderat, bonum opus desiderat.'

25 Ibid., $\mathbb{S}$ hoc enim humanius est (fol. 29ra, n. 2): 's(cilicet) propter autoritatem rerum iudicatarum: nam et libertas data ab eo qui postea servus pronunciatur, vt in qui et a quibus ma(numissi) li(beri) 1. competit (Dig.40.9.19). Vnde not(andum) licet forte de rigore iuris videantur non valere tamen de equitate est dicendum quod valeant, quia equitas praefertur rigori iuris, vt C. de iud(iciis) 1. placuit (Cod.3.1.8) et ar(gumentum) C. de pact(is) l. minorem [sed 'maiorem', Dig.2.14.8] et maxime propter autoritatem rerum iudicatarum quod multa sunt que alias non fierent propter autoritatem rerum iudicatarum vt $s$ (upra) de iusti(tia) et iur(e) l. vlt(ima) (Dig.1.1.11).' 
way, the relationship between public utility and common mistake remains in the background. One has the impression that Odofredus brings up the issue of validity de aequitate only because it was Ulpian's solution to the entire lex Barbarius, so it could not be omitted.

The position of Odofredus on some related texts would confirm this impression. Whenever invoking the common mistake in support of the validity of the deeds, Odofredus always omits any reference to public utility. In some occasions that is unsurprising, especially with regard to the Pauline text on the bequest of the silverware (Dig.33.10.3.5). Commenting on that text Odofredus accepts the reading of the Gloss, ${ }^{26}$ but he is more attracted to the possibility that the prince, being human, might just have made a mistake. Building on this hypothesis, Odofredus focuses on the effects of a widespread mistake, arguing that it does create law. ${ }^{27}$ The silence on common utility is therefore hardly surprising.

In a second case, however, the exclusive focus on the common mistake appears less neutral as to the role of public utility: the case of the slave-arbiter (Cod.7.45.2). ${ }^{28}$ There, Odofredus adheres to the interpretation of the Gloss: a slave mistakenly believed free when he rendered the judgment. Odofredus' explanation is entirely - and very explicitly - based on common mistake. ${ }^{29}$ In

Supra, $\$ 2.5$, text and note 110 .

27 Odofredus, ad Dig.33.10.3.5, \Error (D[omini $]$ Odof[redi $]$... perelegans et elaborata elucidatio, in nouem posteriores libros Infortiati ... Lvgdvni, 1550; anastatic reprint, Bologna: Forni, 1968, fol. 55ra): '... no(tatur) hic inspecta hominum consuetudine vasa argentea non sunt in suppellectili propter hominum seueritatem licet imperatores vtantur. Sed hic error principis facit ius, $i(d$ est), cum imperator possit ius condere, si facit aliquid non eo animo vt sit iudex, tamen ex certa scientia pro iure habetur. Nam communis error facit ius vt $s$ (upra) de offi(cio) pre(torum) 1. barbarius (Dig.1.14.3). Sed quomodo error cum omnia iura habeat in pectore et non verisimile pretorem errare, C. de testamentis 1. omnium (Cod.6.23.19). Respondo hic non videtur errare, tamen errare potest in eo quod homo est, quia omnium habere etc. vt C. de veteri iure enu(cleando) 1. ii (Cod.1.17.2pr).'

28 Text supra, last chapter, note 62.

29 Odofredus, ad Cod.7.45.2, $\mathbb{S}$ Si arbiter (Odofredi ... in secundam Codicis partem, Praelectiones ..., Lvgdvni, 1552; anastatic reprint, Bologna: Forni, 1969, fol. 118vb): 'In 1(ege) ista ponitur talis casus. Quidam fuit delegatus iudex inter me et te: iste iudex sententiauit diffinitiue: et tempore delegationis et tempore diffinitionis cause, ab omnibus liber reputabatur: sed post latam sententiam apparet quod est seruus: nunquid sententia $a b$ eo alias rite lata, irritabitur: Respondet quod non ... in communi opinione liber putabatur ... et hoc casu nulla est dubitatio in l(ege) ista: quia quod ab initio vt s(upra) de admi(nistratione) tu(torum) l. sancimus (Cod.5.37.28pr), vel aliter depulsus est, $\mathrm{i}(\mathrm{d}$ est) quia apparet cum antea fuisse seruus: vnde habetis, si communis opinio iudex qui erat seruus reputabatur liber, valet quod ab eo factum est. Vnde ex l(ege) ista 
itself, that is not surprising: the slave-arbiter pronounced a single judgment, so the utility in keeping his decision is not public but private. However, Odofredus' open reliance on the effects of common mistake seems to question the role of public utility. If common mistake suffices to bestow validity on what would otherwise be void, then there is no reason to invoke public utility, nor to limit its validity to the cases where the common mistake affects a large number of people and not a single litigant.

A third case seems to confirm as much. There, bringing up the issue of public utility would have been all too easy - but Odofredus did not do this. This was the case of the false notary. If one is widely regarded as being a notary and is not, says Odofredus, one's instruments will be valid nonetheless. ${ }^{30}$ The common mistake as to the notary's condition is sufficient to bestow validity on his deeds. Odofredus' position on the false notary is of particular interest because it openly diverges from that of both Azo and Accursius. ${ }^{31}$ The point is of some importance and must be stressed: it is the first time (at least, that we know of) that a jurist moved from the lex Barbarius to argue for the validity of the acts carried out by someone lacking any title whatsoever (that is, not even an invalid one). In applying the lex Barbarius in favour of what is done by a plain impostor, Odofredus does something new and in open contrast with his predecessors. As such, one would expect him to highlight both the main elements of the lex Barbarius: not just common mistake, but also (and especially) public utility. In order to justify the validity of the false notary's instruments, in other words, the obvious thing to do would be to refer to the prejudice that many people would suffer if the instruments were declared void. But Odofredus does not do this: just as in the lex Barbarius, he simply remarks how 'common mistake makes law'. ${ }^{32}$ Common mistake is not a reason to invoke public utility considerations, it

colligetis, quod communis error excusat et ad hoc facit $s$ (upra) de tes(tamentis) 1.i (C.6.23.1) et ff. de offi(cio) preto(rum) 1. Barbarius (Dig.1.14.3) et ff. de sup(pellectili) le(gata) l. ii<i> in fi(ne) (Dig.33.10.3.5).'

30 Odofredus, ad Dig.1.14.3, \$observandum est (In undecim primos pandectarum libros ... Lectura, cit., fol. 29ra, n. 3): 'Item not(andum) quod communis error totius populi facit ius: ad istud accedit C. de testa(mentis) 1. <i. $>$ (Cod.6.23.1) cum similibus suis s(upra) dictis. Ex quo collige ar(gumentum) quod si aliquis in aliquo loco communi opinione putatur tabellio, et non sit, quod eius instrumenta sunt publica et valida, quia communis error facit ius, vt $s$ (upra) dixi.' Cf. Leipzig, UB, 878, fol. 19va-b, lower margin.

31 Although it does not seem very likely, it cannot be ruled out that Odofredus misinterpreted Azo. Azo discussed the validity of the instruments drafted by an unknown but possibly genuine notary, but he did so in a somewhat ambiguous manner. if taken out of context, his words could be easily misinterpreted: see supra, $\$ 2.6$, text and note 139 .

Supra, this chapter, note 30 . 
suffices by itself. Thus the remarkably marginal role of public utility in Odofredus would seem intentional also to a modern reader - just as it did to the jurists writing after him.

Odofredus' application of the lex Barbarius to the false notary is of interest also for another reason: the change in the object of the common mistake. In the lex Barbarius, Odofredus applies the common mistake to the person of Barbarius, not directly to his deeds. Barbarius' deeds acquire validity because the common mistake allows Barbarius to be considered as free and so as praetor. In the case of the false notary, on the contrary, Odofredus applies the common mistake directly to the deeds, not to the person. That of course is the only way to give validity to the instruments drafted by an impostor. However, skipping the source to reach the deeds directly meant allowing for an indiscriminate application of the principle. If common mistake sufficed to bestow validity on the deeds, the position of the person who made them would become wholly irrelevant.

Odofredus' insistence on the role of the common mistake avoided Accursius' problems with the presumed will of the people. His argument was probably stronger than that of Accursius, and was employed to reach the same conclusions. The common mistake as to Barbarius' status cured the defect in his election and thus allowed for the validity of his deeds as praetor. When applied to other situations where the validity of the deeds could not depend on that of their source, however, the strength of Odofredus' argument becomes a major weakness. The point would not be missed by later jurists.

\subsection{The dissent of Jacobus de Arena}

If Odofredus had his reservations about some arguments of the Gloss, he certainly agreed with its conclusions: not only are Barbarius' deeds valid, but Barbarius himself becomes free and therefore also praetor. A generation later, however, things were already beginning to change: criticism from other jurists was no longer limited to the arguments employed by the Gloss, but also began to reach its conclusions.

The first Italian jurist traditionally considered to have denied Barbarius both freedom and praetorship was the Paduan law professor Jacobus de Arena (c.1220-post 1296). ${ }^{33}$ Whether this was actually the case is somewhat doubtful. It is however true that Jacobus de Arena's approach to the lex Barbarius was very

33 The biographical data of Jacobus de Arena are particularly unclear. It is generally assumed that Jacobus started teaching in Padua in the first years of the 1260s, and Fulgosius (Raphael de Fulgosiis, 1367-1427) reported that Jacobus de Arena did not receive his doctorate before he was forty years of age. Hence the usual conclusion that he was born in the early 1220 s. The point is of little relevance in itself, but it might help to establish a link with the first known Italian jurist who 
different from that of Odofredus, and even more from that of Accursius. Jacobus de Arena focused mainly on the validity of the deeds, and only incidentally on the validity of Barbarius' appointment. As we will see, these two points are deeply related.

In his usual abundance of information on the opinion of the others, Albericus de Rosate (c.1290-1360) lists Jacobus de Arena, his student Oldradus de Ponte (d.1335) and Jacobus de Belviso (1270-1335), together with Petrus de Bellapertica (c.1230-1308). For these jurists, says Albericus, the lex Barbarius would pose only one question: the validity of Barbarius' deeds. ${ }^{34}$ As to the freedom issue again according to Albericus - Jacobus de Arena and many other jurists maintained that Barbarius did not become free. ${ }^{35}$ On this basis, continues Albericus, they also excluded the validity of his praetorship. ${ }^{36}$

Had Albericus been as accurate as he was liberal with the amount of information he supplied on other jurists, we would know a great deal more on early postglossators. While the position of Jacobus de Arena was most probably not as described by Albericus, his remark is interesting in that it would

attacked the entire approach of the Gloss on the lex Barbarius - Guido da Suzzara. The possibility that Jacobus de Arena studied under Suzzara is based mainly on his own remark: 'Sed certe audiui hoc a doctore magno domino Guidone de succa ...' (Iacobi de Arena Parmensis ... Commentarij in vniversum Ius civile ..., Lugduni, 1541, ad Cod.3.1.1). Cf. Savigny (1829), vol. 5, p. 350, note 66 (p. 388 , note $f$, in the $2^{\text {nd }}$ edn. of 1850 ). If Jacobus de Arena started to teach in Padua in the early 1260s, then he could have been Suzzara's student only if he had remained a student until his Paduan appointment (hence the relevance of the time of his doctorate). For an overview on Jacobus de Arena's life and work see Lange and Kriechbaum (2007), pp. 435-444, and Quaglioni (2013), pp. 1099-1101, where ample literature is listed.

34 Albericus de Rosate, ad Dig.1.14.3 (In primamff. Veter. part. commentarij, cit., fol. 65ra [sed 69ra]), n. 2: 'quaero quae lectura sit uerior, utrum glo(sae) quae dicit, quod hic formantur tres quaestiones. Vel Odof(redi) qui dicit hic formari quatuor quaestiones quarum quarta est, si populus Romanus scisset eum seruum an liberum effecisset, an lectura Oldr(adi de Ponte) et Pe(tri) de Bel(lapertica) et Iaco(bi) de Are(na) quod hic fit una quaestio tantum s(cilicet) de gestis coram Barbario an ualeant. Credo, quod ista ultima sit melior: nam prima et tertia quaestio, $s$ (cilicet) an Barbarius fuerit praetor uel liber, non bene possunt elici ex tex(to).' According to Albericus, the same last position was also shared by Belviso: 'et hanc etiam sequitur Iac(obus) de Bel(viso)' (ibid., fol. 70rb, n. 20). Ibid., fol. 65va (sed 69va), n. 15: 'quid dicemus? Iac(obus) de Are(na), Rich(ardus Malumbra) Old(radus da Ponte) et fere omnes citramontani, et ultramontani reprobant op(inionem) gl(osae) et dicunt, quod non fuit liber.' Cf. next note. Ibid., fol. 70rb, n. 20: '... Alia lectura fuit Iaco(bo) de Are(na) quod ponat unam $\mathrm{q}$ (uaestionem) $\mathrm{s}$ (cilicet) an fuerit praetor, et an gesta coram eo ualuerint. Et tenet communem opi(nionem) Doctorum, quod non fuerit praetor, nec liber.' When looking at Albericus, we will however see that his sweeping statement as to the 'common opinion of the doctors' should not be taken too seriously: infra, pt. III, $\$ 9$. 
suggest Jacobus de Arena's influence on the next generation of jurists (some of whom were Albericus' own teachers). ${ }^{37}$ It is therefore useful to look briefly at what Jacobus de Arena might have actually said on the matter. The thought of Jacobus de Arena is also important because his position represents one of the first cases where a Citramontanus sought to dissociate himself openly from the Gloss on the lex Barbarius. While this does not mean that he rejected it in toto, his different approach was sufficient for the next generations to remember him as one of the first jurists who rejected the Gloss. When a staunch defender of the Gloss, such as Butrigarius, briefly recalled the dissent of some jurists on the lex Barbarius, for instance, he mentioned only Jacobus de Arena by name. ${ }^{38}$ Finally, the last and possibly main reason to look at Jacobus de Arena lies in his important scheme on the effects of common mistake, which he developed in relation to the lex Barbarius.

The only printed edition of Jacobus de Arena is a collection of his works, sometimes of dubious authenticity. ${ }^{39}$ Even when a text is indeed of Jacobus de Arena, its quality is often wanting. A comparison with manuscript sources ${ }^{\mathbf{4 0}}$ reveals several mistakes in the printed edition: some of little weight, but others very important to the overall meaning of the text. ${ }^{41}$ The following discussion will take those differences into account.

That is, Malumbra and Oldradus: supra, this paragraph, note 35. Cf. Lange and Kriechbaum (2007), p. 666, note 7.

38 Butrigarius, ad Dig.1.14.3 (Iacobi Bvtrigarii Bononiensis, In Primam et Secvndam Veteris Digesti Partem, vol. 1, In Primamff. Veteris Partem Commentaria, Romae, typis Lepidi Fatij, 1606, anastatic reprint, Bologna: Forni, 1978, p. 38, n. 17): 'Alij vt Iac(obus) de Aren(a) intelligunt, quod hic solum formetur vna quaestio, scilicet in verbo "quid dicemus", scilicet de gestis, et antequam respondeat venit discurrendo, et dicendo ipsum functum officio suo, et ex omnibus respondet, quod acta tenent et probat per rationes, vsque in fin(e). Nam nec quaerit an sit Praetor, vel liber, nec de hoc aliquid respondetur, vt tenet glo(sa) ibi.'

39 Cf. Lange and Kriechbaum (2007), pp. 441-444.

40 Especially Madrid, BN 920, fols. 63vb-64ra, the most accurate and complete version of Jacobus de Arena's comment on the lex Barbarius I could find.

41 The most significant differences are listed below (highlighted in italics):

Lyon 1541, fol. 67ra-b

SObstitisse, fol. 67ra: in functione officij preture: et dic seruitutem ei inherentem etiam dum gerit, et quod sequitur quasi sub sentiens ipse Pompo(nius) quasi pretor etc. et quod sequitur. At qui dicat licet pretor non fuerit quin pro certe verum est etc.'
Madrid, BN 920, fols. 63vb-64ra

$\$$ Obstitisse, fol. 63vb: 'in functione officij preture: et dic seruitutem ei inherentem, et dum gerit et consecutur quasi status sentiens ipse pro tempore quasi pretor etc. et quod sequitur ar(gumentum) quasi dicat licet pretor non fuerit quasi pretor contrarium esse etc.' 
We have seen how Accursius inferred from the common mistake of the people their implied will to set Barbarius free for the sake of public utility. ${ }^{42}$ Commenting on that point, Jacobus de Arena provides the first important scheme on the legal effects of common mistake: ${ }^{43}$

When the common mistake does not harm anyone and is held as true, then it is as good as the truth itself, as in the present case and in Dig.33.10.3.5. When on the contrary it does harm, then the solution depends on whether the mistake harms the person who made it or another. If the mistake harms the person who fell in it, he is to be rescued (as in Dig.15.1.30pr and in Dig.4.1.1). If the mistake harms another, then we should distinguish whether this person is the counterparty of the one who gave cause to the mistake or it is a third party. If he is the counterparty, then the mistake is held as true (as in Dig.14.6.3pr). If on the contrary he is a third party, then the mistake does not hold (as in Dig.27.9.8, Cod.1.2.16 and Dig.12.2.17.1).

$\$$ Decernere, fol. 67ra: 'due sunt rationes, prima equitas: secunda pape voluntas: $\$$ hanc, et si potuit, credendum est populum propter vtilitatem publicam voluisse quod potuit.'

$\$$ In glos. functus sit ibi l. iii [i. e. Dig.1.14.3], fol. 67rb, n. 1-2: 'aut nullus leditur: sed error publicus pro veritate censeatur, tunc equiualet veritati ... Si alius, aut is contra quem error laborat, et tunc pro veritate accipitur ... aut tertius, et tunc non ...'
$\$$ Decernere, fol. 63vb: 'due sunt rationes, prima equitas secunda presumpta populi uoluntas: hanc et si potuit, credendum est populum propter uoluntatem populumvoluisse quod potuit.'

\In glos. effeci(sset) 1. iii [i. e. Dig.1.14.3], fol. 64ra: 'aut nullus leditur: si error publicus pro veritate censeatur tunc equiualet veritati ... Si alius, aut is quem contra (sic) error laborat, et tunc pro ueritate accipitur ... aut tertius, et tunc non patitur ...'

Supra, $\$ 2.4$, text and notes 85 and 88 .

43 Jacobus de Arena, ad Dig.1.14.3 (Madrid, BN 920, fol. 64ra): ‘ $\mathbb{I n} \operatorname{glos}(\mathrm{a})$ effeci(sset) 1. iii [i. e. Gloss ad Dig.1.14.3, \effecisset] aut nullus leditur: si error pu(blicus) pro veritate censeatur tunc equiualet veritati: vt hic, et in de supell(ectili) leg(ata) 1 . ii $<$ i $>\mathbb{\$}$ fi. (Dig.33.10.3.5) aut $\mathrm{l}<\mathrm{a}>$ editur et tunc aut errans aut ali(us) si errans succuritur ei, i(nfra) quando actio de pec(ulio) est annalis 1. qu<a $>$ esitum (Dig.15.2.1.10) et $\mathrm{i}(\mathrm{nfra})$ de in integrum restitu(tionibus) 1 . i (Dig.4.1.1). Si alius, aut is quem contra (sic) error laborat, et tunc pro ueritate accipitur, i(nfra) ad mac(edonianum) 1. iii (Dig.14.6.3) aut tertius, et tunc non pat(itur), ut in de excu(sationis) <l. $>$ qui nequem (sic) (Dig.27.9.8) et C. de sacro(sanctis) ec(clesiis) $<$ l. $>$ decernimus (Cod.1.2.16) et i(nfra) de iureiur(ando) 1. ius iurandum quod ex <conventione>, $\mathbb{S}$ i (Dig.12.2.17.1).' The gloss clearly uses a refined dialectical scheme. To make better sense of it, it might be useful to divide the text (skipping the references) as follows: 1. aut nullus laeditur: si error publicus pro veritate censeatur, tunc equivalet veritati: ut hic; 2 . aut laeditur, et tunc aut errans aut alius: 2.i. si errans [laeditur] succuritur ei; 2.ii. si alius [laeditur], 2.ii.a) aut is contra quem error laborat, et tunc [error] pro veritate accipitur, 2.ii.b) aut [is] tertius, et tunc [error] non patitur. 
Jacobus de Arena's text is not the simplest. The above translation is rather free and it benefits from both the passages cited in the text and the summary provided by Cynus. ${ }^{44}$ In the lex Barbarius and the case of the silverware (Dig.33.10.3.5), says Jacobus de Arena, the mistake does not harm anyone in particular. So (presumably on the grounds of public utility) it may be held as true. By contrast, the mistake is to be set aside when its consequences would prejudice someone who erred. This applies in the case of the paterfamilias who thought his son to be dead and was time-barred from exercising the actio de peculio in consequence of his mistake (Dig.15.2.1.10). It also applies in the in integrum restitutio, which Ulpian commended as the chief remedy for the praetor to help those who made mistakes (Dig.4.1.1). ${ }^{45}$ In both cases, the person who makes a mistake is also the one who suffers its consequences. The situation is different when the person who made the mistake and the one who is prejudiced from it do not coincide. Dig.14.6.3 is a classic example in that sense, as it carves out a well-known exception to the Macedonian senatus consultum. The lender to the son-in-power was barred from suing for his debt even when the debtor became legally independent (sui iuris). However, the senatus consultum introduced an exception for cases in which the son-in-power was widely believed to be sui iuris. The creditor could thus sue to claim his debt because of the common mistake as to the status of his debtor. ${ }^{46}$ In this case Jacobus de Arena remarks that the common mistake depended on one contracting party (the son-in-power) and would prejudice the other (the creditor). Barring the application of the senatus consultum, he observes, is tantamount to considering the mistake as true. The case of the son-in-power who behaved as if he were sui iuris is useful for appreciating the difference between this and the last situation in Jacobus de

Cynus, ad Cod.1.2.16, $\$$ Decernimus (Cyni Pistoriensis In Codicem et aliquot titulos primi Pandectarum tomi, id est Digesti veteris, doctissima commentaria ... a iureconsulto celeberrimo Domino Nicolao Cinsnero ... correcta, et illustrata, Francofurti ad Moenum, Impensis Sigismundi Feyerabendt, vol. 1, 1578; anastatic reprint, Frankfurt am Main: Vico Verlag, 2007, fol. 10va): 'Unde Jaco(bus) de Aren(a) refert: aut error publicus laborat contra errantem et succurritur ei vt ff. quando actio de pecul(io) est an(nalis) l. quaesitum (Dig.15.2.1.10), aut contra alium et tunc aut alius est contrahens aut tertius. Si alius per veritate accipitur ut ff. ad mace(donianum) 1. iii (Dig.14.6.3). Si tertius, tunc non vt hic, ff. de re(bus) eo(rum) l. qui neque (Dig.27.9.8).'

45 Dig.4.1.1 (Ulp. 11 ed.): 'Utilitas huius tituli non eget commendatione, ipse enim se ostendit. Nam sub hoc titulo plurifariam praetor hominibus vel lapsis vel circumscriptis subvenit, sive metu sive calliditate sive aetate sive absentia inciderunt in captionem.'

46 Dig.14.6.3pr (Ulp. 29 ed.): 'Si quis patrem familias esse credidit non vana simplicitate deceptus nec iuris ignorantia, sed quia publice pater familias plerisque videbatur, sic agebat, sic contrahebat, sic muneribus fungebatur, cessabit senatus consultum.' 
Arena's scheme. Some of the examples provided in the text are perhaps not the most obvious, apart for the first one, Dig.27.9.8. The secondary importance of the other two texts, ${ }^{47}$ together with the fact that only the first one is also reported in Cynus' summary of the same scheme, ${ }^{\mathbf{4 8}}$ both suggest focusing mainly on Dig.27.9.8. Dig.27.9.8 stated that the transactions made by the false guardian in the name of his ward are void. Hence its relevance to Jacobus de Arena's discussion: unlike the son-in-power who persuaded the counterparty to lend him money under false pretences, the ward did not collude with the false guardian against the third party. But the contract was between the third party and the ward - not between third party and false guardian. Hence, the only equitable solution was to void it.

Applying his reading of the common mistake to the text of the lex Barbarius, Jacobus de Arena inverts Pomponius' argument that the servile condition of Barbarius was no obstacle to his exercise of the praetorship. ${ }^{49}$ Barbarius exercised the office of praetor while he was a slave: being 'quasi praetor' meant not being such de iure. ${ }^{50}$ The Romans, holds Jacobus de Arena, elected him by mistake. ${ }^{51}$ Their mistake, however, being common and not harming anyone, may well produce valid legal effects. For the validity of Barbarius' deeds, in other words, the common mistake would suffice.

By contrast, Jacobus de Arena does not provide a clear answer on the issue of Barbarius' freedom. Nor does he respond to the more important question as to

47 Of the other two texts the first was the lex Decernimus (Cod.1.2.16), on the invalidity of what done against the Christian faith. The text was commonly interpreted as prescribing the ipso iure invalidity of the tyrant's deeds: see e.g. Gloss, ad Cod.1.2.16, $\$$ Decernimus and $\$ Funditus (Parisiis 1566, vol. 4, col. 44). The other text (Dig.12.2.17.1) allowed raising an exception against the oath tendered by the ward without the consent of his guardian. This case might appear more in line with the one on the exception to the Macedonian senatus consultum. Following Jacobus de Arena's scheme, therefore, it should lead to the opposite solution. It is likely, however, that Jacobus de Arena referred to this text as interpreted in the Gloss: a mother who tenders an oath for the child (ad

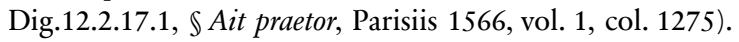

48 Supra, this chapter, note 44.

49 Cf. Dig.1.14.3: 'Sed nihil ei servitutem obstetisse ait Pomponius, quasi praetor non fuerit: atquin verum est praetura eum functum.'

50 Jacobus de Arena, ad Dig.1.14.3, $\$$ Obstitisse (Madrid, BN 920, fol. 63vb): 'in functione officij preture: et dic seruitutem ei inherentem, et dum gerit et consecutur quasi status sentiens ipse pro tempore quasi pretor etc., et quod sequitur ar(gumentum) quasi dicat licet pretor non fuerit quasi pretor contrarium esse etc.' (emphasis added).

51 Jacobus de Arena, ad Dig.1.14.3, $\mathbb{S}$ Et designatus (Commentarij in vniversum Ius civile, cit., fol. 67ra): 'per errorem cum liber crederetur, licet seruus fuerit hic qui preterea designatus fuit.' Madrid MS 920, fol. 63vb, has the same text but emphasises the negation ('sed licet'). 
the validity of his praetorship. Albericus de Rosate took his silence as clear dissent. ${ }^{52}$ Butrigarius, with more precision, lamented that Jacobus de Arena simply jumped to the issue of the validity of the deeds ignoring both freedom and praetorship issues. ${ }^{53}$ The problem is that, at least from the sources we have, both authors would seem to be wrong.

Jacobus de Arena's gloss is remarkably ambiguous. What he says on Barbarius' freedom is simply that Ulpian's words must be taken at face value. This way, he reaches the same conclusion as Odofredus: if the Romans knew that Barbarius was a slave, they would have set him free - but they did not know. Imputing to the people a will they did not possess, concludes Jacobus de Arena, is tantamount to saying that Barbarius would have become free both if the Romans had known of his servitude and if they had ignored it. Barbarius, continues Jacobus de Arena, could have become free only if the Romans had known that he was a slave. ${ }^{54}$ The statement might be taken as a denial of Barbarius' freedom, or perhaps as a way of avoiding the issue - hence the different conclusions of Rosate and Butrigarius. Shortly before this ambiguous statement, however, Jacobus de Arena says something else.

We have seen how Accursius ascribed to the people a will they did not have, so as to avoid their being deceived. ${ }^{55}$ The presumed intention of the people answered a predetermined end, based on public utility. If the end was commendable, the argument remained weak. In a slightly more elaborate way, Jacobus de Arena seemed to say exactly what Accursius said. The will of the Romans was clearly vitiated as to their knowledge of Barbarius' status, but changing his status was within their sovereign power. Since they could have wanted to do what surely was in their power, argues Jacobus de Arena, their actual will to exercise their power should be inferred for the sake of public utility (the Latin expression is particularly refined: 'credendum est populum propter utilitatem publicam voluisse quod potuit'). ${ }^{56}$ So far, it would seem that Jacobus

56 Jacobus de Arena, ad Dig.1.14.3, $\$$ Decernere: 'due sunt rationes, prima equitas: secunda presumpta populi voluntas: hanc, "et si potuit" [cf. Dig.1.14.3: 'cum etiam potuit populus Romanus servo decernere hanc potestatem'], credendum est populum propter vtilitatem publicam voluisse quod potuit, et sic est aliqua 
de Arena is simply rephrasing Accursius without adding any new argument. Jacobus de Arena's gloss however closes with a short but extremely significant conclusion: 'this way there is some will in the person who errs, as in Dig.35.2.1.11'. ${ }^{57}$

The text in Dig.35.2.1.11 provided relief to the heir who failed to realise that a bequest exceeded the portion of the estate of which the testator could freely dispose. ${ }^{58}$ Relief was needed in the form of a special action: the heir could not obtain a possessory interdict since he had already allowed the legatee to take possession of the land. This last point attracted the attention of the Gloss: the heir consented to give execution to the bequest. This means, concluded the Gloss, that one may well be mistaken as to something (the value of the bequest) but consent to something else (the execution of the same bequest). ${ }^{59}$ Commenting on a related text (the silverware in Dig.33.10.3.5), Jacobus de Arena approves of that interpretation: while the heir was initially mistaken, the fact that he executed the bequest would attest his consent to it. ${ }^{60}$ From this perspective, the text on the invalid bequest would support Jacobus de Arena's argument on the lex Barbarius. The will of the people was putative as to their intention to ratify Barbarius' appointment, but it was genuine as to their intention to have Barbarius as praetor.

At first sight, opposing the people's genuine intention to elect Barbarius to their vitiated knowledge as to his status would appear to contradict Jacobus de Arena's previous statement against the presumed will of the same people (i.e. since the Romans did not know of Barbarius' servile condition, it cannot be inferred that they set him free). ${ }^{61}$ In fact, there is no contradiction. In arguing

hic voluntas errantis, vt $\mathrm{i}(\mathrm{nfra})$ ad legem falci(diam) 1 . i $\$$ si legatarius (Dig.35.2.1.11)' (Commentarij in vniversum Ius civile, cit., fol. 67ra, pr-n.1; Madrid, BN 920, fols. 63vb-64ra. I have used both versions, as each contains clear mistakes (supra, this paragraph, note 41 ).

$57 \quad$ Ibid.

58 The Gloss reports the explanation of Vivianus Tuscus: a testator left a number of bequests that in total exceeded three-quarters of the inheritance value. Among them, there was a parcel of land left to Titius. Believing the inheritance value to be higher, the heir gives the land to Titius. Gloss, ad Dig.35.2.1.11, $\mathbb{S}$ Si legatarius (Parisiis 1566, vol. 2, cols. 1464-1465).

59 Gloss, ad Dig.35.2.1.11, \errantis (Parisiis 1566, vol. 2, col. 1465): 'quia putabat plura esse in hereditate quam erant: sed in legato soluendo bene consentiebat: et nihil prohibet aliquem in vno errare, et in alio consentire.'

60 Jacobus de Arena, ad Dig.33.10.3.5, \$Ius facit (Commentarij in vniversum Ius civile, cit., $f o l .119 v b$ ): 'dic quod fuit error in origine, sed consensus in obseruatione: sicut alle(gatum) i(nfra) ad leg(em) fal(cidiam) l. i $\$$ si legatarius (Dig.35.2.1.11).' Jacobus de Arena's comment on this last text (ibid., fol. 122va) is on the contrary very brief and does not touch upon our issue.

61 Supra, this chapter, note 54. 
against the presumed will to set Barbarius free, Jacobus de Arena simply rules out Barbarius having become praetor de iure. Thereafter, in the short conclusion ending with the reference to Dig.35.2.1.11, he seeks to cast a positive light on the people's mistake. Once again, the reason is to be found in Jacobus de Arena's scheme of the mistake. When looking at that scheme, we saw that a mistake is equivalent to the truth when two conditions are fulfilled: first, that it is common; second, that it does not harm anyone. While there is no doubt that the mistake as to Barbarius' status was common, it is less clear whether ending up with a slave as praetor would not cause any harm at all. Proving that the people's mistake as to Barbarius' condition was compatible with their intention to have him as praetor (or at least finding a foothold in the sources to that end), Jacobus de Arena removes the only obstacle as to the application of his scheme on mistake to Barbarius' case. Clearly, the mistake that 'aequivalet veritati' is in our case that on Barbarius' freedom.

At this point we may appreciate why Albericus de Rosate and Butrigarius said that Jacobus de Arena rejected the Gloss and argued only for the validity of the deeds. The mistake in relation to Barbarius neither set him free nor made him praetor - at least, not de iure. It simply removed the obstacle as to the validity of his deeds. The obstacle was Barbarius' status as slave. Because of the common mistake, Barbarius can be treated as if he were free and as if he exercised his praetorship validly. This way, Jacobus de Arena does not reject the Gloss in full: the validity of Barbarius' acts would still depend on his personal status. It is important to remark the point: in Jacobus de Arena the common mistake is not in the validity of the deeds but in the status of Barbarius. The relationship between the validity of the deeds and public utility, therefore, still depends on the status of Barbarius. At the same time, however, Jacobus de Arena does not accept the Gloss' solution based on the presumed will of the people to set Barbarius free. For Jacobus de Arena, Barbarius became neither truly free nor de iure praetor. In rejecting the second part of Accursius' scheme, Jacobus de Arena provides a better explanation as to the validity of the acts carried out by Barbarius while he was in putative freedom (or, as he puts it more nicely, in spe libertatis'). ${ }^{62}$ On the basis of Jacobus de Arena's general theory of common mistake, putative freedom would suffice: being the object of common mistake, and not harming anyone, it may be equiparated to the truth.

Applied to Barbarius' case, the position of Jacobus de Arena on the common mistake might not seem particularly different from that of Odofredus. In both cases the mistake on Barbarius' status allows the production of valid legal effects. cit., fol. 67ra). This gloss is identical to that in Madrid, BN 920, fol. 63vb. 
Among the two jurists, however, there are some important differences, chiefly Jacobus de Arena's more refined position as to the precise nature of the common mistake and the way it operates. For Jacobus de Arena mistakes do not really make law: if widespread, they can only lead to the production of the same effects as a non-vitiated volition would. Hence Barbarius does not become truly (i. e. de iure) a praetor, or actually free. Further, and crucially, what is done under common mistake may be valid only when it does not harm the position of anyone who partakes in the mistake itself. In his abstract and refined scheme, Jacobus de Arena left implied what other people would say expressly: a common mistake cannot be invoked by someone who knew the truth and exploited the others' mistake.

\subsection{Butrigarius and the Accursian Orthodoxy}

Jacobus de Arena's general scheme on the common mistake allowed to separate the issue of Barbarius' praetorship from that of the validity of his deeds. As such, it was an open threat to the position of the Gloss. At the same time, however, the scheme was remarkably sophisticated and considerably useful. Some among the more conservative jurists sought therefore to modify it in a more Gloss-friendly way. The best example in this direction is that of the Bolognese law professor Jacobus Butrigarius (c.1274-1347/8). ${ }^{63}$ Together with his most famous student, Bartolus de Saxoferrato, Butrigarius was among the last main jurists who kept the overall approach of the Gloss to the lex Barbarius.

While Butrigarius was sufficiently open to more modern influences, ${ }^{64}$ he typically accepted them if compatible with the Gloss. This does not mean that he never sided against Accursius - only that he needed particularly strong arguments to do so. Later jurists would remark on his loyalty towards the Gloss: Fulgosius for instance described him as the 'defender of the Gloss'. ${ }^{65}$ Butrigarius

63 For a short recent introduction on Butrigarius' life and work, see Kriechbaum (2013), pp. 1096-1098.

64 When writing on the lex Barbarius Butrigarius does not cite anyone by name, apart from Odofredus and Jacobus de Arena. But it is likely that he was familiar with other approaches, especially that of the Ultramontani - effectively the main group of jurists that denied Barbarius' praetorship. On Butrigarius' sources there are no in-depth studies, and the occasional broad statements might not have helped (see e.g. Dilcher [1960], p. 286). A few remarks from scholars writing over the past thirty years may be found in Lange and Kriechbaum (2007), pp. 624-626, and esp. Kriechbaum (2013), p. 1098.

65 Fulgosius, ad Dig.1.14.3 (Raphaëlis Fvlgosii Placentini ... in primam Pandectarum partem Commentariorum ... vol. 1, Lugduni, Apud Hugonem, et haeredes Aemonis a Porta, 1554, fol. 25vb, n. 9): 'Jac(obus) autem butri(garius), qui semper 
himself did little to dispel that impression. He even famously compared the Gloss to the law, and the contemporary use of the sources as custom: 'I would not move away from the Gloss, for the custom is not against it; you should therefore keep whatever the Gloss accepts, unless the custom is the opposite. Only in that case you may depart from it, just as one moves away from the law because of a contrary custom'. ${ }^{66}$

Butrigarius' commentary on the Vetus was printed twice, both times in Rome, first in $1606^{67}$ and then in 1617 . The second edition was in fact a simple reprint of the first: the text is perfectly identical but for the greatly elaborated and eye-catching title - marketing is not a modern invention. ${ }^{68}$ We will therefore use only the 1606 edition. Manuscript sources, while very different from the printed edition as to the form, seem fairly similar as to the content. In the present work, the printed edition of 1606 will be compared to the only known complete text of his lectura on the lex Barbarius, preserved in Bologna, ${ }^{69}$ together with some other partial manuscript sources. ${ }^{70}$ Any difference that is especially important for our purposes will be accounted for. Otherwise, the text will follow the printed edition, all the more because of the somewhat ambiguous structure of the text in the manuscript sources.

Much of Butrigarius' commentary on the lex Barbarius is a reiteration of what had already been said by others, and it may be safely ignored here. So for instance, to mention only the issues on which Butrigarius lingered the most, the discussion about the lex Iulia de ambitu (which in principle could have voided Barbarius' appointment for having sought the office proactively) is circumvented with the same solution as Odofredus' (seeking an office publicly is

fuit defensor glos(ae), tenet $\mathrm{gl}(\mathrm{osam})$ quod fuit pretor per primum responsum huius legis.' Emphasis added.

66 With a literal translation the image would be even stronger: 'wherever the Gloss stops its feet at, keep it'. Butrigarius, ad Cod.3.4.1 (Iacobus Butrigarii ... super Codice hanc subtilissimam editit lecturam ..., Parrhisiis (sic), a Joanne paruo [1516]; anastatic reprint, Bologna: Forni, 1973, fol. 93rb): 'ergo non recederem a Glo(sa), quia vsus non est contra eam: vbicumque ergo glo(sa) firmat pedes serua eam nisi vsus sit in contrarium: quia tunc recedas ab ea: quia etiam a lege receditur propter consuetudinem contrariam.'

67 Butrigarius, In Primamff. Veteris Partem Commentaria, cit., supra, this chapter, note 38 .

68 The title of the 1617 edition is so long that it must be abridged: Commentaria Ervditissima atque pariter accutissima (sic), In Quamplurimos Ivris Communis Titulos...; Ita vt Fere Dici Potest, saltem per extensionem, in uniuersum ius ... In Dvos Tomos Distribvta. Tomus Primus ... Auctore ... D. Iacobo Bvtrigario Bononiensis ... Romae, Typis Lepidi Fatij, 1617.

69 Bologna, CS 272, fols. 7rb-8ra.

70 Especially Pal. lat. 733, fols. 23vb-24rb. 
lawful). ${ }^{71}$ Similarly, the emperor may well set Barbarius free for public utility considerations, in which case Barbarius' master ought to be compensated for the manumission of his slave. ${ }^{72}$ The point is hardly important for the lex Barbarius, but it is worth mentioning, as it is not often found in Butrigarius. Butrigarius is on the contrary often credited (starting already with Bartolus) ${ }^{73}$ with having relieved the prince of the need of just cause in order to proceed with the expropriation. ${ }^{74}$ In fact, the contradiction is only apparent: the seemingly 'absolutist' position was meant only in abstract terms, as a matter of principle. ${ }^{75}$

71 Butrigarius, ad Dig.1.14.3 (In Primamff. Veteris Partem Commentaria, cit., p. 36, n. 7). Cf. Bologna, CS 272, fol. $7 v a$.

72 Butrigarius, ad Dig.1.14.3 (In Primamff. Veteris Partem Commentaria, cit., p. 37, n. 12): 'Item opp(ono) quod Imperator non possit quem priuare de dominio rei suae, vt 1 . quotie $<\mathrm{n}>\mathrm{s}$ C. de precib(us) Imp(eratori) offeren(dis) (Cod.1.19.2). Sol(utio) potest ex causa, vt hic fauore publicae vtilitatis, sine causa non posset, vt ibi.' Cf. Bologna, CS 272, fol. 7va-b.

73 Bartolus, ad Cod.1.22.6, $\$$ Omnes cvivscunqve (In I. Partem Codicis Bartoli a Saxoferrato Commentaria .... Basileae, ex officina Episcopiana, 1588, p. 112, n. 2): 'Do(minus) Iac(obus) But(rigarius) dicebat simpliciter, quod Princeps potest auferre mihi dominium rei meae, sine aliqua causa. Nam eius potestas, et potestas istarum legum, quae hoc prohibent, procedit a pari potentia: ergo sicut potest istas leges tollere: ergo eodem modo possit dare alteri dominium rei meae, sine causa.'

74 E. g. Canning (1989), p. 80.

75 Butrigarius was always careful to clarify that, in principle, the prince could derogate from the law and so dispense with private property without any just cause. Butrigarius' discussion of the expropriation of Barbarius from his master continues as follows: 'imo puto, quod vbicunqe princeps non errat in facto, et refert ibi contra ius aliquid, quod valeat rescriptum; nam quod ipse non possit aliquem priuare re sua non est ex defectu potestatis suae; sed ideo quia dixit se nolle hoc facere, vbicunque ergo ipse vult, dummodo non fit error in facto, tenet rescriptum, et videtur tollere legem derogatoriam, quae contra hoc est, cum scire omnia praesumatur', Butrigarius, ad Dig.1.14.3 (In Primam ff. Veteris Partem Commentaria, cit., p. 37, n. 12). Cf. Id., ad Cod.7.37.2pr, $\$$ Omnes (Iacobus Butrigarii ... super Codice, cit., fols. 41vb-42ra - the folio numbering starts again with the sixth book of the Code): 'Nota casum contra illos qui dicunt quod princeps per priuilegium non potest ream meam alteri concedere, et dominium mihi auferre: immo potest. Etsi dicas quod est per legem communem. Certe immo ante hanc legem quibusdam concessum per priuilegium vt hic dicit et valebat. Unde quod princeps non possit mihi auferre dominium rerum meum (sic) non est ex defectu potentie: sed si velit et dicat non obstante tali lege bene valet et potest. Aut ergo princeps donat vel vendit rem fiscalem et statum est securus donatarius olim et hodie si proprio motu donauit imperator aliis videretur per importunitatem concessum et posset reuocari: vt in de peti(tionibus) bo(norum) sub(latis) (Cod.10.12), aut rem alienam alienauit ut suam: et tunc olim emptor non erat statim securus, scilicet vsque ad quadriennium poterat a domino conueniri; hodie statim est securus sed donatur regressus in fiscus vsque ad quadriennium ad precium et non vltra vt hic'. 
Butrigarius' defence of the Gloss hardly meant that he advocated the same old literal interpretation of the text as Accursius and the early glossators. As many other late glossators and early commentators, he distinguished normative from descriptive parts of the Roman sources: in so doing he often rearranged a text according to his ultimate purpose. ${ }^{76}$ The fact that such a purpose often coincided with the interpretation of the Gloss (making him the joining ring between Gloss and commentary'), ${ }^{77}$ makes his position all the more interesting. This can be seen in his comment on the lex Barbarius, especially on the debated issues of Barbarius' freedom and the people's mistake. Says Butrigarius:

I ask if [Barbarius Philippus] is free and (according to Cod.7.16.27.1 and Cod.7.16.11) it would seem he is not. Besides, he would deserve a punishment for what he has done, hence he should not be recompensed. What then? The Gloss holds that he is free, but it does not prove it well. You may prove it with the words of the text, when it says that, if [the people] knew [of his servile condition], they would have set him free. And they could have well done as much, for the people had both the will and the power, and so he is free. That the people have the power is certain. But you might say that the people lack the will, for they are mistaken. I reply that the people do have the will, for the common mistake presupposes the truth. Indeed, when the people make a mistake, they provide for that in which they are mistaken (as in Dig.33.10.7.2 and Dig.33.10.3.5). For common mistake is to be taken as consent, and everybody's mistake is held as true. $^{78}$

The last part of Butrigarius' reasoning leads to the same conclusion as Accursius on the presumed will of the people, but it follows a different and safer route. Accursius simply held that public utility allowed the presumption of something

76 A good example is his comment on Cod.1.18.7, the lex Error: Di Bartolo (1997), pp. 208-209. The same lex Error is also useful for our purposes, for it shows both Butrigarius' knowledge of the Ultramontani and his defence of the Gloss: Iacobus Butrigarii ... super Codice, cit., fol. $33 \mathrm{vb}$.

77 Nicolini (1968), p. 873.

78 Butrigarius, ad Dig.1.14.3 (In Primamff. Veteris Partem Commentaria, cit., pp. 37-38, n. 15-17): 'sed quaero, an sit liber, et videtur quod non per l. Arianus $\$$ cohaeres (Cod.7.16.27.1) et 1 . non muta $<\mathrm{n}>\mathrm{t}$, C. de lib(erali) causa (Cod.7.16.11). Praeterea ex isto facto meretur paenam, ergo non debet praemium inde consequi. Quid ergo? Glo(sa) tenet, quod sit liber, sed non bene probat, sed tu proba per text(um) in verbo, nam dicit text(us), quod si sciuisset, fecisset liberum, et facere potuisset; cum ergo adsit potestas, et uoluntas; ergo est liber: quod adsit potestas, certum est; et si dicas non adest voluntas, cum erret. Respon(deo) imo adest; nam communis error praesupponit veritatem; nam populus errando etiam disponit in eo, in quo errat, vt l. labeo in fin(e) (Dig.33.10.7.2) et 1. 3 de sup(pellectili) legat(a) (Dig.33.10.3.5), nam communis error pro consensu habetur, et id, quod est in errore omnium, habetur pro vero.' 
that is not attested - namely, that the people wanted to set Barbarius free. ${ }^{79}$ Butrigarius seeks to reach the same outcome by different means. Interpreting the common mistake as common will, he can argue that the people's will to emancipate Barbarius is not presumptive, but already present in the text.

By stressing the element of volition, Butrigarius downplays the mistake as a pathology of the will. This can be seen also in his comment on the case of the slave-arbiter (Cod.7.45.2). There, Butrigarius compares the condition of the people who elected a slave with that of the ordinary judge who delegated a slave (since the Roman arbiter was considered a delegate judge). In both cases Butrigarius ascribes to the subject who appointed the slave a clear intention to do so in spite of the latter's servile condition. The mistake, in other words, is implicitly qualified as intentional. This way, the issue is no longer whether the subject is mistaken, but whether he has the power to reach his goal. Since the ordinary judge could appoint a delegate but not also set free a slave against his master's wish, says Butrigarius, the deeds of the slave-arbiter would remain precarious. By contrast, the people did possess the power to manumit the slavepraetor, so both his appointment and consequently his deeds were valid. ${ }^{\mathbf{8 0}}$

This operation ultimately follows the same logic as Accursius, but in a subtler way. As in Accursius, the ultimate goal remains that of furthering public utility. This is particularly clear in Butrigarius' adaptation of Jacobus de Arena's scheme on the effects of the mistake. We have seen how Jacobus de Arena based his entire scheme on the presence or absence of damage (laedere). Only the mistake that did not cause harm could be qualified as producing valid legal effects. ${ }^{\mathbf{8 1}}$ Butrigarius replaces harm with utility. The absence of laesio now becomes the presence of utilitas: ${ }^{\mathbf{8 2}}$

To argue as much, as we have seen, Accursius referred to a passage in the Digest where freedom was granted to the slaves despite their master lacking this intention: supra, $\mathbb{} 2.4$, text and notes $87-88$.

80 Butrigarius, ad Cod.7.45.2, $\mathbb{S}$ Si arbiter (Iacobus Butrigarii ... super Codice, cit., fol. $47 \mathrm{ra}$ ): 'ibi fuit populus romanus [qui] dedit ei iurisdictione qui eum poterat facere liberum et presumitur quod fecisset si sciuisset. At hic iudex eum delegauit qui eum liberum facere non poterat.'

81 Supra, this chapter, note 43.

82 Butrigarius, ad Dig.1.14.3 (In Primamff. Veteris Partem Commentaria, cit., pp. 36-37, n. 10): 'Plane, aut loqueris de errore singulorum, et talis non facit ius vt 1.3 S subtilius in $\operatorname{de} \operatorname{condict}($ ione) $\operatorname{caus}(\mathrm{a}) \operatorname{dat}(\mathrm{a})(\operatorname{Dig} .12 .4 .3 .8)$ et 1 . si procurator meus in de acquir(endo) rer(um) dom(inio) (Dig.41.1.35) et l. si per errorem in de iurisd(ictione) omn(ium) iud(icium) (Dig.2.1.15). Si autem loqueris de errore communi et tunc dic, aut publica utilitas suadet id, quod est in errore seruari pro vero, aut suadet non seruari, aut neutrum: primo casu facit ius, vt hic, et 1.3 fi. (Dig.33.10.3.5) et 1 . labeo in fi(ne) in(fra) de suppell(ectile) leg(ata) (Dig.33.10.7.2); secundo casu non facit ius, vt l. decerni- 
Clearly, if you speak of the mistake of single individuals, it does not make law (as in Dig.12.4.3.8, Dig.41.1.35 and Dig.2.1.15). If you refer to a common mistake, then look at whether holding the mistake as true would further public utility, it would not, or it would make no difference. In the first case, the mistake makes law (as here, in Dig.33.10.3.5 and in Dig.33.10.7.2); in the second case it does not (as in Cod.1.3.26 and Dig.1.3.39). In the third case, if the person who falls in the common mistake would benefit from holding it true and letting it make law, then the mistake does make law (as in Dig.14.6.3pr and Cod.4.28.2); if however that person would benefit from not allowing the mistake to make law, then it does not (as in Dig.14.6.20 and Dig.28.5.93).

Butrigarius' scheme is perhaps not as refined as Jacobus de Arena's. Trading harm for utility does not allow to take full account of the consequences of the mistake, especially for the counterparty and even more for third parties. But inverting the logic of Jacobus de Arena also means replacing a negative requirement with a positive one (i. e. from absence of harm to presence of utility). That would seem intentional: the more the accent is on the benefit of the errans, the more the deeds of such errans implicitly acquire intentionality. This is particularly clear in the last part of Butrigarius' scheme, centred on the cases where neither solution would affect common utility. The common mistake that neither furthers nor detracts from public utility, says Butrigarius, is to be interpreted according to the

mus C. de Episc(opis) et Cler(icis) (Cod.1.3.26) et sub de legib(us) l. quod contra rationem (sic, Dig.1.3.39); tertio casu, aut expedit erranti propter communem errorem, quod error facit ius, et quod pro veritate seruetur, et facit ius, vt l. si quis patrem in de Maced(oniano) (Dig.14.6.3) et l. Zenodorus C. eod(em titulo) (Cod.4.28.2). Si autem expedit erranti propter communem errorem, vt non faciat ius, et non facit, vt 1. ad Maced(onianum) 1. vltima (Dig.14.6.20), et in de haer(edibus) instit(uendis) 1. fi. (Dig.28.5.93(92)).' Cf. Bologna, CS 272, fol. $7 v a$; Pal. lat. 733, fol. 24rb, $\$$ reprobari. Butrigarius used the same scheme when commenting on the lex Si arbiter. Id., ad Cod.7.45.2, $\$$ Si arbiter (Iacobus Butrigarii ... super Codice, cit., fol. 47ra): 'Item opp(ono) quod error non faciat ius: vt l. iii $\$$ subtilius ff. de condic(tione) ca(usa) da(ta) (Dig.12.4.3.8). Sol(utio) distingue quia aut erat error singularis et non facit ius: vt 1 . iii $\$$ subtilius (ibid.). Aut est communis et tunc aut suadet communis vtilitas quod habeatur pro veritate et habetur: vt 1. barbarius ff. de offi(cio) preto(rum) (Dig.1.14.3); aut suadet oppositum et non habetur pro veritate: vt l. quod non ratione, ff. de legi(bus) (Dig.1.3.39) et l. decernimus s(upra) de episco(pis) et cleri(cis) (Cod.1.3.26); aut non suadet pro nec contra, et tunc aut expedit erranti quod habeatur pro veritate et habetur, aut non expedit et non habetur, vt colligitur ex 1 . i $\$$ fi.ff. quando act(io) de pecu(lio) est anna(lis) (Dig.15.2.1.10) et ad mace(donianum) 1 . zenodorus (Cod.4.28.2) et 1. si quis <pro> prem(io) (Cod.7.13.3).' While the version in Butrigarius' commentary on the lex Barbarius is somewhat clearer, that in the Code might be closer to the original: cf. Pal. lat. 733, fol. 24rb, \$reprobari; Bologna, CS 272, fol. $7 v a$. A slightly abridged version of the same scheme is found also in Butrigarius' comment on Cod.4.28.2 (the lex Zenodorus, on the exception to the Macedonian senatus consultum): Iacobus Butrigarii ... super Codice, cit. fol. $130 r b$. 
private utility of the single individual who makes it. When this individual does something mistakenly that would go to his detriment, Butrigarius implicitly considers the common mistake as against the specific intention of that person. This entails the assumption that, if that person were aware of the mistake, he would have not acted the way he did. While the mistake has still to be a general one (for the mistake of a single person could not bestow validity on something that is void), its consequences ultimately depend on his own presumed volition. In turn, this presumed volition is either inferred from his benefit or excluded because of his nocument. A modern reader might be tempted to see in this last division some sort of rational agent theory ante litteram.

These remarks help our understanding of the previous quotation from Butrigarius, on the will of the people to set Barbarius free. Butrigarius maintains that the people had the will to emancipate Barbarius for 'the common mistake presupposes the truth' (communis error praesupponit veritatem). This cryptic statement is explained with reference to the volition of people: 'when the people make a mistake, they provide for that in which they were mistaken' (populus errando etiam disponit in eo, in quo errat). The emphasis on the desired outcome of the people's choice allows the way in which this choice was made to be reinterpreted. This way Butrigarius can affirm that 'the common mistake is to be taken as consent' (communis error pro consensu habetur). In so doing the mistake is no longer opposed to the will of the people, but it becomes an integral feature of their volition process. To make sure of the outcome of their choice, Butrigarius in effect forces the people's hand. Keeping Barbarius praetor but slave, he says, would presuppose the intention to infringe the law (it would not be honeste). ${ }^{\mathbf{8 3}}$ Presuming bad faith is of course impossible: another reason to argue for the people's intention to set Barbarius free.

The whole operation might not be logically flawless, but it has its own coherence. To defend the position of the Gloss, Butrigarius seeks to establish a link between Barbarius' election and the people's knowledge of his true status. n. 17): '... cum ergo potuerit hanc dignitatem seruo dare, non ergo sequitur, quod voluerit liberum esse. Resp(ondeo) non, quia licet seruo dare potuerit, non tamen honeste; nam hoc erat inhonestum, quod Populus Romanus haberet suum Praetorem seruum; cum ergo honeste non poterat, potuisse non videtur, vt s(upra) de statu hom(inum), l. vulgo (Dig.1.5.23); videtur ergo voluisse id, quod honestum est, s(cilicet) liberum esse.' It should be noted, however, that even if the people wanted to pursue that dishonest route (i. e. keeping Barbarius praetor but slave), for Butrigarius their action would have been still intentional and not just the product of a mistake. Ibid, p. 36, n. 6: 'et probat iste tex(tum) in fi(ne) nam dicit, quod si populus sciuisset eum seruum liberum fecisset, poterat etiam seruo concedere, per quam concessionem videtur tollere legem prohibentem seruos habere dignitates.' Cf. Bologna, CS 272, fol. 8 ra. 
Doing otherwise would have led to the same conclusion as Accursius - a presumed will of the people to emancipate Barbarius wholly detached from their actual volition.

The importance of the people's consent might also depend on Butrigarius' restrictive stance on the effects of putative freedom. Unlike Accursius, Butrigarius seems to consider the quasi possessio of freedom as insufficient to ensure the validity of the acts carried out while enjoying that quasi possessio. For Butrigarius the quasi possessio of a status produces effects until the truth is discovered, but the validity of such effects remains precarious. When the lack of legal capacity is ascertained, the deeds already done become invalid. By contrast, the common mistake as to the incumbent's status would suffice as to the enduring validity of his deeds. ${ }^{84}$ This way, the presumed will of the people to set Barbarius free is no longer the weak spot in Accursius' reading of the lex Barbarius that previous jurists - from Odofredus onwards - thought it to be. Much to the contrary, in Butrigarius it becomes the very source of the validity of Barbarius' deeds. Butrigarius' theory of the common mistake may well be an adaptation of that of Jacobus de Arena, but it was a very ingenious one, for it led to the opposite result - the de iure validity of Barbarius' praetorship.

84 Butrigarius, ad Cod.7.45.2, $\$$ Si arbiter (Iacobus Butrigarii ... super Codice, cit., fols. 46vb-47ra): 'delegatio confert iurisdictionem, sed per se non potest nisi alia subsequatur quid ergo hec operatur: nunquid quasi possessio libertatis hoc facit? Certe non, quia illa quasi possessio non prodest veritate comperta vt 1 . circa ff. de probatio(nibus) (Dig.22.3.14), sed hoc facit communis error. Et ideo hoc $\mathrm{a}<\mathrm{n}>$ no vidi dubitari de quibusdam auditoribus domini legati, an valeret eorum sententia: quia de delegatione dubitabatur et dicebatur quod valebat, quia erat in quasi possessione delegationis. Ego dicebam quod hoc est verum, donec contrarium reperiatur: sed magis hoc facit communis error ne vitientur gesta coram eis facta.' 


\section{Chapter 4}

\section{Ultramontani \& Co.}

At this point, we might go slightly back in time, and deal with the earliest fullscale attacks on the Gloss. In so doing we will follow neither a strictly chronological order nor a geographical one. Rather, we will try to show how similar ideas in the late thirteenth century were circulating more widely than is often assumed.

Around the same years as Odofredus was seeking to provide a better defence of Accursius' conclusions than Accursius' own, other jurists started a frontal attack at the tradition of literal exegesis embodied in the Gloss. We have seen how Odofredus (who had already detached himself from that tradition), noted in passing how 'others' would deny the validity of Barbarius' praetorship, but he did not say who they were. ${ }^{\mathbf{1}}$ The point is worth mentioning because both Odofredus and those 'others' might have differed as to the conclusion on Barbarius' case, but they shared the same dialectical method. If Odofredus reached the same conclusions as Accursius, he did so in a manner that was much less subservient to the text of the lex - and was in some parts even critical of the Gloss. Some of his contemporaries went beyond him, applying the same dialectical approach to argue against the core of the Accursian reading of the lex Barbarius. Among the first to do so was one of the first teachers of the Orléanese School, Johannes de Monciaco (Jean de Monchy, d. c.1266).

It is not entirely clear whether Monciaco studied under Jacobus Balduini, as Odofredus surely did. ${ }^{2}$ While far from established, ${ }^{3}$ such a possibility would be

1 Supra, $\$ 3.1$, text and note 10. Cf. also Suzzara, ad Dig.1.14.3: 'quidam dicunt quod dic(it) glo(sam) quod non, et hoc est uerum licet glo(sa) dicat eum fuisse pretorem et male dicit', infra, Appendix, 11.2-3.

On Balduini see supra, last chapter, note 1 . There is little doubt that Odofredus studied under Balduini, as he said himself in several parts of his work. Cf. e.g. Spagnesi (2013), p. 1450.

3 Probably the scholar most confident that Monciaco did study under Balduini was Lefebvre (1958), p. 301, although he offered little concrete evidence. Other scholars seemed less certain. Waelkens in particular observed how one of the few sources on Monciaco (a repetitio on Dig.1.3.32 preserved in Florence, BML, AeD 417 ) ascribed to Balduini an opinion (on the time needed for the introduction of a new custom) that was different from that of Balduini himself (twenty-five years instead of the ten years he required). This seems not to have been a typo, for a

Ultramontani \& Co. 
tempting, given their (insofar as we know of Monciaco) fairly similar approach to the sources - lex Barbarius included. The critique of the approach based on a literal interpretation (and so, against the greatest monument to that tradition the Gloss of Accursius) spread mainly through the school of Balduini. His teaching methods did not influence only his own students, but were in turn used by those students to train new generations. So, for instance, when the most illustrious student of Monciaco - Jacobus de Ravanis ${ }^{4}$ - skipped some texts in class, he would tell his students to look them up in Odofredus' commentary. ${ }^{5}$ Ravanis was notoriously opposed to Accursius. While he did not agree with Odofredus on the interpretation of the lex Barbarius, they both shared a more flexible attitude to the sources.

Later jurists typically ascribed the origins of the 'revolt' against the Accursian Gloss to the Ultramontani, especially to the law professors of the School of Orléans. The lex Barbarius is no exception: the debate as to its precise meaning was fuelled by the Orléanese dissent, and from Cynus and Bartolus onwards it became traditional to distinguish two opposite interpretations of Barbarius' case: that of the Citramontani and that of the Ultramontani. This opposition may be found in any legal history textbook, and of course it is to a certain extent the product of a grand narrative that was often rather liberal with facts. According to this narrative the Citramontani were mainly the Bolognese and their sympathisers, while the Ultramontani came to be identified with the jurists of Orléans. We have already seen some Citramontani who did not behave according to this scheme, and we will see more of them. Similarly, not all the French jurists would have enjoyed roasting Accursius alive. ${ }^{6}$ Looking specifically at the lex Barbarius, the very fact that some of the first opponents of Accursius studied or taught in Bologna is already significant. In the long run, the same Bolognese tradition would start bending towards Balduini's new method and progressively detach itself from the old one of Accursius. With hindsight, that was perhaps inevitable: with the passing of time, the limitations of a literal interpretation became increasingly manifest.

further version of the same text (BNF, Lat. 4488, the text was likely not written by Monciaco himself, though) said as much. Waelkens (1984), pp. 19-20 and 25-26 respectively. On the mistake as to the length of time required for a new custom in Balduini see ibid., pp. 18 and esp. 250.

Mejiers identified three cases in Ravanis' work where he referred to Monciaco as his teacher: Meijers (1959a), p. 61, note 230. Far more frequent are the occasions where Ravanis simply wrote 'dominus meus'. See further Feenstra (1986a), pp. 48-49.

5 Bezemer (2005), p. 22.

6 E. g. Chevrier (1968), pp. 979-1004. 


\subsection{Jean de Monchy}

Not much is known of Monciaco: ${ }^{7}$ he taught in Orléans until the early $1260 \mathrm{~s}^{8}$ and died a few years later, likely in the late 1260s. ${ }^{9}$ What is known of his thinking comes mainly from Jacobus de Ravanis. This is also true of Monciaco's reading of the lex Barbarius. Ravanis reports mainly the fact that Monciaco rejected the validity of Barbarius' praetorship: Barbarius' jurisdiction was ipso iure void, Monciaco maintained, just like that of an excommunicated judge. In both cases, all it would take to expose their legal incapacity would be a single litigant recusing their jurisdiction because of their true status. ${ }^{\mathbf{1 0}}$ Succinct as it is, this second-hand information is extremely interesting, especially the parallel between the slave-judge and the excommunicated judge. In a game of academic genealogy, it would be interesting to know whether the critique of Accursius and the parallel with the excommunicate - derived even in part from Balduini himself. That might also help to establish (or to exclude) a link with the doubts of Azo and Ugolino as to the the presumed will of the people, ${ }^{\mathbf{1 1}}$ for Balduini was Azo's student. ${ }^{\mathbf{1 2}}$ Unfortunately I was unable to find any significant gloss of Balduini on the lex Barbarius. ${ }^{\mathbf{1 3}}$

7 Most of the (scant) information that we have on Monciaco comes from research by Meijers, especially Meijers (1959a), pp. 39-43.

$8 \quad$ Ibid., p. 39. Monciaco might have started teaching in Orléans around 1235: Lefebvre (1958), pp. 296-297.

9 The last evidence on Monciaco that Meijers could find dates to 30.4.1265, during the final phases of the negotiation between the pope and Charles of Anjou on the Kingdom of Sicily. On that day Monciaco, who had also taken part in the earlier negotiations, witnessed the document in which Charles accepted the crown of Sicily from the pope's legate. Meijers (1959a), p. 41. A later document reports the day and month of his death (3 February) but not the year (ibid.).

10 Ravanis, ad Dig.1.14.3 (Leiden, Abl.2, fol. 18rb): 'dominus mei dicebat in ista questione quod non fuit pre(tor) quando fuit creatus possit surgere vnius de populo et dicere: tu es suspensus ipso iure, nec videtur quod actum est. Vnde sic si excommunicatus eligetur non valet ipso iure sic nec cum iste eligitur quod seruus est.'

11 Supra, $\$ 2.4$, text and notes $90-91$.

12 Cf. Odofredus, ad Cod.3.36.24, $\$$ Filium quem habentem (Odofredi ... in primam Codicis partem ... Praelectiones ... Lvgdvni, 1552; anastatic reprint, Bologna: Forni, 1968, fol. 180vb): 'dominus Ja(cobus) bal(duinus) qui militum persequebatur doctorem suum dominum Az(onem) dicebat ...'). The link between Azo and Balduini was highlighted by Savigny (1829), vol. 5, pp. 96-97, text and notes 17-18 (pp.105-106, notes $b$ and $c$ in the 2nd edn of 1850) and never questioned thereafter. Among the most recent studies highlighting the point see Conte and Loschiavo (2013), p. 137.

13 Equally interesting would be to know the position on the lex Barbarius of the other jurists of the 'first generation' of the Orléanese law professors who are known to have studied in Italy, Guido de Cumis, Simon of Paris and Pierre of 
Although Ravanis' references to Monciaco are not particularly elaborate, they are sufficient at least to wonder whether Monciaco might have commented extensively on the lex Barbarius. Ravanis referred to his teacher both for his rejection of Barbarius' praetorship and for the parallel with the excommunicate. In his comment on the lex Barbarius, Ravanis also mentioned Monciaco when discussing whether a single person could take advantage of the common mistake. On this last occasion he referred mainly to what Monciaco had said, without adding much. ${ }^{14}$ This last case was a rather specific problem, found only in the most elaborate (and lengthy) discussions as to the scope of the common mistake in the lex Barbarius. If Monciaco drew a parallel between Barbarius and the excommunicate appointed as judge and also ventured into sub-distinctions as to the validity of the common mistake, it would seem very unlikely that he did so in a few lines. A different explanation of course might be that Monciaco discussed the individual knowledge of a common mistake, not with regard to the lex Barbarius but with regard to customary law. But in that case we should also imagine a second rather unlikely event: that Ravanis decided to shift a specific and detailed point on the problem of the validity of a new custom from its sedes materiae (Ravanis' repetitio ${ }^{15}$ on Inst.1.2.9) to a different subject, also moving his teacher's discussion there. It would just seem more likely that Ravanis referred to Monciaco when commenting on the lex Barbarius because it was there that his teacher had discussed the matter. If this conjecture were true, it would make Monciaco's lost commentary on the lex Barbarius one of the most detailed of his times, perhaps on the same level as that of Odofredus.

The analogy between Barbarius and the excommunicate would have great success among civil lawyers, but it was not new. As we will see, canon lawyers had already drawn it long before Monciaco. ${ }^{16}$ Any discussion as to the influence

Auxonne (on whom see esp. Meijers [1959a], pp. 30-35, 36-38 and 43-44 respectively). Unfortunately, my attempts to find any significant gloss of these jurists on the lex Barbarius have proven similarly unsuccessful. Among those three jurists, the most renown was doubtless Guido de Cumis. On his life and works, apart from the above-mentioned study of Meijers (which remains fundamental), mention should be made at least of Feenstra (1996), pp. 26-27; Feenstra (1974), pp. 260-266; Cortese (2013), pp. 1094-1095. More literature on Cumis esp. in the above-mentioned article of Feenstra (1996), p. 26, note 4, and Feenstra (1986b), p. 17.

14 Infra, this chapter, note 60.

15 The repetitio was a special lecture - we might say, a lectio magistralis- on a specific lex. On the point see Bellomo (1995), pp. 137-139; Dondorp and Schrage (2010), p. 27; Waelkens (2015), p. 103. The precise relationship between lectura and repetitio in the sources is of course far more complex: see e.g. Bellomo (1995), pp. 145-147, and esp. Bellomo (2000), pp. 404-424; cf. also infra, this chapter, note 66 .

Infra, pt. II, $\$ 6$. 
of canon lawyers on first Orléanese law professors about the lex Barbarius (and, probably, also beyond it), however, would be mere speculation. Besides, it is more likely that the origin of the parallel with the excommunicate came from the civil law tradition, as we shall see. The widespread use of such a parallel among the Ultramontani and their Italian sympathisers might have facilitated the reception among civil lawyers of what the canonists had to say on the matter. We will come back to the point.

\subsection{Jacques de Révigny}

Shortly before Monciaco concluded his Orléanese teaching, one of his former students, Jacobus de Ravanis (Jacques de Révigny, c.1230-1296), ${ }^{17}$ became his colleague. In the space of a few years (he taught in Orléans until 1270) ${ }^{\mathbf{1 8}}$ his teaching would acquire great fame and prestige, leaving a strong mark both in France and on the 'other side' of the Alps. Meijers identified two manuscripts reporting Ravanis' repetitiones on the Vetus: one in Leiden, the other in Naples. ${ }^{\mathbf{1 9}}$ Later scholars added others, ${ }^{20}$ but not for the lex Barbarius. Of the two manuscripts of Meijers, however, only the Leiden one also contains his repetitio on the lex Barbarius. ${ }^{21}$

In his comment on the lex Barbarius, Ravanis cites only Monciaco. It is however likely that he knew at least some among the earlier jurists mentioned so far. ${ }^{22}$ For instance, the way Ravanis introduces Barbarius' case strongly reminds one - if in a somewhat less colourful manner - of Odofredus. ${ }^{23}$ The extent to which Monciaco's teaching influenced Ravanis on Barbarius' case is far from clear. Ravanis quoted Monciaco only twice during his remarkably long repetitio, and the peculiarities of his reasoning (together with the full-scale attack on the Gloss) would strongly suggest a remarkably original approach. History, however, Zuurdeeg (1989), pp.1-10, and especially Bezemer (1987), pp. 1-4, and Bezemer (1997), pp. 139-143.

18 Waelkens (1984), p. 1.

19 Meijers $(1959 a)$, p. 71.

20 See esp. Bezemer (1987), pp. 116-117.

21 Leiden Abl.2, fols. 17vb-18va. The Naples manuscript skips the repetitio: see Napoli, Branc.III.A.6, fol. 13r-v. See also Lepsius (2008), p. 242, note 52.

22 On Ravanis' sources see esp. van Soest-Zuurdeeg (1989), pp. 64-67.

23 Ravanis, ad Dig.1.14.3 (Leiden Abl.2, fol. 17vb): 'tale barbarius philippus seruus fugitiuus fugit a domino suo et iuit ad ciuitatem romanam et gessit se pro libero homine. Cum vacaret pretura petijt preturam ab imperatore et pretor designatus est. Exercuit officium suum, multa decreuit, multa iudicauit. Deinde venit dominus eius et dixit ei: nescio quae facis tu et vult ipsum retrahere, et sic detectum est ipsum fuisse seruum.' Cf. Odofredus, supra, $\$ 3.1$, note 8. 
is always written posthumously. Ravanis' efforts to produce a remarkably original piece of legal thinking were soon frustrated by the usual 'transmission chain', Bellapertica-Cynus-Bartolus. Bellapertica (who relied abundantly on Ravanis) sought to downplay Ravanis' originality, possibly so as to enhance his own. Cynus reproduced Bellapertica's repetitio almost without change, and Bartolus relied mainly on Cynus for the position of the Orléanese jurists. Most later authors simply read Bartolus. As a result, Ravanis was remembered for having based his interpretation on both public utility and the authority of the sovereign. According to this reading of Ravanis, his position differed from that of the Gloss only in that he treated those two requirements independently from each other, so that one could be present and the other missing. Allegedly, for Ravanis, it was only when the two elements were both present that the deeds would be valid, as in Barbarius' case. ${ }^{24}$ This summary did little honour to its author. What Ravanis did say was something different, and remarkably subtler.

Ravanis' position on the lex Barbarius does not diverge from that of the Gloss only in its conclusion, but starts with its approach to the text itself. The analysis of specific words or excerpts no longer follows the order in the source. Far from providing a textual exegesis, Ravanis restructures the text so as to better match the general point he seeks to make. The great advantage of a non-literal interpretation of the text lies in its flexibility: it becomes possible to reach new conclusions, different from and even contrary to those found in the text itself. $^{25}$

Ravanis opens his comment on the lex Barbarius by rejecting the approach of the Gloss: the lex deals neither with Barbarius' praetorship nor with his freedom, but only with the validity of Barbarius' deeds. ${ }^{26}$ To deny the validity of Barbarius' praetorship, Ravanis inverts the order of the Gloss and discusses Barbarius' freedom first. ${ }^{27}$ The rearrangement is not to make it more logical but to make it functional to the purpose that Ravanis seeks to achieve. If Barbarius' freedom is a prerequisite for the validity of his praetorship, then disproving the one becomes instrumental in denying the other. Having denied both points, Ravanis however allows for the validity of the acts of the slave who became neither free nor

24 For Bellapertica and Cynus see infra, this chapter, note 136. In his summary of Cynus, Bartolus was more succinct: infra, $\$ 5.1$, note 4 .

25 See esp. infra, this paragraph, note 56.

26 Ravanis, ad Dig.1.14.3 (Leiden Abl.2, fols. 17vb-18ra): 'Ex isto themate tria queruntur $s$ (ecundum) glo(sam). Iste erat seruus, nunquam factus est pretor de iure, quia planum est quod de facto fuit. Item nunquam valet quod [MS: qui] iudicauit, et item nunquam est liber. Ad primam non respondet, sed glo(sa) dicit quod quamdiu latuit sua seruitus fuit pretor ... Dico glosa in l(ege) ista non querit nec vnum, de edictis et sententijs vtrum teneant.' See infra in this paragraph. 
praetor. The lex Barbarius, says Ravanis, affirms their validity in pursuance of public utility considerations, so as not to prejudice all the parties who transacted business before Barbarius in the mistaken belief that he was truly praetor. Both in rejecting the tripartition of the Gloss and in approving only of the validity of the deeds, Ravanis (or Monciaco before him?) set an example that would be followed by the other Ultramontani that we will look at.

Public utility, says Ravanis, allows for the validity of what is done under a mistaken belief. ${ }^{28}$ To be able to trigger public utility considerations (and so to produce valid legal effects), however, a mistake must be common. ${ }^{29}$ In case of a single person's mistake, truth prevails. ${ }^{30}$ In saying as much, Ravanis of course does not mean that the mistake of an individual may never excuse him. When his ignorance is justifiable, the single person may well invoke it - but only to bar the application of the rule in that specific case. Thus, the individual mistake may prevent the production of specific effects of a rule or contract. ${ }^{31}$ The common mistake works exactly in the opposite sense: it bestows validity upon something that would otherwise be void. To do that, it is necessary that both the mistake and, especially, the utility be common. So for instance, continues Ravanis, the excommunicate appointed to hear a single case cannot pronounce a valid decision, although he was widely reputed to be in communion with the Church. $^{32}$

28 Ibid., fol. 18ra: 'Item colligit<ur> hoc quod propter multitudinem permittitur aliquid quia multa decreuit si retractarent multi ledentur ... ad hoc est ar(gumentum) quod propter tumultum populi euitandum fit quod alias non fieri, i(nfra) ad l. cor(neliam) de sic(ariis) l. qui cedem (Dig.48.8.16).'

29 On the problem of individual knowledge of the common mistake see infra in the text, and esp. note 60 .

30 Ravanis, ad Dig.1.14.3 (Leiden Abl.2, fol. 18ra): 'Dicunt hoc colligitur quod opinio prefertur veritati. Dico debet colligi quod opinio non singularis sed communis. Item si consonet veritati, preferitur veritati ut $\mathrm{i}(\mathrm{nfra})$ ad acquir(enda)

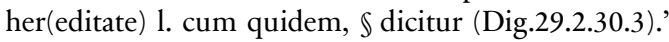

31 Ibid.: 'Error probabilis excusat, etiam singularis. Statutum est in ciuitate ista quod qui vadit de nocte soluat tantum. Tu uenis de nouo ad istam ciuitatem, vadis de nocte. Nonne excusaret te error tuus singularis? Certe sic, quia statuta ciuium non liga $<\mathrm{n}>\mathrm{t}$ ignorantem, $\mathrm{i}(\mathrm{nfra})$ de decret(is) ab ordi(ne) faciend(is) 1 . vlt(ima) (Dig.50.9.6); ad hoc est $\mathrm{i}(\mathrm{nfra})$ de iur(is) et fac(ti) ig(norantia) 1 . i $\mathbb{i}$ (Dig.22.6.1.1).' Cf. Bezemer (1994), p. 102, note 92.

32 Ravanis, ad Dig.1.14.3 (Leiden Abl.2, fol. 18ra-b: 'pone quod imperator deleget excommunicatum: videtur non versatur utilitatis publica, sed sola litigatorum. Ideo dico in illis questionibus quod sententia non valet immo nulla est ipso iure, quia a non suo iudex lata ut C. si $\mathrm{n}(\mathrm{on}) \mathrm{a}<\mathrm{com}>\mathrm{pe}$ (tenti) iudi(ce) (sic) per totum (Cod.7.48).' The Accursian Gloss mentioned the mistake of single litigants when discussing the incompetent judge in Cod.7.48.2, $\$ S i$ militaris (Parisiis 1566, vol. 4, col. 1674). 
The same public utility allows one to consider Barbarius' deeds as valid. This, argues Ravanis, is what Ulpian meant when he said that it was the more human solution ('humanius') to Barbarius' case. ${ }^{33}$ To prove the point Ravanis gives several examples, two of which are particularly interesting. The first is, once again, about the excommunicated judge. If an excommunicate is appointed judge on the common but mistaken assumption that he was not excommunicated, says Ravanis, his decisions would be valid, just as those of the slave appointed praetor. $^{34}$ In the previous example, the excommunicate was appointed to hear a single case: in the absence of common utility, Ravanis denied the validity of the sentence despite the common mistake. ${ }^{35}$ In the second case, on the contrary, the excommunicate was in the same situation as Barbarius: that of an ordinary judge. The parallel between the excommunicated judge and the slave-judge is not new: we have already seen how Monciaco used the same image to stress the precariousness of Barbarius' jurisdiction. Ravanis seeks to strengthen the similarity between Barbarius and the excommunicated judge using one of those subtle arguments that would incense so much later Citramontani: the excommunicate is a criminal (delinquens); the criminal is called 'enslaved to the punishment' (servus poenae); so the excommunicatus is a servus. ${ }^{36}$ In other words - as most other jurists would have put it - the excommunicate loses his legal capacity, becoming similar to a slave.

Ravanis, ad Dig.1.14.3 (Leiden Abl.2, fol. 18ra): 'Tertio subicitur questio nunquid edicta <et> decreta ab eo tenebunt. Dicit iuris consultus quod sic et hoc est humanius alias ledentur qui coram eo litigauerunt.' Ibid., fol. 18rb: 'Item dicit litera "humanius est" ut eius decreta teneant si esset vere pretor ... Possit dicere quod non fuit pretor et quamquam (sic) sint sententie late a non suo iudice ualent tantum ex equitate, vnde licet non teneant de rigore valent de equitate, et hoc innuit illud verbum "humanius est" etc., et sic illa litera "sed nihil" etc. usque in "quid dicemus" etc.' Cf. Dig.1.14.3: '... Sed nihil ei servitutem obstetisse ait Pomponius, quasi praetor non fuerit: atquin verum est praetura eum functum. Et tamen videamus: si servus quamdiu latuit, dignitate praetoria functus sit, quid dicemus? Quae edixit, quae decrevit, nullius fore momenti? An fore propter utilitatem eorum, qui apud eum egerunt vel lege vel quo alio iure? Et verum puto nihil eorum reprobari: hoc enim humanius est.'

34 Ravanis, ad Dig.1.14.3 (Leiden Abl.2, fol. 18ra): 'Pone excommunicatus impetratus est iudex, imperator ignorabat et credebatur communiter quod non esset. Excommunicatus iudicauit, nunquid valebit sententia? Videmus quod sic per 1. istam [scil., the lex Barbarius], excommunicatus seruus est quia delinquens seruus est delicti, C. de sen(tentiam) pas(sis) 1. ult(ima) (Dig.48.23.4). Sic ergo valet quod decreuit barbarius seruus qui credebatur communiter liber in sententia lata ab excommunicato, de quo communiter credebatur quod esset liber valebit.'

35 Supra, this paragraph, note 32.

36 Supra, this paragraph, note 34. 
Allowing the validity of decisions issued by an excommunicate, however, does not mean supporting the validity of the excommunicate's own jurisdiction. If Ravanis takes Monciaco's example of the excommunicate who is appointed judge, he insists that the appointment as judge took place after the excommunication, not before it. The point is important: it is not a question of determining whether further deeds could be valid even after the excommunication, but whether any decision could be valid at all, despite the fact that this judge never had any jurisdiction. To strengthen the point, Ravanis provides another example: that of the praeses provinciae who, unaware that his successor had already arrived to replace him, continued to exercise his office despite his jurisdiction having expired (Dig.1.18.17). ${ }^{37}$ Ravanis is not the first to notice the similarity between this case and that of Barbarius: when commenting on Dig.1.18.17, the Accursian Gloss also referred to the lex Barbarius. ${ }^{38}$ But the reason Ravanis refers to this text when discussing Barbarius is very different from the use made in the Gloss. The Gloss simply observed how 'someone who is unaware can do what someone who is aware could not do'. ${ }^{39}$ Ravanis on the contrary wants to show that, aware or not, the old praeses could not possibly exercise his jurisdiction - just as an excommunicate sitting on the bench. The question is simple: since the new praeses was already in the province, the mandate of the old one could not be prorogated. Doing so would amount to suspending the jurisdiction of the new magistrate. Nonetheless, the Digest considered the deeds of the old praeses to be valid. The reason for their validity is found in a second text that Ravanis cites immediately thereafter. This text came slightly earlier in the order of the first book of the Vetus, and it looked at the opposite scenario: the new proconsul was yet to arrive when the mandate of his predecessor expired. Here there was little difficulty in prorogating the jurisdiction of the old proconsul. In so doing, the

Ravanis, ad Dig.1.14.3 (Leiden Abl.2, fol. 18ra): 'Ecce alia <quaestio> (s)i videtur uel dicitur quod iudex ordinarius finito tempore sui regiminis ignorat [MS: ignorant] aduentus successoris iam erat successor in prouincia et iudicat videtur et hoc est vi ignorantiae ut $\mathrm{i}(\mathrm{nfra})$ de off(icio) presi(dis) l. si forte (Dig.1.18.17) et de of(ficio) procon(sulis) l. meminisse (Dig.1.16.10pr).' The same solution is then applied in case of delegated jurisdiction (the proconsul on the contrary had ordinary jurisdiction), when the mandate of the delegate judge is revoked unbeknownst to the parties. Ibid., fol. 18ra: 'et hoc dicunt ipsi in simili questione: quidam est delegatus, reuocatur eius mandatum, partes ignorant reuocationem, litigant partes coram eo et dicat sententiam. Dicunt quod valet sententia per 1 (egem) istam et per 1 (egem) perall(egatam) $i(n f r a)$ de of(ficio) presi(dis) 1. si forte (Dig.1.18.17) et facit $\mathrm{i}(\mathrm{nfra})$ de sol(utionibus) 1. vero procuratori (Dig.46.3.12).' The text of Dig.1.18.17 is reported supra, $\$ 2.5$, note 101.

38 Supra, $\$ 2.5$, note 102.

39 Ibid. 
text also gave a clear explanation: the prorogation was needed for the 'utilitas provinciae'. ${ }^{40}$ Public utility was of course also the reason for the validity of the deeds of the old praeses in the first case - but the text did not say as much expressly. What Ravanis needed was a clear statement that public utility could be invoked to bestow validity on the deeds without necessarily acknowledging the legitimacy of their source. In the case of the old praeses provinciae the relationship between public utility and validity of the deeds is immediate. The common mistake as to the status of the ex-praeses triggers public utility considerations that allow for the validity of his deeds without at the same time prorogating his jurisdiction.

Having found a foothold in the sources allowing for the desired solution of Barbarius' case, Ravanis moves on to explain its working. This explanation is probably the most interesting part of his commentary on the lex Barbarius. Its first part consists of a peculiar interpretation of the effects of the common mistake. On the point Ravanis' analysis is relatively short but remarkably complex.

For Ravanis, a common mistake bestows validity on something that would otherwise be void, but only so long as the mistake itself is not uncovered. Uncovering the mistake also means removing its effects. The uncovering of the mistake, in other words, operates retrospectively. Since mistakes do not make law, a mistake may only inhibit the application of some particular rules so long as it lasts. Applied to Barbarius, this means that his mistaken status allowed him to act as if he were truly praetor - so long as the mistake lasted. But the moment the truth is uncovered, the effects of the mistake should fade away together with the mistake itself. All Barbarius' deeds should therefore be considered according to his true legal status, and so be declared void. ${ }^{\mathbf{4 1}}$ tum successoris omnia debere proconsulem agere, cum sit unus proconsulatus et utilitas provinciae exigat esse aliquem, per quem negotia sua provinciales explicent: ergo in adventum successoris debebit ius dicere.' The reference to the utilitas provinciae was obviously interpreted as common utility: cf. Gloss ad Dig.1.16.10, $\$$ Debet ius (Parisiis 1566, vol. 1, col. 140).

41 Ravanis, ad Dig.1.14.3 (Leiden Abl.2, fol. 18rb): 'barbarius fuitne pretor quamdiu latuit sua seruitus? videtur quod $\mathrm{n}(\mathrm{on})$. $\mathrm{L}(\mathrm{ex})$ dicit perceptio salarij non facit aliquem decurionem, ut i(nfra) de decurio(nibus) 1. herennius (Dig.50.2.10). Vnde si quis credeatur canonicus et non est, si percipuit distributiones et stipendia hoc non facit ipsum canonicum. Queritur et si iste barbarius se habuit ut pretor et salarium recep(it) tamen ex quo non est electus legitime non est pretor. Item 1. dicit C. si servus export(andus) 1. moueor (Cod.4.55.4) qualiter est nec aliquis fingitur fuisse retro sed detecta seruitute est seruus, ergo fingitur retro fuisse seruus et sic non potuit esse pretor.' Cf. ibid., fol. 18ra: 'Item ad notabile quod error communis facit ius verum est quousque error sit detectus, vnde quousque latuit seruitus est iudex, sed detecta seruitute non est iudex.' Ravanis' 
Ravanis' position on the common mistake is remarkably refined; at least intellectually, more so than that of his contemporary, Jacobus de Arena. Arena insisted on the effects of a common mistake, but did not explain its nature, let alone the relationship between the essence and effects of the common mistake. He simply sought to limit the scope of the common mistake, and found it in unfair prejudice. Where the common mistake would lead to the unjustified prejudice of the person who went along with the mistake, or of a third party, then it does not produce effects. ${ }^{42}$ If compared with Odofredus, ${ }^{43}$ this is clearly an improvement: at least, it imposes a limit to the scope of common mistake. But the underlying principle seems to be the same: if common, a mistake is tantamount to truth, and so can have legal effects - unless equitable considerations inhibit its application to a specific case. Ultimately, the widespread character of the mistake remains the reason for its equiparation to the truth and so the production of valid legal effects. Seeking to provide a more robust argument for this equiparation than Odofredus', Arena drew on several passages in the Roman sources, each one dealing with a specific case on common mistakes. Thus Arena's rule was the product of inductive reasoning: easily applicable to other, discrete cases by way of analogy, but a weak basis for a general, abstract principle. ${ }^{44}$ This way, the (logical) explanation for the legal effects of the common mistake remained somewhat ambiguous.

Also for Ravanis common mistake is potentially all-encompassing. But, and much unlike Odofredus and Arena, for Ravanis it may never be assimilated to the truth. The common mistake is structurally incapable of 'making law' because it may confer only a veneer of validity. So long as the mistake endures, it bestows validity only because it inhibits the application of the underlying cause of invalidity. Uncovering the mistake therefore means exposing the invalidity of the deeds. While the scope of application of the common mistake is unrestricted, in other words, its precarity leaves it fragile.

Applied to the lex Barbarius, however, the fragility of the common mistake also becomes its strength. And here lies Ravanis' genius. The effects of the common mistake may be ephemeral, but they allow an inverted approach to the validity of Barbarius' deeds. The whole issue of the lex Barbarius no longer revolves around the bestowal of validity upon some void deeds. Now the operation is exactly the opposite: depriving the deeds of their previous (albeit

restrictive interpretation of the lex Moveor, functional to his approach as to the consequences of the mistake, would seem in open contrast with that of the Gloss (supra, $\$ 2.3$ ).

42 Supra, $\$ 3.2$.

43 Supra, $\$ 3.1$.

44 Cf. Gordley (2010), esp. pp. 89-100. 
apparent) validity. We have already seen this logical inversion (from valid to void) in the approach of the Gloss on the effects of putative freedom, and it cannot be ruled out that Ravanis took inspiration from it. ${ }^{45}$ But we have also seen how the second part of the Gloss on the lex Barbarius changed its overall position on the matter. ${ }^{46}$ In subordinating the validity of the deeds to that of their source, Accursius' problem was how to confer validity on Barbarius' deeds. Ravanis' concern is precisely the opposite: how the same deeds could be seen to retain their initial validity. The point is very important: Ravanis does not need to make something valid that is void. He must prevent the apparent validity of the deeds from yielding to their true condition when the common mistake is uncovered. It is only at this stage - and for this reason - that Ravanis introduces the other element of his theory, the role of superior authority. The inversion of perspective as to the validity of the deeds also impacts on the role of the superior authority. In Ravanis, the superior authority is invoked not to bestow validity on the deeds, but to ensure that the deeds could retain their initial validity.

Before invoking the superior authority, however, Ravanis had to make sure that its intervention would not apply to the person of Barbarius (as it does in the Gloss) but only to his deeds. It was therefore necessary first of all to disprove Accursius' theory on the presumed will.

The Roman people (or, after the lex Regia, the emperor) surely had the power to set Barbarius free or even to appoint a slave as praetor. ${ }^{47}$ But it does not follow that they wanted to exercise this power. That, says Ravanis, was the mistake of the Gloss. The Gloss 'jumps' to a conclusion that was not supported by the text of the lex Barbarius. ${ }^{48}$ Nor is it possible to invoke Pomponius' remarks on the validity of Barbarius' position. What Pomponius said, argues Ravanis, belongs to the facts of the case ('de themate'), not to their legal outcome. ${ }^{49}$ In other words, (especially for putative freedom) were not: supra, this paragraph, note 41 .

46 Supra, $\$ 2.4$.

47 Ravanis, ad Dig.1.14.3 (Leiden Abl.2, fol. 18ra): 'populus romanus olim cum apud populum romanum residebat imperium potuit seruo etsi manenti seruo decernere istam dignitatem et abrogare [MS: arrogare] 1(egem) quod dicit seruum non posse esse pretorem uel iudicem. Item populus romanus olim si sciuisset eum seruum potuisset ipsum facere [MS: fecisse] liberum, quare si hoc posset populus romanus olim cum apud eum residebat imperium multo fortius imperator in quem translatum est imperium hoc potest uel potuit.'

48 Ibid., fol. $17 v b$ : 'istam questionem legit litera per saltum post illa uerba "designatus est"'

49 Ibid., fol. 18ra: 'Dixit iuris consultus pomponius non nocet ei seruitus quin pretor fuit prefectura functus est, hoc sit per l(egem) istam quod fuit vere pretor. Possent legi verba ista quod essent de themate, et sic denotarent factum non ius.' 
according to Ravanis, Pomponius simply said that Barbarius exercised the praetorship, not that his praetorship was valid. Much to the contrary, for Ravanis the legal outcome of the lex Barbarius is a clear denial that Barbarius ever became praetor. Barbarius was not praetor because he did not become free. ${ }^{50}$ The best evidence for this is Ulpian's remark that the people would have set Barbarius free had they known of his servile condition. This remark, says Ravanis, is not tentative evidence of Barbarius' hypothetical freedom, but clear proof of his enduring servitude. ${ }^{51}$

50 For Ravanis, the invalidity of Barbarius' praetorship has little to do with any obstacle other than his own personal status. That is particulary the case for the lex Iulia de ambitu, which no longer applies in Rome. The point might seem marginal, but in the discussion of previous and coeval jurists on Barbarius' case the lex Iulia acquired a remarkable (at times, somewhat disproportionate) importance, and this strengthened the impression that the fate of Barbarius' praetorship would depend on its interpretation. Looking at Dig.48.14.1pr (Mod. de poen. 2), Ravanis could easily argue that the lex Iulia no longer applied in Rome from the moment that the prince started to appoint magistrates, previously elected by the people. Leiden Abl.2, fol. 18rb: 'Hic dicitur quod barbarius prefecturam petijt et designatus est pretor. Contra, non debuit designari ex quo petijt immo incidit in l. iul(iam) ambitus $\mathrm{i}(\mathrm{nfra})$ ad l. iul(iam) ambi(tus) 1. unica (Dig.48.14.1). Dicunt quidam verum est si petet clam incidet in l. iul(iam) ambi(tus) nec designaretur pretor, si palam coram omnibus licet et sic non incidit in $\mathrm{l}$ (egem) iul(iam) ambi(tus), vnde licet ad palam quod clam non licet, $\operatorname{ar}$ (gumentum) i(nfra) de administr(atione) tuto(rum) 1. non existimo (Dig.26.7.54) et est casus 1. i(nfra) de pollicit(ationibus) l. i $\$$ si quid ob honorem (Dig.50.12.1.1). Dico ali(ter). Dicit glo(sa) [Barbarius] petijt in vrbe romana, vnde qui petit incidit $s$ (cilicet) in iul(iam) ambi(tus). Verum est si alius quam in vrbe, sed barbarius in vrbe petijt et ibi cessat 1 . iul(ia) ambi(tus) ut $i(n f r a)$ e(odem) l(ege) i(nfra) (sic) ad l. iul(iam) ambi(tus) 1. unica (Dig.48.14.1). Dicit glo(sa) quod lex iul(ia) ambi(tus) cessat in urbe romana. Pessime intelligit 1 (egem) quod hoc dicit i(nfra) ad iul(iam) ambi(tus) 1. unica. Dicit 1. illa 1. iul(ia) ambi(tus) cessat in vrbe quia datio magistratum pertinet ad principem. Antequam spectaret datio magistratuum ad principem, illi quibus spectabat corrumptebantur. Sed hodie dicit 1 . illa ex quo spectat ad principem non est verisimile quod sit corruptibilis princeps, immo incorruptibilis. Vnde cessat 1. iul(ia) ambi(tus) in vrbe, quia cessat delictum. Sed non dicit possit licite dari pecunia in vrbe roma pro acquirendo magistratu.'

51 On this point, Ravanis is particularly meticulous in his reconstruction of the exact meaning of the text. Ibid., fol. 18va: 'Item pro hoc est litera, dicit in fine "sed etsi scivisset" populus romanus "seruum esse liberum fecisset"; hoc dicit "etsi" implicat "sed etsi si sciuisset", quod dicit idem est et cum ignorasset ipsum esse seruum, quod ipsum fecit populus liberum. Dico quod non est liber, et hoc dicit litera in hoc "cum humanius est", cum etsi potuit populus romanus seruo l(ibertatem) decernere habuit potestatem ad ar(gumentum) glose, quod dicit hoc verbo "etsi" implicat "sed etsi si sciuisset". Dico quod non est in "etsi" sed in "etsi uel sic". Dicit litera "sed et si sciuisset seruum liberum fecisset". Hoc dicit et hoc 
Having excluded the application of the sovereign power to the person of Barbarius, Ravanis seeks to link that power directly to Barbarius' deeds. The operation presents an obvious difficulty: the actual exercise of the sovereign power would entail the ratification of Barbarius' position. Hence Ravanis invokes that power, but not its exercise. He does so stressing two elements. First, the mistake itself was only partial: the people, says Ravanis, were mistaken only as to the condition of Barbarius, not about his person. The mistake, in other words, was not on the identity of the elected but only on his status. The people wanted Barbarius as praetor - only, they were not aware of his servile condition. Thus, reasons Ravanis, although the will of the people is vitiated, it is still present. The second reason is rather obvious: the people (or the prince) are sovereign. This clearly magnifies the consequences of their volition, because it allows the production of legal effects that a non-sovereign volition (i. e. the will of anyone below the law, not above it as the princeps) could not have. ${ }^{52}$

implicat, hoc videtur ignorauit populus cum fecit serum pretorem, sed et si sciuisset eum esse seruum fecisset eum liberum, $\mathrm{q}$ (uod) $\mathrm{d}$ (icit) non sol(um) pretorem. Vnde si sciuisset eum seruum et liberum et pretorem fecisset, et quod non fuit liber quia imperator hoc non agebat optime facit $\mathrm{i}(\mathrm{nfra})$ de in ius vo(cando) 1. sed si hoc lege $\$$ patronum (Dig.2.4.10.2). Sed si sciuisset eum seruum, fecisset eum liberum, ar(gumentum) C. qui admi(tti) ad bo(norum) pos(sessionem) l. bonorum (Cod.6.9.1).'

52 Ibid., fol. 18rb: 'dico licet fuit pretor quod [MS: quia] tamen detecta seruitute videbantur acta sua non valere, quia dampnato actore dampnantur ea quae egit ut C. de her(eticis) 1. dampnato et 1. ii (Cod.1.5.6pr and 2). Hic tamen vides contrarium. Videtur dicendum quod fuit pretor quia si non face $<$ re $>t$ eum imperator pretorem aut hoc esset propter errorem aut propter iuris prohibicionem. Propter iuris prohibicionem non, quia iuris innhibitio (sic) non ligat imperatorem ut s(upra) de legi(bus) 1. princeps (Dig.1.3.31); propter errorem non, quia fuit error in condicione persone et talis non impedit ut $\mathrm{i}(\mathrm{nfra}) \mathrm{de}$ iud(iciis) 1. ii (Dig.5.1.2pr) et i(nfra) de iur(isdictione) o(mnium) iu(dicium) l. si per errorem (Dig.2.1.15). Ex hoc se(quitur) quod quos deliget imperatorem uel populum quod teneat ipso iure quia iuris prohibicio [scil., against electing praetor a slave] nichil operatur in principem, sed possit dicere quod cum hoc fuit publica vtilitas, vnde ista<e $>$ duo $r$ (ationes) faciunt, communis vtilitas et committentis po(tentia).' The opposite case may be found in Ravanis' repetitio on Inst.1.2.9, on the validity of a new custom introduced by mistake. What if the inhabitants of a city followed a behaviour in the mistaken belief that it was legally required? As a matter of principle, since they observed this behaviour for a sufficiently long time, its observance should lead to the creation of a (legally binding) custom, for 'mistake makes law'. However, since the people lacked the will to introduce this new custom, their mistake does not point to implicit consent but rather to the lack of it. Being mistaken, their power to change the law could not be invoked to keep the custom. On the contrary, their ignorance is considered proof of utter lack of consent. And so, concludes Ravanis, the custom is void. Ravanis, repetitio ad Inst.1.2.9 ('ex non scripto') (BNF, Lat. 4488, 
These two arguments must be read together: the will of the Romans is relevant because they are a sovereign people. Alone, the formal validity of the appointment would not suffice as to the valid exercise of the office. So for instance, says Ravanis, if it was not the Roman people who had elected a slave as praetor but rather a bishop who had appointed an excommunicate as judge, the deeds of the judge would clearly remain void. ${ }^{53}$ The emphasis, in other words, is not on the appointment but on the person who made it.

In turn, this difference would seem to depend on Ravanis' theorisation of the common mistake. Not providing a specific, normative explanation for the validity of what is done under common mistake, Odofredus and Arena could be rather liberal with the use of the expressions such as 'common mistake makes law'. By contrast, the only time in Ravanis' commentary on the lex Barbarius (far longer than those of the two Italians combined) where he says that the common mistake 'makes law', he adds immediately that 'this is true until the mistake is uncovered'. ${ }^{54}$ The lack of a clear definition of the common mistake in the thinking of those jurists entailed its potentially unlimited scope. The definition provided by Ravanis, on the contrary, set clear boundaries to the common mistake. These boundaries, however, also limited its strength, and called for stronger reasons in support of the validity of the acts. If the effects of the common mistake should fade away with the mistake itself, then the simple formal validity of the appointment might not suffice to keep them alive. Hence

fol. 303rb, transcription in Waelkens [1984], pp. 445-446, 11.1-9, 21-36): 'Queritur sexto utrum usus non erroneus exigatur ad consuetudinem inducendam. Pone exemplum. Populus totus huius ciuitatis uel maior pars est usus tali modo quod credebat esse legem et tanto tempore quod sufficit ad consuetudinem inducendam et non est lex. Numquid erit consuetudo? Videtur quod sic, quia error communis facit ius: ff. de officio pretorum 1. Barbarius (Dig.1.14.3); de supellecti(li) legata 1. Labeo, ad fi. (Dig.33.10.7.2 sed Dig.33.10.5.3); ergo et consuetudinem ... Set et populus ex certa scientia potest tollere legem et contrariam legem facere, ergo multo fortius et consuetudinem. Set ad istam rationem dicendum est quod ubi est error, non est consensus in eo in quo est error. Vnde si populus utitur sic, set mouetur in alia ratione, consentit in hoc ut sit ius in futurum, set in ratione decipitur nec in illa consentit ... Requiritur consensus ad consuetudinem. Ergo usus populi errantis eam non inducit.' Cf. Waelkens (1984), p. 240. On the problem of the dialectic mistake-consent in the formation of customs see more generally Cortese (1964), vol. 2, pp. 104-110.

53 Ravanis, ad Dig.1.14.3 (Leiden Abl.2, fol. 18ra): 'Pone quod episcopus huius ciuitatis committit excommunicato; certe ipse non posset hoc facere quod excommunicans possit iudicare.' The example might not be entirely felicitous, since in most cases the bishop could lift the sentence of excommunication. Ravanis might have thought of some particularly serious cases of excommunication, or of some jurisdictional reason why the bishop could not have lifted it (say, it was issued by his metropolite).

54 Supra, this paragraph, note 41. 
the need to recur to the much-criticised Accursian solution of the will of the people, albeit shaped differently.

In so doing, Ravanis' conclusion might seem at first sight somewhat paradoxical. He criticised the presumed will of the people in Accursius more harshly that any previous jurist (so far as we know), only to use it himself. And, when using it, he seemed content with the mere possibility of something that surely did not happen. The harsh critique of Accursius might well depend precisely on the fact that Ravanis did not want to dismiss his solution entirely, but to apply it to a different object (the deeds, not the person). Because Ravanis intended to keep its fundament alive, in other words, it was essential to disprove Accursius' application in the strongest possible terms. Further, Ravanis' tantalising approach to a will that does not materialise (the will to appoint someone as praetor without the intention of actually dispensing from his incapacity) is itself the product of his peculiar position on the common mistake. Ravanis does not need to envisage a positive intervention of the sovereign because of the initial validity of the deeds. As said, his problem is not to ascribe validity to something that is void, but simply to retain a pre-existing validity once the mistake is clarified. Hence Ravanis could consider sufficient the simple fact that the choice of Barbarius was made by the same subject who had the power to dispense with the incapacity, all the more given that the sovereign was mistaken only as to the condition, not also the identity, of the person elected. ${ }^{55}$

Since the sovereign's intervention remains only potential - it gives strength to the election without in effect materialising - Ravanis considered it as only an element in support of the public utility argument invoked by Ulpian. This can be seen in Ravanis' division of the text of the lex Barbarius: first, Pomponius describes the subject matter (Barbarius' discharge of the praetorship), and then Ulpian explains the underlying issue (whether the deeds are valid), and finally provides an answer to it (the deeds are valid out of fairness towards the people, given their common mistake). Ulpian's rhetorical questions (it would be unfair for the people to suffer harm from an election whose invalidity they could easily

Ravanis, ad Dig.1.14.3 (Leiden Abl.2, fol. 18ra): 'confirmat [Ulpianus] suam solutionem duabus rationibus quia valuerunt quae dixit et quae decreuit, propter potenciam eius qui commisit ei iudicari, et istam potenciam committentis ostendit duabus rationibus. Ecce prima: populus romanus olim cum apud eum erat imperium posset ei manenti seruo dare preturam, abrogando l(egem) quod dicit quod seruus iudex esse non potest nec pretor. Ergo imperator hoc multo fortius hoc possit. Secunda ratio est si populus romanus sciuisset eum seruum potuisset eum facere liberum et pretorem. Ergo si hoc olim potuit facere populus multo fortius potest hodie imperator, et sic concludit potencia committentis. Et sic ex potestate committentis et propter vtilitatem valent sua decreta. Et sic vnum queritur et vnum soluitur.' 
have corrected) are only meant to strengthen the answer he has already provided. ${ }^{56}$

That, at least, was Ravanis' intention when insisting that the full 'power of the appointer' (potentia committentis) did not need to be exercised. Downplaying the power of the sovereign, however, was easier said than done. Pointing out that the people had the power to make good their mistake could overshadow the public utility argument. This is probably why Ravanis insisted on requiring the presence of both sovereign power and public utility. Without public utility, says Ravanis, the potentia committentis does not suffice. If the prince were to delegate an excommunicate to pronounce on a single case, the decision would be void. In this case, he explains, there is no public utility, only private one. ${ }^{57}$ At the same time, however, public utility without potentia committentis is of no effect either. Let us suppose, says Ravanis, that the same excommunicate was appointed not as a delegate but as an ordinary judge (so presiding over a number of disputes). If the appointment were made by a bishop, despite the presence of public utility, it would not suffice as to the validity of the decisions. ${ }^{58}$ The lex Barbarius should therefore be interpreted to say that the common mistake will prejudice the validity of the deeds unless public utility and the sovereign 'power of the appointer' are both present. ${ }^{59}$

The emphasis on the 'power of the appointer' might also explain Ravanis' hesitation in rejecting as invalid what done by someone who was aware of the common mistake. If the common mistake on the status of the person elected can produce valid effects not just because of fairness considerations but also because the specific will of the prince towards that person, then denying the validity of his deeds would become problematic even with regard to someone who was fully aware of the underlying incapacity of the elected. Hence Ravanis does not

Ibid.: 'primo ponit thema, secundum quid conferencia ad questionem mouendam, tercio elicit questionem ex themate, quarto res(pondet), quinto confirmat responsionem duabus rationibus, vltimo concludit.'

$57 \quad$ Supra, this paragraph, note 32.

58 Supra, this chapter, note 53.

59 Ravanis, ad Dig.1.14.3 (Leiden Abl.2, fol. 18ra): 'quod dicemus? Dico quod [MS: quia] 1. ista habet singularem rationem. Ego considero potentiam committentis: imperator si vellet et populus possent facere seruum preto(rem). Item utilitatis communis quia plures litigauerunt coram eo. Ista duo, scil(icet) utilitas communis et potentia committentis, faciunt quod condicio seruitutis non noceat.' The importance of the potentia committentis in Ravanis might explain the most conspicuous omission in his discussion: the case of the notary. Not all notaries were appointed by the sovereign. Stating openly that a slave could act as praetor but not as notary was perhaps best avoided. Hence Ravanis entirely skips a point that is found in the work of nearly all other jurists who wrote on our subject. 
say that the single person who knew of Barbarius' state could not avail himself of the common mistake, but simply points out the immorality of such behaviour. ${ }^{\mathbf{6 0}}$

\subsection{Martinus Syllimani}

Before moving on to the next (and last) Orléanese jurist to be studied, mention should be made of a Bolognese law professor, Martinus Syllimani

60 On the subject, Ravanis mainly discusses the problem of the individual knowledge of the immorality of a custom. Is it acceptable to avail oneself of such a custom in full knowledge of its wickedness? The discussion terminates without a clear answer, though Ravanis' personal position seems clear enough: one should not avail himself of an unethical custom. At the end of that discussion, seemingly by analogy, Ravanis recalls the problem of common mistake and individual knowledge. Is it legally admissible to invoke a common mistake with full knowledge of the truth? Again, while the law seems to allow as much, Ravanis' personal opinion is against that. Ravanis, ad Dig.1.14.3 (Leiden Abl.2, fol. 18ra): 'Sed si scientes excusaretne eum communis error? Dominus meus quesiuit a multis religiosis. Est quedam consuetudo contra rationem que potius est corruptela quam sit consuetudo. Pone gratia exempli quod maior natu totum habeat. Quidam peritus qui [MS: quia] maior natu totum occupat. Vnde scit et hoc est error et contra rationem laborat in extremis. Sunt religiosi a dextris et a sinistris. Quid debent tamen sibi consulere? Dicit ille peritus: totam terram teneo, que est contra ratione. Consulitis uos michi quia ego moriar in isto statu? Excusabitne ipsum error communis? Hoc petijt dominus meus a religiosis, et vnus respondit affirmatiue, alter negatiue. Quod excuset communis error est $\arg ($ umentum) $\mathrm{i}$ (nfra) ad maced(onianum) l. iii (Dig.14.6.3) et C. de pigneraticia 1. pignus (Cod.4.24.9). Tamen credo quod non excusat scientem.' The wrong custom that Ravanis had in mind was male primogeniture. See in particular Bezemer (1994), pp. 102-104, text and notes 92-93. See also, more briefly, Bezemer (1990), p. 13, and Bezemer (1997), pp. 6-7. Cf. Meijers (1959a), p. 59, note 223. Ravanis' (or rather, Monciaco's) moral dilemma was then also reported by Albericus de Rosate. Albericus however multiplied the number of religiosi who sided against the bad custom, and so he turned Ravanis' doubts into moral certainty. Albericus de Rosate, ad Dig.1.14.3 (In primam ff. Veter. part. commentarij, cit., fol. 70rb, n. 22-23): '... Et praedicta faciunt ad quaestionem quam hic tangit Ia(cobus) de $\mathrm{Ra}$ (vanis) et dicit dominum suum quaesiuisse a multis religiosis. Consuetudo est ultra montes, quod primogenitus succedat in totum. Aliquis primogenitus erat magnus iurisperitus, et sciebat quod talis consuetudo erat contra ius scriptum, et de hoc habebat conscientiam laesam: an excuset eum consuetudo, ut possit omnia bona paterna retinere, uel teneatur dare fratribus partem eorum? Quidam dicebant, quod sic; quidam, quod non. Tamen plures concordabant, quod ex quo sciebat consuetudinem iniquam, et habebat conscientiam laesam, quod teneretur dare fratribus partem suam, et magis sequi conscientiam, quam consuetudinem.' 
(c.1250-1306). ${ }^{61}$ The scholar who contributed the most to the 'rediscovery' of the School of Orléans, Meijers, argued that Syllimani was the first Italian jurist who knew of Ravanis. ${ }^{62}$ At least with regard to the lex Barbarius, this seems probable. Ravanis' position on the lex Barbarius had a profound influence on Syllimani.

Syllimani taught in Bologna for a long time (at least from 1276 to 1304), and enjoyed remarkable reputation as a scholar. ${ }^{63}$ His reputation in Bologna, it would seem, did not suffer from his criticism of the Gloss, which at times led Syllimani to accept the solution of the Orléanese jurists. ${ }^{64}$ The point is all the more interesting since Syllimani was probably Butrigarius' teacher, ${ }^{65}$ and Butrigarius - as we have seen - was the staunchest defender of the Gloss on Barbarius' case. This might perhaps serve as a reminder that the simple student-teacher relationship does not suffice to presume continuity of thought until proven otherwise.

The main source on Syllimani's reading of the lex Barbarius is BAV, Pal. lat. 733 , fol. 24ra- $b$, which provides a shortened summary of what must have been a rather lengthy additio (or perhaps a lectura per viam additionum). ${ }^{66}$ While in this

61 On Syllimani's life and work see Semeraro (2013), pp. 1296-1297, where further literature is mentioned. See also some interesting, if short remarks of Savigny (1829), vol. 5, pp. 373-376 (pp. 417-420 in the $2^{\text {nd }}$ edn. of 1850).

62 Meijers (1959a), p. 118, text and note 418. According to Meijers, Syllimani was already acquainted with the work of Ravanis by 1285 (ibid., note 418).

63 It might be interesting to note that he was specifically exempted from the banishment of the pro-Ghibelline Bolognese professors (which occurred when the Lambertazzi government was overthrown) at the request of the university. Cf. Semeraro (2013), p. 1296; Savigny (1829), vol. 5, p. 374 (p. 418 in the $2^{\text {nd }}$ edn. of 1850). Other jurists whom we have already encountered did not have the same good fortune. In particular, Jacobus de Arena was probably forced to leave Bologna because of his Ghibelline sympathies: Marcello (1928), p. 854 (as reported by Quaglioni [2013], p. 1100 - I was not able to read Marcello's study). Waelkens (1984), p. 153, text and note 15 (on the number of deeds necessary to introduce a new custom; Syllimani's position was reported by Butrigarius).

The main source on the point is Baldus' commentary on Dig.2.8.11 (Baldi Vbaldi Pervsini ... In Primam Digesti Veteris Partem Commentaria ... Venetiis [apud Iuntas], 1577, fol. 99va, n. 6): 'Ia(cobus) Bu(trigarius) secundum doct(orem) suum Mar(tinum) Sil(limanum).' Cf. Meijers (1959a), p. 117, note 415.

66 Having provided a summary of the traditional division of the lex Barbarius in the Gloss, the hand introduced the different approach of Syllimani: 'Econtra dominus M(artinus) sy(llimani) aliter intellexit l(egem) istam' (ibid., fol. 24ra). The hand further reports the different sub-distinction of the lex by Syllimani (ibid., infra, note 71), and jumps to what might have been (for a Citramontanus) the most innovative part of Syllimani's lectura (infra, note 72). On Syllimani's reading of the lex Barbarius see also some notes in Siena, H.IV.18, fol. 16va-b (which however mainly reports Syllimani's lectura on Dig.1.15). On the lecturae 
manuscript the gloss is of excellent quality, the annotations of Syllimani were added later, quite possibly by some student more interested in the substance than in the form. ${ }^{67}$ The result is somewhat wanting: it gives a general idea of Syllimani's own position, but it leaves many questions unsolved.

As with the Ultramontani, for Syllimani the lex Barbarius would also pose only one question - whether the deeds of Barbarius were valid. Syllimani's reading of the lex Barbarius rules out both the validity of his praetorship and a grant of freedom. The distance from the Gloss is particularly evident in his approach to Barbarius' violation of the lex Iulia de ambitu. We have seen how Accursius commented on the fact that Barbarius sought the praetorship, condemning that behaviour but retaining its outcome ('fieri non debuit, factum tamen tenuit'). ${ }^{\mathbf{6 8}}$ Syllimani replies that the rule was in fact the opposite: neither seeking the praetorship is lawful nor is the election valid ('fieri non debet nec factum tenet'). ${ }^{69}$ While some - admittedly, rather tenuous - textual elements in Syllimani's remarks on the lex Iulia might suggest familiarity with the approach of other contemporary Italians - Guido de Suzzara in particular ${ }^{\mathbf{7 0}}-$, his entire additio would seem strongly influenced by that of Ravanis.

per viam additionum see esp. Bellomo (1997a), pp. 7-8, and, in more depth, Bellomo (2000), pp. 404-424.

67 Pal. lat. 733 reports a gloss of Syllimani ( $f o l$. 24ra, upper margin), a summary of his position (fol. 24ra, bottom), and a shortened version of Syllimani's own lectura (fol. 24ra-b, lower margin).

68 Supra, $\$ 2.2$, note 30.

69 Syllimani, ad Dig.1.14.3, \Designatus - factum tamen tenuit (Pal. lat. 733, fol. 24ra): 'qu<a>e so(lutio) non placet, nam ista est reg<u>la quod fieri non debet nec factum tenet ut $\mathrm{i}(\mathrm{nfra})$ de iudic(iis) $<$ l.> si praetor $\mathbb{\$}$ marcellus (Dig.5.1.75) et C. quando prouoc(are) non est nece(sse) l. uenales (Cod.7.64.7) et C. de leg(ibus) et con(stitutionibus) 1. non dubium (Cod.1.14.5) sed fallit $\mathrm{i}(\mathrm{nfra})$ de iureiur(ando) $<$ l. $>$ nam postea $($ quam $) \mathbb{S}$ si dampnetur (Dig.12.2.9.2) et $\mathrm{i}(\mathrm{nfra})$ quando ap(pellandum) sit 1 . i $\$$ biduum (Dig.49.4.1.5) et $\mathrm{i}(\mathrm{nfra}) \mathrm{de}$ interdictis et releg(atis) l. relegatorum $₫$ ad tempus (Dig.48.22.7.4) et $\mathrm{i}(\mathrm{nfra}) \mathrm{de}$ condict(ione) in(debiti) 1. eleganter $₫$ si quis post (Dig.12.6.23.3). $\mathrm{M}$ (artinus) Sy(llimanus).' This is the only gloss of Syllimani on the lex Barbarius that the hand in Pal. lat. 733 reported in addition to the summary of his additio. In reporting the additio, the same hand was somewhat less clear on the point: 'Item alia ratione quia delinquit petendo preturam et indicit in $1($ egem) miscellam [Cod.6.40, sed 'Iuliam de ambitu', Dig.48.14.1] sic ergo ex delicto non debet habere premium, ut $\mathrm{i}(\mathrm{nfra}) \mathrm{de}$ reg(ulis) iur(is) non fraudantur $\mathbb{S} \mathrm{i}$ (Dig.50.17.134)', ibid. Associating Barbarius' violation of the lex Iulia de ambitu with the need not to reward his delict seems to echo Suzzara's discussion of the salary of the bannitus elected to a municipal magistracy (infra, $\$ 4.6$, text and note 153).

70 Supra, last note. 
The probable influence of Ravanis appears in most of Syllimani's arguments, starting with the division of the text of the lex. Also for Syllimani the beginning of the text introduces the subject ('ponitur unum themam'), from which a single question emerges - that of the validity of Barbarius' deeds. The solution is found on the basis of fairness ('de humanitate'). The text then adds two reasons to this solution (both based on the power of the people), and a final note extending the same conclusion to the power of the prince. ${ }^{71}$ Also the arguments that were used to deny Barbarius' freedom and praetorship would seem to be a summary of those of Ravanis. Pomponius' statement, says Syllimani, simply described the fact that Barbarius exercised the praetorship: Ulpian's conclusion as to the de humanitate validity of Barbarius' deeds would clearly rule out their de iure validity. ${ }^{72}$ The people had no intention of setting Barbarius free. Perhaps, Syllimani even suggested, the moment the Romans realised their mistake they might have deposed him. ${ }^{73}$ It is true, Syllimani concedes, that the slaves who wore the pileus in the funeral procession of the old master became free even against the true intention of the master, so as not to deceive the people (cf. Cod.7.6.1.5). Pace Accursius, however, that text does not dispense with the will of the master, but rather presupposes it. After all, concludes Syllimani, it was because of their master's command that the slaves wore the pileus and took part in the funeral procession. ${ }^{74}$ The will of the people (or of the prince) cannot

71 Syllimani, ad Dig.1.14.3 (Pal. lat. 733, fol. 24ra): 'et in prima parte ponitur unum themam quod incipit "barbarius fil(ippus) se(ruus) fugitiuus" etc. Ex dicto themate procedit una sola questio s(cilicet) an gesta per barbarium ualeant, et soluit quod ualent de humanitate. Et subiciuntur due rationes solutionis: vnae ibi "cum etc. potuit" etc. [cf. Dig.1.14.3: 'cum etiam potuit populus Romanus servo decernere hanc potestatem'], alia est ibi "sed et scisset" [cf. Dig.1.14.3: 'sed et si scisset servum esse, liberum effecisset'], et videtur quamuis potuit idem imperatore (sic) non ergo querit hic an fuerit pretor. Item no(n) querit an fuerit liber.' Cf. Ravanis, supra, this chapter, note 56.

72 Syllimani, ad Dig.1.14.3 (Pal. lat. 733, fol. 24ra): 'Vltimo querimus de utroque $s$ (cilicet) an fuit pretor et an fuit liber, et dico non fuisse pretorem ea ratione quia dic gesta per eum ualere de humanitate ergo non fuit pretor: nam si fuisset ualerent gesta de ipso rigore et non de humanitate ... Item in testu non dicitur eum fuisse pretorem sed preturam functum, $s$ (cilicet) de facto ... Item non e(st) liber quia casus est $\mathrm{i}(\mathrm{n})$ C. de liber(ali) ca(usa) l. non mutant (Cod.7.16.11).'

73 Ibid.: 'et forte fuit reiectus a populo cum temp(ore) sci(ent)e eum seruum. Item $\mathrm{e}(\mathrm{st})$ casus in C. si seruus aut liber etc. decurionatum aspi(raverit) in fi(ne) (Cod.10.33.2).'

74 Ibid., fol. 24ra-b: 'Item non ob(stat) C. de lat(ina) lib(terate) tol(lenda) l. unica $\$$ sed qui domini (Cod.7.6.1.5), ubi dicit seruos qui erint pileati efici liberos ne decipiatur populus uel gentes qui credebant eos esse liberos, quia hoc contingit propter $u o l u<m>$ ptatem testatoris uel heredis qui hoc iussit uel passus e(st) ut irent pileati ad funus.' Cf. Ravanis, infra, note 88 . 
therefore be presumptively ascribed, and in Barbarius' case it is clearly absent. ${ }^{75}$ This is why the lex says that Barbarius discharged the office of praetor while hiding his true condition. ${ }^{76}$

The relevance of Syllimani's interpetation of the lex Barbarius, however, does not lie in a few succinct notes on its pars destruens (denying the validity of praetorship and the freedom of Barbarius). Rather, it depends on the reasons for the validity of the deeds. And here, despite the abbreviated and somewhat confusing manner in which Syllimani's thinking is reported in the sources, Ravanis' influence seems remarkably clear. The common mistake is interpreted in the same (and rather singular) way as Ravanis, and it is on that basis that the role of the sovereign is invoked.

Saying that the common mistake makes law, argues Syllimani, does not mean that it bestows legal validity, but only that it prevents the defect from invalidating the deed. The underlying invalidity, in other words, remains present albeit in latent form. ${ }^{77}$ Thus the common mistake makes law, but only so long as the mistake perdures. ${ }^{78}$ If the validity of the deeds rests on the enduring effects of the common mistake, it should follow that the uncovering of the truth would void them. ${ }^{79}$ And so, when the mistake as to the true status of Barbarius is found out, as a matter of principle everything he did should be void. ${ }^{\mathbf{8 0}}$

75 Syllimani, ad Dig.1.14.3 (Pal. lat. 733, fol. 24ra): 'Item quia populus hoc non gerebat $s$ (cilicet) eum fecit liberum sic nec imperator gerit in libertum alienum per obreptionem coram se arrogatum libertum ingenuum ut $i(n f r a)$ de in ius uoc(ando) 1. sed si hac l(ege) \$ patronum (Dig.2.4.10.2).'

76 Ibid.: 'per hoc dicit in testu quod latuit in dignitate ergo non dicit lib(erum).'

77 Ibid., fol. 24rb: 'Sed quero contra $\mathrm{p}$ (raedic)ta utilitate quod fuit seruus non revocatur gesta per eum. Respo(ndeo) quia populus errauit et communis populus error facit ius ut hic et $\mathrm{i}(\mathrm{nfra})$ de supell(ectili) le(gata) 1. iii (Dig.33.10.3.5). Sed uidetur errorem populi reuocari patefacta utilitate ut $\mathrm{i}(\mathrm{nfra})$ de $\mathrm{h}$ (ered)i(bus) instit(uendis) 1. ult(ima) $\mathbb{\$}$ i (Dig.28.5.93(92)) et $\mathrm{i}(\mathrm{nfra})$ de inof(ficioso) te(stamento) 1. mater in fin(e) (Dig.5.2.19), et ad hoc distingue error singularis persone non facit ius ut $\mathrm{i}(\mathrm{nfra})$, in contra(rium) ille l(eges), sed allego unam $\mathrm{i}$ (nfra) de iur(isdictione) omnium iu(dicium) 1. si per errorem (Dig.2.1.15).'

78 Ibid.: 'Error populi communis quamdiu durat facit ius ut in 1 . nostra et i(nfra) de suppell(ectili) le(gata) 1. iii in fin(e) (Dig.33.10.3.5) C. de testis 1. i [Cod.4.20.1 sed 'de test<ament $>$ is', Cod.6.23.1].' The typo 'de testis' instead of 'de testamentis' will be noted more than once in the course of this work.

79 Ibid.: 'sed re patefacta tunc ille error populi quod [MS: qui] dabat ca(usam) alicui negotio reuocatur ut in dicta 1 . contractus (Dig.44.7.54?) et de heredibus instit(uendis) 1.f. (Cod.6.24.14).'

80 Ibid., fol. 24ra: 'Gesta s(cilicet) per eum medio tempore quamdiu latuit eius condicio ualent ut predict(um).' Incidentally, it might be noted how Syllimani's adherence to Ravanis on the effects of the common mistake is in open conflict with Jacobus de Arena's scheme (supra, $\$ 3.2$, text and note 43 ). 
Alone, therefore, common mistake is not sufficient. But in Barbarius' case there is also another element - public utility. This, argues Syllimani, is why Ulpian said that holding Barbarius' deeds is 'the more humane view to take. ${ }^{\mathbf{8 1}}$ The public utility to which Syllimani refers, however, is not the abstract concept but its practical application: not 'publica utilitas' but rather 'favor gestorum'. This favor depends not only on considerations of public welfare, but primarily on the sovereign will of the people. The mistake of the people, says Syllimani, is not in the person of Barbarius but only in his status: 'the people were not mistaken in the person but in the quality of the person, for they thought him free while he was a slave'. ${ }^{83}$ This is why, at the beginning of his additio, Syllimani refers to the will of the people as the reason for the solution of Barbarius' case. The reference to 'favor gestorum' is not present in Ravanis, but it is a good way of combining Ravanis' references to 'utilitas communis' and 'potentia committentis' as the reasons for the validity of the deeds. ${ }^{84}$ While Syllimani (or rather, the abridged version of his additio) does not quote Ravanis, it seems difficult to doubt his influence: no other known jurist gave a similar explanation of the lex Barbarius.

\subsection{Pierre de Belleperche}

We may now go back to France to look at another important jurist of Orléans, Ravanis' younger colleague, Petrus de Bellapertica (Pierre de Belleperche, c.1230-1308). ${ }^{85}$ While Ravanis highlighted the central role of public utility, Bellapertica did not consider it sufficient. Bellapertica's great novelty was to dispense with the requisite of appointment by the sovereign power. With hindsight, it might be tempting to conclude that he was simply bringing the discussion to its natural outcome: the superior authority that played the part of

81

82 Syllimani, ad Dig.1.14.3 (Pal. lat. 733, fol. 24rb): 'et hic immo re patefacta non reuocatur gesta quia hic duo concurrunt et communis error et fauor gestorum.'

83 Unfortunately the last few lines of Syllimani's comment are heavily shortened in the manuscript (ibid.): 'et errauit hic populus non in personam sed in qualitate persone quia putauit liberum cum esset seruus quia [MS: qui] error non impedit dominii translationem ut $\mathrm{i}(\mathrm{nfra})$ si certum pe(tetur) 1 . cum fundus $\$ seruum (Dig.12.1.31.1) nec etc. iurisdictionis translationem hic etc. in glo(sa) st(at) alia utilia et no(n). Et ista sufitiant ad materiam l(egis) nostre. M(artinus) Sy(llimani).' Cf. Ravanis ('propter errorem non, quia fuit error in condicione persone et talis non impedit'), supra, this chapter, note 52 .

84 Supra, this chapter, note 59.

85 On the life and work of Bellapertica see Meijers (1959a), pp.95-106, and especially Bezemer (2005), where the life of the author is very often examined through his work. 
the deus ex machina in Accursius had already been demoted to a subservient role by previous Orléanese jurists, so now it might easily disappear altogether. Much to the contrary, the position of Bellapertica was revolutionary: he did what Ravanis was not prepared to do.

The only known version of Bellapertica's repetitio on the lex Barbarius, preserved in Madrid, ${ }^{86}$ does little honour to its author. The hand (or some previous manuscript) would appear to have understood little of the text, which hardly motivated it to be accurate. The last part of the text acquires particular relevance - where Bellapertica criticises Ravanis' solution and proposes a new and different one. In the text, Bellapertica's own theory is remarkably short and not particularly well elaborated either. That is somewhat frustrating: most of Bellapertica's lengthy repetitio on the lex Barbarius (more than four-fifths of it) is quite similar to that of Ravanis ${ }^{87}$ - except for what is really important. The last part of Bellapertica's text, where he diverges from Ravanis, starts with the adverb breviter ('in short') and, unfortunately, is true to its word. While it is possible to ascribe this brevity to Bellapertica himself, it is difficult. Many of the examples he uses throughout the text come from Ravanis, but they are significantly more elaborated - and so much longer. ${ }^{88}$ The text adds some more examples that are

86 Madrid, BN 573, fols. 85vb-86va.

87 Beginning with the internal division of the text of the lex:

Bellapertica (Madrid, BN 573, fol. 85vb)

'Primo ponit thema, secundo ponit circumferencias ad questionem, tercio ponit questionem, quarto ponit responsionem, quinto ponit rationes responsionis'

\begin{abstract}
Ravanis (Leiden Abl.2, fol. 18ra) 'primo ponit thema, secundum quaedam [MS: quid] conferencia ad questionem mouendam, tercio elicit questionem ex themate, quarto res(pondet), quinto confirmat responsionem duabus rationibus, vltimo concludit'
\end{abstract}

The 'last' part to which Ravanis alludes ('vltimo concludit') was simply the equiparation of the emperor to the people (cf. Dig.1.14.3: 'Quod ius multo magis in imperatore observandum est'), which could be safely ignored - especially if the sovereign will was of no importance to the solution of the text, as in Bellapertica.

88 An example is the case of the bestowal of the freedom cap (pileus) on the slaves attending their old master's funeral in Cod.7.6.1.5 (a case already discussed in the analysis of the Gloss, supra, $\$ 2.4$ ):

\begin{abstract}
Bellapertica (Madrid, BN 573, fol. 86ra-b)
'Sed nunquid medio tempore fuit liber? Uidetur quod sic iura dicunt quod si dominus seruum suum permittat incidere pileatum autem funus suum per hoc sibi uidetur libertatem concedere ne homines decipiantur: tunc arguo quamcumque potestatem habet dominus eandem
\end{abstract}

Ravanis (Leiden Abl.2, fol. 18va)

'quod si dominus voluit seruum precedere funus [MS: funius] suum pileatum, pileus signum est libertatis, liber est ne omnes decipiantur C. de lati(na) lib(ertate) tolle(nda) 1 . unica $<\$>$ sed et a domini $($ sic $)$ (Cod.7.6.1.5) sic ne omnes decipientur iste fuit liber.' 
not present in Ravanis, even if they have little to do with the solution to the case. ${ }^{89}$ This unnecessary length was a sign of higher polish: Bellapertica intended

\author{
potestatem habet populus, tunc populus \\ uidetur sibi libertatem concedere ut hic \\ ad fi(nem) ergo etc. ar(gumentum) C. de \\ lat(ina) lib(ertate) tollen(da) 1 . i $\$$ sed et \\ qui domini (Cod.7.6.1.5) ... Responde si \\ dominus permittat seruum incedere \\ pileatum uidetur sibi concedere liberta- \\ tem ergo etc. Hoc est verum si populus \\ sciens eum seruum hoc fecisset liber esset,

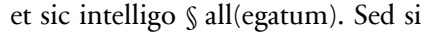 \\ dominus nisi dominus (sic) sciente facie- \\ bat $\operatorname{ar}$ (gumentum) i(nfra) de re iu(dicata) \\ $<$ l.> quidam (Dig.42.1.57).'
}

Another example is the discussion of the (hypothetical) compensation to Barbarius' master for the expropriation of his servant if the people were to set him free. Ravanis dealt with the matter briefly, requiring compensation for an expropriation done for public utility in most cases. By contrast, the same abstract possibility (like Ravanis, Bellapertica also denies Barbarius' freedom) is treated remarkably at length in Bellapertica's repetitio. Bellapertica highlights the need of iusta causa (which in Ravanis was implicit), since private property is part of natural law, not civil law. As such, the prince could dispense with private property not because he is above the (civil) law, but only for public utility considerations. This way, what in Ravanis occupied just a couple of lines became in Bellapertica a lengthy discussion. Bellapertica, ad Dig.1.14.3 (Madrid, BN 573, fol. 86ra): ' $\mathrm{No}(\mathrm{ta})$ quod olim quod populus romanus dum imperium erat apud ipsum uel imperator hodie potest auferre rem meam et alii dare: iste seruus meus erat tamen populus illum potuit decernere pretorem et libertatem ei concedere ut hic ... non credo quod de iure possit sine causa iusta sed cum causa possit; sic intelligo 1 (egem) istam, iusta causa fuit ubi non potuit ydoneus inueniri quod seruus manifestetur ut hic et $\mathrm{i}$ (nfra) de euic(tionibus) 1. lucius (Dig.21.2.11) ... sed sine ca(usa) non possit: ius ciuile iura naturalia inmutare non potest, inst. de iure na(turali) $\mathbb{S}$ sed naturalia (Inst.1.2.11) cum presumitur quod iuste facit ut supra de const(itutionibus) princ(ipium) 1. i (Dig.1.4.1).' Further, the exception mentioned in Ravanis for a specific case (the servitude of iter) became in Bellapertica the centre of a discussion that was even longer than the one above. Ibid., fol. 86rb: 'supponit quod populus uidetur serui libertatem, dare nunquid res publica domino debet reddere estimacionem serui? Hoc est, quaero cum [MS: nec] res publica aufert dominium alicuius a se nunquid sibi tenetur estimacionem reddere? Uidetur quod sic ut C. pro q(uibus) cau(sis) seruus pro $\mathrm{p}$ (remio) li(bertatem) 1. antepenultima (Cod.7.13.2). Uidetur contra, ager meus iuxta uiam publicam est, aq(ua) deuastauit uiam et ager meus erit uia nec estimacionem agri a re publica recipiam ut $\mathrm{i}(\mathrm{nfra})$ quemadmodum seru(itutes) $a$ (mittuntur) si locus $\mathbb{S}$ (enultima) (Dig.8.6.14.1?). Dico supposita glosa quod estimationem domino de(bet) restituere, ar(gumentum) iurium pro parte ista alle(gatum) ad contrarium. Respondo quod si ager meus commutatur in uiam publicam non habeo estimacionem agri, quia per hoc facit commodum possum 
to write a long, complex and exhaustive commentary on the lex Barbarius. This makes it somewhat less probable to argue that its almost abrupt conclusion was intentional.

recipe(re): quia si dimittet certam aliquam tamen accrescerit, ar(gumentum) ad solutionem infra [MS: supra] de resti(tutionibus in) integrum in prin(cipio) (Dig.4.1.1) ideo etc., ar(gumentum) i(nfra) de ad(quirendum) re(rum) do(minio) 1. ma $<$ r tius (Dig.41.1.38) et $\mathrm{i}$ (nfra) de $\mathrm{reg}$ (ulis) iur(is) 1. si nemo (Dig.50.17.181).' Cf. Ravanis, ad Dig.1.14.3 (Leiden Abl.2, fol. 18rb, partial transcription also in Bezemer [1987], p. 116): 'Supponamus quod sit liber, nonne domino dabitur de precio? $\operatorname{Ar}$ (gumentum) C. in qui(bus) ca(usis) s(erui) pro p(remio) lib(ertatem) ac(cipiunt) l. ii (Cod.7.13.2), et sic regulariter videtur: quis amittit pro vtilitate publica rem suam, restituitur sibi precium, nisi in casu si habeat quis fundum iuxta via $<\mathrm{m}>$ publica $<\mathrm{m}>$ et via publica deficiat, accipietur de fundo suo et habeatur via publica nec aliquid ei restituetur, et est valde notabile i(nfra) quemadmodum serui(tutes) amit(tuntur) 1 . sed si locus (Dig.8.6.14pr).' Incidentally, it might be noted that the importance of the division between civil-law and natural-law rights, especially on matters of expropriation, was already present from the first generation of the Orléanese school. See e. g. Monciaco's comment on Cod.1.22.6, transcription in Lefebvre (1958), pp. 303-305.

89 For instance, Bellapertica looks at the case of a slave who becomes bishop: his election to the episcopal see entails the concession of freedom. Since the praetor has higher jurisdiction than the bishop (for, maintains Bellapertica, the decisions of the bishop can be appealed before the praetor), it follows that the appointment to the praetorship should entail emancipation. However, concludes Bellapertica, the case of the bishop cannot be applied by analogy, for it is specifically thought in favour of the Church. Bellapertica, ad Dig.1.14.3 (Madrid, BN 573, fol. 86ra-b): 'Pone si servus alicuius episcopus factus fuerit consequitur libertatem, tunc arguo pretor maior est episcopo quia appellatur ab episcopo ad pretorem et sic uidetur quod sit liber in aut(entica) de sanc(tissimis) e(piscopis) $\$$ si et hoc quidem tamen (Coll.9.15.24[=Nov.123.24]), et in e(odem) ti(tulo) $\$ si quis alius contra [rectius, si quis contra aliquem, Coll.9.15.21(=Nov.123.21pr)]. Responde si seruus sit factus episcopus consequitur libertatem ergo etc. Dico non sequitur ista statuit fauore cleri(ci) sic intelligo $\mathbb{S}$ alle(gatum) sed hic quidem $\operatorname{ar}($ gumentum) $i($ nfra) de re(ligiosis) et sump(tibus) fu(nerum) 1. sunt persone (Dig.11.7.43)'. Cf. Dig.11.7.43 (Papin. 8 quaest.): ' $\ldots$ nam summam esse rationem, quae pro religione facit'. The statement that the decisions of the bishop may be appealed before the praetor would seem to be based on Coll.9.15.24(=Nov.123.24), where Justinian stated that the alleged crimes of any bishop dwelling in Constantinople would be tried before the praetorian prefect. The Gloss did not give much weight to the point since it was a corollary of the prefect's jurisdiction on Constantinople (cf. esp. Gloss ad Cod.1.3.32.2, \$ in tua, Parisiis 1566, vol. 4, col. 80). Commenting on the same novella cited by Bellapertica, the Gloss explained better the issue: the bishop is equal in rank to the prefect. Any difference depends on the specific jurisdictional provisions of the emperor (in the case under discussion, the special jurisdiction granted to the defensor civitatis). Gloss ad Coll.9.15.21[=Nov.123.21pr], \$contradicat, Parisiis 1566, col. 521. 
Just like Ravanis, Bellapertica also inverts the order of the Gloss: ${ }^{90}$ he first denies Barbarius' freedom, then uses his servile status against the main tenet of the Gloss - Barbarius' praetorship - and finally moves to the validity of his deeds. His overall scheme is therefore extremely similar to that of Ravanis. What is surprising, however, is that Ravanis is not mentioned, neither in the lengthy parts where Bellapertica borrows so much from him, nor in the last part where he harshly criticises Ravanis' conclusions. In both cases the silence could easily be intentional. Bellapertica's relationship with Ravanis was notoriously difficult, and the lex Barbarius was no exception: not naming Ravanis when demolishing his approach piece by piece might have been the sensible thing to do. As to the rest of his repetitio, Bellapertica's silence on Ravanis might, on the other hand, depend on the similarity of their positions, which at times - and especially in their critique of the Accursian Gloss - are almost identical. If Bellapertica used Ravanis' text as a blueprint for his own, he might have been reluctant to openly acknowledge as much. The particularly wanting condition of the manuscript containing Bellapertica's repetitio on the lex Barbarius does not allow us to exclude another possibility: Bellapertica might have mentioned Ravanis, but the hand made some confusion. At least on one occasion the hand ascribes to the Gloss what was clearly the position of Ravanis. ${ }^{91}$

The similarity of many of Bellapertica's arguments (even in their order in the text) to those of Ravanis makes it unnecessary to look at them specifically. Similarity however does not necessarily mean identity. This is particularly the case for Bellapertica's elaborated discussion of the applicability of the lex Iulia de ambitu to Barbarius' case, where Bellapertica reaches the same conclusions as intelligitur secundum glosam: ponit tres questiones et ad unam non respondet, an pretor sit non respondet, et an decreta teneant et an liber sit, et istas respondeo secundum quod glosa ponit, quia positio glose non est amica literis et ideo pono casum secundum quod dixi.'

91 Infra, this chapter, note 136. While not likely, it may not be excluded that the fault lies (at least partially) with the reportator of Bellapertica's lecture. As already noted by Meijers, the text of the Orléanese law professors of this period was usually written down by a student acting as reporter (reportator), and not by the teacher himself: Meijers (1959a), p. 61, note 230. This practice is already visible in the first generation of Orléanese law professors: for Guido de Cumis see esp. Bernal Palacios (1986), pp. 270-271. For Bellapertica we even know the name of his main reporter - the Englishman William of Braundeston: Bezemer (2005), pp. 161-162 (including further literature on the point at p.161, note 9). Braundeston (or some colleague of his) left clear traces of his presence in other texts, including some other repetitiones on the Vetus preserved in the same Madrid manuscript (such as the repetitio on Dig.2.9.2.1), but not in the repetitio on the lex Barbarius. See again Bezemer (2005), p. 161, note 12. 
Ravanis following a different route. ${ }^{92}$ With very few exceptions, it is difficult to find something in Bellapertica that had not already been discussed in Ravanis. ${ }^{93}$ Ravanis: both authors discuss the various opinions mentioned in the Gloss, as well as the theoretical possibility that the bribe was paid by a third party unbeknownst to the candidate. Like Ravanis, Bellapertica also observes that, when the power to appoint the magistrates passed from the people to the prince, the lex Iulia de ambitu ceased to apply in Rome. But its abrogation (or disapplication) hardly entailed permission to bribe one's way to public office. On this note, Ravanis concluded his observations on the lex Iulia (supra, this chapter, note 50). But Bellapertica - so far just following Ravanis - adds something interesting. He looks at the reality of his times: not all the offices entail public powers. Or rather, not all dignitates also have iurisdictio. As such, the reason one should not give bribes is no longer the risk of interfering with free elections, since the elections are no longer free anyway (they are appointments by the prince or the superior authority). Clearly one should not think that the offer of some money might corrupt the prince (a point already made by Ravanis: supra, this chapter, note 50). Although of course the prince cannot be corrupted, continues Bellapertica, he could appoint someone regardless of the money received from that person. If the appointment is to an office with iurisdictio, there is the risk of the appointee using his power to recover the expenditure plus interest. That, reasons Bellapertica, would mean that the bribe would ultimately be paid by those subjected to the appointee's jurisdiction. Hence, he concludes, although the lex Iulia is no longer applicable, the prohibition of offering money for appointment to a secular office with jurisdiction still holds. Bellapertica, ad Dig.1.14.3 (Madrid, BN 573, fol. 86ra): 'Hodie distinguitur aut est dignitas cui non est iurisdictio annexa ut quod sit aduocatus et tunc potest ut 1. all(egata) $\mathbb{S}$ si quis (Dig.50.12.1.6), aut habet iurisdictionem annexam ut quod sit pretor et tunc non licet, sicut prohibitum faciunt qui assumunt preposituram (sic) donec non curamus quantum damus, duplum exigemus, et ideo statutum fuit quod non possit petere uel per illa $(\mathrm{m})$ dare quia alias subiecti pauperes fierent et ideo etc.' Bellapertica's solution was reported almost literally by Cynus (infra, this chapter, note 126), but it might also have proven popular in France. For instance, it is also applied by the Toulouse law professor Scaraboti (Arnald Escharbot, fl.1335), ad Dig.1.14.3, BNF, Lat. 4462, fol. 15va. See more broadly Post (1964), pp. 361-362.

93 The main exception is whether Barbarius could be considered as domiciled in Rome. It is perhaps worth mentioning this (otherwise marginal) point, as in Bellapertica's discussion of the domicile of Barbarius it is possible to find some very fine exemplars of what Bezemer called 'lingua Bellapertiana' (Bezemer [2005], pp. 189-190). Arguing against Barbarius' domicile in Rome, says Bellapertica, is a cheap argument ('trufe', lit. 'fraud'), a lie as black as coal ('eburneus'): clearly Barbarius lived long enough in Rome to be domiciled there. Bellapertica, ad Dig.1.14.3 (Madrid, BN 573, fol. 86ra): 'ad 1. istam signantur contra dicitur hic quod iste seruus fugitiuus rome accessit et ibi pretor decretus est. Contra, pretor non potest esse nisi fuit ciuis romanus, et sic opponitur C. e(odem titulo) 1. ii (Cod.1.14.2). Dicit glosa quod verum est, sed hic fuit constitutus pretor scienter ideo etc. Trufe sunt, dico eburneus quod [MS: 
The similarity with Ravanis is particularly evident in Bellapertica's approach to the text of the lex, especially in highlighting the contrast between Pomponius' remark and Ulpian's comment on it. Pomponius' observation that Barbarius exercised the praetorship does not mean that he was praetor. To this purpose, following Ravanis, Bellapertica invokes the classical example of the false decurion (the lex Herennius). Just like the false decurion, Barbarius is a false praetor. This is why Ulpian said that it is 'more human' to hold his deeds as valid - for clearly they were not so de iure. Pomponius' remark - that Barbarius' servile condition was no obstacle to his exercise of the praetorship - hardly proves the validity of his appointment. Otherwise it would be difficult to understand why Herennius did not become a true decurion even though he was widely believed to be such. Similarly, and again following Ravanis, if a false prelate receives a prebend, reasons Bellapertica, that does not make him a true one. ${ }^{94}$ What Pomponius said, in other words, is simply a description of the problem, a 'circumstantial comment to the question' (circumferencia ad quaestionem), not an

qui] ibi non habet domicilium, non potest pretor decerni qui<a $>$ non habet ibi domicilium originale uel constitutum, sed dico iste ibi uixit diu ideo domicilium habet per adquisicionem, ideo etc. sic intelligo l. istam.'

Bellapertica, Madrid, BN 573, fol. $86 r b$

'Tercio queritur uideo quod non fuit liber, nunquid fuit praetor? Uidetur quod non, quare non iure datur [MS: dant] si quis percipiat salaria decurionum qui non erat decurio propter hoc non erit decurio ergo etc. $\operatorname{ar}$ (gumentum) i(nfra) de decur(ionibus) $<$ l. $>$ heren $<$ n $>$ ius (Dig.50.2.10); per hoc uidetur litera innuens quia dicit«humanius est" ut ualeant quae decreuit. Si in ueritate esset pretor, tunc de rigore iuris ualerent. Contra dicitur "nichil ei obfuit" etc., ergo in ueritate fuit pretor: glo(sa) dicit quod fuit pretor probatus error comunis facit ius ergo etc., ut i(nfra) de suppele(ctili) le(gata) 1. iii ad fi(nem) (Dig.33.10.3.5) ... Dico quod tantum ad exercitium fuit pretor sed de iure non habuit ueram pretoriam dignitatem, ut si populus credat decurionem et ideo ut 1. all(egata) herennius (Dig.50.2.10) sicut si cum populum permittet quod recipet quis canonicas distribuciones non propter hoc est canonicus.'

\section{Ravanis, Leiden Abl.2, fol. 18rb}

'Restat ad uidere [MS: uedere] ad duo dubia $q u<a>$ e relinquit lex ista: barbarius fuitne pretor quamdiu latuit sua seruitus? videtur quod $\mathrm{n}(\mathrm{on})$ : 1 (ex) dicit perceptio salarij non facit aliquem decurionem, ut i(nfra) de decurio(nibus) 1. herennius (Dig.50.2.10). Vnde si quis credebatur canonicus et non est, si percipuit distributiones et stipendia hoc non facit ipsum canonicum.' 
answer to it. ${ }^{95}$ Much to the contrary, the remark of Ulpian (validity de aequitate vs. implied invalidity de iure) does not aim at describing the question but rather at solving it. Barbarius is not praetor, but his deeds should be valid on equitable grounds. ${ }^{96}$ Public utility therefore allows us to separate the validity of the deeds from that of their source. It is not possible to say, as the Gloss does, that the uncovering of Barbarius' true status amounts to a supervening event that ought not to prejudice the pre-existing validity of the deeds. ${ }^{97}$ For this would imply the initial de iure validity of such deeds, and so ultimately postulate the actual intervention of the prince - as in Accursius.

Ravanis' solution to the lex Barbarius was to emphasise that the choice of Barbarius as praetor was made by the sovereign, and that the same sovereign was mistaken only as to the status of Barbarius (slave rather than free), not as to his identity. This way, supported by public utility considerations, the sovereign's will to appoint Barbarius allowed retaining the validity of Barbarius' deeds once the common mistake as to their source (Barbarius' praetorship) had faded away. As we have seen, Ravanis probably invoked the will of the sovereign because of his

Bellapertica, ad Dig.1.14.3 (Madrid, BN 573, fol. 86rb): 'dico hic non respondit questioni sed ponit circumferencia ad questionem.' Cf. Ravanis (Leiden Abl.2, fol. $18 \mathrm{r} b$ ): 'videtur dixi quod potest legi ut ibi tangat quaedam conferencia ad questionem mouendam (sic), et sic ius denotant.'

96 Bellapertica, ad Dig.1.14.3 (Madrid, BN 573, fols. 85vb-86ra): 'No(tandum) quod equitas preferenda rigori, de iuris rigore ea que decreuit non ualent ut $\mathrm{i}(\mathrm{nfra}) \mathrm{de}$ iud(iuciis) 1. cum pretor (Dig.5.1.12pr) ideo non conuertitur ut hic et C. de iud(iciis) <l.> placuit (Cod.3.1.8), et est racio propter publicam utilitatem, quia est iudex ordinarius ... multa non transirent nisi propter communem utilitatem, iuxta hoc ob populum multum crimen pertransit in tumultum ut $\mathrm{i}(\mathrm{nfra})$ ad $\mathrm{l}$. cor(neliam) de sic(ariis) <l.> qui cedem (Dig.48.8.16).' Cf. Ravanis, supra, this chapter, note 28.

Bellapertica, Madrid, BN 573, fol. $85 v b$

'Secundo no(tatur) quod legitime factum est ex casu non debet reuocari tempore quo seruus fuit, multa iudicauit propter errorem quod credebatur liber ex causa superuenienti non retractabuntur ut hic $<$ et $>$ ut i(nfra) de in(stitoria) ac(tione) quicumque 1 . $\mathrm{i}$ ad fi. et 1 . se(cunda) (Dig.14.3.5.1-2) et C. de admi(nistratione) tu(torum) $<$ l. $>$ sancimus (Cod.5.37.28pr) et adu(ersum) iudicem notabile uidetur quibusdam non colligi $\mathrm{ab}$ inicio non potest pretor esse cum seruus fuit.'

\begin{abstract}
Ravanis, Leiden Abl.2, fol. 18ra
'primum est quod legitime factum est ex causa superuenienti non retractari, vnde detecta seruitute barbarij eius edicta non retractatur et ad hoc est i(nfra) de in(stitoria) acti(one) $<1$. $>$ quicumque prepositus $1 . \mathrm{i}$ ad fi. et 1 . s(ecunda)

(Dig.14.3.5.1-2). Debent illa colligi quod $\mathrm{ab}$ inicio factum est ratum legitime stat ex post facto non fuit factum legitime ex quo erat seruus servitutem (sic) et seruus iudex esse non potest: dicit quod legitime factum est propter ignorantia.'
\end{abstract}

Cp. Accursius' gloss $\mathbb{R}$ Reprobari (supra, $\$ 2.3$, note 68 ). 
refined approach as to the common mistake. The individual error does not bestow validity upon what is done under mistake, it only provides an excuse to the individual who has participated in the error. By contrast, public utility allows the common mistake to create a veneer of validity - so long as the mistake itself lasts. But public utility cannot entirely make up for the inner caducity of the common mistake: this forced Ravanis to look for something else in support of public utility, the sovereign will.

Bellapertica does not share Ravanis' subtle distinction between common and single mistake: a mistake may simply excuse the errant, whether it is a single person or a whole community. Thus, the common mistake 'makes law' only in the sense that it extends the applicability of the excuse, not that it alters its substance. Whether general or individual, therefore, the mistake can only give rise to a defence. What is void may not become valid, not even for a while. ${ }^{98}$ The ambiguous role of the 'power of the appointer' in Ravanis was deeply connected to his peculiar interpretation of the common mistake. Rejecting the latter removed the logical basis for the former. As such, having denied Ravanis' interpretation of the effects of the common mistake, Bellapertica proceeds to a full-scale critique of Ravanis' position on the will of the sovereign.

The core of his critique lies in a simple but powerful argument: it is not possible to separate mistake from volition in Barbarius' election. What the people wanted was to elect the praetor. Since a slave is ineligible, their mistake about Barbarius' personal status becomes a mistake in the final cause of the election, ${ }^{99}$ not just in the quality of the elected. It follows that the people's will was utterly vitiated and so could not produce any valid effect. ${ }^{\mathbf{1 0 0}}$ 573 , fol. 85vb: 'Verum est facit ius et excusat generaliter et ideo error singularis singulariter excusat ar(gumentum) i(nfra) de dec(retis) ab or(dine) fac(iendi) 1. ult(ima) (Dig.50.9.6) et C. de tabul(ariis) <l.> generali l(ege) (Cod.10.71(69).3), vel dic error communis communiter ius facit: hoc est verum excusat errantes, pone communiter in barbario errabatur.' Ibid., fol. 86rb: 'Responde immo communis error facit ius ita est hic ergo etc. Dico communis error excusat errantem ut i(nfra) de sup(pellectili) le(gata) l. iii (Dig.33.10.3.5), sed non facit quod illud quod nullum est ualeat ut hic ad l(egem) istam.' Ibid., fol. 86rb: 'Respondo ad ar(gumentum) communis error facit ius: dico non facit ius sed quod errantes excusantur.'

99 On the 'confusion between intentio and utilitas on the one hand, and causa finalis on the other': Cortese (1962), vol. 1, p. 186. More specifically, the same Cortese highlighted how in Bellapertica (and, before him, Cumis), the difference between causa impulsiva and causa finalis lies in the person in whose favour the obligation is undertaken. If the obligation is undertaken for the beneficiary's sake, then the causa is impulsiva. If on the contrary the obligation goes to the benefit of the person who undertook it, then it is finalis. Ibid., pp. 226 and 237. Unlike Cumis, however, Bellapertica considered this division between utility of 
In stating as much, Bellapertica invokes two main texts, Cod.6.24.4 and Dig.35.1.72.6. The first text stated that the appointment of the heir made in the mistaken belief that he was the testator's son is void if that belief was the only reason for the appointment. ${ }^{101}$ Ravanis used this text to distinguish between bequests to legitimate and illegitimate offspring. If the testator instituted the illegitimate son heir 'for what he could receive', and the legitimate 'for the rest', then clearly everything would go to the legitimate son. Bellapertica introduced a subtle difference between illegitimate offspring and people legally prohibited from receiving anything. Ravanis' solution, argued Bellapertica, would clearly apply to the latter, but not necessarily also to the illegitimate son. ${ }^{\mathbf{1 0 2}}$ Hence the reason for referring to this lex in Barbarius' case: the testator's causa finalis was clearly lacking in the bequest to the 'false' son who was legally incapable of receiving anything.

The second text (the lex Cum tale, Dig.35.1.72.6) strengthened the conclusion of the first one. This time however Bellapertica did not need to complicate Ravanis' position - it was sufficient to recall it. The text of the lex Cum tale

the obligor and of the obligee as only giving rise to a (rebuttable) presumption, not a legal rule. Compare the comment of Cumis on Cod.6.44.1 with that of Bellapertica on Cod.1.3.52 (transcription in Meijers [1966], pp. 120 and 120-121 respectively; Meijers did not indicate the source for his transcription of Cumis' quaestio. The editors of Meijers' studies, Feenstra and Fischer, tentatively opted for Bod. Laud. lat. 3: ibid., p. 120.). See more broadly Cortese (1962), vol. 1, pp. 183-225 (a short mention also in Cortese (1960), pp. 542-543); Meijers (1966), pp. 115-124, and more recently, though perhaps using a different approach, Volante (2001), pp. 294-300.

100 Bellapertica, ad Dig.1.14.3 (Madrid, BN 573, fol. 86rb): 'probatur errabat populus quare illum in pretorem elegit in causa finali, quia aliter non fuisse pretor; ergo effectus erroneus est et ita ullus sit C. de her(edibus) insti(tuendis) $<$ l. $>$ si pater (Cod.6.24.4) et $\mathrm{i}(\mathrm{nfra})$ de condi(cionibus) et de(monstrationibus) $<\mathrm{l}$. $>$ tale \falsam i. (Dig.35.1.72.6).'

101 Cod.6.24.4 (Gordianus A. Ulpio. PP.): 'Si pater tuus eum quasi filium heredem instituit, quem falsa opinione ductus suum esse credebat, non instituturus, si alienum nosset, isque postea subditicius esse ostensus est, auferendam ei successionem divi severi et antonini placitis continetur.'

102 The discussion is summed up by Cynus of Pistoia, ad Cod.6.24.4, $\mathbb{P}$ Pater (Cyni Pistoriensis In Codicem et aliquot titulos primi Pandectarum tomi, cit., fol. 371ra-b): 'In hac $\mathrm{I}$ (ege) ponit Iaco(bus) de $\mathrm{Ra}$ (vanis) sic exemplum. Testator habens duos filios, vnum legitimum, et alium spurium, sic dixit: "Spurium haeredem instituo, in eo, quod poterit capere, legitimum in residuo." Legitimus totum habebit, et hoc dixit haec $1(\mathrm{ex})$, sed si dixit: "instituo spurio in vncia, et legitimum in residuo", forte fiscus habebit tunc illam vnciam, secundum Ia(cobum) praedictum. Pet(rus de Bellapertica) facit differentiam, inter eum qui ipso iure habere non potest, et eum qui est indignus, vt in primo non intersit, per quae verba fiat institutio in sua persona. Nam semper institutus in residuo, totum habebit. In secundo vero refert, per quae verba procedat institutio, vt supra dictum est.' 
allowed the heir not to execute the testator's legacy if he could prove that it was made on the sole basis of a false motive. ${ }^{\mathbf{1 0 3}}$ Ravanis invoked this lex to argue against the validity of a custom that lacked causa finalis. ${ }^{104}$ Bellapertica used Ravanis' own argument against him: it is precisely because Barbarius' election could not lead to his exercise of the praetorship that the will of the people lacked final cause. Ravanis' distinction between mistake and intention, concludes Bellapertica, has no place in the lex Barbarius: the lack of final cause leaves no residual validity to the vitiated will of the sovereign. ${ }^{\mathbf{1 0 5}}$

Ravanis, it will be recalled, argued for the validity of Barbarius' deeds on two grounds: the public utility of preserving what was done under common mistake and the authority of the sovereign power. Bellapertica removes entirely the sovereign from the equation and downplays the effects of the common mistake. What is left is public utility, and public utility alone. ${ }^{106}$ As already observed, the remarkable brevity of Bellapertica's explanation on the role of public utility might depend on the poor quality of the manuscript source. This makes it difficult to extrapolate the original meaning of Bellapertica from its wording in the manuscript. ${ }^{107}$

103 Dig.35.1.72.6 (Pap. 18 quaest.): 'Falsam causam legato non obesse verius est, quia ratio legandi legato non cohaeret: sed plerumque doli exceptio locum habebit, si probetur alias legaturus non fuisse.'

104 See Ravanis' repetitio ad Dig.1.3.32 (the lex De quibus) (Napoli, Branc.III.A.6, fol. 7rb, transcription in Waelkens [1984], p. 526, 11.49-52): 'Pone testator legauit errans. Queritur an ualeat legatum. Distinguitur: si fuit error in causa impulsiua ualet, si in causa finali non ualet, ut infra, de condi(cionibus) et de(mostrationibus) 1. cum tale $\mathbb{S}$ Falsam (Dig.35.1.72.6).'

105 Bellapertica, ad Dig.1.14.3 (Madrid, BN 573, fol. 86rb): 'Item est error in persona. Item est error in condicione persone, sed error in condicione nunquid impedit actum agendum: mutuo tibi tamquam liber et es seruus, nichilominus contrahitur mutuum ergo etc., ar(gumentum) i(nfra) de furtis $<$ l.> si quis uxori $\llbracket$ si seruus (Dig.47.2.52.28). Dico quod error in condicione persone nunquid actum impedit quam potest cadere in persona illa uera et opinata ut mutuo tibi pecuniam quia inspecta opinata condicione quod es liber potest contrahi. Item inspecta uera condicione quod es seruus nichilominus tibi mutuari potest, sic loquitur 1 . contraria, sed ubi inspecta condicione nota non potest ille actus geri per eum uel in eo cadere, tunc impedit actum. Seruus non potest esse pretor ut ff. de regulis iuris l. quod attinet (Dig.50.17.32) et ideo impedit actum illum quia [MS: quod] non potest esse actus in eo cadere inspecta uera condicione.' Cf. Schermaier (2000), pp. 70-71, where further literature is listed.

106 Bellapertica, $a d$ Dig.1.14.3 (Madrid, BN 573, fol. 86va): 'Breuiter non credo quod sint due rationes, sed una ratio est quare ualeant, solummodo fit communis utilitas, et non plus dictum fuit principi $<\mathrm{s}>$. Ecce mirabilis causis iudicatur seruus iste barbarius nullus casus iudicauit de rigore non ualent. Sed cum tunc multa restaurari, ideo propter utilitatem statutum est quod de equitate ualeant omnes.'

107 The manuscript gives remarkably little weight to the most salient feature of the whole repetitio - the entire point is just summed up in a few lines. If it was not 
Ravanis denied the validity of Barbarius' praetorship, but he did not explain the validity of the deeds exclusively on the basis of public utility. Rather, he highlighted the sovereignty of the same people so as to enhance the importance of their volition despite the invalidity of the election. In requiring something in addition to public utility, however, Ravanis could not sever the deeds entirely from their source. This is the most revolutionary aspect of Bellapertica's position: the validity of the deeds has nothing to do with the position of him from whom they emanate. This leads Bellapertica to state something that would acquire crucial importance later, in the all-important comment of Baldus de Ubaldis: the validity of Barbarius' decisions in any legal proceedings may be argued in favour of the parties, not also of himself. ${ }^{\mathbf{1 0 8}}$ Predicating the validity of the deeds on a teleological basis, the utility of the commonwealth, Bellapertica could be selective in its application. The public utility supporting the common mistake does not also cover the source of the deeds, only its recipients.

Just like Ravanis, Bellapertica also maintains that the common mistake may not be invoked by whoever was aware of the truth. Not sharing Ravanis' distinction between mistake and volition in Barbarius' election, however, Bellapertica could be more open on the matter than his senior colleague. It is not possible to invoke the common opinion when one is aware that it is false, says Bellapertica. In his reasoning, the moral reproach of Ravanis for such a case becomes firm denial on a legal basis. ${ }^{109}$

A difficulty with Bellapertica's interpretation of the lex Barbarius, however, lies in the text of the slave-arbiter (Cod.7.45.2), for the delegate judge

for the importance that the meaning of those lines had among later authors, one might take little notice of them.

108 Ibid., fol. 85vb: 'Dico immo licet ex parte ipsius non legitime fecit, tamen ex parte litigantium sic, ideo etc. Nam error communis excusat ideo etc. iuxta illud error comunis facit ius ut hic et $\mathrm{i}(\mathrm{nfra})$ de sup(pellectili) 1 (egata) 1. iii (Dig.33.10.3) et C. de testis 1. i [Cod.4.20.1, sed 'de test<ament $>$ is', Cod.6.23.1].' On the possible influence of this statement by Bellapertica on Baldus see infra, pt. III, $\$ 11.4 .3$, note 150 .

109 Bellapertica, ad Dig.1.14.3 (Madrid, BN 573, fol. 85vb): 'Quidam errant ibi qui sciebant nunquid illos scientes excusat ut ratum sit inter eos? Uidetur quod sic ut hic dico istud non est verum, errantes excusat non autem scientes ut $\mathrm{i}$ (nfra) de ad(quirenda) haer(editate) $<$ l. $>$ cum quidam $\$ quod dicitur (Dig.29.2.30.3) modo ista similis questio est. Consuetudo est contra rationem, immo corruptela est quod primogenitus totam successionem habeat. Si communiter errarent excusantur, ut ar(guitur) $\mathrm{i}(\mathrm{nfra})$ de supe $<\mathrm{l}>\mathrm{le}$ (ctili) le(gata) 1 . iii ad $\mathrm{fi}(\mathrm{nem})$ (Dig.33.10.3.5). Pone est ubi unius qui scit quod consuetudo est erronea, nunquid potest mori cum toto patrimonio patris suis sine peccato? Credo quod ex quo corruptela est, debet diuidere cum fratribus, ar(gumentum) l. alle(gata) $\mathrm{i}(\mathrm{nfra})$ de ad(quirenda) haer(editate) cum quidam $\$$ quod dicitur (Dig.29.2.30.3).' Cf. Bezemer (2005), p. 88. 
pronounced a single decision, and yet that single decision was valid. Bellapertica solves the problem by interpreting the crucial verb in that lex ('depulsus sit') in the opposite way from the Gloss. For Bellapertica the text dealt with a freedman brought back in servitude after he gave the decision, not with a slave pretending to be free while sitting in judgment. ${ }^{\mathbf{1 1 0}}$ This way, incidentally, Bellapertica's interpretation becomes much closer to the original meaning of the Roman source. The only alternative (chosen by the other jurist who had the same problem as Bellapertica, Odofredus) would have been preferring common mistake to public utility - that is, linking the validity of the deeds directly to the common mistake, without requiring that both the mistake and the utility be common. ${ }^{111}$

The above mention of Odofredus is not fortuitous. Despite its different approach, the position of Bellapertica on the scope of the lex Barbarius is very similar to that of Odofredus - there is no outer boundary to its application. Among them, Odofredus' reasoning appears more linear: common mistake is always sufficient as to the validity of what should be void. If public utility played any role in Odofredus, that role was markedly ancillary to that of common mistake. In Bellapertica, by contrast, the relationship between common mistake and public utility is the opposite: what really matters is public utility. At first sight, this would attest to a more profound elaboration of the normative issues. In fact, Bellapertica's conclusion is even more problematic than that of Odofredus. Refusing any further ground for the validity of Barbarius' deeds other than public utility leads to an obvious paradox: if public utility is triggered by the number of people potentially affected by the mistake, then the more void acts are performed the stronger they become. Bellapertica is perfectly conscious of the point, and he explains it very well - only he does not find it paradoxical.

Just like slaves, excommunicates lack legal capacity. Let us suppose, says Bellapertica, that a judge is excommunicated but that the people are not aware of that. If this judge were to hear a single dispute, his decision would surely be void because of his lack of valid jurisdiction. But, continues Bellapertica, if the same excommunicate were to pronounce many decisions, their number would trigger public utility considerations. Therefore, while each of those decisions - taken in isolation from the others - would remain void, all of them together would become valid for equitable consideration. ${ }^{\mathbf{1 1 2}}$ The example of the excommunicate

110 Bellapertica, ad Dig.1.14.3 (Madrid, BN 573, fol. 86va): 'Dico non est verum si seruus unam sententiam tulit non ualet, sed 1. illa [scil., Cod.7.45.2] loquitur in liberto et retrusus in seruitute, non debet quod legitime factum est retractari.'

111 Supra, $\$ 3.1$, text and note 29.

112 Bellapertica, ad Dig.1.14.3 (Madrid, BN 573, fol. 86va): 'tunc per istam racionem determinari questionem de quibus queritur. Aliquis iudex excommunicatus 
does not seem fortuitous. Ravanis, it will be recalled, used it to distinguish between the invalidity of a single sentence ${ }^{113}$ and the validity of a large number of them - so long, however, as the appointment was made by the sovereign. ${ }^{114}$ The continuity between Bellapertica and Ravanis (and perhaps also Monciaco), however, is only apparent. In Bellapertica, the only reason for the validity of the decisions of the excommunicate lies in the number of people affected by the mistake as to his status. If uncovering the mistake would harm the commonwealth, public utility ought to be invoked.

The same principle may be applied outside the law court. If a false prelate, widely believed to be a genuine one, is elected to some office, will his deeds be valid? For Bellapertica the solution depends exclusively on the kind of office: if the office is such as to give power over a large number of people - Bellapertica gives the example of the false bishop - then the requirement of public utility is fulfilled. Here as well the consequence is paradoxical: the higher the office and the broader its jurisdiction, the stronger the (in principle, void) deeds would become. But, again, that does not seem to trouble Bellapertica, who on the contrary observes approvingly that a false bishop could do what a false priest of a small parish could not. ${ }^{115}$

The distinction between sporadic versus regular exercise of invalid jurisdiction is further elaborated in another example, that of the revocation of delegated jurisdiction. The Gloss dealt with this issue on the basis of the subjective knowledge of the judge. If the judge was aware that his mandate had expired,

procedit in causa, partes ignorant, nunquid decreta ualent? Uidetur quod sic, quia excommunicatus seruo equiparatur ut C. de sen(tentiam) pas(sis) l. ult(ima) (Cod.9.51.13), sed lex dicit si seruus ita processit ualet ergo etc. ut C. de sen(tentiis) 1. ii (Cod.7.45.2) pro rationem quam dixi potest id [MS: is] respondere: aut unam sententiam tantum tulit inter partes, et tunc dico quod non ualet supposito quod excommunicatus non potest sententiam proferre; sed si plura decreuit ut officialiter huius nullo est excommunicatus plura decreuit ea de equitate ualebunt sic est in 1. ista [scil., Dig.1.14.3]. Responde excommunicatus seruo equiparatus etc. ut 1 . all(egata) (Cod.9.51.13) et $\mathrm{i}(\mathrm{nfra})$ qui et a qui(bus) li(beri) ma(numissi) fi(unt) 1. competit (Dig.40.9.19).'

113 Supra, this chapter, note 32.

114 Supra, this chapter, note 34.

115 Bellapertica, ad Dig.1.14.3 (Madrid, BN 573, fol. 86va): 'Item alia questio determinatur: aliquis fuit electus et non fuit in ueritate prelatus, iudicauit multa, nunquid ualent? Dico aut erat episcopus qui populum gubernat, et tunc propter communem utilitatem ualebunt, sed si preesset duobus uel tribus non ualent sententiae, sic intelligo l(egem) istam. Sciui doctores qui contradirent: ea que prelatus facit, si apparet illum non fuisse prelatum, non uale $<n>t$, ut $C$. de her(eticis) et ma(nicheis) l. dampnata (Cod.1.5.6). Dico verum est: de iure non debent acta eius approbari cuius actor reprobatus; dico tamen de equitate ualebunt ut hic.' 
held the Gloss, the proceedings were void; if not, they were valid. ${ }^{\mathbf{1 1 6}}$ Building on what has already been said, however, Bellapertica maintains the opposite. The fact that the judge is aware of the revocation of his jurisdiction puts him in the same position as Barbarius, the excommunicate and the false bishop. They all exercised in bad faith a jurisdiction they knew they did not have, and yet their deeds are valid all the same. Such a validity, therefore, cannot possibly depend on the subjective status of the source of the deeds. Accordingly, concludes Bellapertica, when the mandate of the delegate judge is revoked, the validity of his decisions would depend only on their sheer number. ${ }^{\mathbf{1 1 7}}$

\subsection{Cynus of Pistoia}

As a rule of thumb, it is often said, the easiest way of knowing what Bellapertica might have said on something is to look at Cynus of Pistoia (1270-1336/37). ${ }^{\mathbf{1 1 8}}$ Clichés are misleading, yet seldom completely unfounded. While it would be profoundly unjust to consider Cynus as an imitator of Bellapertica, it is true that on our subject he was not particularly original either. It is however important to recall his position on the lex Barbarius: it was mainly through Cynus that the thinking of Orléanese jurists on the lex Barbarius came to be known to most Italian jurists. This makes particularly important to look at what Cynus reported of the Orléanese position, and especially how. For this reason (besides the very poor quality of Bellapertica's manuscript on the lex Barbarius), some passages of Cynus will be transcribed and translated in the main text even if they are clearly inspired by Bellapertica.

116 Gloss ad Dig.3.3.65, \$ mutata voluntate (Parisiis 1566, vol. 1, col. 398), and esp. ad

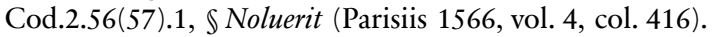

117 Bellapertica, ad Dig.1.14.3 (Madrid, BN 573, fol. 86va): 'Item potest determinari alia quaestio. Causa commissa est delegato, reuocacione facta procedit, nunquid ualet processus? Uidetur quod sic ar(gumentum) huius 1. [scil., Dig.1.14.3]. Quidam modum distingunt aut ille iudex sciebat se reuocatum et tunc non tenet processus, aut partes sciebant eum reuocatum et tunc non valet, aut alter sciuit et tunc tenet in preiudicium scientis non in eius utilitatem $\operatorname{ar}$ (gumentum) 1 . que in procuratore reuocato loquit et ita distinguit $\mathrm{i}(\mathrm{nfra})$ de procurat(oribus) 1 . si procuratorem (Dig.3.3.65) et C. de satisdando 1. una (Cod.2.56(57).1). Dico indistincte. Respondo de iure uero per 1 . istam aut ille iudex processit partibus scientibus et non ualet tunc ut C. de sen(tentiis) (Cod.7.45) et in iur(isdictione) om(nium) iu(dicium) l. priuatorum (Cod.3.13.3), aut illis ignorantibus et tunc aut multa decreuit ita quod si reuocatur ledentur [MS: ledetetur] commune totum tunc ualent aut inter priuatos statuit vnum, et dico quod non tenet.'

118 The accusation started already with Bartolus: see Maffei (1963), p. 49 n. 137. On the point see esp. Gordon (1974), pp. 105-117, and Bezemer (2000), pp. 433-454. 
Cynus opens his lectura on the lex Barbarius observing that it may be read in two ways: either with the Gloss, or after the 'moderns'. ${ }^{119}$ On the subject Cynus was very modern himself: Barbarius was neither free nor praetor. ${ }^{\mathbf{1 2 0}}$ As with the Ultramontani, also for Cynus the text of the lex Barbarius would pose only one question: whether the deeds of Barbarius are valid. ${ }^{\mathbf{1 2 1}}$ Whether to disprove the posthumous criticism of plagiarism of Bellapertica or because of the weight of the tradition, however - like most Citramontani but much unlike the Orléanese - Cynus discusses first and at length the issue of Barbarius' praetorship and only then, briefly, that of his freedom.

As already said, most of Cynus' arguments follow Bellapertica's repetitio. With regard to the invalidity of Barbarius' praetorship, this may be seen in the implicit opposition between validity de humanitate and validity de iure, ${ }^{\mathbf{1 2 2}}$ and especially on the lex Iulia de ambitu. Here in particular Cynus follows Bellapertica not only in dismissing the difference between acting secretly and publicly ${ }^{123}$ as well as that between soliciting one's own appointment and that of someone else, ${ }^{124}$ but

119 Cynus, ad Dig.1.14.3 (Cyni Pistoriensis In Codicem et aliquot titulos primi Pandectarum tomi ..., vol. 2, cit., fol. 13va, n. 1).

120 Ibid., fol. 14ra-va, n. 12-14.

121 Ibid., fol. 14va, n. 14: '... non ob(stat) haec lex, quia dico, quod hic non est nisi vna quaestio, scilicet, an acta valeant?'

122 Ibid., fol. 14ra, n. 12: 'Et primo probatur per hanc leg(em) quae dicit, acta per Barbarium de humanitate, seu aequitate seruari, vel tenere propter communem vtilitatem, contra rigorem iuris. Sed si ipse fuisset Praetor, nulla humanitate, vel aequitate opus esset: quia tenerent de rigore Iuris.'

123 Ibid., fol. 13vb, n. 9: '... Alij dicuunt, quod nullus per ambitum debet eligi. Verum est, clandestine, sed palam sic. Nam multa licent palam, quae non licent clam, vt inf(ra) de admi(nistratione) tuto(rum) l. non existimo (Dig.26.7.54) et no(tandum) C. de contrahen(da) emp(tione) 1. cum ipse (Cod.4.38.5). Ista solut(io) simili modo est nulla, quia contra praedictam leg(em) si quenquam (Cod.1.3.30).'

124 Ibid., fol. 13vb, n. 9-10: 'Aliqui dicunt, quod nullus per ambitum debet eligi ad dignitatem, verum est, ponendo eam per se, sed bene per alium. Ista solutio supponit quod beneficium per symoniam acquisitum per alium, potest quis retinere, quod est falsum: ad quod inducitur, infr(a) de <receptis qui> arbi(trium) 1. 3 (Dig.4.8.3).' Cf. Bellapertica, ad Dig.1.14.3 (Madrid, BN 573, fol. $86 \mathrm{ra}$ ): 'Istud nichil est nec licet dignitatem petere clam nec palam ut in l(ege) all(egata) quemquam (Cod.1.3.30(31)), quare dicunt alii ipsemet non petet et sic intelligitur l. contraria. Sed per alium potest petere ut si amicus meus dignitatem per me petat istud ualet. Dicit 1 . ista quod alius petiit dignitatem pro isto non ualet plus nec potest retinere beneficium per simoniam acquisitum et facit C. de arb(itrium) 1. iii [Cod.2.55(56).3, sed de <receptis qui $>$ arbi(trium) 1. 3, Dig.4.8.3], quare dicunt alii verum est non licet petere dignitatem uerbis expressis ut in l. contraria, sed bonis meritis quod se ostendat ualide ut i (infra) ad l. Iul(iam) repe(tundarum) l. ult(ima) (Dig.48.11.9). Credo quod istud non esse proprie petere quod ostendat se morigeratum quod tunc glo(sa) approbat 
also in maintaining, against widespread opinion, that the lex Iulia would also apply in Rome. The association between Rome and simony is of course too good to be missed by a staunch Ghibelline like Cynus, who allows himself a little digression to note how this false interpretation of the lex Iulia has greatly favoured simoniacal practices within the Church. ${ }^{125}$ Having duly attacked the papacy, Cynus goes back to the main subject and continues with his report of Bellapertica's position, down to the most specific observations. ${ }^{126}$ Similarly, when discussing the (theoretical) question of whether Barbarius' master ought to be compensated if the people were to set his slave free, Cynus gives a lengthy summary of Bellapertica's (particularly exhaustive) discussion, making a point not to omit a single detail. ${ }^{127}$

non licet pro dignitate dare aliquid extra ciuitatem romanam et sic lo(quitur) 1 . contra(ria).'

125 Cynus, ad Dig.1.14.3 (Cyni Pistoriensis In Codicem et aliquot titulos primi Pandectarum tomi ..., vol. 2, cit., fol. 13vb, n. 10-11): '... Alij dicunt, et tenet hoc glo(sa), quod non licet petere dignitatem alibi, sed Romae: quia alibi non habet locum 1. Iul(ia) ambitus, vt in dicta l. vnica (Dig.48.14.1) patet. Et de hoc gaudent symoniaci curiales, dicentes quod in curia Romana non committitur symonia: quia non vendicat ibidem locum sibi ambitio. Sed certe sicut videtur, lupanarij et tonsores, et totus mundus Romae, et in Romana curia viget omnis ambitus, et omnis symonia.' Cf. ibid., fol. 14ra, n. 12: 'Hoc male seruat curia Romana, quae vendit praesidatus suos, in quibus Iustitia est, propterea venalis, sic videmus in ducatu Marchiae et Romandiolae.'

126 Especially on the modern ('de iure novo') distinction between offices that carry jurisdictional powers with them and offices that do not: ibid., fol. 14ra, n. 12: 'quaeritur nunquid dignitatem licet petere, et pro ea pecuniam dare? Distinguo secundum Pe(trum) ... De iure nouo subdistinguendum est. Nam aut dignitas cui non est iurisdictio annexa, verbi gratia, quod sit aduocatus: tunc licet, vt dicto $\$$ sed et si quis (Cod.7.6.1.5): aut habet iurisdictionem annexam, verbi gratia, quod sit Praetor, et magistratus: et tunc nec clam nec palam licet, quia lex praesuponit, quod Rempublicam grauaret, vt in Authen. vt iudi(ces) sine quo(quo) suf(fragio) $\$ 1$ (Coll.2.2pr[=Nov.8pr $\$ 1]$ ) et $\$$ cogitandum (Coll.2.2.1 [=Nov.8.1]).' Cf. Bellapertica, supra, this chapter, note 92.

127 Cynus, ad Dig.1.14.3 (Cyni Pistoriensis In Codicem et aliquot titulos primi Pandectarum tomi ..., vol. 2, cit., fol. 13vb, n. 6-7): 'Quarto et vltimo not(andum) quod populus Romanus, dum erat imperium apud eum, et similiter hodie, potest auferre alicui rei suae dominium. Quod intelligendum est, causa subsistente, vt infr(a) de euicti(onibus) 1. Lucius (D.21.2.11 pr). Causa autem potuit hic esse, scilicet, defectus aliorum, vt inf(ra) de mu(neribus) et ho(noribus) 1 . vt gradatim in fi(ne) (Dig.50.4.11.4). Alias sine causa non posset: quia Imperator constitutit ius ciuile, et ius ciuile naturalia iura tollere non potest, ut no(tatur) sup(ra) de consti(tutionibus) prin(cipum) 1. i (Dig.1.4.1) ... Tamen vnum est proprium in Principe, quia semper praesumitur cum causa facere, vt plene dixi C. de pre(cibus) Impera(tori) offe(rendi) 1. rescripta (Cod.1.19.7)' Cf. ibid., fol. 14va, n. 14: 'Tertio quero, posito quod Imperator faceret eum liberum et Praetorem potest, nunquid tunc debetur praecium eius dari? Videtur quod sic, vt 
Cynus also follows Bellapertica closely on the issue of Barbarius' freedom, and there he seeks to strengthen the Orléanese's conclusion. His reasoning is (slightly) more original with regard to Barbarius' praetorship. In order to disprove Ulpian's argument on the implied will of the people, Bellapertica invoked (among many other texts), also Dig.2.4.10.2. This text stated that the adoption of a sui iuris (i. e. adrogatio) made without knowledge that the adoptee was a freedman does not make him also freeborn. ${ }^{\mathbf{1 2 8}}$ To strengthen the parallel with Barbarius' case, Cynus also refers to Dig.40.12.28. ${ }^{129}$ This text clearly stated that a slave could acquire his freedom only with the consent of his master, but the master's acquiescence would not amount to consent when the master was not even aware of being the owner of that slave. ${ }^{130}$ The reference, not present in Bellapertica (or, it would seem, in the work of other jurists), strengthens the overall argument ('et ista est veritas'). ${ }^{\mathbf{1 3 1}}$ The prince or the Romans might well have set Barbarius free, says Cynus, but only if they acted with full knowledge as to his true status. ${ }^{132}$ Since they did not, Barbarius

C. qui(bus) ex cau(sis) ser(vi) pro prae(mio) 1. 2 (Cod.7.13.2). Videtur contra, $\inf ($ ra) quemad(modum) seruui(tutes) amit(tunt) l. si locus $\$$ fi. (Dig.8.6.14.1). Sol(utio) dicendum est, precium a fisco praestandum, vt dicta 1. 2 (Cod.7.13.2). Non ob(stante) dicta l. si locus $\mathbb{\$}$ fi. (Dig.8.6.14.1) quia et ibi praestandum est precium, secundum Ia(cobum) de $\mathrm{Ra}$ (vanis) et Pe(trum de Bellapertica). Ratio est, quia vicinus eius agri, cedente materia, debet sibi computare incommodum commodo, quod euenire potest, recedente familia, vel per alienationem sibi acquirere, inf(ra) vt de acqui(rendo) re(rum) do(minio) l. Martius (Dig.41.1.38).' Cf. Bellapertica, supra, this chapter, note 88 .

128 Dig.2.4.10.2 (Ulp. 5 ed.): 'Patronum autem accipimus etiam si capite minutus sit: vel si libertus capite minutus, dum adrogetur per obreptionem. Cum enim hoc ipso, quo adrogatur, celat condicionem, non id actum videtur ut fieret ingenuus.' Cf. Bellapertica, ad Dig.1.14.3 (Madrid, BN 573, fol. 86rb).

129 Dig.40.12.28 (Pomp. 12 ad Q. Muc.): 'Non videtur domini voluntate servus in libertate esse, quem dominus ignorasset suum esse: et est hoc verum: is enim demum voluntate domini in libertate est, qui possessionem libertatis ex voluntate domini consequitur.'

130 Cynus, ad Dig.1.14.3 (Cyni Pistoriensis In Codicem et aliquot titulos primi Pandectarum tomi ..., vol. 2, cit., fol. 14rb-va, n. 14): 'Quarto probatur, quod non fuerit liber ista ratione: quia dum populus vel Imperator decerneret sibi Praeturam, hoc non agebat, vt liberum faceret: ergo etc. Optimum ar(gumentum) ad hoc inf(ra) de in ius vo(cando) l. sed si haec $\mathbb{S}$ patronum (Dig.2.4.10.2), et videtur casus ff. de li(berali) cau(sa) 1. non videtur (Dig.40.12.28), et ista est veritas.'

131 Ibid.

132 Ibid., fol. 14rb, n. 13: 'Tertio ad illud quod op(ponitur) quod iuris prohibitio non tenet principem. Respondeo quod verum est, quando scienter facit. Se hic non fecit scienter talem esse conditionem eius, ergo etc., et per hoc inf(ra) de re iudi(cata), 1. quidam (Dig.42.1.57) et C. qui admi(tti) ad bo(norum) pos(sesionem) 1. bonorum (Cod.6.9.1).' 
remained free only de facto. ${ }^{\mathbf{1 3 3}}$ This, concludes Cynus, is how Pomponius' statement should be interpreted: simply stating a fact (Barbarius' exercise of the praetorship), not suggesting the de iure validity of such an exercise. ${ }^{\mathbf{1 3 4}}$

His wholehearted support of Bellapertica, rather unsurprisingly, leads Cynus to choose his approach over that of Ravanis. The way he does so, however, would cast some doubts as to his knowledge of what Ravanis actually said. Cynus repeats almost verbatim Bellapertica's crucial observation against Ravanis (the mistake of the people did not lie just in Barbarius' status, but in the final cause of his election), but he seems to consider it only as another argument against Barbarius' praetorship. ${ }^{135}$ Not elaborating much on Ravanis' position, Cynus does not fully explain the reason for rejecting it. The main (and only) occasion on which he describes the position of both jurists, Cynus simply repeats something he found in Bellapertica: ${ }^{136}$

133 Ibid., fol. 14va, n. 14: 'Non fuit ergo Barbarius de iure Praetor, sed de facto liberorum ostensum est.'

134 Ibid., fol. 14ra, n. 12: 'Solut(io) ad istam literam qua dicit "ei nihil seruitutem obstetisse" etc., respondetur quod ista litera non dicit "eum fuisse Praetorem" sed dicit "eum functum fuisse officio Praetoris". Nec est verum, quod ibi respondetur quaestio, sed ponit differentiam ad quaestionem mouendam, dicendo quod nihil obfuit seruitus: quasi Praetor non fuerit, et Praetoria functum esse de facto, et hoc negari non potest, quin ita non fuerit. Non autem dicit, decidendo quaestionem.'

135 Cynus, ibid., fol. $14 r a$, n. 12

Bellapertica, ad Dig.1.14.3 (Madrid, BN 573, fol. 86rb) supra, this chapter, note 100

'populus, qui eum elegit, errauit in causa 'errabat populus quare illum in pretorem finali, cum alias non fecisset eum Praetorem, nisi liberum putaret. Ergo effectus erroneus est, et ita nullus, vt C. de elegit in causa finali, quia aliter non fuisse pretor; ergo effectus erroneus est et ita ullus sit C. de her(edibus) insti(tuendis) haere(dibus) insti(tuendis) l. si pater $<$ l.> si pater (Cod.6.24.4) et i(nfra) de (C.6.24.4), et infra de condi(cionibus) et de(mostrationibus) 1. cum tale $\$$ falsam condi(cionibus) et de(monstrationibus) (Dig.35.1.72.6).'

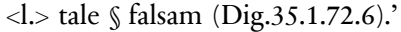

136 Cynus, ad Dig.1.14.3 (Cyni Pistoriensis In Codicem et aliquot titulos primi Pandectarum tomi ..., vol. 2, cit., fol. 14va-b, n. 16): 'Ia(cobus) de Ra(vanis) dicit, quod duplex est ratio, vna est propter authoritatem concedentis, vt populi vel principis; et altera est propter communem vtilitatem: quia multi eorum, et sic intelligit legem istam. Hinc est, quod si altera istarum rationum deficiet, non valet illud quod agitur. Vnde si Epis(copus) huius ciuitatis quendam seruum decreuerit officialem, non valebunt acta coram eo: quia non est haec causa magna authoritas concedentis. Vel pone quod Papa vel Princeps credens seruum liberum delegauit eum inter duos homines: Certe non valebit processus, quia hic deficit publica vtilitas, secundum eum. Pet(rus de Bellapertica) vero dicit, et melius, quod non est duplex ratio imo vna tantum, scilicet communis vtilitas, quae facit hic decreta et gesta per istum seruum valere: nam hic Barbarius multa 
Jacobus de Ravanis argues that the reason is twofold. One lies in the authority that bestows [the office], the people or the prince. The other depends on common utility: there were many of them [who were mistaken]. This is how he understands this lex. It follows that, without either of these reasons, the deeds are void. So, if the bishop of this city appointed some slave as civil servant, anything transacted before him would remain void, for the office was not bestowed by a high authority. Or imagine that the pope or the emperor, thinking that a slave is free, would delegate him to decide the controversy of two people. Surely the proceedings will be void, for there is no public utility, according to Jacobus. Petrus de Bellapertica however argues, and more persuasively, that there is just one reason why the decrees and the acts done by this slave are valid: common utility. Indeed, this Barbarius established and decided many things that would be void from a strictly legal standpoint, but are valid out of fairness, because of common utility, so as not to void many legal proceedings.

Ravanis' interpretation of the role of the sovereign power, as we have seen, was deeply connected with his elaboration of the common mistake. If Cynus was superficial with the former, he did not even look at the latter. This would have important consequences for future developments of the debate on the lex Barbarius, for it was mainly through Cynus that the position of the Orléanese jurists on Barbarius' case came to be known to most Italian jurists. Thus, Cynus' omission of Ravanis' ingenious interpretation of the common mistake might have significantly contributed to its oblivion - later jurists commenting on the same lex would seem to have ignored it. Ravanis' approach to the superior

decreuit et determinauit, quae de rigore non valent, sed propter communem vtilitatem, ne rescindatur tot processus, de aequitate valent et tenent.' As said earlier, Cynus' passage was based on a very similar one of Bellapertica. Because of the very poor quality of Bellapertica's Madrid manuscript, however, that passage should be interpreted in the light of that of Cynus (and not the other way round). In the Madrid text of Bellapertica, the position of Ravanis is attributed to the Gloss, and then even endorsed by Bellapertica himself. Madrid, BN 573, fol. 86rb-va: 'Iuxta hoc quero quarto nec est pretor nec liber, tamen que decreuit ualent de equitate qua est racio dicit glosa, quia communis error facit ius ... ista est racio duplex, una propter auctoritatem concedentis et alia propter publicam utilitatem, seu communem populi auctoritatem, quia populus istum seruum decreuit pretorem et ideo ualent. Alia est racio propter utilitatem communem, quia ex quo multi coram eo litigauerunt ualet propter utilitatem communem. Sic intelligo 1. istam in medio et in fine, et hoc se(quitur) quod si altera istarum deficiat, quod non ualet. Pone episcopus quendam [MS: quoddam] seruum decreuit officialem tunc que ipse decreuit non ualent, uel po(ne) populus uel princeps credens seruum liberum delegauit eum inter duos; ipse cognouit, nunquid ualet processus? Uidetur quod non, quia publica utilitas deficit ergo etc.' There can be little doubt as to the real meaning of this passage, and the mistakes may be easily explained since they are only in the person (of Ravanis, not Accursius and even less Bellapertica) to whom the reasoning is attributed, not in the reasoning itself. Bartolus in his turn summed up Cynus' summary: infra, next chapter, note 4 . 
authority was not forgotten but misunderstood. Relying on Cynus, later jurists would typically remember only that Ravanis somehow required the intervention of the superior authority, not the reasons why, let alone the specific modalities in which that intervention would (or rather, would not) take place.

By contrast, the position of Bellapertica is reported faithfully in all its parts. As with Bellapertica, for Cynus a mistake - whether individual or common to all can only excuse the person who makes it, but it does not produce any further consequence: ${ }^{137}$

It is said that common mistake makes law. I reply that a common mistake does not make law, but it provides an excuse to those who fall in it ... A common mistake excuses those who err, but it does not bestow validity on what does not exist.

On this basis Cynus - again, just like Bellapertica - rejects the opinion that the common mistake would suffice even without public utility considerations. A common mistake may be taken into account only insofar as public utility is concerned: ${ }^{138}$

What is the logic of holding that, although Barbarius was not praetor, his decrees are still valid on fairness grounds? The Gloss says that the reason lies in the common mistake making law (as in Dig.33.10.3.5, Cod.6.23.1 and Dig.14.6.3pr), and on this basis some modern jurists argue that his decrees would be valid even without public utility, having regard only to the common mistake. But Petrus de Bellapertica argues against this because, as I said earlier, the common mistake does not make law, bestowing validity upon what does not exist, but rather excuses those who err.

Coupling common mistake with public utility also means excluding from the scope of the lex Barbarius the case of individual knowledge of a common mistake. Public utility does not operate without good faith. So if a single person is aware of the truth, he may not benefit from the fact that most people are

137 Cynus, ad Dig.1.14.3 (Cyni Pistoriensis In Codicem et aliquot titulos primi Pandectarum tomi ..., vol. 2, cit., fol. 14rb-va, n. 14): 'non obstante quod dicitur, quod communis error facit ius, quia respondeo quod communis error non facit ius, sed facit quod errantes excusantur ... Communis error excusat errantem: non tamen facit, quod illud quod nullum est, valeat.'

138 Ibid., fol. 14va, n. 15-16: 'quaeritur, iste Barbarius nec fuit Praetor, tamen quae decreuit valent de equitate, sed quae est ratio huiusmodi? Dicit glo(sa) quod ratio huius est, quia communis error facit ius, vt infr(a) de sup(pellectili) le(gata) 1.2 [sed 'l. 3': Dig.33.10.3.5] C. de test(amentis), 1. i (Cod.6.23.1), ad Mace(donianum) 1. 2 [sed '1. 3': Dig.14.6.3], et secundum hoc etiamsi non esset publica vtilitas, valerent, inspecto solo communi errore, quod tenent quidam moderniores. Sed $\mathrm{Pe}($ trus $)$ dicit, quod istud nihil est, quia sicut ego dixi $\sup (\mathrm{ra})$ communis error non facit ius, vt valeat quod nullum est, sed excusat errantes.' 
not. ${ }^{139}$ It follows that Barbarius' decisions should be held valid only against such a person and not also to his advantage. ${ }^{\mathbf{1 4 0}}$

Rejecting the necessity of the superior authority's intervention (if only to approve of Barbarius' election, as in Ravanis), Bellapertica did not place any limit on the scope of public utility. This way, as we have seen, the approach became exclusively quantative: the larger the number of void deeds commonly believed valid, the stronger the harm that the commonwealth would suffer, and so the more pressing the public utility considerations. Cynus follows suit, providing the same examples as Bellapertica - the excommunicated judge, the false bishop, and the revocation of the mandate of the delegate judge: ${ }^{\mathbf{1 4 1}}$

139 Ibid., fol. $13 v b$, n. 4: 'quia communis error ... excusat ignorantes, non autem scientes, vt inf(ra) de acqui(renda) haere(ditate) 1 . cum quidam $\$ quod dicitur (Dig.29.2.30.1). Vnde primogenitus, qui secundum consuetudinem Angliae totum patrimonium retinet, si scit consuetudinem illam erroneam esse, peccat.'

140 Ibid., fol. 14va, n. 14-15: 'Quarto quaeritur, po(ne) quod aliqui litigauerunt coram eo suam conditionem scientes, an valeant acta? Videtur quod sic, propter communem errorem et vtilitatem. Item, quia potius error vniuersitatis, quam singulorum debet spectari, inf(ra) quod cuiusque vniuersi(tatis) l. i (Dig.3.4.1).

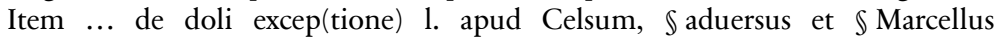
(D.44.4.4.13 and 16). Item probatur ex hac lege: quia hic dicitur, quod valent de aequitate, sed quae equitas esset, quod valeat inter scientes? Certe nulla. Sol(utio) dicunt quidam, quod acta valent contra scientes, sed non pro eis, C. de procu(ratoribus) l. non eo minus (Cod.2.12(13).14), et C. de incest(is) nupt(iis) l. qui contra (Cod.5.5.4) quod verum est, si scientes poterant bene, et sine suo periculo remanere, alias si iuste timebant, tunc excusantur ...'

141 Ibid., fol. $14 v b$, n. 16-18: 'Et ex isto intellectu potest responderi ad plures quaestiones de facto. Ecce, aliquis iudex excommunicatus processit partibus ignorantibus, nunquid valeat processus? Respondeo per rationem praedictam, aut vnam sententiam tantum tulit inter duos, aut plures sententias tulit inter plures, et plura decreuit, tunc de aequitate valebunt ... Eodem modo respondetur ad aliam quaestionem. Ecce, aliquis fuit electus, et in veritate non fuit praelatus, iudicauit, et cognouit: numquid valebit? Dicendum est, aut iste qui gerebat se pro Praelato, erat Episcopus, qui cognouit multa inter multos, et tunc valebunt eius processus de aequitate: aut erat alius Praelatus, qui praeerat duobus, vel tribus, tunc non valebit sententia vel processus eius, per ratione, praedictam. Sed dices tu modo, at vbi gerebat se pro Praelato, erat Episcopus multorum, et multa decreuit, non valent. Eo postea remoto, quia damnato authore, etc. argu(mentum) C. de haereti(cis) 1. damnato (Cod.1.5.6). Respondeo, damnato authore reprobantur acta sua: verum est de rigore, sed de aequitate valent, per hanc legem. Item determinatur et alia quaestio: Ecce quidam delegatus post reuocationem mandati processit, nunquid valet? Respondeo breuiter, aut procedit partibus scientibus, et non valet, vt C. de iuris(dictione) om(nium) iudi(cum) l. priuatorum (Cod.3.13.3): aut partibus ignorantibus, tunc refert: aut multa decreuit, ita quod si retractarentur, laederetur totum: et tunc valet; aut inter paucos cognouit, vel statuit vnum: et tunc non valet.' I am translating 'refert' as 'take note', yet the point is open to interpretation. 
Moving from this rationale, it is possible to answer several questions of fact. Imagine that an excommunicated judge heard a case in which the parties were not aware of his condition. Are the legal proceedings valid? Let me answer applying the same reasoning: either the judge rendered a single judgment to just two parties, or he decided many cases involving many parties. In the second case, his judgments are valid out of fairness ... The same solution applies to a different question. Suppose that one is elected [to an ecclesiastical office], but in truth he was not a prelate. He judged and decided on many things: are his deeds valid? The answer should be that, if the ecclesiastical office held by this person was that of a bishop, who settled many things among many people, then his judgments would be valid out of fairness. But if the office was such that gave him authority only on two or three people, then his decision or judgment would not be valid for the same reason. You might however say that, even if he behaved as a prelate, was the bishop of many people and decided upon many things, the deeds are invalid when he is removed from that position: condemned the author, the deeds are rejected (as in Cod.1.5.6). To this I reply that it is true according to the strictness of the law, but out of fairness his deeds are valid, according to this lex [Barbarius]. This way we can solve also another case: imagine that someone that was delegated were to carry out his mandate after its revocation: are the deeds valid? Let me answer shortly: if the parties knew [of the revocation], then the deeds are not valid (as in Cod.3.13.3). If they did not know, then take note: if he heard many cases, revoking all the judgments would harm all the people involved, and so the deeds are valid. But if he heard few cases, or issued a single decree, then the deeds are not valid.

To some extent, Cynus' reliance on Bellapertica in approaching the lex Barbarius would vindicate the strength of clichés. The importance of Cynus to our subject, however, does not lie just in his faithful - often verbatim - report of Bellapertica, which contributed greatly to the latter's renown among many Citramontani. It also lies in how Cynus reported the position of other jurists - as we shall see, not just that of Ravanis.

\subsection{Guido da Suzzara}

Before moving on to a last important ultramontanus in our story, Guilelmus de Cugno, it may be useful to take a step back and look at another Italian jurist writing a few decades before Cynus: Guido da Suzzara (c.1220-1293). ${ }^{\mathbf{1 4 2}}$ Suzzara's commentary on the lex Barbarius is probably the earliest known frontal attack on the Gloss on Barbarius' case by an Italian jurist. Alone, this would

142 Suzzara is recorded as legista in 1247 , and as doctor legum three years later, in 1250 (Mazzanti [2003], p. 421). This led scholars to date his birth approximatively to the early 1220s. The remarkable success of Suzzara as a jurist as well as a law professor led him to several academic appointments, especially Modena, Bologna and Naples. See further Mazzanti (2003), pp.421-426, and Benatti (2013), pp. 1093-1094, where ample literature is listed. 
make it worth looking at. But our reason for doing so also depends on the crucial influence that Suzzara had on Cugno's position.

While Suzzara shows little hesitation in attacking the Gloss openly, he prefers to follow the order in which the Gloss discussed the main issues of the lex Barbarius. This way, very unlike the Ultramontani, he focuses on the praetorship first, and only then on the issue of Barbarius' freedom. As he excluded the validity of both, it would have probably been easier to deny the freedom first so as to reject the praetorship next, as a logical consequence - just as the Orléanese were doing at the time. But the strength of the traditional approach must be taken into account: Suzzara's students might have expected him to follow the order of the text.

It is one thing however to respect the order of the text, but another not to take liberties in its interpretation. And here Suzzara's approach seems remarkably closer to that of his Orléanese colleagues. Instead of interpreting Pomponius' remark in the light of Ulpian's elaboration, Suzzara plays one against the other. He reads Pomponius' observation (that Barbarius discharged the duties of the praetor) as ascribing full validity to Barbarius' praetorship. This way Ulpian's reasoning becomes an open critique of Pomponius' assertion. It was because Ulpian 'was not happy with his [i.e. Pomponius'] answer' (sua responcione contentus non fuit), says Suzzara, that he suggested the validity of Barbarius' deeds ex humanitate. Read this way, Ulpian would implicitly deny both the freedom and the praetorship of Barbarius. ${ }^{143}$

This critical approach to Ulpian's text was not new: Odofredus had already observed that the Roman people could not have set Barbarius free because they were not aware that he was a slave. ${ }^{\mathbf{1 4 4}}$ Suzzara however goes beyond Odofredus. Looking at the specific situation of Barbarius' election, he agrees that Ulpian's conclusion (all the more in the interpretation of the Gloss) was speculative as it lacked any evidence. But moving to a more abstract and general level, he could affirm that the solution should be the very opposite one. As a matter of principle, mistake is the opposite of consent. It follows that the people's mistake on Barbarius' status is in itself sufficient ground to dismiss any attempt at validating his position. ${ }^{\mathbf{1 4 5}}$

143 Suzzara, ad Dig.1.14.3, infra, Appendix, 11.5-10: 'Vnde licet pomponius dixerit eum fuisse praetorem iuxta consilium ulpiani sua responcione contentus non fuit, vnde quesiuit audita responsione pomp(onii) vnde innuit eum non fuisse pretorem et ita nec liberum, cum ea que coram eo acta sunt valeant humanitatis racione tantum ut sequitur, vnde innuit eum non fuisse pretorem et ita nec liberum.'

144 Supra, $\$ 3.1$, text and note 15.

145 Suzzara, ad Dig.1.14.3, infra, Appendix, 1l.19-24: 'Item licet populus romanus sciuisset eum seruum fecisset eum liberum uel potuisset seruo decernere hanc 
Having denied Barbarius' freedom (and so also his status as praetor), Suzzara however shows little interest in explaining why his acts should be valid. He simply observes in passing that all jurists agreed on the point. ${ }^{146}$ Suzzara might have taken the point for granted - very unlike the modern jurist, no medieval felt the need for complex discussions in support of the common opinion. It is however also possible that Suzzara's approach was more complex and his reasoning was shortened in the extant sources. ${ }^{\mathbf{1 4 7}}$ Both possibilities would make sense in a context where no jurist doubted the validity of Barbarius' deeds. In any case, the rationale of Suzzara's position will soon become clear in his discussion of the scope of the lex Barbarius.

In accepting the validity of Barbarius' deeds while at the same time denying the validity of Barbarius' praetorship (and of his freedom), Suzzara might be following the same approach as the gloss attributed to Azo: approving of Barbarius' putative freedom so as to uphold his deeds while rejecting the putative will of the people to confirm Barbarius in his praetorship. ${ }^{148}$ Also for Suzzara the legitimacy of the source is not essential to the production of valid legal effects. To strengthen this point, Suzzara looks at some other texts allowing for the production of valid legal effects without at the same time acknowledging the validity of their source. He gives only two examples, but very significant ones, both on the deeds of a slave commonly believed free. We have already seen them: one is on the manumission of a slave by someone later on pronounced slave himself (Dig.40.9.19), and the other on the slave acting as a witness to a testament (Cod.6.23.1 and Inst.2.10.7). In both cases the common opinion about the slave's freedom is sufficient as to the validity of the deeds, but it does not change the slave's own position. The first case, argues Suzzara, shows that putative freedom is sufficient ground to bestow freedom upon others - but not

potestatem, hoc est uerum si sciuisset. Sed hic errabat populus quia credebat eum liberum et in ueritate erat seruus. Vnde non uidetur populus ei dedisse libertatem cum nichil tam contrarium sit consensui quam error ut $\mathrm{i}(\mathrm{nfra})$ iur(isdictione) $\mathrm{o}(\mathrm{mnium})$ iu $($ dicium $)<$ l. $>$ si per errorem (Dig.2.1.15). Vnde breuiter dicatis eum non fuisse pretorem nec liberum ut iam dictum est.'

146 Ibid., 11.24-26: 'Facta tamen ab eo valent nec obstant l(eges) all(egatae) in gl(osa) immo per hoc faciunt omnes ut dixi.' Cf. Ravanis, ad Dig.1.14.3 (Leiden Abl.2, fol. 18ra): 'Et secunda questio etc. est ista: nunquid detecta seruitute quod seruus faciat edicta sua desinunt valere. Ad istam respondet secundum omnes quod edicta sua et sententie sue tenent ne qui litigauerunt coram eo ledentur.'

147 When observing that all jurists are in agreement as to the validity of Barbarius' deeds, Suzzara seems to refer to what he previously said on the point ('immo per hoc faciunt omnes ut dixi'). However, the only previous passage in his lectura where he raised the issue was extremely brief ('Et hoc dico, in l(ege) quod ea que fecit debeant valere, non autem erit ipse pretor uel liber'). Infra, Appendix. Supra, $\$ 2.4$, text and note 91 . 
to acquire it. ${ }^{149}$ The other case, he continues, allows for the validity of the testament, but not also for the freedom of the slave who acted as witness. ${ }^{150} \mathrm{It}$ is probably not fortuitous that Suzzara's harsh critique of the presumed will of the people comes just after these remarks: since the validity of the deeds may be preserved independently of the validity of their source, there is no reason to impose on the Roman people a will they did not possess.

The reason for the validity of Barbarius' deeds, which Suzzara affirms but does not explain, is better understood in the second part of his comment, by far the most important: the boundaries within which the lex Barbarius may be applied. Suzzara provides two examples, one on the appointment of someone who could not be validly elected, and the other on the deeds made by someone falsely believed to have been appointed. The first case looks at someone ineligible because banished; the second case focuses on the false notary. It should be noted that the approach of Suzzara is more rhetorical than didactic: the first example is meant to build momentum, and so it finds an explanation only in the discussion of the second one. We have therefore to look at them together.

Let us suppose, says Suzzara, that a banished (bannitus) is elected to some magistracy in a city whose statutes prohibit the election of banniti. ${ }^{\mathbf{1 5 1}}$ Are his decisions valid? In principle, since his election is void, he could not discharge the office. But applying the lex Barbarius, argues Suzzara, it is very possible to

149 Here Suzzara might have been playing with the ambiguity of the term 'pronuntiari' in that text: supra, $\$ 2.3$, text and notes $50-52$.

150 Suzzara, ad Dig.1.14.3, infra, Appendix, ll.11-18: 'Et hoc dico, in l(ege) quod ea que fecit debeant valere, non autem erit ipse pretor uel liber, quia dicit lex quod competit libertas data ab eo qui postea seruus pronunciatus est ut $i(n f r a)$ qui et a quibus ma(numissi) li(beri) no(n) fi(unt) l. competit (Dig.40.9.19). Non autem erit ipse liber. Item non obstat quod seruus qui tempore test(ament)i creditur liber seruus est si testis adhibeatur in test $(\mathrm{ament}) \mathrm{o}$ testim videtur quia ist $<\mathrm{a}>\mathrm{e}$ l(eges) per hoc faciunt. Nam ex hoc ipso libertatem non consequitur ut iam dixi et ill<a $>$ l l(eges) allegate sunt in glosa hic et C. de testa(mentis) (Cod.6.23.1) et insti. 1. de test(amenti) \$ si cum aliquis (Inst.2.10.7).'

151 Suzzara does not clarify whether the banishment was a general one (and so the subject in his example was a bannitus imperii) or just from a specific city. Both solutions are possible. Someone banished from a single city would lose his citizenship (and typically his estate within that city) but retain his legal capacity, whereas the bannitus imperii would lose any right pertaining to the civil law (and so also his legal capacity). Suzzara mentions the case of Cod.10.33.1.2 (a slave posing as aedilis) when referring to the possibility that the prohibition of electing a bannitus was not in the municipal statutes but in the law itself (Appendix, 11.27-28). This might point to a general banishment - entailing capitis deminutio maxima - and so equiparating the bannitus to a slave. The only clear element is that this bannitus was not a citizen of the city where he was elected, otherwise the mistake would not be justifiable (let alone plausible). 
conclude for the validity of his deeds. ${ }^{152}$ Just like in the case of Barbarius, however, Suzzara is clear in rejecting the validity of the banished's appointment. This has very practical consequences: because the election is void, he says, the banished is not entitled to the salary due to the office he discharged. The alternative, argues Suzzara in a statement that would be often cited by later jurists, would mean rewarding someone for breaking the law. ${ }^{153}$

While of remarkable actuality in the coeval city-state scenario of northern Italy, this example does not clarify the scope of the lex Barbarius. In particular, it does not answer a fundamental question: does common mistake alone suffice for the production of valid legal effects? To answer this question, Suzzara gives a second and final example, that of the false notary. A notary lacking title cannot make any valid instrument, he says, despite being widely believed to be a true one. ${ }^{154}$ It is only at this point that Suzzara explains the scope of the lex Barbarius.

152 Suzzara, ad Dig.1.14.3, infra, Appendix, 11.27-35: 'Quid si statutum est in ciuitate ut bannitus non eligatur ad dignitatem, vel $1(\mathrm{ex})$ hoc iubet ut iam dixi de seruo et de liberto (cf. Cod.10.33.1.2), iste eligitur ad aliquam dignitatem populo ignorante. Cum esset bannitus nunquid ualet sententia ab eo lata? Videtur quod non, quia est lata a non competenti iudice, vnde non valet ut C. si a non compe(tenti) in 1. fi. (Cod.7.48.4). Item quia nominaciones in quibus solempnitates deficiunt sicut hic in questione proposita quia ineligibilis erat et tamen electus fuit non valent ut C. de appell(ationibus) l. nominaciones (Cod.7.62.27). Econtra videtur quod sententia ab isto lata valeat ut in ista 1 (ege) in glo(sa) all(egata), et hoc ultimum verum est ut hic probatur. G(uido).'

153 Ibid., 11.36-41: 'Sed nunquid salarium habebit iste bannitus qui fuit electus? Et videtur quod sic ar(gumentum) i(nfra) ad munic(ipalem) l. ticio (Dig.50.1.36pr). Econtra uidetur quod non quia sciebat se ineligibilem. Vnde delinquit dignitatem suscipiendo ex quo delicto premium consequi non debet ut $\mathrm{i}(\mathrm{nfra}) \mathrm{de}$ neg(otiis) g(estis) l. siue hereditaria (Dig.3.5.21(22)), et i(nfra) de int(erdictis) et re(legatis) 1. relegatorum $\$ ad tempus (Dig.48.22.7.4) et istud ultimum verum est. Guido.' The paradox of receiving a reward for having committed a delict is the main thing for which Albericus de Rosate would recall Suzzara in his lectura on the lex Barbarius. Albericus de Rosate, ad Dig.1.14.3 (In primamff. Veter. part. commentarij, cit., fol. 70rb, n. 24): 'Item quaerit an istae (sic) Barbarius eo detecto seruo debeat habere salarium, quod dabatur alijs praetoribus. Uidetur quod sic, $\mathrm{i}(\mathrm{nfra})$ ad munici(palem) 1. Titio (Dig.50.1.36), et idem uidetur posse dici in omnibus officialibus non legitime administrantibus. Gui(dus) de Suz(aria) tenet contrarium, quia [Barbarius] sciebat se seruum, et intelligibilem: et ideo ex eius dolo non debet praemium reportare, sed poenam, ut 1 . siue haereditaria de neg(otis) ge(stis) (Dig.3.5.21(22)) et de int(erdictis) et re(legatis) l. relegatorum $\$$ fin. (Dig.48.22.7.22).' The same image will also be used in Baldus, but this time precisely for the opposite reason: the reward might be due for having furthered public utility: infra, pt. III, $\$ 12.4 .3$, note 186 .

154 Suzzara, ad Dig.1.14.3, Appendix, 1l.42-46: 'Quid de tabellione qui se gerit ut tabellio et non est sed creditur, nunquid valent instrumenta ab eo facta? Videtur quod sic ar(gumentum) huius l(egis) et facit ad hoc i(nfra) de iur(e) fisci l. sed si 
The difference between false notary and false praetor, he reasons, lies in that only the latter was elected. Barbarius' election was invalid; nonetheless, the invalidity did not depend on the lack of passive legitimation of the electors or on the absence of a regular election, but only on the status of the elected. In other words, as Suzzara puts it, 'this Barbarius Philippus was made praetor by those who could make him such, that is, by the people. ${ }^{155}$ The same, he continues, also applies for the already-mentioned case of the slave-witness: his intervention as witness was requested 'by the person who had the power to make a valid will'. ${ }^{156}$ The reference to the slave acting as witness does not only strengthen the example of the banished (and so, ultimately, the interpretation of Barbarius' case), but also better explains its meaning. The power of the people to make Barbarius praetor, says Suzzara, is what allows a distinction between an appointment of the ineligible (as the banished) and a lack of appointment of the impostor (as the false notary). But, so far, this power had been understood as sovereign power: whether presumptively exercised (as in the Gloss) or not (as in Ravanis), the special position of the sovereign made its will qualitatively different from that of any other elector - hence the 'power of the appointer' (potentia committentis) of Ravanis. Because sovereign, the 'appointer' of Barbarius had a different kind of 'power' from that of anyone else. ${ }^{157}$ Hence the point made by Ravanis: if the mistaken appointment was made not by the king but by the bishop, then nothing done by the person so appointed could be held valid. ${ }^{158}$

Putting on the same level the appointment (of the praetor) made by the sovereign people and the appointment (of the witness) made by the testator, Suzzara qualifies the 'power of the appointer' in a very different way. The testator neither intended nor had the power to set the slave-witness free. ${ }^{159} \mathrm{He}$ only had the power to make a valid will - his own. By linking the appointment of the slave-praetor and that of the slave-witness Suzzara shifts the emphasis from the

accepto (Dig.49.14.32) et C. de testa(amentis) 1. i (Cod.6.23.1) et instit. de test(amentis) $\$$ sed si aliquis (Inst.2.10.7). Vos dicatis quod instrumenta ab eo facta non valent ut i(nfra) de rebus eorum 1. qui (Dig.27.9.8pr).'

155 Ibid., 11.46-47: 'iste barbarius philippus fuit a tali creatus in pretorem qui eum creare poterat, $s$ (cilicet) a populo.'

156 Ibid., 1l.48-49: 'Item et in illis duabus 1(egibus) C(odicis) et instit(utionum) (Cod.6.23.1 and Inst.2.10.7) fuit seruus qui credebatur tempore test(ament)i lib(erum) esse adhibitus a tali qui testare poterat'.

157 Supra, this chapter, $\$ 4.2$.

158 Ibid., text and note 53.

159 Nowhere in the sources - or in any comment of the jurists - may be found the suggestion that the slave acting as witness while thought to be free belonged to the testator. Perhaps the reason why no jurists argued as much was that such an interpretation would have weakened the testator's case, not added strength to it. See supra, $\$ 2.3$. 
quality of the person who made the appointment to the procedure followed in the appointment. In both the case of Barbarius and in that of the banished, the procedure followed in their election was perfectly valid. The only ground for invalidity lay in the personal quality of the elected and of the witness - which was precisely the object of the common mistake.

Much unlike the slave-praetor and the slave-witness, however, the problem with the notary did not lie in some hidden personal incapacity preventing his valid appointment, but in the absence of any appointment. Unlike the other cases, the notary was an impostor. ${ }^{160}$ In opposing the case of the banished magistrate to that of the false notary, therefore, Suzzara distinguishes between invalidity and inexistence. The election of the banished ought to be classified among those 'appointments where formal requirements are lacking' ${ }^{\mathbf{1 6 1}}$ (nominaciones in quibus solempnitates deficiunt), just like the appointment of the slavepraetor and that of the slave-witness. But in all such cases the appointment took place, and was made by the rightful appointer. The appointment of the notary, by contrast, is not just vitiated by some procedural defect: it never took place. If the people had no power to elect Barbarius, therefore, his election could not be invoked as the distinguishing feature between his case and that of the false notary. Lacking the power to elect, in other words, the election would have been as good as if it had never happened, and so the same solution for the falsus tabellio should also apply to the falsus praetor. Because the election did in fact take place and was made by the rightful elector, the praetor is not falsus in the same way as the tabellio is. Hence the common mistake may be invoked to strengthen the - so far, precarious - validity of the deeds made by him. But the common mistake alone may not bestow full validity. This was the solution of Odofredus: the common mistake as to the appointment is sufficient as to the validity of the deeds. ${ }^{162}$ To reach this conclusion, it may be remembered, also Odofredus looked at the case of the false notary. The fact that Suzzara opts for the very same example, therefore, does not look fortuitous. Odofredus' approach to the false notary opened a Pandora's box, for it removed any limit to the scope of the common mistake. Using the same example to set precise boundaries to the common mistake meant opposing Odofredus' solution in very clear terms.

The importance of Suzzara's comment is unfortunately matched by its brevity. This necessarily leaves many important questions unanswered. Let us just mention two of them, beginning with the distinction between inexistence

160 Ibid., 11.50-51: 'sed uero a nemine creatur tabellio et instrumenta conficit illa instrumenta non valent ut jam dixi. Guido.'

161 'Item quia nominaciones in quibus solempnitates deficiunt sicut hic in questione proposita quia ineligibilis erat', supra, this paragraph, note 152 .

162 Supra, $\$ 3.1$, text and note 30. 
and invalidity: where should the line between election in violation of procedure and absence of election be drawn? Is the right to elect mentioned as just one of the main requisites for the existence of the election, although vitiated, or does Suzzara consider the whole procedure that the rightful elector has to follow as subordinate to (and so less important than) the legitimation of the elector? A second problem is about the relationship between common mistake and public utility. Nowhere in his short comment on the lex Barbarius does Suzzara mention public utility: is that intentional? Should we conclude that, at least on this point, Suzzara agrees with Odofredus as to the limited importance of public utility? Or is he just taking the presence of public utility for granted? ${ }^{163}$

\subsection{Guillaume de Cunh}

An influential French jurist often grouped together with the main Orléanese ones was Guilelmus de Cugno (Guillaume de Cuhn, d.1336). Despite his importance as jurist and law professor, more is known of Cugno's political and ecclesiastical career than of his scholarly one. ${ }^{164}$ It is known, however, that he taught in Toulouse in the middle of the 1310s. Indeed his lectura on the Vetus dates to the academic year 1315/1316. ${ }^{165}$ There, a remarkably interesting and elaborated lectura on the lex Barbarius may be found. For our purposes, its chief interest lies in that that it would seem to betray Suzzara's profound influence, developing his conclusions and solving most of the unanswered questions listed above. In probably building on Suzzara, Cugno would also seem to provide an

163 The scope of the two above-mentioned issues would become even broader if we were to combine them together. Among the possible combinations of these two issues, one of the most obvious is the case in which the hidden defect was not in the elected but in the elector. In such a case, would Suzzara still qualify the election as having taken place but being invalid, or would he just deem it as nonexistent? In the first case, would the public utility considerations, coupled with the common mistake as to the status of the elector, be sufficient to bestow validity on the deeds of the person so elected?

164 On the life and work of Cugno see Brandi (1892) (a work that is dated but still very useful, although it seems now established that Cugno had little to do with Bologna: Meijers, infra, note 166); Meijers (1959b), pp. 185-189; Fournier (1921), pp. 361-385, esp. 372-385; Krynen (2015), pp. 295-296; Gilles (1971), pp. 217-218, including further literature at p. 217, note 310 .

165 Brandi (1892), p. 64. The lectura on the Vetus, the reportator notes the date of 3 February 1316: Meijers (1959b), p. 187, note 161. Cugno's lectura super Digesto veteri is known in six manuscripts. As the purpose of the next few pages is not to provide a critical edition of Cugno's lectura on the lex Barbarius but only to appreciate its meaning, all quotations will follow only one of these manuscripts, that preserved in Vienna, ÖNB 2257, fol. $74 r b-v b$. The exemplar preserved in Forlì 143, fol. $14 v$, does not show significant differences. 
implicit reply to the Orléanese jurists, and especially the solution proposed by Ravanis. ${ }^{166}$

In his lectura, Cugno does not mention any other jurist. Nonetheless, it would be surprising if he was not aware at least of the most influential authors who wrote on the subject. Besides, some textual elements in his lectura might suggest a good knowledge of authors such as Odofredus ${ }^{167}$ and Bellapertica. ${ }^{168}$

As with Suzzara - and unlike the Ultramontani that we have seen so far Cugno concedes that Barbarius' text posed three questions. ${ }^{169}$ But his approach to the text is more liberal than Suzzara's (which was hardly a literal exegesis) and it would seem closer to that of the Orléanese jurists, first of all in the rearrangement of the order of the text: the issue of Barbarius' freedom now comes before

166 Meijers argued that Cugno knew no Bolognese jurist writing after the Gloss: Meijers (1959a), p. 122, note 443. At least on the lex Barbarius, this might not be entirely accurate.

167 Cugno's familiarity with Odofredus' comment on the lex Barbarius is chiefly suggested by the remarkable similarity of the two authors on the problem of the lex Iulia de ambitu: ÖNB 2257, fol. 74rb-va.

168 Cugno's knowledge of Bellapertica's repetitio on the lex Barbarius is suggested mainly by the remarkable closeness of the two jurists on the issue of Barbarius' domicile (the only point in Bellapertica not present in Ravanis: supra, this chapter, $\mathbb{\$} 4.4$, text and note 93 ). It is worth looking in some detail at Cugno's treatment of the question of Barbarius' domicile to show his peculiar style and especially his independently-minded attitude towards the sources. In favour of Barbarius' domicile, Cugno observes, there are two main points. First, the requirement of the domicile, found mainly in Cod.1.39.2 (Valent. et Marcian. AA. Tatiano PU), was introduced by the emperor, whereas Barbarius' case took place during the Republic ('pot(est) dici quod istud habebat idem ante quam imperium translat(um) esset in imperatore'). If however Barbarius' case were to be considered as an appointment made under the empire, that might strengthen the same favourable conclusion, since the emperor (i.e. Antoninus) had granted Roman citizenship to those dwelling in the province of Rome ('uel dic quod iste barbarius transtulit se rome et uenit domicilium ergo non roma fuit seruus quod hodie clamasti quia qui in ciuitate romana moratur sit liber, ar(gumentum) $s$ (upra) de sta(tu) ho(minum) l. in urbe (Dig.1.5.17)'). Cugno however dismisses both objections with the obvious fact that, properly speaking, a slave cannot have a domicile. Further, if Roman domicile entailed Roman citizenship, then acknowledging the validity of Barbarius' domicile would amount to manumitting Barbarius without providing any compensation to his master ('seruus iste non habet domicilium iuste cum nichil habet cum sit seruus et ideo quia fuga non debet esse dampnosa domino non potest ibi dici habere domicilium ut i(nfra) de pu(blicanis) 1. fi. \$ii (Dig.39.4.16.2?), C. de ser(vis) fu(gitivis) 1. fi. (Cod.6.1.8).' All above quotations are in ÖNB 2257, fol. 74vb.

169 Ibid., fol. 74va: 'utiliter uides in l(ege) ista quod iste barbarius petijt preturam et creatus est. Et ex hoc tres questiones insurgunt. Prima an ex hoc ademptus fuit libertatem $(s i c)$, secundo an fuit pretor, tertio an acta per eum ual<e>ant.' 
that of the validity of his praetorship. As with the Orléanese, the purpose of rejecting Barbarius' freedom was to bar the praetorship. Accordingly, Cugno opens his critique against the Gloss denying Barbarius' freedom in the strongest terms: ${ }^{170}$

Was this Barbarius free? The Gloss says he was, so as to make him praetor and avoid that the people be deceived ... But clearly there is no possible way to argue that he was free.

The reasons invoked by Cugno against Barbarius' freedom combine legal principles with textual analysis. Manumitting Barbarius, he says, is tantamount to donating his freedom. But, if that is a donation, then it is necessary to have the intention to donate (i. e. the animus donandi). Since it is clear that the Romans were not aware of Barbarius' servile condition, they could not have possibly had that intention. ${ }^{171}$ When an appointment requiring the freedom of the person appointed is made in the false belief that latter is free, concludes Cugno, far from entailing the concession of freedom the appointment remains void. ${ }^{\mathbf{1 7 2}}$ The conclusion is somewhat abstract: to strengthen it, Cugno moves to a careful examination of the text, isolating and restructuring its components to reach the opposite result from the original text. In so doing, Cugno's flexible approach towards the text seems to go considerably beyond that of any jurist we have seen so far, Ravanis included.

The first part of Ulpian's argument plays a central role in Cugno's rearrangement of the text. It may be recalled how, in the text of the lex Barbarius, Ulpian first reported Pomponius' cryptic statement - Barbarius' servitude was not an obstacle to his exercise of the praetorship. Thereafter Ulpian observed that it was equitable to hold Barbarius' deeds as valid so as not to harm the commonwealth, all the more given that the same people who elected Barbarius without knowing of his servile condition would have likely set him free if they had known of it. Ulpian introduced his main argument with a question: 'if a slave, so long as he

170 Ibid., fol. 74va: 'An ergo iste barbarius fuit liber? Glo(sa) dic $<$ it $>$ quod sic ut pretor esse possit et gentes no $<\mathrm{n}>$ decipiantur, C. de his qui ue(niam) eta(tis) $1 . \mathrm{i}$ $\$$ in $\mathrm{f}$ (ine) (Cod.2.44(45).1). Sed certe hoc nullo modo potest substinere quod fuit liber.'

171 Ibid.: 'quod probo non potest dari libertas nisi sit animus donandi, C. de donat(ionibus) $<$ l. $>$ ignorans (Cod.8.53(52).10), de transact(ionibus) $<$ l. $>$ cum acquiliana (Dig.2.15.5).'

172 Ibid.: 'quando ergo hic potuit adipisci libertatem cum populus credebat liberum, ad quod facit quod dicitur in milite qui legat seruo qui dicit liberum nam non ideo sit liber, quod fieret si sciret seruum, de tes(tamento) $\operatorname{mi}($ litis $)<\mathrm{l}$. $>$ idem $\$ si seruum (Dig.29.1.30.3).' Cf. Dig.29.1.13 (Ulp. 45 ed.): 'Si servum proprium, quem liberum esse credidisset, miles heredem sine libertate instituit, in ea condicione est, ut institutio non valeat.' 
hid his condition, discharged the office of praetor, what are we to say? ${ }^{173}$ Cugno recalls the point, ${ }^{174}$ and puts it to good use. First, he deliberately interprets the question in isolation from its context. Then he looks at the context, and reads a later statement of Ulpian in the light of his interpretation of the previous one. Ulpian's quotation above contained a temporal adverb, 'so long as' (quamdiu): the slave exercised the praetorship 'so long as he hid his condition'. Read within the context, the statement serves just to introduce the hidden personal incapacity of Barbarius. Isolated from the rest of the text, however, the same adverb would suggest a temporal correlation between the general ignorance about Barbarius' servile status and his exercise of the praetorship: Barbarius continued to hide his true condition for the whole time that he discharged the office of praetor. Having duly stressed the point, Cugno then looks at the context, quoting the later statement of Ulpian: the people would gladly have set Barbarius free, had they known that he was a slave. ${ }^{175}$ At this point, Cugno combines Ulpian's two statements and suggests a meaning that went in the very opposite direction to that of the lex itself. Ulpian's second statement said that the people did not realise the servile condition of Barbarius while he sat as praetor; ${ }^{176}$ the first one explained that Barbarius could exercise the praetorship for the whole time that his servitude remained unknown. In inverting their order, Cugno is also inverting Ulpian's reasoning: Barbarius remained a slave for the whole time that he exercised the praetorship. Furthermore, for Cugno the adverb 'quamdiu' would also suggest a temporal limit to the concealment of Barbarius' true condition. If Barbarius 'discharged the office of praetor' only 'so long as' his servile status remained hidden, argues Cugno, then he must have been brought back to servitude. But the text does not say that, when this happened, his freedom was revoked. It follows, he concludes, that Barbarius never received it. ${ }^{177}$ Lastly, observes Cugno, putting the final nail in the coffin, if

173 Cf. Dig.1.14.3: 'Et tamen videamus: si servus quamdiu latuit, dignitate praetoria functus sit, quid dicemus?'

174 Cugno, ad Dig.1.14.3 (ÖNB 2257, fol. 74va): 'Item per hoc facit hic text(us), quia hic dic(it) "ta(men) uideamus quamdiu seruitute latuit functus pretura" ut hic in \$ uideamus.'

175 Cf. Dig.1.14.3: ' $\ldots$ cum etiam potuit populus Romanus servo decernere hanc potestatem, sed et si scisset servum esse, liberum effecisset. ...'

176 Cugno, ad Dig.1.14.3 (ÖNB 2257, fol. 74va): 'Item hoc dicit textus i(nfra) cum dicit "si populus sciuisset dedisset libertatem", cum ergo ignorauerit non dedit ei.'

177 Ibid.: 'Item non potest dici quod fuit liber, quia non reuocaretur libertas iste cum [MS: et] reuocatus in seruitute ut $\mathrm{p}$ (atet).' It might be interesting to compare Cugno's reasoning with that of Ravanis, supra, $\$ 4.2$, text and esp. note 51 ; cf. also note 33 . 
Barbarius did become free, there would be little point in discussing the validity of his deeds. ${ }^{178}$

Not being free, continues Cugno, Barbarius could not be praetor either. ${ }^{179}$ This statement explains the decision to invert the order of the text and to start with the issue of freedom. To strengthen his conclusion, Cugno now looks at the beginning of the lex Barbarius, so as to exploit the ambiguity in Pomponius' remark 'it is true that [Barbarius] exercised the praetorship' (verum est praetura eum functum). The Gloss, explains Cugno, uses these words to argue for the validity of Barbarius' praetorship. But Pomponius simply stated that Barbarius truly discharged that office, not that he was truly praetor. In so doing, Cugno remarks, the text merely points to the validity of his deeds, not of his office. ${ }^{\mathbf{1 8 0}}$ Besides, Ulpian referred to the validity of the deeds in terms of fairness, not of strict law. That, argues Cugno following Ravanis, would imply the invalidity of Barbarius' praetorship: if he was praetor de iure, then his deeds could not be valid just de aequitate. ${ }^{\mathbf{1 8 1}}$

Considering both the length and the complexity of the arguments used to disprove Barbarius' freedom and praetorship, it might come as a surprise that Cugno devotes little space to explaining the true reason for the validity of his deeds. A possible reason for that lies in the strong influence of Suzzara. As in Suzzara, the reason for the validity of Barbarius' deeds in Cugno's lectura is better

178 Cugno, ad Dig.1.14.3 (ÖNB 2257, fol. 74va): 'Item si liber esset quis dubitaret an acta per eum ualent non erat seruus [MS: seruum].'

179 Ibid.: 'Item non est dubium quod iste non fuit liber, ut probaui s(upra). Ergo non potuit esse pretor, i(nfra) de iudic(iis) cum pretor (Dig.5.1.12).' The power of the prince and the people to appoint a slave as praetor is easily dismissed on the basis of their ignorance as to Barbarius' slavery: 'Et si dicas non uerum est nisi factum esset a principe uel populo, dico quod uerum esset si princeps uel populus hoc scirent eum esse seruum, cum enim ignoret non uidetur facere liberum, cum enim princeps sciens bene uidetur libertate aliter non, $\mathrm{i}(\mathrm{nfra})$ de re iudi(cata) l. quidam consulebat (Dig.42.1.57), i(nfra) de excu(sationibus) tu(torum) (Dig.27.1), item ulp(ianus), de nata(libus) re(stituendis) l. i (Dig.40.11.1): non ergo fuit pretor' (ibid.).

180 Ibid.: 'Sed uideamus an fuit pretor et an habuit dignitatem pretoriam. Glo(sa) $<$ dicit> quod sic, ad quod facit quod hic dicit verum est "tamen preturam functam” ut in $§$ sed nihil [cf. Dig.1.14.3: ‘... Sed nihil ei servitutem obstetisse ait Pomponius, quasi praetor non fuerit: atquin verum est praetura eum functum ...']. Sed tamen dico contrarium quod non fuit pretor, et intelligo quod dicit textus pretor fuit, uerum est de facto quo adhuc ut acta per eum ualeant.'

181 Ibid.: 'Tamen non fuit pretor quod probo: si fuisset pretor frustra quere(tur) an illa quae decreuit ualeant. Item dicit textus summarius est quod ualeant acta per eum: non ergo de rigore ualent, tamen si fuisset uerus pretor acta per eum de iure ualent ut $s$ (upra) de ius(titia) et iur(e) 1. p(enultima) (Dig.1.1.11).' Cf. Ravanis, supra, $\$ 4.2$, text and note 33 . 
explained in the discussion of the boundaries within which this case may be applied.

The validity of Barbarius' deeds, says Cugno, does not depend on his position: much unlike Accursius, there is no need to bestow legitimacy on the source so as to rescue the acts. The deeds are valid 'out of fairness because of the common mistake' (ex <a>equitate propter communem errorem). ${ }^{\mathbf{1 8 2}}$ Their validity, in other words, is based on public utility, which allows for the production of valid legal effects in the presence of common mistake. It is the condition of the mistake of being common (a fact) that allows public utility (a normative consideration) to be invoked. This means that public utility cannot be invoked in isolation from common mistake. ${ }^{\mathbf{1 8 3}}$ It follows that the mistake of a single individual may not lead to the validity of the acts carried out on the basis of that mistake (it could not 'make law').

While common utility presupposes common mistake, the opposite is not true: there can be instances where the common mistake has little to do with public utility. The typical case is the slave-arbiter of Cod.7.45.2. In that text, as we know, the slave was commonly believed to be free (so the mistake was common), but his decision affected only two people (hence there was no public utility). The difference with Barbarius' case does not lie in the different status of the judge (delegate vs. ordinary). On the point Cugno is very clear: in principle, the lex Barbarius applies to both. ${ }^{\mathbf{1 8 4}}$ Rather, the difference lies in the number of subjects affected by the common mistake. Discharging the office of praetor (by definition an ordinary judge), says Cugno, Barbarius might have rendered a thousand judgments: holding such judgments valid would obviously further public utility. But if Barbarius had rendered only a single decision as delegate judge, making that decision valid would only go to the benefit of a single person. That decision would therefore remain void. ${ }^{\mathbf{1 8 5}}$

182 Cugno, ad Dig.1.14.3 (ÖNB 2257, fol. 74va): 'ut acta per eum et de(creta) sic ex equitate propter communem errorem.'

183 Ibid.: 'Sed dic(it) et ita bene acta per eum ualent sic in casu nostro et non fuit sola ratio utilitas publica, sed error communis quia ita bene erat in casu nostro, nam fuit quia communiter credebatur liber et talis error fac(it) ius i(nfra) de sup(pellectili) le(gata) 1. iii $\mathbb{\$}$ fi. (Dig.33.10.3.5) et per hoc fac(it) C. de tes(tamentis) 1. i (Cod.6.23.1) i(nfra) ad maced(onianum) 1. iii (Dig.14.6.3) et fac(it) $s$ (upra) (sic) de sen(tentiis) et interlo(cutionibus) o(mnium) iudi(cium) 1. si arbit(er) C. ii (Cod.7.45.2).'

184 Ibid: : 'Ergo communis sit hic di $<\mathrm{c}>$ tum quod acta per eum ualent, et ita intelligo 1. istam non solum in ordinario sed in delegato.'

185 Ibid.: 'dico quod barbarius fuit iudex del(egatus) inter duos et congnouit, nunquid ualent acta per eum? Uidetur quod non, et hoc est ratio quia acta per eum ualent propter communem utilitatem quia forte tulit mille sententias. Econtra utilitas et error duorum priuatorum $<$ non $>$ potuit sic hoc facere. Sic 
Apart from highlighting the central role of public utility, the parallel between ordinary and delegate judge has another and perhaps even more important reason. Both in the case of the ordinary judge and in that of the delegate, the common mistake is based on the validity of the appointment - not on its occurrence. The question, in other words, is not whether the judge is appointed but whether his appointment would suffice as to the production of valid deeds.

The difference between mistaken appointment and mistaken validity of a (true) appointment is the key to understanding the scope of the lex Barbarius in Cugno - just as it was in Suzzara. To explain the difference, as we have seen, Suzzara gave two examples: the banished unlawfully elected to a magistracy, and the false notary. The approach of Cugno is very similar but not identical. On the one hand, it is less rhetorical: the rationale followed is already explained in the first example that he provides, and further clarified in the second one. On the other, moreover, it betrays the clear influence of the Orléanese jurists. In choosing his examples, Cugno retained the notary but replaced the banished with a different figure, which by then was the 'trademark' of the Ultramontani on the lex Barbarius: the excommunicate.

As a matter of principle, says Cugno, the legal position of a slave is the same as that of an excommunicate - neither has legal capacity. The sentence issued by a slave, he continues, should therefore be void just as that issued by an excommunicate. ${ }^{186}$ Before looking more closely into the matter, however, we might want to focus a moment on the possible origin of this parallel between Barbarius and the excommunicate.

habes quod confessus duorum priuatorum non potuit facere iudicem qui non erat, sed uerus populus, et de iur(isdictione) $\mathrm{o}$ (mnium) iu(dicium) $<$ l. $>$ priuatorum (Cod.3.13.3) et l. fi. de emanci(pationibus) li(bertorum) l. i et l. fi. (sic) (Cod.8.49(48).6 and 1).'In this sense see also the comment of Panormitanus, who quoted Cugno so as to oppose him to Innocent IV. We will see later (infra, pt. IV, $\$ 14.3 .1)$ that the only point in which Panormitanus disagreed with Innocent IV on the scope of the common mistake was the case of the delegate judge. Panormitanus, ad X.1.3.22, $\$$ Quum dilecta (Nicolaus [de Tudeschis], Super Primum Decretali[um] Librum Commentaria, Basileae, 1477): 'Inno(centius) ponit vnam singularem limitationem in hac materia, dicit enim quod materia legis barbarius non habet locum in delegato, ratio diuersitatis quia coram ordinario versatur vtilitas plurimorum cum multi ex necessitate habeant adire ordinarium et ideo communis error facit valere gesta sed in delegato non vertitur nisi vtilitas duorum seu partium. Guil(elmus) de cu(gno) secutus est hanc sententiam in delegato ad vnam causam secus in delegato ad vniuersitatem causarum.'

Infra, this paragraph, note 196. 
As said, this comparison was already present in canon law sources, ${ }^{\mathbf{1 8 7}}$ but it is more likely that the Ultramontani took it from the Gloss. ${ }^{188}$ On the point, the Orléanese are remarkably unhelpful. As to Monciaco, we know that he was probably the first civil lawyer (at least in Orléans) to compare Barbarius to an excommunicate. But this is all we know: Ravanis did not provide further particulars as to the sources used by his old teacher. As to Bellapertica, everything he said on the subject was an adaptation (albeit to very different ends) of what Ravanis had already written. Looking at Ravanis for specific clues as to the origins of the parallel with the excommunicate, however, leaves us none the wiser. His repetitio mentions the excommunicate no less than eight times and in three different contexts. But the only source he mentions is a passage invoked just to score a point in sophistry. ${ }^{189}$

While there is little doubt that Cugno took the same example from the Orléanese, he is more helpful in understanding the possible origin of such a parallel. ${ }^{190}$ One of the sources that he mentions in relation to the excommunicate, ${ }^{191}$ Cod.1.18.1, opened the title 'on the ignorance of law and of fact' (de iuris et facti ignorantia). The text itself had little to do with the lex Barbarius - the emperor (Antoninus) allowed a soldier to raise an exception against a sentence because of the soldier's ignorance of proper pleading. ${ }^{192}$ Commenting on this

187 As the second part of this work will amply show.

188 Supra, this chapter, $\mathbb{\$} 4.1$.

189 Namely, if the delinquens is defined as 'enslaved [servus] to the punishment', and the excommunicate is a criminal, then the excommunicate is a slave - just as Barbarius. Supra, this chapter, note 34. More interesting is the reference to Cod.7.48.4, $\$$ Et in priuatorum (Parisiis 1566, vol. 4, col. 1674-1675), which Ravanis likely has in mind (though the reference in the manuscript is made to the whole Cod.7.48) when distinguishing private from public utility (supra, $\$ 4.2$, text and esp. note 32 ).

190 Infra, this chapter, note 196.

191 Of the other sources mentioned by Cugno when drawing the parallel with the excommunicate, mention should be made of one in particular: Cod.9.51.13. Its relevance to our purposes, however, is mainly a contrario, for it dealt with a case where the invalidity of the deeds could not be cured invoking a common mistake. We have seen how the Gloss used the text of Cod.9.51.13 when discussing the validity of the instruments drafted by a notary subsequently deposed (supra, $\$ 2.6$ ). The Gloss opposed that text to the lex Barbarius, remarking that the will made by someone who would subsequently lose his sui iuris status (the son whose father was later pardoned and restored to his former position) was void, whereas the deeds of Barbarius remained valid because of public utility and common mistake.

192 Cod.1.18.1 (Ant. A. Maximo mil.): 'Quamvis, cum causam tuam ageres, ignorantia iuris propter simplicitatem armatae militiae adlegationes competentes omiseris, tamen si nondum satisfecisti, permitto tibi, si coeperis ex sententia conveniri, defensionibus tuis uti.' 
second text, however, the Accursian Gloss listed some cases in which a party could bring forth a peremptory exception against the decision, and then excluded the possibility of raising other kinds of exceptions - unless of course the decision itself is void. And the decision is void, concluded the Gloss, when rendered by an incompetent or excommunicated judge. ${ }^{193}$ It is possible that the reference to this gloss was suggested by the fact that one of the peremptory exceptions found there was the Macedonian senatus consultum: if the lender lost his suit because he forgot to raise the exception that allowed him to sue the sonin-power, commonly believed to be legally independent, he was still allowed to bring it forth. ${ }^{194}$ The Gloss' short reference to the excommunicate perfectly suited Cugno's purposes: a decision rendered by an incompetent judge (such as a slave - the text of Dig.5.12.2 was clear on the matter) ${ }^{\mathbf{1 9 5}}$ is void, just as that of the excommunicate.

It is clear that this remains conjecture: there is no way to prove that this is the origin of Cugno's parallel between Barbarius and the excommunicate, let alone to suggest that the jurists of Orléans followed the same reasoning as Cugno. Still, between this hypothesis and one involving canon lawyers having a direct influence on a civil lawyer as early as Monciaco (and on a point both very specific and highly complex), however, the first one seems more plausible.

Having argued for the possible origin of this parallel, let us now focus on its use in Cugno. Do common mistake and public utility operate also in the decisions of the excommunicated judge? Let us suppose, says Cugno, that a baron appointed as judge someone who was widely believed not to be excommunicated, whereas in fact he was. Are the decisions rendered by this judge valid? ${ }^{196}$

193 Gloss ad Cod.1.18.1, $\mathbb{S}$ Vti (Parisiis 1566, vol. 4, cols. 158-159): ‘... Alius vbicunque dico iudicium nullum fuisse, quia iudex incompetens vel excommunicatus ... alias autem praeter istos casus post sententiam opponi non potest.'

194 Dig.14.6.11 (Ulp. 29 ed.): 'tamen, si non opposita exceptione condemnati sunt, utentur senatus consulti exceptione: et ita Iulianus scribit in ipso filio familias exemplo mulieris intercedentis.' Incidentally, the association between the title $d e$ iuris et facti ignorantia and the exception to the Macedonian senatus consultum was also present in the Gloss on the same title of the Digest: ad Dig.22.6.3, $\$$ Causa (Parisiis 1566, vol. 1, col. 2097). Here, however, there was no connection with the excommunicated judge.

195 Supra, $\$ 2.1$, note 2.

196 Cugno, ad Dig.1.14.3 (ÖNB 2257, fol. 74va): 'ponit ergo quidam baro creauit iudicem contra da(bat) seruum qui publice credebatur liber, sed [MS: uel] excommunicatus: nunquid debet habere [MS: habet] locum 1(egem) ista? Uidetur quod non, cum nullus possit comp<ar $>$ ari imperiali admi(stratione) C. ad l. a(nte) p(enultima) de nata(libus) resti(tuendis) queris, i(nfra) de nata(libus) re(stituendis) 1. i $\mathbb{S}$ queris [rectius, Cod.6.8.2 and Dig.40.11.3 respec- 
The example is of particular interest especially if compared with that of Ravanis. Ravanis gave two different examples of mistaken appointments of an excommunicate as judge: the first time by the sovereign; the second by a bishop. Only in the first case would the decisions stand for Ravanis, since in the second scenario the 'power of the appointer' could not make up for the defect in the person appointed. ${ }^{\mathbf{1 9 7}}$ The approach of Cugno seems a deliberate critique of Ravanis' conclusion. If we were to take into account the power of the appointer, says Cugno, the occult excommunicate appointed by a baron would hardly be comparable with the occult slave appointed by the emperor. The baron could appoint a judge but not also lift the excommunication; on the contrary, the sovereign had the power to make Barbarius praetor de iure. ${ }^{198}$ But is this distinction really necessary? If the whole purpose is not to ratify the position of the person invalidly elected but only to retain the validity of the deeds issued by such a person, then the 'power of the appointer' becomes considerably less important - whether or not such a power is exercised (as in the Gloss) or can be exercised (as in Ravanis). And the reason for the validity of the deeds is ultimately the common mistake, supported by public utility. ${ }^{199}$

Whether or not the appointor has the power to heal the underlying defect in the appointee, crucially, there has been an appointment. The occurrence of the appointment is necessary to prevent indiscriminate application of the lex Barbarius, but it does not constitute its main foundation. The lex Barbarius, says Cugno, does not rely so much on the superior authority of the appointor as on common mistake. The authority plays a role, but only an ancillary one: ${ }^{200}$

the power to appoint the praetor is not the main ground [of the lex Barbarius]; the main ground lies in the common mistake.

tively - the references between the same title in Code and Digest are inverted], i(nfra) de postul(ando) l. i $\$$ de qu(a) (Dig.3.1.1.10) et hoc proba(tur) expresse ex isto textu, quod uale $<\mathrm{n}>\mathrm{t}$ acta per barbarium: quia populus romanus uel princeps hic poterat eum facere iudicem, sed unus comes uel baro non possit dare istam potestatem seruo uel excommunicato. Et ideo in eo hoc locum habere non possit.'

197 Supra, $\$ 4.2$, notes 34 and 53 respectively.

198 Supra, this paragraph, note 196.

199 Supra, this paragraph, note 182.

200 Ibid., 'Quid dicen(dum)? Dico quod potest habere locum in quolibet alio, quia $\mathrm{r}$ (ati)o principalior $(s i c)$ hac $1(\mathrm{ex})$ habet locum in casu nostro, $s$ (cilicet) propter errorem communem in publico id autem quod sequitur, quia poterat dare pretorem, non est ratio principal(is): cum ergo ut dico ratio principalis sit communis error bene ualebit quod per eum actum est per iura, aliter $\mathrm{C}$. de testis l. i [Cod.4.20.1, sed 'de test<ament $>$ is', Cod.6.23.1] i(nfra) ad mac(edonianum) l. iii (Dig.14.6.3) C. [MS: $\$$ ] de sen(tentiis) 1. si arbit(er) (Cod.7.45.2), i(nfra) qui et a q(uibus) 1. competit (Dig.40.9.19).' 
It follows that the simple fact that the baron had the power to appoint the judge is sufficient as to the validity of the decisions of such a judge. While he clearly lacked the power to appoint an excommunicate as judge, the person he appointed was commonly believed not to be such. This would suffice for the production of valid legal effects: the decisions of the excommunicated judge may stand even if the position of the judge himself does not.

While the role of the superior authority is subservient to that of the common mistake, this does not mean that it can be dispensed with altogether. To stress the point, Cugno moves on to the second example: the false notary. Just like Suzzara before him, Cugno uses this example to limit the scope of the common mistake. In so doing, however, he is considerably more refined (and exhaustive) than Suzzara.

Let us suppose, says Cugno, that someone posed as a notary in a city ('in this city' - perhaps he was referring to Toulouse itself) ${ }^{\mathbf{2 0 1}}$ and exercised that office, letting everyone believe that he was duly appointed by the competent authority. Would the instruments he drafted be valid? Instead of providing an answer, Cugno continues with another image: the false judge who sat on the bench for a long time and rendered many decisions. Are his decisions valid? In linking the self-styled notary with the self-appointed judge, Cugno is both focusing the attention on the scope of the lex Barbarius (as Suzzara did), and also clarifying that common mistake is not sufficient even when supported by public utility. Shortly beforehand, Cugno said that Barbarius might well have decided on a thousand cases. ${ }^{202}$ Cugno did so to strengthen the importance of public utility and oppose the utility of many to that of two single litigants. The cases of the false judge and of the false notary, therefore, affect the commonwealth just as much as that of Barbarius. Nonetheless, Cugno's answer is the same as Suzzara's: the common opinion as to the appointment of a notary or a judge does not suffice for the validity of their deeds. It is also necessary that the appointment, albeit vitiated, did take place. ${ }^{203}$

201 Cf. Meijers (1959b), p. 188, and Krynen (2015), p. 295.

202 Supra, this paragraph, note 185.

203 Cugno, ad Dig.1.14.3 (ÖNB 2257, fol. 74va): 'Nunc uideamus si error communis facit id quod dicis. Ponit in ciuitate ista talis exercuit officium tabellionatus. Nunquid titius ab eo qui habet potestatem dandi credebat publice quod esset tabellio, et ita receperat plura instrumenta, nunquid istrumenta ista ulebunt? Uel pone quidam qui [MS: quod] nunquam fuit datus iudex exercuit iudicaturam per magna tempora, nunquid acta per eum ualebunt? Uidetur quod sic propter errorem communem et uidetur per hoc textum notabilem in tabellione qui non debet facere instrumenta per substitutum, in authe(ntica) $<$ de $>$ iudic(is) (Coll.2.2.1[=Nov.8.1]); si autem fec(it) propter uoluntatem communem istrumenta ualent in aut(hentica) de tabel(lionibus) $\mathbb{S}$ (enultimo), ibi documentis 
To reach this conclusion, it will be remembered, Suzzara contrasted the vitiated appointment of the ineligible with the utter lack of appointment of the impostor. To clarify this difference, however, Suzzara only stressed that both slave-praetor and slave-witness had been appointed by the subject who had the right to do so. This left some ambiguity in Suzzara's conclusion: did he mention the right to appoint just as an example of the requirements for the formal validity of any appointment? Cugno clarified the point, distinguishing between defects in forma and in materia.

The appointment of Barbarius, says Cugno, was formally valid: the electors had the power to proceed with the election, and the election itself was regular. As Cugno has it, 'there was no other impediment but for the person of Barbarius'. Hence the only issue lay in the condition of the person appointed (i. e. in his personal status), a defect in materia. By contrast, continues Cugno, in the case of the false notary (as well as in that of the false judge) the defect was in forma: there was no appointment. Among the two, he observes, a formal defect is more serious: 'a defect in materia can be excused more easily than one in forma' (peccatum materiae facilius excusa (ri) quam form $<a>e$ ). ${ }^{\mathbf{2 0 4}}$

While the distinction between legitimation of the elector and defect of the elected was not particularly original, ${ }^{205}$ its application to Barbarius' case is far less documented. Cugno was among the first - if not the very first - to do as much. This might encourage a brief look at his sources, and the way he used them. When stating that the mistake in materia is not as serious as that in forma, Cugno referred to three texts, the first two from the Digest and the last one from the Code. ${ }^{206}$ The two texts from the Digest dealt with the role of consent in the

etc. (Coll.4.7.1[=Nov.44.1\$4]). Sed dico contra, quod nichil ualent acta per tales: in 1. ista [scil., Dig.1.14.3] error communis et auctoritas eius qui hoc poterat dare non erat aliud impedimentum nisi in p(ersona) barbarij, et ita solus actus peccabat in materia. Cum ergo hic nulla $<\mathrm{m}>$ auctoritate $<\mathrm{m}>$ habebat talis, dico non uale(nt) acta per eum quia peccatum est in forma, cum nullo modo habeat iurisdictionem et peccatum materiae facilius excusa(tur) quam form $<\mathrm{a}>\mathrm{e}, \mathrm{i}(\mathrm{nfra})$ de consti(tuta) pec(unia) 1. i $\$$ eum qui inutiliter (Dig.13.5.1.4), de accep(tilatione) $<$ l. $>$ an inutilis in prin(cipio) (Dig.46.4.8pr), et per hoc text(us) C. de $\mathrm{nu}(\mathrm{mer})$ ariis et actu(ariis) l. actuarios in fi(ne) (Cod.12.49(50).7.1).'

$204 \mathrm{Ibid}$. On the need of proper appointment of the notary for the validity of his instruments see also Cugno's lectura ad Cod.4.21, $\$$ Comparationes (Clarissimi iurisvtriusque ... Guillielmi de cugno: alias de Cugno Lectura super Codice ... [Lugduni, 1513]; anastatic reprint, Bologna: Forni, 1968, fol. 58vb, n. 10).

205 See for instance the discussion of Jacobus de Belviso on the different categories of defects of an election or appointment infra, $\$ 9$, text and note 18 .

206 Cugno, ad Dig.1.14.3 (ÖNB 2257, fol. 74va): 'peccatum materiae facilius excusa(tur) quam form<a $>$ i(nfra) de consti(tuta) pec(unia) l. i $\$$ eum qui inutiliter (Dig.13.5.1.4), de accept(ilatione) $<$ l. $>$ an inutilis in prin(cipio) (Dig.46.4.8pr), et 
formation of contracts. When a stipulatio is void, stated the first text (Dig.13.5.1.4), the counterparty cannot enforce the promise made with the intent of receiving a counter-promise. ${ }^{207}$ At most, concluded the Gloss, the promise could be used as a defence against the person who made it - but surely not as a claim against him. ${ }^{208}$ If however the promise is made with full knowledge of its invalidity, it may not even give rise to a defence. That was the comment of the Gloss on the second case cited by Cugno (Dig.46.4.8pr). ${ }^{209}$ If the formal release of a debt (acceptilatio) is void and the releasor is perfectly aware of its invalidity, the contract may not even be considered as a nonenforceable agreement (nudum pactum). The releasee would therefore not be able to use the void release even by way of defence, because the releasor did not consent to it. ${ }^{210}$ The strong connection between subjective knowledge and the invalidity of the obligation seems to suggest the contrary argument in case of mistake: if the releasor was not aware of the invalidity of the acceptilatio, then the releasee might well use it as a valid pactum. The significance of these two texts to Cugno's purposes becomes clear looking at the third text, that in the Code, the only one dealing with appointments. It was a short text (Cod.12.49(50).7, the lex

per hoc text(us) C. de nu(mer)ariis et actu(ariis) 1. actuarios in fi(ne) (Cod.12.49(50).7.1)', supra, this paragraph, note 203.

207 Dig.13.5.1.4 (Ulp. 27 ed.): 'Eum, qui inutiliter stipulatus est, cum stipulari voluerit, non constitui sibi, dicendum est de constituta experiri non posse, quoniam non animo constituentis, sed promittentis factum sit.'

208 The Gloss noticed that if the counter-promise was void the stipulatio was not enforceable, because the stipulator lacked the intention to bind himself without consideration. At the most, the promissor could invoke the stipulator's promise as a defence against him (i.e. as an exceptio, not an actio). Gloss ad Dig.13.5.1.4, \Eum (Parisiis 1566, vol. 1, cols. 1393-1394): 'Arg(umentum) quod si non valet quod ago vt ago, nec valet vt ualere potest ... Sed qualiter sciam quod stipulari sibi voluerit, non constitui: respondeo ex uerbis que praecesserunt ... facilius exceptio quam actio paratur.'

209 Dig.46.4.8pr (Ulp. 48 ad Sab.): 'An inutilis acceptilatio utile habeat pactum, quaeritur: et nisi in hoc quoque contra sensum est, habet pactum. Dicet aliquis: potest ergo non esse consensus? Cur non possit? Fingamus eum, qui accepto ferebat, scientem prudentemque nullius esse momenti acceptilationem sic accepto tulisse: quis dubitat non esse pactum, cum consensum paciscendi non habuerit?'

210 Gloss ad Dig.46.4.8pr, $\mathbb{S}$ An inutilis (Parisiis 1566, vol. 3, col. 1207): 'Tu et ego facimus acceptilationem inutilem de aliquo debito. Quaeritur vtrum saltem talis acceptilatio habeat vim nudi pacti: vt sic virtute huius tollatur obligatio? Respon(deo) quod non. Diceret aliquis, quomodo potest fieri quod inter nos non fuerit saltem nudus consensus? Respon(deo) quod immo: quia ponamus quod ego sciebam nullius momenti fore acceptilationem quam faciebam: certe non habebit vim nudi pacti, cum nullum consensum habuerim paciscendi quando sciens fui.' Cf. also ibid., ad Dig.46.4.8.1, $\$$ Accepto. 
Actuarios), where the emperor reminded the pretorian prefect that the appointment of certain officers (especially the quartermasters of the fleets) required his own approval. If any such officer had been otherwise appointed, the prefect ought to condemn him and to pronounce void all his deeds. ${ }^{211}$ Instead of remarking on the obvious invalidity of appointments lacking imperial approbation, the Gloss focused on the consequence of such invalidity: 'what done by the person who was not validly elected is void'. In so doing, however, the Gloss added a contrary reference - to the lex Barbarius. ${ }^{212}$ The outcome was the opposite (Barbarius' deeds were valid), but the case was different. And the difference could be interpreted in the light of the previous two texts. Unlike the officers in the text of the Code, Barbarius was appointed by the prince. The appointment followed the proper modalities (it was valid as to its forma), but it was vitiated because of the personal status of the elected (a defect in materia). Nonetheless, the authority with the power to make the appointment also had the intention to do so.

Although vitiated, the appointment is nonetheless legally relevant, as it removes the main obstacle to the validity of the deeds - the defect in forma. Unlike the cases of the false judge and especially of the false notary, in those of Barbarius and of the excommunicated judge the election did take place. The intervention of the authority with the power to make the appointment bestows what later on (from Baldus onwards) would be called coloured title - a formally valid but substantively flawed title to exercise the office. ${ }^{213}$ It is however important to notice that, in Cugno, the presence of a coloured title does not constitute the rationale of the lex Barbarius, it simply marks the outer boundaries of its applicability. While Cugno requires both elements, he is very clear in subordinating the appointment to the common mistake. It is likely that Suzzara meant the same, but the shorter and much less elaborate way in which his thinking has arrived with us does not allow us to say so with certainty. As such, despite the clear influence of Suzzara, it is Cugno's comment on the lex Barbarius that should be considered as the earliest known formulation of the de facto officer doctrine. For the sake of public utility, it is possible to bestow validity on

211 Cod.12.49(50).7pr-1 (Theod. et Valentin. AA. Hierio PP.): 'Actuarios tam classium urbis Constantinopolitanae quam Thymelae equorumque curulium civitatum diversarum non aliter nisi, ut consueverat, manus sanxerit principalis, sublimitas tua praecipiat ordinari. Quod si quis talis sub tua fuerit iudicatione convictus, profectio irritis his, quae vetita contrectavit, etiam congruam indignationem incurret.'

212 Gloss ad Cod.12.49(50).7.1, \$Contrectauerit (Parisiis 1566, vol. 5, col. 302): 'Not(atur) non valere quae fiunt a non iure electo, ar(gumentum) contra(rium) ff. de offic(io) praeto(rum) l. Barbarius (Dig.1.14.3).'

213 Infra, $\$ 12.4 .3$. 
the deeds of someone invalidly appointed to an office in the presence of two conditions: (1) if the invalidity depends only on the legal incapacity of the elected, and (2) if the appointment is on the contrary commonly believed to be fully legitimate.

Having explored both the working of the common mistake and the outer boundaries of its scope, Cugno then moves on to look at its inner boundaries. A mistake may well be common, he says, but not necessarily shared by all. If only one or two people knew of the true status of Barbarius, whereas everybody else thought that his praetorship was perfectly valid, would the decision of Barbarius be valid also in their specific case? In other words, asks Cugno, does the common mistake operate independently of the condition of any single individual, even in favour of anyone who knows the truth? This case in effect is the exact opposite of that previously discussed about the mistake involving only two people. ${ }^{214}$ There, Cugno ruled out the validity of the deeds because of the lack of common mistake. Here on the contrary he excludes the applicability of the common mistake to the specific deeds of those who did not partake in it. The point is not as obvious as it may appear: as Cugno notes, there are some texts in the Digest allowing the production of valid legal effects exclusively when the mistake is individual and not common. Cugno's reference is to two texts dealing with a freeman selling himself into slavery (Dig.1.5.5.1 and Dig.40.12.7.3). It is possible that Cugno did not refer to them when speaking of the individual mistake (which does not produce valid effects) because these texts on the contrary argued for the validity of the transaction. The difficulty of the texts was that they did not simply look at the mistake of a single individual (the buyer), but positively required this mistake not be shared by others (the false slave and the seller) for the transaction to be valid. Unlike the individual mistake as to the jurisdiction of Barbarius, however, in those texts the mistake did not harm those who went along with it. On the contrary, it was precisely because of his ignorance as to the true status of the slave that the buyer could achieve his purpose - purchasing the slave. ${ }^{215}$

214 Supra, this paragraph, note 185.

215 The first, Dig.1.5.5.1 (Marcian. 1 Inst.), provided that it was possible to sell a freeman into slavery to divide the purchase price with him. The Gloss on this text (ad Dig.1.5.5.1, $\mathbb{\$}$ Venire, Parisiis 1566, vol. 1, col. 88) listed four conditions for the validity of such a sale: first, that the freeman was at least twenty years of age; second, that the purchase price was divided between seller and the freeman sold into slavery; third, that the new slave would actually receive his part of the money; 'fourth, that he who buys believed him [to be] a slave' (quarto, quod qui emit, credat eum seruum). The first two conditions were present in the text of the Digest, the third was added ad cautelam. The fourth was not present, but it was a necessary addition to harmonise the text with the medieval legal system, which was much more reluctant to let someone sell himself into slavery than the 
The difference between Barbarius' case and the sale of the false slave allows Cugno to better explain his reasoning on the single individual seeking to exploit the common mistake. Clearly, the knowledge of a single person does not make the mistake any less common. But the reason why the common mistake as to Barbarius' status may produce valid legal effects depends on the public utility considerations underpinning it. Public utility is invoked so as not to prejudice the commonwealth unjustly. But a single person knowing the truth can hardly be considered as unjustly prejudiced. Arguing for the validity of the deeds even in his case, says Cugno, would therefore mean exploiting the fairness considerations for which public utility is invoked. As Cugno has it: 'in our lex the deeds are valid out of fairness: since this person knows [Barbarius' true status], fairness may not be provoked'. ${ }^{216}$

Roman one. This interpretation however added a paradoxical element to the text: for the sale to be valid, the buyer must be mistaken as to the quality of the object of the contract. But only the buyer must be mistaken. To emphasise the last point, the Gloss also reported the opinion of Bassianus, who added a fifth condition stating as much: the mistake must be only of the buyer, not also of the person selling himself ('secundum Ioan[nem Bassianum] potest addi quintum, quod is qui venditur, non sit ignarus suae conditionis'). Although immoral, selling oneself was regarded as valid in the Gloss. But, crucially, its validity depended on the mistake of the buyer alone: if also the seller or the false slave were mistaken, then the sale was void. The second text, Dig.40.12.7.3 (Ulp. 54 ed.), introduced a complication, and in so doing strengthened the glossators' interpretation of the first one. This time the buyers are two, but one of them is aware that the slave to be sold is in fact a freeman. Because of that, since the object of the sale cannot be split or divided pro rata, the text concludes in favour of the validity of the contract. Both the conclusion and the elegant style of the text left the glossators somewhat perplexed. The Gloss (ad Dig.40.12.7, \$Ignorans (Parisiis 1566, vol. 3, cols. 332-333) reported two different opinions, siding with the second. The first interpretation was of Azo: reading the text as a (probably, rhetorical) question ('interrogatiue'), he concluded against the validity of the sale. The other interpretation was older (the Gloss ascribes it to 'Irnerius, Martinus and others') but proved more successful. Unlike Azo, those other jurists took the text at its face value ('legebant plane'). In so doing, they concluded for the validity of the sale: the co-buyer who knew of the free status of the person would benefit from the ignorance of the other ('et sic sciens habet partem propter ignorantiam'). The justification was found in the aim to punish the person who committed a crime in selling himself as a slave ('soluunt quod ignorantia vnius alteri prosit, propter delictum eius qui se vendit ... et secundum hoc no(tatur) quod innocens nocentem excusat.'). Approaching this text to discuss the validity of the deeds done under mistake meant stressing that the mistake was of a single person alone. Despite the knowledge of both seller, person sold and co-buyer, the mistake of the other co-buyer sufficed as to the validity of the transaction.

216 Cugno, ad Dig.1.14.3 (ÖNB 2257, fol. 74va-b): 'ergo iste [Barbarius] fuit pretor et ualent acta per eum propter errorem. Sed pone duo uel tres fuerunt rome qui 


\subsection{On the risk of being quoted by Cynus}

If Cynus added little, if anything at all, to the debate on the lex Barbarius, his weight should not be underestimated, especially for its distorting effect as to the understanding that later jurists would have on the actual position of previous ones.

When looking at Cynus' treatment of the lex Barbarius, we have already noted the role he played in the progressive misunderstanding (and so, ultimately, oblivion) of Ravanis' ingenious approach. ${ }^{\mathbf{2 1 7}}$ Ravanis, however, was not the only victim of Cynus. As a matter of fact, the only position that Cynus managed to report correctly in his reading of the lex Barbarius was that of Bellapertica. Looking briefly at the way he reported (or not) the thinking of other jurists might be of some interest, especially with regard to three of them: Suzzara, Cugno and Dynus de Mugello.

If Cynus devotes little room to Ravanis, providing a grossly simplified account of his elaboration, he pays even less attention to Cugno: ${ }^{\mathbf{2 1 8}}$

some other moderns hold that, where there is no superior authority, the deeds are void because the defect is in forma and not just in materia.

Misunderstanding what Cugno said, Cynus does not give much thought to the matter: since the lex Barbarius is based on equitable considerations, there is little

cognoscebant istum barbarium et sciebant eum esset seruum litigauerunt coram eo. Nunquid ualent acta per eum inter illos? Uidetur quod sic propter utilitatem communem et errorem. Item ex hoc quod error est in populo non potest inspici scientia aliquorum, ar(gumentum) s(upra) de re(rum) di(uisione) $<$ l. $>$ in tan

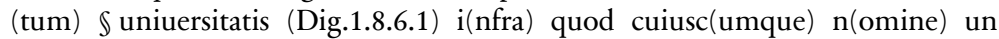
(iuersitatis), <l.> sic(ut) muni(cipium) $\$$ i (Dig.3.4.7.1). Item pro hoc quod [MS: quia] si homo hominem liberum credens seruum officitur seruus, de statu ho(minum) <l.> et seruorum $\mathbb{~} i$ (Dig.1.5.5.1). Sed si scio liberum non uerum. Sed pone quod ego credo seruum, tu scis liberum: non ob(stante) tua scientia efficit seruus i(nfra) de lib(erali) ca(usa) <l.> lib(er)os $\$$ si duo (Dig.40.12.7.3) et per hoc i(nfra) de testibu(s) l. ii (Dig.22.5.2), i(nfra) quemad(modum) serui (tutes) amit(tuntur) <l. $>$ si communem (Dig.8.6.10pr). Sed dico in casu isto quod non ualent acta inter istos: quia in casu nostre 1 (egis) ualent acta ex equitate: cum ergo iste sciat non debet equitatem irritari.'

217 Supra, $\$ 4.5$, text and note 136.

218 Cynus, ad Dig.1.14.3 (Cyni Pistoriensis In Codicem et aliquot titulos primi Pandectarum tomi ..., vol. 2, cit., fol. 14vb, n. 16): 'Sed quidam modernorum dicunt, quod vbi deficit superiorum authoritas, non valent acta: quia peccatur in forma, non in materia sola, ergo, etc. vt inf(ra) de verb(orum) oblig(ationibus) l. i $\$$ quis (Dig.45.1.1) et de accept(ilatione) 1. an inutilis, in princ(ipio), cum si (Dig.46.4.8pr).' While Cynus does not mention Cugno's name, his readers starting already with Bartolus - had little doubt on the point: infra, next chapter, note 4 . 
point in looking at formal requirements. ${ }^{219}$ This way, the requirement that the appointment be made by the subject with the power to grant it (a requirement essential to distinguish invalidity from inexistence of the appointment) becomes a mere formality: a formality that can be easily dispensed with for the sake of public utility. In Cynus' minimalist interpretation, Cugno's insistence on the formal validity of the election becomes a sort of variation on the theme of Ravanis (whose position was in turn reduced to the simple intervention of the superior authority). This would soon lead to the assimilation of Cugno's position with that of Ravanis: they became the two Ultramontani who insisted on the double requirement of public utility and the authority of the sovereign. ${ }^{220} \mathrm{Sic}$ transit gloria mundi.

How well Cynus actually knew Cugno's lectura on the lex Barbarius is far from clear. What seems quite clear, however, is that he did know of at least one more of those 'modern' jurists who solved the lex Barbarius on the basis of the same distinction: Suzzara. Although Cynus does not mention him, most of the (few) things present in Cynus but not in Bellapertica may be found only in Suzzara. This is particularly the case with regard to Suzzara's example of the banished elected to a municipal magistracy. Both to distinguish the validity of his deeds from the invalidity of the appointment and to deny him the magistrate's salary, Suzzara used specific leges and used certain arguments that may not be found in other jurists - but for Cynus. ${ }^{221}$

219 Cynus, ad Dig.1.14.3 (Cyni Pistoriensis In Codicem et aliquot titulos primi Pandectarum tomi ..., vol. 2, cit., fol. 14vb, n. 16): 'Sed certe cum hic operatur ratio aequitatis, non est multum curandum de pacto formae: quia vtrobique fuit aequitas. Et ideo no(tandum) est sententia Pe(tri), pro qua facit quod no(tat) Dy(nus) extra de re(gulis) iuris, cap. 1, 1. 6 [Dynus, De regulis iuris, adVI.5.13.6, $\$$ Beneficium, infra, next paragraph], ista est veritas.'

220 Infra, next chapter, $\$ 5.1$, text and note 4 .

221 So, for instance, to remark on how Barbarius' de facto exercise of his office did not grant him any right to it, Cynus quotes the (traditional) lex Herennius (Dig.50.2.10), but relies more on a short title in the Code dealing with a similar issue, Cod.10.33(32). Unlike the lex Herennius, Cod.10.33(32) referred expressly to slaves (or freedmen), and so was even more suited to Barbarius' case. This title of the Code only consisted of two leges, which were usually read together: the beginning of the second lex was considered the explaination of the first one. The first lex (Cod.10.33(32).1) stated that the slave was to be punished with the full might of the law; the (first part of the) second lex (Cod.10.33(32).2) explained that such a punishment was well deserved, since the slave had 'defiled the dignity' of the office. This title of the Codex is not to be found in Bellapertica's reading of the lex Barbarius (nor in that of Ravanis), but only in Suzzara's discussion of the scope of the lex Barbarius: cf. supra, this chapter, notes 151-152. Suzzara, as we have seen, allowed for the validity of acts carried out by the banished individual who is unlawfully elected to a municipal magistracy but 
When dismissing the objection of those 'modern' jurists obsessing with petty formalities such as Cugno, Cynus invokes the authority of the eminent jurist Dynus de Mugello (Dino Rosoni, c.1253-post 1298). ${ }^{222}$ Dynus did not write on the lex Barbarius but only looked in passing at some specific applications of the common mistake. ${ }^{223}$ Cynus' reference to Dynus was extremely short, but that did not prevent later jurists - starting with Bartolus - from enlisting Dynus in the same group as Cynus and Bellapertica on the interpretation of the lex Barbarius. 224

The reference to Dynus was on a very specific point of his discussion of ecclesiastical appointments. Dynus was not looking at the invalidity of the appointment for some defect in the appointed, but rather for a defect in the appointer. While in principle the unlawful position of the person who made the appointment should invalidate it, says Dynus, nonetheless the appointment is valid if the appointer's position is held as valid by common mistake, and such a mistake preceeds the appointment itself (that is, it does not occur as a consequence of the appointment, but predates it). In such a case, concludes Dynus, the common mistake about the validity of the appointer's position would heal the invalidity of the appointment of the person he appointed. ${ }^{225}$ One

denied him the right to claim the magistrate's salary (supra, this chapter, note 153). Cynus builds on these observations and uses them to strengthen Bellapertica's arguments against Barbarius' praetorship. Cynus, ad Dig.1.14.3 (Cyni Pistoriensis In Codicem et aliquot titulos primi Pandectarum tomi ..., vol. 2, cit., fol. $14 r a-b$, n. 12): 'Tertio probatur, quia l. cauetur, quod licet seruus militet, non propterea sit liber, ergo etc. vt C. qui mili(tare) pos(sunt) l. super seruis, lib. 12 (Cod.12.33(34).6pr). Quarto probatur per 1. i et 2 C. si ser(vus) ad decu(rionatum) as(piraverit) lib. 10 (C.10.33(32).1-2) ... Quinto [rectius, 'sexto'] probatur, perceptio salarij fuit illicita, vt infra de decur(ionibus) 1. et si Herennius [rectius, 'Herennius', Dig.50.2.10].'Another lex mentioned only by Suzzara was Dig.3.5.21 - a text on negotiorum gestio, which Suzzara used so as to deny to the bannitus the salary due to the magistrate. Cynus borrows the same argument in support of Bellapertica. Just as it would be absurd to let the negotiorum gerens recover his expenses if the estate was destroyed through his fault (this was the gist of Dig.3.5.21), reasons Cynus, so it would be unreasonable to reward Barbarius with the praetorship for having deceived the people and usurped that office. Ibid., fol. 14ra-b, n. 12: 'Quinto probatur, quod hic Barbarius, vsurpando sibi illicite officium praefecturae delinquit, et falsum commisit, vt C. ad l. Viscel (liam) 1. vnica (Cod.9.21.1) ... Et sic quia debuit puniri, non debet praemium reportare: et sic non est Praetor, vt infr(a) de neg(otis) ge(stis) l. siue haereditaria (Dig.3.5.21).' Supra, $\$ 4.6$, note 153 .

222 Supra, this paragraph, note 219. On Dynus' life, works and bibliography see Padovani (2013), pp. 769-771.

223 Ibid.

224 Infra, next chapter, $\$ 5.1$, and note 4.

225 Dyni Myxellani ... Commentaria in Regvlas Ivris Pontificii ..., Lvgdvni, apud Antonium Vincentium, 1558, reg.1, p. 24, n. 31-32: 'Septimo quaeritur, quid 
can now better understand why Cynus referred to his passage when arguing against Cugno's requirement of a formally valid appointment. Even if the superior authority had no right to appoint someone (and so, even when the defect is in forma), the common mistake could still be invoked. When speaking of invalid authority and common mistake Dynus refers to the person who made the appointment. But the same reasoning could be applied to the person appointed (and it would: we will see later the similarity of the position of two jurists writing shortly after Dynus, Jacobus de Belviso and Raynerius de Forlì). ${ }^{226}$

Despite the enthusiasm of Cynus, Bartolus and his followers to drag Dynus posthumously into the debate on Barbarius' case, Dynus is neither looking specifically at the lex Barbarius, nor is he interested in discussing the scope of public utility. His focus is only on the common mistake. Dynus discusses the common mistake, occasionally mentioning the lex Barbarius, also in other instances - but never in much depth. The fact that the mistake needs to be common to produce effects, ${ }^{227}$ for instance, could also be applied to the problem of ignorantia facti, so as to distinguish between excusable and nonexcusable ignorance. It is only when some fact is not commonly known, says Dynus, that one's ignorance may excuse him. Where on the contrary the fact is widely known, the contrast between common opinion and mistaken individual belief highlights the culpable ignorance and suggests culpa lata. ${ }^{228}$ Thus the

si credebatur instituentem instituendi habere ius, cum in veritate non haberet: an comperto errore institutio vitietur? Et videtur vitiari debere: quia factum illius qui credebatur esse tutor, et non erat, inutile est ... Econtra videtur vitiari non debere de iure Canonico vel Ciuili, quia tenuit ab initio propter errorem communem qui pro veritate habetur, c. consultationibus, de iure patr(onatus) (X.3.38.19), de supel(lectili) leg(ata) 1. iii $₫$ fi. (Dig.33.10.3.5), l. Labeo, in fi(ne) (Dig.33.10.7.2), et de offi(cio) praeto(rum) <l.> Barbarius Philippus (Dig.1.14.3), et C. de testa(mentis) 1. i (Cod.6.23.1) et de sen(tentiis) interloc(utionibus) om(nium) iud(icium) 1. si arbiter (Cod.7.45.2) et instit. de test(amentis) $\$ sed cum aliquis (Inst.2.10.7). Et ideo liceat postea detegat veritas errori contraria, non vitiabitur institutio quae ab initio tenuit.'

226 Infra, pt. III, $\$ 9$ and $\$ 12.4 .1$ respectively.

227 On the difference between common and individual mistake see Dyni Myxellani ... Commentaria in Regvlas Ivris Pontificii, cit., esp. reg.1, p. 24, n. 33, referring to Dig.29.2.30.1 and especially to Dig.33.10.7 (where Celsus opposes the opinio singulorum to the usus communis: 'non enim ex opinionibus singulorum, sed ex communi usu nomina exaudiri debere').

228 Ibid., reg.13, pp. 88 and 91, n. 3 and 16 respectively. The point was not new. For instance, Bulgarus had already said that the consequences of a mistake depended on the position of the errans (especially on whether he was in good or bad faith) and the kind of mistake. So for instance a mistake on a fact made in good faith is sufficient to avoid its negative consequences. By the same token, although a mistake of law is more serious than a mistake of fact, a mistake of civil law is not as serious as a mistake of natural law. Bulgarus, Summula de iuris et facti 
communis opinio may both cure the invalidity and aggravate the individual liability.

The last time that Dynus refers to the lex Barbarius and the common mistake, he does so to juxtapose truth with appearance. When something occurs to make things appear different from how they truly are, says Dynus, one should not refer to the natural condition of things but to how they seem to be. Hence the people who approached Barbarius believing him true praetor should not be penalised for that. ${ }^{229}$

From this, it is difficult to think of Dynus as siding with Bellapertica and Cynus on the issue of public utility and the lex Barbarius. Yet this is how later jurists often remembered him, on the sole basis of Cynus' short remark.

ignorantia (BL, Royal 11.B.xiv, fol. $53 \mathrm{r} b-v b$, esp. 53va). It is perhaps worth comparing Bulgarus' more general (and abstract) position with the more practice-oriented one of later glossators, which were centred on restitution. See first of all Ugolino's distinctio in Cod.1.18.10 (transcribed in Cortese [1964], vol. 2, pp. 421-422).

229 Dyni Myxellani... Commentaria in Regvlas Ivris Pontificii, cit., reg.8, p. 68, n. 3-4. 


\section{Chapter 5}

\section{A fragile synthesis: Bartolus de Saxoferrato}

As already said, the last important defender of the Gloss on the lex Barbarius after Butrigarius was the most illustrious of his students and the most famed of all commentators: Bartolus de Saxoferrato. By Bartolus' time, the importance of the Ultramontani's arguments on the lex Barbarius could no longer be ignored. Commenting on it, Bartolus had a double purpose - defending the Gloss from the Ultramontani's attack while at the same time applying their conclusions so as to extend the scope of the lex Barbarius. Taken at their face value, these two purposes would hardly seem compatible with each other. This might well account for the ambiguity in his use of some previous jurists, whose position needed some slight reinterpretation to fit in his overall scheme.

\subsection{A strategic defence of the Gloss}

Just like Cynus, Bartolus also opens up his lectura with Barbarius' case, recalling the different position of the Gloss from that of the Orléanese jurists. ${ }^{\mathbf{1}}$ Then he provides a brief summary of what the Orléanese said. To do so, however, he reports only Ravanis' reading (without mentioning him): Ulpian's solution (validity de aequitate) would depend both on public utility and on the power of the sovereign. ${ }^{2}$ Ascribing Ravanis' position to all the Ultramontani (without even sufficiently explaining it) might seem curious, all the more since Bartolus shows good knowledge of Bellapertica's reading of the lex Barbarius (and also, in other parts of his opus, of Cugno's), but not of Ravanis'. On the contrary, there is no other element in the whole of Bartolus' opus to suggest similar knowledge of Ravanis' position on Barbarius' case. As such, Bartolus' emphasis on the role that

$1 \quad$ Bartolus, lectura ad Dig.1.14.3 (Bartoli a Saxoferrato in Primam Digesti Veteris Partem Commentaria ... Basileae, Ex officina Episcopiana, 1588, p. 113, n. 1): 'Haec est bona et subtilis et solemnis lex et legitur dupliciter. Uno modo s(cilicet) glo(sa), alio modo secundum vltramontani.'

2 Ibid., p. 114, n. 2: 'Et secundum hoc diuiditur haec lex in quinque partes. Nam in prima ponitur quoddam thema. In 2 quaedam circunferentia ad q(uestionem) mouendam. In 3 ponitur quaestio. In 4 questionis solutio. In 5 ponuntur due rationes. In summa, hoc dicit, secundum hanc lec(turam): agitata coram pretore minus idoneo propter publicam vtilitatem et propter auctoritatem creantium eum in pretorem tenent et valent. Hoc dicit. Et sic differt a lect(ura) glo(sae) quia hic non dicit, quod fuit liber uel praetor.' Cf. supra, last chapter, note 87. 
'the authority of those who made him praetor ${ }^{3}$ had for the Ultramontani might appear somewhat ambiguous.

Later in the lectura, however, Bartolus is more precise. Most probably relying on Cynus' summary, he divides the Ultramontani according to whether public utility alone suffices, or superior authority is also necessary. Since Bartolus' summary was probably based on that of Cynus, it was a summary of a summary. Cynus himself, as we have seen, was not particularly accurate to begin with: he treated Cugno's requirement of a formally valid appointment as ultimately the same as Ravanis' 'power of the appointer', and invoked Dynus' authority in support of the opposite position of Bellapertica. As a result, Bartolus classified the position of the detractors of the Gloss on the lex Barbarius according to whether public utility sufficed, or whether the presence of superior authority was also necessary. Cugno and Ravanis required both elements, whereas Bellapertica, Cynus and Dynus thought that public utility alone would do. As Cynus used some of Suzzara's examples but did not quote him, Bartolus did not enlist him in either group. Syllimani was not used in Cynus, so did not appear in Bartolus either. ${ }^{4}$

This second occasion where Bartolus refers to the Ultramontani shows that the first one, based only on Ravanis, was not very punctual. A slightly imprecise citation would be hardly remarkable if it were not for the fact that Bartolus deliberately uses the two different references for very different purposes, as we will see when discussing the last part of his lectura on Barbarius' case.

The first time that Bartolus refers to the Ultramontani, he does so to compare their position with that of the Gloss as to the validity of Barbarius' praetorship. In so doing, as we have seen, Bartolus ascribes to all of them the position of Ravanis. In Bartolus' short summary, however, Ravanis seems to emphasise the role of the sovereign authority more than he actually did: exercising their sovereign power ('propter auctoritatem creantium eum in pretorem'), the

Ibid., p. 114, n. 2.

$4 \quad$ Ibid., p. 114, n. 5: 'Quero que est ratio quod acta per iudicem minus idoneum ualent? Iac(cobus) de Raua(nis) et Gul(ielmus) dicunt quod hic est duplex ratio. Prima, auctoritas Principis uel populi, creantis hunc praetorem: ut in uersi(culo) "cum etiam" [cf. Dig.1.14.3: 'cum etiam potuit populus Romanus servo decernere hanc potestatem']. Secunda ratio fuit publica utilitas, nec tot acta coram eo pereant. Et haec secunda ratio probatur ibi: "an fore”, etc. [cf. Dig.1.14.3: 'An fore propter utilitatem eorum, qui apud eum egerunt vel lege vel quo alio iure?']. Petrus et $\mathrm{Cy}$ (nus) post eum tenent, quod fuerit una ratio, s(cilicet) publica utilitas, ne actorum multitudo periret. Et huic opinioni applaudit Dyn(us) ut in c. i in 7 quaestio(ne) extra de reg(ulis) iur(is) li. vi (VI.5.13.7).' The reference was wrong but in that regula Dynus discussed an issue of ecclesiastical prebends and the causa finalis of the grant of a prebend - which might explain the reason for the mistake. 
Roman people appointed Barbarius as praetor. ${ }^{5}$ As a result, the reader is left to ponder the reason for the Ultramontani's disagreement: if they accepted that the sovereign appointed Barbarius as praetor, then it would be difficult to understand why they also denied the validity of such an appointment. Their objections are thus reduced only to very specific issues deriving from entirely different sources. The problem - one might be tempted to conclude - thus becomes a question of detail more than of substance. It might not be ruled out that the Ultramontani's posthumous reputation - quibblers fond of petty sub-distinctions - also has something to do with the way they often appear in fourteenth-century Citramontani, who criticised their approach while often using it. ${ }^{6}$

To understand Bartolus' approach, it is also important to highlight something rather obvious: like most Italians, he followed the order of the Gloss. So, in discussing the lex Barbarius, he first looked at the issue of the praetorship and only then at that of Barbarius' freedom. The Ultramontani, as we have seen, inverted the order in which the validity of the praetorship and freedom appeared in the lex, starting with the latter. It was on the basis of Barbarius' lack of freedom that they denied the validity of the praetorship. The main arguments against the latter were therefore developed in the critique against the former. The point is more important than it might seem. Comparing the position of the Accursian Gloss with that of the Ultramontani according to the exact order in which each subject appeared in the Gloss meant giving to the Gloss a great advantage: rather weak opposition to the first subject. In the first part of his lectura on Barbarius, Bartolus discusses the validity of the praetorship, paying little attention to the Ultramontani and focusing mainly on the Gloss (as interpreted by Butrigarius). Later, when finally recalling some of the more substantial arguments of the Ultramontani, Bartolus could dismiss them by simply inviting his reader to look back at what had already been said on the subject of Barbarius' praetorship. ${ }^{7}$ Whether or not deliberate, his approach

5 Compare Bartolus' summary (supra, this chapter, note 2) with Ravanis' own position (supra, last chapter, esp. note 59). The more pronounced role of the superior authority in Bartolus' summary of Ravanis does not match the summary provided by Cynus, who simply spoke of 'the authority of the person who bestowed [the title]' ('authorita[s] concedentis', supra, last chapter, note 136), not of the rather more specific 'authority of those who created him praetor'.

A somewhat emblematic case, for instance, is Albericus de Rosate's full-scale attack on the subtleties of the 'modern doctors', which opens his commentary on the Vetus. See recently Padovani (2017), pp. 5-9.

Bartolus, lectura ad Dig.1.14.3 (Bartoli a Saxoferrato in Primam Digesti Veteris Partem Commentaria, cit., p. 114, n. 4): 'Et ex his concludunt contra glo(sam). Dico tamen, quod gl(osa) bene loquitur. Non ob(stante) contrarium primum, 
would strengthen the impression - especially in a reader who did not have the text of the Ultramontani at hand - of the futility of such arguments. The only objection of the Orléanese that he briefly discusses with regard to the praetorship was that based on the literal tenor of Pomponius' statement: that the slave Barbarius 'exercised the praetorship'. To dismiss their objection (mere exercise $d e$ facto), Bartolus stresses a point already made by Butrigarius: it is not acceptable to say that Pomponius simply wanted to state a fact, for that fact was so obvious that it would make Pomponius' statement look ridiculous. ${ }^{8}$ Much on the contrary, Bartolus adds, as a jurist Pomponius did not state facts but assigned a normative qualification to them. ${ }^{9}$ Once again, looking for petty arguments, the Ultramontani missed the main point.

On both praetorship and freedom, Bartolus does little more than report Butrigarius' position. So, for instance, the objection about the lex Iulia de ambitu is solved in the same way as Butrigarius did - asking publicly is valid, asking secretly is not. ${ }^{10}$ Bartolus' lengthy discussion of the applicability of the lex Iulia also reports some very specific - and, this time, approving - references to the

1. Herennius (Dig.50.2.10), quia solue ut in glo(sa). Ad l. moueor (Cod.4.55.4pr) responde ut glo(sa) ... Non ob(stante) quod ipsi dicunt, quod acta de rigore ualerent, nedum de aequitate, si fuisset praetor: quia respondeo, ut in praecedenti quaestione' [i.e. on the validity of the praetorship].

$8 \quad$ Butrigarius, ad Dig.1.14.3: 'Item probat dictum Ulp(iani), quod dixit preturam eum functum et si dicas et gessisse offitium pretoris. Sed non fuisse pretorem hoc uidetur derisio: quis ei dubitabat quod fuit functus officio hoc?' (Bologna, CS 272, fol. $7 v b$; the statement is not present in the printed edition, but it is exactly the object of Bartolus' reference).

9 Bartolus, lectura ad Dig.1.14.3 (Bartoli a Saxoferrato in Primam Digesti Veteris Partem Commentaria, cit., p. 114, n. 4): 'Non ob(stat) tex(tus) dum dicit, eum functum praetura: quia secundum do(minum) $\operatorname{Iacob}(\mathrm{um})$ est quaedam decisio: quia bene sciebamus, quod ipse erat functus praetura, ut in tex(to). Dicere enim, quod non iure fuit usus praetura, esset stultitia: imo fuit creatus pretor: et Iurisconsultus respondet ad ius, non ad factum, et dicit quod fuit praetor.'

10 On the point, Bartolus refines Ravanis' approach (ascribing his position to Butrigarius, however): the lex Iulia does not apply in Rome because the magistrates are not elected by the people but rather appointed by the prince, who is incorruptible. This makes sense, reasons Bartolus, but it requires the presence of the prince in Rome. In his absence (in practice, most of the time), the lex Iulia would on the contrary still apply. As such, Bartolus concludes, it is necessary to distinguish between public and secret requests, just as the Gloss said following Bassianus. Ibid., p. 113, n. 1: ' Venio ad glo(sam) ... dicitur hic quod barbarius petijt pretoriam dignitatem et pretor fuit immo incidit in l. iuliam ambitus (Dig.48.14) vnde ob(stat) l. i et per totum i(nfra) ad l. iul(iam) amb(itus) (Dig.48.14) et C. ad 1. iul(iam) ambitus per totum (Cod.9.26). Glo(sa) soluit multis modis. Vna so(lutio) est quod licet non debuerit peti, tamen petita valeat et teneat, ar(gumentum) 1. i $\$$ i quando appel(landum) sit (Dig.49.4.1 pr). Hec so(lutio) videtur contra 1. si quenquem C. epis(copis) et cle(ricis) (Cod.1.3.30); 
Ultramontani. This seems to strengthen the impression that omitting such references from the overall discourse on the validity of the praetorship was deliberate. ${ }^{11}$ We will come back to the point.

vel dic dicit glo(sa) quod hic barbarius petit officium publice et palam non tacite vel simoniace, et ideo non incidit in 1 . iul(iam) ambi(tus) ar(gumentum) 1. i $\mathbb{i}$ de pollici(tationibus) (Dig.50.12.1.1). Hoc videtur bona l(ectura), glo(sa) eam non teneat. Vnde dicit quod officium fuit petitum in ciuitate romana, in qua 1. iulia ambitus non habet locum: vt 1 . i i(nfra) ad l. iul(iam) de ambi(tu) (Dig.48.14.1). Tu dic quod hic so(lutio) optime qu(ando) princeps esset in vrbe et officium peteretur ab eo, quia in eo nulla cadit suspicio: ita debet intelligi 1 . i(sta) secundum Ja(cobum) bu(trigarium); secus si peteretur a populo vt ibi, quia tunc obtineret secunda solutio huius glo(sae), que est Io(hanni Bassiani)' [i. e. the distinction between asking publicly vs. secretly: supra, $\$ 2.2$, note 36 ].

11 Having concluded, after the Gloss, that seeking an office publicly was no offence, it remained to be seen whether it was lawful to couple such a public request with money. Clearly that was out of the question for ecclesiastical offices. But for secular ones Bartolus approvingly recalled Bellapertica's position (possibly through Cynus, who reported it integrally). According to Bellapertica, if an office entailed jurisdictional powers then no money could be offered, lest the subjects be unlawfully squeezed to recover the expense. Cf. supra, last chapter, notes 92 and 126 (on Bellapertica and Cynus respectively). Both Bellapertica and Cynus, however, stated as much to insist on the applicability of the lex Iulia against Barbarius, whereas Bartolus sought to reach the opposite result. The point is also interesting because it would strengthen the impression of Bartolus' selective approach to the Ultramontani's critique. Bartolus did not mention them when discussing the validity of Barbarius' praetorship. But the very detailed reference to their distinction of secular offices (with or without jurisdictional powers) might suggest that the omission was intentional. Bartolus, lectura ad Dig.1.14.3 (Bartoli a Saxoferrato in Primam Digesti Veteris Partem Commentaria, cit., p. 113, n. 1): 'Op(ponitur) dicitur hic quod non incidit in l. iuliam ambitus si a principe petatur, immo a quolibet petere non l(icet) vt l. si quemquem C. de epis(copis) et cle(ricis) (Cod.1.3.30). So(lutio) ibi loquitur in dignitate spirituali, predicta in temporali. Op(pono) ad hoc de $\$$ cogitatio, vt iudi(ces) sine quoquo suffra(gio) coll(atio) ii [Coll.2.2pr=Nov.8pr $\$ 1$; cf. Gloss ad Coll.2.1pr, $\mathbb{\$}$ Cogitarent, Parisiis 1566, vol. 5, col. 83], et ideo dicas quod aut petitur publice et bona fide et sine pecunia et tunc est licitum vt hac l. Aut petitur dignitas et pecunia promittitur et tunc aut queris de dignitate spirituali aut de dignitate temporali. Primo casu non est licitum ut dicta l. si quemquem (Cod.1.3.30) et quomodo oportet epi(scopos) $\mathbb{\$}$ i, coll(atio) i (Coll.1.6.1[=Nov.6.1]). Secundo casu aut dignitas habet secum iurisdictionem annexam aut non. Primo casu non est licitum petere neque pecuniam promittere, vt $\mathrm{d}$ (ictum) $\$ \mathrm{i}$ (Coll.1.6.1 $[=$ Nov.6.1]), et $\$$ cogitatio (Coll.2.2pr[=Nov.8pr $\$ 1]$ ). Secundo casu dignitas peti potest et pro ea pecunia dari vt in de polli(citationibus) 1 . i $\$$ i (Dig.50.12.1.1). Et ideo inter hos casus videtur quod quando dignitas habet iurisdictionem in se annexam praesumitur quod propter pecuniam promissam grauaret subiectos suos, quod non est in alio casu vt colligitur in $\mathrm{d}$ (icto) $\mathbb{\$}$ i (Dig.50.12.1.1) secundum Pe(trum).' 
Discussing the validity of Barbarius' praetorship, Bartolus also looks at the central issue of the common mistake. Again, he bases his solution entirely on Butrigarius, providing a summary of his scheme on the common mistake (and avoiding any mention of that of Jacobus de Arena, which would not lead to the desired pro-Gloss conclusion). When the common mistake furthers public utility, therefore, the mistake should be kept. ${ }^{12}$ Further objections, which the Ultramontani discussed at length, are dismissed in a rather superficial manner. ${ }^{13}$

Having concluded in favour of the validity of Barbarius' praetorship, Bartolus turns to the issue of his freedom. Just as the Ultramontani found it useful to deny his freedom first and to use that conclusion to deny the praetorship later, so Bartolus finds it convenient to keep the order of the Gloss and use the conclusion on the validity of the praetorship to secure Barbarius' freedom as well. Moving from the validity of Barbarius' praetorship, Bartolus could easily dismiss the contrary examples in the sources invoked by the Ultramontani. Those examples ${ }^{14}$ were all about slaves who unlawfully exercised public office: not only did they

Ibid., pp. 113-114, n. 1-2: 'Op(pono), dicitur hic quod agitata coram eo valent, immo videtur quod non, et error communis non facit ius vt sub de legi(bus) 1 . quod non ratione (Dig.1.3.39). So(lutio) hoc contingit propter publicam vtilitatem vt colligitur hic. Op(ponitur), immo error facit ius etiam si non sit communis, vt $\mathrm{i}$ (nfra) ad maced(onianum) l. iii in prin(cipio) (Dig.14.6.3pr). Pro cuius sol(utio) dic secundum Ja(cobum) bu(trigarium) quod aut publica vtilitas suadet quod error communis habeatur pro veritate, et tunc facit ius vt hic. Aut publica vtilitas suadet quod communis error non habeatur pro veritate, et tunc non facit ius vt $\mathrm{d}$ (icta) 1. quid non ratione (Dig.1.3.39). Aut publica vtilitas non suadet pro vel contra, tunc autem errans vult damnum euitare pretextu erroris et tunc communis error facit ius et pro veritate habetur vt d. l. iii in prin(cipio) ad macedo(nianum) (Dig.14.6.3 pr), ad idem l. zenodo(rus) C. ad maced(onianum) (Cod.4.28.2). Aut illius qui errat interest potius quod error non habetur pro veritate, et tunc pro veritate non habetur, vt 1 . i $\$$ si quando actio de peculio est annalis (Dig.15.2.1.10) et l. fi. de here(dibus) insti(tuendis) (Dig.28.5.93(92))'. Cf. also Id., ad Dig.33.10.3, $\$$ Sed et de his (In II. Partem Infortiati Bartoli a Saxoferrato Commentaria ... Basileae, ex officina Episcopiana, 1588, p. 251).

13 Bartolus, lectura ad Dig.1.14.3 (Bartoli a Saxoferrato in Primam Digesti Veteris Partem Commentaria, cit., p. 114, n. 2): 'Opp(onitur) quod immo acta coram eo non valeant, vt 1 . qui alienam $\$$ quidquid $\mathrm{i}$ (nfra) de neg(otis) gest(is) (Dig.3.5.30(31).6). So(lutio) hic fuit legitime factum secundum gl(osam) et ideo facta coram eo valent, ibi non erat legitime factum quia ibi non erat tutrix. Opp(onitur) dicitur hic quod non retractantur l(icet) postea seruus appareat immo ex casu superuenienti debet retractari, cum ad eum casum prouenit a quo incipere non potuisset vt $\mathrm{i}(\mathrm{nfra}) \mathrm{de}<$ receptis qui $>$ arbi(trium) 1 . non distinguemus $₫$ sacerdotio (Dig.4.8.32.4). So(lutio) vt dixi sub de his que sunt sui vel alieni iuris 1. patre furioso (Dig.1.6.8pr).' Cf. Bartolus, ad Dig.1.6.8, \$Patre furioso (ibid., p. 84, n. 3): '.. Item quod legitime factum est non retractatur ex facto superuenienti.'

Esp. Cod.7.16.11; Cod.10.33(32).1-2; Cod.12.33(34).6. 
remain slaves, but they were also punished for their crime. Having already settled the issue of the praetorship in advance, however, Bartolus could easily dismiss those cases as irrelevant. Quite unlike those slaves, Barbarius exercised his office lawfully. ${ }^{15}$

Another advantage of anticipating the discussion about the validity of the praetorship and the role of common mistake becomes evident when it comes to disproving one of the main arguments in the Orléanese arsenal: the fact that Ulpian spoke of humanitas to argue for the validity of Barbarius' deeds. We have seen that the Ultramontani argued the implied invalidity de iure from the validity de aequitate. If the deeds are de iure void, they reasoned, that must depend on the fact that Barbarius was not free - and so, consequently, that neither was he praetor. Law, however, is not maths: changing the order of the addends does change the result. Once again, Bartolus' strategic ordering of the issues at stake plays a key role in their outcome. Of course Barbarius is free de aequitate, he argues. But that does not prove much, since his praetorship is also valid de aequitate. For the common mistake triggers public utility considerations, and on the basis of the same equitable considerations Barbarius becomes free. Ulpian's statement is now a good ally of the Gloss, not a danger to it. ${ }^{16}$ Partem Commentaria, cit., p. 114, n. 3): 'Ultramon(tani) vt Pe(trus) et Ja(cobus) de ra(vanis), Cy(nus) et Guil(elmus) de cu(gno) tenent contra gl(osam). Primo, per $1 . \quad \mathrm{i}$ et ii C. si servus ad decu(rionatum) aspi(raverit) li. xii (Cod.10.33(32).1-2). Preterea dicunt, quod est casus de hoc in 1. non mutant C. de libe(rali) cau(sa) (Cod.7.16.11). Item et si seruus militat non est liber, 1. super seruis C. qui mili(tare) non pos(sunt) (Cod.12.33(34).6) ... Quid dicendum? Dico quod glo(sa) bene dicit: et Iacob(us) But(rigarius) tenet eam hic. Non obs(tante) 1 . i et ii C. si ser(vus) aut liber ad decu(rionatum) aspi(raverit) (Cod.10.33(32).1-2) et est ratio: quia hic fuit liber propter auctoritatem pop(uli) Rom(ani) uel Principis, qui hoc ex causa potuit facere: ut dixi in contrario. Sed in 1 (ege) contraria seruus aspirauit ad dignitatem sine auctoritate alicuius superioris, et in 1 (ege) nostra hoc operatur publica utilitas, et superioris auctoritas. Et eodem modo responde ad 1 (egem) non mutant (Cod.7.16.11) et ad $\mathrm{l}($ egem) super seruis (Cod.12.33(34).6).'

16 Ibid., p. 114, n. 3: 'Praeterea [according to the Ultramontani] si fuisset iste liber, fuisse uerus praetor, et acta coram eo, de rigore iuris ualerent: et tamen text(us) hic dicit, quod de aequitate ualent. Et ex hoc ipso [Ultramontani] concludunt, quod non fuerit liber, et hoc est fortius contrarium ... Non obst(ante) quod ibi dicunt, quia si fuisset liber, de rigore iuris agitata ualuissent ... quia de aequitate dicitur liber et praetor fuisse, et eadem equitate, agitata coram eo ualent: ut in $\mathrm{gl}(\mathrm{osa})$ et text(o).' 


\subsection{Legal ecumenism}

So far, Bartolus' position would appear a slightly revised version of Butrigarius, meant to confute the Ultramontani's objections (which Butrigarius did not mention). Butrigarius however was adamant in insisting that the validity of Barbarius' deeds should follow on from the validity of his appointment. So he did not refer the common mistake to what Barbarius did, but to his ability to serve as praetor. Much unlike Butrigarius, however, Bartolus meant to extend the application of the lex Barbarius to those cases where public utility had to be invoked directly - and exclusively - with regard to the deeds, not also to their source. Here, Butrigarius was of little help. The only time Butrigarius mentioned the notary condemned for forgery, for instance, he simply said that the instruments made before the conviction were valid, and those made thereafter were void: precisely what Accursius had already said a century before him. ${ }^{\mathbf{1 7}}$

To extend the lex Barbarius beyond its 'natural' borders (that is, those of the Gloss), it was necessary to build on what the Orléanese had said. Moving to the issue of the validity of Barbarius' deeds, Bartolus recalls a second time the general position of the Ultramontani. This time, however, the summary is more accurate. But it does not threaten the interpretation of the lex Barbarius in the Gloss. For the subject is now the validity of the deeds, and 'on this everybody agrees', says Bartolus. ${ }^{18}$ Among the Ultramontani, Bartolus recalls, Ravanis and Cugno maintained that Barbarius' deeds were valid both because of public utility and because of the superior authority of the people or prince. Bellapertica, followed by Cynus and Dynus, argued that public utility alone would suffice. ${ }^{19}$ Bartolus had earlier provided a summary of the Ultramontani's position in his lectura on Barbarius. That summary, as we know, was entirely based on Ravanis, and was used to criticise the Ultramontani to the benefit of the Gloss. Bringing up the internal division of the French at this point of the lectura would make sense only if Bartolus sought to take sides against the first group (Ravanis and Cugno), and in favour of the second one (Bellapertica and his sympathisers). Which is exactly what he did. Although for different reasons, neither Ravanis nor Cugno would allow an indiscriminate extension of the lex Barbarius. And that was precisely what Bartolus had in mind.

17 Cf. Butrigarius, ad Cod.2.4.42, $\$$ Si ex falsis (Iacobus Butrigarii ... super Codice, cit., fol. $60 v a)$.

18 Bartolus, lectura ad Dig.1.14.3 (Bartoli a Saxoferrato in Primam Digesti Veteris Partem Commentaria, cit., p. 114, n. 4): 'Quero nunquid acta coram eo valeant ista quaestio non est dubia, quia acta ualent: ut hic uidetur per tex(tum). Et in hoc omnes concordant.'

19 Supra, this chapter, note 4. 
Having reported the two different positions of the Ultramontani (without apparently taking sides), Bartolus proceeds to explore some different cases where the lex Barbarius might be invoked. The first of them is that of the false notary. Are the instruments made by someone who is commonly but mistakenly believed to be notary valid ${ }^{20}$ Bartolus recalls how Ravanis and Cugno opposed this solution, whereas Bellapertica embraced it. Bartolus dismisses the objection of the first two French jurists in a rather perfunctory way, ${ }^{21}$ and approves of

20 Bartolus, lectura ad Dig.1.14.3 (Bartoli a Saxoferrato in Primam Digesti Veteris Partem Commentaria, cit., pp. 114-115, n. 6): 'Et sumit argumentum ad q(uestionem). Pone aliquis gessit se diu pro tabellione, et multa instrumenta et acta confecit; postea apparet ipsum non fuisse tabellionem, quia non habebat priuilegium: an facta per eum valeant?'

21 According to Bartolus' reconstruction, Cugno argued against the validity of the deeds of the false notary on the basis of a provision on the actuarii (i.e. quartermasters). The text in Cod.12.49(50).7.1 required imperial approbation for their appointment. Since the same title of the Code dealt both with actuarii and tabularii, Cugno - again, according to Bartolus - insisted that only the emperor could create a tabularius (a notary) and so denied the validity of the instruments of the false notary, despite the public utility requirement. Elsewhere, Bartolus shows good knowledge of Cugno's actual position (see infra, this chapter, note 26), but when commenting on the lex Barbarius he prefers to overlook some details. Cugno sought to highlight the difference between mistakes as to the appointment procedure and mistakes as to the legal status of the appointed. Reporting that reasoning, however, would have highlighted the difference between the deeds of the false praetor and the instruments of the false notary - exactly what Bartolus would rather avoid. As such, he seeks to shift the focus of Cugno's objection to a wholly different subject. The case of the actuarii, says Bartolus, is a very specific one, for it is about tax collectors who have to be appointed by the prince. Further, he says (through a cross-reference to his comment on a different lex), it is not true that only the emperor may appoint a notary. A judge may well depose a notary: since deposing is the other face of appointing ('eius est creatio, cuius est remotio'), normally those who have the power of deposing someone can also appoint him. Bartolus, lectura ad Dig.1.14.3, ibid., p. 115, n. 6: 'Dic s(ecundum) $\operatorname{Iacob}(\mathrm{um})$ de Rauan(is) et Guilelmum de Cugn(o) hic, qui dicunt quod hic fuit duplex ratio, quare instrumenta facta et acta per eum non ualent: quia licet fuerit una ratio, $s$ (cilicet) publica utilitas, tamen alia cessat, ut auctoritas eius qui potuit hunc creare tabellionem. Pro hoc allegat Gul(ielmus) l. actuarios C. de numera(riis) li(ber) 12 (Cod.12.49(50).7pr) ... Non ob(stante) 1. actuarios, quia loquitur in certis exactorib(us) pecuniae publicae, qui sine licentia Principis hoc non possent. Et ita eam intellexit Guli(elmus de Cugno) s(upra) de adop(tionibus) 1. non aliter (Dig.1.7.18). Et ibi dixi, et in 1. nec ei $\$$ eorum (Dig.1.7.17.1).' Cf. Bartolus, ad Dig.1.7.17.1 (ibid., pp. 88-89, n. 6): 'quaero, quis possit istos tabelliones creare? Et uidetur, quod solus Princeps: ut l. actuarios C. de nume(rariis) et actuar(iis) lib. 12 (Cod.12.49(50).7pr). In contrarium facit, quod imo etiam magistratus: ut in Aut. de defen(soribus) ciui(tatum) $\mathbb{S}$ ex prouinciali (Coll.3.2.4[=Nov.15.3.1]), et eius est creatio, cuius est remotio. Sed magistratus potest remouere [scil., 
Bellapertica's opinion in a similarly questionable manner. ${ }^{22}$ The interest was clearly not much in their reasoning, but simply in the fact that some of them -

tabelliones] propter eorum delictum: ut in Auth. de armis, in fi(ne) [Coll.6.13 in fine $=$ Nov.85.5; cf. Gloss, ad Coll.6.13, $\$$ Solicitudine, Parisiis 1566, vol. 5, col. 345] et in Auth(entica) de tabellio(nibus), $\mathbb{S}$ pe(nultimo) (Coll.4.7.1[=Nov.44.1\$4]). Ergo et creare, et habes C. de magi(stratibus) con(veniendis) 1. fi. (Cod.5.75.6), et est expressum C. de suscep(toribus) et arca(riii) 1. duos, lib. 11 (sed Cod.10.72(70).13) et hoc tenet Guil(elmus). Non ob(stante) 1. actuarios (Cod.12.49(50).7pr), quia ibi est speciale in his, qui exigebant publicam pecuniam: et ciuitas hoc non potest allegare.' As a matter of fact, Bartolus was trying to use Cugno's own argument against him. The whole argument, based as it was on the parallel between bestowing an office and removing it, was elaborated by Cugno, not Bartolus. Cugno sought to legitimise the appointment of notaries by cities and lords, something routinely done in practice but not fully in line with the ius commune (in principle, only the emperor could appoint a notary). Cugno's parallel with the power of the judge to depose the notary was meant to reject the claim that the notary's appointment was the exclusive prerogative of the emperor. Cugno, ad Dig.1.7.18, $\$$ Non aliter (Lucca 373, fol. 9ra, transcription in Valentini [1965-1966], pp. 88-89, note 12): ‘... Ego dico quod [tabelliones] possunt creari per alios quam principe, quod aprobo; si solus princeps crearet tabelliones, ipse solus privaret eos ab officio, non alius, in auth(entica) de defensoribus civitatum, $\mathbb{\$}$ interim, in fine (Coll.3.2.1[=Nov.15.1.1]). Sed ego habeo casum quod judices puniunt tabellionem, ut infra (sed C.) $<$ de $>$ decurionibus, $<$ l. $>$ quilibet (Cod.10.32.40).' Cugno's argument, it might be noted, was perfectly compatible with his stance on the lex Barbarius: appointment by a superior authority is always necessary.

On the specific problem of who may appoint the notary, however, Bartolus is more precise elsewhere. There, however, he refers mainly to Innocent IV (and Durantis, who in turn relied on the pope), who never said that a judge could appoint a notary. At the most (though somewhat reluctantly), Innocent IV allowed that some lords other than the emperor might appoint notaries with the implicit approbation of the emperor. Bartolus, ad Coll.4.7.2(=Nov.44.2), $\mathbb{1}$ Illvd (Svper Avthenticis et Institvtionibvs, Bartoli a Saxoferrato Commentaria ... Basileae, ex officina Episcopiana, 1588, p. 60, n. 4): 'Quaero, quis possit tabellionem creare? Et de eius officio, et de ipsius instrumentis: dic per Inno(centium) in c. i et 2, ext(ra) de fi(de) instr(umentorum) (X.2.22.1-2), et uide quod ipse no(tat) in c. pen(ultimo) et fi. [cf. infra, pt. II, $\$ 7.5$, note 74 and $\$ 8.4$, note 59 respectively], et uide $S$ pe(culum) post eum, de instru(mentorum) caus(a) (sic), $\$$ restat, uer(siculum) "sed si quis potest". Cf. Speculum, lib. 2, partic. 2, De Instrumentorum editione, $8 \$$ Restat, infra, pt. II, $\$ 8.4$, notes 58 and 61 respectively.

22 Bartolus, lectura ad Dig.1.14.3 (Bartoli a Saxoferrato in Primam Digesti Veteris Partem Commentaria, cit., p. 115, n. 6): 'Tu dic, quod instrumenta ualeant, tenendo opin(ionem) Pe(tri), quam in simili tenet Dyn(us) [sed Cynus: see e. g. Milan 1490 edition of Bartolus' lectura, fol. 30v] in c. i (Cod.12.49(50).7.1). Pro hoc uidetur tex(tus) in auten(tica) de tabel(lionibus) $\mathbb{S}$ pe(nultimum) in fi., ibi documentis propter utilitatem contrahentium non infirmandis: ut in Auth(entica) de tabel(lionibus) collat. 4 (Coll.4.7.1[=Nov.44.1\$4]).' We have seen 
Bellapertica and Cynus - allowed for the desired extension of Barbarius' case. Following their reasoning, Bartolus closes his lectura on the lex Barbarius applying the same rationale as the false notary also to the excommunicated judge and to the false prelate.

If a judge renders many decisions but he is later found to be excommunicated, public utility cannot be invoked to lift the excommunication, but it may well make the decisions valid. The problem is even more acute in the case of a prelate exercising an office for a long time, only to be finally exposed as a false prelate. What happens to the deeds he has already made? Again, moving from the traditional interpretation of the lex Barbarius in the Gloss (or even from that of Ravanis), the solution should be against the validity of those deeds. The people who went along with the common mistake clearly lacked the power to make him truly a prelate. Following Bellapertica's reasoning, however, public utility could be referred directly to the deeds without passing through their source. ${ }^{23}$

Seeking to remove any limit to the applicability of the lex Barbarius, Bellapertica rejected the position of the Gloss on Barbarius' status: the source remains invalid, and public utility intervenes directly on the status of the deeds. Bartolus intends to reach the same result without jettisoning the Gloss. So long as it is viable, Bartolus sees public utility as validating both source (Barbarius' status) and deeds (his judgments). When that cannot be achieved, then the same public utility applies directly to the deeds, skipping their source. In spite of all his

earlier that the Authentica required the notary to draft the instruments himself and prohibited his clerks to do so, but for the sake of public utility it did not void the instruments drafted by the clerk (supra, $\$ 2.6$, note 131). Clearly the Authentica referred to the clerk of a true notary, not of an impostor. The Gloss, however, disapproving of the permissive attitude of the Authentica (only the notary may draft the instrument), used the public utility argument to make sure of something rather obvious - that the instruments drafted by the (true) notary before his dismissal from office also remained valid thereafter (supra, $\$ 2.6$, text and note 132). When writing in favour of the validity of the false notary's deeds, Bellapertica was therefore not referring to the same case as the Gloss.

23 Ibid., p. 115, n. 7: 'Item predicta sunt in argu(mento) ad q(uestionem) quod si coram iudice sunt multa agitata, licet postea apparet excommunicatus, acta ualeant. Et idem in praelato, qui multa administrat, ut ualeant quae facit: licet appareat postea, ipsum non fuisse idoneum. Vide quae dixi in 1. 2 C. de senten(tiis) (Cod.7.45.2) et no(ta) in c. sciscitatus de rescri(ptis) (X.1.3.13).' The reference to the praelatus non idoneus would point to a true prelate who could not be appointed to an office because of some personal incapacity. That was not the rationale of Bellapertica's and Cynus' example, however: they referred to the most blatant case of false prelate they could think of - a false bishop. As we will see, Bartolus was probably only trying to improve their example, not to replace it with an entirely different one. Also in Bartolus, in other words, the inidoneitas of the prelate should be ascribed not to his office but to his very consecration, making him a false prelate. 
efforts, however, there was no easy way to square the circle. The two interpretations - that of the Gloss and of Bellapertica - remained incompatible with each other. What Bartolus did was to draw a line between the lex Barbarius and its further applications: each segment was coherent so long as not considered together with the other. One could look at what lay beyond the line, or at what came before it. But not at both together.

If the circle could not be squared, however, its contours could be blurred. Seeking to reconcile the Gloss with its most fierce opponent, Bartolus' 'ecumenical' approach made Bellapertica's extensions of the lex Barbarius (especially on false notary and false prelate) remarkably ambiguous.

\subsection{Ambiguous notaries}

If Bartolus approves of Bellapertica's extensions to the scope of the lex Barbarius, it is possible that he might have followed a slightly different route to reach the same conclusion.

Elsewhere, commenting on a wholly different subject found in the Authenticae (Coll.2.1=Nov.7, Justinian's Novel prohibiting the alienation of ecclesiastical estates), Bartolus wonders whether the instruments of a false notary who exercised his office for a long time - and so drafted many deeds - could be considered valid on the basis of common mistake and public utility. Bartolus here tells his reader not to look at the position of Jacobus de Belviso, but rather to focus on Durandis' Speculum and - interestingly - also on Cugno's reading of the lex Barbarius. Belviso - at least according to Bartolus - argued for the validity of the false notary's instruments. ${ }^{24}$ Durandis, as we will see more in detail later, said the opposite: only a true notary may draft valid instruments. His argument was similar to that of Cugno: a false notary is an impostor who lacks the allimportant formal requirement of having been appointed. Cugno, as we already know, applied the same reasoning to distinguish false notary from slave-praetor. Unlike the self-styled notary, Barbarius was appointed to his office, and the appointment was formally correct. ${ }^{25}$

24 In fact, Belviso referred to Innocent IV to argue for the right of the king (and not just of the emperor) to appoint notaries. Jacobus de Belviso, ad Auth. de tabellionibus, Coll.4.7(=Nov.44) (Commentarii in Avthenticum, cit., fol. 36ra): 'Queritur octauo quis possit facere tabellionem et de eius officio et de ipsius instrumentis: et dic vt notatur per innocen(tium) extra de fi(de) instru(mentorum) c. i et ii et c. penul(timo) et c. fi. (X.2.22.1-2, 15-16) [cf. infra, pt. II, $\$ 7.5$, note 74 , and $\$ 8.4$, note 59 ], et est argumentum quod superior possit suum subditum tabellionem creare vt hoc titulo $\$$ vt tamen (Coll.4.7.1[=Nov.44.1\$4]).'

25 Bartolus ad Coll.2.1.1 (=Nov.7.1), \$Alienationis (Svper Avthenticis et Institvtionibvs, Bartoli a Saxoferrato Commentaria, cit., p. 28, n. 3): 'secundum Iacob(um) de 
This specific reference to Cugno is of course different from the short references that Bartolus provided in his lectura on the lex Barbarius. There, Cugno is always associated with Ravanis and with the latter's requirement of the sovereign will. It is of course possible that Bartolus commented on a specific text of the Authenticae at a very different time from his lectura on the lex Barbarius. But it may not be ruled out that he knew of Cugno's position on the lex Barbarius when writing about it, and simply preferred not to use it for contingent reasons - it did not help his overall point. ${ }^{26}$ Either way, Bartolus' conclusion on the instruments of the false notary would seem completely different depending on where one looks. He approves of the instruments' validity when commenting on the lex Barbarius, and he denies as much when looking (slightly) more deeply at the same matter elsewhere.

A third and final text - by far the longest on the subject that may be found in Bartolus' opus - might offer an explanation, but it also complicates the matter further.

The title of the Digest on the lex Iulia repetundarum (a law dealing with extortion by magistrates and other civil servants) prohibited those found guilty of the crimen repetundae from testifying, judging or prosecuting a crime. ${ }^{27}$

Belu(iso) ... si tabellio fuerit longo tempore in quasi possessione tabellionatus, et publicum officium exercuit, et multa instrumenta confecit, quod talia instrumenta ab eo confecta debeant ualere: remittit ipse ad id quod no(tatur) in cap. i. de fid(e) instru(mentorum) (Coll.6.3.1[=Nov.73.1]) et ad id quod habetur in 1. Barbarius ff. de offic(io) praeto(rum) (Dig.1.14.3); sed tu dic de hac quaestione, ut not(at) Spec(ulum) de instru(mentorum) edi(tione) $\mathbb{S}$ restat, uersic(ulum) "quod si is qui non est notus ei" [Speculum, lib. 2, partic. 2, De Instrumentorum editione, 8. \$Restat, cit., vol. 1, pp. 661-662, n. 32]. Uide Guliel(mus de Cugno) in d. 1. Barbarius (Dig.1.14.3).'

26 This impression is strengthened by Bartolus' reading of Cod.12.50.7 - the same lex he invoked when writing about the lex Barbarius to dismiss Cugno's arguments (supra, this chapter, note 21). When writing on Cod.12.50.7 Bartolus reached the same conclusion as Cugno and he also quoted him openly. Bartolus, ad Cod.12.50.7, $\$$ Actuarios (In II. et III. partem Codicis Bartoli a Saxoferrato Commentaria ..., Basileae, Ex officina Episcopiana, 1588, p. 143): 'Ex fi(ne) l(egis) not(atur) quod licet aliquis habeatur et reputetur per publico officiali, et reuera non sit, ex eo quod non fuerit legitime ordinatus, uel quia reputatur tabellio cum non sit, uel iudex cum non sit: quod acta facta per eum, nullius sint momenti, et ipse faciens punitur. Nec obstat $1(\mathrm{ex})$ Barbarius ff. de off(icio) praesi(dis) (sic) (Dig.1.14.3) quia quandoquem quis est electus solenniter, tamen propter defectum personae non potest esse: et tunc facta per eum, ualent, cum sint publica: ut ibi. Quandoque quis potest esse, sed non electus secundum formam debitam, et tunc facta per eum non ualent: ut hic, et ita tenet Guli(elmus) de Cug(no) in d. l. Barbarius.'

27 Dig.48.11.6.1 (Venuleius Saturninus, 3 publ. iudic.): 'Hac lege damnatus testimonium publice dicere aut iudex esse postulareve prohibetur.' 
Commenting on this prohibition, Bartolus looks at the old problem already debated by Azo and Accursius: are the instruments of a notary condemned for forgery valid? Bartolus was not speaking of forgery but, more generally, of a condemnation 'for any reason that made him infamis'. ${ }^{\mathbf{2 8}}$ The general reference was appropriate: the subject matter was the prohibition from acting as a witness, not forgery. Yet the main reason for excluding a testimonial deposition lay in the infamia of the witness, and the foremost ground for the notary's infamia was forgery. Even before Bartolus' time, there was little doubt that the notary was not only a respectable person but also someone with the power to confer fides publica to a deed. ${ }^{29}$ The problem therefore was whether the prohibition from acting as a witness in court should also entail prohibition from drafting a notarial instrument. The solution to this case would prima facie seem pretty obvious: how could the word of an infamis have more value on paper than in court? Moreover, if the notary exercises a public office, and the infamis is excluded from any public office, then clearly the infamis cannot exercise the office of notary. ${ }^{\mathbf{3 0}}$

Bartolus' conclusion, however, is different. The role of the notary, he says, is not always a public office (a dignitas). ${ }^{31}$ Sometimes it may just be a simple task (munus). True, he concedes, there are sources referring to notaries appointed by the prince. Those sources would clearly point to a public office (and so, to a dignitas), and clearly the infamis cannot exercise the office of a notary public ('notarius ad banchum'). ${ }^{32}$ But this does not mean that anyone simply writing

Infra, this paragraph, note 30 . See also note 33 .

29 Cf. e.g. Bambi (2006), pp. 34-35: what the author says - on the thirteenth century - may a fortiori be applied to the fourteenth.

30 Bartolus, ad Dig.48.11.6.1, $\$$ Hac lege (In II. Partem Digesti novi Bartoli a Saxoferrato Commentaria ... Basileae, Ex officina Episcopiana, 1588, pp. 513-514, n. 2-3): 'Quaero simpliciter, vtrum notarius damnatus ex aliqua causa, quae eum facit infamem, possit conficere instrumenta publica? Videtur quod non. Nam notarius uidetur quodammodo testis: 1 . Domitius s(upra), de testa(mentis) (Dig.28.1.27). Sed infamis non potest testificari ... ergo etc. Pro hoc 1. secunda $\mathbb{S}$ miles $s$ (upra) de his qui not(antur) infam(ia) (Dig.3.2.2.3) et ibi gloss(a) quae dicit ibi, quod infamis repellitur ab omni dignitate, et ab omni officio publico [cf. Gloss ad Dig.3.2.2.3, $\$$ Sacramento, Parisiis 1566, vol. 1, col. 341]. Sed notariatus est officium publicum ... Praeterea, dicitur in 1. i C de man(datis) Princ(ipum) (Cod.1.15.1) quod tabellioniatus est dignitas. Sed infamis repellitur ab omni dignitate: ut 1 . ii C. de $\operatorname{dig}$ (nitatibus) lib. 12 (Cod.12.1.2) ergo, etc.'

31 On the concept of dignitas as public office see infra, $\$ 11.1$.

32 Bartolus, ad Dig.48.11.6.1, $\$$ Hac lege (In II. Partem Digesti novi Bartoli a Saxoferrato Commentaria, cit., p. 514, n. 3-4): 'In contrarium facit, quod alibi dicitur, quod officium tabellioniatus non est dignitas, sed est munus: 1. fin. in princ(ipio) C. qui milit(are) non poss(unt) lib. 12 (Cod.12.33(34).7pr) et ibi gl(osa) [cf. Gloss ad Cod.12.33(34).7pr, $\$$ Si quis-Dominio servi, Parisiis 1566, 
down what the parties have agreed to is discharging such an office. Two individuals, says Bartolus, may simply ask someone to carry out the task (munus) of writing down something for them. Whom they choose for the job is their exclusive concern. For the same reason, he continues, an infamis may well be an arbiter. Two individuals may decide to ask an infamis to render a verdict between them - once again, their choice is their private concern. After all, Bartolus opines, a witness is called by one party against the other. By contrast, a notary (not in the sense of public notary) simply drafts a private contract at the request of both parties. Furthermore, he adds, if neither party recused the judge for his infamia, then the decision would hold: why should the position of the notary's instrument be any different? After this string of counter-arguments, Bartolus finally touches a point of particular importance for us. The above considerations, he concludes, apply all the more when a notary, despite being infamis, is still discharging his office and enjoys a good reputation. In such a case, Bartolus concludes, because of their large number, the instruments are valid - just as in the lex Barbarius. ${ }^{33}$

vol. 5, col. 276], sed infamis non repellitur a muneribus: 1. nec infames. C. de decuri(onibus) lib. 10 (Cod.10.32.12) ... Praeterea uideo, quod infamis potest esse procurator et arbiter: ut Institu. de excep(tionibus) $\$$ fin. (Inst.4.13.11(10)) et 1. Paedius s(upra) de <receptis qui> arbit(rium) (Dig.4.8.7) ... Quid dicemus? ... finaliter dico sic: Ante omnia scias, quod tabellionatus officium non est dignitas, sed munus: 1. fina. in princip(io) cum sua gloss(a) C. qui milit(are) non possunt [Cod.12.33(34).7pr; Gloss cited above in this note] et $\mathrm{d}$ (icta) l. i C. de man(datis) Princ(ipum) (Cod.1.15.1) loquitur de notario Principis assumpto ad scribendum negotia Principis: tunc ille notarius qui eligitur per Principem, habet dignitatem; non tamen officium notariatus in se est dignitas, simpliciter sumendo notarium. Dico ergo, quod infamis non potest exercere officium tabellionatus, quod habeat in se dignitatem: 1. 2 Codic. de digni(tatibus) (Cod.12.1.2) uel quod haberet officium aliquod iniunctum ex publico, ut quod esset notarius ad banchum, uel similia: ut not(atur) in $\mathrm{d}$ (icta) $1.2 \$$ miles $s$ (upra) de his qui not(antur) infam(ia) (Dig.3.2.2.3).'

33 Ibid., p. 514, n. 4: 'Sed si ipse a partib(us) uolentibus assumatur, ut faciat publicum instrumentum, non uideo quid repugnet, quin dicatur publicum munus infamibus non remittitur sed eis magis competit: et sicut potest assumi arbiter a partibus uolentibus, ita potest assumi notarius a partibus uolentibus. Item sicut infamis assumptus iudex a partibus uolentibus et non opponentibus, ualet eius iudicium: ut dixi in l. quidam consulebant s(upra) de re iudic(ata) [i. e. the parties did not recuse the judge before the joining of the issue: cf. Bartolus, ad Dig.42.1.57, In I. Partem Digesti novi Bartoli a Saxoferrato Commentaria ..., Basileae, ex officina Episcopiana, 1588, p. 377, n. 7] ... hoc autem maxime puto esse uerum, quando non obstante infamia ipse est in possessione notariatus, et bonae famae: tunc propter multitudinem gestorum per eum debet ualere: 1 . Barbarius s(upra) de offic(io) praetor(um) (Dig.1.14.3) et Cod. de sentent(iis) 1.2 (Cod.7.45.2). Nec obst(at) quod infamis non potest esse testis: quia in testimonium quis uocatur ab una parte, alia inuita: sed nos loquimur in contractu, qui celebratur utraque parte mandante.' 
This last reference seems somewhat ambiguous - in the lex Barbarius the slave surely discharged a public office (a dignitas), not a private task (a munus). If we assumed that Bartolus did not change his mind between his comment on the false notary in the Authenticae and on the infamis notary in the Digest, he would seem to be intentionally playing with the ambiguity between the two kinds of notaries, downplaying the emphasis on the public nature of the office of notary and highlighting the private law profiles of the task of the scrivener.

This ambiguity might also help to make sense of Bartolus' sudden interest in Bellapertica in his lectura on the lex Barbarius. So long as he is discussing Barbarius' praetorship and freedom, Bartolus rejects the Ultramontani's position. Once arrived at the validity of Barbarius' deeds, however, he invokes Bellapertica to extend the same lex to other cases, first of all that of the notary. In the light of these considerations, Bartolus' choice of the notary as the first extension of the lex Barbarius does not seem fortuitous. As already stated, Bartolus was most probably following Cynus' exposition of Bellapertica, and thus provided a summary of the application of the lex Barbarius according to Cynus' elaboration. In his turn, Cynus was following very closely the order of Bellapertica. Possibly because the issue was not mentioned in Ravanis, however, Bellapertica did not mention the false notary. Cynus realised the omission, and filled the gap at the very end of his lectura: what was said about the other cases should also apply to the 'usual question' of the false notary. ${ }^{34}$ Somewhat surprisingly, Bartolus however decides to invert the order of Cynus' exposition on the point - and only on it. So the cases of the excommunicated judge and of the false prelate now come after that of the notary, not before him. Moreover, while Cynus openly treated the notary's case as a further application of the rationale laid out in the other two instances, Bartolus does precisely the opposite: the solution to the notary's case should also apply to the excommunicated judge and the false prelate.

The double dimension of the notary (public office and private task) makes the passage from the Gloss to Bellapertica somewhat smoother - or at least less dramatic. If considered from the perspective of the munus (and not of the official dignitas), there is nothing wrong in holding the (private) deeds of the notary/ scrivener as valid despite his legal incapacity to discharge the (public) office of tabellio. Once the point was established, however, it was easy to implicitly extend it to the other kind of notary - the public official. This way it was possible to patet, quomodo debet responderi ad quaestionem consuetam, de eo qui se pro tabellione gessit, et non erat, et instrumenta confecit, quae propter authorem, in dubium reuocantur.' 
reach the desired outcome circumventing the main obstacle - the need of formal appointment.

An obvious critique of this conclusion on Bartolus' janus-faced notion of notary lies in the weakness of evidence in its support. The point of course stands, and the conclusion itself is offered only as a mere possibility. And yet, what incensed Baldus the most in Bartolus' reading of the lex Barbarius, as we shall see later, was precisely his ambiguous, two-sided interpretation of the notary.

\subsection{Bartolus ultramontanus?}

If the validity of the deeds should always depend on that of their source, then Barbarius' case might, perhaps, reach the notary (understood as private scrivener), but surely neither the excommunicated judge nor the false prelate. In stating the opposite, Bartolus does not reject the Gloss, but seeks to reconcile it with Bellapertica's conclusions, showing (or trying to show) how both approaches would ultimately follow the same rationale. The Gloss says that, for equitable considerations, Barbarius becomes free and so also truly praetor. Consequently, his deeds are also valid. Conveniently skipping Bellapertica's reasoning on both the invalidity of Barbarius' praetorship and his enduring status as slave, Bartolus highlights the Frenchman's position on the deeds of Barbarius: on equitable grounds they are valid. Both in the Gloss and in Bellapertica, therefore, fairness is invoked not to prejudice the commonwealth, because of the large number of acts carried out by Barbarius. The exact way in which fairness operates is prudently omitted.

The same ambiguous 'ecumenism' can be seen in Bartolus' reading of the slave-arbiter (Cod.7.45.2). As we know, the difficulty of that text lay in that the slave mistakenly thought to be free pronounced a single decision that would exclude public utility considerations, and yet that decision was valid. The Gloss solved the problem relying on putative freedom. ${ }^{35}$ But that was a dangerous example to follow: insisting on the effects of the slave's putative freedom would implicitly undermine the de iure validity of his appointment. ${ }^{36}$ If the arbiter was truly a slave, the only alternative to the Gloss was Odofredus' position: common mistake, even without public utility, is sufficient to bestow validity on the (single) deed. ${ }^{37}$ If Bartolus was reluctant to follow the solution of the Gloss, he clearly could not follow Odofredus either. The only alternative left was opting for a different interpretation of the lex itself, the same interpretation chosen by

36 That, as we have seen, was the main reason for the friction between the two parts of the Gloss on the lex Barbarius: supra, $\$ 2.3-4$.

37

Supra, $\$ 3.1$, text and note 29. 
Bellapertica: the arbiter is not a slave but a freedman, brought back to servitude only after having rendered the decision. ${ }^{38}$ While Bellapertica sought to dismiss a threat to his approach to Barbarius, however, Bartolus sees an opportunity to strengthen the position of the Gloss. Unlike the lex Barbarius, he observes, the text of the lex Si arbiter does not say that the slave eventually became free. This, Bartolus concludes, depends on the fact that one slave rendered a single decision, the other slave many. ${ }^{39}$ Thus, twisting Bellapertica's underlying argument, Bartolus reaffirms the Gloss' solution: for reasons of public utility Barbarius becomes free and praetor, so that his deeds may be valid.

Bartolus' comment on the slave-arbiter is also interesting because it follows the same structure as in his reading of the lex Barbarius. Having insisted on the equitable considerations that make Barbarius free (and so praetor), he extends the same considerations to one of the last cases briefly mentioned in his lectura on Barbarius: the excommunicated judge. So long as the judge is widely believed not to be excommunicated, he says, his decisions would be valid. ${ }^{40}$ The same, he concludes, applies to the infamis judge ${ }^{\mathbf{4 1}}$ and to any other who, because of some legally relevant impediment, may not serve as such. So long as the impediment (be it excommunication, infamia or other) is not publicly known, public utility considerations prevail and the acts carried out by the false judge may be held as valid. $^{42}$

Supra, $\$ 4.6$, text and note 110 .

39 Bartolus, ad Cod.7.45.2, $\mathbb{S}$ Si arbiter (In II. et III. partem Codicis Bartoli a Saxoferrato Commentaria, cit., p. 190): 'Ista lex habet duas lecturas. Secundum primam, communis error excusat. Secundum secundam, casus superuenientes in personam iudicis, sententiam non extinguit. Oppono et uidetur quia ex hac electione effectus sit liber: ut l. Barbarius ff. de off(icio) praeto(rum) (Dig.1.14.3). Sol(utio) ibi propter publicam utilitatem, quia multa gessit, et multa fecit: hic solum unam sententiam dedit.'

40 Ibid.: 'Iuxta hanc legem quaero, quid in iudice excommunicato, an eius sententia ualeat? Respondo, debemus distinguere ut ex hac 1 (ege) colligitur: aut publice reputabatur non excommunicatus, aut erat excommunicatus publice. Primo casu ualet sententia. Secundo casu non, ut extra de re iud(icata) c. ad probandum (X.2.27.24).'

41 Ibid.: 'Et idem possumus quaerere in iudice infami, an eius sententia ualeat? Et distingue, aut erat publice infamis aut habebatur ab omnibus hominibus bonae famae. Primo casu non ualet, secundo sic, per hanc legem. Et quod no(tatur) per $\mathrm{gl}$ (ossam) ff. de test(amentis) <l.> cum lege in fi. (Dig.28.1.26), extra de rescr(iptis) c. sciscitatus (X.1.3.13).' Cf. Gloss ad Dig.28.1.26, $\$$ Putant, in fine (Parisiis 1566, vol. 1, col. 378): 'Item videtur hic quod infamis non potest esse testis in testamento, sed falsum est: quia et seruus, nisi constet apud omnes. Accursius.'

42 Bartolus, ad Cod.7.45.2, \$Si arbiter (In II. et III. partem Codicis Bartoli a Saxoferrato Commentaria, cit., p. 190): 'Idem in alijs defectibus, ex quibus 
At least for the case of the excommunicated judge, it would seem that Bartolus invoked public utility considerations directly to the deeds, bypassing their source. Even there, however, Bartolus sought to explain the point highlighting the procedural dimension (and so downplaying the substantive element). Not recusing the infamis judge prior to the joining of the issue entails acceptance of his jurisdiction. We have seen that Bartolus hinted at the point in his discussion of the validity of the instruments drafted by the infamis tabellio. ${ }^{43}$ In his reading of the lex Si arbiter he was more open on the matter. ${ }^{44}$

detegitur aliquem non esse iudicem, sufficit quem esse in quasi possessione iurisdictionis, et illum defectum non esse publice notum: ut hac l(ex) cum l(ege) super alleg(ata) (Dig.28.1.26).' The meaning of the term 'quasi possessio', especially in Bartolus' approach to our subject, is not always immediate: at times, it is not easy to say with accuracy whether the 'quasi' is used in a 'technical' sense or it betrays a negative undertone. So, for instance, Belviso's false notary (at least, as reported by Bartolus), being in quasi possessio of the office, would point to the fact that he is not de iure entitled to that office (cf. supra, last paragraph, text and notes 25-26). At other times, however, Bartolus speaks of quasi possessio for different and more technical reasons. This is especially the case when he refers to the possession of jurisdictional prerogatives. Quasi possessio was often used in relation to incorporeal things since, strictly speaking, they could not be possessed. Iurisdictio was among them. As Bartolus has it, 'iurisdictio est quoddam ius incorporale. in iure enim consistentia incorporalia sunt: ut ff. de rer(um) diui(sione) 1. i $\$$ i (Dig.1.8.1.1) ergo vendicari non potest, cum ea vendicantur, quae possidentur' (Id., Tractatus de iurisdictione, in Bartoli a Saxoferrato Consilia, Quaestiones, \& Tractatus ... Basileae, ex officina Episcopiana, 1588 , p. 393, n. 6). The concept of quasi possessio was elaborated in relation to the problem of usucapion of servitudes. Writing on servitudes (incorporeal rights par excellence), Bartolus says: 'in istis iuribus incorporalib(us) non cadit aliqua possessio, sed quasi possessio, quae dicitur patientia aduersarii: ut 1. pen(ultima) ff. de serui(tutibus) (Dig.8.1.19)' (Id., ad Cod.3.34.1, $\mathbb{S}$ Si quas, In I. partem Codicis Bartoli a Saxoferrato Commentaria, cit., p. 365, n. 5). By the same token, even the exercise of jurisdiction on the basis of a forged document of the prince confers quasi possessio of jurisdiction, which allows its recipient to pronounce a valid sentence: cf. Bartolus, ad Cod.1.22.2 (ibid., p. 110, n. 6). The first civil lawyer known to have applied the concept of quasi possessio to jurisdiction is Pillius de Medicina. According to Pillius, the possessor could use an actio negatoria utilis - shaped after that on usufruct - to retain his jurisdiction. Celeberrimi Ivre cons(ulti) ac Glosatoris vetustissimi D. Pilei Modicensis Qvaestiones avreae [Romae, 1560], q.102, pp. 178-179. In canon law, the principle that one may have quasi possessio of iurisdictio came with the decretal Conquestus of Gregory IX (X.2.2.16, cf. Potthast [1874], p. 818, n. 9583).

43 Supra, last paragraph, note 33.

44 Bartolus, ad Cod.7.45.2, $\$$ Si arbiter (In II. et III. partem Codicis Bartoli a Saxoferrato Commentaria, cit., p. 190): 'Et ex his apprehende, qualiter debeat formari exceptio contra iudicem. Non enim sufficit dicere "Dico te non esse iudicem meum," sed debeo adijcere "Et te non esse in possessionem iurisdictionis, uel te ab omnibus reputari non iudicem", ut hac lege probatur [scil. 
If procedure could be used to blur the underlying issue between validity of the source (as in the Gloss) and direct application of public utility considerations to the deeds (as in Bellapertica), the same was not possible with the false prelate. There, Bartolus might have opted for the same ambiguity as in the case of the notary. As we have seen, the false notary in Bartolus' reading of the lex Barbarius lay on the very line he drew between the solution for Barbarius' specific case and its further applications. Seen as the last element before that line (i. e. within the scope of the Gloss), the task of the notary would actually refer to the munus of the scrivener; interpreted in the light of what comes after it (i. e. the selective endorsement of Bellapertica), it would rather point to the dignitas of the notary public. Bartolus' reference to the prelate would seem similarly ambiguous.

As stated, Bartolus closed his reading of the lex Barbarius by approving of Bellapertica's argument in favour of the deeds of the prelate who exercised an office for a long time that he was legally incapable of holding (non idoneus). ${ }^{45}$ The exact qualification of this prelatus non idoneus seems as janus-faced as that of the notary: depending on the exact meaning of 'non idoneus', the case might fall within one 'segment' of his analysis or the other. A true priest invalidly appointed to a specific office would look closer to Barbarius' case - ratifying his position would lead to the validity of his deeds. A false priest, on the contrary, would fall on the other side of the line - public utility may rescue the deeds, but not his personal position. While a literal interpretation would point to the first solution, Bartolus' use of the same case in several other parts of his opus would rather suggest the opposite conclusion.

The two most important cases where Bartolus looks at the deeds of the false prelate mistakenly thought to be a true one are both found in connection with guardianship. The first case is the voidability of the contract of the ward who tenders an oath without his guardian's consent (Dig.12.2.17.1). ${ }^{46}$ Commenting

Cod.7.45.2], et de testa(mentis) 1. i (Dig.28.1.1).' Cf. Bartolus, ad Dig.42.1.57 (In I. Partem Digesti novi Bartoli a Saxoferrato Commentaria, cit., p. 377, n. 7): 'Quandoque exceptio concernit personam iudicis: et tunc quandoque sugillat famam, seu honorem ipsius iudicis: ut quia opponitur quod est infamis, uel seruus, ideo non potest esse iudex ... sed si haec exceptio non proponitur, procedit, et ualet iudicium: 1. 2 C. de sentent(iis) (Cod.7.45.2).' Bartolus' reliance on this procedural point might explain why, in his reading of the slave-arbiter case, he extends the solution thought for the excommunicated judge also to the infamis judge but - this time - keeps silent on the infamis notary: cf. supra, this paragraph, note 41 .

45 'Et idem in praelato, qui multa administrat, ut ualeant quae facit: licet appareat postea, ipsum non fuisse idoneum', supra, this chapter, note 23.

46 Dig.12.2.17.1 (Paul 18 ed.): 'Pupillus tutore auctore iusiurandum deferre debet: quod si sine tutore auctore detulerit, exceptio quidem obstabit, sed replicabitur, quia rerum administrandarum ius ei non competit.' 
on it, the Gloss made a general statement: any contract made by those who are not validly appointed may be voided. In stating as much, the Gloss recalled the contrary case of Barbarius. ${ }^{47}$ Commenting on the same text, Bartolus first recalls the Gloss and notes how canon law provided for a similarly broad conclusion with regard to the deeds of the heretic. Then he reconciles the Gloss' opposition between its general statement and the case of Barbarius: unlike other deeds, which should be voided, those made by Barbarius remain valid because of the common mistake as to his status - and so as to the validity of his appointment. Immediately thereafter, perhaps because of his previous canon law reference, Bartolus applies the same rationale as for Barbarius' deeds also to those of the false prelate. If he is widely believed to be a true prelate, says Bartolus, then his deeds are equally valid. ${ }^{48}$ By contrast, he concludes, if someone behaved as a prelate but was not such either in truth or at least in the common opinion, the deeds would remain void. ${ }^{49}$ Taken at its face value, Bartolus' comment would seem to follow Bellapertica's position: common mistake, supported by public utility, allows for the validity of the deeds without passing through the ratification of their source.

In the second case, however, Bartolus seems to say the opposite, although in a rather indirect way. This case concerned the warden who did not provide the required surety for his administration of the ward's estate. This led to the invalidity of his appointment and, consequently, also of his deeds (Cod.2.40(41).4). ${ }^{50}$ Here as well, the Gloss recalled the different case of the lex

Gloss ad Dig.12.2.17.1, $\$$ Non competit (Parisiis 1566, vol. 1, col. 1284): 'in omnibus contractibus quos ineunt hi qui non iure sunt electi: vnde omnia cassantur ... Sed $\arg ($ umentum) contra(rium) supra de offi(cio) praeto(rum) 1. Barbarius (Dig.1.14.3).'

Bartolus was likely referring to the administration of the office, not to sacramental acts (on the distinction see infra, pt. II, \$6-7).

49 Bartolus, ad Dig.12.2.17.1 \Pvpillus (In II. Partem Digesti veteris, Bartoli a Saxoferrato Commentaria ... Basileae, Ex officina Episcopiana, 1588, p. 87, n. 6): 'Vltimo inducit gl(osa) in $\arg ($ umentum) hanc legem in omnibus contractibus, quos ineunt omnes hi qui non sunt iure electi, ut omnia cassentur [supra, this paragraph, note 47] ... facit ad hoc extra de haeret(icis) c. fraternitatis (X.5.7.4) ... Sed contra praedicta argum(enta) facit de offic(io) praet(orum) 1. Barbarius Philippus (Dig.1.14.3). Respon(deo) quod ibi fuit error communis quod facit ius, ut ibi; uel dic, quod si probabiliter dubitatur, quia omnes credunt eum esse praelatum, tunc tenet factum cum eo; alias si nec praelatus est, nec probabiliter creditur, non ualet gestum ab eo, licet se pro praelato gerat: et sic concorda praedicta iura.'

50 Cod.2.40(41).4 (Diocl. and Maxim. AA.): 'Si tutor tuus, qui pro tutelari officio non caverat, iudicio expertus est, contra eum lata sententia iuri tuo officere non potuit, nec ea quae ab eo gesta sunt ullam firmitatem obtinent. Frustra igitur in 
Barbarius, and also reported the opinion of Johannes Bassianus. Bassianus seems to have drawn a parallel between the invalidly appointed warden and the priest consecrated non legitime: in both cases the defect in the 'appointment' would prevent the acquisition of the status. Just as the first is not a warden, in other words, the other is not a priest. ${ }^{51}$ Bassianus' parallel between the invalid appointment to a secular office and the invalid ordination of a priest prompts Bartolus' question: is it possible to extend the lex Barbarius also to the administration of the office by the false priest ${ }^{252}$ Instead of providing an answer, he invites the reader to look 'first and foremost' at Innocent IV's gloss on an important text of the Liber Extra (X.1.6.44). 'In the last part of the gloss', says Bartolus, 'much of the rationale of the lex Barbarius may be seen'. ${ }^{53}$ This reference to Innocent IV might explain the ambiguity as to the precise object of the invalidity (was it the consecration of the priest or his appointment to the office?). In his gloss, Innocent IV dealt with the unworthy prelate, but he also included heretics and even schismatics. It was easy, especially for a civil lawyer, to assume that the case was about a false priest appointed to an ecclesiastical office. The reference to Innocent IV seems to betray a certain circularity in Bartolus' argument. Innocent's gloss (especially its final part, and so precisely the object of Bartolus' reference) stressed the crucial importance of the confirmation of the prelate by the superior authority. Even if the election to an office was invalid, held Innocent, confirmation in the office would cure the underlying defect and

integrum restitutionis auxilium desideras, quando ea, quae ab eo gesta sunt, qui legitimae administrationis personam sustinere non potuit, ipso iure irrita sunt.'

51 Gloss ad Cod.2.40(41).4, \$Firmitatem (Parisiis 1566, vol. 4, col. 376): 'Sed $\operatorname{ar}($ gumentum) contra(rium) ff. de off(icio) praeto(rum) 1. Barbarius (Dig.1.14.3). Item not(andum) secundum Io(hannem Bassianum) quod non legitime ordinatus pro non ordinato habetur.'

52 Bartolus, ad Cod.2.40(41).4, \$Si tutor (In I. partem Codicis Bartoli a Saxoferrato Commentaria, cit., p. 272, n. 4): 'Quaero, quid in praelato non legitime ordinato? Gloss(a) hic uidetur dicere idem. Facit $\mathrm{i}(\mathrm{nfra})$ de eo qui pro tutore 1. 2 (Cod.5.45.2). Tangit gloss(a) ff. de iureiur(ando) 1. iusiurandum quod ex conuentione $\mathbb{~ i ~ ( D i g . 1 2 . 2 . 1 7 . 1 ) . ~ T u ~ d i c ~ p l e n i s s i m e ~ u t ~ e x ( t r a ) ~ d e ~ e l e c t ( i o n e ) ~ c a p . ~ n i h i l ~}$ (X.1.6.44) in fin(e) gloss(ae) [cf. next note], et ibi apparet multum de intellectu l. Barbarius ff. de officio praetoris (sic) (Dig.1.14.3).'

53 Ibid. Taken literally, Bartolus' comment would point to the Ordinary Gloss on the Liber Extra (and so that of Parmensis), not to that of Innocent. The point is important, for the comment of the two canon lawyers were quite different from each other (as we will see later). All the other references of Bartolus to the same X.1.6.44, however, are either to the text itself or to the commentary of Innocent IV. Referring to Innocent's Gloss on the Liber Extra as 'the' gloss might not have been so unusual, at least among civilians. Baldus for instance did the same: infra, pt. III, $\$ 11.6$, note $120, \$ 12.2$, note 13 and $\$ 12.4$, note 124 . On Parmensis' gloss on X.1.6.44 see infra, pt. II, $\$ 8.1$, note 12 . 
bestow validity to the acts carried out in the exercise of that office. ${ }^{54}$ In solving the problem of the validity of the false prelate's deeds with reference to a case in which his position was ultimately ratified, therefore, Bartolus seems to move away from Bellapertica - without expressly saying so.

The same ambiguity in Bartolus' position may be seen more clearly in yet another text on guardianship. Here, Bartolus distinguishes the case of the (true) prelate deposed from his office from that of the prelate who was subsequently found not to be a prelate at all. In this last case, there cannot be any doubt as to the illegitimate status of the source of the deeds. Are the deeds valid all the same? Bartolus answers in the affirmative, and he does so on the basis of four other cases: the two cases above on guardianship (the oath of the ward without his guardian's consent, and the guardian invalidly appointed), the lex Barbarius, and especially ('plene') the same gloss of Innocent IV on X.1.6.44. ${ }^{55}$

Looking beyond the hasty closure of Bartolus' lectura on Barbarius, Bartolus' interest in the approach of Bellapertica would seem just a roundabout way of affirming the position of the Gloss, not of departing from it. In a very different case, however, Bartolus was less ambiguous and did opt for Bellapertica's solution rather openly - only without mentioning him. It is Bartolus' treatise 'On the tyrant' (De tyranno). That is probably the clearest case in Bartolus' opus where public utility is invoked directly for the validity of the deeds without at the same time ratifying the invalid position of their source.

Infra, pt. II, $\$ 7.1$, note 6 .

55 Bartolus, ad Dig.29.2.44, $\mathbb{Q}$ Quotiens (In I. Partem Infortiati Bartoli a Saxoferrato Commentaria ... Basileae, ex officina Episcopiana, 1588, p. 476): 'No(tandum) quod facta a praelato, qui postea remotus est, ualent. Sed quid de factis a praelato, qui postea pronunciatus est non esse praelatus? $\mathrm{Gl}$ (osa) tangit in 1. $3 \mathrm{C}$. in quib(us) cau(sis) in integ(rum) restit(utio) non est neces(saria) (sed Cod.2.40(41).4) et 1 . iusiurandum quod ex conuentione $\$$ pen. s(upra) de iureiu(rando) (Dig.12.2.17.1), et facit s(upra) de off(cio) praet(orum) 1. Barbarius (Dig.1.14.3), et quod ibi no(tandum) ... et plene per Inn(ocentium IV) ext(ra) de elect(ione) c. nihil (X.1.6.44).' The same parallel may be found another time in Bartolus, though this time it is not clear whether the reference is to the false prelate or the prelate invalidly elected to an office (i. e. a prelate having a formally valid but substantially void title). Bartolus speaks only of an 'occult defect' preventing the valid exercise of the prelate's office - just as it should prevent the discharge of Barbarius' praetorship. And indeed Bartolus refers to the lex Barbarius, as well as Innocent IV's comment on X.1.6.44. Bartolus, ad Coll.1.6.8(=Nov.6.1.7), $\$$ Igitur ordinandvs (Svper Avthenticis et Institvtionibvs, Bartoli a Saxoferrato Commentaria, cit., p. 26, n. 4): 'An autem gesta per eum, cuius uitium est occultum, ualeant, uel non? Recurrendum est ad materiam 1. Barbarius ff. de offic(io) praeto(rum), ad id quod no(tat) Inn(ocentius) in c. nihil ext(ra) de elect(ione) (X.1.6.44).' 
As well known, in De tyranno Bartolus distinguished tyrants as despots and usurpers, according to whether they had a valid title or not. The longest part of the treatise is devoted to the problem of the validity of the acts done by the tyrant who usurped power. ${ }^{56}$ There is little doubt that this usurper could not possibly exercise the high public office he had forcibly taken. As a matter of principle, therefore, all his deeds should be void. But this is precisely where public utility considerations come to play: $^{57}$

if the tyranny were to last for a long time in the city, should we say that everything done in court is void? That would be harsh.

Accordingly, Bartolus distinguishes on the basis of whether some deeds would have been made by the free people even without a tyrant, and especially whether the magistrates would have behaved the same way if they had been freely elected by the people. ${ }^{58}$ It is however clear that, de iure, no such deed should stand. But, again, for the sake of public utility it is necessary to cure the underlying invalidity of the deeds by detaching them from their source.

The same problem of the validity of the tyrant's deeds is to be found in the other kind of tyrant - the despot who misused his lawful authority. In that case, one of the kinds of proceedings that were considered valid (although with some hesitation) in the case of the usurper is also deemed valid for the despot: legal proceedings against his own supporters ('contra intrinsecos'). It is only here that Bartolus recalls the lex Barbarius, to argue for the validity of those deeds. The reference to Barbarius' case for the validity of the despot's deeds (and its omission with regard to the deeds of the usurper) does not seem fortuitous, all the more since, aside from Barbarius, Bartolus also refers to other cases normally accompanying the lex Barbarius: the slave-arbiter and the slave-witness. The validity of those deeds would seem therefore connected with the mistaken validity as to their source (the tyrannical regime). ${ }^{59}$ The link is expressly made by Bartolus: the tyrant's deeds are valid only 'so long as the tyrant is tolerated'. In stating as much, Bartolus recalled Innocent IV's comment on X.1.3.13, where

Bartolus de Saxoferrato, De tyranno (Quaglioni [ed., 1983], q.7, pp. 188-196, 11.266-442).

57 Ibid., p. 189, 11.293-295: 'Preterea, insurgeret iniquitas: si enim in civitate duravit tyrannides longo tempore, dicemusne omnia celebrate et acta in curia esse nulla? Durum videtur.' Cf. Cavallar (1997), esp. pp. 303-304.

58 Bartolus, De tyranno (Quaglioni [ed., 1983], q.7, p. 190, 11.309-317). By contrast, the legal proceedings brought against the enemies of the tyrant are void (ibid., p. 189, 11.296-301), whereas those against the supporters of the tyrant might be valid (ibid., pp. 189-190, 11.302-309).

59 For an introduction to the subject see first of all Quaglioni (1983), esp. pp. 15-38. More recently see also Kirshner (2006), pp. 305-309, where ample literature is mentioned. 
the pope dealt extensively with the jurisdiction of the inhabilis in connection with the idea tolerating invalid jurisdiction. ${ }^{60}$

This would seem the only place where Bartolus briefly touches on the link between apparent validity of the deeds and toleration of their source, a link that with Baldus would soon bring a completely different understanding of the lex Barbarius. To understand this link, we must now look to canon lawyers and especially Innocent IV himself. ${ }^{61}$

60 Bartolus, De tyranno (Quaglioni [ed., 1983], q.11, pp. 205-206, 11.615-622): 'Dico quod aut $<$ tyrannus $>$ fecit processus contra suos exititios et rebelles et non valent, quia non debuerunt comparere coram iudice sibi notorie inimico, ut dictum est in precedentibus; ea vero que ipse fecit contra intrinsecos valent donec ipse tolleratur in illa dignitate, ut 1 . Barbarius, ff. de officio pretorum (Dig.1.14.3), et C. de sententiis, 1. si arbiter (Cod.7.45.2), et de testamentis, 1. i (Cod.6.23.1), et extra, de rescriptis, c. sciscitatus (X.1.3.13), et ibi per Innocentium ... Et hec vera donec tolleratur.'

61 Another and even more explicit reference to canon law with regard to the lex Barbarius and the validity of the deeds issued by the person unlawfully discharging an office may be found with regard to the notary. As we have seen, Bartolus applied the lex Barbarius to the infamis and excommunicated judge, as well as to the infamis notary. But he did not apply it to the excommunicated notary. The only time he mentioned the issue he simply told his reader to look at the decretists: 'finally, it remains to be seen whether the excommunicate may draft instruments. As to that, ask the canon lawyers.' Bartolus, ad Dig.48.11.6.1, $\$$ Hac lege (In II. Partem Digesti novi Bartoli a Saxoferrato Commentaria, cit., p. 514, n. 5): 'Vltimo esset uidendum, an excommunicatus possit instrumenta conficere? De hoc interrogabis Canonistas.' 


\section{Part II}

Canon law and the development of the concept of toleration 


\section{Chapter 6}

\section{From Gratian's Decretum to its Gloss}

Bartolus was the last of the main civil lawyers to defend the position of the Gloss on the lex Barbarius. After him, much changed. The change was mainly due to the progressive influence of canon law on civil lawyers. To make sense of this influence, and in particular of its application on our subject, we should now turn our attention to the canon law side of things, focusing in particular on the development of the concept of toleration in a jurisdictional context.

By and large, toleration means forbearance. Applied to jurisdiction, however, the concept of toleration came to acquire an increasingly technical meaning: the validity of the jurisdictional acts despite the wanting legal position of the person who issued them. In turn, this concept of toleration as 'jurisdictional forbearance' underwent another crucial change with pope Innocent IV, who interpreted it in terms of legal representation. The wanting position of the person issuing the jurisdictional deeds could be tolerated because he is not the source of those deeds. Their source is the office exercised by that person. Thus, focusing on the relationship between representative and office meant looking at the physical person in a different way: no longer as an individual, but as the legal representative of the office. From this perspective, the defects in the person become less important - especially if not visible or otherwise not known.

Innocent IV's notion of toleration plays a crucial part in our story. But Innocent did not invent this concept, he transformed it. Hence this chapter will provide a summary of the previous development of toleration during the twelfth and early thirteenth centuries, from the Decretum of Gratian to its Ordinary Gloss. In this period many ecclesiological concepts progressively crystallised into legal ones. Toleration was one of them: from a Christian forbearance of sinners it became justification for the validity of jurisdictional deeds. This increasingly jurisdictional meaning, in its turn, is itself the product of a much broader (and far more complex) change taking place in the same period: the progressive separation of jurisdictional and sacramental spheres. The subject is extremely complex, and we will limit our analysis to what is strictly functional to our subject. This means that some fundamental canon law concepts, which would require several chapters in their own right, will be mentioned only briefly.

In the Dictionarium iuris of Albericus de Rosate there are two entries at the entry 'occultum'. The second is about the impossibility of proving something. The first deals with toleration: 'Occultum est quod ab ecclesia toleratur'. This 
statement may be read in more than one sense. Albericus himself accompanies these words with two references. One concerns the admissibility of testimonial evidence given by heretics in inquisitorial proceedings, and therefore deals with the problem of ascertaining occult crimes. The other deals with the sacraments administered by a fornicating priest, and it provides a different solution depending on whether the sin is occult or notorious. ${ }^{1}$ It is on this second sense of the term that we must focus our analysis: the problem of the validity of the acts done by someone who could not perform them validly if his sinful condition were publicly known. It may be noted that Albericus' reference points to sacramental issues (the sacraments celebrated by the sinner), whereas we are more interested in the jurisdictional ones. As we will see, the concept of toleration stretched both to sacramental and jurisdictional acts. The distinction made between the jurisdictional and the sacramental spheres was not immediate; it took a considerable time to fully develop. This also meant that the emersion of a specifically jurisdictional notion of toleration was itself a slow and complex process.

The concept of toleration is nowadays typically studied in relation to religious tolerance, although in medieval canon law sources it is attested more often in association with occult crimes. ${ }^{2}$ While the two subjects (at least in the early stages of their development) are deeply interrelated, ${ }^{3}$ in the analysis of a large part of contemporary scholarship - especially that of scholars of the history of ideas - the latter tends to be downplayed, if not ignored altogether. ${ }^{4}$ This subject has thus mainly remained the precinct of canon law scholars. Among them, the accent has tended to be more on the distinction between prosecutable and nonprosecutable crimes, and on that - often overlapping - between internal and

Alberici de Rosate ... Dictionarium Iuris tam Civilis, quam Canonici ..., Venetiis, apud Guerreos fratres, et socios, 1572, s.v. 'Occultum': 'Occultum est quod ab ecclesia toleratur, extra de coha(bitatione) cleri(corum) c. Nostra lib.vi. [sed 'Vestra', X.3.2.7] per Archi(diaconum), et de haereticis, c. in fidei fauorem [VI.5.2.5, on the admissibility of testimonial evidence brought by heretics in inquisitorial proceedings].' Cf. Morin (2014), p. 107. The concept of notoriety has been widely studied, but it is mentioned here only for very specific (and narrow) purposes. A more general discussion would risk shifting the focus of these pages. On the subject see e.g. Brundage (1987), pp. 319-320, and more recently Vitiello (2016), pp. 89-113, where ample literature is listed. On the progressive distinction between reputation (fama) and notoriety (notorietas) in the decretists and early decretalists see the classical study of Migliorino (1985), pp. 49-57, Migliorino (2011), pp. 15-20, and Vitiello (2016), pp. 89-96, where further literature is mentioned.

2 Marzoa Rodríguez (1985), pp. 134-135.

3 Cf. M. Condorelli (1960), pp. 21-22.

4 For a recent critique of this approach see Morin (2014), pp. 105-106. 
external forum. ${ }^{5}$ With a few exceptions, ${ }^{6}$ the specific and different problem of the jurisdictional powers of the heretic - and in particular of the occult heretichas received considerably less attention.

\subsection{Sacramental and jurisdictional powers}

To begin this short excursus, it is necessary to touch briefly on a foundamental distinction, that between sacramental and jurisdictional powers. In Gratian's times the problem of theologians and canonists alike (provided that this distinction can really be made so early) was not to distinguish between validity and liceity, but rather to describe the powers of the clergy. ${ }^{7}$ The point is important because, by and large, it was only from the second half of the twelfth century that canon lawyers started to elaborate specific legal principles on the jurisdictional powers of the clergy as opposed to their sacramental ones. ${ }^{8}$ In the Decretum, on the contrary, it is difficult to find more than a few hints at what would become the distinction between the sacramental sphere (ordo) and the jurisdictional one (iurisdictio). ${ }^{9}$ Such a distinction would acquire practical

5 To mention only a few works written in different periods and from different standpoints, see Kuttner (1936), pp. 236-242; Kelly (1992), pp. 414-419, with further literature; Chiffoleau (2006) pp. 367-381 and 412-458.

6 Mainly, the works of Zirkel (1975) and of Lenherr (1987), which will be both often be quoted in this part of the work, especially that of Lenherr. Although the focus is more on simony and not on heresy, mention should also be made of Heitmeyer (1964), esp. pp. 124-166, and of Weitzel (1967), esp. pp. 134-148.

7 Villemin (2003), p. 60.

8 The concept itself of iurisdictio took some time to be neatly defined. This also accounts for the remarkable terminological variety used among the decretists: see e. g. the list in Van de Kerckhove (1937), pp. 421-425. The term iurisdictio appears with increasing frequency from the early decretists, as the author himself notes.

9 See esp. Villemin (2003), pp. 70-72, and Gaudemet (1985-1986), pp. 84-90. On the use of the term iurisdictio in Gratian see Nasilowski (1969), pp. 165-175; Ryan (1972), pp. 316-317, text and esp. note 877, and p. 340; Landau (1995), esp. the brief but sharp observations at pp. 87-88. Most recently see also Wei (2016), p. 238. More literature in O. Condorelli (1997), p. 9, note 6. During the twentieth century, canon lawyers devoted much effort to confuting the last work written (and published posthumously) by the German canon lawyer Rudolph Sohm (1918), pp. 536-674. At the time it was published, Sohm's study was nothing less than a frontal attack on the credo of any self-respecting canon lawyer. Canon law, he argued, remained exclusively focused on sacramental law until the twelfth century; until then the Church governed itself on the basis of the same ecclesiological principles that informed the early Church in the first centuries. What attracted most critism was that Sohm considered Gratian as the last of the old theologians, not the first of the new lawyers. In Sohm's view, 
relevance (prompting in turn more accurate discussions) only from the end of the twelfth century, after some important jurisdictional tasks - especially the power to excommunicate - were entrusted to papal legates who were not always priests. ${ }^{10}$

The distinction between validity and grace in sacraments celebrated by priests who were outside the Church was already present in Gratian's main source on the subject, the Liber de misericordia et iustitia of Alger of Liège (c.1060-1131). In Alger, the validity of a sacrament is a matter wholly different from its grace: an unworthy priest within the Church always confers a valid sacrament, whereas no sacrament conferred by a priest who lies outside the Church may be valid. At the same time, however, for Alger the sacrament produces its effects on the recipient (i. e. it bestows grace) only if he is worthy of it. ${ }^{11}$ Gratian probably found Alger's stance on the subject too broad ${ }^{\mathbf{1 2}}$ and opted for a somewhat different approach, based on the separation of the sacrament (whose conferment is irrevocable) from its effects (which on the contrary might well cease to operate). ${ }^{13}$ By emphasising this separation Gratian laid the basis for the distinction between potestas (the power to confer) and executio (the validity of the conferment). It is important to acknowledge the sacramental context within which this distinction took place we will see how its application on a strictly legal level proved remarkably complex.

the Decretum was the final act of the 'old' sacramental Church, and not the beginning of the 'new' legally minded one. An obvious corollary of Sohm's thesis was that the Decretum knew nothing of the distinction betweeen ordo and potestas. While perhaps Sohm's view was somewhat extreme, it is true that many canon lawyers studied the Decretum on the basis of categories that do not really belong to it, and this has sometimes resulted in an exceedingly legalistic interpretation. Many difficulties that one encounters in seeking to distinguish jurisdictional from sacramental powers in the Decretum may well derive, at least in part, from our legally minded viewpoint more than from Gratian's ambiguity. There is little point in providing references on the long-lasting debate on (and mostly, against) Sohm's views. As to the critics (i. e. almost anyone) see for all Landau (1995), pp. 70-79; as to the few scholars who somehow followed (or at least did not fully reject) Sohm's approach see Chodorow (1972) (in effect, the first to agree with him after more than half a century), pp. 7-10.

10 See esp. Fransen (1970), pp. 212-213.

11 Kretzschmar (1985), pp. 141-155. Cf. Merzbacher (1980), pp. 245-255; Maceratini (1991), pp. 23-25.

12 With specific reference to Gratian's use of Liège in his discussion of the ordinations by simoniacs (C.1, q.1) see Zirkel (1975), pp. 10-20, and Wei (2016), pp. 235-238.

13 Gilchrist (1993), pp. 220-221. 
While sufficiently articulated, the distinction between potestas and executio is hardly consistent in the Decretum. ${ }^{14}$ Gratian stated clearly that ligare and solvere occur through the intervention of the Holy Spirit, Who does not operate outside the Church. ${ }^{15}$ But the problem was ultimately to reconcile theological language with legal rules. From a legal perspective, it was no easy task stating with precision when one lay outside the Church, and even less easy to ascertain as much. It was clear enough with excommunication brought about judicially or applied ipso iure on those who openly sided with an already condemned heresy. But in other situations the issue was more complex. On the one hand, a line of thought could well be declared heretical only after being pursued for some time; on the other, and moreover, it was quite possible for an heretic to pretend to be orthodox and keep his heresy to himself. ${ }^{\mathbf{1 6}}$ This last case, that of the occult heretic, will be of great importance to our subject.

By distinguishing between potestas and executio Gratian managed to avoid clashes with some Church Fathers, notably with Augustine's De Baptismo. When allowing the validity of baptism performed by schismatics, Gratian reasoned, surely Augustine had in mind just the potestas but not also its executio. ${ }^{17}$ While

14 In the words of the classic study of Saltet, 'une masse ... inextricable', Saltet (1907), p. 292. As recently observed by Wei, sometimes Gratian seems to think of potestas as precondition for the actual validity of the sacrament, while other times he refers to potestas only as to the liceity of the sacrament, thereby seemingly implying its valid conferment also when the power to do so is vitiated. Wei (2016), pp. 238-239. On the subject see further the fundamental study of Zirkel (1975), pp. 154-160.

15 See esp. Gratian's lengthy passage in C.24, q.1, p.c.4. Cf. Gilchrist (1993), pp. 226-227, Villemin (2003), p. 53, and esp. Winroth (2000), pp. 40-43.

16 On the subject, Gratian's ambiguities are very clearly described by Huizig (1955), pp. 285-286.

17 See esp. C.1, q.1, p.c.97: '... Sed ne Augustinum in hac sententia penitus reprobemus, intelligamus aliud esse potestatem distribuendi sacros ordines, aliud esse executionem illius potestatis. Qui intra unitatem catholica ecclesiae constituti sacerdotalem uel episcopalem unctionem accipiunt, offitium et executionem sui offitii ex consecratione adipiscuntur. Recedentes uero ab integritate fidei, potestatem acceptam sacramento tenus retinent, effectu suae potestatis penitus priuantur ... De his ergo, qui accepta sacerdotali potestate ab unitate catholicae ecclesiae recedunt, loquitur Augustinus, non de illis, qui in scismate uel heresi positi sacerdotalem unctionem accipiunt ...' On the problems of this text see Saltet (1907), pp. 294-296. Cf. also C.24, q.1, p.c.37 ('… Sed aliud est potestas offitii, aliud executio. Plerumque offitii potestas uel accipitur, ueluti a monachis in sacerdotali unctione, uel accepta sine sui executione retinetur, ueluti a suspensis, quibus amministratio interdicitur, potestas non aufertur ...'), and C.24, q.1, p.c.39 ('Sed istud Augustini intelligitur dictum non propter sentenciam, cuius potestas nulla est extra ecclesiam, sed in detestatione criminum, que in hereticis, sicut in catholicis, eque sunt punienda. Potest tamen illud 
Gratian managed to give a clear and direct answer on baptism, with other sacraments he opted for a more cautious approach. This caution, however, led him to take an unclear position that included mutually contradictory passages. The case par excellence was that of ordinations performed by schismatics and heretics, an issue bound to remain greatly controversial for a long time after the Decretum. Gratian's solution was to distinguish between sacraments of necessity and sacraments of dignity. Only the first (sacramenta necessitatis) could be validly conferred by heretics and schismatics, as they would remain true both 'as to their form' (quantum ad formam) and 'as to their effect' (quantum ad effectum). ${ }^{\mathbf{1 8}}$

This distinction, which echoed Alger's division between forma and gratia, ${ }^{19}$ was however not applied systematically. This left Gratian's text open to different interpretations. Gratian's ambiguity is particularly evident in the context of reordinations, especially with regard to ordinations to priesthood performed by simoniac bishops. ${ }^{20}$ Some scholars have interpreted such ordinations in the

Augustini de potestate baptizandi intelligi, non ligandi, aut soluendi, uel cetera sacramenta ministrandi. Baptisma namque siue ab heretico, siue etiam laico ministratum fuerit, dummodo in unitate catholicae fidei accipiatur, non carebit effectu. Alia uero sacramenta, ut sacri corporis et sanguinis Domini, excommunicationis uel reconciliationis, si ab heretico uel catholico non sacerdote ministrentur, uel nullum, uel letalem habebunt effectum. Unde et ab hominibus fidelibus nullatenus sunt recipienda').

18 C.1, q.1, p.c.39: 'Si ergo sacramenta in modum lucis ab inmundis coinquinari non possunt, si in morem puri fluuii per lapideos canales ad fertiles areolas perueniunt, patet quod symoniaci sacramentum unctionis sibi quidem inutiliter et perniciose habent, aliis autem utiliter et salubriter eandem unctionem administrant. Sicut ergo sunt uera sacramenta hereticorum quantum ad formam, ita sunt uera et non inania quantum ad effectum. Sed notandum est, quod sacramentorum alia sunt dignitatis, alia necessitatis. Quia enim necessitas non habet legem, sed ipsa sibi facit legem, illa sacramenta, que saluti sunt necessaria, quia iterari non possunt, cum sint uera, auferri uel amitti non debent, sed cum penitentia rata esse permittuntur. Illa uero sacramenta, que sunt dignitatis, nisi digne fuerint administrata ita ut digni digne a dignis prouehantur, dignitates esse desinunt, non ut minuatur ueritas sacramenti, sed ut cesset offitium administrandi, uel loco, uel tempore, uel promotione.' For the ambiguity in the text see Ryan (1972), p. 331. Cf. also C.1, q.1, p.c.42.

19 See esp. C.1, q.1, p.c.97. There, Gratian replaces Alger's gratia with effectum. While Alger said that the sacraments of the simonacs are 'vera quidem quantum ad formam sed tamen inania quantum ad spiritualem gratiam', Gratian states that they are 'uera et rata esse quantum ad se, falsa uero et inania quantum ad effectum'. Zirkel (1975), p. 14; see further ibid., pp. 88-114.

20 See esp. C.1, q.1, c.43: 'Si qui episcopi talem consecrauerint sacerdotem, qualem esse non liceat, etiamsi aliquo modo dampnum proprii honoris euaserint, ordinationis tamen ius ulterius non habebunt, nec illi umquam sacramento intererunt, quod inmerito prestiterunt.' Cf. Gratian's dictum post c.43 (C.1, q.1, p.c.43): 'Ecce cum honoris periculum euadant, ut cetera sacramenta sacerdota- 
Decretum as valid although unlawful. ${ }^{21}$ Others (relying mainly on C.1, q.1, p.c. 97 and C.9, q.1, p.c.1) concluded that Gratian's distinction was between the schismatic bishop ordained within the church and the one ordained outside it. The former, having fallen in the schism only after his canonical ordination, may himself validly ordain new priests. Both positions are debated among scholars. ${ }^{22}$ We are not interested in solving the issue, only in briefly mentioning it. Because it is mainly there that the decretists discussed the exercise of invalid jurisdiction and the limits of its toleration.

This last point is useful for introducing a rather obvious but - for our purposes - crucial concept: toleration does not refer to ordo but only to iurisdictio. This is because ordo may never be revoked: sacraments are indelible. Someone who has been validly consecrated never loses his consecration, and so retains ordo. But only those who lie within the Church may exercise their powers validly. So the heretic or schismatic retains ordo even after his full separation from the Church, but loses his iurisdictio. Although toleration is referred to the person, therefore, its object is only the validity or invalidity of his deeds. The distinction between ordo and iurisdictio, however, becomes more complex when looking at the validity not of jurisdictional acts, but of sacramental ones - just like the problem of schismatic ordinations mentioned above. We have seen how Gratian paved the way for the distinction between potestas and executio. This

liter administrare permittantur, ab hoc solo non modo pro heresi uel qualibet maiori culpa, sed etiam pro negligentia remouentur. In quibus omnibus sollicite notandum est, quod sacramentum sacerdotalis promotionis pre ceteris omnibus magis accurate et digne dandum uel accipiendum est, quia nisi ita collatum fuerit, eo desinet esse ratum, quo non fuerit rite perfectum. Cetera enim sacramenta unicuique propter se dantur, et unicuique talia fiunt quali corde uel conscientia accipiuntur. Istud solum non propter se solum, sed propter alias datur, et ideo necesse est, ut uero corde mundaque conscientia, quantum ad se, sumatur, quantum ad alios uero non solum sine omni culpa, sed etiam sine omni infamia, propter fratrum scandalum, ad quorum utilitatem, non solum ut presint, sed etiam ut prosint, sacerdotium datur.' See also C.24, q.1, p.c.37, supra, this paragraph, note 17 . It might be that the ambiguity is mainly in the eyes of the lawyer. More than ambiguity, a theologian contemporary to Gratian might have thought of complexity, arising from the dialectic between theological and ecclesiological considerations: Chodorow (1972), p. 199. See also C.1, q.1, p.c.107: 'Sed hoc [scil., the 1060 pronouncement of Nicholas II against simony] intelligendum est de his, qui ordinantur a symoniacis, quos ignorabant esse symoniacos. Hos facit symoniacos non reatus criminis, sed ordinatio symoniaci.' Cf. Gilchrist (1993), pp. 231-233.

21 Esp. Chodorow (1972), pp. 197-198. See however the harsh critique of Villemin (2003), pp. 40-41.

22 To mention only a few scholars writing in different periods see e. g. Saltet (1907), pp. 293-296; Ryan (1972), pp. 350-352; Villemin (2003), pp. 45-48, where further literature is mentioned. 
separation would later lead to the clear distinction between sacramental and jurisdictional spheres (ordo and iurisdictio), but also to another within the sacramental sphere, that between the state of being consecrated and the power to consecrate others - ordo and executio ordinis. As executio ordinis consists in the exercise of a power, it was often discussed with relation to the toleration principle. As a result, despite the concept of toleration applying only to jurisdictional acts, it is far from infrequent to find it discussed also in relation with sacramental ones. ${ }^{23}$

\subsection{Toleration in the Decretum}

The concept of toleration is not particularly elaborated in the Decretum. Gratian typically used it in a broad and general sense, not in a legal one. ${ }^{24}$ Special mention however deserves the first of the two causae haereticorum, causa 23, and especially its fourth quaestio, mainly devoted to the toleration of the evildoers. There, the concept of toleration is clearly explained in terms of public utility, and public utility is discussed within an ecclesiological and sacramental context. ${ }^{25}$ The subject is extremely complex and it may not be discussed here. For the moment, it is sufficient to highlight the link between toleration and utilitas

23 This closeness between toleration and executio ordinis was however progressively downplayed with the increasing refinement of the distinction between ordo and iurisdictio - or perhaps, with the increasingly legalistic approach to ecclesiastical and sacramental issues and the resulting crystallisation of that distinction. This allows us to avoid embarking in complex discussions on the relationship between executio ordinis and executio potestatis and the precise boundaries between the exercise of ordo and the exercise of iurisdictio. The discussion will therefore only focus on iurisdictio and omit - insofar as viable - references to ordo and executio ordinis.

24 See e.g. D.38, c.12; D.41, c.4; D.100, c.8; C.1, q. 1, c.85; C.2, Q. 6, c.11. Cf. Fabritz (2010), pp. 102-105. A more specific meaning of toleration is to be found in D.19, c.3, where Gratian relies on it to emphasise the duty of obedience to the Holy See.

25 C.23, q.4, esp. c.1-6, c.10, c.37 and c.39. At the risk of stating the obvious, it should be noted that this was hardly a novelty introduced by Gratian. Toleration for the sake of the common good (mostly, for the utilitas ecclesiae) was a concept so widespread that it may be found in even the most uncompromising writers, such as the cardinal Humbert de Silva Candida (Humbert of Moyenmoutier, d.1061, better known for having triggered the Great Schism of 1054), who applied it for anything save simony. Humbert of Silva Candida, Libri Tres Adversus Simoniacos (Golden Robison (ed., 1972), III.32, 11.58-61, p. 375): 'Quapropter in ministris modo quo dictum est promotes vel post promotionem in aliquod crimen lapsis acceptus honor perdurat, quamdiu eorum culpas Ecclesia aut ignorat aut dissimulate et propter utilitatem aliorum sub spe poenitudinis talium tolerat.' 
ecclesiae, to which we will come back. The sacramental context is also important for a different reason: as we shall see, it is there that the most interesting discussions on the concept of toleration among the decretists are to be found.

When discussing toleration Gratian did not mention the case of Barbarius, but he did refer to that of the slave-arbiter. He did so in a dictum, the dictum Tria that would soon acquire a fundamental importance on the subject, because it merged two important Roman law passages that we have already encountered when examining the Gloss: Dig.5.1.12.2 and Cod.7.45.2. Gratian's dictum Tria is found after C.3, q.7, c.1. It reads: ${ }^{26}$

Three are the kinds of impediment that prevent one from being judge: nature, such as the deaf, the dumb and the incurably insane; law, for those expelled from the senate; customs, for women and slaves, not because they lack judgment but because it is established that they cannot discharge public offices. If however a slave was delegated to render a judgment during the time he was believed to be free, and was brought back to servitude after having pronounced the judgment, there is no doubt that his judgment retains the strength of res judicata.

It is easy to see how the first part of the text is a readaptation of Dig.5.1.12.2, while the second part follows Cod.7.45.2 very closely. It is through this last text

26 C.3, q.7, p.c.1: 'Tria sunt, quibus aliqui inpediuntur ne iudices fiant: Natura, ut surdus, mutus et perpetuo furiosus, et inpubes, quia iudicio carent. Lege, qui senatu motus est. Moribus, feminæ et serui, non quia non habent iudicium, sed quia receptum est ut ciuilibus non fungantur offitiis. Verum, si seruus, dum putaretur liber, ex delegatione sententiam dixit, quamuis postea in seruitutem depulsus sit, sententia ab eo dicta rei iudicatae firmitatem tenet.' In his edition of the Decretum, Friedberg identified several possible sources which Gratian might have combined together in his dictum Tria: the Decretum of Ivo de Chartres (V.248 and VI.331), Panormia (IV.78), Tripartita (II.24.7), Pauli Sententiae (I.1A.11), and Polycarpus (V.1.24). Friedberg (1959), vol. 1, col. 524; the point is also noted in Zendri (2007), p. 240, note 40. If the sources of Tria were effectively only those listed in Friedberg, that would highlight the contribution of Gratian: those sources make up for just a small part of the text. As to the content of Tria see the observations of Creusen (1937), pp. 186-188. Cf. also Jacobi (1913), p. 245, and more recently (but only in passing) Brundage (2008), p. 143, note 58 . The text is quoted in some ordines iudiciarii, such as the Bambergensis (ch.17). On the point see recently Brasington (2016), pp. 253-254. Tria has been studied more with regard to the incapacity of the woman to serve as judge than to the incapacity of the slave. See esp. Minnucci (1989), vol. 1, pp.114-120 (on Huguccio's position), and (1994), vol.2, pp. 23 (on the Summa Tractaturus Magister), 32 (on Sicardus), 53 (on the Summa De iure canonico tractaturus), and 98-100 (on the Summa Bambergensis). With specific regard to the incapacity of the slave, Tria is analysed in Miaskiewicz (1940), pp. 46-49, although the author perhaps overstates its relevance for the elaborations of twelfth-century decretists on the lex Barbarius. Miaskiewicz even finds a direct connection between such elaborations and the decretal Intelleximus of Lucius III (X.5.32.1), ibid., p. 47, note 4, although that might appear somewhat doubtful. 
that Barbarius' case entered into canon law. As just said, in the Decretum there is no mention of Dig.1.14.3, but Gratian followed the same interpretation of Cod.7.45.2 as the Gloss: not a freedman made slave again after rendering a judgment, but a slave sitting in judgment while he was wrongly believed to be free.

In spite of their similarities, there was an important difference between Cod.7.45.2 and Dig.1.14.3: in the first case the slave is delegated to pronounce a single judgment; in the second he is vested with the office and so exercises ordinary jurisdiction. Nonetheless, from the second half of the twelfth century the growing knowledge of Roman law sources possessed by many canon lawyers allowed them to see the connection between Gratian's dictum Tria (C.3, q.7, p.c.1) and the lex Barbarius, and to mention the latter with increasing frequency.

Shortly after Tria, Gratian moved to the problem of the validity of the judgments rendered by the wicked judge. After a lengthy argument, Gratian argued for their validity: so long as the wicked judge is tolerated by the Church, his deeds are valid. ${ }^{27}$ The two cases were not necessarily similar: the slave in Gratian's Tria was simply delegated to perform his task, whereas the wicked judges to whom Gratian referred (Ahab, Saul, David and Salomon) were all annointed kings of Israel who later fell into a sinful state. But it did not take long for the decretists to make a connection between the validity of the decision of the (legally incapable) slave and the validity of the judgments of wicked kings. The link is already present in the first Summa on the Decretum, that of Paucapalea.

Paucapalea's Summa (probably written in the late 1140s) ${ }^{28}$ contains a few statements that would be of crucial importance to the development of the concept of toleration, but took a considerable time to be fully accepted. Paucapalea distinguishes between the wicked office holder whom the Church deposes and the one whom the Church tolerates. In both cases the accent is on the office, not on the person: if the Church takes away the office, the person who exercised it is no longer tolerated and may not serve as judge. If on the contrary the Church leaves him in office, although he is wicked he may still judge. The concept of toleration is therefore referred to the person not as an individual, but

27 See the last lines of C.3, q.7, p.c.7: 'Hinc liquido constat, quod mali pastores, dum sententia iusti examinis aliorum crimina feriunt, sibi ipsis nocent, dum sine exemplo suae emendationis aliorum uicia corrigere curant; subditis uero prosunt, si, eorum increpatione correcti uel sententia coherciti uitam suam in melius commutare didicerint. Ac per hoc, dum ab ecclesia tollerati fuerint, eorum iudicium subterfugere non licet.' Cf. Vodola (1986), pp. 116-117. Weigand (1980) pp. 10-11, text and note 34, including further literature. 
as the holder of an office. And the validity of the deeds derives directly from the 'dignity of the office' (dignita[s] officii), despite the indignitas of its holder. ${ }^{29}$

This explanation of the concept of toleration would have a crucial importance for our subject, but it would be questionable to credit it specifically to Paucapalea, who was probably thinking in ecclesiological terms, not in strictly legal ones (i. e. of legal representation). Moreover, only few decretists seem to have followed him on the point. ${ }^{30}$ This might also be due to Paucapalea's ambiguity on the subject, as he did not explain when the wicked was to be deprived of his office, nor what was the scope of the concept of toleration itself. These were the two crucial questions that needed to be answered. Paucapalea's association of the concept of toleration with occult heresy would prove more successful: although not all secret heretics are tolerated by the Church, says Paucapalea, the fact that their heresy is secret leaves the Church with the choice of tolerating them. ${ }^{31}$ This concept, however, was only briefly sketched in Paucapalea. To better appreciate the development of concept of toleration in canon law, we must review the most important decretists preceding Teutonicus' Ordinary Gloss to the Decretum.

29 Paucapalea's Summa, ad C.3, q.7, p.c.1, $\mathbb{I n f ( a m i s )}$ pers(ona) n(ec) procurator pot(est) esse (Schulte [ed., 1890], p. 66): ' $\ldots$.. Sed hoc de illis intelligendum est, qui ab ecclesia officio sunt privati et infamia notati. Alii vero, qui ab ecclesia licet criminosi tolerantur, pro sui tamen dignitate officii et agere in causa possunt et iudicare.' On the concept of dignitas see infra, esp. pt. III, $\$ 11.1$.

30 In particular, Johannes Faventinus, ad C.3, q.7, p.c.2, \$Item in euangelio (Madrid, BN 421, fol. 101vb): 'Indignum est de merito uite tamen quandiu tolerat eum ecclesia quamdiu non est dampnatus ex officio suo potest maiorem et minorem travem deducere et loquitur de dampnatis.' See the Summa Parisiensis, ad C.3, q.7 pr, $\mathbb{S}$ quod iudex (McLaughlin [ed., 1952], p. 121): 'Septima quaestio sequitur, quia quaeritur an judex possit esse qui simili culpa vel majori tenetur. Dicimus ergo quoniam de merito vitae non potest, sed dum ab ecclesia toleratur, propter dignitatem quod judicaverit erit ratum. Et sumpta hac occasione ostendit Gratianus plures lege quae impediunt ne aliquis sit judex. Verum, quia in supposito decreto sit mentio de procuratore - procurator vero dicitur advocatus - ostendit quae impediant ne aliquis possit esse advocatus, ut per contrarium intelligamus quis esse possit.' See also the Summa de Iure Canonico Tractaturus (Weigand, Landau and Kozur [eds., 2010], tom. 2, p. 84, 1l.1-3), ad C.3, q.7 pr, $\mathbb{S Q u o d}$ iudex: 'Hic queritur an criminosus possit iudicare. Et uerum est quod potest de officio non de uite merito, si adhuc toleratur. Precisus autem neutro modo potest.' Cf. ibid., ad C.3, q.7, c.4, \$I Iudicet-quod-condempnet (ibid., p. 86, 11.1-2): 'Is solus potest. Quod uerum est de uite merito, criminosus potest de officio dum toleratur.'

31 Paucapalea, ad C.24, q.1 (Schulte [ed., 1890], p. 104): 'Multis auctoritatibus declaratum est in superiori causa, quod mali ad bonum cogendi sunt, et haeretici nihil nomine ecclesiae possidere debent. Sed quia haereticorum alii manifesti, alii occulti inveniuntur, quorum alii ab ecclesia damnantur, alii tolerantur, ut sunt occulti, nonnullis venit in dubium, utrum post mortem cognita haeresi aliqui 


\subsection{The decretists and the concept of toleration}

The increasingly legally minded attitude of the decretists led to the progressive crystallisation of statements found in the Decretum into legal rules. During this process many of the ambiguities left (or introduced) by Gratian had to be solved. To appreciate the position of early decretists on the problem of toleration, it is important to keep in mind the initial lack of clear boundaries between the jurisdictional and sacramental spheres. This lack of boundaries - one might even say, this ecclesiological unity - had clear repercussions for the very idea of toleration, which was typically discussed first with regard to sacramental issues and then in relation to their jurisdictional consequences.

\subsubsection{From Rolandus to Huguccio}

One of the earliest and important applications of the toleration principle in both sacramental and jurisdictional contexts may be found in the Summa of Rolandus (written in the late 1150s). ${ }^{32}$ As with Gratian, sometimes Rolandus refers to the concept of toleration in rather a general, non-legal sense. ${ }^{33}$ On occasion he mentions the toleration principle with regard to the good of the Church, both in case of necessity ${ }^{34}$ and with regard to the risk of scandal. ${ }^{35}$ But Rolandus also uses the same concept in a more technical sense. Commenting on the issue of the priest ordained by a simoniac, and following Gratian's distinction on the subject, Rolandus contrasts strictness of the law and its equitable dispensation.

excommunicari mereantur?' (emphasis added). The importance of this passage is also ackowledged in Maceratini (1994), p. 372, note 32.

Weigand (1980), pp. 19-22; Weigand (1990) pp. 137-138.

33 E.g. Summa Rolandi, ad C.23, q.4 pr (Thaner [ed., 1874], pp. 89-90): 'Quarto quaeritur, an vindicta sit inferenda. Quod autem vindicta inferenda non sit, probatur. Ait enim Augustinus: Tolerandi sunt mali etc. (C.23, q.4, c.1), idem: Tu bonus tolera etc. (C.23, q.4, c.2), idem: Quid ergo voluit Dominus noster etc. (C.23, q.4, c.3), Quod ergo, inquiunt etc. (C.23, q.4, c.4), idem: Recedite, exite inde etc. (C.23, q.4, c.4 and c.9), idem: Quam magnum etc. (C.23, q.4, c.10) idem: Forte in populo Dei etc. (C.23, q.4, c.11) caus(a) ead(em) qu(aestio) ead(em) cap. I, II, III, IV, IX, X et XI (C.23, q.4, c.1-4, 9-11). Idem ratione probatur. Si omnia hic punirentur, locum divina indicia non haberent iuxta illud Anacleti: Si omnia in hoc saeculo etc. caus. VI. qu. I. cap. VII (C.6, q.1, c.7).'

34 Id., ad C.25, q.1, c.7, $\mathbb{S}$ Quod pro remedio ac necessitate (ibid., p. 105): '... Item generaliter institutum fore cognoscitur, ne quis episcopus praeter conscientiam metropolitani ordinetur, quod si secus actum fuerit in irritum devocetur. Talis vero ordinatio instante necessitate ab ecclesia toleratur iuxta illud Hilarii.'

35 Id., ad C.32, q.4 c.4, $\$$ Tolerabilior (ibid., p. 171): 'quia minus malum est occulte peccare quam manifeste, quoniam minori scandalo ex privato quam manifesto laeditur ecclesia.' 
As a matter of principle, the priest who was ordained in good faith by a simoniac (i. e. unaware of the simony of his ordainer) ought to be cast away from the Church (de juris rigore eiiciantur). Nonetheless, setting aside the rigor iuris, it is possible to tolerate this priest within the Church rather than requiring a second (and proper) ordination (ex dispensatione tolerentur). ${ }^{36}$ Later on, Rolandus applies the same criterion to the ordinations done by the excommunicate: if the recipient of the sacrament was unaware of the excommunication of the bishop who consecrated him, his ordination may be tolerated out of mercy ( $e x$ misericordia tolerari potest). ${ }^{37}$

The toleration of ordinations made by heretics or simoniacs appears again in Rolandus' remarks on the jurisdictional powers of the heretic. There, Rolandus sums up what he already said. This time, the emphasis is more on compliance with the requirements for a valid ordination and less on the good faith of its recipient: if the ordination follows the Church's requirements (forma ecclesiae), the priest ordained may be tolerated within the Church. This time, and unlike the previous cases, Rolandus does not simply exclude the necessity of a second ordination. Instead, he makes clear that the priest who is tolerated within the Church retains valid jurisdictional powers: ${ }^{38}$

Id., ad C.1, q.6 pr (ibid., p. 15). Cf. Weitzel (1967), p. 64.

37 Summa Rolandi, ad C.9, q.1 pr (Thaner [ed., 1874], p. 23): 'Hic primum quaeritur, an ordinatio facta ab excommunicatis rata haberi possit. Excommunicatorum quidam nominatim excommunicantur, quidam non. Item eorum, qui ordinantur ab exeommunicatis, alii ex ignorantia, alii ex contumacia. Ordinatio ergo ab excommunicatis facta, si ab eo, qui eum excommunicatum ignorabat, fuerit suscepta, ex misericordia tolerari potest. Si vero contumaciter ab eo, quem scit excommunicatum, ordinem susceperit, huius ordinatio de iure tolerari non poterit.'

38 Id., ad C.24, q.1 pr (ibid., p. 100): ‘... haereticorum alii sunt ordinati ab his, qui habent potestatem consecrandi ut episcopi, alii non. Item eorum, qui ordinantur ab habentibus potestatem alii ordinantur in forma ecclesiae, alii vero minime. Item ordinatorum $\mathrm{ab}$ habentibus potestatem in forma ecclesiae alii tolerantur $\mathrm{ab}$ ecclesia, alii reprobantur. Ordinati igitur ab his, qui potestatem ordinandi non habuerunt vel ab his, qui habebant, sed in forma ecclesiae minime ordinabant, alios ligare vel solvere non valent. Reliqui vero dum ab ecclesia tolerantur, possunt; reprobati vero non possunt.' The reference to forma is to be read within the opposition forma/vita. Rolandus' summa on C.24, q.1 continues as follows (ibid., pp. 100-101): 'Vel dicamus haereticos non catholicos ab haereticis, si tamen culpabiles fuerint, esse ligndos iuxta illud Augustini: Quisquis etc., Subdiaconus etc. caus(a) ead(em) qu(aestio) ead(em), cap. XXXVIII et XXXIX (C.24, q.1, c.38-39). Sed obiicitur, quod quemadmodum sacramenta ab haereticis in forma ecclesiae ministrata effectu carere non possunt, sic ligatio et solutio ab eis celebrata non minus quam catholicorum suum sortientur effectum. Ad quod dicimus, aliam sacramentorum et aliam ligationis esse rationem. In sacramentis siquidem non uita sed forma, non iurisdictio sed ordo requiritur. 
among the heretics some are ordained by those who have the power to consecrate, such as bishops, others are not. Among those who are ordained by those with the power [to consecrate], some are ordained in accordance with the church's requirements (forma ecclesiae), others are not. As to the ordained by those who have that power and according to the church's requirements, some are tolerated by the church, others are condemned. They who are ordained by those who lacked the power to ordain or by those who did have such power but did not [exercise it] in accordance with the church's requirements, therefore, cannot bind or loose others. The others can, so long as are tolerated by the church, but they cannot if [the Church] rejects them.

This passage would have remarkable success: it may be found for instance in the nearly contemporary Summa Sicut uetus testamentum, ${ }^{39}$ in the Summa Cum in tres partes, ${ }^{\mathbf{4 0}}$ in the Summa Coloniensis, ${ }^{\mathbf{4 1}}$ in the Distinctiones Monacenses, ${ }^{\mathbf{4 2}}$ in the

In ligatione uero uel solutione etiam uita spectatur.' Cf. Lenherr (1987), pp. 195-196.

39 Summa Sicut uetus testamentum, ad C.24, q.1 (Firenze, Conv. Sopp. G.IV.1736, fol. 35v, transcription in Lenherr [1987], p. 268, 11.61-67): '... hereticorum alii sunt ordinati ab his qui habent potestatem consecrandi, alii uero non. Item eorum qui ordinantur $\mathrm{ab}$ habentibus potestatem alii ordinantur in forma ecclesie, alii non. Item ordinatorum ab habentibus potestatem et in forma ecclesie ali (sic) tollerantur ab ecclesia, alii reprobantur. Ordinati ab his qui potestatem ordinandi non habuerunt uel ab eis qui potestatem habuerunt, set in forma ecclesie non ordinabant alios soluere uel ligare non possunt. Reliqui uero, dum ab ecclesia tollerantur, possunt, reprobati uero non possunt ...'

40 Summa Cum in tres partes, ad C.24, q.1 (BNF, Lat. 16540, fol. 67r-v, transcription in Lenherr [1987], p. 276, 11.37-41): '... Huius autem questionis ex hiis que in causa simoniacorum dicta sunt patet solutio: Ordinati enim ab his qui potestatem ordinandi non habuerunt uel ab his qui habebant, set in forma ecclesie minime ordinabant alios ligare uel soluere non ualent. Reliqui uero, dum ab ecclesia tolerantur, possunt, reprobati non possunt ...'

41 Summa 'Elegantius in iure divino' seu Coloniensis (Fransen and Kuttner [eds., 1978], tom. 2, pt. 4, ch. 64 p. 28, 1l.1-4): 'Solutio vera avctoritatibus confirmata in qva hoc dicitvr qvod ordinati extra ecclesiam ab his qui intvs potestatem accepervnt per misericordiam tolerantvr, ordinati extra ab his qvi extra per dispensationem reordinentvr.' This Summa was likely composed in 1169/70: see Fransen and Kuttner (eds., 1969), tom. 1, xi. For a short introduction see Weigand (2008), pp. 183-184.

42 Distinctiones Monacenses, ad C.1, q.1, c.1 (Sorice [ed., 2002], Distinctiones 'Si mulier eadem hora' seu Monacenses, p. 79, 11.63-68): 'Hereticorum alii occulti, alii manifesti. Manifestorum alii sunt infra ecclesiam, alii seipsos abscindunt ab ecclesia, alii iudicio ecclesie eiecti sunt. Item eorum qui iudicio ecclesie precisi sunt alii sunt simpliciter excommunicati, alii depositi uel degradati. Ordinati ab heretico occulto uel ab alio quem sustinet ecclesia ueros ordines suscipiunt et quicquid tales fecerint qui sunt in ecclesia ratum erit.' Unlike most other texts mentioned in the main text, and despite the broad statement ('quicquid tales fecerint ... ratum erit') the Distinctiones Monacenses referred the toleration only to the sacraments of necessity: ibid., p. 81, 11.98-106. 
Summa Lipsiensis, ${ }^{\mathbf{4 3}}$ in Stephanus Tornacensis ${ }^{\mathbf{4 4}}$ and, perhaps through him $^{\mathbf{4 5}}$ also in Johannes Faventinus. ${ }^{46}$ Moreover, Rolandus' words attest to how the toleration principle moves from ordo to iurisdictio: the heretic may exercise valid jurisdictional powers because he was consecrated within the Church (and so validly received ordo) and because the Church has not rejected him yet. While the effects of toleration concentrate mainly on the jurisdictional sphere, its rationale is ultimately ecclesiological. The point is of great importance: the notion of toleration could fully emerge as a legal concept only after the full separation of ecclesiological and jurisdictional considerations.

Toleration of the consecration entails toleration of jurisdiction. Rolandus was very brief but clear on this crucial point. Yet already by Rolandus' time the argument seems to have been controversial: if the Church does not expel a manifest heretic, does this inertia amount to proper toleration? Should the solution be the same for the followers of an already condemned heresy as for

43 Summa Lipsiensis, ad C.24, q.1, c.1, $\mathbb{Q}$ Quod autem ab heretico (Luxembourg 144, fol. 335v, transcription in Lenherr [1987], pp. 306-307, 1l.1-7): 'Notandum quod hereticorum alii sunt ordinati ab hiis qui potestatem ordinandi habent, ut episcopi, aliis non. Item eorum qui ordinantur in forma ecclesie ab habentibus potestatem alii tolerantur ab ecclesia, alii reprobantur. Ordinati ab hiis qui potestatem ordinandi non habuerint uel ab hiis qui habuerunt potestatem, set non in forma ecclesie, alios ligare uel soluere non ualent. Reliqui uero, dum ab ecclesia tolerantur, ualent ...'

44 Tornacensis, Summa, ad C.24, q.1 pr, $\mathbb{S}$ Quod autem ab heretico (Bruxelles 1410, fol. 118r, transcription in Lenherr [1987], p. 271, 11.1-9): 'Notandum quod hereticorum alii sunt ordinati ab his qui potestatem habent consecrandi ut episcopi, alii non. Item eorum qui ordinantur ab habentibus potestatem alii ordinantur in forma ecclesie, alii uero minime. Item eorum qui ordinantur ab habentibus potestatem in forma ecclesie alii tolerantur ab ecclesia, alii reprobantur. Ordinati ab his qui potestatem ordinandi non habuerunt uel ab his qui habebant, set in forma ecclesie minime ordinabant alios ligare uel soluere non ualent. Reliqui uero, dum ab ecclesia tolerantur, possunt, reprobati uero non possunt.'

45 Kuttner (1937), p. 145. Maceratini (1994), pp. 449-450 would on the contrary suggest an influence of Rufinus on the point.

46 Johannes Faventinus, ad C.24, q.1, c.1, $\$$ Quod autem ab heretico (Madrid, BN 421, fol. $160 \mathrm{rb}$ ): 'Notandum quod hereticorum alii sunt ordinati ab his qui potestatem habent consecrandi ut episcopi, alii non. Item eorum qui ordinantur ab habentibus potestatem alii ordinantur in forma ecclesie, alii minime. Item eorum qui ordinantur $a b$ ordinantur $a b$ habentibus potestatem in forma ecclesie alii tolerantur ab ecclesia, alii reprobantur. Ordinati $a b$ his qui potestatem non habuerunt ordinandi uel ab his qui habebant potestatem, set in forma ecclesie minime ordinabant alios ligare uel soluere non ualent. Reliqui, dum ab ecclesia tolerantur, possunt, reprobati uero non possunt .... Cf. Maceratini (1994), pp. 451-453, text and note 288. Faventinus' passage above is also transcribed, though from other manuscripts, in Lenherr (1987), p. 277, 11.1-9. 
those adhering to a new one? These doubts may be found in the contemporary ${ }^{47}$ Summa known as Fragmentum Cantabrigense, of the school of Rolandus. ${ }^{48}$

The continuity between sacramental and jurisdictional effects of toleration made it a thorny subject from the outset. Perhaps this is another reason why the subject attracted a growing interest among the decretists. Let us take the important Summa of Rufinus (1130-1192), written probably in the years $1157-1159 .{ }^{49}$ Rufinus interprets Gratian's dictum Tria in a remarkably narrow sense. If the judge is criminosus and is suffered (subportatur) by the Church, there is a clash between the unworthiness of his person (vitae merito) and his holding of the office (officii merito). As a consequence (and much unlike Paucapalea), he may keep his office, but he cannot judge. ${ }^{50}$ Given his stance on the iudex criminosus, it should not come as a surprise that Rufinus avoids even mentioning the possibility of tolerating the heretic, let alone the simoniac. ${ }^{51}$ Nonetheless, his

Kuttner (1937), p. 129.

Fragmentum Cantabrigense (Cambridge 3321, fol. 4r-v, transcription in Lenherr (1987), p. 269, 11.6-12): 'Si uero heresis eius pateat et si aliquo casu toleretur ab ecclesia, absoluere et ligare potest secundum quosdam. Alii uero talem adhibent distinctionem, quod hereticorum alii secuntur iam predampnatam heresim, si manifesta est heresis eorum, etsi aliquo modo toleret eos ecclesia, non tamen curanda est eorum sententia.'

Singer (ed., 1963), lxvii, note 9; Kuttner (1937), p. 132. Cp. however Gouron (1986) pp. 68-69 (dating it around 1164).

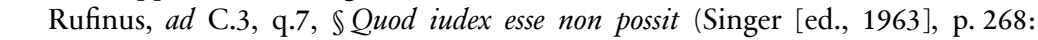
'Sciendum quod in divina scriptura quattuor modis dicitur aliquid fieri posse: scil(icet) facultate nature, iuris permissione, vite merito, officii debito. Refert itaque de iudice reum iudicaturo, utrum et ipse reus criminis teneatur aut innocens sit; item differentia est, utrum iudex de crimine quo tenetur sit ab ecclesia notatus vel adhuc supportatus. Si enim nullo crimine teneatur, omni modo possendi potest condempnare reum criminis, nisi forte ecclesia decepta insontem iudicem condempnasset: tunc enim ex iuris permisso et ex officii debito non valet iudicare, donec sit restitutus. Si vero crimine teneatur, tamen ab ecclesia subportatur, tunc quidem officii debito dumtaxat potest esse iudex, sed vite merito iurisque permisso iudicare non potest. Unde prohibetur tunc index esse aliorum, non quin subditi eius iudicium debeant expetere, sed quoniam ipse, cum sit malus, iudicando alios sibi invenitur obesse: in quo casu omnia huius questionis capitula preter primum intelligenda sunt. Si autem, quia criminosus erat, ab ecclesia notatus est, nulla nisi prima ei iudicandi possibilitas reservatur.'

1 The difference is not only due to Rufinus' divergences with Gratian on the subject (on which see Heitmeyer [1964], pp. 69-94, 101-104, 119-123, and esp. 124-150), but possibly also to his striving for accuracy. So for instance, while in the Decretum ordinations made by the excommunicated but received in good faith are to be accepted out of mercy ('sustinemus misericorditer', C.1, q.1, c.108), in Rufinus such ordinations 'habebuntur rate' (ad C.1, q.1, c.108, $\$$ Si qui a symoniacis usque et tunc pro catholicis habebantur, Singer [ed., 1963], p. 222). 
Summa was sometimes interpreted in exactly the opposite sense, especially in the French milieu. In one of the two manuscripts of Rufinus' Summa preserved in the Bibliotheque nationale de France, the hand (that Singer identified with the author of the Summa Monacensis $)^{52}$ added the concept of toleration twice, once with regard to simoniacal ordinations ${ }^{53}$ and the other on ordinations made by heretics. ${ }^{54}$ Thus, despite his author, the toleration principle also found its way into Rufinus' Summa.

Similarly, while Gratian stated that those who went along with a heresy after their canonical ordination may still confer ordo because 'ab ecclesia misericorditer tollerantur' (C.9, q.1, p.c.3), Rufinus clarifies as much in the sense that 'ordinatio quidam facta ab eis nullo modo irrita esse poterit quantum ad sacramenti veritatem, sed erit vana quantum ad officii executionem' (ad C.9, q.1 pr, ibid., p. 298). Similarly, with regard to the consecrations performed by those who then revert to the Church, Gratian stated that 'seruatis propriis ordinibus misericorditer suscipi iubemus' (C.9, q.1, c.5), while Rufinus noted how 'in suis ordinibus recipiuntur' (ad C.9, q.1 pr, ibid., p. 298). The only time Rufinus uses the verb 'tolerare' in a positive sense is when he refers to the second marriage of a woman who believes her husband to be dead and marries again. In such a case the Church tolerates the marriage and bestows validity upon it, chiefly to recognise the offispring. Id., ad C.27, a.q.1, $\mathbb{Q}$ Quidam votum castitatis babens (ibid., p. 430): '... sciendum est quod matrimonii coniunctio dicitur legitima tribus modis: et quia contrahitur inter legitimas personas - vel que legitime ab ecclesia reputantur -, et quia habet fieri secundum legum instituta, et quia secundum morem uniuscuiusque provincie celebratur. Igitur secundum modum primum hie coniunctio legitima accipienda est, scilicet que contrahitur inter personas legitimas - vel quas ecclesia legitimas esse putat: ideoque toleratur ipsis etiam, qui coniunguntur, se esse inlegitimas personas ignorantibus ideoque sibi legitime coniungi putantibus. Ut: si mulier, putans virum suum mortuum, nubat alii non habenti uxorem, tune quidem legitimum erit matrimonium, propter quod et filii inde suscepti iudicabuntur legitimi' (emphasis added). In such a situation Rufinus might have felt that there was little alternative to using the verb 'toleratur'. For an in-depth analysis of the - complex and articulate position of the heretic in Rufinus see the beautiful pages of Maceratini (1994), pp. 392-414, where ample literature is mentioned.

52 Singer (ed., 1963) p. 200, note 1.

53 Rufinus, ad C1, q.1 (BNF Lat. 4378, transcription in Singer [ed., 1963], pp. 200-201, note 1): '.. Relevantur quattuor modis: necessitate scil(icet) urgente; utilitate, sc(ilicet) si utilis est persona; abrenuntiatione, cum abrenuntiat; satisfactione. Sed in relevatione distinguendum est: quandoque [simonia est] in promovendo, quandoque in promotione, quandoque in promovente. Cum in promovente, nullo modo toleratur; cum in promotione - scil. data pecunia eo inscio -, post renunciacionem toleratur; cum in promovendo, si probaverit se ignorare promoventem simoniacum, toleratur ...'

$54 A d$ C.1 q.7 pr (ibid., pp. 232-233, note 1): ‘ $\ldots \$$ Necessitatis intuitu: Intuitus nec. triplex est: peccantis, peccaturi et corrigentis. Peccantis, quia quandoque tanta est persona, ut, si corrigi non possit, toleratur (em.: toleretur) necessitate; peccaturi, ut: si etas minaretur incontinentiam; corrigentis, quia forte prelatus corrigere non valet.' 
It has been observed how the important Summa of Stephanus Tornacensis (Stephen of Tournai, 1128-1203), probably composed in the 1160 s, ${ }^{55}$ diverges from Rufinus' and bears a stronger resemblance with that of Rolandus. ${ }^{56}$ This is also visible in Tornacensis' use of the concept of toleration. As already mentioned, part of his comment on C.24, q.1, was taken almost verbatim from that of Rolandus. ${ }^{57}$ The concept of toleration in Tornacensis is however both more frequent and better defined than in Rolandus. Unlike Rolandus, Tornacensis uses it very seldom in a loose moral sense. ${ }^{58}$ While not all the examples of toleration in his Summa deal with problems of ordo and iurisdictio, ${ }^{59}$ it is there that Tornacensis uses this concept the most.

When speaking of toleration, Tornacensis operates a neat distinction between ethical and legal judgments. While there is little doubt as to the moral reprobation of the person tolerated ${ }^{\mathbf{6 0}}$ for Tornacensis the fact that he is tolerated entails the faculty to fully exercise his office. This is particularly clear in his comment on C.24, q.1, p.c.4. There, the Decretum stated that the Lord had bestowed the power of loosing and binding (i. e. jurisdictional powers) ${ }^{\mathbf{6 1}}$ only to the true prelates (veris $\left[\right.$ sacerdotibus]), not the false ones (falsis sacerdotibus). ${ }^{62}$ Tornacensis' gloss on veris reads, 'Christians whom the Church tolerates, although otherwise they are evil' (catholicis quos tolerat ecclesia, licet alias sint mali); that on falsis, 'those whom the Church does not tolerate, those deprived of office or any heretic whatsoever' (quos non tolerat ecclesia, degradatis uel quibuslibet

Kuttner (1937), p. 135 (slightly postdating its writing with respect to Schulte [ed., 1965], xx).

Kuttner (1937), p. 135.

58 See for instance Tornacensis' Summa ad C.1, q.1, c.88, $\mathbb{S}$ Chr(istus) $q$ (uid) f(ecit) (Schulte [ed., 1965], p. 137): 'q. d. exemplum nobis tolerandi malos reliquit'. On the surface, the gloss seems to suggest only that the wicked are to be suffered. But all the other glosses both before and after this deal with the sacraments performed by heretics and schismatics.

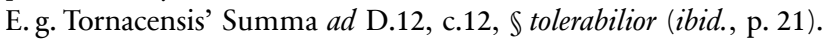

60 See esp. Tornacensis' Summa ad C.1, q.1, c.33, $\$$ Nec intus (ibid., p. 129): 'participationem sacramentorum, i. e. nec ille, qui adhuc toleratur ab ecclesia.' The text upon comment (Augustine's De Baptismo, 4.12) stated 'Nec foris ergo, nec intus quisquam, qui ex parte diaboli est, potest in se, uel in quoquam maculare sacramentum, quod Christi est.' The words 'qui adhuc toleratur ab ecclesia' therefore referred to 'quisquam' is 'ex parte diaboli'.

61 On the reticence of some early decretists to identify the potestas clavium with iurisdictio see Van de Kerckhove (1937), pp. 440-453. The author perhaps overemphasises the importance of the Gratian's reference to the Power of the Keys on the separation between ordo and executio.

62 C.24, q.1, p.c.4: '... Ligandi namque uel soluendi potestas ueris, non falsis sacerdotibus a Domino tradita est ...' 
bereticis). ${ }^{63}$ This interpretation will be followed by other decretists, starting with the Summa of Johannes Faventinus (d. c.1191), composed at the beginning of the 1170s, ${ }^{64}$ and the Apparatus Ordinaturus Magister, written in the following decade. ${ }^{65}$ In both these works the distinction veri-falsi is entirely based on the dichotomy tolerati-non tolerati. ${ }^{66}$ The same distinction will also be used (but, as we will see, in a narrower sense) in Teutonicus' Gloss. ${ }^{67}$ The concept of toleration in Tornacensis is consistent also when the verb form is used in the negative (non tolerari). Not tolerating someone means denying the valid exercise of an office, and so barring the production of any valid legal effect. ${ }^{68}$

63 Tornacensis' Summa ad C.24, q.1, p.c.4, $\$$ Veris and $\$$ Falsis (Bruxelles 1410, fol. 118rb, transcription in Lenherr [1987], p. 272). It is probably in this light that the meaning of tolerare in other passages ought to be read. See e. g. D.32, c.5, $\$ N$ ullus (i.e. 'Nullus missam audiat presbiteri, quem scit concubinam indubitanter habere aut subintroductam mulierem') (Schulte [ed., 1965], p. 48): 'Signatur contra infra C.15 q. ult. C. ult. [C.15., q.8, c.5] et multa similia. Unde quidam solver volentes dicunt canonem istum esse dandae sententiae, quasi quo insinuetur, quid fieri debeat, si detur sententia in eum; nam antequam procedat sententia ex dando canone non est cavendum ab huiusodi, qui usquequo ab ecclesia tolerantur, praetextu criminis eorum officium subterfugere non licet, ut i(nfra) C.3. Q.7 paragrapho ult(imo) [C.3, q.7, p.c.7]'; D.32, p.c.6 \$non spernetur (sic) (ibid., p. 48): 'per damnationis sententiam. Nam quamdiu tolerantur ab ecclesia, si ab habentibus potestatem et in forma ecclesiae ordinati sunt, vera sunt eorum sacramenta, licet non quantum ad ipsos'); D.81, c.3, \sacro nomini (scil., episcopali) (ibid., p. 104): 'Quod esset, si talem ecclesia toleraret'; De cons. D.1 (ibid., p. 261): '... Primum ergo [Gratianus] quasi ad morum informationem ostendens, qui vel quales, ad quos ordines, per quos promovendi vel non; et in his constituti, ob que delicta amovendi vel ex misericordia in eis tolerandi'. See also ad C.1, q.1, c.30, $\$$ Si fuerit iustus (ibid., p. 129): '... hic loquitur de sacramentis necessitatis, quae semper habeant effectum, a quocunque dentur, nisi culpa accipientis impediat, ibi de sacramentis dignitatis. Vel hic agitur de haereticis vel simoniacis ex necessitate vel coactione ab his, quos adhuc tolerat ecclesia, ordinatis, ibi de his, qui iam damnati sunt'.

Maassen's dating of Faventinus' Summa to 1171 (Maassen [1857], p. 31) has been widely accepted by scholars. See e. g. Kuttner (1937), p. 145, and more recently Müller and Pennington (2008), p. 138.

65 On the dating of this Summa see Stickler (1967), pp. 134-137, and Lenherr (1987), p. 238, note 91. See further Maceratini (1994), pp. 633-636.

66 Faventinus, ad C.24, q.1, p.c.1, $\mathbb{S}$ Veris catholicis (Madrid, BN 421, fol. 160rb): 'quos tolerat ecclesia, licet alias sint mali. Falsis quos non tolerat ecclesia.' Apparatus Ordinaturus Magister, ad C.24, q.1, p.c.4, \$potestas ueris (BSB, Clm 10244, fol. 143va, transcription in Lenherr [1987], p. 301): 'idest catholicis, scilicet toleratis ab ecclesia, siue sint boni siue mali, sicut falsi dicuntur omnes non tolerati ab ecclesia.'

67 Infra, this chapter, note 154.

68 E.g. Tornacensis' Summa ad C.1, q.1, c.18, $\$$ Ventum (ad) tertiam q(uaestione) [scil., that he who is ordained by a heretic receives a spiritual wound] (Schulte 
Similarly interested in the concept of toleration is Sichardus of Cremona (c.1155-1215), whose Summa (probably composed between 1179-1181) ${ }^{69}$ seeks to mediate between the firm position of the Decretum on the invalidity of the sacraments performed by those lying outside the Church (in whom the Holy Spirit does not operate) and the more flexible Augustinian position (seeking to facilitate their reconciliation with the Church). The fruit of this mediation is a keen interest in the idea of toleration. ${ }^{70}$ What is important for our purposes is that Sichardus openly links the toleration of heretics with its practical consequences in terms of the exercise of jurisdiction by the heretical office holder tolerated in his office. In so doing, Sichardus highlights the distinction between the office and the personal worthiness of its holder. So long as the holder of the office is tolerated within the Church despite his heresy, says Sichardus, he may issue valid decisions. ${ }^{71}$

Not all the main decretists, however, would rely explicitly on the concept of toleration to explain - and moreover highlight - the separation between person and office in the exercise of jurisdiction by the heretic not (yet) excommunicated. It might be the case that some authors within the Italian milieu were

[ed., 1965], p. 126): '... Intendit Innocentius probare, quia ordinanti ab haereticis non sunt reordinandi, nec in ordinibus ab eis susceptis tolerandi.' See also ad D.32, p.c.6 $\$$ Cet(erum) schismat(icorum) et haeret(icorum) (ibid., p. 49): 'qui damnati sunt et ab ecclesia non tolerantur'; ad D.50, c.56, $\$$ ad subdiaconum (ibid., p. 75): 'nam si supra nec etiam ex dispensatione poterit in eo ordine tolerari.'

69 Kuttner (1937), pp. 151-153.

70 Cf. Lenherr (1987), pp. 217-218.

71 Sichardus of Cremona, ad C.24, q.1 (BSB, Clm 4555 and 11312, fol. $56 v$ and fols. $121 v-122 r$ respectively, transcription in Lenherr [1987], p. 287, 1l.12-25): '... Item qui non est in unitate non consecrat. Est enim consacrare simul sacrare. Item non est Christi corpus quod scismaticus conficit. Item di. xii. Nulli [Di.19.c.5?]. Econtra. quia sacramentum absorberi non ualet, unde recedentes a fide sicut nec baptisma sic nec baptizandi potestatem amitttunt. Item quia dicit Aug(ustinus) excommunicatos ab hereticis non esse recipiendos a catholicis. Item quia uidemus ordinatos $a b$ hereticis in suis ordinibus toleratos, ut ca. i. q. ult. Quod pro [C.1, q.7, c.7]. R(esp.): hereticus si toleratur, potest sententia notare de offitio, set non de iure merito; si non toleratur, nullo modo potest, nec catholicum, nec hereticum. Quod autem Aug(ustinus) dicit non esse recipiendos ab hereticis excommunicatos (sic), non hoc dicit approbando hereticorum excommunicationem, set inprobando criminum detestationem et facilem hereticorum reconciliationem.' It may be interesting to note that the line 'si toleratur, potest sententia notare de offitio, set non de iure merito' appears only in one of the two Munich manuscripts cited above: it is present in BSB, Clm 11312, but not in the main one, BSB, Clm 4555 (ibid., p. 287). The same passage is transcribed by Maceratini (1994), p. 663, note 313, from Augsburg 1, fol. $119 \mathrm{r} a-b$, but the text does not present significant differences. 
somewhat more reluctant to use it than their French counterparts, as we shall soon see. So for instance the Summa of Simon of Bisignano (Simonis de Bisignano, fl. 1170s) ${ }^{72}$ likely written between 1177 and $1179,{ }^{73}$ does not refer to toleration, but qualifies the sentence of excommunication brought forth by the heretic as valid (sententia eius teneat) because the Church has yet to deprive him of his office. Bisignano makes clear that the validity of the sentence has little to do with the unworthy person of the heretic and depends only on his office, but he does not qualify the state of the heretic not yet deprived of his office as toleration. $^{\mathbf{7 4}}$

The great canonist Huguccio (Huguccio Pisanus, d.1210) is rather parsimonious in speaking of toleration as well, but he uses this concept in his Summa (written in the years $1188-1192)^{75}$ on at least three occasions. The first, rather a topos, is with regard to Judas: unlike other heretics (the reference is to Achiatus) who were cast out of the Church, Judas was tolerated within it. Despite his wickedness, therefore, his deeds would retain full legal validly. ${ }^{76}$ The second and more important occasion is on the exercise of jurisdictional prerogatives. It is well known that Huguccio sought to separate the potestas iurisdictionis neatly from the potestas ordinis. ${ }^{77}$ When discussing the iurisdictio of the heretics not yet

72 On Bisignano see esp. Junker (1926), pp. 327-332.

73 Junker (1926), p. 332; Kuttner (1937), p. 149.

74 Simonis de Bisignano's Summa, ad C.24, q.1, c.35, $\mathbb{E}$ ex quo talia predicare (Augsburg 1 and Bamberg Can.38, fol. 49rb and fol. 77rb-va respectively, transcription in Lenherr [1987], p. 286): 'Hinc uidetur innui, quod si hereticus aliquem excommunicat uel degradat, quamdiu eius heresis latet, quod sententia eius teneat, licet non possit hoc de uite merito facere, set de offitio, quo nondum est iuditio ecclesie expoliatus.' Elsewhere, speaking more in general, Bisignano said the opposite, but he did so referring specifically to the personal dignitas and not to the office: ad C.1, q.1, p.c.39, $\$$ Si ergo usque alia sunt dignitatis, Summa in Decretum Simonis Bisinianensis (Aimone-Braida [ed., 2014], pp. 101-102, 11.244-253).

75 Lenherr (1981), pp. 12-13; Kuttner (1937), pp. 157-158; Müller (1994), pp. 71-73.

76 Huguccio's Summa ad D.19, c.8, $\$$ scribe inquit: '... Set exempla de Iuda et scribis et phariseis non uidentur multum efficiacia, quia illi tolerabantur, iste [scil., Achatius] precisus erat.' $\$$ Secundum: 'Tertia [scil., the third reason why it is possible to ratify the deeds of the heretic condemned] est de Iuda qui, licet malus, multa tamen fecit que rata habita sunt.' (Huguccio Pisanus, Summa decretorum, Přerovský [ed., 2006], tom. 1, p. 321, 11.58-59, and 318, 11. 10-11 respectively). On the validity of Judas' deeds ('rata habita') cf. Rufinus' gloss ad C.1, q.1, c.108 ('habebuntur rate'), supra, this chapter, note 51. For a parallel with Gratian's idea of toleration of Judas see recently Moule (2016), pp. 271-272, where further literature is listed.

77 Huguccio did so through the use of another concept, that of potestas executionis. On the point see Ryan (1972), pp. 319-320; Benson (1968), pp. 116-133, esp. 
excommunicated, he clearly states that they would not lose their power to bind and loose. In so doing, Huguccio refers to the concept of toleration, but makes sure to clarify that the validity of the act would depend on the office, not on the person. The jurisdictional acts of the wicked tolerated by the Church are valid 'saltem ex offitio suo', for God operates through the ministry of the wicked (per ministerium malorum) tolerated within the Church, as well as the ministry of the righteous ones. ${ }^{78}$ The third case is to be read in the light of these observations. It is Huguccio's comment on Tria (C.3, q.7, p.c.1). This comment contains one of the earliest references to the lex Barbarius by a canon lawyer. Huguccio cites it to affirm that the prelate who received his orders or a prebend from someone who was believed to be within the Church ought not to be deprived of it when the truth finally emerged. ${ }^{79}$ Huguccio continues his comment on Tria, applying the same rationale to legitimise the offspring of a wedding believed to be valid, thereby providing what is probably one of the first examples of the extension of the toleration principle to marriage issues. ${ }^{\mathbf{8 0}}$

120; Lenherr (1981), pp. 369-372. See also Huguccio's gloss ad C.23, q.1, c.4, $\$$ Non est potestas nisi a deo, siue iubente (Vat. Lat. 2280, fol. 244ra, transcription in Lenherr [1981], p. 36, esp. 1l.1-15). Cp. however the observations of Van de Kerckhove (1937), p. 451.

78 Huguccio, ad C.1, q.1, c.39, $\mathbb{S}$ Raptoribus, fenera (toribus) (Vat. lat. 2280, fol. 93rb$v a$, transcription in Lenherr [1987], p. 297, 1l.18-30): 'Per hos intelliguntur omnes mali iam ab ecclesia precisi et extra ecclesiam positi, de hereticis enim precisis intelliguntur, non de catholicis ab ecclesia tolleratis, licet sint mali, ut infra ea q. Etiam corde [C.1, q.1, c.48] et xxiiii. q.i $\$$ Si autem [C.24, q. 1, p.c.4], ne littera sequens aliter congrueret, omnibus enim catholicis, siue bonis siue malis, sacerdotibus, dum tollerantur ab ecclesia conuenit, saltem ex offitio suo, soluere et ligare ... hanc potestatem exercere potest, ut xxiiii. q.i Manet, Quodcumque [C.24, q.1, c.5-6]. Potest tamen dici, quod et de malis adhuc ab ecclesia tolleratis intelligitur, sicut littera precedens uidetur uelle, quia, etsi per ministerium malorum sicut per bonorum deus peccata dimittit, illud tamen non est dictum nisi bonis et propter bonos.'

79 Huguccio, ad C.3, q.7, p.c.1, $\ d u m$ putaretur (Vat. lat. 2280, fol. 134rb-va, transcription in Wilches [1940], pp. 78-79): 'arguo: illud quod fit ab aliquo, tunc cum creditur id recte facere posse, licet postea inveniatur aliter esse, non debere irritari, et hic habet locum illud generale, scilicet: plus valet quod est in opinione quam quod est in veritate, arguo ff. de officio praetoris, Barbarius (Dig.1.14.3), et ff. de damno infecto, 1. $3 \mathbb{\$}$ hoc autem (Dig.39.2.4.8) et C. de sententiis et intelocutionibus omnium iudicium, l. si arbiter (Cod.7.45.2) et C. 1 q.1 si qui a simoniacis (C.1, q.1, c.108) et C.22, q.1 is autem (C.22, q.2, c.4) et Extra, consultationibus [comp. 1, 3.33.23(=X.3.38.19)] ergo secundum hoc ordinatus vel beneficiatus ab intruso qui credebatur esse catholicus non debet privari ordine vel beneficio.'

$80 \mathrm{Ibid}$., 'et filii nati tunc cum credebatur esse matrimonium licet non esset, legitimi sunt reputandi ut i. Extra, accessit ad praesentiam [(comp. 1, 4.2.6(=X.4.2.5)].' Cf. Albisetti (1980), pp. 194-196. 


\subsubsection{The excommunication by the secret excommunicate}

To test the boundaries of the toleration principle perhaps the best place is C.24, q.1, p.c.39. In this passage Gratian made sure to restrict the interpretation of an Augustinian excerpt on excommunications issued by the excommunicated (epist. 35.2) by highlighting its final goal (to punish the crime: 'in detestatione criminum') and to bar the alternative interpretation (the actual validity of the sentence: 'non propter sentenciam, cuius potestas nulla est extra ecclesiam'). ${ }^{\mathbf{8 1}}$ Gratian stated clearly that the excommunication itself (thus the jurisdictional power to bind and loose) was void, for it was brought by the excommunicated heretic. But what about the excommunication inflicted by the heretic who is not yet excommunicated but who would be excommunicated soon thereafter? Would this excommunication be valid? Ultimately, the problem was to set precise boundaries to the toleration principle: should it also apply to those tolerated only temporarily, or only to those who were tolerated, so to speak, on a permanent basis? The problem was too serious to be overlooked even by those least sympathetic to the concept of toleration itself, such as Rufinus. In principle, Rufinus had little doubt as to the invalidity of the sentence of excommunication: if the heretic cannot judge, how can he excommunicate someone? At the same time, however, he was aware that the invalidity of this sentence could be ascertained only at a later stage. To solve the problem, Rufinus suggested seeking absolution in any case. ${ }^{82}$ Rufinus' solution was vague enough to duck the most intricate issues, first of all the effects of toleration itself - a term that he sought to avoid as much as possible. Among those who allowed for the toleration of the occult heretic, some (including Huguccio) preferred to avoid the problem and interpreted the passage only with regard to the heretic already excommunicated. ${ }^{83}$ Others went further, stating explicitly that the toleration principle also

Cf. C.24, q.1, a.c.1 and p.c.3. See also Vodola (1986), pp. 117-118.

Rufinus, ad C.24, q.1 pr (Singer [ed., 1963], p. 415): 'Si itaque heresim iam damnatam sequitur, eo ipso precisus iudicatur ideoque non potest aliquem deponere vel excommunicare; si autem novam heresim confinxerit, quamdiu per sententim episcoporum reprobatus non fuerit, licet ipse de iure non possit aliquem solvere vel ligare, tamen eum, qui ab eo ligatus fuerit absolutionem querere oportebit, si tamen sub eius iurisdictione positus sit' (emphasis added). The problem is whether 'oportebit' is to be understood in an ethical or a strictly legal sense: in the first sense see Lenherr (1987), p. 199; in the other Maceratini (1994), p. 395. While it may not be excluded that the use of oportere denoted a legal necessity, the opposite interpretation would seem more coherent with Rufinus' overall position on the (non) toleration of the heretic.

Huguccio's Summa, ad C.1, q.1, c.39, \aliquis (Vat. lat. 2280, fol. 93rb-va, transcription in Lenherr (1987), p. 298, 11.52-55); Summa Tractaturus Magister, ad C.24, q.1 pr (BNF, Lat. 15994, fol. 71v, transcription in Lenherr (1987), p. 305, 11.8-10); Summa De iure canonico tractaturus, ad C.1, q.1, a.c.30, $\mathbb{S}$ Set obicitur

6.3 The decretists and the concept of toleration 
applied with regard to the occult heretics who would be excommunicated later. So long as those heretics are tolerated, the validity of their jurisdictional acts is

(Laon 371bis, fol. 108vb, transcription in Lenherr (1987), p. 313, 11.6-9. Cp. however Honorius' Summa decretalium quaestionum, infra, this paragraph, note 85). Less explicit, but possibly in the same direction is the Apparatus Ecce vicit Leo: the gloss ad C.24, q.1, c.39, $\$$ Penitencie recipiatur ('Solutio est in $\$$ sequenti [C.24, q.1, p.c.39], quod scilicet ista sententia appellatur non quia ualent set in odio criminis') must be read together with that ad C.24, q.1, c.38, $\mathbb{S}(Q)$ uisquis ('... Recipiuntur tamen quandoque, quia heretici non probabant, cum nullus propter peccatum occultum debet euitari') and the one ad C.24, q.1 pr (on which see infra, this chapter, note 100) (St. Florian XI.605, fols. 93rb-95ra, transcription in Lenherr [1987], p. 324, 11.15-17, p. 323, 11.5-6, and p. 322, 11.1-15 respectively). Interpreting the first two in the light of the third (which comes first and serves as proemium for the whole quaestio), then the only logical solution would be that the gloss on C.24, q.1, p.c.39 has a narrower scope, and it refers only to those already excommunicated. See also the Summa Animal est substantia, ad C.24, q.1, c.39, \Degradatus (Liège 127.E, fol. 216va, transcription in Lenherr [1987], pp. 327-328, 1l.15-19). A similar position may be found in the Summa Coloniensis, whose stance on the matter is interesting as it represents well the approach of many decretists in the first few decades after the composition of the Decretum, an approach based more on ecclesiological than legal considerations. Someone who is excommunicated cannot excommunicate, says the Summa Coloniensis. His sentence of excommunication would therefore be void. According to the Summa Coloniensis, Augustinus' words mean that, if the crimes for which such a (void) sentence was brought were true, then the effects of that sentence could be kept: 'Qvod excommvnicatvs alios excommvnicare non possit. Illa etiam dubitatio silentio pretereunda non est utrum sacerdos uel episcopus excommunicatus alios excommunicare possit ... Si tamen hereticus aliquis [excommunicatus] asseclas suos pro ueris culpis excommunicauerit, tale uinculum in redeuntibus ab ecclesia non paruipendi Augustino placet ... Non potest excommunicare, idest extra communionem ecclesie facere, sic nec soluere, idest Deo et ecclesie reconciliare; potest tamen pro [ueris culpis et] iustis causis obedientem suum ita ligare ut hec uincula ad aggrauandam penitentiam in redeunte ecclesia agnoscere debeat.' Summa 'Elegantius in iure divino' seu Coloniensis (Fransen and Kuttner [eds., 1978], tom. 2, pt. 7, ch. 74, pp. 194-195, 1l.1-3, 18-20 and 30-34 respectively). The same Summa Coloniensis also attests to the terminological confusion as to sacraments of dignitas still lingering in the early decades of the second half of the twelfth century. Its author first introduces the distinction between sacraments of necessity and of dignity speaking of sacramenta necessitatis and sacramenta voluntatis ('Sunt enim alia necessitatis, alia uoluntatis', ibid., tom. 2, pt. 4, ch. 55, p. 24, 11.2-3). Shortly thereafter, when applying this distinction to sacraments performed by the heretic, he describes the second kind of sacrament as sacramenta dignitatis ('Mali ergo ministri, sint catholici sint heretici ut hic dicunt, uera necessitatis sacramenta conferunt, dignitatis uero sacramenta heretici nullatenus conferre possunt ... Ecce euidenter asserit quod dignitatis sacramentum hereticus conferre non ualet, necessitatis uero sacramenta uera proculdubio hereticus confert', ibid., 11.11-12 and 20-21). Zeliauskas' vast study (1967), in many ways truly impressive, is unfortunately 
full. It follows that the sentences of excommunication that they issued would remain valid even after their own formal excommunication. A clear example in this direction may be found in the Summa decretalium quaestionum of Honorius of Richmond (composed no later than c.1190) ${ }^{84}$ Honorius explained clearly that the sentence of excommunication, being an application of the broader power to bind and loose, does not pertain to ordo but to iurisdictio, so that it flows from enduring participation in the Church. If one is cast away from the Church, he may no longer validly exercise it. However, so long as he is tolerated within the Church, his personal unworthiness (secus de merito) is no obstacle to the exercise of the jurisdictional powers flowing from his office (possunt soluere et ligare ex officio). This means that it is not possible to consider suddenly void a jurisdictional act that was perfectly valid when issued. As such, concludes Honorius, if someone is excommunicated by a prelate who would himself be pronounced excommunicated at a later stage because of the heretical condition in which he already was when he issued the sentence, he has to seek absolution not just for prudence's sake (as with Rufinus), but because the excommunication was legally binding. ${ }^{85}$

not of much use in the present analysis. Zeliauskas discusses briefly the excommunication levied by the heretic, but only focuses on the case of the heretic fallen in an already condemned heresy without comparing it with that of the occult heretic. The author bases his conclusions mainly upon the glosses on C.11, q.3, c.46. That was a very general text, and of course its comments could do little but deny the validity of the excommunication by the heretic. As a result, Zeliauskas could not find a single canon laywer before Innocent IV arguing in favour of the validity of the sentence of excommunication issued by the heretic: Zeliauskas (1967), pp. 111-113. His remarkable set of transcriptions therefore does not take into account the glosses on C.3, q. 7, p.c.1 and C.24, q.1, c.1, which are the most important places where the decretists dealt with the excommunication by the occult heretic.

84 Kuttner and Rathbone (1949-1951) p. 310. See further Grimm (1989), pp. 5-9.

85 Honorius of Richmond, Summa decretalium quaestionum (BSB, Clm 16063, fol. 73rb-va, transcription in Lenherr [1987], pp. 314-315, 11.22-27; punctuation as in the original): 'Ceterum conficere uel sacramenta cetera ministrare ex ordine prouenit. Vnde et ordinem habentes ea possent expedire, secundum G. Preterea soluere uel ligare non est sacramentum dare, set diuine solutioni uel ligationi testimonium dare, quod nec apud Deum nec apud homines heretici facere possunt, ut xxiii q.iiii Ipsa (C.23, q.4, c.24), secundum C. Alii uero heretici, dum adhuc ab ecclesia tolererentur, suos possunt soluere et ligare ex officio, secus de merito. Quid ergo si in tempore (?) quo ligat suum subditum ab ecclesia tolerabantur et postea preciduntur? $\mathrm{R}$ (responde) $\mathrm{O}: \mathrm{Ab}$ aliis soluentur, quod in pluribus articulis contingit, ut xi q.iii. Si episcopus ante (C.11, q.3, c.40).' Although the Summa de Iure Canonico Tractaturus is also attributed to Honorius of Richmond (Weigand [1976], esp. pp. 196-198), it would appear less open to the full acceptance of the toleration principle than the Summa decretalium quaestionum. This may be seen in the way the Summa de Iure Canonico Tractaturus 
If we turn our attention for a moment to France and go back a few decades, we may find some Summae making extensive use of the concept of toleration. The most explicit on it is probably the Summa Parisiensis (probably written in the $1160 s),{ }^{86}$ which makes overabundant use of this concept. Sometimes toleration is used to better explain a passage in the Decretum ${ }^{87}$ or in connection with public utility. ${ }^{88}$ In some occasions it denotes forgiveness, ${ }^{89}$ dispensation, ${ }^{90}$ forbearance, ${ }^{91}$ or has a rather generic sense. ${ }^{92}$ But its more interesting use is to be found in the sacramental sphere. The Summa Parisiensis fully accepts the distinction between sacraments of necessitas and of dignitas, a distinction mainly shaped after Gratian's restrictive interpetation of the Augustinian passages we have seen

deals with the jurisdictional implications of toleration (supra, this paragraph, note 83 ), and with the sacramental ones, on which see esp. its comment on D.32, p.c.6, $\mathbb{S}$ Ad hoc uero: '... utrum sacramenta a criminosis sint suscipienda, quia nondum sunt per sententiam dampnati nisi eorum crimina sint notoria. A quibus, etsi adhuc a prelatis tolerantur, a subditis sacramenta non sunt percipienda nisi forte in morte', Magistri Honorii summa 'De iure canonico tractaturus' (Weigand, Landau and Kozur [eds., 2004], tom. 1, p. 111, 1l.3-6). Cf. also ibid., ad C.3, q.7 pr, $\mathbb{Q}$ Quod iudex, and ad C.3, q.7, c.4, $\mathbb{\$}$ Iudicet - quod - condempnet (both supra, this chapter, note 30 ).

86 McLaughlin (1952), xxxi-xxxiii.

87 See e.g. Summa Parisiensis, ad D.12, c.8, $\$$ Nos consuetudinem (McLaughlin [ed., 1952], p. 12): '... Unde dicit Gregorius, si sunt magnae civitates quae habent episcopos de Donatistis quos revertentes ab haeresi in episcopatu toleramus [the Decretum read 'permanere concedimus'], licet illae civitates debeant habere primates, non tamen volumus hos tales esse primates.'

88 Id., ad D.64 c.8, \$ illud generaliter (ibid., p. 57): 'Contrarium videtur quod dicitur in prima Causa (C.1, q.1, c.40), talis enim i.e. a pseudoepiscopis ordinatus, permittitur celebrare in ecclesia in qua ordinatur est. Et supra habuimus de ordinato sine auctoritate domini papae, praecepto imperatoris, qui permittitur in ordine. Sed illud est speciale, et toleratur quandoque pro utilitate vel dissensione populi, ut in ea in qua ordinatus est ministret tantum ecclesia. Istud vero generale est. Vel dicimus sic ordinatus non erit episcopus, i.e. non habebit generalem potestatem episcopi ut ubique possit exercere officium suum, sed forte ex indulgentia celebrabit tantum in ecclesia sua.'

89 E.g. Id., ad D.22, c.5, $\mathbb{S}$ Qua traditione (ibid., p. 22): 'Papa deposuerat Constantinopolitanum et alios per haeresim, Antiochenus et alii in pace tolerabant resipiscentes ab haeresi ...' Cf. also Id., ad C.1, q.1, c.101, $\mathbb{Q}$ Quidquid (ibid., p. 89).

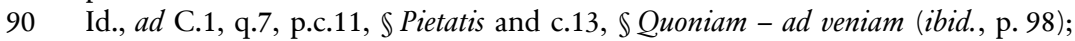
Id., ad C.1, q.7, p.c.17, $\mathbb{S}$ de laicis and c.21, $\mathbb{S}$ maneant in quo inveniuntur (ibid., p. 99); ad C.5, q.2, c.2, $\$$ deportentur (ibid., p. 129); ad C.33, q.2, c.13 $\$$ Audivimus (ibid., p. 251).

91 Id., ad C.11, q.3, c.90, $\mathbb{Q}$ Qui - habet praemium (ibid., p. 129); C.23, q.4 pr (ibid., p. 213).

92 E. g. Id., ad D.38, c.12, $\$$ Non quia; Id., ad D.41, c.3, $\$$ Non cogantur; Id., ad D.45,

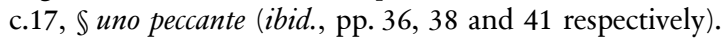


earlier. ${ }^{93}$ Only those who lie within the Church may confer the sacraments of dignitas. As wicked priests tolerated by the Church do lie within it, they may validly confer all sacraments. ${ }^{94}$ The same solution is then applied to the jurisdictional sphere: the heretic tolerated by the Church lies within it, so he retains his full powers to bind and loose. It is with regard to the power of iurisdictio more than of ordo that the Summa Parisiensis uses the concept of toleration more frequently, and with more precision. The author of the Summa has little doubt that the occult heretic may validly exercise his jurisdictional powers to their full extent, and highlights more than most before him the full validity of the jurisdictional acts made by the heretic tolerated ('potestatem habet ligandi atque solvendi, et quaecumque geruntur rata sunt et firma'). In so doing, the Summa Parisiensis openly considers this validity as deriving from the office that the tolerated heretic holds. Tolerating the heretic in the Church therefore means not depriving that person of his office, and so letting him exercise it in full..$^{95}$

93 Supra, this chapter, $\$ 6.1$.

94 Id., ad D.19, c.8, $\$$ Secundum ecclesiae (ibid., p. 19): 'Hoc scilicet continet erroris quod falso argumentatur a simili videlicet a similitudine sacramenti necessitatis ad sacramenta dignitatis. Et argumentatur a similitudine mali non depositi ut Judae ad damnatos. Baptismus siquidem, quia necessarius est ad salutem, datum per excommunicatum, sicut daretur per paganum, non irritatur. Similiter si aliquia malus toleretur ab ecclesia, ut Judas, sacramenta etiam dignitatis data per episcopum recipiuntur in unitate.' See also Id., ad D.32, c.5, $\$$ Nullus (ibid., p. 31): 'Ad hoc capitulum et ad sequens opponit Gratianus ut solvat dicens quia sacramenta, sive per bonum sive per malum, non minus sunt sacramenta, ergo non debet quis abstinere a missa, etc. Sed de his diffusius agitur in prima Causa. Breviter tamen dicendum quoniam dum aliquis toleratur ab ecclesia, sacramenta sunt quae conficit. Similiter qui primo fuit in ecclesia, si se separaverit sive separaretur, non depositus, sacramenta conficit, maxime si in forma ecclesiae. Si vero depositus est, non conficit'; ad C.1, q.1, c.75, $\mathbb{S}$ Sic Christus (ibid., p. 85): 'Hanc oppositionem determinat Gratianus dicens: quia loquitur Hieronymus de occultis haereticis qui tolerantur ab ecclesia, quia aliter sibi contrarius esset, et ad ostendendum quia mali qui sunt in ecclesia conficiant sacramenta sicut boni, inducit multas auctoritates'; Id., ad C.1, q.6: $\$$ Quid vero (ibid., p. 96): 'Quaestio sexta superius est terminata ubi diximus de simoniacis qui tolerantur ab ecclesia et ordinant quia rata est ordinatio. Similiter si sint extra ecclesiam propter simoniam et aliquis ignorantia rationabili ordinatur ab eis.' Cf. also Id., ad C.24, q.1, p.c.37, $\$$ His auctoritatibus (ibid., pp. 226-227).'

95 See esp. Id., ad C.24, q.1 pr (ibid., p. 223): '... haereticorum autem alii tolerantur $\mathrm{ab}$ ecclesia; alii sunt praecisi. Qui ab ecclesia sunt praecisi, omnem potestatem et ligandi et solvendi amiserunt. Quaecumque $a b$ eis geruntur qui tolerantur $a b$ ecclesia, si in forma ecclesiae fiant, rata sunt pro loco, pro tempore, pro dignitate, pro officio, sicut in I Causa dictum est. Dant igitur tales sacramenta etsi non de jure merito, tamen de potestate officii.' Cp. Id., ad C.24, q.1, p.c.4 $\$$ Haec autem (ibid.): 'Multas inducit auctoritates Gratianus ad ostendendum quod qui ab 
A couple of decades after the Summa Parisiensis, the Anglo-Norman Summa Omnis qui iuste iudicat or Summa Lipsiensis (composed shortly after 1185, possibly in 1186$)^{96}$ explains the toleration of jurisdictional acts in a similar fashion. Having clarified that only those who received ordo after the forma ecclesiae may be tolerated ${ }^{97}$ (a point that the Summa Parisiensis omitted), the Summa Lipsiensis explains the jurisdictional consequences of the toleration principle by stressing

unitate ecclesiae praecisus est, quicumque Petri vestigia [non] sequitur, potestatem ligandi et solvendi non habet, et ita pertinent ad quaestionem quae [de] dignitate et excellentia ecclesiae dicuntur.' See also Id., ad C.24, q.1, p.c.37, $\$$ His auctoritatibus (ibid., p. 227): '... Quaeritur etiam si haereticus in Catholicum sententiam excommunicationis dictare valeat, si etiam haereticus haereticum excommunicare queat. Si forte haereticus Catholicum excommunicet nulla [causa] praecedente, sed ut haeresi suae consensiat, quia nulla causa subest, pondere caret sententia. Si vero non ut in haeresim trahat, sed ut pravitate retrahat, haereticus Catholicum excommunicet, tenet sententia, maxime dum toleratur ab ecclesia.' To better appreciate the innovative position of the Summa Parisiensis on the point, it might be useful to look at another Summa composed about a decade later (supra, this chapter, note 41) in Köln. Like the Parisiensis, the Summa Coloniensis also states that the occult heretic tolerated by the Church retains his powers of iurisdictio (Summa 'Elegantius in iure divino' seu Coloniensis, Fransen and Kuttner [eds., 1978], tom. 2, esp. pt. 4, ch. 61, p. 27, 1l.1-8). But then it tests the scope of such toleration when applied to sacerdotal ordinations. It does so by posing the case of a bishop who was received in the Church (out of mercy) despite having been ordained by an excommunicate. In principle, this bishop should be able to exercise his iurisdictio, and so also to confer executio potestatis to any new priest he would consecrate. But on this last point the Summa shows some uncertainties. It acknowledges the validity of the ordinations performed by such a bishop, but not as a consequence of being received within the Church. Rather, the Summa stresses both the large number of priests ordained by the bishop (thus, the public utility element) and the fact that the bishop himself was not only consecrated but also confirmed. Even so, however, the Summa leaves open the possibility that something might be found against the newly ordained priests. After all, reasons the Summa, this bishop was ordained by a heretic, so there is the risk that he might have passed on the same heresy to the new priests he ordained. What is particularly interesting is that the author of the Summa does not consider the validity of their ordination as automatically following from the fact that the bishop was accepted within the Church. The Church did accept the bishop, says the Summa, but it did not provide anything specifically for the priests he consecrated: 'Set queritur si episcopus ab excommunicato consecratus per misericordiam receptus sit qui alios multos ordinauit, de quorum receptione nichil expressum fuit, an debeant et ipsi tolerari. Sane dici potest quod ipso in honore confirmato, nisi aliud aliquid aduersos eos probetur, et ipsi subsistent' (ibid., pt. 7, ch. 77, p. 196, 11.1-5).

96 Kuttner (1937), p. 197, and esp. Landau's Introduction to the Summa 'Omnis qui iuste iudicat' sive Lipsiensis, Weigand, Landau and Kozur (eds., 2007), tom. 1, ix-x. Supra, this chapter, note 43 . 
the relationship between the person tolerated and the office held, thereby fully distinguishing toleration in office from moral approbation of the office holder. ${ }^{98}$

By the close of the twelfth century, the idea of toleration had a sufficiently clear shape. Moving forward a few years but remaining in France, the Apparatus Ecce vicit Leo (probably composed in the first decade of the thirteenth century) ${ }^{99}$ fully distinguishes ordo from iurisdictio, and clearly explains the jurisdictional consequences of the toleration principle: ${ }^{\mathbf{1 0 0}}$

This is the first question, whether a cleric may bind someone with a sentence of excommunication. A distinction should be made between the heretic who follows a new heresy and the one who follows an already condemned one. A new heresy is that which has not yet been condemned by the church; an old heresy is that which has already been condemned. If [he follows] a new heresy he may excommunicate and he is to be tolerated within the church (in ecclesia tolerandus est), for a prelate must always be tolerated within the church until a sentence is brought against him. If however he follows an already condemned heresy he is excommunicated ipso iure together with those who follow it. Being excommunicated he may not excommunicate another, but he may consecrate the sacraments of the church, so long as he follows the church's requirements (forma ecclesie). Hence he consecrates the eucharist and confers baptism, but he may not excommunicate. And this is the reason of the difference: sacraments are administered because of ordo (ratione ordinis) and not of iurisdictio.

98 Summa Lipsiensis, ad C.3, q.7, p.c.2, $\$$ Item in euangelio - probatur: 'Indignus est de merito uite, licet coletur ab ecclesia, idest quamdiu non est dampnatus ex officio suo.' ibid., $\$$ despicitur: 'idest digna inspectione de solito. Ita enim solet fieri, licet hoc fieri non debeat quamdiu toleratur ab ecclesia, ut xv q. ult. c. ult. [C.15, q.8, c.5], supra xxviii. d. Consulendum [D.28, c.17].' (Summa 'Omnis qui iuste iudicat' sive Lipsiensis, Weigand, Landau and Kozur [eds., 2012], tom. 2, pp. 208-209, 1l.1-3 and 3-5 respectively.

99 Kuttner (1937), p. 62. Cf. Schulte (1870), vol. 3, pp. 39-43 [59-63].

100 Apparatus Ecce vicit Leo, ad C.24, q.1, c.1, $\mathbb{Q}$ Quod autem (St. Florian, XI.605, fol. 93rb, transcription in Lenherr (1987), p. 322, 1l.1-15; punctuation as in the original): 'Hec est prima questio, utrum clericus scilicet aliquem possit ligare sententia excommunicationis. Distinguitur ergo de heretico qui aut sequitur heresim nouam aut iam dampnatam. Noua heresis dicitur que non ab ecclesia est dampnata, antiqua que olim est dampnata. Si heresim nouam, potest excommunicare et in ecclesia tolerandus est, $\arg ($ umentum) infra e(adem) q. Achatius (C.24, c.1 c.3). Quod semper prelatus in ecclesia est tolerandus usque ad sententiam contra se latam, arg. supra viii q. iii Nonne (C.8, q.4, c.1). Si autem sequitur heresim iam dampnatam, ipso iure de suis sequentibus est excommunicatus, ut infra e(adem) q(uaestio) c. i et ii (C.24, q.1, c.1-2), unde cum sit excommunicatus, alium excommunicare non potest, ut infra e(adem) q(uaestio) Audiuimus (C.24, q.1, c.34?, De cons. Dist.1 c.30?) infra de cons. di. iiii Non in uobis (De cons. D.4, c.43), non tamen potest excommunicare. Et hec ratio differentie: Sacramenta dantur ratione ordinis non iurisdictionis.' 
While iurisdictio (normally) presupposes ordo, it may not be validly exercised unless within the Church. The status of belonging to the Church, however, is not ethical but juridical. It follows that the concept of toleration is not an exercise of forbearance or an act of mercy, but a legal necessity (in ecclesia tolerandus est). The wicked prelate who is not yet expelled from the Church, therefore, retains full possession of his office and has the right to fully exercise his jurisdictional prerogatives. Once cast away from the Church, however, he may no longer discharge his office, and loses any jurisdictional power associated with it. The concept of toleration therefore postulates a clear distinction between ordo and iurisdictio. Iurisdictio is not (or no longer) just the exercise of the ministry received in the $\operatorname{ord} 0:^{\mathbf{1 0 1}}$ its exercise requires both the valid conferment of ordo and the enduring belonging to the Church. The Apparatus Ecce vicit Leo states clearly that excommunication is a jurisdictional prerogative, and therefore toleration in office entails the power to excommunicate validly. At the same time, however, the same Apparatus bases the distinction between toleration and rejection entirely on the kind of heresy, not also on the condition of the heretic. All followers of a new heresy are to be tolerated, even if they profess it openly. By contrast, someone who secretly adheres to an already condemned heresy cannot be tolerated, even if he is widely believed to be orthodox. This division was not new: it was one of the first interpretations of the (rather unclear) position of Gratian on the subject, ${ }^{\mathbf{1 0 2}}$ which triggered debates as early as in the mid of the twelfth century. ${ }^{103}$

Dividing heretics according to whether their belief was already condemned by the Church or not could make perfect sense for other purposes, but not to clearly define the scope of toleration. For it required to invalidate all the jurisdictional acts already performed by the occult heretic when his heresy was ascertained. Narrowing the effects of toleration only to new heresies thus implicitly required to declare retrospectively void what was commonly believed to be valid. In all likelihood, many of the early decretists who refused to tolerate the person who secretly adhered to an already condemned heresy did not see the issue. The problem became progressively clearer to many canon lawyers when they started to study Roman law more carefully. It is then that the lex Barbarius began to play an important role on the concept of toleration, and precisely in connection with the distinction between heretics already excommunicated and heretics that should be excommunicated. This also means that canon lawyers mainly discussed the lex Barbarius, not in its natural sedes materiae (the list of impediments to render a judgment found in Gratian's dictum Tria, C.3, q.7,

101 See esp. Villemin (2003), p. 83.

102 Supra, this chapter, note 16.

103 Cf. the Fragmentum Cantabrigensis, supra, this chapter, note 48. 
p.c.1), but rather in connection with the jurisdictional powers of the heretic, and so in the second causa hereticorum (C.24), especially its first quaestio.

One of the first cases where the lex Barbarius is used in connection with the jurisdictional powers of the heretic may be found in the Continuatio prima of Huguccio's Summa (the Summa Casinensis, possibly written in 1185-1186). ${ }^{\mathbf{1 0 4}}$ Its author (now considered a student of Bazianus) ${ }^{\mathbf{1 0 5}}$ reports approvingly of the position of Huguccio (and, by then, of many other decretists): the heretic who follows a new heresy not yet condemned by the Church is tolerated in office, and so retains his jurisdictional prerogatives despite his personal wickedness. ${ }^{106}$ Then he looks at the validity of the acts of such an occult heretic, and concludes for their enduring validity even after his heresy is found out. To that end he relies on the lex Barbarius (and, interestingly, not on Tria). The acts of the occult heretic (and so, the heretic believed orthodox) are valid just like the acts of the slave believed free: in both cases they remain valid even after their author is removed from office. ${ }^{107}$

A more complex case involving the lex Barbarius may be found in the French Summa Tractaturus Magister (probably from the years 1182-1185). ${ }^{\mathbf{1 0 8}}$ In this

104 Gillmann (1912), p. 367. See also Prosdocimi (1955) p. 367. Prosdocimi however attributed its authorship to Huguccio himself, ibid., pp. 364-374, with further literature on the earlier debate surrounding the Continuatio prima. On the subject see now the careful analysis of Müller (1994), pp. 87-108 (specifically on its dating see pp. 92-94). Müller also found evidence to argue that what we call Continuatio was initially a much longer work: $i b i d .$, p. 90, text and note 121.

105 Müller and Pennington (2008), pp. 153-154, text and notes 167-168, and esp. Müller (1994), pp. 100-108.

106 Continuatio Prima of Huguccio's Summa, ad C.24 pr (Montecassino 396, fols. 156vb-157ra, transcription in Lenherr [1987], pp. 289-290, 11.7-15): ‘... Hanc questionem Magister competenter determinat dicens, quod prelatus hereticus aut dampnatam sequitur heresim aut nouam confingit. Si iam dampnatam sequitur, quia ipso iure excommunicatus est, ut dicunt quidam, nec oportet, ut specialiter notetur per sententiam, non potest soluere uel ligare: $s i$ uero confingit nouam, quamdiu toleratur ab ecclesia, sententia in subditos sue iurisdictionis lata ligat et absoluit. Et hanc distinctionem nititur probare Gratianus. Quamdiu ergo toleratur, excommunicare potest, non tamen de merito uite.'

107 Continuatio Prima of Huguccio's Summa, ad C.24, q.1, c.35, $\mathbb{S}$ Remouendum (Montecassino 396, fol. 161 rb, transcription in Lenherr [1987], p. 293, 11.9-15; cf. ibid., p. 229): '... Dicas ergo remouendum, idest remotum, fecit enim aliquid propter quod remotus est, et hec expositio habetur ex sequenti cap., quia ex quo publice in dampnatam heresim incidit, non potest aliquem excommunicare, quia incidit in primum et secundum canonem huius cause (C.24, q.1, c.1-2). Set si publice non incidit, quamdiu toleratur ab ecclesia, ea que ab eo fiunt rata sunt, licet postmodum eius heresis cognoscatur, sicut de Barbario Philippo (Dig.1.14.3).'

108 Kuttner (1937), pp. 184-187. 
Summa the concept of toleration was already briefly mentioned with regard to the iudex criminosus in C.3, q.7, ${ }^{109}$ but here the Summa did not look at the case of the slave who sits in judgment, and so it did not refer to the Barbarius case. On the contrary, the lex Barbarius is expressly mentioned when discussing the jurisdictional powers of the heretic (C.24, q.1). There, the Summa moves from the assumption that the heretic who lawfully received the power of ordo also retains that of iurisdictio so long as he is tolerated by the Church. ${ }^{110}$ Although the Summa does not state expressly as much, it seems to imply that the validity of the acts done while the heretic is tolerated in office is not to be questioned after his excommunication. And here we find the most interesting part of the Summa's reasoning on the subject. What happens in the case where a sentence of excommunication is brought on the anonymous author of a crime? This is a quintessential case of occult excommunication: no one knows of the excommunication but for the excommunicate himself. Until he is found out as the perpetrator of the crime that warranted a sentence of excommunication, it is impossible to prevent him from exercising his jurisdictional prerogatives. But are his acts valid? The author of the Summa does answer, but reports how both positive and negative solutions were already advanced among canonists. He does so when commenting on the words 'the excommunicated may not excommunicate': ${ }^{111}$

Hence some argue that in case of excommunication levied in general for some crime, if one excommunicates someone else between the time of the first excommunication and the moment in which he was found out as the author of that crime, the excommunication that he issued is invalid; others say the opposite [relying on] Barbarius Philippus.

109 Supra, this chapter, note 30.

110 Summa Tractaturus Magister, ad C.24, q.1, $\$$ Quod autem (BNF, Lat. 15994, fol. 71va-b, transcription in Lenherr [1987], p. 305, 11.1-8): 'Hereticus ordinatus $\mathrm{ab}$ eo qui non habuerit potestatem ordinandi uel ab eo qui habuerit preter formam ecclesie neminem potest ligare uel soluere. Ordinatus autem ab eo qui habuerit potestatem et in forma ecclesie, quamdiu toleratur ab ecclesia, potest, viii Q.iiii Nonne (C.8, q.4, c.1), postquam precisus est, non potest, infra e(adem) q(uaestio) Audiuimus (C.24, q.1, c.4) nec etiam hereticum. Alia siquidem ratio est in sacramentis, in quibus non amittit potestatem ministrandi, i q.i Quod quidam (C.1, q.1, c.97), alia in sententiis, cum iam amiserit potestatem presidendi, xv q.v Iuratos (C.15, q.6, c.5).'

111 Summa Tractaturus Magister, ad C.24, q.1, c.4, $\$$ Excon(municatus) excon(municare) non po(tuit) (BNF, Lat. 15994, fol. 71vb, transcription in Lenherr [1987], p. 305, 1l.1-5): 'Hinc arguunt quidam, quod excommunicatione facta etiam in generali pro aliquo crimine, si quis interim excommunicauerit aliquem et postea detectus fuerit reus criminis illius, non teneat eius excommunicatio, alii contra, de Bar(bario) Phi(lippo) (Dig.1.14.3).' 
The passage is interesting because it shows that the lex Barbarius was already used by canon lawyers in the early 1180 s to argue in favour of the validity of the jurisdictional acts of heretics who were no longer tolerated within the Church. More than that: it was used to widen the scope of the toleration principle, so as to argue for the enduring validity of jurisdictional acts in particularly ambiguous situations. It is perhaps not fortuitous that the Summa belongs to the French milieu, for we have already seen how the concept of toleration was used, broadly speaking, more openly and in a more technical sense in France than in the Bolognese school. The fact that the toleration principle was already acquiring specific legal features seems to be attested by its absence from the passage above. Immediately before that passage, the author of the Summa Tractaturus Magister dealt with the toleration of the heretic who was not yet excommunicated. In our passage he did not wonder whether the heretic secretly excommunicated should be tolerated, for he had already given a general answer beforehand. Instead, he asked whether the acts of such a heretic should be held as valid although he was not to be tolerated in his office. It is precisely because this Summa understood the concept of toleration in a 'technical' sense (and not just as simple forbearance) that it did not use the term in this context: understood in a jurisdictional meaning, toleration entails full validity of the deeds.

A few years later, the lex Barbarius is used in the Apparatus Ius naturale to answer a different but equally interesting question. The Apparatus (written between the end of the twelfth and the beginning of the thirteenth century) ${ }^{\mathbf{1 1 2}}$ is attributed to Alanus Anglicus. ${ }^{113}$ If that were effectively the case it would be interesting for our purposes, for Alanus had considerable influence on Innocent IV. Glossing on the all-important dictum of Gratian in C.24, q.1, p.c.39 (on the excommunication by the excommunicate), the Apparatus states that the heretic who suffered a major sentence of excommunication ${ }^{\mathbf{1 1 4}}$ would lose any iurisdictio.

112 Weigand (1963), p. 181, note 8. Kuttner had previously dated it slightly more broadly: Kuttner (1937), pp. 67-75.

113 Gaudemet (1993), p. 140.

114 The distinction between minor and maior excommunicatio is increasingly attested from the close of the twelfth century. For a short but clear analysis see Vodola (1986), p. 36. The 'proper' excommunication, entailing full separation from the Church - and so, from the whole of Christian society - was the maior one, whereas the minor excommunicatio consisted in the exclusion from the perception of the sacraments (but not from their consecration: see clearly Innocent IV, ad X.5.8.1, \Irritas [Commentaria Innocentii Quarti Pont. Maximi Super Libros Quinque Decretalium, Francofurti ad Moenum, 1570; anastatic reprint, Frankfurt am Main: Minerva, 1968, fol. 508va, n. 4]), and this is why it is often called suspensio. For a synthetic and lucid analysis of the difference between maior and minor excommunication see the Ordinary Gloss to the Liber Extra, Gloss ad X.5.39.59 (Decretalium domini pape Gregorij noni compilatio (Basileae [Johann 
It follows that the sentence issued by this excommunicate has no effect. But then the author of the Apparatus asks whether a Catholic judge may ratify such a sentence, and he answers in the affirmative. In doing so, he relies on some passages of the Decretum inspired by mercy ${ }^{115}$ or common good, ${ }^{116}$ and especially on Gratian's Tria (C.3, q. 7, p.c.1). Right after this last passage, the Apparatus also cites the lex Barbarius. The reference is slightly more complex than it would appear at first sight. We have seen how in Gratian's dictum Tria the slave sitting in judgment exercised only delegated jurisdiction. But the Apparatus seems to go beyond that, for all the other passages it quotes would clearly presuppose ordinary jurisdiction. ${ }^{117}$

At the beginning of the thirteenth century, two authors use the lex Barbarius in connection with the excommunication issued by the heretic. They move from radically opposite premises but make a similar (and equally refined) use of the Roman source. They are Laurentius Hispanus (d.1248) and the anonymous author of the Summa Animal est Substantia.

Laurentius Hispanus' Glossa Palatina (composed in the years 1210-1214), ${ }^{118}$ in a somewhat generous interpretation of the Third Lateran Council, moves from the assumption that any heretic is already condemned - not just when he suffers a sentence of excommunication or openly follows a doctrine that is already condemned by the Church, but also when his heresy is secret or his belief

Froben \& Amerbach], 1500), $\mathbb{S}$ Si quem, s.v. 'Non tantum minori': '... cum dico excommunico illum: de maiori intelligitur. Minor enim excommunicatio remouet a communione sacramentorum ... maior excommunicatio a corpore christi quod est ecclesia, scilicet communione fidelium ... Est ergo maior excommunicatio a qualibet licita communione et legitimo actu separatio: vnde et Adam excommunicatus fuit ex esu ligni ...' Cf. also ibid., ad X.2.1.10, $\$$ Cum non ab homine, s.v. 'Excommunicari'.

115 C.24, q.1, c.38.

116 C.3, q.6, c.10 and C.24, q.1, c.39.

117 Apparatus Ius Naturale, ad C.24, q.1, p.c.39, $\mathbb{S}$ Set illud (Paris Maz. 1318, fols. 297vb-298ra, transcription in Lenherr [1987], pp. 317-318, 11.1-11): 'Bene soluit Gratianus, generaliter enim est tenendum, quod apud hereticos uel alia ratione $\mathrm{ab}$ ecclesia per maiorem excommunicationem separatos non est aliqua iurisdictio, nec ecclesiastica, ut supra Miramur, Aperte [C.24, q.1, c.37, 36], nec ciuilis, ut xv q.vi Iuratos, Nos sanctorum [C.15, q.6, c.5, 4]. Vnde si talis aliquis sententiam aliquam protulit, siue diffinitiuam siue excommunicationis siue pereceptionis, ipso iure non tenet, nec est tenenda, ut hic, siue in causa ciuili siue in criminali siue spirituali sumptam. Set sententiam, quam ipse tulit, potest iudex catholicus cuius interest ratihabitare, firmare et perinde erit ac, si ab ipso promulgata esset, $\arg$ (umentum) supra e(adem) q(uaestio) Quisquis, Subdiaconus [C.24, q.1, c.38-39], iii q. vi Hec quippe [C.3, q.6, c.10] et q. vii $\$$ Tria [C.3, q. 7, p.c.1], De Barbario Philippo [Dig.1.14.3].'

118 Kuttner (1937), pp. 81-92; Stickler (1966), pp. 543-545. 
has not yet been condemned as heretical. ${ }^{119}$ It follows that, when such a heretic excommunicates someone, his sentence is void. ${ }^{\mathbf{1 2 0}}$

Laurentius, an excellent lawyer, clearly realised that his statement led to a difficult problem: if the heretic is occult, by definition his heresy is not known. As such, the heretic still has the full exercise of his jurisdictional powers. De iure such powers are invalid and their exercise void. But de facto they continue to produce their full effects. If such an occult heretic excommunicates a priest, therefore, the sentence is de iure void, but it is advisable for the latter to celebrate mass secretly, lest he would aggravate his position. ${ }^{\mathbf{1 2 1}}$ Although in truth void, the sentence of excommunication is widely believed to be valid. Seeking absolution is therefore not necessary, only strongly advisable. This way, the position of the Glossa Palatina closely reminds of Rufinus on the point. ${ }^{\mathbf{1 2 2}}$ Just like Rufinus, Laurentius Hispanus' Glossa Palatina shows little sympathy for the toleration principle. Unlike Rufinus, however, Laurentius Hispanus does not avoid speaking of toleration. Rather, he seems to use it in a non-technical way to deliberately emasculate its legal strength.

119 Glossa Palatina, ad C.24, q.1 pr, $\mathbb{S}$ Quod autem ab heretico (Pal. Lat. 658, fol. 70rb, transcription in Lenherr [1987], pp. 318-319, 11.1-9): 'In hac questione dicunt quidam quod, si hereticum alium excommunicat hereticus, ualet, infra c. Quisquis (C.24, q.1, c.38). Set qualiter illud capitulum intelligatur, dicit $\$$ sequente illud c(apitulum) (C.24, q.1, c.39). Alii cum Gratiano distinguunt, an ueterem heresim iam dampnatam sequatur, et tunc non ualet, an nouam configat, et tunc potest, arg(umentum) infra e(adem quaestio) $<\mathrm{c} .>$ Achatius [C.24, q.1, c.3] et infra e(adem quaestio) $\mathbb{S} \mathrm{Si}$ autem in prin(cipio) (C.24, q.1, p.c.4), quia adhuc tolleratur ab ecclesia. Set tu dic indistincte, quod siue ueterem siue nouam sequatur, excommunicatus est, licet sit occultus, et ideo alium non potest excommunicare, extra. de hereticis, <c.> Ad abolendam [1 Comp. 5.6.11(=X.5.7.9)].' Writing several decades later, Guido de Baysio (c.1250-1313) considered Laurentius Hispanus as the strongest ('maxime') opponent of the distinction between occult and notorious heretics, 'qui scripsit quod non credit Gratiano dicenti, quod ex quo incipit praedicare haeresim, ex tunc non potest excommunicare', Baysio, Rosarium super Decreto, ad C.24, q.1, c.35, $\$$ Ait (Venetiis [Herbort] 1481, fol. 321r).

120 Glossa Palatina, ad C.24, q.1 pr, $\mathbb{Q}$ Qui uero heresim iam dampnatam (Pal. Lat. 658, fol. 70rb, transcription in Lenherr [1987], p. 319, 1l.12-15): 'Hec distinctio [scil., between old and new heresies] hodie locum non habet, nam omnis heresis est dampnata et omnis hereticus excommunicatus, quantumcumque sit occultus, et ideo non potest alios excommunicare.'

121 Ibid., $\mathbb{Q}$ Qui uero heresim iam dampnatam (transcription ibid., ll.15-19): 'Vnde si scirem prelatum meum esse hereticum, quia nouam [scil., heresim] fingit, nec tamen predicaret, si me excommunicaret, celebrarem in occulto, set non in aperto, quia cum non possem probare eum esse hereticum et ita nec me excommunicatum deponerer.'

Supra, this chapter, note 82 . 
As we have just seen, the Summa Tractaturus Magister avoided speaking of toleration with regard to the excommunication levied by the occult excommunicate, because it did not consider it as falling within the scope of the toleration principle. ${ }^{\mathbf{1 2 3}}$ The Glossa Palatina shows a similarly clear understanding of the relationship between the jurisdictional side of the toleration principle and the holding of an ecclesiastical office. Indeed, it clearly states that the sentence of excommunication is void, and yet it is to be tolerated as long as the person who issued it is himself tolerated in office. ${ }^{\mathbf{1 2 4}}$ But if tolerating a void sentence simply means postponing the acknowledgement of its legal invalidity, then the same should also apply to the toleration of the office holder who issued it. Laurentius Hispanus said clearly that the occult heretic is excommunicated, and that no excommunicate may validly exercise any jurisdiction. Just as with the sentence, tolerating the heretic in office therefore only amounts to postponing the acknowledgement of his lack of jurisdiction. As such, in the Glossa Palatina the legal effects of toleration are very different from those described by most decretists that we have so far encountered. Tolerating the sentence rendered by the occult heretic does not mean accepting its legal validity, only postponing its invalidity. While the Glossa Palatina does not clarify how this should occur, it would seem that its author is not thinking of voidability, but of ipso iure voidness - only, postponed invalidity. When stating that the void sentence must be tolerated (in the comment on C.24, q.1 pr), Laurentius Hispanus' Glossa Palatina refers twice to Gratian's dictum Tria, and so to the slave who sits in judgment. ${ }^{\mathbf{1 2 5}}$ This reference is to be read together with Laurentius Hispanus' Apparatus to the Compilatio Tertia (roughly contemporary with the Palatina). ${ }^{\mathbf{1 2 6}}$ There, he observes that 'sometimes the opinion of the collectivity [universitas] is to be followed more than truth itself', and then he refers again to Tria, this time also adding a reference to the lex Barbarius. ${ }^{\mathbf{1 2 7}}$ Laurentius Hispanus wrote this last

123 Supra, this chapter, note 111.

124 Glossa Palatina, ad C.24, q.1 pr, $\mathbb{\$}$ Quod autem ab heretico (Pal. Lat. 658, fol. 70rb, transcription in Lenherr [1987], p. 319, 11.9-12): 'Alia tamen que agit tenent, dum tolleratur, arg. Iii q.vii $\mathbb{\lessgtr}$ Tria (C.3, q.7, p.c.1). Set et sententia excommunicationis quam tulit toleranda est, dum ipse est occultus, licet sit nulla, $\arg ($ umentum $)$ predicti $\mathbb{S}($ C.3, q.7, p.c.1) et extra, de iure patronatus, <c.> Consultationibus [1 Comp. 3.33.23(=X.3.38.19)]'; ibid., $\mathbb{S}$ Qui uero heresim iam dampnatam (transcription ibid., 1l.19-20): 'Set quid de alia sententia? Idem, quia nulla est, etsi quam tulit, set tamen tolerabitur postea, $\arg ($ umentum) iii q.vii $\$$ Tria (C.3, q.7, p.c.1).'

125 Supra, last note.

126 McManus (1991), pp. 46-47.

127 Laurentius Hispanus, ad 3 Comp., 1.14.1(=X.1.21.4), \$opinioni sit ueritas preferenda (transcription in McManus (1991), pp. 300-301, ll.11-13): ' ... Quandoque enim opinio uniuersitatis plus attenditur quam ipsa ueritas, supra iii q. vii $\$$ Tria (C.3, q.7, p.c.1); ff. de offic(io) pret(orum) <l.> Barbarius (Dig.1.14.3).' 
statement on truth and opinion when commenting on a passage taken from Innocent III's decretal 'Nuper a Nobis' (1199), on the problem of the validity of the second marriage contracted in the mistaken but (under certain circumstances) justifiable assumption that the first spouse was deceased. In the decretal, Innocent III stated that the person who remarried believing in good faith to be widowed should not be considered as bigamous, for sometimes 'the opinion is to be preferred to the truth'. ${ }^{\mathbf{1 2 8}}$ The reference to the universitas in Laurentius Hispanus' Apparatus was therefore not in the original source (Innocent III's decretal) ${ }^{\mathbf{1 2 9}}$ but in the lex Barbarius, which he cited to explain the decretal. Referring to the collective but mistaken opinion was the only way for Laurentius Hispanus to avoid a logical impasse: the sentence issued by the occult excommunicate is void from the very beginning, and yet it is tolerated as if it were valid so long as the heresy is not found out. Until then, the collectivity continues to believe him as orthodox, and so his jurisdictional acts are also believed to be valid. Both the exercise of his office and the validity of his acts therefore depend on the perception of validity - which, however, does not make them valid. Perhaps this idea of perception of validity helps to better appreciate the meaning of toleration in Laurentius Hispanus, a concept lying midway between voidability and postponed (or rather, suspended) voidness.

As anticipated, the French Summa Animal est Substantia (Summa Bambergensis, probably written in 1206-1210) ${ }^{\mathbf{1 3 0}}$ moves from the opposite position. Unlike the Glossa Palatina, it fully accepts the distinction between old and new heresies, and maintains that the priest who has fallen in with a new heresy retains full jurisdicional powers so long as he is not judicially excommunicated, because until then he is tolerated by the Church. ${ }^{\mathbf{1 3 1}}$ His toleration entails the full validity

129 The idea that opinio might have more weight than veritas was hardly new, and is sometimes (though not often) also found in the Decretum, especially in C.22, q.2, c.4. Honorius for instance relied on this passage when commenting on C.3, q.7, p.c.1, and concluded that in Barbarius' case the opinion prevailed over the truth. Summa de Iure Canonico Tractaturus, ad C.3, q.7, p.c.1, \Verum si seruus (Weigand, Landau and Kozur [eds., 2010], tom. 2, p. 84, 11.3-5): 'Hinc arg. opinionem ut ueritatem ualere. Item ff. de officio pretorum 1. Barbarius (Dig.1.14.3). Quandoque plus ualet opinio, ut arg. xxii q.ii Omnis qui mentitur (C.22, q.2, c.4).' Cf. Id., ad C.22, q.2, c.4, \$ melior est (ibid., p. 344, 1l.5-6): 'Hinc arg. plus esse quod est in opinione quam quod in ueritate.' But Honorius saw no connection between this case and the problem of heresy. On the contrary, as we have seen, he considered the sentence of excommunication by the heretic not yet excommunicated as fully valid.

130 Stickler (1971), pp. 73-75; Kuttner (1937), p. 207.

131 Summa Animal est Substantia, ad C.24, q.1, c.39, \$Degradatus (Liège 127.E, fol. 216va, transcription in Lenherr [1987], pp. 327-328, 11.15-19): 'contra. supra 
of his acts, which will remain valid even after his excommunication. At this point, however, the author of the Summa wonders what would happen in a case where a bishop was not truly tolerated, but only appeared to be. This might happen, for instance, if he was already excommunicated, but only secretly - i. e. not publicly. The problem, in other words, was whether the solution for the occult heretic who is not yet excommunicated should apply also to the heretic occultly excommunicated. In principle, the difference between the two cases is obvious: if a heretic is excommunicated, he is already deprived of his jurisdictional powers. Nonetheless, since the excommunication is not public, he would appear to retain his office. Should his jurisdictional acts be considered valid all the same? The Summa goes further, and asks what happens in the case of a false bishop. The analogy is clear. Unlike the powers of ordo, the powers pertaining to iurisdictio flow only if (and so long as) the prelate remains within the Church. It follows that the bishop cast away from the Church has the same jurisdictional power as one who is no bishop at all - none. The problem therefore is to draw a line between the validity and invalidity of jurisdictional acts when reality and appearance diverge. To do so, the Summa openly relies on the lex Barbarius: ${ }^{132}$

ea. q. Audiuimus (C.24, q.1, c.4), ubi dicitur, quod excommunicatus excommunicare non potest. Solutio: Augustinus approbauit, non quia ualet, set in odium instius. Vel intelligatur de istis qui adhuc tollerantur ab ecclesia, quia sententia talium ualet, viii q. iiii Nonne (C.8, q.4, c.1).' The text of this passage should be read in conjunction with two others: ad C.24, q.1 pr, $\mathbb{Q}$ Quod autem ('Si autem incidit in nouam, cum non sit precisus, quamdiu tolleratur ab ecclesia, potest excommunicare et cetera facere, infra ea q. Achatius [C.24, q.1, c.3], nec debemus ante sententiam eum uitare, viii q. i Nonne [C.8, q.4, c.1] et haberi pro prelato', and ad C.1, q.1, c.39, $\mathbb{S}$ Foris ('quia, cum hereticus sit excommunicatus ipso iure, excommunicare non potest, xxiiii q. i Audiuimus [C.24, q.1, c.4], contra xxiiii q. i Quisquis et Subdiaconus [C.24, q.1, c.38-39], ubi uidetur, quod teneat sententia excommunicationis lata per hereticum. Set quod ibi dicitur non fit per momentum sententie, set in odium criminis. Vel aliter: illa sententia lata fuit a schismaticis qui adhuc tolerantur ab ecclesia et ideo tenuit'), transcription ibid., p. 325, 11.18-21, and p. 324, 11.1-6 respectively.

132 Summa Animal est Substantia, ad C.24, q.1, c.4, $\$$ Absoluendo (Liège 127.E, fol. 212va, transcription in Lenherr [1987], p. 326, 1l.1-17, punctuation as in the original). The case in the Decretum was that of someone excommunicated by an archbishop who was himself (publicly) excommunicated. The passage in the Summa opens by making it clear that the absolution from the excommunication issued by the excommunicate was valid only de facto, since de iure there was no need of it: 'de facto, similiter xi q. iii Excellentissimus [C.11, q.3, c.102] et extra. de ap(pellationibus), Ad presentiam [1 Comp. 2.20.22(=X.2.28.16)]. The part translated (somewhat loosely) in the main text follows immediately thereafter. The logical connection is clear: if the excommunication inflicted by the publicly excommunicated archbishop warranted only a de facto absolution, what would happen if the high prelate was secretly excommunicated? The text reads: 'Set queritur: Aliquis episcopus excommunicatus occulte excommunicat aliquem, 
A bishop occultly excommunicated excommunicates someone else. Should we avoid the person who is excommunicated this way? We should not do so, for the bishop, being himself excommunicated, could not excommunicate him. It follows that we must not avoid such a person. On the other hand, the church approves of whatever the bishop did, so it appears that such a person was indeed excommunicated through the church's approbation (per approbationem ecclesiae). It follows that he must be avoided, on the basis of the lex Barbarius Philippus. While in truth the bishop's decisions were void, however they retained their validity because approved by the res publica. I say that that person was not excommunicated and yet we must avoid him, for we believe that he was indeed excommunicated. If we were to disregard the excommunication, we would commit a mortal sin. The same applies if one were to pose as bishop of this city when he was not, but we believed him to be such. If he were to excommunicate someone, we should avoid the person excommunicated. This is not because the person who received the sentence of excommunication was truly excommunicated: he was not, for the false bishop had no jurisdiction on him. Rather, it is because we believed that he had jurisdiction on us, and so we must avoid the person thus excommunicated, lest we would fall in mortal sin.

First of all, the difference between toleratio and approbatio should be noted. The Summa does not say that the true bishop who is secretly excommunicated is tolerated by the Church, but that the Church somewhat approves of his deeds. At first sight, approbatio would seem stronger than toleratio: not merely tolerating something, but approving of it. However, it should be noted that the object of the approbation is not the person but the deeds (and, even so, only to a limited extent).The passage does not speak of toleration for two reasons. First, in relation to the exercise of jurisdictional powers, tolerating always refers to the person, not just to his deeds. It is only because the person is tolerated in office that the deeds are valid. The concept of toleration is absent because in the Summa Animal est Substantia its boundaries are set by the presence or absence of excommunication. ${ }^{133}$ Once excommunicated (whether publicly or secretly), a prelate is no

debemusne eum uitare quem excommunicauit? Videtur quod non, quia ipse non potuit eum excommunicare, cum esset excommunicatus, ergo non debemus eum uitare. Set contra. ecclesia approbat quicquid fit ab eo nec citat (?) in eius persona licet in accusationibus earum, ergo uidetur quod iste sit excommunicatus per approbationem ecclesie et quod debeat uitari, arg. le. De Barbario Philippo, ff. de offitio pretoris 1. Barbarius Phil(ippus) (Dig.1.14.3), quia in rei ueritate nulle eius erant sententie et tamen, quia res publica approbauit, ualuerunt. Dico quod iste non est excommunicatus et tamen eum debemus uitare, quia credimus eum excommunicatum esse. Aliter, si contempneremus, peccaremus mortaliter. Et hoc potest uideri, si aliquis modo simularet se esse episcopum istius uille et tamen non esset, set crederemus, si excommunicaret aliquem, deberemus eum uitare et tamen non esset excommunicatus, quia ille non erat iudex suus, set hoc, ne peccaremus mortaliter, eum credamus esse nostrum iudicem.'

Supra, this paragraph, note 131 . 
longer tolerated in office. The validity of the deeds therefore does not flow from the exercise of office, but only from the volition of the Church. Speaking of approbation of the deeds therefore allows separation of the act from its source. The second reason the passage above does not speak of toleration is that toleration entails the full validity of the acts done by the person tolerated in office. From a legal standpoint, the excommunication brought about by the secretly excommunicated is void. This requires to interpret the concept of approbatio ecclesiae in a rather narrow sense. The Church's approbation of the excommunication is not referred to the person excommunicated, but only to the community of the faithful. They should behave as if the person were truly excommunicated, when he is not. The reason is simple: since they cannot know that the excommunication was void, if they ignored it they would commit a mortal sin. A justified belief in the validity of the sentence of excommunication requires compliance, irrespective of its actual validity. The sentence of excommunication produces effects, that are limited as to their scope (to use a slight anachronism, ultimately limited to the internal forum): the conscience of people who could not know that the bishop was no longer tolerated within the Church. This way, the Summa relies on the lex Barbarius but it does not apply it in full. In Barbarius' case, says the Summa, the approbation of the commonwealth bestowed full validity on something that in itself was void ('in rei ueritate nulle eius erant sententie et tamen, quia res publica approbauit, ualuerunt'). The validity of the deeds is not limited to the subjective sphere of their recipients (it would make little sense there), but is ascribed to the deeds themselves. By contrast, the Summa makes it perfectly clear that the jurisdictional act of the bishop secretly excommunicated would remain void in itself, so that it may not alter the status of its recipient ('Dico quod iste non est excommunicatus'). Ultimately, on the specific problem of the void excommunication that appears valid, the Summa Animal est Substantia comes to similar conclusions as Rufinus ${ }^{134}$ - but through a very different and considerably more refined legal analysis.

\subsection{Johannes Teutonicus and the Ordinary Gloss on the Decretum}

After this short overview of the concept of toleration among the early decretists, we should proceed to examine the position of the author of the standard Gloss to the Decretum, Johannes Teutonicus (d.1245). To better appreciate his thinking, we will look both at his Gloss on the Decretum and at his apparatus to the Compilatio tertia, and also occasionally to the Compilatio quarta. However, since 
most of his remarks on toleration come from his glosses on the Decretum, it is important to mention (at the risk of saying the obvious) that Teutonicus' apparatus on the Decretum was re-elaborated by Bartholomaeus Brixiensis (d.1258). It was this new version (and not Teutonicus' own) that would become the Ordinary Gloss on the Decretum. When describing Teutonicus' position on the concept of toleration we will therefore seek to distinguish between his writings and Brixiensis' additions. Doing so is important to have a better idea as to the position of mainstream canonists before Innocent IV wrote his own extensive commentary on the Liber Extra. ${ }^{135}$

Examining Teutonicus' Gloss against Brixiensis' printed edition, it would appear that several cases in which the concept of toleration is invoked in general - and not with regard to a specific jurisdictional context - are not from Teutonicus. ${ }^{136}$ While this does not mean that Teutonicus uses the same concept exclusively in a legal sense, the occasions where he employs it with a rather loose meaning are significantly less frequent. ${ }^{\mathbf{1 3 7}}$ More often it is possible to find references to toleration in Teutonicus with regard to occult sins (which are not

135 For Teutonicus' Gloss I relied on Pal. lat. 624, and for the printed Ordinary Gloss, on the Basel edition of 1512. Unless otherwise stated, all transcriptions follow Teutonicus' glosses in Pal. lat. 624. Because the accent in on Teutonicus, most differences between his work and the printed edition of the Gloss will be left to footnotes, unless strictly functional to the discussion of Teutonicus' own position.

136 Unlike Teutonicus, Brixiensis' Gloss uses the concept of toleration to avoid a greater evil (e. g. Gloss ad C.23, q.4, p.c.17, \$ Hinc etiam: 'Gratianus adhuc probat auctoritate Augus(tini) exponentis verba prophete: quod in his qui non sunt nostri iuris nequit disciplina exerceri. Postea ponit alium casum in quo mali sunt tolerandi quam puniendi. $s$ (cilicet) quando multitudo est in scelere et schisma timetur si corrigantur et ad hoc inducit sequens c. (C.23, q.4, c.18)', Basileae 1512, fol. 272rb; cp. Pal. Lat. 624, fol. 196rb), and more in general in (unspecified) cases of necessity (e.g. Gloss ad C.1, q.7, p.c.6, $\$$ Necessaria: 'Dicit hic quod propter necessitate quandoque rigor canonum relaxatur: vnde propter necessitatem ex monachis vel laicis clerici eliguntur et ordinati ab hereticis tolerantur', and ad C.9, q.1, c.5, $\$$ Ordinationes: 'hoc c. diuiditur in duas partes ... In secunda parte dicit quod illi qui receperunt ordinem a schismaticis quondam tamen catholicis episcopis ex misericordia in suis ordinibus tolerantur si boni sunt, propter necessitatem: sed cessante necessitate sacri canones proprium robur obtineant ...', Basileae 1512, fols. 182va and 126vb; cp. Pal. Lat. 624, fols. $90 v b$ and $133 v b$ respectively).

137 E.g. Teutonicus, ad D.19, c.8, $\mathbb{\$}$ Vel qualis (scil., 'A deo autem non queritur quis, vel qualis predicet'): 'hoc intellige de toleratis: alias bene queritur vt xlii di. quiescamus (D.42, c.2). Nam nemo potest predicare nisi mittatur ut xvi q. $\mathrm{i}<\mathrm{c}$. $>$ adicimus (C.16, q.1, c.19), uel loquitur secundum antiqua tempora quando omnes poterant predicare. Jo.' (Pal. Lat. 624, fol. 13va; cf. Basileae 1512, fol. 19ra). 
justiciable for lack of evidence), ${ }^{\mathbf{1 3 8}}$ in order to avoid scandal ${ }^{139}$ or for both reasons, ${ }^{\mathbf{1 4 0}}$ and occasionally as an application of the venire contra factum proprium principle (i.e. to bar something that would contradict one's own previous conduct). ${ }^{141}$

138 E.g. Teutonicus, ad C.23, q.4, p.c.16, $\$$ His ita respondetur: 's(cilicet) auctoritatibus quibus probauit malos esse tollerandos. Jo.' (Pal. Lat. 624, fol. 196rb; cf. Basileae 1512, fol. 272ra). Brixiensis added other cases of toleration with reference to occult sins. See e.g Gloss ad C.2, q.1, c.6, $\$$ Unus ex vobis: 'hoc c. diuiditur in duas partes. In prima parte ponuntur verba domini ad discipulos, s(cilicet) vnus ex vobis me traditurus est. In secunda parte ponuntur verba augustini exponentis verba domini: quibus probat quod conuictus vel confessus condemnari debet: alioquin est tolerandus: et loquitur hoc c. de iuda et. c. superius scilicet nichil (C.2, q.1, c.4)' (Basileae, 1512, fol. 129va; cp. Pal. lat. 624, fol. 93ra).

139 Teutonicus, ad C.11 q.3, c.94, $\$$ Obediebant: 'iul(ianus) [scil., Julian the Apostate] adhuc tolerabatur ab ecclesia ne suscitaret scandalum aduersus christianos. Jo.' (Pal. lat. 624, fol. 147va; cf. Basileae 1512, fol. 200ra); ad C.1, q.1, c.40, \$Si qui a pseudo: 'non canonice electis toleratis tamen sic lxii di. c. i ar(gumentum) contra xii q. ii alienationes (C.12, q.2, c.37) et q. v c. ii contra (sic) (C.12, q.5, c.2). Solutio ibi propter scandalum in ecclesia ... hic in ecclesia propter scandlum cum occultum sit delictum in ecclesia cum intitulatus est et no. in alia suscipitur uidetur hoc cum emit ordinem illud cum dignitatem uidetur beneficium. Jo.' (Pal. Lat. 624, fol.76rb; cf. Basileae 1512, fol. 108vb); See also ad D.4, c.6, $\$$ Consuetudine (Pal. lat. 624, fol. 2rb; Basileae 1512, fol. 4va); ad D.51, c.1 $\$$ Remittenda (Pal. lat. 624, fol. 41vb; Basileae 1512, Aliquantos, fol. 57va). An indirect reference to toleration (in opposition to deposition) may also be found in Teutonicus' apparatus on Lateran IV, ch. 3 (De haereticis), $\$$ Excommunicamus ... Dampnati uero secularibus potestatibus ... relinquantur: 'Alias licet sit clericus depositus pro crimine, adhuc ecclesia tuebitur ipsum, quia adhuc secundum regulam ecclesie uiuere debet, ut lxxxi di. $<$ c. $>$ Dictum (D.81, c.8), nisi sit incorrigibilis, ut extra ii de iudic(iis) $<\mathrm{c} .>$ cum non ab homine [2 Comp. 2.1.3(=X.2.1.10)] ... Jo.' (García y García ed. [1982], p. 188, 11.5-8).

140 E. g. Teutonicus, ad C.23, q.4, c.1, $\mathbb{\text { Vindicta: }}$ 'vindicta quandam infertur coelo ultionis: quandam infertur amore correctionis. Primo modo non est inferenda. et secundum hoc loquentur capitula que dicunt uindicte illationem prohibendam. Secundo modo licite infertur. Alii sic distingunt criminum: quaedam sunt occulta quaedam manifesta. Super occultis non est inferenda nisi delinquens sociam habeat multitudinem: tunc enim propter scandalum tolerantur vt i(nfra) c. quidam et c. seq. et c. non potest (C.23, q.4, c.18, 19 and 32) ... Jo.' (Pal. Lat. 624, fol. 194va; cf. Basileae 1512, fol. 270va).

141 In this last sense, Teutonicus referred to toleration mainly in two cases. The first is about elections: the same people who elected the unworthy with full knowledge of his condition, he says, must thereafter tolerate him. This is particularly clear in Teutonicus' apparatus on the Compilatio quarta, ad 4 Comp. 1.8.2(=X.1.14.12), $\$$ reputare (scil., 'ad obtinendum beneficium ecclesiasticum eos debet ideoneos reputare'), Apparatus Glossarum in Compilationem Quartam, in Antonii Augustini Archiepiscopi Tarraconensis Opera omnia ..., vol. 4 (Lucae, 1769, typis Josephi Rocchii), pp. 622-623: 'Nota, quod qui reputatus est dignus una dignitate, si 
At first sight, Teutonicus' Gloss on Gratian's dictum Tria would suggest a rather broad notion of toleration. So long as tolerated by the Church, says Teutonicus, both the criminosus and the infamis prelate may pronounce a valid sentence. This however applies if the infamia is not brought about judicially. By extension, continues Teutonicus, the infamis appointed to an office may validly exercise it until deposed. ${ }^{\mathbf{1 4 2}}$ This idea of toleration seems based on the distinction between the office and the personal status of the office holder: the criminosus, says Teutonicus, may validly exercise his jurisdictional prerogatives not because of his personal worthiness (ex vitae merito) but rather because of the office he holds (ex officio suo). ${ }^{\mathbf{1 4 3}}$ Continuing to exercise his office aggravates his moral condition (for he commits a sin), but does not undermine the validity of the jurisdictional act.

postea eligitur ad alteram, tunc reputabitur dignus ... Item quid dices, si aliquis regularis, vel criminosus toleratus est in officio sacerdotali, numquid si talis eligitur in dignitatem, potest excipi contra illum ab illis, qui eum toleraverunt in officio sacerdotali? Videtur hic, quod non, quia qui eum reputaverunt dignum ordine, et beneficio reputabunt dignum ... Jo.' The second case refers to the legal capacity of the criminosus or the infamis to sue. In principle, an infamis could not accuse another infamis. But the bishop may not prohibit a criminosus or infamis from doing so, says Teutonicus, if he had so far tolerated him despite being aware of his condition. Teutonicus, ad C.2, q.7, c.25, $\$$ Equalitas: '... nec infamis infamem: nec criminosus criminosum accusat. vt vi q. i qui crimen (C.6, q.1, c.6) nisi prius eum tolerauit sciens eum talem ... Sed potest dici hoc esse speciale in episcopo ut non possit remouere ab accusatione sua illos quos prius tolerauit ... Jo.' (Pal. Lat. 624, fol. 104rb; cf. Basileae 1512, fol. 145vb).

142 Teutonicus, ad C.3, q. 7, p.c.1, $\mathbb{I}$ Iudex: 'hic quaer(itur) an criminosi uel infames possint esse iudices. Et quidem si non tolerantur ab ecclesia non possunt. Si tolerantur bene possunt, et tenet eorum sententia. Ipsi tamen peccant iudicando. Uel distingue an aliquis sit infamis per sententiam ut tunc non possit, an alis ut tunc possit, illud tamen certum est quod si infamia obiicitur alicui qui est electus in iudicem quod propter hoc remouetur, licet huc usque fuerit toleratus vt extra ii de rescript(is) <c.> sciscitatus [2 comp. 1.2.9(=X.1.3.13)] ex extra de exces(sis) pre(latorum) $<$ c. $>$ inter [3 Comp. 5.14.4(=X.5.31.11)] et ff. ad l. iul(iam) de ui priuata 1. i (Dig.48.7.1pr). Criminosi ergo possunt iudicare ex officio suo, non ex uite merito. Jo.' (Pal. lat. 624, fol. 112rb; cf. Basileae 1512, $\mathbb{Q}$ Quod iudex, fols. $156 \mathrm{vb}-157 \mathrm{ra})$.

143 Ibid. Cf. Summa Magistri Rolandi, ad C.3, q.7 (Thaner [ed., 1874], p. 18): 'Septimo loco quaeritur, an iudex esse possit, quem cum reo par inficit malitia. Ad haec: quorumdam iudicum crimina sunt latentia, aliorum sunt manifesta. Quorum crimina sunt latentia, iudicare quidem possunt de officio, non tamen de vitae merito.' The same opposition between officium and vita may be found in Faventinus, but this author sought to avoid a sharp contrast by writing of vita and 'legal permission': 'si uite merito iurisque permissionem iudicare non potest, verum prohibetur tunc iudex esse aliorum.' (Johannes Faventinus, ad C.3, q.7, $\mathbb{S Q u o d}$ uero iudex fieri non possit, Madrid, BN 421, fol. 101vb). 
So far, it would seem that Teutonicus follows a line of thought dating back to Paucapalea, and that, unlike decretists such as Rufinus and especially Laurentius Hispanus, he embraces a broad notion of toleration. The opposite is true. This may be seen already by comparing Teutonicus' Gloss with the printed edition. The Ordinary Gloss adds another gloss before the one we have just seen. Also this other gloss speaks of toleration, but instead of distinguishing between officium and vita, it contrasts officium with ius. This way, it seems to emphasise that the toleration principle depends on the exercise of an office, and this entails a derogation from general legal principles. ${ }^{\mathbf{1 4 4}}$ The difference between Teutonicus and the Ordinary Gloss might seem a detail, but it is a revealing one. Teutonicus avoids the juxtaposition of toleration and law on purpose: his scope of toleration was remarkably narrow. It is probably no coincidence that, in his gloss commented on above, Teutonicus seems to refer more to the criminosus than to the infamis. Tolerating the jurisdiction of the criminosus would create fewer difficulties. So, while he applies the concept of toleration to the criminosus sacerdos and acknowledges his jurisdiction, ${ }^{\mathbf{1 4 5}}$ Teutonicus appears considerably more reluctant to do as much with the infamis, especially in the most extreme cases (which, for our purposes, are the most interesting): the slave and the excommunicate. It is with regard to the jurisdiction of the heretic that Teutonicus sets the boundaries of the concept of toleration. But it is significant that, in so doing, he looks at the jurisdiction of the slave.

As mentioned, Teutonicus' approach to the toleration of the heretic is remarkably narrow. He makes full use of the distinction between ordo and iurisdictio, ${ }^{\mathbf{1 4 6}}$ and applies the toleration principle to argue for the validity of the

144 Gloss, ad C.3, q.7, p.c.1, casus ad $\$ Quod iudex (Basileae 1512, fol. 156vb): 'Hic intitulatur septima q(uaestio) $\mathrm{q}($ uae) quaeritur an iudex esse possit qui pari delicto cum reo vel maiori inficitur: et quod non possit iudicare multis auctoritatibus probatur. Consueuit tamen dici quod donec iudex toleratur quod iudicare potest ex officio suo sed non de iure merito vt in e $(o) \mathbb{v}$ vl(timo) (C.3, q.7, p.c.1).'

145 Teutonicus, ad C.24, q.1, p.c.37, \$ Gladio: 'nihilominus tamen remanet prelatus: vnde dum toleratur poterit me iudicare. viii q. iiii $<$ c. $>$ nonne $($ C.8, q.4, c.1) ... Jo.' (Pal. Lat. 624, fol. 218vb; cf. Basileae 1512, cit., fol. 293ra).

146 Probably the clearest example of the distinction between ordo and iurisdictio in Teutonicus is to be found with regard to the invalidity of the excommunication brought by an excommunicated (despite a serious oversight of the hand in the manuscript). Teutonicus, ad C.24, q.1, c.4, \$excommunicatus: 'et ita excommunicatus non potest excommunicare sed suspensus excommunicatur xi q. iii $\$$ euidenter (C.11, q.3, p.c.24). Nunquid ergo non potest excommunicare? Dico referre an sit suspensus ab offitio uel iurisdictione: nam et si ab offitio tantum ea non poterit que offitij sui sunt, puta celebrare et similia. Sed ea potuit que iurisdictionis sunt, ut dare prebendam et excommunicare, quia hac iurisdictionis, extra ii de elec(tione) $<c$. $>$ transmissam [2 Comp. 1.3.7(=X.1.6.15)]. Econ- 
sacraments of dignity (i. e. which required valid iurisdictio to be conferred) of the wicked priests so long as they remained within the Church. ${ }^{147}$ Like several other decretists, Teutonicus also applies the concept of toleration to argue for the validity of the iurisdictio of both the heretic who received valid ordo and repented of his heresy ${ }^{\mathbf{1 4 8}}$ and the priest consecrated in good faith by the simoniac. ${ }^{149}$ At the same time, Teutonicus denies that such a heretic would retain any jurisdictional power if cast away from the Church. ${ }^{150}$ Unlike most of the decretists that

trario esset si suspenderetur a iurisdictione et non ab officio quia posset ea que essent officii, non autem que sunt iurisdictionis. Si autem ab utroque tunc neutrum ... Jo.' (Pal. Lat. 624, fol. 214va). I have integrated the transcription with a few words (in italics) from the Basel edition of 1512 (fol. 288vb). In all likelihood, the contraction (and so, the logical contradiction) in the manuscript is due to an mistake of the hand.

147 Esp. Teutonicus, ad D.50, c.31, $\mathbb{S}$ Sub gradu: '... Item obicitur si enim iste potest baptizare, ergo et sacrificare, ut dicit in c. Respondo i q. $\mathrm{i}<\mathrm{c}$. $>$ sicut christus (C.1, q.1, c.75). Sed ibi loquitur de adhuc tolerato. Jo.' (Pal. Lat. 624, fol. 39vb; cf. Basileae 1512, $\$$ Baptizare, fol. 54ra). See also Id., ad C.1, q.1, c.30, $\mathbb{\text { Transiens: }}$ 'i(nfra) c. sic populus [C.1, q.1, c.61, against the validity of the sacraments celebrated by the heretic] contra. Solutio hic de sacramentis necessitatis que semper habent effectum, nisi culpa suscipientis impediat. Ibi de sacra(mentis) dignitatis. Uel hic de ficte ordinatis ab hiis quos ecclesia tolerat. Uel dic quod sunt polluta quantum ad illos, vt xlviiii di. c. vlt. (D.49, c.2) Jo.' (Pal. Lat. 624, fol. 75vb; cf. Basileae 1512, $\$$ Transit, fol. 108ra). Cf. ad C.1, q.1, c.82, $\mathbb{U} U t$ euidenter (Pal. Lat. 624, fol. 79ra; cf. Basileae 1512, fol. 112va).

148 The point was important to dispense the repented heretic from the requisite of reordination. Teutonicus, ad C.1, q.1, c.97, $\$$ Quod quidam: 'Opinio est quorundam quod sacerdos uel episcopus recedens de ecclesia ad hereticos sacramentum baptismi non admittit, sed sacramentum ordinis amittit. Istud inprobat aug(ustinus) multiplicer ... secundo sic: quia consuetudo ecclesie est: quod cum tales redeunt non solent reordinari: si eos ecclesia uult tolerare. Jo.' (Pal. Lat. 624, fol. 80va; cf. Basileae 1512, fol. 114rb).

149 Teutonicus, ad C.1, q.1, c.108, $\$$ Si qui: ' hic intelligit hoc c. de precisis qui tamen nesciebantur esse precisi ab ordinatis. Nam opinio eius est quod si occultum est eum ordinatore symoniacum esse, quia tolleratur ordinatus suscipit executionem ut xv q. vi c. ult. (C.15, q.6, c.5); dispensari: si vero sciuerit illum simoniacum esse deponi debet ... Jo.' (Pal. Lat. 624, fol. 82va; cf. - though not identical - Basileae 1512, fol. 116va).

150 Probably Teutonicus' clearest gloss on the subject is ad C.9, q.1, a.c.1, $\mathbb{Q}$ Quod ordinatio: 'hic querit an ordinatio facta ab excommunicato rata sit. Excommunicatus hic dicitur precisus ab ecclesia propter heresim uel schisma uel aliquam causam. Dicit Io(hannes Faventinus) et Rufinus quod qui recepit ultimam manus impositionem in ordinem episcopalem in ecclesia ordinem confert, sed non executionem ordinis. Si autem extra, nichil confert i (d est) nec ordinem nec executionem: cum tales nihil habeant, ar(gumentum) i q. vii $<\mathrm{c}$. $>$ daibertum (C.1, q.7, c.24) xix di. c. propter (D.19, c.10) i q. i <c. si quis confugerit (C.1, q.1, c.52). Licet hec opinio reprobatur i q. vii <c.> conuenientibus (C.1, q.7, c.4) et $\mathrm{i}(\mathrm{nfra})$ c. ordinationes (C.9, q.1, c.5). Dicas ergo quod siue quis recipiat ultimam 
we have seen so far, however, Teutonicus maintains that the heretic is severed from the Church not from the moment of excommunication, but from the very moment he embraces the heresy, irrespective of whether the heresy itself be new or already condemned. ${ }^{\mathbf{1 5 1}}$ In so doing, Teutonicus openly sides with Laurentius Hispanus' Glossa Palatina. ${ }^{152}$

What just said is also important to appreciate the different meaning that Teutonicus gives to other sources he uses for his apparatus on the Decretum. In particular, Teutonicus incorporates Sichardus' dichotomy between veri and falsi sacerdotes almost without changes, ${ }^{\mathbf{1 5 3}}$ thereby ascribing the power to bind and loose also to the wicked priests tolerated by the Church. ${ }^{154}$ Crucially, however,

manus impositionem siue in ecclesia siue extra, dum tamen forma ecclesie seruet in ordinando semper ordinem confert. Sed non semper executionem: et hoc siue scienter siue ignoranter ordinetur ab eo sed in hoc solo est differentia quod ordinati ab episcopo qui recipiunt manus impositionem ultimam in ecclesia, siue ignoranter siue scienter. Si alias digni fuerit possunt tolerari vt i(nfra) e(a quaestio) c. ii et iii (C.9, q.1, c.2-3) nisi in quatuor casibus. Si sunt maculati iterata unctione ut i q. vii <c.> saluberimum in fi(ne) (C.1, q.7, c.21), uel si sunt ordinati symoniace a symoniaco ut $\mathrm{i}(\mathrm{nfra}) \mathrm{c}$. ab excommunicato (sic) (C.9, q.1, c.4), uel si sunt rebaptizati vt de con. di. iiii <c.> eos (D.4, c.118 De cons.), uel si ad subuersionem fidei adheserit hereticis et in contemptum ecclesie uoluerunt ordinari ab eo qui extra ecclesiam recepit inpositionem si scienter nunque tolerantur. $\mathrm{Si}$ ignoranter et hoc probauerint tolleratur, $\mathrm{vt} \mathrm{i}(\mathrm{nfra}) \mathrm{c}$. ordinationes (C.9, q.1, c.5). Hec ergo si fides tua quod heretici et excommunicati et depositi uera sacramenta conferunt, et uerum corpus christi conficiunt, vt notaui i q. i $<$ c. $>$ dominus declarauit (C.1, q.1, c.87). Jo.' (Pal. Lat. 624, fol. 133va; cf. Basileae 1512, fol. 182rb).

151 Id., ad C.24, q.1, a.c.1, $\mathbb{Q}$ Quod autem: 'In hac questione dicunt quidam quod si hereticum alium excommunicat hereticus ualet et $\mathrm{i}(\mathrm{nfra})$ c. quisquis (C.24, q.1, c.38). Set qualiter illud c. intelligatur dicit $\$$ qui sequitur illud capitulum (C.24, q.1, c.38). Alii cum gratiano distinguunt an ueterem heresim iam dampnatam sequatur et tunc non ualet an nouam confingat et tunc potest, ar(gumentum) $\mathrm{i}(\mathrm{nfra})$ c. achatius (C.24, q.1, c.1 and esp. 3) et $\mathrm{i}(\mathrm{nfra}) \mathbb{\$}$ si autem, in prin(cipio) (C.24, q.1, p.c.4) quod adhuc toleratur ab ecclesia. Sed tu dic indisctincte: quod siue ueterem siue novam sequatur excommunicatus licet sit occultus et immo alium non potest excommunicare, extra de hereticis ad abolendam [1 Comp. 5.6.11(=X.5.7.9)] ... Jo.' (Pal. Lat. 624, fol. 214rb; cf. Basileae 1512, fol. 288va). Cf. Zeliauskas (1967), pp. 262-263.

152 Teutonicus' gloss on C.24, q.1, a.c.1, reported in the last note, was taken verbatim from the Glossa Palatina (supra, this chapter, note 119, and infra in this paragraph, note 157). Both on our subject and in general, the Glossa Palatina exercised a powerful influence on Teutonicus' Gloss. See for all Kuttner (1974), pp. 571-572.

153 Supra, this chapter, note 63.

154 Teutonicus, ad C.24, q.1, p.c.4, $\mathbb{S}$ Veris (scil. 'Ligandi namque uel soluendi potestas ueris, non falsis sacerdotibus a Domino tradita est', Pal. Lat. 624, fol. 214va; cf. Basileae 1512, fol. 289ra): 'i(d est) catholicis s(i) toleratis ab ecclesia 
just as with Laurentius Hispanus - and quite unlike Sichardus himself Teutonicus places the occult heretics not among the veri but rather with the falsi sacerdotes. Toleration, in other words, does not apply in case of heresy - any heresy.

In adopting Laurentius Hispanus' view, however, Teutonicus has to deal with the same problem faced by the Glossa Palatina: what happens to the sentence of excommunication issued by the occult heretic? Teutonicus has little choice but to follow the same solution as the Palatina: such a sentence ought to be tolerated so long as the heresy of the person who issued it remains occult. But - and here Teutonicus is very clear - the sentence itself is void. ${ }^{155}$ In stating as much Teutonicus refers expressly to Gratian's dictum Tria, and in particular to the case of the slave sitting in judgment. While Gratian concluded in favour of the enduring validity of the sentence even after the servile condition of the judge was discovered, ${ }^{156}$ Teutonicus considers it invalid and only provisionally tolerated. In stating as much he relies on the Glossa Palatina, to which he adheres so thoroughly as to report verbatim even its suggestion of celebrating secretly if excommunicated by an occult heretic. ${ }^{157}$ Teutonicus' statement that the sen-

siue sint boni siue sint mali ar(gumentum) xi q. iii iul(ianus) (C.11, q.3, c.94). Jo.'

155 Id., ad C.24, q.1, a.c.1, $\$$ Quod autem (Pal. Lat. 624, fol. 214rb; cf. Basileae 1512, fol. $288 v a)$ : 'alia tamen que agit tenent dum toleratur, $\arg ($ umentum) iii q. vii $\$$ tria (C.3, q.7, p.c.1) sed et sententia excommunicationis quam tulit toleranda est dum ipse est occultus licet sit nulla, ar(gumentum) predi(ctum) $\mathbb{S}$ (scil., C.3, q.7, p.c.1) et extra de iure pa(tronatus) <c. $>$ consultationibus $[1$ Comp. 3.33.23(=X.3.38.19)].' The last reference in the gloss would strenghten the interpretation as to the voidness of the sentence of excommunication, as the text referred to (X.3.38.19) was clear on the invalidity of the patronatus once the falsus patronus is found out.

156 C.3, q.7, p.c.1: '... sententia ab eo dicta rei iudicatae firmitatem tenet', supra, this chapter, note 26 .

157 See the text of the Glossa Palatina (left) and of Teutonicus text in the Gloss (right). The minimal differences (often hand's mistakes) in Teutonicus are underlined.

Glossa Palatina, ad C.24, q.1 a.c.1, $\mathbb{Q}$ Qui uero heresim iam dampnatam (Salzburg, Erzabtei a.XII.9, fol. 171ra; Pal. Lat. 568, fol. 70rb, transcription in Lenherr [1987], p. 319, 11.12-20):

'Hec distinctio hodie locum non habet, nam omnis heresis est dampnata et omnis hereticus excommunicatus, quantumcumque sit occultus, et ideo non potest alios excommunicare. Vnde si scirem prelatum meum esse hereticum, quia
Johannes Teutonicus, ad C.24, q.1, a.c.1, $\$$ Qui vero (Pal. lat. 624, fol. 214rb; cf. Basileae 1512, fol. 288va):

'Hec distinctio hodie locum non habet: nam omnis heresis est dampnata et omnis hereticus est excommunicatus quantumcumque sit occultus et ideo non potest alios excommunicare. unde si scirem prelatum meum esse hereticum quia 
tence, although invalid, is to be tolerated, should therefore be read in the same sense as the Palatina: postponing the acknowledgement of its legal invalidity.

To understand the scope of toleration in Teutonicus we have to focus on his reading of the slave-judge in Tria. The position of the slave, thought to be free, who issued a decision is not dissimilar from that of the secretly excommunicated prelate who sat in judgment. The decisions of this excommunicate, says Teutonicus, are void regardless of the common opinion as to the validity of his jurisdiction. ${ }^{\mathbf{1 5 8}}$ In stating as much he provides a single source attesting to the opposite - Tria itself. ${ }^{\mathbf{1 5 9}}$ Teutonicus acknowledges the same (and the only) obstacle when discussing the consequences of an invalid election. If the election is found to be vitiated, its invalidity would extend to any deed of the elected except for what Gratian said in Tria. ${ }^{\mathbf{1 6 0}}$ It was therefore necessary for Teutonicus to deal with this text.

nouam fingit, nec tamen predicaret, si me excommunicaret, celebrarem in occulto, set non in aperto, quia cum non possem probare eum esse hereticum et ita nec me excommunicatum deponeret. Set quid de alia sententia? Idem, quia nulla est, etsi quam tulit, set tamen tolerabitur postea, arg. iii q. vii $\$ Tria (C.3, q.7, p.c.1). Eadem dic et de scismatico, maxime cum scisma non possit esse sine heresi nisi forte in summo pontifice, ut si duo crearentur et uterque crederet ecclesiam apud se esse.' nouam fingit nec tamen preiudicaret: si me excommunicaret celebrarem in occulto sed non in aperto quia cum non possum probare eum esse hereticum et ita nec me nec (sic) excommunicetur deponeret. Sed quid de alia sententia? Idem quia nulla est sed quam tulit sed tamen tolerabitur postea ar. iii q. vii $\llbracket$ tria (C.3, q.7, c.1). Eadem dic et de schismatico maxime cum schisma non possit esse sine heresi, nisi forte in summo pontifice ut si duo crearentur et uterque crederet eo apud esse (sic) Jo.'

On the point that all heretics should now be considered as excommunicated see also Teutonicus, ad C.24, q.1, p.c.37, $\$$ Testimonia (Pal. Lat. 624, fol. 218vb). Teutonicus, apparatus on Compilatio tertia, ad 5.4.1(=X.5.7.10), \$Firmitatem: 'Quid si ab ignorantibus ipsum [scil., hereticum] esse talem eligatur et sententiam dicat? Respon(deo): tamquam a non suo iudice lata non ualet, xi. q.i. c. penult. (C.11 q.1 c.49) supra de consue(tudine) <c.> ad nostram, lib. eodem. (3 Comp. 1.3.2[=X1.4.3]) C. si a non compet(ente) iud(ice) 1. ult. (Cod.7.48.4) et extra de re iud(icata) <c. $>$ ad probandum, lib. iiii (4 Comp. 2.11.2[=X.2.27.24]). Arg. contra iii q. vii Tria, in principio (C.3 q.7 d.p.c.1)', transcription by Kenneth Pennington, available online: http://legalhistorysources.com/edit501.htm (last accessed 6.8.2018).

159 Ibid.

160 Teutonicus, Apparatus Glossarum in Compilationem Quartam, cit., ad Comp. 4, 1.3.3 (=X.1.6.37, scil., the person elected abbot but then found out not to be a monk), $\$$ nullum robur(ibid., p. 616): 'Arg(umentum) quod licet aliquis habitus fuit pro electo, nihilominus detecto postea vitio electionis, omnia per ipsum facta cassantur, $\arg ($ umentum) 12 q. $2<$ c. $>$ Alienationes (C.12, q.2, c.37), 25 q.1 $<\mathrm{c} .>$ Omne (C.25, q.1, c.8), supra, de haereticis, <c.> Fraternitatis [sed 1. Comp. 5.6.4(=X.5.7.4)], $\arg$ (umentum) contrar(ium) 3 q. $7 \$$ Tria (C.3, q.7, p.c.1). Jo.' 
The situation of the slave commonly believed to be free, says Teutonicus, is different from that of the excommunicate who is widely reputed to be in communion with the Church. That is not because the common mistake is different or because it leads to the two cases having different results. The reason lies in the lex Barbarius itself. The judgments issued by Barbarius would remain void, if it was not for the prince who ratified them. ${ }^{\mathbf{1 6 1}}$ Stating as much, Teutonicus seeks to emasculate the strength of the lex Barbarius - and so, ultimately, of Gratian's dictum Tria - because of the potential threat to his restrictive interpretation of the toleration of the heretic.

Teutonicus comes back to the problem of toleration - and its relationship with the lex Barbarius - when discussing whether a void sentence of excommunication could be ratified. Is it possible to ratify the sentence of excommunication pronounced by someone lacking jurisdiction? Teutonicus provides elaborate reasoning in a typically dialectical fashion (where the solution eventually adopted would come after the arguments invoked against it). Prima facie it would seem possible, says Teutonicus, since several sources allow for the ratification of something initially void - be it a mandate, an election, an adoption or even a sentence pronounced by a woman or a slave. Despite the reference to the woman sitting in judgment (which appears only in Tria), significantly enough Teutonicus refers only to the lex Barbarius. ${ }^{\mathbf{1 6 2}}$ The position

161 Teutonicus, ad C.3, q.7 pr (Pal. lat. 624, fol. 112rb; cf. Basileae 1512, $\$$ Dum putaretur, fol. 157ra): 'Ecce quantum communis opinio operatur, sic extra i. de iure pa(tronatus) $<\mathrm{c} .>$ consultationibus [1 Comp. 3.36.23(=X.3.38.19)], extra i qui fi(lii) sint leg. $<\mathrm{c} .>$ cum int(er) [1 Comp. 4.18.2(=X.4.17.2)] et i q. i $<\mathrm{c} .>$ si quis a simoniacis (C.1, q.1, c.108) et C. de testa(mentis) 1. i (Cod.6.23.1); $\operatorname{ar}$ (gumentum) contra extra iii qui fil(ii) sint leg(itimi) $<$ c. $>$ per tuas [3 Comp. 4.12.1(=X.4.17.12)] et contra xxiiii di. c. ult. (D.24, c.7) xxix q. ii $<$ c. $>$ si quis ingenuus (C.29, q.2, c.4) et di. viii <c.> ueritate (D.8, c.4) et ff. de iudicis l. ii in prin(cipio) (Dig.5.1.2pr). Sed nunquid id est si excommunicatus facit sententiam qui publice dicitur habetur per non excommunicato? No(tatur) ut extra de re iudi(cata) $<$ c. $>$ ad probandum [4 Comp. 2.11.2(=X.2.27.24)] et est ratio quare aliud sit in seruo quia seruus in multis causibus habet personam standi in iu(dicio) ut xii q. ii $\$$ qui manumittitur (sic) (C.12, q.2, c.58). Sed excommunicatus in nullo. Uel dic quod nec sententia serui teneret nisi confirmata fuisse a principe. Jo.' Although Teutonicus was not citing the lex Barbarius expressly, the last statement might allude to it: see infra in the main text.

162 Id, ad C.9, q.2, c.1, \$excommunicatio (Pal. Lat. 624, fol. 133va; cf. - with some changes - Basileae 1512, fol. 182vb): 'Sed queritur si unus iudex possit sententiam excommunicationis latam ab alio ratam habere, ar(gumentum) quod sic, i(nfra) c. lugdunen(sis) (C.9, q.2, c.10) et iii q. vi <c.> hec quippe (C.3, q.6. c.10) et lxiii di. <c.> salonitane (D.63, c.24). Nam factum falsi procuratoris possum ratum habere, extra iii de officio (iudicis) dele(gati) c. ult(imo) [3 Comp. 1.18.11(=X.1.29.32)], extra iii de parrochiis (sic) <c. $>$ coram [3 Comp. 
of this reference is probably not fortuitous either. The text cited immediately before it allowed for the ratification of a vitiated adoption - but only if this ratification came from the emperor. ${ }^{163}$ In the light of what Teutonicus said with regard to the sentence pronounced by the slave, this seems no coincidence. Emperor aside, Teutonicus does not seem to believe much in the possibility of ratifying a sentence - not just a sentence so peculiar as that of excommunication, but any sentence. After the reference to the lex Barbarius he turns to the opposite arguments, highlighting especially a letter of Innocent III that would later be included in the Liber Extra (X.1.4.3) clearly stating that a sentence issued by an incompetent judge is void ('sententia a non suo iudice lata nullam obtineat firmitatem'). ${ }^{\mathbf{1 6 4}}$ This way Teutonicus could side against the ratification of a sentence of excommunication. The ratification, he explains, would make valid what was void. So it would bestow validity on the (void) sentence from the moment that it was pronounced. But excommunication should not operate retroactively. Moreover - and crucially for our purposes - only the prince may ratify a void decision. ${ }^{165}$

3.22.1(=X.1.29.34)] ff. de iudi(ciis) <l.> licet (Dig.5.1.56), et electionem qua nulla est possum ratam habere, extra iii de elec(ione) $<$ c.> quod sicut [3 Comp. 1.6.13(=X.1.6.28)]. Item adoptio iniusta potest confirmariff. de adop(tionibus) $<$ c. $>$ adoptio (Dig.1.7.38). Item sententia femine et serui confirmatur, licet nulla sit vt ff. de of(ficio) preto(rum) <l.> barbarius (Dig.1.14.3), extra iii de arbi(tris) $<\mathrm{c} .>$ dilecta (sic) [3 Comp. 1.25.1(=X.1.43.4)], et est arg(umentum) inst(itutiones) de testa(mento) mili(tari) $\mathbb{S}$ sed et si quis (Inst.2.11.4). Nam et per appellationem potest confirmari quod nullum est, ff. rem ra(ta) ha(beri) 1 . iii $\mathbb{S}$ falsus (Dig.46.8.3.1).'

163 Dig.1.7.38 (Marcellus, 26 dig.): 'Adoptio non iure facta a principe confirmari potest.'

164 Teutonicus, ad C.9, q.2, c.1, \excommunicatio (Pal. Lat. 624, fol. 133va; cf. Basileae 1512, fol. 182vb): '... Sed contra extra iii de consue(tudine) $<$ c. $>$ ad nostram [3 Comp. 1.3.2(=X.1.4.3)]. Item quod meo nomine gestum non est non possum habere ratum ut ff. de nego(tiis) $\mathrm{g}$ (estis) $<$ l. $>$ si pupilli (Dig.3.5.5.2). Item cuius presentia desideratur eius ratihabitione non potest confirmare. Instit. de auct(oritate) tu(torum) (Inst.1.21).'

165 Ibid. (Pal. Lat. 624, fol. 133va; cf. Basileae 1512, fols. 182vb-183ra): '... Item si sententia excommunicationis confirmaretur retro esset quis excommunicatus, quod esset absonum. Dicas ergo quod sententia que nulla est non potest ratihabitione confirmare: quia sententia plus habet iuris quam facti, et illa lege ff. re(m) ra(ta) ha(beri) (Dig.46.8.3.1) fuit sententia lata a suo iudice sed contra ius et sufficit quod litigator credat se condempnatus ad hoc ut teneat iudicium, ff. famil(iae) herc(iscundae) $<\mathrm{l}$. $>$ cum putarem (Dig.10.2.36). Solus tamen princeps potest sententiam que nulla est confirmare, ar(gumentum) iii q. vi $<$ c. $>$ hec quippe (C.3, q.6, c.10), quia et ipse mutat sub alia re ... Jo.' 
To recapitulate, by the early thirteenth century the concept of toleration was sufficiently elaborated among canon lawyers, although far from uncontroversial. Something of their debate might have been used by civil lawyers, but admittedly not much. The 'jurisdictional side' of the concept of toleration was slowly emerging as a notion distinct from (and potentially even clashing with) its ecclesiological substratum. But this development was hardly mature enough to allow an analogical application that was wholly detached from other considerations. The great innovation of Innocent IV, as we are about to see, was to provide a consistent, refined and strictly legal interpretation of the concept of toleration that could be easily adopted by civil lawyers because they could see it as both legally coherent and - especially - self-consistent, and so also applicable outside ecclesiological matters. 


\section{Chapter 7}

\section{Innocent IV and toleration}

The turning point in the interpretation by civil lawyers of the lex Barbarius came with their reception of the position of Sinibaldus de' Fieschi (c.1195-1254), from 1243 Pope Innocent IV. This is why we have to look at Innocent IV in far greater detail than the previous canonists.

Until the early thirteenth century, as we have just seen, canon lawyers developed the concept of toleration in an ecclesiological context, with occasional references to the non-justiciability of occult sins. It was within this concept that they looked at the lex Barbarius, whether in its original form in the Digest or through the mention of slave-arbiter in Gratian's dictum Tria. Nonetheless, the idea of toleration remained a somewhat vague concept, as the decretists agreed on neither its scope nor its exact meaning. In its vague shape, this concept could not be applied to strictly legal issues, whether of canon or civil law. The vague treatment of the concept of toleration entailed a similarly vague approach to the lex Barbarius. This is why Innocent IV is so important for our purposes: no other medieval canon lawyer - whether earlier than, contemporary with or later than Innocent - insisted so much and with such precision on the meaning, working and scope of the concept of toleration. Innocent IV explained the concept of toleration in terms of legal representation. This allowed him to give a precise and legally minded interpretation of the idea of toleration and, in so doing, to widen its scope considerably.

\subsection{Confirmation and toleration}

To understand Innocent's approach to the subject we have to look throughout his entire commentary on the Liber Extra. He did not provide a definition of the concept of toleration, but rather applied it to a variety of specific cases. One of the clearest statements on the subject is to be found in his comment on X.1.6.44. There, Innocent distinguishes between the case in which one receives valid authority but then ought to be dismissed from office and that where one has never received any valid authority. In the first case his acts are valid so long as he remains vested with his office. Remaining vested with the office from which one ought to be dismissed is tantamount to being tolerated in it: ${ }^{1}$

1 Innocent IV, ad X.1.6.44, $\$$ Administrent (Commentaria Innocentii Quarti, cit., fol. $74 v b$, n. 3): 'omnes qui habuerunt canonicum ingressum, licet post fiant 
What is done by those who entered lawfully in their office is to be kept, even if subsequently they turn into heretics or simoniacs - so long as they are tolerated.

Before looking at the issue of toleration, we must first understand the precise meaning of entering lawfully into office for Innocent IV. In order to have canonicum ingressum in a dignity, for Innocent it was necessary to be both appointed and confirmed in it. For our purposes it is very important to stress the element of confirmation: as we shall see, it was crucial in Innocent's interpretation of the lex Barbarius. The confirmation ratified the appointment, and especially the election. ${ }^{2}$ The higher the office, the more canon lawyers discussed the element of confirmation and highlighted its importance. ${ }^{3}$ Innocent insisted on the point more than most canonists: the elected cannot administer until confirmed in his office. ${ }^{4}$ But the pope went further than that.

For Innocent the confirmation of the elected by the superior authority is not only necessary, but it may even heal the defect in the election. This happens not only in general terms, when there is some irregularity in the election, ${ }^{5}$ but even for simony. ${ }^{6}$ It does not of course apply only to high offices such as the episcopal

haeretici, vel simoniaci, ratum est quod fit ab eis quousque tolerantur, ut in d. c. nonne (C.8 q.4 c.1), infra, de do(lo) et contu(macia) <c.>veritatis (X.2.14.8).'

2 See for all Gaudemet (1979), pp. 159-166.

3 See the classical study of Benson (1968), esp. pp. 60-149.

4 See esp. Innocent IV, ad X.1.6.15, $\$$ Confirmationem (Commentaria Innocentii Quarti, cit., fol. 46rb-va, n. 1). It should however be added that if the elected starts to administer before being confirmed, then confirmation is presumed. The issue was more procedural than substantive: a problem would typically arise only when the elected was challenged by a previous occupant of the same office. See Id., ad X.1.6.15, $\$$ Confirmationem (ibid., fol. $46 v a-b$, n. 2): ' Vel potes dicere, et melius, quod isti sic electi et confirmati, per se omnia bona ecclesiarum suarum, vel dignitatum, vel praebendarum suarum, si non habent contradictores, possunt sua authoritate occupare ... Si vero non habeant contradictores, non tenentur aliquid probare de iustitia confirmationis, nec tenentur probare aliquid de iustitia electionis, et hoc ex eo apparet, scilicet, quod illi qui tenent bona ecclesiae, alias non debent res suas sibi restituere, nisi probent suam confirmationem tenere, quia si praedicti electi, id est, confirmati, non essent praelati, vel nisi tuitione confirmationum defenderetur, isti non liberarentur eis solummodo inuestitis.'

$5 \quad$ Id., ad X.1.6.44, $\$$ Administrent (ibid., fol. 75rb-va, n. 4): 'Nec repellitur talis ab agendo huiusmodi exceptione, quod non sit Episcopus, sed fur, quia non intravit per ostium canonicae electionis, cum ipse et omnia gesta eius tolerat authoritate, et intentione confirmationis.'

6 Ibid., fol. 75rb-va, n. 4-5: 'si autem non sit intrusus sua autoritate, sed confirmatur per superiorem cum ex confirmatione potestatem recipiat administrandi sup(ra) eodem [titulo] l. praealle(gata) transmissam (X.1.6.15) sive canonica fit electio, sive non, etiam si sit simoniacus in ordine, et in ipso beneficio tenebit, quicquid cum eo fit, et ratione officii ratum est 19 di. $<$ c. $>$ secundum (D.19, c.9) et est verum hoc quandiu toleratur 8 q. ulti. $<$ c. $>$ nonne (C.8 q.4 c.1) ... Item 
one. For instance, after stating that the acts of anyone who had acquired an office by using violence must be retracted, ${ }^{7}$ Innocent IV carves out an exception for a case where such an office holder was then confirmed in the role. ${ }^{\mathbf{8}}$ Although the pope implies as much more often than he states it expressly, it should be noted that Innocent considers the confirmation as curing the invalidity of the election only if the superior proceeds with full knowledge of the underlying defect. ${ }^{9}$ This means that, prior to confirming the election, the superior authority must enquire as to both the election and the person elected, lest the confirmation itself be void. ${ }^{\mathbf{1 0}}$

If however the election is invalid because the irregularities in the election are such as to void it, the confirmation cannot replace the election itself. So it is necessary that, when the superior authority ratifies an invalid election, the electors must still be of the same mind about the elected ('durante voluntate eligentium'). ${ }^{\mathbf{1 1}}$ The perduring will of the electors is necessary because, in principle, an utterly void election may not be confirmed. ${ }^{\mathbf{1 2}}$ If the appointment is confirmed, says Innocent, the unworthy is to be tolerated in his office. What does this mean exactly?

obiicitur, si est simoniacus, ergo est suspensus ab officio, et administratione ipso iure: ut not(atur) infra, de simo(nia) <c.> per tuas (X.5.3.35) ergo non valent, quae cum eis fiunt, vel saltem excipi potest. Respon(deo) licet sit suspensus a iure, tamen facta eius defenduntur authoritate confirmationis.'

$7 \quad$ Id., ad X.2.13.5, $\mathbb{~ I n ~ l i t e r i s ~ ( i b i d . , ~ f o l . ~ 2 2 6 v a - b , ~ n . ~ 1 ) . ~}$

$8 \quad$ Ibid., fol. $227 v a$, n. 5.

9 Id. ad X.1.6.32, \$ Confirmauit (ibid., fol. 63ra, n. 1): 'confirmatio electionis tenet etiam si electio fit nulla, dummodo fiat ex certa scientia confirmationis, et durante voluntate eligentium.' Cf. Agostinelli (1920), p. 53.

10 Innocent IV, ad X.1.6.32, $\$$ Confirmauit (Commentaria Innocentii Quarti, cit., fol. $63 \mathrm{rb}, \mathrm{n} .2$ ): 'Item confirmatio semper fieri debet cum causae cognitione, scilicet vt semper inquiratur de forma, et processu electionis, et de persona electi. $\inf (\mathrm{ra})$ eo (titulo) <c.> nihil (X.1.6.44) et nisi inquiratur non valet confirmatio, $\arg$ (umentum) prae(dictae) decre(talis) nihil, ff. de transact(ionibus) $<$ c. $>$ cum hi \si praetor (Dig.2.15.8.17).'

11 Supra, this paragraph, note 9.

12 Innocent IV, ad X.1.6.32, \$Confirmauit (Commentaria Innocentii Quarti, cit., fol. $63 \mathrm{rb}, \mathrm{n} .3$ ). The position of the electors becomes particularly important when the confirmation is not made with full knowledge of the underlying defect in the election. In this case, if the electors ordinarily ('de iure communi') lack the power to elect, the burden of proof as to the validity of the election is on the elected: Id., ad X.5.30.3, \$Licentia (ibid., fol. 523rb, n. 1): 'In electione autem, si constet eam factam per eos, ad quos non spectat de iure communi, semper ante confirmationem, et post confirmationem facta sine causae cognitione oportet electum probare potestatem datam electoribus' (emphasis added). 


\subsection{Toleration and representation}

We have seen that the idea of toleration of the unworthy has a complex history. Declaring that the acts of the unworthy but lawful holder of an office are valid so long as he is is tolerated in that office was a statement sufficiently accepted (though not unanimously) among canon lawyers, who discussed it extensively in relation to the distinction between the sacramental and jurisdictional acts of the clergy, especially of the heretical bishop. In his extensive commentary on the Liber Extra, Innocent IV refers to such earlier discussions only sporadically. One case is to be found, revealingly enough, in the title on the excommunicated, deposed or interdicted cleric who continues to celebrate sacraments (De clerico excommunicato, deposito vel interdico ministrante, X.5.27): ${ }^{13}$

Others say, and more correctly so, that whether one is good or bad, even heretic or excommunicated, so long as tolerated by the Church through his election and confirmation - even if that were to take place among sinners and even among heretics or excommunicates -, in that he is tolerated, he validly enters into his spiritual wedlock [scil., with the church] until the chaff be separated from the wheat.

For Innocent IV the legal mechanism through which the toleration principle operates (and so the reason why the unworthy may exercise valid authority so long as tolerated in office) ultimately depends on legal representation. The starting point is rather obvious, but extremely important: the acts done by the person in the exercise of his office are effectively imputable to the office, not to the person. Hence, the legal effects do not flow from the person, but rather from the office he holds. We have already seen some hints of this idea as early as in Paucapalea. ${ }^{14}$ But in the century between Paucapalea and Innocent, such hints still lacked any legal ground: neither Paucapalea nor those who followed him associated toleration with legal representation, but considered it a practical application of ecclesiological principles. What Innocent did was to build extensively on these hints, so as to provide a solid - and, especially, legal - basis for the concept of toleration: ${ }^{15}$

Id., ad X.5.27.10, $\$$ Irritanda (ibid., fol. 522rb): 'Alii dicunt, et vt videtur melius, quod siue bonus, siue malus etiam haereticus, vel excommunicatus, dum toleratur ab ecclesia per electionem, et confirmationem, etiam si fiat a peccatoribus, etiam ab haereticis vel excommunicatis, dummodo tolerantur, bene contrahit in huiusmodi matrimonio spirituali, quousque separetur palea a granis.'

14 Supra, last chapter, notes 29 and 30.

15 Innocent IV, ad X.5.39.34, \$ Circa temporalia (Commentaria Innocentii Quarti, cit., fol. 552ra, n. 3): 'Item dum tolerantur in aliqua dignitate, et sint occulti, non nominatim excommunicati: satis videtur quod possint excommunicare, beneficia conferre, literas impetrare, quia haec, ipsa dignitas facere videtur, et non persona excommunicata 8 q. 4 <c.> nonne (C.8, q.4, c.1).' Cf. Fedele (1936), pp. 341-345. 
While tolerated in some office, the occult excommunicate may well excommunicate, grant benefices and receive petitions, for it is not the person of the excommunicate who does so, but rather his office.

This text is typical of Innocent: concise and perfectly logical one the one hand, extremely bold in its legal consequences on the other. The text presupposes a thorough separation between the person and the office, and applies the toleration principle on the basis of such a separation. So long as the incumbent continues to validly represent his office (or rather, so long as the office is considered to act validly through the person who represents it) the condition of the person itself is irrelevant as to the validity of the acts done by the office through him.

Representation should be viewed within corporation theory. By and large, the discussion of canon lawyers focused on the corporation's decision-making process and on the scope (and limits) within which its representative could validly act on its behalf. ${ }^{16}$ The contribution of Innocent IV to this subject was extremely important and is well known. ${ }^{17}$ Most studies on the development of

16 On the subject the literature is wide. To give only a few references, the obvious starting point is the work of Tierney (1998), pp. 98-117 (among the previous studies of the same author, see esp. Tierney [1951], pp. 420-426). See also the classic studies of Congar (1958), pp. 210-221 and 224-234, Post (1964), pp. 91-162 and Padoa Schioppa (1976), pp. 117-123. More recently see also Pennington (2004), pp. 365-375.

17 See esp. Melloni (1990), pp. 101-131, with ample literature, esp. at pp. 102-106 (and, in the introduction, at p. 13, note 14); Melloni (1992), pp. 290-298. The author has published a small part of his work on Innocent's approach to corporation theory in English: Melloni (1986), pp. 188-193. Cf. Tierney (1998), pp. 99-108, and, more recently, Walther (2005), pp. 203-206. See also Panizo Orallo (1975), pp. 227-342. For a short and clear summary of Innocent's ideas see Ruffini (1936), pp. 13-20, and more recently Bueno Salinas (1985), pp. 17-24. What has attracted most attention of Innocent IV's corporation theory was the ambiguous meaning of the expression 'fingatur una persona': see esp. Innocent's comment on X.2.20.57(=VI.2.10.2), $\$$ in animas (Commentaria Innocentii Quarti, cit., fol. 270vb, n. 5). Innocent's concept of persona ficta, from Girke onwards, triggered a vast debate. As it is well known, Gierke had his own reasons to criticise Innocent and the whole concept of corporation in canon law. Beyond the discussion of the precise meaning of persona ficta, Innocent IV's concept (and institutionalisation) of corporation was in effect the very opposite of Gierke's idea of Germanic corporation as voluntaristic and especially bottomup collectivity. Cf., among the more recent contributions, Tierney (1998), pp. 91-95; Walther (2005), pp. 209-210; Meder (2015), pp. 54-59. Progressively the debate shifted from the dialectic between Germanistic and canon law concept of corporation towards the precise meaning of legal person in Innocent. If ideology played a comparatively lesser role, nonetheless also this second 'phase' of the debate would appear (of course, with the benefit of hindsight) somewhat artificial, as it moved from the implied premise that subsuming the medieval 
corporation theory among canon lawyers, however, overlooked the interaction between toleration and representation. This is probably because such interaction operates at a deeper level, and does not usually affect the capacity of the representative to express the will of the corporate body. The exercise of jurisdiction may affect the corporation when the representative decides something on its behalf. But when the prelate exercises his jurisdiction not as a representative of a specific corporate body but just as a prelate, he is expressing his own will and not that of a specific corporation. Scholars have therefore focused exclusively on the representation mechanism occurring between universitas and the physical person. The point however is that, for Innocent, whenever a prelate exercises any jurisdictional power he is always representing an office - because, as a private person, he would have no jurisdiction. As such, the mechanism of representation operates both when the prelate acts on behalf of a corporation and when he exercises the jurisdiction pertaining to his own office. In both instances Innocent vests the representative with the office. The issue of whether and to what extent the prelate needs the consent of the chapter to act (and so, the limits of the generalis administratio of the procurator), therefore, does not shed full light on the different problem of the relationship between incumbent and officium but remains somewhat external to it, as it deals with the external limits of the exercise of such an officium, not on its internal working.

\subsection{Scope of toleration}

For Innocent IV, legal representation entails the functional identification between person and office: in the execution of his office, the person is the office. ${ }^{18}$ So long as this identification holds, the office acts through the person.

canon law approach within the geometrical boundaries of modern legal categories was not only possible but even desirable. As Feenstra put it, 'le mot fingere a eu sans doute chez les décrétalistes un tout autre sens qu'il ne l'avait chez Savigny et tant d'autres auteurs modernes'. Feenstra (1956), p. 413. See further Michaud-Quantin (1970), pp. 206-211; H. Hofmann (1974), pp. 132-134; Becker (2000), pp. 111-113. For an overview of the different interpretations see Panizo Orallo (1975), pp.379-387, Rodriguez (1962), pp.309-312, and esp. Melloni (1990), pp. 116-125.

18 Cf. Tierney (1998), pp. 122-123; cf. ibid., p. 85. It is not fortuitous that, in his discussion of corporation in medieval canon law, the same Tierney focuses considerably more on Hostiensis than Innocent IV (ibid., pp. 99-108). With regard to corporations, this functional identification between prelate and office in Innocent IV has been studied mostly with regard to the passages where the pope would appear to deny any residual jurisdiction of the ecclesiastical corporation (Innocent IV, ad X.1.2.8, $\mathbb{S C u m}$ accessissent, esp. $\mathbb{S}$ Sedis, and ad X.1.3.21, $\mathbb{S}$ Teneatur [Commentaria Innocentii Quarti, cit., fol. $4 r a-b$, and fol. 19 
No matter how unworthy the person may be, his acts are valid because they are done by the office - not by the private person who represents it. The representation mechanism, therefore, provides both the rationale and the boundaries of the toleration principle. Without proper representation, there cannot be toleration. When this identification between person and office does not hold, the legal incapacity of the person precludes the validity of his acts. This is the case, for example, of a person acting as just a member of a collegiate body. There, it is not the single individual who holds the office, but rather the collegiate body itself. In this regard, Innocent provides an example specifically dealing with the concept of toleration. An excommunicate may be suffered in his office as canon of a cathedral chapter. ${ }^{19}$ But when the chapter makes an election and this canon takes part in it, the election is invalid. For the toleration principle refers to the office, and in this case the office does not belong to the canon, but rather to the cathedral chapter itself. ${ }^{20}$ When on the contrary a single person represents the office, then office and person coincide. Whether the person is worthy of his office or not, so long as the office operates through him, the deeds will be valid. Clearly, this does not amount to approving of the person as an individual, but focuses on that person only as representative. Representation provides the legal basis for toleration.

As already stated, what is tolerated is not the unworthy condition of the person (whether moral, legal or typically both), but rather his holding of the office despite his personal unworthiness. This is why the toleration principle operates only in favour of those who hold public office, and only to the extent of its exercise. To appreciate the link between excommunication, public office and the validity of the acts in Innocent's thinking we may first look at the different

$r a-b$, n. 4 respectively]). See for all Tierney (1998), pp. 98-99. For a simple introduction on the point see the classical study of Gillet (1927), pp. 128-140, and 163-168. Cf. Rodriguez (1962) pp. 305-307; Panizo Orallo (1975), pp. 297-299; Melloni (1990), pp. 109-110; Brundage (2013), pp. 101-102.

19 For a short introduction on the concept of capitulum see first of all the works of Michaud-Quantin (1970), pp. 82-90.

20 Innocent IV, ad X.1.4.8, \$S Suspensus (Commentaria Innocentii Quarti, cit., fol. 34rb, n. 5): 'Vnde si canonici excommunicati, vel suspensi eligant licet tolerentur, et etiam non sunt nominatim excommunicati vel suspensi, tamen excipi potest contra personas eorum, C. de ori(gine) iur(is) 1. i (rectius, Dig.1.2.1) et cassatur quod fit ab eis, quia non dicitur quilibet canonicorum habere publicum officium, sed capitulum potest dici habere publicum officium in electione et aliis, quae ad illud pertinent.' Other canon lawyers remarked the invalidity of the deliberation of the chapter, but did not put it in relation to the absence of representation mechanism. See e.g. Abbas Antiquus (Bernardus de Monte Mirato, c.1225-1296), ad X.2.27.24, $\mathbb{S}$ Ad probandum (Lectura Aurea Domini Abbatis Antiqui super quinque libris Decretalium, Argentine [Johannes Schott], 1510; anastatic reprint, Frankfurt am Main: Vico Verlag, 2014, fol. 128rb). 
effects of excommunication on a person qua legal representative and on a person qua private individual. When Innocent IV sought to limit the effects of excommunication in his decretal Pia (VI.2.12.1), he ultimately followed the same rationale: public excommunication severs any link between the office and the person, but does not necessarily affect the acts made by the excommunicate as a private person. ${ }^{21}$ Elsewhere, commenting on a decretal of the previous Innocent on the Petrine chair (Innocent III), he was even clearer on the point. The person who is publicly excommunicated, says Innocent IV, is suspended from office, so he cannot exercise it. It follows that he is prohibited from exercising any act pertaining to it. While he may not alienate ecclesiastical goods (for he cannot adminster the Church's estates), he may still validly dispose of his own property. Indeed, continues Innocent IV, such an excommunicate may even do the same for other people as their mandatee, for any contract that he makes as a private person remains valid. ${ }^{22}$

The difference between individual and representative can be better appreciated by looking at the legal effects of a judicial condemnation. When the legal effects are such as to preclude the validity of any further act of the person, those acts will be invalid. However, this does not apply if the condemned person holds an office. In such a case, argues Innocent, so long as he is tolerated in his office he will be able to act validly: ${ }^{23}$

21 Innocent IV, Apparatus on decretal Pia (=VI.2.12.1), $\$$ Duraturis, recension 2 (Vodola [ed., 1986], pp. 211-12, 11.50-57): 'Sed hec est differentia inter ea que aguntur extra iudicium et ea que aguntur in iudicio: quia ea que aguntur in iudicio ualent, et ea que aguntur extra iudicium non ualent, ut instrumenta et huiusmodi que fiunt ex officio publico, si est sententialiter dampnatus. Licet aliqui contradicant. Si autem sint talia que non aguntur ex officio publico, ut emptio, contractus, et huiusmodi, illa ualent etiam si publice et solempniter sit excommunicatus, ut not(tatur) supra de $\operatorname{dol}(\mathrm{o})$ et contum(acia) $<$ c. $>$ Veritatis (X.2.14.8), et infra eodem t(itulo) <c. $>$ Exceptionem (X.2.25.12).' On Innocent's position in the decretal Pia see the same Vodola (1986), pp. 88-92.

22 Innocent IV, ad X.2.14.8, $\mathbb{E}$ Excommunicationem (Commentaria Innocentii Quarti, cit., fol. 240vb, n. 1): 'excommunicatus enim cum suspensus sit, et administrare non possit, alienare res ecclesiae non potest, quod intelligendum viditur de nominatim excommunicatis et publice ... Item res suas vendere, donare, et alias emere potest, id est, teneret contractus si faciat 11 quaest. $3<\mathrm{c}$.> quoniam mul(tos) in fin(e) (C.11, q.3, c.103) et expressius infra, de sen(tentia) exc(ommunicationis) $<$ c. $>$ si vere (X.5.39.34) ubi dicitur, quod etiam novos contractus cum eis inire licet, et forte constituat procuratorem ad negotia, oritur inter eos actio mandati, non enim invenimus huiusmodi contractus censeri nullos a iure.'

23 Id., ad X.5.1.24, \Et famam (ibid., fol. 495vb, n. 10): 'Item nota quod sententia lata, statim sortitur quosdam effectus. Verbi gratia, si talis sit poena imposita, quae libertatem aufert, ulterius eius testimonium non valet, nec aliquid ex testamento capiet ... Sed non idem dicimus in his, quae ratione officii facit, puta 
Also note that a judicial decision produces immediately some effects. For instance, if the imposed penalty is such as to deprive one of his freedom, then his testimony will no longer be valid, nor he will be able to receive anything from a will ... But this does not apply to what is done in the exercise of an office - say, if one is a prelate and renders a judgment. In such a case, the acts will hold so long as he is tolerated (as in C.8, q.4, c.1) ... Anything is tolerated because of the office that one exercises (as in D.19, c.8 and in Dig.1.14.3)

It follows that the only way to prevent the validity of any further act done by the holder of an office is to issue a condemnation in order to specifically depose him from his office: ${ }^{24}$

but if a legal decision deposes him or deprives him of the marks of his office, then the judgment rendered by this prelate is void (as in Dig.3.2.2.2 and Dig.5.1.12pr). Nor could it be said that he is tolerated; he should be rather called intruder. We believe, however, that if one is condemned of a crime, either in a civil or a criminal judgment, then his bishop or prelate may deprive him of his benefice (as in C.2, q.1, c.18), but he has to summon him and render a judgment against him - if he appears in court. If he does not appear, his bishop or prelate will condemn him in the same way, for the crime ascertained by legal judgment is notorious.

In other words, it is necessary that the prohibition to exercise an office be the direct effect of a specific legal decision issued to deprive someone of his office. It is not sufficient that the deposition is just an indirect effect of the condemnation. For it is only in the first case that the person is thoroughly severed from the office, so that the representation mechanism ceases altogether to apply. The point is further discussed in Innocent IV's comment on another decretal of Innocent III, Literas vestras (X.3.8.9). After observing how an ecclesiastical prebend ought not to be conferred on someone while still in someone else's possession (for that would trigger litigation and animosity), Innocent IV examines the relationship between the prebend (and especially the office associated with it) and its current possessor. Since the latter no longer has a valid title (having lost it ipso iure), he

si sit praelatus et sententiam ferat, tenebit quamdiu toleratur, 8 quaest(io) quarta $<$ c. $>$ nonne (C.8, q.4, c.1) ... omnia enim tolerantur propter officium, quod administrat, scilicet 19 distin. $<$ c. $>$ secundum (D.19, c.8) ff. de offic(io) praeto (rum) <l.> Barbarius (Dig.1.14.3).'

24 Ibid., fols. 495vb-496ra, n. 10: '... nisi esset in eum lata sententia depositionis, vel spoliatus esset insignibus dignitatis, tunc enim sententia a tali praelato lata, non tenet ff. de his qui no(tantur) infam(ia) 1. secunda \igitur [sed 'ignominiae', Dig.3.2.2.2], ff. de iudi(ciis) <l.> cum praetor (Dig.5.1.12pr) nec potest dici, quod toleretur, sed intrusus dicitur. Credimus tamen, quod ex quo sententia de aliquo crimine lata est contra aliquem sive criminaliter, sive civiliter agitur, quod episcopus vel praelatus suus potest eum spoliare beneficiis, quod sub eo habet, 2 q. $1<\mathrm{c} .>$ multi (C.2, q.1, c.18) tamen debet eum vocare, et contra eum sententiam ferre, si invenietur, et si non inveniatur, eodem modo damnabit eum, quia notorum est crimen per sententiam.' 
now possesses it only de facto. De iure, the prebend is vacant and may be assigned to another. Nonetheless, the possessor was formerly elected and confirmed in the office associated with the prebend: if he continues to exercise it, his acts may be still imputed to the office. To fully sever the relationship between person and office, it is therefore necessary to remove him with a legal decision. ${ }^{25}$

For Innocent, only the legal deposition, or the notoriety of the crime (to which we shall come back), may fully sever the person from his office. This is why Innocent often remarks that, so long as the excommunication remains occult, the excommunicate can validly exercise his office without restriction of any sort. This principle extends also to feudal relationships. The manifest heresy of the lord releases his vassals from their duties towards him. ${ }^{\mathbf{2 6}}$ However, Innocent IV argues, one is not solved from one's duties to a lord who is an occult heretic: so long as his heresy remains occult, this heretic lord is to be fully tolerated in his position. ${ }^{27}$

We have seen how the emersion of the legal features of the concept of toleration are strictly associated with the progressive separation between the sacramental and the jurisdictional sphere. The ambiguities in the elaboration of the concept of toleration that we have so far encountered are fundamentally due to the lack of full separation between the two spheres. By contrast, the clarity of Innocent IV on the subject of toleration ultimately depends on the complete separation of jurisdictional powers from sacramental ones.

Excommunicating and absolving from the excommunication are - in principle - both jurisdictional acts. On the point there was little doubt among canon lawyers. ${ }^{28}$ But only Innocent IV used this division to argue that an occult

Id., ad X.3.8.9 (ibid., fol. $377 \mathrm{rb}$, n. 2): 'Plus placet, quod ideo dicitur vacare de iure, quia in veritate praelatus non est: vt not(atur) sup(ra) de elec(tione) $<\mathrm{c}$. $>$ cum dilectus (X.1.6.32). De facto tamen non de iure est praelatus vel canonicus, quia eius electio est confirmata, vel de eo prouisum per eum, ad quem pertinet collatio, et ideo tenent, et valent, quaecumque eo fiunt nomine dignitatis suae, vel praebende. ff. de offi(cio) praeto(rum) <l.> Barbarius (Dig.1.14.3), et ideo necessaria est amotio sententialis.'

26 Cf. X.5.7.16: 'Absolutos se noverint a debito fidelitatis et totius obsequii, quicunque lapsis manifeste in haeresim aliquo pacto, quacunque firmitate vallato, tenebatur adstricti ...'

27 Innocent IV, ad X.5.7.16 \$Manifeste (Commentaria Innocentii Quarti, cit., fol. 507vb): 'Secus si occulte, $\arg$ (umentum) s(upra) $\operatorname{simo(nia)}$ c. vlt(imo) (X.5.3.46) 11 q. 3 c. 3 et c. Iulianus (C.11, q.3, c.3 and c.94) ibi loquitur de apostata tolerato.' Cf. the Ordinary Gloss to the Liber Extra, infra, next chapter, note 5 .

28 E.g. Gloss ad X.1.6.15, $\mathbb{S}$ De talibus (Decretalium domini pape Gregorij noni compilatio, cit.): 'Scilicet pertinentibus ad iurisdictionem: puta sicut est iudicare excommunicare corrigere iuramenta recipere a vassallis confirmare inuestire beneficia proferre et consimilia ... Bern(ardus).' Innocent's clearest statement 
excommunicate could validly excommunicate. ${ }^{29}$ We have seen how problematic such a case was for earlier decretists. For Innocent, on the contrary, it is a direct consequence of the toleration principle, which entails that the tolerated may validly exercise all the jurisdictional prerogatives related to his office. ${ }^{\mathbf{3 0}}$

Innocent goes even beyond that, and extends the same rationale to simony. If his simony is occult, says Innocent, a prelate who ought to be suspended from his office may be tolerated in it. ${ }^{31}$ The toleration of the Church entails the validity of the simoniac's discharge of his office in any jurisdictional (and so, to use a modern term, also administrative) matter. ${ }^{32}$ Innocent's position on the scope of the toleration principle depends on its rationale. Its extension to the case of simony was consistent with it, but that did not make it any less daring very few canonists would have argued as much. ${ }^{33}$ Nonetheless, as we shall see, Innocent really meant as much.

Another important occasion where Innocent draws a sharp line between occult and manifest crimes entailing the deposition from office, invoking the

on the point may be found when discussing about lifting the sentence of excommunication, ad X.5.31.18, $\mathbb{S}$ Violare (Commentaria Innocentii Quarti, cit., fol. $527 v b$, n. 3): 'Absolvere autem excommunicatum per sententiam non est ordinis, sed iurisdictionis, sicut excommunicatio 2 q. $1<$ c. $>$ nemo (C.2, q.1, c.11) sed absolutionis solennia exhibere, sicut est dicere orationes cum stola et psalmum poenitentialem (sic), et in ecclesiam introducere ordinis et officii est.' Innocent IV, ad X.5.39.34, \$ Circa temporalia (ibid., fol. 552ra, n. 3): 'nec ob(stant) 24 q. 1 c. 2 et 3 (C.24, q.1, c.2-3), vbi dicitur, quod excommunicatus non potest excommunicare: quia ibi loquitur de nominatim excommunicato, etiam non tolerator (sic).' See also supra, this chapter, note 15.

30 The difference with previous canon lawyers also depends on Innocent's more careful and in-depth analysis of the very concept of jurisdiction: see e.g. Legendre (1964), p. 123.

31 Innocent IV, ad X.5.3.35 \$Secure ministret (Commentaria Innocentii Quarti, cit., fol. 502va, n. 3): 'occultus autem simoniacus in beneficio quamvis non sit suspensus ipso iure, sed suspendendus 1 q. 3 c. 12 et 3 (C.1, q.1, c.1-3).'

32 '... omnia quae faciunt administrando temporaliter tenent, quousque ab ecclesia tolerantur', Id., ad X.5.3.35, $\mathbb{S}$ Vitium simoniae (ibid., fol. 502va, n. 2).

33 Just by way of example, Teutonicus criticised Huguccio for arguing that the priest ordained by a simoniac would retain the power of ordo - implying that any power related to iurisdictio was all the more to exclude. Innocent went far beyond Huguccio: the pope was adamant in stating that the simoniac not only retains ordo (e. g. Id., ad X.5.8.1, $\$$ Irritas, ibid., fol. 508va, n. 4) but, so long as tolerated, he would also keep iurisdictio. Cf. Teutonicus' apparatus on the Compilatio tertia, ad Comp. 3, 5.2.7(=X.5.3.35), $\$$ Ex relatione: '... Huguccio tamen dicit quod licet quis scienter recipit ordinem a symoniaco, tamen quamdiu toleratur, confert uera sacramenta, $\arg ($ umentum) xv q. ult. c. ult. (C.15, q.8, c.5) sed ei obuiat quod hic dicitur et xxiii q. iiii <c. $>$ Tres personas (C.23, q.4, c.12).' Transcription by Kenneth Pennington, available online at: http://legalhistorysources.com/edit501.htm (last accessed 6.8.2018). 
toleration principle in favour of the first and denying it for the second, is in his discussion about fornicating priests. Here, the problem was whether the faithful should receive confession and communion by such a priest. The question was of particular importance given that both sacraments ought to be received at least once a year. ${ }^{34}$ A decretal of Lucius III (X.3.2.7) stated that the faithful could receive sacraments from a fornicating priest so long as he was tolerated and his crime remained occult, ruling for the opposite solution if the fornication was notorious. ${ }^{35}$ At the beginning of his comment on the same decretal, Innocent states as much. ${ }^{36}$ However, he adds, if the faithful is aware of the secret state of fornication of the priest, he or she may refuse to receive sacraments from that priest, but only if this refusal does not generate scandal. In such a case, by contrast, the faithful must receive the sacraments from the tolerated occult fornicator. ${ }^{37}$ The same, concludes Innocent, applies to any sort of occult crime

Cf. X.5.38.12.

On notorietas in X.3.2.7 see most recently Schmoeckel (2016), pp. 210-212. Innocent IV, ad X.3.2.7, \$Abstinere (Commentaria Innocentii Quarti, cit., fol. 349vb, n. 1): 'sic abstinere licet occulta esset fornicatio, vel etiam si esset aliud crimen quam fornicatio a proprio sacerdote in his officijs, quae ab eo audire non cogitur, qualia sunt, quae habes $\inf (\mathrm{ra})$ de poe(nitentiis) et remis (sionibus) <c.> omnis (X.5.38.12).'

Id., ad X.3.2.7, $\$$ Abstinere (ibid., fol. 349vb, n. 1): 'et etiam est sciendum, si ex eius abstinentia contra talem sacerdotem, sed fornicatorem, et toleratum scandalum non generetur, alias autem non licet abstinere, nam et dominus corpus suum dedit Iudaeis, de consec(atione) dist. $2<\mathrm{c} .>$ non prohibeat (De cons. D.2, c.67).' Cf. Id., ad X.5.3.7, $\mathbb{S}$ Potest (ibid., fol. 499rb, n. 3): 'sed homicidarum et etiam excommunicatorum occultorum, licet sint suspensi a iure, si tamen alias occultum sit, et tu scis, non debes eorum officia euitare.' The implications of such statements might verge on unorthodox conclusions, especially with regard to the sacraments celebrated by an heretic. So elsewhere Innocent specifies that it is not possible to force a Catholic to receive sacraments from an excommunicated priest although he is tolerated in office. In saying as much, however, Innocent argues that the opposite solution would apply to other kinds of unworthiness. Id., ad X.5.8.1, \$Irritas (ibid., fol. 508ra, n. 3): 'Nec est contra 9 q. 1 c. 1 et 3 (C.9, q.1, c.1 and 3) ... quia ibi loquitur, quando per sententiam vel renunciationem non habebant executionem, nec tolerabantur ab ecclesia, et ideo aliis eam dare non poterant. Hic autem plus est in excommunicatis, quod etiam si tolerentur, dummodo probari possit, si vocent aliquem ab ordines, vel alia sacramenta, potest ei dici, non recipiam hoc a te, quia es excommunicatus, unde tibi participandum non est, et ex hac causa legitima est appellatio, secus autem esset in allis, puta irregularibus infamibus, et aliis praedictis, et quia non esset contra eos admittenda talis exceptio, non recipiam hoc a te, quia es irregularis, sufficit enim quod toleretur 8 quaestio fi. $<$ c. $>$ nonne (C.8, q.4, c.1).' Cf. also Id., ad X.2.27.24, $\$$ Infirmandam (ibid., fol. $314 v a$ ). The possibility of refusing contact with an excommunicate - and a fortiori to refuse to receive sacraments from him, Innocent says, has little to do with the toleration principle. Id., ad X.1.6.44, 
committed by a prelate. Heinous as the occult crime may be, even simony or murder (both entailing ipso iure suspension from office), the prelate is to be tolerated in it so long as not formally removed. ${ }^{38}$ By contrast, if the crime entailing suspension from office is notorious, any Christian may lawfully avoid him, even if he is still tolerated in office. ${ }^{39}$ This last statement is important as it strengthens the link between the toleration principle and the concept of representation. Whatever his sins, a prelate is to be tolerated in office so long as he may lawfully discharge it. But the moment the relationship between prelate and office is severed (such as in the case of manifest crime triggering the ipso iure suspension from office), then the toleration becomes only a question of fact, unable to produce legal consequences. If such a prelate were to retain his position, this would not amount to proper toleration but only to de facto forbearance. As such, it could not confer validity on the enduring exercise of the office that the prelate no longer validly represents.

At the beginning of this analysis of Innocent IV we saw how he applied the toleration principle only to cases in which the holder of an office received it lawfully. ${ }^{\mathbf{4 0}}$ The reason is simple: legal representation applies only in that case. Neither the person who is no longer legitimately vested with an office nor the

\Administrent (ibid., fol. $75 v a$, n. 5): 'excommunicato autem propter periculum excommunicationis poterat obstare agenti, siue sit confirmatus, siue non, sed facta ab excommunicato tolerato non retractantur, inf(ra) de dona(tionibus) $<\mathrm{c}$. $>$ inter dilectos (X.3.24.8).' Similarly, while (as we have seen) the occult simoniac may validly exercise his office in any jurisdictional matter, he may not celebrate mass. Id., ad X.5.3.7, $\mathbb{P}$ Potest (ibid., fol. 499ra-b, n. 3): 'Item alij licite audiunt officium aliorum criminosorum, nisi sint suspensi per sententiam, sed simoniacorum officium audire non debent, etiam si nulla sententia feratur contra eos. Est enim in eis speciale, sicut in notorijs fornicatoribus, quod eorum officia audire non debent, 32 dist. $\mathbb{S}$ verum (D.32, p.c.6). Ergo speciale in notorio fornicatore et simoniaco, quod etiam si tolerantur ab ecclesia, cuique licet eorum officium euitare: vt hic 32 di. $\$$ verum (D.32, p.c.6).'

38 Id., ad X.3.2.7, $\$$ Operis (ibid., fol. 350ra, n. 2): 'sed et si crimina pro quibus a iure suspenduntur, sunt occulta, quandumcunque sint grauia, vt simonia, homicidium, et huiusmodi: tamen euitari non debent in his, quae ab eis recipi debent de iure, $\arg$ (umentum) hic de consec(atione) dist. $2,<\mathrm{c}$. $>$ non prohibeat (De cons., D.2, c.67), et idem videtur etiam dicendum in occulto excommunicato, 6 q. fi. $<$ c. $>$ tantum (C.6, q.2, c.2), su(pra) de offi(cio) ordi(narii) $<$ c. $>$ si sacerdos (X.1.31.2).'

39 Ibid. (fols. 349vb-350ra, n. 2): 'et hoc dicimus generale, quod omnium suspensorum a iure etiam sine scientia hominis, si crimina pro quibus ius eos suspendit $\mathrm{ab}$ officijs, vel quocunque alio actu sunt notoria per facti euidentiam, quod cuicunque licet eos vitare in his, quae eis interdicta sunt, licet adhuc idem suspensi tolerentur a suis praelatis, et idem dicendum videtur in regularibus, quia et ipsi suspensi a iure dici possunt.' 
one who has forcibly seized it may legally represent the office. For Innocent, they are both 'intruders' in the office. The intrusus, in other words, is not tolerated in the office because there is no representation mechanism at work. Acts carried out in such a way remain those of a private person, they do not become acts of the office. More precisely, the office cannot act through that person. Whether he ceases to represent his office lawfully or he assumes it unlawfully, therefore, his acts are void for they are not imputable to the office. ${ }^{41}$ It should be noted that the reference to the intrusus had a specific meaning: someone who unlawfully occupies a position in the Church. The Ordinary Gloss on the Decretum, for instance, considered the heretical bishop an intrusus so as to deny that priests consecrated by him could validly exercise their ministry. ${ }^{\mathbf{4 2}}$ For Innocent intrusus is usually the prelate who either has seized his office or, and especially, has not been confirmed in it by the superior authority. As he lacks the power to validly represent the office, whatever he does remains void. ${ }^{\mathbf{4 3}}$

\subsection{Some specific applications}

Having established the boundaries within which the principle of toleration applies in the thinking of Innocent IV, we may proceed to look at some specific cases in which it operates. The most relevant for our purposes is that of the legally unfit judge: its importance is both general and specific. General, for it highlights the connection between representation and toleration. Specific, for Barbarius sits in the office of praetor - the judge par excellence.

41 Innocent IV, ad X.1.6.44, $\mathbb{S}$ Administrent (Commentaria Innocentii Quarti, cit., fol. $75 \mathrm{ra}$, n. 3): 'multo fortius cassantur, si a principio non haberent canonicum ingressum, ut quia simoniace, vel per intrusionem, vel schismatice, vel quia haereticus, vel excommunicatus assumptus est, vel alias etiam contra ius naturale est electio de eo facta, et etiam non est confirmata, alienationes enim et ordinationes ab eo factae non valent.'

42 The bishop retained ordo, but could not exercise it validly - so the new priests would receive ordo but not executio ordinis. Gloss ad C.9, q.2, c.5, $\$$ Ordinationes: '... In prima parte dicitur quod illi qui receperunt ordines ab episcopis ordinatis in heresi, vel ab intrusis, non tolerantur in suis ordinibus quo ad executionem, nisi probent se nesciuisse in tempore ordinationis eos fuisse damnatos. Jo.' (Basileae 1512, fol. 182va; cf. Pal. Lat. 624, fol. 133vb). For the (later) interpretation of intrusus as invasor see Fedele (1936), pp. 329-330.

43 Innocent IV, ad X.1.6.44, $\mathbb{\$}$ Administrent (Commentaria Innocentii Quarti, cit., fol. $75 r a-b$, n. 4): 'Nam ubi aliquis est intrusus, in aliqua ecclesia sine authoritate superioris qualis est omnis non confirmatus, puta quia sua authoritate occupavit, vel aliorum potentum, quicquid facit non tenet, sive alienando, sive praebendas conferendo, sive agendo, sive iudicando, nec liberantur ei solventes 16 q. $7<\mathrm{c}$. $>$ si quis de(inceps) (C.16, q.7, c.12) sicut etiam non tenerent, si a quocunque extraneo fierent, non enim debet esse melioris conditionis, quia vitiosus est.' Cf. infra, pt. III, $\$ 11.6$, note 125 . 
If a legally unfit person serves as an ordinary judge, ${ }^{44}$ says Innocent, he must be tolerated in that office and his deeds will be valid. The same however does not apply to the delegate judge, for the office does not operate through him. Innocent provides two different explanations for this distinction. The first is more pragmatic: so long as the ordinary judge is tolerated in his office, holds Innocent, the parties cannot raise any objection to his jurisdiction on the basis of his status. ${ }^{45}$ Since he retains his office it would be absurd to object to his legal capacity to sit as a judge in one case, only to have him judging the next. ${ }^{46}$ By contrast, the delegate judge has an ad hoc jurisdiction - he can hear only specific cases. ${ }^{47}$ So it is possible to recuse the delegate judge by raising an exception to his status - say, by arguing that he is a slave or infamis - provided of course that the exception be raised before the joining of the issue. ${ }^{48}$ The second explanation provided by Innocent is more sophisticated and deeply linked with his overall argument on toleration. According to him, the reason it is not possible to object

For a simple introduction to the difference between ordinary and delegated iurisdictio see the study on Hostiensis by Heintschel (1956), esp. pp. 145-148. On its early development in canon law see the classical early work of Legendre (1964), pp. 117-123.

45 Innocent IV, ad X.1.3.13, \$S Sciscitatus (Commentaria Innocentii Quarti, cit., fol. 12ra, n. 2): 'Sed quaeritur, an hae exceptiones de impotentia iuris vel facti contra ordinarium possint opponi? Respondeo, hae exceptiones locum habent contra delegatum, contra ordinarium autem quandiu toleratur in dignitate, locum non habent, ut notat(ur) infra de offic(io) delegat(i) <c. $>$ cum super (X.1.29.23) ... Item nec praetextu infamiae vel seruitutis sententia retractabitur. Item not(atur) quod infamis non potest se excusare a iudicando, nisi excipiatur contra eum, $\arg$ (umentum) C. de decu(rionibus) $<$ l. $>$ nec infamis et l. infamiam (Cod.10.32.10 and 8), ff. de offi(cio) praeto(rum) <l.> Barbarius (Dig.1.13.4).'

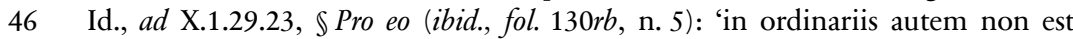
admittenda talis exceptio, tu es seruus vel infamis, cum quandiu toleratur, omnes sententiae eius tenent, ff. de offic(io) praet(orum) $<$ l. $>$ Barbarius (Dig.1.13.4) ... et est ratio diversitatis [i. e. between ordinary and delegate judge], quia absurdum esset, quod ordinario semel amoto a iudicando, vel aliquo alio quod ratione officii facere tenetur, postea in dignitate remaneret.'

47 Ibid., 'secus autem in delegato, qui vult illam causam tantum, quae in delega$\mathrm{t}$ (ione) continetur ratione illius commissionis facere, quod non debet.'

48 Id., ad X.1.3.13, \$ Sciscitatus (ibid., fol. 12rb-va, n. 2): 'et hae exceptiones, quod sit infamis, vel seruus, vel mulier, vel alias moribus, vel legibus prohibeatur, cum sint declinatoriae iudicii ante litem contestatam proponendae et probandae sunt, $\arg$ (umentum) de $\operatorname{arbit}($ ris) $<$ c.> dilecti (X.1.43.4), C. de excep(tionibus) 1. pe(nultima) (Cod.8.35.12).' Cf. also Id., ad X.1.29.23, $\$$ Pro eo (ibid., fol. 130va, n. 6): 'et ideo licitum est apponere eam contra delegatum antequam iudex fiat, id est, antequam sit in eo statu, quod iurisdictio eius elidi non possit, vel antequam partes in ipsum consentiant: ut not(atur) supra, de rescrip(tis) $<$ c. $>$ sciscitatus (X.1.3.13): sed post quod iudex fuerit, non habet locum haec exceptio infamiae, vel servitutis, quae non apponitur, ne iudicetur, sed ne iudex fiat.' 
to the jurisdiction of the ordinary judge lies in that the exception based on his status is indirect. The law, argues Innocent, prohibits someone who is a slave or infamis from serving as a judge; it does not also prohibit him from rendering a judgment. It is only because of the prohibition on serving as a judge that such a person should not issue a judgment. But, so long as the person does serve as ordinary judge, the defence would be of little avail - the judge should be deprived of his office first. ${ }^{49}$ The point might seem a cavil, but in fact openly challenged the restrictive interpretation of Gratian's dictum Tria provided by some early decretists, especially Rufinus. ${ }^{50}$ By contrast, and precisely for the same reason, Innocent allows the delegate judge to be recused by challenging his jurisdiction: given the delegated nature of his powers, it is sufficient to object to their validity to bar the jurisdiction of the delegate judge on the specific case for which he received his jurisdiction. ${ }^{51}$

Id., ad X.1.29.23, Pro eo (ibid., fol. 130rb-va, n. 5-6): 'Item alia ratio est, quia praedicti scilicet, servi et infames non prohibentur expresse iudicare, sed per consequens, quia prohibentur ne iudices fiant, ff. de re iudic(ata) 1. 1 (Dig.42.1.1), ff. de iudi(ciis) <l.> cum praetor (Dig.5.1.12.2). Quando ergo fiunt iudices, potest excipi, quod non fiant, quia infames sunt, sed si fiant licet infames vel servi sint, tamen iudices erunt, ff. de offic(io) praeto(rum) $<$ l.> Barbarius (Dig.1.14.3). Per consequens ergo omnia facient, quae ad iudicem pertinent. Nec obstabit exceptio infamiae, vel servitutis, volenti iudicare, cum haec exceptio non impediat iudicare, sed tantum iudicem fieri, ut dictum est.'

50 Supra, $\$ 6.3 .1$, text and note 50. It is interesting to note how Innocent came to this conclusion on the basis not of canon law sources (as Rufinus did), but only of Roman law ones.

51 A different (but straightforward) issue is the validity of the acts of the delegate judge when the ordinary judge suffers a sentence of excommunication. Deprived of its source, the delegation may no longer produce any effect and so the acts of the delegated (made after the excommunication of the ordinary) are void. Innocent IV briefly touched on this subject, not as a scholar but as pope, in the bull Romana Ecclesia, which he issued (on 17.3.1246) against the Archbishop of Rheims. The part of Innocent's decretal that then found place in the Liber Sextus (VI.1.8.1) was only the revocation of the Archbishop's edict (the edict that the Archbishop issued to advocate to himself the whole caseload of the suffragan whom he had excommunicated). In her masterly study, Vodola argues that the revocation of the edict was made on the basis that the suffragan was excommunicated for personal sins and not for the way he exercised his office (Vodola [1986], p. 119, text and note 40). The interpretation is however doubtful. Innocent's text states: 'Edictum uero ... penitus revocamus; quia, si etiam tenerentur ijdem episcopi pro suis culpis uinculo excommunicationis adstricti, non tamen ex culpis ipsis, cum id non inveniatur a iure concessum, ad Remensem archiepiscopum iurisdictio devolueretur eorum, sed alia forte pro illis pena ipsis canonica posset infligi' (Kessler [ed., 1942], p. 178, 8a, 1l.10-18). Vodola bases her interpretation on the distinction between personal sins and exercise of office. The revocation of the edict, however, was made on the basis 
An interesting confirmation of Innocent's position on both the toleration of the prelate exercising ordinary jurisdiction and the toleration of the simoniac may be found in the Libelli iuris canonici of Roffredus de Epiphanio (better known as Roffredus Beneventanus, c.1170-post 1244). There, Roffredus recalls a decision rendered by the future Innocent IV when still a cardinal. Roffredus was discussing the issue of whether a simoniac is entitled to collect the tithes that pertain to his office. He did not elaborate on the subject, but simply reported the opinion of Johannes Teutonicus (hardly an advocate of the toleration principle) on the (rather loose) idea that many sinners ought to be tolerated after the example of Judas. ${ }^{52}$ It is one thing to tolerate the simoniac, says Roffredus,

that its ground was not one for which the metropolitan could advocate the suffragan's jurisdiction to himself (see e. g. the explanation of Johannes Andreae, ad VI.1.8.1, $\mathbb{\$}$ Romana [Ioannis Andreae ... In sextum Decretalium librum Nouella Commentaria ..., Venetiis, apud Haeredem Hieronymi Scoti, 1612, fol. 42rb-va]). The exercise of office was present in Innocent's decretal, although not with regard to the excommunicated suffragan but rather with regard to the officers delegated by him. Attention should rather be drawn to the part of the decretal immediately preceeding the above text (a part that did not find a place in the Sextus). This part deals with the validity of the acts of the officials delegated by the same suffragan. It reads: 'Et cum in officialem alicuius suffraganei sui excommunicationis sententiam ex aliqua rationabili causa profert, illos, qui uices ipsius gerunt, propter hoc excommunicationis uinculo non astringat, cum non communice $<\mathrm{n}>\mathrm{t}$ ob id officiali eidem in crimine, qui ecclesiastice censure districtione pro eo, quod suum exerce $<\mathrm{n}>\mathrm{t}$ officium, non $\operatorname{ar}<\mathrm{c}>\mathrm{ta}<\mathrm{n}>$ tur; ea tamen, que ipsi gerendo huiusmodi uices agunt, illo taliter excommunicato manente, si iurisdictionem tantum recipiunt ab eodem, non pos $<\mathrm{s}>$ unt obtinere uigorem' (Kessler (ed., 1942), pp. 177-178, n. 7, 1l.1-9). Reading together the two parts of the decretal, we do find Vodola's distinction between personal sins and exercise of the office, but they do not refer to the same subject. The personal sins ('si etiam tenerentur ijdem episcopi pro suis culpis uinculo excommunicationis adstricti') constitute the ground for the excommunication of the suffragan; the exercise of the office is the reason why the officers delegated by the excommunicated did not partake in his excommunication. The delegated officers exercised an office belonging to the suffragan, and they did so in the name of the same suffragan. The delegate judge acted in the name and on behalf of the true representant of the office. When the latter no longer represented the office, the link between office and delegate judge was automatically severed.

52 Roffredus de Epiphanio, Libelli iuris canonici, Argentinae [Johann Grüninger], 1502, pt. 4, $\$$ An expense sunt deducende de decimis, fol. 14vb: 'Sed credit Jo(hannes Teutonicus) quod quamdiu ab ecclesia tolleratur quod possum ei soluere: nam multi tolerantur vt iudas: vt ii q. i $<$ c. $>$ multi (C.2, q.1, c.18).' The text quoted in this and the next few notes may also be read in the more accessible Avignon 1500 edition (anastatic reprint, Augustae Taurinorum: Ex officina Erasmiana, 1968, Corpus Glossatorum Juris Civilis, VI.2, G. C. Caselli ed., fol. 14va).

Teutonicus' reference to Judas as a case of toleration (in the sense of forbearance in order to avoid scandal) is perhaps clearer elsewhere: see supra, last chapter, 
another to let him bring forth a legal suit to enforce his claims. So what happens if the simoniacal prelate brings an action to get the tithes? The judge, he answers, may not hear his claim. ${ }^{53}$ Nonetheless, Roffredus continues, this is not what he saw in the Roman Curia.

The bishop of Gallipoli, says Roffredus, sued an abbot to enforce his rights on tithes. The abbot raised an exception based on the bishop's alleged simony, but the future Innocent IV - by then, Cardinal Sinibaldus - dismissed it on the ground that the bishop was tolerated by the Church. So long as he was tolerated, Sinibaldus allegedly said, the bishop had the right to enforce any right pertaining to his office. ${ }^{54}$ In Roffredus' report Sinibaldus therefore denied the exception because the bishop had been confirmed in his office. According to Roffredus, Sinibaldus stated that the accusation of simony could not be brought in the form of an exceptio but only as accusatio. ${ }^{55}$ The last two statements are of particular importance, as they fit perfectly with Innocent's interpretation of the toleration principle. As toleration is based on representation, the unworthiness of the office holder, whatever its cause, may not void the election if the prelate is confirmed in office - as the bishop of Gallipoli was. Further, and more importantly, the same concept of legal representation underpinning the toleration of the unworthy means, as we have seen, that it is not possible to object to the jurisdiction of an ordinary judge (such as a bishop, whose office entitles him to

note 138. The reference to Teutonicus' interpretation of C.2, q.1, c.18 is in effect more on the procedural effects of excommunication (ad C.2, q.1, c.18, $\$$ seculari (Pal. Lat. 624, fol. 93vb; partially in Basileae 1512, fol. 132ra). On the point, the printed Gloss insists more on the idea of toleration (meant as Christian forbearance) than Teutonicus: ad C.2, q.1, c.18, casus ad $\$$ Multi curriguntur (Basileae 1512, fol. 131vb). See however Teutonicus ad C.2, q.1, c.19, $\$ s i$ peccauerit (Pal. Lat. 624, fol. 94ra; cf. Basileae 1512, fol. 132rb).

53 Roffredus, Libelli iuris canonici, cit., pt. 4, $\$$ An expense sunt deducende de decimis, fol. $14 v b$ : 'Sed quid si prelatus petat: et ego obijtiam ei quod sit symoniacus: nunquid debeo audiri.'

54 Ibid.: 'vidi tamen in curia romana aliter pronunciatum per dominum sinibaldum tituli sancti lauren(tii) in licinia praesbyterum car(dinalem). Nam dum episcopus gallopolitanus peteret $\mathrm{ab}$ abbate de victo iura episcopalia: et opposita fuisset ei praedicta exceptio a procuratore abbatis et vellet eam probare ipsum non admisit, a cuius interlocutoria dum procurator abbatis appellasset, papa cum fratribus ipsum appellante non admittit: imo cum verecundia ipsum remouit, et his rationibus. Quia quamdiu ab ecclesia toleratur non debet repelli: imo ad omnia tanquam episcopus debet admitti, vt ii q. i $<$ c. $>$ multi corriguntur (C.2, q.1, c.18), et viii q. iiii $<$ c. $>$ nonne directa $($ C.8, q.4, c.1), et vi q. ii $<\mathrm{c}>$ si tamen episcopus (C.6, c.2, q.1).'

55 Ibid.: 'Preterea contra electum confirmatum non admittitur quis in in modum exceptionis sed in modum accusationis: ergo multofortius non debet excipi contra episcopum iamdiu (sic) in episcopatu extantes: vt extra de accusa(tionibus) $<$ c. $>$ super his (X.5.1.16).' 
ordinary jurisdiction within his diocese) by way of exception. An exception bars a specific action in a single suit, but it does not sever the link between the unworthy prelate and his office. So the bishop, as ordinary judge, would still retain his full jurisdiction. It is therefore necessary to bring an action specifically aimed at deposing the unworthy from office. Until then, the unworthy is to be tolerated in office - and so he is fully entitled to its exercise.

If we are to consider Roffredus' report as true, therefore, the position of Innocent IV in his commentary on the Liber Extra was the same as that of Sinibaldus acting as a judge. ${ }^{56}$ Although Roffredus hardly approved of Sinibaldus' decision ${ }^{57}$ there is no solid reason to dismiss his report, especially as

56 If this episode is true, it is difficult to date it with more precision than within the fifteen years separating Innocent's appointment as auditor and his election to the Petrine Chair in 1243. Sinibaldus de Fieschi was auditor litterarum contradictarum from 14 November 1226 to 30 May 1227 (Cerchiari [1920], vol. 2, p. 9), and then Vice-Chancellor from 31 May 1227. Shortly thereatter, on 18 September 1227, he became cardinal but (rather exceptionally) he retained for a while the office of Vice-Chancellor (his successor appears in the sources only on 9 December of the same year: Potthast [1874], vol. 1, p. 939). It is possible that he rendered this judgment in the short period in which he was already cardinal and still ViceChancellor. But it may not be ruled out that he did so at a later time. Innocent's involvement in the Roman Curia continued even after his appointment as rector of the March of Ancona (from February 1235 to December 1240), for he appointed some substitutes (we know of at least two) and spent a considerable part of his time in the Curia. See esp. Paravicini Bagliani (1972), vol.1, pp. 65-67, where ample literature is listed. Cf. Piergiovanni (1967), p. 149.

57 Describing Sinibaldus' judgment, Roffredus observed that it was harsh ('sed durum videtur') and hardly justifiable in law. The simoniac was ipso iure suspended from office (Roffredus de Epiphanio, Libelli iuris canonici, cit., pt. 4, An expense sunt deducende de decimis, fol. 14vb: 'nam video quod symoniacus in ordine est ipso iure suspensus: vt extra de $\operatorname{symo}($ nia $)<c$. $>$ si quis ordinauerit (X.5.3.45).'), so the abbot's exception would have amply sufficed to bar his action. For Roffredus, the toleration principle was a consequence of the principle ecclesia de occultis non iudicat. As such, it would apply so long as the sin remained hidden. Seeking to enforce the rights he acquired through simony, however, the bishop made his simony manifest. Just as a thief could not bring an action on theft, argued Roffredus, so the bishop could not enforce the rights unlawfully acquired. Similarly, he continued, the bishop could not invoke his possession of the office, for that too was acquired unlawfully. 'Item nonne videtur necessarium quod soluantur sibi decime: quia est in posssessione, et quam toleratur ab ecclesia. Respondeo quia toleratur, quia usque modo fuit eius peccatum occultum; sed si illud volo facere manifestum, quare non sum audiendus. Nam si est fur vt dictum est, ergo non agit cum sit odiosus. Nam fur furti non agit, vt ff. de furtis $<$ l.> qui vas (Dig.47.2.48) ... Item non prodest ei sola possessio: quia illa est improba, et improba possessio firmum titulum possidenti non prestat: vt C. de acq(uirenda) pos(sessione) <l.> improba et 1 . nec ex vera (Cod.7.32.7 and 9). Item si aliquis agit vti possidetis non prodest ei possessio: 
Roffredus was a privileged witness of many episodes happening in the Roman Curia (as his Libelli iuris canonici would amply show), and, more specifically, for his account of Sinibaldus' decision was also reported in Guido de Baysio's Rosarium. $^{58}$

\subsection{Toleration, common mistake and public utility}

While the toleration principle applies only to those holding an office, it derives not from a mechanical application of legal representation, but rather from public utility considerations. ${ }^{59}$ Holding an office, argues Innocent IV, is

quominus possit quis contra ipsum excipere quod vi aut clam seu precario possidet: vt C. vti possidetis l. i (Cod.8.6.1), et ff. vti possidetis l. i (Dig.43.7.1),' ibid.

In his reproach against the decision of the future pope, Roffredus displayed a sense of humor: the prince (and so the pope) is lex animata, so he may derogate from positive law, and so his harsh decision is itself to be tolerated ('sed durum videtur, sed quia lex animata principit licet ita sit per quam durum tamen tollerandum est', ibid).

58 Baysio however took Roffredus' account out of context, and referred it to a question on vitiated possession. The error is understandable since, as we shall see, Innocent wrote an extensive commentary on the question of whether the possession of jurisdiction is to be tolerated (and so the jurisdiction enforced) when glossing on X.3.36.8. In Baysio's version, therefore, Sinibaldus invoked the toleration principle to uphold the bishop's vitiated possession of his office and to allow him to exercise the rights flowing from that office. Guido de Baysio, Rosarium super decreto (Venetiis [Herbort], 1481), ad C.8, q.4, c.1, $\$$ Nonne directa: 'Item si aliquis agit vti possidetis non prodest sibi possessio quominus possit excipere quod vi aut clam seu precario possideret ... dicit tamen ipse rof(redus) quod uidit in curia romana aliter pronuntiari per dominum sinibaldum in $s$ (ancto) la(urentio) praesbiterum cardi(nalem). Nam dum episcopus quidam peteret ab abbate iura episcopalia et opposita fuisset predicta exceptio a procuratore abbatis et eam uellet probare ipsum non admittit a cuius interlocutoria cum procura(tione) abbatis appellasset dominus papa cum fratribus ipsum appellantem non admisit immo cum verecundia repulit et hoc rationibus istis: quia quamdiu ab ecclesia tolleratur non debet repelli immo ad omnia ut episcopus debet admitti ii q. i <c.> multi (C.2, q.1, c.18), vi q. ii <c.> si tantum (C.6, q.2, c.2).' The two references in the text were added by Baysio. The first ((C.2, q.1, c.18) is an extremely general reference to toleration, the second (C.6, q.2, c.2) is one of the main sources of the principle ecclesia de occultis non iudicat, which was how Baysio - quite unlike Innocent - would often interpret the toleration principle: infra, $\$ 8.3$.

59 On the concept of public utility in Innocent IV see esp. Innocent IV, ad X.3.35.6, $\$$ Summus (Commentaria Innocentii Quarti, cit., fols. 432vb-433ra-b, n. 2, 3 and esp. 4). Cf. Galli (2008), p. 155. See also more broadly Leveleux-Teixeira (2010), pp. 262-264 and 267-270. The canon law concept of utilitas ecclesiae, it may be noted, is not too distant from the civil law idea of publica utilitas. This closeness may be found as early as in Teutonicus' Gloss on the Decretum. When 
sufficient reason for the people to rely on someone's authority. If the office holder suffers some supervening legal incapacity, the people may not be aware of that and continue to rely on what they see - that is, on the simple fact of his holding the office. To be sure, he ought to be removed from it, but so long as he is not (and so, as long as he is tolerated in that office) this is sufficient reason for the validity of the deeds, which would otherwise be void. Ultimately, therefore, it is for the sake of the common good that his acts are held as valid. ${ }^{60}$

A clear example of this may be found in Innocent's discussion of the validity of the appointment of a procurator (procurator ad lites) by the excommunicate. As a general principle, an excommunicate may not sue. ${ }^{61}$ So if he appointed a procurator to that end, the appointment should be void. But what if the excommunicate holds a public office? The answer, according to Innocent, depends both on the kind of excommunication and on the reason he sought to sue. If the excommunication is done by way of legal pronouncement (i. e. an excommunication ferendae sententiae), ${ }^{\mathbf{6 2}}$ or is manifest, then the procuration is void. This, as we have seen, is just an application of the toleration principle. The appointment of the procurator is done in the exercise of an office that the excommunicate should no longer discharge. But if the excommunication is latae sententiae (i.e. it does not depend on a judicial decision but occurs ipso iure) and remains occult, then the same person is tolerated in his office. Being still able to exercise the office, the appointment of the procurator is valid, and the exception of excommunication (which would otherwise suffice to bar the action) may not

commenting on C.1, q.7, p.c.6 (a dictum where Gratian observed that some crimes are tolerated by the Church out of mercy), Teutonicus observed that the same happens in Roman law ( $\mathbb{\text { utilitatis: }}$ 'Sic et ius ciuile quaedam admittit propter utilitatem, ff. de pigno(ribus) $<$ l.> sed an vie (Dig.20.1.12). Jo.' (Pal. Lat. 624, fol. 90vb; cf. Basileae 1512, fol. 126va). Cf. Eschmann (1943), p. 139.

60 This of course does not mean that there may not be public utility considerations (and so, validity of the deed) without legal representation. A good example is X.3.16.1, which discusses the validity of the deeds made by a prelate who has already been deposed. In principle, such deeds are void. But they may receive execution if they further the utilitas ecclesiae. More correctly, the Church is not bound to them, nisi in utilitatem ecclesiae sit versum. In his lengthy comment on the point, Innocent IV makes it clear that the possibility of giving execution to any such deed has nothing to do with the position of the person who made it (nor with his toleration in office), but exclusively with the utilitas ecclesiae. Innocent IV, ad X.3.16.1, $\$$ Conuersam and $\$$ Pacisci (Commentaria Innocentii Quarti, cit., fols. 390vb-391vb).

61 Vodola (1986), pp. 73-92.

62 On the distinction between excommunication latae sententiae and ferendae sententiae (or rather, on the progressive development and widening of the former) see Vodola (1986), pp. 28-35, and more in-depth Jaser (2013), pp. 359-373. 
be raised. ${ }^{63}$ If however the office holder so excommunicated were to appoint a procurator not in the discharge of his office but for personal reasons - and so, acting as a private person (pro se) - then his treatment would be no better than any other private individual, and the appointment will be void. It is only in the exercise of his public office, reasons Innocent, that the occult excommunicate acts for the sake of public utility. ${ }^{64}$

But what exactly is this public utility? A few lines later in the same passage Innocent reiterates the same concept. This time however he speaks of the validity of the appointment not 'for public office and public utility' (ratione publicae utilitatis, et publici officii), but rather 'for public office and public ignorance' (propter publicam ignorantiam, et propter publicum officium). Such reasons justify the different treatment between private persons and office holders. On their basis it is possible to hold as valid something that in normal circumstances would be void. Public utility considerations therefore depend on common ignorance as to the excommunicated status of the office holder, and so on common mistake. This is why Innocent cites the lex Barbarius in this occasion. ${ }^{65}$ There may be little doubt as to the proximity between public utility and public ignorance, for the same concept is repeated yet again soon thereafter. ${ }^{66}$ The point is interesting as it strengthens the conclusion that public utility in this case lies in the protection of

63 Innocent IV, ad X.1.38.15, $\mathbb{S}$ Sententia (Commentaria Innocentii Quarti, cit., fol. 172ra, pr and n. 1): 'Bene dicit, quod hi qui erant innodati per sententiam, quia si non essent per sententiam innodati, sed a canone, sive esset occultum, sive notorium, tamen constitutio procuratoris ab eis facta teneret, nec posset huiusmodi procurator per exceptio(ne) repelli, cum tolleretur in officio eius cuius authoritate procurator constitutus est 6 q. $2<$ c. $>$ si tantum (C.6, q.2, c.2), $\arg$ (umentum) 8 q. $4<$ c. $>$ nonne (C.8, q.4, c.1). Sed quando per sententiam sunt damnati, sive occultum, sive manifestum sit, non possunt constituere procuratorem.'

64 Id., ad X.1.38.15, \Sententia (ibid., fol. 172ra, pr): 'si autem non pro universitate, sed pro se quis constituat procura(torem) tunc bene repellitur exceptione, etiam si tantum a canone est excommunicatus, et etiam si sit occultum, et est ea ratio diversitatis, quia ibi tolerantur, quae fecit ratione publicae utilitatis, et publici officij, quod exercet, at in alio casu, ubi publicum officium non excercet, non expedit.'

65 Id., ad X.1.38.15, $\mathbb{S}$ Sententia (ibid., fol. 172ra, n. 1): 'vel dic quod aliter est circa illos, qui sunt in publicis officiis, aliter in contractibus, qui celebrantur cum aliis, vel in negotiis quae alios tangunt, ut sunt in instrumenta, et testimonia cuiuslibet iurisdictionis voluntariae, et contentiosae excercitium, ubi propter publicam ignorantiam, et propter publicum officium aliqua valent, et habent effectum quae aliter non haberent, ff. de offi(cio) praesi(dis) (sic) 1. Barbarius (Dig.1.14.3), C. de testa(mentis) 1. 1 (Cod.6.23.1).'

66 Id., ad X.1.38.15, $\mathbb{S}$ Sententia (ibid., fol. 172rb, n. 1): 'quia iam ibi adest alia ratio, sci(licet) quod teneat propter communem ignorantiam, et publicum officium.' 
the people, who could not be aware of the underlying status of the excommunicate. This is why the toleration principle does not apply either in the case of excommunication ferendae sententiae or when the crime entailing the deposition from office is notorious. A sentence entails legal truth, against which one cannot plead ignorance. ${ }^{67}$ Notoriety bars public utility considerations in that it does not excuse ignorance as to the true status of the office holder.

The same rationale is also visible in the case of the notary who forges a document. ${ }^{68}$ Forgery is surely cause enough to deprive a notary of his office. But so long as he is tolerated in it, says Innocent, the documents he produces are valid. ${ }^{69}$ Innocent IV does not elaborate further on the point, but he justifies his conclusion on the basis of public utility. In so doing, he relies again on the lex Barbarius. ${ }^{70}$ It seems therefore likely that the public utility considerations in this case, just as in that of the appointment of the procurator, lie in the common ignorance as to the unworthy status of the notary. Both the occult heretic and the notary forging false documents ought to be dismissed from office. The parallel is strengthened by reference to another observation from Innocent, this time on the validity of the documents drafted by the excommunicated notary. Here again he stresses the relationship between representation and toleration. Just like the appointment of a procurator by an excommunicated office holder, the instruments made by an excommunicated notary are valid despite the excommunication. In both cases the act is made not 'motu proprio', and so by the person as a private individual, but 'ratione publici officii', and so because of the office they exercise. $^{71}$

On the point see infra, $\$ 11.6$.

In this sense also Wilches (1940), p. 163.

By Innocent's time the fides of the notarial documents was already due more to the quality of the notary's (public) office than to his condition as an especially reliable and trustworthy (private) person. Cf. Bambi (2006), pp. 29-41.

Innocent IV, ad X.5.7.4, \$Damnantur (Commentaria Innocentii Quarti, cit., fol. $506 \mathrm{rb}, \mathrm{n} .1$ ): 'In scripturis autem tabellionum et aliorum publicum officium gerentium secus est, quia licet fecerint vnam chartam falsam, aliae nihilominus valent, quamdiu in officio tolerantur, $\arg ($ umentum) 8. c. vlt. nonne (C.8, q.4, c.1) et est hoc propter publicam vtilitatem, ar(gumentum) ff. de off(icio) praesi(dis) (sic) $<$ l.> Barbarius (Dig.1.14.3).'

Id., ad X.2.25.10, $\mathbb{}$ Duraturis (ibid., fol. 295va, n. 3): 'in iudicijs constat, quod quicquid facit excommunicatus, valet, vt hic. Idem dicimus extra iudicium, nam si sit notarius excommunicatus, non tamen sententialiter damnatus, et faciat instrumentum, valebit, licet aliqui dicant contra, $\operatorname{ar}($ gumentum) pro eis, $\operatorname{supr}(\mathrm{ra})$ de procu(ratoribus) consulti (X.1.38.15). Sed alij respondent illam decr(etalem) loqui de illis, qui praestant authoritatem his, quae dicuntur in instrumentis, hic autem loquitur de illis, qui praestant authoritatem in instrumento, quod sit authenticum, et non in his, quae dicuntur vel fiunt in instrumento. Item pro eis est 3 q. $4<$ c. $>$ nullus (C.3, q.4, c.6). Sed ipsi respondent, quod ibidem loquitur de 
Civil lawyers amply discussed the case of the notary in relation to the scope of the lex Barbarius. As Barbarius was a false praetor, they sought to apply the same conclusions to the false notary. In so doing, as we shall see, they often relied on Innocent IV. ${ }^{72}$ In his commentary, however, Innocent did not speak specifically of the false notary. If we were to apply his rules as to the boundaries of the toleration principle, we should conclude that a falsus tabellio could not be tolerated in his office, for he was never appointed to it. Yet this (speculative) conclusion would clash with public utility considerations because of the public ignorance argument. If the false notary drafted instruments for a long time, then not tolerating him would amount to rejecting all his instruments - with a clear prejudice to the commonwealth, which mistakenly relied on them. The point is important: if the toleration principle often relies on public utility and public utility is in turn triggered by common mistake, could the toleration principle operate even beyond representation, and so even when without a valid appointment to the office?

With regard to the notary, there is only one case where Innocent hints at this issue. When the authenticity of his appointment is doubtful, Innocent says, it is possible to prove it by testimonial evidence. The object of the witness testimony, however, is not the authenticity of the notary, but rather the fact that he exercised the notarial office. Indeed Innocent adopts for the notary the same verb found in the lex Barbarius: 'publice officio notarij fungebatur'. This does not seem fortuitous, as immediately thereafter he quotes the lex Barbarius itself, as well as two of the main leges usually invoked with it (Dig.14.6.3 and Cod.6.23.1). ${ }^{73}$ Further, he continues, such a testimonial would be stronger if the notary made a large number of instruments. ${ }^{74}$ Clearly, more documents drafted by the false notary would strengthen the public utility argument.

Whether that means that Innocent approved of the validity of the instruments drafted by someone commonly believed to be a notary, however, is quite

scripturis, quas faciunt excommunicati non ratione publici officij, sed proprio motu, item loquitur ibi in condemnatis, hic loquitur de toleratis.'

72 See infra, pt. III, $\$ 13.2$, and esp. pt. IV, $\$ 14.1-14.2$. With specific regard to Innocent IV, see also pt. II, $\$ 8.4$.

73 Id., ad X.2.22.1, $\mathbb{S}$ Authenticam (Commentaria Innocentii Quarti, cit., fol. 273va, n. 2): '... Crederem autem, quod sufficeret si per testes probaretur, quod publice officio notarij fungebatur, ff. ad Macedo(nianum) 1 . tertia, in principio (Dig.14.6.3), ff. de officio praesidis (sic) 1. Barbarius (Dig.1.14.3), C. de test(amentis) 1. prima (Cod.6.23.1).'

74 Id., ad X.2.22.1, $\$$ Authenticam (ibid., fol. 273va, n. 2): 'Idem forte et si appareant instrumenta per eos facta inter multos super contractibus legitimis, quae firma maneant et sine contradictione, nec credunt aliqui in hoc casu sufficere duo instrumenta, imo tot quod bene apareat eum commune officium omnibus gerere.' 
doubtful. Innocent only said that the common opinion as to the authenticity of the notary could be used against an exception of forgery. His discussion was centred on whether the signature of two witnesses is sufficient to consider a notarial document valid, especially if the notary is dead. ${ }^{75}$ Immediately thereafter, Innocent distinguished between a notarial document and the letter of excommunication with the bishop's seal: only the former is presumed to be valid. ${ }^{76}$ It is more likely, therefore, that Innocent referred to the common opinion argument not as an alternative to the valid appointment, but rather as evidence of it.

Elsewhere, Innocent states clearly that the only effect of common opinion is to invert the burden of proof as to a question of fact: if the common opinion is that someone was truly a prelate, or that a couple was truly married, or that a person was truly a notary, says Innocent, then it is up to the counterparty to disprove as much. ${ }^{77}$ This, however, normally applies only to past events, and typically to the status of people that are now deceased. For if the prelate or the notary are still alive and are in possession of their office, he continues, the issue is no longer just a simple question of fact. The possession of an office is stronger than the common opinion against its valid acquisition. It follows that such a contrary opinion, although common, is not sufficient as to invert the burden of proof. $^{\mathbf{7 8}}$

Ibid.

76 Id., ad X.2.22.1, \$ Authenticam (ibid., fol. 273vb, n. 4-5).

77 Id., ad X.5.40.34(=VI.5.12.1), \$Memoriam (ibid., fol. 573ra-b, n. 3-4): 'Item no(tatur) quod haec communis opinio idem est, quod communis credulitas, et ideo oportet famam esse, et etiam credulitatem cum aliqua ratione ... et quia solus Deus scrutatur animam, ideo ille qui fert testimonium de opinione si interrogetur, quomodo scit hanc communem opinionem, respondebit, non scio, sed solus Deus nouit. Sed credo causam autem credulitatis subijciat, quia sic verbis exprimebat, vel aliam quam volet, et hac ratione, quia tantum de credulitate respondet, quia testificatur super opinionem, videtur si interrogatur, quomodo scit, quod sit communis opinio, respondebit, quia sic audiui a multis ... Item est iusta causa si dicat cum multi exprimerent suam opinionem. Et haec vera videntur, si dicitur contractus alicuius praelati mortui non valere, quia non fuit praelatus, vel contra instrumenta tabellionis mortui, quod non fuit tabellio, vel contra filios, quod non fuit matrimonium inter parentes, et sic videtur viuere ille, qui communi opinione dicitur mortuus, et sic in similibus, $\arg$ (umentum) ... 34 q. i. c. i (C.34, q.1, c.1), ff. de offi(cio) praeto(rum) <l.> Barbarius (Dig.1.14.3).' The scope allowed to the common opinion in Innocent IV would therefore seem somewhat narrower than sometimes assumed: see already Lefebvre (1938), pp. 269-270.

78 Innocent IV, ad X.5.40.34(=VI.5.12.1), \$Memoriam (Commentaria Innocentii Quarti, cit., fol. 573rb, n. 4): 'secus autem esset si praelatus viueret, vel tabellio, vel maritus, nam in his casibus et similibus si praedicti agerent, puta, quia praelatus repeteret suam ecclesiam in cuius possessione alius esset, vel alter 
Toleration furthers public utility because of the non-manifest defect of the office holder - and so, of the common mistake as to his actual condition. This however does not mean that common mistake as to one's legal capacity leads necessarily to toleration. Toleration may only prolong the validity of legal representation for the sake of public utility, not replace it altogether. ${ }^{79}$ As such, in many cases there is a clear trade-off between upholding the scope of the toleration principle and protecting the good faith of those who mistakenly relied on appearances. When dealing with this problem, Innocent would normally prefer the toleration principle to public utility. ${ }^{80}$ Doing otherwise would have blurred its boundaries and weakened its rationale. Occasionaly, the choice between toleration principle (and so, representation) and public utility triggered by the common mistake was an easy one to make. For instance, that is the case in a legal proceeding where the procurator for the plaintiff acted on the basis of false documents, whose falsity was unknown to the plaintiff. Should the lex Barbarius be invoked to uphold the proceedings? Innocent answers in the negative, for Barbarius' deeds were tolerated for the utility of many, whereas in the present case the utility of a single plaintiff is at stake. ${ }^{\mathbf{8 1}}$ But can this rationale be read a contrario, so as to stretch the toleration principle beyond the boundaries of representation when there are more people unaware of the underlying invalidity (thus invoking public utility without legal representation)? When Innocent formulates the question most explicitly, his answer is a clear no. It is a situation very similar to the last one. When a decision is rendered on the basis of a false suit (petitio), but both parties are unaware of its falsity, should the decision stand? In cases of contentious jurisdiction the judge does not normally have compulsory jurisdiction, so he is not able to operate ex officio. To establish his jurisdiction on the matter, reasons Innocent, the petitio must therefore be

alterum peteret, vel tabellio peteret aliquem cessare a diffamatione sua super eo, quod non esset tabellio, nam in his casibus non videtur, quod communis opinio in alium transferat probationem, et est ratio, quia multa sunt pro reo, scilicet, quia est in possessione, et quia negat quod non est in alijs casibus: tamen et huic aliter subuenitur.'

79 Supra, this paragraph, notes 65-66.

80 See however infra, this paragraph, note 85 .

81 Innocent IV, ad X.1.3.22, \Subscriptione (Commentaria Innocentii Quarti, cit., fol. 19vb, n. 1): 'Sed dices videtur, quod processus debuerit tenere, quia ignorabant literas obreptitias, ff. de offic(io) praesi(dis) $<$ l. $>$ si forte. (Dig.1.18.17), ff. de offic(io) praeto(rum) $<$ l. $>$ Barbarius (Dig.1.14.3), sed dicit illa tolerata propter vtilitatem multorum, qui habuerunt necesse agere apud eum, cum praefecturam teneret et praesidatum et in illa 1. si forte (Dig.1.18.17) licet adueniente successore, non debeat exercere iurisdictione, tamen habet eam. Hic autem cum causa vna tantum commissa sit, non est multa vtilitas subditorum, vnde propter hoc non est tolerandus eius processus.' Cf. Wilches (1940), p. 89. 
valid. If not, in pronouncing his decision the judge is not exercising his office validly. If the petitio is void, argues Innocent, the sentence was rendered by an incompetent judge and so is itself void. As such, he states, it is not possible to invoke the lex Barbarius on the basis of the common ignorance of the parties. ${ }^{\mathbf{8 2}}$

The difference between common opinion (fama) and toleration principle may also be seen in a remark of Innocent on the difference between possession and ownership. For possessory claims fama is sufficient both in case of presumed marriage (to claim possession of the wife's estate) and to keep possession of a beneficium that the prelate is widely regarded as being entitled to. The effects of fama, adds however Innocent, do not translate into substantive rights: in neither case could fama give rise to a defence against a petitoria actio ${ }^{83}$ Common opinion, as we have seen, may only invert the burden of proof as to questions of fact: it does not make law.

The same conclusion is also attested to outside the courtroom. We have seen earlier that a prelate who is not confirmed in office may not validly exercise it. This means that all his deeds are void, and so also is his administration of the ecclesiastical goods within the office he holds invalidly. As a consequence, says Innocent, those who pay him are not freed from their debt ('nec liberantur ei solventes'), for they would be paying to a third party, not to the representative of the office to which the debt is owed. Paying to a prelate who cannot validly exercise his office, therefore, is no different from paying to any third party whatsoever ('sicut etiam non tenerent, si a quocunque extraneo fierent'). ${ }^{84}$ There is little doubt that innocent third parties are going to suffer prejudice. But the alternative would be to question the very foundation of the toleration principle, and that is a price that Innocent is (usually) unwilling to pay. ${ }^{85}$

Innocent IV, ad X.1.3.20, $\$$ Forsan (Commentaria Innocentii Quarti, cit., fol. 17rb, n. 7): 'Et si quaeratur a quo habet iurisdictionem, dicunt quidam a lege, quae dat eis cognitionem et diffinitionem in hoc dubio, et ita suie iuste, siue iniuste iudicet, pro veritate sumitur talis sententia, nisi suspendatur per appellationem 2 q. 6 si sententia (C.2, q.6, c.29), ff. de iusti(tia) et iur(e) 1. penu(ltima) (Dig.1.1.11). Melius videtur dici, quod non tenet sententia, C. si a non compe(tente) iudic(e) l. i (Cod.7.48.1), nec de hoc forte cognoscet. Alij dicunt, sed non bene, quod in veritate iurisdictionem non habuit per literas falsas, et tamen quod fecerat tenet propter communem ignorantiam litigantium ff. de offi(cio) praeto(rum) <l. $>$ Barbarius, et ff. eo [titulo, sed 'de officio praesidis'] l. si forte (Dig.1.18.17), sed certe hoc non videtur stare, etiam si modo constaret, quod falsae fuerint literae: quia sententia a non suo iudice lata non tenet.'

83 Id., ad X.23.11, $\mathbb{S}$ Illvd Qvoqve (ibid., fol. 281vb, n. 2, and fols. 281vb-282ra, n. 3 respectively).

84 Supra, this chapter, note 43.

85 A single time in his opus, however, Innocent did offer a less uncompromising solution. If the intruder is widely regarded as lawful incumbent and he does 
If the mistake cannot be invoked when it clashes with the toleration principle, however, it may well be invoked to trigger its application. This is clearly visible in the case of a double appeal: as a rule, an appeal before the pope is to be preferred to an appeal before the archbishop. But if the archbishop was not aware of the appeal before the pope, says Innocent, then his decision (in the case he was commenting on, a sentence of excommunication) is valid. Thus, concludes Innocent referring to the lex Barbarius, what would otherwise be void may be held as valid 'because ignorance allows to tolerate what is done in the exercise of a public office'. ${ }^{86}$

In Innocent's thinking, the difference between a common mistake supported by public utility considerations and the toleration principle may also be seen in his discussion of the validity of the confession to a priest who is wrongly believed to have been appointed to the parish. The problem went to the core of the distinction between ordo and iurisdictio: the priest was a true one, but he was not appointed to the office, and so he lacked jurisdiction over the parishioners. Absolution pertained to iurisdictio, not to ordo. As such, the issue was whether his lack of valid appointment would render the absolution given by him invalid despite the good faith of the penitent.

The absolution given by such a priest is valid, argues Innocent, but if the penitent discovers the truth he must seek absolution from a 'true prelate'. However, he continues, this is not necessary if the prelate is tolerated in the office he does not lawfully occupy. So long as the prelate is tolerated by his superior,

everything that the true incumbent would do (so that no third party could possibly realise the lack of representation), then the debtor of the office who pays to him might be freed, after the example of the exception to the Macedonian senatus consultum. Innocent IV, ad X.2.13.5, \$Prius (ibid., fol. 228ra, n. 8): '... Credimus tamen, quod si aliquis vtitur generaliter in omnibus, quae concurrunt facienda secundum morem suae dignitatis iure episcopali, vel canonicali, vel consimili, quod illi qui cum eis contrahunt, vel soluunt debita eis, quod liberantur, et excusantur ff. ad Maced(onianum) 1. 3 (Dig.14.6.3).'

86 Id., ad X.2.28.7, \$ Cognouerit (ibid., fol. 318vb, n. 1): 'Si autem [archiepiscopus] ignorauit, eum iurisdictionem habeat, tenet citatio et sententia excommunicationis ... est ratio, quia ignorantia facit tolerari ea, quae fiunt ratione publici officij, C. de testa(mentis) 1. 1 (Cod.6.23.1), ff. de offic(io) praesi(dis) (sic) <l.> Barbarius (Dig.1.14.3).' Here as well Innocent emphasises the exercise of a public office - and not the simple mistake - as the ultimate reason for the validity of the archbishop's decision. Contrast for instance the position of Teutonicus in his apparatus on the Compilatio tertia, ad 3 Comp., 1.6.6(=X.1.6.21), $\mathbb{S}$ apostolicam inuocauit: 'Magis autem deferendum fuit appellationi facte ad papam, ut supra de offic(io iudicis) del(egati) c. i lib. i (1 Comp., 1.21.1). Si tamen archiepiscopus ignorans de appellatione alterius eum excommunicasset, tenet excommunicatio ratione ignorantie, ut supra de appell(ationibus) <c.> Si duobus, lib. i (1 Comp., 2.20.7[=X.2.28.7]). Jo.' (Pennington [ed., 1981], p. 55, 11. 18-21). 
Innocent argues, the absolution he gives is perfectly valid and the penitent does not need to confess again. ${ }^{87}$ The position of Innocent is revealing of his stance on the scope of the toleration principle. The power to absolve from sin was ultimately an expression of solvere and ligare, and it clearly pertained to iurisdictio. Allowing the full validity of the absolution granted by someone who lacked iurisdictio was therefore problematic for Innocent. Hence the distinction on the basis of whether the unworthy prelate was tolerated or not in his office. The absolution given by the priest who was not tolerated in his office (more specifically, not tolerated by the superior authority) is valid only because it was very difficult to decide otherwise - it would have been difficult denying absolution to a penitent in good faith for a mistake that could not possibly be imputed to him (all the more given that the mistake was based solely on the jurisdictional powers of a validly consecrated priest). ${ }^{\mathbf{8 8}}$ But the validity of this absolution depended on ecclesiological grounds, not on legal principles. Hence, if the penitent were to discover the truth, the need of a further confession to a priest who did have the (jurisdictional) power to remit his sins. By contrast, the

Innocent IV, ad X.1.6.54, $\$$ Deceptae (Commentaria Innocentii Quarti, cit., fol. 78$v a-b)$ : 'potest dici animas non deceptas, cum ab omnibus habeatur praelatus, et valet poenitentia ab eo recepta, veniam enim meruit, quia ignorans delinquit, 8 di. $<$ c. $>$ consuetudo (D.8, c.8). Sed si sciat antequam moriatur, credimus quod de nouo debet ire ad verum sacerdotem, et ab eo absolui, infr(a) de poeni(tentiis) $<$ c. $>$ omnis, in prin(cipio) (X.5.38.12). Et idem dicimus in poenitentia, quod in ordinante diximus, inf(ra) de simo(nia) $<$ c. $>$ per tuas (X.5.3.35), vel potest dici, quod vere absoluitur quamdiu toleratur a superiore, 8 q. $4<\mathrm{c}$. $>$ nonne (C.8, q.4, c.1).' Taken literally, the last part of this comment might seem to support the toleration of a false priest commonly believed to be such. The reference to C.8, q.4, c.1, however, would clearly point to a true prelate who was not holding his office validly. The question is therefore of iurisdictio and not of ordo.

88 It is significant that those who rejected the validity of the confession spoke only of the case of the faithful who would later find out the true status of the praelatus - not also of the (equally possible) case of the penitent who died without ever discovering it. This position was maintained especially by Abbas Antiquus, but it did not prove successful. Abbas Antiquus, ad X.1.6.54, $\mathbb{\$}$ Dudum (Lectura Aurea Domini Abbatis Antiqui super quinque libris Decretalium, cit., fol. 35rb): 'Dicunt quidam quod licet postea sciat se confessum fuisse ei qui non poterat ipsum solvere, quod non tenebatur de illis criminibus iterum confiteri, quamdiu ab Ecclesia toleratur, arguo viii, q. iiii, $<$ c. $>$ nonne (C.8, q.4, c.1). Sed dic contra, quod tutius est, et eidem simile i(nfra) de presb(ytero) non bap(tizato), c. ult. (X.3.43.3), et viii di. $<$ c.> veritate (D.8, c.4).' On this passage see also Wilches (1940), pp. 111-112. Abbas Antiquus' position seems ultimately inspired by the opposite principle: upholding ecclesiological considerations above strictly legal (and jurisdictional) ones. On the point see also Abbas Antiquus, ad X.1.6.44, $\$$ Nibil (Lectura Aurea Domini Abbatis Antiqui super quinque libris Decretalium, cit., fol. $32 v b-33 r a)$. 
validity of the absolution given by the falsus praelatus tolerated in office by the superior authority has nothing to do with the penitent's state of excusable ignorance as to the prelate's true status. Rather, the validity of the sacrament ultimately derives from the link between toleration and jurisdiction. The power to absolve belongs to iurisdictio, and toleration entails the full validity of all jurisdictional powers deriving from the office. Hence a second absolution is not needed. Just like the problem of the sentence of excommunication levied by the occult excommunicate, however, this is an extreme case, where sacramental and jurisdictional powers may not be fully separated. Applying the toleration principle without further distinctions, therefore, meant sacrificing sacramental considerations to jurisdictional ones. This explains the reluctance of later canon lawyers to accept Innocent's solution, as we shall see. ${ }^{89}$

What just said, however, does not mean that Innocent had little consideration for public utility based on common ignorance. We have seen earlier that if the excommunicate tolerated in office appoints a procurator, the counterparty may not bring the exception of excommunication to bar the suit. What happens if a private person is to be excommunicated, and the counterparty does not bring the same exception against his procurator? Until Gregory IX (and especially with him), the judge was meant to quash the proceedings and, if he did not, the decision could be avoided retrospectively. Innocent IV put an end to this with his decretal Pia (mentioned above). If the counterparty did not bring the excommunication exception, the decision would stand. ${ }^{90}$ In the case of the excommunicate tolerated in office, we saw how Innocent justified his position, referring both to the public office and to the common mistake. According to Innocent, the rationale is very similar for a suit brought forth by a private person whose opponent did not raise the exception of excommunication during the proceedings. The legal transaction will not be retrospectively avoided, says Innocent, because of the common ignorance and the public utility of the contracting parties. ${ }^{91}$

89 Infra, next chapter. See also pt. IV, $\$ 14.3 .1$.

90 On Innocent's position in the decretal Pia and the reasons behind its enactment see Vodola (1986), pp. 88-92.

91 Innocent IV, ad X.1.38.15, \$Consulti (Commentaria Innocentii Quarti, cit., fol. 172rb, n. 2): 'Sed quaeris rationem quare ex quo tenet constitutio procu (ratoris) quare ad minus post absolutionem non tenetur exequi mandatu? Respon(detur) excommunicatus non habet exercitium litis, et ideo illud mandare non potest, ar(gumentum) 1 q. 7, <c. $>$ Daibertum (C.1, q.7, c.24), sed quod habet mandat(um) scilicet quod teneat, quod cum eo factum fuerat, sicut teneat, si cum excommunicato de nouo actum esset, et propter communem ignorantiam et publicam contrahentium vtilitatem.' 
Few other cases are so revealing of Innocent's approach as his commentary on the decretal Fraternitatis (X.5.7.4), where he goes through most of what has been said so far - though, interestingly, in reverse order. We have seen the distinction between sacraments of necessity and of dignity, and how the heretic ordained by a Christian retains his ordo but loses iurisdictio. We have also seen that the iurisdictio may be validly exercised (bestowing legal validity upon the deeds) so long as the heretic retains the office from which he ought to be deposed. In his commentary on X.5.7.4 Innocent IV says all this, starting from the last point and ending with the first. The importance of this passage lies in its confirmation of the link between the sacramental sphere and the toleration principle on the subject of the validity of acts. The reverse order in Innocent's reasoning is also important. With Innocent, the concept of toleration acquires a specifically legal dimension; yet even in Innocent it is possible to find echoes of the separation between the sacraments of necessity and of dignity that triggered the progressive emersion of the very notion of (jurisdictional) toleration during the twelfth century.

X.5.7.4 stated that the condemnation of the heretic would also extend to his writings. ${ }^{92}$ In the Ordinary Gloss on the Liber Extra, Bernardus Parmensis remarked that, although the writings of the heretic may contain something useful, nonetheless they should follow the same fate of their author, so they are inadmissible in court. ${ }^{93}$ It is likely that Innocent has that interpretation in mind when commenting on the same text. For he opens his comment with the inadmissibility of a testimonial deposition or of a notarial document containing some falsehood, even if it was made in good faith. ${ }^{94}$ The decretal said that the instrument was void because of the condemnation of its author (damnantur

X.5.7.4: 'Cum Coelestinus atque Pelagius in Ephesina synodo sint damnati, quomodo poterunt illa capitula recipi, quorum damnantur auctores.'

93 Gloss ad X.5.7.4, \$Pelagius (Decretalium domini pape Gregorij noni compilatio, cit.): 'Isti duo damnati erant in synodo ephesino de heresi; dubitabat patriarcha antiochenus an scripta ipsorum essent recipienda, et dicitur quod non: quia exquo condemnatus est auctor, et scripta illius admitti non debent ... quamuis aliqua vtilia sint ibi, $\arg$ (umentum) $s$ (upra) de testi(bus) $<$ c. $>$ licet (X.2.20.23) ... Item $\operatorname{ar}$ (gumentum) quod destructo principali destruitur accessorium, sicut in $\mathrm{c}$. praedicto (X.1.1.2): et hoc diximus. Bern(ardus).'

94 Innocent IV, ad X.5.7.4, \$Fraternitatis (Commentaria Innocentii Quarti, cit., fol. 506rb, n. 1): '... Si inter contrahentes auctum est, quod soluatur pecunia argentea, et notarius, vel testis dicit de aurea, quae melior est, et vtilior est ambobus contrahentibus, nam hoc mendacium licet sit pium, et vtile, tamen reddit instrumentum, vel testimonium inutile ... Siue ignoranter, siue scienter falsum admisceat, non valebit instrumentum, vel testimonium, quod sic probatur, quia nunquam debet ponere in instrumento vel testimonio, nisi quod in veritate novit et vidit, et in hoc non posset esse ignorantia, 3 q. $9<\mathrm{c}$. $>$ testes hortamur pura (C.3, q.9, c.20).' 
auctores), and Bernard concluded approvingly that 'destructo principali destruitur accessorium, ${ }^{95}$ Innocent however cursorily remarks that this is not the case when one exercises a public office. ${ }^{96}$ Immediately thereafter he focuses on the position of the notary. Because of the public office he exercises, Innocent notes, even if he forges a false document his other instruments will still be valid. Forgery, however, is the most serious ground for dismissing a notary from office. So Innocent adds that the notary could still validly exercise his office so long as he was tolerated in it, because of the same public utility considerations as in the lex Barbarius. ${ }^{97}$ It was only from the moment that the notary was condemned for forgery that he would not be able to exercise his office: from that moment - and not before - any (new) instrument he drafted would be void. ${ }^{98}$

When condemned, the notary is deposed from office and may no longer draft valid instruments. Does this mean that the condemnation always entails the invalidity of the deeds? In the jurisdictional sphere this is certainly so, but not in the sacramental one. Immediately after his discussion of the notary, Innocent moves on to the sacraments received from a heretic. This last part of Innocent's comment is by far the longest. The validity of a sacrament ultimately depends on who operates through it. In the sacraments of necessity, to put it rather bluntly, the person administering them is only a vehicle, for it is only God Who operates through them. The priest administering them, therefore, cannot pervert their substance: they remain holy - and so valid - despite the unworthiness of whoever administers them. It follows that the relationship is ultimately between God and the sacrament's recipient: if the latter thinks that he is receiving the sacrament from a true Catholic, he shall receive it validly. ${ }^{99}$ Because of this, in

Supra, this paragraph, note 93.

Innocent IV, ad X.5.7.4, \Damnatur (Commentaria Innocentii Quarti, cit., fol. 506rb, n. 1): 'hoc habet locum in exceptionibus scripturarum, et in omnibus alijs qui publica authoritate non habent officium sibi iniunctumm, 9 dist. $<$ c. $>$ si ad sa(nctas) (D.9, c.7), 16 di. c. 1 (D.16, c.1), 37 di. $<$ c. $>$ si quid (D.37, c.13).' Ibid., fol. 506rb, n. 1, text supra, this chapter, note 70.

8 Id., ad X.5.7.4, \$D Damnatur (ibid., fol. 506rb, n. 1): ‘... licet autem dicta cuisquam ratione personae nisi alias falsa probentur redargui non possunt de falso, si tamen publica persona accusata et condemnata fuerit de falso, et extunc instrumenta et dicta eius ratione personae robore carebunt, supra, de testi(bus) $<$ c.> testimonium (X.2.20.54).'

9 Ibid., fol. 506rb, n. 2: 'In sacramentis secus est, quia sacramenta ab haereticis recepta, quo ad essentiam vera sunt, 32 di. $\$$ verum (D.32, p.c.6). Item effectum virtutis habent, vel proprias virtutes dignitatis habent, quia veneranda sunt in se, et gratiam etiam conferunt, si qui illa scienter sumant $\mathrm{ab}$ eo, quem non putant haereticum.' To argue as much, Innocent relied on the locus classicus that Judas (the heretic by definition) administered baptism validly. Indeed, Innocent continued, if someone wanted to prohibit Judas from baptising, fearing that those who received baptism this way would be deceived, he would sin: 'De Iuda 
case of extreme necessity (and so, in puncto mortis) it is possible for any sort of excommunicated or suspended priest to administer all sacraments of necessity. ${ }^{100}$ In the sacraments of dignity, however, the person who administers them plays a more substantial role. As such, if he lacks executio ordinis ${ }^{\mathbf{1 0 1}}$ he may not confer it validly, despite the good faith of the recipient. ${ }^{102}$

enim constat, quod fuit haereticus, arg. 1 q. $1<\mathrm{c} .>$ eos qui (C.1, q.1, c.21) et tamen baptizati ab eo gratiam receperunt, nam alias peccasset, qui eum emisit, cum alijs ad baptizandum, cum sic baptizati ab eo deciperentur, 1 q. $1<\mathrm{c}$. $>$ Christus (C.1, q.1, c.88) etc.' (ibid., fol. 506rb-va, n. 2). Innocent's words are particularly telling as very shortly beforehand in this commentary he defined the heretic focusing on the concept of perversio sacramentorum: 'haereticus dicitur, qui peruertit sacramenta ecclesiae vt simoniacus. i. q. i. $\langle$ c. $>$ eos qui (C.1, q.1, c.21). Item diuisus ab vnitate ecclesiae, 7 q. i <c.> denique (C.7, q.1, c.9).' (Id., ad X.5.7.3, $\$$ Vel schismaticum, ibid., fol. 506ra). The ultimate rationale for the distinction between ordo and iurisdictio (scil., whether God alone operates in the sacrament) could also be described in more legally-oriented terminology. This, it should be noted, was remarkably more appealing for civil lawyers - and indeed it was another point on which Innocent exercised considerable influence on them. So long as God alone operates in the sacrament, says Innocent, it might be possible to speak of validity according to natural law. Sometimes positive law derogates from it, so as to punish the unworthy who continues to minister the sacrament. But because the sacrament is valid according to natural law, then it would be unfair to penalise the faithful who hears Mass celebrated by heretics and excommunicated if he is unaware of their condition. Id., ad X.5.8.1, $\$$ Irritas (ibid., fol. 508vb, n. 4): '... Item cum haec poena [i.e. the prohibition against heretics and excommunicates to celebrate Mass] non sit imposita a iure naturali, imo ius naturale vult, quod eum solus Deus in collatione operetur, quare vicarius Christi immeritam iniungeret poenitentiam ignorantibus, licet enim ex causa decreverit poenitentiam scientibus contra contemptum, tamen iniustum est imponere poena ignorantibus sine causa.'

100 Id., ad X.5.7.4, \$Damnatur (ibid., fol. 506va-b, n. 3): 'nam cum solus Deus gratiam conferat, non minister, non attenditur qualis sit minister, nisi in eo qui scienter contra constitutiones ecclesiae recipit. Idem dicimus in omnibus praecisis, puta depositis, excommunicatis, et suspensis a collatione sacramentorum, siue a iure, siue ab homine sint suspensi ... qui licet suspensi sint a collatione sacramentorum, tamen in articulo mortis corpus Christi, et baptismum conferunt ... Et hic est casus, in quo licite communico cum excommunicatis, et hi dando baptismum non peccant, posset tamen dici, et non male, quod a suspensis a iure toleratis omnia sacramenta vbi non confertur executio, sed gratia, vt in poenitentia, extrema vnctione, et caeteris consimilibus licite recipiantur, quia solus Deus ibi alias hoc operatur, ar(gumentum) 19 di. $<\mathrm{c} .>$ secundum (D.19, c.8), 1 q. 1 <c.> Iudas (C.1, q.1, c.46).'

101 On the concept of executio ordinis (and its distinction from ordo) see supra, $\$ 6.1$.

102 Innocent IV, ad X.5.7.4, \$Damnatur (Commentaria Innocentii Quarti, cit., fol. $506 \mathrm{vb}$, n. 4): 'Executionem autem ordinis nullus suspensus dat, quia quod non habet, dare non potest, 1 q. $7<$ c.> Daibertum (C.1, q.7, c.24).' 
The closeness between the instruments drafted by the heretical notary and the sacraments celebrated by the heretical priest might appear puzzling. In fact, it was perfectly logical: Innocent explains the distinction between ordo and iurisdictio also in terms of toleration in office. This should not come as a surprise, if we think that the concept itself of toleration finds its origins in the progressive elaboration of that distinction. So long as he is tolerated, says Innocent, the heretical bishop (as any other occult excommunicate) retains his iurisdictio. Being tolerated within the Church, he can confer not only ordo (which he could bestow in any case, having been consecrated lawfully) but also the power to exercise it validly (executio ordinis). ${ }^{\mathbf{1 0 3}}$ Conversely, the moment the heretic is no

103 Id., esp. ad X.5.8.1, \$Irritas (ibid., fol. 508ra, n. 3): 'Idem dicendum videtur de irregularitate ordinatoris, vel ordinati, quod non impedit executionem, quin conferatur habitu et exercitio arg. $56 \mathrm{di}$. $<$ c. $>$ apostolica canon(icamque) et c. ul. (D.56, c.12 and 14) sub de renunc(iatione) $<$ c. $>$ nisi cum $\$$ personae (X.1.9.10). Idem dicendum videtur et de infamia, nam simoniaci etiam in beneficio sunt infames. C. de epis(copis) <c.> si quenquem $\$$ ul. (Cod.1.3.30.6), et tamen executionem conferunt, sub de $\operatorname{simo}($ nia) $<\mathrm{c} .>$ per tuas (X.5.3.35). Et hoc dicendum videtur de excommunicatis occultis, et de omnibus aliis praedictis, quod quamdiu tolerantur ab ecclesia executionem ordinum conferunt.' Here as well, Innocent IV appears consistent in his thinking. As the occult simoniac is tolerated in his office, he retains the jurisdictional powers deriving from it - and so also executio ordinis. But the notorious simoniac, not being tolerated in office, may not exercise it validly. As such, he lacks executio and may not confer it in his turn. Id., ad X.5.3.35 \$ Secure ministret (ibid., fol. 503ra-b, n. 4): 'Quod verum credimus in omnibus aliis criminosis, sed in simoniacis et fornicatoribus notoriis speciale est, quod etiam sine sententia licet ab eorum obedientia recedere, 32. dist. $\$ verum (D.32, p.c.6), et secundum hoc potest intelligi decre(talis) ista [scil., D.32, p.c.6: 'non debet quis ordinem recipere ab eo, quem credit simoniacum'], quia iste ordinatus credebat, quod ordinator suus ex relatione multorum esset notorius simoniacus ... Pro his autem sufficiens ratio esse videtur, quia cum haec poena non inveniatur in canonibus, quod recipiens ordinem ab haeretico, vel quecunque alio criminoso tolerato, nos poenas extendere non debemus, de poe. dist. 1 poenae (De pen., D.1, c.62); speciale tamen est in notorijs simoniacis et fornicatore, si autem coactus recipit ordinem a simoniaco, recipit executionem, 1 q. $1<\mathrm{c} .>$ constat (C.1, q.1, c.111). Nos autem hoc non credimus, imo generaliter dicimus nullum qui non habet, posse dare executionem, et quod factum est, de dispensatione factum fuit, et repete, quae dicuntur, 32 di. $\$$ verum (D.32, p.c.6).' At times, however, Innocent's position on the subject appears more complex. This is particularly the case in his lengthy commentary on X.1.6.44. After a long discussion of the validity of the acts of those already removed from their office, having reviewed a number of (sometimes, conflicting) sources, Innocent concludes by separating jurisdictional acts from sacramental ones. For the latter, argues the pope, the unworthy tolerated in office needs a specific dispensation. Innocent's position might appear slightly ambiguous, for X.1.6.44 dealt with the unworthy elected in office who exercised it until his deposition. In such a situation it is understandable that Innocent would require a dispensation for the 
longer tolerated in the Church, while he retains ordo (as any sacrament, consecration is indelible), he loses any power that requires enduring participation in the Church - and so both iurisdictio and executio ordinis). In this case, says Innocent, it is not possible to invoke the toleration principle to argue in favour of his jurisdictional acts, even in the case of ignorance as to his true status. ${ }^{\mathbf{1 0 4}}$

Tolerating the legal representative of a public office furthers public utility: Innocent is quite clear on this point. Public utility however should not be seen just as the ultimate reason for the toleration principle, but as a qualitative constraint to its application. This is why the principle of toleration applies to any sinful priest so long as the reason why he should be deposed remains occult. By contrast, when the sinful state becomes manifest, Innocent is remarkably clear that the toleration principle no longer applies. For particularly henious crimes, the effects of notoriety are the same as those of a sentence of deposition: from that moment the unworthy prelate is severed from his office, and any act he carries out may no longer be imputed to it. As simony was the gravest case of unworthiness, it should come as little surprise that Innocent states as much with particular clarity when discussing the toleration of the simoniac. While the occult simoniac is to be tolerated in office, if his simony is notorious there is no need to wait for the formal (and judicial) deposition. ${ }^{105}$ The same applies in case

elected to perform any sacramental act - especially ordinations (to which he specifically referred). Indeed Innocent would often repeat that, without confirmation, the elected could not lawfully exercise his office. On the other side, however, the literal tenor of the passage would appear more general, as it refers to any heretic or simoniac, even those who were confirmed in office. Id., ad X.1.6.44, $\$$ Administrent (ibid., fol. 74vb, n. 3): 'Sed pone quod isti, qui sic administrant post remouentur, nunquid tenet quod ab eis factum est: $\arg (\mathrm{u}$ mentum) ... ff. de offi(cio) praeto(rum) <l. $>$ Barbarius (Dig.1.14.3), 3 q. 7 \$ tria (C.3, q.7, p.c.1). Arg(umentum) contra(rium) infra, de haere(ticis) $<$ c. $>$ fraternitatis (X.5.7.4), 12 q. 2. <c.> alienationes (C.12., q.2, c.37), 25 q. $1<\mathrm{c} .>$ omnia (C.25, q.1, c.12), 12 q. $2<$ c.> precarie (C.12, q.2, c.44), ff. de eo qui pro tut(ore) 1. si is (Dig.27.5.2), ff. de re(bus) eo(rum) qui sub tu(tela) quod neq(ue) (sic) (Dig.27.9.8). Sol(utio) dicimus, quod omnes qui habuerunt canonicum ingressum, licet post fiant haeretici, vel simoniaci, ratum est quod fit ab eis quousque tolerantur, vt in d. c. nonne (C.8, q.4, c.1), infra, de dol(o) et contu(macia) <c. $>$ veritatis (X.2.14.8), nisi forte essent ordinationes, vel alia spiritualia, quae quo ad executionem irritae sunt, nisi interueniat dispensatio, 1 q. $1<\mathrm{c} .>$ si quis a simonia(cis) (C.1, q.1, c.108), 9 q. 1 c. 1 et 2 (C.9, q.1, c.1-2).'

104 Id., ad X.1.4.8, $\$$ Suspensus (ibid., fol. 34rb, n. 4): 'Quidam tamen dicunt, sed non placet, quod [suspensus] excommunicare possit, et praebendas dare, et alia facere quae sunt ex iurisdictione, non de ordine, $\arg$ (umentum) infra, de elect(ione) $<$ c.> ex transmissa (sic) (X.1.6.15). Et haec inteligimus vera, nisi suspensus est ab officio et beneficio, vel officium tantum cum ratione officij competat beneficium, 81 dist. <c. $>$ si quis sacerdotum, et c. eos (D.81, c.17-18).'

105 Id., ad X.1.6.44, $\mathbb{S}$ Administrent (ibid., fol. 75rb-va, n. 4-5): ' $\ldots$ potestatem recipiat administrandi ... etiam si sit simoniacus in ordine ... et est verum hoc quamdiu 
of notorious excommunication. ${ }^{106}$ The notoriety of the simony or the excommunication bars any public utility consideration - there is no need to protect the good faith of the people if they are (or they ought to be) fully aware of the condition of the holder of the office.

Notoriety not only dispenses with public utility, but it may even detract from it. This happens especially in the case of scandal. Avoiding scandalum is a corollary of furthering public good - it is precisely because public good is to be furthered that scandal must be avoided. ${ }^{107}$ The subject of scandalum vitandum is very broad, but there are only few cases where Innocent IV links it expressly to the subject of toleration. We have already seen one of them - the faithful aware of the occult sin of fornication of his or her parish priest may refuse to receive sacraments from him only if that does not create scandal in the community. ${ }^{\mathbf{1 0 8}}$ The main case discussed by Innocent is a variation on the subject - the case of married priests. ${ }^{109}$ In principle, the ordination of a Latin priest with the Greek rite, while forbidden, is to be tolerated. But the opposite may be more problematic, for in the Greek rite priests are married. When a Latin priest is therefore ordained with the Greek rite, argues Innocent, his marriage may be tolerated only for a brief spell. Leaving a married priest in charge of a community that follows the Latin rite (by Innocent's time, the overwhelming majority of churches in Western Europe) for very long, he reasons, would on the contrary be a source of great scandal. And this is why such a situation may not be tolerated. ${ }^{110}$ The rationale of this passage seems to be that a prolonged state of

toleratur ... nisi sententia vel inhibitio data est contra eum, infra, de dolo $<\mathrm{c}$. $>$ veritatis (X.2.14.8) vel nisi alias esset notorium eum suspensum infra, de re iud(icata) $<$ c. $>$ ad probandum (X.2.27.24), 32 dis. $<$ c. $>$ preter (D.32, c.6), optime habetur infra, de excess(sibus) praela(torum) $<$ c. $>$ tanta (X.5.31.18) ... licet sit suspensus a iure, tamen facta eius defenduntur authoritate confirmationis, nisi esset notorius simoniacus, quia tunc licet subditis ab eo recedere, 32 dist. $\$$ verum (D.32, p.c.6).'

106 Id., ad X.5.3.35 \$Secure ministret (ibid., fol. 502va, n. 3): 'et quod dicimus de simoniacis suspensis, idem dicimus de omnibus notorijs excommunicatis depositis et suspensis.'

107 Cf. Fossier (2009), pp. 320-323 and esp. 327-331, where ample literature is mentioned. Most recently see also Bianchi Riva (2016), pp. 3-4. On scandalum as the outer boundary of toleration see also (more broadly) Innocent's letter of 27.5.1249 (E. Berger [ed., 1887], vol. 2, p. 85, n. 4554).

108 Supra, this chapter, note 37.

109 In another case Innocent speaks of toleration to avoid scandal in a rather cursory way: ad X.1.15.1, \$Idem (Commentaria Innocentii Quarti, cit., fol. 105va, n. 1).

110 Id., ad X.1.11.9, $\$$ Nolumus (ibid., fol. 99ra-b, n. 1-2): ‘... hic non prohibet ordinari graecos a latinis, vel econuerso, sed prohibet commixtiones et consuetudines rituum obseruari in ordinibus, id est, quod episcopus graecus secundum ritus suos, puta extra quatuor tempora, vel alios consimiles ordinat clericum latinum, et eodem modo, nec latinus debet ordinare graecum contra ritus suos 
wedlock would perforce become notorious. In such a case toleration is not possible: instead of furthering the common good, it would harm the commonwealth.

\subsection{Innocent IV and the lex Barbarius}

Unlike previous (and, sometimes, later) canonists, Innocent was remarkably precise in his use of the verb 'tolerare', ${ }^{\mathbf{1 1 1}}$ and that depends on the close link between toleration and representation. Several of the quotations from Innocent reported above mention the lex Barbarius. ${ }^{\mathbf{1 1 2}}$ Does this mean that Innocent considered Barbarius' case as a particularly good example of toleration? Later jurists often thought so. Yet Innocent IV was not just one of the greatest canon

approbatos ... Vel dic, quod licet prohibeatur facere [scil., ordaining to the priesthood a Latin with the Greek rite] vt hic tamen factum tolerantur, vt in contrario, et not(andum), quod ordinatus a graeco, et vtens matrimonio contracto secundum graecos in sacris ordinibus, si breuem moram tractaturus sit apud latinus tolerandus est vtens contracto matrimonio, si vero longam moram traheret, non esset tolerandus propter scandalum, et nunquam debet sibi dari ecclesia latinorum, nisi primo continentiam promittat: Latinus autem nec apud graecos, nec latinos matrimonio vtetur contracto.' Cf. Id., ad X.1.11.11, \$toleratur (ibid., fol. 99va).

111 In the previous pages mention was made of all the most important cases where Innocent used the verb 'tolerare' in his commentary on the Liber Extra. Among the other cases that have not been mentioned, some use it in the same sense: $a d$ X.2.2.14, $\mathbb{S}$ Sententia (ibid., fol. $198 v b$, pr, on the possibility of tolerating ex dispensatione someone who should be deposed); ad X.2.24.11, \$Praeiudicat (ibid., fol. $284 \mathrm{vb}$, on the toleration of a prelate who ought to be expelled from his office); ad X.1.19.1, \$Ordinari (ibid., fol. 110vb, n. 2: if a cleric who should not be generalis administrator of religious estates is lawfully appointed as such, he may not be prohibited from administering so long as he is tolerated). Very occasionally, however, Innocent writes of toleration without reference to an office (and so without connection to representation). He does so only in a very few cases, four in total within his entire commentary on the Liber Extra, of which three are about procedural irregularities and one about defective possession: ad X.2.4.1, $\$$ Non per positiones (ibid., fol. 205va, n. 3: if in the libellus there is no petitio but only the exposition of the facts, so long as the defendant does not object, such a defective litis contestatio is to be tolerated by the judge); ad X.2.27.25, $\mathbb{\text { Actio }}$ (ibid., fol. 351ra [rectius, fol. 315ra], n. 3: although the wife may not vindicate her dowry, if she does so and the husband tolerates it, the vindicatio is valid); ad X.4.3.3, \$In ecclesijs (ibid., fol. 469rb, n. 3: even without banns, the marriage is to be considered as valid and the spouses' negligence is to be tolerated to avoid exposing the offspring to the risk of illegitimacy); ad X.1.41.2, \$Pertineret (ibid., fol. 178ra, n. 9: when a monastery possesses something irregularly, if such irregularity is tolerated the possession is valid).

112 Supra, this chapter, notes 45, 46, 49, 65, 70, 73, 81, 82, 86, 97 and 104. 
lawyers of his times. He was also remarkably knowledgeable in civil law. A closer look at Innocent's approach to the lex Barbarius would reveal a more ambivalent position: while he could not avoid citing it when writing of toleration, he was well aware that that lex was a double-edged sword.

A first case where he looked at the lex Barbarius more carefully than simply citing it in passing may be found - revealingly enough - when discussing the effects of the confirmation on the vitiated election of a prelate. We have seen how Innocent insists that confirmation would cure the underlying defects of the election, or at least would allow the elected to validly exercise his office. At the same time, however, he is clear in requiring that the confirmation must take place. Saying as much, the pope recalls the text of the lex Barbarius: could Barbarius' case be invoked to argue against the need for confirmation? Although he immediately sides with the negative solution, Innocent observes that this lex might seem to bestow validity on the deeds of someone invalidly elected, and possibly even lacking confirmation. ${ }^{\mathbf{1 1 3}}$ Indeed Innocent is aware of the debate among civil lawyers as to whether Barbarius was confirmed in his office, and even recalls how the lex Herennius was used to argue against the validity of his appointment. ${ }^{144}$ The problem is, he observes, that the lex Barbarius does not provide a clear answer as to whether the slave truly became praetor: Ulpian did not say whether Barbarius was actually confirmed. ${ }^{115}$ Despite this ambiguity, continues Innocent, it is not possible to argue by analogy with the lex Barbarius that a prelate can be tolerated in office despite not being validly elected or confirmed. ${ }^{116}$ It is quite possible to invoke the toleration principle on the basis

113 Innocent IV, ad X.1.6.32, $\mathbb{S}$ Confirmauit (Commentaria Innocentii Quarti, cit., fol. $63 \mathrm{rb}$, n. 2): '.. licet sit nulla confirmatio, tamen quae dicit, et quae facit quamdiu tolerantur valent 8 q. nonne (sic) (C.8, q.4, c.1) ff. de offi(cio) praeto(rum) $<$ l. $>$ Barbarius (Dig.1.14.3), quamuis posset dici quod illa l. loquitur quando tenet confirmatio.'

114 Ibid.: '... sed satis bene creditur alijs, quod possit obijci, quod confirmatio non teneat, $\arg ($ umentum) de decur(ionibus) 1. vlt(ima) (Dig.50.2.14 sed 10). Alij tamen hoc non fatentur probato tamen in modum exceptionis, quod cum confirmatio nulla est non tenebit, quod egit, quia non est communis ignorantia, licet res inter alios acta non praeiudicet.'

115 Ibid., fol. 63rb, n. 3: 'Sed potest quaeri de confirmatio, cuius electio non tenet, an sit praelatus huius ecclesiae et certe iurisconsultus interrogatus de ista quaestione non respondit, sed dixit, quod ea quae dicit, et quae facit valerent, ff. de offi(cio) praeto(rum) $<$ l. $>$ Barbarius (Dig.1.14.3).'

116 Ibid.: ' '... nobis autem videtur, quod siue electio non teneat, siue confirmatio non est electus praelatus, 62. dist. per totum (D.62), i q. i $<$ c. $>$ ordinationes (C.1, q.1, c.113).' 
of the common mistake, continues Innocent, provided however that there is the 'support of the confirmation'. 117

Because of its underlying ambiguity, Innocent considered the lex Barbarius more of a threat than a support to his arguments. ${ }^{\mathbf{1 1 8}}$ This is particularly clear in his comment on Innocent III's decretal Nuper a Nobis (on a second marriage made in the mistaken belief of the death of the previous spouse). As we have seen earlier, Innocent III declared that in such a case 'the opinion is to be preferred to the truth'. ${ }^{119}$ Commenting on these words, Innocent IV hastens to clarify that, in normal circumstances, it is the other way round: truth must prevail over mere opinions. The few exceptions, such as the present one, are inspired by equitable considerations: protection of the offspring, or of third parties in good faith, or of the testator's will. Then, concludes Innocent IV grudgingly, there are few other cases where no such specific (and commendable) reason may be found, such as the lex Barbarius. ${ }^{\mathbf{1 2 0}}$

117 Ibid.: '... sed in eo quod dicunt, quod quae dicit, et quae facit tolerantur, bene dicunt propter communem ignorantiam, et propter tuitionem confirmationis, $\arg ($ umentum) $\sup (\mathrm{ra})$ e (o titulo) $<\mathrm{c} .>$ transmissam (X.1.6.15), et no(tandum) $\sup (\mathrm{ra})[$ rectius, infra] e(odem titulo) <c. $>$ nihil (X.1.6.44) ... nec valet si obijciatur, si non est praelatus, quomodo aget, quomodo valebunt quae cum eo qui est praelatus fierent. Respondeo, bene ex bono et aequo animo propter communem ignorantiam, vel quia potestatem administrandi recipit ex confirmatione, supra eo(dem titulo) $<\mathrm{c}$. $>$ transmissam (X.1.6.15), et vide simile, quia si sententietur pro aliquo super aliqua re, quae non fit sua sententia, non facit eam suam, ff. de condi(ctione) inde(biti) <l.> Iulianus (Dig.12.6.60) ...' In this passage the conjunction 'vel' ('propter communem ignorantiam, vel quia potestatem administrandi recipit ex confirmatione') might suggest that the confirmation is not necessary if someone is commonly believed to be a priest. On the contrary, this 'vel' should be read in the sense of $e t$, just as Innocent did a few lines before ('propter communem ignorantiam, et propter tuitionem confirmationis').

118 In his vast study on the invalid excommunication, Zeliauskas seems to say the opposite: for him, Innocent IV pronounced in favour of the validity of the excommunication by the excommunicate because of the lex Barbarius. Zeliauskas (1967), pp. 263-264. The argument however does not seem to be sufficiently supported in the sources.

119 Supra, \$6.3.2, text and note 128 .

120 Innocent IV, ad X.1.21.4, $\mathbb{R}$ Reputandi (Commentaria Innocentii Quarti, cit., fol. 112va, n. 1): 'Et est verum, quod veritas praeualet opinioni. Contraria casualia sint, et praefertur enim opinio in fauorem contrahentium et odium decipientum, ff. ad maced(onianum) 1. 3 (Dig.14.6.3). Vel in fauorem prolis et testamentorum, inf(ra) qui fil(ii) sint legi(timi), <c.> cum inter (X.4.17.2), C. de testa(mentis) 1. 1 (Cod.6.23.1), vel aliqua communis opinio praefertur veritati ff. de offi(cio) praeto(rum) <l.> Barbarius (Dig.1.14.3).' This passage of Innocent is to be read together with his comment on X.4.1.18: if the spouse is aware that his or her first marriage is valid and not void, a second marriage is not to be tolerated (Id., ad X.4.1.18, \$Protulerunt, ibid., fol. 465rb: 'nullo modo tolerandum est secundum matrimonium'). 
The ambiguity in the lex Barbarius however could be played to Innocent's advantage. Ambiguous as it was, the text of the lex was in favour of Barbarius' confirmation by the prince, and the Accursian Gloss, as we have seen, stressed this point greatly. Innocent was happy to follow the civil lawyers' intepretation: it was much safer for his own purposes to accept Barbarius' confirmation in office than to question it.

Innocent says as much openly on two occasions. The first is in his lengthy discussion of the validity of elections. If the unworthy prelate is elected to an office and administers it without having being confirmed, says Innocent, the moment he is removed from the office everything he has done would be invalid. To strengthen the point, he quotes, inter alia, both the lex Barbarius and its closest equivalent in the Decretum, Gratian's dictum Tria. ${ }^{\mathbf{1 2 1}}$ Both texts, however, speak of the unworthy so as to defend the validity of their deeds. Their citation therefore makes sense only if interpreted as referring to the unworthy who is confirmed, so as to differentiate his case from that of the unworthy who is not confirmed. This seems the case here, for just a few lines later Innocent recalls how others used the same lex Barbarius to argue for the opposite solution. According to such interpretation, which Innocent considers to be contrary to his own, common mistake and public utility allow for the validity of the acts carried out by the elected who is not confirmed, after the example of Barbarius' case. ${ }^{\mathbf{1 2 2}}$ Innocent answers sharply: the text says that Barbarius' deeds are valid because he was confirmed in office. ${ }^{\mathbf{1 2 3}}$ This statement dispels any ambiguity in Innocent's previous reference to the lex Barbarius and Gratian's dictum Tria. Incidentally, the same statement also strengthens the conclusion that, for Innocent, public utility and common mistake do not operate outside representation. Indeed, Innocent continues arguing against the opinion favouring the validity of the deeds of the bishop-elect who would not receive confirmation. In that case the bishop was unworthy: although elected, he would not be confirmed but rather deposed from office. Yet he was already in possession of his diocese. Because of that,

121 Id., ad X.1.6.44, $\$$ Administrent (ibid., fol. 74vb, n. 3): 'Sed pone quod isti, qui sic administrant post remouentur, nunquid tenet quod ab eis factum est: $\arg (\mathrm{u}-$ mentum) ... ff. de offi(cio) praeto(rum) <l.> Barbarius (Dig.1.14.3), 3 q. 7 \$ tria (C.3, q.7, p.c.1).'

122 Ibid., fol. $75 \mathrm{ra}$, n. 3: 'sed de isti non confirmatis dicunt aliqui, quod si aliqua fecerit in iudicio, vel etiam extra iudicium ex officio, vt emancipationes et similia, quod propter errorem communem, et vtilitatem publicam valet, ff. de offi(cio) prae(torum) $<$ l. $>$ Barbarius (Dig.1.14.3).'

123 Ibid.: 'Quamuis posset responderi, quod ibi [i.e. in Dig.1.14.3] ideo tenet, quia erat praetor confirmatus a praefecto praetorio (sic!), vel ipsa electione, sed non confirmatus, nec electus non est Praelatus, sed fur, ff. de decur(ionibus) $<\mathrm{l}$. $>$ Modestinus (Dig.50.2.10), 1 q. $1<\mathrm{c}$.> ordinationes et c. si quis neque (C.1, q.1, c.113 and 115).' 
Innocent says, some would argue for the validity of his deeds, so as not to deceive any third party dealing with him. Nonetheless, Innocent dismisses this solution ('sed non placet'): without confirmation, he was not legally entitled to exercise his office. ${ }^{124}$

The second case where the pope relies on the lex Barbarius as an example of an unworthy confirmed in office is in his (similarly lengthy) commentary on X.3.36.8. There, Innocent explains the difference between the de facto and de iure exercise of jurisdiction in terms of representation. The text of X.3.36.8 discussed whether a bishop could validly suspend an abbot and put his abbey under interdict if the abbey was within the borders of the bishop's diocese but not under his jurisdiction. In the specific case under discussion the problem was that, although de iure the abbey was not under the jurisdictional remit of the bishop, the abbot had nonetheless promised obedience to him. While the Ordinary Gloss on the Liber Extra discusses the text exclusively in procedural terms, ${ }^{125}$ Innocent IV takes a much broader stance. If someone does not have the right to exercise jurisdiction on another but enters into possession of such a jurisdiction, can he issue a sentence of excommunication or an interdict against the other person? Innocent's answer is in the negative: in order to excommunicate or to place someone under interdict, it is necessary to enjoy valid (i.e. $d e$ iure) jurisdiction on them. The simple de facto possession of jurisdiction does not suffice. ${ }^{\mathbf{1 2 6}}$ What is particularly interesting is Innocent's reasoning. The simple possession of jurisdiction (its de facto exercise) does not entail the validity of the jurisdictional acts issued by such a possessor. ${ }^{127}$ For the jurisdictional act to be

124 Ibid: : 'Alij dicunt, sed non placet, quod quandiu est in possessione episcopatus, etiam non confirmatus valent, non solum praedicta sed alia omnia, quae facit, nec illudatur contrahentibus, et quia tanta subtilitas de facili verteretur in pernicem ecclesiae, C. de ver(borum) signi(ficatione) 1 . cum quidam (Cod.6.38.4), C. ad Treb(ellianum) 1. pe(nultima) (C.6.49.7).'

125 A first gloss (bearing the name of Bernardus Parmensis) focused on the validity of the mandate to the procurator (Gloss ad X.3.36.8, \$Ratihabitione [Decretalium domini pape Gregorij noni compilatio, cit.]). A second and last one discussed time limits for raising an exception during the proceedings (ibid., $\mathbb{\$}$ Repromissit).

126 Innocent IV, ad X.3.36.8, $\$$ Cvm dilectvs filivs (Commentaria Innocentii Quarti, cit., fol. $437 v b$, n. 1): 'Hic satis expresse colligi videtur, quod quamuis aliquis sit in possessione subiectionis aliquorum, non tamen valet excommunicationis sententia in eum lata, nam videtur quod hic episcopus fuerit in possessione subiectionis Abbatis huius, et tamen non valet excommunicatio ab ipso episcopo in eum lata, et consimili ratione videtur etiam de alia sententia, puta si condemnasset eum in ciuili vel criminali actione. Et certe quidam hic fatentur subiectionis huius monasterij, non tenet eius sententia excommunicationis, vel alia.'

127 Ibid., fol. $437 v b$, n. 2: 'Sed iudicare vel excommunicare, non sunt fructus iurisdi(ctionis) quia nec propriae fructus dici possunt, imo labor et onus.' 
valid, it is necessary to be vested with the office from which such jurisdiction flows. And this is particularly clear in the case of a sentence of excommunication, because it is the Church that suspends or casts away a sinner. Clearly, the Church operates through Her ministers. But the ministers may do so only because they represent the Church and act in Her name. Ultimately, therefore, it is a question of representation: only a prelate elected and confirmed in his office may exercise the jurisdictional prerogatives of that office. ${ }^{128}$ It follows that the sentence issued by the bishop who does not enjoy jurisdiction on the abbey de iure but simply de facto is void and of no effect. ${ }^{129}$ This conclusion, Innocent notes, does not go against the lex Barbarius, which may not be invoked so as to argue for the validity of the bishop's de facto exercise of jurisdiction on the abbey. Barbarius' deeds, says the pope, were valid not because he was commonly considered praetor, but rather because he was confirmed in his office by the emperor. This way, Barbarius' confirmation cured the underlying defect of his fraudulent election. ${ }^{130}$ Precisely because of that, concludes Innocent, the lex Barbarius may be considered an example of the same principle underpinning the toleration of the unworthy prelates confirmed in office. ${ }^{131}$

128 Ibid., fol. 438ra, n. 2: 'Item in hoc casu [scil., 'in quolibet praelato confirmato'], non dicitur praelatus confirmatus esse in possessione excommunicandi aliquos, quia eos excommunicauit, vel alias iudicauit, quia non nomine suo eos iudicat, sed ecclesiae, vnde ipsa per eum dicitur quaerere vel retinere possessionem iudicandi, vel excommunicandi.'

129 Ibid.: 'sed in hoc casu, scilicet, quando excommunicaret vel iudicaret illos in quorum possessione erat ecclesia, sed in veritate subiecti non erat, non valebit excommunicatio in eos lata, quia sicut dictum est, non est fructus possessionis vel commodi excommunicare, vel iudicare.'

130 Ibid., fol. $437 v b$, n. 2: 'Item non est contraff. de offi(cio) praeto(rum) <l.> Barbarius (Dig.1.14.3) vbi dicitur, quod sententiae latae ab eo, qui erat in possessione tenent, licet praetor non esset, sed ibi respondent, illud ideo esse non potest, quia in possessione erat, quia vere iudicandi potestatem acceperat $\mathrm{ab}$ Imperatore, et omnia alia faciendi, quae ad praetorem pertinebant, licet non esset legitimus praetor, sed per obreptionem.'

131 Ibid., fol. 438ra, n. 2: 'Et idem dicendum est in quolibet praelato confirmato, et de hoc no(tatur) sup(ra) de elect(ione) $<$ c. $>$ nihil. (X.1.6.44).' 


\section{Chapter 8}

\section{Toleration in the aftermath of Innocent IV}

Before turning our attention again to the civil lawyers to appreciate what influence Innocent's notion of toleration had on their approach to the lex Barbarius, we should briefly look at the reception of Innocent's ideas among canon lawyers, to see whether and to what extent they accepted them. We will look only at a few pre-eminent canonists active within a century from the pope's death. This very short comparison might serve to better highlight Innocent IV's innovative and highly refined elaboration.

\subsection{Parmensis and the Gloss on the Liber Extra}

First of all, we might want to look at what Innocent's contemporaries made of the concept of (jurisdictional) toleration. Their position seems to strengthen the conclusion that Innocent's ideas were hardly a refinement of an already accepted common opinion.

If we look at the Summa on the Liber Extra of Goffredus de Trano (c.1200-1245), probably written in the years $1241-1243^{1}$ and so coeval with Innocent's own Apparatus on it, we find remarkably little use of the concept of toleration. The term is present only a few times, one with regard to toleration on moral grounds, ${ }^{2}$ and two others with regard to our subject. There, Goffredus acknowledges the toleration of the heretic not yet excommunicated, and so the production of valid jurisdictional acts, ${ }^{3}$ but he does not elaborate much further on either the precise meaning of toleration or on its scope.

1 Schulte (1877), vol. 2, p. 90; Bertram (1971), p. 79; Bertram (2012), p. 157.

2 Goffredus de Trano, ad X.1.40.2 (Summa perutilis et valde necessaria super titulis decretalium ... (Lugduni [Jean de Moylin], 1519; anastatic reprint, Aalen: Scientia Verlag, 1968, fol. 68ra, n. 3): 'non enim ob metum damni debet mortale peccatum committi, quia potius debemus omnia mala tollerare quam in peccatum mortale consentire.'

3 Id., ad X.1.31.9 (ibid., fol. 55rb-va, n. 9): 'Impeditur autem iurisdictio ordinarij per suspensionem ordinarij si ab officio suspendatur. Item per excommunicationem, quia suspensus ab officio intelligo suspensum ab ordinaria potestate et excommunicatus excommunicare non potest vt xxiiii q. $\mathrm{i}<\mathrm{c}$. $>$ audiuimus (C.24, q.1, c.4), nec alia iudicare vt in de sen(tentia) et re iudi(cata) $<$ c. $>$ ad probandum (X.2.27.24). Si vero ordinarius sit alias in mortali crimine constitutus et si de merito vite iudicare non possit vt iii q. vii <c. $>$ qui sine peccato iudicet (C.3, q.7, 
The Ordinary Gloss on the Liber Extra, compiled by Bernardus Parmensis (Bernardus de Botone, d.1266) mentions the toleration principle only occasionally. When it does so, in most cases it seems to give little weight to it. ${ }^{4}$ Similarly, a few times the Gloss refers to the lex Barbarius, but typically just among many other citations, without relying especially on it. ${ }^{5}$ The fact that Parmensis drew largely from the glosses on the Compilationes Antiquae of authors earlier than Innocent might partially explain why he makes little use of the concept of toleration as shaped by Innocent. However, when Parmensis does make use of the toleration principle, his position appears different from that of the pope. Let us look at a few such cases. First, that of the legal decisions of the infamis. So long as not publicly excommunicated, says the Gloss, the decision rendered by an infamis judge is valid. In stating as much the Gloss invokes both the lex Barbarius and Gratians' dictum Tria. This, however, applies only if neither party raised an objection against the judge until the sentence was given (and so even after the joining of the issue). ${ }^{6}$ In stating as much, the Gloss follows the traditional approach - but not that of Innocent. As we have seen, when commenting on the same point (X.1.3.13) Innocent stressed that the parties could not object to the jurisdiction of the infamis ordinary judge by way of exception. ${ }^{7}$ A second case is that of the excommunicated judge. While a sentence is void if one of the judges who pronounced it was publicly excommunicated, says the Gloss, it stands valid if the excommunication was secret. The Gloss openly justifies such a conclusion

c.3) et c. sequentibus (C.3, q.7, c.4-7); de potestate tamen iurisdictionis potest quamdiu fuerit tolleratus iudicare vt ix q. iiii <c.> nonne (rectius, C.8, q.4, c.1).' See also Id., ad X.5.3.7 (ibid., fol. 201va, n. 7): '... Et quod proxime dixi quilibet peccator potest missam cantare praeter symoniacum sic intellige quilibet non praecisus quilibet tolleratus.'

4 Gloss ad C.1.11.11, $\mathbb{\$}$ Toleratur (Decretalium domini pape Gregorij noni compilatio, cit.): 'hec fuit comparatiua permissio: vt hoc innuitur. Ar(gumentum) i(nfra) de preben(dis) <c.> cum iam dudum (X.3.5.18), forte propter scandalum et multitudine talis consuedudo toleratur ...'). Cf. also the position of the Ordinary Gloss ad X.1.14.2, $\$$ Etatem; ad X.2.13.13, $\$$ Tolerare; ad X.3.2.7, \$ Occultum; ad X.4.1.2, $\$$ Tolerari (the only one of this list reporting Bernardus Parmensis as its author);

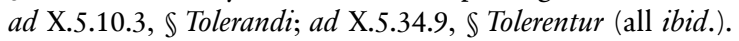

5 Gloss ad X.2.21.7, $\$$ a prohibendo (ibid., the deposition of a witness who becomes infamis thereafter remains valid), and ad X.2.25.12, $\$$ Publice (ibid., the vassals of an occult heretic are not released from their duties towards him). Neither gloss reports its author.

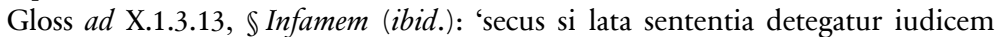
fuisse infamem iii q. vii $\mathbb{S}$ tria, ver(siculum) verum (C. 3, q. 7, p.c.1), et ff. de offi(cio) preto(rum) <.l> barbarius (Dig.1.14.3), et C. de testa(mentis) 1. i (Cod.6.23.1); secus in excommunicatione: quia sententia publice excommunicati nulla est i(nfra) de re iudi(cata) <c.> ad probandum (X.2.27.24).' Supra, last chapter, notes 45 and 48. 
by reference to the common mistake, as it recalls both the lex Barbarius and the sources most closely related to it (the slave-arbiter in Tria and the slave-witness in Cod.6.23.1). But it does not hint at the concept of toleration. ${ }^{8}$ The difference between Innocent and the Ordinary Gloss becomes even more pronounced in a third case, that of the unworthy prelate invalidly appointed to a parish who hears the penitent's confession (X.1.6.54). When the election is vitiated, states the Gloss, the prelate may not exercise jurisdiction on the parishioners. It is only the faith of the faithful that renders the absolution valid. ${ }^{9}$ The Gloss however does not enquire as to the specific status of the prelate - whether or not he was tolerated in his office. Nor does it say that a further confession is necessary when the faithful discovers the truth about the prelate not tolerated in office. Its conclusion is therefore more logical than that of Innocent - it is difficult to put a sacrament under a resolutive condition! From a legal standpoint, however, the more coherent argument was that of Innocent. By contrast, the more linear approach adopted by the Gloss is also revealing of its scant interest in the legal ramifications of the toleration principle.

It is probably on the requirement of confirmation that the position of the Gloss differs most from that of Innocent. In its discussion of the election of an unworthy the Gloss gives ample details as to the punishment of both elector and

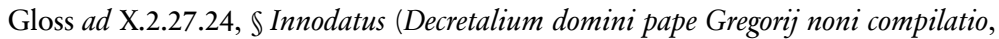
cit.): 'sic sub de excep(tionibus) <c.> exceptionem (X.2.25.12) ad fi(nem), vbi de hoc aliud si occulte: quia tunc nec ipse nec alii ipsum tenebant vitare quia diuinare non poterant, vnde cum communi opinione liber et absolutus habeatur et credatur quicquid interim facit viz. iii q. $7 \$ 3$ ver(siculum) verum si seruus (C. 3, q. 7, p.c.1) et ff. de offi(cio) praetor(um) <l. $>$ barbarius (Dig.1.14.3), C. de testa(mentis) 1. i (Cod.6.23.1).' Those scholars who argued the opposite often relied more on different issues, especially the scope of the maxim de occultis non iudicat ecclesia. See e. g. Miaskiewicz (1940), p. 51, note 6. On the position of the Ordinary Gloss on the Liber Extra regarding the invalidity of the sentence rendered by the person who was publicly excommunicated see also the gloss ad X.3.49.7, $\$$ Tempore valiture (Decretalium domini pape Gregorij noni compilatio, cit.).

9 Gloss ad X.1.6.54, $\$$ Decepte (ibid.): 'quia cum desierit esse prelatus ipsorum: nihil potestatis habebat in eis, vnde non poterat illas alias soluere vel ligare, $\mathrm{i}(\mathrm{nfra}) \mathrm{de}$ peni(tentiis) et remis(sionibus) $<$ c. $>$ omnis vtriusque (X.5.38.12) ... Sed nunquid valebit illis absolutio illius talis prelati siue penitentia per illum imposita? Non videtur: quod (sic) nullam potestatem habet ligandi vel soluendi: sicut non valet sententia a non suo iudice lata, $\mathrm{i}(\mathrm{nfra})$ de iudi (cis) $<$ c. $>$ at si clerici (X.2.1.4) et si sic periebant. In casu isto non credo quod perirent: non quod ille hoc posset, sed propter fidem quam habebant de sacramento: cum crederent illum adhuc esse suum prelatum, et ita in sola fide saluantur, $\mathrm{i}(\mathrm{nfra})$ de baptis(mo) et eius effec(tu) $<$ c.> debitum (X.3.42.4).' On the subject, the position of the Gloss remained predominant until the early fifteenth century (i.e. before Panormitanus): infra, pt. IV, $\$ 14.3$. 
elected, ${ }^{\mathbf{1 0}}$ and explains that the deeds of the elected who is not confirmed may not stand valid unless the elected lies (hierarchically) immediately below the pope. ${ }^{11}$ In the case discussed in X.1.6.44, argues the Gloss, the acts of the unworthy prelate would stand because he received papal dispensation. ${ }^{\mathbf{1 2}}$ Both argument and conclusion were different from those found in Innocent's comment on the same decretal. ${ }^{13}$ But Innocent did not reach his - contrary conclusion only because he discussed the matter more generally and avoided the case of papal dispensation. Quite probably, Innocent was against the solution adopted in the Ordinary Gloss. The Gloss also allowed for the validity of the administration of the diocese (and so, for the validity of the exercise of the office) without confirmation for two other reasons: because the bishop-elect was already in possession of his diocese, ${ }^{\mathbf{1 4}}$ and because 'being excessively subtle one might jeopardise ecclesiastical goods. ${ }^{15}$ The last words referred to the case in which the suffragan bishop-elected was far away from his metropolitan. The solution was therefore based on common sense: prohibiting him from exercising his office until confirmed in it would have led to the paralysis of the diocese. When commenting on the same passage, however, Innocent said expressly that any reason based on the possession of the office or on the need to avoid excessive subtlety in legal reasoning does not suffice to justify the validity of the acts done by the prelate who is elected but not confirmed. ${ }^{\mathbf{1 6}}$

Gloss ad X.1.6.44, $\$$ Suspendatur (Decretalium domini pape Gregorij noni compilatio, cit.).

11 Gloss ad X.1.6.44, $\$$ Administrent (ibid.). The Gloss was careful in wording the statement 'qui subsunt nullo medio romano pontifici'. When Bernardus compiled the Gloss, the traditional privilege of the metropolitan to administer after his election (i. e. without papal confirmation) was increasingly under attack by canon lawyers. It may well be that the wording was crafted so as to echo Alexander IV's decree (of 1257) requiring papal confirmation for the 'prelateselect of churches which pertain, without intermediary, to the Roman Church'. See Benson (1968), p. 185, text and note 50.

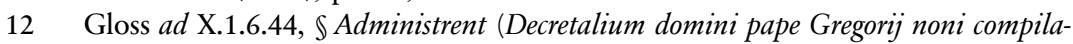
tio, cit.): 'Sed pone quod talis prelatus tempore confirmationis sue reperitur minus idoneus: et sic repellitur: nunquid ea quae medio tempore fecit sunt cassanda ... Sed contrarium verum est in hoc casu: quia fuit inquiera $(s i c)$ administratione: et in quasi possessione prelationis de licentia pape.'

13 Supra, last chapter, esp. notes 121-123.

14 Supra, this paragraph, note 12 . Without confirmation such a possession was not fully legitimate, so the Gloss spoke of quasi possessio.

15 Gloss ad X.1.6.44, $\$$ Administrent (Decretalium domini pape Gregorij noni compilatio, cit.): 'Sed quid si suffraganeus esse valde remotus a suo metropolitano: nunquid eodem modo potest ministrare? Videtur quod sic ... et si nimia subtilitate vtamur res ecclesiarum depereunt.' Supra, last chapter, note 124. 


\subsection{Hostiensis}

In the case of Henricus de Segusio, cardinal Hostiensis (c.1200-1271) - together with Innocent IV, arguably the most important and influential canon lawyer of the thirteenth century - the situation is different. In his Lectura Aurea the concept of toleration is present on several occasions, for instance to avoid scandal, ${ }^{17}$ and as a manifestation of benevolence (especially in contrast to strict law). ${ }^{18}$ Hostiensis speaks of toleration with regard to the exercise of jurisdictional powers by those who ought to be removed (or have not been validly appointed in the first place). ${ }^{19}$ As with Innocent, Hostiensis remarks that the

In this sense, an interesting passage of Hostiensis may be found not with regard to the jurisdiction of the occult heretic but to that of the wicked ruler: Hostiensis, ad X.3.34.8, $\mathbb{S}$ Rursus (Lectura siue Apparatus domini Hostiensis super quinque libris Decretalium, Argentine ... Johannes Schottus, 1512, vol. 2, fol. 136va): '... Potest etiam papa assistere regi hierusalem, ad quem spectat de iure sicut credendum est: ex quo contrarium non apparet. Quinimmo et contra alios infedeles et si non teneant terram in qua iurisdictionem habuerint principes christiani: potest papa tamen iuste facere preceptum et constitutionem quod non molestent iniuste christianos qui eorum iurisdictioni subsunt, et etiam eos in totum eximere a iurisdictione et dominio eorundem, ar(gumentum) in(fra) de iude(is) c. i et c. cum sit et c. ex speciali et c. fi. (X.5.6.1, 16, 18-19), di. liiii, di. $<$ c. $>$ mancipia et c. sequen(s) (D.54, c.13-14). Immo et si male tractent christianos potest eos priuare per sententiam iurisdictionem et dominio quod super eos habent. Sed hoc non nisi ex magna causa: debet enim eos quantum potest tolerare, dummodo non sit periculum christianis nec exinde graue scandalum generetur.' See also Id., ad X.3.5.6, $\mathbb{S}$ Cum teneamur (ibid., vol. 2, fol. 15ra): 'Si mandatum quod fecit papa pro aliquo beneficiando non debet: quia aliud habet beneficium sufficiens, vel non potest sine scandalo exequi. Hoc ducet papa equanimiter tolerandum.'

18 In this sense see esp. the case of a person who abjured his heresy but then relapsed into it. Id., ad X.5.7.9, \$Illos quoque (ibid., vol. 2, fol. 278rb-va) '... Alii tamen dicunt quo iste est casus specialis in fauorem fidei, et quod omnino reddidit se indignum audientia: ex quo abusus est prima gratia sibi facta. Et hoc credo verius de rigore ... nullo modo amplius reconciliabuntur: audietur tamen defendendo se super aliis criminibus accusati ... Prima tamen opinio de exuberanti equitate et benignitate tolerari potest ...' See also Id., ad X.3.5.26, $\$$ Verum (ibid., vol. 2, fol. 24va): '... Sed quare tenetur episcopus integrare prebendas has? Respondeo, quia licet non teneret factum episcopi: tamen non poterat quod fecerat reuocare, ne quis contra venire ... Tu dic: quod episcopus intendebat numerum [scil., prebendarum] augmentare: et ideo tenuit receptio. Sed non fiebat ex causa rationabili, vel non sufficiebat vtrique facta diuisio [of a same prebenda] et ideo reintegrare tenetur ... Vel hoc de benignitate fit: quod talis receptio toleretur, quia de rigore iuris esset cassanda secundum quidam ...'

19 See esp. Id., ad X.1.14.13, \$ Licet igitur (ibid., vol. 1, fol. 114ra): ‘... Quid si aliquis irregularis vel criminosus in sacerdotali officio toleratur in aliqua ecclesia: nunc ad aliquam dignitatem eligitur in eadem, nunquid hi qui ipsum tolerarunt poterunt excipere contra ipsum.' 
toleration of the unworthy priest applies only when he is confirmed in office. ${ }^{\mathbf{2 0}}$ While he seems to approve of the distinction between person and office as the ultimate rationale of toleration, ${ }^{\mathbf{2 1}}$ Hostiensis does not elaborate much on the legal features of the concept, or on its precise scope. ${ }^{22}$ When he speaks of toleration with regard to the exercise of jurisdictional powers, he typically reports what Innocent said on the matter without any addition. This is the case, for instance, with his comment on the decretal Sciscitatus (X.1.3.13), which for Innocent was of paramount importance for the toleration of the ordinary judge. $^{\mathbf{2 3}}$ There, Hostiensis merely provides a summary of Innocent's comment without building on it, or (and much unlike the pope) showing particular interest in its technicalities. ${ }^{\mathbf{2 4}}$ Hostiensis does the same in the case of the notary

Id., ad X.2.28.46, $\$$ Nos ergo (ibid., vol. 1, fol. 418rb): 'talis prouisio [scil., the duty of obedience to a prelate even though illegitimus vel homicida] habet vim non tantum electionis sed etiam confirmationis. Et confirmato prelato obediendum est etiam lite pendente, et quamdiu ab ecclesia toleratur vt patet viii q. i $<\mathrm{c}$. $>$ nonne (rectius, C.8, q.4, c.1), sub de elec(tione) $<\mathrm{c} .>$ transmissam (X.1.6.15) et in eo quod legitur et no(tandum) in(fra) de accusat(ionibus) $<$ c. $>$ olim I. V. et P, $\$$ prouisio (X.5.1.26).'

21 Id., ad X.2.14.8, $\$$ Nos igitur, s.v. 'excommunicationem' (ibid., vol. 1, fol. 285vb): 'Dicunt aliqui, et forte non male: quod si praelatus excommunicatus ratione officij sibi commissi aliquid spirituale exerceat, puta prouidendo alicui de prelatura vel canonicatu, vel si representatum sibi instituit, vel electionem confirmat, valet quod agit, quamdiu ab ecclesia toleratur, ar(gumentum) viii q. iiii <c.> nonne (C.8, q.4, c.1) ... Nisi forte esset notorium, vel alias probari posset, quod esset publice excommunicatus.' It is interesting to note that Hostiensis referred to 'some people' (aliqui) instead, more directly, to Innocent IV. While Hostiensis was probably alluding to a line of thought running from Paucapalea to Tornacensis and beyond, the omission seems nonetheless peculiar, because Innocent was far more explicit (and thorough) on the subject than most. On the subject, he would have been the obvious author to cite, all the more given Hostiensis' profound knowledge of Innocent's writings.

22 In this regard it is telling that Hostiensis considered the question of the exercise of jurisdictional acts of the occult excommunicate ultimately as a manifestation of the principle ecclesia de occultis non iudicat, and not - unlike Innocent - of the different principle of toleration. See esp. Id., ad X.5.39.34, $\$$ Si vere (ibid., vol. 2, fol. $356 \mathrm{ra}$ ): 'executionem enim ordinum vel beneficia confere (sic) vel acquirere non possunt excommunicati etiam occulti: quia non sunt ad hoc habiles seu capaces ... licet de facto teneat quousque ecclesie exinde facta fuerit fides, quia non iudicat de occultis, s(upra) de simo(nia) <c.> sicut nobis (sic) (X.5.3.29).'

23 Supra, last chapter, notes 45 and 48.

24 Hostiensis, ad X.1.3.13, $\$$ Nos vero (Lectura siue Apparatus domini Hostiensis super quinque libris Decretalium, cit., vol. 1, fol. 13ra): '... hoc autem hota quod secundum $\mathrm{d}($ ominum $) \mathrm{n}$ (ostrum) [scil., Innocent IV] nemo potest se excusare a iudicando pretextum infamie nisi contra eum excipiatur, ar(gumentum) C. de decurio(nibus) <l.> infamia et 1 . nec infame (Cod.10.32.8 and 12). Sed nec pretextu infamie vel seruitutis lata sententia retractatur, ff. de of(ficio) praeto 
whose legitimacy was later questioned. Here he does not refer expressly to Innocent, but his comment verges on a literal transcription of the pope's. ${ }^{25}$

By contrast, Hostiensis shows more interest in the toleration principle with regard to sacramental issues, especially the ordinations done by occult heretic tolerated by the Church. ${ }^{26}$ Here as well, however, his position does not diverge

(rum) $<$ l. $>$ barbarius (Dig.1.14.3). $\mathrm{H}<\mathrm{a}>\mathrm{e}$ etiam exceptiones contra delegatum tamen competunt, non contra ordinarium quis diu in suo ordine et officio tolleratur vt no(tatur) in(fra), de offi(cio) del(egati) <c.> cum super (X.1.29.23), secundum d(ominum) $\mathrm{n}$ (ostrum) in(fra) de cohabi(tatione) cle(ricorum) et $\mathrm{mu}($ lierum) <c.> vestra (X.3.2.7).' Cf. Innocent IV, supra, last chapter, notes 37-39.

25 Hostiensis, ad X.2.22.1, $\mathbb{S}$ Si scripturam (Lectura siue Apparatus domini Hostiensis super quinque libris Decretalium, cit., vol. 1, fol. 336va): '... Si tamen negetur illum qui instrumentum confecit fuisse notarium, necesse esse hoc probare per testes, vel per aliud instrumentum de officio sibi commissum confectum vt et no(tatur) $\mathrm{i}(\mathrm{nfra})$ c. i in prin(cipio) (X.2.22.1); sed et sufficeret si probaretur per testes, quod tempore illo quo fuit factum instrumentum quod nunc in dubium reuocatur officio notarij siue tabellionis publice fungebat, ar(gumentum) ff. ad macedonianum 1. iii (Dig.14.6.3), ff. de offi(cio) praeto(rum) <l.> barbarius (Dig.1.14.3), C. de testamentis 1. i (Cod.6.23.1), et forsan hoc potest intelligi s(upra) de

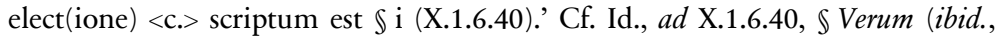
vol. 1, fol. 65rb). Possibly because of his reliance on Innocent on the subject, Hostiensis does not discuss the question in its most obvious sedes materiae: see his commentary on X.2.22.15 (ibid., vol. 1, fol.347ra-va). Perhaps for the same reason, in another occasion in his (even by Hostiensis' own standards, remarkably lengthy) commentary on the same title he briefly touches upon the case of a document customarily believed to be authentic, but does not bring up the forgery issue: Id., ad X.2.22.9, $\$$ Super tertio vero (ibid., vol. 1, fol. 343ra-b).

26 See esp. a long passage in his comment on X.5.8.1, \$Illos vero (ibid., vol. 2, fol. 282va): '... Idem videtur dicendum et de irregularitate ordinatoris vel ordinati, qua tamen talis est quod non impedit executionem quin conferatur habitum et exercitio (sic) sine actu, puta quia defectum patit ... talibus $\operatorname{ar}$ (gumentis) lvi di. <c.> apostolica et c. cenomanenses et c. si (D.56, c.12-13 and 10 ) sub de renunciatione $<$ c. $>$ nisi quum pridem $\mathbb{S}$ persone (X.1.9.10). Inde videtur dicendum et de infamia, nam simoniaci etiam beneficio sunt infames ... Hoc idem videtur dicendum de excommunicatis occultis et de omnibus alijs supradictis, $s$ (cilicet) quod executionem conferant quamdiu ab ecclesia tollerantur, ar(gumentum) i q. i <c.> Christus (C.1, q.1, c.88), vi q. v c. ii et iii (C.6, q.5, c.2-3). Et etiam tales recipiunt executionem licet ligatam vt dictum est de homicida et tamen sunt indigni de conse (cratione) di. ii $<$ c. $>$ non prohibeat (De cons. D.2, c. 67), nec obstat ix q. i c. i et iii (C.9, q.1, c.1 and 3), sub de ord(inatis) ab episcopo c. i et ii (X.1.13.1-2) quia ibi loquitur de illo qui non tolerabatur ab ecclesia sed per sententiam vel denunciationem erat iam ei executio interdicta. Unde nec ipsam alij dare potest saluo excommunicato de quo dici potest quia quamuis toleretur dummodo probari possit excommunicatio possum prohibere volenti ordinari ne ab eo recipiat ordines quia excommunicatus est, vel possum ei dicere: non recipiam a te ordines cum excommunicatus 
much from that of Innocent. ${ }^{27}$ Both Hostiensis' greater interest in the concept of toleration as applied to sacramental issues and his closeness to Innocent's position may be also seen in Hostiensis' treatment of the ordinations of Latin priests after the Greek rite. In his comment on X.1.11.9 he employs the expression 'being tolerated' (tolerari) eight times in a relatively short passage. ${ }^{28}$ In so doing Hostiensis openly adheres to the interpretation of Innocent (who also applied the concept of toleration to that subject). ${ }^{29}$ But Hostiensis' attention is more on the underlying validity of the consecration of the priest than on whether he should retain his office. Because of the different perspective, Hostiensis shows little interest in enquiring as to the precise boundaries and the exact working of the concept of toleration. This different focus may be seen in Hostiensis discussion of the validity of a confession heard by a prelate subsequently dismissed from office (X.1.6.54). As we have seen, in his comment on this decretal Innocent distinguished between justifiable ignorance and proper toleration principle - only the latter renders the confession valid, while excusable ignorance leads to a precarious validity only for pastoral reasons. ${ }^{30}$ On the contrary, Hostiensis reaches the same positive conclusion in both cases because 'whoever is a priest can truly absolve', and because of the justifiable ignorance of the faithful. In so doing, therefore, Hostiensis' poisition lies between that of Innocent and that of the Ordinary Gloss. While the Gloss relied on the faith of the penitent so as to dispense with a second confession in any case, ${ }^{31}$ Hostiensis gives a more refined legal shape to it: as the penitent's mistake is justifiable, and since the falsus praelatus is tolerated in office, the confession is valid. In stating as much, Hostiensis seems to refer to what Innocent said, seeking at the same time to underplay the pecularity of the pope's position. As a result, in Hostiensis toleration becomes more a justification for the common mistake of the penitent rather than the legal reason for the validity of the

sis nec debet tecum participare, et ex hac causa possit legitime appellari. Secus est in infamibus irregularibus et alijs supradictibus in quibus non est admittenda talis exceptio: sufficit enim quod ab ecclesia tollerentur, ix q. iiii $<\mathrm{c}$. $>$ nonne (rectius, C.8, q.4, c.1). Ratio diuersitatis hec esse quia cum excommunicato communicari non potest sine periculo in alijs secus. Quod autem dictum est de excommunicato id intelligas de notorio fornicatore et simoniaco quia a talis obedientia propria auctoritate recedi potest, xxxii di. $\$$ verum (D.32, p.c.6).'

Cf. Innocent IV, supra, last chapter, note 103.

Hostiensis, ad X.1.11.9, $\$$ Quum secundum regulas (Lectura siue Apparatus domini Hostiensis super quinque libris Decretalium, cit., vol. 1, fol. 104rb-va). See also Id., ad X.1.11.10, $\$$ Si vero (ibid., vol. 1, fol. 104vb).

Innocent IV, ad X.1.11.9, supra, last chapter, note 110.

Innocent, ad X.1.6.54, supra, last chapter, note 87.

Gloss ad X.1.6.54 (supra, this chapter, note 9): 'cum crederent illum adhuc esse suum prelatum: et ita in sola fide saluantur.' 
absolution. ${ }^{32}$ Innocent would never have said that any true priest can absolve: priesthood pertains to ordo, absolution to iurisdictio. ${ }^{33}$ What attracted the interest of civil lawyers in Innocent's doctrine of toleration was precisely its neat legal shape and its precise and unambiguous boundaries - which Hostiensis was not always keen to provide because of his different sense of priorities between legal analysis and pastoral considerations. ${ }^{34}$ This might explain why civil lawyers made comparatively little use of Hostiensis when writing on the subject, whereas they relied extensively on Innocent.

\subsection{Guido de Baysio}

If we look at another but slightly later pre-eminent canonist, Guido de Baysio (c.1250-1313), we can see the influence of Innocent but also its limits. As with Hostiensis, Baysio shows no particular inclination to read the concept of toleration in specifically jurisdictional terms. This may be seen in Baysio's comment on some of the locus classici on the subject in the Decretum. In his discussion of the incipit of C.2, q.1, c.18 ('Multi corriguntur ut Petrus; multi tollerantur ut Iudas'), for instance, the concept of toleration is based on the distinction between notorious and occult sin. ${ }^{35}$ But the reason for tolerating the latter depends exclusively on the impossibility of proving the crime judicially. So

Hostiensis, ad X.1.6.54 $\$$ Dudum (Lectura siue Apparatus domini Hostiensis super quinque libris Decretalium, cit., vol. 1, fol. 77ra): '... Excusantur autem anime subditorum propter iustam ignorantiam, $\arg$ (umentum) viii dis. $<$ c. $>$ consuetudo (D.8, c.8), et quia prelatus ab ecclesia toleratus in de cohabi(tatione) cle(ricorum) et $\mathrm{mu}($ lierum $)<\mathrm{c}$. $>$ vestra (X.3.2.7), viii q. iiii $<\mathrm{c} .>$ nonne (C.8, q.4, c.1). Dicunt autem quidam: quod ex quo subditi saltem per sententiam depositionis de veritate sunt certificati debent accedere ad verum sacerdotem et ab eo absolui, in de peniten(tentia) $<$ c. $>$ omnis (De pen., D.1, c.37) et melius in de presby(tero) non bap(tizato) $<$ c. $>$ veniens (X.3.43.3). Tu dicas hoc esse consilium cautum: non tamen est de necessitate iuris. Nam qualiscunque sit presbyter vere absoluit, ex quo curam tenet, dummodo seruet formam ecclesie, quamdiu probabilis est ignorantia et ab ecclesia toleratur, vt in premissis iuribus et ff. de offi(cio) preto(rum) $<$ l. $>$ barbarius (Dig.1.14.3) et in de consecra(tione) $<$ c. $>$ eccle(sia) (De cons., D.4, c.45).'

33 Supra, last chapter, esp. $\$ 7.5$.

34 Much has been written on Hostiensis' understanding of aequitas canonica. Yet even there the link between aequitas and pastoral considerations has often been neglected. It is worth recalling what said by Lefebvre several decades ago: Lefebvre (1952), pp. 318-321.

35 Guido de Baysio, ad C.2, q.1, c.18, $\mathbb{\$}$ Multi (Rosarium super decreto, Venetiis [Herbort], 1481): ' $\ldots$. per petrum intellige notorios peccatores, per iudam uero occultos, quia eius crimen erat occultum.' The negative provision contained in this chapter (the occult crime is not to be judged) did not necessarily also entail 
the (lengthy) commentary of Baysio on the mali who are tolerated within the Church focuses on the occult crimes that are known only to God and may not be judged by men. Similarly, the key-text C.2, q.1, c. $6^{36}$ is the object of a particularly detailed comment by Baysio on probatory and procedural issues, without mention of the concept of toleration. ${ }^{37}$ This does not mean that Baysio rejects Innocent's arguments. Indeed elsewhere he refers to C.2, q.1, c.18 to argue that toleration entails the validity of the administration of an office: the tithe paid to the priest tolerated in office releases the debtor. ${ }^{38}$ The ultimate reasons underpinning the toleration principle in Baysio - and so also informing its precise scope - do not entirely match those found in Innocent.

There is little doubt that Innocent influenced Baysio's position on our subject. This influence is particularly clear on Baysio's discussion of the possibility of recusing the jurisdiction of the heretic. ${ }^{39}$ At least in principle, Baysio would seem to have accepted Innocent's reasoning on the limits and modalities of such recusation - namely the distinction between the prohibition on serving as judge and the prohibition on rendering a judgment. ${ }^{40}$ But on the crucial link between confirmation in office and toleration he shows some hesitation - does it really

the positive prescription to tolerate the sinner's jurisdiction: a hint might be found in Baysio's Tractatus super haeresi (in Johannes Dominicus Mansi [ed.], Sacrorum conciliorum Nova, et Amplissima Collectio ..., vol. 25, Venetiis, apud Antonium Zatta, 1782, col. 423).

36 C.2, q.1, c.6: 'Item Augustinus. Unus ex uobis me traditurus est. Bene dixit: ex uobis, et non: ex nobis. Ex uobis enim est, a quibus per iudiciariam potestatem confessus aut conuictus exclusus non est. A me uero, qui nullis indigeo argumentis, et omnia certissime noui, separatus et diuisus est. Tale est, ac si diceret: Etsi ego per occulti iudicii sententiam eum dampnatum habeo, uos tamen adhuc illum per tollerantiam sustinete.'

37 Baysio, ad C.2, q.1, c.6, $\mathbb{S}$ Unus ex vobis (Rosarium super decreto, cit.).

38 Id., ad C.8, q.4, c.1, Nonne directa (ibid.): ‘... quamdiu ergo prelatus toleratur possum ei soluere decimam, nam multi tolerantur ut iudas, ii q. i $<$ c. $>$ multi (C.2, q.1, c.18).'

39 See esp. Id., ad VI.1.14.14, $\$$ Item habere negatur (Guido de Baysio, Apparatus Libri Sexti, Mediolani [Jacobus de Sancto Nazario de Ripa, \& Bernardinus de Castelliono], 1490, fol. 45vb). Baysio followed Innocent also on the issue of

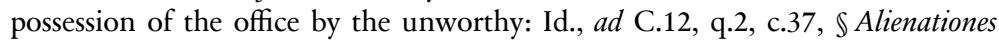
(Rosarium super decreto, cit.): '... dicas quod si proponatur exceptio tu non est praelatus non bene excipitur. Sed si ita dicatur tu non est praelatus nec in possessione praelationis es nec haberis pro praelato tunc bene excipitur, et tunc ante lit(em) conte(statam) debet agens docere de sua possessione uel quasi ... de hoc plene no(tatur) ex(tra) de elec(tione) $<$ c. $>$ nihil et c. transmissam (X.1.6.44 and 15) et ibi de hoc per inno(centium).' Cf. Innocent IV, ad X.1.6.44 and ad X.1.6.15, supra, last chapter, notes 5-6 and 4 respectively.

40 Baysio, ad C.3, q.7, p.c.1, $\mathbb{I n f a m i s}$ (Rosarium super decreto, cit.): '... et no(ta) quod infames et serui non prohibentur expresse iudicare, sed per consequens quia prohibentur ne iudices fiant, ut hic et ...ff. de iudi(ciis) $<$ l. $>$ cum pretor 
need to be based on legal representation? Baysio seems to accept that confirmation in office entails toleration of the acts carried out in the exercise of that office, but he finds the alternative explanation for the validity of the deeds - legal relevance of the common mistake out of fairness considerations - just as good. ${ }^{\mathbf{4 1}}$

Not taking a clear side between the two arguments, Baysio appears somewhat ambiguous when discussing cases of toleration that are far more serious than the simple payment of a tithe. The foremost example is the validity of the excommunication issued by the secret excommunicate tolerated in office. The gravity of this case requires a clear analysis as to the reasons underpinning the toleration. If the validity of the deeds is based on common mistake, says Baysio, then that is not reason enough for the validity of the excommunication itself. If on the contrary the reason lies in the confirmation in office, he continues, then the excommunication might be considered valid. ${ }^{\mathbf{4 2}}$ Baysio is fully aware that Innocent's reasoning is based on legal representation, so that for Innocent the excommunicate does not excommunicate in a personal capacity but rather as the office he (validly though unworthily) represents. ${ }^{43}$ Nonetheless, Baysio is reluctant to push this argument to its extreme (but logical) consequences, and

(Dig.5.1.12), secundum inno(centium), qui ita no(tat) extra de off(cio) dele(gati) $<$ c.> cum super (X.1.29.23).' Cf. Innocent, ad X.1.29.23 (supra, last chapter, note 49).

41 Id., ad D.62, c.3, \$nullus in episcopum (ibid.): 'dicunt quidam quod sine electio non teneat sine confirmatio: non est praelatus ... et no(tandum) xxii di. c. pe. (D.22, c.6). Dicit tamen quod que dixit et fecit tollerantur propter tuitionem confirmationis, ar(gumentum) extra de elec(tione) <c. $>$ transmissa (X.1.6.15), nec ob(stat) secundum eos si obijciatur si non est praelatus quando aget, quando ualebunt que fecerit. Nam hoc contingit ex bono et equo propter commune ignorantia, uel quia potestatem administrationis recipit ex confirmatione ar(gumentum) pre(cedentem) c. transmissa (X.1.6.15).'

42 Id., ad C.11, q.3, c.1, $\$$ Sententia (ibid.): 'Et dicas quod in sententia excommunicationis plus consideratur veritas quam opinio vt si feratur ab eo qui non habet iurisdictionem, licet quod ad opinionem habeatur pro iudice non tamen valet sententia et hoc est propter specialitatem excommunicationis secundum vin (centium hispanum) ... licet contrarium possit sustineri.' Cf. Id., ad VI.5.1.1, $\$$ Cum medicinalis (Apparatus Libri Sexti, cit., fol. 114rb and esp. 114vb).

43 See esp. Id., ad C.24, q.1, c.1, $\$$ Quod autem (Rosarium super decreto, cit.): '... vnde dicebat Inno(centius) quod dum tales tollerantur in aliqua dignitate et sunt occulti non nominati satis uidetur quod possunt excommunicare, beneficia conferre, literas impetrare. Quia hic ipsa dignitas facere uidetur et non ipsa persona excommunicata ... facta enim eorum tuetur praetor, nec ob(stat) i(nfra) q. ii et iii (C.24, q.2-3) vbi dicitur quod excommunicatus non potest excommunicare: quia loquuntur de nominatim excommunicato et interdicto et non tollerato secundum inno(centium) qui ita no(tat) ex(tra) de sen(tentia) ex(communicationis) <c.> si uere (X.5.39.34).' Cf. Innocent IV, ad X.5.39.34, supra, last chapter, note 15 . 
he shows his preference for the contrary conclusion - that the sentence of excommunication issued by the secret excommunicate is void. ${ }^{44}$

This conclusion, in clear contrast with Innocent's position, seems to show Baysio's preference for common mistake as the basis of toleration. It does not appear fortuitous that Baysio grants far more space to the common mistake than Innocent did. Baysio relies on Innocent to draw a line between excusable ('probabilis') and non-excusable ('crassa et supina') ignorance. ${ }^{45}$ But, once duly qualified, he lets such ignorance produce effects that Innocent would have never allowed. This is particularly clear in Baysio's discussion of acquisitive prescription based on false belief. If the false bishop widely believed to be legitimate alienates some goods or rights pertaining to the diocese he invalidly administers, this (invalid) title gives raise to usucapion, argues Baysio, just like the possession of territories beyond the true boundaries of the diocese. In both cases, he explains, the reason is that common mistake on circumstances of fact does make law, as the lex Barbarius and similar leges clearly show. ${ }^{46}$

Baysio, ad C.24, q.1, c.4, $\$$ Audiuimus (Rosarium super decreto, cit.): 'dicas quod sententia excommunicationis ab excommunicato quantumcunque occulto prolata est nulla dummodo postea detegatur et est ratio quia cum sit extra communionem ecclesie non potest habere hanc potestatem.'

45 Id., ad VI.5.11.1, \$ Irregularitatem (Apparatus Libri Sexti, cit., fol. 115ra).

46 Id, ad C.10, q.3, c.6, $\mathbb{S}$ Quia (Rosarium super decreto, cit.): 'Alii dicunt idem si esset titulus erroneus qui dat causam prescribendi secundum eos extra de iurepa (tronatus) <c.> cura (X.3.38.11), sed tu dic super hoc esse distinguendum, quia erroneus titulus aut est erroneus iure aut in fact. $\mathrm{Si}$ in iure nunquam dat causam prescribendi, quia iuris ignorantia non prodest usucapere uolentibus, ff. de iuris et facti igno(rantia) 1. iiii et l. ignorantia et 1. regula (Dig.22.6.4, 1 and 9), ff. de usuca(pionibus) $<$ l. $>$ ubi lex et l. nunquam (Dig.41.3.24 and 31). Ubi autem est erroneus in facto, uerbi gratia si ille qui concessit episcopalia aliquibus locis siue ecclesijs credebatur episcopus et non erat, talis titulus licet erroneus dat titulum prescribendi; uel potest dici erroneus titulus in facto, quando episcopo possidet latiorem dyocesim quam sua si credens eam esse totam de sua dyocesi, licet in ueritate non sit cum terminos et confines sue dyoc(esis) ignoraret, et episcopalia in aliena dyoc(esi) prescribat. Hec probari possunt ff. de off( (cio) preto(rum) $<$ l.> barbarius (Dig.1.14.3), ff. de iure fis(ci) <l.> si in accep(to) (sic) (Dig.49.14.32), C. de testa(mentis) 1. i (Cod.6.23.1), C. de sen(tentiis) interloc(utotionibus) om(ium) iudi(cium) 1. ii (Cod.7.45.2), ff. ad macedoni(anum) 1. iii (Dig.14.6.3), institu. de testamen(tis) in $\$$ testes (Inst.2.10.6). Error enim facti facit ius; error uero iuris minime.' The extensive number of Roman sources quoted by Baysio beyond the lex Barbarius is interesting: the impression is that Baysio sought to use, so to speak, nearly all the weapons in the civil law arsenal on the subject. 


\subsection{The Speculum Iudiciale}

Although sometimes Innocent's arguments are filtered though the Lectura Aurea of Hostiensis, the Speculum Indiciale of Guilelmus Durantis (Guillaume Durand, c.1230-1296) made considerably more abundant use of the concept of toleration than his 'master' Hostiensis. ${ }^{47}$ The Speculum greatly contributed to the spreading of canon law principles among civil lawyers. Given its great influence, we will look in a little more detail at its approach to the lex Barbarius and the deep influence of Innocent.

A first trace of Innocent's ideas on toleration may be seen in the Speculum's treatment of the plaintiff. While a plaintiff acting in his own name does not need to prove his right before the joining of the issue, when he acts in the name of another he does. ${ }^{\mathbf{4 8}}$ This however, continues Durantis, does not apply if he is discharging an ecclesiastical office. In such a case he shall be forced to prove his right only if the defendant objects both that he is not a true prelate and that he is not in possession of his office. ${ }^{49}$ This and similar comments do not necessarily prove that Durantis would thoroughly adhere to Innocent's concept of toleration - one may find the same statement, for example, in Baysio. ${ }^{50}$ It is to matters of excommunication that we have to look. And here there seems to be little doubt as to the profound influence of Innocent on Durantis. So long as the excommunicate is not deposed from office, writes Durantis, he retains the full jurisdictional powers deriving from it, and so he may pronounce a valid sentence. In arguing as much Durantis makes clear that toleration is based on proemium of his Speculum (Specvlum Ivris, cit., vol. 1, p. 3, n. 16). On the point see specifically Gallagher (1978), p. 23. Whether Durantis actually studied under Hostiensis is however not clear: see e. g. Lange and Kriechbaum (2007), p. 479. Speculum, lib. 1, partic. 2, De Actore (Specvlum Ivris, cit., vol. 1, pp. 180-181, n. 73-74).

49 Ibid., lib. 1, partic. 2, De Actore (vol. 1, p. 181, n. 74): 'Alij dicunt, et melius, quod si proponatur exceptio sic: "tu non es praelatus", non bene excipitur. Si uero dicatur: "tu non es praelatus, nec es in possessione praelationis, neque haberis pro praelato", tunc bene, et hoc casu ante litis contestationem debet agens docere de sua possessione, uel quasi.' By the same token, argues Durantis, it is possible to object to the jurisdiction of someone who acts as a bishop and claims a payment due to his church. Speculum, lib. 1, partic. 2, De Actore (ibid., vol. 1, p. 180, n. 72): 'Sed pone, quidam dicens se episcopum cuiusdam ecclesiae in Graecia uel in Barbaria, conuenit me in curia nomine illius ecclesiae, cui me dicit obligatum in centum, ego dico "non te cognosco episcopum esse, nec in possessione episcopatus esse". Nunquid ante litis contestationem tenetur probare se episcopum esse, uel saltem in administrationibus ipsius ecclesiae in possessione esse? Videtur quod sic.' Supra, last paragraph, note 39. 
legal representation. ${ }^{51}$ Because toleration relies on representation, it is necessary that the tolerated be in a position to exercise his office validly. This means not only that he needs to be confirmed in office, but also - just as in Innocent - that the confirmation must be given in full knowledge of the reason the appointment was not valid, otherwise it may not be presumed that the superior authority intended to dispense with the legal requirements. ${ }^{52}$

As toleration depends on the exercise of a public office, the condition of the excommunicated judge may not be extended to the excommunicated arbiter. Discussing this subject (De Arbitro et arbitratore) Durantis reports the opinion of Vincentius Hispanus (d.1248), ${ }^{53}$ according to whom the full knowledge of the

51 Speculum, lib. 2, partic. 3, De Executione sententiae, 1. $\mathbb{\$}$ Est (Specvlum Ivris, cit., vol. 1, p. 814, n. 4-5): 'Item sententia excommunicationis secum trahit suam executionem, et ubique excommunicato sua beneficia denegantur, ut extra de appel(lationibus) <c. $>$ pastoralis (X.2.28.53). Mandatur tamen quoddamomodo executioni, quando publicatur, uel etiam aggrauatur ... Item etiam aliae sententiae statim quosdam sortiuntur effectus, si enim in ea talis infligitur poena, quae adimat libertatem ... Secus tamen est in his, quae ratione officij agit: puta si est praelatus, et sententiam fert: tenet enim sententia, quandiu toleratur, viii quaestione iiii $<\mathrm{c} .>$ nonne $(\mathrm{C} .8, \mathrm{q} .4, \mathrm{c} .1)$, iii quaestione vii $\mathbb{\$}$ tria, prope princip(ium) (C.3, q.7, p.c.1), extra de cohab(itatione) cle(ricorum) et $\mathrm{mu}($ lierum) $<\mathrm{c}$. $>$ nostra (rectius, vestra: X.3.2.7), xix distinctio $<\mathrm{c}$. $>$ serui (rectius, D.54, a.c.1), ff. de offic(io) praetor(um) 1. Barbarius (Dig.1.14.3), nisi forte lata esset in eum sententia depositionis, uel spoliatus esset insigniis dignitatis ... tunc enim sententia a tali praelato lata, non tenet, ff. de his, qui not(antur) infa(mia) 1 .

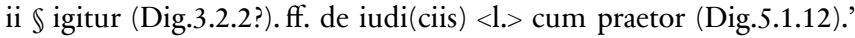

52 Speculum, lib. 1, partic. 1, De dispensationibus, 9. \$Qualiter (ibid., vol.1, pp. 87-88, n. 3-4): 'Dicunt autem quidam, quod ubicumque episcopus scienter facit aliquid contra ius commune: et est tale factum, in quo ipse dispensare potest, pro dispensatione habetur, maxime ubi nullus ex hoc laeditur, ut ex(tra) de biga(mis) <c. $>$ super eo (X.1.21.2), et ex(tra) de cler(icis) coniug(atis) $<$ c. $>$ diuersis (X.3.3.5) et ex(tra) de fi(liis) presby(terorum) $<\mathrm{c}$.> ueniens (X.1.17.5) ... Alij dicunt, et melius, quod ad hoc ut dispensare intelligatur oportet, praecedere ea, quae praesumi faciunt dispensandi uoluntatem, scilicet, quod praecesserit cognitio summaria super causis dispensationis: puta, an sit necessitas uel utilitas, uel alias iusta causa subsit, ff. de in ius uoc(andum) l. libertus (Dig.2.4.15) ... Nunquid ergo episcopus promouendo indignum, intelligitur dispensare cum illo? Et uidetur quod non ... Ioan(nes Teutonicus) dixit, quod circa notum solo facto dispensat, sed non circa ignotum. Tu dic, quod si episcopus dicit se dispensasse, uel aliquis dicat secum dispensatum esse, non est ei credendum, nisi hoc probet. Debet enim dispensatio probari per testes uel etiam per literas dispensationis.' In mentioning the possibility of a cognitio summaria, Durantis was not going against Innocent's requirement that the confirmation should be given with full knowledge of the underlying cause of invalidity. Elsewhere, also Innocent stated that a cognitio summaria (but not also just a nominal one) would do: Commentaria Innocentii Quarti, cit., ad X.1.6.32, \$ Confirmauit (fol. 63rb, n. 2). Cf. Gillmann (1933), esp. pp. 99-100; Schulte (1875), vol. 1, pp. 199-205. 
arbiter's excommunication prior to his appointment would bar the exception of excommunication against the execution of the verdict rendered by that arbiter. To this Durantis replies that one is never bound by the decision of an excommunicated arbiter, whether or not one knows about the excommunication. ${ }^{54}$

Just as in Innocent, also in Durantis the rationale of the toleration principle lies in public utility considerations. This is particularly evident in Durantis' explanation of the reason why the notary who forged some documents, so long as tolerated in office, may continue to draft them validly. Public utility considerations, says Durantis, uphold the validity of the instruments of such a notary as much as they do with the sentences pronounced by the excommunicated judge tolerated in office. ${ }^{55}$ Indeed, he argues, the tabellio is called a notary public precisely because his office was created for the sake of public utility. ${ }^{\mathbf{5 6}}$

The parallel with the judge who is an occult heretic is not fortuitous. What if it is the notary who is a heretic, asks Durantis? Of the two alternative solutions, he says, whichever preserves the validity of the instruments is to be preferred. So long as he is not condemned for heresy - and so, as long as he is tolerated in office - then his instruments will be valid. Durantis reaches this conclusion, he says, having consulted a number of jurists who approved of it, and also taken into account the position of Innocent IV. Just as in the lex Barbarius, the rationale is not letting the people (here, the contracting parties) be deceived ('ne contrahentes hoc ignorantes decipiantur'), for they could not be aware of the notary's underlying incapacity. ${ }^{57}$ The similarity with the judge tolerated in office

54 Speculum, lib. 1, partic. 1, De Arbitro et arbitratore (Specvlum Ivris, cit., vol. 1, p. 108, n. 10-11): 'Ego credo, quod siue scienter, siue ignoranter arbitrum excommunicatum eligerim, non teneor sibi communicare, nec tenet compromissum.'

55 Speculum, lib. 2, partic. 2, De Instrumentorum editione, 9. \$Instrumentum (ibid., vol. 1, p. 671, n. 21): '... licet tabellio confecit unum instrumentum falsum, nihilominus ualent alia uera instrumenta per eum confecta, quandiu in officio toleratur: et hoc est propter publicam utilitatem, ut in concor(dia) quas habes

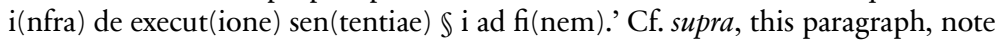
51.

56 Speculum, lib. 2, partic. 2, De Instrumentorum editione, 7. $\$$ Nunc (Specvlum Ivris, cit., vol. 1, p. 652, n. 2): 'De notario autem dicetur i(nfra) $\$$ prox(imum) cuius officium dicitur publicum, quia ob publicam utilitatem est inuentum.' The next paragraph to which Durantis referred (8. \Restat, ibid., vol. 1, pp. 656-664) was centred on the fides publica of the notary's instruments ('Fides quibus instrumentis adhibenda sit').

57 Speculum, lib. 2, partic. 2, De Instrumentorum editione, 8. \$Restat (vol. 1, p. 662, n. 34): 'Quid si confectum instrumentum ab haeretico sit? Respon(deo), dico quod non ualet, si confectum est post quam fuit de haeresi condemnatus; secus si ante, dum ut catholicus agebat et contrahebat, $\arg ($ umentum) $\ldots$ in prae(dicta) 1 . 
becomes even stronger in the case of the excommunicated notary: so long as his excommunication remains occult, says Durantis, any new instrument he drafts will be valid. ${ }^{58}$

The notary is tolerated in office, explains Durantis, so as not to deceive the people who are unaware of the reason why his appointment should be terminated. Could the same principle be invoked to uphold the validity of an instrument that was made by a false notary who was however commonly reputed to be a true one? In effect, the question is whether the rationale of the toleration principle could be invoked also beyond the scope of representation. The issue seems a good way of testing the extent to which Durantis followed Innocent. And he did follow him: for Durantis also the toleration principle does not apply outside representation.

The starting point of his reasoning is very similar to that of Innocent. In order to become notary it is necessary to be appointed. Innocent insisted on the exclusive right of the highest authorities (pope, emperor and - somewhat

Barbarius (Dig.1.14.3) ... C. de haeret(icis) 1. Manichaeos, ibi, cuiquam coniuncto (sed 'convicto': Cod.1.5.4.3), etc. ... et in praed(icta) $\mathbb{\$}$ tria (C.3, q.7, p.c.1) ... ff. de supel(lectili) leg(ata) 1. i in fi. et l. iii $\$$ fi. (Dig.33.10.1 and 33.10.3.5) ... Arg(umentum) contra, quod etiam prius confectum non ualeat: si tamen confectum est post quam tabellio in haeresim inciderit ... Prius dictum plerique sapientes a me consulti approbauerunt: $\arg$ (umentum) eius, quod no(tatur) in praed(icto) c. exceptionem (X.2.25.12) et, secundum Papam, in prae(dicto) c. fraternitas (sic) (X.5.7.4), et ne contrahentes hoc ignorantes decipiantur.' Cf. Innocent, ad X.5.7.4, supra, last chapter, note 70 .

58 On the point, however, Durantis relies on the toleration principle as well as on the procedural limitations to the exception of excommunication, first of all the limitations contained in Innocent IV's decretal Pia. The references to the lex Barbarius and Gratian's dictum Tria, therefore, are not necessarily evidence of Durantis' reliance on the toleration principle. Speculum, lib. 2, partic. 2, De Instrumentorum editione, 8. $\$$ Restat (Specvlum Ivris, cit., vol. 1, p. 661, n. 31): 'Quid si instrumentum confectum est a tabellione, qui erat excommunicatus? ... Tertij, quos dominus meus [scil., Hostiensis] sequi uidetur, dicunt, et melius, ut uidetur, quod quandiu eius excommunicatio est occulta, ualet instrumentum ab eo confectum: uel etiam si sit manifesta, non tamen probari potest, $\arg$ (umentum) pro eis, ff. de off(icio) praet(orum) <l.> Barbarius (Dig.1.14.3), iii q. vii c. insanus (sic!) $\mathbb{S}$ tria, in prin(cipio) uers(iculum) uerum (C.3, q.7, p.c.1), C. de testa(mentis) l. i (Cod.6.23.1) ... secus, si sit notoria, ut ex(tra) de excep(tionibus) $<$ c.> exceptionem (X.2.25.12), de hoc not(andum) secundum Papam [i.e. Innocent IV], extra de excep(tionibus) pia $§$ si uero (VI.2.12.1).'

The same procedural reason underpins another passage where Tria is quoted: the legal proceedings involving an excommunicated procurator are valid if he was an occult excommunicated. Speculum, lib. 1 , partic. 3, De procuratore, $\$ 1$. Ratione (ibid., vol. 1, p. 204): '... Sed si sit occultus, credo, quod processus habitus cum eo tenet, ex(tra) de excep(tionibus) <c. $>$ pia, li. vj (VI.2.12.1), iii q. vij $<\mathrm{c}$. $>$ infamis, $\mathbb{S}$ tria in prin(cipio) (C.3, q.7, p.c.1).' 
reluctantly - other authorities, especially independent kings) to appoint notaries. ${ }^{59}$ Durantis goes beyond that with a daring but very clear parallel: just as bread and wine are transubstantiated into the Body and Blood of Christ, so no one is born a notary, but he has to be created such. ${ }^{\mathbf{6 0}}$ It follows that the common mistake alone does not suffice to make the instrument valid. The most interesting part of Durantis' reasoning lies in his parallel with the lex Barbarius. Its rationale, he says, may be invoked to uphold the instruments made by the unworthy who was created notary by someone who had the power to do so. But the lex Barbarius may not be used to dispense altogether with the requirement of the appointment to the notarial office. So, for instance, if after someone is made notary it is found out that he was legally unfit for such an office (say, he was a slave), his appointment would hold. Barbarius himself, continues Durantis, was a slave but was made praetor by the Roman people: this is why the law says that his sentences were valid. It is therefore necessary, in order to tolerate the legally incapable in office, that he was appointed to it by someone who had the legal authority to do so. ${ }^{61}$

59 Innocent IV, ad X.2.22.15, $\mathbb{S}$ Tabellio (Commentaria Innocentii Quarti, cit., fol. 279vb, n. 1): 'De tabellionibus dicunt quidam, quod quilibet potest facere tabellionem ... Nobis autem videtur aliter, scilicet, quod nullus potest facere tabellionem praeter Papam et Imperatorem, qui horum vsum approbarunt, et inuenerunt, nisi forte consuetudo vel speciale priuilegium Papae, vel Imperatoris alicui hoc concesserit specialiter.' Later on, Innocent carved out an exception for

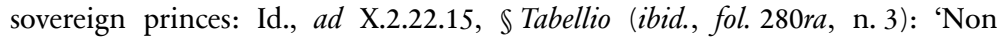
credimus, quod alius subditus ecclesiae, vel imperio possit facere tabellionem, praeter Papam vel Imperatorem ... credimus tamen quod alij reges qui habent supremum, et merum imperium possent idem statuere de tabell(ionibus) si vellent.' The fact that, in practice, many other authorities appointed notaries is readily explained in terms of implicit consent of the sovereign: Id., ad X.2.22.15, Tabellio (ibid., fol. 280rb, n. 4): 'Nec etiam mireris quod per consuetudinem posset induci, quod aliquis inferior principe $(s i c)$ posset facere notarios ... et est ratio in consuetudine ad hoc, vt valeat oportet, quod interueniat consensus superioris principis tacitus, vel expressus.'

On the origins of the imperial and papal appointment of notaries see Meyer (2000), pp. 12-35 and 45-46 respectively. An important step strengthening the principle that notarial appointments were a prerogative of the emperor was the Diet of Roncaglia of 1158 . While the Roncaglia Statute referred only to judges ('omnes iudices a principe administrationem accipere debent et iusiurandum prestare'), the same provision was soon extended by analogy to notaries: ibid, p. 28.

60 Speculum, lib. 2, partic. 2, De Instrumentorum editione, 8. \$Restat (Specvlum Ivris, vol. 1 , p. 663, n. 39): '.. non enim nascitur quis tabellio, immo fit simile de consecrat(ione) dist. ii <c.> panis et calix (De cons. D.2, c.39).'

61 Speculum, lib. 2, partic. 2, De Instrumentorum editione, 8. \$Restat (ibid., vol. 1, pp. 661-662, n. 32): 'Quid si is, qui non est notarius publicus, exercuit tabellionatus officium, sed postmodum apparet eum notarium non fuisse, nunquid instrumenta per eum confecta publica erunt, et fidem facient? $\operatorname{Arg}$ (umentum) 
What has been said so far on Durantis is also useful for interpreting his approach to the role of common opinion as to the defunct notary's appointment: does it suffice to hold the instruments valid? We have seen that such a case was somewhat ambiguous in Innocent's commentary - while there is little doubt that Innocent meant it only as evidence of the true appointment, he did not say that openly. Durantis says what Innocent ${ }^{62}$ (and, after him, Durantis' 'master' Hostiensis) ${ }^{63}$ said: a common belief in the authenticity of the notary's appointment is to be taken as evidence of it. ${ }^{64}$ For the same public utility considerations Durantis argues for the validity of the canonical election when recorded by a lay notary and not, as it should be the case, a clerical one. Ultimately, the rationale is not too dissimilar from that for toleration of the occult excommunicate. If the electors were not aware of the lay status of the notary who presided over it then the election is valid, just as in the lex Barbarius, 'not to let the people be deceived'. ${ }^{65}$

quod sic, in prae(dicta) 1. Barbarius (Dig.1.14.3) et in prae(dicto) $\mathbb{\$}$ tria in prin(cipio) (C.3, q.7, p.c.1) et ff. qui, et a quibus, 1. i (Dig.40.9.1), C. de testam(entis) 1. i (Cod.6.23.1). Dic, quod si habuit priuilegium ab eo, qui potestatem habuit creandi notarios, licet ex postfacto appareat eum non posse notarium esse, puta quia seruus est ... tunc instrumenta eius ualebunt, ut patet in Barbario, qui fuit a populo electus et ideo eius sententiae ualerunt. Si uero nullum priuilegium habuit, tunc communis error non potuit eum facere notarium, ut ex(tra) de cler(ico) non ord(inato) $\min ($ istrante) $c$. i et ii (X.5.27.1-2), $\arg$ (umentum) C. de iur(isdictione) om(nium) iud(icium) <l.> priuatorum (Cod.3.13.3) ... unde non ualent talia instrumenta, ff. de bonis (sic) eorum, qui sub tut(ela) uel cur(a) sunt, l. qui neque (Dig.27.9.8), C. de sacrosan(tis) eccle(siis) <l.> decernimus (Cod.1.2.16).'

62 Supra, last chapter, note 73.

63 Supra, this chapter, note 25.

64 Speculum, lib. 2, partic. 2, De Instrumentorum editione, 8. \$Restat (Specvlum Ivris, cit., vol. 1, p. 663, n. 39): 'Probabit enim, quod publica fama et communis opinio est, illum esse publicum notarium, et quod publice conficit instrumenta in singulis contractibus, et quod instrumenta $\mathrm{ab}$ eo confecta pro publicis habentur in tali ciuitate, uel dioecesi, et quod exercet officium tabellionatus et tanquam tabellio fungitur publicis muneribus, ff. de off(icio) praet(orum) $<$ l. $>$ Barbarius (Dig.1.14.3), iii q. vii c. infamis, $\mathbb{\$}$ tria (C.3, q.7, p.c.1), C. qui, et aduersus quos, 1. i (Cod.2.41.1), ff. ad municip(alem) 1. fi. $\$$ fi. (Dig.50.1.38.6).'

65 Speculum, lib. 2, partic. 2, De Instrumentorum editione, 8. $\$$ Restat (ibid., vol. 1, p. 661, n. 28-29): 'Quid ergo, si tabellio laicus scribit uota canonicorum in scrutinio electionis? ... Officium enim tabellionatus publicum est ... Et publica negotia sunt clericis interdicta ... Sed cum dixeris, existentis in sacris debere interdici tabellionibus officium, saltem in secularibus, quaeritur, si fiat tabellio, et instrumentum conficiat in illis [scil., sacris], an ualeat? ... Multa enim fieri prohibentur, quae iam facta tenent. Dicit dominus meus in prae. $\$$ sub. $\$$ clericis [see infra this note] quod non ualet, si publice et solenniter fuerit eis indictum; secus, si occulte, ne homines decipiantur, ff. de off(icio) $\operatorname{praet}($ orum $)<$ l.> Barbarius (Dig.1.14.3), ex(tra) de simo(nia) $<$ c. $>$ quoniam simoniaca ad fi(nem) 
Durantis' interpretation of the lex Barbarius in his discussion of the false notary might perhaps be used to better appreciate his position in the only case in the whole Speculum where the toleration principle is used in open contrast with Innocent's interpretation. It is the case of a cardinal acting as papal legate without having a formal appointment. There, Durantis simply reports the opinion (which he takes to be the mainstream one) in favour of the validity of the cardinal's deeds. Such an opinion, he says, invoked the lex Barbarius and its interpretation that common mistake makes law. Durantis simply reports it without taking sides (as he normally does), neither confuting nor endorsing it. ${ }^{66}$ His reluctance, quite unusual for him, might well depend on the fact that such a

(X.5.3.40), i(nfra) de sta(tu) monac(horum) uers(iculum) xxvij [ibid., vol. 2, lib. 3, partic. 3, p. 419, n. 33]. Et puto, quod clerici in causa spirituali et ciuili possunt uti tali officio.' The reference to Hostiensis ('dominus meus') in Durantis' text is (rather unusually for him) not entirely clear. Taken literally, the only possible reference would be $₫$ At si clerici (Hostiensis ad X.2.1.4, Lectura siue Apparatus domini Hostiensis, cit., vol. 1, fol. 119rb), but there the reference to the notary has little to do with Durantis' reasoning. From the previous text of Durantis (Speculum, lib. 2, partic. 2, De Instrumentorum editione, 8. \$Restat (Specvlum Ivris, cit., pp.659-661, n. $22 \mathrm{ff}$.$) ) it would clearly appear that the$ 'abovesaid paragraph' ('praedicto $\$$ ') is in Hostiensis' commentary on X.2.22.15 (which was the sedes materiae of Durantis' discussion). But there Hostiensis does not say what Durantis would have him do. It seems more probable that Durantis referred to Hostiensis' comment on X.2.22.1, $\mathbb{S}$ Si scriptura (Lectura siue Apparatus domini Hostiensis, cit., vol. 1, fols. 336va-337va), where Hostiensis did support the validity of a dubious public document when its author was commonly believed to be notary. Later on in the same occasion Hostiensis also referred to the document made occulte by the notary, arguing for its validity (although in the specific case the rationale had little to do with public utility: ibid., vol.1, fol. $337 \mathrm{ra}-b$ ).

On the specific problem of the lay notary fulfilling tasks that canon law reserved to clerical notaries, beyond Hostiensis' commentary on X.2.22.15 see also his commentary on X.1.6.42, $\$$ Statuimus (ibid., vol. 1, fol. 68ra-b), where he discussed the matter more in detail and argued for the validity of the document drafted or task performed by a notarius laicus in all cases but for canonical elections. The reverse situation ('instrumentum confectum a tabellione clerico etiam in temporalibus') was also valid without any restriction: Hostiensis, ad X.3.50.8, \$Sicut te accepimus (ibid., vol. 2, fol. 195ra).

66 Speculum, lib. 1, partic. 1, De legato, 4. \$Superest (Specvlum Ivris, cit., vol. 1, p. 35, n. 18): 'Quid ergo, si quis se pro legato gerit, cum non sit: quia saepe etiam cardinales mittuntur nuncij pro certis negotijs, sine plenae legationis officio, nec ad prouinciam certam? Et quidem dicunt aliqui, quod ualebunt eius sententiae, si gentes ad eum bona fide, tanquam ad legatum, communiter recurrebant: quia communis error facit ius, iii q. vii $<\mathrm{c} .>$ infamis, $\mathbb{S}$ tria (C.3, q.7, p.c.1), ff. de off(icio) praetor(um) 1. Barbarius (Dig.1.14.3), ff. ad Macedo(nianum) 1. iii (Dig.14.6.3). Quos ergo absoluit, absoluti erunt: ut ex(tra) de sent(entia) excom(municationis) <c.> ad eminentiam (X.5.39.20).' 
conclusion would clash with Innocent's interpretation of the toleration principle, and so with what Durantis himself has said so far.

Ironically, it is probable that this opinion derived from Innocent himself. Innocent stated that the papal legate could absolve from excommunication even outside the province to which he was sent as legate. ${ }^{67}$ If he did so, argued Innocent, the excommunication would be lifted validly, on the basis of the de facto consent of the Church. ${ }^{68}$ This statement is hardly a feast of common mistake. The validity of the deeds depends on the presumed confirmation from above - the Church is considered to approve of them de facto. It is significant that, quite unlike Durantis, Innocent was careful not to invoke the lex Barbarius and especially the issue of the common mistake and the protection of those who relied on it in good faith. What Durantis did not fully appreciate was that, in Innocent's argument, the consent of the Church was not merely putative, but derived from the very specific office of the legate in question. Innocent was not referring to any papal legate, but only to a specific class with particularly broad powers - the legate de latere (i. e. 'from the [pope's] side'). A decretal of Gregory IX, Excommunicatis (X.1.30.9), stated that only a legatus de latere could absolve from excommunication outside the province to which he was sent. ${ }^{69}$ This is why Innocent referred only to cardinals: for Innocent, only a cardinal could be a legatus de latere. ${ }^{70}$

While the subject of papal legation is extremely complex and it may not be dealt with here, it is however important to remark the jurisdictional nature of such legation, and read it in the context of the growth of the appellate jurisdiction of Rome: cf. Rennie (2013), pp. 173-174. Innocent IV, ad X.1.30.3 (sed. 4), \$Ex ipso (Commentaria Innocentii Quarti, cit., fol. 146rb): 'et sic quod de facto approbat ecclesia Ro(mana) sufficit, vt habeatur pro iure.' See further infra, this paragraph, note 70 . As a matter of fact, the decretal left the point implicit, since it prohibited any legate who was not de latere from excommunicating or absolving from excommunication anyone outside the province to which he was sent. Innocent IV's interpretation was therefore very much in line with both the wording and the rationale of the decretal, so much so that other decretists such as Goffredus de Trano and Abbas Antiquus said just the same. See further Figueira (2006), p. 92, and K. Hofmann (1929), pp. 23-24.

To fully appreciate the decretalists' debate on the geographical boundaries of legatine powers, Gregory IX's decretal Excommunicatis should be read together with another decretal of Innocent III, Novit ille (X.1.30.7), confirming the validity of the interdict imposed on France by Innocent III's legate Peter of Capua in 1199. See the same Figueira (2006), pp. 76-92 (where Innocent IV's position on X.1.30.7 and X.1.30.9 is discussed at pp. 85-88 and $92-93$ respectively).

70 Innocent IV, ad X.1.30.3 (sed .4), $\$ E x$ ipso: 'non solum ipsos de prouincia, sed etiam alios extra prouinciam decretam potest delegatus absoluere, inf(ra) eod(em titulo) <c.> excommunicatis (X.1.30.9), et sic quod de facto approbat ecclesia 
It is however possible that Durantis had in his hands some unknown elaboration of Innocent's statement. When Albericus de Rosate briefly discussed the matter, he cited Durantis and, apparently, the same passage of Hostiensis invoked by Durantis on the validity of the deeds of a putative papal legate. ${ }^{71}$ What Hostiensis did say, however, was the same as Innocent. ${ }^{72}$ More specifically, Hostiensis approved of Innocent's conclusion on the validity of the jurisdictional act of the cardinal-legate outside the province to which he was sent: the de facto approval of the Church is sufficient to consider such an act as valid de iure. ${ }^{73} \mathrm{Far}$ from putting into question Innocent's stance on the lex Barbarius, therefore, the powers of the cardinal-legate to act even beyond his mandate would seem consistent with Innocent's concept of the office and its powers.

\subsection{Johannes Andreae}

Before moving back to the civil law side of things, we should look at a last and very influential canon lawyer - Johannes Andreae (Giovanni d'Andrea, c.1270-1348). The reason to look at him after Durantis is not based only on chronology, but also on Johannes' frequent quotations from the Speculum. In contrast with both Hostiensis and Baysio, Johannes Andreae shows an interest in the legal aspects of the concept of toleration. In so doing, he adheres more closely to Innocent's doctrine, even warning his reader that Hostiensis skipped

Ro(mana) sufficit, vt habeatur pro iure,ff. de legi(bus) $<1 .>$ de quibus (Dig.1.3.32), ff. de adop(tionibus) <l.> emancipatam (sic) (Dig.1.7.36). Et hoc intelligo verum in legato, qui a latere Papae mittitur, scilicet, Cardinali, inf(ra) de sen(tentia) excom(municationis) <c. $>$ ad eminentiam, c. ea noscitur (X.5.39.20 and.13). Alij autem legati qui non sunt Cardinales, et qui ex priuilegio sunt legati, non plus habent potestatis, quam in priuilegio continetur.' Cf. Id., ad X.1.30.9, P Pro latere (ibid., fol. 147ra): 'latus Principis siue Papae sunt Card(inales), ff. ad 1. Iul(iam) Maiest(atis) <l.> si quis eum (Cod.9.8.3?) et hi, scilicet, Cardinales extra prouinciam hominem alterius prouinciae absoluere possunt.' Cf. Figueira (1980), pp. 264-281.

71 Albericus de Rosate, ad Dig.1.14.3 (In primamff. Veter. part. commentarij, cit., fol. 70va, n. 29): 'Item quaero, quidam gerebat se pro legato apostolicae sedis, qui non erat, nunquid gesta per eum, uel coram eo ualebunt? Dic plene, ut no(tatur) per Host(iensem) in summa de off(icio) legati (X.1.30) $\$$ quid pertinet, ver(siculum) quid ergo si quis gerat, et in $\operatorname{Spec}(\mathrm{ulo})$, de legato $₫$ superest uidere, ver(siculum) quid si quis se pro legato.' While the reference to the Speculum is clear (supra, this paragraph, note 66), I was not able to find that to Hostiensis' Summa.

72 Hostiensis, ad X.1.30.4, $\mathbb{Q}$ Quod translationem and $\$ E t$ si quidem (Lectura siue Apparatus domini Hostiensis, cit., vol. 1, fol. 163ra-b).

73 Ibid., fol. 163rb: 'hoc enim secundum d(ominum) n(ostrum) [scil., Innocent IV] licet quod istud de facto romana ecclesia approbauit quod sufficit ad hoc vt habeatur per iure.' 
some important points of it, ${ }^{\mathbf{7 4}}$ possibly because of Hostiensis' disapproval of those legal subtleties that were so dear to the pope. ${ }^{75}$ Unlike Hostiensis, Johannes Andreae does share Innocent's interest in those subtilitates: it was perhaps this common interest that allowed him to follow Innocent more closely on our subject (and beyond it). The point should not be underestimated, given Johannes Andreae's deep influence on later jurists - canon lawyers as much as civil lawyers.

In his discussion of the toleration principle Johannes Andreae follows Innocent very closely. The toleration principle operates only in the exercise of a public office, ${ }^{76}$ and it bestows validity on situations where a private person could not act validly. ${ }^{77}$ To highlight the difference between office holder and

74 See esp. Johannes Andreae, ad X.1.6.44, \$nichil (Ioannis Andreae ... In primum Decretalium librum Nouella Commentaria ..., Venetiis, Apud Haeredem Hieronymi Scoti, 1612, fol. 120vb, n. 28): 'Scias, quod Inn(ocentius) posuit hic magnam glosam de qua non curauit Hostie(nsis) remittens ad no(tas) de scismati, ca. i (X.5.8.1).' Hostiensis was rather selective in his discussion of Innocent: with regard to the same subject, see esp. Hostiensis, ad X.5.8.1, \$Illos vero (Lectura siue Apparatus domini Hostiensis, cit., vol. 2, esp. fol. 282va).

75 Johannes Andreae, ad X.1.38.15, $\$$ Sententia (In primum Decretalium librum, cit., fol. 289rb, n. 4): 'Hosti(ensis) de gl(osa) Inn(ocentii) [scil., on the same X.1.38.15] dicit, quod subtilitates, quibus hic vtitur, sibi non placent.'

76 Id., ad X.2.13.5, \$ In literis (Ioannis Andreae ... In secundum Decretalium librum Nouella Commentaria ..., Venetiis, Apud Haeredem Hieronymi Scoti, 1612, fol. 75rb-va, n. 11-12): 'Scripsit etiam hic Innoc(entius) quod si aliquis possideat episcopatum, vel aliam dignitatem, vel canonicatum, et omnia, quae occurrunt, gerat generaliter tanquam episcopus, vel tanquam archiepis(copus), vel tanquam canonicus, omnes illi, qui sic ei publice se gerenti soluunt debita, liberantur, et contrahentes cum eo excusantur, $\arg$ (umentum) ff. ad Mace(donianum) 1. 3 et supra de iud(iciis) <c.> cum deputati (X.2.1.16). Alij tamen contradicunt ... Et hoc teneas, quicquid infra vel supra no(tatum), isti tamen secundum Innoc(entium) quamdiu sunt in possessione tuendi sunt in ea, infra de inst(itutionibus) $<$ c. $>$ cum venissent (X.3.7.6), et eis reddendi sunt fructus castrorum, et villarum, quas possident: quia in hoc est commodum possessoris, vt fructus percipiatur. Si tamen talis a possessione cadat non habet aliud, vel ad minus aeq(uum) bonum remedium, quam vt praedictarum rerum, dum modo non sint sacrae, vel spirituales, restitutionem petat et agat proprio nomine tamquam spoliatus possessione iuris canonici, vel alterius dignitatis; et sic potest intelligi, quod hic dicit, nempe de iure proprietatis agere non potest, nisi probaret titulum ... Alii etiam missi in possessionem auctoritate superioris, sed non confirmati, petere possunt et generalem restitutionem iuris pertinentis ad dignitatem suam nomine suo; quia et illud in genere nomine suo possident, sed restitutionem specialium, siue spiritualium iurium nomine suo petere non possunt, cum illa suo nomine non possederint, sed potius nomine dignitatis.'

77 Id., ad X.1.4.8, $\mathbb{S}$ Cum dilectus (In primum Decretalium librum, cit., fol. 58rb, n. 25): 'etiam excommunicatum ad electionem non vocandum, cum non possit eligere: et illi soli sunt vocandi, qui debent, et possunt intereste (sic) ... nec ob(stat) 8 q. 4 
private individual, Johannes Andreae contrasts privata with publica persona: in his exercise of a public office, the incumbent is himself a public person: he does not act as individual but only as representative. ${ }^{78}$ As such, so long as legal representation continues, his deeds should be judged according to the legal capacity not of the individual, but of the office. This is how Johannes Andreae interprets (and uses himself) Innocent's statement 'anything is tolerated because of the office that one exercises'. ${ }^{79}$ So long as regularly appointed (i.e. both

nonne (C.8, q.4, c.1), quia illud verum in his, quae spectant ad aliquos ratione publici officij, ff. de offic(io) praesi(dis) 1. i (Dig.1.18.1), de off(icio) praeto(rum) $<1 .>$ Barbarius.' Id., ad X.1.38.15, $\$$ Sententia (ibid., fol. 289rb, n. 4): 'Inno(centius) formans hic satis magnam $\mathrm{gl}(\mathrm{osam})$ dicit se intelligere de sententia lata ab homine: nam si a canone forent excommunicati, etiam si notoria esset excommunicatio, teneret tamen procuratoris constitutio ab eis facta, nec posset procu(rator) repelli, quamdiu excommunicati tolerantur in officio, cuius auctoritate constituerunt procuratorem ... quod verum puto, quando ab vniversitate constituitur proc(urator). Nam si a priuato bene repelletur, etiam sit constituens esset excommunicatus a canone, quanuis occultus, si tamen non excipietur, teneret, quod faceret procu(rator) ... vel dic, quod etiam circa illos, qui sunt in publicis officiis, et in his, quae sunt in publicis officiis (sic) vt in contractibus, qui celebrantur cum aliquo alio, vel aliis, vel negotiis, quae tangunt alios vt sunt ista, sententiae, testimonia, instrumenta, et exercitium cuiuslibet iurisdictionis voluntariae, vel contentiosae, vbi propter publicam ignorantiam, vel publicum officium aliqua valent, et effectu habent, quem alias non haberent, vt ff. de offi(cio) praeto(rum) <l.> Barbarius (Dig.1.14.3), C. de testa(mentis) 1. i (Cod.6.23.1).' Cf. also Id., ad X.1.6.34, $\$$ Venerabilem (ibid., fol. 65vb, n. 14).

78 Id., ad VI.2.12.1, \$alia communibus (In sextum Decretalium librum, cit., fol. 75vb, n. 11-12): 'si excommunicatus extra iudicium aliquid facit vt priuata persona, indistincte valet in suum detrimentum, sed ad vtilitatem suam nil facere potest ... Si vero tanquam persona publica, vel in iudicijs vt priuata vel publica et erat occultus, videlicet quod agit siue pro se, siue contra se ... Item si manifestus, sed non potest probari; si sit notorius iudex ex officio ipsum repellere debet.'

79 Id., ad X.5.1.24, $\mathbb{Q}$ Qualiter (Ioannis Andreae ... In quintum Decretalium librum Novella Commentaria, Venetiis, Apud Haeredem Hieronymi Scoti, 1612, fol. 16va, n. 21): 'no(tatur) quod sententia lata statim sortitur quosdam effectus, ver(bi) gra(tia) si sit talis poena imposita, quae libertatem aufert, vlterius eius testamentum non valet, neque aliquid ex testamento capiet, ff. de legat(is) 3 l. i $\mathbb{~ a ~}$ praefecto (Dig.32(.1).1.4), ff. de poenis <l.> qui vltimo, et 1 . ad bestias (Dig.48.19.19 and 31), sed non idem dicimus in his, quae ratione officij facit, puta si sit praelatus, et sententiam ferat, tenebit, quamdiu toleratur, 8 q. $4<\mathrm{c}$. $>$ nonne (C.8, q.4, c.1), nam si contrarium diceretur, absurditas sequeretur ... Omnia enim tolerantur propter officium, quod administrat, 19 dist. $<$ c. $>$ secundum (D.19, c.8), ff. de off(icio) prae(torum) <l.> Barbarius (Dig.1.14.3), nisi esset in eum lata sententia depositionis, vel expoliatus esset in similibus dignitatibus. Tunc enim sententia a tali lata non tenet, ff. de his, qui no(tantur) infam(ia), 1. 2 \igitur (Dig.3.2.2.3) ... nec potest dici, quod toleretur, sed intrusus dicitur.' Compare it with Innocent's comment on X.5.1.24, supra, last chapter, note 23 . 
elected and confirmed), ${ }^{80}$ the prelate tolerated in office retains full administration of it. ${ }^{\mathbf{8 1}}$ The necessity of the confirmation - and here Johannes Andreae is perhaps even clearer than Innocent - depends on the fact that only upon confirmation is the elected able to act in the name of the office. ${ }^{\mathbf{8 2}}$

80 Johannes Andreae, ad X.5.27.10, \$Irritanda (In quintum Decretalium librum, cit., fol. 89ra, n. 5): 'dicit Innoc(entius) plus sibi placere istos [scil., indignos] a iure non suspensos. Dixit Inno(centius) in addi(tione) alios dicere (sic), et videtur melius, quod siue sit bonus, siue malus, etiam haereticus, vel excommunicatus ab ecclesia toleratur per electionem, et confirmationem, etiam si fiat a peccatoribus, vel haereticis, vel excommunicatis toleratis bene contrahitur inter hos matrimonum spirituale, donec separentur paleae a granis.' Cf. Innocent IV, supra, last chapter, $\$ 7.2$, text and note 13 .

81 See esp. Johannes Andreae, ad X.1.6.44, $\$$ nichil (In primum Decretalium librum, cit., fol. 121ra, n. 28-29): 'omnia, quae facit electus, cui defertur administratio a iure, vt hic ... vel per superioris confirmationem, valent, etiam si canonica non fuit electio, et etiam si simoniacus fuisset in ordine, vel beneficio: habuit $\mathrm{n}(\mathrm{am})$ per confirmationem ius administrandi, $s$ (upra) e(odem titulo) $<$ c. $>$ transmissam, et c. qualiter (X.1.6.15 and 17), vnde, licet postea remoueatur, auctoritate et tuitione confirmationis valent, quae gessit ar(gumentum) ff. quid cum falso tutore 1. i $\mathbb{S}$ pe(nultimo) (Dig.27.6.5), ff. de mino(ribus) $<1 .>$ ait pretor, $\mathbb{S}$ permittitur (Dig.4.4.7.2) ... contraria loquantur in his, quae gesta confirmatio non tuetur: haec vera, quamdiu toleratur, 8 q. $4<\mathrm{c} .>$ nonne (C.8, q.4, c.1) vel nisi sententia, vel inhibitio data esset contra eum ... vel nisi aliter esset notorium illum suspensum ... vel nisi sit intrusus, vt quia sua, vel potentum auct(oritate) occupauit ecclesiam, cuius facta non valent, nisi sicut extranei ... nec liberantur eis soluentes ff. condi(cione) indebiti, si vrbana (Dig.12.6.55) ... Ex his pateat, quod praelatus agens nomine ecclesiae non repellitur per has exceptiones: "tu non intrasti per ostium canonicae electionis", "tu es haereticus", "tu es simoniacus", "pater tuus fuit immediatus praelatus ecclesiae, cuius nomine agis", vel similes. Confirmatio nam omnia tuetur, vt dixi ... Respondeo quod per illam transfertur in eum onus probandi, quod sit rite confirmatus ... ad quod aliter non tenetur, ex quo administrasset sciente et patiente superiore, ad quem spectat confirmatio, C. de seruitu(tibus) 1. 2 (Cod.3.34.2). Ex illa enim pacientia titulum habet praesumptum, ex quo releuatur ab honere probandi, nisi prohibetur aliquid contra ipsum.' On the necessity of confirmation prior to valid administration of the office see also ibid., fol. $120 v b$, n. 27.

82 See esp. Id., ad X.1.6.15, $\mathbb{S}$ Transmissam (In primum Decretalium librum, cit., fol. $82 \mathrm{rb}$, n. 10): 'Potest tamen differentia notari inter confirmatos, et non confirmatos, quod confirmati admittantur nomine ecclesiarum suarum, ex quo de confirmatione constat, nec potest obiici quod iniuste sint promoti, quasi confirmatione praetoris omnia roborentur, quod cum falso tutore 1 . i (Dig.27.6.1) et no(tantur) inf(ra) eo (titulo) <c.> nihil (X.1.6.44), imo ex quo sunt confirmati, sua auctoritate possunt apprehendere bona ad beneficia sua spectantia.' If Johannes Andreae is clearer than Innocent in that he links confirmation directly to representation, it should however be noted that by Johannes Andreae's time the precise scope of confirmatio was clearer, whereas Innocent was writing at a time when its precise scope (and, on specific issues, effect) was still debated. 
For the same reason, and again following Innocent, Johannes Andreae does not extend the toleration principle to delegated jurisdiction: it is only the incumbent in office that may be tolerated, not also his deputy. ${ }^{83}$ Toleration relies on representation. Hence a prelate is not able to legally represent his office when he was not confirmed in it, when he is deposed with a legal sentence, or if his incapacity is notorious. ${ }^{84}$ In such cases, the absence of representation entails the lack of toleration. It follows that - just as in Innocent - for Johannes Andreae the common mistake as to the office holder's legitimacy is not sufficient for the validity of his deeds. ${ }^{85}$

The distinction between common mistake and toleration principle is important in understanding Johannes Andreae's position on Barbarius' case. While he mentions the lex Barbarius fairly often when writing of toleration, the only place in his opus where he explains his views on it is, significantly, also the place where he defines most clearly the scope and the working of the toleration principle itself. In his Quaestiones Mercuriales (or rather, his comment on the Regulae iuris

83 Id., ad X.1.3.13, \Sciscitatus, and ad X.1.3.20, Super literis (ibid., fol. 26vb, n. 14-16, and fol. 33vb, n. 46-47 respectively). A partial exception (not present - at least explicitly - in Innocent) is made for the case of a plurality of delegated: see Id., ad X.1.6.30, $\mathbb{I n}$ causis (ibid., fol. 104ra, n. 42): 'quid si vnus ex compromissariis excommunicatus est, an valeat ipsorum communis electio? Respond(deo) quod non, si publice est excommunicatus ... Si vero occulte, tunc si duo tantum sunt compromissarii, non valebit ... Si vero sunt tres, vel plures, adhuc videtur idem: quia non vt receperunt sententiam dixerunt ... si plures alii dicunt, quod ex quo ille tertius excommunicatus praesens est, non obest excommunicatio, sicut nec contradictio ... Hoc certum, quod in datione potestatis dictum fuisset, quod omnes, vel maior pars prouiderent, non obesset occulta excommunicatio partis minoris, ff. de (receptis qui) arbit(rium) $<1$. $>$ sed si ita (Dig.4.8.8).'

84 On the limits of toleration in Johannes Andreae (and on Innocent's influence on him) see esp. Id., ad X.2.14.8, $\mathbb{S}$ Veritas (In secundum Decretalium librum, cit., fol. $97 v b$, esp. n. 8).

85 See especially the problem of the payment to the false creditor: Id., ad X.1.6.15, \Transmissam (In primum Decretalium librum, cit., fol. 82rb, n. 11): 'si contradictores habent, qui bona praedicta possidebant, oportet, quod doceant se confirmatos, et ab eo, qui potestatem habuit confirmandi: non tamen habent probare de iustitia suarum confirmationum, vel electionum. Confirmationem vero ideo probant: quia illi, qui bona ecclesiae possident, aliter non liberantur soluendo, nisi praelatis, vel talibus, qui tuitione confirmatorum defendatur, et idem de inuestitis dicendum est, ex quo de inuestitura apparet, sed illam probari oportet.' Cf. Innocent ad X.1.6.44, supra, last chapter, note 43. See further Johannes Andreae's commentary on X.1.3.22, \$Irritandum (in primum Decretalium librum, cit., fol. 35vb, n. 13-14), and compare it with Innocent's reading of the same decretal (ad X.1.3.22, $\$$ Subscriptione), supra, pt. II, $\$ 7.5$ esp. note 81 . 
of the Liber Sextus), ${ }^{86}$ Johannes Andreae writes a long commentary on mora (VI.5.13.60). There, after dealing with time bar issues to raise an exception to the validity of the appointment, he moves on to discuss more substantive profiles of the appointment itself, including also the validity of the sentence rendered by the excommunicate. Although the occult excommunicate should not serve as judge, says Johannes Andreae, one might argue from some sources (especially the lex Barbarius and the dictum Tria) that his being tolerated - and the ensuing validity of the decisions he would issue - lie in the common opinion as to his apparent status. This however is not the case. The legal reason behind the toleration of the unworthy, he continues, is not just the common mistake as to their true status, but rather the fact that they received their office validly. Therefore, concludes Johannes, the common but mistaken opinion as to their legitimate authority may be invoked, but only when the mistake concerns the enduring validity of their appointment, not its initial validity. In other words, without a valid appointment (i.e. election and confirmation in office) the common mistake has no legal relevance. To be invoked, the mistake must be supported by the initial validity of the title. This means that the validity of later deeds is ultimately still based on the validity of the initial conferment of the title. Someone who is tolerated in office is someone who occupied it lawfully, but at some point did something for which he ought to be deposed from his office. The toleration principle covers the acts done between the moment in which such a person should have been deprived of his office and the moment that he actually lost it. In contrast, the intrusus may never be tolerated, because he never had a valid title to discharge the office. ${ }^{87}$

The name Quaestiones mercuriales derives from the fact that the work initially grouped together the questions debated on Wednesdays (dies mercurii), probably along with other more formal disputationes (O. Condorelli [1992], pp. 137-138). Its later elaboration, moving towards a full-scale commentary on VI.5.13, required an in-depth review of the original material (ibid., pp. 140-143). Johannes Andreae, ad VI.5.13.25 (Ioannis Andreae ... In titulum de Regulis iuris Nouella Commentaria ... Venetiis, Apud Franciscum Franciscium, 1581, sub reg. mora, fol. 44rb, n. 13): 'qui in veritate iudex non est, vt quia seruus, uel excommunicatus tamen occultus et ab ecclesia toleratus, ex quo communi opinione iudex habetur, valet, quod per ipsum agitur, de re iudi(cata) $<$ c. $>$ ad probandum (X.2.27.24), iii questio vii $\mathbb{S}$ tria (C.3, q.7, p.c.1), ff. de offic(io) praeto(rum) <l. $>$ Barbarius (Dig.1.14.3). Saepe enim communis opinio praefertur veritati.' Shortly thereafter, Johannes Andreae narrows down this last broad statement and clarifies its scope. Common opinion, he says, can make up for the loss of title, but only if the holder of the office did initially receive a valid title to discharge it: 'Non obstant contraria ... quae procedunt in intruso, qui a principio non habet titulum, sed secus in illo, qui a principio titulum habuit, et superioris auctoritatem: nam licet postea incidat in poenam priuationis, valent tamen quae agit, quandiu toleratur, et creditur ex primo titulo licite possidere' (ibid., n. 15). 
Johannes Andreae applies the same reasoning to the case of the excommunicated notary, who may validly draft instruments so long as his excommunication remains occult. ${ }^{88}$ By the same token, and again following Innocent, Johannes Andreae argues for the validity of the instruments drafted by the notary who committed a forgery. That is surely reason enough to suffer infamia and be deposed from office. Because of the public office that he exercises, however, the notary would still be able to produce new instruments until deposed from office with a legal sentence. ${ }^{\mathbf{8 9}}$ Here as well Johannes adheres to Innocent's position, and rejects the application of the toleration principle to the false notary widely believed to be a genuine one. Toleration is based on legal representation, and representation does not apply to the intruder. It follows that only a true notary may be tolerated in office: the common opinion as to his condition may well be invoked, but only for probatory purposes in a legal dispute on the authenticity of a specific instrument, not to make the instrument valid, let alone to validate the position of the person who drafted it. ${ }^{90}$ turn, heavily relied on Innocent: supra, this chapter, note 25).

Johannes Andreae, ad X.5.7.4, $\$$ Fraternitatis (In quintum Decretalium librum, cit., fol. $46 v b$ ): 'intelligit Innocen(tius) hoc [scil., 'Damnato auctore damnantur eius scripturae et libri et opera', X.5.7.4] in expositionibus scripturarum, et omnibus alijs confectis ab his, qui non gerunt publica officia ... In scripturis autem tabellionum, et aliorum publicum officium gerentium secus est: quia licet vnam chartam falsam fecerint, nihilominus valent aliae, quamdiu in officio tolerantur, $\operatorname{argum}($ entum) 9 q. $4<\mathrm{c} .>$ nonne $(\mathrm{C} .8, \mathrm{q} .4, \mathrm{c} .1) \ldots$ et hoc propter publicam vtilitatem, ne venientes ad eos decipiantur, argum(entum) ff. de off(icio) praeto(rum) 1. 4 (sed 3, Dig.1.14.3) ... si tamen publica persona de falso accusata, et condemnata fuerat, ex tunc instrumenta, et dicta eius carebunt robore ratione personae.'

90 Id., ad X.2.22.1, $\mathbb{S}$ Si scripturam (In secundum Decretalium librum, cit., fols. 162vb $-163 \mathrm{ra}, \mathrm{n} .2$ ): 'Quid si negetur illum, qui instrumentum confecit, fuisse notarium? Hanc quaestionem intellige, quando quaestio est inter duos, quorum alter vtitur instrumento: secus si quaestio esset cum ipso notario. Ac dixit ipse Inn(ocentius) in decre(talem) veniens, de ver(borum) signif(icatione) [X.5.40.34=VI.5.12.1; cf. supra, last chapter, notes 77-78], cuius verba videas in Spe(culo), de proba(tionibus) $\mathbb{S}$ i ad fi(nem), ver(siculum) verum [Specvlum Ivris, cit., vol. 2, p. 179, n. 5] ... Dicit Innocen(tius) quod necesse est hoc probare per testes, vel per aliud instrumentum de officio sibi commisso confectum ... sed et sufficeret, si probaretur per testes, quod tempore illo, quo fuit factum instrumentum, quod nunc in dubium reuocatur, officio notarij, vel tabellionis publice fungebatur, ar(gumentum) ff. ad Macedo(nianum) 1. 3 (Dig.14.6.3), ff. de officio praeto(rum) <l.> Barbarius (Dig.1.14.3) ... Et secundum hoc potest intelligi supra de elec(tione) scriptum est $\$$ i (X.1.6.40). Idem forte, si appareant multa et diuersa instrumenta inter multos, et diuersos per manus eiusdem confecta super contractibus legitimis, quae firma manent, et sine contradictione 
From what has been said so far, it would seem that Johannes Andreae adhered unreservedly to Innocent's position. That is certainly the case for issues dealing with plain jurisdictional matters. However, just like Hostiensis and Baysio, in cases bordering on sacramental matters Johannes Andreae was somewhat more reluctant to follow Innocent. ${ }^{91}$ In Johannes Andreae the accent on ecclesiological matters is not as pronounced as in Hostiensis, but he is not as ready as Innocent to sacrifice them to legal principles either. So, while Johannes follows Innocent on the issue of the sacraments performed by the occult fornicator tolerated in office, ${ }^{92}$ he appears more willing to protect the faithful from the danger of communicating with the occult heretic tolerated in office - even (and quite unlike Innocent) at the cost of rejecting his jurisdiction. ${ }^{93}$ It is significant that Johannes speaks of toleration also with regard to the valid exercise of sacramental powers: just like most other unworthy prelates, he says, the secret excommunicate who is tolerated by the Church retains the executio of his powers

aliqua tanquam vera et publica ab omnibus recipiuntur communiter, et etiam approbantur.'

91 Johannes Andreae appears as keen to cite Innocent when he agrees with him as he seems reluctant to make his name when he does not. In the two main cases that we are going to discuss - the excommunication by the occult heretic and the confession to the falsus praelatus - Johannes Andreae opted for vague reference to 'others' when reporting Innocent's opinion.

92 Johannes Andreae, ad X.3.2.7, $\$$ Abstinere (Ioannis Andreae ... In tertium Decretalium librum Nouella Commentaria ..., Venetiis, Apud Haeredem Hieronymi Scoti, 1612, fol. 8vb-ra, n. 4-5): 'sic abstinere licet, etiam si occulta esset fornicatio, vel esset aliud crimen, quam fornicatio a proprio sacerdote, in his officiis, quam ab eo audire non cogitur ... et est sic faciendum, si ex tali abstinentia contra talem sacerdotem, s(cilicet) fornicatore, et toleratum scandalum non generetur, alias autem non licet abstinere. Nam et dominus Iudae corpus suum dedit ... secundum Inn(ocentium) ... Omnium suspensorum a iure, idest sine sententia hominis, si crimina, pro quibus ius eos suspendit ab officijs, vel quolibet actu, sint notoria facti euidentia, licet cuicunque eos in his vitare, etiam si a praelatis tolerentur ... Si vero crimina, pro quibus a iure suspenduntur, sint occulta, licet grauia, vt simonia, homicidium, et huiusmodi, tamen euitari non debent in his, quae ab ipsis de iure recipi debent ... idem in excommunicato occulto.' By contrast, following Innocent, the sacraments ought not be received from a notorious fornicator, for he is not tolerated in office: 'tales quorum fornicatio est notoria, ab ecclesia non tolerantur' (ibid., fol. 10rb, n. 22).

93 E. g. Id., ad X.1.6.44, \$ nichil (In primum Decretalium librum, cit., fol. 121ra, n. 29). Johannes Andreae appears to be fully aware that Innocent's position - by the pope's own admission - was far from unanimous. Id., ad X.5.3.35, $\mathbb{E}$ Errorem (In quintum Decretalium librum, cit., fol. 32vb, n. 4): 'no(tat) Innocent(ius) hic quod secundum quosdam a deposito, excommunicato, vel suspenso quantuncunque occulto non sunt recipienda ecclesiastica sacramenta ... et secundum Innocen (tium) occulto peccatori quantuncunque etiam excommunicato tenemur ministrare officia, sicut et alijs.' 
relating to ordo (that is, has executio ordinis). ${ }^{94}$ This means, for instance, that a bishop may not prohibit the parishioners from receiving sacraments from the unworthy rector of a parish so long as the latter is tolerated. ${ }^{95}$ In Johannes Andreae, the concept of toleration does not follow the boundaries of the distinction between ordo and iurisdictio - applying to any jurisdictional act and avoiding the sacramental sphere. Just as it is sometimes applied with regard to sacramental issues, so - and contrary to Innocent - it does not cover all manifestations of jurisdictional powers.

A first important case is that of the occult simoniac: quite unlike Innocent, in Johannes Andreae's view the toleration principle does not extend to him. ${ }^{96}$ In stating as much, Johannes refuses to follow the pope's strict division between ordo and iurisdictio. Such a distinction may be a necessary legalism, but ultimately it remains somewhat artificial. This is particularly clear in the case of the secret excommunicate. In principle, so long as the excommunication remains occult, it should not affect one's legal capacity. ${ }^{97}$ But does this mean that

Id., ad X.5.8.1, $\mathbb{S}$ Subiacere (In quintum Decretalium librum, cit., fol. 53va, n. 7): 'Alij autem criminosi, vt adulteri, fures, periuri, et huiusmodi, licet quamdiu sunt in peccato, celebrare non debeant ... tamen constitutionum non habent ligatam executionem sui ordinis ... hoc idem videtur dicendum de excommunicatis occultis, et omnibus alijs supradictis, scilicet quod executionem conferant, quamdiu ab ecclesia tolerantur, argum(entum) i q. i $<$ c.> Christus (C.1, q.1, c.88).'

95 Id., ad VI.5.12.1, $\$$ Veniens (In sextum Decretalium librum, cit., fol. 171vb, n. 5).

96 Id., ad X.5.3.35, $\mathbb{S}$ Errorem (In quintum Decretalium librum, cit., fol. 33rb, n. 8): 'non licet ab obedientia superioris recedere, et ipsum spernere, quantumcunque notorius sit, nisi in duobus casibus, scilicet si est simoniacus in ordine, vel notorius fornicator, 32 dist. $\$$ verum (D.32, p.c.6). In omnibus ergo alijs criminosis aliud est, quamdiu ab ecclesia tolerantur, argumen(tum) 15 q. fi. c. fi. (C.15, q.8, c.5).' The difference with Innocent's commentary on the same point may seem of little importance (what they say is very similar), but in fact it is very significant. Innocent allowed the superior authority to be disobeyed treating him as if he was already deposed from office and so already without valid jurisdiction - in case of notorious fornication or notorious simony. Johannes Andreae however speaks of simony in general, thus seemingly including also the occult simoniac. Compare the passage of Johannes Andreae with Innocent commentary on X.5.3.35 supra, $\$ 7.5$, note 103 .

97 Johannes Andreae, ad X.5.27.8, \$nominatim (In quintum Decretalium librum, cit., fol. 87 ra): 'licet generalis sententia omnes liget, tamen si quis ex inclusis lateat, non imputatur communio, nisi convincatur vel publicetur ...' See also Id., ad X.1.4.8, $\$$ Cum dilectus (In primum Decretalium librum, cit., fol. 58rb, n. 28): 'si excommunicati, qui vocandi non sunt, se ingerant electioni, si sunt occulti, non repellentur: alias fieret eis iniuria, 2 q. $1<\mathrm{c}$. $>$ multi (C.2, q.1, c.18) ... nec nocet non excommunicatis, si talem occultum secum ad eligendum admittant: quia non debent eum repellere, vt dixi; nec eis imputatur.' Cf. Id., ad X.5.39.34, $\$$ Circa temporalia (In quintum Decretalium librum, cit., fol. 141va, n. 3): 'hic dixit 
the secret excommunicate retains the power to excommunicate others? We have seen resistance to this conclusion in several pre-eminent canon lawyers writing before Innocent. Even after Innocent, and despite his profound influence, few canonists were prepared to stretch the toleration principle to the extreme case of excommunication by an occult excommunicate. Excommunication may well be a jurisdictional act, ${ }^{98}$ but even in the fourteenth century there was still sufficient resistance to looking at fundamental ecclesiological issues through the lens of legal reasoning. Siding with Hostiensis and Baysio, Johannes Andreae carved out a specific exception to the toleration of the occult heretic so as to avoid also encompassing the sentence of excommunication. ${ }^{99}$

Johannes' dissent against what one might be tempted to call the protopositivist attitude of Innocent is also visible in the case of the confession to the falsus praelatus: if the faithful discovers the truth later, says Johannes Andreae, he must confess again. ${ }^{\mathbf{1 0 0}}$ Here the explanation is particularly important: the falsus praelatus might well be tolerated and so absolve validly, says Johannes, but that is true in a legal sense, not in a sacramental one. ${ }^{101}$ As we will see, it is only from the fifteenth century that opposition to Innocent's legalistic attitude would be fully overcome. It is however important to stress that, on the toleration principle, this opposition was restricted only to the above few extreme cases, that is, to the most blatant conflicts between sacramental and jurisdictional approaches. On all other (jurisdictional) matters, Innocent's doctrine of toler-

Inn(ocentius) satis videri, quod occulti non nominatim excommunicati, quamdiu tolerantur in dignitate, possint excommunicare, beneficia conferre, et literas impetrare, quia non persona, sed dignitas illud facere videtur.'

98 See e.g. Gloss ad X.1.6.15, $\$$ De talibus (Decretalium domini pape Gregorij noni compilatio, cit.): 'Scilicet pertinentibus ad iurisdictionem: puta sicut est iudicare excommunicare corrigere iuramenta recipere a vassallis confirmare inuestire beneficia proferre et consimilia ... Bern(ardus).'

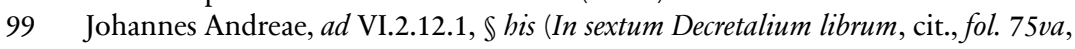
n. 9): 'dicit ergo [Hostiensis] idem in iudice, quod in actore, quia tenet sententia excommunicati occulti, hoc verum salua sententia excommunicationis, quam dicit nulla, ex quo detegitur nunc per excommunicatum fuisse lata, quia cum sit extra communione ecclesiae, alium extra ponere non potest $24 \mathrm{q} .1<\mathrm{c}$. $>$ audiuimus (C.24, q.1, c.4).' As a matter of fact, Hostiensis did not deal with the validity of the excommunication issued by an occult excommunicate. But most decretalists qualified his silence as implicit dissent against Innocent. Cp. however Zeliauskas (1967), p. 264.

100 Johannes Andreae, ad X.1.6.54, $\$$ Dudum (In primum Decretalium librum, cit., fol. 129va, n. 42). In a rather long discussion, Johannes Andreae reports the opinion of both sides, but then opts for the need for a second confession.

101 Id., ad X.1.6.54, $\$$ Suspendit (In primum Decretalium librum, cit., fol. 128vb, n. 25): 'licet a iudiciali possit absoluere, non tamen reconciliari.' 
ation quickly became the common opinion among canon lawyers. Now it remains to be seen what civil lawyers made of it, and how it changed the understanding of the lex Barbarius. 


\title{
Part III
}

\author{
Baldus de Ubaldis \\ and the limits of representation
}




\section{Chapter 9}

\section{Toleration without representation: Albericus de Rosate}

Innocent's concept of toleration would have a crucial influence in the civil lawyers' interpretation of the lex Barbarius through the work of Baldus. This of course does not mean that, before Baldus, Innocent was not well known to civil lawyers. From at least the late thirteenth century, Innocent's work was sufficiently well known among the Citramontani. Whether the same is also true for the Ultramontani, and especially the Orléanese jurists, is not entirely clear although it would seem likely. Ravanis had some knowledge of canon law, ${ }^{\mathbf{1}}$ and Innocent was among the canon lawyers most cited by Bellapertica. ${ }^{2}$ The point, however, is not whether civil lawyers knew of Innocent, but whether they relied on his ideas when commenting on the lex Barbarius. Thirteenth-century canon law was in many respects remarkably more sophisticated than civil law, and Innocent's legal reasoning was often remarkably more advanced than most coeval canon lawyers. Adapting Innocent's ideas to civil law might appear easy only with the benefit of hindsight.

To better appreciate the point, before turning to Baldus we shall briefly look at Albericus de Rosate, perhaps not the most original thinker but an influential and widely known jurist nonetheless. His position on the lex Barbarius is neither particularly coherent nor remarkably subtle. For our purposes, its main interest lies in that it is one of the earliest attempts of a civil lawyer to use the canon law

Some scholars, relying especially on late fifteenth- and sixteenth-century sources, attributed to Ravanis a profound knowledge of canon law. This in particular was the position of Maffei, relying on several sources: Casalupis (Gian Battista Caccialupi, c.1420-1496) called Ravanis 'in theologia magister'; Trithemius (Johannes Tritheim, 1462-1516) spoke of him as 'sacrae paginae professor'; Diplovatatius similarly said that he was magister theologiae before starting to teach civil law. Maffei (1967), p. 55. Admittedly, such terms would seem to refer to someone other than the person described in Bezemer's brilliant portrait of Ravanis - a Roman law professor who knew some canon law but was hardly an expert on it: Bezemer (1997), pp. 4-6. Cf. also Bezemer (1990), pp. 10-11, and Bezemer (1994), p. 104.

2 In his study on Bellapertica, Bezemer counted twelve passages in which he referred to Innocent IV: Bezemer (2005), p. 118; cf. ibid., p. 123. But such passages are only in Bellapertica's commentary on the Code and in some repetitiones on it. Whether Bellapertica also looked at Innocent when commenting on the Vetus, and especially on the lex Barbarius, we do not know. 
concept of toleration in the elaboration of the lex Barbarius. This short analysis of Albericus will serve mainly to better understand the difference between him and Baldus (to whom we shall devote far more attention).

Albericus relies on toleration without a clear understanding of it. Innocent subordinated toleration to confirmation: the unworthy or incapable of holding an office may be tolerated in it only if confirmed by the superior authority. Albericus however seems to consider the possibility that the superior authority might confirm the unworthy as sufficient to tolerate him in office. This way, Innocent's concept of toleration becomes a variation on the theme of Ravanis' view of the sovereign's role: the deeds of Barbarius are valid because his incapacity to serve as praetor could have been cured by the subject who appointed him. Albericus' similarity with Ravanis might not be fortuitous: among the Ultramontani who wrote on the lex Barbarius, Albericus seems to be familiar only with Ravanis. ${ }^{3}$ While the result is admittedly far from impressive, Albericus' position attests to the growing attention of civil lawyers towards the canonists' notion of toleration in office. ${ }^{4}$

\section{See next note (4).}

For this reason, it might be interesting to look at his sources on Barbarius' case. Albericus de Rosate gave ample space to the lex Barbarius, both in its sedes materiae (Dig.1.14.3) and in his commentary on the slave-arbiter (Cod.7.45.2). In so doing, he relied on a large number of jurists, both civilians and canon lawyers. Among the civil lawyers, his sources are remarkably variegated: apart from frequent references to the Gloss (often to criticise it), he cites Ubertus de Bobio, Gabrielis de Ofelettis, Albertus Galeottus Parmensis, Martinus Syllimani, Raynerius de Forlì, Azo, Jacobus de Arena and Jacobus de Belviso, his former teachers Richardus Malumbra and Oldradus da Ponte (cf. Lange and Kriechbaum [2007], p. 666, text and note 7), Guilelmus Durantis, Odofredus, Butrigarius, Suzzara, Dynus de Mugello (quoted both for his civil and his canon law works), Ravanis and Bellapertica. Among them, Albericus relied mainly on Belviso and Durantis (whose Speculum he mentioned twenty times). While his references to other Citramontani tend to be sufficiently accurate, the extent of his knowledge of the Ultramontani is less clear. Albericus shows good knowledge of Ravanis (and this will be important in examining his approach to the lex Barbarius), whereas he might have only indirect and partial access to Bellapertica. In comparison with Ravanis, Bellapertica is quoted considerably fewer times, and on one of these few occasions the reference is indirect: 'it is said that Petrus de Bellapertica was of this opinion' (et in ista opi(nione) dicitur fuisse Pe. de Bel.), Albericus de Rosate, ad Dig.1.14.3 (In primamff. Veter. part. commentarij, cit., fol. $71 \mathrm{ra}, \mathrm{n} .33$ ). Cynus is not mentioned, and Cugno is quoted very sporadically, and always together with other jurists - typically Ravanis. In comparison with the civil lawyers, the canon lawyers quoted by Albericus de Rosate on the lex Barbarius are fewer, but some of them appear with remarkable frequency. The author most quoted is surely Innocent IV with seventeen different passages of his commentary on the liber Extra. That however does not take into account the passages cited more than once, in particular Innocent's comment on X.1.29.23, 
If we are to believe Albericus, not only Jacobus de Arena, Oldradus da Ponte and Richardus Malumbra were against Barbarius' freedom, but 'nearly all the Citramontani and the Ultramontani. ${ }^{5}$ Whether or not this position was so widespread, Albericus surely agrees with it, invoking the traditional objections to Barbarius' freedom ${ }^{6}$ and especially the Romans' lack of intention to set Barbarius free due to their ignorance as to his servile status. ${ }^{7}$ At the same time (and, again, unlike the Gloss) Albericus also dismisses the relevance of Barbarius' putative freedom. Such a de facto possession of freedom remains legally irrelevant because it was acquired in bad faith. ${ }^{8}$ If Barbarius remained a slave, then, the only way to argue for the validity of his praetorship would be invoking the sovereign's absolute power (i. e. loosed from the constraints of positive law) ${ }^{9}$

X.3.36.8, and especially on X.1.6.44 (a comment of extreme significance for the toleration principle, which Albericus quotes five times in his discussion of Barbarius' case). After Innocent IV, the canon lawyer on whom Albericus relies the most is Guido de Baysio (whom he mentions ten times). The other canon lawyers cited by Albericus are Hostiensis (five times), Bernardus Papiensis and Johannes Andreae (four times each), Bernardus Compostelanus (Antiquus) (twice) and Bartolmaeus Brixiensis (once).

5 Albericus de Rosate, ad Dig.1.14.3 (In primamff. Veter. part. commentarij, cit., fol. 65va [sed 69va], n. 15): 'Iac(obus) de Are(na) Rich(ardus Malumbra) Old (radus de Ponte) et fere omnes citramontani, et ultramontani reprobant op(inionem) gl(osae) et dicunt, quod non fuit liber.' Cf. supra, pt. I, \$3.2, note 34.

6 Ibid., fol. 70ra, n. 20. This is particularly the case with the leges Herennius and Moveor (Dig.50.2.10 and Cod.4.55.4 respectively) and with the argument that Ulpian's reference on the validity of the acts de bumanitate would be an implied confirmation of their invalidity de iure.

$7 \quad$ Albericus de Rosate, ad Cod.7.45.2 (Alberici de Rosate Bergomensis ivrisconsulti clarissimi ... In Secundam Codicis Part[em] Commentaria ..., Venetiis, 1585; anastatic reprint, Bologna: Forni, 1979, fol. 117rb, n. 9): 'Si vero peccatum est in qualitate: tunc est nulla, vt $\mathrm{i}(\mathrm{nfra})$ si seruus, aut liber ad dignitatem (sic) aspira(verit) 1. 1 et 2 lib. 10 (Cod.10.33.1-2) ... Non ob(stante) 1 Barbarius (Dig.1.14.3), quia non habuit dignitatem: quia populus ignorauit eum seruum: et sic non habuit animum dandi libertatem, $\operatorname{argu}($ mentum) ff. de in ius $\operatorname{vocan}($ do) 1. sed si hac, $\mathbb{S}$ patronum (Dig.2.4.10.2) et de excu(sationibus) tu(torum) 1. idem Vlp(ianus) $\$$ i (Dig.27.1.12.1) et s(upra) qui admitti ad bono(rum) posses(ionem) possunt 1. bonorum (Cod.6.9.1).'

8 Albericus de Rosate, ad Dig.1.14.3 (In primamff. Veter. part. commentarij, cit., fols. 65ra [sed 69ra]-69va, n. 11): 'Item op(ponitur) quod nulla humanitas hic uersetur, quia de iure stricto hoc debet esse, quia Barbarius propter fugam erat in quadam possessione libertatis, ut i(nfra) de aedil(icio) edi(cto) l. qui sit fugutiuus $\$$ idem recte (Dig.21.1.17.10) ... ergo omnia per eum fieri potuerunt et in eum cadere ... Sed dic, quod illa quasi possessio erat dolosa et furtiua, vt C. de ser(vis) fug(itivis) 1. i (Cod.6.1.1) et ideo commodum non affert.'

9 For an introduction to the subject of ordained and absolute power in both canon and civil law see Pennington (1993), pp. 106-118. 
to make an ad hoc exception to the rules. But that would be possible only with the precise intention of doing so: ${ }^{\mathbf{1 0}}$

There is no doubt that [Barbarius] was not free, as I just proved ... so he could not be praetor. You might say that this is true unless he was made [praetor] by the prince or the people, but that is true only if the prince or the people knew that he was a slave and wanted to use their plenitude of power, otherwise it is not true. Since they ignored [about that], they did not intend to make him legally capable. Indeed it is only when they know that they are considered to enable (as in Dig.42.1.57).

We have seen that the Gloss' interpretation of Dig.42.1.57 built on the consent of the parties as to the jurisdiction of the minor to argue for the validity of his appointment to the praetorship with the consent of the prince. ${ }^{\mathbf{1 1}}$ The whole argument of the Gloss, however, relied on the clear intention to enable a minor to sit in judgment, and so first of all on the parties' knowledge as to his true age. Hence Albericus' reference to that case: the appointment of Barbarius by the Roman people or the prince could be seen as an exception to the law only if they knew of Barbarius' servile status. Further, even if the sovereign had the power to dispense with the requirements of the law, appointing a slave as praetor would have been 'dishonest', and this of course would strongly discourage a similar interpretation of the prince's presumed will. ${ }^{\mathbf{1 2}}$

Ulpian's argument as to the presumed will of the people to set Barbarius free and consequently allow him to become praetor, reasons Albericus, was a conjecture built to reach a different purpose: bestowing validity on Barbarius' deeds because of the common mistake and public utility considerations. The way he seeks to prove as much, admittedly, is not particularly coherent. We might distinguish Albericus' approach in three phases: Albericus (1) highlights the effects of common mistake (following Butrigarius); (2) applies them to the

Albericus de Rosate, ad Dig.1.14.3 (In primam ff. Veter. part. commentarij, cit., fol. 70ra, n. 20): 'Item non est dubium, quod non fuit liber, vt s(upra) proxi(ma) $\mathrm{q}($ uaestione) probaui ... Et si dicas uerum est, nisi factus fuisset a principe vel populo, dico hoc verum esse si princeps, vel populus sciuissent eum seruum, et uoluissent vti plenitudine potestatis: alias non, C. de legi(bus) l. digna uox (Cod.1.14.4) et de leg(atis) 3 l. ex imperfecto (Dig.32(.1).23), cum igitur ignorauerint non uidentur uoluisse eum habilitare, nam solum quando sciunt uidentur habilitare, i(nfra) de re iudi(cata) l. quidam consulebat (Dig.42.1.57).'

11 Supra, pt. I, $\$ 2.4$.

12 Albericus de Rosate, ad Dig.1.14.3 (In primamff. Veter. part. commentarij, cit., fol. $65 v b$ [sed $69 v b]$, n. 17): '... Sed ad hoc posset respondere quod licet populus seruo, existenti seruo, potuerit conferre praeturam, non tamen honeste quia inhonestum est quod seruus praetor existat ... et ea uidemur posse quae honeste possumus, ut $\mathrm{i}(\mathrm{nfra})$ de uer(borum) sig(nificatione) 1 . nepos Proculo (Dig.50.16.125), uidetur ergo populus uoluisse quod honeste potuit, $s$ (cilicet) quod esset liber et praetor.' 
specific context of elections (after Belviso); and (3) finally interprets their consequences in terms of toleration (in a confused reading of Innocent IV, which in effect is more reminiscent of Ravanis). We shall now look at each 'phase' in turn.

(1) For the role of the common mistake, Albericus elaborates on the scheme provided by Butrigarius: ${ }^{\mathbf{1 3}}$

If you speak of a single mistake, it does not make law (as in Dig.41.1.13 and Dig.2.1.15) but it excuses from punishment if the mistake was a likely one ... If we speak of a common mistake, the mistake of the collectivity, then we should distinguish according to whether keeping it as if it were the truth does further public utility or not. If it does, then the mistake makes law and is considered true as in the present case [i. e. Dig.1.14.3] and in Dig.33.10.3.5. This, as noted in the Gloss on Dig.34.2.37, ${ }^{14}$ applies so long as the mistake is not detected. Once found out, however, the mistake does not apply to future cases, as proven in the leges above.

So long as the mistake is not detected, we should ask ourselves whether public utility is served by the opposite solution, that is, by arguing that the common mistake does not make law. If that is the case, then the common mistake is not to be held as true, nor does it make law (as in Dig.1.3.39 and Cod.1.2.16). If the common mistake neither furthers public utility nor goes against it, then we should enquire whether holding the mistake as true would benefit the person who is erring or not. If it would, then the mistake makes law and is to be kept as

13 Ibid., fol. 65rb [sed 69rb], n.9. The translation is rather free. The text reads: 'So(lutio) aut loqueris de errore singulari, et talis error non facit ius, ut de acqui(rendo) re(rum) do(minio) 1. si procurator (Dig.41.1.13) et de iur(isdictione) om(nium) iud(icium) l. si per errorem (Dig.2.1.15), talis tamen error si sit probabilis excusat a pena ... aut loquimur de errore communi, vel universitatis, tunc aut utilitas publica suadet errorem pro veritate servari: et tunc facit ius et pro veritate servatur ut hic et in de supel(lectili) $\operatorname{leg}($ ata $)<1$. $>3 \$$ si ubi de hoc (Dig.33.10.3.5) et l. Labeo in fin(e) (Dig.33.10.7.2), et de errore universitatis not(atur) in $\mathrm{gl}(\mathrm{osa})$ in(fra) de aur(o) et ar(gento) le(gatis) 1. ornamentorum [Dig.34.2.37, on which see next note] quod verum est, donec error latet, sed eo detecto non, quo ad futura, ut dictis l(egibus) probatur. Et hic dum dicit "quamdiu latuit", aut publica utilitas suadet contrarium, s(cilicet) errorem communem ius non facere, et tunc nec pro veritate non servatur nec facit ius, ut 1. quod non ratione (Dig.1.3.39) et l. decernimus (Cod.1.2.16), aut publica utilitas nec suadet, nec dissuadet, et tunc aut expedit erranti, quod error pro veritate servetur, et faciat ius et servatur, et facit ius ut in ad Macedo(nianum) 1. si quis patrem (Dig.14.6.3) et C. eod(em) [titulo] 1. Zenodorus (Cod.4.28.2). Si autem expediat erranti, quod error communis non faciat ius, non facit, ut in ad Macedo(nianum) 1. fi. (Dig.14.6.20) et de haere(dibus) insti(tuendis) 1. fi. (Dig.28.5.93(92)).' Cf. Butrigarius' scheme of the common mistake, supra, pt. I, $\$ 3.3$, note 82 .

14 Gloss ad Dig.34.2.37, $\$$ Heredis (Parisiis 1566, vol. 2, col. 1280): ‘... qui soluit, vel fuit confessus extra ius muliebrem vestem ... Item nec testatoris error facit ius ... sed vniversitatis sic vel principis, vt $s$ (upra) de offi(cio) $\mathrm{p}$ (retorum) 1 . fi. (Dig.1.14.3).' 
true (as in Dig.14.6.20 and Cod.4.28.2). If the person who is erring is better served by arguing that the common mistake does not make law, then we should argue accordingly (as in Dig.28.5.93).

We have previously seen how Butrigarius built on Jacobus de Arena's scheme, but replaced the absence of harm with the presence of utility. Butrigarius did so to colour with intentionality the acts carried out under a mistake (where the mistake would benefit someone who went along with it). ${ }^{15}$ Albericus follows Butrigarius, but detaches implied will from common mistake. This way, his scheme on the role of the common mistake ends with a different conclusion: ${ }^{\mathbf{1 6}}$

the law presupposes the will in the person who promulgates it (as in Dig.1.4.1pr and Inst.1.2.4). As the error removes the will, it takes away the force of the law. Hence I say that a mistake does not make law ... but it produces some legal effect, which the legal system would not otherwise acknowledge.

(2) Having established that the common mistake could result in legally relevant effects, Albericus seeks to ascribe those effects directly to Barbarius' deeds, and not to his person. To do so, he turns to the specific cause of invalidity in the lex Barbarius: a mistake in the condition of the elected, and so an error in qualitate. On the subject, Albericus follows closely the position of Jacobus de Belviso. We might want to briefly look at it (also because, we shall see, it is the same scheme used by Baldus, who ascribed it to Raynerius de Forlì). ${ }^{17}$ Belviso first distinguished according to whether the statute or the law regulating the election

Supra, pt. I, $\$ 3.1$.

Albericus de Rosate, ad Dig.1.14.3 (In primam ff. Veter. part. commentarij, cit., fol. $65 \mathrm{rb}$ [sed 69rb]), n. 9: ' ... ius praesupponit voluntatem in promulgantem ut sub de consti(tutionibus) prin(cipum) 1. 1 (Dig.1.4.1pr) et Insti. de iure natu(rali) $\$$ lex (Inst.1.2.4), error autem non stat cum voluntate, imo tollit legis effectum ut $\mathrm{d}$ (icta) 1. quod non ratione (Dig.1.3.39); dico quod error non facit ius ... sed facit de iure aliquid efficaciam sortiri, quod alias non sortiretur iure communi.' Cf. Albericus de Rosate, ad Cod.7.45.2 (In Secundam Codicis Part[em] Commentaria, cit., fol. 116va, n. 2): 'uidendum est ergo, an sit uerum quod communiter dicitur et allegatur, s(cilicet) quod error communis faciat ius aliquo casu, et dicendum quod non: quia error est contrarius consensui, ut ff. de iurisdi(ctione) om(nium) iudi(cium) 1. si per errorem (Dig.2.1.15) et in iure constituendo requiritur consensus tacitus, uel expressus, ut ff. de legibus l. sed ea, et s(upra) de legi(bus) 1. humanum (Cod.1.14.8) et ff. de legi(bus) 1. i (Dig.1.3.1).'

Infra, $\$ 12.4 .1$. Our interest in elections is strictly limited to Barbarius' case. Hence the absence of specific references to medieval elections, not least as the electoral systems were numerous and different from each other. For a specific example see the procedure introduced by the Florentine 1328 reform, on which a good account in English may be read in the classic study of Najemy (1982), pp. 99-125, esp. 102-110. For an introduction to procedural law in medieval Italian cities see Vallerani (2005), pp. 19-73, which may be also read in the English translation (2012), pp. 12-71. More in general see Christin (2014). 
contained any provision avoiding the choice made against its requirements. If so, then the common mistake could not be invoked and anything done by the elected would be void. The effects of the mistake could be taken into account only in the absence of a similar provision. In Aristotelian fashion, Belviso grouped invalid elections in four kinds, depending on whether the invalidity lay in form, matter, accident or quality. ${ }^{\mathbf{1 8}}$ For Albericus' purposes, the most important kinds of defect were those in the form of the election and in the condition of the elected - the interpretation of the former would strongly condition that of the latter. When the defect is in materia (such as not having an election), explains Albericus, the common mistake cannot produce any effect. By contrast, a defect in forma (that is, in the modalities prescribed for the election) is not as serious: there, common opinion acquires more relevance. In turn, a defect in qualitate (such as the eligibility of the elected) is even less serious than one in forma. If it is possible to cure the defect in forma, therefore, there is even less need for the defect in qualitate to be prejudicial to the validity of the election.

The precondition for ratifying the defect in forma, Albericus explains, is that the vitiated election be made by the subject who had the right to elect. The implied argument is that, if the elector knew of the defect, he could make up for it. ${ }^{19}$ That however is not the case when the right to elect does not belong to the

Albericus de Rosate, ad Cod.7.45.2 (In Secundam Codicis Part[em] Commentaria, cit., fol. 116vb, n. 6): '.. Ipse Iac(obus de Belviso) distinguit, aut in statuto, uel lege, ex cuius uirtute erat facienda electio, uel collatio continetur, quod quicquid secutum fuerit, nullius sit ualoris, et tunc gesta non ualent, et error communis nihil operatur, ut d. 1. actuarios (Cod.12.49(50).7), et s(upra) de legi(bus) l. non dubium (Cod.1.14.5), et ad hoc facit dictio quicquid, quae est signum distributiuum, ut ff. de here(dibus) insti(tuendis) l. hoc articulo (Dig.28.5.29) ... et illa uerba secutum fuerit, quae comprehendunt non solum actum praesentem sed omnes posteriores, ut $\mathrm{d}$ (icta) l. non dubium (Cod.1.14.5). Si uero illa uerba non sunt, in l(ege), constitutione uel statuto, tunc aut peccatum est in electione, uel collatione, uel in forma, uel materia: aut in accidenti, aut in qualitate.'

Ibid.: 'si quidem est in forma, ut puta, quia non est seruata solennitas in eligendo: tunc, aut competit a iure electoribus ius eligendi, aut ab homine. Primo casu, ut quia facta est electio a populo, uel capitulo, et peccatum est in sola forma, et secuta confirmatio solennis et consecratio, ubi est necessaria, tunc gesta valent.' In his commentary on the lex Barbarius Albericus de Rosate clarifies that the validity of such an election (i.e. when the electors did not exercise a delegated power but their own) would also depend on whether any of such electors opposed the election. Albericus de Rosate, ad Dig.1.14.3 (In primamff. Veter. part. commentarij, cit., fol. 71 ra, n. 35): 'Aut in electione non fuit limitatio: tunc aut est peccatum in forma electionis, ut in solennitate eligendi: tunc aut electoribus competebat ius eligendi a lege aut ab homine. Primo casu tenent acta et gesta, si nullus ab initio extitit contradictor; alias secus.' See further Id., ad Cod.7.45.2 (In Secundam Codicis Part[em] Commentaria, cit., fol. 116vb, n. 6): 'et error communis prodest, non tamen est necessarius, et hoc quando ab initio 
elector, but it is simply delegated to him. In such a case, violation of the prescribed modalities would necessarily void the election. ${ }^{20}$ According to Albericus, the difference may be easily explained referring to natural law. For natural law, clear intention would suffice. The formal requisites prescribed to manifest such an intention are not part of natural law, but only added by positive (i. e. civil) law. ${ }^{21}$ The same difference, continues Albericus, may be clearly seen in a will made without the required formalities: so long as the will of the testator is clear, the bequest made in accordance with the invalid testament would stand. ${ }^{22}$ By contrast, compliance with the formal requirements is necessary if the

nullus extitit contradictor, ut dicta 1 . fina. $\$$ item rescripserunt $<\mathrm{ff}$. $>$ de decu(rionibus) (Dig.50.2.12.3).' The reference was particularly appropriate. We have already seen how the title de Decurionibus was often invoked with regard to the lex Herennius (Dig.50.2.10) to argue that mere enlistment as decurio did not make one such de iure. But this other text, found just after the lex Herennius, specified that if a person had consented to the appointment of someone else as decurio, he could not invoke a legal obstacle against the appointment afterwards.

20 Id., ad Dig.1.14.3 (In primam ff. Veter. part. commentarij, cit., fol. 71ra, n. 35): 'Secundo casu non valent acta per illum, quia electio seu collatio non habuit radicem nec fundamentum, ar(gumentum) d(icta) 1. actuarios (Cod.12.49(50).7) et C. si a non compe(tenti) iud(ice) per totum (Cod.7.48) et extra de hereti(cis) c. fraternitatis (X.5.7.4).' See further Id., ad Cod.7.45.2 (In Secundam Codicis Part [em] Commentaria, cit., fols. 116vb-117ra, n. 6): 'Si autem electoribus competat ius eligendi $a b$ homine, ut puta ex compromisso vel alia concessione facta ab homine: tunc si peccatum est in forma eligendi, non valet electio nec prodest confirmatio, et gesta non valent et error nihil operatur, quia hoc casu non habet aliquod fundamentum: vt d. l. actuarios (Cod.12.49.7) et in q. i c. principatus (C.1, q.1, c.25), extra de haereti(cis) c. fraternitatis (X.5.7.4), et 12 q. $2<\mathrm{c} .>$ alienationes (C.12, q.2, c.37).'

21 Id., ad Cod.7.45.2 (In Secundam Codicis Part[em] Commentaria, cit., fol. 117ra, n. 6): 'Et ratio diuersitatis inter hunc et praecedentem casum est: quia in superiori casu interuenit consensus legitimus eligentium et electi, qui solus de iure naturali ad electionem, et alios contractus sufficit: vt extra de transla(tione) c. inter corporalia (X.1.7.2), et ff. de pact(is) 1. i in prin(cipio) (Dig.2.14.1pr).'

22 Ibid., fol. 117ra, n. 7: 'sic etiam dicimus de testa(mento) non solemni: quia voluntas est legitima de iure naturali potest per haeredem impleri: vt s(upra) de fideicom(issis) 1. 2 et 1 . veritas (Cod.6.42.2 and.23).' The first lex invoked (Cod.6.42.2) prohibited the general heir from suing the beneficiary of the fideicommissum that was void because lacking the prescribed requirement, if the fideicommissum had already received execution. In executing the fideicommissum, the executors had carried out the will of the testator. While the Roman text stressed the importance of both the actual will of the testator and its execution according to the conscience of the executors, the Gloss focused exclusively on the former. In so doing, it highlighted the opposition between form and substance, so that the violation of the formal requirement clearly appeared a simple procedural obstacle to executing the testator's unambiguous will. Cf. Gloss ad Cod.6.42.2, $\$$ Etsi inutiliter (Parisiis 1566, vol. 4, col. 1388): 'Testamentum minus solenne fecisti, heredem instituisti, fundum per fideicommissum mihi reliquisti, 
elector is simply delegated to carry out the election, because in this case the form in which the election should take place is an integral feature of the delegation itself. $^{23}$

In the case of Barbarius, the defect was not in the form of the election but in the condition of the elected. ${ }^{24}$ As said, a defect in forma is more serious than one in qualitate. ${ }^{25}$ It follows that, when the defect lies in the condition of the elected

heres tuus restituit, et decessi herede relicto: an heres tuus heredi meo de precio mouere possit quaestionem, quaeritur? Respond(endum) quod non, cum voluntati tuae in fideicommis(so) praestando satisfactum videatur.' Also the second lex cited by Albericus (Cod.6.42.23) needs to be read according to the interpretation provided in the Gloss. Unlike in the first lex (Cod.6.42.2), in the text of Cod.6.42.23 the actual will of the testator was not clear, and so the heir could not be compelled to give execution to the bequest unless he bound himself to. The Gloss followed the (rather unequivocal) meaning of the text, but added that the heir might also be forced to execute the bequest if the actual will of the testator could be somehow ascertained. Cf. Gloss ad Cod.6.42.23, $\mathbb{\$}$ Si veritas (Parisiis 1566, vol. 4, col. 1398): 'Si nullum testamentum fectisti, vel fecisti, sed minus solenne, et in eo legata reliquisti: an compellendus sit heres ea praestare, quaeritur? Respond(etur) quod non: nisi causa transactionis promisisset: vel alio modo eus voluntatem agnouisset' (emphasis added).

23 Albericus de Rosate, ad Cod.7.45.2 (In Secundam Codicis Part[em] Commentaria, cit., fol. 117ra, n. 7): 'quod non est, quando eis competit ius eligendi ab homine, quia cum receditur a forma eis tradita, nullum ius transfertur in electum: vt ff. quod cuiusque (sic) vniuersi(tatis) 1 . item eorum $\$$ si decuriones, versi(culum) hoc si ita [sed 'sed si ita', Dig.3.4.6.1].' Admittedly, the reference was perhaps not the strongest. The second part of Dig.3.4.6.1, to which Albericus expressly referred, simply stated that one may not appoint an arbiter to decide on a possible future controversy that, at the time of the appointment, had not yet occurred. The Gloss gave the same interpretation, such that Accursius used this passage to highlight the difference between delegation and mandate (ad Dig.3.4.6.1, $\$$ Decretum, Parisiis 1566, vol. 1, col. 408).

24 Albericus de Rosate, ad Cod.7.45.2 (In Secundam Codicis Part[em] Commentaria, cit., fol. $116 v a$, n. 2): 'Item error, ille ab ipso initio fuit in conditione personae, et in dignitate praeturae. Item ibi interuenit omnis solennitas in electione: nisi in defectu personae electi.' Cf. ibid., fol. 117ra, n. 7: '... nec ob(stat) 1. Barbarius (Dig.1.14.3) quia ibi electio habuit fundamentum: nec defectus aliquis fuit, nisi in persona electi: qui seruus erat ... Item in 1 . Barbarius error populi sumpsit originem ab ipso principio, in personam electi, qui putabatur liber.'

25 Ibid., fol. $117 \mathrm{ra}$, n. 7: '... et maius est peccatum formae quam personae: nam sententia si est nulla propter formam non confirmatur, vt s(upra) de testa(mentis) 1. non dubium (Cod.6.23.16). Sed si est nulla propter personam, sic, vt not(atur) ff. de appel(lationibus) 1. si expressim (Dig.49.1.19).' It might be noted that Albericus de Rosate does not specify what exactly such a defect in the quality of the person might be. Nor did the text he invokes in support of his thesis suggest anything the like. Dig.49.1.19 simply stated that when a decision goes directly against the law ('Si expressim sententia contra iuris rigorem data fuerit'), it may never become res judicata. Cf. Gloss ad Dig.49.1.19, $\mathbb{S}$ Si expressim and 
and the elector did not act upon a mandate, then the common mistake may be invoked to make up for the defect. To do so, however, Albericus (again following Belviso) requires two further elements, both deriving from the need that the mistake be justifiable and widespread. First, the defect in the elected must be occult; second, the common opinion as to the lack of such a defect must be formed prior to the election. Requiring that the defect in the elected be occult is rather obvious: a notorious impediment would make the mistake inexcusable. ${ }^{\mathbf{2 6}}$ The second requirement makes sure that the mistake as to the status of the elected is genuinely common. A mistake on the legal capacity of the elected that does not predate the election is probably a consequence of the election, not its

\$Praescriptione (Parisiis 1566, vol. 3, col. 1597). When the invalidity is in materia the election is 'turpiter facta', and so void not only for the civil law but even for the natural law. Albericus de Rosate, ad Cod.7.45.2 (In Secundam Codicis Part[em] Commentaria, cit., fol. 117ra, n. 9): 'Si vero peccatum est in materia, puta quia nulla facta est electio, vel ab electoribus non habentibus ius eligendi, et talis tanquam legitime electus multa gessit, tunc gesta a tali non valent, nec error communis facit ius: quia non habet fundament(um) vt $\mathrm{d}$ (icto) c. principatus (C.1, q.1, c.25) ... talis enim electio, licet non sit turpis, nec de re turpi, tamen est turpiter facta, et ipso iure non tenet, etiam de iure naturali, vt not(atur) per Inno(centium) d(icto) c. quod sicut (X.1.6.28) [cf. Innocent IV, ad X.1.6.28, $\$$ Propter bonum pacis, Commentaria Innocentii Quarti fol. 59va-b, n. 8-10] et $\operatorname{ar}($ gumentum) ff. de pac(tis) 1. si unus $\$$ pacta quae turpem (Dig.2.14.27.4) ... Et ideo nihil valet quod sequitur ex ea, vt d(icta) 1. actuarios (Cod.12.49.7) et s(upra) de legi(bus) 1. non dubium (Cod.1.14.5).' Cf. Albericus de Rosate, ad Dig.1.14.3 (In primamff. Veter. part. commentarij, cit., fol. 71ra, n. 35): 'Aut est peccatum in materia, puta quia nulla est facta electio, vel electoribus non competebat ius eligendi, tunc error communis nihil operatur nec tenent acta per illum vt d. 1. Herennius, de decur(ionibus) (Dig.50.2.10) et C. de sacrosan(ctis) eccle(siis) 1. decernimus (Cod.1.2.16) et $\mathrm{i}(\mathrm{nfra})$ de rebus eorum, qui sub tute(la) 1. qui neque (Dig.27.9.8), ubi de hoc et pro hoc facit quod no(tat) Inn(ocentius) extra de elec(tione) c. nihil et c. quod sicut (X.1.6.44 et 28).'

Albericus de Rosate, ad Dig.1.14.3 (In primam ff. Veter. part. commentarij, cit., fol. 71 ra, n. 37): 'aut est peccatum in qualitate personae electi: tunc aut uitium est manifestum, aut occultum. Primo casu non ualent gesta, ut d(ictum) c. nihil (X.1.6.44) et C. si a non compe(tenti) iudi(ce) per totum (Cod.7.48), quia non suffragatur error communis, quod est necesse ut hac l. Secundo casu tenent gesta si est error probabilis, ut hac l. secus si non probabilis, ut s(upra) dixi. Et hoc tenet Iac(obus) de Bel(viso) qui de hoc satis not(atur) d(icta) 1. 2 C. de sententiis (Cod.7.45.2), licet alii etiam aliud requirant, $s$ (cilicet) utilitatem publicam multorum, vt s(upra) dixi.' Cf. Albericus de Rosate, ad Cod.7.45.2 (In Secundam Codicis Part[em] Commentaria, cit., fol. 117ra-b, n. 9): 'Si vero peccatum est in qualitate, puta in persona electi, aut vitium est notorium, et non valent gesta, vt i(nfra) si a non competen(ti) iud(ice) per totum (Cod.7.48): quia hoc casu error non potest esse, quod est necessarium, vt l. Barbarius (Dig.1.14.3) et d. c. nihil (X.1.6.44). Si occultum, et error probabilis, gesta valent, vt d(icta) l. Barbarius. Secus si error non esset probabilis, et communis.' 
cause. Provided that the mistake is common, 'through such a plausible mistake the law supplies to the defect and bestows validity [on the election] as if the defect did not exist'. ${ }^{27}$ If on the contrary the common mistake is formed after the election, then it is not excusable: 'the law does not make up for the defect'. ${ }^{28}$

(3) If Belviso's scheme was useful in highlighting the relevance of the common mistake, however, it would also lead to the validity of Barbarius' election - and not just of his deeds. Belviso considered the power of the electors to ratify the election as a necessary precondition for the relevance of their common mistake, but he did so only to limit the scope of the mistake. So long as the ratification was within the electors' powers, then the common mistake sufficed to bestow validity on the election itself. This is why Albericus de Rosate seeks to detach himself from Belviso: to ratify the election made under common mistake, argues Albericus, the electors should actually confirm the elected in his place - the abstract power to do so is not sufficient.

This way, Albericus divides the deeds of the elected under common mistake into three groups: (1) the electors lack the power to ratify the election; (2) they have the abstract power to do so; (3) they proceed with the actual ratification. On the one hand, this distinction allows a rejection of the argument that public utility alone would suffice to bestow legal strength on the common mistake. ${ }^{29}$ On the other hand, and crucially, the same distinction allows detachment from Belviso's conclusion: the abstract power to ratify the source, if coupled with common mistake and public utility, suffices as to the validity of the deeds but not also of their source. ${ }^{30}$

Albericus de Rosate, ad Cod.7.45.2 (In Secundam Codicis Part[em] Commentaria, cit., fol. 117ra-b, n. 9): 'Sic ergo distinguit ipse Ia(cobus de Belviso) aut ante electionem, vel collationem dignitatis, honoris, vel officij, error communis, habebat originem, aut post. Primo casu, quia per talem errorem ab ipso principio putabatur valere electio, vel collatio, gesta valent: quia per talem errorem probabilem lex supplet defectum, et facit valere ac si defectus non existeret, vt hac 1. (scil., X.1.6.44) et d(icta) 1. Barbarius (Dig.1.14.3), cum concor(dat) sic, et in $1.3 \$$ fi. de suppel(lectili) leg(ata) (Dig.33.10.3.5) praecesserat error testamentum, uel contractum.'

28 Ibid., fol. $117 \mathrm{rb}$, n. 9: 'Si vero error communis incipit habere originem post electionem, vel collationem, tunc postea superueniens, non potest facere gesta valere: quia ingressus est vitiosus, et error, licet communis, est improbabilis: quia debuit veritas exquiri. Et ideo lex hoc casu non supplet defectum, ar(gumentum) ff. de iuris(dictione) om(nium) iudi(cium) 1. si per errorem (Dig.2.1.15).'

29 Id., ad Dig.1.14.3 (In primamff. Veter. part. commentarij, cit., fol. 70rb, n. 25): 'quidam tamen dicunt sola $<\mathrm{m}>$ publicam utilitatem sufficere, ut gesta quae erant multa ualeant de humanitate.'

30 Id., ad Cod.7.45.2 (In Secundam Codicis Part[em] Commentaria, cit., fol. 116vb, n. 3): 'error non facit ius: sed quando error causatur a facto populi, praesumpta uoluntas populi concurrens cum errore probabili, facit ius: si ad hoc concurrat 
The abstract power of the superior authority to ratify the position of the elected seems to recall Ravanis. But Albericus de Rosate prefers to invoke the canon law concept of toleration. For our purposes, this is the most interesting part of his whole reading of the lex Barbarius: so long as he is tolerated by the authority who had the power to confirm him, says Albericus, the secretly ineligible person acts validly. ${ }^{31}$

publica, uel communis utilitas, et talis sit defectus qui potuisset suppleri per populum, et ita loquitur 1 . Barbarius ... Si uero error populi non causatur a facto populi: sed alterius, tunc nec error, nec uoluntas populi facit ius.' Cf. ibid., fol. 116va, n. 2: 'Et quod error communis faciat ius solet allegari haec $\mathrm{l}(\mathrm{ex})$ (i. e. Cod.7.45.2) cum concor(dat) quod praeal(legatam) 1. Barbarius (Dig.1.14.3), cum concor(dat) ubi de hoc not(atur) in gl(osa) et per Doct(ores) et quae est canonizata $<$ in $>$ d(icto) c. tria, 3 q. 7 (C.3, q.7, p.c.1). Sed aduertendum est, quo casu loquantur d(ictae) 1(eges) [scil., Cod.7.45.2 et C.3, q.7, p.c.1] et 1. Barbarius, loquitur in electione facta a populo romano, uel Principe, et sic interuenit ibi error probabilis, causatus a facto populi, seu principis. Item interuenit publica utilitas, quia [Barbarius] fecit edicta et decreta, ut ibi potest, quae sunt leges generales, ut Instit. de iure natu(rali) $\mathbb{S}$ praetorum quoque edicta (Inst.1.2.7). Interuenit et(iam) communis utilitas, quia [Barbarius] multa alia gessit ad communem utilitatem spectantia. Item populus Romanus, uel princeps, potuissent omnem defectum supplere, quia uerisimile est populum fecisse, si eum seruum sciuisset, quia liberum fecisset, ut ibi in litera dicitur.' To argue as much, Albericus also recalls the case of the funeral procession of the slaves wearing the felt cap (the pileus, representing the concession of freedom) without their master intending to actually set them free. In that case there was both common mistake and public utility (preventing people from being deceived), but - importantly their master also had the power to emancipate the slaves. Ibid., fol. 116va, n. 2: '... 1. i $\$$ sed et qui pileati s(upra) de lati(na) lib(ertate) tollen(da) (Cod.7.6.1.5) loquitur, ubi populus errat: sed dominus erat sciens, qui poterat seruis dare libertatem, et ideo ne populus decipiatur, liberi fiunt.' Incidentally, it might be noted that the remark that the master 'poterat seruis dare libertatem' is not to be found in the Gloss. Cf. Gloss ad Cod.7.6.1.5, $\$$ Sed et qui (Parisiis 1566, vol. 4, col. 1528).

31 See esp. Albericus de Rosate, ad Dig.1.14.3 (In primamff. Veter. part. commentarij, cit., fol. 70va, n. 28): 'Arch(idiaconus) uidetur sentire, quod gesta valeant quousque tollerantur, ut no(tatur) per eum 62 dist. c. fin. (D.62, c.3) [supra, pt. II, $\$ 8.3$, note 41]. Immo quod plus est dicit idem in intruso, ut no(tatur) per eum 12 q. 2 $<$ c.> alienationes, in prin(cipio) (C.12, q.2, c.37) [supra, pt. II, \$8.3, note 39], ad hoc extra de elect(ione) c. nihil est (X.1.6.44), cum ibi no(tatur) per Ber(nardum Parmensis) [supra, pt. II, $\$ 8.1$, note 12] ... Et uide Inn(ocentium) plenissime extra de rest(itutione) spo(liatorum) c. in literis (X.2.13.5) [on the invalidity of the acts done by the person who entered in possession of a benefice with violence, unless he was subsequently confirmed in it], et de relig(osis) do(mibus) c. cum dilectus (X.3.36.8) [on the invalidity of jurisdictional acts by the possessor not confirmed in office], et in Spe(culo) de act(ore) ver(siculo) "sed pone quidam dicens se episcopum” [supra, pt. II, $\$ 8.4$, note 49]. Et ad praedicta etiam facit quod not(atur) per ... Inn(ocentium) de relig(iosis) do(mibus) c. cum dilectus (X.3.36.8) [supra, pt. II, $\$ 7.6$, note 126].' 
Despite the large number of citations of Innocent IV and other canon lawyers applying Innocent's concept of toleration, ${ }^{32}$ Albericus de Rosate shows little understanding of it. And without a clear understanding of toleration, in effect, Ravanis' idea of the 'power of the appointer' (potentia committentis) might look sufficiently close to the abstract notion of tolerating someone in office. Ravanis' appointer (who could make up for the defect of Barbarius) thus becomes very similar to Innocent's superior authority (who tolerates the unworthy in office). Of course the two positions are hardly similar: Innocent's tolerance is the product of legal representation, which presupposes the (actual) confirmation. The mere possibility that the unworthy could be confirmed would clearly not suffice for the validity of the deeds. But Albericus takes the concept of toleration at its face value: forbearance. This way, tolerating Barbarius in office means allowing him to discharge the office of praetor without actually confirming him in that position. Toleration, in other words, has little to do with the distinction between person and office. It is another way of expressing the theoretical possibility that the superior authority would ratify the invalid position of the person who discharges the office - a variation on the theme of Ravanis, just with more canon law references.

Ravanis' 'power of the appointer', as we have seen, was somewhat ambiguous: if the appointer had the power to ratify the choice made under common mistake, then either that power is presumed as actually exercised or it is irrelevant. Indeed Belviso's solution was not too dissimilar from that of Accursius. Albericus sought to avoid it without falling into the ambiguity shown by Ravanis. Hence the idea of toleration (in the sense of forbearance), for it lies between full exercise of the 'power of the appointer' (i. e. ratification) and non-exercise of that power. For Albericus, toleration seems to imply some degree of acceptance without its full consequences.

The closeness with Ravanis can be seen from the examples provided by Albericus de Rosate - some of them are strongly reminiscent of the Orléanese jurist. If a bishop or a count appointed a slave as his vicar without knowing of his true condition, says Albericus, the deeds of this slave-vicar would be void: unlike the Roman people and the prince, neither bishop nor count have the power to cure the underlying defect. ${ }^{33}$ 'What lacks any ground may not be confirmed',

32 Supra, this chapter, note 4.

33 Albericus de Rosate, ad Dig.1.14.3 (In primamff. Veter. part. commentarij, cit., fol. 70rb, n. 24-25): 'Modo ueniamus ad ultimum, et adducamus hanc l(egem) et eius materiam ad plures quaestiones de facto occurrentes. Et primo quaero quidam episcopus uel comes quendam seruum constituit uicarium suum ignorans eum seruum: nunquid ualebunt, gesta per eum? Videtur quod non, quia licet uersetur publica utilitas, tamen deficit potestas constituendi seruum 
holds Albericus, and so is not tolerated either. ${ }^{34}$ So the deeds of the false prelate shall be void, ${ }^{35}$ as well as those of the putative papal legate ${ }^{36}$ and, of course, the instruments of the notary apparent. ${ }^{37}$ Alone, common opinion does not suffice, ${ }^{38}$ even if supported by public utility.

uicarium, quae potestas erat in 1 (ege) ista in populo, et principe.' Cf. Ravanis, supra, pt. I, $\$ 4.4$, text and note 53 .

34 Albericus de Rosate, ad Cod.7.45.2 (In Secundam Codicis Part[em] Commentaria, cit., fol. 117ra, n. 8): 'Item hoc casu [i.e. the formal invalidity of the election made by the delegate] non obstat confirmatio: quia illud quod non habet aliquod fundamentum, non potest confirmari, vt potest in pro non scripto, caduco, et quasi, $s$ (upra) de cad(ucis) tol(lendis) $\$$ in primo et $\$$ pro secundo vbi de hoc (Cod.6.51.1.3-4).'

35 Albericus de Rosate, ad Dig.1.14.3 (In primamff. Veter. part. commentarij, cit., fol. 70va, n. 27-28): 'quaero generaliter, an gesta per eum, qui credebatur praelatus cum non esset, valeant. $\mathrm{Gl}($ osa) videtur tenere quod non, C. de eo, qui pro tut(ore) neg(otia) gess(it) 1. 2 (Cod.5.45.2) ... Et quod non ualeant bene facit $\mathrm{i}(\mathrm{nfra}$ ) de reb(us) eorum, qui sub tutela sunt, 1 . qui neque (Dig.27.9.8) ... et $\mathrm{i}(\mathrm{nfra})$ de iureiur(ando) l. iusiurandum quod ex conuentione $\$ \mathrm{i}$ (Dig.12.2.17.1).' The two passages in the Gloss to which Albericus referred stated that a void appointment invalidates all the deeds made by the person so appointed: Gloss $a d$ Cod.5.45.2, \Exceptione (Parisiis 1566, vol. 4, col. 1121: 'Etiam post litem contestatam: quia similis est exceptioni falsi procuratoris: vt supra de procura(toribus) 1. licet (Cod.2.12(13).24), et idem in praelato vt possit repelli si quoquo modo possit vitiari eius electio, vt exceptione repellatur'), and Gloss ad Dig.12.2.17.1, $\$$ Non competit (1566 Parisiis, vol. 1, col. 1284: 'sic ergo not (andum) bonum $\arg$ (umentum) in omnibus contractibus quos ineunt hi qui non iure sunt electi: vnde omnia cassantur, vt hic, et C. de sacrosanc(tis) eccles(iis) $<$ l. $>$ decernimus (Cod.1.2.16) ... Sed $\arg$ (umentum) contra $s$ (upra) de offi(cio) praeto(rum) 1. Barbarius (Dig.1.14.3). Si vero tenuit ab initio institutio, sed postea aliquo casu cassatur, secus'). Commenting on those passages (especially on the first one, Cod.5.45.2) Albericus distinguished an appointment to a secular office from one to an ecclesiastical one. In so doing, he showed good acquaintance with the mainstream decretists' position on the toleration principle. Cf. Id., ad Cod.5.45.2 \$Cum non vtiliter (Alberici de Rosate ... In Primam Codicis Partem Commentarij ..., Venetiis, 1586; anastatic reprint, Bologna: Forni, 1979, fol. 276vb).

36 Id., ad Cod.7.45.2 (In Secundam Codicis Part[em] Commentaria, cit., fol. 117va, n. 12): '... Quarto si aliquis tanquam legatus sedis apostolicae se gessit, et multa fecit, nunquid valebunt si de eius legatione non fiat fides, de hoc in Specu(lo) de legato, $\mathbb{\$}$ superest videre, versi(culum) quid si quis se pro legato [supra, pt. II, $\$ 8.4$, note 66], et plenissime dixi s(upra) de manda(tis) prin(cipum) l. vnica (Cod.1.15).' Cf. Albericus de Rosate, ad Cod.1.15, $\mathbb{S}$ Si quis adserat (Alberici de Rosate ... In Primam Codicis Partem Commentarij, cit., fol. 54rb, n. 3): 'Iudicio meo quicquid dicatur, opus est de iure probari delegationem, et legatione, vel saltem quasi possessionem legationis.'

37 Id., ad Dig.1.14.3 (In primam ff. Veter. part. commentarij, cit., fol. 70vb, n. 31-32): 'Item quaero, an instrumenta confecta per eum qui publice credebatur tabellio cum non esset ualeant. Et idem potest quaeri de illo, qui exercuit officium 
The most interesting aspect of Albericus' approach to the lex Barbarius lies not in his misunderstanding of toleration, but in his attempt to subsume the office

iud(icis) cum iudex non sit uidetur, quod sic per l(egem) istam et C. de tabula(riis) 1. generali li. 10 (Cod.10.(69).3), et pro hoc etiam in Aut(hentica) de tabel(lionibus) $\$$ pen(ultimo) (Coll.4.7.1[=Nov.44.1\$4]), ubi dicitur quod tabellio non debet facere instrumenta per substitutum, sed cum faciat ualent. Vltramontani tenent contrarium quia dicunt esse peccatum in forma, quia supponitur, quod non fuit iudex nec tabellio, sed in l(ege) ista peccatum est in materia, quia hic electio facta erat per illos qui eligere potuerant et peccatum materiae facilius excusatur, quam peccatum formae, $\arg$ (umentum) $i(n f r a)$ de const(ituta) pec(unia) 1. i $\$$ eum qui inutiliter (Dig.13.5.1.4), et de accep (tilatione) 1. an inutilis (Dig.46.4.8), et ad hoc allegant pro casu praeall(egato) 1. actuarios C. de num(erariis) li. 12 (Cod.12.49(50).7) ... non ob(stante) $\$$ penul (timo) de tabel(lionibus) (Coll.4.7.1[=Nov.44.1\$4]) quia ibi substitutus habebat authoritatem, et commissionem ab eo, qui facere poterat instrumenta per se, et ideo ibi ille error sustinetur, sed in quaestionem praedicta $<\mathrm{m}>$ a nullo habebat authoritatem, et ideo gesta non ualent.' See also Id., ad Dig.50.2.8, $\$$ Decurionibus (Alberici de Rosate ... In Secundamff. Noui partem Commentarij ..., Venetiis, 1585; anastatic reprint, Bologna: Forni, 1982, fol. 232ra, n. 1-2): 'No(tatur) ... si quis sit in quasi possessione tabellionatus, et multa fecerit instrumenta, vel sit inscriptus in matricula tabellionum, quod hoc non sufficiat, nec teneant instrumenta per eum facta, nisi doceat se creatum tabellionem ab eo, qui super hoc habuerit potestatem, et quod talia instrumenta non valeant: facit $\sup (\mathrm{ra}) \mathrm{de}$ eo qui pro tuto(re) nego(tia) gerit 1.2 (Dig.27.5.2) ... et quia in ista quasi possessione tabellionatus videtur esse malae fidei, et quia de tabellionatu debet probare per literas, $\arg$ (umentum) C. de mand(atis) princ(ipum) l. i (Cod.1.15.1) et $\sup (\mathrm{ra})$ de offi(cio) praesi(dis) [sed 'proconsulis'] 1 . nec quicquam $\mathbb{S}$ ubi decretum (Dig.1.16.9.1) et quia est praesumptio contra eum, et ideo probare tenetur, ut C. de prob(ationbus) 1. siue possidetis (Cod.4.19.16). Sed quod instrumenta teneant, videtur per 1. Barbarius (Dig.1.14.3).'

38 Common opinion alone can at the most invert the burden of proof as to the validity of the appointment. On the point Albericus follows Innocent IV closely. Cf. Abericus de Rosate, ad Cod.7.45.2 (In Secundam Codicis Part[em] Commentaria, cit., fol. 117va, n. 12): '... Secundo quod si aliquis longo tempo(re) habitus est pro rite ordinato, praesumitur legitime ordinatus, sine alia probatione, vt no(tatur) per Inno(centium) d(icto) c. innotuit, de eo, qui furtiue ordines suscepit (X.5.30.3), quae glo(sa) notabilis est ad istam materiam praesumptionum [Cf. Innocent IV, ad X.5.30.3, \$Innotvit nobis (Commentaria Innocentii Quarti, cit., esp. fol. 523ra)]. Shortly thereafter, in the same commentary on Cod.7.45.2, Albericus continues on the subject. Albericus de Rosate, ad Cod.7.45.2 (In Secundam Codicis Part[em] Commentaria, cit., fol. 117va, n. 12): '... Item si aliquis gessit se pro praelato, vel aliquis tenuit aliquam tanquam vxo(rem) nunquid sufficiat sine alia probatione, dic vt no(tatur) per Innoc(entium) de praesump(ionibus) c. illud (X.2.23.11), de praelato videtur tenere $\mathrm{gl}(\mathrm{osam})$ quod non sufficiat: imo etiam post litem contest(atam) videtur posse opponi talis exceptio, tu non es praelatus, $s$ (upra) de eo, qui pro tutore negotia gerit, 1. ii (Cod.5.45.2) et dic, vt ibi dixi.' Cf. Innocent IV, ad X.2.23.11, \$Ilud quoque (Commentaria Innocentii Quarti, cit., fols. 281vb-282ra, n. 3). 
within the person. Innocent's position was based on the separation between the office and its holder, and so on the distinction between the person as individual and the person as representative. What is tolerated is not the individual, but the legal representative of the office. Removing the notion of representation from the equation, Innocent's concept of toleration might well be seen as the canon law equivalent of Ravanis' 'potentia committentis'. 


\section{Chapter 10}

\section{Baldus' writings on the lex Barbarius}

Baldus' position on Barbarius' case is extremely complex. But it left a deep mark, as it determined interpretations of the lex Barbarius for centuries to come, ultimately laying the ground for the modern doctrine of the de facto officer. After Baldus very little changed until modern times - hence Baldus' central position in the present work. The complexity of his reasoning, however, also meant that its subtler parts were progressively lost. All that remained was Baldus' conclusion and, of equal importance, the limits within which it could be applied.

\subsection{Two authors for one repetitio}

Bartolus' lectura on the lex Barbarius was the last work to be considered before looking at canon law - and especially Innocent IV. Indeed, the influence of canon law marked a watershed in analysing the lex Barbarius, and ensured the lasting influence of Baldus' conclusions on the subject. The fact that Bartolus continued to be cited until modern times is easily explained: the most important writing on the lex Barbarius, a lengthy repetitio ${ }^{\mathbf{1}}$ of Baldus, was attributed also to Bartolus and printed in many editions of his commentary on the Digestum Vetus.

Jason de Mayno (1435-1519) said openly as much at the beginning of his repetitio on Dig.1.14.3, telling his readers that a repetitio of Baldus may be found in Bartolus' comment on the lex Barbarius. ${ }^{2}$ In support of his conclusion Mayno advanced a single but strong argument: the style of the repetitio. The quotations

$1 \quad$ On the repetitioin general see supra, pt. I, $\$ 4.1$, note 15.

2 Mayno, ad Dig.1.14.3 (Excellentissimi iuris utriusq[ue] doctoris domini Iasonis de mayno Mediolane $[n]$ sis Lectura in prima parteff. veteris ..., Venetijs, per Baptistam de Tortis, 1512, fol. 36va-b): 'Primo aduerte quod reperitur quedam repetitio inserta in lecturis Bar(toli), et Panor(mitani) in c. cum dilecta de res(criptis) (X.1.3.22) sepe eam allegat pro repeti(tione) Bar(toli) ... Nullatenus credo quod sit bart(oli), quia nimium discrepat a stillo (sic) bar(toli), maxime dum sepe allegat auctoritates Aristo(telis), Salusti et Ciceronis, quod est alienum a stillo bar(toli). Dico ergo quod vere est repetitio bal(di) et ita etiam est inserta in lecturis bal(di) et ibi in fi(ne) dicitur quo anno fuit per $\mathrm{Bal}(\mathrm{dum})$ perusii repetita et immo $\mathrm{i}$ (nfra) semper allegabo pro repeti(tione) $\mathrm{Bal}(\mathrm{di})$.' Despite all this, when commenting on the following book of the Vetus, Mayno referred to the repetitio as written by Bartolus: ad Dig.2.13.6.1, ibid., fol. 143va, n. 6 (where he attributes it to 'Bar(tolus)'; while easy to make, the typo 'Bar.' instead of 'Bal.' seems 
of Aristotle, Sallust and Cicero, argued Mayno, are wholly alien to Bartolus' style but perfectly suited to that of Baldus. ${ }^{3}$ Mayno's argument was then reported almost verbatim by Diplovatatius without further explanation. ${ }^{4}$

Mayno was not new to questioning Bartolus' authorship of some passages of his lectura on the Vetus, especially in the first book. Another text that he singled out as clearly not of Bartolus, the comment on the lex Omnes populi (Dig.1.1.9), ${ }^{5}$ is in fact today considered one of the few parts of the comment on the first book of the Vetus that was surely written by Bartolus. ${ }^{6}$ As checking the authenticity of each and every single text of Bartolus' opus is a nearly impossible task, scholars looked at larger parts of it. With particular reference to the Vetus, a long tradition from Savigny ${ }^{7}$ to contemporary scholars defended Bartolus' authorship, ${ }^{\mathbf{8}}$ despite some hesitation. ${ }^{9}$ In arguing for Bartolus' authorship of the commentary on the first book of the Vetus printed under his name, Savigny

unlikely because repeated twice in the space of a few lines). I am grateful to Osvaldo Cavallar for our stimulating discussion of the problem of the repetitio's style and its attribution to Baldus. Mayno's reference to Panormitanus (Niccolò de' Tedeschi) is also of some interest. It refers mainly to Panormitanus' lectura on an important decretal strictly related to the same subject, Cum dilecta (X.1.3.22). Compare the repetitio of Baldus with Panormitanus' lectura ad X.1.3.22, $\mathbb{Q}$ Quum dilecta (Super Primum Decretali[um] Librum Commentaria, Basileae, 1477 $[$ fols. $47 v-49 r])$. A good part of Baldus' repetitio creeps into the text from [fol. 48v], though it skilfully blends in with Panormitanus' own reasoning. This was probably facilitated by the fact that both Baldus and Panormitanus were building on Innocent IV. On Panormitanus' reliance on Innocent see infra, pt. IV, $\$ 14.3 .1$.

3 Supra, this paragraph, note 2. The only author brave enough to list Baldus' references of classical authors was Horn (1967), pp. 110-111 (on Aristotle) and p. 112 (on Cicero) - a more detailed breakdown ibid, pp. 148-149. Sallust however does not appear in Horn's study. As to Baldus' knowledge of Aristotle see recently Conetti (2005), pp. 511-513, stressing the importance of the intermediation of Remigio de' Girolami (1235-1319).

4 Thomas Diplovatatius, Liber de claris iuris consultis, s.v. 'Bartolus' (Schulz, H. Kantorowicz and Rabotti [eds., 1968], p. 275, 11.7-13). On the point see esp. Lepsius (2008), p. 228, note 12.

5 Mayno, ad Dig.1.1.9, $\$$ Omnes Populi (Lectura in prima parteff. veteris, cit., fol. 14ra): '... Item aduerte quod lectura que attribuitur Bar(tolo) in hoc libro non fuit Bar(toli) sed alterius qui forte per eo legebat.'

6 See for all Lepsius (2013), p. 178. This, incidentally, was also Diplovatatius' opinion, Liber de claris iuris consultis, s.v. 'Bartolus' (Schulz, H. Kantorowicz and Rabotti [eds., 1968], pp. 274-275).

7 Savigny (1831), vol. 6, pp. 144-148 (pp. 162-165 in the $2^{\text {nd }}$ edn of 1850).

8 Esp. Paradisi (1960) pp. 27-29, and Calasso (1965), pp. 644-645. See further Lange and Kriechbaum (2007), p. 723, text and note 315, and Lepsius (2014), p. 605 , note 10 .

9 Maffei (1963), p. 8, text and note 21. Cf. more recently Lepsius (2008), p. 228, note 12 . 
had doubts only in two cases. The first was precisely the repetitio on the lex Barbarius. ${ }^{10}$

After he denied Bartolus' authorship of his lectura on the lex Omnes populi, Mayno's credibility suffered a severe blow. Even the (admittedly, few) modern scholars who wrote extensively on the civil lawyers' approach to lex Barbarius mentioned Mayno's caveat in passing - if they did. ${ }^{\mathbf{1 1}}$ The irony is that Mayno was right. In the case of the lex Omnes populi, Mayno did not explain his reasons for denying Bartolus' authorship, nor did he suggest a different author. ${ }^{12}$ By contrast, on the lex Barbarius he pointed to Baldus as the true author of the repetitio and was more careful in grounding his objection. The references to Aristotle, Sallust and Cicero also aroused the suspicion of a contemporary of Mayno, Felinus Sandeus (1444-1503). Like Mayno, Sandeus also remarked how the style of the repetitio would suit Baldus better than Bartolus. ${ }^{13}$ Bartolus never quoted Aristotle directly: at times he was influenced by Aristotelian ideas, but always filtered them through the re-elaboration of others. ${ }^{\mathbf{1 4}}$ The references to Cicero and Sallust are all the more suspicious - it would be the single time in his entire opus where Bartolus referred to either of them.

Looking at the manuscript tradition offers limited help - or rather, complicates things. Unlike Bartolus, Baldus published his repetitiones within the corpus of his lecturae. ${ }^{15}$ Often, the repetitiones appear only in the printed editions, and it is very difficult to trace their manuscript tradition. In any case, no known

10 Savigny (1831), vol. 6, p. 147 (p. 165 in the $2^{\text {nd }}$ edn. of 1850).

11 Among the (few) authors who took notice of Mayno's warning, Rampazzo (2008), pp. 416-417, mentions it, but he does not seem to take a position on the matter (though he later ascribes the repetitio to Baldus, ibid., p. 445).

12 Mayno, supra, this chapter, note 5.

13 Sandeus, ad X.1.3.22 (Commentaria Felini Sandei ... in V. libr. Decretalium ... pt. 1, Basileae, Officina Frobeniana [1567], cols. 681-682, n. 3, \Lex Barbarius): 'Et adde $\mathrm{Bal}$ (dum) in rep(etitione) $\mathrm{d}$ (ictae) 1 (egis) Barbarius ... licet in certis lecturis Bar(toli) impressis attribuatur Bart(olo) illa repe(titio), sed est etiam in lecturis Bald(i), et forte melius, attento stylo.' Cf. also (and this time without hesitation) ad X.1.3.2, \ Periurus (ibid., col. 382, n. 5).

14 In his public law treatises Bartolus usually refers to Aristotles via Aegidius Colonna (c.1243-1316): see Bartolus de Saxoferrato, De regimine civitatis (Quaglioni [ed., 1983], q.2, 11.87-89 and 140-141, pp. 153 and 155 respectively). Other times he mentions only Aegidius, but the passages referred to are of clear Aristotelian origin: see again Bartolus' De regimine civitatis (ibid., q.2, 11.420-422, and q.3, 1l.453-454, pp. 167 and 168-169 respectively), and De tyranno (ibid., q.12, 1l.751-755, p. 212). A large part of quaestio 8 of the same De tyrannois in effect a re-elaboration of what was written by Aegidius: compare Aegidius Colonna's De Regimine Principum, Romae, 1561, 3.2.10, with Bartous' De tyranno (Quaglioni [ed., 1983], q.8, 11.444-544, pp. 196-202).

15 I am greatly indebted to Vincenzo Colli for his generous help (also) on this intricate matter. 
manuscript of Baldus' commentary on the Vetus contains the repetitio. Bartolus' lectura on the lex Barbarius may be found in any manuscript of his commentary on the Vetus (at least, those that contain the first book of the Digest). ${ }^{\mathbf{1 6}}$ None of them contains the repetitio - with a single exception. One manuscript - the only one I could find - does contain the full repetitio on the lex Barbarius. The problem is that this manuscript is that of Bartolus, not of Baldus. ${ }^{\mathbf{1 7}}$ This manuscript perfectly matches the printed editions of the repetitio in Bartolus' editions. ${ }^{\mathbf{1 8}}$ However, the close similarity between manuscript and printed sources also means that the repetitio in the manuscript contains the same references to Cicero, Sallust and Aristotle as the printed editions. ${ }^{19}$ This already might cast some doubt as to Bartolus' authorship. Further, the repetitio is not found after the lectura, ${ }^{\mathbf{2 0}}$ but with a group of repetitiones on the Vetus written at the end of the whole lectura on the Vetus. ${ }^{21}$ It may therefore not be ruled out that the repetitio on Dig.1.14.3 came from a different source and was just grouped together with the others. The part of the manuscript containing Bartolus' lectura on the Vetus is dated $1425,{ }^{22}$ and the hand seems to be fairly consistent also for the repetitiones that immediately follow the lectura. This single manuscript does not necessarily prove Bartolus' authorship of the repetitio. What it does suggest, rather, is that

16 E. g. BSB, Clm 547, fols. 28ra-vb; BNF, Lat. 4495, fols. 33va-34va; BNF, Lat. 4493, fols. 26ra-va; BSB, Clm 5476, fols. 28va-29rb; BAV, Urb. lat. 172, fols. 43ra-vb; Toledo 36-3, fol. 21ra-vb; Lat. Vat. 2594, fols. 252ra-255rb. On the contrary, Berlin Savigny 22 skips the first book of the Digest, and BNF, Lat. 4494 omits the first four books. Similarly incomplete is Bruxelles, II 1437 (on which see Feenstra [1962], p. 230).

17 BL Arundel 473, fols. 247ra-249va. The text bears the name of 'Bartolus doc(tor) legum' (ibid., fol. 249va). Another manuscript of Bartolus' commentary on the Vetus, Lat. Vat. 2618, fol. 244v, contains a summary of the last part of the repetitio on Barbarius, that on its application to the notary's case. I am indebted to Susanne Lepsius for pointing me to both manuscripts.

18 As it will be seen shortly (infra, next paragraph), the printed editions of Bartolus and Baldus on the repetitio on the lex Barbarius are slightly different. The text of the repetitio in Arundel 473 is very similar to most printed editions of Bartolus, not of Baldus. It is possible that the text printed under the name of Bartolus comes from an earlier and better manuscript tradition, of which Arundel 473 might be the only known example.

19 BL Arundel 473, esp. fol. $247 v a$.

20 Bartolus' lectura on the lex Barbarius is ibid., fols. 33ra-34ra.

21 The lectura on the Vetus occupies most of the manuscript (fols. $3 \mathrm{ra}-243 \mathrm{rb}$ ); the repetitiones (ad Dig.1.3.32, Dig.1.7.22, Dig.1.14.3, Dig.2.5.2, Dig.2.8.11, and Dig.5.2.14) are on fols. 243va-256vb. Thereafter the manuscript closes with Bartolus' lectura on Dig.6.1, fols. 257ra-265rb.

22 Ibid., fol. 243rb. Together with the date of its composition, the manuscript also bears the name 'Iacobo de Cuero'. 
the repetitio was circulating under the name of Bartolus in the early decades of the fifteenth century.

If the manuscript tradition does not solve the problem of the attribution (or rather, it would tentatively bend it towards Bartolus), we should look elsewhere. A very modest textual argument in favour of Baldus' authorship might be found in another part of his opus: hinting at the problem of the false notary, Baldus invited his reader to look at what he said on the lex Barbarius, where he wrote 'fully' (plene) on the subject. ${ }^{23}$ Baldus' lectura was very concise on the point. ${ }^{24}$ By contrast, the repetitio dealt with the subject in full (and we will devote much attention to it). ${ }^{25}$

There is however a different and rather obvious argument that would prove Mayno's conclusion - thus strongly suggesting Baldus' authorship of the repetitio. Leaving aside the style, the substance of the repetitio on Dig.1.14.3 goes completely against Bartolus' lectura on the same text, whereas it perfectly matches that of Baldus. ${ }^{26}$ The repetitio consists of three parts: a lengthy and erudite introduction, a long discussion of the lex Barbarius, and a final section on other applications of the same principle. Even discounting the introduction (where the suspicious references to the classical authors are found), the rest of the text would stand in open contradiction with Bartolus' lectura. The point is important: the whole of Bartolus' lectura on the lex Barbarius openly conflicts with the repetitio. And, as far as the lectura is concerned, there is little doubt as to Bartolus' authorship. ${ }^{27}$ Quarto, et Quinto Codicis ... commentaria ... Lvgdvni [typis Gaspar \& Melchior Trechsel], 1539, fol. 57ra, n. 2): 'Ego de hoc plene not(atur) ff. de offi(cio) preto(rum) 1. barbarius (Dig.1.14.3).' Veteris Partem Commentaria, cit., fol. 56ra, n. 29-30).

25 Infra, $\$ 13.2$.

26 Leaving aside some marginal additions at the very end of the repetition. Before dating the repetitio and wishing its author eternal rest, in a few lines (clearly added by some later hand) the printed text unwittingly contradicts the whole careful argumentation of the repetitio: the same public utility that inspired the validity of the deeds might well be invoked to consider that the prince made Barbarius truly praetor. Baldus, repetitio ad Dig.1.14.3 (In Primam Digesti Veteris Partem Commentaria, cit., fol. 58vb, n. 32): 'hic sit finis 1(egis) propter vtilitatem. Ista ratio tangit intentionem partes litigantes, et ibi; tamen ista ratio tangit \{effectum\}, et causam efficientem, et ibi. Sed si illa ratio tangit intentionem creantis, cuius summum Imperium demostratur qu<i>a potest dispensare de officio in statu seruitutis et libertatis.' On the use of italics and curly brackets in the transcription of this repetitio see infra, next paragraph.

Supra, this paragraph, note 16. 
Much to the contrary, accepting Baldus' authorship all contradictions would disappear. The repetitio deals in a single place with several issues that Baldus discussed in other parts of his writings, seeking to merge them together in a coherent and unitary discourse. While the main focus of the lectura is Barbarius, the repetitio moves from the slave to explore a variety of other instances. The lex Barbarius happens to be the best place to discuss them, but it is not a case of analogical extension of Barbarius' case to other similar instances. For Baldus, as we shall see, the lex Barbarius itself was but an adaptation of the Innocentian concept of toleration. The whole problem of the lex Barbarius was a question of representation: in the repetitio Baldus sought to clarify its application and, in so doing, set clear boundaries to its extension. This is probably why the repetitio builds on Innocent IV even more than the lectura (where the influence of Innocent was already extremely significant). While it is perhaps possible to get a superficial understanding of Baldus' lectura without knowledge of Innocent's thought, the same cannot be said for the repetitio. Without constant and in-depth reference to Innocent, the repetitio would make precious little sense.

Thus, while the only manuscript evidence would prima facie depose in favour of Bartolus' authorship, in the present work the repetitio will be considered as written by Baldus. Some editors paid attention to Mayno's caveat. In a few printed editions of Bartolus' commentary on the Vetus, between the lectura on the lex Barbarius and the repetitio, the editor put a note in large characters: 'this repetitio is not of Bartolus but of Baldus (as anyone familiar with Baldus' commentaries may notice here), and Jason [de Mayno] attests to that'. ${ }^{28}$ Of course not all Bartolus' editions report this caveat. ${ }^{29}$ Perhaps, not all editors were moved by Mayno's remarks. But the difference is often a question of sheer

'Haec repetitio non est Bar(toli) sed Baldi (ut cuilibet intuenti commentaria $\mathrm{Bal}(\mathrm{di})$ hic apparere potest) et testatur Iason': Lvcernae iuris Bartoli a Saxoferrato Commentaria in primamff. Veteris partem ... Lugduni [de Portonaris], 1538, fol. 61v; Bartoli a Saxoferrato in Primam Digesti Veteris Partem Commentaria, Augustae Taurinorum, Apud Haeredes Nicolai Beuilaquae, 1577, fol. 33v; Bartoli a Saxoferrato in Primam Digesti Veteris Partem Commentaria Cum Additionibvs, Basileae, 1588, p. 115. In the exemplar of the 1477 Milanese editio princeps of Baldus' repetitio on Dig.1.14.3 that I consulted (preserved in the Biblioteca Capitulare Feliniana of Lucca), at the beginning of the repetitio a hand writing reads: 'hec repetitio est posita in lectura Bar(toli) tamquam ab eo composita. Sed stillus est Baldi' (Lectura super I. parte Digesti, cit. infra, this chapter, note 38, fol. $83 v b$ ).

29 The Basel edition of the Commentaria of 1562 for instance does not report it (Bartolus de Saxoferrato, Opera Omnia ..., vol. 1, Basileae: Hieronymus Froben, 1562; anastatic reprint, Frankfurt am Main: Vico Verlag, 2007, p. 76). 
timing: Mayno's caveat is in the lectura on Barbarius' case that he gave in $1485,{ }^{\mathbf{3 0}}$ and published (most likely, in extended form) a few years later. ${ }^{31}$ By then, Bartolus' work was already printed with increasing frequency, one edition following another with little time for careful checking. It comes as little surprise, for instance, that the late fifteenth-century Venetian editions of Bartolus' lectura on the Digest - published almost every year - printed the repetitio without forewarning. ${ }^{32}$

\subsection{Lectura, repetitio, additio}

If it were not for Baldus' crucial role in the interpretation of the lex Barbarius, there would be little point in making an in-depth analysis of the manuscript and printed editions of his work on it. ${ }^{33}$ But given his importance, and the fact of the double attribution of his repetitio, we might say a few more words on the subject.

Baldus worked on the Vetus for most of his life. When he died (in 1400) he was still working on the second part of his lectura Digesti veteris (i. e. books 12-23 of the Digest). ${ }^{34}$ The first part (books 1-11 of the Digest), which is more important for our purposes, also has a complex history. We know of two different manuscript versions of it. One was made in Perugia before 1390; the other (whose place of composition is not clear) contains new additions sometimes even multiple ones on the same lex (i. e. commenta reiterata) - but omits other parts found in the Perugia version. ${ }^{35}$ It is however important to stress that the manuscript tradition of Baldus' work on the Vetus is limited. As such, the most obvious criterion for verifying the authenticity of a specific additio found in printed editions - looking at the manuscripts - does not always work with Baldus. The same can be said for some of Baldus' repetitiones which, as said, he published together with the lecturae. This makes it all the more important to follow the printed editions.

Baldus' lectura on the first part of the Vetus was published in 1476 by Sixtus Riessinger in Naples. ${ }^{36}$ For the first four books of the Digest (i.e. pars prima

$30 \quad$ Infra, pt. IV, $\$ 14.1 .4$, note 33.

31 The first edition of Mayno's commentary on the first part of the Vetus dates to 1492: Di Renzo Villata (2013), p. 997.

32 See e.g. the editions of $1478 ; 1479 ; 1480 ; 1488$ (fols. $25 v-28 r$ ); 1490; 1492 (fols. 45r-48v); 1493; 1494 (fols. 36r-39v); 1499. Cf. the Milanese edition of 1490.

33 In effect, the specific conclusions on this repetitio would just confirm the scheme proposed by Vincenzo Colli, whom I wish to thank for his generous help.

34 Colli (2005), p. 82, text and note 163.

35 Colli (2008), p. 245. Cf. Colli (2000), pp. 412-417; Colli (2005), pp. 70-73.

36 Lectura super prima parte Digesti veteris, inpressa neapoli ... per uenerabilem Sixtum riessinger ... die XXV Mai mille CCCC LXXVI. 
prime partis), this is the editio princeps of his lectura. ${ }^{37}$ The following year Andrea Zarotto published the same first part of Baldus' lectura on the Vetus in Milan. ${ }^{38}$ This edition omits several texts that are present in the first one, but it also contains many additions (as well as commenta reiterata). ${ }^{39}$ The 1476 Neapolitan edition contains only Baldus' lectura on Dig.1.14.3. ${ }^{40}$ On the contrary, the 1477 Milanese edition has also his repetitio on the same lex, ${ }^{\mathbf{4 1}}$ which it reports as given in Perugia by Baldus in $1366 .{ }^{42}$ If we think of his long career, it would therefore seem that Baldus wrote this repetitio when he was 39 or 40 years old, and so still relatively young. ${ }^{43}$

The Milanese edition of 1477 had a long-lasting fortune, as it was used for several important incunabula editions (especially the Milanese edition of 1488 , the Venetian one of 1493, and the 1498 edition of Lyon), as well as the wealth of sixteenth-century editions of Baldus' lectura on the prima prime partis of the Vetus. ${ }^{44}$ Pretty much all printed editions of Baldus' repetitio on the lex Barbarius (whether directly or indirectly) follow the 1477 edition. Since the 1477 edition is not particularly accurate on this text (it might have relied on a faulty manuscript), this effectively means that no edition of the repetitio on the lex Barbarius published under the name of Baldus is particularly good either. Ironically, the repetitio reads rather better in most editions of Bartolus, which must have followed a different manuscript tradition. ${ }^{45}$

Colli (2000), p. 410.

Lectura super I. parte Digesti [Mediolanii] Impressum atque expletum reperies die VIII. mensis Augusti [1477] nobili officina magistri Antonii Zaroti Parmensis. Colli (2000), p. 410.

Lectura super prima parte Digesti veteris, 1476, cit. [fols. 35rb-37vb].

Lectura super I. parte Digesti, 1477, cit. [fols. 84vb-88rb].

Ibid. [fol. $88 \mathrm{rb}$ ]: 'Reppetita est hec lex per egregium atque peritissimum utriusque iuris doctorem excellentissimum dominum Baldum de perusio sub Anno Mccclxvi in ciuitate Perusii cuius anima requiescat in pace.'

Baldus was born on 2 October 1327: Colli (2005), p. 27, note 6.

Colli (2000), p. 410.

Compare for instance the editions of Bartolus' Commentaria of Basel 1562 (Froben) and Basel 1588 (ex officina Episcopiana), and the late fifteenth-century editions of his Lectura printed in Venice (1478, 1479, 1480, 1488, 1490, 1492, 1493, 1494, 1499, all apud Iunctas; the last one, rather unusually, has a summary of the repetitio before its text: fol. 37r), Milan (1490), Lyon (c.1493), with Baldus' Commentaria in the Venetian editions of 1572, 1577 and 1599 (all apud Iunctas; the third was consulted in its anastatic reprint of 2004 (Goldbach: Keip Verlag)). These editions match very well the manuscript version of the repetitio contained in the already-mentioned Arundel 473, fols. 247ra-249va: cf. supra, this chapter, note 18 . 
Baldus' (admittedly, few) ${ }^{\mathbf{4 6}}$ manuscripts on the Vetus report only his lectura on the lex Barbarius. ${ }^{47}$ There is a single (limited) exception: the Munich manuscript $\mathrm{BSB}, \mathrm{Clm}$ 6640. This manuscript contains two versions of Baldus' lectura. The first version corresponds mostly to its printed edition, but towards the end (when Baldus discusses more general issues of jurisdiction) it drifts away from it. ${ }^{48}$ This last part of the first version of the lectura, however, is not present in any other known manuscript. The second version of the lectura in the same manuscript merges the first part of Baldus' (standard) lectura on the lex Barbarius and the second part of his comment on a close-by lex (Dig.1.16.4.2, on the office of the Roman proconsul). ${ }^{49}$

Our problems with Baldus and the lex Barbarius are not over: two new Venetian editions of 1506 and 1507 enlarged the Milanese 1477 edition with some more additiones. ${ }^{\mathbf{5 0}}$ There, a third text on the lex Barbarius appeared: a long additio, titled 'Additio Bal.' As with the repetitio, there is no manuscript tradition for this additio. Nonetheless (and unlike other additiones of these Venetian

Cf. Colli (2000), pp. 407-408.

Baldus' lectura on Dig.1.14.3 may be found in Madrid, BN 2137, fols. 79ra-85ra; Stralsund Hs 290, fols. 80rb-86va; BAV, Ross. 1163, fols. 43rb-46rb. BSB, Clm 3062 skips it, together with most of the last part of the first book of the Digest. BSB, Clm 6640, fols. 75vb-80ra. From the beginning of fol. $79 \mathrm{ra}$ (=fol. 56ra, n. 34 in the Venetian edition of 1577) the manuscript begins to diverge from the printed edition, and the difference becomes increasingly pronounced towards the end.

The first part corresponds to the beginning of the standard printed text of Baldus' lectura: compare BSB, Clm 6640, fols. 80rb-82va, with the 1577 edition, fols. 54vb-55va, n. 1-17. Towards the end of fol. $82 v a$ in the MS, a sign divides two lines (which however run continuously). From the line below the sign (the fifth-last line of the column) the text is the same as the second half of Baldus' lectura on Dig.1.16.4.2 in any printed edition: compare the MS, fols. 82va-84rb,

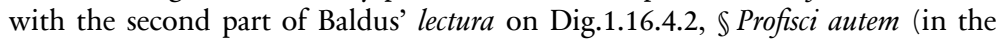
1577 printed edition, fol. 61ra-vb, n. 11-27). Although the manuscript combines two different lecturae, its reading makes perfect sense. The second part (the comment on Dig.1.16.4.2) is in fact a small treatise on the office of the proconsul. As Medieval jurists equiparated proconsul to the podestà (or rather, built the normative framework of the podesta around the Roman law provisions on the proconsul), Baldus' comment was a small treatise on syndication, dealing with the scope of the powers of the proconsul/podestà, and his liability. Cf. esp. Lepsius (2008), pp. 247-248.

The first edition was made in Venice by Gregorio de Gregoriis in 1506. This edition was then used for another Venetian edition of 1507 by Giorgio Arrivabene, and for a Lyon edition of 1508 by Jacques Sacon. Colli (2000), pp. 410-411, text and notes 8-10. Cf. also Colli (2005), p. 80, note 156. I was not able to look at the Gregoriis' edition but I could look at that of Arrivabene. It contains first the lectura (fols. 56vb-59vb), then the repetitio (fols. 59vb-61vb) and finally the 'new' additio (fols. 61vb-62vb). 
editions), for the additio on the lex Barbarius there seems to be no reason to doubt of its authenticity. ${ }^{51}$ The text of the additio - which will be examined more closely later on - is perfectly compatible with the repetitio, both in its style and especially in its approach and conclusions. At times (especially towards the end), the additio seems to elaborate further on what has already been said in the repetitio. This further elaboration hardly questions Baldus' authorship of either additio or repetitio. On the contrary, it would perfectly suit a scholar like Baldus, who never ceased to work on the Vetus - and thus who wrote about it for more than thirty years after the repetitio.

This additio assembles together two sets of glosses on the lex Barbarius. Among them, the second set is considerably longer. The first set of glosses ${ }^{52}$ shortly sums up what has already been said in the lectura and may be safely neglected. Its only interest lies in the conspicuous number of references to Innocent IV - even larger than usual. The second set of glosses ${ }^{53}$ is more interesting, especially as it shows other sources on which Baldus relied for his reading of the lex Barbarius (besides Innocent, that is). After a short summary of the Gloss, ${ }^{54}$ it explains the Ultramontani's interpretation, 'according to Petrus [de Bellapertica] and his followers', ${ }^{55}$ as well as Jacobus de Arena. ${ }^{56}$ The way Baldus reported Bellapertica in the additio would seem to suggest that (possibly unlike Bartolus) he looked at Bellapertica directly, and not through Cynus ${ }^{57}$ whom on the contrary he quoted seldom and sometimes even inaccurately. ${ }^{58}$

With the very marginal exception of a few lines in BSB, Clm $6640,{ }^{59}$ the whole known work of Baldus on the lex Barbarius is contained in the 1506 and 1507 Venetian editions. The present work is however based on a later Venetian edition, that of 1577 . The 1506/7 editions provided the basis for a new and slightly improved edition of 1572 , once again printed in Venice. With regard to the lex Barbarius, the main difference is that the 1572 edition adds some lines of

Some additiones in the 1506 and 1507 Venetian editions are not of Baldus but come from other authors: see Colli (2000), p. 411, note 9.

Baldus, additio on Dig.1.14.3 (In Primam Digesti Veteris Partem Commentaria, cit., fol. 59ra, n. 1-3).

53 Ibid., fol. 59ra-vb, n. 3-15.

54 Ibid., fol. 59ra-b, n. 3-4.

55 'secundum Pe(trum) et suos sequaces', ibid., fol. 59rb, n. 5.

56 Ibid., fol. 59ra-b, n. 4-5.

57 While Cynus reported everything that Bellapertica said, he did not always use his words. In the additio, Baldus looks at the lex Iulia de ambitu and reports Bellapertica's remarks against those who insisted that the lex Iulia did not apply in Rome. Unlike Cynus, Baldus reported Bellapertica's vocal protest against such a fraud ('trufe'): 'secundum Pe(trum) truffa est', fol. 59va, n. 11. Cf. supra, pt. I, $\$ 4.6$, note 93 .

$58 \quad$ Infra, $\$ 12.1$, text and note 9.

59 Supra, this chapter, note 48. 
the repetitio that, so far, were only present in the printed editions of Bartolus. In turn, the 1577 edition is nearly identical to the 1572 one, only very slightly improved. The choice of a later edition is also made to facilitate the reader, as the 1577 edition is remarkably easier to find than the 1506/7 ones.

Although more complete, the early sixteenth-century Venetian editions followed a different and possibly less accurate manuscript of Baldus' repetitio from that used in the 1477 Milanese edition. Not only are some citations wanting, ${ }^{\mathbf{6}}$ but sometimes sentences lack a few words, and some (though few) periods even lack full sentences. As already said, however, the text of the repetitio in the 1477 edition itself is not as good as that found in most printed editions of Bartolus. As such, the text of the repetitio (from Baldus' edition of 1577) will be integrated with that in Bartolus' printed editions. Having rejected Bartolus' authorship of the text, this might seem a paradox. Still, it is a useful one. The choice of Bartolus' edition was considerably easier to make: on the repetitio on the lex Barbarius, most of them are nearly identical. This work will use the 1588 Basel edition of Bartolus' commentary on the Vetus, ${ }^{\mathbf{6 1}}$ being one of the most accurate and easy to find.

While the text in the notes will normally follow Baldus' 1577 Venetian edition, words in italics will signal integration from the repetitio printed under the name of Bartolus. When on the contrary something is present only in the 1577 Venetian edition of Baldus, it will be reported in curly brackets. The notes will also give ample room to other places of Baldus' opus, so as to appreciate their closeness with the repetitio. Parentheses are used for abbreviations and to suggest the source of a quotation. Given the number of quotations from the lectura, repetitio and additio of Baldus on the lex Barbarius, the edition (Venetiis 1577) will be omitted in the notes.

Lastly, at the cost of stating the obvious, establishing a clear chronology between lectura, repetitio and additio is not possible. Any expression in the next chapters describing Baldus as 'returning' or 'coming back' to a specific point in the repetitio or the additio does not imply a chronology. ${ }^{62}$

60 And occasionally funny, as the reference to the Decretum's chapter Dilectissimi (C.8, q.2, c.2), which in the 1570s editions is reported as 'Dulcissimi': Baldus, repetitio ad Dig.1.14.3 (In Primam Digesti Veteris Partem Commentaria, cit., fol. $58 v b$, n. 32).

61 Bartolus [sed Baldus], repetitio ad Dig.1.14.3 (Bartoli a Saxoferrato in Primam Digesti Veteris Partem Commentaria, 1588, cit., pp. 115-121).

62 It is more probable in fact that Baldus wrote his repetitio on the lex Barbarius before several other texts touching on the subject throughout his opus. In some cases this seems clear: the repetitio bears the date of 1376 (supra, this paragraph, text and note 42), and Baldus wrote his commentary on the Liber Extra only in the 1390s (infra, next chapter, note 64). 


\section{Chapter 11}

\section{The anatomy of representation}

To make sense of Baldus' reading of the lex Barbarius we should be mindful that, for Baldus, Barbarius' case is a problem of legal representation. Barbarius exercised an office he was not entitled to. The question is therefore whether he could be tolerated in that office. Dealing with Barbarius' case, Baldus ultimately explores the limits of representation. It is therefore with it that we must begin, for Baldus' reading of the lex Barbarius can only be understood if we have a clear idea about his concept of representation, especially with regard to public offices. Having examined the 'mechanism' of representation in Baldus (and the crucial influence of the Innocent IV's thinking), we will then proceed, in the next chapter, to Baldus' reading of lex Barbarius. Finally, we will look at the further extensions of this lex (or rather, at other and more direct applications of the concept of toleration), especially on excommunicated judges, illegitimate prelates and, moreover, false notaries.

In this chapter we will look at representation, especially with regard to public offices. Ultimately, the main difference between Baldus and Innocent lay in Baldus' more flexible approach: for Baldus, representation did not necessarily entail full identification between the office and its incumbent. We have seen how Innocent based his concept of toleration entirely on representation. Baldus followed suit, but his more flexible approach to representation also allowed him to reach different conclusions from those of Innocent on toleration and so, ultimately, on the lex Barbarius. This is not necessarily an apologia for Baldus: flexibility, as we will see, sometimes came at the price of ambiguity.

As just said, Innocent's influence led Baldus to consider the concept of toleration as a specific application of representation. This chapter will seek to explain the relation between the two concepts in Baldus' thinking. What might appear a long detour is in fact necessary to fully appreciate Baldus' remarkably complex approach to the lex Barbarius. Thus, the relevance of this apparent digression will become progressively clear towards the end of this chapter, and especially in the next one.

To understand the relationship between incumbent and office, we will start with the concept of dignitas (of both person and office). Then we shall seek to distinguish them, focusing especially on the difference between obligations of the office and obligations of the person. Having clarified the difference, we will look at both outer and inner limits of representation. In some cases, especially for collegiate offices, no single person is entitled to act on behalf of the office - 
and so, strictly speaking, no individual person is the legal representative of the office. But there are also situations where the representative of an individual office (and so, the incumbent) may not 'force' the office to assume certain obligations. An analysis of such situations is important to better understand the difference between person and office.

Thereafter, we will finally move to Baldus' concept of toleration. There, we will use some concepts previously elaborated with regard to representation, to see whether and to what extent Baldus' notion of toleration - and, especially, its scope - matched that of Innocent. In so doing, we will be able to appreciate how the subtle difference between Baldus' and Innocent's positions on representation influenced their notion of toleration. Toleration tests the boundaries of representation. In highlighting the difference between incumbent and office, Baldus' notion of representation led him to develop a subtly different analysis of toleration from that of Innocent. This way, Baldus came very close to the modern idea of 'agency triangle' (or rather, to the concept behind this modern image), ${ }^{1}$ highlighting the dychotomy between the internal and the external validity of agency (on which see infra). The modernity of these ideas is as alluring as it is dangerous. When a concept is found in both contemporary and older sources, there is always a temptation to interpret its 'old' meaning through our understanding of the 'new' one. This is why we shall endeavour to follow Baldus' own examples and reasoning as much as possible: doing so might prove a good antidote against that temptation (or at least limit the damage).

In this chapter, some key concepts will be recalled time and again. This is not meant to test the patience of the reader. These concepts are as important as they are multifaceted, and that makes it necessary to build on what has been said previously - or rather, to 'dig' increasingly deeper into those concepts, reaching one layer after another. To understand Baldus' approach to the lex Barbarius, the last and longest paragraph of this chapter is by far the most important. But it would not make sense without the previous ones.

Innocent IV and Baldus de Ubaldis are probably the favourite medieval authors of historians of political thought. The former developed a legal doctrine of corporation as a 'fictive person' (persona ficta), the latter used it to provide a legal vest to the notion of kingdom. ${ }^{2}$ While of course there might always be something more to add, the matter has little to do with our subject. Except for one, crucial aspect: the influence of Innocent on Baldus' concept of office

1 On the relationship between representation and agency in this part of the book see infra, in this paragraph.

2 See first of all Canning (1983), p. 24, and esp. Canning (1989), pp. 185-197. More recently see also, inter multos, Tuner (2016), pp. 18-20, and Lee (2016), pp. 74-77. 
occurred in terms of both general principles and of a specific legal approach (provided that the two can actually be separated). Adapting Innocent's concept to (slightly) different purposes, Baldus also imported its ultimate rationale representation. Much has been written on the subject, ${ }^{3}$ but not from a legal perspective. This has resulted in some omissions, some of them crucial for our purposes. Historians stressed the complementariety between person and office. In so doing, however, they left aside cases where the person cannot act for the office. Those cases are of particular interest, because it is only there that some legal problems emerge clearly. To make full sense of these problems, in turn, it is necessary to look in more depth at the legal position of the office not just as different from that of its representative, but as opposed to it. The case of Barbarius is precisely one of them - or rather, is the case where Baldus dealt more deeply with the opposition between office and incumbent.

In this chapter we will often note Innocent's influence on Baldus. Previous civil lawyers did refer to Innocent. More often than not, however, such references tended to be either generic (a specific point of Innocent was quoted without full understanding of its deeper meaning or of its broader implications), or just made ad abundantiam (the jurist had already made his point and simply sought confirmation from some high authorities). The approach of Albericus de Rosate provides a good example in this sense. On the contrary, Baldus relies on Innocent in a much more informed, profound and systematic way. ${ }^{4}$ This influence does not mean that he had a submissive attitude towards the pope. Baldus simply found most of Innocent's arguments persuasive. At times, however, he could be sharply critical of him. Occasionally he went as far as remarking how other civil lawyers praised the 'Innocentian dialectics' (dialectic $[a]$ Innocentian $[a])^{5}$ more out of reverence for his high office than because of the quality of his arguments. ${ }^{6}$ Baldus' writings on the lex Barbarius showed his reliance on Innocent, but also its limitations.

On the dignitas of the crown and the role of the king the literature is bountiful. With specific reference to Baldus, it suffices to cite E. Kantorowicz (1957), pp. 291-302, 336-338, 397-401, and Canning (1989), pp. 86-90. Cf. also Riesenberg (1956), pp. 150-157; Wahl (1970), pp. 326-328; J. Black (2009), pp. 63-67; Canning (2014), pp. 156-157.

4 It has been argued that, together with Johannes Andreae, Innocent IV was the most quoted author in Baldus, not just for his commentaries on canon law, but also for those on civil law and even feudal law: Bertram (2002), p. 451, note 66. See esp. Baldus, ad Cod.7.55.1, $\$$ Si non singuli (svper VII, VIII et Nono Codicis, cit., fol. 87rb, n. 19): 'venio ad dialecticam Innocentianam.'

6 It is difficult to render the subtle irony of the Latin text in English: 'Concludo igitur quod dictum Inno(centii) potius processit de plenitudine potestatis quam de iudicii rigore: licet alii doctores applaudant Innocentio propter reuerentiam et auctoritatem papatus. Ad pleniorem autem intelligentiam oportet inquirere 
A final note on terminology. In discussing representation issues, this and the next few chapters will sometimes refer to agency. So far, the discourse on representation has focused on the right of the incumbent to discharge the office. Especially when looking at canon lawyers, the question has therefore been whether and to what extent legal representation applied. In this part of the work, however, the distinction between agent and principal will acquire an increasingly central role, and especially the relationship between principal, agent and third parties. This three-sided relationship, often known as an agency triangle, is key to understanding Baldus' approach to the lex Barbarius, and more in general to his assessment of the validity of the acts carried out by the person who lacks the right to validly represent the office. This way, thinking in terms of a principal-agent relationship helps to gain a better insight into a rather complex reasoning.

\subsection{Dignitas: worthiness and aptitude}

To look at the relationship between office and incumbent, we should start with the concept of dignitas. Dignitas has two different meanings - or rather, two different objects: it can be referred both to an office and to a person. This is still visible in modern English, where 'dignity' signifies both the quality of being worthy of honour and an honourable position. These two meanings are complementary: only someone worthy of honour should occupy an honourable position; in turn, the honourable position attests to the honour of its holder. This circularity depends on the complexity of the concept of dignitas as applied to a person, for it means at the same time worthiness and aptitude - both the ethical condition of the person and his legal capacity to receive or hold something. ${ }^{7}$

While complex, dignitas is not a bicephalous concept. Rather, it is a single concept with both an ethical and a legal meaning, which complement each other. The medieval world fully accepted the Pauline argument that any power is ordained by God ${ }^{\mathbf{8}}$ - both in the sense that it comes from God and that its specific

de veritate et de iudicio' (ibid., fol. 87va). The reference to the plenitude of power (plenitudo potestatis) had precious little to do with Innocent's argument (cf. Innocent, ad X.2.27.26[=VI.2.14.3], \$ Iudicium, in Commentaria Innocentii Quarti, cit., fol. $316 \mathrm{ra}-v b$ ), but more to do with Innocent himself. In other words, Baldus mischievously suggests that many jurists might have accepted the pope's interpretation of the law because the pope could change the law. The implied argument of course is that, unless the pope did actually change the rule, his interpretation was totally wrong.

7 Rossi (2012), pp. 150-152, where further literature is listed.

8 Rom. 13:1: 'non est potestas nisi a Deo; quae autem sunt, a Deo ordinatae sunt.' Cf. Aquinas (Cai [ed., 1953]), vol. 1, c.13, lect.1, \$1021, p. 190. The literature on 
hierarchical position depends on His will. The jurists found a clear confirmation of this in the Roman sources. Roman law was the product of a society of unequals, where it was perfectly normal that the dignores would occupy a higher rank in society. Their social privileges, importantly, were also legal ones. The medieval reinterpretation of Roman law through the lens of Christian thought led to the justification of the social hierarchy in terms of authority (the will of God), and to its rational explanation in terms of the superior moral qualities of those higher up the social ladder.

The concept of dignitas is vast, but we shall focus only on what Baldus says. The easiest way to do this is to look at some practical examples of the combination between the subjective and objective, and the moral and legal elements of dignitas, as referred both to people and to offices.

An easy starting point in the sources is the Digest's title on the senators (by definition the highest Roman class). The Romans considered of consular rank not only men, but also women - for instance, a senator's wife. But clearly a man of consular rank took precedence over a woman of the same rank (Dig.1.9.1). ${ }^{9}$ Commenting on this text, Baldus notes that, as a general principle, 'the man is worthier [dignor] than the woman'. ${ }^{\mathbf{1 0}}$ And he proceeds immediately to apply this moral distinction of dignitas to legal scenarios. The patron (patronus) of an ecclesiastical benefice normally has the right to present a cleric to be appointed to that benefice when it becomes vacant. What happens, asks Baldus, if the heirs of the patron cannot agree among themselves as to the next cleric to present? If the heirs are a son and a daughter, the solution is simple: 'the voice of the man is to be preferred to that of the woman, because it is worthier'. ${ }^{11}$ A first and foremost consequence of this higher dignitas of the male, continues Baldus, is the lex Salica (agnatic succession to the throne). ${ }^{12}$ It is difficult to find a stronger link between subjective and objective meanings of dignitas.

Dignitas, as said, is not a concept referred just to persons. It also designates offices. The same dialectic between moral and legal qualities informing personal dignitas is also found in the idea of office as dignitas. Going back to the 'worthier voice' of the man, the text immediately following it in the Digest provides an

the medieval reading of the Pauline passage is bountiful. On its application to our subject, see for all Costa (1969), pp. 383-385.

9 Dig.1.9.1pr (Ulp. 62 ed.): 'Consulari feminae utique consularem virum praeferendum nemo ambigit. Sed vir praefectorius an consulari feminae praeferatur, videndum. Putem praeferri, quia maior dignitas est in sexu virili.'

10 Baldus, ad Dig.1.9.1 \$Consulari (In Primam Digesti Veteris Partem Commentaria, cit., fol. $49 v a$, n. 1): 'Dignior est vir quam foemina.'

11 Ibid., 'Item facit quod si patronus ecclesiae decessit superstite filio, et filia, et discordant in presentando quod debet preferri voc masculi tanquam dignior.'

12 Ibid., fol. $49 v a$, n. 2. 
excellent example. It speaks of a senator expelled from the senate for his unworthiness (ex turpitudine). This ex-senator in disgrace may not judge or give witness. On the basis of that text, Baldus wonders whether the supervening indignitas should also prevent someone from deposing as witness. ${ }^{13}$ Being witness, says Baldus, 'is itself a dignitas. ${ }^{\mathbf{1 4}}$

Depending on its owner, a voice may be worthier (dignor). Applied to a specific legal function, the same voice becomes an office (dignitas). The higher dignitas of the man explains why in some countries the supreme dignitas - the Crown - is precluded to those less worthy (women). The higher the office (dignitas), the more worthiness (dignitas) one needs to possess.

If dignitas is a personal quality, a legal requirement and an office, then - going back to the image of the worthier voice - the voice is even stronger when its possessor occupies an office himself. So, says Baldus, the testimony of 'the person who holds an office' (qui est in dignitate) is stronger than that of someone who does not. ${ }^{15}$ This depends both on the fact that holding a dignitas (office) is proof itself of the dignitas of its holder, and on the fact that the deposition is not just that of the person, but of the dignitas of his office.

On the same basis, Baldus could well say that 'the worthier should occupy a higher rank', and the higher rank is determined by its closeness to that of the master - in the specific case, the proconsul. ${ }^{16}$ The highest dignities may be conferred only by the worthiest person - the prince (who in turn occupies the highest dignitas of all). ${ }^{17}$ The higher the dignitas of the office, the higher the personal dignitas that is required to hold it. Since the higher rank is worthier, its incumbent should possess a higher dignitas in moral, social and legal terms each of the three both requires and explains the others. Their mutual dependence is shown clearly by the fact that the holder of a superior dignitas should not only

As Bartolus informs us, witnesses enjoyed different degrees of attendibility according to their dignitas, for at the same time the judge had to assess 'quanta fides habenda sit testibus, qui et cuius dignitatis et cuius existimationis sint' (Bartolus, Tractatus testimoniorum, in Lepsius [ed., 2003], vol. 2, p. 234, $\$$ Testium).

14 Baldus, ad Dig.1.9.2 \$Cassius Longinus (In Primam Digesti Veteris Partem Commentaria, cit., fol. 49vb, n. 2): 'Item testimonium est dignitas $\mathrm{i}(\mathrm{d}$ est) status illaesus absque macula.'

Id., ad Dig.22.5.3pr, $\mathbb{S}$ Testium fides (Baldi Vbaldi pervsini Ivrisconsvlti ... In Secundam Digesti vet[eris] partem Commentaria ... Venetiis, 1586, fol. 179va, n. 1): 'magis creditur ei, qui est in dignitate, quam ei qui non est in dignitate.' Id., ad Dig.1.16.4.3, $₫$ Antequam vero (In Primam Digesti Veteris Partem Commentaria, cit., fol. 62ra, n. 3): 'dignores debent altiori loco sedere, et altior locus est, qui est domino magis propinquus.'

17 Id., ad Dig.2.1.3, \$Imperium (ibid., fol. 73ra, n. 7): 'solus Princeps confert magnas dignitates.' 
be worthier (dignor), but also appear such. So, for instance, the abbot should be dressed better than the monk because, explains Baldus, he is worthier (dignor) than him. ${ }^{18}$ Referred to a person, dignitas is ultimately a question of proportionality between moral worthiness and legal aptitude. When the person holds an office, the same question of proportionality arises: the personal dignitas (in both its meanings) must be commensurate to the dignitas of the office.

The correspondence between inner and outer dignitas is not just a question of appearances. It points to the symmetry between dignitas of the person and dignitas of the office. In the typical scholastic fashion of disputatio, the Gloss posed a paradox. The emperor is unworthy of being just a governor (praeses). But the office of the governor is clearly lower than that of the emperor. If the emperor is not worthy of being a governor, does that mean that he is unworthy of the empire too? The answer was of course negative: the lower rank was unworthy of the prince, not vice versa. ${ }^{19}$ But the point is interesting: the incompatibility between the lower rank of the office and the higher status of the person implied that also the office had a dignitas, which could be described both in terms of worthiness and of aptitude. Baldus elaborates much on this gloss: 'the pope is not worthy [dignus] of being chaplain', just as 'Caesar is not worthy [dignus] to be a decurion'. ${ }^{20}$ With these examples Baldus captures the relationship between the worthiness and aptitude of the person, and their reflection on the office. Moral worthiness entails legal aptitude. But the opposite is also true. The suitability to exercise a certain position is also related to the moral worthiness of its holder, for it measures it. Pope and emperor would be 'overqualified' for those minor offices, and so unsuitable to them. ${ }^{21}$ To associate them with those lower ranks would be even offensive: in a world of 'ordained vestitus quam monachus, quia dignor.' indignus est quod sit praeses: ergo indignior imperio? Respon(deo) minores ordines sunt indigni eo: non ipse eis.'

20 Baldus ad Dig.1.9.4, $\$$ Qui indignus (In Primam Digesti Veteris Partem Commentaria, cit., fol. 50va, n. 2): 'Opponit gl(osa) Papa non est dignus esse cappellanus, ergo non est dignus esse Papa. Respon(deo) omnia continet sub se dignitas suprema. Vel aliter, Papa non est dignus plebanus villae Canalis, ergo non est dignus papatu. Nam illa est falsa: quia Papa dignus est, sed villa Canalis indigna, nec est tanti capax. Et idem in Imperatore: nam Caesar non est dignus esse Decurio, $i(d$ est) decurionatus non est dignus Caesare, nec aliqua inferior dignitas ratione proportionis digna est amplecti quod supremus est.'

21 Hence the association often found in medieval jurists between dignitas and idoneitas. E. g. Rossi (2012), p. 151. See more broadly Peltzer (2015), pp. 23-37. The reverse, as usual, is true: inidoneitas also means indignitas. See for all Peters (1970), esp. pp. 116-134. 
powers' (potestates ordinatae), the specific position of each person attests to a higher or lower degree of personal worthiness. The dignitas of the office should be commensurate with the dignitas of the person holding it. The reason why pope and emperor are not worthy of lower offices is that the dignitas of those offices is itself lower than that of the person of the pope or the prince. Those lower offices are not able to accommodate those two supreme dignities. The term chosen by Baldus to signify this inability is 'non capax'. ${ }^{22}$ Just like 'capacity' in modern English, capax meant both ability and spaciousness. A lower dignitas cannot accomodate the 'size' of the supreme one, nor would it be worthy of a higher dignitas to be 'squeezed' into a lower one.

\subsection{Office and incumbent}

Having briefly looked at the concept of dignitas in its ramifications (person and office, and - within each - worthiness and aptitude), it is now important to look at the difference between office and incumbent in Baldus. To do so, we may distinguish four levels, four degrees of separation between person and office. First, obligations of person vs. obligations of the office. Second, individual offices vs. collegiate bodies. Third, individual offices where the person is worth of the dignitas but seeks to exercise it in a way that is unworthy of the office. Fourth, individual offices where the person representing the office is unworthy of it. Thus, beginning with agency, we will conclude with toleration.

Quite understandably, Innocent IV elaborated the concept of the legal person mainly with regard to ecclesiastical issues. Baldus adapts that concept to secular matters, first of all the notion of kingdom. Hence the famous image of the king as guardian of the Crown. That image has been more often looked as a metaphor than as a specific legal reference. Describing the prince as a guardian, as Reisenberg famously said, allows a distinction between the 'abstraction of sovereignty and its momentary possessor'. ${ }^{23}$ This powerful metaphor is in effect also a specific legal reference. Few medieval lawyers were also great poets (Cynus is of course the proverbial exception). In juridical discourse metaphors have legal consequences, because they are legal analogies. The description of the prince as guardian and the Crown as ward is often found in Baldus, especially in some of his more politically minded consilia. It was one of them ${ }^{24}$ that prompted Reisenberg's statement. In that same consilium, a few lines after the metaphor of the king-guardian, Baldus points to the passage in the Digest (Dig.34.9.22)

24 Baldus, cons.3.159 (Venetiis 1580), infra, this chapter, note 35. 
that emphasises the most difference between the person of the guardian and the quality of being guardian. Obligations, duties and liabilities assumed by the guardian in the exercise of the wardship, states that text of the Digest, may not be imputed to the guardian as a person. ${ }^{25}$ Indeed in Roman law the punishment for the guardian's misconduct was precisely to lift this separation and condemn the guardian to pay those debts out of his own pocket.

The Crown is immortal, and it always needs a king. When the old king dies, the new one is born - 'the king is dead, long live the king!' Kantorowicz famously analysed the point. ${ }^{26}$ Commenting on Baldus in particular, he gave a masterful description of the image of the king as phoenix. ${ }^{27}$ The parallel was probably not a creation of Baldus, but he found it very apt to explain the relationship between king and Crown. Just like the emperor, there is only one phoenix at any given time. In the phoenix, a single individual and an abstract category coincide. This makes the metaphor even stronger: although the only living phoenix dies, the phoenix does not. The strength of the metaphor makes it particularly suited to describe the king-Crown relationship. In his capacity as representative of the Crown, the previous individual to wear it is in no way different from the next - just as the new phoenix will be physically identical to the old one. The phoenix dies but at the same time it dies not, and so does the king. ${ }^{28}$

Poetry, alas, lasts only for a brief spell - it serves a precise purpose. So, immediately after the phoenix metaphor, Baldus goes back to business: the legal proceedings entrusted to the holder of an office pass on to the next incumbent, he says, for his predecessor was not given the task as an individual but as representative of his office. ${ }^{29}$ In their quality of representative of the office, old

Cf. Dig.34.9.22 (Tryphon. 5 disput.). The passage is both long and remarkably complex - further comments on it would risk shifting the focus of the present analysis and so will be omitted.

E. Kantorowicz (1957), chapters 6 and 7, esp. pp. 291-313, 318-342, 409-413. Cf. Meder (2015), pp. 46-47 and 49-53, where ample literature is mentioned. E. Kantorowicz (1957), pp. 388-390.

28 Baldus, ad X.1.29.14, Quoniam abbas (Baldvs svper Decretalibvs ... Lugduni, excudebat Claudius Seruanius, 1564, fol. 89va, n. 2): 'Dicit ber(nardus parmensis) quod dignitas non moritur sed persona quia indiuidua sepe pereunt quod summis dignitatibus non est concessus.'

29 Ibid., fol. 89vb, n. 3: 'Dicit In(nocentius) quod quando causa committitur loco vel dignitati mortuo commissario vel remoto transit delegatio ad ipsam dignitatem.' Cf. Innocent IV, ad X1.29.14, $\$$ Quoniam Abbas (Commentaria Innocentii Quarti, cit., fol. 123ra, n. 1): 'successores procederent in causa, cum sit iurisdictio penes loca et dignitates, et non penes personas.' For this reason the new incumbent is considered the same person as the old one. Innocent elaborated further on the point in his discussion of the dispossession of the right to make an 
and new incumbent are precisely one and the same - just like the phoenix. Leaving aside political thought, we should focus on the 'legal side' of the phoenix. Somewhat prosaically, the question might very well be: when a phoenix dies, does the mortgage on the nest pass on to the new bird? Baldus' concept of legal representation in (to use an anachronism) ${ }^{\mathbf{3 0}}$ public law is best explained through the example of the king as representative of the Crown. To better understand that concept, our focus should be more on the obligations of the office. This would provide important insights as to the 'mechanism' of representation and, at the same time, on its limitations.

One of the classical texts of Baldus on the immortality of the dignitas is his consilium on whether the obligation assumed by the old king binds his successor. Baldus' answer is based on the distinction between obligations undertaken by the king as a person and obligations assumed in the name of the Crown. ${ }^{31}$ When the prince dies, it is only the representative who dies - not the dignitas itself. To stress the difference between the eternal dignitas of the Crown and the mortal nature of its incumbent, Baldus sometimes speaks of 'office' to describe the position of the latter. So for instance, at the beginning of his commentary on the Code he states that the 'the office of the emperor is for the term of his life'. ${ }^{32} \mathrm{Had}$ he spoken of dignitas, the statement would have made considerably less sense.

An even better example - both in absolute terms and also for historical reasons (by the late fourteenth century the empire had seen better days) - is that

appointment (cf. infra, this chapter, note 94). When the election was made by someone other than the rightful elector, he could demand its annulment. If the rightful elector died, the faculty to demand the annulment would pass on to his successor, because the harm was done not to his person, but rather to the office he represented. Hence the successor is considered ('fingitur') one and the same person with his predecessor ('finguntur enim eodem personae cum praedecessoribus'). That, however, does not apply to collegiate offices: the members of the chapter can be replaced, but they do not succeed to one another in the sense of being identified with the predecessor. This identification can happen only through the office, but no single member of the chapter represents it individually ('sed in canonicis secus. Nam canonici qui substituuntur, canonicis non succedunt in honore et onere, sed capitulum eis succedit'). Innocent, ad X.1.6.28, $\$$ Propter bonum pacis (Commentaria Innocentii Quarti, cit., fol. 58vb, n. 5).

30 Cf. Chevrier (1965), pp. 841-859.

31 Baldus, cons.3.159 (Consiliorvm sive Responsorvm Baldi Vbaldi Pervsini ..., Venetiis, apud Dominicum Nicolinum, et Socios, 1580, fols. 45rb-46va). See for all Canning (1989), pp. 86-90.

32 Id., ad Const. De novo codice componendo, $\mathbb{\$}$ Oportet preuenire (Baldi de Pervsio ... super Primo, Secvndo \& Tertio Codicis commentaria luculentissima ... Lvgdvni [typis Gaspar \& Melchior Trechsel], 1539, fol. 2vb, n. 8): 'officium imperatoris est ad vitam', emphasis added. 
of the papacy, the 'supreme dignity' (dignitas suprema). ${ }^{33}$ The pope may die, says Baldus, but the papacy does not. The question is therefore to see what obligations incurred by the previous pope (or prince) are transferred to the new one. ${ }^{34}$ If the obligation was undertaken by the office (through the person of its previous incumbent), then the simple change in the person of the incumbent would not extinguish it. In law, there is no change in the person of the obligor: it is always the office. ${ }^{35}$ Thinking in terms of a transfer of obligation is therefore misleading: we should think in terms of a change in the person of the legal representative.

The dignitas does not suffer. Baldus famously said as much contrasting the emperor Constantine, who allegedly suffered from leprosy until healed by pope Sylvester I, with his imperial 'dignitas, which does not die nor suffer'. ${ }^{36}$ The dignitas may neither feel nor will: properly speaking, volition pertains only to the physical person representing it. ${ }^{37}$ If the dignitas can only will through the person of its representative, it also needs the same person to act. Alone, the dignitas may not act. ${ }^{38}$ Although rather self-evident, this is nonetheless important. Because

Id., ad Dig.1.9.4, $\mathbb{S}$ Qui indignus (In Primam Digesti Veteris Partem Commentaria, cit., fol. 50va, n. 2).

34 Id., cons.3.159 (Consiliorvm sive Responsorvm Baldi Vbaldi Pervsini, cit., fol. 45va, n. 3): 'imperator in persona mori potest: sed ipsa dignitas, seu imperium immortalis est, sicut et summus Pontifex moritur, sed summus Pontificatus non moritur, et ideo quae procedunt a persona, et noua fede, personalia sunt, si a successiua uoluntate dependent. Si autem statim transferunt secum in plenum tunc mors collatoris non impedit beneficium, quin duret tempore successorio.'

35 Ibid., fol. 45vb, n. 4-5: 'in contractib(us) Regum est expressum, quod contractus transeunt ad successores in regno, si celebrati sunt nomine dignitatis, extra, de re iud(icata) c. abbate in prin(cipio) lib. 6 (VI.2.14.3), et extra de iureiur(ando) c. intellecto per Inn(ocentium) [cf. Innocent, ad X.2.24.33, \$Intellecto, Commentaria Innocentii Quarti, cit., fol. 289va], nec mirum, quia in regno considerari debet dignitas, quae non moritur ... unde cum intellectu loquendo, non est mortua hic persona concedens, $s$ (cilicet) ipsa reipublica regni, nam uerum est dicere, quod respublica nihil per se agit, tamen qui regit rempublicam, agit in uirtute reipublicae, et dignitatis sibi collatae ab ipsa republica. Porro duo concurrunt ut in Rege: persona, et significatio. Et ipsa significatio, quae est quoddam intellectuale, semper est perseuerans enigmatice, licet non corporaliter: nam licet Rex deficiat, quod ad rumbum, nempe loco duarum personarum Rex fungit, ut ff. de his, quib(us) ut indi(gnis) 1. tutorum (Dig.34.9.22), et persona Regis est organum, et instrumentum illius personae intellectualis, et publicae.'

36 Baldus, proemium ad Digestum Vetus (In Primam Digesti Veteris Partem Commentaria, cit., fol. 3ra, n. 38): 'dignitas qua non moritur, nec patitur.'

37 Id., ad Dig. 1 Const. Omnem, $\mathbb{\$} 7$, Haec autem tria (ibid., fol. $5 v b$, n. 6): 'volunctas proprie attribuitur personae: sed improprie attribuitur dignitati. Et ideo si verba in dignitate non sonant, in dubio praesumuntur sonare in personam.'

38 Id., repetitio ad Dig.4.4.38.1, \$Item quod dicitur (ibid., fol. 246rb, n. 45): 'ecclesia sine Papa nihil agit: ideo oportet quod per alium regatur, sicut et regitur minor.' 
the opposite is not true: the person may well act not as representative of the office but as individual. The problem, as Baldus puts it, is that in both cases the person is always the 'immediate cause' (causa immediata) of an act. This makes it difficult to determine when the act should be ascribed to the office and not to the individual person. It is not fortuitous that the most important comments of Baldus on the difference between person and office deal with succession - first of all, to the throne. Because the most efficient way to divide person from office is to remove the physical person from the picture, so as to determine which obligations and rights should pass on to the next incumbent in office. ${ }^{39}$

The difference between a direct and an indirect relationship between the person and the office appears most clearly in the opposition between Caesar and his wife. One of the most quoted texts of Baldus on the immortality of the Crown deals with succession. 'The dignitas does not die' (dignitas non moritur), so the new prince takes the place of the old one. In effect, Baldus' text dealt with a slightly different and rather more technical matter. Baldus was commenting on the second of the two books of the Digest devoted to legacies (Dig.31). This book contained two texts, one after the other, on which medieval jurists usually commented together (Dig.31(.1).56-57). ${ }^{\mathbf{4 0}}$ The first text stated that, if the testator left a bequest to the prince but the emperor died before the testator,

39 See esp. Id., cons.3.121 (Consiliorvm sive Responsorvm Baldi Vbaldi Pervsini, cit., fol. 34ra, n. 6): 'quaedam sunt, quae competunt personae in dignitate, ita quod persona sit causa immediate: dignitas autem sit causa remota. Quaedam uero sunt, quae competunt dignitati principaliter, et quia dignitas informat suum subiectum competunt personae: quia dignitas sine persona nihil agit, in primis extincta persona, quae erat finale subiectum actus: expirat ipse actus pendens, quia persona facit locum actui ... Et ideo quaecunque sunt singularis fidei, et industriae, tanquam singulares animi passiones morte annihilantur et non transmittuntur, vnde fidem, et industriam nemo transmittit. In secundis autem, quae competunt dignitati per prius, et personae in dignitate positae per posterius, et per sic necesse esse, quia (ut dixi) iurisdictio sine persona nil agit, ut ff. de origi(ne) iur(is) 1. 2 \$ post originem iuris (Dig.1.2.2.13). Ibi attendimus dignitatem tanquam principalem: et personam tanquam instrumentalem. Vnde fundamentum actus est ipsa dignitas, quae est perpetua, extra de offic(io iudicis) deleg(ati) c. quoniam abbas (X.1.29.14). Cf. Id., cons.3.217 (ibid., fol. 63va, n. 3): 'Cum persona sit assumpta loco finalis causae prorograndi ab alio non futuro, personalis, quae est alia in substantia hominis, et non persona idealis, quae est dignitas, ipsa facit locum prorogationi, et non dignitas, igitur extincta persona extinguitur prorogatio.'

40 E.g. Vivianus Tuscus, ad Dig.31(.1).56, casus ad $\$$ Quod principi (Parisiis 1566, vol. 2, col. 901): 'Legaui imperatori, et ipse decessit ante diem legati cedentem, id est ante mortem meam: certe ad sequentem imperatorem transmittur. Secus autem esset in Augusta, cui legatum esset et $\mathrm{h}(\mathrm{oc}) \mathrm{d}$ (icit) $\mathrm{l}(\mathrm{ex})$ seq(uens) (i. e. Dig.31(.1).57). Vivianus.' 
then the bequest would go to the next emperor. ${ }^{41}$ The second text looked at the bequest to the Augusta (the emperor's wife) and stated the opposite: if the testator bequeathed something to the Augusta but she predeceased him, then the bequest would be void. ${ }^{42}$ The Gloss sought to explain the difference: the Augusta enjoys most of Caesar's privileges, but not all of them. So for instance she cannot legislate. ${ }^{43}$ Clearly the Gloss said nothing on legal representation the contrary would be surprising. ${ }^{44}$ In his comment on the same text, Bartolus went a step beyond the Gloss: a bequest left to the incumbent in an office goes to the successor only if the link between person and office is direct (as in the case of Caesar), not also when the link is indirect (like that of Caesar's wife). ${ }^{45}$ It follows that a bequest to the bishop not as a specific person but as incumbent in the office does pass on to his successor. But, Bartolus observed, the same does not apply to his vicar: the vicar of the bishop is not the representative of the office, but rather the representative of the person - the bishop - who acts as representative of the bishopric. ${ }^{46}$

In his turn, Baldus goes a step beyond Bartolus. This however is a very significant step, for it would establish an important principle. The difference between Caesar and his wife is that the dignitas - in the sense of office - is attached only to the prince. The wife of the incumbent has a dignitas simply by association. The dignitas of the office does not die. So the bequest to Caesar is always valid, because it was meant to the office, not the specific incumbent (or rather, the recipient was determined by reference to the office, which is immortal). But the Augusta has a dignitas only in the sense of social (and so, moral) standing, not also in the sense of legal representation (and so, of office). dies legati cedat, ab hominibus ereptus est, ex constitutione divi Antonini successori eius debetur.'

42 Dig.31(.1).57 (Mauricius, 2 Iul. et Pap.): 'Si Augustae legaveris et ea inter homines esse desierit, deficit quod ei relictum est, sicuti divus Hadrianus in Plotinae et proxime imperator Antoninus in Faustinae Augustae persona constituit, cum ea ante inter homines esse desiit, quam testator decederet.'

43 Gloss ad Dig.31(.1).56, $\mathbb{S}$ Si augustae (Parisiis 1566, vol. 2, col. 901): '... tu dic eadem priuilegia, sed non omnia: nam nec legis condendae.'

44 Looking at what the most renown jurists between the Gloss and Baldus wrote on the subject might easily provide a good basis for a prehistory of representation theory in civil law, but that would go far beyond our purposes.

45 Bartolus, ad Dig.31(.1).56, $\$$ Quod Principi (in II. partem Infortiati, cit., p. 105, n. 1): 'Relictum sub nomine dignitatis, transit ad successorem in dignitate, si dignitate, quis habet per se: secus si per consequentiam alterius.'

46 Ibid., n. 3: 'Et sic facit ista lex, quod si relinquitur episcopo sub nomine dignitatis, transit ad successorem: secus si relinqueretur uicario: quia tunc non transit in sequentem uicarium.' 
She is Augusta simply by association with the incumbent on the throne, so when she dies her (personal) dignity dies too. 'Such a dignitas dies with the person', and a new one is created by association with the ever-existing office of the Crown: 'with a new Augusta, a new dignitas is created'. ${ }^{47}$ It is in the light of this explanation that Baldus recalls Bartolus' example of the bequest to the bishop and to his vicar. The different perspective also leads to a different explanation of the same example. Just like Caesar, says Baldus, the office of the bishop is immortal and always the same: since it does not die, the bequest may well be received by the next incumbent. But the office of the vicar, he continues, is closer to the dignity of the Augusta: just as a woman becomes Augusta only when she is married to the representative of the Crown, so a man is episcopal vicar only when another man becomes representative of the bishopric and appoints him. ${ }^{48}$

The same difference between person as individual and person as legal representative is clearly visible in Baldus' comment on another text, this time in the Code. There, the emperor decreed that provincial governors could refer criminal cases to him only after having notified the parties. ${ }^{49}$ Commenting on this text, Baldus wonders what would happen if the governor did consult the prince, but the prince died before he could reply. Should the governor start the

Baldus, ad Dig.31(.1).56, $\$$ Quod Principi (Baldi Vbaldi ... In Primam et Secvn[dam] infortiati partem, Commentaria ... Venetiis [apud Iuntas], 1577, fol. 151vb): 'Relictum dignitati, qua quis habet per se, non potest effici caducum, quia dignitas non moritur: secus si relinquatur dignitati, quam quis habet per alium, quia talis dignitas moritur cum persona, et facit hoc ad rationem quam assignat tex(um) extra, de praeben(dis) c. dilecto (X.3.5.25), et no(tatur) quod in l. quod Princi(pi) (31(.1).56) dignitas vacat, et 1. si Augusta (Dig.31(.1).57), dignitas desinit. In tex(tu) constitutionis tamen, non continet haec constitutio ius singulare, sed commune, quia Imperium, et dignitas semper est et non moritur; et facit quod no(tatur) s(upra) de pac(tis) l. tale pactum, in fi(ne) (Dig.2.14.40.3). In 1. si Augusta (Dig.31(.1).57), Augusta non habet dignitatem ex se, sed per modum cuiusdam dependentiae, $\mathrm{i}(\mathrm{d}$ est) accessionis, et ideo in tali dignitate non habet successorem, vnde sua dignitas eius morte finitur, et cum noua Augusta noua dignitas creatur.'

48 Ibid., 'et ideo dicit Bar(tolus) quod si relinquitur Episcopo, et Episcopus moritur, viuo testatore, quod debetur successori; secus, si relinquitur Vicario, et Vicarius moritur viuo testatore, quia Vicarius de nouo creatus non habebit istud legatum secundum Bar(tolum). Item no(tatur) in 1. quod Principi (Dig.31(.1).56), quod legatum quod immortali relinquitur non potest effici caducum, vel quasi: vnde quando relinquitur pauperibus in genere, quia genus non potest perire, istud legatum non potest effici caducum.’

49 Cod.7.61.2 (Valentinianus and Valens AA. ad Viventium PP.): 'Super delictis provincialium numquam rectores provinciarum ad scientiam principum putent esse referendum, nisi ediderint prius consultationis exemplum. Quippe tunc demum relationibus plena maturitas est, cum vel adlegationibus refelluntur vel probantur adsensu.' 
procedure anew or could the next prince just reply to the petition addressed to his predecessor? The petition was addressed to the prince in his capacity as representative of the Crown and not as a private individual, reasons Baldus. And the governor is awaiting a reply from the Crown, not from the private person who wears it. Hence Baldus concludes that the new incumbent may reply to the petition addressed to the Crown in the person of the previous emperor. This text of the Code (especially in its medieval interpretation) referred to the decisions rendered by the emperor in his quality of highest judge. Clearly the decision of this supreme judge did not depend on the personal qualities of the physical prince, but from the position of the emperor as the apex of the hierarchical jurisdictional structure. ${ }^{50}$ This strengthens Baldus' conclusion: the petition of the governor is clearly addressed to the Crown, he says, because in its decision is 'engraved' the dignitas of the Crown itself ('illa dignitas imprimit in actu quam gerit'). ${ }^{51}$ This powerful image helps to clarify further the difference between acts of the person and of the office.

Once the rule is neatly described, Baldus applies it to more complex cases. What if the testator appointed as executor the prior of the Dominicans, and the prior died before he could carry out the task? The choice of the Dominican prior, argues Baldus, is dictated by the dignitas of his office: the testator appointed him 'as a person made perfect in Christ'. The dignitas of that position attests to the moral worthiness of its incumbent. So the choice was not dictated by the specific qualities of the individual, but rather by the qualities needed to hold that office. The appointment as executor therefore passes on to the next prior. The opposite solution, adds Baldus, would apply if the incumbent in an office were to be appointed as arbiter, since the choice of the arbiter depends on personal considerations. As such, explains Baldus, even if the person appointed as arbiter were to hold an office, that would not add anything to the verdict: 'the dignitas would not bestow anything on the deed'. Unlike the decision of the prince in the

50 Incidentally, it might be noted that the higher jurisdiction of the emperor is strictly related to his dignitas. To have jurisdiction over the parties, the judge had to enjoy a higher status - he should be superior to them. Hence the supreme dignitas of the emperor entailed the highest degree of jurisdiction.

51 Baldus, ad Cod.7.61.2, \$S Super delictis (svper VII, VIII et Nono Codicis, cit., fol. 99rb, n. 3): 'Quero si preses consuluit principem et princeps moritur an debeat expectari responsum successoris. Respondeo quia consultatio concernit principaliter dignitatem que non moritur vt 1 . quod principi, de leg(atis) ii (Dig.31.(1).56) licet persona sit organum ipsius dignitatis sine quo dignitas nil facit ... aut tanquam dignitas non expirat aut tanquam persona in dignitate: et tunc illa dignitas imprimit in actu quam gerit aut demostrat cum quo geratur. Primo casu commissio est realis, secundo est personalis: quia prima persona est immediata causa commissionis.' 
text of the Code, in other words, the arbiter's office would not 'engrave' its dignitas on the verdict. ${ }^{52}$

While much of Baldus' thinking on representation is based on Innocent IV, sometimes he builds on other pre-eminent canon lawyers, chiefly Johannes Andreae. ${ }^{53}$ One of these cases is particularly relevant for our purposes. Johannes Andreae wondered whether the oath to a prelate would still bind even after the prelate's deposition from office. He answered in the negative on the basis of the reverse situation: if the prelate swore as representative of the office ('if the praelatus swore as praelatus'), then his persona would not be bound once divested from that office. ${ }^{54}$ The juxtaposition between persona and praelatus (and the image of the persona divesting itself of the praelatura) is further developed by Baldus. If the prelate tendered his oath 'not as himself in his own person, but as someone else in the person of the church', then the dismissal from office or its renunciation would release him from the obligation. In this case, Baldus relies on the prohibition on enforcing a judgment against the guardian (curator) of the insane after the death of the insane person. ${ }^{55}$ Just as the ex-guardian, reasons Baldus, the prelate is no longer bound because he ceased to represent the office for which he swore the oath. The solution of course would be the opposite, he continues, if the prelate incurred in the debt not 'for the utility or necessity of

52 Ibid., 'Respon(deo) aut fides sumitur ratione officii vt quando testator reliquit executorem priorem predicatorum et transit ad successorem: ei enim committitur tanquam persone perfecte in Christo ... aut dignitas actu nihil confert: et tunc expirat vt in compromissa: quia compromittere est quod personale.' This discourse is further elaborated in the lectura institutionum that bears the name of Baldus, but it is not reported here, for the author of that work is in fact Bartolomeo da Novara: cf. Maffei (1990), pp. 5-22. Compare Innocent IV, ad X.1.29.43, Eligere (Commentaria Innocentii Quarti, cit., fol. 144va, n. 3) with the comment on Inst.2.16.7, $\$$ Substituitur, found in Baldi Vbaldi Pervsini ... Praelectiones In quatuor Institutionum libros ..., Venetiis, 1577 (fol. 26rb-va, n. 2-5).

53 Supra, this chapter, note 4.

54 Johannes Andreae, ad X.1.6.34, \$Iuramentum huiusmodi (In primum Decretalium librum Nouella Commentaria, fol. 108vb, n. 38): 'et sic not(andum) quod si iuro alicui praelato, ipso deposito, non teneor personae ratione iuramenti ... pari ratione videtur, quod si praelatus vt praelatus denarios, vel quicquid aliud dare iurauit, dimissa praelatura, persona non remanet obligata, $\mathrm{i}(\mathrm{nfra})$ de no(vis) ope(ris) nun(ciatione) c. 2 (X.5.32.2) ..., et hoc est verum, quod de pecunia dictum est, si in vtilitatem praelaturae pecunia fuit versa: aliter secus ...'?

55 Dig.26.9.5pr (Papin. 5 resp.): 'Post mortem furiosi non dabitur in curatorem qui negotia gessit iudicati actio, non magis quam in tutores, si modo nullam ex consensu post depositum officium novationem factam et in curatorem vel tutorem obligationem esse translatam constabit.' 
the church, but for his own business'. ${ }^{56}$ The most interesting part of this passage - something that is not found often in Baldus - is the description of the way in which the incumbent assumes an obligation for the office. When the prelate tenders his oath for the church, says Baldus, it is not the person of the prelate who does so: the prelate acts 'as someone else' (tamquam alius). Hence the relationship with the case of the ex-guardian: after the death of the insane, the guardianship is extinguished. So it is not possible to enforce a judgment against the guardian: the guardian, reasons Baldus, no longer exists. What is left is only the individual who used to exercise that role. And this individual is liable only for his own obligations.

\subsection{Collegiate bodies and possessory issues}

Just as the Crown needs the king, so the church needs the prelate: 'the church may do nothing without the prelate, nor the prelate can do anything without the church'. ${ }^{57}$ The metaphors of the phoenix and of the wardship, previously used for the Crown, are here replaced by the ecclesiological concept of 'mystical body' where the prelate, becoming one with the church, is considered almost as the 'true soul' (vera anima) that directs the 'true body' (verum corpus) of the church. ${ }^{58}$ But here as well the purpose is eminently practical: to explain - and circumscribe - the concept of representation. Without the 'body' (the church), the prelate would be, so to speak, 'pure soul': he could not act. This is because his action would not be that of the representative, but of a private individual - and so, ultimately, not done as prelate. ${ }^{59}$

Between Crown and church, however, there is an important difference. Not all ecclesiastical dignities are individual offices. It is only when the office is

Baldus, ad X.1.6.34, $\mathbb{S}$ Venerabilem (Baldvs svper Decretalibvs, cit., fol. 65vb, n. 14): 'Quero prelatus nomine prelature iurauit aliquid soluere debere tandem vitio suo depositus est ab officio, vel renuntiauit in manibus superioris, vtrum sit liberatus a vinculo iuramenti, dicit Io(hannes) an(dreae) quod sic, quia non iurauit tanquam ipse in propria persona, sed tanquam alius in persona ecclesie [cf. supra, this paragraph, note 54], ff. quando ex facto tutorum, $<\mathrm{l}$. $>$ vel post mortem (Dig.26.9.5), quod verum est si debitum erat contractum pro vtilitate vel necessitate ecclesie secus si pro negotiis proprijs.'

57 Id., ad X.2.13.5, $\$$ Item cum quis (ibid., fol. 150ra, n. 5): 'Ultimo no(tatur) quod ecclesia sine prelato nihil agit nec prelatus sine ecclesia sicut tutor onerarius non habens administrationem, vtff. de sol(utionibus) 1 . quod si forte $\mathbb{S i}$ (Dig.46.3.14.1).'

58 Ibid., 'Ex his apparet quod ecclesia et prelatus sunt vnum corpus misticum sicut verum corpus et vera anima ipsius sunt vnum quid naturale.' Cf. Meder (2015), pp. 44-46.

59 Supra, this paragraph, note 57. 
represented by a single person that proper representation occurs. A typical example is that of the bishop: whenever the bishop exercises his jurisdiction, he does not do so as an individual person, but rather as the incumbent of the dignitas he represents. ${ }^{\mathbf{6 0}}$ The image of the bishop is also useful for introducing another figure, that of the cathedral chapter that should elect him. ${ }^{\mathbf{6 1}}$ Unlike the episcopal dignitas, the chapter is a collegiate body: no private individual in a collegiate body may be considered to act as its legal representative. We have seen that the office does not will. But the formation of its volition may be entrusted to a single person or to a plurality of individuals. In this second case, the will of no single individual translates directly in the volition of the office. This is why the case of the chapter was a favourite of Innocent for highlighting the difference between the two instances.

Baldus elaborates on the point when looking at issues of the possession of incorporeals. As no one may take possession of what has no body, in Roman law a servitude is typically lost through non-use. Some servitudes, however, are not meant to be used. They are called negative servitudes. In the case of negative servitudes, the right is lost through passive acceptance of a behaviour that is incompatible with the servitude itself. So, for instance, the right to a view is lost when the owner of the building that enjoys that servitude lets his neighbour build up without doing anything. Could the right of election be lost in the same way? Except for servitudes, a right is not lost by simple non-use. But, on a practical level, the possession of that right might. Therefore, asks Baldus, if an appointment is made by someone other than the person who has the right to do it without opposition, does this inertia lead to the loss of the possession of the right? The answer, explains Baldus, depends on whether the person who did not

60 Baldus, ad Cod.3.34.2, \Si aquam (svper Primo, Secvndo \& Tertio Codicis, cit., fol. $217 v b$, n. 53): 'Sed pone quod episcopus vtatur iurisdictioni episcopali: quero an dicatur in episcopali possesione sine ecclesia uel persona. Dicit Inno(centius) quod ecclesia, quia is possidet cuius nomine possidetur, vt no(tat) Inno(centius) de reli(giosis) do(mibus) c. cum dilectus (X.3.36.8). Intellige quod non possidet persona, s(cilicet) nomine suo proposita; sed si nomine appellatiuo possidet, bene possidet.' We have seen how Innocent relied on X.3.36.8 to highlight the difference between de facto exercise of jurisdiction and de iure representation supra, pt. II, $\$ 7.6$.

61 It should however be noted that, by the second half of the fourteenth century (when Baldus was writing), the role of the chapter in the episcopal election was more important in theory than in practice: by then, episcopal elections were mostly papal appointments. In the period between Innocent's and Baldus' times, the old practice of the election had progressively been eroded by the increasing intervention of a series of popes (starting with Innocent IV himself). This effectively made a good part of the complex set of provisions on elections in canon law somewhat obsolete. Cf. most recently Larson (2016), pp. 75-76, text and note 4 , where ample literature is listed. 
oppose the usurpation of the right represented the office by himself, or was simply one of the individuals who contributed to form the office's will. In other words, if the right to make the election belonged to an individual office, then the office would lose the possession of that right through the inertia of its representative. If however the right belonged to a collegiate office (such as the chapter), then the solution would be the opposite. The reason, concludes Baldus, is that the persons who make the election act 'as a chapter' (ut capitulum), not 'as single individuals' ( $u$ t singuli). Given the collegiate nature of the office, the inertia of any single person may not be imputed to the office itself. ${ }^{62}$ In stating as much Baldus relies openly on Innocent (who, admittedly, was perhaps clearer on the point). ${ }^{63}$ Later, when writing his commentary on the Liber Extra (and so, interestingly, during the Great Schism) ${ }^{\mathbf{6 4}}$ Baldus would apply the same reasoning to the cardinals' possession of the right to elect the pope: the cardinals hold that right not in their own name, but for the universal Church. As such, he argues, even if they were to lose possession of that right, the Church would still retain it. ${ }^{65}$

Baldus, ad Cod.3.34.2, $\$$ Si aquam (svper Primo, Secvndo \& Tertio Codicis, cit., fol. 117rb, n. 42): 'Queritur an negligens perdiderit possessionem. Sol(utio), secundum Innoc(entium) aut electio erat penes capitulum aut penes istum negligentem tanquam penes singularem personam. Primo casu aut eodem iure spectabat electio ad omnes, et tunc non perditur possessio. Et ratio est ista: quia ille potest perdere possessionem qui eam haberet; sed iste non habet possessionem, sed capitulum: ergo eam perdere non potest. Capitulum vero eam retinet: quia eligentes eligent vt capitulum, non vt singuli.'

63 Innocent IV, ad X.1.6.24, $\$$ Qvaerelam (Commentaria Innocentii Quarti, cit., fol. 54va, n. 3): 'Et not(atur) quod licet per vnum annum, vel plures ego omiserim ex causa petere debitam pensionem, vel si vna vice omisi interesse electioni, non propter hoc amitto possessionem, quae sine animo non amittitur, sed quando petam pensionem, si denegetur, tunc amitto possessionem, argu(mentum) C. de ser(vitutibus) et aqua l. fin. (Cod.3.34.14) et tunc possum vti interdicto recuperandae possessionis ... Et hoc verum est, quando sum in possessione interessendi electioni, sed secus esset si essem in possessione, quod solus eligerem, quia tunc si alius eligat, et pro electo habeatur a subditis bene amitto possessionem, quia non videor habere animum retinendi possessionem, cum electum ab alio patiar vti dignitate sua, sed cum debeo interesse electioni electio, non fit nomine cuiuslibet canonici singulariter, sed nomine capituli, et ideo non priuatur possessione ille qui contemnit et qui non interest, quia capitulum quod est in possessione eligendi, non priuatur possessione eligendi, nec etiam ille, qui non interest, quia ille non suo nomine hoc ius possidebat, sed capituli'.

64 Baldus wrote his commentary on the Liber Extra (rather, on the first two books and the beginning of the third) in the last decade of the fourteenth century: see esp. Colli (2005), pp. 77-79. Cf. Canning (1989), p. 9, note 30.

65 Baldus, ad X.1.3.25, $\$$ Olim ex literis (Baldvs svper Decretalibvs, cit., fol. 38ra, n. 21): 'sive per veros cardinales sive per falsos papa eligatur ecclesia semper retinet 
Other possession-related issues help to gain further insights into the matter. If a prelate loses possession of his office, asks Baldus, should he act in his own name or in the name of the office he represents? Relying once again on Innocent, Baldus opines that the prelate might well act in either capacity - as a private person or as the lawful representative of the office. Acting as a private person would be easier, for he should only prove the dispossession. Acting as the representative of the office would also be possible, just slightly more complex, since the prelate should first of all prove his right to represent the office. ${ }^{66}$ In relying on Innocent, Baldus omits a detail in the pope's reasoning. That detail is trivial in itself, but interesting for our purposes. Also for Innocent the dispossessed prelate could act either in his own name or - with a slightly more complex procedure - in the name of the office (just as Baldus reports). But then, added Innocent, it would be perhaps better that the prelate acted in his own name. For the intruder sought to deprive the incumbent of his office, not to dispossess the office itself. ${ }^{67}$ The comment was only apparently a sophism: in

possessionem vt l. quesitum [sed 'l. Qui fundum'] ff. quemadmodum ser(vitudes) amit(tuntur) (Dig.8.6.12), nec potest ecclesia vniuersalis desinere possidere quia non potest expelli. Ita quia in iuribus incorporalibus nemo mero iure eiicitur vt ff. de vsu(rpationibus) l. sequitur $\$$ si viam (Dig.41.3.4.26), et si expellerentur cardinales tamen quia ipsi non possident nomine suo sed nomine totius catholice ecclesie ipsa vniuersalis ecclesia non perdit possessionem eligendi.' Cf. Tierney (1998), p. 195; Wilks (1963), p. 511, note 5.

66 Id., ad Cod.3.34.2, \$Si aquam (svper Primo, Secundo \& Tertio Codicis, cit., fol. 218ra, n. 60-62): 'Item queritur an prelatus expulsus aget interdicto recuperande possessionis vel ex canone reintegranda suo nomine an nomine dignitatis. Respondeo: restitutione possessionis prelature et iuris episcopale et generaliter et in genere petit suo nomine: sed restitutione fundi vel domus petit nomine ecclesie. Officium enim est proprium persone ipsius; res autem et possessio iterum est ecclesie non persone, vt in c. <in> literis (X.2.13.5) per Inno(centium). Iuxta hoc queritur an prelatus suo nomine habeat aliquam possessionem rerum ecclesie. Dicit Inno(centius) quod suo nomine habet naturalem sed nomine ecclesie habet naturalem et ciuilem in d. c. in literis (X.2.13.5), ergo duo possident naturaliter $\mathrm{s}$ (cilicet) prelatus et ecclesia quod est impossibile. Item si prelatus suo nomine possidet, ergo suo nomine agit quod $s$ (upra) ipse negasse videtur, sed respondet utroque modo potest agere, sed consultius facit agere nomine proprio: quia si ageret nomine ecclesie haberet necesse se probare canonicum vel prelatum esse nec sufficeret sibi esse in possessione ... Sed si agit nomine suo sufficit sibi probare de nuda possessione secundum Inn(ocentium). Aperte dicit ergo hic Innoc(entius) quod agenti nomine ecclesie non sufficit probare de possessione: sed debet probare de canonica installatione.'

67 Innocent, ad X.2.13.5, $\mathbb{S}$ Prius (Commentaria Innocentii Quarti, cit., fol. 228ra-b, n. 8): 'Sed alijs qui nituntur authoritate superioris, et ius habent in dignitate, vt sunt confirmati, non est vtile proponere interdictum recu(perandi) pos(sessione) suo nomine ad recuperandam possessionem rerum ablatarum, quae ad dignita- 
fact, it was a subtle point. Dispossession of lands, buildings or rights pertaining to ecclesiastical offices was common practice (and a very frequent cause of legal disputes). In those cases the offence was clearly addressed to the office, which would suffer a prejudice. But it is difficult to see exactly why dispossessing the person should amount to a prejudice to the office. Hence Innocent's point.

\subsection{Incumbent versus office}

The most interesting pages of Baldus on representation issues are on individual offices, not collegiate ones. Here lies Baldus' most original contribution to Innocent's theory: the inner limits of the validity of the commands of the incumbent. In this regard, the description of officium in terms of dignitas is of particular importance. We have seen that the double meaning of dignitas - moral and legal - does not apply only to the person holding the office, but also to the office itself. The office is a dignitas not only in the legal sense of a persona ficta. The Pauline image of the world as a concentric series of 'ordained powers' that we saw earlier ${ }^{68}$ coloured the office with both legal and moral values. So for instance the dignitas of the papacy is supreme, not just because it is placed at the apex of the jurisdictional pyramid, but also because it embodies Christian values in their highest degree. And this higher moral worthiness justifies the exercise of a jurisdiction higher than any other. The same goes for the dignitas of the (imperial) Crown. The two meanings of dignitas (legal and moral) are closely related with each other, but the person of the incumbent can be easily separated from the office he represents. The office acts only through its legal representative, but not all the legal consequences of the person's acts (in terms of legal obligations) are to be referred to the office. We have already seen as much.

In particular cases, it is even possible to separate (at least in part) the legal meaning of dignitas from the moral one. The typical example in medieval canon

tem pertinent, quia non possidet pertinentia ad dignitatem nomine suo, sed nomine dignitatis, nomine ergo dignitatis quae est expoliatio intendet possessorium, vel petitorium. Si tamen vellet suo nomine petere restitutionem possessionis in genere iuris canonicalis episcopalis generaliter, et in genere bene faceret, quia illud in genere possidet nomine suo tantum, et quia spoliator ipsum spoliare intendebat, non ecclesiam, $\sup ($ ra) de caus(a) pos(sessionis) $<\mathrm{c}$. $>$ cum super (X.2.12.4). Tamen ad hoc, vt possit petere restitutionem possessionis generaliter, oportet quod superioris authoritate eius, scilicet, ad quem pertinet ex officio habuit possessionem generalem dignitatis, scilicet, per installationem, vel alium modum consuetudinarium, vel etiam sententiam, vt hic et $\inf (\mathrm{ra})$ sequitur.' By contrast, when it is the intruder who is deprived of possession, he may seek to be reinstated but can only act as a private individual ('et agatur proprio nomine tanquam spoliati possessione iuris canonici', ibid).

Supra, this chapter $\$ 11.1$, text and note 8 . 
law is that of the insane bishop. The mentally ill bishop cannot be forced to resign from his dignitas, but he may be deprived of its exercise because of his incapacity. ${ }^{69}$ We have already seen the opposition between subjective and objective dignitas with regard to unworthy prelates - schismatics, heretics and the like. In such cases the prelate was morally unworthy, and that ethical baseness ought to translate into legal incapacity. So the heretic was fully indignus - both unworthy and, in principle, also unfit. In the case of the insane bishop, much to the contrary, the lack of legal fitness to exercise his office has nothing to do with the underlying moral worthiness. This separation between the two faces of the personal dignitas entails a similar division with regard to the office. While retaining the dignitas of his office (he is still the head of the diocese), explains Baldus, the bishop however loses the power to act for it. ${ }^{70}$ The interest in this case lies ultimately in that the symmetry of the dignitas of person and office is maintained. The bishop remains morally worthy, but he is now legally unfit. Consequently, he is still worthy of the dignitas of his office, but is unable to exercise it.

We have previously seen how Baldus separated the person from the office and distinguished between obligations of the person qua individual and qua representative. If we coupled this distinction with the symmetry between the dignitas of the person and of the office, we may reach a further degree of separation between representative and office in Baldus - something that is not to be found in Innocent. The act of the king that goes against the dignitas of his office, says Baldus, is void.

To explain this point, we might go back to the image of the king as custodian of the Crown. The separation between person and office allowed a distinction between the personal obligations of the king and the undertakings of the Crown. But the same separation leads to another and more difficult issue: the validity of the acts carried out by the person of the sovereign against the Crown. The most important canon law source on the subject is probably Honorius III's decretal intellecto (X.2.24.33), which Baldus cites when distinguishing between the obligations of the person and those of the Crown. ${ }^{71}$ The decretal absolved and notes.

70 Baldus, ad Dig.26.5.8.1, $\mathbb{S}$ Si praetor (In Primam et Secvn[dam] infortiati partem, cit., fol. 29rb): 'Furor vel dementia superueniens non tollit dignitatem, sed administrationem sic. $\mathrm{H}(\mathrm{oc}) \mathrm{d}(\mathrm{icit})$ in tex(to) “momenti”: per hunc $\mathbb{\$}$ determinatur quod si Episcopus fiat furiosus, licet remanet Episcopus, non potest conferre praebendam quasi propter furorem sit priuatus exercitio dignitatis.' Cf. Dig.26.5.8.1 (Ulp. 8 de omn. trib.): '... quamvis enim praetor vel praeses sit nec furor ei magistratum abroget, attamen datio nullius erit momenti.'

71 Supra, this chapter, note 35. 
the king of Hungary from his oath to keep the previous alienations of the Crown's rights. The oath should not be kept, said Honorius, because it was incompatible with the crowning oath that the king had sworn beforehand, when he undertook to preserve the rights of the Crown. ${ }^{72}$ The case has been widely studied, ${ }^{73}$ but it is mentioned here for a different reason. It is on that decretal that Baldus builds the distinction between valid and invalid commands of the king. Baldus could have looked at the canon law sources prohibiting the incumbent from acting against the utility of the Church, but such examples might have not been useful with regard to the prince - just as they were not particularly elaborate with regard to the pope. ${ }^{74}$ Hence he opts for a reference to natural law: the orders of the person of the king that detract from the dignitas of the Crown are 'contra ius naturale' and so void. So the king may not order a subject to sacrifice his life for nothing, for that would go against natural selfpreservation. By contrast, when the same sacrifice is requested for the sake of the kingdom, then the command is valid. ${ }^{75}$ For our purposes, the most relevant

72 X.2.24.33: 'Intellecto iamdudum, quod carissimus in Christo filius noster Hungariae rex illustris alienationes quasdam fecerit in praeiudicium regni sui et contra regis honorem, nos, super hoc affectione paterna consulere cupientes, eidem regi dirigimus scripta nostra, ut alienationes praedictas, non obstante iuramento, si quod fecit de non revocandis eisdem, studeat revocare, quia, quum teneatur, et in sua coronatione iuraverit etiam, iura regni sui et honorem coronae illibata servare, illicitum profecto fuit, si praestitit de non revocandis alienationibus huiusmodi iuramentum, et propterea penitus non servandum.'

73 While the literature on the decretal Intellecto is vast, mention should be made at least of the classical work of Riesenberg (1956), pp. 48-58 and esp. 113-144 and 161-175, together with that of Post (1964), pp. 393-401 (where, significantly, the author ascribes the inalienability clause to the dignitas of the kingdom). For a more specific focus on the decretal as studied against the background of the relationship between the Hungarian Crown and the papacy see in particular Sweeney (1975), pp. 235-251, and Sweeney (1976), pp. 89-96. See also more recently Štulrajterová (2011), pp. 219-250, where further literature is listed.

74 In principle, even Innocent IV accepted that the pope could not act in a manner prejudicial to the 'general state of the Church'. But that limit proved a rather narrow one - particularly in Innocent, who clearly stated that the pope's command must be obeyed even if unjust. See esp. Innocent, ad X.5.39.44, $\$$ Mortale (Commentaria Innocentii Quarti, cit., fol. 555rb, n. 3): '... Sed quid si papa iniustum praecipiat, qui superiorem non habet, cum quo agi possit, potest dici, quod si de spiritualibus vel ecclesiasticis personis aliquid praecipit, etiam iniustum illud seruandum est, quia nemini licet de eius factis iudicare, 40 distin. $<$ c. $>$ si Papa (D.40, c.6), 11 quaestio $3<$ c. $>$ cuncta (C.11, q.3, c.17).' On the point see e.g. Tierney (1998), pp. 82-83, text and note 6, and esp. Buisson (1982), pp. 260-265 (where the passage of Innocent - here abridged - is reported in full, p. 262 note 134).

75 Baldus, cons.3.159 (Consiliorvm sive Responsorvm Baldi Vbaldi Pervsini, cit., fol. 46rb, n. 7-8): '... dumtamen non faciat aliquid, per quod minuatur honor 
element of Baldus' argument is not the reliance on natural law as an inner constraint on the power of the king, ${ }^{76}$ but rather, and once again, the distinction between representative and office. The command of the incumbent is void because it cannot possibly be imputed to the office he represents. So it remains the simple volition of someone who, as an individual, has no authority over the

coronae, uel status Regni, ut extra de iureiu(rando) c. intellecto (X.2.24.33) et ex hoc sequitur, quod donatio facta Titio militi ualuit. Secundo, praemittendum est, quod praeceptum Regis est seruandum, dum tamen sit iustum, uel saltem non iniustum. Unde si Rex praeciperet subdito suo, quod interficeret seipsum, uel iret ad locum, in quo trucidaretur ab hoste, uel mitteret filium suum ad uictimam, in hoc non est parendum Regi: quia talia mandata sunt contra ius naturale. Sed si mandat alicui, quod defendat patriam, et honorem Regis, etiam si hoc non posset fieri sine periculo, parendum est Regi: quia hoc ius regni erit etc. ... Per hoc reuertor ad propositum, si Rex mandauit, quod miteret filium suum pro obside, unus Christianus in manus saracenorum, uel crudelis tyranni, non ualeret mandatum: ut 1 . ut uim,ff. de iust(itia) et iu(re) (Dig.1.1.3) et ff. de cap(tivis) et $<$ de $>$ postl(iminio) reuer(tis) (sic), l. postliminium $\mathbb{S}$ filius (Dig.49.15.19.7), et totum hoc redigendum est ad arbitrium boni uiri; et per hoc apparet, utrum illi praecepto de mittendo filium in obsidem debuerit parere, uel non, ar(gumentum) ff. quod me(tus) ca(usa) 1 . isti quidem in fi. (Dig.4.2.8.3).' While the reference to Dig.1.1.3 was fairly obvious, that to a text as specific as Dig.49.15.19.7 was probably suggested by the comment in the Gloss, which linked patria potestas with natural affection, thereby suggesting (especially to a later jurist like Baldus) the connection with natural law. Cf. Gloss ad Dig.49.15.19.7 \Charitas (Parisiis 1566, vol. 3, col. 1673): 'id est patria potestas, quae fuit inducta propter affectionem liberorum iure ciuili Romanorum.' A similar position, although less elaborate, may be found in some passages of Baldus on the Liber Extra, especially ad X.2.19.9 (Baldvs svper Decretalibvs, cit., fol. 170va, n. 7): 'non tamen posset imperator donare claues imperii, sicut ille qui tenet claues portarum tenetur eas resignare successori, alias potest dici proditor vt no(tatur) C. de acq(uirenda) pos(sessione) l. fi. (Cod.7.32.12), ff. de le(gats) ii l. cum pater $\mathbb{S}$ pat(er) pluribus (Dig.31(.1).77.21). Item non potest viscera imperii euiscerare: quia esset homicida sue dignitatis.' The text is translated in English by Canning (1989), p. 87. Somewhat surprisingly, Baldus' comment on the decretal Intellecto itself is not particularly useful for our purposes, apart from its opening words: 'Rex debet esse tutor regni non depopulator nec dilapidator' (Baldus, ad X.2.24.33, Baldvs svper Decretalibvs, cit., fol. 214va, n1). See also Id., cons.1.271 (Consiliorvm sive Responsorvm Baldi Vbaldi Pervsini, cit., fol. 81vb, n. 3), on the relationship between prince and fisc. Cf. E. Kantorowicz (1953), p. 184; Riesenberg (1956), p. 18, note 31, and p. 150, note 13; Post (1964), pp. 345 and 388, note 51; Wahl (1970), pp. 320-324; Canning (1989), p. 216, note 38. The same Canning recently translated into English the most relevant part of the abovementioned consilium on the fisc: Canning (2015), p. 115.

76 The subject clearly borders on the vast theme of the progressive emergence of natural law principles as a constraint on the power of the ruler, a complex and manifold subject that may not be discussed here. For its application in Baldus see e. g. Pennington (1993), pp. 207-210. 
commonwealth. Otherwise stated, the king is the 'procurator maximus', chosen for his qualities: his higher dignitas, meant primarily in terms of moral worthiness, makes him especially suitable - dignus - for the role. ${ }^{77}$ But he is still a procurator. And so the same legal mechanism applies as for any other kind of representation. Just like any other representative, the king's jurisdiction derives from the right to exercise his office. When he gives a command that cannot be ascribed to the office, the command is void. After all, as Baldus says elsewhere, it is the king who is 'bound to his office', not the other way round. ${ }^{78}$

Assessing the validity or invalidity of the ruler's command, therefore, does not involve - at least directly - moral judgments, but legal representation. However, retaining the representation of the office - so de iure jurisdiction over the subjects - does not mean being able to do anything with the office. The proportionality of the dignitas of the incumbent to that of the office also works as a constraint on his actions. The more the office acquires specific and autonomous features (its own dignitas in both its moral and legal meanings), the more the principle of non-contradiction enters the picture: the office cannot act against itself. When the causa immediata of the act - the will of the incumbent - would lead to that, his volition may not be referred - as causa remota - to the office. It follows that an order of the king that would detract from the dignitas of his office cannot be ascribed to the office itself. In this case the order is void because it is not given by the king as representative of the royal dignitas but as a private person. The ward-guardian relationship is particularly useful for this purpose, for it presupposes the full separability between the two persons. And only a full separation between king and Crown could allow the case of a king to go purportedly against the interest of the Crown. To explain the point, once again Baldus uses the metaphor of the king as warden of the Crown. But, as always, the metaphor is a legal analogy: just as the guardian cannot kill the ward, so the prince may not

Baldus, cons.1.327 (Consiliorvm sive Responsorvm Baldi Vbaldi Pervsini, cit., fol. $101 v b$, n. 7): 'Imperator est procurator maximus, tamen non est proprietatis imperii dominus, sed potius officialis ex eius electa industria, vt ff. de curatore furiosi, 1. cuius bonis (Dig.27.10.9).' The lex Cuius bonis explained that the heir of the curator should not succeed him because he might not be suitable for the role. Cf. Dig.27.10.9 (Nerat. 1 membr.): ‘... Nam et tunc ex integro alius curator faciendus est neque heres prioris curatoris onerandus, cum accidere possit, ut negotio vel propter sexus vel propter aetatis infirmitatem vel propter dignitatem maiorem minoremve, quam in priore curatore spectata erat, habilis non sit.' In recalling that lex in the present discussion, Baldus highlights the role of the prince as procurator as opposed to dominus: he is elected to the office because he possesses the required qualities, not because he is entitled to it.

78 Baldus, ad X.2.24.33, \Intellecto (Baldvs svper Decretalibvs, cit., fol. 214vb, n. 5): 'Imperator rei sue potest dare legem quam vult et non obligatur homini sed deo et dignitati sue, que perpetua est.' 
be 'the murderer of his dignitas' (bomicida su<a>e dignitatis). ${ }^{79}$ The guardian must act in the interest of the ward. When he clearly does not, he is not acting in his capacity of guardian. The same applies with ecclesiastical offices: when the prelate acts in the name of the church he represents, he should not cause harm to the church. ${ }^{80}$ The resulting invalidity of the act is of great interest: the deed is void despite the presence of valid legal representation. Valid representation, therefore, does not necessarily ensure the validity of the deed.

Incidentally, it might be noted that the reason why Baldus does not follow Bartolus' famous distinction of tyrants between usurpers and despots ${ }^{\mathbf{8 1}}$ lies precisely in his more elaborate notion of representation and its inner constraints. The moral unworthiness of the despot (who however holds a valid title) is not sufficient to sever the link with the office. The despot, in other words, still retains full jurisdiction because he continues to be the lawful representative of the office. So his subjects may not rebel against him as if he were a usurper. ${ }^{\mathbf{8 2}}$ At the same time, however, this ruler may not invoke his valid title to impose on the office a will that would defile its dignitas. The prince acting for his private advantage and not in the interest of the commonwealth, says Baldus, would be 'almost a tyrant' (quasi tyrannus). ${ }^{83}$

\subsection{Confirmation in office}

We have said earlier that the last degree of separation between person and office in Baldus was the case of the individual office where the person representing the office is unworthy of it. This is in effect very close to Innocent's doctrine of toleration, which will be of extreme importance in the analysis of Baldus'

Ibid., ad X.2.19.9, supra, this paragraph, note 75 .

80 See e. g. Baldus, ad Cod.3.34.2, \$Si aquam (svper Primo, Secvndo \& Tertio Codicis, cit., fol. 218va, n. 73): '... si [praelatus] contraxerit nomine ecclesie vel dignitatis cum ius sit quesitum ecclesie non potest preiudicare ecclesie.'

81 Supra, pt. I, $\$ 4.4$.

82 Baldus, ad Dig.1.1.5, $\mathbb{}$ Ex hoc iure (In Primam Digesti Veteris Partem, cit., fol. 11rb, n. 6-8): 'Secundo quaeritur, an regem propter suas iniustitias intolerabiles, et facientem tyrannica subditi possint expellere? ... Contrarium est verum, quia subditi non possunt derogare iuri superioris: vnde licet de facto expellant: tamen superior non amittit dignitatem suam'. Cf. Canning (1988), pp. 463-464, and Canning (1989), pp. 218-219.

83 Id., ad Feud.1.13(14)pr (Lectura super Usibus feudorum, Papiae [Birreta et Girardengus], 1490 [fol. 26ra]): '... Unde imperator quasi tyrannus esset si non tanquam respub(lica) gereret se: et multi alij reges qui priuate sue vtilitati negociant(ur), quia predo est qui non vtilitatis domini sed proprie studet.' Cf. Canning (1989), pp. 90-91. 
reading of the lex Barbarius. Before looking at toleration in Baldus, therefore, it is important to briefly mention his stance on the role of confirmation.

We have often remarked how closely Baldus' doctrine of representation followed that of Innocent. When looking at Innocent, we have seen how the pope emphasised - more than most canon lawyers - the role of confirmation. Not only is confirmation always necessary to represent the office validly, but it may even cure the invalidity of the appointment itself. Just as the invalid election followed by confirmation leads to its full validity, however, so for Innocent the valid election without confirmation entails the invalidity of the exercise of the office - without exception.

Baldus also follows Innocent on the importance of confirmation. Finding a foothold in the Roman sources was not easy, but Baldus manages to identify an (admittedly, loose) parallel with canon law sources in the title of the Code on the guardianship of high-ranking wards (Cod.5.33). One of its provisions allowed the 'old laws' to be followed and a number of suitable persons to be selected, among whom the pretorian prefect would choose one. ${ }^{\mathbf{8 4}}$ This two-step procedure of selection and appointment in Roman law might somehow recall the two-phase procedure of election and confirmation in canon law. ${ }^{85}$ Having found proof of a sort that confirmation also applied to secular offices, it remains to be seen whether it would also produce the same effects in civil law.

Innocent made sure to put as much distance as possible between the true and the false incumbent. He did so both highlighting the healing effects of confirmation on the underlying defects of the elected, and levelling the accusation of being an intruder at anyone who administered the office without

Cod.5.33.1.1 (Valentinianus, Theodosius et Archadius AAA. Proculo PU.): 'Et si regendis pupillaribus substantiis singuli creandorum pares esse non possunt, plures ad hoc secundum leges veteres conveniet advocari, ut, quem coetus ille administrandis negotiis pupillorum dignissimum iudicabit, sola sententia obtineat praefecturae, super cuius nomine, sollemnitate servata, postea per praetorem interponatur decretum.'

85 Baldus, ad Cod.5.45.2, \$Non vtiliter (svper Quarto, et Quinto Codicis, cit., fol. $199 v b$ ): 'videtur quod prelatus non admittatur ad agendum nisi faciat fidem de sua prelatione, $\mathrm{i}(\mathrm{d}$ est) quando sit electus et confirmatus quod est no(tatum) $s$ (upra) de tu(toribus) et cu(ratoribus) illu(strium) perso(narum) 1.1 (Cod.5.33.1).' Both leges (the one commented upon, Cod.5.45.2, and the one just referred to, Cod.5.33.1) would strengthen Baldus' argument on the necessity of the confirmation, and could be opposed to others stating 'quod sufficit esse in possessione pacifica et quod publice reputatur pro prelato, et not(atur) in c. querelam, de elect(ione) (X.1.6.24)', ibid. On the contrary, the leges above are clear: 'ubi requiritur confirmatio tutoris, et non est facta: ibi non tenet iudicium', ibid. 
first being confirmed. Baldus follows Innocent - almost - to the letter. ${ }^{\mathbf{8 6}}$ Any defect in the person who is in possession of the office can be divided into two kinds, according to whether or not he is confirmed in office. Without confirmation, the possessor (whether validly elected or not) is an intruder, and so an 'utterly false prelate' (funditus falsus praelatus). Even if the pope himself was found to be an intruder, says Baldus, not only all his spiritual deeds, but also his temporal ones would be quashed. ${ }^{87}$ His sentences would have the same strength as of those of a false judge - that is, none. ${ }^{88}$ The intruder in office is the opposite of its legal representative. Absence of confirmation amounts to lack of representation: 'anyone who is not confirmed is an intruder'. The legal inability to represent the office entails the invalidity of any deed made in the name of the office. $^{89}$

By contrast, someone who is confirmed is never 'utterly' a false prelate and so neither is he an intruder. ${ }^{90}$ Confirmation is different from election, says Baldus,

The only exception is the validity of the administration done by the bishop-elect (that is, after the election but before the confirmation). The position of Innocent was uncompromising (supra, pt. II, \$7.6, text and note 124), but in the Gloss of Parmensis that position was accused of subordinating the good of the Church to legal subtleties (supra, pt. II, $\$ 8.1$, note 15 ). On the matter, Baldus sides against Innocent: seeking to apply the law to the letter, he argues, would do more harm than good. Baldus, ad X.1.6.44, $\mathbb{\$}$ nichil (Baldvs svper Decretalibvs, cit., fol. 69vb, n. 10): 'illi qui nunquid habuerunt canonicam possessionem quia non intrauerunt per ostium dicuntur intrusi, inde confirmatio superioris administrationem eorum tuetur fauore ecclesie et contrahentium secum: quia non expedit ecclesie in omni contractu de iuris apicibus disputare et quia exercitium possessionis est sicut quoddam ire et agere quod competit ex natura possessionis.' Perhaps to avoid the problem about the precise boundaries between ordo and iurisdictio, Baldus often prefers to speak of spiritual and temporal spheres: see esp. infra, this chapter, $\$ 11.7$.

88 Baldus, ad X.1.6.44, \nichil (Baldvs svper Decretalibvs, cit., fol. 70va, n. 13): 'Quia modo dubitatur si papa est intrusus tamen hic est dubium vtrum valeant gesta per eum. Dicit Inn(ocentius) quod nullus intrusus potest exercere spiritualia licet communis opinio laboret pro ipso: vnde licet interim conniuentibus oculis transeamus tamen decreta veritate quicquid ad spiritualia pertinet cessabitur et etiam alienationes temporales et omnes sententie $a b$ eo prolate precedentes tanquam a iudice incompetenti, immo tanquam a falso iudice late.' The point is interesting also because Baldus wrote this text during the Great Schism: supra, last paragraph, note 64 .

89 Baldus, ad Cod.3.34.2, $\$$ Si aquam (svper Primo, Secondo \& Tertio Codicis, cit., fol. 219ra, n. 84): 'Omnis enim non confirmatus intrusus est: et ideo nec ei nec gestis ab eo ius ciuile fauet nec patrocinatur: et nil valet in his quae facit temporaliter vel spiritualiter.'

90 Ibid., fol. 218va, n. 73: 'quandoque ille qui est in possessione est funditus falsus prelatus: et talis possessio non patrocinatur: vt not(atur) in l. ii ff. alias C. quando 
but it presupposes it. ${ }^{91}$ It follows that an ipso iure void election cannot be confirmed. ${ }^{92}$ On the matter, once again, Baldus builds on what Innocent said. Innocent distinguished invalid elections according to the kind of rule that was violated. If it was a rule of natural law (which for him ultimately meant, of divine law), ${ }^{93}$ then the election was ipso iure void and it could not be confirmed. By contrast, when the invalidity depended from the violation of a rule of positive law, the election could be confirmed. ${ }^{94}$

Regrettably, Innocent did not explain this difference in detail. More precisely, he did not say which rules in the election process were of natural law and which of positive law. The main example he gave of an election made in breach of natural law was remarkably ambiguous, for he referred to simony. Simoniacal elections are void also for natural law, said Innocent, so the elected ought not to

ex fac(to) tu(toris) (Dig.26.9.2; Cod.5.39.2), quandoque non est funditus falsus, quia habet confirmationem superioris.' This confirmatio, explains Baldus, 'valet licet confirmatus sit indignus', ibid.

91 Baldus, ad X.2.13.5, In literis (Baldvs svper Decretalibvs, cit., fol. 149va, n. 5): 'confirmatio ... est actus diuersus, et per se fiens: non tamen per se stans.'

92 Ibid., n. 6: 'Quero aliquis est intrusus fuit confirmatus per superiorem an teneat confirmatio: respondeo non.' In this case Baldus referred to the intrusus to signify someone who was not even elected.

93 See for all the simple but profound introduction of Kuttner (1949-1950), esp. pp. 87-105.

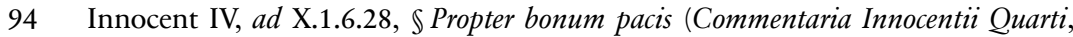
cit., fol. 59rb-va, n. 8-9). The importance of this passage for Baldus' approach to the lex Barbarius (both here and in the next chapter) suggests to report the most important parts of it: 'vix est electio, nisi omnia iura solennia obseruentur, et tamen ideo non est nulla, nec cassatur electio. In alio autem casu, scilicet, quando ea interueniunt, quare est nulla electio de iure positiuo, sed alia de iure naturali, tunc distingue: quia si dolus vel delictum electi, vel eligentium fecit, quod electio sit nulla etiam de iure naturali, vt quia intrusus est vel simoniace electus, tunc semper habet locum regula praedicta, scilicet, quod deponatur ordinans et ordinatus, nec tenent ordinationes eorum, quod ad executiones, 62 distinct. c. i (D.62, c.1) ... si autem dolus vel delictum non fuit tale, quod electionem faceret nulla, sed annullandam, vt contemptus alicuius qui electioni interesse debet, tunc non debet renunciare beneficium si quaesitum, nec peccat tenendo contra voluntatem contempti, nisi prohibeatur a iudice ... si autem delinquit tacendo irregularitatem suam, tunc omnibus modis debet offerre renunciationem suam, et peccat tacendo beneficium, sed tamen dispensabit superior in aliquibus irregularibus.' The distinction seems based on the opposition between voidness and voidability: when the election is made in violation of a human rule (i. e. of positive law) but not of natural law, then it is necessary to pronounce such an election void. The pronouncement is constitutive: it avoids the election. The point is of great importance: so long as not formally pronounced void, the voidable election also confers executio. This is the case, for instance, of the elected who would not disclose his personal incapacity. In 
be confirmed, but rather deposed together with the electors. ${ }^{95}$ The ambiguity lies in that arguing that simoniacal elections remain ipso iure void would clash with all the cases where the same Innocent used the occult simoniac confirmed in office as an example of toleration. While the point remains unclear (Baldus would later say that Innocent simply changed his mind), ${ }^{\mathbf{9 6}}$ it would seem that Innocent was focusing on the issue of ordo, not of iurisdictio. Indeed, he continued saying that the ordinations made by those who bought their election would not hold, for they lacked executio ordinis. ${ }^{97}$ It might well be, therefore, that Innocent simply referred to the invalidity of sacramental acts performed by the simoniac, not to his jurisdictional powers. ${ }^{98}$

Let us leave for the moment the case of ipso iure invalidity of the election. The image of the intrusus who did not have canonical entry derived from the Gospel: the Lord is the Door ('Ego sum ostium'), and those who enter through that Door shall be saved. By contrast, he who does not enter through that Door does not

this and similar cases, concludes the pope, 'ordinationes eius executionem habent, quia non erat nulla electio de iure naturali, sed deponendus erat' (ibid., fol. 59va, n. 8).

95 Ibid. Commenting on the same subject (but before distinguishing between violations of natural law and of positive law) Innocent also considered ipso iure void the election of the bishop made by the emperor or a king (ibid., ad X.1.6.28, S infirmanda, fol. $58 v a-b, \mathrm{n} .3-4)$. Such an election may be quashed even after the confirmation, argued Innocent, despite the formal validity of both confirmation and consecration ('licet confirmatio et consecratio rite factae sint', ibid., fol. $58 \mathrm{vb}$, n. 4).

96 Infra, next chapter, note 53.

97 Supra, this paragraph, note 94 . The only reference provided by Innocent on the consequences of simoniacal elections in this passage was a text of the Decretum (D.62, c.1), which argued for the invalidity of the simoniacal election of a bishop, and similarly avoided the ordinations made by such pseudoepiscopi. Dealing only with sacramental issues, however, the text left untouched the validity of the administrative (and so, jurisdictional) deeds of those 'pseudobishops'.

98 This was also the impression of later civil lawyers, who read Innocent as allowing the confirmation of the occult simoniac - and criticised him for that. See for instance Albericus, reporting the thinking of his teacher Jacobus de Belviso: '... secundum Inno(centium) si est confirmatus per superiorem et est occultus de symonia, valent gesta: quia ex confirmatione accipit potestatem administrandi, $<$ extra $>$ de elect(tione) c. transmissa (X.1.6.15), et not(atur) per d(ictum) c. quod sicut et c. nihil (X.1.6.28 and 44) et ar(gumentum) ff. quod falso tutore autho(re) 1. i $\$$ pen(ultimo) (Dig.27.6.1.5) ... quod non placet Ia(cobo) praedicto: quia in $\$$ pe(nultimo) (Dig.27.6.5) praetor decreuit se ratum habiturum, quod plu(s) operatur quam simplex confirmatio.' Albericus de Rosate, ad Cod.7.45.2 (In Secundam Codicis Part[em], cit., fol. 117ra, n. 9). 
come from Christ, and seeks only to steal and kill. ${ }^{99}$ To stress Innocent's point on the strength of the confirmation, Baldus looks back at the origin of the metaphor of the intruder and gives an extreme case: what if the intruder himself was elected by those who steal and kill - that is, by robbers? Not only is this prelate a robber (according to the image in the Gospel), but he is actually appointed by other robbers. The strength of this image gives the measure of the strength - and the scope - of confirmation itself. The election by the robbers is surely voidable, says Baldus, but it is not ipso iure void. If this prelate were to be confirmed by the superior authority, therefore, even such a repugnant election would hold. ${ }^{100}$

\subsection{Toleration and representation}

The intruder is someone who is not confirmed by the superior authority. When the superior authority removes the lawful incumbent from office, it also removes the confirmation previously bestowed upon him. This way, from Innocent's perspective, the status of the deposed is ultimately the same as that of the nonconfirmed.

As deposition severs the link between incumbent and office, it does not operate retroactively. Whatever was done between confirmation and deposition was done by the lawful representative, and so remains valid even after his deposition. ${ }^{101}$ In severing the link between person and office, however, the

99 John, 10:9-10. Cf. Baldus, ad X.1.6.44, \$nichil (Baldvs svper Decretalibvs, cit., fol. $69 v a$, n. 3): 'Intrusus enim dicitur omni qui non intrat per ostium id est qui non habet canonicum ingressum.'

100 Baldus, ad Cod.3.34.2, \Si aquam (svper Primo, Secvndo \& Tertio Codicis, cit., fol. 219ra, n. 81): 'Sed quid si electus a predone est confirmatus a superiore? Respon(deo) omnes ei tamquam legitimo respondebunt: propter vim confirmationis facte cum ordine iuris: ut no(tatur) in $\mathrm{d}$ (icto) c. in literis (X.2.13.5) per Innoc(entium). Nam electio facta a predone non est nulla ipso iure, sed debet cassari postquam constet quod inique possidet, et non ante. Et ideo in re dubia tenet confirmatio, vt d(ictum) c. in literis (X.2.13.5) per Inno(centium). Innocent stated the rule (supra, pt. II, $\$ 7.1$, notes $7-8$ ), but the example of the robbers was from Baldus.

101 The point is particularly clear in the case of the confirmation of someone who could not be confirmed. The Liber Extra provided for the deposition of both the confirmed and the person who confirmed him. This way, the problem of the validity of the acts became particularly acute. Baldus ad X.1.6.44, \$ nichil (Baldvs svper Decretalibvs, cit., fol. $69 v a$, n. 2): 'In gl(osa) magna [scil., Innocentii] ibi "sed pone" querit gl(osa) nunquid facta ab eo qui administrabat vt prelatus qui tamen postea est remotus valeant [cf. Innocent, ad X.1.6.44, $\mathbb{S}$, Administrent (Commentaria Innocentii Quarti, cit., fol. 74vb, n. 3), supra, pt. II, \$7.6, note 121] ... et dic quod si status remotionis non apponitur ad principium tituli sed ad ius iam 
deposition prevents the continuation of the representation mechanism: the deposed is no longer entitled to act in the name of the office. If he continued to occupy it, that would just amount to undue ('abusiva') possession. Deposition, says Baldus, 'changes the cause of possession from something into nothing. ${ }^{102}$ Any further deed would therefore be void. ${ }^{103}$

While the status of the acts carried out by the intruder or the deposed is clear in both cases they are void - the problem is to qualify the acts of someone who is neither an intruder nor fully legitimate to exercise the office. On the point, it is important to recall what was said earlier on the concept of dignitas. The relationship between dignitas of the office and dignitas of its holder renders all the more acute the problem of the indignitas of the person. If dignitas means both moral worthiness and legal fitness, those non digni are (morally) unworthy as much as they are (legally) unfit. Because of their indignitas, they are precluded from reaching higher offices. ${ }^{104}$ Letting the indignus occupy a dignitas would be a contradiction in terms. But what if it happens? As we have seen, Innocent's answer was based on the concept of toleration. In turn, toleration was built on the confirmation of the superior authority and the distinction between apparent fitness and occult unworthiness of the confirmed in office.

quesitum non reuocatur gesta bona fide ... Tu dic standum esse huic decretali que tradit mediam iuris dispositionem vt valeant cetera preter alienationes: iste enim qui est in isto medio statu non dicitur intrusus sed quasi quidam curator bonorum.'

102 Baldus, ad X.1.6.44, $\$$ nichil (Baldvs svper Decretalibvs, cit., fol. 69vb, n. 10): 'Adde quod nullus habens canonicum ingressum ad titulum et possessionem est intrusus nisi sit depositus vt hereticus vel per sententiam superioris quia depositio mutat causam possessionis de aliqua in nulla, siue de canonica in abusiuam, etiam si de facto possessio continuetur.'

103 On the point, Baldus might have misread a passage of Innocent. Baldus reports disapprovingly - of the pope's insistence that the deposed should also be dispossessed, lest he validly continue to take part in the formation of the will of the office. Innocent however was only referring to possessory matters without any reference to representation issues. Baldus, ad Cod.3.34.2, $\$$ Si aquam (svper Primo, Secundo \& Tertio Codicis, cit., fol. 218rb, n. 66): 'Sed hic queritur an canonicus priuatus canonicatu per sententiam perdat ipso iure stallum in choro et locum in capitulo: an vero opus quod distalletur per superiorem. Dicit Inno(centius) in c. in literis (X.2.13.5) quod requiritur distallatio sicut degradatio secundum Innocen(tium). Sed ego credo quod etiam si esset in possessione nullos actus potest interim facere in choro vel capitulo' (ibid., fol. 219ra, n. 84-85). Cf. Innocent, ad X.2.13.5 (Commentaria Innocentii Quarti, cit., fol. 228$r a-v a$, n. 8-11).

104 Baldus, ad Dig.3.1.7, $\mathbb{Q}$ Quos probibet (svper Primo, Secundo \& Tertio Codicis, cit., fol. 171 ra, n. 2): 'inhabiles ad honoribus, et dignitatibus repellantur ex officio superioris.' 
Toleration in office is not Christian forbearance but legal representation. Stressing the dignitas of the office, it is possible to overlook the indignitas of someone who occupies it, so long as that indignitas remains occult. This is not pragmatism - one would expect anything of Innocent but that. The apparent contradiction of the indignus enjoying a dignitas in fact attests to the crucial importance of confirmation, and explains its link with the toleration principle. The indignus could hold a dignitas and exercise the office because someone worthier (dignor) than him allowed as much by confirming him in that office. This way the requirement of confirmation by the superior authority shifts the focus from the indignitas of the person confirmed to the superior dignitas of the authority who confirmed him. We have seen how for Innocent only the occult unworthy could be tolerated in office. Limiting the scope of toleration only to occult indignitas is deeply connected with this shift of focus towards the higher dignitas of the superior authority, because only the latter is manifest. The occult indignitas of the individual is therefore contrasted with the manifest dignitas of the person who confirmed him in office. This contrast ultimately highlights the distinction between person qua individual and person qua incumbent. Confirmation in office gives a legal basis to this distinction and strengthens the opposition between hidden moral unworthiness and visible legal capacity. The defect in the individual is hidden, the approbation of the incumbent by the superior dignitas (i.e. his confirmation in office by him who holds a higher office) is manifest. Confirmation thus shifts the accent from the person to the representative: it bestows jurisdictional powers upon the incumbent but does not heal his hidden unworthiness as a person. So long as the defect remains occult, the person continues to exercise the office validly, because the identification between person and office allows an exclusive focus on the representative of the office and not on the person of the representative.

It may be recalled that, for Innocent, toleration would cease both when the crime of the unworthy became widely known and when it was legally ascertained. Baldus explains the affinity between these two cases (widespread knowledge and legal decision) by distinguishing between notorious and manifest crimes. A manifest crime is a plainly visible one, whereas a crime is notorious when either widely known or presumedly known. A crime may become plainly visible, for instance, when 'self-evident and irrefutable evidence' emerges during the trial. This also means that the manifest crime could be occult at the beginning. By contrast, says Baldus, the notoriety of the crime is such both 'at the beginning and the end'. ${ }^{105}$ Notoriety, however, has less to do with actual

105 Id., ad X.3.2.8, $\mathbb{\$}$ Tua (Baldvs svper Decretalibvs, cit., fol. 260rb, n. 22): 'Hec est differentia inter notorium et manifestum: quia notorium est in prin(cipio) et in 
'irrefutable evidence' and more with presumptive status. Notoriety may well derive from a widespread rumour. Rumours point towards a certain conclusion, but they are not full proof. In the words of Innocent (recalled by Baldus), they do not establish the truth, but provide a further reason to look for it. ${ }^{106}$

A legal decision goes in the same direction; only with more strength. What if, asks Baldus, a crime is not clearly ascertained (since there is no conclusive evidence) and yet the defendant is condemned all the same? Baldus' answer is that the crime would not be manifest but it would be notorious. In this case the notoriety does not derive from a widespread rumour but from legal truth, 'from the authority of the decision, which is taken as truth'. ${ }^{107}$ Unlike the notoriety of a rumour, legal truth couples presumption of knowledge (as the rumour) with a sort of 'presumed manifestness'. The crime is not manifest in itself, but it is presumed to be such. And this presumption is irrebuttable. The sentence of deposition of the unworthy, therefore, operates on two levels: it both makes the indignitas notorious and it establishes its truth judicially. Judicial condemnation makes the indignity both notorious and manifest. Hence the impossibility of tolerating the deposed from office. The requirement that the defect be occult means that toleration in office does not apply either in a case of supervening manifest indignitas (i.e. after the confirmation) or in a case of supervening manifestation of a pre-existing indignitas.

On the subject of toleration, Baldus relies on Innocent as usual. But he does not always reach the same solution, nor does he provide exactly the same explanation when he agrees with the pope. In particular, Baldus stretches the boundaries of toleration further than Innocent. He does so, as we shall see, by highlighting the importance of the possession of the office and downplaying the difference between possession and entitlement.

fi(ne), manifestum autem potest esse occultum in prin(cipio) quod sit manifestum in fine litis per probationes apertissimas et inexpugnabiles.'

106 Id., ad X.3.2.7, \$Vestra (ibid., fol. 259rb, n. 2): '... et iste est casus in quo probatur notorium et non probatur factum scilicet in notorio fame (sic) que describitur grosso modo vox populi et in vulgari dicimus vox populi vox dei, quia opi(nio) in qua omnes concurrunt vel maior pars, presumitur in se habere rationem ... et tamen per istam famam non probatur veritas, sed est quoddam motiuum ad inquirendum, secundum Inno(centium) i(nfra) eo [titulo] c. fi. [sed X.3.2.8, $\$$ Notorium; cf. Innocent IV, Commentaria Innocentii Quarti, cit., fol. 320ra-vb, n. 1-4].'

107 Baldus, ad X.3.2.7, $\$$ Vestra (Baldvs svper Decretalibvs, cit., fol. 259rb, n. 2): 'Sed pone quod nullo modo factum [scil., the fornication committed by a priest] est probatum, et tamen sententia condemnatoria est lata: nunquid crimen dicatur notorium? Respondeo sic, propter authoritatem sententie que habetur pro veritate, vt ff. de re(gulis) iur(is), 1. res iud(icata) (Dig.50.17.207).' 
Possession is a very malleable legal concept. Jurists often found it more useful than the black-and-white notion of right, especially in medieval public law. Innocent was not fond of ambiguities: any 'grey area' in the law ought to be reduced to its ultimate components, so as to be able to choose between them either black or white. Many practical situations, however, are intrinsically ambiguous. In such cases, forcing the application of general principles would mean squeezing the facts into neat legal categories. Baldus shows more interest in those 'grey areas'. The lex Barbarius, as we shall see, is one of such cases. This explains Baldus' greater emphasis on the concept of possession than on that of right.

The first and foremost consequence of the toleration principle is that the supervening invalidity, so long as it is occult, does not result in the automatic deposition of the incumbent from his office. It follows that even if the incumbent used his office to commit an offence, he would still retain the right to exercise it - until deposed by a legal decision. The Accursian Gloss discussed this specific matter especially with regard to the church's steward (oeconomus) who alienated ecclesiastical land in violation of an imperial edict. ${ }^{\mathbf{1 0 8}}$ The Gloss reached the conclusion that the steward was not automatically deposed from office because of the particular wording of the edict itself. ${ }^{109}$ Recalling that case, on the contrary, Baldus insists - as Innocent did - on the need for a specific sentence of condemnation in order to divest the incumbent of his office. ${ }^{\mathbf{1 1 0}}$ Unlike the Gloss, for Baldus the need for a legal sentence to depose the incumbent does not depend on the wording of a specific provision. Even if the law established the automatic dismissal from office for certain offences, so long as the offence remained occult the office holder would be able to exercise it validly. This is particularly clear in Baldus' discussion of the notary who lets his clerk draft the instrument. ${ }^{111}$ Since the offence is not manifest, says Baldus, the notary may continue to hold his office until deposed with a legal decision. ${ }^{\mathbf{1 1 2}}$

108 Cod.1.2.14.3 (Leo et Anthem. AA. Armasio PP.).

109 See next note.

110 Baldus, ad Cod.1.2.14.3, \Sane (svper Primo, Secvndo \& Tertio Codicis, cit., fols. 23vb-24ra, n. 2): 'Non obst(ante) quod sit priuandus officio: quia quamdiu non priuatur per sententiam retinet officium et exercitium officij: quod est notandum. Conclude ex hoc quod licet quis delinquerit in officio, tamen quamdiu superior non amoueat eum valent gesta per eum ... Quinto querit glo(ssa) in $\$$ economus nunquid iste economus sit priuatus vel priuandus dicit glo(ssa) quod est priuandus per sententiam propter verbum priuetur. Secus si dixisset priuatus sit.' Cf. Gloss ad Cod.1.2.14.3, S Oeconomus (Parisiis 1566, vol. 4, col. 35).

111 Supra, pt. I, $\$ 2.6$.

112 Baldus, ad Cod.1.2.14.3, \Sane (svper Primo, Secvndo \& Tertio Codicis, cit., fol. 24ra, n. 2): 'Adde tamen quod vbi non requiritur sententia dispositiua: si 
The conclusion is a rather sensible one: as the offence is not known, the automatic deposition would create chaos, for it would entail the ipso iure invalidity of any deed done between the commission of the offence and its eventual ascertainment. Baldus' reasoning, however, is not based on common sense but on the Innocentian concept of toleration. Yet Baldus adds something more than Innocent: the reason the person of the notary is still the legal representative of his office even having committed an offence that calls for his removal from it is that he remains in quasi possessio of the office. ${ }^{\mathbf{1 1 3}}$

In this case, possession of the office (the quasi is due to the fact that the office is incorporeal $)^{114}$ works as a bridge between proper toleration and deposition. It is here, in this grey area, that Baldus' position begins to diverge from that of Innocent. To appreciate the point - and make sense of this difference - we should look at the case of the incumbent who is secretly removed from office (occultus exhautoratus). The case is very similar to that of the occult excommunicate: when looking at canon lawyers, we have seen how problematic that case was. Just as Innocent applied the toleration principle to the occult excommunicate, so Baldus argues that the person secretly removed from office should be allowed to continue representing it. In principle, the solution should be the opposite: the deposed should be equiparated to the intruder. However, argues Baldus, the fact that the deposition is secret also means that the deposed is left with unchallenged possession of his office. Just as the case of the notary, therefore, if any deed of the incumbent done after his secret deposition were to be void, this would create a series of retroactive invalidities (or rather, postponed declarations of nullity) for any transaction relying either directly or indirectly on such deed. Again, chaos. However, Baldus adds, the explanation for the validity of the deeds might be elsewhere: the superior authority secretly deprived the person of his entitlement to represent the office, but left him in possession of it. This means that 'some vestiges' (reliqui<a>e qu<a>edam) of the initial confirmation still remain. ${ }^{115}$

tamen factum reuocatur in dubium requiritur sententia declaratoria ... facit quod not(atur) in aut(hentica) de tabel(lionibus) $\$$ penul. (coll.4.7.1 [=Nov.44.1\$4]), vbi dicit gl(ossa) quod si tabellio per sententiam legis est priuatus officio tabellionatus, hoc tamen non est declaratum per sententiam hominis, sed est occultum. Et iste tabellio exercet officium quia est quasi in possessione officii quod valent instrumenta sua quod alibi in iure ciuili non habes.' Cf. supra, pt. I, $\$ 2.6$, note 131 .

113 Baldus, ad Cod.1.2.14.3, $\mathbb{\$}$ Sane (svper Primo, Secundo \& Tertio Codicis, cit., fol. 24ra, n. 2).

114 On the concept of quasi possessio see supra, pt. I, $\$ 5.4$, note 42 . We will look at its use in Baldus' reading of the lex Barbarius next chapter, esp. note 96.

115 Baldus, ad Cod.3.34.2, $\$$ Si aquam (svper Primo, Secondo \& Tertio Codicis, cit., fol. 219ra, n. 83-84): 'Nunc de octauo puncto, scilicet de obedientia et iurisdictione: an sit obediendum minus iusto prelato qui est in pacifica possessione 
Possession of the office by the secretly deposed is admittedly ambiguous, as it lies between judicial deposition and 'proper' toleration. It is neither of them: this is an important difference with Innocent, who on the contrary made secret excommunication and occult deposition the standard bearers of the toleration principle. The legal implications of rejecting both conclusions - neither full deposition nor full toleration - are explained in Baldus' commentary on the Liber Extra.

In his Ordinary Gloss on the Liber Extra, Bernardus Parmensis disagreed with Laurentius Hispanus and Johannes Teutonicus, who both argued for the validity of administration by those suspended from office. The case might appear somewhat ironic, considering that, as we have seen, Hispanus and Teutonicus were among the most vocal opponents of the toleration principle. In fact, it made perfect sense: neither of them had a fully developed notion of representation with regard to individual offices. Their scant sympathy for toleration is therefore perfectly compatible with their position on the effects of suspension from office. Much to the contrary, for Bernardus the suspended from office could not validly exercise it. So long as the suspension lasted, for Bernardus it would entail the same effects as actual deposition from office. ${ }^{\mathbf{1 1 6}}$ Innocent IV concluded

officii sui: et an possit exercere iurisdictionem suam in rebelles et videtur quod sic: vt in $\mathrm{d}$ (icta) l. barbarius (Dig.1.14.3). Sed in illa $\mathrm{l}$ (ege) concurrebant tria, scilicet superioris summa auctoritas, error communis qui idem operatur quod veritas i(nfra) de test(amentis) 1. i (Cod.6.23.1) et publica vtilitas ... Idem si concurrerent alia duos, s(cilicet) error communis et publica vtilitas, licet cesset superioris auctoritas: ut $\mathrm{p}$ (atet) in occulto exautorato, vt no(tatur) in aut(hentica) de tabel(lionibus) $\$$ pe(nultimo) (coll.4.7.1[=Nov.44.1\$4]). Sed potest dici quod in exautorato adhuc remanent reliquie quedam: vt not(atur) de aucto(ritate) tut(orum) 1. si pluribus (Dig.26.8.4). Secus ergo in eo qui nunquam fuit auctoritate superioris fretus seu prelatus, sed forte per falsas literas obtinuit reputari prelatus, ar(gumentum) ff. de iudi(ciis) $<\mathrm{l}$. $>$ non idcirco $\$$ cum postea (Dig.5.1.44.1), et quod not(at) Inno(centius) in c. in literis, de resti(tutione spoliatorum) [Innocent, ad X.2.13.5, infra, this paragraph, note 125].' The reference to Barbarius' confirmation is not to be taken too seriously: here, Baldus mentioned Barbarius' case in general terms: see infra, next chapter, note 26. As we will see shortly, on the contrary, when commenting on the lex Barbarius Baldus is extremely clear in denying as much.

116 Bernardus Parmensis, ad X.1.4.8, $\$$ A suspensis (Decretalium domini pape Gregorij noni compilatio, cit.): 'suspensus enim non potest eligere nec eligi ... Sed nonne iudicare et praebendas dare est iurisdictionis? vti quia i(nfra) de elec(tione) $<\mathrm{c}$. $>$ nosti (X.1.6.9), et excommunicare, i(nfra) de elec(tione) $<\mathrm{c}$. $>$ transmissam (X.1.6.15), nunquid suspensus potest huiusmodi iurisdictionem exercere? Dicunt quidam quod episcopus suspensus potest excommunicare, et praebendas dare: et respondent illi decre(tali) quia diuiersitatem (X.3.8.5) quod ille episcopus erat ab officio suspensus et iurisdictione. Sed dicunt quod canonicus suspensus eligere non potest: quia cum sit suspensus nihil officii retinet. Secus est in praelato ... 
in the same way as Bernardus, but with more precision: suspension might just refer to the enjoyment of the prebend associated with the office (a rather common form of punishment). That could not be equated to deposition, for it would not deprive the suspended of the right to represent the office. It is only when the suspension is from the exercise of the office, clarified Innocent, that 'suspended' may be equiparated to 'deposed': in both cases the representation mechanism is severed, whether temporarily or permanently. ${ }^{\mathbf{1 1 7}}$

At this point, however, Innocent looked at the case where the suspension from office is not known, and the prelate is commonly believed not to be suspended. Are the deeds he carries out in the exercise of the office valid? Some, Innocent said, would argue as much, especially in case of a suspension occurring ipso iure and not flowing from a judicial condemnation (unlike the violation of some law or canon, a sentence is irrebuttably presumed to be known). ${ }^{\mathbf{1 1 8}}$ In that case, their conclusion would be that the suspended is tolerated in office because of ignorance as to his true status. This, however, was not the correct solution for Innocent. Arguing that toleration in office may occur out of mere ignorance would amount to watering down the legal meaning of the toleration principle itself. More specifically, it would mean replacing representation with common mistake: the validity of the deeds would no longer depend on legal representation but on the dubious brocard that common mistake makes law. Hence Innocent disagreed with this solution not as to its outcome, but as to the legal principles invoked to reach it. ${ }^{\mathbf{1 1 9}}$

Alii dicunt et melius quod episcopus suspensus non potest excommunicare, nec interdicere, nec dare prebendas, i(nfra) de exces(sibus) prela(torum) c. vlti(mo) (X.5.31.18) ... Joh(annes) et Lauren(tius) hoc concedunt, quod suspensus ab officio tamen potest excommunicare et praebendas dare: et intelligunt illam decre(talem) quia diuersitatem (X.3.8.5) cum erat suspensus ab officio et iurisdictione. Ego autem non credo quod suspesus ab homine possit dare praebendas: vt hic dicitur, licet Lau(rentius) et Joh(annes) concedant quod possit excommunicare et praebendas dare.'

117 Innocent IV, supra, pt. II, $\$ 7.5$, note 104.

118 Cf. Baldus, supra, this paragraph, note 107.

119 Innocent IV, ad X.1.4.8, $\$$ Suspensus (Commentaria Innocentii Quarti, cit., fol. 34rb, n. 4): '... Item dicunt quidam quod licet non valeat in spiritualibus, quod facit excommunicatus vel suspensus, valet tamen in temporalibus quamdiu toleratur ex ignorantia, quia forte sunt suspensi a iure, non per sententiam, et ideo omnia eius facta tenent $\arg$ (umentum) 8 q. $3<$ c. $>$ nonne (rectius, C.8, q.4, c.1). Sed hoc verum non credimus in his quae ratione publici officii faciunt, argu(mentum) ff. de offi(cio) praeto(rum) 1. Barbarius (Dig.1.14.3).' 
Baldus devotes only a few lines to the matter - few but crucial. First, he reports the different positions (without quoting anyone by name). ${ }^{\mathbf{1 2 0}}$ Then he concludes by saying something extremely important: ${ }^{\mathbf{1 2 1}}$

the person who is occultly suspended may do anything as to the others, but not as to himself. In other words, he can grant to anyone but he cannot have something granted unto himself.

The secretly suspended from office may exercise his office validly - but only towards third parties, not himself. In stating as much, Baldus shows that the separation between internal and external validity in the agent-principal relationship is not a modern concept. The above quotation from Baldus seems to fully presuppose it. As we shall see, this was one of the cases in which Baldus did not follow Innocent. The opposition between internal and exernal validity of agency lies at the very core of Baldus' reading of the lex Barbarius - and it would later provide the basis for the development of the de facto officer doctrine. Baldus' solution depends on the combination of two factors: first (as in Innocent), the separation between person and agent; second (and quite unlike the pope), the legal relevance of the possession of the office by the secretly suspended or deposed.

When distinguishing between obligations of the person qua individual and qua representative of the office, as we have seen, Baldus relied on practical examples involving a third party. As the examples always dealt with some kind of obligation, the presence of third parties might appear a truism. Even so, it is an important truism. Applied to principal-agent situations, the obligation against third parties creates a triangle: agent, office and third party. Just like the dychotomy between the internal and external validity of the acts, the 'agency

120 Baldus, ad X.1.4.8, $\mathbb{S}$ Suspensus (Baldvs svper Decretalibvs, cit., fol. 47va, n. 17): 'In $\mathrm{gl}$ (ossa) suspensus enim queritur vtrum suspensus possit iudicare prebendas dare vel iurisdictionem aliquam exercere, quidam dicunt quod sic licet non possit eligere nec eligi; gl(ossa) finaliter tenet contrarium et intelligit hoc verum in suspensis ab homine nisi sit minor suspensio $i(n)$ partecipatione excommunicati. Alij dicunt quod ea que competunt ratione officii non potest facere qui suspensus est ab officio sed ea que competunt ratione beneficii potest facere sicut potest locare predia beneficii sui.' It seems likely that the gloss suspensus to which Baldus referred was that of Innocent and not that of the Ordinary Gloss. In both the lectura and the repetitio on the lex Barbarius Baldus speaks of the 'great gloss' on the Liber Extra with regard to Innocent's commentary, not that of Bernardus Parmensis: infra, next chapter, notes 13 and 124. Cf. the similar approach of Bartolus, supra, pt. I, $\$ 5.4$, note 53.

121 Baldus, ad X.1.4.8, $\mathbb{S}$ Suspensus (Baldvs svper Decretalibvs, cit., fol. 47va, n. 17): 'Item no(tatur) quod occulte suspensus omnia potest quo ad alium licet non quo ad se, i(d est) omnibus potest conferre sed non potest sibi conferri.' 
triangle' is also a trite concept in today's agency theory. But this was not the case in Baldus' time.

Baldus describes this triangular situation in several cases dealing with the succession of the incumbent in office. Some cases focus on the obligation contracted by the previous incumbent, others deal with the incumbent's appointment to a specific role (e.g. testamentary executor). In both scenarios, however, the problem is ultimately the same: distinguishing between agent and person. Both counterparty (in the first group of cases) and appointor (in the other group) are third parties, and occupy one 'angle' of the triangular relationship. In approaching those cases, Baldus (and, before him, Innocent) moves from this 'angle' - that is, from the position of the third party. The way the triangle is drawn has important consequences for the solution of the case.

Sometimes Baldus links this 'angle' directly to the 'angle' of the office, and at other times to that of the individual representing it. In this last case (i.e. where the third party deals with the agent qua person), there is in effect no triangle: the fact that this person also happens to be the legal representative of the office is irrelevant. So the relationship would remain only between the third party and the individual who happens to be also the incumbent in office. Not a triangle, but a segment. When the third party deals with the agent qua representative of the office, by contrast, the legal relationship is between third party and office. Since the office can only will or act through a person, ${ }^{\mathbf{1 2 2}}$ that relationship has to be extended to the agent as well. Hence the need for a triangular relationship. But the triangle (thus the third 'angle' - the person of the agent) comes into play only because of the immediate relationship between third party and office (i.e. Baldus' causa remota of the agent's deeds). ${ }^{\mathbf{1 2 3}}$ When the primary relationship is between third party and office, therefore, the person of the agent is of little importance. In a manner of speaking, the agent is fungible. ${ }^{\mathbf{1 2 4}}$ It is this fungibility that ensures the succession of the new agent in the same contract or appointment as his predecessor. This is why, in all such cases, Baldus examines the triangular relationship always in the same direction: from the third party to the office, and only then from the office to the agent.

Let us look at the same triangle from the opposite direction. So long as the person is entitled to represent the office, the transaction between office and third party will be valid. This was also Innocent's conclusion: full symmetry between internal and external validity of agency. The office acts validly towards the thirds

123 See again supra, this chapter, $\$ 11.2$.

124 Hence the ultimate legal meaning of the metaphor of the phoenix, where the individual is defined by the species (ibid., text and note 28 ). 
when the agent acts validly towards the office (i. e. when he can validly represent it). The difference with Baldus lies in that Innocent excluded the relevance of another and weaker kind of relationship between person and office: not legal entitlement, but possession.

To appreciate the different position between Innocent and Baldus on the external validity of the deeds (in our triangle, the relationship between office and third party), we should look at the issue of payment of debts. When does payment to the false agent release the debtor? Innocent had already posed the question. He did so to remark that common mistake does not suffice: the debtor is not released from his debt to the office if he pays someone who only appeared to be the agent, whereas he was not. The debtor owes his debt to the office, not the person as an individual. And since the agent apparent cannot represent the office, the debtor is in effect paying to a third party altogether. ${ }^{125}$ Baldus seems to follow suit: 'I am not surprised that sometimes those who pay are deceived - he says - for the legislator is no friend of mistake'. ${ }^{\mathbf{1 2 6}}$ As a matter of principle, without the confirmation of the superior authority the simple possession of an office (even if it follows a valid election) does not become legal representation. When speaking of the mystical body of the church to describe the link between prelate as legal representative (the soul) and church as office (the body), as we have seen, ${ }^{\mathbf{1 2 7}}$ Baldus explains that the prelate who cannot be the 'soul' of the church may not act in its name. In that case, the prelate was in possession of the 'body' of the church (the ecclesiastical office) but he lacked valid appointment to it. Not being able to act in the name of the church, says Baldus, that prelate was like a 'honorary guardian without administration'. ${ }^{\mathbf{1 2 8}}$ Only confirmation, as we

125 Innocent IV, ad X.1.6.44, \Administrent, supra, pt. II, $\$ 7.3$, note 43 . See also, and more specifically, Id., ad X.2.13.5, \$I In literis (Commentaria Innocentii Quarti, cit., fols. 226vb-227ra, n. 3): 'Sed quaero quid facient subditi debitores huiusmodi violenti possessoris? Respon(deo) non respondebunt de iuribus pertinentibus ad dignitatem, quam violenter possidet, nec potest conqueri hic violentus praelatus de eis, qui spoliauerunt eum non reddendo sibi debitam obedientiam ... quia ipsi non spoliant, cum non fuerit in possessione recipiendi huiusmodi $a b$ eis, licet fuerit in violenta possessione dignitatis cui haec debentur ... imo nec subditi per violentiam debent malaefidei possessorem expellere de possessione ... sed denegare possunt sine violentia, tamen in ea in quorum mala possessione erat possessor, quod sic probatur, quia si sponte soluat, praestat malaefidei possessori causam peccandi. Item non liberatur subditus debitor per talem solutione, quin dignitati teneatur, cum non ei, sed dignitati sit obligatus.'

126 Baldus, ad X.2.13.5, \$In literis (Baldvs svper Decretalibvs, cit., fol. 149va, n. 8): 'nec mirum quod aliquando decipiantur soluentes, quia legislator non est amicus errorem.'

127 Supra, this chapter, note 58.

128 Supra, this chapter, note 57. 
know, allows de iure representation. By contrast, a payment to the 'false prelate' who is in possession of the office with the authority of the superior does release the debtor. ${ }^{129}$ In that case, the authority of the superior entails confirmation in office - despite the (hidden) true condition of the prelate.

So far, the position of Baldus would appear the same as Innocent. Baldus, however, is less uncompromising (admittedly, not a difficult task). Possession should not be always dismissed so easily. If the prelate does not have a valid title to exercise the office but he plainly possesses it, considering the whole business as legally irrelevant would be - at least on a practical side - problematic. Material possession is a tangible approximation of substantive right. Possessing something is prima facie evidence of being entitled to it - holding something because of an underlying right on it. Undisputed possession of an office does not lead to the right of discharging it, but it might suffice to create a semblance of legal representation. As Baldus puts it, 'the habit does not make the monk, but rather shows him to be such if it was put on him by the person who has the power and the authority [to do so]. ${ }^{130}$ Possession would therefore suggest the existence of legal representation, but it does not prove it - still less create it. This can make things extremely difficult for the debtor. Let us suppose, says Baldus, that the intruder in an ecclesiastical office comes to the debtor and says: 'I am in possession and I am publicly called and treated as prelate by all others, hence you should do the same'. What should the debtor do? As a matter of principle, he should ask him to prove his right before paying him what he owes to the office. ${ }^{131}$ But unchallenged possession of the office would typically point to an

129 Baldus, ad Cod.3.34.2, $\$$ Si aquam (svper Primo, Secondo \& Tertio Codicis, cit., fol. 218vb, n. 76): 'Sed quid ... si debitores sponte soluant falso prelato qui tamen est in possessione an liberentur ab ecclesia? Dic quod non, de condic(tione) ob causam $<$ l. $>$ si procuratori falso (Dig.12.4.14), de fur(tis) l. falsus (Dig.47.2.43) et 1. si quis vxori $\$ apud labeonem (Dig.47.2.43), nisi sit in possessione auctoritate superioris. Nam licet talis auctoritas non valeret excusati sunt soluentes ne circumueniantur auctoritate superioris, ar(gumentum) C. de his qui ve(niam) eta(tis) impe(traverunt) 1. i (Cod.2.44(45).1) ... et ita sentit Inno(centius) extra de resti(tutione spoliatorum) c. in literis (X.2.13.5).' Cf. supra, pt. II, $\$ 7.3$, text and note 43.

130 Baldus, ad X.2.13.5, \$Item cum quis (Baldvs svper Decretalibvs, cit., fol. 149vb, n. 3): '... habitus monachum non facit, licet ostendit eum monachum si sit ei impositus per habentem potestatem vel authoritatem.'

131 Ibid.: '... Sed ecce aliquis tanquam prelatus agit contra debitorem ecclesie, debet debitor ostendere de prelatura, $\mathrm{i}(\mathrm{d}$ est $)$ de mandato: "alias non possum tibi soluere"... dicit prelatus: "ego sum in possessione et publice vocor et tractor tamquam prelatus per alios vniuersos: ergo et per te debeo tractari." An interesting twist on the same issue is the problem of the payment into the hands of the abbot for a debt owed to the monk. The case was remarkably subtle: as monks take a poverty vow, it is more likely that the debt was owed to the 
underlying right to administer it - again, the habit does not prove the monk's status, but the cowl is usually given by the abbot. In the mouth of a jurist, the adagio of the monk is more complex than it might appear, for 'habit' (babitus) was typically contrasted with 'act' (actus). As Baldus has it (interestingly, when commenting on the lex Barbarius), 'habitus denotes law'. ${ }^{132}$ Habitus does not make the monk, but it strongly suggests that one is such. So, coming back to the problem of the improper payment, Baldus concludes that a judge might well consider the debtor who paid the false agent in possession of the office to be released. In such a case, says Baldus, the situation would be very close to that of the ward's business transacted by the false guardian (Dig.27.6.1.5): under certain circumstances, the praetor might ratify the deed. ${ }^{133}$ We should pay attention to this example, and the fact that the praetor did not simply consider the payment valid, but ratified it for equitable considerations. In the same way, when the judge releases the debtor who paid the false agent in possession of the office, the validity of the payment (and so the release of the debtor) is not a legal effect of the common mistake, but depends on the authority of the judge. Stating as much, Baldus makes sure to avoid bestowing internal validity on abusive agency.

When Baldus dealt with the validity of the acts carried out by the secretly deposed, as we have seen, ${ }^{134}$ he argued that leaving him in possession somewhat colours his possession with a 'vestige' of the previous confirmation in office. This trace of the initial confirmation lingers on, so that the incumbent is not

monastery and not to the person of the monk. Hence Baldus' solution: the payment to the abbot does release the debtor unless paying into the hands of the monk was a modal condition of the obligation itself. Baldus, ad Cod.7.56.1, Si neque (svper Primo, Secundo \& Tertio Codicis, cit., fol. $88 \mathrm{ra}$ ): 'Quero quid si soluatur abbati id quod debetur monacho an soluens liberatur: ... Tu dic quod aut est quesitum ius monasterio et liberatur, vt l. i s(upra) de bo(nis) mater(nis) (Cod.6.60.1). Aut non est quesitum: vt quia per modum implende conditionis: et tunc secus vt in contrariis, quod tene menti. Bal(dus).'

132 Baldus, lectura ad Dig.1.14.3, cit., fol. $57 \mathrm{ra}$, n. 43: 'actus in factum sonat, habitus vero ius designat.'

133 Baldus, ad X.2.13.5, \$Item cum quis (Baldvs svper Decretalibvs, cit., fol. 149vb, n. 3): '... dic quod sufficit prelato quod sit in vniuersali possessione: licet iste debitor nunquam agnouerit debitum nec fuerit confessus illum esse prelatum dummodo pro prelato publice reputetur: vt i(nfra) e(o titulo) c. in literis (X.2.13.5). Ego dico quod iudex cauere debet se ratum habiturum quod cum eo gestum erit vel non tenetur debitor soluere ... vt 1 . i $\$$ idem pomponius ff. quod cum fal(so) tut(ore) $\mathrm{au}<\mathrm{c}>\mathrm{t}$ (ore) (Dig.27.6.1.5) et ratione dubii videtur decretum.' It seems significant that Baldus said as much when commenting upon the only point of the Liber Extra (X.2.13.5) where Innocent admitted the possibility that the payment to the intruder in office might (exceptionally) free the debtor: supra, pt. II, $\$ 7.5$, note 85 .

134 Supra, this paragraph, note 115. 
completely deposed from office. Stated otherwise, if the deposition occurs secretly and therefore leaves the deposed in unchallenged possession this is not the same as full deposition. The occult character of the deposition leaves tangible proof of the initial confirmation (a 'vestige' of it): the enduring possession of the office. Suspension is not as serious as deposition - this was the reason for the whole dispute between Laurentius Hispanus and Johannes Teutonicus on the one side, and Bernardus Parmensis and Innocent IV on the other. While Innocent solved the problem of the secretly suspended from the administration of the office by referring to the toleration principle, as we have seen, Baldus highlighted the role of possession. The 'vestige' of confirmation was meant mainly to describe that possession as lawful. And it is on the basis of the lawful possession of the office that Baldus solved the case of the occult deposed not on the basis of toleration, as on the contrary Innocent did.

If the unchallenged possession of the office suffices to underplay the effects of the occult deposition, then it should be all the more relevant for a simple suspension. Unlike the intruder in office who just appears to be its lawful representative, in this case there is no need of a judge sympathetic towards the debtor's mistake to hold the payment valid. But, importantly, this validity pertains only to the external side of agency: in our triangle, to the relationship between third party and office. As the superior authority has withdrawn its approval of the office holder (secretly deposing or suspending him from office), the internal side of agency is compromised. So, when the person acts on behalf of the office to make a transaction with himself, the third party and the individual who acts as agent coincide. In this case, the external side of agency is in effect just a replica of the internal side. In rejecting the validity of the acts carried out by the agent in relation to himself as private individual ('the person who is occultly suspended may do anything as to the others, but not as to himself) ${ }^{135}$ Baldus therefore denies the internal validity of agency in the case of occult suspension of the agent. The point is rather obvious, but it has little to do with conflict of interest. The suspension of the incumbent is occult and so hidden to everyone but the incumbent himself.

In case of the secretly suspended, Baldus looks first at the external validity of agency (to approve of it), and only then at the internal one (to deny it). Once again, coming back to the agency triangle, the figure is drawn moving from the 'angle' of the third party. As usual, the direction is important: had Baldus started with the person of the agent, it would have been difficult to justify the external validity (office-third party) after having denied the internal one (agent-office). 
Possession does not entitle the agent to represent the office, but it might justify the third party dealing with the office in the person of its possessor. It is also important that the validity is not maintained on the basis of the common mistake. That would mean undoing the whole Innocentian concept of toleration as based on agency. Rather, the validity derives from the peculiarity of the agent's possession: not just the de facto holding of the office, but lawful possession deriving from the 'vestige' of the previous legal entitlement to it. We have seen how, in principle, deposition for Baldus 'changes the cause of possession from something into nothing. ${ }^{136}$ But that statement referred to manifest (or rather, notorious) deposition. By contrast, occult deposition does not remove completely the 'cause of possession' - at least for third parties. We will come back to the point when we look at Baldus' interpretation of the lex Barbarius: there, the same concept of lawful possession of the office plays a crucial role. ${ }^{137}$

Baldus' interpretation of the occult suspension from office does not lead to a widening of the scope of toleration, but rather to the blurring of the difference between entitlement and possession. Innocent insisted on the lack of toleration (and so, on the invalidity of the deeds) not for the occult suspension from office, but only for the manifest one. Having allowed the toleration of the secretly deposed, it would have been self-contradiction not to apply the same criterion to the secretly suspended. Rather, Innocent used the case of occult suspension to highlight the difference between individual office and collegiate body. Occult suspension produces tangible consequences for individual members of the chapter, because none of them individually is the representative of the office. By the same token, on the contrary, the same occult suspension does not prevent the valid exercise of the office when it is entrusted to a single person. ${ }^{138}$ Occult suspension, therefore, falls within the scope of toleration, and so the incumbent, although indignus (in the sense here of legally unfit) retains full administration of the office.

In restricting the validity of the administration only to the external side of agency, Baldus says something different. Toleration depends on entitlement, and so on the right to represent the office. Hence for Innocent there could not be different 'degrees' of toleration, so he never spoke of a 'vestige' of confirmation. Someone who is tolerated in office is still entitled to its full exercise, whereas someone who is no longer entitled to it may not be tolerated but rather treated as an intruder. In opposing external validity and internal invalidity, Baldus trades

136 Supra, this paragraph, note 102.

137 Infra, next chapter, $\$ 12.4 .3$.

138 Innocent IV, ad X.1.4.8, $\mathbb{S}$ Suspensus (Commentaria Innocentii Quarti, cit., fol. 34$r a-b$, n. 4). More in particular, see supra, pt. II, $\$ 7.3$, note 20 , and $\$ 7.5$, note 104. 
toleration in office with lawful possession of it. Despite its name, the concept of toleration is rather inflexible as to its scope. Baldus seeks to introduce more flexibility to it, but this opens the door to an ambiguity unknown to the Innocentian elaboration. Lawful possession of office thus allows the symmetry between the two sides of agency to be severed, and possibly to reach beyond the scope of Innocent's toleration. But possession does not amount to full representation, and so not to proper toleration either.

Whether or not the theoretical foundations of Baldus' solution are particularly sound, Baldus gives more space to possession than Innocent did. This, as we shall see, will be of paramount importance in his reading of the lex Barbarius, and so for the later developments of the de facto agent doctrine, because it introduces a third element (the coloured title) between mere appearance and full entitlement: neither just the product of common mistake, ${ }^{139}$ nor the result of proper representation.

The greater importance of possession in Baldus can be also seen in a different but equally important context. We have seen earlier how Innocent distinguished between violations of positive law of and natural law in an election: a violation of natural law led to the ipso iure invalidity of the appointment and could not be ratified by ensuing confirmation, which would also be void. ${ }^{140}$ In stating as much, however, as already mentioned, Innocent did not provide clear examples. ${ }^{141}$ That might have been deliberate. By Innocent's time the requirement of confirmation was widely accepted in principle but not yet universally held as always necessary. Innocent insisted on its necessity in all cases. ${ }^{\mathbf{1 4 2}}$ Listing specific cases where the confirmation was invalid could have been multiplied by way of legal analogy, undermining the whole point. Baldus on the contrary is more detailed on the subject. However, such detail is not aimed at filling Innocent's gap, but rather at underpinning Baldus' shift from (proper) toleration to lawful possession of the office.

Baldus does not look at specific cases of ipso iure invalidity of the election (or, at least, he does not do as much in connection with toleration and agency). Rather, he focuses on the consequences of invalid confirmation. Where the

139 Cf. Baldus, lectura ad Dig.1.14.3, cit., fol. 56vb, n. 40: 'fama pro titulo non habetur.'

140 Supra, last paragraph, note 94.

141 Supra, last paragraph, text and note 94.

142 Innocent was at the same time one of the canon lawyers most determined to insist on the need for confirmation, and one of the first popes who began the process that eventually led to the replacement of canonical elections with papal appointments (supra, this chapter, note 61). The two points might be more related to each other than often assumed. 
underlying defect is manifest, reasons Baldus, the ensuing invalidity of the confirmation does not pose many problems. But what if the defect is hidden? In this case the superior authority might not even be aware of its existence. The same problem would ultimately apply to any third party dealing with the office. When looking at the case of the payment to the agent apparent we have seen that, as a matter of principle, the debtor should have asked the incumbent to prove his right to represent the office before paying up. ${ }^{143}$ The case of ipso iure invalidity of the election makes things particularly difficult. Because even if the debtor did ask, the incumbent could have proven both his election and, especially, his confirmation. When the confirmation cannot cure the invalidity of the election, it becomes nearly impossible to distinguish appearance from reality. All that may be seen is a formally valid election and a similarly valid confirmation. This explains Baldus' peculiar and very careful choice of words to describe such a case: the confirmation is valid 'so long as [the prelate] is in possession of the authority of the superior'. ${ }^{\mathbf{1 4 4}}$

To explain these words, we might want to look back at the way Baldus relied on the concept of possession of the office for the case of occult deposition. Secretly deposing the agent while leaving him in possession did not fully sever the link with the superior authority, Baldus maintained, and so left the agent in an ambiguous position, lying midway between proper toleration and full deposition. Possession worked as tangible evidence of that (only half-severed) link - its 'vestige'. In the present case, on the contrary, the link between superior authority and agent is itself invalid, and it is invalid from the outset (so that there may not be any 'vestige' of its former full validity left). Hence Baldus refers the concept of possession not to the office, but directly to the authority of the superior. This makes the status of the agent even more ambiguous than that of the occult suspended: his confirmation is ipso iure invalid, but the superior authority that confirmed him is not aware of this. Hence the idea of possessing the confirmation as opposed to being confirmed. The concept of possession of

143 Supra, this paragraph, note 131.

144 Baldus, ad Cod.3.34.2, $\$$ Si aquam (svper Primo, Secvndo \& Tertio Codicis, cit., fol. 218va, n. 73): 'Premitte quanquam ille qui est in possessione est funditus falsus praelatus: et talis possessio non patrocinatur ... quanquam non est funditus falsus, quia habet confirmationem superioris, tunc autem confirmatio est nulla ipso iure: aut valet licet confirmatus si indignus: prio $<$ re $>$ casu aut est vitium patens et repellitur, aut latens et non repellitur, $\operatorname{ar}$ (gumentum) ff. de mi(noribus) 1 . verum $\$ ex facto (Dig.4.4.11.2) et 1 . minor xxv an(nis) ex aspectu (Dig.4.4.32) ... Secundo casu non repellitur quamdiu est in possessione autoritate superioris, ar(gumentum) de off(icio) presi(dis) (sic) $<$ l.> barbarius (Dig.1.14.3), de rescri(ptis) <c.> sciscitatus (X.1.3.13) per Innoc(entium).' Cf. Innocent, supra, pt. II, $\$ 7.4$, note 45 . 
confirmation was (unsurprisingly) not present in Innocent, but the pope's unwillingness to fully explain the consequences of the ipso iure void election left a gap that ought to be filled, especially when the invalidity was occult. The latent condition of some defects left a grey area between absence and presence of confirmation, both because of the requirement for full knowledge (certa scientia) in the superior authority that made the confirmation, ${ }^{\mathbf{1 4 5}}$ and because of the limits of the confirmation itself. For both reasons the latent defect in the elected could not be considered to be healed with confirmation. Hence the idea that the elected who may not be confirmed receives possession of the superior's authority. Here as well, possession works as a link of sorts. Connecting the agent to the superior, it shifts the perspective from the indignitas of the agent to the superior dignitas of the higher authority. ${ }^{\mathbf{1 4 6}}$ This way, the question becomes one of higher jurisdiction: 'As the superior considers him as such [i. e. as confirmed], so anyone else must regard him so'. ${ }^{\mathbf{1 4 7}}$ In stating as much, Baldus quotes the same text he invoked when discussing the payment to the agent apparent: the praetor may ratify the business transacted by the false guardian (Dig.27.6.1.5). ${ }^{148}$ The point is important. In the case of payments to the agent apparent, the agent insisted on this right because 'all others' held him as true representative of the office. ${ }^{\mathbf{1 4 9}}$ Those 'others' were, in effect, all third parties. Hence Baldus invoked the text of the praetor who ratified the false guardian's deed to stress that the release of the debtor who paid into the hands of the false agent depended on the authority of the judge (on his iurisdictio), not on the belief of the thirds. But in the case of ipso iure void election invalidly confirmed by the superior authority, the false agent is not relying on the common belief of the thirds, but on the same authority of the judge. A superior authority has by definition a higher iurisdictio. ${ }^{\mathbf{1 5 0}}$ It is on the

145 Cf. Innocent IV, ad X.1.6.32, \$ Confirmauit (Commentaria Innocentii Quarti, cit., fol. 63ra-b, n. 1-2), supra, pt. II, \$7.1, notes 9-10.

146 Cf. supra in this paragraph.

147 Baldus, ad Cod.3.34.2, $\mathbb{S}$ Si aquam (super Primo, Secvndo \& Tertio Codicis, cit., fol. 218va, n. 73): '... nam ex quo superior eum habet pro tali ergo a quolibet alio debet haberi, ff. quod fal(so) tu(tore) au $<\mathrm{c}>\mathrm{t}$ (ore) 1 . i $\$$ item pomp(onius) (Dig.27.6.1.5).'

148 Compare the last note with Baldus' comment supra, this paragraph, note 133.

149 Supra, this paragraph, note 131.

150 It is the higher iurisdictio that defines the higher authority, and so the quality of being superior: the higher authority is maior in that it may judge the inferior. Hence the maxim 'the person who judges me is [my] lord' (qui me iudicat dominus est), on which see most emphatically the coronation sermon of Innocent III, In consecratione Pontificis Maximi, Sermo II (in Id., Opera, Coloniae, apvd Maternvm Cholinvm, 1575, p. 189). Cf. Huguccio's Summa, ad C.2, q.5, c.10 (Admont 7, fol. 159va; transcription in Maceratini [1994], p. 624). 
basis of that iurisdictio that third parties cannot refuse to acknowledge the agent apparent. Being 'in possession of the authority of the superior' ultimately means being able to invoke the same higher iurisdictio in support of an otherwise invalid title.

Referring the element of possession not to the office but to the superior's approbation brings the agent apparent as close as possible to full entitlement to the office - without reaching it. ${ }^{151}$ This extreme closeness ultimately depends on the simple fact that the possession of the superior's authority changes the perspective from which the agency triangle is observed. In this case, it is the agent who invokes the superior before the third party. The movement is not from the third party to the office (designating external validity), but from the agent to the office (implying internal validity). In other words, it is on the basis of the possession of internal validity that the agent apparent is able to exert full external validity. Because of this shift in perspective, the invalid confirmation for an irremediable but occult defect in the election becomes an approximation of proper agency - and so of proper toleration in office. The point will be further elaborated examining Baldus' reading of the lex Barbarius.

\subsection{Toleration and sacramental issues}

Before concluding this analysis on the scope of Baldus' concept of toleration, mention should be made of the thorny problem of those jurisdictional matters that border on sacramental issues. We have seen how Innocent drew a clear line between ordo and iurisdictio, and applied the toleration principle to all jurisdictional matters, none excluded. But we have also seen the reluctance of other eminent canon lawyers to follow suit. By Baldus' time the common opinion among canonists was still to follow Innocent's concept of toleration with the exception of those borderline cases. As we will see later, it was only with Panormitanus that Innocent's position also began to be fully accepted on those subjects. When writing, Baldus therefore sided with the mainstream approach among canonists. Hence his reasoning on the subject is not dissimilar from that of Hostiensis, Baysio and Johannes Andreae. ${ }^{152}$

151 Cf. Baldus, ad Cod.3.34.2, $\$$ Si aquam (svper Primo, Secundo \& Tertio Codicis, cit., fol. 218vb, n. 75): 'Et generaliter nemo presumitur priuilegiatus nisi doceat de priuilegio et nemo presumitur confirmatus nisi doceat de confirmatione. C. de diuer(sis) offi(ciis) 1. probatorias li. xii (Cod.12.59(60).9).'

152 This would suggest that Baldus' position was rather common among the civil lawyers who dealt with the subject. Albericus for instance said as much mainly on the basis of Baysio. Albericus de Rosate, ad Cod.7.45.2 (In Secundam Codicis Part [em] Commentaria, cit., fol. 116rb-va, n. 1): 'Et utrum excommunicatus, uel 
Baldus acknowledges that jurisdictional powers pertain to the jurisdictional sphere, not the sacramental one. ${ }^{153}$ But when a jurisdictional act has immediate effects on the sacramental sphere, he qualifies the act according to its consequences. Perhaps to avoid the obvious problem of the origin of the act (jurisdictional as opposed to sacramental), he does not speak of ordo and iurisdictio, but rather of authority in temporal and spiritual matters.

On spiritual matters, truth is more important than opinion. ${ }^{\mathbf{1 5 4}}$ Baldus finds this maxim quite useful in solving the problem, because it shifts the analysis from toleration as the product of confirmation in office (as Innocent) to toleration as the simple consequence of common mistake. So Baldus can argue that the toleration of the indignus whose defect is latent is sufficient for his exercise of the office in temporal matters (so long as he is confirmed), but not in

haereticus occultus, possit alium excommunicare, no(tatur) in $\mathrm{gl}($ ossa), et per eum [scil., Baysio] 24 q. i in summa et c. audiuimus [C.24, q.1, c.4, cf. supra, pt. II, $\$ 8.3$, note 44$]$ et de ista materia excommunicationis, satis nota(ndum) i(nfra) si a non compe(tenti) iudi(ce) 1. fi. (Cod.7.48.4). Cf. Albericus de Rosate, ad Dig.1.14.3 (In primamff. Veter. part. commentarij, cit., fol. 70va, n. 26-27): 'Item est bene notandum, quod Arch(idiaconus) tenet $11 \mathrm{q} .3 \mathrm{c}$. in sententia pastoris (C.11, q.3, c.1) quod speciale est in sententia excommunicationis lata ab eo, qui credebatur iudex, et non erat, quod nulla est, et non ligat illum contra quem est lata ... Sed an sententia haeretici, qui reputabatur catholicus teneat? Dic, quod non vt no(tatur) 24 q. 1 in summa (C.24, q.1 pr), et plene per Arch(idiaconum) extra de off(icio) delegati, c. penult(imo) li. 6 (VI.1.14.14).' Cf. Baysio, supra, pt. II, $\$ 8.3$, note 39 .

153 Baldus, ad X.1.6.15, $\mathbb{S}$ Transmissam (Baldvs svper Decretalibvs, cit., fol. 57ra, n. 1): 'Electus confirmatus etiam non consecratus potest omnia quae sunt iurisdictionis: sed non ea que sunt ordinis et dignitatis episcopalis, et sic habet iurisdictionem ita et banna et omnia que iurisdictioni accedunt ... quero extra de his quae pertinent ad iurisdictionem. Gl(osa) dicit sicut iudicare excommunicare subaudi absoluere ... Item dicit gl(osa) quod similia quae consistunt in iurisdictione hoc enim scias per regulam: quia omnia que non requirunt ministerium consacrationis dicuntur pertinere ad iurisdictionem.' Cf. the Ordinary Gloss to the Liber Extra, supra, pt. II, $\$ 8.5$, note 98 .

154 E.g. Baldus, ad Cod.7.45.2, $\mathbb{S}$ Si arbiter (svper VII, VIII et Nono Codicis, cit., fol. $52 \mathrm{rb}, \mathrm{n} .10$ ): 'Sed nunquid in puris spiritualibus aliquid operetur error communis. Respondeo non, xi q. iii c. i (C.1, q.3, c.1).' Cf. Id., ad Cod.3.34.2, $\$$ Si aquam (svper Primo, Secvndo \& Tertio Codicis, cit., fol. 219ra, n. 84): 'Item iste spirituales pene debent potius inniti veritati quam opinioni.' The lex Barbarius could not therefore find application in spiritualia. See esp. Baldus, ad Cod.7.16.11, $\$$ Non mutant (super VII, VIII et Nono Codicis, cit., fol. 12va): 'Publici honores proprii vel paterni non faciunt de seruo liberum qui ad honorem improbe aspirauit. Non ob(stat) 1. barbarius (Dig.1.14.3), quia est speciale in dignitate pretoria, vel ibi licet acta valeant seruus est, vel ibi speciale in populo romano, vel ibi propter publicam vtilitatem: et quod ibi dicit in pretore multofortius esset in papa inteligibili quod valerent temporaliter facta non spiritualiter, dic ut not(at) Inno(centius) extra de elect(tione) c. nihil (X.1.6.44).' 
spiritual ones. ${ }^{155}$ Because confirmation could not cure the ipso iure invalidity of the election due to the gravity of the indignitas, it could only lead to a provisional validity of his administration so long as the defect remained hidden. This, we have just seen, works on secular matters (in temporalia). But in spiritualia, where the accent is on the truth of things, that provisional validity would not suffice. The consequences of this approach become particularly clear with regard to the power of binding and loosing. As we have seen, for Innocent that power was always and exclusively a jurisdictional one. In Baldus, however, the shift from the jurisdictional/sacramental opposition to the temporal/spiritual opposition, and the emphasis on the contrast between truth and opinion, both lead to a different conclusion about the power to excommunicate. The occult excommunicate may continue to exercise his office, says Baldus, with the ensuing validity of all his jurisdictional deeds - apart from excommunication. ${ }^{156}$ 'Since it is God Who binds, He does not bind against the truth.' A putative bishop is in the same condition as a putative praetor, but that is only with regard to the (temporal) jurisdiction deriving from the secular office. ${ }^{157}$ By the same token, argues

155 Baldus, ad Cod.3.34.2, $\$$ Si aquam (svper Primo, Secundo \& Tertio Codicis, cit., fol. 219ra, n. 85): 'Confirmatus autem, cuius confirmatio est propter occultum vitium confirmata, omnia temporalia potest. Spiritualia vero non potest, vt si [praelatus] est falsus, hereticus vel scismaticus: vt no(tatur) de ele(ctione) $<\mathrm{c} .>$ nihil est (X.1.6.44) per Inn(ocentium).' As we have seen, however, Innocent's position was not precisely as reported by Baldus: Innocent said as much, but he included absolution and excommunication among the jurisdictional (or, in Baldus' language, temporal) matters. Referring to Innocent's general statements was correct in form but somewhat misleading in substance.

156 Baldus, ad X.2.14.8, $\mathbb{\$}$ Veritatis (Baldvs svper Decretalibvs, cit., fol. 154va-b, n. 6): 'no(tandum) quod quando quis prelatus est excommunicatus statim suspensus est ab omni officio et ab omni iurisdictione non solum quo ad spiritualia, sed etiam quo ad temporalia, quod est verum si est publice excommunicatus: secus si est excommunicatio occulta, quia valent gesta inter ignorantes, vt $\mathrm{i}(\mathrm{nfra})$ de re iudi(cata) c. ad probandum (X.2.27.24), saluo quod etiam occulte excommunicatus alium excommunicare non potest, vt in c. ii i(nfra) de eo qui renu(nciavi) epis(copatui) (X.1.13.2).' Cf. Albericus de Rosate, supra, this paragraph, note 152.

157 Baldus, repetitio ad Dig.1.14.3, cit., fol. 58rb-va, n. 23: 'Sed quid de sententijs spiritualibus istorum Episcoporum putatiuorum, an ligant? Et videtur quod non: nam cum Deus ligat, non ligat contra veritatem, ar(gumentum) i(nfra) de condi(ctione) ob causam, 1. si pecuniam $\$$ si seruum (Dig.12.4.5.1), vnde in sententia excommunicationis plus consideratur veritas quam opinio ut no(tat) Arc(hidiaconus) xi q. iii <c.> sententia pastoris (C.11, q.3, c.1). Credo ergo quo ad tertiam huiusmodi conclusionem habebit [cp. Baldus' Venetian edition of 1577: 'et credo contrarium quo ad ecclesiam huius mundi, quia habet'] administrationem iurisdictionis, et meri et mixti imperii tam in ciuilibus quam in criminalibus, et per inquisitionem et iudicis officium, vt hic, et hoc est verum in spiritualibus, quae fiunt ratione publicae vtilitatis, et publici officij: secus in aliis, ut not(at) 
Baldus, confession to a falsus praelatus is valid only because of the penitent's faith, not because of the power of that 'defrauder of souls'. What would suffice in secular matters cannot suffice in spiritual ones. ${ }^{158}$

Inn(ocentius) de consue(tudine) c. cum dilectus (X.1.4.8) et no(tat) Arc(hidiaconus) ix q. i <c.> Nos in homine (C.9, q.1, c.6) vbi omnino vide per eum.'

158 Baldus, ad X.1.6.54, $\mathbb{}$ Dudum (Baldvs svper Decretalibvs, cit., fol. 73rb, n. 5): 'No(tandum) quod ille qui non est praelatus, non potest absoluere vel ligare et facit quod apostaticus dicitur esse deceptor animarum, et de hoc non est dubium, tamen illi qui credunt in eum non confundentur: quia excusat publicus error et bona fides secundum Ber(nardum) et Inn(ocentium) quod est notandum, quod intellige quo ad deum: quia cor contritum et humiliatum deus non spernit [cf. Psalm 50(51):19], sed quo ad forum iudiciorum inspicitur veritas in litigando et solvendo, vel quasi possessio cum iusto errore: vt lex Barbarius (Dig.1.14.3), et fuit quaestio de facto vtrum cautio vsurarum prestita putatiuo sacerdoti reddat vsurarium testabilem, et dixi quod sic.' Cf. supra, pt. II, $\mathbb{\$} 7.5$, note 87 , and $\$ 8.1$, note 9 . See also Wilches (1940) p. 117. The difference of Baldus' position from that of Innocent is also visible on the subject of the fornicating priest. There, however, the difference does not lie in what Baldus says, but in what he omits. Like Innocent, Baldus also holds that parishioners may receive sacraments from such a priest, so long as his crime is occult. But Innocent's reference to the possibility of forcing the parishioner to receive sacraments from the occult fornicator is not to be found in Baldus. Cf. Baldus, ad X.3.2.7, $\mathbb{S}$ Vestra (Baldvs svper Decretalibvs, cit., fol. 259rb): 'A clerico fornicario non notorio licite audimus diuina et precipimus ecclesiastica sacramenta, sed si esset notorius abstinere debemus non tamen ea intentione, vel animo quo credamus officia vel ecclesiastica sacramenta per tales fore polluta.' 


\section{Chapter 12}

\section{Baldus and the lex Barbarius}

\subsection{A different perspective}

In the traditional reading of the Gloss, as we have seen, the validity of the deeds had to follow on from the legitimation of their source: Barbarius becomes free and a true praetor, hence his deeds are valid. This approach, still applied in the early fourteenth century by Butrigarius, did not consider the person of Barbarius and the office of praetorship as two wholly different subjects. Either Barbarius is fully praetor, or no deed of the office of praetor can be valid. The Ultramontani reached the opposite conclusion, especially in the interpretation of Bellapertica, but they implicitly moved from the same premise. It was precisely because Barbarius did not enjoy a valid status that the validity of the acts could not be ascribed to their source. As such, the reason for their validity had to be found elsewhere, outside of the source itself. So public utility would operate directly on the acts, skipping their source entirely - which therefore remained invalid. This opposite approach implicitly shared the same view as to the source of the acts: ultimately, it implied that agent and office substantially coincided. If the two approaches did not share this common premise, Bartolus could not have used them together. So long as it was possible to hold the act valid by validating the position of Barbarius, for Bartolus the Accursian Gloss sufficed. Where this could not work, Bartolus followed Bellapertica and invoked public utility directly on the acts. The office - as a subject different from its incumbent - never came into the picture.

Just as rescuing the person of Barbarius meant validating the exercise of his office, so leaving him a slave amounted to the full rejection of his praetorship. Barbarius was not an individual person acting as representative of the office of praetorship. The office was ultimately a dignitas vested in the individual person. As such, either that person became fully legally capable, or the office remained wholly unable to produce valid acts. This bi-dimensional approach, which levels the office to the person, does not mean that the above jurists did not know or that they disapproved of the concept of persona ficta.$^{\mathbf{1}}$ They simply did not make 
systematic use of it. More exactly, it is only with hindsight that individual office and collegiate body should both necessarily be construed as legal persons (or at least as different subjects from those of their physical representatives). Speaking of public office did not necessarily entail a full separation between office and person. We have seen that when looking at Bartolus' treatment of the notary: the public notary exercises a public office. But this public office is a dignitas vested in the individual person, and ascribed to that person qua individual. Corporations were different: there, the distinction between person and office was more immediate - it was plainly visible. Moreover, it was necessary. The late medieval urban world is a system of corporations. The city itself is ultimately a corporation. Most jurists lived in cities, often self-governing ones. This led them to focus on the mechanism of representation: how could the actions of the single be imputed to the whole. ${ }^{2}$ This way, they looked increasingly at canon law,

Cod.1.3.31(32) (ibid., p. 424: the text is taken from Firenze, BML, Plut. 6, sin. 6, fol. $30 v$ ), then looks at Ravanis. While Ravanis did not use the term persona representata in his comment on the same lex of the Code, he did so on other occasions, especially in his comment on Dig.3.4.7.2, which is entirely based on the concept of representation (Feenstra also provides a critical edition of this comment from the only two known manuscripts of Ravanis' lectura on the Vetus, the Neapolitan and Leiden MSS [cf. supra, pt. I, $\$ 4.4$, text and note 21], ibid., pp. 425-427. From Ravanis' comment on Dig.3.4.7.2 it appears that the term persona representata was already used by his teacher Monciaco (ibid., p. 428). Feenstra does not mention Cugno, but also this jurist used the concept at least in his lectura on Dig.3.4.7, whose most relevant part is transcribed in D'Urso (2000), p. 530, note 56. The same D'Urso gives a partial transcription of Revigny's lectura on Dig.3.4.7 and on Dig.4.2.9.1 (ibid., p. 529, note 55, and p. 539, note 80 respectively). On the subject of representation, the passage of Bartolus that attracted most scholarly attention is probably his comment on Dig.48.19.16.10: see esp. Navarrete (1962), pp. 351-360 and 366-372 (the last pages focusing in particular on Bartolus' comment on Dig.41.2.1.22); D'Urso (2000), pp. 542-548; Walther (2005), pp. 196-200. Legal personality was a concept not unknown to the glossators either. For instance, the glossators most frequently cited in the first part of this work, Bassianus, Azo, Hugolinus and Accursius, all dealt with the imputability of certain deeds of the individual to the universitas: see e. g. D'Urso (2000), pp. 524-531. For a useful synthesis see Mehr (2008), pp. 216-232. Cf. also the next two notes.

On the subject, a starting point is still the work of Michaud-Quantin (1970), pp. 305-326. Cf. Coing (1985), pp. 262-268; Quillet (1971), pp. 186-189. See also some short but extremely acute observations of Nörr (1992), pp. 194-197; Tierney (2016), pp. 62-63; A. Black (1990), xiv-xxx; A. Black (2003), pp. 16-31; Birocchi (1995), pp. 414-415, where further literature is listed; Cortese (1995), vol. 2, pp. 238-240; Todescan (1982/83), pp. 63-64; H. Hofmann (1974), pp. 152-165 (this last one however pays little attention to the glossators). See also Cortese (1964), vol. 2, pp. 110-122 (although he writes about the will of the 
adapting many principles devised for canonical elections to the secular sphere. ${ }^{3}$ Within this relationship individual-universitas civil lawyers even discussed the problem of the criminal liability of the corporation for the deeds of its individual members. ${ }^{4}$ So they did work with the concept of agency, but mainly where the principal was a collectivity, not an individual office. The similarity between representative of a corporation and bearer of an individual office would strike only a modern as self-evident. In itself, it is not necessarily so obvious.

Both Innocent's profound influence and his own legal training in canon law made Baldus more aware of the similarity between collegiate bodies and individual public offices. In both cases the question was one of representation, and so the same principles developed for ecclesiastical offices could be applied to secular ones. This is what makes Baldus' approach to the lex Barbarius so different from that of previous civil lawyers. The relationship is no longer between two parties (the Romans and Barbarius) but between three, for the office of the praetor is not the same subject as the individual who occupies it.

Baldus' reading of Barbarius' case is based on the full separation of office and person. In so doing he openly relies on Innocent's position, by far the most quoted author by Baldus in his lectura and especially in both repetitio and addition on the lex Barbarius. ${ }^{5}$ It was because of Innocent's elaboration that Baldus could arrive at a wholly new reading of it. The crucial difference with the previous interpretations did not lie in the distinction between validity of deeds

universitas on the introduction of a custom, Cortese's observations can be easily applied to our subject, as the author himself suggests). As with many other public law subjects, legal personality in medieval civil law has not received overwhelming attention by legal historians. This sometimes led medieval jurists to be read through the lens of political thinkers or philosophers. A well known example is the recurring temptation to invoke Ockham (especially as filtered through the works of Michel Villey) to interpret the approach of medieval lawyers to the subject of corporations in a remarkably restrictive fashion. On the problem, see e. g. Kriechbaum (1996), pp. 38-39; Nörr (1992), pp. 194-196.

See for all the recent and magistral study of Christin (2014).

4 See e. g. Ullmann (1948), pp. 77-96, Michaud-Quantin (1970), pp. 327-330, and in particular Chiodi (2001), pp. 100-127. Cf. also Quaglioni (2002), pp. 418-420. In his excellent essay, Chiodi also casts a different light on the well-known gloss of Accursius on Dig.3.4.7.1, where he famously stated that 'vniversitas nil aliud est nisi singuli homines qui ibi sunt' (Gloss ad Dig.3.4.7.1, $\$$ Non debetur, Parisiis 1566 , vol. 1, cols. 409-410). The statement is traditionally read as an unequivocal rejection of the legal capacity of the universitas. Reading the same words within their broader context, however, it would seem that Accursius was simply seeking to exclude the vicarious liability of the town for the damages directly imputable to its individual members. Chiodi (2001), pp. 117-119, where ample literature is mentioned. 
and invalidity of their source (that was already achieved with the Ultramontani). The difference lay in the concept of office itself, which should be fully distinguished from the person discharging it. In so doing, Baldus inverted the (already revolutionary) position of Bellapertica: the source of the deeds is not Barbarius but the praetorship. So both deeds and praetorship are valid. It is the person of Barbarius that remains a slave.

This conclusion presupposes complex reasoning, which we will now explore in some detail. But it also shows a distance with Innocent on the specific case of Barbarius. If the slave remains a false incumbent, then Barbarius' case does not fall within the scope of toleration. And indeed Baldus' solution on this case builds on what was already said in the previous chapter, especially on the shift from proper toleration to lawful possession of the office. It is precisely this twist to Innocent's doctrine that paved the way for the later theory of de facto officer and, moreover, the possibility of distinguishing between internal and external validity of agency.

Baldus' position entails a clear rupture with the previous civil law tradition. The lex Barbarius is not just a clear example of the application of public utility to public law issues. It describes an extreme case of agency in public law.

For the Gloss and its followers, reasons Baldus, the only way to bestow validity upon Barbarius' deeds was to consider their source as legitimate: 'the deeds depend on the status, for if [Barbarius] was not praetor and free, his deeds would not be valid. Hence he is praetor and free, so that his deeds be valid. ${ }^{6}$ All the jurists who followed the Gloss invoked the healing effects of the common mistake to the person of Barbarius first, and only then also to his deeds. To save the validity of the acts, in other words, it was necessary to rescue their source. The problem that earlier civil lawyers, especially of the Bolognese school, encountered here was that they could not keep the issue of the validity of the acts separate from that of the validity of the appointment. And the fact that Ulpian spoke in positive terms about the validity of the acts was taken as confirmation as to the validity of their source too. Their reasoning is clear: how could one insist on the validity of the acts while denouncing as invalid the source from which they flowed? The position of the Gloss was straightforward - too much so, Baldus observes. More than simple, it was in fact simplistic. 'If the opinion of the gloss were true - he notes sarcastically - there would be no reason for fatiguing [on this text], for Barbarius would have been true and lawful praetor. ${ }^{7}$

Baldus, repetitio ad Dig.1.14.3, cit., fol. 57vb, n. 10: '... gesta dependent a statu, quia si non esset praetor et liber, non ualerent acta per eum, vt ergo ualeant acta per eum, ideo est praetor et liber.' 
While Baldus is not as critical of the Ultramontani as he is of the Gloss, he does not accept their reading either. ${ }^{8}$ Ravanis' position, sophisticated as it was, remained fragile: it rejected the Gloss and yet its conclusion was - at least to some extent - fairly close to it. The stance of Bellapertica was uncompromising, but for that reason it could not have boundaries: equitable considerations always apply and always suffice. This bypassed representation altogether, and that alone suffices for Baldus to reject it in toto. Cugno's views, perhaps, could have been more easily adapted to Innocent's approach - especially in Baldus' interpretation of it. But in his writings on the lex Barbarius Baldus quotes Cugno just once, and even that single reference is rather ambiguous. ' Even if Baldus knew Cugno's lectura on the lex Barbarius (which is far from clear), he did not use it.

\subsection{Barbarius and the problem of toleration}

Applied to the relationship between agent and office, toleration means highlighting the enduring legal representation despite the unfitness (indignitas) of the agent. This is already visible at the beginning of Baldus' lectura on the lex Barbarius, with regard to the prohibition of the lex Iulia de ambitu. Simony is prohibited by divine law for ecclesiastical offices, says Baldus, not temporal ones. As for temporal offices, surely no prohibition would apply to the prince, who is above the (civil) law. The same goes for the pope when conferring temporal

would make Barbarius' acts valid de iure, whereas the lex Barbarius clearly speaks of validity de aequitate: 'Item oppo(nitur) si Barbarius fuit praetor, ergo gesta per eum valent de rigore. Sol(utio) eadem aequitate, quia est praetor in habitu, exercet in actu, quia ab vna causa, et ratione procedit et esse et operari secundum Iac(obum Butrigarium)' (ibid., fol. 57va, n. 9).

8 Baldus often quotes the Ultramontani in his opus. While sometimes he acknowledges the worth of their observations, in other occasions (and probably more often) he does not seem particularly impressed with them, occasionally showing his disapproval in rather vocal terms. One of such occasions is his tractatus de Pactis (Venetiis, 1577, fol. 5ra, n. 84): 'these jackasses of Ultramontani have no other joy than confuting the Gloss' ('isti asini Ultramon(tani) non habeant aliam beatitudinem nisi in reprobando glos(am)'). Cf. Meijers (1959a), p. 119.

Baldus recalled how both Cugno and Cynus maintained that the lex Barbarius would apply on the basis of both public utility and superior authority (not a very accurate statement). Baldus, repetitio ad Dig.1.14.3, cit., fol. 57vb, n. 10-11: 'Item non deberemus implicare tot inconuenentia, quid dicemus? Dicit Guil(elmus de Cugno) et $\mathrm{Cy}$ (nus de Pistoia) hic quod hic Barbarius non fuit praetor verus, sed putatiuus, et secundum hoc haec $1(\mathrm{ex})$ dicit hic, propter publicam vtilitatem, et superioris autoritatem, et errorem communem valent gesta, etiam a minus legitimo praetore. Et hoc solum determinat haec $\mathrm{l}(\mathrm{ex})$ de valentia actuum exercitorum, quandiu latuit inhabilitas Barbarii, et alia quae dicit circunferentia, sunt rationes ad probandum gesta ualere secundum eos.' 
dignities. ${ }^{10}$ But then, asks Baldus, what about the lex Iulia de ambitu? Duly revised, the traditional explanation in the Gloss - so much criticised by the Ultramontani - could prove useful. The Gloss argued for the validity of the appointment made in violation of the lex Iulia on the basis of the effects of putative freedom: 'it should not happen, but if it did, it would hold' ('fieri non debuit: factum tamen tenuit'). ${ }^{\mathbf{1 1}}$ Baldus recalls that maxim but explains it in a completely different way. The reason why 'it would hold' does not depend on the effects of apparent status (i.e. putative freedom), ${ }^{\mathbf{1 2}}$ but rather on toleration. Precisely with regard to the lex Iulia (and so, in case of simony), the maxim could be used to highlight the most striking case of toleration: that of the occult simoniac. As Innocent had it, Baldus recalls, 'anything is tolerated because of the office that one exercises'. ${ }^{13}$ Simony is no exception: so long as he is tolerated, the occult simoniac is the unworthy but lawful representative of the office, and so his (jurisdictional) deeds are valid. ${ }^{14}$ Thus, Baldus' conclusion is a frontal attack

Id., lectura ad Dig.1.14.3, cit., fol. 55ra, n. 10: ' ... immo si Principi datur pecunia pro officio suo, ista non est simonia, quia istud non est prohibitum in officiis secularibus iure diuino, sed iure civili, cui Caesar non subest, ergo et Papa sua temporalia potest vendere absque aliqua pravitate.'

11 Supra, pt. I, $\$ 2.2$, note 36.

12 Supra, pt. I, $\$ 2.3$.

13 Baldus, lectura ad Dig.1.14.3, cit., fol. 54vb, n. 6: 'opp(onitur) et videtur quia etiam temporalem non liceat administrationem postulare, quoniam incidit in 1. Iul(iam) de ambitu, quae impedit promouendum, vt $\mathrm{i}(\mathrm{nfra})$ ad $\mathrm{l}$. Iuli(am) de ambi(tu) l. i (Dig.48.14.1.1). Respondent quidam quod fieri non debet: factum tamen tenet, donec per superiorem toleratur in officio. Et sic simoniaca promotio in temporalibus est aliqua, quamdiu superior eam non rescindit, vt $\mathrm{i}(\mathrm{nfra})$ de decre(tis) ab or(dine) fa(ciendis) 1. ambitiosa (Dig.50.9.4pr). Nam multa non debent fieri: tamen facta tenent, i(nfra) quando app(ellandum) sit l. i $\$$ biduum (Dig.49.4.1.5). Omnia enim tolerantur propter officium quod administrat, ut no(tat) Inn(ocentius) extra, de accu(sationibus) c. qualiter et quando (X.5.1.24), in gl(osa) magna, ver(siculum) "sed non"' Cf. Innocent IV, ad X.5.1.24, \et famam, supra, pt. II, $\$ 7.3$, note 23.

Incidentally, Baldus seems among the very few civil lawyers not particularly impressed with the old argument of Bassianus' students (supra, pt. I, \$2.2) that seeking an office to help out the others is to be praised. Baldus, cons.2.53 (Consiliorvm sive Responsorvm Baldi Vbaldi Pervsini, cit., fol. 12ra): 'certe non est ambitio virtutibus quaerere honores, vt 1 . Barbarius Philippus ff. de off(icio) praet(orum) (Dig.1.14.3).'

14 Id., lectura ad Dig.1.14.3, cit., fol. 55ra, n. 7-8: 'et hoc verum in his quae ille simoniacus gerit temporaliter, vt hic: secus, si spiritualiter, nam nemo dat quod non habet. In spiritualib(us) $n(a m)$ potius veritas quam opi(nio) ponderatur i q. $\mathrm{i}$ c. Daibertum (rectius, C.1, q.7, c.24), et no(tandum) per Inn(ocentium) de rest(itutione) spo(liatorum) c. olim col(umna) iii [cf. Innocent IV, ad X.2.13.12, esp. $\$$ Conditione, in Commentaria Innocentii Quarti, cit., fols. 230vb$231 \mathrm{ra}, \mathrm{n} .3]$... sed in temporalib(us) valent omnia quae faciunt administrando temporaliter, quamdiu ab ecclesia tolerantur. Immo contra temporalia exigentes 
against nearly two centuries' discussion of the relationship between the lex Iulia and Barbarius' case.

The reference to occult simony (and, with it, to Innocent's position) is particularly appropriate for introducing the toleration principle on Barbarius' case. We have seen Baldus' distinction between manifestness and notoriety. In lay terms, occult is the opposite of manifest: the first conveys the idea of something hidden, the second means plainly visible. ${ }^{15}$ But when the defect in the office holder is legally ascertained, from occult it becomes not just manifest but notorious. When deriving from a legal decision, notoriety is stronger than widespread opinion (fama) : it is legal truth - both notorious and manifest. ${ }^{\mathbf{1 6}}$ Just as occult indignitas is no obstacle to the exercise of the office because of the confirmation of the superior authority, therefore, so condemnation by a superior authority both deprives the office holder of his confirmation, and also renders his indignitas manifest and presumptively known (or rather, it does not excuse its ignorance). When occult unfitness is judicially ascertained, the effects of the initial confirmation - or approbation - of the superior authority cease altogether, thereby preventing any further valid exercise of the office.

If the debate on the lex Iulia served to introduce the concept of toleration, it remained to be seen how to apply this concept to the analysis of the lex Barbarius. Speaking of toleration exclusively on the basis of canon law could undermine its strength in civil law: some references to Roman sources ought to be provided. Therefore, immediately thereafter, Baldus lists a number of cases that might serve the purpose. The most relevant are two texts of the Digest (Dig.1.5.20, and Dig.39.5.15). ${ }^{17}$ The first text reads: 'Anyone who becomes insane is considered to retain both the position and dignitas he previously held, and his magistracy and authority; just as he retains the ownership of his property. ${ }^{18}$ In his comment on this text, Baldus observes that since the insane keeps his dominium, he also

non potest excipi quod fuerint promoti per simoniam: quia in arbitrio superioris est tolerare eos, vnde inferior de iure superioris non potest opponere, vt no(tatur) per Inn(ocentium) extra, de simonia c. per tuas, in princ(ipio) gl(osae) quae incipit, "Quicunque n(am)".' Cf. Innocent IV, ad X.5.3.35, $\$$ Vitium simoniae (Commentaria Innocentii Quarti, cit., fol. 502rb, n. 1).

15 Supra, last chapter, note 105.

16 Ibid., note 107.

17 Baldus, lectura ad Dig.1.14.3, cit., fol. 54vb, n. 6: '... idem dicimus in his quae ratione officii, etc. Et hoc probatur ex coniunctione duarum legum, supra de sta(tu) ho(minum) 1. qui furere (Dig.1.5.20), et de don(ationibus) 1. post contractum (Dig.39.5.15).'

18 Dig.1.5.20 (Ulp. 30 ad Sab.): Qui furere coepit, et statum et dignitatem in qua fuit et magistratum et potestatem videtur retinere, sicut rei suae dominium retinet.' 
retains his iurisdictio. ${ }^{19}$ The fact that he may no longer exercise it does not undermine the point, because 'the exercise of jurisdiction does not pertain to the substance of jurisdiction. ${ }^{20}$ So the insane magistrate would retain his iurisdictio even if unable to exercise it. The principle is the secular equivalent of the canon law rule on the insane bishop. ${ }^{21}$ Just like the servile condition, insanity was a defect in the person that prevented his valid appointment to an office - so much so that the two defects appeared together in the often quoted dictum of Gratian Tria (C.3, q.7, p.c.1). ${ }^{22}$ The reference to insanity has clear limits: Dig.1.5.20 was a case of supervening incapacity, ${ }^{23}$ whereas Barbarius was already a slave (and so legally incapable) when elected praetor. Hence Baldus quotes a second text, Dig.39.5.15. According to it, 'donations made after the accusation of a capital crime are valid, unless the defendant is convicted'. ${ }^{24}$ Just as Barbarius was a slave when elected to the praetorship, so the donor had already committed a capital crime when he made the donation. Admittedly, also this second text could offer limited help: the donation would be invalidated if the donor were eventually found guilty of the charge, whereas (as we shall see) Baldus will argue for the enduring validity of Barbarius' deeds. Despite neither text could offer a watertight foothold for the application of the toleration principle to Barbarius' case, their combined reading would serve the purpose. On the one hand, the objections that Baldus' reader would raise when mentally comparing the lex Barbarius to one text would be (prima facie) overcome when moving to the other. On the other, moreover, Baldus' intention is not to persuade his reader

Baldus ad Dig.1.5.20, $\mathbb{Q}$ Qui furere (In Primam Digesti Veteris Partem Commentaria, cit., fol. 33ra): 'Sicut retinetur dominium, ita et iurisdictio.'

Ibid., 'No(tatur) quod exercitium iurisdictionis non est de substantia iurisdictionis, quid patet, quia licet furiosus non exerceat, tamen retinet iurisdictionem in habitu, etiam si staret per longissimum tempus.'

21 Supra, last chapter, note 70.

22 Cf. supra, pt. II, \$6.2, text and note 26.

23 A similar case was that of the short fragment of Dig.5.1.6 (Ulp. 6 ed.: 'Caecus iudicandi officio fungitur'). The Gloss was clear in stating that the praetor who became blind could continue to exercise his office, but only because it was a condition supervenient to his appointment. Gloss ad Dig.5.1.6, \$Caecus (Parisiis 1566, vol. 1, col. 677): 'Titius dum esset in officio constitutus, habebat ordinariam vel delegatam iurisdictionem: et ita morbo superueniente lumen amisit. Nunquid postea suo fungi poterit officio, vt poterat a principio? Et dicit quod sic. Sed videtur quod non: vt supra de postu(lando) 1. i $\$$ casum (Dig.3.1.1.3), quae videtur contraria, sed non est: quia ibi a principio erat caecus, hic postea.' Cf. ibid., $\$$ Fungitur: 'cum ante esset iudex quam esset caecus: sed de nouo fieri non potest; secus in postulatore: vt supra de postu(lando) 1. i $\$$ casum (Dig.3.1.1.3).'

24 Dig.39.5.15 (Marcianum, ad 3 Inst.): 'Post contractum capitale crimen donationes factae non valent ex constitutione divorum Severi et Antonini, nisi condemnatio secuta sit.' 
that the toleration principle, as defined by Innocent, fully applied to Barbarius' case. Baldus simply wants to highlight the similarity between the lex Barbarius and the concept of toleration. To that end, however, he faces a formidable problem: relying on Innocent's idea of toleration while skipping its cornerstone - confirmation by the superior authority.

We have amply seen how toleration depends on confirmation. If even a perfectly worthy (dignus) person could not exercise the office without confirmation, the requisite was all the more essential for the unworthy. So long as the elected is confirmed by the superior authority, the invalidity of the election for the defect in the person of the elected is no obstacle to the valid exercise of the office. Similarly, supervening unworthiness does not remove the confirmation as long as the indignitas remains occult.

The importance of confirmation as a necessary prerequisite of toleration explains why, for Innocent, Barbarius had to be confirmed by the prince. Whether or not he was deeply persuaded by the argument of the Gloss, it was necessary for Innocent to approve of it. Otherwise, that single Roman law text would have seriously undermined his entire elaborate reasoning. Accepting Barbarius' confirmation by the emperor was Innocent's solution to a very marginal problem in his overall theory, which therefore deserved only marginal attention. Barbarius' case, in other words, did not need to be fully explained. It had to be neutralised. ${ }^{25}$

Innocent's solution was however Baldus' problem. Confirming Barbarius in his praetorship would have meant accepting the reading of the Accursian Gloss, which was something that Baldus was not prepared to do. Hence Baldus sought to adapt Innocent's toleration theory: applying it to the lex Barbarius while leaving Barbarius in slavery. It is important to keep in mind the reason for Baldus' different approach. The somewhat paradoxical position he found himself into (to invoke Innocent on Barbarius' case it is necessary to forget what the pope said on Barbarius' confirmation) forced Baldus to be particularly explicit in stressing the difference between person and office. This makes his approach to the lex Barbarius all the more interesting: in no other part of his opus does Baldus describe the difference between agent and office so openly as in his comment on Barbarius.

The paradox was that the outcome of Accursius' position (though not of course the reasoning behind it) was perfectly suited to Innocent's representation theory - and indeed Innocent approved of it. Baldus however could not possibly accept the presumed will of the people as explained in the Gloss. Bartolus' lame attempt at reconciling the Ultramontani with Accursius was fragile enough 
without also taking into account canon law influences. Hence Baldus' dilemma. Accepting the intervention of the superior authority would be an excellent example of the virtues of confirmation - in principle. Specifically on Barbarius' case, however, that would lead to the wrong conclusions. Innocent himself tried to be as vague as possible on the matter - and he could afford to, because his focus was not on Barbarius. Baldus could not, for he sought to give a detailed analysis of the Barbarius text. And a close reading of the lex Barbarius could not escape the critique of the old opinion of the Gloss. Toleration was the best way to solve Barbarius' case, if only toleration could be somehow applied skipping its very precondition - confirmation. ${ }^{26}$

26 Before going any further, it should be said that Baldus was not always coherent on the point. On some occasions, he might have found Barbarius' case too useful to be overlooked. So Baldus sometimes relied on it as an example of confirmation of the indignus in office, typically following Innocent's reasoning. See Baldus ad Cod.3.34.2, $\$$ Si aquam (svper Primo, Secundo \& Tertio Codicis commentaria, cit., fol. 219ra, n. 83): 'Nunc de octauo puncto, scilicet de obedientia et iurisdictione: an sit obediendum minus iusto prelato qui est in pacifica possessione officii sui: et an possit exercere iurisdictionem suam in rebelles? Et videtur quod sic: vt in $\mathrm{d}$. 1. barbarius; sed in illa 1 (ege) concurrebant tria, scilicet superioris summa auctoritas: error communis ... et publica vtilitas.' Id., ad Cod.8.47.2pr, $\mathbb{I m p u -}$ berem (svper VII, VIII et Nono Codici, cit., fol. 180vb, n. 4): 'Ibi pretorem vel pro quibus cauetur cognitionem pretor iniunxit ibi per populum romanum. Dicit glos(a) imo fortius valet apud cesarem quam olim apud populum et est propter fictionem quia fingitur maiorem partem populi ibi esse sed in principe nulla est fictio sed est voluntas mera clara et expedita, vt 1 . barbarius de offi(cio) preto(rum) (Dig.1.14.3).' Id., ad X.1.6.34, $\$$ Venerabilem (Baldvs super Decretalibvs, cit., fol. $65 v b$, n. 14): 'si eligitur pretor per gentem que non recognoscit superiorem efficitur legitimus atque liber, quia propter inclytam virtutem etiam si populus erraret fingitur consensisse propter bonum publicum, ff. de offi(cio) pret(orum) 1. barbarius philippus (Dig.1.14.3).' Id., ad X.1.6.44, $\$$ nichil (ibid., fol. 69va, n. 4): 'Item ex dictis Inn(ocentii) collige quod nullus confirmatus in curia dicitur proprie intrusus quia authoritas confirmationis tuetur eum, ff. de offi(cio) preto(rum) l. Barbarius (Dig.1.14.3), qui proprie adaptatur confirmatis a supremo cardine, i(d est) a populo romano olim vel a principe.' Ibid., fol. 69vb: 'l. barbarius ... dicit quod propter publicam vtilitatem et authoritatem et propter publicum errorem et propter publicam authoritatem (sic) que constitunt in magistratibus creatis licet perperam valent gesta a minus iusto pretore nec possunt pretextu non iurisdictionis infringi; et adde quod dixi C. de test(amentis) in 1. i (Cod.6.23.1) in lec(tione) mea.' Ibid., fol. 69vb, n. 11: 'Sed hic quaeritur quare tenetur facta barbarij. Respondeo vel quia praefectus pretorio confirmauit vel quia non indiguit confirmatione quia totus populus eum elegit secundum Inno(centium).' See further Baldus, ad Cod.6.23.1, $\mathbb{\$}$ Testes (Baldi de Pervsio Ivrisconsvlti clarissimi, svper Sexto Codicis Iustiniani libro Commentaria luculentissima ... Lvgdvni, typis Gaspar \& Melchior Trechsel, 1539, fol. 57va, n. 12): '... non $\mathrm{ob}$ (stante) $\mathrm{l}$ (ege) barbarius quia ibi interuenit decretum superioris.' See further supra, last chapter, note 115 , and infra, next chapter, note 62 . A last case is, once 
Relying on canon law terminology (especially in its use by Innocent), Baldus often stated that Barbarius lacked canonicum ingressum and so was an intrusus. ${ }^{27}$ The intruder, as we know, is the opposite of the tolerated in office. Hence Baldus' problem: how to apply toleration without confirmation?

In his commentary on the lex Barbarius, the first item in Baldus' agenda was to make sure to exclude the confirmation by the prince. So Baldus starts by recalling the main obstacles in the text to the validity of Barbarius' praetorship. A first obstacle is the classical lex Herennius (mere enlistment as decurion does not make one such), ${ }^{28}$ and similar other leges. ${ }^{29}$ Recalling a typical argument of

again, in Baldus' comment on Cod.3.34.2, $\mathbb{\$}$ Si aquam (svper Primo, Secvndo \& Tertio Codicis commentaria, cit., fol. 218va, n. 73): when the defect in the election is latent, 'confirmatus ... non repellitur quamdiu est in possessione autoritate superioris, ar(gumentum) de offi(cio) presi(dis) (sic) $<$ l. $>$ barbarius (Dig.1.14.3), de rescri(ptis) <c.> sciscitatus (X.1.3.13) per Innoc(entium).' The mistaken reference to the title on the officium praesidis instead of the officium praetorum happens rather frequently in Baldus, but only when he is just mentioning the lex Barbarius in passing. The same mistake is also found in Innocent (who similarly referred to the lex Barbarius in passing): see e. g. supra, pt. II, $\mathbb{\$ 7 . 6}$, note 123 . This might strengthen the impression that, in such cases, Baldus' reference to the lex Barbarius was rather superficial and based on Innocent's writings. When discussing specifically on Barbarius' case, much on the contrary, Baldus is extremely clear in rejecting the confirmation by the prince. He excludes as much in lectura, repetitio and additio on the lex Barbarius. These three texts were not written at the same time, so they attest to the continuity of Baldus' position on the matter. As such, it would be very surprising if Baldus did change his mind on the subject, not to mention that the cases in which he hints at Barbarius' confirmation are vastly outnumbered by those in which he denies as much throughout his opus, as we will see throughout this chapter. Allowing for the ratification of Barbarius's position would have contradicted Baldus' entire reasoning. On the contrary, it was precisely the separation between person and office that allowed Baldus to distinguish between the invalidity of Barbarius' appointment and the validity of his deeds.

27 Baldus, lectura ad Dig.1.14.3, cit., fol. 55va, n. 20; fol. 55vb, n. 23; fol. 56vb, n. 40; Id., repetitio ad Dig.1.14.3, cit., fol. $57 v b$, n. 10 and 12. We will deal with the most significant parts of the additio later in this chapter, especially towards the end.

28 Id., lectura ad Dig.1.14.3, cit., fol. 55rb, n. 14: '... opponitur et videtur quod Barbarius non fuerit verus praetor, sed putatiuus, vt i(nfra) de decur(ionibus) 1. Herennius (Dig.50.2.10), nam qui secundum legem creatus non est verus praetor non est, sicut nec verus decurio, qui non est electus secundum legem quae loquitur de electione decurionum: adeo vt etiam si perceperit commodum officii, tamen officium non dicatur habere, vt ibi patet. Sol(utio) ibi percepit commodum officii, $\mathrm{i}(\mathrm{d}$ est) salarium sine titulo: quia non erat electus, vt no(tatur) i(nfra) de fal(sis) l. eos $\$$ qui se (Dig.48.10.27.2), secundum gl(ossam) et de illo intelligitur quod incidit in crimen falsi.' Cf. Dig.50.2.10 (Mod. 1 Resp.): 'Herennius Modestinus respondit sola albi proscriptione minime decurionem 
the Ultramontani Baldus also notes that, if Barbarius was truly praetor, then the whole issue as to the validity of his acts would make no sense. ${ }^{30}$ Another point made by the Orléanese jurists is further used to highlight the difference between Pomponius' remarks on Barbarius and Ulpian's explanation: ${ }^{31}$

you say that Barbarius became praetor by this lex, and this is false. It is true that Pomponius said that the servile condition was of no obstacle [to the praetorship]. However, Ulpian referred that only with regard to its exercise, and when he asked whether [the servile condition] prevented [the entitlement to] the true dignitas, he did not offer a solution. But in acknowledging that solution only as to the exercise [of the praetorship], he seems to deny as much for the rest.

Another favourite argument of the Ultramontani was that Ulpian's skills, remarkable and manifold as they were, failed short of reading people's minds. Baldus follows suit: 'who can read the mind of someone who keeps silent?' Ulpian's statement that the people would have set Barbarius free had they known of his servitude, he says, remains speculative. ${ }^{32}$ Again after the Ultramontani, Baldus also reads the same statement of Ulpian a contrario. Ulpian said that if the people had known that Barbarius was a slave, they would have set him

factum, qui secundum legem decurio creatus non sit.' Baldus' reference on the false decurion's salary came from the Gloss: supra, pt. I, $\$ 2.2$, text and note 45 . In the lectura on Barbarius' case (lectura ad Dig.1.14.3, cit., fol. 55rb, n. 15) Baldus refers in particular to Dig.49.1.12 (Ulp. 2 opin.), which stated that the duumvir appointed without the legal requirements but simply owing to popular demand is void.

30 Id., repetitio ad Dig.1.14.3, cit., fol. 57vb, n. 10: 'praeterea si Barbarius fuit praetor, queritur quare formatur quaestio de actibus exercitis, an valeant, quis dubitat valere, cum sint facta a iusto praetore.' Baldus also deliberately twists the Gloss' reasoning, with an irony that no contemporary jurist could have failed to notice. In the repetitio ad Dig.1.14.3 (cit., fol. $57 v b$, n. 11) he says: 'Item pro gl(osa) sic facit, quia si Barbarius esset minus legitima persona, ergo pro nulla deberet reputari, in quod cuiusque uni(versitatis) nom(ine) 1 . i $\$$ quod si nemo (Dig.3.4.1.2). Et confirmo gl(osam) tali ratione.' Clearly the Gloss said as much only to warn about the gravity of the consequences of denying the validity of Barbarius' praetorship. Instead, Baldus pretends to take the Gloss at its face value.

31 Baldus, lectura ad Dig.1.14.3, cit., fol. 55rb, n. 15: 'tu dicis, quod Barbarius fuit praetor per hanc l(egem) et hoc videtur falsum. Nam licet Pompo(nius) dixerit "ei non obfuisse seruitutem", tamen Vlpian(us) exponit quo ad exercitium, sed quo ad veram dignitatem an obfuerit, quaerit, et non soluit. Quinimmo ex quo de exercitio tantum fatetur, de alijs negare videtur.'

32 Ibid., fol. 56rb, n. 32: 'Quaeritur ergo, an Barbarius fuerit liber effectus? Et glo(sa) dicit quod sic in potestate enim, et voluntate simul concurrentibus proficitur omnis actus humanus ... sed hic est potestas, et voluntas ficta circa libertatem conferendam, et hoc aperte dicit litera. Sed certe imo requiritur tertium, $s$ (cilicet) scientia, quae hic non est, et licet iurisconsultus dicat, quod liberum fecisset, non loquitur de iure sed de facto, quando enim potest Iurisc(onsultus) scire intentionem populi, quis enim silentis novit mentem?' 
free. But this could also mean that if they had ignored his servile condition they would have left him as a slave. ${ }^{33}$

As a matter of principle, there is little doubt that the emperor could have confirmed Barbarius despite his servile condition. The question is however whether he wanted to. Discussing the lex Iulia de ambitu, Baldus' lectura clearly accepts the (abstract) faculty of the superior authority to confirm the election of the unworthy - and so, of tolerating him in office. The point is further developed in the repetitio. Again, the argument moves from the analogy with the confirmation by the superior of a murderer or even an occult simoniac elected to an ecclesiastical office. In so doing, Baldus relies especially on Innocent IV and Guido de Baysio (who, on the matter, followed Innocent). ${ }^{34}$ Despite the gravity of the personal condition, concludes Baldus, the confirmation by the superior bestows full validity on the appointment. ${ }^{35}$

We have seen earlier how the confirmation of the unworthy by the superior authority allows the object of the dignitas to shift from that of the unworthy to

33 Ibid., n. 35: 'Et per hoc facit, quia litera videtur corrigere dictum Pomponii. Item, quia loquitur conditionaliter, s(cilicet), "si sciuisset", et $\arg ($ umentum) a contrario sensu sumpto ex illa conditionali: secus et, si ignorauit.' Baldus comes back to the subject in the repetitio ad Dig.1.14.3 (cit., fol. 58ra, n. 14-16), especially to look at the (theoretical) problem of the validity of Barbarius' emancipation in terms of expropriation of private property (Barbarius was a slave, so he belonged to his master). Baldus discusses the issue not because of a change of heart between lectura and repetitio, but only for the sake of completeness - just like the Ultramontani did (supra, pt. I, $\mathbb{\$} 4.4$, note 88 ). On the point, Baldus' discussion is not dissimilar from that of the thirteenth-century Orléanese professors, with some obvious differences mainly due to the growth of natural law ideas during the century separating them.

34 Supra, pt. II, $\$ 8.3$.

35 Baldus, repetitio ad Dig.1.14.3, cit., fol. 57vb, n. 11: 'vbi est defectus solum in persona electi, confirmatio superioris tribuit ei ius, et idem est in promotione. $\mathrm{Vn}(\mathrm{de})$ si homicida, qui est irregularis, vel simoniacus confirmetur in Episcopum, valet confirmatio, et erit prolatus tuitione confirmationis superioris, $\arg$ (umentum) quod fal(so) tut(ore) autor(e) 1. i $\$$ idem Pompo(nius) (Dig.27.6.1.5), Arch(idiaconus) viii $q$. $i$ c. in scriptis (C.8, q.1, c.9). Nam in eum hoc ius cadere potest, uirtute confirmationis. Inn(ocentius) ext(ra) de concess(ione) praeben(dae) c. cum in nostris in prin(cipio) (X.3.8.6). Sed certum est, quod promotio Barbarij habuit uim electionis et confirmationis. Facit quod no(tat) Arch(idiaconus) lxiii dist. in synodo (D.63, c.23), cum alium actum non requirat, sed trahit secum suum effectum, sicut confirmatio, de condi(cionibus) et de(monstrationibus) 1. publi(us) (Dig.35.1.36pr) et no(tatur) per Inn(ocentium) in c. cum nihil, de elec(tione) (rectius 'nihil est': X.1.6.44) c. cum inter canonicos (X.1.6.21) et c. cum dilectus (X.1.6.32), eo tit(ulo) per Inno(centium), et hoc verum in confirmatione Principis.' Innocent's statement should be referred only to the occult simoniac, not to the notorious one: cf. Innocent IV, ad X.1.6.44, \administrent (Commentaria Innocentii Quarti, cit., fol. 75va, n. 5). 
that of the superior. This way, the symmetry between dignitas of the office and dignitas of its incumbent is kept: the unworthy sits in office not because of his own dignitas, but because of that of the authority who confirmed him. This symmetry however also requires the gravity of the indignitas to be matched by a correspondingly higher dignitas of the superior. Not any superior authority, in other words, may confirm a particularly serious defect (a 'vitium intolerabile') in the elected. ${ }^{36}$ Moving to civil law, and transposing these canon law rules into secular ones, Baldus concludes by arguing that only the appointment by the sovereign authority can remove any legal obstacle deriving from the person of the appointed, even the most serious ones. The authority of the sovereign allows the unworthy to exercise his office validly, because it is almost as if the sovereign himself acted through him. ${ }^{37}$ The dignitas of the office is therefore more than matched by the dignitas of the sovereign. The intervention of the prince does not cure the underlying indignitas of the appointee to the office. It replaces it with its own dignitas. Speaking of replacement and not of full healing entails a subtle but important difference: the dignitas of the superior authority takes the place of the indignitas of the office holder, but it does not heal it. The moment this approbation no longer holds, the incumbent in office loses the support of the superior dignitas and is left with his own indignitas, so that he is precluded from exercising his office any further.

Baldus, repetitio ad Dig.1.14.3, cit., fol. 57vb, n. 11: 'sed confirmatio inferioris non valet, si in electione sit vitium intolerabile, ita intelligo Inn(ocentium) in $\mathrm{d}$ (icto) c. cum dilectus (X.1.6.32) et adde quod no(tat) Inn(ocentius) de dolo, $<$ c. $>$ cum olim (X.2.14.7), et facit de excu(sationibus) tut(orum) qui test(ament)o (Inst.1.25.18).' Cf. ibid., fol. 58rb, n. 22: 'Sed quid si Papa ex certa scientia tales [indignos] promouet? Dico, quod dispensare videtur, de re iudi(cata) l. quidam consulebant (Dig.42.1.57) et no(tandum) in 1. ii C. de diuer(sis) offi(ciis) lib. xii (Cod.12.59.2). Inferiores autem non dispensant nisi causa cognita, et in casib(us) permissis, vt in c. at si clerici, extra de iudi(ciis) (X.2.1.4) per Ber(nardum Papiensis) et per Inno(centium), extra de fi(liis) presby(terorum) c. veniens (X.1.17.5) ubi dicit quod non potest haberi pro legitima dispensatione factum temerarium inferiorum, quod est valde no(tum).' See also Baldus' lectura ad Dig.1.14.3, cit., fol. 56va, n. 38-39.

37 Id., lectura ad Dig.1.14.3, cit., fol. 56va, n. 37-38: 'Et vt sparsi per oppositionem tituli in vnum distinctionis fontem colligant, dic quod aut quis promouetur a Principe, vel quasi, vt a populo, qui in sua viuit libertate, vt Romanus, et Gallicus. Et tunc aut proprio motu et omnia valent, quia proprius motus omnem obreptionem excludit, vt in c. si motu proprio, de praeben(dis) lib.vi. (VI.3.4.23) aut ad supplicationem alterius; et tunc aut quo ad fauorem aliorum multorum, vel Reipublicae, vt in balneis, et statuis; et valent omnia, non quasi ipse fecerit, qui indignus est, sed quasi fecerit Princeps, qui auctoritatem dedit. C. de ve(teri) iu(re) enu(cleando) l. i $\$ omnia (Cod.1.17.1.14).' 
So far, Baldus seems to be following Innocent's thinking closely. Baldus, however, must avoid its logical conclusion - without confirmation, the unworthy remains an intruder. Hence he continues his reasoning by introducing two problems. One is general, on the mechanism of the confirmation; the other is more specific, on the actual intention of the prince to confirm unworthy people such as Barbarius.

The general problem is that the confirmation of the superior is valid only if the superior knew of the defect of the person elected to the office. On the point Baldus has an easy card to play: because of his scant interest in the lex Barbarius, Innocent did not say expressly that the prince knew of Barbarius' defect when confirming him in office. Interpreting Innocent's own principles in the light of a different reading of the lex Barbarius, therefore, Baldus could use them against the validity of Barbarius' praetorship. Innocent was very clear on the need for knowledge: confirmation may even ratify an invalid election, but only if the superior acted 'with full knowledge' (ex certa scientia) of the cause of invalidity. ${ }^{38}$ Baldus follows suit. In his lectura he moves from the case of the occult simoniac so as to draw - once again - an analogy with the case of Barbarius. The confirmation by the superior who has no knowledge of the underlying defect does not cure the simoniac election. By the same token, the confirmation of Barbarius cannot cure his servile status if it was not disclosed to the prince. In the lectura Baldus says as much in general terms. ${ }^{39}$ In the repetitio he is more explicit: Barbarius was not confirmed by the prince, but even a hypothetical confirmation would be void, for it would be given without knowledge of the underlying defect. ${ }^{40}$

Cf. Innocent IV, ad X.1.6.32, $\mathbb{S}$ Confirmauit (Commentaria Innocentii Quarti, cit., fol. $63 \mathrm{ra}$, n. 1 , and fol. $63 \mathrm{rb}, \mathrm{n} .2$ ), supra, pt. II, $\$ 7.1$, notes 9 and 10 respectively. The above discussion of the confirmation of the unworthy and the indignitas of the confirmed might help us to better appreciate why confirmation required full knowledge of the underlying defect. As we have seen, the intervention of the superior authority replaced the indignitas (unworthiness and so unfitness) of the office holder with its own higher dignitas. On the basis of that higher dignitas the unworthy could be considered fit to exercise the office (and - from the outside worthy of doing so). It is however not possible to imagine that the dignitas of the superior might replace the indignitas of the tolerated in office without the precise intention of the superior authority. And the superior could act intentionally only if fully aware of the underlying indignitas.

39 Baldus, lectura ad Dig.1.14.3, cit., fol. 55ra, n. 9: '... aut nulla intervenit confirmatio, et nihil valet, nec ad liberandum, nec ad obligandum; aut intervenit confirmatio, sed invalida propter vitium latens, et tunc valent gesta ad liberandum, sed non ad obligandum ipsa $<\mathrm{m}>$ dignitatem, vel officium; aut intervenit confirmatio efficax, et tunc omnia valent, quia praetor suum factum tueri debet.'

40 Baldus, repetitio ad Dig.1.14.3, cit., fol. 57vb, n. 10: 'praeterea aut Barbarius est praetor de iure communi, aut dispensatiue: primo modo non, quia non capax, nec secundo, quia super defectu praesumpto, quia non intelligitur dispensatum, 
The same conclusion may be reached through different and more general reasoning. There are four cases in which one seeks an office, says Baldus in the lectura: (1) when the office already belongs to someone (who is just seeking to recover its possession), (2) when one is elected but not yet confirmed and installed in office, (3) when one is unworthy of it or unable to exercise it, and (4) when none of the above cases applies. The choice of the superior authority as to the conferment of the office, explains Baldus, is only about this forth case - and so, on the request made by someone who is neither entitled nor unable to discharge an office. In the other three cases there is no choice to be made, either because it is only a question of enforcing or allowing a rightful claim (as in the first and second cases respectively), ${ }^{\mathbf{4 1}}$ or because the request is inadmissible and should not even be made (as in the third case). Barbarius' situation clearly falls in this third case, and a void request should not even be taken into account. ${ }^{42}$

Having ruled out the validity of a hypothetical confirmation in general terms, Baldus then seeks to dismiss the possibility that this might have occurred in practice. The fact that Ulpian contemplated such a possibility compels Baldus to discuss it, and he does so in several ways.

A first and rather direct way is turning the Gloss against itself. In the lex Barbarius the Gloss did not speak of a clear intention of the prince to ratify Barbarius' election, but assumed as much on the basis of the presumed will. Elsewhere, however, commenting on the lex Quidem consulebat (Dig.42.1.57), the Gloss was far more explicit. As we have seen in the analysis of the Gloss, ${ }^{43}$ this lex drew a parallel between the minor chosen as iudex and appointed as

de re iudi(cata) 1. quidam consulebant (Dig.42.1.57) et de excus(ationibus) tut(orum) <l.> idem (Dig.27.1.12pr), et de nat(alibus) rest(ituendis) $l . i$ (Dig.40.11.1), de pecu(lio) leg(ato) <l.> cum dominus (Dig.33.8.19pr).'

41 Considering also the second case (that of the elected seeking confirmation in office) in terms of rightful claim might imply that confirmation is a right of the elected. The point was of course more complex, but Baldus' argument was instrumental to a different purpose - denying the validity of a possible petition by Barbarius.

42 Baldus, lectura ad Dig.1.14.3, cit., fol. 55ra, n. 10: 'aut dignitas est sua, aut sibi debita ex praecedenti ordinatione, puta quia electus aut si indebita, puta quia inhabilis et indignus, aut neutro istorum modorum. Primo casu quis potest eam petere, et vendicare, extra de iudi(ciis) c. fi. (X.2.1.21). Secundo casu potest petere, vt confirmetur, et legitime inchoatum est sine debito, vt consumetur, extra, de elect(ione) c. cum inter canonicos (X.1.6.21). Tertio caso non potest petere, C. si seruus aut liber(tus) ad decu(rionatum) aspi(raverit) 1. ii lib. $x$ (Cod.10.33.2) ... Quarto casu est in superioris arbitrio notare petentem de ambito, necne; et si superior admittit, non censetur impetrans ambitiosus, sed dignus.'

Supra, pt. I, $\$ 2.4$. 
magistrate. In the first case the validity depended on the consent of the parties; in the second, on the will of the prince. The Gloss remarked on the similarity between the legal incapacity of the minor and that of the slave, in order to highlight the will of the prince. If the prince could make up for the incapacity of the minor, why not also for that of the slave? The Gloss however did not push the equation as far as suggesting that the prince would deliberately appoint a slave as praetor. Rather, it used the analogy to argue that, in principle, the prince could heal the irregularity in Barbarius' praetorship. ${ }^{\mathbf{4 4}}$ In his lectura, much to the contrary, Baldus highlights the implicit innuendo in the Gloss, with the deliberate intent to weaken its conclusion. In the case of a minor, says Baldus, the only incapacity is the minor age. In the case of Barbarius, however, the incapacity is much more serious. It is therefore not possible to imagine that the prince would have appointed Barbarius despite his status as a slave. Doing so would amount to ascribing unworthy behaviour to the prince, 'for it may not be presumed that the prince wanted to infringe the ius commune (as in Cod.3.28.35pr), ${ }^{45}$ nor that he wanted to promote odious and criminal people (as in Dig.31.1.88.11)', 46

The same point is further elaborated in the repetitio. There, not only does Baldus describe Barbarius as unworthy (indignus), but also refers this unworthiness - by extension - to the debate on his praetorship. The baseness of Barbarius makes it unworthy to even speculate about his possible freedom: 'arguing in favour of Barbarius, who deceived the people, would be unworthy (indignum),

Ibid., esp. note 81 .

Literally, the reference is to Cod.3.28.33pr (the lex Si quis), but that is very likely a typo for Cod.3.28.35pr (the lex Si quando): cf. Baldus, ad Cod.3.28.35pr, $\mathbb{S} S i$ quando (svper Primo, Secondo \& Tertio Codicis, cit., fol. 195ra), n. 1: 'nota quod princeps sub verbis generalibus non intelligitur velle concedere illud quod est iniquum vel absurdum: vnde licet concedat alicui quod libere possit testar, tamen non potest filium praeterire vel exheredare sine causa.'

Id., lectura ad Dig.1.14.3, cit., fol. 55va, n. 16: 'Et si dicatur si Princeps hoc obtulisset, dispensasset. R(espondeo), hoc nego: quia non praesumitur quod Princeps velit infringere ius commune, C. de inof(ficioso) te(stamento) l. si quis in princ(ipio) (Cod.3.28.33pr, sed Cod.3.28.35pr) nec praesumit quod velit, promouere odiosos et multiplicter criminosos, $\arg$ (umentum) de leg(atis) ii $<$ l.> Lucius $₫$ Lucius Titius damam (Dig.31.1.88.11).' This last lex (Scaevola 3 resp.) was one of the several Roman law texts that highlighted the importance of ascertaining the testator's precise will. But it was one of the few ones to make clear that, when the will had to be referred to specific facts or actions, it should be ascertained by looking at the precise moment when such facts or actions were committed. Applied to the appointment of Barbarius by the prince, this criterion would bar the Gloss' argument of presumed will (which sought to interpret the intention of the prince at the time of the appointment according to the future consequences that such an appointment would have). 
first of all because, having committed a crime and being infamis, he did not enter lawfully in his office. ${ }^{, 47}$

A second and more nuanced way to dismiss the actual occurrence of Barbarius' confirmation was introducing a semantic distinction. Allowing something, Baldus notes, might denote approbation or just forbearance. For instance, nothing could happen against God's will. But not everything happens because God wants it to. Sometimes God just allows things to happen without necessarily approving of them. In the same way, argues Baldus, when the prince allows something he might just suffer it to happen without endorsing it. ${ }^{48}$

Also on this point, Baldus goes further in the repetitio. There, he is determined not to allow even the mere possibility of a hypothetical confirmation. ${ }^{49}$ To do so, he highlights the ambiguity of the final statement of the lex Barbarius - that the prince could set Barbarius free 'much more' (multo magis) than the people. From Azo onwards, as we have seen, this passage was always interpreted in a restrictive way: the sovereignty of the prince is the same as that of the Romans, but it is easier for a single individual to decide something than it is for a large group of people. ${ }^{50}$ Baldus however exploits the ambiguity in the words 'multo magis' to turn the explanation of the Gloss against itself: while a single person might decide more swiftly than a whole people, it is much easier for a single individual

Id., repetitio ad Dig.1.14.3, cit., fol. 57vb, n. 10: 'Barbario autem fauere, qui decepit populum, indignum est, et maxime quia criminosus, et infamis non habuit canonicum ingressum.'

Id., lectura ad Dig.1.14.3, cit., fol. 56va, n. 38: 'Principe dico fecisse permissiue, non formaliter, sicut Deus permittit: tamen Deus non facit; aut loquimur ad fauorem obrepentis, et tunc quantum est in se, ipse non meretur honorem, sed pudorem.' To better explain Baldus' concept of forbearance, it might be useful to look at the related concept of patientia superioris. In Baldus, such a patientia would seem to entail tacit approbation through inertia. The difference with explicit approbation (i.e. confirmation/ratification) is that patientia of the superior authority does not produce the full consequences of confirmation, but it simply inhibits the effects of its absence. Unlike patientia, forbearance does not entail a judgment value, and so neither tacit approval. The concept of patientia superioris in Baldus is particularly clear in his main writing on tyranny, the commentary on the lex Decernimus (Cod.1.2.16). Tyrant, says Baldus, is only the usurper whom the prince is unable to subdue, not also the usurper whom the prince tolerates (patitur) because he rules well. It follows that the deeds of such a tolerated usurper are valid. Cf. Baldus, ad Cod.1.2.16, critical edition in Quaglioni (1980), p. 79, n. 2.

49 Baldus, repetitio ad Dig.1.14.3, cit., fol. 58vb, n. 30: 'nec possumus arguere in contrarium ex litera conditionali, quae dicit "si scisset", quia verum si scivisset et creasset; sed praesumitur non creaturus esse, si sciuisset indignum, quia non praesumitur id factum esse quod fieri non debeat.' Supra, pt. I, $\$ 2.4$. 
to be mistaken than for the whole community. ${ }^{51}$ So the interpretation of the Gloss is wrong. What the lex really meant, concludes Baldus, is that Barbarius would be in a stronger position if he was created emperor himself. For so long as one is Christian, no personal defect may be invoked to prevent his coronation as emperor. ${ }^{52}$ The explanation is apparently eccentric in respect of the context. In fact, it purportedly undermines the strength of the whole passage. Clearly Barbarius was no emperor. So one may safely overlook the passage and, with it, the possibility of Barbarius' confirmation by the emperor. The difference with the Gloss could hardly be more pronounced: far from being the cornerstone of the whole reading of the lex Barbarius, the reference to the prince becomes a marginal curiosity.

In the additio on the lex Barbarius Baldus follows a different and more direct approach to adapting Innocent's conclusions on Barbarius (toleration because

51 It might be noted that, by Baldus' time, the possibilty that the prince made a mistake was discussed more openly than in the time of Accursius (cf. supra, pt. I, $\$ 2.5$ ). So for instance Bartolus already said that, swhile not likely, the prince might well make a mistake: Bartolus, ad Dig.33.10.3.5, $\mathbb{\$}$ Sed et de his (In II. Partem Infortiati, cit., p. 251, n. 3): 'non est uerisimile quod [princeps] erret, sed errare potest.' In stating as much, Bartolus was building on what Jacobus de Arena had already said: if the prince enacts a new provision in the mistaken belief that he was just applying an old one, the new provision is void: 'Finaliter Iac(obus) de Are(na), quem sequitur Old(radus de Ponte), dicit multum bene, iudicio meo: Quandoque Princeps uel alius qui habet ius condendi, errat in ipsa legis constitutione, quam in ueritate non intendit legem constituere sed utitur tanquam sit iam constitututum: tunc non facit ius talis error, quoniam deficit consensus' (ibid., p. 250, n. 1).

52 Baldus, repetitio ad Dig.1.14.3, cit., fol. 58vb, n. 30-31: 'Venio ad vltimam partem, dicitur hic quod multomagis in Imperatore. Contra, quia immo pari ratione, et quia pari potestate, et sicut in natura pari vnus alio maior non est \{secundum August(inum)\}, et no(tatur) de manu(missis) \{vind(icta)\} 1. apud eum (Dig.40.1.14pr): ita nec id praesertim, quia a populo processit 1. i de consti(tutionibus) prin(cipum) (Dig.1.4.1), 1. ii $\$$ novissime, de orig(ine) iu(ris) (Dig.1.2.2.11). Sol(utio) verum ex parte potestatis, sed ex parte consensus facilius, et verius consentit vnus, quam plures, ut $l$. $i$ in $f(n e)$ in(fra) de acqui(renda) pos(sessione) (Dig.41.2.22); facit quod no(tat) Inn(ocentius) in c. gravem de sent(entia) excom(municationis) (X.5.39.53). Secundo opp(onitur) si errat Princeps, errat vnus, et non error communis: ergo multo minus debet dicere, non multomagis $\{\mathrm{Sol}(\mathrm{utio})$, non attenditur hic error communis respectu creantis, sed respectu subditorum, et secundum $\mathrm{h}(\mathrm{oc}) \mathrm{d}$ (ictum) multomagis quam in populo, vel dic nouam expositionem multomagis\} quam in Barbario, et sit sensus, vt si Barbarius fuisset creatus Imperator, minus noceret ei seruitus quam praetor, quia Imperatori nihil opponi potest, dummodo sit catholicus \{sicut sunt Alamani, qui sunt optimo catholici, et fideles, sicut et Papae\} Expositione glo(sae) \{ergo\} loquit in Imperatore creante, ergo etiam in Imperatore creato quod no(tatur).' 
confirmation by the prince) towards the desired outcome (toleration despite the lack of confirmation). This different approach is based on one of the most successful and widely employed legal techniques in the history of the ius commune: selective quotation. The selection in question comes from three comments of Innocent. In the first (his comment on X.1.6.28), the pope stated that some elections may not be confirmed and the acts remain void. In the second (his comment on X.1.6.32) - according to Baldus - Innocent changed his mind. There, the pope allegedly argued that even if the confirmation is void, nonetheless the acts carried out by the elected are valid on the basis of public utility and the common mistake as to the validity of the election itself. This, observes Baldus, is true if the defect lies only in the election, not also in the confirmation. Indeed, he concludes, Innocent himself said as much when commenting on X.1.6.17. ${ }^{53}$

The best lies always contain some truth. In the first passage (X.1.6.28) the pope distinguished between election carried out in violation of natural and positive law. As we have seen, ${ }^{54}$ only the first kind is ipso iure void and therefore may not be confirmed. In such a case, the elected remains an intruder, so his deeds are void. We have also seen that the only example provided by Innocent was, somewhat ambiguously, that of simony. ${ }^{55}$ The second passage of Innocent quoted by Baldus contains the most important comment on the lex Barbarius made by Innocent in his whole opus. The summary provided by Baldus is correct in its form, but misrepresents in the substance. Baldus refers only to the beginning of Innocent's reasoning. There, the pope was simply observing that, at first sight, the lex Barbarius might lend validity to the acts despite the lack of confirmation by the prince. Innocent said as much in canon law language: the confirmation might be void, and yet Barbarius seems to be tolerated in office, so his acts are valid. ${ }^{56}$ Immediately thereafter, however, Innocent continued and said that a different explanation might well be that the lex Barbarius referred only

Id., additio ad Dig.1.14.3, fol. 59rb, n. 9: 'tamen hoc quod Inno(centius) dicit in c. quod sicut (X.1.6.28), modificat in c. cum dilectus, eo ti(tulo) (X.1.6.32), quod licet sit nulla confirmatio, acta valent fungente publica vtilitate et errore communi per hanc l(egem) [scil., the lex Barbarius]. Ego dico hoc esse verum vbi delictum est in sola electione. Si autem est in confirmatione, dubito an acta valerent, et est $\arg ($ umentum) quod no(tatur) i(nfra) qui satis(dare) $\operatorname{cog}$ (antur) 1 . quotiens vitiose (Dig.2.8.6), cum si nam non valerent si nulla confirmatio esset facta, et no(tat) idem Inn(ocentius) de ele(ctione) qualiter (X.1.6.17) et ad 1. nostram.'

54 Supra, last chapter, note 94.

$55 \mathrm{Ibid}$. As said, it is possible that Innocent was only thinking in sacramental terms, not also in jurisdictional ones.

56 Cf. supra, pt. II, $\$ 7.6$, note 113. 
to cases where the confirmation by the prince was validly given. ${ }^{57}$ This was clearly Innocent's choice, so he went on stressing the need of valid confirmation in any case. ${ }^{58}$ Baldus however ignores the rest of Innocent's passage. To strengthen his conclusion, Baldus points to a third comment of Innocent (X.1.6.17). There, says Baldus, not only did Innocent affirm that the deeds of the elected are void if he is not confirmed in office, but he even gave Barbarius' case as an example of lack of confirmation. As a matter of fact, in that comment Innocent did say that the administration of the office is void without proper confirmation. And he also added that, on the contrary, proper confirmation cures the defect in the election. To stress the point, he reported two cases in the sources: the case where the confirmation cured the invalidity was precisely the lex Barbarius. ${ }^{59}$

\subsection{Common mistake and public utility}

Seeking to use toleration without confirmation, Baldus has to bar any route leading to the validity of Barbarius' praetorship. That means first of all excluding confirmation by the prince or the people, but also checking the consequences of the common mistake.

We have seen earlier how the Gloss coloured with intentionality the common mistake for the sake of public utility: the people's mistake as to Barbarius' status

Ibid.

Ibid., text and note 116.

Innocent IV, ad X.1.6.17, $\$$ Tenere (Commentaria Innocentii Quarti, cit., fol. 48ra): 'quia non fuit electio confirmata: alias secus, ff. de off(cio) praeto(rum) <l.> Barbarius (Dig.1.14.3), infra, de iurepatro(natus) <c.> consultationibus (X.3.38.19).' Innocent recalled these two cases so as to oppose one to the other: the specific case of the patron (patronus) to which he referred was that of someone who was found to be the rightful patron (i.e. holder of the ius patronatus) in a legal decision, while in fact he was only in possession of the ius patronatus and, worse still, in a bad faith possession. Commenting on that case, Innocent drew a distinction between ius patronatus and public office: the patron in bad faith is still acting as a private person, not in the exercise of an office. The legal decision (wrongly) acknowledging his ius patronatus, therefore, does not count as confirmation in it: cf. Innocent, ad X.3.38.19, $\mathbb{\$}$ Consvltationibvs, ibid., fol. $442 v a-b$, n. 1-3). This way, the contrast with the other case, that of Barbarius, becomes clear. Both the patron and Barbarius were in bad faith, but only the latter exercised a public office. Innocent therefore did not seek to narrow the effects of the confirmation of an invalid election. Rather, he applied the toleration principle on the basis of representation: in the case of the patron there was no legal representation, so the judicial decision acknowledging him as patronus could lead neither to toleration nor, consequently, to the validity of the acts. 
is to be qualified as implicit consent for public utility considerations. So, while the people were not aware that they had elected a slave, they should be considered willing to set that slave free so as to ratify his acts as praetor. In the elaboration of the Ultramontani, the common mistake was described in terms of public utility. Cugno insisted that the common mistake ought to be read in the light of public utility, and should not be invoked alone. Bellapertica relied exclusively on public utility: for him, the only function of the common mistake was to trigger public utility considerations, and then to fade away. Bartolus' attempt to combine Bellapertica with the Gloss left little room for the common mistake as well. The validity of Barbarius' praetorship (which Bartolus described after the Gloss) depended on the presumed will of the people (where the mistake became presumed will, and so intentionality), while the validity of his deeds (on which Bartolus followed Bellapertica) derived exclusively from public utility.

Also in Baldus public utility is the ultimate reason for the validity of Barbarius' deeds. But - and quite unlike Bellapertica - public utility does not apply directly. It remains in the background. The mechanism by which the deeds become valid is an adaptation of Innocent's concept of toleration. Just as in Innocent, so in Baldus toleration ultimately furthers public utility. This however does not mean that toleration can be invoked for public utility considerations. Toleration must come first. Innocent spoke of public utility only after having clearly structured and fully explained his concept of toleration. This was deliberate: invoking a direct application of public utility would have led to obliterating the whole concept of representation. It was much safer to consider toleration as a manifestation (and so, an indirect application) of public utility, making sure that public utility would operate through toleration and not directly. Baldus does the same. With regard to the lex Barbarius, invoking public utility directly would lead either to the confirmation of Barbarius being presumed (as in Accursius), this way blurring the difference between intruder and lawful agent, or - even worse - to an unbridled and indiscriminate application of public utility (as in Bellapertica), and so, ultimately, to the denial of representation itself.

If not tamed, common mistake could become a problem. The main reason Baldus discusses it is therefore to bar its possible application either to the person of Barbarius (making him truly praetor and circumventing the role of the superior authority) or to his deeds (making them valid and skipping the whole representation issue). The first instance is to be completely excluded: common mistake must not lead to presumed will. The second one is of course different. Without common mistake, there would be no reason to invoke public utility to begin with. What must be avoided is a direct application of the common mistake to the deeds. 
As Baldus says in the repetitio, the three reasons that traditionally supported Barbarius' praetorship - common mistake, confirmation by superior authority and public good - may not stand all together: one would exclude the other. ${ }^{\mathbf{6 0}}$ Highlighting their mutual incompatibility, Baldus seeks both to exclude the occurrence of confirmation and to narrow down the effects of the common mistake, subordinating it to public utility.

Public utility and ratification of Barbarius' position by the superior authority may well stand together - the former can be considered the reason for the latter. This is what the Gloss did: looking at the common mistake in the light of public utility, the Gloss qualified the mistake of the people as implied consent. Seeking to avoid that result, Baldus focuses more on the relationship between superior authority and common mistake, so as to play one against the other. An obvious way to do so is to recall the Ultramontani's slogan on the opposition between consent and volition. Baldus does as much in the lectura: as mistake is the opposite of consent, a mistaken choice is no choice at all. ${ }^{61}$ In the additio Baldus comes back to the point, but more subtly. The Gloss ascribed intentionality to the common mistake, and argued for presumed will to confirm Barbarius. In so doing, it focused almost exclusively on the common mistake and considered the

60 Baldus, repetitio ad Dig.1.14.3, cit., fol. 58ra, n. 17: 'Modo restat quaerere, an communis error populi, publica auctoritas, et communis vtilitas, omnia illa tria essentialiter requirantur ad ualidationem actorum? Et videtur quod sufficiat superioris auctoritas cum quasi possessione libertatis, vt C. de sen(tentiis) l. si arbiter (Cod.7.45.2). Econtra videtur quod propter periculum multorum dispenset haec lex, et sit finalis ratio, publica vtilitas \{uel quasi\}, econtra videtur quod sufficit solus error communis, quia facit ius, et maxime in iudice ordinario, cui subditus nibil potest opponere, ex quo est in pacifica quasi possessione iurisdictionis autoritate superioris, vt no(tat) Inn(ocentius) per hanc l. de offi(cio) dele(gatis) <c. $>$ cum super (X.1.29.23), Arch(idiaconus) viii quaest(io) iiii c. nonne (C.8, q.4, c.1), vbi omnino vide(tur) nam quasi possessio non debet esse sterilis. Parit ergo vsum quendam, qui est exercere ipsam iurisdictionem, vt not(at) Inno(centius) de resti(tutione) spol(iatorum) c. literis (X.2.13.5).'

61 Baldus, lectura ad Dig.1.14.3, cit., fol. 55rb, n. 12: 'error est contrarius consensui, et impedit actum, maxime iurisdictionalem, ut in de iu(risdictione) om(nium) iu(dicium) 1. si per errorem (Dig.2.1.15).' Cf. Dig.2.1.15 (Ulp. 2 de omn. trib.): '... non consentiant qui errent: quid enim tam contrarium consensui est quam error ...?' Baldus said something very similar in a consilium. The subject was a dispute as to the ius patronatus among the heirs of the founder of a charitable institution (hospitale) in the city of Arezzo. One party was mistakenly considered to be the sole patronus, and Baldus was probably advising his opponent. To exclude the legal relevance of the mistake, among other things, Baldus invoked the lex Barbarius 'secundum lectura modernorum, quae tenet, quod Barbarius non fuerit, vt supra praetor, ex eo quod populus si sciuisset, liberum effecisset.' Baldus, cons.2.399 (Consiliorvm sive Responsorvm Baldi Vbaldi Pervsini, cit., fol. $107 v a-b$, n. 1). 
will of the prince as flowing from it. But even if the prince had truly ratified Barbarius' election, says Baldus, the validity of his appointment would have depended on the prince's authority, not on the common mistake. In other words, there may be no direct relationship between common mistake and Barbarius' praetorship. ${ }^{62}$ In the repetitio Baldus is more explicit: without the intervention of the superior authority (which, in the lex Barbarius, does not occur), it would be useless invoking the common mistake - whether of the whole people, or even 'of the whole world'. ${ }^{63}$

Having solved one problem, Baldus moves to the other: the relationship between common mistake and public utility. The Gloss emphasised the mistake not only to justify the validity of Barbarius' appointment, but especially to rescue his deeds. In so doing, it stressed the maxim 'common mistake makes law'. This maxim is clearly problematic, for it might well lead to the neglect, or even the implicit exclusion, of public utility - ultimately, the position of Odofredus. To avoid that result, Baldus seeks to emphasise the instrumentality of common mistake to public utility. Common mistake may produce legal effects only insofar as it furthers public utility, but not by itself. ${ }^{64}$ The mistake may be

Baldus, additio ad Dig.1.14.3, cit., fol. 59va, n. 12: 'Ibi "Qui facit ius" [scil. Gloss ad Dig.1.14.3, $\$$ functus sit, "hic autem est plus, scilicet communis error, qui facit ius', supra, pt. I, $\$ 2.2$, note 45$]$, hoc non videtur verum. Vnde quaero, si Barbarius fuit liber antequam praetor designaretur, et constat quod non, vt i(nfra) de prob(ationibus) <l.> circa eum (Dig.22.3.14), et l. moueor, in prin(cipio) (Cod.4.55.4pr) ergo error communis, qui tunc aderat ius libertatis non praestat, ergo glo(sa) male dicit. Nam posito quod esset praetor, hoc non facit error communis, sed auctoritas superioris; vnde error non est ratio immediata, etiam tenendo quod Barbarius fuerit praetor. Sed ratio est auctoritas superioris.' Cp. Bartolus, supra, pt. I, $\$ 5.3-4$, notes 33 and 44.

63 Baldus, repetitio ad Dig.1.14.3, cit., fol. 58vb, n. 29: 'Deinde quaero, quomodo colligitur hic, quod error communis facit ius? Nam si non interuenisset hic factum superioris, nedum error populi, sed $\{$ etiam\} error totius mundi non pareret ius aliquod.'

64 On this basis Baldus rejects (without mentioning him expressly) one of the arguments advanced by Bartolus, based on the analogy with the failure of the parties to recuse the incompetent judge. In that case, observes Baldus, the reason for the validity of the decision of the incompetent judge depends on the parties' negligence in not having objected to his jurisdiction prior to the joining of the issue. By contrast, in the lex Barbarius the problem is not the people's negligence but their ignorance based on a mistaken belief. Besides, the text of the lex Barbarius speaks of the validity of both Barbarius' decisions and his statutes (on which supra, pt. I, $\$ 2.1$, note 24 ), and clearly the simple lack of objections as to the validity of the source cannot lead to the validity of a new statute. So, argues Baldus, the validity of the deeds of Barbarius cannot depend on omitting to raise an exception against his person ('in exceptione omissa') but on the validity of the office ('in creatione officii'), which ultimately depends on public utility. Baldus, 
invoked to uphold the deeds of Barbarius only through public utility. This is possible only if the mistake is a common one: a mistake of the whole people affects the entire commonwealth and so triggers public utility considerations. Highlighting the universality of the mistake therefore means invoking public utility considerations. ${ }^{65}$ In the Roman law sources, Baldus observes, there are cases where the mistake invalidates even the deeds of public authorities. But in these cases, he argues, the deeds were made for the sake of individuals, not for the common good. ${ }^{66}$ This strengthens the need to subordinate common mistake to public utility. Shifting the discussion from common mistake to public utility has the further advantage that it implicitly answers (in the negative) the question of whether the common mistake makes law, without at the same time contradicting the rationale of the whole lex Barbarius. The idea that a mistake may create law is hardly appealing to Baldus. In his repetitio he deals with some passages in the sources that might lead to that conclusion, only to qualify them as specific exceptions made on equitable grounds. ${ }^{67}$ Normally, he notes, the

lectura ad Dig.1.14.3, fol. 55vb, n. 25: 'contra hoc opponitur, et videtur quod acta coram Barbario teneant de iustitia rigoris, quia cum nihil fuerit obiectum contra iurisdictionem: ergo mero iure tenet processus, C. de excep(tionibus) l. si quia (Cod.8.35.12) omissio exceptionis declinatoriae personam iudicis legitimat. Sol(utio) istud est verum quando exceptio omittitur per negligentiam, sed hic non fuit negligentia sed ignorantia, vel error. Praeterea 1. nostra loquitur non solum in processibus, sed etiam in statutis, in quibus nulla prorogatio interuenit: vnde l. nostra non fundatur in excep(tione) omissa, sed in creatione officii, quia haec l. iustificat non ex persona, sed ex causa, s(cilicet) publicae vtilitatis.'

65 Baldus, lectura ad Dig.1.14.3, cit., fol. 55rb, n. 12: 'Sol(utio) ibi in errore privatae personae, hic in errore publico, $\mathrm{i}(\mathrm{d}$ est) populi, vel publicae personae, hoc est Caesaris. Actus nam quod publicae auctoritati innititur, validior esse debet propter publicum favorem.' Cf. also Id., ad Dig.2.1.15, $\mathbb{\$} S i$ per errorem (In Primam Digesti Veteris Partem, cit., fol. 80rb).

66 Id., lectura ad Dig.1.14.3, cit., fol. 55rb, n. 12: 'Sol(utio) in illis l(egibus) tractatur de commodo priuatorum, hic de vtilitate vniuersorum saltem potentia, et aptitudine.'

67 The reference is mainly to the third party in good faith, who is allowed to recover his debt despite the senatus consultum Macedonianus. At first sight, this might seem a case where common mistake would suffice despite the lack of common utility. On the contrary, explains Baldus in his repetitio, the protection of the third party in good faith depends on a specific exception to the senatus consultum itself. Baldus, repetitio ad Dig.1.14.3, cit., fol. 58vb, n. 29: 'Sed opponitur, et videtur quod non solum in facto communi, et generali, sed etiam in facto contractu speciali communis error ius facit inter partes, vt ad Mace$\mathrm{d}$ (onianum) 1. iii (Dig.14.6.3) et C. ad Maced(onianum) 1. Xenodorus (Cod.4.28.2). Sol(utio) istud speciale hodie in exceptione macedoniani. Nam ille qui credit eum cui mutuat, esse patremfa(milias) non contemnit Macedonianum. Et ideo \{contemnendus\} non est $\{\mathrm{nec}\}$ damnificandus in amissione pecuniae mutuatae, quia agit de damno vitando, vbi error facti non nocet.' 
opposite is true: when the belief is against the truth, truth prevails. Barbarius' case is rather peculiar, he concedes, but that does not mean that mistake could make law - let alone make Barbarius a true praetor. ${ }^{\mathbf{6 8}}$

Speaking of common mistake, Baldus introduces the most important element of his reading of the lex Barbarius: the difference between person and office. Among the many reasons against the validity of Barbarius' election a first and obvious one is Barbarius' fraud. Posing as a suitable candidate to the praetorship, observes Baldus in the lectura, is clearly dolus causam dans (i.e. the kind of fraud without which something - in this case, the election - would have not occurred), leading to the invalidity of the appointment. ${ }^{69}$ While useful in rejecting the validity of Barbarius' praetorship, however, the argument of dolus causam dans might also reach his deeds and similarly void them. To avoid that, Baldus comes back to the point in his repetitio, where he recalls the case of the

Ibid., n. 30: 'In 1(ege) nostra apparet quod opinio communis praeualet veritati. Alibi vero nihil valet, nisi cum veritate concurrat, de acqui(renda) here(ditate) 1 . cum quidam $\$$ quod dicitur (Dig.29.2.30.1). Alibi dicitur veritas opinioni praefertur, $\mathrm{i}(\mathrm{nfra})$ de iniur(iis) l. eum qui $\mathbb{\$}$ fi. (Dig.47.10.18.5), gl(osa) $\mathrm{i}(\mathrm{nfra}) \mathrm{de}$ haere(dibus) insti(tuendis) l. Tiberius Caesar (Dig.28.5.42) dicit quod ubi ignoramus certitudine vountatis veritas preferenda est [cf. Gloss ad Dig.28.5.42, $\mathbb{E}$ Et hoc titum, Parisiis 1566, vol. 2, col. 481]; immo Inn(ocentius) dicit quod veritas regulariter est preferenda. Fallit quandoque vt hic cum simi(libus) vt notatur per Inn(ocentium) de biga(mis) <c. $>$ nuper (X.1.21.4), in isto generali non insisto ad praesens. Deinde no(tat) gl(osa) quod legitime actum \{est\}, ex supervenienti casu non retractatur, et colligitur istud notabile quo ad acta, quia legitime processerunt, non quo ad effectum Barbarii, quia non processit legitime secundum verum intellectum.' Cf. Innocent IV ad X.1.6.32, \$ Confirmauit (supra, pt. II, $\$ 7.6$, note 120 ).

69 Baldus, lectura ad Dig.1.14.3, cit., fol. 55va, n. 16-17: 'Item dolus Barbarii dedit causam electioni: quia simulauit se dignum. Ergo electio non valuit, de nata(libus) resti(tuendis) 1. i (Dig.40.11.1). Item dignitas non cadit in servo. Item errans non consentit. Item error in qualitate substantiali videtur esse error finalis causae, C. de haer(edibus) insti(tuendis) 1. si pater (Cod.6.24.4). Item Barbarius, quia seruus, non potest esse in possessione praeturae, ergo nec in proprietate, qua iuris est ... Item ubi non est consensus, ibi non est ma(teria) et per consequens nec forma et sic deficiunt prima principalia fiendi et effendi.' Cf. Gloss ad Dig.40.11.1, $\mathbb{P}$ Principe (Parisiis 1566, vol. 3, col. 329): 'Quidam seruus iuit ad principem, et dixit ei se fuisse natum ex ingenua matrem tamen postea effectus erat seruus aliqua ex causa iusta: et impetrauit a principe se restitui natalibus. Dicitur quod cum appareat eum natum ex ancilla, non tenere hoc rescriptum. Fran(ciscus) Accur(sius).' Baldus' reference to Cod.6.24.4 was also very appropriate: according to that text, the appointment of an heir made in the mistaken belief that he was the testator's son is void if the mistake was the sole reason for the appointment. 
suitor approaching the peregrine praetor in the mistaken belief that he was the urban praetor (as the text of Dig.2.1.15 was commonly interpreted). ${ }^{70}$ The text of this lex was clear: the mistake in the person invalidates the jurisdictional act. ${ }^{71}$ Hence the risk that this lex could be extended also to Barbarius' case. To avoid that risk, the Gloss stressed the difference between common and individual mistake: while in the case of the peregrine praetor it was only a single claimant to be mistaken, in that of Barbarius it was the whole people. The two mistakes are therefore different, and so are their consequences. ${ }^{72}$ Baldus agrees as to the difference between the two cases, but he suggests a different explanation for it. In one case the claimant relied on the jurisdiction of the wrong praetor; in the other, on the validity of the acts of the false praetor. In Barbarius' case therefore the accent is no longer on the source (the person) but on the act (the sentence). So, concludes Baldus, when the Gloss spoke of common mistake (and thus of implicit consent), this should be referred to the acts of Barbarius, not to Barbarius himself. ${ }^{73}$

The point is more important than it might appear at first sight. So long as the person of Barbarius coincides with the dignitas of the praetorship, referring the common mistake to the deeds and not to their source would make little sense for it is obvious that the mistake was about the praetor. This is why the Gloss highlighted the difference between the two cases in terms of quantity, not of quality. A large number of people were mistaken as to the person of the praetor Barbarius, whereas in the case of the peregrine praetor the mistake was of a single individual. Baldus on the contrary moves from the distinction between person and office. Unlike the claimant approaching the wrong praetor, those approaching Barbarius were mistaken as to his legitimation to exercise his office, not as to the office itself.

70 Cf. Gloss ad Dig.2.1.15, $\$$ Si per errorem and $\$$ Detegit (Parisiis 1566, vol. 1, cols. 172 and 173 respectively).

71 The text of Dig.2.1.15 is reported supra, pt. I, $\$ 2.5$, note 103.

72 Gloss ad Dig.2.1.15, $\$$ Nibil (ibid., note 105).

73 Baldus, repetitio ad Dig.1.14.3, cit., fol. 58ra, n. 13-14: ‘... Item oppo(no) dicitur hic, in alia ratione literae, quod error habetur pro consensu. Imo contrarium tenet $\mathrm{gl}$ (osa), $\mathrm{s}$ (cilicet) quod pro dissensu, ut l. si per errorem, de iur(isdictione) om(nium) iu(dicium) (Dig.2.1.15). Sol(utio) ibi error vnius personae, hic populi secundum gl(osam). Vel ibi error dat causam actui exercitio: hic est error incidens, quia habebat hic populus in latenti qualitate personae, non autem fuit dolo inductus ad eligendum. Tu autem dic quod error non habetur pro consensu quo ad Barbarium immo nec acta indigent fictione, sed ualent ex aequitate quam habent in seipsis.' 


\subsection{From Innocent to Barbarius: Baldus' three-step approach}

Having dismissed the possibility that Barbarius did become praetor, Baldus can proceed in his reconstruction of the lex Barbarius in terms of legal representation, applying Innocent's concept of toleration and thereby justifying the validity of the deeds. The problem now is how to apply Innocent's concept of toleration without its key component of confirmation.

If Barbarius was not confirmed in office, how could he be tolerated in it? Formulated in such a direct way, the question could have only a negative answer. Hence Baldus dances around the issue, dealing with it several times, and each time looking at a particular facet of the question. The only undisputed part of the lex Barbarius was the fact that Barbarius exercised the office of praetor - and so, enjoyed possession of that office (whether or not that possession was lawful). Baldus' problem is how to make Barbarius' possession of the praetorship sufficient for the production of similar effects as (proper) toleration in office. He does so in a rather complex way, which may be summed up in three steps: voidable election, legitimate possession of the office, and external validity of agency.

Baldus' approach is of paramount importance, as it serves as a bridge between the Innocentian concept of toleration and the modern concept of de facto officer. In so doing, Baldus arrives to explain the difference between internal and external validity of agency. It is therefore important to look at each of Baldus' three steps in detail. Given the complexity of Baldus' reasoning, however, we might want first to understand why such a complex discourse was needed. If the only clear element in Barbarius' case was that he discharged the praetorship, then why not focus directly on the exercise of the office?

As a matter of principle, the simple exercise of praetorship remains de facto possession, not de iure entitlement to the office. Mere possession of office without any right to it qualifies the possessor as intruder. ${ }^{74}$ The exercise of the office by such an intruder would amount to mere de facto possession, which does not suffice to create any link between agent apparent and office. ${ }^{75}$ Nor could the dari hec regula quod intrusus dicitur omnis qui interrogatus cur possideat non potest aliter respondere nisi quia possideo.'

75 Such possession would amount to just actus and not habitus - or, more originally (though the metaphor is of Innocent), to displaying the insigna of an office without the right to exercise it. Baldus, lectura ad Dig.1.14.3, cit., fol. 57ra, n. 43: 'Vlterius quaero, an quis possit intitulari in eo quod non posset possidere? Et videtur quod sic, nam ita fuit de Barbario. Sed certe hoc fuit de facto, $\arg ($ umentum) de acquir(enda) posse(ssione) 1. i $\$$ si vir vxori (Dig.41.2.1.4), et sic Barbarius habuit iurisdictionem actu, et non habitu, actus in factum sonat, habitus vero ius designat.' Ibid., fol. 56va, n. 35: 'Barbarius insigna habuit sine 
common mistake be invoked in support of the de facto possession. Full separation of public utility from legal representation would mean allowing the intruder to represent the office he unlawfully seized. This would be, more or less, a plain admission that the end justifies the means - if the intruder did well, then public utility could be invoked to ratify what was void. That is not something Baldus is prepared to accept: it would deny the entire concept of representation as elaborated by Innocent. Baldus seeks to build on Innocent's ideas and adapt them to a secular context. He has no intention of undermining them.

The first step in Baldus' approach is aimed at distinguishing Barbarius from a mere intruder in office. To do so, Baldus seeks to provide a veneer of validity to Barbarius' appointment by qualifying his election not as utterly void but as voidable. Then, importantly, Baldus does not proceed directly to invoke public utility on the deeds, but insists on Barbarius' lawful possession of the office first. The distance between Barbarius' position and the application of public utility is deliberate. Speaking of public utility before - at the second stage - would have meant bestowing validity on Barbarius' precarious praetorship (if not de iure, at least de aequitate). Doing as much would have led to denying Innocent's concept of toleration, and ultimately also of representation.

The ultimate purpose of Baldus' approach is not to find an indirect way of vesting Barbarius with the praetorship, but to ascribe Barbarius' deeds to the office - and so make them valid. Hence, the precarious validity of Barbarius' office (i.e. the first step) is used exclusively to cast a different light on his possession of the jurisdiction of the praetor: not de iure entitlement, but not $d e$ facto seizure either. That suffices to speak of lawful possession. This is Baldus' second step. Enjoying legitimate possession of ordinary jurisdiction of course does not amount to full entitlement to it, but does at least justify its exercise. Focusing on the exercise of jurisdiction of the office, in turn, allows movement from the relationship between agent and office to that between the office and the third parties. This is the beginning of the third and last step in Baldus' approach. Having established a link between Barbarius and the jurisdiction flowing from the office, it is finally possible to invoke public utility. At this point, however, the object of public utility is not Barbarius' entitlement to discharge the office, but

dignitate, nam insigna differunt a dignitate, de offi(cio) proc(onsulis) 1. i (Dig.1.16.1).' Here, the parallel is with the proconsul leaving Rome towards the province assigned to him. According to Dig.1.16.1 (Ulp. 1 Disp.), although he is entitled display the insigna of his rank from the moment he walks out of Rome, he may not exercise the related potestas until he reaches his province. See also on the point Baldus' repetitio ad Dig.1.14.3, cit., fol. 57va, n. 9. Cf. Innocent, supra, pt. II, $\mathbb{\$} 7.3$, note 24 , where the image of the insigna of the office may be found immediately after the reference to Barbarius (ibid., note 23). 
directly the exercise of the jurisdiction flowing from the office. This way, public utility is not in direct relationship with Barbarius but with the exercise of the office, an exercise directed to those third parties subjected to the office's jurisdiction. If we think back of the 'agency triangle', this means invoking public utility not with regard to the relationship between agent and office (internal validity of agency), but only to that between office and third parties (external validity of agency). This way, public utility can be used not to ratify Barbarius' position, but only the validity of the acts towards their recipients. Having briefly explained Baldus' three-step approach, we may turn analysing each part of it.

\subsubsection{Voidable election}

As said, the first step in Baldus' complex argument is qualifying Barbarius' election not as thoroughly void but simply as voidable. On the subject, Baldus recalls the distinction made by Raynerius de Forlì (Raniero Arsendi, d.1358), ${ }^{76}$ who in turn probably adapted the scheme of Belviso that we saw in Albericus de Rosate. ${ }^{77}$ If the statute did not expressly provide for its violation, Raynerius would distinguish between defects in form, substance, accident and quality. ${ }^{78}$ Although our interest in the subject is instrumental to understanding Baldus' reasoning, it has little to do with election practice at large, ${ }^{79}$ nor does it depend on Raynerius' reading of the lex Barbarius (which likely had little to do with toleration and legal representation). ${ }^{80}$ As such, we shall limit ourselves to a brief

Raynerius was one of the great fourteenth-century civilians, but his fame was soon eclipsed by that of Bartolus. Cf. most recently Belloni (2014), pp. 577-578. In his repetitio Baldus quoted Raynerius extensively, but only on general issues related to elections - not on his position on the lex Barbarius (which was possibly very different from his own: see infra, this paragraph, note 80 ).

77 Supra, $\$ 9$.

78 The main (but just formal) difference with Belviso's scheme, therefore, is that Raynerius' defect in substantia is Belviso's defect in materia.

79 Cf. supra, $\$ 9$, note 17 . While filtered through Raynerius, the use of Aristotelian language in Baldus is of some interest also because of its public law context. Although Baldus made frequent use of Aristotelian language in (what we would consider as) different branches of the law, the analysis of modern lawyers has typically focused on private law, contracts in particular (especially that of sale): see for all the work of James Gordley, especially Gordley (1991), pp. 50-61; Gordley (2000), pp. 108-114; Gordley (2004), pp. 444-445. Cf. Berman (1983), pp. 246-247. See further Canning (1989), pp. 104-113; Walther (1990), pp. 126-127; Walther (1992), pp. 122-126.

80 According to Albericus de Rosate, Raynerius held Barbarius' deeds as valid out of fairness towards their recipients while denying the de iure validity of both his praetorship and his freedom. Albericus de Rosate, ad Dig.1.14.3 (In primamff. 
summary of Raynerius' scheme of invalidity in the elections. $i$. Form: the validity of an election held in violation of a formal requirement (e.g. some specific modalities prescribed for it) depends on whether the elector had also the power to amend the rules of the election. If so, then the elector could also ratify its violation. $i i$. Substance: the violation of a substantive requirement provided for the election (e. g. carrying out the election, or allowing to vote those who had no right to do so, etc.) voids the election, together with any act made by the person unlawfully elected. ${ }^{\mathbf{8 1}}$ iii. Accident: violations of prescriptions not pertaining to

Veter. part. commentarij, cit., fol. $70 \mathrm{rb}$, n. 20): '... Ray(nerus) in utraque $\mathrm{q}$ (uaestione) dubitando tamen dicit posse dici, quod durante errore populi non fueri praetor nec liber: et ideo eius conditione detecta acta per eum non ualent de rigore, sed de aequitate.' Although somewhat cryptic, Albericus' observations on Raynerius might suggest some affinity with the Ultramontani, Ravanis in particular. A short gloss of Raynerius on the lex Barbarius, however, would suggest otherwise: 'Constituentis autoritas error communis ... libertatem valere quod alias non valeret' (Vat. lat. 1141, fol. $15 \mathrm{rb}$, $\$$ Barbarius, transcription in Martino [1984], p. 156). The gloss is admittedly too short to draw any firm conclusion, but the reference to the common mistake - and not to public utility - might suggest to interpret the 'constituentis autoritas' as something different from Ravanis' 'potentia committentis'. In any case, it would seem that Raynerius did not require a second element beyond the common mistake. According to Baldus (often a source more reliable than Albericus), Raynerius distinguished on the basis of whether the common mistake preceded the election or was itself a consequence of the election (just as Belviso did before him: supra, pt. III, $\$ 9$, text and note 27). Only in the first case, held Raynerius, is the mistake legally relevant: Baldus, lectura ad Dig.1.14.3, cit., fol. 56vb, n. 40: 'do(minus) Rayn(erius) de Forlì ... sic notabiliter ait, dicens circa errorem communem distingue, quia aut error communis praecessit electionem, seu collationem dignitatis, vel officii, et tunc an valeat electio, et collatio, et probetur communis error, et valent acta et gesta: quia lex tollit omnem defectum, ut hac l. Barbarius (Dig.1.14.3) et 1. 2 C. de sententia (Cod.7.46.2), 3 q. 7, c. tria (C.3, q.7, p.c.1).'

81 Baldus, lectura ad Dig.1.14.3, cit., fol. 56vb, n. 40-41: 'Secundo vero distingue si quaeratur an teneant acta, et gesta per non iure electum, dic aut in electione est clausula quae retractat expresse quicquid fuerit aliter secutum, aut non. Primo casu non tenent acta per eum per $\mathrm{d}$ (ictam) 1 . in his, et per 1 . actuarios (Cod.12.49.7) et per auth. cassa, C. de sacrosan(ctis) eccl(esiis) (Auth. ad Cod.1.2.12[=Frid.2.1]). Secundo casu, aut est peccatum in forma electionis, vt quia in ea non est solemnitas obseruata, et tunc aut electoribus competit ius a lege, et sic suo iure, aut ab homine, et sic alieno. Primo casu tenent acta, et gesta, si nullus ab initio extitit condictor: alias secus ... Secundo casu non valent acta per eum: quia electio, seu collatio non habuit radicem, nec fundamentum, $\arg ($ umentum) d(icta) 1. actuarios (Cod.12.49.7), et C. si a non competen(ti) iud(ice) per totum (Cod.7.48) et extra, de haere(ticis) c. fraternitatis (X.5.7.4). Si aut peccatur in materia, puta quia nulla facta est electio, quia electoribus nullum competit ius eligendi; tunc error communis nil operatur, nec tenent acta per illum vt 1. Herennius (Dig.50.2.10), C. de sac(rosanctis) eccl(esiis) 1. decernimus (Cod.1.2.16), et in de reb(us) eor(um) l. qui necque (Dig.27.9.8) cum simi(libus), 
the substance of the election, but often equally important to its validity and so typically not ratifiable. ${ }^{\mathbf{8 2}} \mathrm{iv}$. Quality: violations of the requirements as to the person of the elected. Where the personal defect in the elected was manifest, the election could not be ratified and all the deeds of the elected are void. Where on the contrary his defect was concealed (and thus a case of common mistake), then it is possible to hold the acts of the elected as valid if that would further public utility. ${ }^{83}$

Raynerius' four-fold distinction allows Baldus to qualify Barbarius' election as voidable, and not ipso iure void. Barbarius' election was formally valid but

et hoc no(tat) Inno(centius) extra de elec(tione) c. fi. et c. quod sicut (X.1.6.60 et 28).'

82 It is the case of an election bought with money. If we are to believe Baldus, the validity of such an election or appointment is (conditionally) admitted by canon lawyers but denied by civil lawyers. For the civil lawyers (and Baldus among them), the election is void and the common mistake may not be invoked, so the acts of the person so elected are invalid. For the canon lawyers, especially after Innocent IV, the election is valid provided that the simony is occult and that the election is confirmed by the superior authority. Baldus, lectura ad Dig.1.14.3, cit., fol. $56 \mathrm{vb}$, n. 41 : 'aut est peccatum in accidenti, puta quia electio est facta per pecuniam, et sic simoniaca; et tunc dicunt quidam quod error communis nihil operatur et acta non tenent, quia talis electio processit a radice auaritiae, quae est mater omnium malorum ... alii dicunt quod electio praedicta habuit radicem et fundamentum, et valent acta, et gesta, vt no(tat) Io(hannes Teutonicus) $1 \mathrm{q} .1 \mathrm{c}$. cito [C.1, q.1, c.16: cf. its gloss $\$$ Multiplici, Basileae 1512, cit., fol. 105va], et c. omnis (C.1, q.1, c.112). Inno(centius) vero dicit quod si talis electio fuit confirmata per superiorem, et crimen est occultum, quod tunc valent acta, et gesta, cum ex confirmatione potestatem recipiat administrator, extra, de electio(ne) c. transmissa (X.1.6.15), vt ipse videtur notare in d. c. vlt. (ibid.) et c. quod sicut (X.1.6.28) ... Prima opinio tenent legistae, et Iacob(us) de Bel(viso); opinio Inno(centii) tenent canonistae.' In singling out Belviso, Baldus would seem to consider him not fully in line with most civil lawyers in other respects. This is probably due to Belviso's allegedly different stance on the relationship between public utility and common mistake. At least according to Baldus, Belviso held that common mistake sufficed, even without public utility: see next note.

83 Baldus, lectura ad Dig.1.14.3, cit., fol. 56vb, n. 41: 'Aut est peccatum in qualitate, puta in persona electi, et tunc aut vitium est manifestum, aut occultum. Primo casu non valent acta et gesta, vt d. c. nihil (X.1.6.44), et C. si a non compet(enti) iudic(e) per totum (Cod.7.48): quia non suffragatur error communis, quid est necesse, vt hac 1. Barbarius (Dig.1.14.3). Secundo casu tenent acta, et gesta, si est error probabilis, vt sub dixi. Et hoc tenet Iac(obus) de Belu(iso), tamen Vltramon(tani) et nos legistae tenemus, quod ibi requiratur aliud, s(cilicet) publica vtilitas multorum, videtur sub saepius dixi. Et hoc probatur in litera 1. nostrae et per hoc intelligas quod no(tatur) in d. l. iusiurand(um) $1 . \mathrm{i}$ in de iureiur(eiurando) (Dig.12.2.2) et quod not(atur) in $S p e(c u l o)$ de actore $\$ 1$ ver(siculum) "Sed pone, quidam dicens se Episcopum" [supra, pt. II, $\$ 8.4$, note 49].' 
substantively flawed. As Baldus puts it, Barbarius was elected rite but not recte. Baldus highlights the point, contrasting Barbarius' case with that in the lex Actuarios (Cod.12.49(50).7), on the invalidity of the appointment of an official because his nomination was reserved to the prince. ${ }^{\mathbf{8 4}}$ In so doing, Baldus provides the same interpretation as Cugno (without however mentioning him). ${ }^{85}$ The appointment of the officials in the lex Actuarios was not rite: the election was done by someone who lacked the power to elect (in Raynerius' scheme, a defect in substantia). That suffices to contrast the ipso iure invalidity of the appointment of the officials with the voidability of Barbarius' election, done by the rightful elector according to the prescribed formalities. ${ }^{86}$ Until revoked, therefore, Barbarius would have a title of sort, and his praetorship would be a true one - it would be 'vera'. The result is an ambiguous position - neither entitlement to the office, nor plain intrusion: precisely what Baldus wanted to achieve. This ambiguity is the result of the combination of a formally valid election (and so, 'rite') with an occult defect in the person of the elected (which makes the election 'non recte'). As a consequence, says Baldus, the praetorship of Barbarius is 'true but revocable': ${ }^{87}$

if the question is whether Barbarius had a firmly rooted (radicatam et incommutabilem) praetorship, the answer is no. But the answer is different if the question is whether he had a true and revocable praetorship though unworthily (indigne) received, all the more as long as the defect remains hidden.

Supra, pt. I, $\$ 4.2$, note 211.

85 Cf. supra, pt. I, $\mathbb{\$} 4.2$.

86 Baldus, lectura ad Dig.1.14.3, cit., fol. 55vb, n. 22: 'opponitur non valeant gesta a minus legitime electo, ut 1 . actuarios, C. de nume(rariis) et actuar(iis) lib. xii (Cod.12.49(50).7) et ibi no(tatur) ergo non valent gesta Barbarii. So(lutio) Barbarius fuit rite assumptus, licet non recte, sed in 1 . contraria non fuit rite electus, quia per non habentes potestatem, et quare non seruata forma a superiore praefixa, et sic non ob(stat), quia rite factum non valet ipso iure, sed rite factum licet non recte per eum, qui habet potestatem, valet, licet debeat cassari, si debito modo cassatio petitur.' The distinction between rite and recte election was not new. See e. g. Albericus de Rosate, ad Cod.7.45.2 (In Secundam Codicis Part[em] Commentaria, cit., fol. 117ra, n. 8): 'Item non ob(stat) d(icta) $\mathrm{l}(\mathrm{ex})$ fi. $\$$ Item rescripserunt, de decu(rionibus) (Dig.50.2.12.3) quia ibi [scil., in Barbarius' case] electio facta erat rite: licet non recte, vt ibi patet in litera, inter quae est differentia, vt no(tatur) ff. de inof(ficioso) test(amento) 1. 2 (Dig.5.2.2) et sic ibi habuit fundamentum: alias secus esset, vt eo ti(tulo) 1 . Herennius (Dig.50.2.10).'

87 Baldus, lectura ad Dig.1.14.3, cit., fol. 55va, n. 20: '... aut quaeritur, vtrum Barbarius habebat praeturam radicatam, et incommutabilem; et dico quod non, aut vtrum habebat veram praeturam reuocabilem, tamen tanquam collatam indigne: et videtur quod eam (sic) fortius est quandiu latuit vitium, et defectus.' 
To better understand Baldus' statement, we might look at another example that he gives on the election held in violation of the requisites prescribed for the person of the elected: ${ }^{\mathbf{8 8}}$

The Florentine law provides that only a true Guelph of Guelph descent may be elected as podestà of Florence, otherwise the election would be ipso iure void. Now, the Florentines elected some Ghibelline, who was mistakenly accepted by the people and discharged his office. When eventually he claimed his salary, it was objected to him that he was not true podestà, and so he was not entitled to the salary, for to receive the salary truth must be followed (as in Dig.50.1.36pr). He replied that he was true podestà, that he was considered as such, and that he performed that office - just as the Gloss has it here [i. e., in the lex Barbarius]. He also argued that, while his election was illegitimate (incompetenter) at first, for his electors lacked the power to do so and infringed the law, nonetheless the people were considered to have ratified it on the basis of the present lex. Much on the contrary, it is not plausible that the people wanted to derogate from their laws, and this is the true opinion, for the electors could have not bound the city without complying with the form of the law (as in X.1.6.52). This applies if [the defect] was notorious, or clear to these electors. In doubt, however, it should be presumed that [the election] was done in good faith, and so it does not appear to be done wrongly but correctly (as in D.35.1.32 and D.17.1.30).

The example seems to build on Guido de Suzzara's issue of the salary of the banished elected to a magistracy. ${ }^{89}$ The occult Ghibelline is well suited to

Ibid., fol. 56ra, n. 27-28: 'Statuto Florentiae cauetur quod nullus possit eligi in potestatem Florentiae nisi sit Guelphus verus, et de domo Guelpha. Et si secus fiat, electio non valeat ipso iure, modo electionarii elegerunt quendam Gibellinum, quis per errorem populi fuit receptus, et gessit officium tandem ille petit salarium, obiicitur ei quod non fuit verus potestas. Ergo salarium habere non debet, quia in praeceptione salarii veritas debet attendi in ad munici(palem) 1. Titio cum esset (Dig.50.1.36pr). Econ(tra) ipse dicit, quod fuit verus potestas, et ita habitus et reputatus, et quod fuit officio functus, vt hic s(ecundum) $\mathrm{gl}$ (osam) et licet fuerit electus a principio incompetenter a non habentibus mandatum, et contra formam statuti: tamen populus fingitur ratificasse, $\arg ($ umentum) huius 1 . in ver(siculo) "nam et si placuisset" [cf. Dig.1.14.3], sed certe immo non est verisimile quod populus velit derogare suis statutis, et ista videtur vera opi(nio) quia electores non poterunt obligare commune, forma non servata, de elec$\mathrm{t}$ (ione) c. cum in veteri (X.1.6.52); et hoc si erat notorium, vel certum istis electoribus, sed in dubio praesumitur factum bona fide, et ideo non videtur factum male, sed bene, ar(gumentum) in(fra) de condi(cionibus) et dem(onstrationibus) 1. quamuis (Dig.35.1.32) et in man(dati) 1. si hominem (Dig.17.1.30).'

89 Cf. supra, pt. I, $\$ 4.3$, text and note 153 . While Baldus does not mention Suzzara, during the fourteenth century the association between banished and reward became rather popular. Baldus could easily have found it, for instance, in the same Raynerius de Forlì: cf Raynerius' repetitio ad Dig.1.1.9 (Repetitionum seu commentariorum in varia iurisconsultorum responsa, Lugduni, Apud Hugonem à Porta, \& Antonium Vincentium 1553, vol. 1, fol. 7vb, n. 57). 
Barbarius' case: whether the Florentine are fully sovereign or not, surely it lies within their power to scrap the exclusion of Ghibellines from their city statutes. In Baldus' text, the Ghibelline claiming his salary as podestà is almost reading from the Accursian Gloss on the lex Barbarius. With this example, therefore, Baldus can better highlight the difference between his approach and that of the Gloss. Both Barbarius' and the Ghibelline's elections are formally correct (rite), and in both cases the elector could remedy the defect by ratifying the election. Just as in Barbarius' case, however, the hidden defect in the podestà does not entail the implied will of the Florentines to condone it. Pace Accursius, a voidable election cannot be considered as tacitly ratified. Moreover, in this example the validity of the election is clearly related to the enduring condition of the defect as occult. The problem with the salary, which brings up the underlying issue of the validity of the appointment, emerges only when the defect becomes manifest. So long as the true colours of the elected remained hidden, the common mistake of the electors would suffice to consider the election as provisionally valid: not ipso iure void, but voidable. Precisely the condition of Barbarius: 'true and revocable praetorship ... as long as the defect remains hidden'.90

\subsubsection{Possession of ordinary jurisdiction}

A voidable election confers a 'true but revocable praetorship'. Baldus however does not focus on the provisional validity of the praetorship, but only on the entry of Barbarius into office. Focusing on the voidability of Barbarius' praetorship would ultimately lead to acknowledging its validity until the eventual deposition. That would be a variation on the approach of the Gloss: even if the validity of Barbarius' position remained precarious, it would still be the reason for the validity of his deeds. But this is not Baldus' intent. In speaking of voidable praetorship, Baldus only sought to justify Barbarius' entry into office, thereby distinguishing him from a simple intruder. ${ }^{91}$ To acquire lawful possession of the office, says Baldus, 'three things are required, that is, election, acceptance and entry into office. Thereafter, one is [already] in possession even before doing anything. ${ }^{92}$ In Roman law, the lawfulness of possession is determined by

90 Supra, this paragraph, note 87.

91 Baldus, lectura ad Dig.1.14.3, cit., fol. $55 v b$, n. 23: 'notandum tamen est quod propter bonum agere non iustificat intrusus, quia nec Barbarius iustificat omnino in semetipso, dato quod non esset proprie intrusus.'

92 Ibid., 'et certe tria requirunt, scilicet electio, acceptatio, et ingressus officii, i(nfra) de condit(ionibus) et de(monstrationibus) 1. publius (Dig.35.1.36), quo facto etiam ante quam aliquid gerat, est in possessione.' 
looking at the moment of its acquisition. If the election of Barbarius was voidable, then he entered office holding a title (revocable, but provisionally valid). That would suffice to qualify his possession of the office as lawful - and so to distinguish him from an intruder. Legitimate possession of the office, it may be recalled, was the second step in Baldus' reading of the lex Barbarius. But why was it so important for Barbarius to have lawful possession of the praetorship, if this never became legal entitlement? The answer depends on the specific office of the praetor - an office entailing jurisdiction. Possession of the office of praetor also meant possession of the jurisdiction flowing from it. Lawful entry into office would entail legitimate possession of the office, and so also of its jurisdiction. In medieval law, jurisdiction (iurisdictio) meant power. ${ }^{93}$ Possessing jurisdiction meant exercising power. Hence the importance of qualifying Barbarius' possession of the office as lawful: legitimate possession of jurisdiction meant legitimate exercise of power. Distinguishing Barbarius from an intruder, therefore, would ultimately allow entry into office without acknowledging its full validity.

To better understand the point, we should look at the difference between possession of things and of offices. The Roman praetor, we have often noticed, is an ordinary judge and so has ordinary jurisdiction. In medieval civil law, ordinary jurisdiction is normally referred to the territory. So for instance a lordship would typically entitle someone to the exercise of jurisdiction within it. In case of the office of the ordinary judge, on the contrary, the jurisdiction pertains to his person - the territory is relevant only to delimit the boundaries of his jurisdiction, not to allow its exercise. Otherwise stated, the powers of the judge depend on the right to exercise his office, not on the lawful control of a territory. As Baldus has it, 'with regard to the judge, office and jurisdiction are almost one and the same'. ${ }^{94}$ Possession of an office therefore amounts to

As is known, the medieval concept of iurisdictio derived from the conflation of two distinct categories, iuris-dictio (to 'say' the law) and iuris-ditio (the 'power' of the law). Of the two, medieval jurists considered the latter (iuris-ditio) to be the general one. Understood as a general category, therefore, iurisdictio had no jurisdictional meaning, but simply meant 'authority'. See e.g. Gloss ad

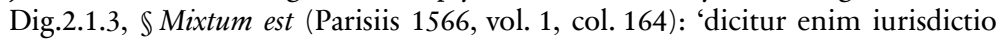
a ditione, quod est potestas, et iuris, q(uod) d(icit) legitima potestas.' Cf. supra, pt. I, $\$ 2.1$, note 25 .

94 Baldus, ad Cod.2.46(47).3, \Cum scimus esse (svper Primo, Secundo \& Tertio Codicis, cit., fol. $156 \mathrm{rb}, \mathrm{n} .2$ ): 'No(tandum) istum tex(tum) propter quem dicunt doc(tores) quod iurisdictio ordinaria et contentiosa inheret territorio et quod limites iurisdictionis sunt secundum limites territorij: et hoc et verum quod iurisdictio est in territorio tanquam in re. Sed in iudice est tanquam in persona. Et respectu iudicis iurisdictio et officium iudicis vniuersaliter consideratum est quasi vnum et idem. Unde tituli qui tractant de officiis magistratuum nomine 
possession of its jurisdiction. This is Baldus' goal: using the concept of possession to argue for the validity of Barbarius' jurisdiction, while at the same time denying his full entitlement to the office of judge.

Lawful possession, working as a bridge between simple facts and proper rights, can often become an ambiguous concept. When applied to incorporeal entities this ambiguity is all the more acute, because of the difficulty in clearly distinguishing between their lawful and unlawful possession. Offices are incorporeal, hence their possession is often described as quasi possessio - just like the possession of other incorporeals, first of all servitudes. ${ }^{95}$ Following Innocent, Baldus affirms that (quasi-)possession of the office does not allow its valid exercise - it must be confirmed by the superior authority. ${ }^{\mathbf{9}}$ At the same time, however, the fact that the office is incorporeal does not entail different degrees of possession: either there is full possession of the office or there is not. Dignities, says Baldus, are formal entities - they have form but no specific matter. Their form is given by the law, according to the purpose for which they are established. ${ }^{97}$ Speaking of unlawful but legally relevant possession, therefore, is only possible for corporeals - not also for incorporeals, and especially not for dignities. Because of the relationship between representative and individual office, possessing a dignity has a stronger meaning than possessing a thing. It means vesting the representative with the office. With an office, therefore, either

officii assumunt per iurisdictione.' On the relationship between jurisdiction and territory in medieval learned law see Siméant (2011), esp. pp. 119-122, where further literature is listed.

95 Cf. supra, pt. I, $\$ 5.4$, note 42.

96 This is particularly clear in Baldus' repetitio, where he relies on Innocent IV's distinction between cases of quasi possessio in which no confirmation is required and cases in which it is needed. Clearly Innocent had in mind ecclesiastical offices, but the distinction is useful for Baldus so as to deny the full validity of Barbarius' appointment. Baldus, repetitio ad Dig.1.14.3, fol. 58ra, n. 12-13: 'Item opp(onitur) et videtur quod acta valeant de rigore iuris ex quo barbarius erat in quasi possessione officii. Nam sola quasi possessio sufficit in temporalibus, extra de iure pat(ronatus) c. consultationibus (X.3.38.19). Sol(utio) dicit Innocen(tius) quod illud est verum in his quasi possessionibus in quibus non requiritur decretum superioris, vel in quasi possessione iuris eligendi, et praesentandi; secus vbi requiritur auctoritas superioris. Nam si illa sit interposita de iure, valet quod fit de rigore. Si autem de facto, loquitur haec lex, et Inno(centius) de elec(tione) c. nihil (X.1.6.44).'

97 On the point see esp. Baldus, ad Cod.2.18.20, $\$$ Tutori vel curatori (svper Primo, Secundo \& Tertio Codicis, cit., fol. 142ra, n. 1): 'Tutor vel curator differunt a gestore: quia primorum officium est necessarium et finitur necessitate cessante. sed officium simplicis gestoris est voluntarium et voluntate propria terminatur ... Officium quod habet formam a iure sumit effectum vel finem secundum dispositionem legalem. Sed officium quod suscepit quamlibet formam secundum voluntatem gerentis regulatur ab ipsa.' 
there is full possession or there is not. One may not be an 'almost bishop' (semiepiscopus), says Baldus to state a crucial concept: possession of an office pertains to the law, not to the realm of facts. ${ }^{98}$ Possession of a dignitas is another way of describing the lawful exercise of the office. Indeed, says Baldus following Innocent once again - 'dignity, administration, jurisdiction and office are mutually connected and almost inseparable'. ${ }^{99}$ This way, it becomes

98 Id., ad Cod.3.34.2, \$ Si aquam, ibid., fol. 218rb, n. 64-65: 'Nunc de quarto puncto dicendum est $s$ (cilicet) qualiter possessio perdatur. Circa quod dicendum est quod duplex est possessio. Quedam est enim indiuisibilis, vt ecce papa et imperator possident plenitudinem potestatis, ecclesia et imperium se non secat in partes: nec diuidit se. Item dignitates sunt indiuisibiles: vnde non potest quis esse semiepiscopus vel semidoctor. Item et seruitutes vnde non potest quis habere semiuiam et semiusum. Sunt enim omnes seruitutes in forma indiuisibili constitute: que forma nisi per perfectione haberi non potest vnde entibus imperfectis non proprie conuenit forma ff. ad l. falci(diam) 1 . si is qui quadringenta $\$ quedam (Dig.35.2.80.1). Quedam sunt possessiones diuidue, vt possessio agri et possessio vsufructus: quia vsufructus non solum est qualis sed est quantus ... Item no(tatur) quod quedam sunt possessiones quae constitunt officio vel dignitate et sic constitunt in iure, et iste statim perduntur quod quis est priuatus dignitate: vt no(tat) Inno(centius) de conces(sione) preben(dae) c. cum nostris (X.3.8.6) ... quedam sunt possessiones que constitunt in facto vt possessio fundi: tunc requiritur amotio facti nec sufficit amotio iuris ...'

99 Ibid., fol. 217va-b, n. 48: 'Nunc accedamus ad Inno(centium) in c. ex literis, de resti(tutione) in integrum (X.1.41.4), et ibi tractat Inno(centius) qualiter acquiratur possessio generalis et specialis in iuribus et in rebus ... Primo ergo queritur qualiter acquiratur possessio iuris episcopalis vel archidiaconalis ... dicit Innoc(entius) quod possessio generalis iuris episcopalis acquiritur per installationem factam in sede deputata in tali dignitate, ar(gumentum) C. de offi(cio) prefec(ti) aug(ustalis) 1. i (Cod.1.37.1) ... secundum Inno(centium) intellige quod acquiratur generalis possessio dignitatis et administrationis et iurisdictionis: nam dignitati inest administratio et administrationi inest iurisdictio: vnde sunt annexa et quasi inseparabilia dignitas et administratio et iurisdictio et officium, $s$ (upra) vbi et apud quos 1. fi. (Cod.2.46(47).3).'Similar reasoning might be found in Bartolus. Significantly enough, however, in Bartolus the object of quasi possessio was not the office of the judge, but simply his jurisdiction. A forged rescript of the prince, says Bartolus, is clearly not sufficient to bestow jurisdiction. But if it looks genuine, then it suffices to give quasi possessio of jurisdiction, and so to allow its recipient to render valid decisions. Bartolus, ad Cod.1.22.2 (Primam Partem Codicis Commentaria, cit., Basileae 1588, p. 110, n. 6): 'Quaero utrum rescriptum omnino falsum quod nunquam emanavit de cancelleria Principis tribuat iurisdictionem? ... Mihi videtur quod, si quidem rescriptum non habet manifestam falsitatem, ipse iudex, cui videtur dirigi, potest de ista falsitate cognoscere et pronunciare se esse vel non esse iudicem. Ita intelligo infra 1. prox(imam) [scil., Cod.1.22.3], ubi coram eodem iudice potest opponi de falsitate. Ratio: quia illud rescriptum, licet ei non det iurisdictionem, tamen constituit eum in quasi possessione iurisdictionis, propter uod habet iustam cognitionem et pronunciationem.' 
extremely difficult to distinguish clearly between lawful exercise of jurisdiction and valid administration of the office: precisely Baldus' purpose.

The great paradox of the lex Barbarius was that a slave exercised ordinary jurisdiction (iurisdictio ordinaria). The authority - thus the legal strength - of that position did not derive from any delegation, but from the office itself. Yet slaves are the living embodiment of indignitas. A slave is the most indignus, as we have seen, both in the sense of moral worthiness and in that of legal incapacity. For Innocent (and for Baldus) confirmation of the unworthy produced valid legal effects because of the higher dignitas of the superior authority. Thus, the presence of confirmation shifted the focus from the indignitas of the person who was confirmed to the higher dignitas of the person who confirmed him. The same mechanism (the shift of focus from the indignitas of the inferior to the dignitas of the superior) also applies in the distinction between the exercise of ordinary and delegated jurisdiction.

Delegated jurisdiction does not presuppose any dignitas in the person who receives it. Its recipient, the delegate, simply exercises it on behalf of the delegator. 'Delegated jurisdiction' says Baldus, 'is simply some task pertaining to a slave, and its exercise is valid because the delegated acts as servant and exercitor of the jurisdiction of another person, the ordinary [judge] who delegated him'. ${ }^{100}$ The use of the term exercitor is interesting. Properly speaking, it was the technical term for designating the person responsible for the ship in a commercial context, typically a slave. Hence the reference to the slave. In stating as much, of course, Baldus did not intend to say that one would typically delegate his jurisdiction to a slave. He wanted to stress the difference between ordinary and delegated jurisdiction. The source of the jurisdiction of the delegate lies elsewhere - in the person of the delegator. As such, it does not require any dignitas in the delegate, either in terms of worthiness or, especially, of legal capacity - even a slave could do it! The 'proper' office of the judge is only that of the ordinary one. Ultimately, therefore, the delegate judge does not exercise the office of the judge, he simply does the (ordinary) judge's bidding.

Having explained delegated jurisdiction, Baldus moves on to the ordinary form. Ordinary jurisdiction, he says, must 'take root' in its incumbent. ${ }^{101}$ It is

100 Baldus, lectura ad Dig.1.14.3, cit., fol. 55va, n. 19: '... iurisdictio delegata non est aliud, nisi quoddam exercitium quod seruo competit: quia cum sit minister, et exercitor iurisdictionis alienae personae ordinarii, quam delegauit, inspecta, et repraesentata, valere debet quod agitur, $\arg$ (umentum) i(nfra) de dona(tionibus) inter vir(um) et vxo(rem) l. <si $>$ mulier (Dig.24.1.9).' The translation is somewhat liberal.

101 On the point, canon law has not changed much over the centuries. A good way of explaining Baldus' statement could be comparing it with the 1917 Canon Law Code, can.197\$1: 'Ordinary power of jurisdiction is that which is automatically 
difficult to think of a stronger metaphor to signify the compenetration between office and its representative. The strength of the metaphor is used to exclude the inhabilis: because the slave is legally incapable, iurisdictio ordinaria cannot 'take root' in a slave. ${ }^{\mathbf{1 0 2}}$ So, as we have seen, for Baldus the slave Barbarius could not have a 'rooted' (radicata) praetorship: 'rooted' is tantamount to 'unalterable' (praetura radicata et incommutabilis), whereas Barbarius' praetorship was 'revocable' (revocabilis). ${ }^{\mathbf{1 0 3}}$ Just as Barbarius could not have a 'rooted' praetorship, he could not enjoy 'rooted' ordinary jurisdiction deriving from that office. But Baldus did not seek to 'root' the praetorship in Barbarius (that is, to make him de iure praetor), only to make his possession of the praetorship legitimate. This is why he remarks that Barbarius' revocable praetorship was 'true'. ${ }^{104}$ Toleration could not be invoked on the basis of a voidable election that was not confirmed by the superior authority. But the deep relationship between office and possession allows possession to be qualified in the light of that - fragile but legally relevant - link with the office. If the praetorship is 'true', in other words, then possession of the jurisdiction flowing from it cannot be unlawful.

As we have seen in the first part of this work, most civil lawyers dealing with the case of the slave-praetor also referred to that of the slave-arbiter (Cod.7.45.2, the lex Si arbiter). Sometimes they did so in order to remark the similarity of the two cases (the validity of the deeds despite the servile condition of the two slaves). At other times, and more often, they sought to highlight their difference (plurality of decisions and public utility in the case of Barbarius vs. single decision and private utility in that of the arbiter). Also Baldus highlights the difference between the two cases. Only, he does so not on the basis of the number of decisions (and so, of the distinction public vs. private utility), but rather according to the different kinds of jurisdiction exercised by the two slaves - ordinary vs. delegated.

In the lex Si arbiter, the arbiter was a slave but, unlike Barbarius, he exercised only delegated jurisdiction. As such, Baldus notes, he was acting on the instructions of someone who did possess (valid) ordinary jurisdiction. The validity of the decision of the slave-arbiter, therefore, depended both on the

attached to an office; delegated power is that which is committed to a person' (Potestas iurisdictionis ordinaria ea est quae ipso iure adnexa est officio; delegata, quae commissa est personae). The current version (in the 1983 Code, can.131ฐ1) is slightly less evocative of its medieval roots (Potestas regiminis ordinaria ea est, quae ipso iure alicui officio adnectitur; delegata, quae ipsi personae non mediante officio conceditur). Cf. Deutsch (1970), p. 183.

102 Baldus, lectura ad Dig.1.14.3, cit., fol. 55va, n. 19: '... sed iurisdictio ordinaria debet esse radicata, sed in seruo non potest radicari.'

103 Supra, last paragraph, note 87.

104 Ibid. 
common mistake as to his true status and on the delegation of authority. As we have seen earlier, in the Roman sources there were three main cases where a slave was mistaken for a freeman. Besides the arbiter and the praetor, the third case was that of the slave, widely reputed to be free, who witnessed a testament. Unlike the other two, the slave-witness performed a private act. ${ }^{105}$ In that case, reasons Baldus, common mistake alone sufficed to guarantee the validity of the deed. ${ }^{106}$ If so, he concludes, the mistake should produce effects all the more when coupled with delegated jurisdiction, for the delegate simply acts on behalf of the ordinary judge who gave him that power - not on his own authority. ${ }^{107}$ This parallel between slave-witness and slave-arbiter serves to build a crescendo, which culminates with the slave-praetor. As a matter of principle, says Baldus, delegated jurisdiction should be interpreted restrictively. Yet the decision of the false arbiter is kept despite the personal inhabilitas. Unlike the slave who acted as arbiter, he continues, the slave who acted as praetor exercised ordinary jurisdiction, and iurisdictio ordinaria should on the contrary be interpreted extensively. So, concludes Baldus, quashing the false praetor's decisions but keeping the false arbiter's verdict would be illogical. ${ }^{\mathbf{1 0 8}}$

105 Like most other jurists, when discussing the slave-witness case Baldus referred exclusively to the passage in the Code (Cod.6.23.1) and overlooked the one in the Institutes (Inst.2.10.7). When looking at the Gloss, we have seen how the former referred exclusively to the common mistake, whereas the latter said that the validity of the testament depended on the generosity of the prince (supra, pt. I, $\$ 2.3)$.

106 It may be recalled that the case of the slave-witness was progressively read as based exclusively on a common mistake (as in Cod.6.23.1), and not on the generosity of the prince, who ratified the will ex sua liberalitate (Inst.2.10.7). Supra, pt. I, $\$ 2.3$, text and notes $57-59$.

107 Baldus, repetitio ad Dig.1.14.3, fol. 58ra, n. 13: 'respectu delegantis iurisdictio delegata est ordinaria ... ordinaria iurisdictio est publica auctoritate, et vtilitate respectu iurisdictionis in seipsa, idem in 1 . munerum $\$$ iudicandi, de mu(neribus) et ho(noribus) (Dig.50.4.18.14). Respectu vero actus exerciti inter Titium et Seium, non attenditur qualitas iurisdictionis, quia non denominatur a priuatis, vt l. i $\$$ publicum, de iust(itia) et iu(re) (Dig.1.1.1.2). Cy(nus) vero dicit quod lex contraria loquitur in liberto, non in seruo, quod nihil est, quasi in id quod non est iurisdictio, valeret propter communem errorem vt $1 . i$ C. de test $a$ (mentis) (Cod.6.23.1), multo magis quod est iurisdictionis, quia est magis fauorabile.' Cynus’ argument, as we know, came from Bellapertica: supra, pt. I, $\$ 4.6$, note 110.

108 Baldus, repetitio ad Dig.1.14.3, fol. 58ra-b, n. 17-18: 'sol(utio), credo quod potissima [cp. Baldus' 1577 edition: 'pessima'!] ratio sit error communis, et superioris autoritas, vt d(icta) 1. si arbiter (Cod.7.45.2). Nam ita debet illa lex intellegi, quod ibi communi errore pro libero habebatur. Item ibi, interuenit superioris autoritas, $\mathrm{i}(\mathrm{d}$ est) delegatio superioris; et sic est illud in iurisdictione delegata, quae est extraordinaria, et odiosa, vt C. de dila(tionibus) 1. si quando 
It is now clear why Baldus followed the traditional interpretation of the Gloss on the slave-arbiter, and not that of Bellapertica and Bartolus. The arbiter rendered his judgment while secretly a slave, and was found out (and brought back to servitude) only thereafter. ${ }^{109}$ If the arbiter was a freedman who would relapse into servitude after having given the decision (the other reading of the lex Si arbiter), the whole point of the two slaves exercising different kinds of jurisdiction would be lost. ${ }^{110}$

The closeness between lawful possession of a public office and its exercise also meant that the possessor does not need to justify his possession. The Accursian Gloss held that the judge does not need evidence to prove what is notorious (and so known to all), but he does to prove what is known to him personally. ${ }^{111}$ Baldus applies the same principle also to the exercise of an office. Reiterated and unchallenged exercise of a public office means notorious exercise of it. Widespread reputation as the rightful representative of a public office, therefore, exonerates the incumbent from having to prove his entitlement. Notorious

(Cod.3.11.2), ergo idem in iurisdictione ordinaria, quae est fauorabilis, necessaria, et amplianda, l. i $\mathbb{S}$ cum vrbem, de off(icio) praef(ecti) urb(i) (Dig.1.12.1.4).'

109 Supra, pt. I, $\$ 2.3$, text and notes 63-64.

110 Even in that case, however, the different interpretations would not seriously undermine Baldus' argument. Whether the arbiter was a slave or a freedman when he rendered his decision, says Baldus, what matters is that he received jurisdiction from the ordinary judge. As such, the sentence of the slave-arbiter would be valid regardless of the interpretation of 'in servitutem depulsus' in Cod.7.45.2. Baldus, lectura ad Dig.1.14.3, cit., fol. 56va, n. 35-36: 'Vnum non omitto quod $\mathrm{Cy}$ (nus) dicit hic, quod 1. ii C. de senten(tiis) et interlo(cutionibus) om(ium) iudic(icium) (Cod.7.45.2) non habet locum in seruo: quia ibi non versatur publica vtilitas, cum sit factum singulare. Nam male loquitur, quia iurisdictio est iuris publici in vniuersali, et singulari, quam in quolibet suo singulari a publico fonte auctoritate, et vtilitate procedit, sub de iu(stitia) et iure, 1. i $\$$ publicum (Dig.1.1.1.2), et ideo etiam in seruo ibi loquitur.' The more emphasis is on the delegans, in other words, the less the legal capacity of the delegatus becomes relevant. Elsewhere Baldus compares the delegate judge to a messenger (nuntius). Baldus, ad X.1.3.22, $\mathbb{Q}$ Quum dilecta (Baldvs svper Decretalibvs, cit., fol. 35va, n. 6): 'Et not(andum) quod iudex delegatus equiparatur nuntio, quia nunquid sit dominus litis et in nullo debet excedere vires mandati, $\mathrm{i}(\mathrm{nfra})$ de offi(cio iudicis) deleg(ati) <c.> si pro debilitate (X.1.29.3), ff. de verb(orum) obli(gationibus) <l.> qui rome $\$$ callimachus, in fi(ne) (Dig.45.1.122.1).'

111 Gloss ad Cod.2.41(42).1, $\mathbb{\$}$ In consilio (Parisiis 1566, vol. 4, col. 378): ' $\mathrm{i}(\mathrm{d}$ est) in arbitrio siue deliberatione iudicis. Et no(tatur) quod iudex potest iudicare siue attendere id quod ei est notum vt notorium: etiam si ei non probatur ab aliqua partium. Erat enim hic notorium eum fuisse decurionem. Secus si est notum non vt notorium, sed vt priuato: quia tunc magis ad probationem respicit: vt ff. de offi(cio) praesi(dis) l. illicitas $₫$ veritas (Dig.1.18.6.1), et $\mathrm{i}(\mathrm{nfra})$ de his qui ve(niam) aeta(tis) impe(traverunt) 1. ii (Cod.2.44(45).2).' 
possession would therefore presumptively suggest de iure entitlement to the office. ${ }^{112}$

The public nature of the office should trigger representation, shifting the analysis from the person as individual to the person as agent of the office. When lawful possession of the office is not based on de iure entitlement to it (as in the case of Barbarius), proper representation may not occur. Nonetheless, this possession still leads to a shift in perspective, albeit a partial one: from individual person, if not to lawful incumbent, at least to lawful possessor of the office. This shift is extremely important: possession of a public office leads to the presumption of valid representation. ${ }^{\mathbf{1 1 3}}$ Until this presumption is disproved, the exercise of jurisdiction is therefore valid. It follows, says Baldus, that Barbarius is fully entitled even to punish those who would recuse his jurisdiction - unless of course they were able to prove his servile status. ${ }^{\mathbf{1 1 4}}$ Barbarius' power to impose

112 Baldus, ad Cod.2.41(42).1, \$In consilio (svper Primo, Secundo \& Tertio Codicis, cit., fols. 154vb-155ra, n. 7): 'Tertio opp(onitur) quando enim iudex hic considerat publicum officium cum de hoc non esset aliquid sibi probatum ab aliqua partium respondet glo(sa) quod hoc erat notorium. Ubi ergo officium est notorium non est necessaria probatio, gl(osa) loquitur in officio ordinario. Si ergo quis publice gessit se pro potestate vel vicario licet non appareat de electione tamen semper presumitur pro ordinaria iurisdictione. Item si quis se gessit pro priore vel consule mercatorum et sic fuit reputatus publice, facit 1 . barbarius de of(ficio) preto(rum) (Dig.1.14.3). Facit etiam l. ciues et incole $\mathrm{i}(\mathrm{nfra}) \mathrm{de}$ ap(pellationibus) (Cod.7.62.11). Sufficit ergo quod sit notorium quod aliquis gessit se pro potestate priore vel consule ... in notoriis iudex supplet defectum probationis partium.'

113 Id., lectura ad Dig.1.14.3, cit., fol. 56va, n. 35: '... Et no(tatur) quod materia $\mathrm{l}$ (egis) nostrae habet locum in his, quae sunt ratione publici officij, non in alijs, extra de consuet(udine) c. <cum> dilectus (X.1.4.8) secundum Innoc(entium), et in his quae tangunt ius aliorum, non solius facientis, vel patientis, extra, de procu(ratoribus) <c.> consulti (X.1.38.15) per Inno(centium). Illud est no(tandum) quod pro eo qui in possessione iurisdictionis ordinarie inuenitur, praesumitur, licet hic status naturaliter inesse non possit, de offi(cio iudicis) deleg(ati) $<\mathrm{c} .>$ cum in iure (X.1.29.31), per Inno(centium) etc. ... $\arg$ (umentum) contrarium: quia nemo praesumitur officialis, nisi probetur, l. prohibitum C. de iur(e) fi(sci) lib. x (Cod.10.1.5), vide Cy(num) C. vbi causa sta(tus) 1. i [cf. Cyni Pistoriensis In Codicem, cit., ad Cod.3.22.1, fol. 152rb, esp. n. 7]. Et no(tatur) quod lex loquitur de eo, qui non debuit admitti ad officium: tamen admissus est.'

114 Ibid., fol. 55vb, n. 26: 'Et adde, quod ille qui sine causa declinat iurisdictionem, potest puniri de contemptu, 2 q. 7 c. Metropolitanum (C.2, q.7, c.45) ... et Inn(ocentius) dicit quod potest verus contumax reputari, quia non videtur stetisse declinans suam iurisdictionem, secundum Innocentium, et ideo Barbarius potuisset punire friuole declinantes suam iurisdictionem, puta quia opponebatur alia exceptio quam seruitutis, vel obiecerunt de servitute, et non probauerunt.' On the subject see also Baldus, cons.2.178 (Consiliorvm sive 
his jurisdiction on litigants is not mutually incompatible with the litigants' ability to disprove his jurisdiction: the moment Barbarius' jurisdiction is successfully recused, his possession of the office changes from notorious (and so, presumptively lawful) to manifestly unlawful. ${ }^{\mathbf{1 1 5}}$

Until disproven, notorious possession of a public office suffices as to its exercise. This conclusion might appear very similar to proper toleration, but - at least in principle - it is not. The recusation issue mentioned above helps bring to light the underlying difference. When the office is 'rooted' in the person, his supervening incapacity is of no obstacle to the enduring legal representation of the office: the friction between incapacity as an individual and capacity as a representative is precisely the core of the toleration principle. So those subjected to the (jurisdiction of the) office may not recuse its legal representative because of his personal unworthiness. ${ }^{116}$ By contrast, mere possession of the same office creates a more fragile link with it: the moment the personal incapacity of the possessor is unveiled, the link between possession and lawful exercise of the office is severed. The difference is clear in principle, but rather opaque in practice. Baldus made deliberate use of this ambiguity so as to shift the focus towards toleration - without saying so openly.

Ultimately, lawful possession of the office without proper toleration reaches the same result as the case of the occult deposition that we encountered in the last chapter. ${ }^{117}$ In both cases there is not (or no longer) proper representation, and so neither is there toleration. The validity of the deeds depends on lawful

Responsorvm Baldi Vbaldi Pervsini, cit., fol. 48rb). Asked whether the Anziani of Bologna had the power to jail someone despite lacking iurisdictio, Baldus answers that they did: just like Barbarius, the Anziani had quasi possessio of this kind of jurisdiction, and that was sufficient as to its valid exercise. ' $\mathrm{D}$ (omini) Antiani sunt in quasi possessione istius iurisdictionis, quod sufficit ad eius exercitium, vt ff. de offi(cio) prae(torum) 1. Barbarius (Dig.1.14.3).' Recently Jane Black argued that Baldus applied the notion of quasi possessio also to the concept of plenitude of power: J. Black (2009), p. 65, note 183 (relying on BAV, Barb. Lat. 1408, fol. 137v).

115 Baldus makes the same point (though in a less elaborate fashion) when discussing possessory matters, so as to distinguish between falsus praelatus in unchallenged possession of the office and simple intruder. Baldus ad Cod.3.34.2, $\$$ Si aquam (svper Primo, Secvndo \& Tertio Codicis, cit., fol. 218ra, n. 62): 'Aut quis est in possessione sed non est verus prelatus: et tunc aut possidet pro prelato ita communiter reputatur, aut pro possessore quia inuasit de facto officium prelati. Primo casu agere potest nisi aduersarius probet eum non prelatum: quia pro eo presumitur qui in pacifica possessione reperitur.'

116 Baldus, ad X.1.3.13, $\mathbb{S}$ Sciscitatus (Baldvs super Decretalibvs, cit., fol. 28ra-b, n. 8): 'Quero an <iudici> ordinario possit opponi exceptio quod est homicida vel adulter. Respondeo non secundum Inn(ocentium) quia autoritas ordinarij officij non excluditur per solam infamiam facti superuenientem officio iam radicato.'

117 Supra, last chapter, $\$ 11.6$. 
possession of the office. In the case of the secretly deposed, possession is lawful because of the occult character of the deposition - the superior authority deprived the incumbent of his right to the office, not of his possession of it. To deprive the incumbent of his lawful possession, physical dispossession would have been unnecessary: all that it was needed was to render the deposition notorious. Leaving the old incumbent in possession without issuing a formal sentence of deposition, as Baldus had it, left a 'vestige' of the initial confirmation in office. ${ }^{118}$ Something similar happened in the case of Barbarius. Baldus said that Barbarius enjoyed a 'true praetorship', not that he was 'true praetor' neither de iure (with ratification by the prince or the people) nor de aequitate (invoking public utility directly on his personal condition). Barbarius remains a slave, and so legally unable to represent the office validly. Nonetheless, the mistake in qualitate (in his personal status) makes the election voidable, because this qualitas (slavery) is occult. The precarious validity of the election suffices for Barbarius to lawfully enter the office, and so to acquire lawful possession of it. The implicit argument is that, when the defect became manifest, he would lose possession of the office - just as the occult deposed would when his deposition becomes manifest. Until that moment, however, both slave and deposed would retain lawful possession of an office to which neither is entitled.

Possession is the visible face of the underlying real right. It does not look at the inner relationship between person and thing, but at its external manifestation. It should project to the outside world the consequences of that entitlement - that is, the right to enjoy the thing - in our case, to exercise the office validly. Speaking of possession of the office - and, even more, of the jurisdiction of the office - Baldus highlights the external face of representation without bestowing validity on the internal relationship between person and office. Applied to the agency triangle of the last chapter, that means shifting the focus from the internal side (person-office) to the external one (office-thirds). Precisely what Baldus did with regard to the occult deposed.

We have seen how Baldus relied on the element of possession to argue for the validity of the acts of the occult deposed without however qualifying that case as toleration (and so, legal representation). This way, the occult deposed was neither fully intruder nor properly tolerated in office. Playing (in a very un-Innocentian way) with the occult character of the deposition, Baldus sought to highlight the (limited) lingering effects of the confirmation. This way he could push the occult deposition outside the threshold of proper representation - but not too far from it. In the case of Barbarius, Baldus moves from the opposite direction to get to the same point of arrival: he pulls Barbarius' case towards representation, 
coming as close as possible to its threshold without crossing it, and so without reaching the scope of proper toleration. In practice, the outcome is very similar to qualifying Barbarius as being tolerated in office. But, in legal terms, the difference between title and possession remains clear. This avoids plain selfcontradiction: toleration presupposes confirmation, but confirmation would lead to the acceptance of Accursius' position. Stressing the element of possession of the office, and especially of its ordinary jurisdiction, Baldus reaches nearly the same result in practice - but not in law.

Just after stating that Barbarius had a 'true and revocable praetorship ... as long as the defect remains hidden', ${ }^{119}$ Baldus' lectura continues as follows: ${ }^{\mathbf{1 2 0}}$

therefore the deeds are valid as if [done] by the true praetor, albeit unworthy, who is to be stripped of his praetorship by the superior. The same applies to any dignitas, whether secular or ecclesiastical, because of the jurisdiction that attaches to it (as in Innocent's comment on X.1.3.13).

Baldus' reference to Innocent does not point to the concept of toleration, but rather to its procedural consequences. According to Innocent, as we have seen, the parties cannot raise any objection against the ordinary judge on the basis of his status. First, said the pope, the judge must be deposed from office. ${ }^{\mathbf{1 2 1}}$ Baldus' approach is remarkably subtle. For Innocent, the validity of the jurisdictional deeds of the ordinary judge is a consequence of his toleration in office. Innocent moved from the internal relationship between agent and office towards its external manifestations. As toleration in office entails the right to exercise it, in order to prevent external manifestations of agency it is necessary to cut the (internal) link between agent and office first. For Innocent, therefore, lawful possession of ordinary jurisdiction is only an external consequence of the underlying agency relationship. By contrast, relying on the simple (but legitimate) possession of the office, Baldus jumps directly to the lawful possession of ordinary jurisdiction, thereby skipping the underlying agency relationship.

In the repetitio Baldus comes back to the point so as to explain it better. In principle, possession should be the tangible manifestation of the underlying right. Barbarius lacks that right, but he has lawful possession of the office. In Baldus' words, he is not de iure entitled to the office, but neither does he exercise it only de facto. Barbarius has 'coloured possession' of the office. In Baldus'

119 Supra, this chapter, note 87.

120 Baldus, lectura ad Dig.1.14.3, cit., fol. $55 \mathrm{va}$, n. 20: 'et ideo valent gesta tanquam a vero praetore, licet minus digno, et cui praetura per superiorem esset interdicenda. Et idem dico in omnibus dignitatibus, quia est annexa iurisdictio, sive sint seculares vt hic, siue sint ecclesiasticae, hoc sensit Inn(ocentius) extra de rescri(ptis) c. sciscitatus (X.1.3.13).'

121 Cf. Innocent, supra, pt. II, $\$ 7.4$, note 45. 
words, Barbarius is 'one who never was in office de iure, but de facto in coloured possession'. ${ }^{122}$ Possession of the office is therefore not a manifestation of the underlying entitlement to it - that would amount to sitting in the office de iure. The dichotomy de iure / de facto does not leave room for a third genus: ultimately, Barbarius is still praetor only de facto. But because Barbarius entered into office lawfully, through a voidable election, he is no intruder either. Qualifying him simply as de facto possessor would have implied that Barbarius lacked 'canonical entry' into office. Hence the reference to coloured possession - a lawful possession of the office that, from the outside, would point to the underlying right of the incumbent. Possession looks at the external manifestations of that right, at the exercise of the office towards third parties. It presupposes a title that de iure does not exist in Barbarius' case. 'Coloured possession' of the office is ultimately an indirect route towards Innocent's concept of toleration.

This indirect (and rather opaque) approach towards toleration is clearly visible in Baldus' three-fold distinction of unjust exercise of an office: ${ }^{\mathbf{1 2 3}}$

Sometimes one was never in office de iure, but de facto in coloured possession - as in our lex. Other times one was in office both de iure and de facto, but he should be deprived of it, for instance because he obtained the office fraudulently. In such case the deeds are valid even as to those who knew [of the fraud], because he was truly [the representative of the office], and he dealt as true [representative] - until removed by the superior. Other times still one used to sit in office, but he no longer does. In this case, the deeds are void if he is judicially deposed.

It might be noted how this distinction does not match Innocent's one. For Innocent the first case (de facto exercise of office with coloured possession) is tantamount to the third one (exercise of office after formal deposition). In both cases the person exercising the office is but an intruder, and this bars representation. As the concept of toleration is rooted in legal representation, only the second case can be described as toleration (thus valid exercise of the office). Also in Baldus the first of the three cases (coloured possession) is in principle different from the second (proper toleration), but in practice it leads to the same consequences with regard to the exercise of the office. The opposition is now between first and second cases on the one side, and third case on the other. This

123 Baldus, repetitio ad Dig.1.14.3, cit., fol. 58va, n. 27: 'Conclude tres casus. Quandoque quis nunquam fuit in officio de iure, sed de facto in colorata possessione, et loquitur l(ex) nostra [scil., Dig.1.14.3]. Quandoque fuit de iure et facto, tamen erat priuationi subiectus, $\{\mathrm{vt}\}$ quia dolo obtinuerat officium vel dignitatem; et tunc valent interim gesta et quo ad scientes, quia vere est talis, et pro quali se gerit, donec per superiorem remoueatur. Quandoque quis iam fuit in officio, sed hodie non est: tunc an valeant gesta? Si quidem per sententiam sit amotus non valent.' 
stinction between coloured possession and proper toleration remains, but it is now of little significance in practice. Immediately after the passage above, Baldus continues: ${ }^{\mathbf{1 2 4}}$

If in our lex some deeds were made after that a sentence of deposition was passed against Barbarius, then they would not be valid (as noted by Innocent in X.5.1.24). But if his jurisdiction is revoked for the mistake as to himself, the deeds done so far are tolerated.

The reference to Innocent was to the passage where the pope wrote most clearly on the strength of toleration: 'anything is tolerated because of the office that one exercises ${ }^{\mathbf{1 2 5}}$ - a statement that Baldus had already reproduced literally in his lectura. ${ }^{126}$ Innocent's statement, however, referred exclusively to the true incumbent in office (i. e. the unworthy confirmed and not yet deposed). Speaking of coloured possession Baldus shifts the focus from the internal relationship (Barbarius-praetorship) to the external one (exercise of praetorship-third parties). Innocent always required symmetry between the two relationships. For the pope, it was always the person of the unworthy that was to be tolerated, not his deeds. The validity of the deeds was the consequence of the toleration of the unworthy in office. In the text quoted by Baldus, Innocent said that after the deposition the prelate may no longer be tolerated, but he should be considered an intruder. It followed, concluded the pope, that any further decision 'would not hold' (non tenet). ${ }^{127}$ In recalling Innocent's text, on the contrary, Baldus applies the concept of toleration not to the person but directly to the acts. Thus, in the span of a few lines, the concept of coloured possession of the office moved from a qualified case of de facto possession to an explicit application of the toleration principle.

The same use of the concept of 'coloured possession' may be found in Baldus' commentary on the Liber Extra. It may be recalled Innocent's uncompromising stance on the need of confirmation prior to administration: without it, any deed

124 Ibid., fol. 58va-b, n. 27-28: 'Nam si in 1(ege) nostra [scil., Dig.1.14.3] essent gesta postquam depositionis sententia esset lata contra barbarium, et tunc gesta non valerent, ut no(tat) Inno(centius) de accu(sationibus) c. qualiter (X.5.1.24) in glo(sa) magna. $\operatorname{Sin}$ autem est alias adempta iurisdictio propter errorem ipsius, adhuc acta tolerantur, de resti(tutione) spol(iatorum) c. audita (X.2.13.4) et de hoc tangitur i(nfra) si cer(tum) pet(etur) 1. eius, in princ(ipio) (Dig.12.1.41) et facit quod no(tatur) i(nfra) de condi(cione) inde(biti) 1 . si non sortem $\$$ qui filio (Dig.12.6.26.8).' Cf. Innocent, next note.

125 Supra, $\$ 7.3$, note 23. In saying as much, Innocent recalled the lex Barbarius (but, as we have seen, he approved of the Accursian Gloss and so of Barbarius' confirmation by the prince).

126 Cf. Baldus, supra, last chapter, $\$ 11.2$, text and note 13.

127 Supra, pt. II, $\$ 7.3$, note 24. 
would be void. The point where his position conflicted most acutely with that of most canonists was on the case of the suffragan bishop-elect: being too distant from his metropolitan to wait for confirmation, this suffragan took up his pastoral duties without it. For Innocent, 'possession of the bishopric' (possessio episcopatus), even if lawfully acquired, was not sufficient for the validity of the acts. ${ }^{128}$ This conclusion, as we have seen, was criticised as it subordinated the welfare of the Church to legal subtleties. ${ }^{\mathbf{1 2 9}}$ But Innocent (at least in principle) had a point: invoking equitable considerations to make up for the lack of confirmation would undermine legal representation. To strengthen his conclusion, the pope dismissed the most dangerous case found in the sources - that of Barbarius. The slave, said Innocent, was confirmed in office - so that case could not be invoked in support of the bishop-elect. ${ }^{130}$ Baldus does not intend to follow the pope in his uncompromising position, but neither does he want to weaken Innocent's concept of representation (or to recant his own different reading of the lex Barbarius). ${ }^{\mathbf{1 3 1}}$ Hence he resorts to the 'coloured possession' of the office. Although not confirmed, Baldus maintains, the suffragan was lawfully elected bishop - so he had canonical entry. This possession is lawful but does not derive from de iure entitlement to the exercise of the office: just as with Barbarius, it is possessio colorata. Coloured possession must suffice in this case, lest the administration of the diocese be paralysed (the main point of Innocent's critics on the bishop-elect's case). ${ }^{\mathbf{1 3 2}}$ Stating as much, Baldus strengthens the concept of coloured possession implicitly invoking public utility. He would do the same in the lex Barbarius, but in much more explicit terms, as we are now going to see.

\subsubsection{Public utility and representation: internal vs. external validity}

In the tripartition of Baldus' approach (voidable election, possession of jurisdiction, and validity of acts), it remains now to look at the third step. It is only at

128 Supra, pt. II, $\$ 7.6$, text and note 124.

129 Supra, pt. II, $\$ 8.1$, text and notes 15 and $\$ 8.5$, note 75 .

130 Supra, pt. II, \$7.6, text and note 123.

131 Although, admittedly, some short statements earlier in the same comment might give that impression: supra, this chapter, note 26.

132 Baldus, ad X.1.6.44, \nichil (Baldvs svper Decretalibvs, cit., fol. 69vb, n. 11): 'Sed si ad exercendum iurisdictionem non sufficeret possessio colorata sequeretur inconueniens quod interim in re publica ius non redderetur et fieret spelunca latronum. Oportuit ergo mediam iuris dispositionem inueniri propter emergentes casus quae dilationem non recipiunt et non expectant plene discutionis euentum super proprietate ipsius iurisdictionis, istud est naturaliter certum quod facte cause: verbi gratia si latro interim suspensus est non possunt retractari quia non possunt reduci in pristinum statum.' 
this point, it may be recalled, that Baldus invokes the concept of public utility explicitly. As any public office, that of praetor aims at furthering public good. It follows that: ${ }^{133}$

Barbarius was not promoted for his own benefit, but for the sake of the public good, of which the magistracies are a manifestation (as in Dig.1.1.1.2), and that final cause is true.

It is here that Baldus introduces the concept of public utility. If the final cause of public offices is furthering public good, then their exercise should be inspired to fairness (aequitas), because fairness furthers public good: ${ }^{134}$

All that is useful to the commonwealth is equitable. Equity is nothing but a certain piety, which must be kept especially on what concerns the commonwealth, as the author of the Somnium Scipionis states at the beginning, when he says 'foster justice and piety'.

The point is more specific than it might seem. Stressing the relationship between fairness and public good means analysing equity in teleological terms. Most Roman law sources described fairness in terms of balance between the parties: equity (aequitas) aims towards balance (aequilibrium). ${ }^{\mathbf{1 3 5}}$ In a public law context however there are not two parties but a single one: the res publica or commonwealth. This does not mean that Roman sources did not impose private sacrifices for the sake of common good. ${ }^{136}$ It means that they did not consider the position of the collectivity (whose common utility should be furthered) and that of the individual (which might be sacrificed) as equals, as the scales of the balance to be levelled. In a public law context, fairness was not applied to the zero-sum game of the private law context. Without a counterparty to consider, in other words, equity could be applied in a far more pronounced, goal-oriented manner.

133 Id., lectura ad Dig.1.14.3, cit., fol. 55vb, n. 23: 'Barbarius non fuit promotus propter seipsum, sed propter bonum publicum, quod repraesentatur in magistratibus, vt 1 . i $\mathbb{S}$ publicum, ff. de iusti(tia) et iur(e) (Dig.1.1.1.2), et illa causa finalis fuit vera.' Cf. Dig.1.1.1.2 (Ulp. 1 Inst.): '... Publicum ius in sacris, in sacerdotibus, in magistratibus constitit.'

134 Ibid., fol. 55ra-b, n. 11: 'Omne $\mathrm{n}(\mathrm{am})$ quod in publico utile est, id aequum est. Aequitas $\mathrm{n}(\mathrm{am})$ nihil aliud est, nisi quadam pietas quae maxime debet esse circa Reipub(licam), vt ait auctor in prin(cipio) de somnio Scipio(nis), ibi dum dicit: "Iustitiam cole et pietatem" [Cicero, De Re Publica, 6.15], etc.'

135 The Roman law concept of aequitas is complex, and scholarly literature on it is exceedingly vast. As the subject falls entirely outside the scope of the present work, it would make little sense to provide specific references. For its shift towards medieval law suffice it to recall Gaudemet (1951), pp. 465-499, and Cortese (1962), vol. 1, pp. 47-53 and 66-71; Cortese (1999), pp. 1038-1043. Cf. more recently also Zwalve (2013), pp. 15-37.

136 E.g. Cod.10.44.2; Cod.11.4.1.1; Cod.11.4.2; Cod.12.29.2.1. 
Baldus looks at Barbarius' case from this perspective, just as Ulpian did. Keeping the validity of Barbarius' deeds is 'more humane' (bumanius) both for the Roman jurist and the medieval one. The difference lies in the possibility of fully separating representative from office. If the person does not coincide with the office, the source of the deeds is not Barbarius, but the praetorship. This is why, as we have seen, Baldus speaks of 'true praetorship' and not of 'true praetor' ${ }^{\mathbf{1 3 7}}$ and why he refers the concept of toleration directly to the deeds and not to Barbarius. ${ }^{138}$ Public utility may bestow validity on the source of the deeds. That source, however, is no longer Barbarius, but the office itself: ${ }^{139}$

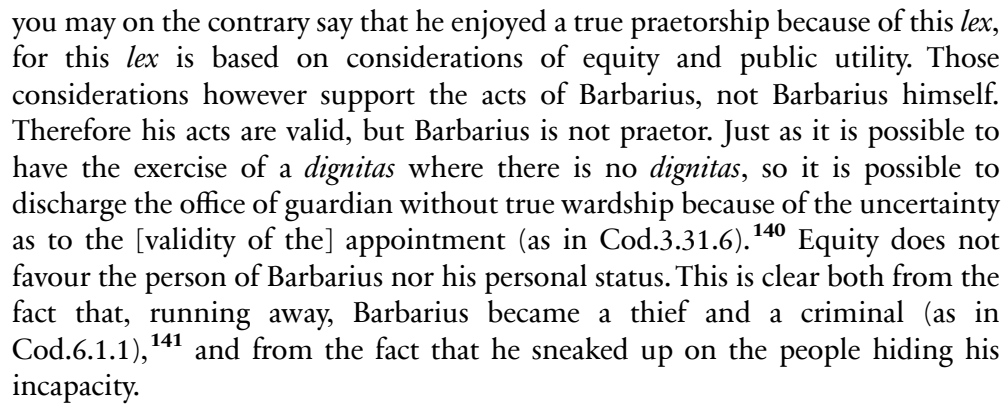

This passage explains why Baldus is always so careful in distinguishing entitlement from possession of the office. The accent is on the exercise of the office, which is valid for public utility reasons. But public utility is invoked for the benefit of the commonwealth, to make the acts valid. Qualifying the acts as valid for the sake of public utility means applying public utility directly to the relationship between office and third parties (the people). The Gloss and its followers did the same but, moving from the assumption that person and office coincided, they could not distinguish the valid exercise of the office from the

137 Supra, this chapter, $\$ 12.4 .1$, text and note 87.

138 Supra, this chapter, \$12.4.2, text and note 124.

139 Baldus, lectura ad Dig.1.14.3, cit., fol. 55rb, n. 15: 'aut dicit eum fuisse in vera praetura per rationem huius 1 (egis) tunc cum ratione huius 1 (egis) sit aequitas, et publica vtilitas, et illae rationes faueant actib(us) Barbarii, sed non Barbario; ergo acta valent, sed Barbarius non est praetor, et sic inuenitur administratio dignitatis, ubi non est dignitas, sicut invenitur administratio tutelae, absque vera tutela ratione dubii, vt C. de peti(tione) hae(reditatis) 1 . si putas (Cod.3.31.6), quod enim aequitas non faueat personae Barbarii, nec eius statui (sic), apparet, quia fugiendo erat fur et criminosus, C. de ser(vis) fu(gitivis) 1 . i (Cod.6.1.1) et quia obrepsit populo tacendo suam inhabilitatem.'

140 Cf. Id., ad Cod.3.31.6, $\$ S i$ putas (svper Primo, Secvndo et Tertio Codicis, cit., fol. 201ra, n. 6).

141 Cod.6.1.1 (Diocl. et Maxim. AA. Aemiliae) stated that the runaway slave commits the theft of himself. 
lawful position of Barbarius - the latter was necessarily instrumental to the former. Ravanis' 'power of the appointer' was ultimately based on the same premise. Because that premise was also unavoidable for Bellapertica and Cynus, they rejected any link between deeds and their source.

Public utility justifies the 'exercise of the dignitas where there is no dignitas', says Baldus. The ambiguity is intentional, and it would be lost had he spoken of office (officium). Referring to dignitas for both office and Barbarius, Baldus highlights their contrast. The slave remains legally incapable of lawfully representing the office, he is indignus of that dignitas first of all in the 'technical' sense of legal incapacity. Immediately after the above passage, Baldus continues to play with the ambiguity of the term dignitas. This is the only time in the lectura on the lex Barbarius where he associates Barbarius with the adjective 'worthy' (dignus). In so doing, Baldus does not seek to justify Barbarius' exercise of the office, but to invoke a punishment on him for it: 'Barbarius was liable of several crimes, so he is worthy $[$ dignus $]$ of punishment'. ${ }^{142}$ This way the two-sided concept of dignitas strengthens the contrast between Barbarius and the office.

Importantly, this contrast does not abate with the intervention of public utility. On the contrary, public utility makes it even stronger, for it highlights the difference between the two faces of the agency triangle. ${ }^{143}$ Public utility intervenes directly on the external side, to justify the validity of the exercise of the office for the sake of the recipients of the acts (the commonwealth). Also Bellapertica invoked a teleological approach to public utility. But he did so to skip entirely the relationship between acts and their source - because the source was the person of Barbarius, unlawfully vested with the office. ${ }^{144}$ Baldus' different perspective, on the contrary, allows public utility to be invoked not just towards the third parties, but primarily in favour of the validity of the relationship between office and third parties. Ultimately, the acts are still valid because of public utility considerations. But those considerations operate in favour of the external side of agency: the office-thirds relationship.

Looking at the external side of agency, in turn, calls for the internal one. This leads to the most innovative element of Baldus' approach, namely considering the exercise of the office by the unworthy who cannot lawfully (de iure) represent

142 Baldus, lectura ad Dig.1.14.3, cit., fol. 55va, n. 16: 'Barbarius plura delicta cumulauit, vnde poena dignus est.' In stating as much, it may not be excluded that Baldus implicitly referred to Suzzara's argument on the paradox of rewarding Barbarius (as he would do shortly thereafter, in a more pronounced manner, when speaking of the salary of the Florentine Ghibelline elected podestà: supra, this chapter, $\$ 12.4 .1$, text and note 89 ). On Baldus' use of dignitas against Barbarius see also the repetitio, supra, $\$ 12.2$, note 47 .

143 Cf. supra, last chapter, $\$ 11.6$.

144 Supra, pt. I, $\$ 4.6$. 
it as valid for the recipients of the acts issued by the office, but not for the unworthy himself: ${ }^{\mathbf{1 4 5}}$

as there may be found nothing in Barbarius but for coloured title and coloured possession, then he is praetor with regard to the others, but not to himself.

Baldus' concept of 'coloured title' has little to do with its use in common law (the appearance of legal entitlement to possession or property). Rather, it is the transposition of the 'coloured possession' to the internal side of the agency relationship. Strictly speaking, coloured title does not exist. The title looks at the inner relationship between office and incumbent - either there is title or there is not. Hence Baldus normally speaks only of coloured possession of the office, ${ }^{\mathbf{1 4 6}}$ for possession looks at the external side of agency. The peculiarity of the present case - and its difference from the others - lies in that, invoking public utility, Baldus intentionally highlights the contrast between the two faces of agency. He wants to make sure that his complex elaboration would not be misinterpreted by associating public utility and the validity of the acts with Barbarius' personal status - after all, this was still the position of jurists such as Bartolus. What allowed Barbarius to exercise the office was the element of lawful possession without the underlying title - thus, coloured possession. Because of public utility considerations, this sufficed to produce valid legal effects on third parties that is, as to the relationship between office and the people. This is what Baldus ultimately means when he says that Barbarius had 'true and revocable praetorship', albeit not 'rooted' in his person. ${ }^{147}$ Barbarius' indignitas prevented the office from 'taking root' in him and made the praetorship revocable, so the title remains only a coloured one.

Seen from the internal side of agency, a revocable praetorship is no praetorship at all - again, coloured title is no title. This is why Baldus looks at the internal side of agency, the legal entitlement to sit in office, only after insisting on the strength of its possession. Because the moment the focus shifts towards the relationship between agent and office, there is only one possible conclusion -

145 Baldus, lectura ad Dig.1.14.3, cit., fol. 55rb-va, n. 15: 'vnde nihil videtur in Barbario reperiri nisi coloratus titulus, et colorata possessio: est ergo praetor quo ad alios, non quo ad se.'

146 Supra, this chapter, notes 123 and 132.

147 Supra, this chapter, $\$ 12.4 .1$, text and note 87. Cf. also Baldus, ad X.1.3.14, $\$$ Quoniam autem (Baldvs svper Decretalibvs, cit., fol. 29va, n. 2): 'Item quod qui demonstrat non datur quod iurisdictio potest esse absque exercitio ff. de stat(u) ho(minum) l. qui furere (Dig.1.5.20), sed interdum est exercitium absque natura et radicabili iurisdictione, ff. de offic(io) preto(rum) l. barbarius (Dig.1.14.3). Ibi exercitium in possessione fundatur imo in publica vtilitate saltem aptitudine.' 
lack of agency. Baldus states as much at the same time, as he stresses the effects of public utility on the relationship between office and third parties: ${ }^{\mathbf{1 4 8}}$

It is not important to the commonwealth that Barbarius is made praetor, but that the deeds are valid because of the common mistake. So we may conclude that Barbarius did not enjoy a true praetorship but a putative one, and that he was praetor only in name and in the exercise [of the office] with regard to the others and not to himself, for he did not have a true dignitas.

This passage explains further what said in the previous, shorter one. It moves from public utility - triggered by the common mistake and so by the risk of harming the commonwealth - to reach both sides of agency. The internal side is rejected: Barbarius was praetor only 'in name', and did not have a true dignitas. But the external side of agency is upheld: stating that Barbarius was praetor as to 'the exercise' of the office means qualifying that exercise as valid. Coupling together the - mutually opposing - conclusions as to internal vs. external sides of agency, the result is that 'he is praetor with regard to the others, but not to himself. ${ }^{149}$

This crucially important conclusion ${ }^{\mathbf{1 5 0}}$ is better explained in Baldus' repetitio. If 'the deeds depend on the status', ${ }^{151}$ then public utility should necessarily be invoked with regard to the person of Barbarius (the old position of the Gloss: the validity of the acts depends on that of their source). However, distinguishing between person and office and stressing the importance of lawful possession of the office, Baldus may come to the opposite conclusion without jeopardising the public utility argument: ${ }^{152}$

148 Baldus, lectura ad Dig.1.14.3, cit., fol. 55va, n. 15-16: 'Item non interest Reipublicae quod Barbarius fit praetor, sed quod acta valeant propter communem errorem bene interest Reipublicae: quare concluditur, quod Barbarius non sit in vera praetura, sed putatiua, et quod ipse fuit praetor nomine et administratione quo ad alios non quo ad se: quia non habuit veram dignitatem.'

149 Supra, this paragraph, note 145.

150 It may not be ruled out that Baldus derived this point (adapting it to a very different context) from Bellapertica. Rejecting the validity of the source and focusing exclusively on the validity of its acts, Bellapertica looked at the relationship between act (the sentence) and third party (the litigant parties). This let him to consider the act to be unlawful (non legitime factum) as to Barbarius, but lawful as to its recipients: supra, pt. I, $\$ 4.6$, note 108 . Among the commentaries of the Orléanese jurists on the lex Barbarius, it may be recalled, Bellapertica's was the main - perhaps even the only - one used by Baldus in his work on the lex Barbarius: supra, $\$ 10.2$, text and note 57.

151 Baldus, repetitio ad Dig.1.14.3, cit., fol. 57vb, n. 10, supra, this chapter, note 6.

152 Ibid.: '... licet non esset praetor de iure, sufficit quo ad litigantes quod erat praetor de facto, C. de senten(tiis) l. si arbiter (Cod.7.45.2) et ar(gumentum) l. i de testa(mentis) (Cod.6.23.1). Si ergo dicis Barbarium esse praetorem, et 
although he was not praetor de iure, it is sufficient for the parties that he was praetor de facto ... Therefore, if you said that Barbarius was praetor, and that his appointment had validity in itself, that would be unnecessary, for it would go to the private benefit of Barbarius, not to the common good ... In respect of public utility, maintaining that Barbarius was praetor would be in vain: the opposite solution would suffice as to the validity of the deeds and the preservation of public utility.

For the validity of the deeds - that is, for the external side of agency - Barbarius' factual exercise of the praetorship would suffice. It would, because Barbarius was not a mere intruder: Baldus saw to that by stressing the importance of the voidability of the election. This, as we have seen, gave Barbarius coloured possession of the office, thus lawful possession of ordinary jurisdiction. Barbarius received a 'true and revocable praetorship': ${ }^{153}$ while this did not amount to $d e$ iure entitlement, it allowed mention of coloured possession. Not being an intruder, Barbarius was not a false praetor. At the same time, however, he was legally incapable of representing the office. This opposition is the key to separating external from internal validity of agency: ${ }^{\mathbf{1 5 4}}$

\begin{abstract}
if we maintain that [Barbarius] was not praetor as to himself but that he should be considered praetor as to the others, it is necessary to explain something. One thing is to object 'you have not been created', another is to say 'you cannot be'. Where there is neither fact nor law, it is possible to raise the exception of falsehood. Where on the contrary something is true as to the facts but not as to the law, one cannot be considered as false [falsus], but legally incapable [inhabilis]
\end{abstract}

Properly speaking, Barbarius was not falsus praetor because he was formally elected. What he lacked was not the fact of the election to praetorship, but rather the legal requirements allowing that fact to result in his de iure entitlement to the office. The issue therefore is not of falsitas, but of inhabilitas. Inhabilis is someone who lacks dignitas in its 'technical' sense of legal capacity. This way, the question becomes very similar to that of the incompetent judge (another reason Baldus elaborates the distinction between fact and law in terms of exceptio). We have seen earlier in Baldus' lectura that the possession of ordinary jurisdiction allowed

creationem suam habere ualentiam in seipsa, hoc redundat ad priuatam vtilitatem Barbarij, non ad bonum publicum ... praesupponere Barbarium praetorem esset fustra respectu publica vtilitatis, quia licet sit oppositum, valerent gesta, et seruatur publica vtilitas.'

153 Supra, this chapter, $\$ 12.4 .1$, text and note 87.

154 Baldus, repetitio ad Dig.1.14.3, fol. 57vb, n. 12: 'sed tenendo, quod quantum ad se non fuerit praetor, sed quo ad alios praetor debeat reputari, tunc oportet soluere, quae alia est exceptio "tu non es creatus", alia "tu non potest esse". Nam vbi abest factum et ius est exceptio falsi, et hoc non hic, quia non erat defectus in facto sed in iure, vbi vero adest veritas facti sed non iuris, iste non dicitur falsus sed inhabilis, vt no(tatur) in(fra) de proc(uratoribus) l. quae omnia (Dig.3.3.25).' 
Barbarius to impose his jurisdiction over the parties, so long as the underlying defect of servitude (thus the legal incapacity) remained hidden or anyway not proven. ${ }^{155}$ Barbarius was not truly an ordinary judge, but he appeared as such to the litigants: the question is not simply a difference between appearance and reality, but between lawful possession and legal entitlement. ${ }^{156}$ Barbarius was not a true praetor, but he had lawful possession of the praetorship because he entered into office after being elected and while the inhabilitas (the defect in qualitate) remained occult. ${ }^{157}$ The difference between 'true praetor' and 'true praetorship' is relevant only as to the inner relationship between person and office. From the outside, 'true praetorship' would suffice as to the validity of the deeds, because the deeds are not those of Barbarius but of the office. Saying that Barbarius' deeds are valid only 'as to the others' denies the agency relationship with the office, and links the office directly to those subjected to its jurisdiction (i. e. the third parties).

The distinction between internal and external validity of agency in Baldus' reading of the lex Barbarius is strictly dependent on the separation between person and office. This separation is always present in Baldus' elaboration of the lex Barbarius: there are never two parties (Barbarius and the people) but always three. Barbarius is the agent, but the agent remains distinct from the office he represents. The presence of a third subject between Barbarius and the people allows the common mistake to be qualified as pertaining to the office-third parties relationship, not to the agent-office relationship. The question therefore is not whether the agent is entitled to represent the office validly, but whether the office could validly issue the acts towards the third parties. Arguing for the validity of the relationship between office and thirds (because of public utility triggered by the common mistake) does not imply also ratifying the relationship between office and agent: ${ }^{158}$

155

156 Baldus, repetitio ad Dig.1.14.3, fol. 58ra, n. 16: '... Et sic dicatur quod Barbarius non fuit liber nec praetor, ergo fuit iudex incompetens: quo(modo) acta valent? Respondeo quo ad subditos iudex competens esse videtur, ut s(upra) dixi; sed in seipso secus. Sicut ergo non potest habere dominum, ita non potest habere iurisdictionem, ar(gumentum) de statu ho(minum) 1. qui furere $\{\$$ in verbo habitu\} (Dig.1.5.20).'

157 Cf. the four-fold division of defects in the election, supra, this chapter, $\$ 12.4 .1$.

158 Baldus, ad Cod.3.34.2, $\mathbb{S}$ Si aquam (svper Primo, Secundo \& Tertio Codicis, cit., fol. 219ra, n. 85): 'communis autem opi(nio) licet firmat gesta barbarij: non autem firmat eius preturam, quia detecta veritate est amouendus de officio, et sic aliis prodest: sed barbario non prodest de quo formatur ibi questio et non soluitur secundum verum intellectum: de hoc in $\mathrm{d}$ (icto) c. in literis (X.2.13.5) per Inn(ocentium).' Cf. Innocent, ad X.2.13.5, $\$$ In literis (Commentaria Innocentii Quarti, cit., fols. 226vb-227ra, n. 3 and \$Prius, ibid., fol. 228ra, n. 8). 
while common opinion strengthens (firmat) the deeds of Barbarius, it does not strengthen (firmat) his praetorship: when the truth is uncovered he is to be removed from office

Firmare means both strengthening, hardening, as well as confirming, establishing. Common opinion does not establish the validity of Barbarius' praetorship because, as we know, the dignitas of ordinary jurisdiction may not 'take root' in a slave. ${ }^{\mathbf{1 5 9}}$ Hence the praetorship remains 'revocable' (revocabilis) and not 'rooted' (radicata). ${ }^{160}$

Barbarius, says Baldus elsewhere with metaphysical transport, 'was not in the true substance of the office'. And truth, he continues, is the other face of being. ${ }^{161}$ It would follow that Barbarius was nothing. This, however, applies only to the inner relationship between Barbarius and the office, not to the external relationship between office of ordinary judge and parties of a lawsuit: ${ }^{\mathbf{1 6 2}}$

Barbarius was nothing as to himself, but he was something as to the parties litigant.

The opposition between internal and external validity of agency - the invalidity of the praetorship as to himself and its validity as to the others - is not to be found in previous civil lawyers. To reach it, Baldus builds on Innocent's separation between person and office. ${ }^{163}$ Between Baldus and the pope, however, there is a crucial difference: for Innocent the external validity of agency (the validity 'as to the others') always depends on its internal validity (validity 'as to himself). Toleration allows the indignitas of the person qua individual to be overcome, focusing on the person qua agent. And it is on that basis that the office could act validly towards the thirds. In order to highlight the distinction between individual and agent, Innocent brings the person qua agent as close as possible to the office. If this closeness allows the emphasis to be shifted from the unworthiness of the individual to the enduring legal capacity of the agent, at the same time it does not leave much room to the office as a different subject

159 Supra, this chapter, note 102.

160 Supra, this chapter, note 87.

161 Baldus ad Cod.7.45.2, \Si arbiter (svper Primo, Secvndo \& Tertio Codicis, cit., fol. 52va, n. 16): 'Et ideo dicunt doc(tores) in 1. barbarius (Dig.1.14.3), quod licet valeant gesta tanquam solenniter facta: tamen barbarius non erat in vera substantia officij. Concordat regula philosophi dicentis: quod ens et verum conuertuntur, et vnum quodque sicut se habet ad esse sic ad veritatem, secundo metaphi(sicae).' Cf. Horn (1967), p. 148.

162 Baldus, repetitio ad Dig.1.14.3, fol. 58ra, n. 16: 'Concludamus ergo tres finales conclusiones. Prima est de Barbario quod non fuit praetor. Secunda de actib(us) exercitis quod valuerunt. Tertia quod barbarius nihil fuit quod ad se, sed quo ad litigantes aliquid fuit. Et sic casu, et fortuna populus Romanus fuit seruus, et subiectus suo. \{Nempe fortuna in omni re dominatur\}.' Cf. Rampazzo (2008), pp. 433-434. 
from the agent that represents it. Hence the need of symmetry between internal and external validity of agency: the relationship between office and thirds is functionally the same as the one between agent and office. Keeping agent distinct from office, Baldus could go beyond that, and fully separate the two 'sides' of agency.

The difference between internal and external validity of agency is particularly evident in Baldus' additio on the lex Barbarius. There, Baldus moves from the invalid election of the prelate whose incapacity remains however occult, to look at Barbarius' case from the perspective of the commonwealth - and so, from the external side of agency: ${ }^{\mathbf{1 6 4}}$

I rather think that the deeds are valid if [Barbarius] is in possession, and the common mistake and public utility both argue for this. I prove it this way. A prelate is bound to his subjects to render them justice, and may be compelled to do as much ... This is an obligation in rem [realis], for the dignitas itself is bound to its subjects to do as much, and that amounts to a real right. So it is as if the collectivity of the subjects had quasi possessio ${ }^{165}$ of this right ... Hence I argue that this possession of the subjects justifies the legal proceedings in their favour because of their good faith, given that the prelate was in bad faith. The subjects possess this right as a collectivity, not as individuals, otherwise there would be infinite possessions. As there is but one possession for all of them together, a decision passed against some of them as individuals does not harm the whole of them (as in Dig.1.8.6.1).

Invoking public utility directly on the external side of agency, and fully distinguishing between obligations of the office and those of the person, Baldus can even speak of a real right of the third party towards the office. The obligation of the office of the judge is to grant justice to those under its jurisdiction.

164 Baldus, additio ad Dig.1.14.3, cit., fol. 59rb-va, n.9-10: 'Verius credo quod valeant gesta, si est in possessione, et communis error et publica vtilitas hoc suadent. Hoc probo. Prelatus est obligatus subditis ad faciendum eis iustitiam, et

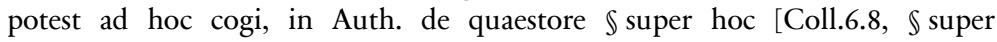

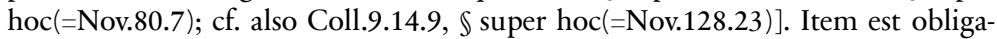
tio realis, nam ipsa dignitas est obligata subditis ad hoc, et sic ex hoc resultat ius reale. Igitur quasi possidetur hoc ius ab vniuersitate subditorum. ... Ex hoc concludo quod ista quasi possessio subditorum iustificat processum in eorum fauorem propter eorum bonam fidem, dato quod prelatus habeat malam fidem, dico etiam quod istud ius possidet vniuersitas subditorum, non singuli, quia sic infinite essent possessiones, cum non sit nisi vna in omnibus, et ideo sententia aliquorum singulorum non noceret etiam eis, vt 1 . in tantum, $\mathbb{S}$ vniuersitatis (Dig.1.8.6.1).' Cf. esp. Id., additio ad Dig.1.8.6.1, $\$$ Vniuersitatis (In Primam Digesti Veteris Partem, cit., fol. 49vb).

165 Baldus writes of quasi possessio both because that specific right lacks a corporeal dimension (cf. supra, pt. I, $\$ 5.4$, note 42 ), and especially because a collectivity may not possess in the same way as an individual person: cf. e. g. Id., ad X.2.14.9, $\$$ Contingit (Baldvs super Decretalibvs, cit., fol. 156vb, n. 38). 
Described this way, the obligation clearly refers to the office, not to the person who exercises it. Hence Baldus qualifies it as a real right - a right against a thing, not a person. The holder of that right is the commonwealth (the collectivity of those under the office's jurisdiction), and the presence of the commonwealth allows public utility considerations. In suing before the illegitimate agent (Barbarius or the prelate), the people are exercising their right against the office. The simple possession of the office (instead of full de iure entitlement) by the prelate or Barbarius suffices as to its valid exercise because of the good faith of the people (which triggers public utility). But the validity is only towards the commonwealth (external validity), not to the false agent (internal validity). Looking at the commonwealth as a collectivity (universitas) not only avoids logical problems (the 'infinite possessions'), but especially strengthens the public utility considerations. Any single decision that harms an individual member of the commonwealth 'does not harm the whole'. So the administration of justice always goes to the benefit of the commonwealth, and even what is prejudicial to the individual furthers public utility.

Immediately after this passage, Baldus adds something else. If the rationale of public utility lies in the right of the people to receive justice, it follows that the scope of the lex Barbarius should only encompass the acts issued by the praetor at the parties' request, although the text of the lex says otherwise. ${ }^{166}$ Baldus does not elaborate further on the point - the additio groups together a series of short glosses. Does that mean that the other deeds of Barbarius should be void? The text of the lex Barbarius referred both to legislative and judicial deeds, ${ }^{167}$ and that was also the interpretation of the Accursian Gloss. ${ }^{168}$ Even so, the possibility that Baldus did intend to restrict the validity of Barbarius' deeds only to those that could be issued at the party's request is not based only on a few lines in the additio.

In the preamble to the lectura on the same lex Barbarius, summing up the position of the Gloss, Baldus seems to imply a correlation between the kind of acts that Barbarius could issue and the difference between internal and external validity of agency. According to the Gloss, he says, the validity of the acts would depend on the fact that Barbarius became true praetor for equitable reasons (de aequitate).The same equitable reasons, he goes on, would also entail the validity of all his acts, whether legislative or jurisdictional - and, within the latter, both

Id., additio ad Dig.1.14.3, cit., fol. 59va, n. 10: 'Ista ratio concludit quod gesta per Barbarium valuerunt, de rigore quidem videtur contra tex(tus). Sol(utio) fateor quod ratio concludit in his, quae gesta sunt ad petititonem subditorum; sed litera loquitur etiam de alijs, in quibus cessat dicta ratio: certe nunquam cessat. Bal(dus).'

167 Cf. Dig.1.14.3: '... Quae edixit, quae decrevit, nullius fore momenti?'

168 Supra, pt. I, $\$ 2.1$, note 24 . 
those at the party's request (ad petitionem partis), and those of the court's own motion (ex mero officio). Finally, he continues, the Gloss concludes that Barbarius' praetorship was de iure valid both 'as to himself' and 'as to the others'. ${ }^{169}$ This summary seems to imply a crescendo: the validity of Barbarius' praetorship is initially affirmed on equitable grounds, but the breadth of the deeds that he is able to issue is such as to presuppose the de iure validity of his praetorship (and so, both internal and external validity of agency). The position of this summary of the Gloss - at the very beginning of Baldus' lectura - signals the difference with Baldus' own interpretation. Indeed, towards the end of the same lectura, Baldus reaches a different conclusion. The exercise of a public office is both the reason and the limit of the validity of Barbarius' deeds: the validity does not extend to what he may do outside of the exercise of the office. ${ }^{\mathbf{1 7 0}}$ The rationale is the same as that of Innocent's toleration - indeed, Baldus quotes the comment of

169 Baldus, lectura ad Dig.1.14.3, cit., fol. 54vb, pr: '... Et ratio quare gesta valuerunt est, quia de aequitate fuit verus praetor: et quia aequum est acta valere propter publicam vtilitatem, et communem errorem: et hoc est verum tam in iudicando, quam in statuendo, et tam in gestis ad petitionem partis, quam ex mero officio. Ergo concluditur quod praetura fuit functus et quo ad se, et quo ad alios non solum de facto, sed de iure.'

170 While Baldus clearly follows Innocent IV on the subject (toleration does not operate outside public offices), he is more careful about the possible repercussions of this conclusion (especially when the deed is to be considered as actus necessarius, and in case of good faith possession of fruits). Baldus, repetitio ad Dig.1.14.3, cit., fol. 58ra, n. 20: 'Sed quid dicemus in his, quae non fiunt per modum iurisdictionis vt in contractibus, an de aequitate valebunt facti contractus stricti iuris a minus legitimo prelato, sicut est intrusus de facto? Non valent xii q. ii $<$ c. $>$ alienationes (C.12, q.2, c.37). Si vero auctoritate superioris, tamen illa auctoritas non valuit, quia confirmatus erat excommunicatus, qui habetur pro mortuo quo ad spiritualia pro non confirmato, vt not(at) Innoc(entius) in c. nihil est (X.1.6.44), tamen subdistingue: aut est actus necessarius et valet, $\arg$ (umentum) de mino(ribus) 1. ait pretor $\mathbb{S}$ permittitur (Dig.4.4.7.2), et de pro(curatoribus) $l$. procurator totorum in fine (Dig.3.3.63), et $\arg$ (umentum) huius 1 (egis) quia iurisdictio est necessaria, et debet subditis impartiri, ut in autentica de

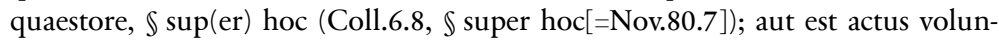
tarius, et tunc aut concernit proprietatem rerum, aut fructus. Primo casu non valet contractus, $\arg$ (umentum) C. de his qui pro tuto(re) 1. ii (Cod.5.45.2), de iureiu(rando) l. iusiurandum $\$ 1$ (Dig.12.2.17.1); secundo casu valet si erat in bona fide quod administrationem facti, licet non habeat ius plenum, $\arg$ (umentum) extra, de elec(tione) <c.> querelam (X.1.6.24), ne praela(ti) vices suas c. fin. (X.5.4.4).' But even this last exception is to be qualified, as in some situations it should not apply. This is particularly the case with illegitimate wardens, for they cannot prejudice the ward's property. The repetitio continues (ibid.): 'Et hoc in prelatis; secus in tutoribus non legitimis, qui nihil possunt nec in iudicio, nec extra in praeiudicium domini, vt l. qui neque, de reb(us) eo(rum) (Dig.27.9.8), nam dominus in eorum administratione non succedit, nec cogitur ratum habere, vt l. filiae, de sol(utionibus) (Dig.46.3.88).' 
the pope that most highlights the difference between acts done in the exercise of the office and those done as a private individual. ${ }^{171}$ Innocent however did not intend to restrict the scope of the acts that the unworthy tolerated in office could carry out. At the same time, the distinction between internal and external validity is not to be found in Innocent either. The two points might be related to each other. For Innocent, the toleration of the occult unworthy validates the internal side of agency: the tolerated is legally entitled to represent the office validly. The external validity - the validity of the acts towards their recipients - is but a consequence of the internal validity. Baldus' distinction between validity 'as to the others' and invalidity 'as to himself' is ultimately the consequence of lack of confirmation. Because Barbarius is not confirmed in office, he lacks the right to represent it validly. If we wanted to credit Baldus with remarkable coherence and continuity in his thinking, even if possibly elaborated over a span of many years, we might therefore read the lectura in the light of what said in the additio, and so narrow the validity of the acts of the apparent judge - who has coloured possession of the office - only to those that require a lawsuit. The point however remains unclear. ${ }^{172}$

The distinction between validity of the acts for their recipient and invalidity of the same acts for the person who carried them out was not new. It was an old sacramental problem. Are the sacraments celebrated by the heretic valid? In answering that question, one of the great canon lawyers of the early thirteenth century, Johannes Teutonicus, used the same distinction as Baldus. Teutonicus, it will be recalled, was hardly sympathetic to the jurisdictional applications of the concept of toleration. But he had to make sense of an apparent contradiction in Gratian's Decretum. There, at a short distance from each other, a first passage stated that the sacraments are not defiled by the impure (C.1, q.1, c.30), and a second, on the contrary, held that the impurity of the soul does pollute the sacrament (C.1, q.1, c.61). The most common explanation was to distinguish between sacraments of necessity and those of dignity. ${ }^{173}$ But Teutonicus added

171 Id., lectura ad Dig.1.14.3, cit., fol. 56va, n. 35: 'no(tandum) quod materia literae nostrae habet locum in his, quae fiunt ratione publici officii, non in alijs, extra de consuet(udine) c. <cum> dilectus (X.1.4.8), secundum Innoc(entium), et in his quae tangunt ius aliorum, non solius facientis, vel patientis, extra, de procu (ratoribus) <c.> consulti (X.1.38.15), per Inno(centium).' Cf. Innocent, ad X.1.38.15, $\mathbb{S}$ Sententia, cit. supra, pt. II, $\$ 7.5$, notes 63-66.

172 The case, discussed in the next chapter, of the legislation issued by the unworthy bishop tolerated in office may not be applied, even by analogy, to the present scenario. Quite unlike Barbarius, this is a proper case of toleration (where the external validity of the acts is supported by the internal validity of the appointment). Infra, $\mathbb{\$} 13.1$.

Supra, pt. II, $\$ 6.1$. 
two further possibilities, both seeking to narrow the scope of the first text. One explanation could be that the first text referred to priests ordained by those tolerated by the Church. Given his scarce approval of toleration, however, Teutonicus added that such ordinations were only 'imagined' (ficte). But there could be a second explanation, which would better ensure the consistency of the two texts. Stating that the sacraments were not contaminated by the impure who celebrated them, continued Teutonicus, the text might have meant that the sacraments would be polluted (and so void) only for the priests administering them, and valid for the faithful receiving them. ${ }^{174}$ Whether or not Baldus looked at this passage is not clear (although, being part of the Ordinary Gloss on the Decretum, it would be surprising if he did not know of it). But its importance lies not in a hypothetical influence on Baldus, which may not be proven. Rather, it lies in the alternative solution: either the impure priest was tolerated, or the sacrament he celebrated was pure for its recipients and polluted for him. Unwittingly, Teutonicus showed the limits of toleration: being tolerated would entail the validity of the act both for the others (ad alios) and also for the person who issued it (ad se). By contrast, limiting the validity to the recipients amounted to an implicit denial of toleration.

Baldus applies the same reasoning - and so the distinction between se and alios - to the occult excommunicate: 'while the occult excommunicate is not excommunicated as to the others, nonetheless he is excommunicated as to himself [ad seipsum], that is, to his own damage and not to the detriment of the others [ad alios]. ${ }^{175}$ In this case, the excommunicate was tolerated in office because of his confirmation. ${ }^{\mathbf{1 7 6}}$ This is why Innocent's comment on the same passage said nothing of the distinction ad selad alios, and focused only on the validity of the excommunicate's acts. ${ }^{177}$ From an ecclesiological perspective,

174 Teutonicus, ad C.1, q.1, c.30, \Transiens (Pal. Lat. 624, fol. 75vb; cf. Basileae 1512, cit., $\mathbb{S}$ Transit, fol. $108 \mathrm{ra}$ ): 'i(nfra) c. sic populus (C.1, q.1, c.61) contra [cf. Gloss ad C.1, q.1, c.61, $\mathbb{S}$ Sic populus (Basileae 1512, cit., fol. 110vb)]. Solutio hic de sacramentis necessitatis que semper habent effectum, nisi culpa suscipientis impediat: ibi de sacra(mentis) dignitatis, uel hic de ficte ordinatis ab hiis quos ecclesia tolerat, uel dic quod sunt polluta quantum ad illos vt xlviiii. di. c. vlt. (D.49, c.2) Jo(hannes).' Cf. supra, pt. II, \$6.4.

175 Baldus, ad X.2.27.24, $₫$ Ad probandum (Baldvs svper Decretalibvs, cit., fol. 234rb, n. 1): '... licet occultus excommunicatus non sit excommunicatus quo ad alios est tamen excommunicatus quo ad seipsum, i(d est) ad damnum suum non alterius: nam sicut vulnus dicitur quod videtur, vlcus dicitur quod intus latet ita iste vlceratus est licet alius quam ipse non videat maculam.'

176 Ibid., fol. 234rb, pr.

177 Contrast Baldus' position (supra, this paragraph, note 175) with that of Innocent, ad X.2.27.24, $\mathbb{S}$ Infirmandam (Commentaria Innocentii Quarti, cit., fol. 314va). 
surely the pope did not condone the excommunication of the prelate. But the reprobation pertained to his condition as an individual, so it was of no consequence when he acted as representative of his office. The fact that Baldus also brought up the distinction ad selad alios in this context reveals a different approach to toleration: even when looking at the person as representative of the office, Baldus never reaches the same degree of identification between incumbent and office as Innocent did. Ultimately, this is what allowed Baldus to consider the external validity of agency as something different from, and potentially even in contrast with, its internal validity.

Toleration presupposes full integration between unworthy incumbent and office. This is the logical consequence of Innocent's concept of representation, where the representative tends to identify with his office. There is however a subtle line between integration and assimilation. For Baldus, the office is never thoroughly assimilated with the person. Even when the office remains in the background and the agent is in front, the stage, so to speak, is always threedimensional. Highlighting the direct imputation of legal obligations to the office, its separation from the agent lingers even when the agent has full title to exercise the office. So, we have seen, even the king cannot bend the office of the Crown into doing something that would defile its dignitas. ${ }^{\mathbf{1 7 8}}$ This was something that Innocent never said. ${ }^{\mathbf{1 7 9}}$ When the acts detract from the dignitas of the office, therefore, they remain the acts of a private individual and may not be imputed to the office. The dignitas of the supreme office of the Crown relates to the commonwealth: the direct relationship between office and the people (the external side of agency) works as a constraint on the relationship between agent and office (the internal side of agency). Hence the main obligation of the king was preserving the state of the commonwealth (status regni), because that obligation was first and foremost of the Crown towards the commonwealth, to the point that it even defined the Crown itself. ${ }^{\mathbf{1 8 0}}$ The external side of agency, the relationship between office and third parties, helps to define the nature of public offices, and it colours that relationship with public utility.

178 Supra, last chapter, $\$ 11.4$.

179 Admittedly, however, the image of the king acting as a tyrant was a topos, but that image was not easily transferred to the pope. Rather, the problem in canon law was whether the heretical pope could be deposed - and, especially, by whom (D.40, c.6). It was not (or not directly) whether his acts prior to the deposition were valid. Cf. esp. Moynihan (1961), pp. 68-69, 80, 84-85 and 90-91; Tierney (1998), pp. 117-120.

180 See first of all the classical work of Post (1964), esp. pp. 269-290. It is significant that, in his discussion, Post associates the concept of status regni with that of the inalienability of those Crown's rights considered necessary for public utility reasons (ibid., esp. pp. 280-282). 
Highlighting the external side of agency, and the public utility underpinning the relationship between public office and commonwealth, Baldus underplays the invalidity of the internal side. Invoking public utility when looking at the relationship between commonwealth and praetorship, as Baldus does, means highlighting the obligation of the office of the judge towards the commonwealth. The strength of that obligation allows the wanting status of the agent Barbarius - to be overcome. Both in the case of the Crown and in that of the office of ordinary judge the principal relationship is between office and people; the one between office and agent becomes somewhat secondary. And the same rationale used to deny the validity of the acts of the true agent (the king lawfully sitting on the throne) is ultimately applied to ascribe valid effects to those of the false agent (the slave unlawfully sitting on the bench).

The role of public utility, and its importance in the relationship between dignitas and commonwealth, can also be seen in the issue of Barbarius' freedom. The point is not of importance as to the conclusion - for Baldus, Barbarius remains a slave. But it is of interest to appreciate the extent of the separation between internal and external sides of agency: Baldus even wonders whether the strength of the external validity might make up for the weakness of the internal validity.

Unlike the validity of both deeds and praetorship, Barbarius' freedom was the only issue that Ulpian left unsolved: the text, says Baldus, is 'open' on the matter. Even allowing for the validity of the praetorship would not necessarily entail the freedom of the slave-praetor. ${ }^{181}$ The Accursian Gloss meant as much when it said that the prince could have appointed Barbarius as praetor without making him free. ${ }^{182}$ But if the two issues are not necessarily related, it might well be possible to reach the opposite result: that Barbarius became free without enjoying a valid praetorship. As said, the argument is merely speculative, but the reasoning is nonetheless interesting. We have seen how, for Baldus, Barbarius was not dignus of the praetorship, which was 'unworthily received'. ${ }^{183}$ The way in which he exercised his praetorship, however, somewhat cleansed this initial unworthiness. One might not be worthy to become an Apostle of the Lord, argues Baldus referring to St Paul, ${ }^{184}$ and yet his acts may be worthy of the apostolate all the same. More importantly, Baldus continues, the fact that the dignitas of praetor-

181 Baldus, lectura ad Dig.1.14.3, cit., fol. 56rb, n. 32: 'Viso de praetura, et de gestis Barbarii, videamus nunc de eius libertate, quam, vt dixit, potest esse praetura circumscripta libertate, vt videtur textus apertus, et ideo praetura non arguit de necessitate in libertate.'

182 Supra, pt. I, $\$ 2.4$, note 83.

183 Supra, this chapter, note 87.

1841 Cor. 15:9. 
ship falls on someone unworthy of it does not tarnish the office. On the contrary, it is for the office to clean the baseness of the person who exercises it, so long as this exercise is worthy of the office. ${ }^{185}$ Since Barbarius proved himself worthy of the dignitas of the praetorship, such a dignitas might cleanse its holder of his personal indignitas. 'Indeed, as he did what was useful to the commonwealth, he deserves a reward. ${ }^{186}$ This was an intentional twisting of a previous statement in the same lectura (Barbarius deserves only punishment). ${ }^{187}$ This passage might have even induced some later hand in the repetitio to colour with reluctance Baldus' conclusion against Barbarius' freedom. ${ }^{188}$ The whole reasoning had a predetermined end (Barbarius remains a slave), but it would have been unthinkable in Innocent: not just for the unholy parallel between a deceitful slave and the Apostle of the gentiles, but especially because of the relationship between person and office. Moving from the external side of agency Baldus reached the internal one. This time, however, the purpose was not to keep internal invalidity fully separate from external validity, but to wonder whether the external side might influence - and even heal - the internal one.

185 Baldus, lectura ad Dig.1.14.3, cit., fol. 56rb, n. 33: 'erit ergo ratio: quia expedit honori Reipublicae regi per dignum receptum, aut factum, sicut Apostolatus aut dignum recipit, aut dignum facit, et sic dignitas non vilis sit in persona vili. Et sic aufert sordem ab ipsa.'

186 Ibid., n. 34: 'nam faciens in publico quod vtile est, meretur praemium, de haer(edibus) insti(tuendis) 1. testamento domini (Dig.28.5.91), et ad Sil(anianum) 1. si quis in graui $₫$ hi quoque (Dig.29.5.3.15).'

187 Supra, this paragraph, text and note 142.

188 '\{Concedo\} et idem dico quod Barbarius non fuit liber', Baldus, repetitio ad Dig.1.14.3, cit., fol. 58ra, n. 15. The verb 'concedo' is not to be found in any edition of the 'Bartolian' repetitio on the lex Barbarius. Incidentally, this use of the verb concedere is somewhat alien to Bartolus' own style. Ascribed to Baldus, however, it would sound more plausible, as he used it other times to narrow down his conclusions, especially on debated and complex issues. See e. g. Baldus ad Cod.6.44.1 (svper Sexto Codicis Iustiniani, cit., fol. 155ra, n. 17). 


\section{Chapter 13}

\section{Extensions of the lex Barbarius to other cases (or vice versa)}

As with previous civil lawyers, we might now turn our attention to Baldus' application of the lex Barbarius to analogous instances - especially the secretly deposed notary, the secretly excommunicated judge and the putative prelate. With an important caveat: quite unlike the other civil lawyers that we have seen, Baldus does not apply the rationale of the lex Barbarius to other cases. In fact, he does precisely the opposite: he highlights the similarity of those other cases with that of Barbarius, so as to strengthen his interpretation of it. In Baldus those other cases are straightforward applications of Innocent's concept of toleration (where the external validity of agency depends on its internal validity), whereas Barbarius' case is an indirect adaptation of the same principle, an adaptation that circumvents the fundamental problem of the lack of confirmation (thus severs the symmetry between internal and external validity). Stressing the similarity between improper (Barbarius) and proper toleration (judge, priest and notary), Baldus seeks to consolidate his reading of the lex Barbarius. He does so by inverting the roles: it appears to be the lex Barbarius that is extended by analogy to the other straightforward cases of toleration, whereas in fact the opposite is true. The outcome is remarkable. At least, later jurists must have thought so, because they had little doubt as to the deep similarity between Baldus' interpretation of the lex Barbarius and Innocent's interpretation of the other cases.

\subsection{Judges and prelates}

While in the lectura Baldus applies the lex Barbarius (albeit in a rather concise way) mainly to the putative or deposed notary, in the repetitio he also looks at two other cases: the excommunicated judge and the false priest. We might want to follow the general order of the repetitio, and so deal with the notary last. All three cases are straightforward examples of proper toleration, but the difference - thus their order within the repetitio - lies in the way in which each of them is compared to Barbarius. Since, as already stated, the ultimate purpose of Baldus is not to extend the lex Barbarius to these other instances but to use them to strengthen his approximation to toleration in Barbarius' case, he orders these cases so as to highlight their increasing similarity with that of Barbarius. 
In the repetitio, the first case to appear is that of the excommunicate judge. This is the easiest of the three, because it is analysed as a straightforward application of Innocent's concept of toleration. We have seen how Baldus' repetitio divided the legal incapacity of the agent into three groups - holding an office only de facto, being in a condition for which one should be deprived of one's office, and having already been deposed from it. ${ }^{1}$ Barbarius fell into the first category, for he never was praetor de iure (and so, as to himself - ad se). The judge, on the contrary, is 'true judge in himself (verus iudex in seipso). The fact that his excommunication is secret allows him to be tolerated in office - and so to continue to represent it validly. ${ }^{2}$ On the point, Baldus explicitly relies on a passage of Innocent, where the pope referred to the lex Barbarius in order to highlight the importance of public office and public utility. Because of the public nature of the office exercised, said Innocent, the occult character of the judge's incapacity is reason enough to invoke the toleration principle so as to hold the acts as valid, just as in the lex Barbarius. ${ }^{3}$ Unlike for the pope, however, for Baldus the two cases are different: only that of the judge is a proper case of toleration and so, of representation. Therefore Baldus explains that the validity of the acts of the secretly excommunicated judge is 'much stronger' (multo fortius) ${ }^{4}$ than the validity of those of Barbarius. In admitting the lesser strength of Barbarius' acts (because, unlike the case of the secretly excommunicated judge, that of Barbarius fell outside proper toleration), Baldus however implicitly affirms their validity. This way, Baldus begins to subtly depart from Innocent's position.

1

Supra, last chapter, note 123.

Baldus, repetitio ad Dig.1.14.3, cit., fol. 58rb, n. 20: 'Sed quid dices de vero iudice, qui tamen erat excommunicatus occulte, an teneat processus suus? Videtur quod non, vt no(tatur) in 1. i C. de iu(ris) et fac(tis) igno(rantia) (Cod.1.18.1). Tu dic contrarium, quia occulte excommunicatus partib(us) obesse non debet, arg(umentum) 1. nostrae [scil., Dig.1.14.3], nam iste excommunicatus est verus iudex in seipso, ergo multo fortius valent gesta vel acta quam in Barbario: facit quod no(tat) Inn(ocentius) in c. consulti, de procu(ratoribus) (X.1.38.15).' On Innocent see supra, pt. II, $\$ 7.5$, note 65. Cf. Baldus, ad X.2.27.24, $\$$ Ad probandum (Baldvs svper Decretalibvs, cit., fol. 234rb, n. 1): 'No(tandum) quod sententia iudicis publice excommunicati iure non tenet ergo a contrario sensu secus non excommunicatio esset clandestina vel occulta, de hoc ... de offi(cio) preto(rum) 1. barbarius (Dig.1.14.3). ... Ista autem distinctio publice et non publice sit in iudice et tabellione propter authoritatem publici officii et similiter in teste, quia publica vtilitatem habet et locum quo ad ignorantes. Nam in sciente non est vis vtrum publice vel non publice vt c. $\mathrm{i}$ (nfra) de rescrip(tis) libr. vi (VI.1.3.1) et C. si seruus vel liber(tus) ad decuri(onatum) aspi(raverit) 1. ii li. $x$ (Cod.10.33.2).'

Cf. Innocent IV, ad X.1.38.15, $\mathbb{S}$ Sententia, supra, pt. II, $\$ 7.5$, notes 64-65.

Supra, this paragraph, note 2 . 
The absence of confirmation entails the lack of internal validity of representation. The parallel between the judge and Barbarius therefore seems shaky. But it was necessary: from Monciaco onwards, nearly all the civil lawyers we have previously encountered dealt with the case of the excommunicated judge, Bartolus included. Dealing with it first, and in a rather succinct manner, served to underplay its - structural - difference with Barbarius. Blurring the underlying difference (and speaking of stronger vs. weaker validity instead of valid vs. void), Baldus sought to show the continuity between proper and improper cases of toleration. This way, even a straightforward case of toleration (thus of fully valid representation), that of the judge, does not look so structurally different from that of Barbarius. As we shall now see, the other cases are not described in terms of proper toleration. This is hardly fortuitous: in omitting any reference to toleration, Baldus seeks to strengthen the apparent continuity with Barbarius' case, and thus support his adaptation of the Innocentian toleration principle outside proper agency.

Immediately after the excommunicated judge, Baldus' repetitio moves on to the case of the illegitimate prelate: would his acts remain valid even after his deposition from office? Before answering, Baldus invokes several Roman sources dealing both with the slave-master relationship and with the dominus-procurator one. Some of those cases denied validity to the acts of the slave or the procurator, while others considered them valid. The difference, Baldus explains, depended on whether the slave or the representative was acting upon the authority of a public office - and so for public utility - or upon the authority of a private person - and so for that person's private utility. Hence the connection with the prelate: as his office is public, reasons Baldus, its exercise furthers public utility. ${ }^{5}$

Baldus, repetitio ad Dig.1.14.3, fol. 58va, n. 23: 'Sed quid de actis motis a minus iusto prelato, vel ab eo, qui postea remotus est ab actu vel ab officio vel dignitate vel administratione, an teneat iudicium? Videtur quod sic, arg(umentum) eius quod not(atur) $\mathrm{i}$ (nfra) de iudi(ciis) 1 . non idcirco $\$$ cum postea (Dig.5.1.44.1) et in rem $\mathrm{ra}(\mathrm{tam}) \mathrm{ha}$ (beri) 1. procu(ratoris) ad exhibendum $\mathbb{\int}$ fi. (Dig.46.8.8.2); contrarium facit $\mathrm{i}$ (nfra) de solu(tionibus) 1. dispensatorem (Dig.46.3.62), si cer(tum) pe(tetur) <l. $>$ eius qui (Dig.12.1.41), de admi(nistratione) tu(torum) $<$ l. $>$ vulgo (Dig.26.7.23), et 1. actor, in rem ra(tam) ha(beri) (Dig.46.8.9). Dic que prima pars est vera in prelatis, ex quo sunt in pacifica possessione $\arg$ (umentum) 1 . nostrae [scil., Dig.1.14.3] et de elec(tione) c. querelam (X.1.6.24). Secunda pars esset vera in tutoribus et simplicib(us) administratoribus, de quibus etiam loquitur gl(osa) \{quae est $\mathrm{i}(\mathrm{nfra})\}$ de procura(toribus) 1. quae omnia (Dig.3.3.25) et adde quod no(tat) Di(nus de Mugello) in c. i. extra de re(gulis) iur(is) li vi. in viii q. (VI.5.13.8) ubi sentit, quod $1(\mathrm{ex})$ nostra habet locum in publicis officiis auctoritate et vtilitate: secus si vtilitate privatorum vel privatorum utilitate et auctoritate secundum Dyn(um), et officium praelatorum censetur publicum auctoritate et vtilitate, arg(umentum) s(upra) de iusti(tia) et iur(e) 1 . i 
The argument might appear a simple reiteration of something already said repeatedly, thus quite plethoric. In fact, it highlights the connection between public utility and the exercise of a public office. The emphasis on the exercise of the office - and not on the holder's entitlement to it - is a subtle way of bringing up the prelate's lawful possession of the office. It is on this basis that Baldus answers the question above. The prelate's 'unchallenged possession' (pacifica possessio) of the office, argues Baldus, allows for the enduring validity of the acts even after the prelate's deposition. This way, Baldus could say that the solution to the illegitimate prelate's case can be found not in the underlying relationship between prelate and office (i.e. proper toleration - thus internal validity of agency), but 'on the basis of our law', the lex Barbarius. ${ }^{6}$

Looking back, once again, at Baldus' three-fold division of the incapacities of those holding an office, ${ }^{7}$ the unworthy prelate would clearly fall into a different category from Barbarius' one: whereas the prelate ought to be deposed from the office that he lawfully represents, Barbarius has only coloured possession of the office. This is why Baldus stresses the element of possession without mentioning the validity of the appointment. Doing so, the unworthy prelate (the quintessential case of 'proper' toleration) would seem an application of the lex Barbarius. Thus, while seemingly solving the problem of the unworthy prelate through the lex Barbarius, Baldus in fact strengthens his interpretation of Barbarius through the case of the unworthy prelate.

To stress the point, shortly thereafter in the same repetitio Baldus looks at the closest equivalent to the false praetor in canon law: the false bishop. Let us suppose, he says, that a servant runs away from a monastery and is made bishop by the pope. Better still, he continues, let us imagine that an apostate is promoted bishop. It is difficult to think of a starker opposition between office and person. Indeed, apostate/bishop is a relationship just as conflicting as servant/praetor, and this is why Baldus finds this example so appealing. The symmetry is perfect: both are de iure ineligible, yet both sit in high offices. Just like Barbarius, so long as the apostate is mistakenly believed to be Christian, his jurisdictional acts are valid. The situation, continues Baldus, is different in the case of some other (serious but not so extraordinary) impediments. So for instance the murderer may well become a true bishop. Of course he is indignus and should be deposed; but so long as he is not, he is entitled to represent the office, and so to exercise it validly. ${ }^{\mathbf{8}}$

$\$$ publicum ius in sacris \{sacerdotibus etc.\} (Dig.1.1.1.2).' Cf. Dynus de Mugello, supra, pt. I, $\$ 4.8$, text and note 229.

6

7

8 
The unworthy prelate in the previous example was a clear case of toleration, which however Baldus described as if it were an application of Barbarius' case. The example of the bishop serves to strengthen the same argument. Just like the slave-praetor, the apostate-bishop falls outside the scope of proper toleration: his election is clearly unlawful. Nonetheless, like Barbarius, his (invalid) appointment allowed him to take possession of the office. So his acts are valid because of the public utility triggered by the common mistake. The difference between false and true bishop was suggested to Baldus by a passage of Innocent (which he openly recalls), where the pope described the outer boundaries of toleration according to whether the election was ipso iure void or not. As we have seen, Innocent distinguished different cases of indignitas. Where the indignitas was not such as to preclude ipso iure the validity of the election, the 'right of the dignitas' could 'fall on the elected'. It was the case of the (not manifest) murderer - which Innocent often recalled as a typical example of toleration. By contrast, other times the indignitas was so serious as to preclude ipso iure the validity of the election. Among those cases, the pope listed the election of a woman or a child, thus echoing Gratians' dictum Tria (C.3, q.7, p.c.1). ${ }^{9}$ What Innocent meant, however, was the reverse of Baldus' conclusion. If the dignitas could not 'fall' on the unworthy ipso iure, then the unworthy could not be tolerated in office - and so his acts would be void. In law, Baldus' false bishop is identical to the false praetor Barbarius. In both cases Baldus seeks to reach the effects of Innocent's toleration doctrine, even if neither case falls within its scope.

The case of the false bishop is also useful for a different purpose: clarifying a point that was left out of Barbarius' case. The text of the lex Barbarius did not refer only to Barbarius' judicial acts, but also to his legislative ones ('quae edixit, quae decreuit'). Of course the latter was not proper law-making (the praetor would simply issue his edict, not pass new legislation). The medieval equiparation of the praetor to a spectabilis magistrate confirmed the point, for it implicitly denied him the highest level of iurisdictio (merum imperium), encompassing the

promotio, puta ad Episcopatum? Et dic quod non sunt Episcopi; tamen vale $<\mathrm{n}>\mathrm{t}$ quae faciunt, ex quo a communi errore pro Episcopis reputantur, ut hic. Et iste casu frequenter contingere potest. Ratio autem quare non est episcopus, quia hoc ius non cadit in apostata, secus in homicida, in quo cadit $\{$ hoc $\}$ ius ipso iure, et ideo est verus Episcopus. Inn(ocentius) de conces(sione) praeben(dae) $<$ c. $>$ cum nostris (X.3.8.6), donec remoueatur. Nam remouendus est tanquam criminosus et indignus. Sed quandiu non priuatur, verus praelatus est, nec ob(stante) in(fra) de fideicom(missariis) liber(tatibus) 1 . cum vero $\mathbb{S}$ subuentum (Dig.40.5.26.7) quia ibi agitur de praeiudicio tertij \{hic non. Nam ibi de iure tertii\}, hic de iure solius concedentis, puta Papae.'

Innocent IV, ad X.3.8.6, \Possidebat (Commentaria Innocentii Quarti, cit., fols. 373vb-374ra, n. 1). 
power to enact new law. ${ }^{\mathbf{1 0}}$ So in the Accursian Gloss, Barbarius could only put forward a new statute, not enact it. ${ }^{11}$ But Barbarius' case could be applied to other situations, some of which presupposed that the occult unworthy would also exercise (proper) legislative powers - as in the case of the bishop. When Bellapertica (and then Cynus after him) also applied his reading of the lex Barbarius to the putative bishop, he referred only to the jurisdictional acts. ${ }^{\mathbf{1 2}} \mathrm{A}$ bishop, however, had both jurisdictional and legislative powers: what would happen to his decrees if he was removed from office?

The example of the bishop-apostate is particularly useful in this regard. Moving from a decretal of Boniface VIII stating that the decrees of a bishop do not apply beyond his diocese (VI.1.2.2), Baldus wonders whether the decrees of the bishop-apostate would remain valid even after he is found out and deposed from office. ${ }^{13}$ The answer, once again, comes from Innocent IV. ${ }^{\mathbf{1 4}}$ As the toleration principle entails full validity of the exercise of office, all kinds of acts issued while tolerated in office should be valid. This applies to sentences as much as decrees. Unlike a sentence, however, a decree is able to produce new effects even a long time after its enactment.

Letting such decrees produce new effects after the deposition of the unworthy would be both inequitable and in open conflict with the very rationale of the concept of toleration (given that all effects of toleration would cease with a formal deposition, and the unworthy previously tolerated would then become a simple intruder). The only solution therefore is to quash such decrees the moment the indignus is no longer tolerated in office. Innocent IV said as much only in passing, and Baldus makes sure to state expressly what Innocent had left implied - the annulment of the decree does not operate retroactively. ${ }^{15}$

Cf. supra, pt. I, $\$ 2.1$, note 25 .

Ibid., note 24.

Supra, pt. I, $\$ 4.6$, note 115 , and $\$ 4.7$, note 141 , on Bellapertica and Cynus respectively.

3 The reference to VI.1.2.2 was very suitable, as it also dealt with the problem of whether justifiable ignorance could be considered as a valid defence against the application of an episcopal decree.

4 Innocent IV, ad X.1.6.44, $\$$ Administrent (Commentaria Innocentii Quarti, cit., fol. $74 v b, \mathrm{n} .3)$ : 'ratum est quod sit ab eis quousque tolerantur, vt in $\mathrm{d}$ (icto) c. nonne (C.8, q.4, c.1), infra, de do(lo) et contu(macia) <c.> veritatis (X.2.14.8), nisi forte essent ordinationes, vel consecrationes, vel alia spiritualia, quae quod ad executionem irritae sunt ... vel nisi essent leges, vel ordinationes, quae fecisset, quae in eius opprobrium cassantur, infra de haer(eticis) $<$ c. $>$ fraternitatis (X.5.7.4).'

Baldus, repetitio ad Dig.1.14.3, cit., fol. 58rb, n. 22: 'Sed quid de his quae isti prelati putatiui ordinant per modum legis condendae, vt in c. animarum \statuto, de consti(tutionibus) li. vi (VI.1.2.2) an valeant? Breviter casus est 
In his last references to canon law issues in the repetitio, Baldus deals with a case that falls clearly within the scope of toleration, but also has important repercussions on Barbarius' case - the problem of subjective mistake. Given the central role of the office in his reading of the lex Barbarius, Baldus devotes less attention to the problem than most Ultramontani (who on the contrary invoked public utility directly to the acts of Barbarius). If a bishop is translated (i. e. transferred) to another diocese but, unaware of that, continues to exercise his old office, his acts will be valid. ${ }^{16}$ The question was simple to answer, yet it was already stretching Innocent's concept of toleration (for the bishop no longer enjoyed the superior authority's approval to exercise his previous office). Shortly thereafter Baldus looks at the opposite situation: the mistaken belief that one's status is invalid. Here Baldus gives the example of someone who mistakenly thinks he has been excommunicated. Can he sit in judgment? In effect, this case

hic, quod sic. Tamen dicit Inno(centius) quod licet processus exerciti per modum iurisdictionis inter partes non veniant cassandi, vt hic: secus in legibus, quia sunt cassandae quo ad futura damnata auctoritate, vt no(tat) Inno(centius) de elec$\mathrm{t}($ ione) $<\mathrm{c}$. $>$ nihil est (X.1.6.44). Tamen ista cassatio non trahit effetum suum retro.'

16 Ibid., fol. 58va, n. 27: 'Quid si papa transtulit Episcopum de uno Episcopatu ad alium Episcopatum, ignorans tamen primus Episcopus aliqua gessit: \{quaeritur\} an valeant? Et videtur quod sic, quia Papa non videtur executionem officij adimere ignoranti, de resti(tutione) spo(liatorum) c. audita (X.2.13.4), nisi ex eo quod sit plene translatus de iure, argu(mentum) in(fra) de off(icio) praesi(dis) 1. si forte (Dig.1.18.17), ar(gumentum) contra de manu(missis) vin(dicta) l. si pater et l. pater ex provincia (Dig.40.2.4pr and Dig.40.2.22), et ar(gumentum) i(nfra) de iud(iciis) 1. ii $\mathbb{S}$ i (Dig.5.1.2.1), $u b i$ non requiritur scientia, sed $i b i$ fauore iudiciorum. Hic autem est oppositum: alia non obstante, et ideo valet iudicium, quod fecerunt litigantes coram eo, et quia in legibus contrariis tractabatur de lucro captando: hic de damno vitando, saltem de \{euitando\} damno expensarum \{factarum $\}$ in lite: facit quod no(tatur) i(nfra) de proc(uratoribus) l. Pompo(nius) $\$$ sed et si his (sic) (Dig.3.3.40.2).' Baldus' solution on the bishop, it should be noted, depends on his ordinary jurisdiction. Writing on the case of the slavearbiter (and so, on the contrary, on a case of delegated jurisdiction), Baldus recalls Butrigarius' example of the delegates whose title was dubious but widely believed to be valid (supra, pt. I, $\$ 3.3$, note 84 ). While Butrigarius solved the problem simply invoking the common mistake, Baldus distinguishes according to whether, despite the common mistake, the delegate was aware of the invalidity of his title or not. If he was aware of it - and even if he was the only one to know of its invalidity - then his decision would be void. Baldus, ad Cod.7.45.2, $\mathbb{S} S$ arbiter (Super VII, VIII et Nono, cit., fol. 52rb-va, n. 13): 'Sed pone quod iste dele $<$ ga $>$ tus erat reuocatus tamen publice credebatur quod non esset reuocatus. Respondeo, si quidem ipse sciebat se reuocatum ipso iure non valet processus, vt nota(tur) ff. de procuratori l. si pro<curatorem $>$ absent $<$ em $>$ [cf. e. g. the Lyon edition of 1556, fol. 27rb (sed 53rb)] (Dig.3.3.65). Secus si ignorat, vt not(atur) ff. si certum petetur l. eius qui, $\mathbb{\$}$ i (Dig.12.1.41 in fine).' 
is exactly the opposite as that of Barbarius. Baldus' answer is positive: he may judge. Baldus bases his solution on the ground that the false belief is not common, but just that of a single person. ${ }^{17}$ However, he says elsewhere, even if the false belief was widespread, when the truth were to lead to the validity of the acts, it would still prevail on the common mistake. ${ }^{18}$ Ultimately, in this case, common mistake would not be supported by public utility.

\subsection{Notaries}

While Baldus deals with the issue of the notary apparent also in the lectura on the lex Barbarius, it is in the repetitio that he elaborates more on it. We may therefore start there. We have seen that earlier civil lawyers, especially the Ultramontani (and, with them, first Cynus and then also Bartolus) looked at the case of the false notary as an application of the lex Barbarius. Stressing the relationship with the false praetor, their stance on the false notary depended on whether the lex Barbarius required only public utility or also a formally valid appointment. If public utility alone sufficed to make Barbarius' acts valid, then the same solution would also apply to the false notary. ${ }^{19}$ On the other hand, those who also

Id., repetitio ad Dig.1.14.3, cit., fol. 58vb, n. 28: 'Sed quid si non est ignorantia circa factum superioris, sed circa qualitatem suae personae labitur, vt quia credit se excommunicatum cum non sit, an valeat processus? Credo quod sic, de condi(cionibus) et demon(strationibus) $<\mathrm{l}$. $>$ multum (Dig.35.1.21), quod circa impedimenta iuris inspicitur veritas, non sua opi(nio) singularis, et ar(gumentum) $\mathrm{i}(\mathrm{nfra})$ de $\mathrm{iu}(\mathrm{ris})$ et $\mathrm{fac}(\mathrm{ti})$ ign(orantia) 1 . regula $\mathbb{S}$ qui ignorauit (Dig.22.6.9.4).'

18 Id., ad Cod.7.45.2, $\$$ Si arbiter (Svper VII, VIII et Nono, cit., fol. 52rb-va, n. 6): 'Quero quid econtra si reuera erat liber sed communi opinione reputabatur seruus et erat in possessione seruitutis? Et dicunt quidam quod sententia valet. Nam aut veritas facit actum valere, et tunc inspicitur veritas; aut errror vel opinio facit rem valere, et tunc inspicitur opinio. Et ideo dico quod si quis habetur pro excommunicato et non est, tamen sententia sua valet: et contra si non habetur pro excommunicato et est similiter valet, vt not(atur) ff. de testamen(tis) l. cum lege, in fine (Dig.28.1.26), gl(osa) est multum singularis.' Cf. Gloss ad Dig.28.1.26, $\mathbb{S}$ Putant, supra, pt. I, $\$ 5.4$, note 41.

19 Baldus often remarks how the office of the notary furthers public utility. He even explains that the parallel between a notary and a public slave (i. e. a slave owned by the res publica) in the Roman sources does not mean that the notary is also a slave but rather a public servant - that is, someone at the service of the people. Baldus, ad Cod.10.71(69).3 (Arcad. et Honor. AA. Hadriano PP., a provision dealing with the appointment of tabularii, preferably to be chosen among freemen, but also among slaves with their master's approval - hence the link with Barbarius), $\$$ Generali lege (Lectura acutissimi ... domini Baldi de Perusio super tribus libris Codicis ... [Lugduni, Garnier] 1541, fol. 42rb, n. 4): 'Sed modo $\mathrm{op}$ (ponitur), quia notarius dicitur seruus publicus vt 1 . non quasi ff. rem ra(tam) 
considered the formal validity of the appointment necessary argued for the invalidity of the false notary's instruments. ${ }^{20}$

Significantly enough, Baldus opens his discussion of the notary without any reference to Barbarius: either of the above approaches would have been dangerous to his purposes. Stressing the need for a valid appointment could have implicitly highlighted Barbarius' lack of confirmation; relying on public utility alone would have contradicted the very foundations of representation. Instead, Baldus begins by distinguishing true from false notaries. In so doing he recalls Azo's teaching and especially Innocent's position: only appointment by the competent authority makes a notary. ${ }^{21}$ Only at this point does Baldus bring up the difference with Barbarius: the slave was formally elected praetor, whereas the false notary was never appointed. Barbarius' defect was in his person (an occult defect in qualitate), not in the way his title was bestowed upon him. Much to the contrary, the notary apparent received no title (not even a voidable one). This means that, unlike Barbarius, his possession of the office is unlawful. Unlawful possession, in turn, entails invalid exercise of office. ${ }^{22}$

haberi (Dig.46.6.4 sed Dig.46.6.2). Solu(tio) est liber homo tamen dicitur seruus publicus quia publice omnibus seruit et ex eorum stipulationibus omnis queritur.' Cf. Gloss ad Cod.10.71(69).3, \$ Generali - solidis (Parisiis 1566, vol. 5, col. 111): ' '.. quare ergo dicuntur serui publici? Respon(deo) quia ex eorum stipulatione quaeritur, vt ex stipulatione serui, maxime his qui non possunt stipulari ... alias a seruiendo, non a seruando dicuntur serui.'

20 Especially Cugno and Suzzara: supra, pt. I, $\$ 4.2-3$.

$21 \quad$ Supra, pt. II, $\$ 8.4$, note 59.

22 Baldus, repetitio ad Dig.1.14.3, cit., fol. 58rb, n. 18-19: 'Ponamus quod deficiat autoritas superioris, nunquid error communis sufficiat? Exemplum in eo qui diu pro notario se gessit \{cum non esset\}, an valeant instrumenta? Semper enim falsum commisit, dum se in notarium subscripsit, et videtur quod non valeant de rigore sed de equitate, ar(gumentum) 1. nostrae [scil., Dig.1.14.3] et C. de test(amentis) 1. i (Cod.6.23.1). Nam notarius est testis approbatus a iure, vt 1. hac consultissima $\$ vl(timo) (Cod.6.22.8.2). Azo dicit contrarium in auth(entica) de fide instrum(entorum) (Coll.6.3[=Nov.73]), vbi dicit nullo modo valere [cf. supra, pt. I, $\$ 2.6$, note 139]; et idem tenuit hic Guil(elmus de Cugno) per 1. actuarios, C. de nume(rariis) et actuar(iis) (Cod.12.49.7); non ob(stante) haec 1. quia hic non erat aliquis defectus, nisi in persona barbarij, qui (sic) defectus dicitur defectus materiae. Sed in questione proposita est defectus formae; immo est funditus falsitas, vt $\mathrm{i}(\mathrm{nfra}) \mathrm{de}$ fal(sis) 1. eos $₫$ qui se (Dig.48.10.27.2). Vnde suae scripturae non debet credi, $\mathrm{i}(\mathrm{nfra})$ de eden(do) 1 . si quis ex argentariis $\mathbb{S} \mathrm{i}$ (Dig.2.13.6.1) et C. de proba(tionibus) 1. iubemus (Cod.4.19.24). Tenetur tamen iste scribens partibus ad interesse, vt 1 . vlt(ima) C. de magi(stratibus) conuenien(dis) (Cod.5.75.3). Non obstat l. i C. de testam(entis) (Cod.6.23.1), quia ibi in officio testis, in quo non requiritur autoritas superioris, sed tabellio nemo est nisi qui a superiore creatur, no(tat) Innocen(tius) de fi(de) instrumentorum, c. cum P. tabellio (X.2.22.15), nec iuuat possessio, quia in ea fuit mala fide versatus: 
Arguing as much, having stressed the difference with the notary who holds a valid title, is an indirect way of bringing Barbarius' case closer to that of the true notary. This affinity is not noted on the basis of the valid appointment (Barbarius' praetorship was 'revocable') ${ }^{\mathbf{2 3}}$ but on that of the 'canonical entry' into office, and so on the way possession of the office is acquired. The approach builds on the interpretation of the unworthy prelate who should be deposed from office. There, as we have seen, Baldus insisted on the prelate's lawful possession of the office (rather than legal representation) so as to make that case look closer to that of Barbarius. In the same way, but a contrario, Baldus now stresses the lack of appointment of the false notary so as to highlight his unlawful possession, and so to mark the difference with Barbarius. The more the accent is on the lawful acquisition of the possession of the office, in other words, the closer Barbarius' case looks to proper toleration.

It may be interesting to compare the careful distinction between Barbarius and the false notary in Baldus' repetitio with the rather more superficial way he proceeds elsewhere, especially in his comment on the slave-witness in Cod.6.23.1. There, Baldus wonders whether the same positive solution (i.e. validity of the testament) should also be extended to the instruments drafted by the putative notary. At first sight, he observes, one should conclude in the affirmative - the role of the notary is precisely that of a witness, only stronger. ${ }^{24}$ After a careful and lengthy examination, however, Baldus concludes for the opposite solution. This is hardly surprising of course. What is interesting is that Baldus applies the same three-fold distinction of unlawful exercise of an office as he did when justifying Barbarius' position: ${ }^{25}$ de facto exercise of the office; exercise of office after having been deposed from it; commission of a crime that calls for the deposition from the office so far validly exercised. Only in the third case (that is, proper toleration) are the instruments valid. ${ }^{\mathbf{2 6}}$ Not commenting on

facit quod no(tant) doct(ores) <in $>$ C. de fid(e) inst(rumentorum) l. si solennibus (Cod.4.21.7).'

23 Supra, last chapter, $\$ 12.4 .1$, text and note 87.

24 Baldus, ad Cod.6.23.1, $\mathbb{S}$ Testes (svper Sexto Codicis, cit., fol. 57rb, n. 12): 'Sexto quero nunquid lex nostra habeat locum in tabellione putatiuo vt eius instrumenta inter ignorantes confecta valeant ac si esset iustus tabellio, et videtur quod sic: quia licitum est arguere de teste ad tabellionem.'

25 Supra, last chapter, note 123.

26 Baldus, ad Cod.6.23.1, $\mathbb{\$}$ Testes (svper Sexto Codicis, cit., fol. 57va, n. 12): ‘... Solu(tio) aut nunquam fuit creatus tabellio aut fuit creatus et depositus: aut fuit creatus et deponendus, non tamen depositus. Primo casu non valent sua instrumenta per leges et rationes per hac parte inductas, quia eius officium nullum est, nec habet originem veritatis. Secundo casu similiter non valent sua instrumenta, quia per depositionem perdidit auctoritatem, vt ff. de infa(mia) l. ii, $\$$ miles (Dig.3.2.6.2.3), i(nfra) de dignitate, l. iudices (Cod.12.1.12) ... Hoc est 
Barbarius, Baldus had all the interest to keep the situation of the slave-witness distinct from that of the false notary: using the first to legitimise the second could have undermined the structure of representation, and so the boundaries within which a public office could be validly discharged. ${ }^{27}$ As such, instead of embarking in subtle distinctions between simple and coloured possession, Baldus distinguishes only between possession deriving from a valid appointment and possession resulting from mere factual exercise of the office. Put in these terms, the solution is obvious: the false notary has no claim to the office, so his acts are void. ${ }^{28}$

As said, in the lectura on the lex Barbarius Baldus is more concise on the notary apparent than in the repetitio. ${ }^{29}$ The reason is that he already dealt with the issue shortly beforehand, when commenting on the lex Cassius Longinus (Dig.1.9.2). This lex is a short passage taken from Marcellus, reporting how the jurist Gaius

verum nisi eius depositio occulta sit: tunc enim de rigore acta non valent, vt notatur in aut(hentica) de testi(bus) $\$$ pe(nultimo) (Coll.7.2.9[=Nov.90.8]), quia adhuc quedam reliquie remanserunt ... Tertio casu valent instrumenta, quia licet aliquis sit ab officio deponendus, tamen antequam deponatur valent quecumque fiunt officii pretextu. Omnia enim tolerantur propter officium quod administrat donec in eum sit lata sententia depositionis: vel spoliatus sit insignibus vel notatus sit infamia vel per legem nominatim sit priuatus officio, vt $s$ (upra) de here(ticis), aut(hentica) credentes, in fi. (Auth. ad Cod.1.5.4, $\$$ Credentes) et per Inno(centium) extra de accus(ationibus) c. qualiter, in fin(e) (X.5.1.24), vbi omnino videas.' Cf. Innocent IV, ad X.5.1.24, $\$$ Et famam, supra, $\$ 7.3$, notes 23-24.

27 Incidentally, this might explain why Baldus made little use of the slave-witness case in his reading of the lex Barbarius. Cod.6.23.1 was a locus classicus among civilians in support of Barbarius' case. Opting for an indirect application of Innocent's toleration principle, however, the point became of secondary importance for Baldus.

28 Baldus, ad Cod.6.23.1, $\mathbb{S}$ Testes (svper Sexto Codicis, cit., fol. 57rb-va, n. 12): ‘... quia nunquam fuit tabellio qui exercuit officium mala fide, et ideo quasi possessio ex tali exercitio inducta nihil potest operari: quia est iniusta et clandestina quae nihil operatur in his que iuris sunt iuxta nota(tur) per Innoc(entium) in c. nihil, de elect(ione) (X.1.6.44). Item solus princeps confert tabellionatum vel habens autoritatem ab eo, non vsus priuatorum vt no(tatur) de fide instru(mentorum) c. cum P. tabellio per Inn(ocentium) (X.2.22.15). Item hoc tenet do(minus) Azo in summa aut(henticae) de instrum(entorum) cau(tela) et fide (Coll.6.3[=Nov.73]), non ob(stante) l(ege) barbarius (Dig.1.14.3) quia ibi interuenit decretum superioris.' On Innocent see supra, pt. II, $\$ 8.4$, note 59. On Azo see supra, pt. I, $\$ 2.6$, note 139.

29 Baldus, lectura ad Dig.1.14.3, cit., fol. 56ra, n. 29-30: 'Ecce quidam tanquam tabellio confecit longo tempore instrumenta. Postea apparet quod non est tabellio: quia creatus a non habente potestatem a Principe, vel a Rege. Certe ille nullus est, et instrumenta sua sunt nulla, quia non sunt facta publica persona, licet faciant aliquam praesumptionem.' See also infra, this chapter, note 49. 
Cassius Longinus denied a senator expelled from the senate for infamous behaviour the right to testify or to preside in court. ${ }^{30}$ The case was straightforward, but medieval lawyers always had a touch for complicating things. The Gloss suggested that the senator's infamous behaviour occurred in the exercise of his office: the senator was bribed. ${ }^{31}$ The reading of the Gloss made the case extremely serious - how could a high-ranking official continue to discharge his office after having patently abused it? This way, the passage became the perfect place to look at the notary, for the most obvious reason a notary would become infamis is forgery. Any public officer who committed a crime in office is to be deprived of it, ${ }^{32}$ but a condemnation for forgery would also entail infamia: the condemned, says Baldus, 'is to be considered as if he was dead'. ${ }^{33}$ This death is of course civil death - lowering the dignitas of the person to that of a slave. Hence the link with Barbarius: both are legally incapable, and both legal incapacities are occult (that is, neither notorious nor legally ascertained). Between slavepraetor and infamis notary, however, there is an important difference: the legal incapacity of the notary is a supervening one. What are its consequences? To answer the question Baldus draws a parallel with another public office whose dignitas is vastly superior to that of a simple notary, that of the count.

Medieval civil lawyers sought to equiparate Roman (or rather, early Byzantine) ranks with medieval dignities, so as to find a foothold in the sources for new titles clearly not present in Rome. The count (comes) was a step below the Roman senator: he was not illustris but spectabilis - just like the praetor. ${ }^{34}$ This makes the present case of particular interest for our purposes: Barbarius' incapacity preceded his appointment to the rank of spectabilis, whereas the incapacity of the spectabilis count is a supervening one. If a count is condemned

Dig.1.9.2 (Marc. 3 dig.): 'Cassius longinus non putat ei permittendum, qui propter turpitudinem senatu motus nec restitutus est, iudicare vel testimonium dicere, quia lex Iulia repetundarum hoc fieri vetat.'

31 Gloss ad Dig.1.9.2, $\$$ Turpitudinem (Parisiis 1566, vol. 1, col. 120).

32 Baldus, ad Cod.1.3.17, $\$$ Placet (super Primo, Secundo \& Tertio Codicis, cit., fol. $38 v b$ ): 'no(tatur) quod ille qui delinquit in officio est priuandus matricula et officio et beneficio.'

33 Baldus ad Dig.1.9.2, $\mathbb{S}$ Cassius Longinus (In Primam Digesti Veteris Partem, cit., fol. 50ra), n. 6: 'Item condemnatus de falso habetur pro mortuo C. de transa(ctionibus) 1. transigere (Cod.2.4.18) per $\mathrm{Cy}($ num), nisi sit restitutus in integrum per Papam, vel Imperatorem in de postu(lando) 1. i $\$$ de qua (Dig.3.1.1.10), extra, de re iud(icata) c. cum te (X.2.27.23), per Inno(centium).' Cf. Cynus, ad Cod.2.4.18 (Cyni Pistoriensis In Codicem, cit., fol. 64ra, n.9): 'per maculam falsitatis homo deuenit ad nihilum inter homines, quia dicitur homo postea sine fide et sine conscientia.' Cf. Innocent IV, ad X.2.27.23, \infamia (Commentaria Innocentii Quarti, cit., fol. 314rb-va, n. 2).

34 Supra, pt. I, $\$ 2$, text and note 5. 
for theft or false witness, Baldus wonders, should he lose his title even if the king does not depose him? ${ }^{35}$ The question explains the link between notary and count: in both cases the problem is whether the infamous behaviour that disqualifies someone from exercising an office should produce its full consequences from the commission of the act or from the moment it is judicially ascertained. Here as well Baldus relies on Innocent's elaboration of the toleration principle. Although there is no doubt that the count ought to be removed from his dignitas, until his deposition (thus as long as he is tolerated) he is legally able to fully represent the office. ${ }^{36}$ The same, continues Baldus, applies to the infamis tabellio. As with the infamis senator in Dig.1.9.2, the infamous notary is legally entitled to continue in the exercise of his office until formally deposed from it. This, notes Baldus, is hardly satisfactory, especially on matters that require full honourability. Nonetheless there is little alternative, all the more since some passages of the Digest explicitly say as much. ${ }^{37}$ Once again Baldus relies on Innocent, whose influence on the point is particularly evident: the reason for the above conclusion, explains Baldus, lies in the public office of the notary. Until deprived of his office, he remains its lawful representative, and so he is still entitled to exercise it. ${ }^{38}$

35 Baldus ad Dig.1.9.2, $\mathbb{S}$ Cassius Longinus (In Primam Digesti Veteris Partem, cit., fol. $49 v b$, n. 1): 'hic quaeritur, an comes condemnatus per furto vel falso in mille perdat comitatum quem habet a Rege, a quo non reperitur ammotus? Et videtur quod sic, quia comites sunt spectabiles, sed omnis infamis perdit dignitatem, ergo perdit comitatum: quia est ei annexa dignitas.'

36 Ibid., fol. 49vb, n. 1: 'His quaerit, an comes condemnatus pro furto vel falso in mille perdat comitatum ... Et per hoc facit Inno(centius) qui dicit quod in his quae ratione officij quis facit, puta si sit praelatus, tamen quod facit infamis, donec priuetur officio, de accu(sationibus) c. qualiter et quando, in $\mathrm{gl}$ (osa) mag(na) [cf. Innocent IV, ad X.5.1.24, $\$$ Et famam, in Commentaria Innocentii Quarti, cit., fol. 495vb, n. 10]. Item dicit quod irregularis et homicida remanet in sua dignitate, et praelatura, donec remoueatur ab ea, vt ipse not(at) extra de conces(sione) praeben(dae), c. cum nostris (X.3.8.6). Iste ergo est magis deponendus quam depositus, vt no(tat) ipse Inn(ocentius) de fo(ro) compe(tenti) c. postulasti (X.2.2.14).' Cf. Innocent IV's lengthy gloss Assignarunt on X.3.8.6 (Commentaria Innocentii Quarti, cit., fol. 375ra-vb, n. 1-4, esp. fol. 375rb).

37 The reference is to the bank-keeper's heir, 'humilis et deploratus', in Dig.2.13.6.1. Baldus, ad Dig.1.9.2, $\mathbb{\$}$ Cassius Longinus (In Primam Digesti Veteris Partem, cit., fol. 49vb, n. 3): 'Item testimonium est dignitas $\mathrm{i}(\mathrm{d}$ est) status illaesus absque macula. Sed infamia est macula legib(us) et morib(us) reprobata, et non debet in consortium bonorum admitti infamis, alias qua differentia esset inter bonos et malos? Certe nulla, quod est absurdum. Et hoc tamen glossa in $\mathrm{d}$ (icta) 1 . si quis ex argentariis $\$$ cogentur (Dig.2.13.6.1) in contrarium facit.' Cf. Gloss ad Dig.2.13.6.1, \$Cogentur (Parisiis 1566, vol. 1, col. 247).

38 Baldus, ad Dig.1.9.2, \$Cassius Longinus (In Primam Digesti Veteris Partem, cit., fol. $49 v b$, n. 3): 'nam donec priuatur priuilegio tabellionatus, tabellio est. Et sic 
Baldus reaches the same conclusion also in the repetitio on the lex Barbarius. ${ }^{39}$ There, he also makes sure to apply the same reasoning for the period between the commencement of the legal proceedings and the eventual condemnation of the notary - the notary may therefore draft new instruments even during his trial for forgery. This conclusion has little to do with presumption of innocence. ${ }^{40}$ It simply derives from the fact that the representation mechanism ceases only with deposition, and condemnation does not retroact to the joining of the issue. ${ }^{\mathbf{4 1}}$

videtur quod facit ratione publici officii, hinc est quod infamia ordinario non potest opponi, vt no(tat) Inn(ocentius) de resc(riptis) c. sciscitatus (X.1.3.13) [cf.

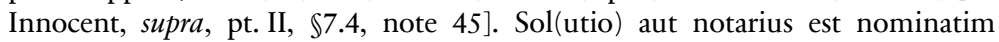
priuatus officio et tunc aut per hominem in loco publico et consueto, et deinceps sua instrumenta non valent: sed iam facta non perdunt robur i(nfra) de eden(do) 1. praetor $\$ his esset desiit (Dig.2.13.4.4). Aut [privatus officio] per l(egem), et tunc valent, donec sit declaratum, vt in Auth(entica) de tabel(lionibus) $\mathbb{S}$ pe (nultimo) in $\mathrm{gl}(\mathrm{osa})$ ord(inaria) [cf. Gloss ad Coll.4.7.1(=Nov.44.1\$4), $\$ D o c u$ mentis, Parisiis 1566, vol. 5, col. 225]. Aut notarius non est expresse prohibitus ab officio et tunc aut est infamia ex delicto commisso extra officium; et retinet officium, donec priuetur. Priuari nam debet et potest, ex quo est infamis, sed si non priuatur, videtur quod facit, quia facit legis auctoritate. Et lex potius quam persona ponderanda est.'

39 Baldus, repetitio ad Dig.1.14.3, cit., fol. 57ra, n. 6: '... In tabellione autem certum est quod instrumentum suum non vitiatur: licet postea efficiatur infamis ... Item non vitiatur instrumentum si eius infamia vel priuatio prius velata et occulta postea detegatur, vt in aut(hentica) de tabel(lionibus) $\mathbb{\$}$ vlti(mo) (Coll.4.7.2 [=Nov.44.2]), in gloss(a) que incipit "hoc est $\arg ($ umentum)" quod est multum nota(ndum).' Cf. supra, pt. I, $\$ 2.6$, note 132 .

40 The point is too complex to be dealt with here, but it is important to note that the increasingly frequent description of the defendant's rights in natural law terms did not imply a fully-fledged legal presumption that the same defendant was innocent until proven otherwise. As recently argued, 'the modern use of the phrase "presumption of innocence" would have been, to a medieval jurist, a violent presumption of innocence, because it refers to an assumption that stands unless it is disproven', Vitiello (2016), p. 98 (emphasis in the text). Cp. Pennington (2003), pp. 112-119, and Pennington (2016), pp. 141-152.

41 Baldus, repetitio ad Dig.1.14.3, cit., fol. 58va, n. 25-27. It is worth reporting the passage in full: not only is it quite important, but it also provides a good example of the differences in the text of the repetitio as found in the standard printed editions of Baldus and Bartolus. 'Sed quid si notarius non est adhuc damnatus de falso, sed pendet processus, an interim possit instrumenta conficere? Et videtur quod non, ut C. de procu(ratoribus) 1. reum criminis (Cod.2.12.6), $\arg$ (umentum) de excu(sationibus) tu(torum) l. diximus (Inst.1.10.12), quia idem operatur processus pendens, quod sententia, de excep(tionibus) 1 . fundum et 1 . fundi (Dig.44.1.16 and 18), ad idem facit de li(berali) causa $<1 .>$ qui de libertate (Dig.40.12.29), de solu(tionibus) l. quod si forte $\mathbb{~ i ~ ( D i g . 4 6 . 3 . 1 4 . 1 ) , ~ d e ~ a d m i ( n i s - ~}$ tratione) tu(torum) 1. chirograph(is) $\mathbb{S}$ pe(nultimo) (Dig.26.7.57.1). Econtra videtur quod pendentia processus operatur idem quod sententia absolutoria, 
Supervening occult incapacities do not fully separate agent from office: the count retains his lordship and the notary his office until the incapacity is legally ascertained. This of course means that, after being deposed from office, the exnotary cannot produce any valid instrument. But what about the instruments already made? Baldus touches on the point in the lectura, arguing (as one would expect) that the deposition of a judge or a notary from office should not affect acts already issued - just, he adds, as the acts carried out by Barbarius while his servile condition was unknown should not be affected by his eventual removal from office. ${ }^{42}$

quia dubium et certum parib(us) passibus ambulant pro reo, sed non operatur idem condemnatoria, unde ex quo interim est in possessione officii videtur quod possit officium exercere nisi expresse interdicatur, vt 1 . moris, de poenis (Dig.48.19.9) et 1 . chirographis, $\mathbb{S}$ vlti(mo) (Dig.26.7.57.1), ad idem facit quod not(atur) i(nfra) de infami(a) l. furti $\$ \mathrm{i}$ (Dig.3.2.6.1), nam et miles antequam sit exauctoratus, pro milite est tractandus, facit quod no(tatur) i(nfra) de infa(mia) 1 .

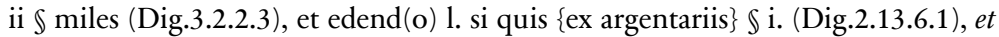
$i b i$ per Odo(fredum) [Cf. Odofredus, ad Dig.2.13.6.1, $\$$ coguntur et successores, In undecim primos pandectarum libros, cit., fol. 68rb-va]. Credo quod haec pars sit verior, quia licet interim ad nouum honorem aspirare non possit: tamen executio officii prioris non denegatur, quia est in quasi possessione, cuius vsus quod interim sibi competit iure proprio, nam etiam interim notarius est. Non $\mathrm{ob}$ (stante) C. de suspe(ctis) tu(toris) 1. eum \{quem\} (Cod.5.43.7), quia officium tutele est gratia alterius tantum introductum, et non interest tutoris: secus in officio tabellionis. Nam honor est sibi credi, et sua interest officium publicum autoritate et utilitate priuatus. Et facit, quia in dubio constitutus potest licite possidere, et vti possessione, de oper(is) no(ui) nun(tiatione) l. si prius \{cum si\} (Dig.39.1.15), et sic interim non auferunt sibi bona, et ita non debet $\{$ ei $\}$ auferri officium, nec status, argu(mentum) de sta(tu) hom(inum) 1. qui furere (Dig.1.5.20); nec etiam fama, C. de infa(mis) 1. nullam (Cod.2.11.14). Honestius tamen facit, si interim abstinet a nouis instrumentis, imo videt quod sit omnino prohibitus, sicut ferre testimonium, vt $\mathrm{i}(\mathrm{nfra})$ de testi(bus) 1 . iii $\$$ lex Iulia (Dig.22.5.3.5), et $\{$ l. testimonium\} 1. ii (Dig.22.5.2) et not(andum) in l. i de reis postu(latis) libro xi (sed Cod.10.60(58).1). Nisi dicas aliud in teste simplici, aliud in tabellione. Nam infamis non potest esse testis: tamen potest exercere tabellionatum, nisi in officio delinquerit et sit ammotus ab eo. Item dictum tabellionis est magis autenticum, quam dictum testis, vt no(tandum) insti. de

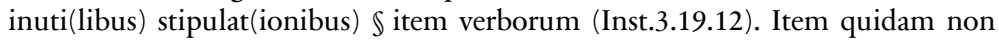
possunt esse testes in iudicio, sed in contractibus sic C. de haereticis, l. quoniam (Cod.1.5.21 pr), non credo fidem totaliter annihilari, sed diminui, si postea culpabilis esse iudicetur.'

42 Id., lectura ad Dig.1.14.3, cit., fol. 56va, n. 36: 'Item scias quod licet iudex, vel notarius sint depositi, tamen gesta non repelluntur, nam innuit quod Barbarius quamdiu latuit [cf. Dig.1.14.3: 'si servus quamdiu latuit ...'] eius qualitas, stetit in praetura, quasi tacite dicat, fuit postea remotus, vel detectus nullus secundum varios intellectus, tamen actus retro exerciti sunt efficaces, facit quod no(tatur) in(fra) de infa(mia) l. furti, $\mathbb{S}$ i per glo(sam) [cf. Gloss ad Dig.3.2.6.2, $\mathbb{S}$ Si ab initio, 
Formulated this way, the question of the validity of the previous acts of the notary was remarkably easy to answer. Indeed, Baldus' answer in the lectura is the same as that provided in the Gloss on the Authentica 'On the notaries' (De Tabellionibus), ${ }^{\mathbf{4 3}}$ which was widely accepted on this point. ${ }^{\mathbf{4 4}}$ Baldus' answer was almost obvious - but not so his parallel with Barbarius. The difference between the two cases was self-evident. The regularly appointed notary was no longer tolerated in office, the false praetor was removed from an office he never had $d e$ iure. Stressing the enduring validity of the acts made before their deposition, however, Baldus implicitly blurs the difference between the two cases. The impression, once again, is that the parallel with Barbarius served more to strengthen the false praetor's acts than the instruments of the true notary, who was fully entitled to his office.

Coming back to the subject in the repetitio, Baldus poses a subtler question: could an instrument made by the notary before his deposition be published and receive execution thereafter? The question is not merely whether the previous acts should be retrospectively invalidated (that would be a rhetorical question), but whether they could produce new effects after their source was deprived of validity. In this light, in effect the question becomes very similar to that on the validity of the decrees of the apostate made bishop, and it is not fortuitous that the two questions are found very close to each other in the repetitio. ${ }^{45}$ Their similarity leads to the same answer (once again based on Innocent): deposition from office does not operate retrospectively. But the difference between the kinds of acts - notarial instruments and statutes - entails a different position as to their validity in the future (that is, from the moment of the deposition of the person who issued them). In the case of the statute, the choice was only between letting an act produce its full effects sine die or depriving it of any legal strength from the moment of deposition of the authority that issued it. As such, there was little choice but to quash it. Giving execution to an instrument made before the removal from office of the person who made it, however, is a different matter. The difference lies in that the parties are entitled to rely on its validity, since it was made when the notary was still tolerated in office. Denying that validity would amount to voiding retrospectively the instrument itself. ${ }^{46}$

Parisiis 1566, vol. 1, cols. 345-346] et in(fra) de ope(ris) lib(ertorum) 1. hoc demum (Dig.38.1.38pr), et extra, ne cler(ici) vel mo(naci) c. sicut (X.3.50.8).'

43 Cf. supra, pt. I, $\$ 2.6$, note 132.

44 Often through the (somewhat clearer) reading of Jacobus de Belviso, supra, pt. I, $\$ 2.6$, text and note 136 .

45 Supra, last paragraph, note 15.

46 Baldus, repetitio ad Dig.1.14.3, cit., fol. 58va, n. 24: 'quid de notario ab officio priuato, an vetera instrumenta perficere, et publicare poterit? Et videtur quod non, quia deficit in fide. In contrarium videtur quia fides illa in praeteritum 
A last problem on the validity of the notary's instruments in Baldus' lectura on the lex Barbarius concerns his secret deposition. If the notary is already secretly condemned for forgery, asks Baldus, are the acts he issues thereafter valid? When commenting on the lex Cassius Longinus, as we have seen, Baldus drew a clear line between validity of instruments drafted before the condemnation and invalidity of instruments made thereafter. In that case, however, the notary's deposition was a formal one, publicly known because judicially ascertained. Does the same apply also to secret condemnation? The question is in effect very similar to that of the excommunicated judge (which Baldus discusses in the repetitio). ${ }^{47}$ In that case, however, the purpose was mainly to draw a parallel with Barbarius. In the present case, avoiding (yet another) comparison with Barbarius, Baldus could afford to be somewhat more precise. The issue is but a secular adaptation of the canon law problem about the jurisdiction of the excommunicate, and the solution similarly depends on the division between public and occult excommunication. Public excommunication, says Baldus, would surely entail removal from office - just as it would preclude the validity of the appointment itself. ${ }^{48}$ But (and here the influence of Innocent is obvious) full separation of the agent from the office occurs only when the agent's incapacity is legally ascertained or otherwise notorious. Occult heresy and excommunication, says Baldus, produce the same effects as a secret condemnation for forgery. In

aestimatur, et ista pars est vera, quia alii non debet nocere sententia lata contra notarium, de infa(mia) l. Lucius in fi. [Dig.3.2.21 (Paul. 2 resp.): ' $\ldots$ cum non oportet ex sententia sive iusta sive iniusta pro alio habita alium praegravari'] et facit quod notat Inn(ocentius) de haeretici c. fraternitatis (X.5.7.4) [Cf. supra, pt. II, $\$ 7.5$, note 98$]$. Ex quo sententia amotionis sortitur suum effectum, ex tunc non valent scripturae postea inchoate, sed retro vetera consumare potest, quia sententia non mutat vim retro, argu(mentum) vt causae post pu(bertatem) adsit tut(or) 1. i (Cod.5.48.1.1).' Cf. Id., ad Cod.7.45.2, $\$$ Si arbiter (svper VII, VIII et Nono Codicis, cit., fol. 52va, n. 15): 'Et idem dico in notario qui post compilationem instrumentorum monachus est effectus vel alias officium perdidit, non suo vitio sed alio defectu vel etiam sua culpa. Nam vetera instrumenta perficere potest: sed noua inchoare non potest.' Cf. Id., ad Cod.6.23.1, $\mathbb{\$}$ Testes (super Sexto Codicis, cit., fol. $57 \mathrm{rb}$, n. 10): 'Quarto quero nunquid communis opinio habeatur pro veritate? Et dic quod aut de contraria veritate est dubium aut est certum. Primo casu aut actus pendet ex veritate et inspicitur veritas, aut pendet ex opinione et tunc inspicitur opinio. ... Secundo casu refert, aut loquimur quo ad actum gerendi in posterum et inspicitur veritas iam detecta, aut quo ad actum exercitii in preteritum, et tunc refert aut equitas fauet opinioni et inspicitur opinio vt ff. de offi(cio) preto(rum) 1. barbarius (Dig.1.14.3), aut fauet veritati et inspicitur veritatisff. quando actio de pecu(lio) est annalis 1 . quesitum (Dig.15.2.1.10).'

47 Supra, last paragraph, note 2.

48 Baldus, lectura ad Dig.1.14.3, cit., fol. 56ra, n. 30: 'Sed pone quod bene fuit creatus tabellio, tamen tunc erat excommunicatus; ergo non valuit creatio.' 
both cases the notary may continue to discharge his office validly until the condemnation is made public or becomes otherwise notorious. ${ }^{49}$ This time, it will be noted, Baldus speaks only of de iure entitlement to the office and not of lawful possession. It seems significant that, in so doing, he avoids any mention of Barbarius.

Civil lawyers and canon lawyers alike both relied on the lex Barbarius to reach a positive solution for the validity of the instruments drafted by the occult inhabilis notary. At first sight, Baldus' approach might appear similar, whereas in fact it moves from the opposite direction: it is Barbarius' case that needs the support of the notary - as well as that of the judge and of the prelate. For they are proper cases of toleration, that of Barbarius is not. Baldus' skilful approach, however, would lead later jurists to highlight the continuity between those figures and to overlook the subtle underlying distinction.

It may be interesting to conclude this chapter with some remarks on Baldus' treatise On the Notaries (Tractatus de Tabellionis), ${ }^{50}$ which is effectively a compendium of Innocent's thinking.

Ibid.: 'vel pone in haeretico, qui longo tempore confecit instrumenta inter ignorantes, certe valent instrumenta tanquam publica, ut hic, si erat excommunicatus, vel haereticus occultus; secus si manifestus. Sed pone, sicut de facto vidi, quod erat tabellio: tamen Episcopus eum condemnauit de falso secrete in camera sua, et ipse postea inter ignorantes confecit instrumenta, quaeritur an valeant? Et videtur quod non, cum sit degradatus, ut dixi in 1. Cassius [Dig.1.9.2: cf. supra, this paragraph, note 38]. In contrarium videtur, quia non desinit omnino esse tabellio, ut l. si pluribus de aucto(ritate) tut(orum) (Dig.26.8.4). Item sententia legis qua non declaratur ab homine, non priuat ab exercitio, vt no(tatur) in Auth. de tabel(lionibus) $\mathbb{S}$ pe(nultimo) (Coll.4.7.1[=Nov.44.1\$4]).' Baldus develops the point further when commenting on the arbiter-slave. Baldus, ad Cod.7.45.2, $\mathbb{S} S i$ arbiter (super VII, VIII et Nono Codicis, cit., fol. 52va, n. 14): 'Quid dices de questione facti? Episcopus in camera et in secreto damnat quaedam notarium de falso, populum hoc ignorans confluebat ad eum instrumenta facientem sicut per prorsus: nunquid valent instrumenta per errorem iustum et propter primordium veritatis, quod sumit naturam a primeua origine veritatis; et si quidem degradatus a lege propter delictum occultum, et valent instrumenta ex quo crimen est occultum, ista est glo(sa) singula in aut(hentica) de ta(bellionibus) $\$$ penul(timo) (Coll.4.7.1[=Nov.44.1\$4]), que incipit "hic est argumen(tum)", ver(siculum) "item not(andum)" [cf. supra, pt. I, $\$ 2.6$, note 132]. ... Publice enim debet fieri sententia non in secreto loco tex(tum) est i(nfra) eo (titulo) 1. cum sententiam presidis (Cod.7.45.6).'

50 The treatise was attributed to other jurists, Bartolus included. In fact, it was among the earliest works of Baldus, pre-dating of several years the repetitio on the 
When Bartolus sought to apply Bellapertica's ideas to the notary apparent, he insisted that his appointment was not the exclusive prerogative of the prince. ${ }^{51}$ Stressing the need of certain formal requirements for the validity of the notary's appointment would highlight the negative consequences of their absence. The more the notary had to be created such, in other words, the more the putative notary would be seen as an impostor. The point was made explicitly by Suzzara and Cugno to exclude the false notary from the scope of the lex Barbarius, ${ }^{52}$ and it was probably for the same reason that Ravanis omitted the notary's case from his lengthy lectura: behind Barbarius was the 'power of the appointer' (potentia committentis); behind the false notary was only the common mistake.

Baldus' position is remarkably close to that of Innocent, almost a summary of it. In principle, says Baldus, only the prince may appoint a notary; ${ }^{53}$ lower authorities might do as much only with the permission (even just tacit) of the prince. ${ }^{54}$ The long exercise of the office and the common opinion as to the

lex Barbarius, and possibly also the lectura on it. Cf. Valentini (1965-1966), pp. 46-53, text and notes (esp. notes 39 and 41). See also Colli (2005), p. 47, note 58 , where further literature is listed.

$51 \quad$ Supra, pt. I, $\$ 5.2$, note 21.

52 Supra, pt. I, $\$ 4.6$, note 154 , and $\$ 4.7$, note 203 respectively.

53 Baldus, Tractatus de tabellionibus (Valentini [ed., 1965-1966], p. 85, 11.40-44, and pp. 86-87, 11.3-6 respectively): 'primo quero quis possit creare tabelliones et ei concedere auctoritatem condendi instrumenta; et uidetur quod nemo nisi princeps, quia per tabellionem alteri acquiritur, ut 1 . non aliter enim ff. de adoptionibus (Dig.1.7.18), ergo oportet quod habilitetur a principe, sicut dicitur de illo qui habilitatur ad postulandum ... Idem tenet Ynocentius in capitulo ultimo, in prima glosa, Extra, De fide instrumentorum (nunc X.2.22.15), ubi dicit quod nemo subditus pape vel imperatori potest creare tabelliones, sed ipsi soli

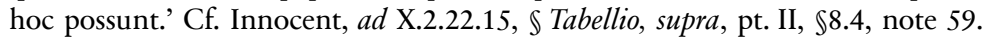

54 Baldus, Tractatus de tabellionibus (Valentini [ed., 1965-1966], pp. 94-95, 11.4-6): 'Secundo quero nunquid consuetudo possit inducere quod inferior a principe possit creare tabelliones. Respondeo: Ynnocentius in dicto capitulo finali, Extra, de fide instrumentorum (nunc X.2.22.15), tenet quod sic et est ratio, secundum eum, quia ad hoc ut valeat consuetudo, requiritur consensus superioris, scilicet principis, tacitus uel expressus, ut ipse notat, Extra, de consuetudine, super rubrica (X.1.4).' Cf. Innocent IV, ad X.1.4, De consuetudine (Commentaria Innocentii Quarti, cit., fol. 31va, n. 4). There, the pope referred to a custom contrary to the law, or at least able to adversely affect its application. Because of that, Innocent required full knowledge (certa scientia) of the superior authority as to the applicability of such a custom: 'Item oportet quod sit inducta de scientia eius, qui super eos, vbi inducitur habet ordinariam iurisdictionem et potestatem condendi leges ... et non sufficit toleratio.' Cf. also ibid., fol. 32ra, n. 10. The custom allowing lower authorities to appoint notaries is ultimately an application of the same principle - hence the need of 'consensus superioris': supra, pt. II, $\$ 8.4$, note 59 . 
legitimate status of the notary, therefore, served only as a - rebuttable presumption as to his valid appointment. ${ }^{55}$ The legal strength of the notarial deeds drafted by him depends on the exercise of a specific public office, but that office cannot be validly exercised without prior lawful appointment. Once the agency relationship is validly established, however, the supervening legal incapacity in the person of the agent precludes the continuation of the representation mechanism only if the incapacity is notorious. So a publicly excommunicated notary may not validly draft any instrument, because he may no longer act in the name of the office. ${ }^{56}$

55 Baldus, Tractatus de tabellionibus (Valentini [ed., 1965-1966], pp. 100-101, 11.38-42): 'Tertio quero quid si ille, qui confecit instrumentum, negatur fuisse notarius, qualiter probabitur eum notarium fuisse. Ynocentius in c. i, Extra, De fide instrumentorum, primum post principium, dicit quod debet probari privilegium seu auctoritas per testes vel per publicum instrumentum. Sufficit tamen, secundum eum, si probetur per testes quod publice officio notarii fungebatur, quod multa instrumenta confecerit de aliis legitimis contractibus, firmis manentibus.' Cf. Innocent, ad X.2.22.1, $\$$ Si scripturam, supra, pt. II, $\mathbb{\$} 7.5$, note 74 .

This passage in Baldus' treatise should be read together with his comment on both the slave-witness and especially the slave-arbiter. Baldus, ad Cod.6.23.1, $\$$ Testes (svper Sexto Codicis, cit., fol. 57ra, n. 3): 'quando veritas et fama discordant magis attenditur fama ratione publici instrumenti quam veritas. Item potest esse quod de testamento apparet notoria scriptura manu testatoris vnde aduersarius non potest eam inficiari, et ideo non negat veritatem sed solemnitatem: supposita ergo veritate hec lex determinat quod testamentum sit solemne, et sic heres institutus in eo succedit. Si autem aduersarius negaret veritatem, tunc ipsa veritas per seruos non posset in iudicio probari: quia non videtur esse testis ille qui de iure non est testis ...' Id., ad Cod.7.45.2, \$Si arbiter (svper VII, VIII et Nono Codicis, cit., fol. 52rb, n. 11): 'Quero quid si aliquis reputatur tabellio cum non appareat quod fuerit constitutus tabellio. Respondeo si quidem aliqua sunt indicia vt quia est in matricula tabellionum sua instrumenta valent ex presumptione matricule: quia matricula inducit presumptionem et incorporationem et inuestituram ... Si autem non sunt alias indicia et fuit in longa possessione, id est longo exercitio, valent sua instrumenta.' This however - just as in Innocent remains a rebuttable presumption. So, concludes Baldus (ibid.), 'officium tabellionis non potest acquiri per rerum naturam sed sola auctoritate principis vt eleganter notat Inno(centium) de fide instrumentorum c. cum P. tabellio (X.2.22.15).' Cf. Innocent IV, ad X.2.22.15, $\mathbb{\$}$ Tabellio, supra, pt. II, $\$ 8.4$, note 59. Baldus, Tractatus de tabellionibus (Valentini [ed., 1965-1966], pp. 134-135, 11.16-19): 'Decimoseptimo quero nunquid tabellio excommunicatus possit conficere publica instrumenta. Bar(tolus) in l. Eadem in fine ff. ad legem Juliam repetundarum (Dig.48.11.6), dubitat de hoc; sed dicendum est quod non, ut est casus in titulo De statutis et consuetudinibus contra libertatem Ecclesie, $\$$ Credentes, coll. X (Const. Friderici II Imp., tit. unicus, $\$$ Credentes), et in Auth. Credentes, C. De hereticis (Auth. Credentes, ad Cod.1.5.4) et Extra, eodem titulo, C. Excommunicamus, $\mathbb{S}$ Credentes (X.5.7.13.5).' More than uncertain ('Bartolus ... dubitat de hoc'), as reported by Baldus, Bartolus simply ducked the 
It may be recalled that Bartolus highlighted the task of the tabellio (writing documents for others) so as to blur the difference between public scrivener and public notary. This way he could conclude that the formal appointment was not always necessary to make a notary, and so apply Bellapertica's reading of the lex Barbarius also to the notary apparent. ${ }^{57}$ That conclusion, however, is precisely what Baldus seeks to avoid - hence his open criticism of Bartolus. What Bartolus suggested, remarks Baldus, would mean that the office of the notary is not a dignitas. ${ }^{58}$ The difference is important, for representation applies only to public offices. And Baldus is very clear that the notary exercises a public office: not just a public task, but a dignitas. ${ }^{59}$ This is precisely the reason his instruments are deemed authentic. ${ }^{\mathbf{6 0}}$

issue telling his reader to 'ask the canonists' on the matter: Bartolus, ad Dig.48.11.6, supra, pt. I, $\$ 5.4$, note 61 .

$57 \quad$ Supra, pt. I, $\$ 5.3$, note 32 .

58 Baldus, Tractatus de tabellionibus (Valentini [ed., 1965-1966], pp. 136-140, 11.27-42) Bartolus in 1. Eadem, $\mathbb{~ i , ~ s u p r a ~ a l l e g a t o ~ ( D i g . 4 8 . 1 1 . 6 ) ~ t e n e t ~ c o n t r a r i u m , ~}$ videlicet, quod tabellio infamis conficere possit instrumenta; movetur ratione: quia officium tabellionatus non est dignitas, sed est munus, ut notat glosa in lege finali, in principio, C. Qui militare non possunt, libro XII. Cf. Gloss ad Cod.12.33(34).7pr, $\$$ Si quis-Dominio servi, Parisiis 1566, vol. 5, col. 276. See also Baldus, ad Dig.3.2.2.3, $\$$ Miles qui (svper Primo, Secundo \& Tertio Codicis, cit., fol. 172rb, n. 3).

59 Baldus, Tractatus de tabellionibus (Valentini [ed., 1965-1966], p. 140, 1.50, and pp. 140-141, 1l.1-3 respectively): 'quod sit officium publicum tenet Ynocentius in c. i, Extra, De fide instrumentorum [infra, next note]. Quod autem non sit munus publicum, patet evidenter ex diffinicione: dicitur enim munus publicum, "quod in administranda re publica cum sumptu sine titulo dignitatis subimus", hec diffinicio, seu descripcio, habetur ad litteram in 1 . Honor, $\mathbb{S}$ Munus, ff. De muneribus et honoribus (Dig.50.4.10).' Cf. Dig.50.4.10 (Mod. 5 different.): 'Honorem sustinenti munus imponi non potest: munus sustinenti honor deferri potest.'

60 Baldus, Tractatus de tabellionibus (Valentini [ed., 1965-1966], pp. 104-105, 11.7-9): 'Quinto quero quale sit officium tabellionis. Respondeo, secundum Ynocentium in c. I. Extra, De fide instrumentorum (X.2.22.1), quod eius officium est publicum et commune, et ideo creditur eius scripture, tamquam publice, sine alio adminiculo.' Cf. Innocent IV, ad X.2.22.1, $\mathbb{\text { Authenticam }}$ (Commentaria Innocentii Quarti, cit., fol. 273va, n. 2): 'Item publicam scripturam appello generaliter omnem scripturam, cui creditur sine alio adminiculo de iure, vel consuetudine speciali infr(a) eodem [titulo], cum dilectus (X.2.22.9) si autem esse specialis consuetudo praeter scripturas tabellionum, et acta iudiciorum, omnes scripturas reputo priuatas, cum ad hoc officium non specialiter sint deputatae personae, per quas factae sunt. Et appello publicam scripturam quae sine adminiculo viuae vocis alicuius notarij, qui forte mortuus est, vel testium qui similiter mortui sunt authoritatem habet, in Authentic. de fide instrumen-

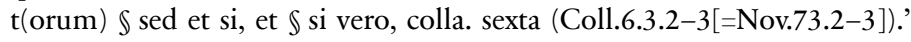


Looking at Baldus' writings on the lex Barbarius, we have more than once noted how his knowledge of Cugno's lectura on the same lex remains unclear. In his treatise on the notaries, however, Baldus shows in-depth knowledge of it. And he uses that knowledge to further disprove Bartolus' conclusion on the possibility of extending the lex Barbarius also to the false notary widely reputed as such. Bartolus referred to Cugno - to dismiss his opinion - at a crucial juncture of his analysis: having just approved of the Gloss, and before seeking to extend the validity of the acts also to cases that would fall outside the scope of the Gloss. To do so, he rejected Cugno's argument (on the need for a formal appointment) in a rather perfunctory manner, twisting Cugno's own words. ${ }^{61}$ That does not escape Baldus, who on the contrary explains Cugno's position well and, in so doing, implicitly criticises Bartolus' reconstruction. ${ }^{62}$

To conclude these short remarks on Baldus' treatise On the Notaries, it may be interesting to recall the dispute between the town of Pirano and the local bishop that we saw at the beginning of this work. When the bishop sought to deny the validity of the town's privileges by questioning the appointment of the notary who drafted the town's mandate to the counsel, the counsel insisted on the common opinion as to the validity of the notary's appointment. ${ }^{63}$ In his treatise, Baldus gives his reader some advice as to what to do if confronted with a similar case. A 'careful lawyer', he says, should do anything in his power to remark the

Supra, pt. I, $\$ 5.2$, note 21 .

62 Baldus, Tractatus de tabellionibus (Valentini [ed., 1965-1966], pp. 143-145, 11.9-22): 'Vigesimo quero: tabellio excommunicatus vel infamis, non obstante excommunicacione vel infamia, diu stetit in possessione tabellionatus et bone fame, numquid valeant instrumenta per eum scripta? Bartolus videtur in hoc sibi contrarius in 1. Eadem lege, $\mathbb{\$}$ i supra allegato (Dig.48.11.6), et tenet indubitanter pro sic per 1. Barbarius ff. De officio pretorum (Dig.1.14.3) et per 1. ii C. De sententiis (Cod.7.45.2). Guilelmus de Cunio, quem sequitur idem Bartolus, in dicta 1. Barbarius tenet contrarium, videlicet quod licet diu fuerit in possessione tabellionatus, tamen non valent eius instrumenta, et ista secunda opynio est vera, pro qua est casus in 1. Generali, C. De tabulariis, libro X (Cod.10.(69).3). Nec obstat 1 . Barbarius, quia ibi erat peccatum in materia tantum; nam ibi intervenerat communis error et auctoritas eius, qui hanc poterat dare jurisdictionem, nisi fuisset aliud impedimentum in persona Barbarii, qui erat servus; sed in questione nostra fuit peccatum in forma et in materia: nam hic non intervenit error et auctoritas eius, qui posset creare tabelliones, et peccatum forme est majus quam peccatum in materia et magis tolleratur peccatum in materia tantum, ut 1. i $\$ Eum qui, ff. De constituta pecunia (Dig.13.5.1.4) et 1 . An inutilis, in principio, ff. De acceptilatione (Dig.46.4.8). Item non obstat 1. ii, C. De sententiis (Cod.7.45.2), quia loquitur in liberto, qui poterat esse judex tempore quo judicavit licet postea fuerit revocatus in servitudinem ex causa ingratitudinis vel alia.' Cf. ibid., pp. 101-103, 11.42-48. Supra, pt. I, $\$ 2.6$, text and note 124 . 
common opinion as to the validity of the notary's appointment. He should say that the notary was a true one and that he was widely reputed as such, that he was in possession of his office and that he had no legal incapacity preventing him from discharging it. ${ }^{64}$ The similarity is remarkable. There is only one difference: unlike the counsel for the town, Baldus does not quote the lex Barbarius. Throughout his lengthy treatise $O n$ the Notaries Baldus studiously avoids referring to Barbarius' case, despite dealing in detail with heretical, excommunicated and infames notaries. After all that we have seen, the point seems far from irrelevant. The validity (or invalidity) of the notary's instruments is a direct application of Innocent's toleration theory - the validity of Barbarius' acts is not. In this treatise Baldus refers to the lex Barbarius only when mentioned by other jurists whom he quotes (and even there, mostly to disagree with them). ${ }^{65}$ Stressing the importance of the common opinion as to the appointment and the possession of the office, Baldus just follows Innocent: both elements were evidence of the underlying valid appointment of the notary, not a way of making up for its absence. ${ }^{66}$

64 Baldus, Tractatus de tabellionibus (Valentini [ed., 1965-1966], p. 103, 11.48-50 and 1.1): 'Et ideo quando contra instrumentum opponitur quod ille, qui scripsit illud, non erat tabellio, cautus advocatus debet articulari facere, quod tempore confectionis dicti instrumenti, ille qui scripsit erat tabellio, et in quasi possessione officii tabellionatus, et quod pro tabellione habebatur et reputabatur ab omnibus cognoscentibus eum, et quod erat liber homo et talis conditionis, quod non prohibebatur esse tabellio.'

65 Baldus, Tractatus de tabellionibus, supra, this paragraph, note 62, and in Valentini [ed., 1965-1966], pp. 101-103, 11.42-48. Supra, pt. II, $\$ 7.5$, text and notes $73-74$. 


\section{Part IV}

Barbarius post Baldum 


\section{Chapter 14}

\section{From the lex Barbarius to the brocard error communis ius facit}

\subsection{Late commentators and early simplifications}

On the lex Barbarius very little happens after Baldus, with the exception of one important thing: the progressive simplification of his approach. This simplification would progressively detach Barbarius' case from the underlying issue of valid representation - and so, from the toleration principle. To some extent, the modern interpretation of the lex Barbarius, and so the de facto officer doctrine in civil law, is not the result of a progressive development but of a crystallisation of medieval ideas in the brocard communis error facit ius. More than progression, in effect regression. ${ }^{1}$

\subsubsection{Angelus de Ubaldis}

Although the commentary of Angelus de Ubaldis (1327/8-1407) on the lex Barbarius is based on Innocent $\mathrm{IV}^{\mathbf{2}}$ his interpretation of the pope is somewhat creative. While Baldus studiously circumvented the main obstacle to the application of Innocent's toleration doctrine (confirmation by the superior authority), Angelus would appear to ignore it.

The first part of Angelus' lectura on the lex Barbarius reports faithfully what Innocent said on the toleration of the unworthy, both in general terms and

1 The short remarks in next few pages will not allow in-depth discussions on specific points. One of them is the lex Iulia de ambitu. The question of whether Barbarius did violate the lex Iulia de ambitu continued to occupy a central position in the scholarly debate for a long time. Just to give a later example, the seventeenth-century Brussels edition of Bugnyon's treatise on abrogated laws (edited by Libert François Christyn) has a long addition on the question of the sale of offices. This addition is based largely on medieval and early modern commentaries on the lex Barbarius, with regard to the applicability of the lex Iulia de ambitu to the appointments made by the prince. Bugnyon (1677), lib. 4, tit. 26, p. 48.

2 Cf. Lepsius (2008), p. 244, text and note 56. 
specifically on Barbarius. ${ }^{3}$ Despite the invalidity of his election, Barbarius is tolerated in office because of common utility. ${ }^{4}$ Being tolerated in a public office however presupposes the right to validly exercise it. This, explains Angelus, can be achieved only with confirmation. ${ }^{5}$ What gives the right to discharge the office (the potestas administrandi) however is not the election but the confirmation; Barbarius' incapacity invalidated the election, but was no obstacle to his confirmation. ${ }^{6}$ So far, it would seem that Angelus was following the pope to the letter, even if that would have meant accepting the reading of the Gloss - and so the presumed will of the prince to confirm Barbarius' election. The opposite is true.

Having duly summed up the central tenets of Innocent's concept of toleration, Angelus then proceeds to twist their application systematically. Innocent according to Angelus - argued that toleration also applies to the prelate who, having 'canonical entry' into office, turns into a heretic. ${ }^{7}$ The statement is true,

3 Angelus de Ubaldis, ad Dig.1.14.3 (Angeli Perusini conspicuae iurisprudentiae uiri in primam digesti ueteris partem $c 0<m>$ mentaria, Mediolanii [Beninus \& Johannes Antonius de Honate] 1477 [fols. 35vb-36rb]). Most of the applications of the lex Barbarius in Angelus de Ubaldis' work may be found in his lectura on the Code: Angelus de Ubaldis, ad Cod.4.19.23, \$ iubemus (Lectura domini Angeli de Perusio super C(odice) ..., 1534 [Lugduni], Vincenti Portonariis, fol. 82rb, n. 3); ad

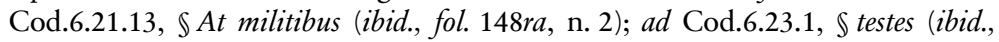
fol. 150ra, n. 3); ad Cod.7.45.2, \$Si arbiter (ibid., fols. 206vb-207ra).

$4 \quad$ Id., ad Dig.1.14.3 (in primam digesti ueteris partem, cit. [fol. 35vb]): 'Item dicit Inno(centius) eo ti(tulo) $<\mathrm{c}$. $>$ cum dilecta (X.1.3.22) quod toleratur processus barbarii propter multam utilitatem subditorum, unde secus si tanta utilitas non censetur, puta quia creditur delegatus qui non est.' Cf. supra, pt. II, $\$ 7.5$, esp. note 81 .

$5 \quad$ Angelus de Ubaldis, ad Dig.1.14.3 (in primam digesti ueteris partem, cit. [fol. 35vb]): 'dicit Inno(centius) de consuetudine <c.> cum dilectus (X.1.4.8) iuxta finem, quod excommunicatus uel suspensus qui ignoranter in officio tolleratur est si quod facit ratione publici officii illud tolleratur per hanc l(egem), secus si aliud gerant puta canonici excommunicati uel suspensi procedunt ad actum electionis et quid possit facere excommunicatus quia suspensus ibi uide per eum. Et dicit Inno(centius) de electionem $<$ c. $>$ qualit(er) (X.1.6.17) quod gesta per hunc barbarium ualent quia fuit confirmatus pretor, secus si confirmatio non interuenisset sed solum electus.' Cf. Innocent, supra, respectively pt. III, $\$ 11.6$, note 119 , and pt. II, $\$ 7.6$, note 117 .

6 Angelus de Ubaldis, ad Dig.1.14.3 (in primam digesti ueteris partem, cit. [fols. $35 \mathrm{vb}$ $-36 \mathrm{ra}$ ]): 'Item dicit Inno(centius) de elec(tione) <c.> cum dilecti (X.1.6.32) quod barbarius non fuit pretor ex electione sed ex confirmatione, unde tenuit confirmatio ualent ergo gesta per hunc et per prelatum non canonice electum tamen canonice confirmatum ex bono et equo et quia potestatem administrandi accepit ex confirmatione.' Cf. Innocent, supra, pt. II, $\$ 7.1$, note 9.

$7 \quad$ Angelus de Ubaldis, ad Dig.1.14.3 (in primam digesti ueteris partem, cit. [fol. 36ra]): 'Audi<s> Inno(centium) dicentem de elec(tione) <c.> nihil (X.1.6.44) ... 
as we have seen, so long as the 'canonical entry' was preceded by both election and confirmation. Deliberately ignoring as much, ${ }^{\mathbf{8}}$ Angelus does not consider confirmation in office to be a prerequisite for canonical entry: for him, a simple election seems to suffice. Applied to the toleration principle, this means that confirmation is not necessary for the valid exercise of the office. ${ }^{9}$ Arguing that canonical entry does not depend on confirmation but on simple election leads to the very opposite conclusion on Barbarius to that of Innocent: Barbarius' election did not need to be ratified by the prince. As such, concludes Angelus, common mistake and public utility would suffice to argue for the validity of Barbarius' acts. ${ }^{10}$

Angelus does not say openly that a voidable election suffices for canonical entry into office, but he seems to imply as much by equating canonical entry with lawful acquisition of the possession of the office (just like Baldus). As such, concludes Angelus, the acts of the putative prelate are valid if he is in possession of his office; otherwise they are void. ${ }^{\mathbf{1 1}}$ In effect, this is very similar to what Baldus said, with the difference that Baldus never spoke of toleration in office without prior confirmation. Baldus did not twist Innocent's position ${ }^{\mathbf{1 2}}$ - he simply tried to circumvent its less palatable applications. Angelus on the contrary does not hesitate to qualify as proper toleration what in Baldus was only coloured title. This is particularly clear in Angelus' comment on the case of the slave-arbiter (Cod.7.45.2). ${ }^{13}$ There, Angelus states that the unlawful pos-

quod gesta per prelatum qui canonicum habuit ingressum sed per heresim superueniente remouetur non cassantur nisi essent ordinationes, consecrationes uel alia spiritualia quae quo ad executionem irrite sunt nisi interueniat dis-

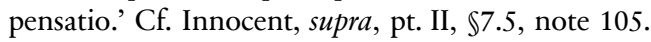

8 Given the insistence of the pope on the point, it seems quite difficult to imagine that Angelus' approach was unintentional.

9 Angelus de Ubaldis, ad Dig.1.14.3 (in primam digesti ueteris partem, cit. [fol. 36$\mathrm{ra}$ ]): 'Si autem canonicum ingressum non habuit nec fuit confirmatus tunc omnia gesta per eum sunt nulla.'

10 Ibid., 'sed si fuit confirmatus uel etiam solum electus nec erat necessaria confirmatio tunc propter communem errorem et publicam utilitatem quandiu in officio tolleratur ualent gesta per eum ut hic et ff. quod fal(so) tu(tore) 1. i $\$$ p(enultimo) (Dig.27.6.15).'

11 Ibid., 'Item si prelatus, ille qui reputatur prelatus, non est in possessione prelature indistincte gesta per eum non tenent, de iure pa(tronatus) c. consultationibus (X.3.38.19).'

12 With the exception of Barbarius' confirmation in Innocent: supra, pt. III, \$12.2.

13 Angelus interprets this lex as if the arbiter was delegated to preside over a number of legal proceedings, not to a single case, so that public utility considerations could be invoked. Angelus de Ubaldis, ad Cod.7.45.2, \$Si arbiter (Lectura domini Angeli de Perusio super C(odice), cit., fols. 206vb-207ra): 'Potes dicere quod hic loquitur de delegato ad vniuersitatem causarum: tunc enim versatur communis vtilitas; secus si ad vnam causam tantum: quia tunc cessat ratio.' 
session of jurisdiction does not suffice for toleration, even if supported by common mistake as to its validity. In order for the acts to be valid, it is necessary to hold a title of sort to exercise the office. Invalid as the title may be, it makes the difference between proper toleration in office and mere de facto possession of the same office. ${ }^{14}$

Considering the lex Barbarius as a case of toleration in office, Angelus has no difficulty in invoking its direct application to other cases, especially the notary who forged an instrument, entirely skipping Baldus' careful distinction between the two situations. If the case of Barbarius does fall within toleration, then there is no need to imagine a third genus between intruder and proper toleration. So the lex Barbarius can be invoked to extend the concept of toleration to the notary who should be removed from office. Until condemned, ${ }^{15}$ the notary will be able to exercise his office validly because of common mistake and public utility, just as in Barbarius' case. ${ }^{\mathbf{1 6}}$ By contrast, and again following Innocent, toleration in office after judicial condemnation is mere forbearance - which does not lead to the validity of further acts. ${ }^{17}$

\subsubsection{Raphael de Fulgosiis}

As we have abundantly seen, Baldus' complex reading of the lex Barbarius may be fully appreciated only by keeping Innocent's thinking in mind. 'Adjusting' the position of the pope made things considerably easier, and allowed Baldus' approach to be greatly simplified, just as his brother Angelus seems to have done.

Ibid., fol. 207ra: 'si probatur delega(tionem) factam non esse, licet communis opi(nio) sit et etiam quasi posses(sio) iurisdi(ctionis) non sufficit: et sic intelligitur opi(nionem) Innocen(tii); secus si procedat titulus quantumcunque iniustus ex eo quia tribuit inhabili.'

15 More precisely, so long as the condemnation remains secret: 'si depositio erat occulta tenent instrumenta' (ibid., ad Cod.6.23.1, $\mathbb{S}$ Testes, fol. 150ra, n. 3).

16 Id., ad Coll.2.6.1(=Nov.12.1), \$Pro incestis(Opus ac lectura authenticorum prestantissimi doctoris domini Angeli de vbaldis de Perusio ..., Venetiis [De Tortiis], 1489, fol. $9 v b)$ : '... instrumenta per eum facta post eius falsitatem commissam non ualent, nisi forte tenerent propter publicam vtilitatem et communem errorem vt fuit in barbario, vt l. barbarius de of(ficio) praeto(rum) (Dig.1.14.3).' Although the tone is dubitative ('forte'), elsewhere Angelus states as much in clearer terms: see next note, and Angelus' comment on Cod.6.21.13, \$At militibus (Lectura domini Angeli de Perusio super C(odice), cit., fol. 148ra, n. 2).

17 Id., ad Cod.4.19.23, \ iubemus (Lectura domini Angeli de Perusio super C(odice), cit., fol. $82 \mathrm{rb}, \mathrm{n} .3$ ): '... et hoc intelligo verum donec [tabellio] in officio toleratur: vt in 1. barbarius ff. de offic(io) presi(dis) (sic) (Dig.1.14.3) ... Si vero esset condemnatus de falsa scriptura: tunc aliam scripturam deinde non posset conficere de nouo licet in officio toleretur.' Cf. Innocent IV, ad X.3.2.7, $\$$ Operis, supra, pt. II, $\$ 7.3$, note 39 . 
A more efficient way of reaching the same goal was of course to remove the pope entirely from the picture. One of the first eminent jurists who did so was Fulgosius (Raphael de Fulgosiis, 1367-1420).

As a doctor in utroque iure (i. e. in both canon and civil law), Fulgosius must have known Innocent IV's writings well. But he was not particularly impressed with them, and certainly not on our subject: 'in my opinion Innocent approached this subject with wavering footstep as usual.' ${ }^{18}$ Fulgosius was no more lenient with the traditional reading of Accursius: 'pace the Gloss' (cum pace glose), Barbarius remains a slave, for neither the Romans nor the emperor had any intention to 'tarnish the praetorship' with a slave (preturam maculare seruili conditione). ${ }^{19}$

Already from these short remarks Fulgosius may be considered as representative of many later civil lawyers. Rejecting the Gloss (and thus, it is important to remember, also Bartolus), he finds it natural siding with Baldus. But his poor interest in Innocent's refined thinking leads him to prune Baldus' complex reasoning, skipping entirely the indirect application of the toleration principle. The main points left from this simplification are two. First, the validity of the acts depends on public utility, triggered by the common mistake. Second, to avoid an indiscriminate application of public utility, lawful possession of the office is required: for that purpose, a voidable election suffices. As a result of this simplification, Baldus may well be considered to follow the reading of the Ultramontani $^{\mathbf{2 0}}$ - especially that of Cugno.

Fulgosius accepts the main tenet of the Orléanese and their sympathisers - full separation between source and acts. When the common mistake furthers public partem Commentariorum ..., vol. 1, Lvgdvni, Apud Hugonem et haeredes Aemonis à Porta, 1554, fol. 25vb, n. 9): 'iudicio meo ibi Inno(centius) more suo incerto pede vagetur.' The reference was to Innocent's comment on X.1.6.32 and 44. Ibid., fol. 26rb, n. 14. See further ibid., fol. 25vb, n. 9 (where Fulgosius lists the usual objections against Barbarius' praetorship, especially the opposition between humanitas and strict law).

20 Ibid., fol. 25va, n. 1: 'Legitur duobus modis lex ista, vno modo secundum glos(am), Jac(obum) de are(na), Jac(obum) but(trigarium) et Bart(olum). Alio modo secundum Jac(obum) de ra(vanis), Pet(trum) et Cy(num) et Bal(dum).' It is on the basis of Baldus ultramontanus that Fulgosius disproves the reading of the Gloss: 'Bal(dus) addit tres rationes. Prima certum est quod iure communi non fuit pretor, sed nec publica vtilitas exigit, vt ipse sit liber. Nam satis est quod acta coram eo valeant. Unde non est recedendum a iure communi. ... Mouetur secundo nam beneficium per obreptionem obtentum nullum est ipso iure. ... Tertio mouetur, nam cum ipse princeps vel populus ignorauerit ipsum seruum, non intelligitur dispensasse super eo quod ignorabat ... Et ad hunc text(um) dicunt vltramonta(ni) et $\mathrm{Bal}(\mathrm{dus})$ quod hic formatur vnica tantum questio scilicet an acta valeant, vel non' (ibid., fol. 25vb, n. 9). 
utility, the object of the mistake may be held as true. ${ }^{21}$ The problem is whether public utility and common mistake suffice, or the intervention of the superior authority in some form is also necessary. For Fulgosius this means choosing between the approach of Bellapertica and Cynus on the one side, and that of Cugno and Baldus (!) on the other. After some hesitation, he sides with Baldus. ${ }^{22}$ Fulgosius does not elaborate further as to the actual role of the superior

21 On the matter, Fulgosius provides an abridged reading of Butrigarius' scheme, duly cleansed of any support for the Gloss: '... Sed aliquando queritur, an error communis habeatur pro veritate quantum ad effectus, docto(res) dixerunt aut publica vtilitas suadet haberi pro veritate, et habetur pro veritate: vt hic et l. i C. de testa(mentis) (C.6.23.1) et $\mathbb{S}$ sed cum aliquis, insti. eo(dem) titu(lo) (Inst.2.10.7). Sed aliquando publica vtilitas suadet haberi pro falsitate, et tunc non habetur pro veritate, $\arg$ (umentum) l. quod vero, contra s(upra) de legi(bus) (Dig.1.3.14). Aut publica vtilitas nihil horum suadet, et tunc aut interest errantis haberi pro veritate, et non habebitur pro veritate: vt 1 . Zenodorus C. ad macedonia(num) (Cod.4.28.2) et l. iii i(nfra) ad macedo(nianum) (Dig.14.6.3). Sed aliquando interest errantis haberi pro falsitate, et tunc habetur pro falsitate: vt ... 1. i \ fin. quando act(io) de pecu(lio) (Dig.15.2.1.10)' (ibid., fol. 26ra, n. 9). Fulgosius does not openly quote Butrigarius in his commentary on the lex Barbarius, but he does so when reporting the same scheme in his lectura on the slave-witness: Fulgosius, ad Cod.6.23.1, $\$$ Testes (Raphaëlis Fulgosij Placentini ... in D. Iustiniani Codicem Commentariorum ..., vol. 2, Lvgdvni, Apud Hugonem et haeredes Aemonis à Porta, 1547, fol. 39vb, n. 5).

22 This is particularly clear in Fulgosius' interpretation of the false notary's case: despite the presence of public utility, a false notary cannot draft valid instruments. Fulgosius, ad Dig.1.14.3 (in primam Pandectarum partem Commentariorum, cit., fol. 26ra, n. 12): 'Superest vna dubitatio que sit ratio quare acta valeant, cum non sit iustus pretor. Guil(elmus de Cugno) dicit contingere ex tribus: quorum si quid desiit non valebunt gesta. Primo communis error, secundo publica vtilitas, tertio superioris auctoritas: et si deficiat quid horum, puta aliquis gessit se pro tabellione cum nunquid habuisset auctoritatem, et confecit multa documenta, non valebunt talia documenta, et allegat tex(tum) 1 . actuarios C. de numera(riis) et actua(riis) lib. xii (Cod.12.49(50).7). In hanc sententiam inclinat Bal(dus) referens consonantem Azo(nem) in summa de fide instrum(entorum) [Coll.6.3(=Nov.73), supra, pt. I, $\$ 2.6$, note 139]; Pet(rus) et Cy(nus) sunt contra: quia sufficit communis error et publica vtilitas, per aut(henticam) de tabel(lionibus) $\mathbb{S}$ penul(timo) (Coll.4.7.1[=Nov.44.1\$4]), vbi videtur glo(sam) hoc dicere [cf. supra, pt. I, $\$ 2.6$, note 132], et in hoc videtur mihi Inno(centius) in c. i ad fi(nem), de fide instrumen(torum) per l. iii i(nfra) ad macedo(nianum) [supra, pt. II, $\$ 7.5$, note 73$]$, et in hanc sententiam videtur magis inclinare Bart(olus) [supra, pt. I, \$5.3], et in veritate hec questio satis est ambigua. Et ad 1. actuarios (Cod.12.49(50).7), respondet Bart(olus) quod illa loquitur in casu speciali. Nescio tamen in quam partem magis inclinem, verum tamen sententia Azo(ni), $\mathrm{Bal}(\mathrm{di})$ et Guil(elmi) in stricta disputatione videtur mihi verior: quia tamen contraria sententia humanior est, et quia sussulta est magna auctoritate, videtur mihi tenenda in iudiciis.' 
authority, but it would seem that he meant a formally valid but substantively flawed election. ${ }^{23}$

\subsubsection{Paulus de Castro}

Ironically, one of the jurists who followed Baldus' interpretation of Barbarius' case more faithfully, Paulus de Castro (c.1360-1441), seems not to have written any comment on Dig.1.14.3. ${ }^{24}$ Given his pre-eminent position among fifteenthcentury civil lawyers and his lasting influence, it is worth looking at those other parts of his opus where he applied (Baldus' elaboration of) the lex Barbarius.

As a matter of principle, says Castro, Innocent's concept of toleration applies to the ordinary judge who becomes infamis and so legally incapable, not to the legally incapable who discharges the office of judge. It follows - contrary to Innocent's view - that the litigants could recuse the slave sitting in judgment even after the joining of the issue. ${ }^{25}$ This way, Castro adheres strictly to the

23 This conclusion is strengtened by Fulgosius' short comment on the case of the slave-arbiter: although the appointment was flawed by a mistake as to the slave's status, the validity of the decision, says Fulgosius, ought to be assessed according to the time when it was made, even though the status of the judge was only putative: 'conditio iudicis ferentis sententiam, vera vel putatiua, perspicitur secundum tempus iudicii et date sententie ... et idem putant doct(ores) in omni alio defectu, qui impediat iudicari: verbi gratia, erat aliquis excommunicatus, qui communi opinione putabatur non excommunicatus.' Fulgosius, ad Cod.7.45.2, $\$$ Si arbiter (in D. Iustiniani Codicem Commentariorum, cit. fol. 158rb, n. 1).

24 Castro's printed editions skip title 14 of the first book of the Digest; the same can be seen in manuscript sources: see e. g. BSB, Clm 6675 .

25 Castro, ad Dig.5.1.12.2, $\$$ Non autem omnes (Pavli Castrensis ... In Primam Digesti Veteris partem Commentaria ..., Lugduni, 1585, fol. 126va, n. 5): 'Dicit etiam Inn(ocentius) quod exceptio infamiae non potest opponi contra iudicem ordinarium quousque in officio toleratur, ar(gumentum) $s$ (upra) de offi(cio) praet(orum) 1. Barbarius (Dig.1.14.3), melius in 1. Cassius s(upra) de sena(toribus) (Dig.1.9.2), quae omnia dicta sunt notanda et declarant istum tex(um), et vide quod idem no(tat) in c. super literis ante fi(nem), extr(a) de rescri(ptis) [cf. supra, pt. II, $\$ 7.5$, note 82 ]. Quidam autem prohibentur morib(us) vt foeminae: quia turpe est vt se ingerant publicis officiis. Item serui, et dicit Inn(ocentius) et etiam spe(culator) in ti. de excep(tionibus) $\$$ nunc videndum, ver(siculum) "sed quaero" [Specvlum Ivris, cit., lib. 2, partic. 1, De Exceptionibus et Replicationibus, 2. $\$$ Nunc uidendum, vol. 1, p.511, n. 6], quod ista exceptio debet opponi ante lit(em) cont(estatam) et postea non. Tu dic in seruo contrarium, quia est incapax iurisdictionis, cum pro nihilo reputetur de iure ciuili: et ideo non cadunt in eodem quae sunt iuris ciuilis, sicut ciuilis obligatio et iurisdictio, et sic processus coram eo agitatus non potest valere.' Cf. Castro, ad Dig.5.1.44.1, $\$$ Cum postea (In Primam Digesti Veteris partem Commentaria, cit., fol. 139, n. 5). 
principle that toleration in office applies only to the supervening incapacity. ${ }^{26}$ Proper toleration, however, is not necessary to the validity of the acts. Lawful possession of the office would suffice, when coupled with common mistake and public utility. Castro explains the point in his analysis of the slave-arbiter (Cod.7.45.2). Because of the underlying legal incapacity, the appointment of the slave is substantively flawed but formally valid. The substantive invalidity bars full (i. e. de iure) entitlement to the exercise of jurisdiction (and so, proper toleration), but the formal validity suffices for Barbarius to receive possession of it (or rather, 'exercise and use of jurisdiction'). ${ }^{27}$ As with Baldus, Castro separates entitlement from lawful possession of jurisdiction. While Castro does not go into detail on the representation mechanism underpinning the toleration concept, this separation allows him to distinguish the position of the person from that of the office he exercises. ${ }^{28}$ Commentaria ..., Lugduni, 1585, fol. 128rb, n. 2): 'et sic no(tatur) mirabilem effectum communis reputationis, quia facit quem haberi pro idoneo et habili, licet non sit. Idem in testa(mentis) l. cum lege (Dig.28.1.26), et ibi no(tatur) ff. de test(amentis), et per istam 1(egem) [scil., Cod.7.45.2] patet, quod si iudex est excommunicatus vel est infamis, si tamen reputabatur contrarium, valent acta coram eo, vt c. ad probandum, de re iu(dicata) (X.2.27.24).' Castro further elaborates on the point when writing on the revocation of delegated jurisdiction for the death of the delegator, focusing on its effects in case the parties remain unaware of it. If the parties do not raise an exception, says Castro, the judge may render a valid pronouncement. On the subject Castro agrees with Innocent. The solution, continues Castro, is different in case of an ordinary judge: the parties may not raise any objection as to his legal capacity. That, however, applies only if he was truly an ordinary judge. Otherwise, the lex Barbarius applies. Castro, ad Dig.12.1.41, $\mathbb{S}$ Eius qui (Pavli Castrensis ... In Secundam Digesti Veteris partem Commentaria ..., Lugduni, 1585, fol. 20va, n. 11): '... Inno(centius) in c. licet, de offi(cio iudicis) deleg(ati) (X.1.29.30) tenet contrarium, dicens quod post mortem delegantis non finitur iurisdictio delegata ipso iure, sed ope exceptionis ... sufficit ergo, quod exceptio non fuerit opposita, vt valeant acta ... pro opi(nione) Inn(ocentii) facit 1. si forte, de offi(icio) praesid(is) (Dig.1.18.17), et c. si duobus, de app(ellatione) (X.2.28.7), vbi ignorantia iudicis credentis se iurisdictionem habere in aliqua causa, cum non habeat, faciat acta valere. ... Aliud in iudice ordinario, vbi agitur de maiori praeiudicio, cum omnes ad ipsum recurrant, dummodo semel fuerit ordinarius vere, licet ignoret finitum esse officium, d. l. si forte (Dig.1.18.17), vt sit ordinarius de praesenti, licet non in certa causa, iniqua censebatur esse, vt in d. c. si duobus. Si autem nunquam fuisset, nec esset, dic vt 1. Barbarius, s(upra) de offi(cio) praeto(rum) (Dig.1.14.3).'

27 Id., ad Cod.7.45.2, $\$ S i$ arbiter (In Secundam Codicis partem Commentaria, cit., fol. $128 \mathrm{rb}, \mathrm{n} .2$ ): 'et sic non haberet iurisdictionem, habebat tamen exercitium iurisdictionis et vsum, quod tantundem valet, acsi haberet iurisdictionem.'

This seems strengthened by Castro's reading of the locus classicus of the Code on tyranny, the lex Decernimus (Cod.1.2.16). That lex, says Castro, requires any act of 
In turn - and, again, following Baldus - for Castro the lawful exercise of possession of the office (and thus of its jurisdiction) allows for the validity of the acts when that possession is coupled with common mistake and public utility. This is particularly clear in Castro's discussion of the notary. The putative notary cannot draft valid instruments: his quasi possessio of the office is just de facto exercise of it. The common mistake as to its validity can only invert the burden of proof as to the title (just as Innocent and Baldus had it), but cannot bestow legal validity on his instruments. ${ }^{29}$ By contrast, the notary secretly deprived of his office (and so widely considered as still holding a valid title) can draft new documents. ${ }^{30}$ The difference, explains Castro, depends on the presence of a formally valid title. A formally valid title would suffice because the object of the common mistake is not the existence of a title, but only its substantive validity. Public utility can make up for the substantive invalidity, but not also for the complete lack of any title. In Barbarius' case, he continues, the slave was formally elected, although the election was substantively invalid. Without a formal title, however, 'the common opinion or mistake would have no ground', and so 'it would not bestow validity on the instruments'. ${ }^{31}$ Just as in Baldus, a voidable

the tyrant to be quashed. This however does not necessarily also apply to the decisions of the judges serving under the tyrant. If their jurisdiction is based not on statutes and privileges made by the tyrant, but rather on the ius commune or municipal statutes, then their decisions would hold - after the lex Barbarius. The reason, concludes Castro, is that the judges are simply exercising the jurisdiction that pertains to the city. Castro, ad Cod.1.2.16, $\mathbb{\$}$ Decernimus (Pavli Castrensis ... In Primam Codicis partem Commentaria..., Lugduni, 1585, fol. 12ra, n. 1): 'Omnia quae facta sunt tempore tyrannidis superueniente iusto dominio debent rescindi, hoc dicit tota lex, quod intellige de his, quae facta sunt per modum legis vel priuilegij. Si vero per viam iustitiae per eius officiales, tunc aut fundantur in legibus et priuilegijs praedictis, et idem, aut in iure communi, vel statutis loci, et tunc debent firma permanere, arg. in 1. Barbarius ff. de officio praeto(rum) (Dig.1.14.3) quia dicti officiales magis dicuntur vti iurisdictione cohaerente loco, vel territorio, quam data a tyranno qui nullam habet.'

29 See esp. Id., ad Cod.4.21.7, $\$$ Si solennibus (In Primam Codicis partem Commentaria, cit., fol. 192vb, n. 3-4). Cf. Id., ad Dig.14.6.1.3, \$In filiofamiliae (In Secundam Digesti Veteris partem Commentaria, cit., fol. 96rb-va, n. 11-12).

30 '... et si ista priuatio sit occulta, valent instrumenta per ipsum confecta.' (Castro, ad Cod.6.23.1, In Secundam Codicis partem Commentaria, cit., fol. 38rb, n. 2). The opposite applies of course if the deposition is notorious. Even then, however, the ex-notary would be able to give execution to previously drafted instruments (as Baldus had it): 'confecta vero ante priuationem non irritantur: imo etiam si non erant publicata, poterit publicare, quia eius delictum non debet nocere contrahentibus, qui ad ipsum habuerint recursum tempore quo erat habilis, etiam si eius inhabilitas sit notoria' (ibid.).

31 Ibid. n. 3-4: 'et praedicta procedunt, quando semel fuit notarius, sed postea priuatus, vel effectus inhabilis. Si autem nunquid fuit notarius, tamen communi existimatione habeatur pro notario, et postea detegitur, quod non est, an valeant 
election does not allow the exercise of the office, but suffices as to its lawful possession.

In comparison with Angelus de Ubaldis and Fulgosius, Castro's precision on the subject was already quite uncommon. With the passing of the time, this became increasingly rare. So for instance Castro's most illustrious student, Alexander Tartagni (Alexander de Imola, 1424-1477), provided a rather sketchy commentary on the lex Barbarius. Relying entirely on Baldus' summary of Innocent, Tartagni made little effort to fully appreciate Innocent's position, and this ultimately resulted in a superficial understanding of Baldus himself. ${ }^{32}$ By Tartagni's time this approach was extremely widespread: the interest of most jurists was to provide a summary of what older authorities had already said, not to delve even deeper into the matter. The growing consent towards Baldus' position became common opinion, and this further contributed to reducing any incentive for a thorough analysis of the subject - or of Baldus himself.

\subsubsection{Jason de Mayno}

Jason de Mayno (1435-1519) is among the last civil lawyers to deal extensively with the lex Barbarius, on which he published a (possibly, extended) version of the repetitio that he gave in Pavia on 14 February 1485 (n.c.). ${ }^{33}$ While not very original, his repetitio is particularly useful for appreciating the position of most early modern authors on our subject. By the close of the Middle Ages, the centuries-long game of indirect quotations had multiplied to the point of blurring many differences between authors. At least on the lex Barbarius, Mayno's references to previous jurists are often hardly accurate. ${ }^{34}$ On a practical

instrumenta per ipsum confecta? No(tatur) in Spe(culo), de instr(umentorum) edi(tione) $\$$ restat, ver(siculum) "si is qui" et $\$$ instrum(entum), ver(siculum) "quid ego si tabellio" [supra, pt. II, $\$ 8.4$, note 58 , and 55 respectively], vbi distinguitur, an fuit creatus per priuilegium imperiale, quod tamen erat inualidum, et sic communis opi(nio) fundatur in aliqua causa inductiua eius, et tunc valeant instrumenta, per d(ictam) 1 (egem) Barbarius (Dig.1.14.3). Nam, et ibi precedebat electio populi rom(ani) licet fuisset inualida, quia erat seruus, et ignorabatur, vnde non erat praetor, et tamen gesta coram eo erant valida, aut nullum praecesserat priuilegium, vel creatio notariatus, et tunc communis opinio vel error qui non habet fundamentum, non faceret instrumenta valere, per 1. Herennius Modestinus ff. de decur(ionibus) (Dig.50.2.10).'

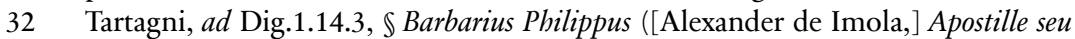
Additiones ad Bar(tolum) ... super prima parteff. veteris ... [Venetiis, 1488] [fols. $8 v b-9 r a])$.

33 Mayno, ad Dig.1.14.3 (Lectura in prima parteff. veteris, cit., fol. 40va, n. 12).

34 Mayno's references to Baldus are no exception. For instance, the only time that Mayno argues for the opposite solution to that of Baldus is on the effects of the 
level, the point is not as serious as it might appear: if the inaccuracy greatly affected the reasoning leading to a certain conclusion, it did not touch the conclusion itself. On the contrary, blurring the precise differences among various authors greatly contributed to the strengthening of the common opinion, and its crystallisation.

With regard to the lex Barbarius, as Mayno recalls, the common opinion is definitely against the Gloss, Butrigarius and Bartolus. ${ }^{35}$ By Mayno's time, the 'winning side' is clearly that of Baldus. The most revealing aspect of Mayno's repetitio, however, is not its approbation of Baldus' position but its remarkable simplification. Even a jurist as knowledgeable and careful as Mayno ${ }^{36}$ could no longer fully appreciate the reason for certain subtleties in Baldus. That was also a consequence of the blurring of the difference between confirmation and election. By the late fifteenth century the process leading to the replacement of episcopal elections with papal appointments was nearly complete. ${ }^{37}$ Canon lawyers still discussed election by the cathedral chapter, but largely because the main canon law sources dealt with this subject at some length - not because it was still of much relevance. Thus, Innocent's all-important difference between election and confirmation in office was lost, and so was Baldus' subtle adaptation of Innocent's toleration principle outside its proper boundaries.

Without a clear difference between election and confirmation, Mayno could only distinguish between intruder and elected. If 'elected' was almost coterminous with 'appointed', it was difficult to think of an elected that was not confirmed. ${ }^{38}$ This assimilation between election and confirmation greatly simplified the issue: it was now only a matter of distinguishing between intentional dispensation from legal incapacity and mistaken appointment of the legally incapable. Since intentional dispensation was a theoretical possibility of little practical relevance, ${ }^{39}$ the question focused mainly on the mistaken

secret deposition. Misunderstanding Baldus' position, in fact Mayno reached a similar conclusion: ibid., fol. 40rb, n. 12.

35 Ibid., fol. 36vb, pr: 'apparebit communior opinio est contra glo(sam) et Bar(tolum) quod barbarius neque liber nec verus pretor fuit.' Cf. ibid., fol. 37va, n. 4: 'An si inhabilis eligeretur a populo credente eum habilem et exerceret officium puta preturam esset verus pretor et intelligeretur habilitatus ... eadem opi(nionem) tenet $\mathrm{Ja}$ (cobus) bu(trigarius) et bar(tolus) et raro alii.'

36 Cf. supra, pt. III, $\$ 10.1$, text and note 2.

37 Supra, pt. III, $\$ 11.3$, note 61.

38 Mayno, ad Dig.1.14.3 (Lectura in prima parteff. veteris, cit., fol. 40ra, n. 12): 'Limita nunc istam 1 (egem) precedere quando barbarius fuit rite electus in pretorem et confirmatus $a b$ habente potestatem, tunc gesta ab eo valent propter communem errorem et vtilitatem pu(blicam), ita loquitur ista 1.; secus si sine electione barbarius in pretura se ingessisset, quia tunc acta non valerent: ita Inno(centius) in c. nihil de elec(tione) (X.1.6.44).' 
appointment of the inhabilis. Without a clear difference between election and confirmation, the voidable appointment would become automatically coloured title to exercise the office. Because of public utility, in turn, this title would suffice for the production of valid acts.

Mayno was more careful than most jurists who came after him. So he showed some hesitation as to the ultimate consequences of Baldus' approach (if coloured title and public utility suffice, why not apply the lex Barbarius also to the popess Johanna?). ${ }^{40}$ But, by and large, he followed Baldus. While Mayno quoted generously from Innocent, such quotations came mostly through either Baldus or his brother Angelus. ${ }^{41}$ Also in Mayno, the apparent continuity between Baldus and the pope dispensed with the task of looking carefully at Innocent, and greatly strengthened Baldus' position. At the same time, however, Mayno's superficial knowledge of Innocent did not allow him to make full sense of Baldus' insistence on the importance of possession of jurisdiction. ${ }^{42}$ Discarding

40 In abstract, observes Mayno, interpretations of the lex Barbarius may be applied to any similar case. Baldus himself, he says, applied it to the election of the pope. But one could go even further than that. There is little difference between the inhabilitas of a slave and that of a woman: in Dig.5.1.12.2 both are prevented from serving as judges because of customs - moribus). So, continues Mayno, if Barbarius can validly exercise the praetorship, then in principle under the same conditions a woman should be allowed to discharge the office of pope. Mayno, ibid., fol. 40ra, n. 11-12: 'restat per complemento huius 1. quod infinitio facturum me dixi potere extensiones et limitationes ad hanc l. Primo, istam 1. loquentem in officio pretoris extendit $\mathrm{Bal}(\mathrm{us})$ in 1 . non mutat C. de libe(rali) ca(usa) (Cod.7.16.11) vt habeat locum in papa, quia si inhabilis eligeretur ad papatum puta fuit in illa femina omnia gesta propter solemnem electionem communem errorem et vtilitatem pu(blicam) valerent.' The reference to Baldus is correct, but Baldus mentioned the case of the pope only to narrow the scope of toleration to the jurisdictional sphere and not also the sacramental one, just as Innocent did. Cf. Baldus, ad Cod.7.16.11, $\$$ Non mutant, supra, pt. III, $\$ 11.6$, note 154. Mayno follows the same distinction between jurisdictional and sacramental spheres, though without a clear understanding of the different positions of Innocent and Baldus (he quotes the former as interpreted by the latter: Mayno, ad Dig.1.14.3 (Lectura in prima parteff. veteris, cit., fols. 39vb-40ra, n. 11). See esp. Mayno's lengthy discussion ibid., fol. 40rb-va, n. 12.

42 This is particularly evident in Mayno's main critique of Baldus. Barbarius' defect, says Mayno, was in the efficient cause: a slave lacks legal capacity, so he cannot make legally valid acts. Unlike other kinds of defects (such as the lack of the formalities required for the act), common mistake cannot make up for this. Baldus, observes Mayno, tried to solve the problem by stressing the importance of jurisdiction, but that explanation remains 'fragile'. Ibid., fol. 37vb, n. 4-5: 'regula est quod communis error facit ius ... intellige istam regulam quod communis error facit ius, verum est concurrente titulo et quasi possessione vt hic apparet in barbario ... notabiliter limita quando defectus esset in solemnitate vel in causa materiali, puta in testibus adhibitis in testamento qui reputabantur 
the role of possession of jurisdiction led Mayno to further highlight the formal validity of the election. At this point, any difference between positions as different as those of Cugno and Baldus was totally lost. Just like Fulgosius, Mayno described Baldus' position in the same terms as that of Cugno: a formally valid appointment that is however voidable because of the occult incapacity of the person appointed. This opposition between validity as to forma (of the appointment) and invalidity as to qualitas (of the appointee) would provide an easy explanation for the extension of the lex Barbarius to other cases, primarily to that of the inhabilis notary. ${ }^{43}$ The complex reasoning on representation and the boundaries of toleration is lost, just like the difference between internal and external validity of agency.

\subsubsection{Felinus Sandeus, delegate judges and public utility}

As said, the progressive simplification of the underlying issues made a good part of both Innocent's and Baldus' reasoning superfluous. ${ }^{44}$ In particular, Baldus'

idonei, tunc verum est quod communis error facit ius d(icta) 1. i C. de testa(mentis) (Cod.6.23.1). Sed si defectus esset in substantia seu in causa efficienti, puta quia testator erat seruus et reputabatur liber, vel erat in potestate patris et reputabatur sui iuris: tunc si faceret testamentum vel alium actum propter istum communem errorem non faceret ius nec statutum valeret, quia defectus in causa efficienti non sic de facili dispensatur sicut in substantia vel in causa materiali ... respondet $\mathrm{Bal}$ (dus) fragiliter quod ibi speciale est fauore iurisdictionis, et si dicis quod ista limitatio est contra tex(tum) nostrum vbi defectus erat in causa efficienti i(d est) in ipso barbario, respondet Bal(dus) quod contrarium est verum, quia ista lex communis error non faciat ius quo ad substantiandum preturam in persona barbarii, licet propter publicam vtilitatem acta valeant; nam fatetur $\mathrm{Bal}$ (dus) quod in hac $\mathrm{l}$ (ege) barbarius non fuit verus pretor nec liber motus auctoritate Aristotelis: quia ens et verum conuertuntur inducendo vt per eum [cf. Baldus, supra, pt. III, $\$ 12.4 .3$, note 161]. Tamen dubia est hac limitatio si bene consideres.'

43 Mayno, ad Dig.1.14.3 (Lectura in prima parteff. veteris, cit., fol. 39rb, n. 8): 'Istam conclusionem limita procedere proprie in istis terminis: quia cum sit defectus in forma creatus instrumenta annullantur; secus quando fuisset creatus tabellio legitime licet esset defectus in persona, puta quia seruus vel excommunicatus seu hereticus occulte, et sic esset solum defectus in materia seu in persona tunc instrumenta per eum facta propter publicam vtilitatem et communem errorem valerent. Ita proprie loquitur ista l(ex).' For more applications of the lex Barbarius see Repertorivm sev Index ordine elementario digestus in commentaria Iasonis Mayni ... Lugduni, apud Sebastianum Gryphium, 1533, s.v. 'facta, factum'. Cf. Derrett (1958), p. 285.

44 In effect, looking at Baldus in search of a solution for the issue of the de facto officer, the most obvious element that one would find is public utility. If even modern scholars could say that Baldus considered the lex Barbarius as an outright application of public utility (e. g. Horn [1968], p. 109), it is difficult to reproach 
three-step process leading to the adaptation of Innocent's toleration principle became unnecessary, for there was no longer any reason to avoid applying Innocent's toleration principle directly to Barbarius' case. As Innocent's approach was increasingly read through that of Baldus, the simplified reading of Baldus (often mediated through the summary provided by other jurists) resulted in a simplification of Innocent's thinking as well. Innocent's concept of toleration was based on representation. The superficial approach of many late medieval and early modern jurists discouraged in-depth analysis of the representation mechanism, and led to the acceptance of Baldus' conclusions on the basis of his authority.

When a conclusion is the product of complex reasoning, however, its application without a clear understanding of its rationale can create problems. In turn, those problems call for further simplification. Let us take for instance the relationship between public office and public utility. The exercise of a public office is itself an expression of public utility. Downplaying the central role of the office, however, it became necessary to highlight the importance of public utility, blurring the difference between proper representation and simple delegation. Applied to the office of the judge, this meant removing the underlying difference between ordinary and delegated jurisdiction. Toleration worked only within agency: so long as the unworthy could validly represent a public office, the office would still act through that person qua agent, despite his unworthiness qua individual. Delegation is no agency, and so Innocent excluded the delegate judge from the scope of toleration. Tolerating the delegated in an office he did not legally represent would be a self-contradiction. ${ }^{45}$ Excluding the ratification of Barbarius' position (and so, the internal validity of agency), as we have seen, Baldus had to work outside toleration and so outside proper representation. This led him to highlight the importance of the exercise of ordinary jurisdiction. To that end, one of the arguments he used was the parallel with the slave-arbiter case (Cod.7.45.2).

In that case the slave-arbiter exercised delegated jurisdiction to issue a single decision, and yet the Roman source was clear as to the validity of that decision. If the exercise of delegated jurisdiction without public utility sufficed for the validity of the act of the slave-arbiter, reasoned Baldus, then all the more the acts of the slave-praetor in the exercise of ordinary jurisdiction could not possibly be void. ${ }^{46}$ Simplifying the reasoning of both Innocent and Baldus, what was left

early modern authors for having looked at Baldus' outcome more than at the rather complex route he followed to reach it.

45 Supra, pt. II, $\$ 7.4$, notes $45-47$.

46 Supra, pt. III, $\$ 12.3$, text and notes 108 and 110. 
was only the bare fact that, unlike Innocent, Baldus extended the lex Barbarius also to the delegate judge who was secretly inhabilis. Since the requirements of the lex Barbarius - public utility and coloured title - were both present also for the delegate judge, late medieval authors saw no reason for Innocent's limitation and sided with Baldus. So, by the late fifteenth century, Felinus Sandeus (Felino Sandei, 1444-1503) could well say that 'all doctors are against Innocent, on the basis of Cod.7.45.2'. ${ }^{4}$

Supporting Baldus without a clear understanding of his position, however, could be problematic. The case discussed in Cod.7.45.2, as we know, dealt with a single decision by the delegate judge who was in fact a slave. Extending the lex Barbarius to the delegate judge in the name of public utility would require a series of acts, or at least a large number of recipients. Precisely the opposite of what was described in Cod.7.45.2. Baldus sought to highlight the importance of ordinary jurisdiction: when jurisdiction was delegated, the recipient was simply acting at the ordinary judge's behest - even a slave could do that. ${ }^{48}$ Baldus therefore did not think that the slave-arbiter was a proper application of the lex Barbarius. But a simplified - and generously abridged - reading of his commentary would point precisely to that conclusion: invoking public utility, Baldus went beyond Innocent and held the acts of the delegate judge who was secretly inhabilis as valid, just like those of Barbarius. Reading the whole issue in terms of public vs. private utility, it was inevitable that both Innocent and Baldus would be seriously misunderstood. Innocent never said that private utility bars the application of toleration. That would have been a self-contradiction: toleration depends on representation. So if the occult heretic or excommunicate were to be deposed after having rendered a single decision, clearly that single decision would hold. Innocent, as usual, was more precise: he observed that toleration could not be extended beyond the boundaries of legal representation, all the more when its application would be limited to a single lawsuit, and so to private utility. ${ }^{49}$ Baldus was more explicit: even if Barbarius issued a single act, since he did so in the exercise of ordinary jurisdiction, that act would still be valid. ${ }^{\mathbf{5 0}}$ Again, the difference between Innocent and Baldus

Sandeus, ad X.1.3.22 (Commentaria Felini Sandei ... in V. libr. Decretalium ... pt. I, cit., cols. 681-682, n. 3, \$Lex Barbarius): 'lex Barbarius habet locum etiam in delegato. Omnes Doc(tores) hic contra Inno(centium) per 1. ii C. de senten(tiis) (Cod.7.45.2).'

$48 \quad$ Supra, pt. III, $\$ 12.3$.

49 Cf. supra, pt. II, $\$ 7.5$ esp. note 81.

50 Baldus, repetitio ad Dig.1.14.3, cit., fol. 58rb, n. 18: 'et per hoc [scil., on the basis of the iurisdictio ordinaria of the praetor] puto, quod si Barbarius non exercuisset nisi vnicum actum, ille vnicus actus valeret, et de aequitate ita valuit primus actus quem fecit, sicut vltimus.' 
depended on representation. Operating outside it, Baldus had to emphasise the lawful exercise of ordinary jurisdiction, so as to equiparate it to the external validity of the agency relationship (i. e. the relationship office-third party in the agency triangle). In stressing the validity of the (hypothetical) single act of Barbarius, Baldus remarked the strength of the lawful possession of ordinary jurisdiction.

Detaching public utility from legal representation, however, Baldus' statement became now a problem. So the same Sandeus proceeded to reconsider Baldus' position. In Sandeus' account, Baldus considered the exercise of a public office by the occult inhabilis as valid if that affected at least a few people (and not necessarily the whole commonwealth), because the public nature of the office would ensure the connection with public utility. The obvious exception, of course, was a single act - which could not possibly be valid. ${ }^{51}$

\subsection{Early modern times}

\subsubsection{Simplifying the simplification}

From the early sixteenth century onwards, progressively fewer jurists showed any real interest in studying the lex Barbarius. Early modern writers would typically provide simplified accounts of the late medieval simplifications that we have just seen. What remained of Baldus' complex approach was just the double requirement of public utility and coloured title, crystallised in the brocard communis error facit ius.

Public utility is a rather vague concept: alone, it can mean anything. So no jurist ever put its relevance in question. Its main function was now to justify the brocard and limit its application, loosely speaking, to public law issues (even though the reason for this limitation was no longer remembered). ${ }^{52}$ Despite all the simplification process it went through, by contrast, coloured title remained a less immediate concept, and not all early modern authors made use of it. A large number of jurists, from Lessius ${ }^{53}$ to Cocceius $^{54}$ and even

Felinus Sandeus, ad X.1.3.22 (Commentaria Felini Sandei ... in V. libr. Decretalium, pt. I, cit., col. 681, n. 3, $\mathbb{\$}$ Lex Barbarius): Et dicit Bald(us) in d. 1. ii (Cod.7.45.2) quod sufficit, quod publica utilitas uersetur in qualitate officij, licet non in singulari actu exercitij: forte, quia usus sit, quantum ad paucos.'

52 Cf. Deroussin (2001), pp. 61-63.

53 On Lessius see infra, this chapter, $\$ 14.3 .2$, text and esp. note 135.

54 Samvelis de Cocceji ... Jvris Civilis Controversi, Pars II, Francofurti ad Viadvm, Impensis Jo. Godofredi Conradi, 1718, lib. 22, tit.4, q.1, p. 112 ('an notarii putativi, sive falsi, instrumenta valeant?'), resp.2: 'Loquitur de vero Notario creato, sed qui talis esse non poterat, forte quia servus est, hujus acta valent.' 
Menochius $^{55}$ (which is to say, from the least to the most practice-oriented writers) spoke of coloured title to signify formally valid appointment. Other authors did not speak of coloured title but of confirmation by the superior authority unaware of the defect in qualitate. This can ben already seen in late fifteenth-century authors such as Antonius Corsetti (c.1450-1503) ${ }^{56}$ and Bartholomaeus Socinus (1436-1507) $)^{57}$ and early sixteenth-century ones such as Aymonis Cravetta (1504-1569), ${ }^{58}$ and then in Dutch jurists such as Arnoldus Vinnius $(1588-1657)^{59}$ and Johannes Voet $(1647-1713) .^{60}$ The difference is just a formal one: the aim is always to bestow validity on the acts while denying it to their source. Stressing the power of the superior authority is hardly a revival of Accursius' fortunes, but rather a consequence of the need to avoid the unbridled application of the common mistake. ${ }^{\mathbf{6 1}}$ The lex Barbarius principle applies only

Iacobi Menochii ... De adipiscenda et retinenda possessione amplissima et doctissima commentaria ( $3^{\text {rd }}$ edn.), Venetiis, Apud Ioannem Baptistam Somaschum, 1576, De retinenda possessione, remedium 6 , fol. $156 v$, n. 71 .

Corsetti, Repertorium in opera Nicolai de Tudeschis [Venetiis, c.1486] s.v. 'error communis'.

Socinus, Regulae et Fallentiae Juris Bartholomaei Socini ... a Benedicto Vaudo ... reuisae ... ( $4^{\text {th }}$ edn.), Coloniae Agrippinae, Apud Ioannem Busaeum, 1663, reg.282, pp. 386-387.

58 Aymonis Cravettae ... Consiliorum, siue Responsorum, tom. 5, Apud Ioan. Wechelum, impensis Sigismundi Feyrabendii, 1589, cons.958, p. 314, n. 9.

59 Vinnius, ad Inst.2.10.7 (Arnoldi Vinnii JC. In Quatuor Libros Institutionum Imperialium Commentarius Academicus, Et Forensis, Lugduni, Typis Petri Bruyset, Sumptibus Fratrum Detournes, 1755, pp. 331-332): 'Ridiculum vero est, quod vulgo ex hoc loco colligunt, communem errorem jus facere: non enim error, sed in errore summa Principum auctoritas jus hoc benigne et speciali favore ultimae voluntatis constituit. ... Latius hic exspatiantur doctores dum quaerunt, an gesta $\mathrm{ab}$ his, qui se pro scribis aut notariis gerunt, cum non sint, sed communi errore tales habeantur, et instrumenta ab his facta, valeant. Et sic vulgo distinguitur, ut referat, utrum aliqui publica auctoritate hujusmodi persona per errorem imposita sit, an quis ipse sibi privatim eam assumpserit: illo casu valere quod gestum est, per 1. 3. de off(icio) praet(orum) (Dig.1.14.3) hoc casu acta non valere, et speciale esse, quod in casu hujus $\mathbb{\$}[$ scil., Inst.2.10.7] testamento succurritur.'

60 Voet, Commentarius ad Pandectas ( $4^{\text {th }}$ edn.), Bruxellis, Apud Simonem Serstevens, 1723, tom. 1, ad Dig.1.14.3, pp. 79-81. Voet insists on the validity of Barbarius' acts both for public utility ('ex aequitate et humanitate') and for the tacit approbation of the superior authority ('non propter communem errorem; sed propter designationem seu electionem, et discusso errore subsecutam tacitam comprobationem eorum, qui eligendi ac comprobandi potestatem habent', ibid., p. 80, n. 6$)$.

61 In this regard Zasius (Huldrych Zäsi, 1461-1535) provides a good example, as he bases his interpretation of the lex Barbarius on the distinction intruder/non intruder. Anyone who is not a mere intruder can be included in the scope of the lex. Zasius, ad Dig.1.14 (Dn. Vdalrici Zasii ... In primam Digestorvm Partem 
when the invalidity lies in the defect of the person appointed, not of the appointment itself. The appointment must be regular (both as to the procedure and as to the authority presiding over it). The title, therefore, is coloured only because of the incapacity of the person who received it. ${ }^{62}$

Admittedly, however, not all civil lawyers required anything other than public utility to apply the Barbarius principle. Sometimes a jurist is too succinct on the subject to draw any clear conclusion from his text. So for instance Hugo Donellus (Hugues Doneau, 1527-1591) invoked only public utility, but it is probable that he did so to deny the application of the lex Barbarius on the basis of

Paratitla, siue titulariae annotationes ... Basileae, Apvd Mich[aelem] Ising[rin], 1539, pp. 26-27, at p. 27): 'superioris autoritas, error communis, publica utilitas, excusant ab incompetentia magistratus uel officij; quod maxime procedit ad ante acta. At uero uitio detecto, uitiaretur futura administratio. Bart(olus) Alex(andrus Tartagni) in d. 1. Barbarius (Dig.1.14.3). Vnde si aliquis esset homo proprius, et in magistratu manumitteret alios, libertas ualet 1 . competit, infra qui et a quib(us) (Dig.40.9.19). Et ut gesta militaria in milite exautorato, sic gesta iudicialia in iudice excommunicato tolerantur quamdiu uitium latet. ... Vnde si Papa ignorans ordinat homicidam in sacerdotem uel episcopum, perinde habetur ac si sit cum eo dispensatum. Poterat enim dispensari: et hoc intelligas quo ad ante gesta. Nam uitio patente, remouendus est ut criminosus: secus si non extaret crimen. Bar(tolus) et Bald(us) hic latius. ... De praelato qui non rite eligitur sic habeas: Si sit de facto intrusus, nihil ualet quod per eum geritur. Si autem alias sui uitium, tunc necessarij contractus ualent, uoluntarij non, nisi quo ad fructus. Bald(us) diffuse post Bart(olum) in d. l. Barbarius, qui pro hoc allegat.'

62 This is particularly clear in Merlin's Répertoire $\left(4^{\text {th }}\right.$ edn., vol. 6, 1813), s.v. 'Ignorance', $\$$ II, p. 9, n. 9: 'Lorsqu'il s'agit d'actes fait par le ministère d'officiers publics que l'on ignorait être incapables d'y procéder, il ne suffit pas que l'erreur soit générale: il faut encore qu'elle soit fondée sur un titre coloré, c'est-à-dire, sur un titre conféré par celui à qui en appartient le pouvoir.' Cf. ibid. (vol. 4, 1812), s.v. 'erreur', p. 836, n. 6: 'Il fault cependant que cette Erreur publique ait quelque fondement et quelque apparence de régularité, en sorte qu'elle ne serve qu'à couvrir le vice qui se rencontre dans la forme du titre, ou dans la capacité de celui qui exerce des fonctions publiques. Car si un homme, sans aucun titre, avait fait quelques fonctions publiques, cet homme serait un faussaire; et tout ce qu'il aurait fait serait nul.' It should be noted that most of the répertoires written between the late eighteenth century and the early (or middle) nineteenth tended to reproduce what already found in other similar works. For instance, the last quotation from Merlin may be found verbatim in the earlier répertoire (its first edition dates to 1775-1783) of Joseph-Nicholas Guyot (1728-1816), Répertoire Universel et Raisonné de Jurisprudence civile, criminelle, canonique et bénéficiale ..., vol. 7 ( $2^{\text {nd }}$ edn., Paris: Visse, 1784), s.v. 'erreur', p. 71. This seems to attest (and might have contributed to strengthening) a widespread common opinion as to the need of coloured title, and its precise nature. 
the mere common mistake. ${ }^{63}$ Similarly, Philippus Decius (1454-1535) did not speak of coloured title either, but he clearly implied it. ${ }^{64}$ In case of (a few) other jurists, such as the French Jean-Baptiste Dantoine (d.1720), however, the insistence on public utility and the silence on coloured title would seem deliberate. ${ }^{65}$ If that were truly the case, then it might not be excluded that the discussions taking place in the seventeenth century among canon lawyers (which we are about to see) were - once again - having a strong influence on the civil lawyers. ${ }^{\mathbf{6}}$

63 Oswald Hilliger (ed.), Donellus Enucleatus sive Commentarii Hugonis Donelli de iure Civili in Compendium ... redacti ... Jenae, vol. 1, 1611, Sumptibus et typis Christophori Lippoldi, lib. 1, ch. 5, p. 9, not.a: 'Error igitur vulgaris est, communem errorem jus facere ... Error enim consensui, quem jus omne requirit, contrarius, absurdumque est jus, quod aequum et bonum, ex erroribus nasci.... In 1.3 de offic(io) Praetor(um) (Dig.1.14.3), quod acta Barbarii rata manent, ratio est commodum publicum, non error. ... Quae acta antea observata, non revocantur, non quia error jus faciat, sed propter utilitatem publica, quia multa facta fuerant, quae fiereri prohibentur.' Unlike most other jurists, Donellus excludes the case of the slave-witness from the scope of the lex Barbarius: there, the will was valid not because of common utility but for the specific permission of the emperor: 'quia imo testamentum eo casu (quando scilicet servus pro libero habitus testamentum signavit) ipso iure nullum, alioqui subventione Imperatoris opus non esset. Dicitur $\mathrm{n}(\mathrm{am})$ in $\mathrm{d}$ (icto) $\$ 7$ (Inst.2.10.7) liberalitate principis subveniri. Ergo non mero jure. Et non error, sed summa potestas Imp(eratoris) ac benignitas illius juris causa est ... quia ex illo errore facti nihil imputari potest testatori' (ibid.).

64 Decius, Consiliorvm sive Responsorum ... Philippi Decii Mediolanen(sis), vol. 2, Venetiis, Hieronymus Polus, 1580, cons.522, fol. 182va-b, n. 1-2 (on the validity of the election of the excommunicate). The same might be said of some commentaries on the customs of Paris, such as that of Ferrière. Claude de Ferrière, Nouveau Commentaire sur la coutume de la Prévoté et vicomté de Paris ..., tom. 2, Paris, Paulus-du-Mesnil, 1741, art. 289, p. 253.

65 Dantoine, Les Règles du Droit Civil, dans le même ordre qu'elles sont disposeés au dernier Titre du Digeste ..., Lion (sic), chez Claude Plaignard, 1725, rég. 175, pp. 518-519. Cf. Deroussin (2001), p. 221.

66 Either way, when the importance of public utility was highlighted and that of the coloured title downplayed or even ignored, sometimes the result was to stretch the application of the lex Barbarius even beyond the desired reach. A principle never put in question was that the lex Barbarius applied only to mistakes of fact, not of law. Stressing the public utility rationale of the lex Barbarius, however, could lead to a blurring of the difference between error iuris and error facti. Suffice it to recall two very different episodes that seem to clash with this summa divisio between fact and law. The first is to be found in Bijnkershoeck' Observationes Tumultuariae. There, Bijnkershoeck reports a dispute over the validity of the custom of Middelharnis, a town on the South Holland island of Goeree-Overflakkee, according to which two witnesses would suffice for a handwritten testament. The Senate of Holland, on 24.12.1705, accepted the point, but required more evidence on such a custom. Cornelii van Bijnkershoek ... Observationes Tumultuariae (Meijers, de Blécourt and Bodenstein [eds., 1926], 
By the late sixteenth century, a 'crowd of jurists' (iuris interpretum caterva) had already commented on the lex Barbarius. ${ }^{67}$ Thereafter, the crowd became an army. Among the most representative jurists of this ever-growing group mention might be made of Ernstius, ${ }^{68}$ Landus, ${ }^{69}$ Faber, ${ }^{70}$ Caldera, ${ }^{71}$ López Madera, ${ }^{72}$

vol. 1, obs.154, pp. 67-68). The interesting point is not whether the custom was eventually upheld, but Bijnkershoeck's comment that, if the people of Middelharnis did effectively believe in that custom, then the will would be valid according to the lex Barbarius. The second episode is the famous 'Mountrouge weddings' case of 1883. The mayor of Mountrouge (a town south of Paris) did not follow the provision of a law of 1837 , requiring mayors to follow a precise seniority order when delegating municipal counsellors to celebrate civil marriages. In principle, therefore, all the civil marriages celebrated in Mountrouge were void. As the mayor had ignored a law, the common mistake argument could not be invoked to make up for ignorantia legis. The court was however able to pronounce for the validity of the weddings by shifting the perspective: if the mistake of the mayor was on the law, that of the spouses was clearly on a fact the wrong belief that the public officer in front of them was competent to celebrate their marriage. See esp. Mazeaud (1924), pp. 943-944. Cf. Roland and Boyer (1986), vol. 2, p. 303. From this perspective, there seems to be a coloured title. But the court did not provide a definition of coloured title. This omission might have been deliberate, for coloured title traditionally consisted of a formally valid appointment whose only defect lay in the quality of the person appointed. Here, however, the mistake was clearly in the procedure itself. That might not be the first time that a French court tacitly applied the lex Barbarius to what ultimately was an error iuris. If we are to believe Loniewski (1905), pp. 24-25, the Parliament of Paris reached the same conclusion as early as in 1598, allowing the application of the lex Barbarius on a mistake of law.

67 The expression is of Mascardus, Conclusiones Probationvm, cit., tom. 2, concl. 648, fol. $37 r$, n. 1.

68 Henrici Ernstii ... Breviores annotationes in librum primum digestorum ..., in Gerhard Meerman (ed.), Novus thesaurus juris civilis et canonici, continens varia et rarissima optimorum interpretorum ... opera, Hagae-Comitum, Apud Petrum de Hondt, 1753, vol. 6, p. 852.

69 Constantii Landi ... in jus civile, sparsim contentarum exercitationum libellus, in Everhard Otto (ed.), Thesaurus Juris Romani $\left(2^{\text {nd }}\right.$ edn.), vol. 3, Trajecti ad Rhenum, apud Joannem Broedelet, 1733, col. 1404.

70 Antonii Fabri ... Rationalia In Pandectas: Ac Primum In Pandectarum partem primam ..., S. Gervasii, Ex Typis Vignonianis, 1604, ad Dig.1.14.3, p. 55.

71 Eduardo Caldera, Variarum lectionum, Matriti, Excudebat Cosmas Delgadus, 1614, lib. 2, ch. 7, fols. 31ra-34vb.

72 Gregorii Lopez Maderae ... Animadversionum juris civilis, liber singularis, in Otto (ed.), Thesaurus Juris Romani, cit., vol. 3, 1733, ch. 6, cols. 442-444. 
Constanus, ${ }^{73}$ Lycklama, ${ }^{74}$ van Bronkhorst, ${ }^{75}$ Cujas, ${ }^{76}$ Mascardus, ${ }^{77}$ Turnebus, ${ }^{78}$ Paezo (Plauzio Pezone), ${ }^{79}$ de Maqueda, ${ }^{80}$ Gabrieli, ${ }^{81}$ Kettwig, ${ }^{82}$ Schröter, ${ }^{83}$ Ackersdijck, ${ }^{84}$ Weißbrodt, ${ }^{85}$ Rasch, ${ }^{86}$ Campianus, ${ }^{87}$ Heineccius ${ }^{88}$ - the list

73 Antonii Guiberti Constani... Quaestionum juris memorabilium liber, in Otto (ed.), Thesaurus Juris Romani, cit., vol. 5, 1735, ch. 11, cols. 408-410, and ch.20, cols. 443-444, n. 8-14.

74 Marcus Lycklama, Membranarvm libri qvinque ... Franekarae, ex officina typographica Romberti Doyma, 1608, membr.1, ecloga 6, pp. 23-35.

75 Euerardi Bronchorst ... Enantiophanon centuriae quatuor, et Conciliationes eorundem ..., Francofurti ad Moenum, 1643, assertio 20, p. 20 ff. As I was not able to access Bronkhorst's volume, I relied on Rampazzo (2008), p. 409, note 193.

76 Iacobi Cviacii ... Observationvm et emendationvm, lib (ri) XVIII-XXIIII ..., Coloniae Agrippinae, Apud Ioannem Gymnicum, 1587, lib. 18, ch. 33, pp. 51-54.

77 Iosephi Mascardi Ivrisconsvlti ... Conclusiones Probationvm Omnivm qvae in vtroque Foro quotidie versantur ... Francofurdi (sic) ad Moenum, impensis haeredum Sigis. Feyrab., 1593, tom. 2, concl. 648, fols. 37r-41r, esp. fol. 38v, n. 16 (sacraments of occult heretics), fol. $38 v$, n. 17 (decision of occult excommunicated), fol. 40r, n. 57 (decision by invalidly appointed judge), fol. $39 v$, n. 51 (instruments of putative notary).

78 Adriani Tvrnebi Adversariorum Tomi III ..., Argentinae, Sumtibus Lazari Zenzneri, 1599, book 7, ch. 7, col. 198.

79 Camillus Plautius Paezo, in l. Barbarius De officio Praetoris singularia commentaria, Patavii, 1554.

80 Paulus de Maqueda Castellano, Commentaria haec, L. Barbarius Philippus III, ff. de officio praetoris ..., Salmanticae, excudebat Didacus à Cussio, 1615.

81 Commvnes conclusiones Antonii Gabrielii ... In Septem Libros distributae, Francofurti, impensis Rulandiorum, Typis Ioannis Bringeri, 1616, lib. 1 (De probationibus), concl. 8, pp. 44-46.

82 Mentetus Bebaeus Kettwig, Disputatio juridica inauguralis ad legem Barbarius Philippus, Franekarae, 1690.

83 Johann Wilhelm Schröter, Discursus legalis ad difficilem et intricatam l. Barbarius Philippvs ... Giessae, Friderici Kargeri, 1675.

84 Willem Cornelis Ackersdijck, Dissertatio juridica inanguralis ad L. 3. Digestorum de Officio praetorum ..., Trajecti ad Rhenum, ex officina Joannis Broedelet, 1757.

85 Johann Andreae Weißbrodt, Disputatio Juridica de Judice Putativo, ad L. Barbarius 3 de Offic. Praet. ..., Francofurti ad Viadrum, 1681, Typis Johan. Coepselli, 1681.

86 Petrus Rasch, Disquisitio juridica inauguralis ad L. Barbarius Philippus 3. D. de Officio Praetorum, Hardervici: apud Joannem Moojen [1783].

87 Augustini Campiani ... de Officio Et Potestate Magistratuum Romanorum Et Jurisdictione, Libri Duo, Genevae, Apud Marcum-Michaëlem Bousquet \& socios, 1725, pp. 222-237.

88 Io. Gottlieb Heineccii ... Elementa Ivris Civilis, secvndum Ordinem Pandectarvm comoda avditoribvs methodo adornata ( $6^{\text {th }}$ edn.), in Io. Gottlieb Heineccii ... Opervm ad Vniversam Ivris Prvdentiam ..., vol. 5, Genevae, Impensis Hered. Cramer, et Fratr. hilibert., 1748; anastatic reprint, Frankfurt am Main: Vico Verlag, 2010, pt. I, $1.14, \$ 205-207$, p. 59. 
could well go on. ${ }^{\mathbf{8 9}}$ By the sixteenth century, the questions of the common mistake and especially of the putative judge, notary and priest were ubiquitous and unremarkable. Any self-respecting jurist felt the need to mention the case of Barbarius, mostly in passing, between one erudite remark and the other. ${ }^{\mathbf{9 0}}$ Looking at each of them (from the early sixteenth century to the mid-eighteenth), wading through the forest of disputationes academicae, animadversiones, annotationes and the like would be pointless.

Similarly, if little could be gained from an in-depth examination of legal humanists, it is hardly for want of material. Combining historical with philological issues, the lex Barbarius was a honeytrap for legal humanists. If ambiguous statements such as Pomponius' 'quasi praetor non fuit' led to lengthy debates among modern scholars, they proved almost irresistible for the humanist jurists. ${ }^{91}$ Indeed virtually all of them dealt with Barbarius' case. Despite the

I am not even mentioning works such as Robertus' animadversiones or Costanus' Quaestiones, which touch upon the subject. It would probably be easier to compile a list of the jurists who did not mention Barbarius' case than those who did. For more jurists, especially early modern French ones, see Deroussin (2001), esp. pp. 221-228. See further the list in Lucifredi Peterlongo (1965), p. 25, note 75.

90 So for instance Campianus referred to Baldus when noting the relevance of the public office in the lex Barbarius. Although Barbarius does not become praetor, says Campianus, his acts are valid both because of public utility and because they are referred to a public office. But then the author moves on, and the crucial importance of the last point is lost. Augustini Campiani ... de Officio Et Potestate Magistratuum Romanorum, cit., p. 234: '... non reprobandum esse sententiam Baldus censuit, quia haec publicae utilitatis, et officii causa geruntur.' Cf. Rampazzo (2008), p. 434, note 280.

91 For instance, for Hotman the 'non' ought to be elided. Franc. Hotomani Ivrisconsvlti, Quaestionum illustrium Liber [Genevae], 1573, Excudebat Henr. Stephanus, q.17, pp. 128-136, at p. 131: 'Quo loco tollendam negationem, quis non videt? ... Quod cum ipsa meridie clarius sit, demiror tam multos in tanta luce caligasse.' In the same sense (but with a more refined and articulated discussion based on the overall meaning of the text) Cujas, Iacobi Cviacii ... Observationvm et emendationvm, lib[ri] XVIII-XXIIII ..., Coloniae Agrippinae, Apud Ioannem Gymnicum, 1587, lib. 18, ch. 33, pp. 51-54, at 52. See also Bachovius, ad Dig.1.14.3 (Reinhardi Bachovii ... Commentarii in primam partem Pandectarum..., Francofurti, Sumptibus Joannis Berneri ... Excudebantur Spirae Nemetvm, Typis Georgii Bavmeisteri, 1630, p. 320). Other humanists opted for more invasive philological surgery. In his Observationes ad ius atticum et romanum, for instance, Hérauld reconstructed the text as 'Ita evm servvm mansisse, qvasi non fverit praetor'. Didier Hérauld, Observationes ad ius atticum et romanum, in Desiderii Heraldi Quaestionum quotidianarum tractatus. Ejusdem observationes ad ius atticum et romanum, Paris, 1650, lib. 5, ch. 10, n. 2, p. 364. Other humanists preferred to use the lex Barbarius as a pretext for erudite historical digressions: see for all Govea, Antonii Goveani ..., Lectionvm Iuris Variarvm Libri duo, in 
amount of ink they spilled on the subject, however, their erudite discussions left the legal issues wholly untouched.

A typical example is Jacobus Gothofredus (1587-1652). The jurists of old, he noted, were extremely prolix on the lex Barbarius - Baldus for instance needed as many as three different lecturae to explain it! ${ }^{92}$ With the typical modesty of the humanist scholar, Gothofredus however stated that he would only need a few pages to finally shed some light on the matter and bring it back to its pristine state. ${ }^{93}$ All in all Gothofredus took the text to be original, save perhaps the final reference to the emperor, which could well be an unwelcome addition of the usual Tribonian. ${ }^{94}$ The main difficulty, he observed, is to tell Ulpian apart from Pomponius. ${ }^{95}$ After a long digression on historical and philological examples, Gothofredus agreed with the traditional civil law approach: the lex Barbarius requires public utility ${ }^{96}$ and a formally valid title. ${ }^{97}$

Declarationvm, Variarvm Lectionvm et Resolvtionvm Ivris Libri XXII, Diversorum Clarissimorum Iurisconsultorum Recentium ..., Coloniae Agrippinae, Apud Ioannem Gymnicum, 1599, lib. 1, ch.6, pp. 398-400. For further references on humanist jurists on the lex Barbarius see esp. Weißbrodt, Disputatio Juridica de Judice Putativo, cit., membr.1, n. 12 and 19, pp. 9-10 and 13-14 respectively, and Schröter, Discursus legalis ad difficilem et intricatam l. Barbarius Philippvs, cit., membr.1, dect.4, pp.9-10. For a more in-depth summary of other jurists with philological interests (especially Cujas, Hotman, Lycklama, Paezo, Gothofredus, Bachovius, and Faber) see Rampazzo (2008), pp.421-430, 441-444 and 447-463. See also the (shorter) analysis of Cujas, Faber and Gothofredus in Lucifredi Peterlongo (1965), pp. 20-28.

92 Gothofredus, De electione magistratus inhabilis seu incapacis per errorem facta, Dissertatio. Ad L. Barbarius Philippus 3.ff. de Officio Praetorum, Genevae, Sumpt. Ioannis Ant. et Samuelis de Tournes, 1654, ch. 1, p. 4.

93 Ibid., ch. 3, p. 11: 'Id quod nunc statuere iuuat: iam enim germanam lucem pristinamque sanitatem, quam dudum expectat, huic legi reddamus.'

94 Ibid., ch. 14, p. 27: 'si modo Vlpiani et non Triboniani hic versiculus est.'

95 Ibid., ch. 2, p. 7: 'Tandem Ulpiani verba a Pomponii sententia difficulter separes.' The part on Pomponius, concludes Gothofredus, must be emended as follows: 'Sed nihil ei seruitutem obstitisse ait Pomponius: quia, si Praetor non fuerit, adquin verum est, Praetura eum functum' (ibid., ch. 4, p. 11). The proposed emendations have the advantage of being limited in number, yet very significant as to their consequences. To reach the desired outcome, it is just sufficient to separate 'quasi' into 'qua' and 'si', and slightly massage 'atquin' into 'adquin' (ibid., ch. 4, pp. 11-12).

96 Ibid., ch. 10. p. 21: 'Humanius igitur in specie huius 1 . non vt stricto juri id opponatur, quod vulgus censet, verum vt in ambiguis id potius sequendum indicetur, quo absurdum vitetur, quoque communis vtilitas procuretur' (emphasis in the text).

97 Esp. 'nos vero versamur in casu, quo quis agendi substantiam habet, seu characterem et personam: ex electione publica et solemni' (ibid., ch. 14, p. 25), and 'Nos enim in eo casu versamur, vbi licet inhabilis incompetens seu incapax 


\subsubsection{The fonctionnaire de fait}

In-depth research on the application of the lex Barbarius by early modern and modern courts goes well beyond the scope of this work. But the subject should at least be mentioned to show its practical importance and the remarkable continuity between the medieval lex Barbarius and the modern de facto officer doctrine.

Many decisions relying on the lex Barbarius may be found in early modern European courts, from the Rota of Rome ${ }^{\mathbf{9 8}}$ to the Great Council of Mechelen. ${ }^{99}$ Early modern French courts often relied on Barbarius' case, especially on the validity of the acts of putative notaries and putative prelates. Many such

aliquis, secundum legem tamen creatus est: titulumque proinde habet' (ibid., ch. 14 , p. 26).

98 In scholarly literature little is to be found on the applications of the lex Barbarius by the Rota of Rome, but that is mainly because of the scarce scholarly interest in the twilight of the ius commune combined with the (similarly scarce) interest for practice-oriented sources. What can be found are just a few pages in Fedele (1936), pp. 374-376, and Agostinelli (1920), p. 61, notes 1 and 5. Both authors look mainly at some compilations of decisions of the Roman Rota, especially the collection printed in Milan in 1731, S(acrae) Romanae Rotae Decisiones recentiores in compendium redactae ... a nonnullis mediolanensis Athenaei sociis, Mediolani, 1731, vols. 1-4 and 6. Such collections however were seldom punctual, so a careful study among the early modern printed editions of the Rota's decisions would likely reveal more decisions on the subject. Among the most important decisions of the Roman Rota applying the lex Barbarius mention might be made of 4.11.1587 (ibid., vol. 2, dec.4), 5.5.1614 (ibid., vol. 3, dec.542), 12.5.1617 (ibid., vol. 2, dec.483), 23.5.1618 (ibid., vol. 2, dec.641), and 10.6.1695 (Sacrae Rotae Romanae Decisiones nuperrimae nunc primum collectae, Romae, apud Simonem Occhi, 1753, vol. 4, dec.391).

99 The reference is especially to its decision of 11.1.1628. The constitution of 21.3.1524 of Charles II of Burgundy (the emperor Charles V) allowed notaries to exercise their office only within the city where they were sworn in. After the rebellion against the Habsburgs, the provision was confirmed in 27.11.1608 (cf. Voet, ad Dig.1.14.3, Commentarius ad Pandectas, cit., p. 81, n. 7). In the small town of Zouteveen (south of Delft), however, there was no notary. So a notary of Delft was called there to draft a testament. Although the testament was then challenged because the notary lacked the authority to draft it, the Council of Mechelen invoked the lex Barbarius to pronounce for its validity. The case is described in Gehlen (2002), p. 57. Cf. also Dionysius van der Keessel, Theses Selectae juris hollandici et zelandici ad supplendam Hugonis Grotii introductionem ad jurisprudentiam Hollandicam, et definiedas celebriores juris Hollandici controversias, in usum auditorum vulgatae, Lugduni Batavorum, apud S. et J. Luchtmans, 1800, thesis 295, p. 98: 'Quamvis Notarii praxin exercere extra locum, ubi admisi sunt, prohibeantur, testamentum tamen coram iis ab eo, qui legem ignorabat, bona fide factum non videtur invalidum esse, Decis. Sen. Supr. 11. Jan. 1628' (emphasis in the text). 
decisions may be found from the Bailliage of Troyes (southern Champagne) ${ }^{\mathbf{1 0 0}}$ to the Parlements of Dijon, ${ }^{101}$ Toulouse, ${ }^{102}$ Poitou, ${ }^{103}$ and especially Paris. ${ }^{104}$ In the course of the nineteenth century the lex Barbarius principle, now increasingly referred to as fonctionnaire de fait theory, was applied far beyond the traditional cases of marriage and testament: ${ }^{105}$ from administrative deeds (the most obvious application of the lex Barbarius) ${ }^{\mathbf{1 0 6}}$ to contracts of sale by the owner-apparent and

100 See e.g. Legrand, Coutume De Bailliage De Troyes Avec Les Commentaires De Mr Louis Legrand ... $4^{\text {th }}$ edn., Paris, Chez Motalant, 1737, tit.6 (Droit des successions), art.97, gl.4, n. 32, p. 48, reporting an arrêt of 11.7 .1590 on a putative prelate, and another of 4.10 .1595 on a putative notary. Legrand himself noted that priests were expressly forbidden from drafting testaments (except for extreme circumstances) at least from the time of François I. Perhaps Legrand was referring to the specific custom of Troyes, for the custom of Paris (art.289-291) was rather clear in allowing prelates (specifically, the vicar of the parish in which the testator was resident) to draft wills. Cf. e. g. Claude Duplessis, Traitez de Mr Duplessis ... sur la Coutume de Paris ..., Paris, Chez. Nicolas Gosselin ..., 1699, pp. 716-717.

101 See e.g. the arrêt of 1656 of the Parliament of Dijon, pronouncing for the validity of a will where one of the witnesses was banished, but commonly believed not to be such. Cf. Merlin's Répertoire ( ${ }^{\text {th }}$ edn., vol. 6, 1813), s.v. 'Ignorance', $\mathbb{S I I}$, p. 9, n. 9.

102 For the Parliament of Toulouse an arrêt of 1587 is reported in Maynard, Notables et singulières questions de droit écrit, jugées au Parlement de Toulouse ..., Toulouse, chez François Henault, Jean-François Robert, 1751, vol. 1, ch. 64, p. 52, and another of 1608 in Loniewski (1905), p. 24. Both dealt with prelati putativi, but the first seems to be more interesting, as it focused on the presence of a coloured title to distinguish between praelatus putativus and mere usurper.

103 Joseph Boucheul reports an arrêt of the Parliament of Poitou of 30.12.1604, on the instruments made by a notary who was not 25 years old yet (and so, unable to discharge the office of notary). Boucheul, Coûtumier general, ou Corps et compilation de tous les commentateurs sur la cô̂tume du comté et pays de Poitou ..., Potiers, chez Jacques Faulcon, 1727, tom. 2, tit.13, art.376, n. 9, p. 607. Another case (later but undated) on the notary apparent is mentioned ibid., n. 6, p. 606.

104 So for instance a 1593 arrêt of the Parliament of Paris declared valid the testament made by the notary who did not take the required public oath. On this case see Loniewski (1905), p. 23; Boyer (1998), p. 51; Roland and Boyer (1986), vol. 2, p. 300. Cf. Duplessis, Traitez de Mr Duplessis ... sur la Coutume de Paris, cit., p. 715.

105 For these 'traditional' applications see e. g. Boyer (1998), pp. 52-61; See further Mazeaud (1924), p. 939; Loniewski (1905), pp. 111-116; Roland and Boyer (1986), vol. 2, pp. 299-306, and especially the impressive work of Deroussin (2001). Specifically on the occult incapacity to serve as witness (whether in a wedding or a testament) see Carillo (1842), vol. 14, s.v. 'Testimonio Instrumentario', $\$ 2$, pp. $749 a-758 b$ (especially foreigners commonly believed to be nationals, and minors or disertors commonly believed to be fully legally capable).

106 See esp. the decision of the Conseil d'État of 2.7.1807 (approving of the validity of the adminstrative deeds lacking the signature of a competent officer): Boyer (1998), p. 52. 
even ultra vires acts of company directors. ${ }^{\mathbf{1 0 7}}$ Thus, in France there is no solution of continuity between the medieval lex Barbarius and the modern theory of the fonctionnaire de fait. The same may be said of the German Scheinstandesbeamter doctrine. In a response of 30 May 1681, for instance, the University of Frankfurt an der Oder invoked the lex Barbarius to argue for the validity of the decisions of the judge regularly appointed but not sworn in. ${ }^{108}$ As in France, during the nineteenth century German courts widened the scope of the doctrine, ${ }^{\mathbf{1 0 9}}$ but the underlying rationale remained the same.

\subsection{Toleration in late medieval and early modern canon law}

Given the importance of canon law in the interpretation of the lex Barbarius, a few words might be spent to sketch its later developments. Unlike what happened with Baldus and the civil lawyers, however, late medieval and early modern canon lawyers did not progressively simplify the position of Innocent IV, but rather increasingly accepted its ultimate consequences. By the time that Innocent's influence on our subject started to wane among the civil lawyers, therefore, it became stronger in canon law.

\subsubsection{Toleration and sacraments}

We have seen earlier how the main thirteenth- and fourteenth-century canon lawyers accepted Innocent's doctrine of toleration in its main tenets, but not in its full scope. While Innocent's distinction between person and office proved extraordinarly popular, its implications on the sacramental sphere were downplayed. With few exceptions, ${ }^{\mathbf{1 1 0}}$ most canon lawyers rejected Innocent's position

107 See e.g. the cases in Mazeaud (1924), esp. pp. 937-959. Cf. Roland and Boyer (1986), vol. 2, p. 305 (on the sale by the owner-apparent - the case De la Boussinière of 1897).

108 Weißbrodt, Disputatio Juridica de Judice Putativo, cit., membr.3, pp. 34-35, n. 23.

109 E.g. Knütel (1989), pp. 359-363.

110 Among the canon lawyers writing between Innocent and Panormitanus, specific mention deserves Petrus de Palude (Pierre de la Palud, c.1275-1342). Interestingly, Palude was remarkably close to Innocent's positions on toleration also on a sacramental level - without however fully sharing the underlying reason, which in Innocent was legal representation. This is particularly clear on the subject of the confession to a putative prelate. In principle, says Palude, any obstacle as to the validity of the confession, whether occult or manifest, should preclude its validity: 'Queritur ... vtrum omne impedimentum quod si esset manifestum feceret confessionem iterari, quando est occultum faciat similiter iterari ... videtur quod sic: quia dicit extra de electione c. Dudum (X.1.6.54) quod per ipsum anime miserabiliter sunt decepte, quod non fuisset sic absolute, quod non 
on the validity of the excommunication issued by the occult excommunicate, ${ }^{\mathbf{1 1 1}}$ as well as the absolution by the putative prelate. ${ }^{112}$ From the fifteenth century,

tenetur amplius confiteri, ergo etc. Contra, quia sententia lata a seruo qui putabatur publice liber et pretor rata est: ac si impedimentum nullum fuisset, ergo a simili in proposito.' But if the confessor is the ordinarius (that is, the priest to whom the dignitas was conferred), and not someone delegated by him, then the same rationale as in the lex Barbarius applies: because of the common utility of his community, the common mistake - so long as based on justifiable ignorance - is sufficient to qualify the absolution as valid: 'Aut igitur confessor iste erat ordinarius, puta quia habebat parrochiam sibi intitulatam, et tunc valet absolutio per eum impensa; aut delegatus, vt quia habebat commendatam: et tunc non valet sicut in foro exteriori. Quod probatur dupliciter. Primo quia vtilitas publica prefertur priuate, vnde etc. propter vtilitatem eorum qui apud eum gesserunt ff. de offi(cio) preto(rum) 1. Barbarius Philippus (Dig.1.14.3), qui est in iudice ordinario coram quo tota communitas habet litigare: et melius est vunm impunitum relinquere quam tot innocentes ledere. Sed ex parte iudicis delegati, qui non habet cognoscere nisi inter priuatos versatur vtilitas priuata: nec debet rigor iuris communis relaxari propter vtilitatem paucorum ... Et quod dicunt tertio de falso procuratore [cf. Dig.47.2.43.1], dico quod vbi est probabilis ignorantia: vt quia prius fuit verus postea occulte fuit revocatus valet ... Et huic simile quod dicunt C. si a non compe(tenti) iudi(ce) per totum (Cod.7.48) vbi dicit non valere: nec distinguitur vtrum esset incompetentia publica vel occulta.' Ultimately, concludes Palude, the reason lies in that the remission of sins is part of iurisdictio, not of ordo: the toleration principle bestows strength on all the jurisdictional acts of the person who is tolerated in office, absolution included: illud quod a iure statuitur in vno casu, eo ipso statutum reputatur in simili: vnde cum supposita potestate ordinis vterque forus quo ad potestatem iurisdictionis sit eiusdem rationis: quod in vno statuetur quo ad hoc in alio reputabitur statutum. Et ideo est quinta opinio [i. e. that of Petrus himself], quod confessus bona fide habenti occultum impedimentum iuris positiui non tenetur amplius confiteri.' Petri de Palude ... quartus sententiarum liber [Coloniae Agrippinae], in officina Johannis parui [1514], dist.17, q.6, fols. 85ra-86va. For more details on the last part of Palude's reasoning see Wilches (1940), pp. 113-115. While Palude is influenced by Innocent (on whom he often relies), he stresses more the public utility argument than the representation mechanism. Even the distinction between ordinary and delegate judge (in our case, the titular of the office and the priest by him delegated) is entirely based on public vs. private utility: the delegate looks after a single case, the ordinary after the whole community. This different approach, however, can lead to the opposite conclusion from that of Innocent: when the delegate judge hears a number of cases, or the delegate priest hears a number of confessions, then the utility becomes public and so the deeds acquire validity. See further Wilches (1940), p. 91, text and note 3.

111 For the position of the main decretists writing after Hostiensis but before Panormitanus see Wilches (1940), pp. 155-156. See also Corsetti's Repertorium in opera Nicolai de Tudeschis, cit. s.v. 'error communis'.

112 This subject attracted more the decretists' attention, as the positive solution was not as daring as that on the excommunication. Nonetheless, most authors 
however, the sacramental implications of Innocent's doctrine of toleration began to be increasingly accepted. That was mainly because of the influence of the greatest canon lawyer of the first half of that century, Niccolò de' Tedeschi (1386-1445, better known as Panormitanus after his appointment as archbishop of Palermo). Not only did Panormitanus fully accept Innocent's concept of toleration, ${ }^{113}$ but he was also remarkably more explicit than most other canon lawyers in describing it in terms of legal representation. ${ }^{\mathbf{1 1 4}}$

Panormitanus' reliance on Innocent is particularly clear in his comment on X.1.6.44. There, Panormitanus distinguishes three main cases. The first is the most obvious scenario where the putative prelate can rely only on common mistake: he has neither title nor even possession of the office. As such, his deeds are clearly void: the lex Barbarius, says Panormitanus, requires common opinion as much as superior authority. Alone, common opinion does not suffice. ${ }^{115}$ The

preferred the negative conclusion. A reasoned list of the main decretists before Panormitanus may be found in the same Wilches (1940), pp. 111-119.

113 The only difference is that Panormitanus, as most fourteenth-century canon lawyers before him, applies the toleration principle also to the iudex delegatus. Panormitanus, ad X.1.3.22, $\$$ Quum dilecta (Super Primum Decretali $[$ um] Librum Commentaria, cit.): 'Inno(centius) ponit vnam singularem limitationem in hac materia, dicit enim quod materia legis barbarius non habet locum in delegato, ratio diuersitatis quia coram ordinario versatur vtilitas plurimorum cum multi ex necessitate habeant adire ordinarium et ideo communis error facit valere gesta sed in delegato non vertitur nisi vtilitas duorum seu partium. ... Moderniores communiter impugnant hoc dictum Inno(centii) et non immerito, nam textus videtur in oppositum iii q. vi $\$$ tria in verbo "verum" (C.3, q.7, p.c.1).' As we know, the limitation imposed by Innocent was not based on public utility, but on representation: the office acted through its proper representative, not the representative's delegate. Nonetheless, later authors did not have such scruples, especially after that Panormitanus had restricted the whole issue to the presence of public utility in the deeds of the delegate: see e.g. the already mentioned Philippus Decius as well as Henricus Henriquez (Enrique Henriquez, 1536-1608), on whom see Wilches (1940), pp. 94-100. By Lessius' times the position of the moderniores was by far the mainstream one: Lessius, De Ivstitia et ivre, Lovanii, ex officina Ioannis Masij, 1605, lib. 2, ch. 29, dubit.8, n. 66, p. 338. See further Wilches (1940), pp. 98-100; Miaskiewicz (1940), pp. 63-64; Herrmann (1968), pp. 84-87. Cf. also supra, pt. I, $\$ 4.2$, note 185.

114 On Innocent's influence over Panormitanus on the subject of toleration see Wilches (1940), pp. 156-158 and esp. Fedele (1936), pp. 355-356.

115 Panormitanus, ad X.1.6.44, \$Nichil (Super Primum Decretali[um] Librum Commentaria, cit.): 'Et primus casus sit quando gerebat se pro praelato tamen non erat in possessione et tunc indubitanter non valent gesta ... nec hoc casu communis error substineret gesta ex quo deficit possessio ... nec communis error iuuat, ex quo deest auctoritas superioris. Nam lex barbarius praeallegata (Dig.1.14.3) fundat se super communi errore et super auctoritate superioris. Nam ille seruus qui putabatur liber, habuit officium a superiore, et sic con- 
obvious outcome of this case serves as to better highlight the different position of the other cases: the prelate whose election or confirmation is vitiated, and the prelate who, having received valid confirmation, then commits some serious but occult crimes calling for his ipso facto deposition. In both second and third cases, argues Panormitanus, the deeds of the prelate remain valid. In the second case, despite the underlying defect in the election or confirmation, both common opinion and superior authority are present. ${ }^{116}$ By the same token, the deeds are valid also in the third case, which is the typical example of toleration in Innocent. ${ }^{117}$

As said, Panormitanus accepts without reservation Innocent's position and applies it on those jurisdictional matters bordering on sacramental issues. This means that Panormitanus applies the toleration principle both to the confession to the putative prelate and especially to the excommunication by the occult excommunicate. As to the confession to the putative prelate, Panormitanus is

currebant duo: scilicet, auctoritas superioris et communis utilitas. Secus autem vbi adesset vnum tantum, vt tenuit hic Inno(centius) et bene, et Baldus in repetitione dictae legis, Barbarius.'

116 Ibid.: 'Tercius casus cum quis se gerit pro praelato et habuit confirmacionem a superiore sed ex aliquo defectu non tenuit confirmacio vel electio et tunc gesta per ipsum non debent retractari ex quo alias legitime gesta sunt cum hoc cuncurrat auctoritas superioris et communis error. Vnde sumus in casu 1. barbarius praeal(legatae) (Dig.1.14.3) et factum tenet, iii q. vii $\mathbb{S}$ tria verbo "verum" (C.3, q.7, p.c.1), et in 1. si arbiter, C. de sent(entiis) et interlo(cutionibus) om(nium) iudi(cium) (Cod.7.45.2), et tenet sententia lata a delegato qui putabatur liber licet postea appareat eum fuisse seruum, sic ergo tenent gesta a delegato propter communem errorem et auctoritatem superioris, multo fortius debent tenere in ordinario in cuius offitio versatur maior vtilitas publica. Et idem dicendum in questione huius glo(ssae) [scil., Innocent's gloss on X.1.6.44 $\$$ Administrent, on which supra, pt. II, $\$ 7.1$, esp. note 6], nam ex quo iste electus habebat potestatem administrandi auctoritate huius iure, debent tenere omnia gesta alias legitime facta licet postea cassetur sua electio vel pronuncietur nulla. Et intelligo quando communis error concurrebat, ut quia putabatur communiter eum esse legitime electum, quod etiam sentit ista glossa.' On the possibility that the confirmation itself (and not just the election) is invalid, Panormitanus was perhaps somewhat more flexible than Innocent, although it may well be that Panormitanus was thinking of a case where the confirmation was simply voidable, not thoroughly void.

117 Panormitanus, ad X.1.6.44, $\$$ Nichil (Super Primum Decretali[um] Librum Commentaria, cit.): 'Quartus casus principalis cum is qui gerebat se pro praelato fuit electus et confirmatus seu prouisus per superiorem, tamen postea aliquid egit propter quod fuit priuatus ipso facto praelatura: puta quod incidit in heresim ... et tunc si ista priuatio fuit occulta tenent omnia gesta. Et idem videtur quando dubitatur de priuacione, ex quo tolerabatur in offitio debent tenere acta omnia interim gesta.' Cf. Fedele (1936), pp. 355-356; Wilches (1940), pp. 144-145, text and note 1 . 
careful to distinguish the intrusus commonly believed to be prelate from the putative prelate tolerated in office: only the second may validly exercise the office. It follows that the remission of sins does not depend on the faith of the penitent (as on the contrary still maintained by most canon lawyers), but on the power to bind and loose - and so, on the jurisdictional powers of the prelate tolerated in his office. ${ }^{\mathbf{1 1 8}}$ Panormitanus' position on the validity of the excommunication issued by the occult excommunicate is even more revealing of his close adherence to Innocent's position. In principle, Panormitanus says, someone who lies outside the Church should not be able to cast anyone else outside of it. Hence, he continues, most canon lawyers deny the validity of the sentence of excommunication issued by the occult excommunicate (with the problematic outcome of a void sentence that must be kept until the true status of the person who issued it would finally emerge). However, says Panormitanus, there is a 'remarkable statement' of Innocent IV against that, which is 'probably more true'. Excommunication pertains to the jurisdictional sphere. If tolerating the

118 On the one hand, the intrusus may not remit the sins even though he is widely believed to be validly exercising his office: 'Nota quod intrusus in beneficio non potest absoluere etiam in foro penitentiali: quamquam eum quilibet presbyter in ordinacione sua recipiat potestatem ligandi et absoluendi, illam tamen potestatem recipit in habitu non autem in actu ex quo non habet subditos ad hoc c. omnis vtriusque (X.5.38.12).' On the other hand, when the putative priest received a valid title, his absolution is valid: 'In glo(sa) in verbo "decepte", ibi “non credo quod perirent”, etc. [cf. Gloss ad X.1.6.54, $\$$ Decepte, supra, pt. II, $\$ 8.1$, note 9]. Signa istam particulam vsque ad finem et numquam tradas obliuioni, nam sepe numero practicatur dictum glo(sse) cum multi teneant beneficia minus canonice. Et potest dubitari nonquid valeant gesta per istum prelatum et respectu fori contentiosi seu respectu temporalioum dixi plene in c. nihil $s$ (upra) e(odem titulo) quo ad spirituali respectu fori penitentialis ... dicit Inno(centius) quod iste anime non erant decepte, quia ex quo habebatur pro prelato et tollerabatur a superiore vere absoluebantur ab illo, viii, q. iiii, nonne (C.8, q.4, c.1) [cf. Innocent, supra, pt. II, $\$ 7.5$, note 87] et ad tex(tum) potest dici quod anime decipiebantur quantum erat in isto prelato. Item potest dici, quod ex quo notorium erat illum non habere titulum canonicum in benefitio, quod vere decipiebantur anime, quia non datur tunc tolerantia. ... Posset tamen circa dictum glo(sae) dubitari, quid si aliquis esset intrusus, ita quod numquam habuisset superioris auctoritatem, nunquid gesta per istum in foro contentioso valeant, dic quod non. ... Sed in foro anime posset dici quod sic, propter fidem sacramenti ex quo subditi credebant illum esse prelatum, presertim cum non sit peccatum male intelligere ius positivum ... in his qui habuerunt [scil., istitucionem a superiore] et ex causa superuenienti fuerunt ipso iure priuati, et non obstante priuacione iuria tolerabantur non credo confessionem de necessitate irritandam, quia vt dicunt Inno(centius) et hosti(ensis) racione tolerantie vere iste absoluit per d(ictum) c. nonne (C.8, q.4, c.1).' Panormitanus, ad X.1.6.54, $\$$ Dudum (Super Primum Decretali $[u m]$ Librum Commentaria, cit.). Cf. Miaskiewicz (1940), pp. 56-57; Wilches (1940), pp. 119-123. 
occult excommunicate amounts to holding his deeds as valid, it follows that his sentence of excommunication, for public utility considerations, shall also be valid. ${ }^{119}$ Commenting on Innocent's distinction between what the excommunicate does in the exercise of a public office and as a private person, ${ }^{\mathbf{1 2 0}}$ Panormitanus comes back on the subject, linking together public utility considerations with legal representation in a remarkably explicit way. Whether the excommunication is manifest or occult, the person of the excommunicate always lies outside the Church. However, it is not the person qua individual who excommunicates, but rather the office he represents, which acts through the person qua legal representative ('et tunc gesta regulariter tenent favore iuris publici quia dignitas videtur exercere et non persona'). It follows that, so long as the person can still validly represent the office, the sentence of excommunication will be validly issued. ${ }^{\mathbf{1 2 1}}$

119 Panormitanus, ad X.1.3.41, \ab excommunicato (Super Primum Decretali[um] Librum Commentaria, cit.): 'Item pone exemplum in iudice excommunicato, nam excommunicatus maiori non potest alium excommunicare quia cum sit ipse extra ecclesiam non potest alium extra ecclesiam ponere vt in c. audiuimus xxiiii q. i (C.24, q.1, c.4) et ibi vide bo(nam) glo(ssam) et in summa eiusdem cause cadit tamen notabile dubium, si iudex occulte excommunicatus aliquem excommunicat, numquid teneat sententia? [cf. supra, \$6.4, esp. note 146] Et glo(ssa) tenuit in dicta summa excommunicationem esse nullam, licet debeat obseruari donec constiterit iudicem esse excommunicatum. Et ita communiter solent doctores tenere. Sed in contrarium ego allego singulare dictum Inno (centii) in c. si vere, i(nfra) de sen(tentia) excommuni(cationis) [cf. Innocent IV, ad X.5.39.34, supra, pt. II, $\mathbb{\$} 7.2$, note 15], vbi tenet contrarium, et forte illa opinio verior, quia excommunicatio est iurisdictio(nis) et ea quae fiunt a iudice non notorie excommunicato tenent ratione publicae vtilitatis vt in c. ad probandum, de re iudi(cata) (X.2.27.24).'

120 Cf. supra, pt. II, $\$ 7.3$, note 22.

121 Panormitanus, ad X.2.14.8, $\mathbb{}$ Veritatis ([Nicolaus de Tudeschis], Primae partis in Secundum Decretalium Librum Commentaria, Basileae [Wenssler], 1477). Because of its importance, the relevant parts of this text are here transcribed. 'Nunc venio ad glo(ssam): notat Inno(centius) quae $(s i c)$ versatur virca validitatem gestorum cum excommunicato seu per excommunicatum [cf. supra, pt. II, $\$ 7.3$, note 22] ... dico quod quedam geruntur ratione publici officij et illa valent si excommunicatus est tolleratus, ista quod communi opinione habebatur pro non excommunicato, l. Barbarius ff. de offi(cio) preto(rum) (Dig.1.14.3), iii q. vii <c.1, vers.> "verum" (C.3, q.7, p.c.1), tamen per Inno(centium) hic et in c. si vere de sen(tentia) exco(mmunicationis) (X.5.39.34), et in c. nichil, de electio(ne) (X.1.6.44) [cf. supra, pt. II, $\$ 7.3$, note 22 , and $\$ 7.1$, note 6 respectively] ... Si gesta sunt ab excommunicato qui communi opinione habebatur pro absoluto et hec communis opinio erat probabilis vt quia excommunicatio non erat publice lata, et tunc gesta regulariter tenent fauore iuris publici: quia dignitas videtur exercere et non persona, vt in l. barbarius ff. de offi(cio) pretoris (sic) (Dig.1.14.3), iii q. vii <c.1, vers.> "verum" (C.3, q.7, p.c.1); tamen est melius in c. ad 
Panormitanus' support of Innocent on the application of jurisdictional toleration to both the absolution by the putative prelate and the excommunication by the occult excommunicate of course did not entail immediate acceptance by all jurists. For instance, in the sixteenth century Mascardus still rejected both cases, ${ }^{122}$ although by and large canon lawyers increasingly accepted them. ${ }^{123}$ The problem of the validity of the absolution by a putative prelate was then developed especially by Francisco Suárez (1548-1617), who elaborated a more refined (and complex) theory that better defined the scope of the

probandum, de re iudi(cata) (X.2.27.24) in decisa, ubi valet confirmatio facta ab excommunicato tollerato ita et collatio et similia, et hoc communiter tenetur per doctores ... dixi regulariter quod dubitatur de validitate excommunicationis ab excommunicato tollerato late. Nam communis opinio videtur quod excommunicatio non teneat licet debeat obseruari donec constiterit excommunicatorem fuisse excommunicatum, ratio quia cum excommunicatus sit extra ecclesiam non potuit alium ponere extra ecclesiam ... Idem Hosti(ensis) et jo(hannes) an(dreae) recitando in c. pia de excep(tionibus) (VI.2.12.1) ... Inno(centius) in dicto c. si vere (X.5.39.34) sentit oppositum ex quo excommunicator tollerabitur et illa opi(nio) Inno(centii) videtur michi tutior et verior: quia ex quo tolerabatur dignitas et non persona, videtur excommunicare: que quidem dignitas excommunicata non est.' Cf. Innocent IV, ad X.5.39.34, \$ Circa temporalia, supra, pt. II, $\$ 7.2$, note 15. See also Panormitanus, ad X.2.27.24, $\$$ Ad probandum ([Nicolaus de Tudeschis], Tertiae partis in Secundum Decretalium Librum Commentaria, Basileae [Wenssler], 1477): ' $\ldots$ etiam in spiritualibus valent gesta ratione publici officij ab excommunicato tolerato quod est notandum ... dic tu quod hec fuit originaliter opinio Innocen(tii) in c. cum dilectus, de consue(tudine) (X.1.4.8), vbi posuit notabilem relatam quod in his que non geruntur ratione publici non est differentia inter excommunicatum publicum et occultum [cf. Innocent, supra, pt. III, $\$ 11.6$, note 119$]$ ]... Nam in istis cessat ratio publice vtilitatis. ... Venio ad secundum membrum principale, quando actum quem exercet talis excommunicatus competit ratione publici officij: et tenet Jo(hannes) Cal(derinus) quod siue sit actus temporalis, siue spiritualis communis opinio iuuat, arg. 3, q. 7, c. <tria, vers. $>$ "verum" (C.3, q.7, p.c.1), ff. de offi(cio) preto(rum) 1. barbarius (Dig.1.14.3) et $\mathrm{d}$ (icta) l. ii de sen(tentiis) et interl(ocutionibus) (Cod.7.45.2) in tex(to) nostro a contrario sensu. Hec dicit uera nisi sententia excommunicationis que non tenet lata ab excommunicato quantumqunque occulto ... Attende quia Inn(ocentius) expresse voluit contrarium in $\mathrm{d}$ (icto) c. si vere, de sen(tentia) excommuni(cationis) (X.5.39.34), vbi dixit tenere excommunicationem, collationem et similia a tolerato excommunicato lata, quia dignitas hec exercet, et non persona [cf. Innocent, supra, pt. II, $\$ 7.3$, note 22], et hec opinio forte verior, licet Jo(hannes) And(reae) in c. pia, de exce(ptionibus) li. 6 (VI.2.12.2) teneat primam [scil. opinionem] et communiter teneatur.' Part of this text is also transcribed in Fedele (1936), p. 344, note 74.

122 E. g. Mascardus, Conclusiones Probationvm, cit., tom. 2, concl. 648, fol. 38v, n. 33 and fol. $39 r$, n. 39 respectively.

123 For a reasoned list of decretalists on the two subjects see Wilches (1940), pp. 123-134 and 152-159 respectively. See further Herrmann (1968), pp. 88-90. 
ignorance as to the lack of jurisdiction of the confessor. ${ }^{124}$ The approach of Suárez met with great success among later canon lawyers and moral theologians alike. ${ }^{125}$ On the validity of the excommunication issued by the occult excommunicate, similar weight had the work of Thomas Sánchez (d.1616). ${ }^{\mathbf{1 2 6}}$ Sánchez sought to shield Innocent's theory from theological objections while accepting all its main points. ${ }^{127}$

The Council of Trent issued an important decretal on clandestine marriages, Tametsi. This decretal regulated the validity of marriage in stricter terms than before, as it required the sacrament to be performed by the spouses' parish priest or the priest by him validly delegated, before at least two witnesses. ${ }^{\mathbf{1 2 8}}$ After Tametsi, rather unsurprisingly, the case of the marriage performed by the putative prelate became a topos in canon law. It is difficult to find a canon lawyer - or a moral theologian - who did not write extensively on the issue. This of course also fuelled the debate on the similar problem of the absolution given by the putative prelate. ${ }^{129}$

\subsubsection{Coloured title}

Innocent's position, requiring both common mistake and superior authority, remained undisputed among canon lawyers - all the more after the staunch support of Panormitanus - and for a long time. Among the most important writers endorsing $\mathrm{it}^{\mathbf{1 3 0}}$ mention should be made of Navarrus (Martin de

124 R. P. Francisci Suarez ... De Sacramentis, pt. 2 ..., Venetiis, Ex Typographia Balleoniana, 1748, disput. 22, sect. 6, pp. 261-262.

125 See further Fedele (1936), pp. 368-374; Miaskiewicz (1940), pp. 90-98; Creusen (1937), p. 189.

126 Sánchez, Disputationvm de Sancto Matrimonii Sacramento Tomi Tres, Antverpiae, Apud Martinum Nutium, 1607, tom. 1, lib. 3, disp.22, q.3, n. 34-35, pp. 294-296.

127 Ibid., n. 35, p. 295: 'Quia cum adsit communi error facti, cum titulo, aequitas poscit vt omnino valeat quicquid gerit: quia dignitas potius quam persona agit.' On Sánchez's influence see Creusen (1937), pp. 189-191.

128 Concil.Trid., Sess. 24, c.1, de reform. matrimonii, Richter and Schulte (eds, 1853), pp. 216-218, at 217. On the - rather complex - history of this decretal see the monumental and recent study of Reynolds (2016), pp. 896-982, esp.977-982, where the author provides a summary of the scope of the decretal in its final form.

129 E.g. Fedele (1936), p. 362; Deroussin (2001), pp. 451-453, where further literature is listed.

130 A remarkably longer list of canon lawyers up to the late sixteenth century who adhered to Innocent's position may be found in Sánchez, Disputationvm de Sancto Matrimonii Sacramento Tomi Tres, cit., tom. 1, lib. 3, disp. 22, pp. 286-300, esp. q.5, pp. 299-300, n. 49-52. See also the (shorter but more representative) 
Azpilcueta, 1492-1586), ${ }^{131}$ Diego de Covarrubias (1512-1577), ${ }^{132}$ Thomas Sánchez (mentioned above), ${ }^{\mathbf{1 3 3}}$ Dominicus Tuscus $(1535-1620),{ }^{134}$ Leonardus Lessius (Lenaert Leys, 1554-1623), ${ }^{\mathbf{1 3 5}}$ Aegidius Coninck (Giles de Coninck, 1571-1633), ${ }^{136}$ Agostinho Barbosa (1589-1649), ${ }^{137}$ and Anaklet Reiffenstuel (c.1641-1703). ${ }^{138}$ While the majority of canon lawyers would continue to

list in Mascardus, Conclusiones Probationvm, cit., tom. 2, concl. 648, fol. 40v, n. 88. For a reasoned list of the most important followers of Innocent IV up to the 1917 Canon Law Code see Herrmann (1968), pp. 95-98; Miaskiewicz (1940), pp. 82-87. See also Wilches (1940), pp. 123-127 and 160-176; Fedele (1936), p. 367, note 122; Creusen (1937), pp. 188-191.

131 Azpilcueta, Enchiridion sive Manvale Confessariorvm et Poenitentivm ..., Mogvntiae, excudebat Balthasarvs Lippivs, sumptibus Arnoldi Mylii, 1601, ch. 9, n. 11, pp. 141-142: 'absolutio data ab eo, qui titulum habet, licet malum, a superiori, et virtute eius possessione accepit, non est irrita secundum Innocentium quem Panormitanus et communis ibi sequuntur, et idem dico de absolutione data ab eo, qui aliqua de causa bonum titulum, quo fruebatur, amisit: dummodo amissio illa non esset notoria.'

132 Covarrubias, Practicarum quaestionum liber vnus, in Didaci Covarrvvias ... Opera Omnia ..., Venetiis, apud Haeredem Hieronymi Scoti, 1581, tom. 2, ch. 19, n. 9 , p. 505 (on the notary who made a forgery). See also Id., In Bonifaci Octavi Constitvtionem, in Didaci Covarrvvias ... Opera Omnia ..., Venetiis, apud Haeredem Hieronymi Scoti, 1581, vol. 1, $\$ 7$, n. 9 , p. 398 and $\$ 11$, n. 4, p. 420 (respectively, on the validity of the jurisdictional acts of the occult excommunicated in general and specifically of his sentence of excommunication).

133 Sánchez, Disputationvm de Sancto Matrimonii Sacramento Tomi Tres, cit., tom. 1, lib. 3, disp.22, pp. 286-300, esp. q.5, n. 49-52, pp. 299-300.

134 Tuscus, Practicarum Conclusionvm Ivris in omni foro frequentiorvm Dominici TT.S. Onvphrii ... Card. Tuschi, ( ${ }^{\text {rd }}$ edn.), Lvgdvni, ex Officina Ioannis Pilehotte, sumpt. Ioannis Caffin, \& Francisci Plaignard, 1634, tom. 3, concl. 330, esp. p. 146, n. 8.

135 Lessius was one of the first authors who explained the toleration principle in terms of supplied jurisdiction provided by the Church for public utility, thereby leading to the formulation of the supplet ecclesia principle in the 1917 Codex Iuris Canonici (CIC). Lessius, De Ivstitia et ivre, lib. 2, ch. 29, dubit.8, n. 67, p. 339: 'Supradicta locum habere, non solum in foro contentioso, sed etiam in sacramentali ... Ecclesia defectum iurisdictionis non minus hic, quam in foro externo supplere potest, et vult, concurrente titulo colorato, et communi errore.' Cf. 1917 CIC, lib. 2, pt. I, tit.5, can.209: 'In errore communi aut in dubio positivo et probabili sive iuris sive facti, iurisdictionem supplet Ecclesia pro foro tum externo tum interno.'

136 De Coninck, Commentariorvm ac Disputationvm in Vniuersam doctrinam D. Thomae De Sacramentis et Censvris Tomi Duo, Antverpiae, apud Haeredes Martini Nvtl, 1619, tom. 2, disp. 8, dub. 3, concl. 6, n. 22, p. 470.

137 Barbosa, Augustini Barbosae ... Pastoralis Solicitudinis, sive De Officio et Potestate Episcopi ..., Venetiis, 1707, Apud Natalem Feltrini, tom. 1, pt. II, alleg.32, n. 94, p. 337 (on the marriage celebrated by the parrochus putativus).

138 Reiffenstuel, Jus Canonicum Universum clara methodo ivxta titulos qvinque librorvm Decretalium in Quaestiones distributum .... Monachij, Sumptibus Viduae et 
require both public utility and the intervention of the superior authority (often describing the latter as 'coloured title'), from the beginning of the seventeenth century others began to highlight the importance of public utility, arguing that it sufficed for the validity of the jurisdictional acts even without any title. ${ }^{139}$ Probably the first to maintain as much was Basilius Pontius (1569-1629) in his treatise on marriage (first printed in 1624).

Any modern canon law work on supplied jurisdiction seems to cite Pontius, without however necessarily examining his approach. We have often seen that medieval jurists discussed putative jurisdiction moving from the lex Barbarius (or its canon law equivalent, Gratian's dictum Tria), then focusing on the jurisdiction of the excommunicated judge and typically concluding with the false or excommunicated notary. The same occurred with most early modern canonists until Pontius. Pontius wanted to reach the opposite conclusion: public utility suffices despite the lack of a coloured title. To do so he inverted the scheme, starting first with the notary. The advantage of doing so was clear: the case of the notary marked the outer boundaries of the toleration principle, so that his deeds were regarded as valid only in rather limited situations. Only a true notary could be tolerated in office after his deposition, so long as that remained occult. Being quite selective in his citations, Pontius led his reader to believe that the common opinion among the jurists was on the contrary in favour of the validity of the false notary's instruments. ${ }^{140}$ Pontius' arguments might not strike as compelling. But the strictness of the decretal Tametsi made urgent to widen the scope of the toleration principle, lest any marriage not celebrated by the parrochus or his delegate would be void. ${ }^{\mathbf{1 4 1}}$ Indeed, it is probably not fortuitous that Pontius allowed for the validity of the acts of the intruder only with regard to the parrochus putativus.

Haeredum Johannis Hermanni à Gleder, 1700-1702, lib. 2 (1700), tit.1, $\$ 8$, n. 199, p. 29. For a specific application see ibid., lib. 1 (1700), tit.3, $\$ 10$, n. 234, p. 221 (on the expiration of the mandate).

139 R.P.M.F. Basilii Pontii ... De sacramento matrimonii tractatvs cum appendice de matrimonio catholici cum haeretico ... Venetiis [Combi.], 1645, lib. 5, ch. 20, n. 1-9, pp. 224-225.

140 Ibid., n. 5-6, pp. 224-225. Pontius' selective quotations allowed him to overcome the objections of a contemporary and highly authoritative jurist, Thomas Sánchez. On the subject, Sánchez was merely the last of a very long series of canonists, but Pontius' readership was familiar with him. This might explain Pontius' efforts to describe Sánchez (and not himself) as going against the common and consolidated opinion of canon lawyers (ibid., n. 5-7).

141 See esp. Iacobi Pignatelli ... Consvltationvm Canonicarvm ..., tom. 6, Venetiis, Apud Paulum Balleonium, 1688, cons.3, pp. 6-8, esp. p. 7, n. 14-16. 
From Pontius onwards, starting with Johannes Sanctius (Juan Sánchez), ${ }^{\mathbf{1 4 2}}$ an increasing number of authors started to follow this new - and simpler approach. While the old position of Innocent probably remained the majority one, ${ }^{143}$ the 'new' doctrine became increasingly widespread among canonists. ${ }^{\mathbf{1 4 4}}$ Ignoring the position of those Ultramontani who said as much centuries before them, they stressed the novelty of their approach, ${ }^{145}$ which ultimately culminated in the Canon Law Code of 1917 and the omission of the need of coloured title. ${ }^{146}$

\subsection{Bellapertica the American (or, a hint at the common law side of things)}

Early modern canon lawyers were not the last to reach the same conclusions as Bellapertica. The honour belongs to nineteenth-century American judges. In their defence, however, it must be said that the de facto officer doctrine had a different history in England, and its connection with its Continental sister is somewhat doubtful.

The starting point in common law is usually identified with the Abbot of Fountain's case (1431). ${ }^{147} \mathrm{~A}$ new abbot of Fountain was elected with a minority of votes. Although the election was invalid, this abbot exercised his office for a while. When another abbot was lawfully elected, he was confronted with some obligations undertaken by his unlawfully appointed predecessor, who had purchased some goods for the abbey using its seal. ${ }^{148}$ Confronted with one such sealed bonds, the new abbot refused payment arguing that the person who

142 Sanctius, Selectae, illaeque practicae disputationes de rebus in administratione sacramentorum, Venetiis: Apud Bertanos, 1639, disp.44, n. 3, in fine, p. 275.

143 The point was also acknowledged by Pontius' followers: see the list of excerpts in Miaskiewicz (1940), p. 85, note 164.

144 For a list of the main ones see Miaskiewicz (1940), pp. 85-87. Cf. Wilches (1940), pp. 176-186; Fedele (1936), pp. 366-367, esp. note 122.

145 As stated by a pre-eminent canonists and moral theologian of the seventeenth century, Antoninus Diana (1585-1663): 'Notent hoc Confessarii, quia haec opinio est nova, et satis probabilis, et ex illa bono communi magis consulitur, quam si praeter communem errorem titulus quoque foret necessarius.' R.P.D. Antonini Diana ... Coordinati, seu Omnium Resolutionum Moralium ... Tomus Primus, Venetiis, Ex Typographia Balleoniana, 1728, tract.3, De sacramento poenitentiae, resp.19, n. 3, p. 67. Cf. Miaskiewicz (1940), p. 86.

146 Supra, this paragraph, note 135. See further inter alios Deutsch (1970), pp. 189-190.

147 YB 9 H. 6, fols. $32 v-34 v$, pl.3 (1431).

148 While the consequences of sealing a document in common law are obvious, it might be interesting to observe that the sigillum was one of the main features of a corporation in canon law, and its use was left to the person representing the same corporation. See e. g. Gillet (1927), p. 154. 
had used the seal was a mere usurper. In canon law, that might have sufficed. The problem, however, was how to frame that defence in a common law court. Pleading a general issue would have left the whole business to the jury (which would have likely found against the abbot). Pleading confession and avoidance would have had similarly little hope of success. What the abbot needed was to show that the plaintiff had only an apparent cause of action, not a true one (that is, just colour). The problem was that the plaintiff's colour looked quite strong. The best defence in substantive terms - the fact that the previous abbot was just a usurper - could not be translated in procedural terms, for it would have amounted to claiming that the plaintiff lacked any colour as abbot. Such a claim would have been plainly false, and indeed the court dismissed it at once. ${ }^{149}$ The Year Book does not report the outcome of this case, only the difficulties of the abbot as to how framing his plea. From what the Year Book does report, however, it seems quite likely that the court held the bond as valid. This seems also the opinion of most of the (admittedly few) extant decisions on the subject from the late sixteenth century onwards.

The first of them, Knowles v Luce (1580), was on surrender and admittance of copyhold tenure before a steward of the manor who lacked proper title. ${ }^{150}$ The King's Bench highlighted the difference between possession of coloured title (colour \& nul droit) and mere usurpation of an office (n'ad colour ne droit). The coloured title of the steward, argued the Bench, is sufficient to hold a court because the tenants are not obliged to examine the authority of the steward, nor should the steward give account to them. ${ }^{151}$ More such decisions on the subject begin to be found shortly thereafter, ${ }^{152}$ especially with regard to invalidly appointed or irregular officers. ${ }^{153} \mathrm{Up}$ to the end of the seventeenth century, it

149 YB 9 H. 6, fol. 32v, per Strange J. See inter alios Constantineau (1910), pp. 9-10; Dixon (1938), pp. 289-290.

150 Knowles v Luce (1580) Moore 109; 72 E.R. 473.

151 Knowles v Luce (1580) Moore 109, 112; 72 E.R. 473, 474 (per Manwood J, referring to the Abbey of Fountain's case).

152 On copyhold tenure and de facto stewards see further Rous v Arters (1587) 4 Co. Rep. $24 a$; 76 E.R. 927; Dillon v Freine (1589) 1 Co. Rep. 120a; 76 E.R. 270; Harris vJays (1599) Cro. Eliz. 699; 78 E.R. 934; Parker v Kett (1697) 1 Ld. Raym. 658; 91 E.R. 1338. Most works on the early cases of de facto officers also cite Coke's report on Tey's Case (5 Rep. 38a-b, Trin. 34 Eliz.) because of the application of the maxim 'fieri non debuit sed factum valuit' (ibid., 38b) to an unjust fine, but it is difficult to find a link between that case and our subject.

153 The first known case on the subject is Leak v Howell (1596), Cro Eliz. 533; 78 E.R. 780 , on duties paid to a de facto deputy customer (on which see Pannam [1966-1967], p. 40). Other cases include Knight v Corporation of Wells (1695) Lutw. 508; 125 E.R. 267; R. v Pursehouse (1733) 2 Barn. K.B. 264; 94 E.R. 490; R. v Malden (1767) 4 Burr. 2135; 98 E.R. 113. See further Pannam (1966-1967), p. 41. 
would seem that the courts followed the double standard imposed by Knowles $\mathrm{v}$ Luce: common mistake and coloured title are both necessary. At the beginnig of the eighteenth century the King's Bench however seemingly changed position with Parker v Kett (1701). ${ }^{\mathbf{1 5 4}}$ There, the Bench decided that the surrender of copyhold in fee tail made to the de facto deputy of a deputy-steward was a good surrender, despite the lack of any title, even a coloured one. The reputation of being steward sufficed: 'such steward is no other, than he who has the reputation of being steward, and yet is not a good steward in point of law.' ${ }^{155}$ Although references to the need of coloured title may be occasionally found thereafter, ${ }^{\mathbf{1 5 6}}$ English courts no longer required it. ${ }^{157}$

Pace Innocent IV, common law developed its doctrine of de facto officer without any significant reference to legal representation and toleration doctrine. ${ }^{158}$ Requiring the presence of a coloured title was ultimately only a way to distinguish de facto officers from intruders, not a consequence of representation. Admittedly, the connection with representation was lost also by early modern civil lawyers. But the weight of previous authorities was often stronger in civil law than in common law. English courts found easier to dismiss the requirement of coloured title than their Continental counterparties.

By contrast, coloured title remained a prerequisite in the American approach to the de facto officer doctrine. While the rationale of the doctrine was clearly the protection of third parties in good faith (and so public utility triggered by the common mistake), ${ }^{\mathbf{1 5 9}}$ the coloured title could not be disregarded. As late as in all the official acts of the Lancaster kings as de facto sovereigns ('late kings of England successively in dede, and not of ryght', 1 Edw. IV. c. 1). Despite the point is often mentioned in relation to our subject, from the available case law it would seem that the bench did not look at corporation theory when deciding on de facto officers. Something not too different from the Act of Parliament above happened in the United States in the aftermath of the Civil War, with the often quoted decision of the US Supreme Court in Texas v White, 74 US (7 Wall.) 700 (1868).

159 Esp. Norton v Shelby County 118 U.S. 425, 442 (1886) (per Field J): 'The doctrine which gives validity to the acts of officers de facto, whatever defects there may be in the legality of their appointment or election, is founded upon considerations of policy and necessity, for the protection of the public and individuals whose 
the mid-nineteenth century, the US Supreme Court was adamant on the need of coloured title. ${ }^{160}$ It was only in the early 1870 s that American courts relented on the subject, and began to consider the coloured title only as one of the possible elements for such an officer. On the point, the most important decision is State v Carroll (1871), ${ }^{\mathbf{1 6 1}}$ which provided the standard definition of $d e$ facto officer. ${ }^{162}$ In that case, the existence of a de facto officer was questioned on the basis of a rather strict interpretation of coloured title, for the appointment had been made under a statute then found to be unconstitutional. Innocent IV would have likely approved, but the Connecticut Supreme Court did not. When reading the reasons put forward by the Court, it is difficult not to think of an up-to-date version of Bellapertica. ${ }^{163}$ Subsequent case law clarified the

interests may be affected thereby. Officers are created for the benefit of the public, and private parties are not permitted to inquire into the title of persons clothed with the evidence of such offices and in the apparent possession of their powers and functions. For the good order and peace of society their authority is to be respected and obeyed until in some regular mode prescribed by the law their title is investigated and determined.'

160 See esp. Worth v Mattison 59 U.S. (18 How.) 50 (1855). See further Wallach (1907), pp. 479 and 481-483; Constantineau (1910), pp. 127-139.

16138 Conn. 449; 9 Am. Rep. 409. The salient parts of the decision may also be read in Goodnow (1906), pt. 2, pp. 144-149. Cf. Tooke (1927-1928), pp. 944-946.

162 'An officer de facto is one whose acts though not those of a lawful officer, the law, upon principles of policy and justice, will hold valid so far as they involve the interests of the public and third persons, where the duties of the office were exercised: First, without a known appointment or election, but under such circumstances of reputation or acquiescence as were calculated to induce people, without inquiry, to submit to or invoke his action, supposing him to be the officer he assumed to be. Second, under color of a known and valid appointment or election, but where the officer had failed to conform to some precedent requirement or condition, as to take an oath, give a bond, or the like. Third, under color of a known election or appointment, void because the officer was not eligible, or because there was a want of power in the appointing or electing body, or by reason of some defect or irregularity in its exercise, such ineligibility, want of power, or defect being unknown to the public. Fourth, under color of an election or appointment by or pursuant to a public unconstitutional law, before the same is adjudged to be such' (text in Goodnow [1906], pt. II, p. 147).

163 'The de facto doctrine was introduced into the law as a matter of policy and necessity, to protect the interests of the public and individuals, where those interests were involved in the official acts of persons exercising the duties of an office without being lawful officers.... But to protect those who dealt with such officers when apparent incumbents of offices under such apparent circumstances of reputation or color as would lead men to suppose they were legal officers, the law validated their acts as to the public and third persons, on the ground that, as to them, although not officers de jure, they were officers in fact, whose acts public policy required should be considered valid. It was not because of any quality or character conferred upon the officer or attached to him by reason of any defective 
scope of the doctrine, ${ }^{\mathbf{1 6 4}}$ but did not alter its main tenets nor added much to its rationale. ${ }^{165}$

election or appointment, but a name or character given to his acts by the law, for the purpose of validating them' (text in Goodnow [1906], pt. II, pp. 145-146, emphasis in the text).

164 See on the point the extremely detailed study of Constantineau (1910) and the more recent work of Pannam (1966-1967), pp. 50-57, and Clokey (1985), p. 1126, where further literature is listed. The same Clokey provides a reasoned list of the main reasons invoked in support and against the de facto doctrine in the American case law from the 1960s onwards ibid., pp. 1128-1139.

165 Among the most recent decisions on the subject should be mentioned Ryder $\mathrm{v}$ United States (94-431), 515 US 177 (1995). In this case the US Supreme Court pronounced against the de facto validity of the decision of a panel of judges invalidly appointed. Nonetheless, it did so because there was no mistake on the validity of the appointment, as the petitioner had immediately objected to the composition of the court. Without a common mistake, there was clearly no public utility consideration at stake. Interestingly, instead of briefly dismissing the point, the Court looked at its main decisions on the subject, mainly those of the late nineteenth century, so as to stress their importance. See esp. Norton $\mathrm{v}$ Shelby County, 118 US 425, 441-442, 446 (1886); Ball $\mathrm{v}$ United States, 140 US 118 (1891); McDowell v United States, 159 US 596, 601-602 (1895). 


\section{Conclusion}

The obvious way to conclude this book would be to provide a summary of what has been said in its various chapters: the interpretation of the lex Barbarius provided by the Accursian Gloss, the difference between Citramontani and Ultramontani, the approach of the canon lawyers and in particular of Innocent IV to the similar problem of the occult heretic, the influence that Innocent had on Baldus, the originality of Baldus' own approach, his distinction between internal and external validity of agency, and the progressive misunderstanding and simplification of Baldus and Innocent, leading eventually to the crystallisation of the double requirement of coloured title and common mistake.

Another and perhaps more interesting conclusion could be wondering whether it was really necessary to follow all those twists and turns in the road leading from Accursius to the formation of the de facto officer doctrine. Because of the non-linear development of our subject, both answers are possible. Better stated, given the complex historical development of the subject, the question itself may have two different meanings. If the question is whether this complex analysis was needed to make sense of the later developments of the subject, the answer seems to be negative. For instance, there is little connection between the Ultramontani and Baldus. It might therefore be possible to skip the first without compromising too much our understanding of the second. Similarly, because the position of Innocent came to be progressively simplified, the elaborate approach of Baldus was also generously and increasingly pruned until both authors (Innocent and Baldus) came to be interpreted as saying more or less the same thing. An in-depth analysis of their specific arguments is therefore not necessary to understand the approach of later jurists.

If however our question is whether this lengthy analysis was necessary to make sense of the route - and not just of the point of arrival - then the answer seems to be different. It is only with hindsight that the solutions of the Bolognese jurists first and then also of the French ones could be considered outdated and so less important. The influence of canon law on the civil lawyers' interpretation of the lex Barbarius was not something that was bound to happen sooner or later. It is also only with hindsight that certain interpretations may be relegated to a secondary rank: in their heyday they ranked among the most advanced positions on the subject. To understand why Baldus ventured into his complex reasoning on Barbarius' case, therefore, it is not possible to avoid (nor to shorten too much) either the Accursian position or the Orléanese dissent. The jurists of Orléans fully exposed the limits of the reading of Accursius, and those limits also became increasingly clear among the Citramontani. Any solution to 
the Barbarius problem leading to the ratification of the slave's praetorship would necessarily have meant approving of Accursius' much-criticised position. So Baldus had to adapt Innocent's concept of toleration to a different scenario - one in which the agent was never validly appointed. It is because of this added difficulty that Baldus came to distinguish so clearly between the internal and external validity of agency.

Perhaps the most important element in this study has been the progressive influence of canon law on civil lawyers. Overlooking the role of canon law, the whole development of our subject from the second half of the fourteenth century onwards would simply not make sense. Thus, the canon law concept of toleration of the jurisdiction of the unworthy provides a remarkably good example of the profound influence that canon law had on civil law, especially on its growing (proto-)public law component. In turn, the same idea of toleration allows a look at the rapid passage from ecclesiological to legal concepts within canon law itself (or rather, at the progressive crystallisation of ecclesiastical principles into legal rules). With specific reference to the concept of toleration, it seems hardly fortuitous that this passage culminated with a canonist as legally minded as Innocent IV.

One of the few authors who noticed the crucial importance of Innocent IV's position for the development of the lex Barbarius and the modern de facto officer theory lamented that the pope did not bring that theory to its 'logical' (i.e. modern) conclusions. In insisting on both the election and especially the confirmation by the superior authority, this author said, Innocent subordinated public utility considerations to the presence of a valid title. As such, the ignorance as to the true condition of an office holder could not shield third parties in good faith from the consequences of their mistake. ${ }^{1}$ If we were to look at the same issue from Innocent's perspective, however, it would be our modern interpretation that appeared curious, for such an approach would entail forsaking the basic principles upon which the entire structure of legal representation was built. As a lawyer, Innocent never had much doubt that the system was more important than the man. If one of them had to be sacrificed, it was not going to be the system.

The most 'advanced' solution, advocated especially by the American courts from the second half of the nineteenth century, was in fact almost as old as Innocent's one. Ultimately, it was the same approach as Bellapertica's: public utility suffices. It is however telling that this solution was first (and for a very long time, only) proposed by civil lawyers - and not by canon lawyers.

1 Fedele (1936), p. 344. Fedele extended the same critique to Panormitanus, for having adhered too closely to Innocent's position without realising its shortcomings (ibid., p. 357). 
Jettisoning the requirement of valid title (thus the link with the superior authority) to the exclusive benefit of public utility would have exposed nearly any ecclesiastical office to serious threat. The threat was as much legal as it was political, for it would have undermined the hierarchical structure of the Church itself. Confirmation in office by the superior ecclesiastical authority had a clear centripetal effect: shifting the decision-making process higher up in the Church hierarchy. Innocent's insistence on the need of confirmation in any case, and without any exception, had a deliberate centralising aim. Subordinating the toleration principle to confirmation in office avoided clashes with that aim. Far from challenging the central role of confirmation, tolerating the unworthy in office highlighted its importance: the unworthy retained his office because of the superior authority's confirmation - not because of those who elected him in the first place. The legal consequence of this approach was that the toleration principle could work only to extend the initial validity of the appointment, not to replace it. Hence the office could be exercised only by the agent who was fully entitled to represent it. External validity of agency was a consequence of internal validity - a deliberate consequence. Innocent rejected our 'modern' solution not because he could not see it, but because it would have not made much sense to him.

Innocent's concept of toleration meant thinking of individual offices in terms of legal representation. This might appear obvious to the modern reader, but it was remarkably innovative. Corporation theory was developed mostly, if not only, with regard to universitates. For individual offices, it was much easier to think of individual persons vested with specific powers than of different subjects from the physical persons acting for them. Here lies the genius of Innocent: applying the basic principles of legal personality also to individual offices. A bishop is both the physical person anointed as successor of the Apostles and the legal representative of an office. What he does qua legal representative cannot be done qua individual. The same can be said of any prelate and, more broadly, any holder of a public office (an officium, not a simple munus). With Innocent, jurisdictional toleration becomes a manifestation of legal representation. And it applies only to individual offices precisely because of the identification between representative and office: the formation of the will of the office, and its external manifestation towards the thirds, is entrusted to the single individual qua representative. But if the agent were to consist of a plurality of individuals (as in the cathedral chapter) then no single individual could be considered the legal representative, and so it would be possible to exclude any of them from the relationship with the office. With individual offices it is precisely the impossibility of doing so that leads to the toleration of the person as representative of the office. This toleration is however based on the possibility of distinguishing the person as individual from the person as representative, and predicating the 
validity of the representation not on the basis of the condition of the individual, but exclusively on the link with the office. Representing the office, the person $q u a$ individual gives way to the person qua agent.

If the identification between agent and office allowed Innocent to develop his concept of toleration as a manifestation of legal representation, it also set firm boundaries on its further development. The difference between Baldus and Innocent lay in the symmetry between internal and external sides of agency. For Innocent, toleration ultimately prolonged the validity of the agency relationship - hence the person unworthy qua individual could still validly discharge the office qua agent. The external validity of agency (the relationship between office and third parties), therefore, depended on its internal validity (the relationship between agent and office). The office could act validly because - and insofar as the person could validly represent the office. Baldus severs that symmetry, and argues for the external validity of agency despite the invalidity as to its internal side. The slave Barbarius is praetor 'with regard to the others' but 'not to himself, he is 'nothing as to himself but 'something as to the parties litigant'. ${ }^{2}$ The difference depends on the relationship between agent and office. Baldus could oppose internal invalidity to external validity because he kept agent and office more distant from each other than Innocent. What Innocent did was to some extent the very opposite of what previous civil lawyers did: instead of smothering the office with the person (qua individual), smothering the person (qua agent) with the office.

Baldus' reading of the lex Barbarius sought to avoid this identification between agent and office. The agent would still lack the right to act in the name of the office, but the office could nonetheless act validly towards third parties. The way Baldus came to sever the symmetry between internal and external validity of agency, however, cannot be explained just as the outcome of an abstract reasoning. It must be read against the background of contemporary dicussions on the subject.

We have seen that Baldus also hinted at this distinction between the two sides of agency in other parts of his opus. But he never devoted a full-scale legal analysis to the matter. It is only with regard to Barbarius' case that he elaborated the concept fully. He did so because he had to. Baldus built on Innocent's concept of representation. But, for Innocent, there could not be representation without full entitlement to the office. And this entitlement necessarily required confirmation by the superior authority. Toleration was therefore subordinated to confirmation. Applied to the lex Barbarius, Innocent's reasoning would lead to the same conclusion as the Accursian Gloss - Barbarius' election was ratified by 
the people or the prince. The need to avoid this conclusion forced Baldus into a complex and elaborate discourse, seeking a different way to explain the lawful exercise of the office - not de iure entitlement to the office, but lawful possession of it. This different approach allowed Baldus (admittedly not without some ambiguities) to highlight the difference between agent and office. It is precisely because the slave Barbarius would never acquire de iure entitlement to discharge the office of praetor that Baldus sought to keep agent and office as distant as possible from each other. This way Baldus never reached the same degree of identification between agent and office as Innocent. Even when the person is acting qua agent of the office towards the thirds, the office would always remain clearly visible in the picture, as a different and distinct subject from its representative. This is also why Baldus did not speak of toleration with reference to Barbarius: in Innocent's elaboration, toleration required full integration between agent and office.

Without Innocent's insistence on the need of confirmation, Baldus could perhaps have applied the concept of toleration to Barbarius without great difficulty. But Innocent's unrelenting position on confirmation forced Baldus to find a different path and, in so doing, continue the development of agency theory. The only way to understand why Innocent's position was so problematic for Baldus is to appreciate the position of previous civil lawyers on the lex Barbarius, and the increasingly critical stance that many of them took on the Accursian solution. Coming back to what was said at the beginning of this conclusion, we might appreciate how the complex route leading to Baldus' solution on Barbarius - the separation between the internal and the external validity of agency - is ultimately (once again) a product of the non-linear development of the history of legal thought. A 'functional' reading of our subject, skipping or abridging what does not lead to its modern developments, would risk to overlook it.

When appreciating the remarkable modernity of Baldus' approach, we should also be mindful that it is the product of a complex, multifaceted but still unitary discourse. For the student of medieval law - and, more broadly, of medieval thought - the challenge is often to appreciate this underlying unity. Some links are surprising only because we no longer partake in this unity, which is perhaps the most fascinating and elusive feature of the medieval world. 


\title{
Appendix
}

\section{Guido da Suzzara (c.1225-1292), ad Dig.1.14.3}

\author{
A: BNF, Lat. 4488, fols.328vb-329ra (322vb-323ra) \\ B: BNF, Lat. 4489, fol.6ra \\ C: Madrid, BN 823, fol.132va-vb
}

In 1. Barbarius. Quero in prime que sit in l(ege) ista an barbarius philippus fuit pretor. quidam dicunt quod $\operatorname{dic}($ it $)$ glo(sam $)^{\mathbf{1}}$ quod non, et hoc est uerum licet glo(sa) dicat eum fuisse pretorem et male dicit propter impedimentum sue persone, quia seruus erat qui ad dignitatem non potest aspirare ut C. si servus vel

5 liber(tus) ad decur(ionatum) aspi(raverit) 1 . unam. ${ }^{2}$ Vnde licet pomponius dixerit eum fuisse praetorem iuxta consilium ulpiani sua responcione contentus non fuit, vnde quesiuit audita responsione pomp(onii) vnde innuit eum non fuisse pretorem et ita nec liberum, cum ea que coram eo acta sunt valeant humanitatis racione tantum ut sequitur, vnde innuit eum non ${ }^{3}$ fuisse pretorem et ita nec

10 liberum. Guido de suzaria.

Et hoc dico, in l(ege) quod ea que fecit debeant valere, non autem erit ipse pretor uel liber quia dicit lex quod competit libertas data ab eo qui postea seruus pronunciatus est ut $\mathrm{i}$ (nfra) qui et a quibus ma(numissi) li(beri) no(n) fi(unt) 1. competit. ${ }^{4}$ Non autem erit ipse liber. Item non obstat quod seruus qui tempore test(ament)i creditur liber seruus est si testis adhibeatur in test(ament)o testem

1 According to the scholar who worked the most on these three manuscripts, Federico Martino, B would derive from a different archetype than A, but it was influenced by A through a couple of intermediate manuscripts. Martino (1981), pp.17-23. This is clearly visible already in the second line of the transcription. Instead of 'pretor. quidam dicunt quod dic(it) glo(sam)', MS A reads 'p.dic. glo.', which (especially if compared with MS C) seems to stand for 'p(retor) dic(it) glo(sa)'. MS B however read 'p.dic. glo.' as 'predicta glosa', and so added a verb to it ('dicat'). Martino's conclusions would point to a closer affinity between A and $\mathrm{C}$, whereas several instances in the present transcription would suggest a stronger link between the two Parisian manuscripts (A and B). In either case, both the Parisian and the Madrid manuscripts might derive from some common intermediate manuscript.

2 Cod.10.33.1.

3 'non' interlined in B.

4 Dig.40.9.19.

1 in 1.] super 1. C 2 quidam dicunt quod dic(it) glo(sam)] dic(it) glo(sa) A 2-3 pretor. quidam dicunt quod dic(it) glo(sam) quod non, et hoc est uerum licet glo(sa) dicat] predicita glo(sa) dicat B 3 dicit] dicitur B 4 potest] possunt $\mathrm{C} \quad$ vel] aut $\mathrm{C} \quad 5$ unam] una $\mathrm{C} \quad 6$ fuisse] om $\mathrm{C}$ responcione] racione $\mathrm{B} \quad 7$ quesiuit] de hoc que sunt $\mathrm{A}$ responsione] racione $\mathrm{B}$; questione responsione $\mathrm{C}$ fuisse] esse A 8 et ita] om $\mathrm{C} \quad 10$ Guido de suzara] om $\mathrm{C} \quad 11 \mathrm{in}$ ] ar(gumentum) C 12 quod] om $\mathrm{C}$ postea] et ipse $\begin{array}{llllll}\text { A-B } & 13 \text { pronunciatus] pronunciatur B no(n) fi(unt)] om A-B } 14\end{array}$ liber] om $\mathrm{B} \quad 15$ seruus est] et est seruus C 
videtur quia iste $\mathrm{l}$ (eges) per hoc faciunt. Nam ex hoc ipso libertatem non consequitur ut iam dixi et ille 1 (eges) allegate sunt in glosa hic et $\mathrm{C}$. de testa(mentis) ${ }^{5}$ et insti. 1 . de test(amenti) $\$$ si cum aliquis. ${ }^{6}$

Item licet populus romanus sciuisset eum seruum fecisset eum liberum

uel potuisset seruo decernere hanc potestatem, hoc est uerum si sciuisset. Sed hic

errabat populus quia credebat eum liberum et in ueritate erat seruus. Vnde non uidetur populus ei dedisse libertatem cum nichil tam contrarium sit consensui quam error ut $\mathrm{i}(\mathrm{nfra})$ iur(isdictione) $\mathrm{o}(\mathrm{mnium})$ iu(dicium) si per errorem. ${ }^{7}$ Vnde breuiter dicatis eum non fuisse pretorem nec liberum ut iam dictum est. Facta tamen ab eo valent nec obstant 1 (eges) all(egate) in gl(osa) immo per hoc faciunt omnes ut dixi. Guido de.

Quid si statutum est in ciuitate ut bannitus non eligatur ad dignitatem, vel 1 (ex) hoc iubet ut iam dixi de seruo et de liberto, ${ }^{8}$ iste eligitur ad aliquam dignitatem populo ignorante. Cum esset bannitus nunquid ualet sententia ab eo lata? Videtur quod non quia est lata a non competenti iudice, vnde non valet ut C. si a non compe(tenti) in 1 . fi. ${ }^{9}$ Item quia nominaciones in quibus solempnitates deficiunt sicut hic in questione proposita quia ineligibilis erat et tamen electus fuit non valent ut $\mathrm{C}$. de appell(ationibus) 1 . nominaciones. ${ }^{\mathbf{1 0}}$ Econtra videtur quod sententia ab isto lata valeat ut in ista 1 (ege) in glo(sa) all(egata) et hoc ultimum verum est ut hic probatur. G. The reference is however clearly a typo: when citing this lex, Suzzara refers to the case of the slave witnessing a will (Cod.6.23.1), not to a dispute over his freedom (as in Cod.4.20.1). Later on, both A and B cite the same lex as 'C. de testa(amentis)'. See infra, 1l.17-18.

Inst.2.10.7.

Dig.2.1.15.

Cod.10.33.1.2.

Cod.7.48.4.

10 Cod.7.62.27

16 quia] quod A-B ipso] ipse C 17 consequitur] consequitur sicut nec hic libertatem non consequitur $C$ allegate sunt] sunt allegate $C$ et] om C 18 et] om B aliquis] aliud B 19 fecisset eum] effecisset C 20 hanc] et hanc $B$ hoc est uerum si sciuisset] om A; est uerum est si hoc sciuisset B 20-21 Sed hic errabat populus] non est si hoc errabat A 21 populus] om B quia credebat eum liberum] credebat enim eum liberum C et in ueritate erat seruus] et erat in ueritate seruus C 22 tam contrarium sit consensui] sit tam contrarium consensui A-B 24 dictum est] dixi C $25 \mathrm{ab}$ eo] om $\mathrm{C}$ obstant l(eges)] obstat lex C 26 omnes ut dixi. Guido de.] om A-B 27 est] om A-B ut] quod C $28 \mathrm{l}(\mathrm{ex})$ hoc iubet] leges hoc iubent $\mathrm{C} \quad 28$ de liberto] libero A-B eligitur] eligetur A-B aliquam] om A-B 29 Cum esset bannitus] esse bannitum et A-B sententia] sententiam A-B 30 lata] latam A-B est] videtur A-B 31 nominaciones] 'nominantes' corrected into 'nominaciones' B 34 in glo(sa)] et concor(dat) hic C 35 G.] om A-B 
Sed nunquid salarium habebit iste bannitus qui fuit electus? Et videtur quod sic ar(gumentum) i(nfra) ad munic(ipalem) l. ticio. ${ }^{11}$ Econtra uidetur quod non quia sciebat se ineligibilem. Vnde delinquit dignitatem suscipiendo ex quo delicto premium consequi non debet ${ }^{12}$ ut $\mathrm{i}(\mathrm{nfra}) \mathrm{de}$ neg(otiis) g(estis) 1 . siue

40 hereditaria ${ }^{13}$ et $\mathrm{i}(\mathrm{nfra})$ de int(erdictis) et re(legatis) l. relegatorum $\$ ad tempus $^{\mathbf{1 4}}$ et istud ultimum verum est Guido.

Quid de tabellione qui se gerit ut tabellio et non est sed creditur nunquid valent instrumenta ab eo facta? Videtur quod sic ar(gumentum) huius l(egis) et facit ad hoc i(nfra) de iur(e) fisci l. sed si accepto ${ }^{15}$ et C. de testa(amentis) $1 . \mathrm{i}^{\mathbf{1 6}}$ et

45 instit. de test(amentis) $\$ sed si aliquis. ${ }^{17}$ Vos dicatis quod instrumenta ab eo facta non valent ut $\mathrm{i}(\mathrm{nfra})$ de rebus eorum 1 . qui. ${ }^{18} \mathrm{Nec}$ obstat $\mathrm{l}$. ista ${ }^{19}$ quia iste barbarius philippus fuit a tali creatus in pretorem qui eum creare poterat, $s$ (cilicet) a populo. Item et in illis duabus 1 (egibus) $\mathrm{C}$ (odicis) et instit(utionum) ${ }^{\mathbf{2 0}}$ fuit seruus qui credebatur tempore test(ament)i lib(erum) esse adhibitus a tali qui testare poterat,

50 sed uero a nemine creatur tabellio et instrumenta conficit illa instrumenta non valent ut jam dixi. Guido.

11 Dig.50.1.36pr.

12 It is likely that $\mathrm{C}$ incorporated some annotation from an intermediate manuscript here. Cf. infra, 11.43-44 in the critical apparatus.

13 Dig.3.5.21(22).

14 Dig.48.22.7.4.

15 Dig.49.14.32.

16 Cod.6.23.1.

17 Inst.2.10.7 (sed cum aliquis).

18 Dig.27.9.8pr.

19 Scil., Dig.1.14.3.

20 Cod.6.23.1 and Inst.2.10.7 respectively.

36 habebit] om A-B 36 qui fuit electus? Et videtur] sed qui fuit electus videtur $\mathrm{C} \quad 37$ uidetur] om A-B 37-38 quod non quia sciebat se ineligibilem] quod habere non deb<e >at quia iste se ineligibilem $\mathrm{C} \quad 38$ Vnde] immo C suscipiendo] recipiendo C 39 consequi non debet] consegui etc. ex eodem eius facto quis penam et premium consequi non debet habere premium penam ex delicto $\mathrm{C} 40 \mathrm{i}(\mathrm{nfra})] \mathrm{om} \mathrm{C}$ relegatorum] relegator $\mathrm{A}$ ad] om $\mathrm{B} \quad 41$ verum est Guido] in hac questione est ipsa ueritas C Guido] G. de. B $42 \mathrm{ut}$ ] in A sed] hoc A 43-44 et facit ad hoc] Item qui uestem romanam portat romanum censetur ut $\mathrm{C} 44$ accepto] accepta A-B et] Item et ar(gumentum) legum $\mathrm{C} \quad 45$ sed si aliquis] sed si quid A-B instrumenta ab eo facta] om A-B 46 valent] valunt $A$ ut $i(n f r a)$ de rebus eorum 1. qui] om C 46-47 barbarius philippus] barba A-B 47 a tali creatus] creatus a tali C qui eum creare poterat $s$ (cilicet) a populo] $s$ (cilicet) a populo qui eum creare potuit $\mathrm{C} \quad 48 \mathrm{C}$. et instit.] in inst. de test. $\$ sed cum aliquis et C. de testa. 1. i. C 50 uero] om $\mathrm{C}$ instrumenta conficit illa instrumenta] facit instrumenta illa A-B 51 jam] om A-B Guido] G. B 


\section{Bibliography}

\section{Manuscripts}

Admont 7

Assisi, BSC 216

Augsburg 1

Avranches 156

Balliol 297

Bamberg Can. 38

Bamberg, Msc. Jur. 11

Basel, UB, C.I.4

BAV, Barb. Lat. 1408

BAV, Barb. Lat. 1409

BAV, Ross. 1163

BAV, SMM 124

BAV, Urb. Lat. 172

BAV, Pal. Lat. 568

BAV, Pal. Lat. 624

BAV, Pal. Lat. 658

BAV, Pal. Lat. 731

BAV, Pal. Lat. 732

BAV, Pal. Lat. 733

BAV, Pal. Lat. 734

BAV, Pal. Lat. 735

BAV, Pal. Lat. 738

BAV, Pal. Lat. 739

BAV, Pal. Lat. 740
Admont, Stiftsbibliothek, MS 7

Assisi, Fondo Antico presso la Biblioteca del Sacro Convento, MS 216

Augsburg, Kreis- und Stadtbibliothek, MS 1 Avranches, Bibliothèque du fonds ancien,

Manuscrits, MS 156 (antea 21)

Oxford, Balliol College, MS 297

Bamberg, Staatsbibliothek, Can. 38

Bamberg, Staatsbibliothek, Handschriften,

Msc. Jur. 11 (antea D.I.6)

Basel, Universitätsbibliothek, Handschriften, MS C.I.4

Biblioteca Apostolica Vaticana, Codices Barberini Latini, MS 1408

Biblioteca Apostolica Vaticana, Codices Barberini Latini, MS 1409

Biblioteca Apostolica Vaticana, Codices Rossiani, MS 1163

Biblioteca Apostolica Vaticana, Santa Maria

Maggiore, MS 124

Biblioteca Apostolica Vaticana, Fondo Urbinate, MS Lat. 172

Biblioteca Apostolica Vaticana, Codices Palatini latini, MS 568

Biblioteca Apostolica Vaticana, Codices Palatini latini, MS 624

Biblioteca Apostolica Vaticana, Codices Palatini Latini, MS 658

Biblioteca Apostolica Vaticana, Codices Palatini latini, MS 731

Biblioteca Apostolica Vaticana, Codices Palatini latini, MS 732

Biblioteca Apostolica Vaticana, Codices Palatini latini, MS 733

Biblioteca Apostolica Vaticana, Codices Palatini latini, MS 734

Biblioteca Apostolica Vaticana, Codices Palatini latini, MS 735

Biblioteca Apostolica Vaticana, Codices Palatini latini, MS 738

Biblioteca Apostolica Vaticana, Codices Palatini latini, MS 739

Biblioteca Apostolica Vaticana, Codices Palatini latini, MS 740 
BAV, Vat. Lat. 1408

BAV, Vat. Lat. 2280

BAV, Vat. Lat. 2512

BAV, Vat. Lat. 2594

BAV, Vat. Lat. 2618

Bern, Cod. 6

BL, Arundel 473

BL, Add. 14858

BL, Harley 3700

BL, Royal 11.B.xiv

BL, Royal 11.C.III

BNF, Lat. 4378

BNF, Lat. 4459

BNF, Lat. 4461

BNF, Lat. 4462

BNF, Lat. 4463

BNF, Lat. 4488

BNF, Lat. 4489

BNF, Lat. 4493

BNF, Lat. 4494

BNF, Lat. 4495

BNF, Lat. 15994

BNF, Lat. 16540

Bologna, CS 272

Bologna, CS 285

Bruxelles 1410

BSB, Clm 20

BSB, Clm 547

BSB, Clm 3062

BSB, Clm 3887
Biblioteca Apostolica Vaticana, Codices Vaticani latini, MS 1408

Biblioteca Apostolica Vaticana, Codices Vaticani latini, MS 2280

Biblioteca Apostolica Vaticana, Codices Vaticani latini, MS 2512

Biblioteca Apostolica Vaticana, Codices Vaticani latini, MS 2594

Biblioteca Apostolica Vaticana, Codices Vaticani latini, MS 2618

Bern, Burgerbibliothek, Handschriften, Cod. 6

London, British Library, MS Arundel 473

London, British Library, MS Additional 14858

London, British Library, MS Harley 3700

London, British Library, MS Royal 11.B.xiv

London, British Library, MS Royal 11.C.III

Paris, Bibliothèque nationale de France,

MS Lat. 4378

Paris, Bibliothèque nationale de France,

MS Lat. 4459

Paris, Bibliothèque nationale de France,

MS Lat. 4461

Paris, Bibliothèque nationale de France,

MS Lat. 4462

Paris, Bibliothèque nationale de France,

MS Lat. 4463

Paris, Bibliothèque nationale de France,

MS Lat. 4488

Paris, Bibliothèque nationale de France,

MS Lat. 4489

Paris, Bibliothèque nationale de France, MS Lat. 4493

Paris, Bibliothèque nationale de France, MS Lat. 4494

Paris, Bibliothèque nationale de France,

MS Lat. 4495

Paris, Bibliothèque nationale de France,

MS Lat. 15994

Paris, Bibliothèque nationale de France,

MS Lat. 16540

Bologna, Collegio di Spagna, MS 272

Bologna, Collegio di Spagna, MS 285

Bruxelles, Bibliothèque royale, MS 1410

München, Bayerische Staatsbibliothek, Codices latini monacenses, MS 20

München, Bayerische Staatsbibliothek, Codices latini monacenses, MS 547

München, Bayerische Staatsbibliothek, Codices latini monacenses, MS 3062

München, Bayerische Staatsbibliothek, Codices latini monacenses, MS 3887 
BSB, Clm 4555

BSB, Clm 5476

BSB, Clm 6640

BSB, Clm 6675

BSB, Clm 10244

BSB, Clm 14022

BSB, Clm 14028

BSB, Clm 16063

Cambridge 3321

Cologny, Bodmer 100

Douai 575

Firenze, BML, AeD, 158.1

Firenze, BML, AeD, 417

Firenze, BML, Edili 65

Firenze, BML, Plut. 6 sin. 3

Firenze, BML, Plut. 6 sin. 6

Firenze, Conv. Sopp. G.IV.1736

Forlì 143

Gent, Hs. 23

Girona 46

København, KB 394.1

Kórnik, BK 824

Laon 371 bis

Leiden, Abl.2

Leiden, BPL 6C

Leipzig 878

Liège 127.E

Lucca 373

Luxembourg 144

Madrid, BN 421

Madrid, BN 573

Madrid, BN 824
München, Bayerische Staatsbibliothek, Codices latini monacenses, MS 4555

München, Bayerische Staatsbibliothek, Codices latini monacenses, MS 5476

München, Bayerische Staatsbibliothek, Codices latini monacenses, MS 6640

München, Bayerische Staatsbibliothek, Codices latini monacenses, MS 6675

München, Bayerische Staatsbibliothek, Codices latini monacenses, MS 10244

München, Bayerische Staatsbibliothek, Codices latini monacenses, MS 14022

München, Bayerische Staatsbibliothek, Codices latini monacenses, MS 14028

München, Bayerische Staatsbibliothek, Codices latini monacenses, MS 16063

Cambridge, University Library, MS 3321

Cologny, Fondation Martin Bodmer,

Cod. Bodmer 100

Douai, Bibliothèque municipale, MS 575

Firenze, Biblioteca Medicea Laurenziana, Acquisti e Doni, MS 158.1

Firenze, Biblioteca Medicea Laurenziana, Acquisti e Doni, MS 417

Firenze, Biblioteca Medicea Laurenziana, Edili, MS 65

Firenze, Biblioteca Medicea Laurenziana, Plutei, MS 6 sinistri 3

Firenze, Biblioteca Medicea Laurenziana, Plutei, MS 6 sinistri 6

Firenze, Biblioteca Nazionale Conventi soppressi, MS G. IV 1736

Forlì, Biblioteca Comunale 'Aurelio Saffi', MS 143

Gent, Universiteitsbibliotheek, Handschriften, MS 23

Girona, San Félix, MS 46

København, Kongelige Bibliotek, Gl. kgl. sml. 394 folio, pt. I

Kórnik, Biblioteka Kórnicka Polska Akademia Nauk, Rekopisy, BK 824

Laon, Bibliothèque municipale, MS 371bis

Leiden, University Library, MS d'Ablaing 2

Leiden, University Library, Bibliotheca Publica Latina MS 6 C

Leipzig, Universitätsbibliothek, MS 878

Liège, Bibliothèque de l'Université, MS 127 E

Lucca, Biblioteca Capitolare Feliniana, MS 373

Bibliothèque Nationale de Luxembourg, MS 144

Madrid, Biblioteca Nacional de España, MS 421

Madrid, Biblioteca Nacional de España, MS 573

Madrid, Biblioteca Nacional de España, MS 824 
Madrid, BN 920

Madrid, BN 2137

Montecassino 396

Napoli, Branc.III.A.6

ÖNB 2257

ÖNB 2265

Padova 941

Paris Maz. 1318

Salzburg, Erzabtei a XII 9

Berlin, Savigny 22

Siena H.IV.18

St. Florian XI.605

Stockholm, KB, B 680

Stralsund Hs 290

Toledo 36-3

Torino F.II.14

Troyes 174
Madrid, Biblioteca Nacional de España, MS 920

Madrid, Biblioteca Nacional de España, MS 2137

Montecassino, Biblioteca Abbaziale, MS 396

Napoli, Biblioteca nazionale, MS Branc.III.A.6

Wien, Österreichische Nationalbibliothek, MS 2257

Wien, Österreichische Nationalbibliothek,

MS 2265

Biblioteca Universitaria di Padova, MS 941

Paris, Bibliothèque Mazarine, MS 1318

Salzburg, Erzabtei St. Peter, Benediktinerstif, Bibliothek, MS a XII 9

Berlin, Staatsbibliothek, MS Savigny 22

Siena, Biblioteca Comunale, MS H.IV.18

St. Florian, Stiftsbibliothek, MS XI 605

Stockholm, Kungliga Biblioteket, Handskrifter, MS B 680

Stralsund, Archivbibliothek, MS Hs 290

Toledo, Biblioteca de la Catedral, MS 36-3

Torino, Biblioteca Nazionale Universitaria,

MS F.II.14

Troyes, Bibliothèque municipal, MS 174

Works published before 1800

Abbas Antiquus (Bernardus de Monte Mirato)

- Lectura Aurea Domini Abbatis Antiqui super quinque libris Decretalium, Argentinae [Johannes Schott] 1511; anastatic reprint, Frankfurt am Main: Vico Verlag, 2014

Ackersdijck, Willem Cornelis

- Dissertatio juridica inauguralis ad L. 3. Digestorum de Officio praetorum ..., Trajecti ad Rhenum, ex officina Joannis Broedelet, 1757

Albericus de Rosate

- Alberici de Rosate Bergomensis ivrisconsulti clarissimi ... In primamff. Veter [is] part[em] commentarij, Venetiis, 1585; anastatic reprint, Bologna: Forni, 1974

- Alberici de Rosate ... In Secundamff. Noui partem Commentarij ..., Venetiis, 1585; anastatic reprint, Bologna: Forni, 1982

- Alberici de Rosate ... In Primam Codicis Partem Commentarij ..., Venetiis, 1586; anastatic reprint, Bologna: Forni, 1979

- Alberici de Rosate Bergomensis ivrisconsulti clarissimi ... In Secundam Codicis Part[em] Commentaria ..., Venetiis, 1585; anastatic reprint, Bologna: Forni, 1979

- Alberici de Rosate ... Dictionarium Iuris tam Civilis, quam Canonici ..., Venetiis, apud Guerreos fratres, et socios, 1572 
Angelus de Ubaldis

- Angeli Perusini conspicuae iurisprudentiae uiri in primam digesti ueteris partem co $<m>$ mentaria, Mediolanii [Beninus \& Johannes Antonius de Honate] 1477

- Lectura domini Angeli de Perusio super C(odice) ... [Lugduni], Vincenti Portonariis, 1534

- Opus ac lectura authenticorum prestantissimi doctoris domini Angeli de vbaldis de Perusio ..., Venetiis [De Tortiis], 1489

Azo

- Azonis svmma avrea ... Lvgdvni, 1557; anastatic reprint, Frankfurt am Main: Minerva, 1968

- Summa Azonis ... Venetiis, Sub Signo Angeli Raphaelis, 1581; anastatic reprint, Frankfurt am Main: Vico Verlag, 2008

- Summa Codicis per Dominum Azonem [Venetiis, 1489]

- Azonis, Ad singulas leges XII librorum codicis iustinianei, commentarius ... Parisiis, Apud Sebastianum Nivellium 1577; anastatic reprint, Augustae Taurinorum: ex officina Erasmiana, 1966

Bachovius, Reinhardus

- Reinhardi Bachovii ... Commentarii in primam partem Pandectarum ..., rancofurti, Sumptibus Joannis Berneri ... Excudebantur Spirae Nemetvm, Typis Georgii Bavmeisteri, 1630

Baldus de Ubaldis

- Baldi Vbaldi Pervsini ... In Primam Digesti Veteris Partem Commentaria ... Venetiis [apud Iuntas], 1577

- Baldi Vbaldi pervsini Ivrisconsvlti ... In Secundam Digesti vet[eris] partem Commentaria ... Venetiis [apud Iuntas], 1577

- Baldi Vbaldi pervsini Ivrisconsvlti ... In Primam et Secun[dam] infortiati partem, Commentaria ... Venetiis [apud Iuntas], 1577

- Baldi Vbaldi pervsini Ivrisconsvlti ... Commentaria in Digestum Nouum ... Venetiis, Apud Iuntas, 1577

- Tractatvs de Pactis Pervtilis et Necessarivs, Baldi Vbaldi Pervsini ... Venetiis, 1577

- Baldi de Pervsio ... super Primo, Secundo \& Tertio Codicis Commentaria luculentissima ... Lvgdvni [typis Gaspar \& Melchior Trechsel], 1539

- Baldi de Pervsio Ivrisconsvlti clarissimi, svper Quarto, et Quinto Codicis Iust [iniani] lib[ris] Commentaria luculentissima ... Lvgdvni [typis Gaspar \& Melchior Trechsel], 1539

- Baldi de Pervsio Ivrisconsvlti clarissimi, svper Sexto Codicis Iustiniani libro Commentaria luculentissima ... Lvgdvni, typis Gaspar \& Melchior Trechsel, 1539 
- Baldi de Pervsio Ivrisconsvlti clarissimi, svper VII, VIII et Nono Codicis, Commentaria luculentissima ... Lvgdvni, typis Gaspar \& Melchior Trechsel, 1539

- Lectura acutissimi ... domini Baldi de Perusio super tribus libris Codicis ... [Lugduni, Garnier], 1541

- Lectura super prima parte Digesti veteris, inpressa neapoli ... per uenerabilem Sixtum riessinger ... mille CCCC LXXVI

- Lectura super I. parte Digesti [Mediolanii] nobili officina magistri Antonii Zaroti Parmensis [1477]

- Baldi Vbaldi Ivriscons[ulti] clarissimi Commentaria Ad quatuor Institutionum libros ..., Avgvstae Tavrinorvm, Apud haeredes Nicolai Beuilaquae, 1576

- Baldi Vbaldi Pervsini ... Praelectiones In quatuor Institutionum libros ..., Venetiis, 1577

- Consiliorvm sive Responsorvm Baldi Vbaldi Pervsini ..., Volumen PrimumQuintum, Venetiis, apud Dominicum Nicolinum, et Socios, 1580

- Baldvs super Decretalibvs ... Lugduni, excudebat Claudius Seruanius, 1564

- Lectura super Usibus feudorum, Papiae [Birreta et Girardengus], 1490 Barbosa, Agostinho

- Augustini Barbosae ... Pastoralis Solicitudinis, sive De Officio et Potestate Episcopi ..., Venetiis, Apud Natalem Feltrini, 1707

Bartolus de Saxoferrato

- Bartolus de Saxoferrato, Opera Omnia ..., vol. 1, Basileae: Hieronymus Froben, 1562; anastatic reprint, Frankfurt am Main: Vico Verlag, 2007

- Bartoli a Saxoferrato in Primam Digesti Veteris Partem Commentaria, Augustae Taurinorum, Apud Haeredes Nicolai Beuilaquae, 1577

- Lvcernae iuris Bartoli a Saxoferrato Commentaria in primamff. Veteris partem ..., Lugduni [de Portonaris], 1538

- In Primam Partem Digesti Veteris Bartoli a Saxoferrato Commentaria ..., Basileae, ex officina Episcopiana, 1588

- In Primam Partem Infortiati Bartoli a Saxoferrato Commentaria ..., Basileae, ex officina Episcopiana, 1588

- In Secundam Partem Infortiati Bartoli a Saxoferrato Commentaria ..., Basileae, ex officina Episcopiana, 1588

- In Primam Partem Digesti novi Bartoli a Saxoferrato Commentaria ..., Basileae, ex officina Episcopiana, 1588

- In Secundam Partem Digesti novi Bartoli a Saxoferrato Commentaria ..., Basileae, ex officina Episcopiana, 1588 
- In Primam Partem Codicis Bartoli a Saxoferrato Commentaria ..., Basileae, ex officina Episcopiana, 1588

- In Secundam et Tertiam partem Codicis Bartoli a Saxoferrato Commentaria ..., Basileae, ex officina Episcopiana, 1588

- Svper Avthenticis et Institvtionibvs, Bartoli a Saxoferrato Commentaria ..., Basileae, ex officina Episcopiana, 1588

Belviso, Jacobus de

- Commentarii in Avthenticum et Consvetvdines Fevdorvm, Aureliae: 1511; anastatic reprint, Bologna: Forni, 1971

Boucheul, Joseph

- Coûtumier general, ou Corps et compilation de tous les commentateurs sur la cô̂tume du comté et pays de Poitou ..., Potiers, chez Jacques Faulcon, 1727

Bronkhorst, Eberhard van

- Euerardi Bronchorst ... Enantiophanon centuriae quatuor, et Conciliationes eorundem ..., Francofurti ad Moenum, 1643

Bugnyon, Philibert

- Philiberti Bugnyon Legum abrogatarum et inusitatarum in omnibus curiis, terris, jurisdictionibus, \& dominiis regni Francia tractatvs ..., Bruxelles [Christyn], typis Petri de Dobbeleer, 1677

Butrigarius, Jacobus

- Iacobi Bvtrigarii Bononiensis, In Primam et Secvndam Veteris Digesti Partem, vol. 1, in Primam ff. Veteris Partem Commentaria, Romae, typis Lepidi Fatij, 1606; anastatic reprint, Bologna: Forni, 1978

- Commentaria Ervditissima atque pariter accutissima (sic), In Quamplurimos Ivris Communis Titulos ... Ita vt Fere Dici Potest, saltem per extensionem, in uniuersum ius .... In Dvos Tomos Distribvta. Tomus Primus. ... Auctore ... D. Iacobo Bvtrigario Bononiensis ... Romae, Typis Lepidi Fatij, 1617

- Iacobus Butrigarii ... super Codice hanc subtilissimam editit lecturam ..., Parrhisiis (sic), a Joanne paruo [1516]; anastatic reprint, Bologna: Forni, 1973

Caldera, Eduardus

- Variarum lectionum, Matriti, Excudebat Cosmas Delgadus, 1614

Campianus, Augustinus

- Augustini Campiani ... de Officio Et Potestate Magistratuum Romanorum Et Jurisdictione, Libri Duo, Genevae, Apud Marcum-Michaëlem Bousquet \& socios, 1725

Cocceius, Samuel de

- Samvelis de Cocceji ... Jvris Civilis Controversi, Pars II, Francofurti ad Viadrvm, Impensis Jo. Godofredi Conradi, 1718

Colonna, Aegidius,

- De Regimine Principum, Romae, 1561 
Coninck, Giles, de

- Commentariorvm ac Disputationvm in Vniuersam doctrinam D. Thomae De Sacramentis et Censvris Tomi Duo, Antverpiae, apud Haeredes Martini Nvtl, 1619

Constanus, Antonius Guibertus

- Antonii Guiberti Constani ... Quaestionum juris memorabilium liber, in Everhard Otto (ed.), Thesaurus Juris Romani, vol. 5 ( $2^{\text {nd }}$ edn.), Trajecti ad Rhenum, apud Joannem Broedelet, 1735

Corpus Iuris Civilis

- Pandectarvm Ivris Civilis, tomus primvs-quintvs ..., Parisiis, Apud Gulielmum Merlin ... et Gulielmum Desboys ..., ac Sebastianum Niuellium ..., 1566

Corsetti, Antonius

- Repertorium in opera Nicolai de Tudeschis [Venetiis, c.1486]

Covarrubias y Leyva, Diego de

- Practicarum quaestionum liber vnus, tom. 2, in Didaci Covarrvvias ... Opera Omnia ..., Venetiis, apud Haeredem Hieronymi Scoti, 1581

Cravetta, Aimone

- Aymonis Cravettae ... Consiliorum, siue Responsorum, tom. 5, Apud Ioan. Wechelum, impensis Sigismundi Feyrabendii, 1589

Cugno, Guillelmus

- Clarissimi iurisvtriusque ... Guillielmi de cugno: alias de Cugno Lectura super Codice ... [Lugduni, 1513] (anastatic reprint, Bologna: Forni, 1968)

Cujas, Jacques

- Iacobi Cviacii ... Observationvm et emendationvm, lib[ri] XVIII-XXIIII ..., Coloniae Agrippinae, Apud Ioannem Gymnicum, 1587

Cynus de Pistoia

- Cyni Pistoriensis In Codicem et aliquot titulos primi Pandectarum tomi, id est Digesti veteris, doctissima commentaria ... a iureconsulto celeberrimo Domino Nicolao Cinsnero ... correcta, et illustrata, Francofurti ad Moenum, Impensis Sigismundi Feyerabendt, 1578; anastatic reprint, Frankfurt am Main: Vico Verlag, 2007

D’Aguessau, Henri-François

- Oeuvres de M. Le Chancelier d'Aguesseau, Paris, chez les Libraires Associés, 1764

Dantoine, Jean-Baptiste

- Les Règles du Droit Civil, dans le même ordre qu'elles sont disposeés au dernier Titre du Digeste ..., Lion (sic), chez Claude Plaignard, 1725

Decius, Philippus

- Consiliorvm sive Responsorum ... Philippi Decii Mediolanen[sis], vol. 2, Venetiis, Hieronymus Polus, 1580 
Diana, Antoninus

- R. P. D. Antonini Diana ... Coordinati, seu Omnium Resolutionum Moralium ... Tomus Primus, Venetiis, Ex Typographia Balleoniana, 1728

Dynus de Mugello

- Dyni Myxellani ... Commentaria in Regulas Ivris Pontificii ..., Lvgdvni, apud Antonium Vincentium, 1558

Donellus, Hugo

- Oswald Hilliger (ed.), Donellus Enucleatus sive Commentarii Hugonis Donelli de iure Civili in Compendium ... redacti ..., Jenae, vol. 1, Sumptibus et typis Christophori Lippoldi, 1611

Duplessis, Claude de

- Traitez de $M^{r}$ Duplessis ... sur la Coutume de Paris ..., Paris, Chez. Nicolas Gosselin ..., 1699

Durantis, Guillelmus

- Gvl[ielmi] Dvrandi Episcopi Mimatensis I.V.D. Specvlum Ivris ..., Basileae, apvd Ambrosivm et Avrelium Frobenios Fratres, 1574; anastatic reprint, Aalen: Scientia Verlag, 1975

Ernstius, Henricus

- Henrici Ernstii ... Breviores annotationes in librum primum digestorum ..., in Gerhard Meerman (ed.), Novus thesaurus juris civilis et canonici, continens varia et rarissima optimorum interpretorum ... opera, HagaeComitum, Apud Petrum de Hondt, vol. 6, 1753

Favre, Antoine

- Antonii Fabri ... Rationalia In Pandectas: Ac Primum In Pandectarum partem primam ..., S. Gervasii, ex Typis Vignonianis, 1604

Fulgosius, Raphaelis

- Raphaëlis Fulgosij Placentini ... in primam Pandectarum partem Commentariorum ..., Lvgdvni, Apud Hugonem et haeredes Aemonis à Porta, 1554

- Raphaëlis Fulgosij Placentini ... in D. Iustiniani Codicem Commentariorum ..., vol. 2, Lvgdvni, Apud Hugonem et haeredes Aemonis à Porta, 1547 Gabrieli, Antonius

- Commvnes conclvsiones Antonii Gabrielii ... In Septem Libros distributae, Francofurti, impensis Rulandiorum, Typis Ioannis Bringeri, 1616

Goffredus de Trano

- Summa perutilis et valde necessaria super titulis decretalium ..., Lugduni [Jean de Moylin], 1519; anastatic reprint Aalen: Scientia Verlag, 1968

Gothofredus, Jacobus

- De electione magistratus inhabilis seu incapacis per errorem facta, Dissertatio. Ad L. Barbarius Philippus 3.ff. de Officio Praetorum, Genevae, Sumptibus Ioannis Ant. et Samuelis de Tournes, 1654 
Govea, Antonius

- Antonii Goveani ..., Lectionvm Iuris Variarvm Libri duo, in Novarvm Declarationvm, Variarvm Lectionvm et Resolvtionvm Ivris Libri XXII, Diversorum Clarissimorum Iurisconsultorum Recentium ..., Coloniae AgrippiGratian nae, Apud Ioannem Gymnicum, 1599

- Decretum Gratiani, Basileae [Johann Petri \& Johann Froben], 1512 Guido de Baysio

- Rosarium super Decreto, Venetiis [Herbort], 1481

- Tractatus super haeresi, in Johannes Dominicus Mansi (ed.), Sacrorum conciliorum Nova, et Amplissima Collectio ..., vol. 25, Venetiis, apud Antonium Zatta, 1782

- Apparatus Libri Sexti, Mediolani [Jacobus de Sancto Nazario de Ripa, \& Bernardinus de Castelliono], 1490

Guyot, Joseph-Nicholas

- Répertoire Universel et Raisonné de Jurisprudence civile, criminelle, canonique et bénéficiale ... ( $2^{\text {nd }}$ edn., 27 vols), Paris, Visse, 1784-1785

Heineccius, Johann Gottlieb

- Io[hannis] Gottlieb Heineccii ... Elementa Ivris Civilis, secvndum Ordinem Pandectarvm comoda avditoribvs methodo adornata ( $6^{\text {th }}$ edn.), in Io. Gottlieb Heineccii ... Opervm ad Vniversam Ivris Prvdentiam ..., vol. 5, Genevae, Impensis Hered. Cramer, et Fratr. Philibert., 1748; anastatic reprint, Frankfurt am Main: Vico Verlag, 2010

Heraldus, Desiderius

- Desiderii Heraldi Quaestionum quotidianarum tractatus. Ejusdem observationes ad ius atticum et romanum, Paris, 1650

Hostiensis (Henricus de Segusio)

- Lectura siue Apparatus domini Hostiensis super quinque libris Decretalium, Argentine, impensis J. D. doctoris Georgij übelin: Johannes Schottus, 1512

Hotman, Franciscus

- Franc[isci] Hotomani Ivrisconsvlti, Quaestionum illustrium Liber [Genevae], Excudebat Henr. Stephanus, 1573

Innocent III (Lotharius de Segni)

- D[omini] Innocentii pontificis maximi ejus nominis III Opera quae quidem obtineri potuerunt, omnia ..., Coloniae, apvd Maternvm Cholinvm, 1575

Innocent IV (Sinibaldus de Fieschi)

- Commentaria Innocentii Quarti Pont. Maximi Super Libros Quinque Decretalium, Francofurti ad Moenum [Martin Lechler, Sigmund 
Feyerabend], 1570; anastatic reprint, Frankfurt am Main: Minerva, 1968

Jacobus de Arena

- Iacobi de Jacobus de Arena Parmensis ... Commentarij in vniversum Ius civile ..., Lugduni, 1541

Johannes Andreae

- Ioannis Andreae ... In primum Decretalium librum Nouella Commentaria ..., Venetiis, Apud Haeredem Hieronymi Scoti, 1612

- Ioannis Andreae ... In secundum Decretalium librum Nouella Commentaria ..., Venetiis, Apud Haeredem Hieronymi Scoti, 1612

- Ioannis Andreae ... In tertium Decretalium librum Nouella Commentaria ..., Venetiis, Apud Haeredem Hieronymi Scoti, 1612

- Ioannis Andreae ... In quintum Decretalium librum Novella Commentaria, Venetiis, Apud Haeredem Hieronymi Scoti, 1612

- Ioannis Andreae ... in sextum Decretalium librum Nouella Commentaria ..., Venetiis, Apud Haeredem Hieronymi Scoti, 1612

- Ioannis Andreae ... In titulum de Regulis iuris Nouella Commentaria ... Venetiis, Apud Franciscum Franciscium, 1581

Johannes Teutonicus

- Apparatus Glossarum in Compilationem Quartam, in Antonii Augustini Archiepiscopi Tarraconensis Opera omnia ..., vol. 4, Lucae, typis Josephi Rocchii, 1769

Kettwig, Mentetus Bebaeus

- Mentetus Bebaeus Kettwig, Disputatio juridica inauguralis ad legem Barbarius Philippus, Franekarae, 1690

Landus, Constantius

- Constantii Landi ... in jus civile, sparsim contentarum exercitationum libellus, in Everhard Otto (ed.), Thesaurus Juris Romani, vol. 3 ( $2^{\text {nd }}$ edn.), Trajecti ad Rhenum, apud Joannem Broedelet, 1733

Legrand, Louis

- Coutume De Bailliage De Troyes Avec Les Commentaires De Me Louis Legrand ... (4 $4^{\text {th }}$ edn.), Paris, Chez Motalant, 1737

Lessius, Leonardus

- De Ivstitia et ivre caeterisque Virtitibus Cardinalibus libri IV ..., Lovanii, ex officina Ioannis Masij, 1605

Gregorius IX (Ugolinus di Segni)

- Decretalium domini pape Gregorij noni compilatio ..., Basileae [Johann Froben \& Amerbach], 1500

Lycklama, Marcus

- Marci Lycklama, Membranarvm libri qvinque ... Franekarae, ex officina typographica Romberti Doyma, 1608 
López Madera, Gregorius

- Gregorii Lopez Maderae ... Animadversionum juris civilis, liber singularis, in Everhard Otto (ed.), Thesaurus Juris Romani, vol. 3 ( $2^{\text {nd }}$ edn.), Trajecti ad Rhenum, apud Joannem Broedelet, 1733

Maqueda, Paulus de

- Commentaria haec, L. Barbarius Philippus III,ff. de officio praetoris ..., Salmanticae, excudebat Didacus à Cussio, 1615

Mascardus, Josephus

- Iosephi Mascardi Ivrisconsvlti ... Conclusiones Probationvm Omnivm quae in vtroque Foro quotidie versantur ... Francofurdi (sic) ad Moenum, impensis haeredum Sigis. Feyrab., 1593

Maynard, Géraud de

- Notables et singulières questions de droit écrit, jugées au Parlement de Toulouse ..., vol. 1, Toulouse, chez François Henault, Jean-François Robert, 1751

Mayno, Jason de

- Excellentissimi iuris utriusq[ue] doctoris domini Iasonis de mayno Mediolane $[n]$ sis Lectura in prima parteff. veteris, Venetijs, per Baptistam de Tortis, 1512

- Repertorivm sev Index ordine elementario digestus in commentaria Iasonis Mayni ..., Lugduni, apud Sebastianum Gryphium, 1533

Menochius, Jacobus

- Iacobi Menochii ... De adipiscenda et retinenda possessione amplissima et doctissima commentaria, $3^{\text {rd }}$ edn., Venetiis, Apud Ioannem Baptistam Somaschum, 1576

Navarrus (Martín de Azpilcueta)

- Enchiridion sive Manvale Confessariorvm et Poenitentivm ..., Mogvntiae, excudebat Balthasarvs Lippivs, sumptibus Arnoldi Mylii, 1601

Odofredus de Denariis

- In undecim primos pandectarum libros ... Lectura, Lvgdvni, P. Compater \& B. Guido, 1550; anastatic reprint, Bologna: Forni, 1967

- D(omini) Odof(redi)... perelegans et elaborata elucidatio, in nouem posteriores libros Infortiati ... Lvgdvni, 1550; anastatic reprint, Bologna: Forni, 1968

- Odofredi ... in primam Codicis partem ... Praelectiones ... Lvgdvni, 1552; anastatic reprint, Bologna: Forni, 1968

- Odofredi ... in secundam Codicis partem, Praelectiones ..., Lvgdvni, 1552

Panormitanus (Nicolò Tedeschi)

- Nicolaus [de Tudeschis], Super Primum Decretali[um] Librum Commentaria, Basileae [Wenssler], 1477

- Nicolaus de Tudeschis], Primae partis in Secundum Decretalium Librum Commentaria, Basileae [Wenssler], 1477 
- Nicolaus de Tudeschis], Tertiae partis in Secundum Decretalium Librum Commentaria, Basileae [Wenssler], 1477

Paulus de Castro

- Pavli Castrensis ... In Primam Digesti Veteris partem Commentaria ..., Lugduni [Compagnie des libraires], 1585

- Pavli Castrensis ... In Secundam Digesti Veteris partem Commentaria ..., Lugduni [Compagnie des libraires], 1585

- Pavli Castrensis ... In Primam Digesti Noui Partem Commentaria ..., Lugduni [Compagnie des libraires], 1585

- Pavli Castrensis ... In Primam Codicis partem Commentaria ..., Lugduni [Compagnie des libraires], 1585

- Pavli Castrensis ... In Secundam Codicis partem Commentaria ..., Lugduni [Compagnie des libraires], 1585

Petrus de Palude

- Petri de Palude ... quartus sententiarum liber [Coloniae Agrippinae] in officina Johannis parui [1514]

Pignatelli, Giacomo

- Iacobi Pignatelli ... Consvltationvm Canonicarvm ..., tom. 6, Venetiis, Apud Paulum Balleonium, 1688

Pillius de Medicina

- Celeberrimi Ivre cons(ulti) ac Glosatoris vetustissimi D. Pilei Modicensis Qvaestiones avreae [Romae, 1560]

Placentinus

- Placentini Ivrisconsulti vetvstissimi, in svmmam institvtionvm ... libri IIII, Moguntiae [15]35; anastatic reprint, Augustae Taurinorum: Ex officina erasmiana, 1973

- Placentini Summa Codicis ..., Moguntiae [Schöffer], 1536; anastatic reprint, Torino, Bottega d'Erasmo 1962

Plauzio Pezone, Camillus

- In l. Barbarius De officio Praetoris singularia commentaria, Patavii, 1554.

Pontius, Basilius (Basilio Ponce de León)

- R.P. M. F. Basilii Pontii ... De sacramento matrimonii tractatus cum appendice de matrimonio catholici cum haeretico ... Venetiis [Combi.], 1645

Raynerius de Forlì

- repetitio ad Dig.1.1.9, in Repetitionum seu commentariorum in varia iurisconsultorum responsa, vol. 1, Lugduni, Apud Hugonem à Porta, \& Antonium Vincentium, 1553

Reiffenstuel, Anaklet

- Jus Canonicum Universum clara methodo ivxta titulos quinque librorvm Decretalium in Quaestiones distributum ..., Monachij, Sumptibus Viduae et Haeredum Johannis Hermanni à Gleder (2 vols.), 1700-1702 
Roffredus de Epiphanio

- Libelli iuris canonici, Argentinae [Johann Grüninger], 1502

- Libelli iuris canonici [Avignon, Petrus Rohault], 1500; anastatic reprint, Augustae Taurinorum: Ex officina Erasmiana, 1968; Corpus Glossatorum Juris Civilis, vol. 6.2)

Rome, Rota of

- Sacrae Rotae Romanae Decisiones nuperrimae nunc primum collectae, vol. 4, Romae, apud Simonem Occhi, 1753

Sánchez, Thomas

- Disputationvm de Sancto Matrimonii Sacramento Tomi Tres, Antverpiae, apud Martinum Nutium, 1607

Sanctius, Johannes

- Selectae, illaeque practicae disputationes de rebus in administratione sacramentorum, Venetiis: Apud Bertanos, 1639

Sandeus, Felinus

- Commentaria Felini Sandei in V. libr. Decretalium ... pt. 1, Basileae, Officina Frobeniana [1567]

Schröter, Johann Wilhelm

- Discursus legalis ad difficilem et intricatam l. Barbarius Philippvs ... Giessae, Friderici Kargeri, 1675

Socinus, Bartholomaeus

- Regulae et Fallentiae Juris Bartholomaei Socini ... a Benedicto Vaudo ... reuisae ... ( $4^{\text {th }}$ edn.), Coloniae Agrippinae, Apud Ioannem Busaeum, 1663

Suárez, Francisco

- R. P. Francisci Suarez... De Sacramentis, pt. 2 ...,Venetiis, Ex Typographia Balleoniana, 1748

Tartagni (Alexander de Imola)

- Apostille seu Additiones ad Bar(tolum) ... super prima parteff. veteris ... [Venetiis, 1488]

Turnebus, Adrianus

- Adriani Tvrnebi Adversariorum Tomi III ..., Argentinae, Sumtibus Lazari Zenzneri, 1599

Tuscus, Dominicus

- Practicarum Conclusionvm Ivris in omni foro frequentiorvm Dominici TT.S. Onvphrii ... Card. Tvschi, tom. 3 ( $3^{\text {rd }}$ edn.), Lvgdvni, ex Officina Ioannis Pilehotte, sumptibus Ioannis Caffin, \& Francisci Plaignard, 1634

van der Keessel, Dionysius

- Theses Selectae juris hollandici et zelandici ad supplendam Hugonis Grotii introductionem ad jurisprudentiam Hollandicam, et definiedas celebriores 
juris Hollandici controversias, in usum auditorum vulgatae, Lugduni Batavorum, apud S. et J. Luchtmans, 1800

Vinnius, Arnold

- Arnoldi Vinnii JC. In Quatuor Libros Institutionum Imperialium Commentarius Academicus, Et Forensis, Lugduni, Typis Petri Bruyset, Sumptibus Fratrum Detournes, 1755

Vivanus Tuscus

- Casus longi super Digesto vetere [Lyon, Syber, 1490]

Voet, Johannes

- Commentarius ad Pandectas ( $4^{\text {th }}$ edn.), Bruxellis, Apud Simonem Serstevens, 1723

Weißbrodt, Johann Andreae

- Disputatio Juridica de Judice Putativo, ad L. Barbarius 3 de Offic[io] Praet[orum] ..., Francofurti ad Viadrum, Typis Johan. Coepselli, 1681

Zasius, Ulrichus

- Dn. Vdalrici Zasii ... In primam Digestorvm Partem Paratitla, siue titulariae annotations ... Basileae, Apvd Mich[aelem] Ising[rin], 1539

Works published after 1800

Abbondanza (1963)

Adler (1928)

Agostinelli (1920)

Aimone-Braida (2014)

Albisetti (1980)

Amelotti (1985)
Abbondanza, Roberto, s. v. 'Baldovini, Iacopo', in Dizionario Biografico degli Italiani, vol. 5 (1963), pp. 521-525

Adler, Ada (ed.), Suidae Lexicon, vol. 1 (Leipzig: Treubner, 1928)

Agostinelli, Alfredo, Il funzionario di fatto (Campobasso: Colitti, 1920)

Aimone-Braida, Pier Virginio (ed.), Summa in Decretum Simonis Bisinianensis (Città del Vaticano: Biblioteca Apostolica Vaticana, 2014; Monumenta iuris canonici, series A, Corpus glossatorum, vol. 8)

Albisetti, Alessandro, Contributo allo studio del matrimonio putativo in diritto canonico. Violenza e buona fede (Milano: Giuffrè, 1980)

Amelotti, Mario, Il documento nel diritto giustinianeo. Prassi e legislazione, in G. Archi (ed.), Il mondo del diritto nell'epoca giustinianea (Ravenna: Edizioni del Girasole, 1985), pp. 125-137 
Ankum (1989)

Bambi (2006)

Becker (2000)

Behrmann (1995)

Bellomo (1982)

Bellomo (1992)

Bellomo (1995)

Bellomo (1997a)

Bellomo (1997b)

Bellomo (2000)

Belloni (2014)

Benatti (2013)
Ankum, Hans A., Les tabellions romains, ancêtres directs des notaires modernes, in Atlas du notariat: le notariat dans le monde (Deventer: Kluwer, 1989), pp. $5-48$

Bambi, Federigo, Fides, la parola, i contesti. Ovvero, alla ricerca della publica fides, in V. Piergiovanni (ed.), Hinc publica fides: il notaio e l'amministrazione della giustizia (Milano: Giuffrè, 2006), pp. 23-47

Becker, Hans-Jürgen, Die Steinerne Brücke zu Regensburg als "Juristische Person", in D. Klippel (ed.), Colloquia für Dieter Schwab zum 65. Geburtstag (Bielefeld: Gieseking, 2000), pp. 105-116

Behrmann, Thomas, Ein neuer Zugang zum Schriftgut der oberitalienischen Kommunen, in H. Keller and T. Behrmann (eds.), Kommunales Schriftgut in Oberitalien. Formen, Funktionen, Überlieferung (München: Fink, 1995)

Bellomo, Manlio, Consulenze professionali e dottrine di professori. Un inedito 'consilium domini Accursii', 7 (1982) Quaderni catanesi di studi classici e medievali, pp. 199-219

Bellomo, Manlio, La scienza del diritto al tempo di Federico II, 3 (1992) Rivista internazionale di diritto comune, pp. 173-196

Bellomo, Manlio, L'Europa del diritto comune (Rome: Il Cigno, 1989; English translation, The Common Legal Past of Europe (L. G. Cochrane transl.), Washington: The Catholic University of America, 1995)

Bellomo, Manlio, Factum proponitur certum, sed dubio est de iure, in M. Bellomo (ed.), Die Kunst der Disputation. Probleme der Rechtsauslegung und Rechtsanwendung im 13. und 14. Jahrhundert (München: Oldenbourg, 1997), pp. 1-28

Bellomo, Manlio, Sulle tracce d'uso dei "libri legales”, in 103 (1989) Atti della Società Ligure di Storia Patria, pp. 33-51, and now in Id., Medioevo edito e inedito (Roma: Il Cigno, 1997), vol. 1, pp. 121-138

Bellomo, Manlio, I fatti e il diritto: tra le Certezze e $i$ Dubbi dei Giuristi Medievali (secoli XIII-XIV) (Roma: Cigno, 2000)

Belloni, Annalisa, Bartolo studente e maestro e $i$ suoi commentari, in Bartolo da Sassoferrato nel VII centenario della nascita: diritto, politica, società (Spoleto: Centro italiano di studi sull'alto medioevo, 2014), pp. 559-584

Benatti, Corrado, s. v. 'Guido da Suzzara', in Dizionario biografico dei giuristi italiani (Bologna: Mulino, 2013), vol. 1, pp. 1093-1094 
Benson (1968)

A. Berger (1991)

E. Berger (1887)

Bergmann (1965)

Berman (1983)

Bernal Palacios (1986)

Bertram (1971)

Bertram (2002)

Bertram (2012)

Besta (1896)

Bezemer (1987)

Bezemer (1990)

Bezemer (1994)

Bezemer (1997)
Benson, Robert L., The Bishop-Elect: A Study in Medieval Ecclesiastical Office (Princeton: Princeton University Press, 1968)

Berger, Adolf, Encyclopedic Dictionary of Roman Law (Transactions of the American Philosophical Society, vol. 43, pt. 2, 1953, repr. 1991)

Berger, Élie (ed.), Les Registres d'Innocent IV (4 vols., Paris: Thorin, 1881-1919)

Bergmann, Friedrich C. (ed.), Libri de iudiciorum ordine: Pilii Medicinensis Summa de ordine iudiciorum; Tancredi Bononiensis ordo iudiciarius; Gratiae Aretini Summa de iudiciario ordine (Gottingae, apud Vandenhoeck et Ruprecht, 1842; anastatic reprint, Aalen: Scientia Verlag, 1965)

Berman, Harold J., Law and Revolution. The Formation of the Western Legal Tradition (Cambridge (Mass.): Harvard University Press, 1983)

Bernal Palacios, Arturo, Reportatio of a Lectura on the title "De Actionibus" (Inst. 4,6 rub. - 6) of Guido de Cumis (MS Vat. lat. 2689, fol. 5), 54 (1986) Tijdschrift voor rechtsgeschiedenis, pp. 269-286

Bertram, Martin, Der Dekretalenapparat des Goffredus Tranensis, 1 (1971) Bulletin of Medieval Canon Law, pp. 79-83

Bertram, Martin, Zwei vorläufige Textstufen des Dekretalenapparats Papst Innozenz' IV, in V. Colli (ed.), Juristische Buchproduktion im Mittelalter (Frankfurt am Main: Klostermann, 2002), pp. 431-479

Bertram, Martin, Kanonisten und ibre Texte (1234 bis Mitte 14. Jh.) (Leiden: Brill, 2012)

Besta, Enrico (ed.), L'opera d'Irnerio, vol. 2, Glosse inedite d'Irnerio al Digestum Vetus (Torino: Loescher, 1896)

Bezemer, Kees, Les répétitions de Jacques de Révigny: recherches sur la répétition comme forme d'enseignement juridique et comme genre littéraire, suivies d'un inventaire des textes (Leiden: Brill, 1987)

Bezemer, Kees, Les Quaestiones disputatae orléanaises dans les commentaires de Jacques de Révigny, 58 (1990) Tijdschrift voor Rechtsgeschiedenis, pp. 5-38 Bezemer, Kees, French Customs in the Commentaries of Jacques de Revigny, 62 (1994) Tijdschrift voor Rechtsgeschiedenis, pp. 81-112

Bezemer, Kees, What Jacques Saw. Thirteenth century France through the eyes of Jacques de Revigny, professor of law at Orléans (Frankfurt am Main: Klostermann, 1997) 
Bezemer (2000)

Bezemer (2005)

Bezemer (2010)

Bianchi Riva (2016)

Birocchi (1995)

A. Black (1990)

A. Black (2003)

J. Black (2009)

Boyer (1998)

Brandi (1892)

Brasington (2016)

Brundage (1987)

Brundage (2008)

Brundage (2013)

Bueno Salinas (1985)
Bezemer, Kees, Word for Word (or not): on the Track of the Orléans Sources of Cinus' Lecture on the Code, 68 (2000) Tijdschrift voor Rechtsgeschiedenis, pp. $433-454$

Bezemer, Kees, Pierre de Belleperche. Portrait of a legal puritan (Frankfurt am Main: Klostermann, 2005)

Bezemer, Kees, The Infrastructure of the Early Ius Commune: The Formation of Regulae, or its Failure, in J.W. Cairns and P. J. du Plessis (eds.), The Creation of the Ius Commune. From Casus to Regula 57-75

Bianchi Riva, Raffaella, Dal consenso al dissenso. $\mathrm{La}$ rilevanza giuridica dello scandalo nelle elezioni episcopali (secc. XII-XV), 10 (2016), Historia et Ius (paper 3)

Birocchi, Italo, Persona giuridica nel diritto medioevale e moderno, in Digesto delle discipline privatistiche, Sezione civile, XIII, 1995, pp. 408-420

Black, Anthony (ed.), Community in Historical Perspective (Cambrige: Cambridge University Press, 1990)

Black, Anthony, Guild and State. European Political Thought from the Twelfth Century to the Present (revised edn., London: Transaction Publishers, 2003)

Black, Jane, Absolutism in Renaissance Milan. Plenitude of Power under the Visconti and the Sforza 1329-1535 (Oxford: Oxford University Press, 2009) Boyer, Laurent, Sur quelques adages: notes d'histoire et de jurisprudence 156 (1998) Bibliothèque de l'école des chartes, pp. 13-76

Brandi, Brando, Notizie intorno a Guillelmus De Cunio: le sue opere e il suo insegnamento a Tolosa (Roma: Forzani, 1892)

Brasington, Bruce C. (ed.), Order in the Court: Medieval Procedural Treatises in Translation (Leiden: Brill, 2016)

Brundage, James A., Law, Sex, and Christian Society in Medieval Europe (Chicago: University of Chicago Press, 1987)

Brundage, James A., The Medieval Origins of the Legal Profession (Chicago: Chicago University Press, 2008)

Brundage, James A., Medieval Canon Law (London: Longman, 1995; repr. 2013, Abingdon: Routlege)

Bueno Salinas, Santiago, La noción de persona jurídica en el derecho canónico (Barcelona: Herder, 1985) 
Buisson (1982)

Cai (1953)

Calasso (1965)

Canning (1983)

Canning (1988)

Canning (1989)

Canning (2014)

Canning (2015)

Caprioli et al. (2004)

Carillo (1842)

Cascione (2003)

Cavallar (1997)

Cerchiari (1920)
Buisson, Ludwig, Potestas und Caritas. Die päpstliche Gewalt im Spätmittelalter ( $2^{\text {nd }}$ edn., Köln: Böhlau Verlag, 1982)

Cai, Raphael (ed.), S. Thomae Aquinatis ... super Epistolas S. Pauli lectura (Taurini, Romae: Marietti, 1953)

Calasso, Francesco, s.v. 'Bartolo da Sassoferrato', in Dizionario Biografico degli Italiani (Roma: Società grafica romana), vol. 6 (1965), pp. 640-669 Canning, Joseph, Ideas of the State in Thirteenth and Fourteenth-Century Commentators on the Roman Law, 33 (1983) Transactions of the Royal Historical Society, pp. 1-27

Canning, Joseph, Law, Sovereignty and Corporation Theory, in J. H. Burns (ed.), Cambridge History of Medieval Political Thought, c. 350 - c. 1450 (Cambridge: Cambridge University Press, 1988), pp. 454-476

Canning, Joseph, The Political Thought of Baldus de Ubaldis (Cambridge: Cambridge University Press, 1987; reprint, 1989)

Canning, Joseph, Ideas of Power in the Late Middle Ages, 1296-1417 (Cambridge: Cambridge University Press, 2014)

Canning, Joseph, Kantorowicz's interpretation of Baldus' corporation theory in the light of later research, in T. Frank and D. Rando (eds.), Ernst Kantorowicz (1895-1963). Political History as Cultural Inquiry (Pavia: Pavia University Press, 2015), pp. 111-122

Caprioli, Severino; Crescenzi, Victor; Diurni, Giovanni; Mari, Paolo; Peruzzi, Piergiorgio (eds.), Glosse Preaccursiane alle Istituzioni, Strato Azzoniano, vol. 2 (Roma: Istituto Storico Italiano per il Medio Evo, 2004)

Carillo, Filippo, Dizionario universale ossia repertorio ragionato di giurisprudenza e questioni di diritto di Merlin, vol. 14 (Venezia: Antonelli, 1842)

Cascione, Cosimo, Consensus. Problemi di Origine, tutela processuale e prospettive semantiche (Napoli: Editoriale Scientifica, 2003)

Cavallar, Osvaldo, Il tiranno, $i$ dubia del giudice, e $i$ consilia dei giuristi, 155 (1997) Archivio Storico Italiano, pp. 265-345

Cerchiari, Emmanuele, Capellani papae et Apostolicae Sedis Auditores causarum sacri palatii apostolici (4 vols., Romae, typis polyglottis Vaticanis, 1919-1921) 
Chevrier (1965)

Chevrier (1968)

Chiffoleau (2006)

Chiodi (2001)

Chiodi (2013)

Chodorow (1972)

Christin (2014)

Clokey (1985)

Coing (1985)

Colli (2000)

Colli (2005)

Colli (2008)

M. Condorelli (1960)

O. Condorelli (1992)
Chevrier, Georges, Les critères de la distinction $d u$ droit privé et du droit public dans la pensée savante médiévale, in Études d'bistoire du droit canonique dédiées à Gabriel Le Bras (Paris: Sirey, 1965), vol. 2, pp. 841-859

Chevrier, Georges, Jacques de Révigny et la Glose d'Accurse, in G. Rossi (ed.), Atti del Convegno internazionale di studi Accursiani (Torino: Giuffrè, 1968), vol. 3, pp. 979-1004

Chiffoleau, Jacques, 'Ecclesia de occultis non iudicat'? L'Eglise, le secret, l'occulte du XIIe au XVe siècle, 14 (2006) Micrologus, pp. 359-481

Chiodi, Giovanni, “Delinquere ut universi”. Scienza giuridica e responsabilità penale delle universitates tra XII e XIII secolo, in Studi di Storia del diritto (Milano: Giuffrè, 2001), vol. 3, pp. 91-199

Chiodi, Giovanni, s.v. 'Ugolino Presbiteri' in Dizionario biografico dei giuristi italiani (Bologna:

Mulino, 2013), vol. 2, pp. 1994-199

Chodorow, Stanley, Christian Political Theory and Church Politics in the Mid-Twelfth Century. The Ecclesiology of Gratian's Decretum (Berkeley, Los Angeles, London: The University of California Press, 1972)

Christin, Olivier, Vox populi. Une histoire du vote avant le suffrage universel (Paris: Seuil, 2014)

Clokey, Kathryn A., The De Facto Officer Doctrine: The Case for Continued Application, 85 (1985) Columbia Law Review, pp. 1121-1139

Coing, Helmut, Europäisches Privatrecht, vol. 1 (München: Beck'scheVerlagsbuchhandlung, 1985) Colli, Vincenzo, Un testimone della Lectura Digesti veteris di Baldo degli Ubaldi datato 1387, 27 (2000)

Ius Commune, pp. 407-425

Colli, Vincenzo, Le opere di Baldo. Dal codice d'autore all'edizione a stampa, in C. Frova, M. G.

Nico Ottaviani, S. Zucchini, VI Centenario della Morte di Bado degli Ubaldi (Perugia: Università degli Studi, 2005), pp. 25-85

Colli, Vincenzo, A proposito di autografi e codici d'autore dei giuristi medievali (sec. XII-XIV), in V. Colli and E. Conte (eds.), Iuris Historia: liber amicorum Gero Dolezalek (Berkeley: Robbins Collection Publications, 2008), pp. 213-247

Condorelli, Mario, I fondamenti giuridici della tolleranza religiosa nell'elaborazione canonistica dei secoli XII-XIV (Milano: Giuffrè, 1960)

Condorelli, Orazio, Dalle 'Quaestiones Mercuriales' alla 'Novella in titulum de regulis iuris', 3 (1992) Rivista Internazionale di diritto comune, pp. $125-171$ 
O. Condorelli (1997)

O. Condorelli, Roumy and

Schmoeckel (2009-2016)

Conetti (2005)

Congar (1958)

Constantineau (1910)

Conte and Loschiavo (2013)

Cortese (1960)

Cortese (1962-1964)

Cortese (1966)

Cortese (1999)

Cortese (1995)

Cortese (2009)

Cortese (2013)
Condorelli, Orazio, Ordinare-Iudicare. Ricerche sulle potestà dei vescovi nella Chiesa antica e altomedievale (secoli II-IX) (Roma: Il Cigno, 1997)

Condorelli, Orazio; Roumy, Franck; Schmoeckel, Mathias (eds.), Der Einfluss der Kanonistik auf die europäische Rechtskultur (5 vols., Wien, Köln, Weimar: Böhlau, 2009-2016)

Conetti, Mario, Baldo e la politica viscontea. Appunti a questiones e consilia, in Carla Frova, Nico Ottaviani, Stefania Zucchini (eds.), VI centenario della morte di Baldo degli Ubaldi, 1400-2000 (Perugia: Università di Perugia, 2005), pp. 473-522

Congar, Yves M.-J., Quod omnes tangit, ab omnibus tractari et approbari debet, 36 (1958) Revue Historique de Droit Français et Étranger, pp. 210-259

Constantineau, Albert, A treatise on the de facto doctrine: in its relation to public officers and public corporations based upon the English, American and Canadian cases including comments upon extraordinary legal remedies in reference to the trial of title to office and corporate existence (Rochester, NY: Lawyers Co-Operative Publishing company, 1910)

Conte, Emanuele; Loschiavo, Luca, s.v. 'Azzone' in Dizionario biografico dei giuristi italiani (Bologna: Mulino, 2013), vol. 1, pp. 137-139

Cortese, Ennio, s.v. 'Causa (diritto intermedio)', in Enciclopedia del Diritto, vol. VI (Milano: Giuffrè, 1960), pp. 535-547

Cortese, Ennio, La norma giuridica: spunti teorici nel diritto comune classico (2 vols, Milano: Giuffrè, 1962-1964)

Cortese, Ennio, s.v. 'Errore (diritto intermedio)', in Enciclopedia del Diritto, vol. XV (Milano: Giuffrè, 1966), pp. 236-246

Cortese, Ennio, Lex, Aequitas, Utrumque Ius nella prima civilistica, in "Lex et iustitia" nell'utrumque ius: Radici antiche e prospettive attuali (Città del Vaticano: Libreria Editrice Vaticana, 1989), pp. 95-119, and now in Id., Scritti, vol. 2 (U. Birocchi and U. Petronio, eds.), (Spoleto: Centro Italiano di Studi sull'alto medioevo, 1999), pp. 1019-1043

Cortese, Ennio, Il diritto nella storia medievale (2 vols., Roma: Il Cigno, 1995)

Cortese, Ennio, Passeggiando fra $i$ libri antichi di Giovanni Gualandi, 60(1) 2009 Studi Urbinati, AScienze giuridiche, politiche ed economiche, pp. 53-61 Cortese, Ennio, s.v. 'Guido de Cumis', in Dizionario biografico dei giuristi italiani (Bologna: Mulino, 2013), vol. 1 
Costa (1969)

Creusen (1937)

D’Urso (2000)

De Franceschi (1924)

Deroussin (2001)

Derrett (1958)

Deutsch (1970)

Di Bartolo (1997)

Di Renzo Villata (2013)

Dilcher (1960)

Dixon (1938)

Dondorp (2010)

Errera (2006)

Errera (2007)
Costa, Pietro, Iurisdictio. Semantica del potere politico nella pubblicistica medievale (1100-1433) (Milano: Giuffrè, 1969)

Creusen, Joseph, Pouvoir dominatif et erreur commune, in Acta Congressus Iuridici Internationalis VII saeculo a decretalibus Gregorii IX et XIV a codice iustiniano promulgatis, vol. 4 (Romae: apud custodiam librariam Pont. Instituti utriusque iuris, 1937), pp. 181-192

D’Urso, Francesco, Persona giuridica e responsabilità penale. Note storico-giuridiche a proposito di recenti riforme, 29 (2000) Quaderni Fiorentini, pp. 511-550

De Franceschi, Camillo (ed.), Chartvlarium piranense: raccolta dei documenti medievali di Pirano, vol. 1 (1062-1300) (Parenzo: Società istriana di archeologia e storia patria, 1924)

Deroussin, David, Le juste suject de croire dans l'ancien droit français (Paris: De Boccard, 2001)

Derrett, John D. M., Factum Valet: the adventures of a maxim, 7 (1958) International and Comparative Law Quarterly, pp. 280-302

Deutsch, Bernard F., Ancient Roman law and Modern Canon law (pt.7), 30 (1970) The Jurist pp. $182-192$

Di Bartolo, Stefano, Il casus legis nell'opera di Iacopo Bottrigari sr. Alcuni esempi dell'uso della dialettica nella metodologia giuridico-esegetica dello Studium bolognese, 8 (1997) Rivista Internazionale di Diritto Comune, pp. 179-216

Di Renzo Villata, Gigliola, s.v. 'Giasone del Maino', in Dizionario biografico dei giuristi italiani (Bologna: Mulino, 2013), vol. 2, pp. 995-999

Dilcher, Hermann, Die Theorie der Leistungstörungen bei Glossatoren, Kommentatoren und Kanonisten (Frankfurt am Main: Klostermann, 1960)

Dixon, Owen, De Facto Officers, 1 (1938) Res Judicata, pp. 285-292

Dondorp, Harry; Schrage, Eltjo J. H., The Sources of Medieval Learned Law, in J. W. Cairns and P. J. du Plessis (eds.), The Creation of the Ius Commune. From Casus to Regula (Edinburgh: Edinburgh University Press, 2010), pp. 7-56

Errera, Andrea, Lineamenti di epistemologia giuridica medievale. Storia di una rivoluzione scientifica (Torino: Giappichelli, 2006)

Errera, Andrea, The Role of Logic in the Legal Science of the Glossators and Commmentators, in P. G. Stein and A. Padovani (eds.), The Jurists' Philosophy of Law from Rome to the Seventeenth Century (Dordrecht: Springer, 2007), pp. 79-156 
Eschmann (1943)

Fabritz (2010)

Fasolt (2004)

Fedele (1936)

Feenstra (1956)

Feenstra (1962)

Feenstra (1974)

Feenstra $(1986 a)$

Feenstra $(1986 b)$

Feenstra (1996)

Ferrara (1980)
Eschmann, Thomas, A Thomistic Glossary on the Principle of the Preeminence of Common Good, 5 (1943) Medieval Studies, pp. 123-165

Fabritz, Peter, Sanatio in radice: Historie eines Rechtsinstituts und seine Beziehung zum sakramentalen Eheverständnis der katholischen Kirche (Frankfurt am Main: Peter Lang, 2010)

Fasolt, Constantin, The Limits of History (Chicago: University of Chicago Press, 2004)

Fedele, Pio, Il funzionario di fatto nel diritto canonico, in Studi in onore di Francesco Scaduto, vol. 1 (Firenze: Cya, 1936), pp. 321-388

Feenstra, Robert, L'histoire des fondations. À propos de quelques études récentes, 24 (1956) Tijdschrift voor Rechtsgeschiedenis, pp. 381-448

Feenstra, Robert, Bartole dans le Pays bas, in D. Segoloni (ed.), Bartolo da Sassoferrato: studi e documenti per il VI centenario (2 vols., Milano: Giuffrè, 1962), vol. 1, pp. 173-281

Feenstra, Robert, Les Casus Institutionum de Guido de Cumis (manuscrits et editions), 29 (1968-1969) Mémoires de la Société pour l'Histoire du Droit et des Institutions des anciens pays bourguignons, comtois et romands, pp. 231-253, now in Id., Fata iuris romani: études d'histoire du droit (Leyde: Presse Universitaire de Leyde, 1974), pp. 260-282

Feenstra, Robert, Influence de l'enseignement $d u$ droit romain sur les nations etrangeres, in Actes $d u$ congrès sur l'ancienne université d'Orléans (XIIIeXVIIIe siecles), Orléans, 1962, now in Id., Le Droit savant au moyen âge et sa vulgarisation (London: Variorum, 1986), pp. 45-61

Feenstra, Robert, L'enseignement du droit à Orléans, Etat de recherches menées depuis Meijers, new series 9 (1985) Bulletin de la Société archeologique et historique de I'Orléannais, now in Id., Le Droit savant au moyen âge et sa vulgarisation (London: Variorum, 1986), pp. 13-29

Feenstra, Robert, L'École de droit d'Orléans au treizieme siècle et son rayonnement dans l'Europe medievale, 13 (1992) Revue d'histoire des facultés de droit et de la science juridique, now in Id., Legal scholarship and doctrines of private law (Aldershot: Ashgate, 1996), pp. 23-42

Ferrara, Roberto; Valentini, Vittorio (eds.), Liber sive matricula notariorum comunis Bononie (1219-1299) (Roma: Consilio nazionale del notariato, 1980; Fonti e strumenti per la storia del notariato italiano, vol. 4) 
Figueira (1980)

Figueira (2006)

Fournier (1921)

Fossier (2009)

Fransen (1970)

Fransen and Kuttner (1969-1990)

Friedberg (1959)

Gallagher (1978)

Galli (2008)

García y García (1982)

Gaudemet (1951)

Gaudemet (1979)

Gaudemet (1985-1986)

Gaudemet (1993)
Figueira, Robert C., The Canon Law of Medieval Papal Legation (Cornell University, PhD dissertation, 1980)

Figueira, Robert C., The Medieval Papal Legate and his Province: Geographical Limits of Jurisdiction, in R. C. Figueira (ed.), Plenitude of Power. The Doctrines and Exercise of Authority in the Middle Ages: Essays in Memory of Robert Louis Benson (Aldershot: Ashgate, 2006), pp. 73-106

Fournier, Paul, s.v. 'Guillaume du Cun, légiste', in Histoire littéraire de la France, vol. 35 (Paris: Imprimerie Nationale, 1921), pp. 361-385

Fossier, Arnaud, 'Propter vitandum scandalum'. Histoire d'une catégorie juridique (XIIe-XVe siècle), 212 (2009) Mélanges de l'École française de Rome Moyen Âge, pp. 317-348

Fransen, Gérard, Jurisdiction et Pouvoir Législatif, in Acta conventus canonistarum (Città del Vaticano: Typis Polyglottis Vaticanis, 1970), pp. 212-220

Fransen, Gérard; Kuttner, Stephan (eds.), Summa 'Elegantius in iure divino' seu Coloniensis (Monumenta Iuris Canonici. Series A: Corpus Glossatorum, vol. 1; Città del Vaticano: Biblioteca Apostolica Vaticana, tom. 1-4, 1969-1990)

Friedberg, Emil (ed.), Corpus Iuris Canonici (Tauchnitz: Leipzig, 1879; anastatic reprint, Graz: Akademische Dr. und Verl. Anst., 1959)

Gallagher, Clarence, Canon Law and the Christian Community: the Role of Law and the Church According to the Summa Aurea of Cardinal Hostiensis (Roma: Università Gregoriana editrice, 1978) Galli, Patrick, Regimen, administratio, dignitas dans l'exégèse juridique: le cas de l'Apparatus d'Innocent $I V$, in J. Krynen and M. Stolleis (eds.), Science politique et droit public dans le facultés de droit européennes (XIII-XVIII siècle) (Frankfurt am Main: Klostermann, 2008), pp. 143-156

García y García, Antonio (ed.), Constitutiones Concilii quarti Lateranensis una cum commentariis glossatorum (Monumenta iuris canonici, Series A: Corpus glossatorum, vol. 2; Città del Vaticano: Biblioteca Apostolica Vaticana, 1982)

Gaudemet, Jean, Utilitas Publica, 29 (1951) Revue historique de droit français et étranger, pp. 465-499 Gaudemet, Jean, Les élections dans l'église latine des origines au XVIe siècle (Paris: Lanore, 1979)

Gaudemet, Jean, Pouvoir d'ordre et pouvoir de jurisdiction. Quelques repères historiques, 29 (19851986) L'année canonique, pp. 83-98

Gaudemet, Jean, Les sources du droit canonique: VIIIe-XXe siècle (Paris: Éditions du Cerf, 1993) 
Gehlen (2002)

Gilchrist (1993)

Gilles (1971)

Gillet (1927)

Gillmann (1912)

Gillmann (1933)

Gloria (1877)

Gloria (1879)

Golden Robison (1972)

Goodnow (1906)

Gordley (1991)
Gehlen, Antoon F., La Signification de la Lex Barbarius Philippus pour le Notariat en Hollande et Zelande aux 17 eme et 18eme Siecles, in L. de Ligt; J. de Ruiter; E. Slob; J. M. Tevel; M. van de Vrugt; L. C. Winkel (eds.), Viva Vox Iuris Romani. Essays in Honour of Johannes Emil Spruit (Amsterdam: Gieben, 2002), pp. 51-59

Gilchrist, John, Simoniaca haeresis and the Problem of Orders from Leo IX to Gratian, in S. Kuttner and John J. Ryan (eds.), Proceedings of the Second International Congress of Medieval Canon Law (Città del Vaticano: Biblioteca Apostolica Vaticana, 1965), now in J. Gilchrist, Canon Law in the Age of Reform, 11th-12th Centuries (Aldershot: Variorum, 1993), pp. 209-235

Gilles, Henri, Trois Consultations Des Doctores Tholosani En Faveur Du Monastère De Prouille, 39 (1971) Tijdschrift voor Rechtsgeschiedenis, pp. 157220

Gillet, Pierre, La Personnalité juridique en droit ecclésiastique spécialement chez les Décrétistes et les Décrétalistes et dans le Code de droit canonique (Malines: Godenne, 1927)

Gillmann, Franz, review of Joseph Creusen, Tabulae fontium traditionis christianae (Friburgi Brisgoviae: Herder, 1911), 92 (1912) Archiv für katholisches Kirchenrecht, pp. 365-370

Gillmann, Franz, Wo war Vincentius Hispanus Bischof?, 113 (1933) Archiv für katholisches Kirchenrecht, pp. 99-107

Gloria, Andrea (ed.), Codice diplomatico padovano dal secolo sesto a tutto l'undecimo (Venezia: Regia Deputazione veneta di storia patria, 1877)

Gloria, Andrea (ed.), Codice diplomatico padovano dall'anno 1101 alla pace di Costanza (25 giugno 1183) (vol. 1, Venezia: Regia Deputazione veneta di storia patria, 1879)

Golden Robison, Elaine (ed.), Humberti Cardinalis Libri Tres Adversus Simoniacos: A Critical Edition with an Introductory Essay and Notes (Princeton University, PhD Thesis, 1972)

Goodnow, Frank J., Selected Cases on American Administrative Law (Chicago: Callaghan \& company, 1906)

Gordley, James R., The Philosophical Origins of Modern Contract Doctrine (Oxford: Clarendon Press, 1991) 
Gordley (2000)

Gordley (2004)

Gordley (2010)

Gordon (1974)

Goria (2000)

Gouron (1986)

Grimm (1989)

Gualandi (1968)

Haenel (1964)

Härtel (2005)

Härtel (2011)
Gordley, James R., Good Faith in Contract Law in the Medieval Ius Commune, in R. Zimmerman and S. Whittaker (eds.), Good Faith in European Contract Law (Cambridge: Cambridge University Press, 2000), pp. 93-117

Gordley, James R., Mistake in Contract Formation, 52 (2004) The American Journal of Comparative Law, pp. 433-468

Gordley, James R., Ius Quaerens Intellectum: The Method of the Medieval Civilians, in J. W. Cairns and P.J. du Plessis (eds.), The Creation of the Ius Commune. From Casus to Regula (Edinburgh: Edinburgh University Press, 2010), pp. 77-101 Gordon, William M., Cinus and Pierre de Belleperche, in A. Watson (ed.), Daube Noster. Essays in Legal History for David Daube (Edinburgh and London: Scottish Academic Press, 1974), pp. 105-117

Goria, Fausto, Ricusazione del giudice e iudices electi da Costantino a Giustiniano, in S. Pugliatti and A. Sanguinetti (eds.), Legislazione, cultura guridica, prassi dell'impero d'oriente in età giustinianea tra passato e futuro (Milano: Giuffrè, 2000), pp. 153-209

Gouron, André, Sur les sources civilistes et la datation des Sommes de Rufin et d'Etienne de Tournoi, 16 (1986) Bullettin of Medieval Canon Law, pp. 55-70 Grimm, Benno, Die Ehelehre des Magister Honorius: ein Beitrag zur Ehelehre der anglo-normannischen Schule, 24 (1989) Studia Gratiana (monographic number)

Gualandi, Giovanni, Un gustoso episodio della vita di Accursio e la data della composizione della "Glossa magna" al "Digestum Vetus", 33 (1964-1965) Studi Urbinati, now in G. Rossi (ed.), Atti del Convegno internazionale di studi accursiani. Bologna, 21-26 ottobre 1963, vol. 2 (Milano: Giuffrè, 1968), pp. 459-92

Haenel, Gustav F. (ed.), Hugolini dissensiones dominorum (Leipzig, 1834; reprint Aalen: Scientia Verlag, 1964)

Härtel, Reinhard; Mittermüller, Franz; Reismann, Bernhard; Goller, Johanna (eds.), Die älteren Urkunden des Klosters S. Maria zu Aquileia (1036-1250) (Wien: Österreichische Akademie der Wissenschaften, 2005)

Härtel, Reinhard, Studi sui documenti del monastero di S. Maria di Aquileia (1036-1250), 89-90 (2011) Memorie storiche forogiuliesi, pp. 11-72 
Heintschel (1956)

Heitmeyer (1964)

Herrmann (1968)

H. Hofmann (1974)

K. Hofmann (1929)

C. Hohenlohe (1937)

Horn (1967)

Horn (1968)

Huizig (1955)

Jacobi (1913)

Jaser (2013)

Junker (1926)

E. Kantorowicz (1981)

H. Kantorowicz and Buckland (1969)
Heintschel, Donald E., The Concept of an Ecclesiastical Office in the Commentaries of the Early Decretalists, 16 (1956) The Jurist. Studies in church law and ministry, pp. 131-153

Heitmeyer, Heinrich, Sakramentenspendung bei Häretikern und Simonisten nach Huguccio (Roma: Pontificia Universitas Gregoriana, 1964)

Herrmann, Horst, Ecclesia Supplet. Das Rechtsinstitut der kirchlichen Suppletion nach c. 209 CIC (Amsterdam: Grüner, 1968)

Hofmann, Hasso, Repräsentation. Studien zur Wortund Begriffsgeschichte von der Antike bis ins 19. Jahrbundert (Berlin: Duncker \& Humblot, 1974)

Hofmann, Karl, Die freiwillige Gerichtsbarkeit (iurisdictio voluntaria) im kanonischen Recht (Paderborn: Schöningh, 1929)

Hohenlohe, Constantin, Einfluss des Christentums auf das Corpus iuris civilis (Wien: Hölder, Pichler, Tempsky, 1937)

Horn, Norbert, Philosophie in der Jurisprudenz der Kommentatoren: Baldus philosophus, 1 (1967) Ius Commune, pp. 104-149

Horn, Norbert, Aequitas in den Lebren des Baldus (Köln, Graz: Böhlau, 1968)

Huizig, Peter, The Earliest Development of Excommunication Latae Sententiae by Gratian and the Earliest Decretists, 3 (1955) Studia Gratiana, pp. 277-320

Jacobi, Erwin, Der Prozeß im Decretum Gratiani und bei den ältesten Dekretisten, 3 (1913) Zeitschrift der Savigny-Stiftung für Rechtsgeschichte, Kan. Abt., pp. 223-343

Jaser, Christian, Ecclesia Maledicens. Rituelle und zeremonielle Exkommunikationsformen in Mittelalter (Tübingen: Mohr Siebeck, 2013)

Junker, Josef, Die Summe des Simon von Bisignano und seine Glossen, 15 (1926) Zeitschrift der SavignyStiftung für Rechtsgeschichte, Kan. Abt., pp. 326500

Kantorowicz, Ernst H., The King's Two Bodies: A Study in Mediaeval Political Theology (Princeton: Princeton University Press, 1957; $6^{\text {th }}$ reprint, 1981)

Kantorowicz, Hermann; Buckland, William W., Studies in the Glossators of the Roman Law. Newly Discovered Writings of the Twelfth Century (1938; new edn., Peter Weimar (ed.), Aalen: Scientia, 1969) 
Kelly (1992)

Kessler (1942)

Kirshner (2006)

Knütel (1989)

Kretzschmar (1985)

Kriechbaum (1996)

Kriechbaum (2013)

Krynen (2015)

Krynen (1994)

Kuttner (1936)

Kuttner (1937)

Kuttner (1950)
Kelly, Henry A., Inquisitorial due process and the status of secret crimes, in S. Chodorow (ed.), Proceedings of the Eighth International Congress of Medieval Canon Law (Città del Vaticano: Biblioteca Apostolica Vaticana, 1992), pp. 407-427

Kessler, Peter-Joseph, Untersuchungen über die Novellen-Gesetzgebung Papst Innozenz' IV, pt. 1, 62 (1942) Zeitschrift der Savigny-Stiftung für Rechtsgeschichte, Kan. Abt., pp. 143-330

Kirshner, Julius, Bartolo of Sassoferrato's De tyranno and Sallustio Buonguglielmi's Consilium on Niccolò Fortebracci's Tyranny in Città di Castello, 68 (2006) Mediaeval Studies, pp. 303-331

Knütel, Rolf, Barbatius Philippus und seine Spuren. Falsus praetor, parrochus putativus, Scheinbeamter, in Dieter Schwab, Dieter Giese, Joseph Listl, Hans-Wolfgang Strätz (eds.), Staat, Kirche, Wissenschaft in einer pluralistischen Gesellschaft (Berlin: Dunkel \& Humblot, 1989), pp. 345-365

Kretzschmar, Robert, Alger von Lüttichs Traktat 'de Misericordia Et Iustitia': Ein kanonistischer Konkordanzversuch aus der Zeit des Investiturstreits. Untersuchungen und Edition (Ostfildern: Jan Thorbecke Verlag, 1985)

Kriechbaum, Maximiliane, Actio, ius und dominium in den Rechtslebren des 13. und 14. Jabrhunderts (Ebelsbach: Aktiv Druck \& Verlag, 1996)

Kriechbaum, Maximiliane, s. v. 'Iacobo Bottrigari', in Dizionario biografico dei giuristi italiani (Bologna: Il Mulino, 2013), vol. 1, pp. 1096-1098

Krynen, Jacques, s.v. 'Cun, Guillaume de', in P. Arabeyre, J.-L. Halpérin and J. Krynen (eds.), Dictionnaire bistorique des juristes français, XIIe-XXe siècle (2 ${ }^{\text {nd }}$ edn., Paris, PUF, 2015), pp. 295-296

Krynen, Jacques, L'Eglise dans la Lectura super codice de Guillaume de Cunh, in L'Église et le droit dans le Midi, 29 (1994) Cahiers de Fanjeaux, pp. 101-116

Kuttner, Stephan, Ecclesia de occultis non iudicat, Acta Congressus Juridici Internationalis: VII saeculo a decretalibus Gregorii IX et XIV a codico Iustiniano promulgatis (Roma: Pontificum Institutum Utriusque Juris, 1936), pp. 225-246

Kuttner, Stephan, Repertorium der Kanonistik (1140-1234) (Città del Vaticano: Biblioteca Apostolica Vaticana, 1937)

Kuttner, Stephan, Natural Law and Canon Law, 3 (1949-1950) Natural Law Institute Proceedings, University of Notre Dame, pp. 85-116 
Kuttner (1949-1951)

Kuttner (1974)

Landau (1995)

Landau (1996)

Lange (1997)

Lange and Kriechbaum (2007)

Larson (2016)

Lee (2016)

Lefebvre (1938)

Lefebvre (1952)

Lefebvre (1958)

Legendre (1964)

Lenel (1918)

Lenherr (1981)
Kuttner, Stephan; Rathbone, Eleanor, Anglo-Norman Canonists of the Twelfth Century: An Introductory Study, 7 (1949-1951) Traditio, pp. 279-358

Kuttner, Stephan, s. v. 'Johannes Teutonicus', in Neue deutsche Biographie, vol. 10 (Berlin: Duncker \& Humblot, 1974), pp. 571-573

Landau, Peter, Sakramentalität und Jurisdiktion, in G. Rau, H.-R. Reuter and K. Schlaich (eds.), Das Recht der Kirche, vol. 2 (Gütersloh: Kaiser, 1995), pp. 58-95

Landau, Peter, Die Bedeutung des kanonischen Rechts für die Entwicklung einheitlicher Rechtsprinzipien, in H. Scholler (ed.), Die Bedeutung des kanonischen Rechts für die Entwicklung einheitlicher Rechtsprinzipien (Baden-Baden: Nomos, 1996), pp. 23-47

Lange, Hermann, Römisches Recht im Mittelalter, vol. 1, Die Glossatoren (München: Beck, 1997)

Lange, Hermann; Kriechbaum, Maximiliane, Römisches Recht im Mittelalter, vol. 2 (München: C. H. Beck'sche Verlagsbuchhandlung, 2007) Larson, Atria A., Archiepiscopal and Papal Involvement in Episcopal Elections: The Origins and Reception of Lateran IV cc. 23-24 from the Third Lateran Council to the Liber Sextus, 102 (2016) Zeitschrift der Savigny-Stiftung für Rechtsgeschichte, Kan. Abt., pp. 73-98

Lee, Daniel, Popular Sovereignty in Early Modern Constitutional Thought (Oxford: Oxford University Press, 2016)

Lefebvre, Charles, Le pouvoirs du Juge en droit canonique. Contribution historique et doctrinale à l'étude du canon 20 sur la méthode et les sources en droit positif (Paris: Sirey, 1938)

Lefebvre, Charles, "Aequitas canonica" et "periculum animae" dans la doctrine de l'Hostiensis, 8 (1952) Ephemerides iuris canonici, pp. 305-321

Lefebvre, Charles, De quelques fragments de Jean de Monchy sur le Code, 26 (1958) Tijdschrift voor Rechtsgeschiedenis, pp. 294-315

Legendre, Pierre, La pénétration du droit romain dans le droit canonique classique de Gratien à Innocent IV: (1140-1254) (Paris: Jouve, 1964)

Lenel, Otto, Textkritische Miszellen, 39 (1918) Zeitschrift der Savigny-Stiftung für Rechtsgeschichte, Rom. Abt., pp. 119-171

Lenherr, Titius, Der Begriff 'Executio' in der Summa Decretorum des Huguccio, 150 (1981) Archiv für katholisches Kirchenrecht, pp. 5-44 and 361-420 
Lenherr (1987)

Lepsius (2003)

Lepsius (2008)

Lepsius (2013)

Lepsius (2014)

Leveleux-Teixeira (2010)

Litewski (1999)

Loniewski (1905)

Lucifredi Peterlongo (1965)

Lynch (1976)

Maassen (1857)

Maceratini (1991)
Lenherr, Titius, Die Exkommunikations- und Depositionsgewalt der Häretiker bei Gratian und den Dekretisten bis zur Glossa ordinaria des Johannes Teutonicus (St. Ottilien: Eos Verlag, 1987)

Lepsius, Susanne, Der Richter und die Zeugen: eine Untersuchung anhand des Tractatus testimoniorum des Bartolus von Sassoferrato (Frankfurt am Main: Klostermann, 2003)

Lepsius, Susanne, Prätor und Prokonsul: Übersetzungsleistungen und Neuschöpfungen der mittelalterlichen Legisten im Umgang mit den römischen Ämtern, in J. Krynen and M. Stolleis (eds.), Science politique et droit public dans les facultés européennes (XIIIe-XVIIIe siècle) (Frankfurt am Main: Klostermann, 2008), pp. 223-250

Lepsius, Susanne, s. v. 'Bartolo da Sassoferrato', in Dizionario Biografico dei Giuristi Italiani (XII-XX Secolo) (Bologna: Mulino, 2013), vol. 1, pp. 177-180

Lepsius, Susanne, Bartolus' Auseinandersetzung mit dem Digestum Novum: zwischen lectura und commentum, in Bartolo da Sassoferrato nel VII centenario della nascita: diritto, politica, società (Spoleto: Centro italiano di studi sull'alto medioevo, 2014), pp. 601-629

Leveleux-Teixeira, Corinne, L" "Utilitas publica” des Canonistes. Un outil de régulation de l'ordre juridique, 32 (2010) Revue Française d'Histoire des Idées Politiques, pp. 259-276

Litewski, Wiesław, Der römisch-kanonische Zivilprozeß nach den älteren ordines iudiciarii (Krakow: Jagellonian University Press, 1999)

Loniewski, Alfred, Essai sur le rôle actuel de la maxime "Error communis facit ius" (Aix: J. Nicot, 1905)

Lucifredi Peterlongo, Maria E., Contributi allo studio dell'esercizio di fatto di pubbliche funzioni (Milano: Giuffrè, 1965)

Lynch, Joseph H., Simoniacal Entry into Religious Life from 1000 to 1260. A Social, Economic and Legal Study (Columbus: Ohio State University Press, 1976)

Maassen, Friedrich, Beiträge zur Geschichte der juristischen Literatur des Mittelalters: insbesondere der Decretisten-Literatur des zwölften Jabrbunderts (Wien: K. K. Hof- und Staatsdruckerei, 1857)

Maceratini, Ruggero, Aspetti della posizione giuridica dell'eretico in alcune opere della riforma gregoriana, in M. Ascheri (ed.), Scritti di storia del diritto offerti dagli allievi a Domenico Maffei (Padova: Antenore, 1991), pp. 1-25 
Maceratini (1994)

Maffei (1963)

Maffei (1967)

Maffei (1990)

Maiolo (2007)

Marcello (1928)

Martino (1981)

Martino (1984)

Marzoa Rodríguez (1985)

Mazeaud (1924)

Mazzanti (2003)

McLaughlin (1952)

McManus (1991)

Meder (2015)
Maceratini, Ruggero, Ricerche sullo status giuridico dell'eretico nel diritto romano-cristiano e nel diritto canonico classico: da Graziano ad Uguccione (Padova: CEDAM, 1994)

Maffei, Domenico, La 'Lectura super Digesto Veteri' di Cino da Pistoia (Milano: Giuffrè, 1963)

Maffei, Domenico, Il giudice testimone e una 'quaestio' di Jacques de Revigny, 35 (1967) Tijdschrift voor Rechtsgeschiedenis, pp. 54-76

Maffei, Domenico, Bartolomeo da Novara (d.1408) autore della 'Lectura Institutionum' attribuita a Baldo degli Ubaldi, 63 (1990) Rivista di storia del diritto italiano, pp. 5-22, now in in Id., Studi di storia delle Università e della letteratura giuridica, Goldbach: Keip Verlag, 1995, saggio n. 13.

Maiolo, Francesco, Medieval Sovereignty. Marsilius of Padua and Bartolus of Saxoferrato (Delft: Eburon, 2007)

Marcello, Amalia, Opere giustamente e ingiustamente attributite a I. d'A., 61 (1928) Rendiconti del Regio Istituto lombardo di scienze e lettere, pp. 852-861

Martino, Federico, Ricerche sull'opera di Guido da Suzzara (Catania: Tringale, 1981)

Martino, Federico, Dottrine di giuristi e realtà cittadine nell'Italia del trecento. Ranieri Arsendi a Pisa e a Padova (Catania: Tringale, 1984)

Marzoa Rodríguez, Angel, La Censura de excomunion. Estudio de su Naturaleza Juridica en ss. XIII-XV (Pamplona: Ediciones Universidad de Navarra, 1985)

Mazeaud, Henri, La Maxime Error communis facit jus, 23 (1924) Revue trimestrielle de droit civil, pp. 929-964

Mazzanti, Giuseppe, s.v. 'Guido da Suzaria', in Dizionario Biografico degli Italiani, vol. 61 (2003), pp. 421-426

McLaughlin, Terence P. (ed.), The Summa Parisiensis on the Decretum Gratiani (Toronto: Pontifical Institute of Medieval Studies, 1952)

McManus, Brendan J., The Ecclesiology of Laurentius Hispanus and His Contribution to the Romanization of Canon Law Jurisprudence, with an Edition of the Apparatvs Glossarvm Lavrentii Hispanii in Compilationem Tertiam (PhD dissertation, Syracuse University, 1991)

Meder, Stephan, Doppelte Körper im Recht. Traditionen des Pluralismus zwischen staatlicher Einheit und transnationaler Vielheit (Tübingen: Mohn Siebeck, 2015) 
Mehr (2008)

Meijers (1926)

Meijers (1959a)

Meijers (1959b)

Meijers (1966)

Melloni (1986)

Melloni (1990)

Melloni (1992)

Merlin (1812-1815)

Merzbacher (1980)

Meyer (2000)

Miaskiewicz (1940)
Mehr, Ralf, Societas und Universitas. Römischrechtliche Institute im Unternehmensgesellschaftsrecht vor 1800 (Köln: Böhlau, 2008)

Meijers, Eduard M.; de Blécourt, Anne S.; Bodenstein, Helgard D. J., (eds.), Cornelii van Bijnkersboek ... Observationes Tumultuariae, vol. 1 (Haarlem: Tjeenk Willink, 1926)

Meijers, Eduard M., L'Université d'Orléans au XIIIe siècle, in Id., Études d'Histoire du Droit (R. Feenstra and H.F.W. Fischer (eds.), Leyde: Universitaire pers Leiden, vol. 3, 1959), pp. 3-148

Meijers, Eduard M., La première époque d'épanouissement de droit à l'université de Toulouse (1280-1330), in Id., Études d'Histoire du Droit (R. Feenstra and H. F. W. Fischer (eds.), Leyde: Universitaire pers Leiden, vol. 3, 1959), pp. 167-208

Meijers, Eduard M., Les théories médiévales concernant la cause de la stipulation et la cause de la donation, in Id., Études d'Histoire du Droit (R. Feenstra and H. F. W. Fischer (eds.), Leyde: Universitaire pers Leiden, vol. 4, 1966), pp. 107-131 Melloni, Alberto, William of Ockham's Critique of Innocent IV, 46 (1986) Franciscan Studies, pp. 161-203

Melloni, Alberto, Innocenzo IV. La concezione e l'esperienza della cristianità come regimen unius personae (Genova: Marietti, 1990)

Melloni, Alberto, Ecclesiologia ed istituzioni. Un aspetto della concezione della cristianità di Innocenzo IV, in S. Chodorow (ed.), Proceedings of the Eighth International Congress of Medieval Canon Law (Città del Vaticano: Biblioteca Apostolica Vaticana, 1992), pp. 285-307

Merlin, Philippe-Antoine, Répertoire universel et raisonné de jurisprudence $\left(4^{\text {th }}\right.$ edn., Paris: chez Garnery, 1812-1815)

Merzbacher, Friedrich, Alger von Lüttich und das Kanonische Recht, 66 (1980) Zeitschrift der SavignyStiftung für Rechtsgeschichte, Kan. Abt., pp. 230260

Meyer, Andreas, Felix et inclitus notarius. Studien zum italienischen Notariat vom 7. bis zum 13. Jahrbundert (Tübingen: Max Niemeyer, 2000; Bibliothek des Deutschen Historischen Instituts in Rom, vol. 92)

Miaskiewicz, Francis S., Supplied Jurisdiction according to Canon 209 (Washington D.C.: Catholic University of America Press, 1940) 
Michaud-Quantin (1970)

Migliorino (1985)

Migliorino (2011)

Minnucci (1989-1994)

Morin (2014)

Moule (2016)

Moynihan (1961)

Müller (1994)

Müller and Pennington (2008)

Najemy (1982)

Nasilowski (1969)

Navarrete (1962)

Nicolini (1940)
Michaud-Quantin, Pierre, Universitas. Expressions du Mouvement Communautaire dans le Moyen Âge Latin (Paris: Vrin, 1970)

Migliorino, Francesco, Fama e Infamia. Problemi della società medievale nel pensiero giuridico nei secoli XII e XIII (Catania: Giannotta, 1985)

Migliorino, Francesco, "La Grande Hache de l'histoire". Semantica della fama ed dell'infamia, in I. Lori Sanfilippo and A. Rigon (eds.), Fama e Publica Vox nel Medioevo (Roma: Istituto Storico Italiano per il Medio Evo, 2011), pp. 5-21

Minnucci, Giovanni, La capacità processuale della donna nel pensiero canonistico classico, 2 vols. (Milano: Giuffrè, 1989-1994)

Morin, Alejandro, Toleratio malorum, pecadores ocultos y herejías, 11 (2014) Glossae. European Journal of Legal History, pp. 104-116

Moule, Gregory S., Corporate Jurisdiction, Academic Heresy, and Fraternal Correction at the University of Paris, 1200-1400 (Leiden: Brill, 2016)

Moynihan, James M., Papal Immunity and Liability in the Writings of the Medieval Canonists (Roma: Gregorian University Press, 1961)

Müller, Wolfgang P., Huguccio. The Life, Works and Thought of a Twelfth-Century Jurist (Washington: The Catholic University of America, 1994)

Müller, Wolfgang P.; Pennington, Kenneth, The Decretists: The Italian School, in W. Hartmann and K. Pennington (eds.), The History of Medieval Canon Law in the Classical Period, 1140-1234 (Washington, D.C.: Catholic University of America, 2008), pp. 121-173

Najemy, John M., Corporatism and Consensus in Florentine Electoral Politics, 1280-1400 (Chapel Hill: University of North Carolina Press, 1982)

Nasilowski, Kazimierz, De distinctione potestatis ordinis et iurisdictionis a primis Ecclesiae saeculis usque ad exeuntem decretistarum periodum, in A. Scheuermann and G. May (eds.), Ius Sacrum (München, Paderborn, Wien: Verlag Ferdinand Schöningh, 1969), pp. 165-179

Navarrete, Urbano, La posesión de las "universitates" especialmente en caso de extinción de todos sus mienabros, según Bartolo, in AA.VV., Bartolo di Sassoferrato. Studi e documenti per il VI centenario, vol. 2 (Milano: Giuffrè, 1962), pp. 347-372 Nicolini, Ugo, La proprietà, il principe e l'espropriazione per pubblica utilità: studi sulla dottrina giuridica intermedia (Milano: Giuffrè, 1940) 
Nicolini (1968)

Nörr (1992)

Padoa Schioppa (1976)

Padovani (2011)

Padovani (2013)

Padovani (2017)

Palmieri (1914)

Panizo Orallo (1975)

Pannam (1966-1967)

Paradisi (1960)

Paravicini Bagliani (1972)

Parlopiano (2015)
Nicolini, Ugo, I giuristi postaccursiani e la fortuna della glossa in italia, in G. Rossi (ed.), Atti del convegno internazionale di Studi Accursiani (1968), vol. 3, pp. 801-943

Nörr, Knut W., Zur Frage des subjektiven Rechts in der mittelalterlichen Rechtswissenschaft, in D. Medicus, H.-J. Mertens, K. W. Nörr, W. Zöllner (eds.), Festschrift für Hermann Lange zum 70. Geburtstag (Stuttgart, Berlin, Köln: Kohlhammer, 1992), pp. 193-204

Padoa Schioppa, Antonio, Sul principio della rappresentanza diretta nel Diritto canonico classico, in S. Kuttner (ed.), Proceedings of the Fourth International Congress of Medieval Canon Law (Città del Vaticano: Biblioteca Apostolica Vaticana, 1976), 106-131

Padovani, Andrea, 'Tenebo bunc ordinem'. Metodo e struttura della lezione nei giuristi medievali (secoli XII-XIV), 79 (2011), Tijdschrift voor Rechtsgeschiedenis, pp. 353-389

Padovani, Andrea, s.v. 'Dino Rossoni del Mugello', in Dizionario biografico dei giuristi italiani (Bologna: Il Mulino, 2013), vol. 1, pp. 769-771

Padovani, Andrea, Dall'alba al crepuscolo del commento. Giovanni da Imola (1375 ca. - 1436) e la giurisprudenza del suo tempo (Frankfurt am Main: Klostermann, 2017)

Palmieri, Giovanni Battista (ed.), Wernerii Summa Institutionum, in G. B. Palmieri (ed.), Scripta anecdota glossatorum, Primi voluminis additiones (Bononiae: ex aedibus Angeli Gandolphi typis societatis Azzoguidianae, 1914)

Panizo Orallo, Santiago, Persona jurídica y ficción: estudio de la obra de Sinibaldo de Fieschi (Inocencio IV) (Pamplona: Ediciones Universidad de Navarra, 1975)

Pannam, Clifford L., Unconstitutional Statutes and De Facto Officers, 2(1) (1966-1967) Federal Law Review, pp. 37-71

Paradisi, Bruno, La diffusione europea del pensiero di Bartolo e le esigenze attuali della sua conoscenza, 26 (1960) Studia et documenta historiae et iuris, pp. $1-70$

Paravicini Bagliani, Agostino, Cardinali di curia e "familiae" cardinalizie dal 1227 al 1254 (2 vols., Padova: Antenore 1972)

Parlopiano, Brandon, Propter deformitatem: Towards a Concept of Disability in Medieval Canon Law, 4 (2015) Canadian Journal of Disability Studies, pp. 73-102 
Peltzer (2015)

Pennington (1981)

Pennington (1993)

Pennington (2003)

Pennington (2004)

Pennington (2016)

Peters (1970)

Piergiovanni (1967)

Post (1964)

Potthast (1874-1875)

Přerovský (2006)

Prosdocimi (1955)

Quaglioni (1980)

Quaglioni (1983)
Peltzer, Jörg, Idoneität. Eine Ordnungskategorie oder eine Frage des Rangs?, in C. Ardenna; G. Melville (eds.), Idoneität - Genealogie - Legitimation. Begründung und Akzeptanz von dynastischer Herrschaft im Mittelalter (Köln, Weimar, Wien: Böhlau, 2015), pp. 23-37

Pennington, Kenneth (ed.), Johannis Teutonici Apparatus glossatum in Compilationem tertiam, tom. 1 (Città del Vaticano: Biblioteca apostolica vaticana, 1981; Monumenta iuris canonici. Series A: Corpus Glossatorum, vol. 3)

Pennington, Kenneth, The Prince and the Law. Sovereignty and Rights in the Western Legal Tradition (Berkeley, Los Angeles, Oxford: University of California Press, 1993)

Pennington, Kenneth, Innocent Until Proven Guilty: The Origins of a Legal Maxim, 63 (2003) The Jurist: Studies in Church Law and Ministry, pp. 106-124

Pennington, Kenneth, Representation in Medieval Canon Law, 64 (2004) The Jurist. Studies in Church law and ministry, pp. 361-383

Pennington, Kenneth, The Jurisprudence of Procedure, in W. Hartmann and K. Pennington, The History of Courts and Procedure in Medieval Canon Law (Washington D.C.: Catholic University of America Press, 2016), pp. 125-159

Peters, Edward, The Shadow King. Rex Inutilis in Medieval Law and Literature (New Haven and London: Yale University Press, 1970)

Piergiovanni, Vito, Sinibaldo dei Fieschi decretalista. Ricerche sulla vita, 14 (1967) Studia Gratiana, pp. 126-154

Post, Gaines, Studies in Medieval Legal Thought (Princeton: Princeton University Press, 1964)

Potthast, Augustus (ed.), Regesta pontificum Romanorum (2 vols., Berlin: de Decker, 1874-1875)

Přerovský, Oldřich (ed.), Huguccio Pisanus, Summa decretorum (Monumenta iuris canonici, Series A, vol. 6; Città del Vaticano: Biblioteca Apostolica Vaticana, tom. 1, 2006)

Prosdocimi, Luigi, La 'Summa Decretorum' di Uguccione da Pisa, Studi Preliminari, 5 (1955) Studia Gratiana, pp. 349-374

Quaglioni, Diego, 1980, Un "Tractatus de Tyrannis": II commento di Baldo degli Ubaldi (1327?-1400) alla lex Decernimus, C. de Sacrosanctis Ecclesiis (C. 1, 2, 16), 13 (1980) Il pensiero politico, pp. 64-83 Quaglioni, Diego (ed.), Politica e diritto nel Trecento italiano. Il 'De Tyranno' di Bartolo da Sassoferrato (1314-1357) (Firenze: Olschki, 1983) 
Quaglioni (2002)

Quaglioni (2013)

Quillet (1971)

Rampazzo (2008)

Rennie (2013)

Reynolds (2016)

Richter (1853)

Riesenberg (1956)

Rodriguez (1962)

Roland (1986)

Rossi (2012)

Ruffini (1936)

Ryan (1972)

Saltet (1907)
Quaglioni, Diego, 'Universi consentire non possunt'. La punibilità dei corpi nella dottrina del diritto comune, in C. Nubola and A. Würgler, Suppliche e 'gravamina'. Politica, amministrazione, giustizia in Europa (secoli XIV-XVIII) (Bologna: Mulino, 2002), pp. 409-425

Quaglioni, Diego, s.v. 'Iacopo d'Arena', in Dizionario biografico dei giuristi italiani (Bologna: Il Mulino, 2013), vol. 1, pp. 1099-1101

Quillet, Jeannine, Universitas populi et Représentation au XIV siècle, in A. Zimmerman, Der Begriff der repraesentatio im Mittelalter. Stellvertretung, Symbol, Zeichen, Bild (Berlin: de Gruyter, 1971), pp. 186-201

Rampazzo, Natale, Quasi Praetor non fuerit. Studi sulle elezioni magistratuali in Roma repubblicana tra regola ed eccezione (Napoli: Satura, 2008)

Rennie, Kriston R., The Foundations of Medieval Papal Legation (Palgrave Macmillan, 2013)

Reynolds, Philip L., How Marriage Became One of the Sacraments. The Sacramental Theology of Marriage from its Medieval Origins to the Council of Trent (Cambridge: Cambridge University Press, 2016)

Richter, Aemilius L.; Schulte, Johann F. von (eds.), Canones et decreta Concilii Tridentini ex editione Romana a. MDCCCXXXIV repetiti ... (Lipsiae: Typis et sumptibus B. Tauchnitii, 1853)

Riesenberg, Peter N., Inalienability of Sovereignty in Medieval Political Thought (New York: Columbia University Press, 1956)

Rodriguez, Manuel J., Innocent IV and the Element of Fiction in Juristic Personalities, 22 (1962) The Jurist, pp. 287-318

Roland, Henri; Boyer, Laurent, Adages du droit français ( $2^{\text {nd }}$ edn., 2 vols., Lyon: l'Hermès, 1986)

Rossi, Guido, Indignitas, Heresy and Schism: Canon Law and the iurisdictio of the mali pastores, 129 (2012) Zeitschrift der Savigny-Stiftung für Rechtsgeschichte, Kan. Abt., pp. 149-173

Ruffini, Francesco, La classificazione delle persone giuridiche in Sinibaldo dei Fieschi (Innocenzo IV) ed in Federico Carlo di Savigny, in Id., Scritti giuridici minori, vol. 2 (Milano: Giuffrè, 1936), pp. 3-90 Ryan, John J., The Separation of 'Ordo' and 'Iurisdictio' in its Structural-Doctrinal Development and Ecclesiological Significance (PhD dissertation, Münster University, 1972)

Saltet, Louis, Les reordinations (Paris: Gabalda, 1907) 
Sarti (1990)

Sarti (2013)

Savigny (1829-1831)

Schermaier (2000)

Schmoeckel (2016)

Schrage (2001)

Schulte (1870)

Schulte (1880)

Schulte (1890)

Schulte (1965)

Schulz, H. Kantorowicz and Rabotti (1968)

Semeraro (2013)

Siméant (2011)

Singer (1963)
Sarti, Nicoletta, Un Giurista tra Azzone e Accursio. Iacopo di Balduino (... 1210-1235) e il suo "Libellus Instructionis Advocatorum" (Milano: Giuffrè, 1990)

Sarti, Nicoletta, s.v. 'Iacopo Balduini', in Dizionario biografico dei giuristi italiani (Bologna: Il Mulino, 2013), vol. 1, pp. 1095-1096

Savigny, Friedrich C. von, Geschichte des römischen Rechts im Mittelalter, vols. 5-6 (Heidelberg: Mohr, 1829-1831; $2^{\text {nd }}$ edn., 1850)

Schermaier, Martin J., Die Bestimmung des wesentlichen Irrtums von den Glossatoren bis zum BGB (Wien, Köln, Weimar: Böhlau, 2000)

Schmoeckel, Mathias, Vom Allgemeinbekannten zum Gerichtsbekannten: Das allmähliche Verschwinden der Notorietät und die Veränderungen des römisch-kanonischen Beweisrechts in der Frühen Neuzeit, 102 (2016) Zeitschrift der Savigny-Stiftung für Rechtsgeschichte, Kan. Abt., pp. 200-241

Schrage, Eltjo J. H., Rechtsquellen aus der Sicht der Glossatoren, in L. Capogrossi Colognesi et al. (eds.), Iuris vincula. Studi in onore di Mario Talamanca (Napoli: Jovene, 2001), vol. 7, pp. 409-424 Schulte, Johann F. von, Zur Geschichte der Literatur über das Dekret Gratians (3 vols., Wien: K. K. Hofund Staatsdruckerei, 1870)

Schulte, Johann F. von, Geschichte der Quellen und Literatur des Canonischen Rechts (3 vols., Stuttgart: Ferdinand Enke, 1875-1880)

Schulte, Johann F. von (ed.), Die Summa des Paucapalea (Giessen: Emil Roth, 1890)

Schulte, Johann F. von (ed.), Die Summa Stephanus Tornacensis über das Decretum Gratiani (Giessen: Roth, 1891; anastatic reprint, Aalen: Scientia Verlag, 1965)

Schulz, Fritz; Kantorowicz, Hermann; Rabotti, Giuseppe (eds.), Thomae Diplovatatii Liber de claris iuris consultis, pars posterior (Bononiae: Institutum Gratianum, 1968 (=Studia Gratiana, vol. 10)) Semeraro, Martino, s.v. 'Martino Sillimani', in Dizionario biografico dei giuristi italiani (Bologna: Il Mulino, 2013), vol. 2, pp. 1296-1297

Siméant, Clarisse, L'influence $d u$ droit romanocanonique mediéval sur la construction juridique $d u$ territoire, in F. Roumy, M. Schmoeckel, O. Condorelli (eds.), Der Einfluss der Kanonistik auf die europäische Rechtskultur, vol. 2 (Köln, Weimar, Wien: Böhlau, 2011), pp. 115-131

Singer, Heinrich (ed.), Die 'Summa Decretorum' des Magister Rufinus (Paderborn: Schöningh, 1902; anastatic reprint, Aalen: Scientia Verlag, 1963) 
Sohm (1967)

Sorice (2002)

Spagnesi (2013)

Stickler (1966)

Stickler (1967)

Stickler (1971)

Štulrajterová (2011)

Sweeney (1975)

Sweeney (1976)

Tamassia (1981)

Thaner (1874)

Tierney (1951)

Tierney (1998)
Sohm, Rudolph, Das altkatholische Kirchenrecht und das Dekret Gratians, in Festschrift der Leipziger Juristenfakultät für Dr. Adolf Wach (München, Leipzig: Duncker \& Humblot, 1918; repr. Darmstadt: Wissenschaftliche Buchgesellschaft, 1967)

Sorice, Rosalba (ed.), Distinctiones 'Si mulier eadem hora' seu Monacenses (Monumenta iuris canonici, series A, Corpus glossatorum, vol. 4; Città del Vaticano: Biblioteca Apostolica Vaticana, 2002)

Spagnesi, Enrico, s.v. 'Odofredo Denari', in Dizionario biografico dei giuristi italiani (Bologna: Mulino, 2013), vol. 2, pp. 1450-1452

Stickler, Alfons M., Il decretista Laurentius Hispanus, 9 (1966) Studia Gratiana, pp. 461-549

Stickler, Alfons M., Zur Entstehungsgeschichte und Verbreitung des Dekretapparats 'Ordinaturus Magister Gratianus', 12 (1967) Studia Gratiana, pp. 111-141

Stickler, Alfons M., Zum Apparat Animal est Substantia, 1 (1971) Bulletin of Medieval Canon Law, pp. $73-78$

Štulrajterová, Katarína, The Non-alienation Clause in the Hungarian and English Coronation Oaths: A Justified or Unjustified Papal Assumption? 29 (2011) Bulletin of Medieval Canon Law, pp. 219-250

Sweeney, James R., The Problem of Inalienability in Innocent III's Correspondence with Hungary: A Contribution to the Study of the Genesis of "Intellecto”, 37 (1975) Medieval Studies, pp. 235-251

Sweeney, James R., The decretal Intellecto and the Hungarian Golden Bull of 1222, in Études présentées à la Commission pour l'Histoire des Assemblées d'Etats LVI by Album Elemér Mályusz (Bruxelles, 1976), pp. 89-96

Tamassia, Nino, Odofredo. Studio storico-giuridico (Bologna: Tip. Fava e Gardagnani, 1894; reprint, Bologna: Forni, 1981)

Thaner, Friedrich (ed.), Die Summa Magistri Rolan$d i$ (Innsbruck: Wagner'sche Universitäts-Buchhandlung, 1874)

Tierney, Brian, A Conciliar Theory of the Thirteenth Century, 36 (1951) The Catholic Historical Review, pp. $415-440$

Tierney, Brian, Foundations of the Conciliar Theory. The Contribution of the Medieval Canonists from Gratian to the Great Schism ( $3^{\text {rd }}$ edn., Leiden: Brill, 1998) 
Tierney (2016)

Todescan $(1982 / 83)$

Tooke (1927-1928)

Tuck (1998)

Tuner (2016)

Ullmann (1948)

Valentini (1965-1966)

Vallerani (2012)

Van de Kerckhove (1937)

Van Soest-Zuurdeeg (1989)

Villemin (2003)

Vitiello (2016)

Vodola (1986)
Tierney, Brian, Corporatism, Individualism, and Consent: Locke and Premodern Thought, in M. E. Eichbauer and K. Pennington (eds.), Law as Profession and Practice in Medieval Europe: Essays in Honor of James A. Brundage (2011 Ashgate; reprint Abingdon: Routledge, 2016), pp. 49-72 Todescan, Franco, Dalla "Persona Ficta" alla "Persona Moralis”, 11/12 (1982/83) Quaderni Fiorentini per la storia del pensiero giuridico italiano, pp. 59-93

Tooke, Charles W., De Facto Municipal Corporations under Unconstitutional Statutes, 37 (1927-1928) Yale Law Journal, pp. 935-954

Tuck, Richard, Natural Rights Theories: Their Origin and Development (Cambridge: Cambridge University Press, 1979; reprint, 1998)

Tuner, Henry S., The Corporate Commonwealth. Pluralism and Political Fictions in England, 1516-1651 (Chicago, London: The University of Chicago Press, 2016)

Ullmann, Walter, The Delictal Responsibility of Medieval Corporations, 64 (1948) Law Quarterly Review, pp. 77-96

Valentini, Vittorio, Il "tractatus de tabellionibus" di Baldo degli Ubaldi attribuito anche a Bartolo da Sassoferrato nonché a Gozzadino de' Gozzadini, 34 (1965-1966) Studi Urbinati, pp. 3-169

Vallerani, Massimo, La giustizia pubblica medievale (Bologna: Il Mulino, 2005; English translation, Medieval Public Justice (S. R. Blanshei, transl.), Washington: Catholic University of America Press, 2012)

Van de Kerckhove, Martinien, La notion de jurisdiction chez les Décrétistes et les premiers Décrétalistes (1140-1250), 49 (1937) Études Franciscaines, pp. $420-455$

Van Soest-Zuurdeeg, Liesbeth J., La Lectura sur le titre De Actionibus (Inst. 4.6) de Jacques de Révigny (Leiden: Brill, 1989)

Villemin, Laurent, Pouvoir d'ordre et pouvoir de jurisdiction. Histoire théologique de leur dinstinction (Paris: Éditions du Cerf, 2003)

Vitiello, Joanna C., Public Justice and the Criminal Trial in Late Medieval Italy. Reggio Emilia in the Visconti Age (Leiden: Brill, 2016)

Vodola, Elizabeth, Excommunication in the Middle Ages (Berkeley, Los Angeles, London: University of California Press, 1986) 
Volante (2001)

Waelkens (1984)

Waelkens (1990)

Waelkens (2015)

Wahl (1970)

Wallach (1907)

Walther (1990)

Walther (1992)

Walther (2005)

Watson (1985)

Wei (2016)

Weigand (1963)
Volante, Raffaele, Il sistema contrattuale del diritto comune classico. Struttura dei patti e individuazione del tipo. Glossatori e Ultramontani (Milano: Giuffrè, 2001)

Waelkens, Laurent J. M., La théorie de la coutume chez Jacques de Révigny: édition et analyse de sa répétition sur la loi De quibus (D.1,3,32) (Leiden: Brill, 1984)

Waelkens, Laurent J. M., L'influence de l'école de droit d'Orléans sur la doctrine bolonaise à la fin $d u$ XIIIe siècle, in F. Stevens and D. van den Auweele (eds.), "Houd voet bij stuk", Xenia iuris historiae G. Van Dievoet oblata (Leuven: K. U. Leuven, 1990), pp. 193-208

Waelkens, Laurent J.M., Amne adverso: Roman Legal Heritage in European Culture (Leuven: Leuven University Press, 2015)

Wahl, James A., Immortality and inalienability: Baldus de Ubaldis, 32 (1970) Mediaeval Studies, pp. 308-328

Wallach, K. Richard, De facto office, 22 (1907) Political Science Quarterly, pp. 450-483

Walther, Helmut G., Die Legitimität der Herrschaftsordnung bei Bartolus von Sassoferrato und Baldus de Ubaldis, in E. Mock and G. Wieland (eds.), Rechts- und Sozialphilosophie des Mittelalters (Frankfurt am Main: Peter Lang 1990), pp. 115-139

Walther, Helmut G., "Verbis Aristotelis non utar, quia ea iuristae non saperent." Legistische und aristotelische Herrschaftstheorie bei Bartolus und Baldus, in J. Miethke (ed.), Das Publikum politischer Theorie im 14. Jabrhundert (München: Oldenbourg, 1992), pp. 111-126

Walther, Helmut G., Die Konstruktion der juristischen Person durch die Kanonistik im 13. Jabrhundert, in Selbstbewusstsein und Person im Mittelalter. Symposium des Philosophischen Seminars der Universität Hannover vom 24. bis 26. Februar 2004 (Würzburg: Königshausen \& Neumann, 2005), pp. 195-212

Watson, Alan (ed.), The Digest of Justinian (4 vols., Philadeplhia: University of Pennsylvania Press, 1985)

Wei, John C., Gratian the Theologian (Washington: The Catholic University of America Press, 2016) Weigand, Rudolf, Die bedingte Eheschließung im kanonischen Recht, vol. 1 (Münchener Theologische Studien III, Kan. Abt. 16; München: Max Hueber, 1963) 
Weigand (1976)

Weigand (1980)

Weigand (1990)

Weigand (2008)

Weigand, Landau and Kozur (2004-2010)

Weigand, Landau and Kozur (2007-2014)

Weitzel (1967)

Wilches (1940)

Wilks (1963)

Winroth (2000)

Zabbia (2013)

Zeliauskas (1967)
Weigand, Rudolf, Bemerkungen über die Schriften und Lehren des Magister Honorius, in S. Kuttner and K. Pennington (eds.), Proceedings of the Fifth International Congress of Medieval Canon Law (Città del Vaticano: Biblioteca Apostolica Vaticana, 1976), pp. 195-212

Weigand, Rudolf, Magister Rolandus und Papst Alexander III., 149 (1980) Archiv für katholisches Kirchenrecht, pp. 3-44

Weigand, Rudolf, Frühe Kanonisten und ibre Karriere in der Kirche, 76 (1990) Zeitschrift der SavignyStiftung für Rechtsgeschichte, Kan. Abt., pp. 135155

Weigand, Rudolf, The Transmontane Decretists, in W. Hartmann and K. Pennington (eds.), The History of Medieval Canon Law in the Classical Period, 1140-1234 (Washington D.C.: Catholic University of America Press, 2008), pp. 174-210 Weigand, Rudolf; Landau, Peter; Kozur, Waltraud (eds.), Magistri Honorii summa 'De iure Canonico Tractaturus' (Monumenta Iuris Canonici, series A, vol. 5; Vatican City: Biblioteca Apostolica Vaticana, tom. 1-3, 2004-2010)

Weigand, Rudolf; Landau, Peter; Kozur, Waltraud (eds.), Summa 'Omnis qui iuste iudicat' sive Lipsiensis (Monumenta iuris canonici, series A, Corpus glossatorum, vol. 7; Città del Vaticano: Biblioteca Apostolica Vaticana, tom. 1-3, 2007-2014)

Weitzel, Joseph, Begriff und Erscheinungsformen der Simonie bei Gratian und den Dekretisten (München: Hueber, 1967)

Wilches, Felix A., De errore communi in iure Romano et Canonico (Romae: Apvd Pontificivm Athenaevm Antonianvm, 1940)

Wilks, Michael J., The Problem of Sovereignty in the Later Middle Ages (Cambridge: Cambridge University Press, 1963)

Winroth, Anders, The Making of Gratian's Decretum (Cambridge: Cambridge University Press, 2000)

Zabbia, Marino, L'investitura notarile e la validita degli instrumenta alle soglie del Duecento. Il caso del notaio Domenico da Pirano, 10 (2013) Scrineum Rivista, pp. 191-214

Zeliauskas, Joseph, De Excommunicatione Vitiata apud Glossatores (1140-1350) (Zürich: Pas Verlag, 1967) 
Zendri (2007)

Zirkel (1975)

Zwalve (2013)
Zendri, Christian, Elementi canonistici nella "Compilatio Antiqua" dei "Libri Feudorum", in G. Dilcher and D. Quaglioni (eds.), Gli inizi del diritto pubblico. L'età di Federico Barbarossa: legislazione e scienza del diritto/Die Anfänge des öffentlichen Rechts. Gesetzgebung im Zeitalter Friedrich Barbarossas und das Gelebrte Recht (Bologna: Il Mulino; Berlin: Duncker \& Humblot, 2007), pp. 231-253 Zirkel, Adam, 'Executio Potestatis'. Zur Lehre Gratians von der geistlichen Gewalt (St. Ottilien: Eos Verlag, 1975)

Zwalve, Willem J., The Equity of the Law: Law and Equity since Justinian, in E. Koops and W.J. Zwalve (eds.), Law and Equity. Approaches in Roman Law and Common Law (Leiden: Brill, 2013), pp. 15-37

\section{List of cases}

Abbot of Fountain's case, YB 9 H.6, fols. 32v-34v, pl.3 (1431)

Ball v United States, 140 U.S. 118 (1891)

Dillon v Freine (1589) 1 Co. Rep. 120a; 76 E.R. 270

Harris v Jays (1599) Cro. Eliz. 699; 78 E.R. 934

Knight v Corporation of Wells (1695) Lutw. 508; 125 E.R. 267

Knowles v Luce (1580) Moore 109; 72 E.R. 473

Leak v Howell (1596) Cro Eliz. 533; 78 E.R. 780

McDowell v United States, 159 U.S. 596 (1895)

Norton v Shelby County, 118 U.S. 425 (1886)

Parker v Kett (1697) 1 Ld. Raym. 658; 91 E.R. 1338

R. v Malden (1767) 4 Burr. 2135; 98 E.R. 113

R. v Pursehouse (1733) 2 Barn. K.B. 264; 94 E.R. 490

Rex. v Bedford Level Corporation (1805) 6 East 356

Rous v Arters (1587) 4 Co. Rep. 24a; 76 E.R. 927

Ryder v United States (94-431), 515 U.S. 177 (1995)

Scadding v Lorant (1851) 3 H.L.C. 418; 10 E.R. 164

State v Carroll 38 Conn. 449; 9 Am. Rep. 409 (1871)

Texas v White 74 US (7 Wall.) 700 (1868)

Tey's Case, 5 Co. Rep. 38a-b (1592)

Worth v Mattison 59 U.S. (18 How.) 50 (1855) 
Index

List of Things and Places

abbot $281,351,387,524-525$

absolution $211,213,223,268-270,285,291,515,520-521$

agency

and representation 5, 8, 263-266, 277, 348, 383-385, 399

internal vs. external validity of $387-391,400,424-425,450-461,463$, 502-504, 531-533

triangle $346,383,388,426,441-442,448-450$

confirmation/ratification in office 280-282, 371-372, 406-419, 442

analogy $41,92,99,226,278,369,390,409,411,413,463$

apostate 466-468, 478

Apparatus Ordinaturus Magister 207

aptitude $348,351-352$

arbiter $36-40,70-71,85,122,145,175-179,184,197,241,285$,

296-297, 359-360, 436-438, 479, 491, 496, 502-503

Armenia 58

banished 136-139, 146, 157, 430

baptism 193-194, 217

benefice $245,267,249,349$

bequest $51,70,79,120,324,356-358$

bishop 28, 52-56, 138, 149, 281-282, 311, 329, 469, 484

apostate $466-468,478$

archbishop 268

bequest to $357-358$

bishop-elect 280, 286, 445

diocesan 53

excommunicated 201, 227-228

false $124-125,132-133,226,294,466-467$

heretical $5,7,202,244,254,274$

incumbent in the office of $357-358,362,531$

insane 366, 404

is ordinary judge 259

metropolitan 286, 445

of Gallipoli 258 
of Trieste 53, 56

putative 227,395

schismatic 195

simoniacal 194, 258

suffragan 256 n.51, 286, 445

tolerated in office $226,228,258$

true $227,466-467$

vicar of 358

Bologna 17, 62, 82, 90, 107

bribe 474

brocard $7,382,489,492,504$

burden of proof $265,267,497$

candlestick 51

canonical entry see entry into office

cardinal 257-258, 287, 301-303, 363

cavil 54, 256

Champagne 513

chaplain 351

chapter $246-247,363,499,531$

chronology 303, 343

Citramontani $\quad 62,90,96,126,133,163,317-319,529$

see also Italy

clandestine 521

clergy 191, 244

cleric $217,244,300,349$

clerk 56,379

commentators $12,63,84,161,489$

common opinion $35-36,52,59-60,122,135,150,181,236$, 265-267, 308-309, 326, 330, 453, 485, 497-499, 516-517

commonwealth $122-124,132,142,150,155,177,228,264,277$, 369-370, 421, 446-450, 454-455, 459-461, 504

concealment 143

concession 44, 142

condemnation $25,174,248-249,271-272,378-379,382,403,474,476$, 479-480, 492

confession $252,268-269,285,290,312,396,517,525$

see also sacrament

confirmation $\quad 280-282,296,302,308,318,329,347,370-378,385-395$,

403, 406-419, 442, 490, 499-500, 530-533

Connecticut, Supreme Court of 527 
consecration $182,195,202-203,275,290$

Constantinople 56

convent 53

conviction 168

corporation 245-246, 346, 398-399, 531

Curia of Rome 258-260

custom $51,82,92,121,197$

de facto officer doctrine $3,5,10,153,333,383,390,400,424,489$, $512-514$

in England 524-526

in the United States of America 526-528

in early modern Europe 504-514

deceit $44,78,142,272,297-300,385,413,461$

decretalist 7

decretist $7,195,197-200,204,207-208,218-219,224,228,232-233$,

241,251

decurion 29-30, 117, 351, 407

delegation $325,435,437,502$

denial $78,101,122,418,458$

deposition 53, 58, 174, 249-251, 263, 271, 275, 350, 360, 375-376, 378-382, 388-389, 391, 431, 440-441, 443-444, 465-466, 468, 472, $475-479,517,523$

despot 184,370

dialectic $6,62,89,237,347,349$

dignitas 17, 26-27, 174-176, 180, 199, 214-215, 345, 348-370, 376-377, 392, 397-398, 403, 408-410, 423, 434-435, 442, 447-448, 450-454, 459-461, 467, 474-475, 483

dignity 242, 348, 355, 358, 433-434

Dijon, Parlement of 513

diocese $52-53,259,281,286,294,366,445,468-469$

dismissal $56-57,360,379$

dispensation $200-201,214,286,499$

dispossession 364-365, 441

disputatio 351,510

dissent $65,74,78,90,312,529$

Distinctiones Monacenses 202

donation 142, 404

ecclesiological $7,189,191,196,199-200,203,239,241,269,312,361$, 530 
election

by robbers 375

formal validity of 151-153

in violation of the lex Iulia de ambitu 24, 27-29, 68, 82, 116 n. 92, 126,

164, 401-402, 409, 489 n.1

invalid vs. inexistent $139-140$

invalid 236, 285

ipso iure void 390,392, 467

of a banished 136-139

of Barbarius as praetor $25,40,65-68,72,87,104,108,119-122$,

132-134, 139, 441

ratification of $242-242,278,371-373,409-412,490-491,499-501$, 517,530

simoniacal 26, 374, 411

validity of $280,300,322-327,390-392$

voidable $375,416,424-431,436,451$

elector $138-140,151,243,285,300,323-327,374,427-431$

rightful 139-140, 429

emancipation $19,45,67$

see also manumission

emperor $17,29,31,33-35,40,44-45,51,83,100,130,147,149,153$, 238, 282, 298, 351-359, 405, 409, 415, 493, 511

see also sovereign; prince

endorsement $180,301,414,521$

enforcement $152,258,360-361,412$

England 524

enlistment $29-30,33,158,162,407$

entry into office $242,242,374,407,431-432,443,445,447,490-491$

equity $10,39-40,69-70,77,99,118,123,142-145,156,161,167$,

177-178, 200, 279, 387, 401, 421, 425, 445-447, 455-456

see also fairness

error $30,51,67,87,119,145,322,504$

excommunicate

judge $91-97,103-105,123-125,132-133,146-150,171,176-179$, 236, 345, 463-465, 469, 479, 523

publicly 248,284

secretly $250-251,274,293-294,300,310-312,380,395,458$,

463-464, 503, 515-520

toleration of $218,244-245,261-263,283,293-297,310$

excommunication $97,149,171,234,247-248,268,281-282,296-297$, 302 
by an excommunicate $209-228,235,238,251,270,293-294$, $311-312,515-519,521$

ferendae sententiae 193, 261, 263

latae sententiae 261

manifest 277-278, 479

occult $250,284,298,311,464,479$

excuse $95,119,131,151,159,263,321,403$

expel 197, 203, 216, 350, 474

expropriation $48,68,83$

faculty 206, 409

fairness $34,39,69,104-105,109,130-131,133,144-145,155,177,293,446$ see also equity

faith $36,39,61,87,125,131,201,225,233,266,268-269,271,273,276$, $279,285,290,302,319,396,430,454-455,518,526,530$

faithful 133, 228, 252, 276, 285, 290, 310, 312, 458

fame $53,93,161,267,390,403,426,482,484$

fitness 366,376

flexibility $11,63,94,345,390$

Florentine 322, 430-431, 448

fonctionnaire de fait see de facto officer doctrine

forbearance $189,214,218,221,329,377,414,492$

forgery $52,58,168,174,179,263,265,272,309,434,474,476,479,492$ forgiveness 214

formality $157-158,324,429,500$

formation $12,152,362,529,531$

fornication $190,276,378,396 \mathrm{n} .158$

see also priest, fornicating

Fragmentum Cantabrigense 204

France 4, 64, 93, 111, 205, 214, 217, 221, 514

see also Orléans

Frankfurt an der Oder, University of 514

fraud 282, 422, 443

freedman $31,123,128,178,198,438$

freedom $22,33,35-41,43-47,51,61,67-68,73,77-80,85,88,94$,

$100-101,108-110,115,126,128,134-136,141-144,163-164,166$, $176-177,184,249,319,402,413,460-461$

freeman $31,33,58,154,437$

French 4, 61-62, 90, 140, 168-169, 177, 205, 209, 219, 221, 225, 507, 512, 529

see also Orléans; Ultramontani 
funeral 44, 109

Gallipoli 258

generosity $6,33,35,40,44,222,335,339,500,503,529$

Ghibelline 127, 430-431

glossators $5-7,12,18,34,41,84$

Gospel 374-375

gravity $293,395,409-410$

guardian 19-20, 49, 77, 180-183, 352-353, 360-361, 369-371, 385, 387, 392,447

Guelph 430

habit $\quad 386-387$

heir $44,49,79,120-121,324$ n.22, 349

heresy $193,199,203,208,217-219,222-223,225,233-235,250,297$, 479

heretic

jurisdiction of $5,191,203,211,215,221,233,287$ n.17, 292

toleration of $199,203-204,208-212,215,221,224,232,237,244$, 250, 271, 289

evidence given by 190

sacraments administered by $194-195,272$

ordinations by 201-202, 205

secret/occult $7-8,193,199,211-212,218-219,223-226,235,250$, 297, 312, 485, 490, 529

honour $94,112,348,475,524$

humanity 39-40,109, 126, 134, 167

Hungary 367

ignorance $50-51,95,143,147,154,159,262-264,267-268,270,275$, 290, 294, 297, 319, 382, 403, 521

justifiable 95, 225, 228, 290, 326

see also mistake

illegitimacy $120,183,345,430,455,465-466$

immortality $353-354,356-358$

impediment $151,178,197,218,326,466$

impostor $56,71-72,138-139,151,172,481$

inadmissibility 271,412

incapacity $17,30,42,67,91,99,104-105,120,139,143,154,176,180$, 198, 247, 261, 297, 299, 307, 318, 352, 366, 404, 413, 435-436, 440, 
447-448, 451-452, 454, 464, 466, 474, 477, 479, 482, 485, 490, 495-496, 499, 501, 506

incompatibility $19-20,351,362,387,419,440$

incorporeal $362,380,433$

incumbent 9-10, 88, 245-246, 305, 307, 345-371, 375-380, 384, 387-389, 391, 397, 400, 410, 435, 438-444, 449

indignitas 199, 350, 366, 376-378, 389, 392, 394-395, 401, 403, 405, 410, 413, 435, 448-449, 453, 461, 466-468

see also unworthiness

ineligibility $67,119,136,138,151,328,466$

inexistence 139, 157

infamia 17, 23, 37, 174-176, 178-179, 179 n.44, 231-232, 255-256, 284, 309, 414, 474-475, 495

inhabilis $17,30,185,412,436-437,451-452,480,500-501,503-504$

interdict $79,244,281,302$

intruder $249,254,308-309,364,371-376,380,386-389,407,411,416$,

418, 424-425, 429, 431-432, 441, 443-444, 451, 468, 492, 499, 518, 523

Istria $53-54$

Italians $\quad 61-62,72,93,103,107-108,125,130,133,163,208$

see also Citramontani

Italy $6,52,56,91,137,322$

Judas 209, 257

judge $17-20,23,31,36-37,42,47,55,85,91-92,96-97,103-105$, $122-125,132-133,145-146,148-151,153,171,173,176-179$,

197-198, 204, 211, 214, 220, 222, 227, 235-238, 254-259, 266-267, $270,277,284,288,292,296-297,305,308,345,350,359,372$,

387-388, 392, 394, 420, 432-435, 437-438, 442, 451-454, 457, 460,

463-465, 470, 477, 479-480, 495, 502-503, 510, 514, 523

see also jurisdiction

minor 41

excommunicated see excommunicate, judge

slave acting as see slave, acting as judge

judgment $23,58,70-71,123,133,145,197-198,237,249,292,360-361$, 369,438

see also sentence

jurisdiction $5,7-8,19,23,27,41,91,96-98,123-125,154,179,185$,

189-192, 195-196, 198, 200-201, 203-204, 206, 208-233, 236-239,

244-246, 250-251, 255-259, 266, 268-275, 281-285, 291-292, 295,

$303,307,310-312$, 320, 341, 359, 362, 365, 369-370, 374, 377,

392-395, 404, 423, 425-426, 432-442, 451-457, 466-468, 479, 492, 
496-497, 500-504, 517-521, 523, 530-531

of the heretic see heretic, jurisdiction of

possession, of see possession, of jurisdiction

jury 525

justice $446,454-455,527$

justifiable $95,225,290,326$

Koper 52, 53 n.114

legal proceedings $122,130,133,184,353,454,476$

legate 301-303

Leiden 93

lender 76, 148

limitation $62,90,347,354,503-504$

litigant $71,91,150,440,452-453,495,532$

magistrate $2,12,18-20,23-24,29,97,139,157,173,184,404,413,430$

mandate $49,54,97,124-125,132-133,237,303,326,484$

manumission 19, 31-34, 38, 46-47, 49, 65, 68, 83, 85, 135, 142 see also emancipation

marriage $210,225,265,267,276,279,358,513,521-523$

see also sacrament

Mechelen, Great Council of 512

mercy 201, 218, 222

metaphor $352-353,361,369,375,436$

mistake

as pathology of volition 85

justifiable 326

individual $86-87,95,119,145,154-155,159-160,423$

common $7,30,33-41,49-52,65-72,75-77,80-81,84-88,92$,

95-100, 103-106, 110-111, 118-114, 130-140, 145-150, 153-160,

166-172, 181, 236-237, 262-270, 279-280, 293-294, 298, 302,

307-308, 320-323, 326-327, 382, 385, 416-423, 437, 450, 452, 470,

491-497, 505-507, 526

see also ignorance

monk 29, 351, 386-387

murderer 253, 370, 409, 466-467

mystical body 361,385

Naples 93, 339-340, 398

necessity $59,132,194,200-201,218,271-273,306,360,390,457$ 
notary $52-54,297-301,380,398$

difference with scrivener $174-177$

dismissed from office $57-58,168,174,263,272,474-480,492,497$ excommunicated $263,298,309,482,523$

false $52,56,71-72,136-139,146,150-153,169-173,176,180,264$, $298,301,309,337,470-475,523$

heretical 274,297

putative $53,55,58-60,169,175,264-265,330,481-485,497,510$

see also tabellio

notoriety $60,90,115,190,249-250,252-253,263,274-277,291,307$, 310 n.92, 311 n.96, 326, 377-378, 389, 403, 430, 438, 439 n.112, 440-441, 474, 479-480, 482, 497 n.30

oath 77 n.47, 180, 183, 360-361, 367

obligation 119 n.99, 152, 345-346, 352-356, 360-361, 365-366, 383-384, 454-455, 459-460, 524

oeconomus 379

officer $3,5,10,12,153,333,383,400,424,474,489,512,524-527$, $529-530$

omission $59,68,130,176,184,347,524$

ordination $24,26,182,194-195,201,205,276,289-290,374,458$

Orléans $\quad 6,61,89-91,93-94,106-107,111-112,125-126,128,130,134$, 140-142, 146-148, 161, 164, 167-168, 317, 329, 408, 493, 529

see also Ultramontani

opinion see common opinion

Padua 56, 72

papacy $127,355,365$

Paris, Parlement of 513

parish 124, 268, 276, 285, 311, 513, 521

phoenix 353-354, 361

pileus 44-46, 109

Pirano 54-55, 484

podestà 341 n.49, 430-431

Poitou, Parlement of 513

possession

of diocese 280, 286, 294

of ecclesiastical prebend 249, 267

of freedom 36-40, 67, 319

of jurisdiction $281,425,431-436,500-501$

of land 79,365 
of office $218,265,286,295,364,372,378-393,400,424-425$,

431-455, 466-467, 471-473, 485, 491-493, 496-498, 533

of rights $362-363$

of the superior's authority 391-393

postglossators 63,73

prebend $117,210,249-250,382$

predecessor $97,353,354 \mathrm{n} 29,359,384,524$

prefect $18-19,44,371$

prelate

and representation $246,249,259,360-361,364-366,370,385-386$, 454-455

confirmation of $182,278,282,286,307,517$

deposed 183, 275, 360, 444, 466

excommunicated $227,236,310$

false $117,124,171-172,176-177,180-183,206,295,330,372,375$

heretical 5

putative $124,133,210,265-270,280,382,454,491,512,515-521$

schismatic 182

simoniacal $26,251,258$

tolerated in office $217-218,226,231,253,268-270,278,282$, 285-286, 306, 454, 490, 518

prerogative $23,209,218-220,231,251,282,481$

priest

excommunicated 273

false $124,180-182$

fornicating 190,252

heretical 192, 225, 274

ordained by simoniacs 194-195, 200-201, 215 n. 95, 233, 254

putative prelate 268

tolerated $215,234,268-269,275-276,288,290-292,458$

prince $17-18,29,34,41-43,46,48,51,65,70,83,102,105,109,118$,

$128,153,168,174,237-238,280,320,329,350-352,354-359,367$,

$370,401,405,407,410-417,420,429,441,460,481,490-491,533$

acting for his private advantage $369-370$

representative of the Crown 352, 354-359

see also sovereign; emperor

proceedings see legal proceedings

proconsul $18,97,341,350$

procurator 246, 261-263, 266, 270, 369, 465

pronouncement $26,32,261$ 
ratification $102,181,237-238,327,329,419,441,502,530$

recipient,

of bequests 357

of delegated jurisdiction 435,503

of sacraments $192,201,228,272-273,458$

of the jurisdictional acts of Barbarius 122, 426, 448-449, 457-458

release $152,250,292,360,385-387,392$

reordination 194

representation $5,8-10,189,199,241,249,253-254,258,281-282,293$, 296, 305-309, 345-348, 361-370, 375-393, 398-401, 418, 439-441, $482-483,516,526,531-532$

revocation

of delegated jurisdiction 124-125

of mandate 132-133

of the acts of the agent apparent 69

of title 429, 444

Roman Curia see Curia of Rome

Romans 43, 64, 77-79, 103, 109, 128, 142, 319, 349, 399, 414, 493

Rome, Rota of 512

sacrament $26,190-196,200-201,211$ n.83, 214-217, 244, 252, 270-276, $285,310-312,393-395,457-458,516-517,521$

administered by schismatics see schismatic, sacraments administered by administered by heretics see heretic, sacraments administered by recipient of see recipient, of sacrament

and toleration see toleration, and sacramental issues

salary $137,157-158,430-431$

scandal 200, 230, 252, 276, 287

schism 195-196, 363, 372

schismatic

ordinations by $194-195$

sacraments administered by 193

scholastic 6,351

scrivener $176-177,180,483$

senator $349-350,474-475$

senatus consultum 76,148

sentence $25-26,32,36-37,96,124,146-147,209,211,213,217$, 220-225, 227-228, 231, 235, 237-238, 263, 267-268, 270, 275, 281-282, 284, 294-295, 307-309, 312, 343, 372, 378-379, 382, 423, $441,444,468,518-519$

see also judgment 
servitude $32,36,78,101,123,142-143,178,197,362,408,433,438,452$ silverware $51,70,76,79$

simoniac

election of $26,373-374$

occult $275,311,402,409,411$

ordinations by $200-201,205,233$

toleration of $204-205,242,257-258,275,402,409$

simony $24,68,127,201,242,251,253,258,275-276,311$ n.96, 373, 401-403, 416

slave

acting as arbiter $36-38,70-71,85,122-123,127-128,145,177-178$, 197-198, 438, 495-496, 502-503

acting as judge $37,123,198,219-222,232,235-236,238,255-256$, 453, 460, 495

and putative freedom $31-40,111,135,237,437$

manumission of $44-46,67,83,109$

witnessing a testament $33-36,135-138,437,472-473$

acting as praetor $12,17,20-21,43,64,142-143,164,167,278,299$, 319-320, 400, 404-405, 435-437, 441, 453, 493, 530

Slovenia 52

soul

as metaphor for incumbent in ecclesiastical office 361,365

defrauder of 396

impurity of 457

sovereign $\quad 41,45,78,94,102-105,110-111,118-121,124,130,138,149$,

157, 161-163, 173, 318-320, 366, 410, 431, 526 n.158

see also emperor; prince

sovereignty $45,122,352,414$

spouse $225,279,521$

statute $23,136,322,426,431,468,478,527$

steward

of a church 379

of a manor 525-526

succession $349,356,384$

successor $49,97,354,357,531$

Summa

Bambergensis (Animal est Substantia) $197 \mathrm{n} .26$

Sicut uetus testamentum 202

Cum in tres partes 202

Coloniensis 202, 212 n.83, 216 n.95

Glossa Palatina 222-225, 234-236 
Lipsiensis (Omnis qui iuste iudicat) 203, 216-217

Monacensis 205

Tractaturus Magister 219-221, 224

Parisiensis 214-216

Casinensis 219

see also Apparatus; Distinctiones; Fragmentum

tabellio $54-56,58,60,71,137,139,150,170,173,176,179,264-266$, 297-300, 330-331, 380, 471-473, 475, 479-485, 492, 498, 501

see also notary

testament

of a son sui iuris 57

validity of 324,472

witnessed by a slave $33-36,135-138,437$

title

absence of $71,249,294,386,393,471,497,516$

coloured $153,390,443,449,491,500,503-507,521-527,529$

validity of $153,184,308,370,432,472,475,492,497,511,530-531$

toleration

and common mistake 184, 264-268, 293-294, 307-309

and confirmation in office $241-244,292,306,318,372,380,385-389$,

$405,444-445,458,517$

and forbearance $184,189-190$

and legal representation $244-247,263-264,329,443,459,464-465$, 502-504

and notoriety $263,276-277$

and ordinary jurisdiction $\quad 254-259,307$

and public utility $260,266-268,277,297-298,417-418,519$

and sacramental issues 250-254, 271-275, 289-291, 311-312, 393-396, 514-523

and validity of excommunication see excommunication, by an excommunicate 209-228, 235, 238, 251, 270, 293-294, 311-312, $515-519,521$

in Albericus de Rosate $317-321,328-332$

in Angelus de Ubaldis 489-492

in Baldus de Ubaldis 345-346, 375-382, 388-395, 401-409, 415-418, $424,440-444,457-459,463-472$

in Goffredus de Trano 283

in Guido de Baysio 291-294

in Hostiensis 287-291

in Innocent IV 241-282 
in Johannes Andreae 303-312

in Panormitanus $516-519$

in Paulus de Castro 495-496

in Raphael de Fulgosiis 492-493

in the decretists 200-210

in the Decretum 196-199

in the Gloss on the Liber Extra 284-286

in the Ordinary Gloss on the Decretum 228-239

in the Speculum Iudiciale 295-303

of excommunicate see excommunicate, toleration of

of heretics see heretic, toleration of

of jurisdictional acts 27, 185, 195

of prelate see prelate, tolerated in office

of simoniacs see simoniac, toleration of

Toulouse, Parlement of 513

Troyes, Bailliage of 513

tyrant $77,183-184,370,414,459,497$

Ultramontani $\quad 89-90,93,95,108,126,141,146-147,157,161-169,176$, $317-319,342,397,400-402,405,408,418-419,469-470,493,524,529$

unfitness $30,254-255,299,366,376,389,401,403$

universitas 224-225, 246, 398-399, 455

unworthiness $182,192,204,209,213,243-244,247,258-259,269,272$,

$275,280-282,285-286,310-311,329,350-352,366,370,376-378$, $405,409-413,440,444,453,457,460,466-468,502,531-532$

see also indignitas

usurper

and intruder in office 525

and tyrant 184,370

utility $\quad 47-48,56,68-72,75-76,78,80,83-87,94-98,104-105,111$, $118-119,121-124,130-132,140,145,150,153,155,157,162,168$, 171-172, 177-181, 183-184, 196, 214, 260-266, 275-276, 280, 297, $300,320-322,337,397,400,416-421,425-426,436,441,445-451$, $455,460,464-466,469-471,490-494,496-497,500-507,519,523$, $526,530-531$

private $71,87,105,360-361,370,436,451,465,503$

warden see guardian 


\section{List of Names}

Names are listed by surname, unless they are commonly referred to by first name (such as Bartolus) or by some other name (such as Panormitanus)

Accursius 5-6, 18-48, 61-66, 84, 88-90

Ackersdijck, Willem Cornelis 509

Alanus Anglicus 221

Albericus de Rosate 8, 73-74, 78, 80, 189-190, 317-331, 347

Albertus Galeottus Parmensis 59-60

Aldericus, bishop of Koper 52-55

Alger of Liège 192-194

Aristotle 334-336

Angelus de Ubaldis 489-492, 498, 500

Arena, Jacobus de $72-81,85-88,99,319,322$

Augustine 28, 193

Azo 18, 22-29, 33-34, 37-38, 46-47, 58-60, 68, 91

Balduini, Jacobus $\quad 6,62,89-91$

Baldus de Ubaldis 2-5, 8-11, 185, 317-485, 489-504, 529-533

Barbosa, Agostinho 522

Bartholomaeus Brixiensis 229

Bartolus de Saxoferrato 83, 94, 158-159, 161-185, 333-340, 343, $357-358,397-398,418,481,483-484$

Bassianus, Johannes 22, 27-28, 33, 47, 68, 182

Baysio, Guido de 260, 291-295, 409

Bellapertica, Petrus de (Pierre de Belleperche) 94, 111-133, 147, 156-158, 161-162, 168-172, 176-180, 183, 342, 397, 400-401, 418, 448,524

Belviso, Jacobus de 58, 60, 73, 172, 321-323, 326-327, 329, 426

Boniface VIII (Benedictus Caetani) 468

Bronkhorst, Everardus 509

Butrigarius, Jacobus $74,78,81-88,107,164-168,320-322$

Caldera, Eduardo 508

Campianus, Augustinus 509

Castro, Paulus de 495-498

Cicero 334-336

Cocceius, Samuel von 504

Coninck, Aegidius (Giles de Coninck) 522

Constanus, Antonius Guibertus 509 
Corsetti, Antonius 505

Covarrubias y Leyva, Diego de 522

Cravetta, Aymonis 505

Cugno, Guilelmus de (Guillaume de Cuhn) 134, 140-159, 161-162, 168-173, 401, 429, 484, 501

Cujas, Jacques 509

Cumis, Guidus de 10

Cynus de Pistoia 76-77, 94, 125-133, 156-160, 162, 176

Dante Alighieri 9

Dantoine, Jean-Baptiste 507

Decius, Philippus 507

Dio, Cassius 21

Diplovatatius, Thomas 334

Donellus, Hugo (Hugues Doneau) 506-507

Durantis, Guilelmus (Guillaume Durand) 295-303

Dynus de Mugello (Dino Rosoni) 158-162

Ernstius, Henricus 508

Faber, Antonius (Antoine Favre) 511

Faventinus, Johannes 203, 207

Fulgosius (Raphael de Fulgosiis) 81, 493-495

Gabrieli, Antonius 509

Goffredus de Trano 283

Gothofredus, Jacobus 511

Gratian 7, 191-200, 211, 231, 235-237, 457

Gregory IX (Ugolino de Segni) 270, 302

Heineccius, Johannes Gottlieb 509

Honorius of Richmond 213

Hostiensis (Henricus de Segusio) 287-291, 295, 303-304, $310-312$

Huguccio (Pisanus) 55, 209-211, 219

Innocent III (Lotharius de Segni) 52, 55, 255, 279

Innocent IV (Sinibaldus de Fieschi) 2-3, 7-9, 182-185, 189, 239, 241-312, 317-318, 329, 338, 345-347, 363-365, 371-390, 393-394, 399-418, 424-425, 442-445, 453, 457, 464-471, 489-495, 498-503, $514-521,529-533$ 
Johannes Andreae 304-313, 360

Kantorowicz, Ernst 8-9, 353

Kettwig, Mentetus 509

Landus, Constantius 508

Lanfrancus de Cremona 29

Laurentius Hispanus 222-225, 234-235, 381, 388

Lessius, Leonardus (Lenart Leys) 504, 522

López Madera, Gregorius 508

Lycklama, Marcus 509

Malumbra, Richardus 319

Maqueda, Paulus de 509

Mascardus, Josephus 509, 520

Mayno, Jason de 333-339, 498-501

Meijers, Eduard Maurits 93, 107

Menochius, Jacobus 505

Monciaco, Johannes de (Jean de Monchy) 89-93, 96-97, 147

Navarrus, (Martín de Azpilcueta) 520

Odofredus de Denaris 28, 62-72, 89-90, 93, 99, 123, 134, 139-141, 177

Oldradus da Ponte 73, 319

Paezo (Plauzio Pezone), Camillus 509

Panormitanus (Niccolò de' Tedeschi) 516-521

Parmensis, Bernardus (Bernardus de Botone) 271, 283-284, 381, 388

Paucapalea 198-199, 204, 244

Placentinus 22, 34, 36

Pomponius Sextus 20-21, 24, 29, 77, 100-101, 104, 117, 134, 164, 408, 511

Pontius, Basilius 523-524

Rasch, Petrus 509

Ravanis, Jacobus de (Jacques de Révigny) 90-124, 129-132, 138, 141-144, 147-149, 156-157, 161-162, 168-169, 317-318, 329, 401

Raynerius de Forlì (Raniero Arsendi) 159, 322, 426-429

Reiffenstuel, Anaklet 522

Reisenberg, Peter 352

Riessinger, Sixtus 339 
Roffredus Beneventanus (Roffredus de Epiphanio) 257-260

Rolandus 200-206

Rufinus 204-206, 211-213, 223, 256

Sallust (Gaius Sallustius Crispus) 334-336

Sánchez, Thomas 521-522

Sanctius, Johannes (Juan Sánchez) 524

Sandeus, Felinus (Felino Sandei) 335, 503-504

Savigny, Friedrich Carl von 334

Schröter, Johann Wilhelm 509

Sichardus de Cremona 208, 234-235

Simonis de Bisignano 209

Singer, Heinrich 205

Socinus, Bartholomaeus 505

Suárez, Francisco 520

Suzzara, Guido de 108, 133-141, 144-146, 150-153, 157, 430, 481

Syllimani, Martinus 106-111, 162

Sylvester I 355

Tartagni, Alexander (Alexander de Imola) 498

Tornacensis, Stephanus (Stephen of Tournai) 203, 206-207

Turnebus, Adrianus (Adrien Turnèbe) 509

Tuscus, Dominicus (Domenico Toschi) 522

Ugolino de Presbyteris 22, 27-28, 45-48, 91

Ulpian, Gnaeus Domitius Annius 5-6, 19-23, 37-41, 44-45, 49, 104, 117-118, 134, 142-144, 408, 511

Vincentius Hispanus 296

Vinnius, Arnoldus 505

Voet, Johannes 505

Weißbrodt, Johann Andreas 509

Zarotto, Andrea 340 